The Skandapurāṇa 


\section{SUPPLEMENT}

TO

\section{GRONINGEN ORIENTAL STUDIES}

Published under the auspices of the J. Gonda Foundation

Royal Netherlands Academy of Arts and Sciences

\section{Editor}

H. T. Bakker, Groningen

Editorial Board

P. C. Bisschop · D. D. S. Goodall · H. Isaacson

The titles in this series are listed at brill.com/goss 
Peter Bisschop and Yuko Yokochi - 978-90-04-46103-1 Downloaded from Brill.com04/26/2023 02:09:47PM 


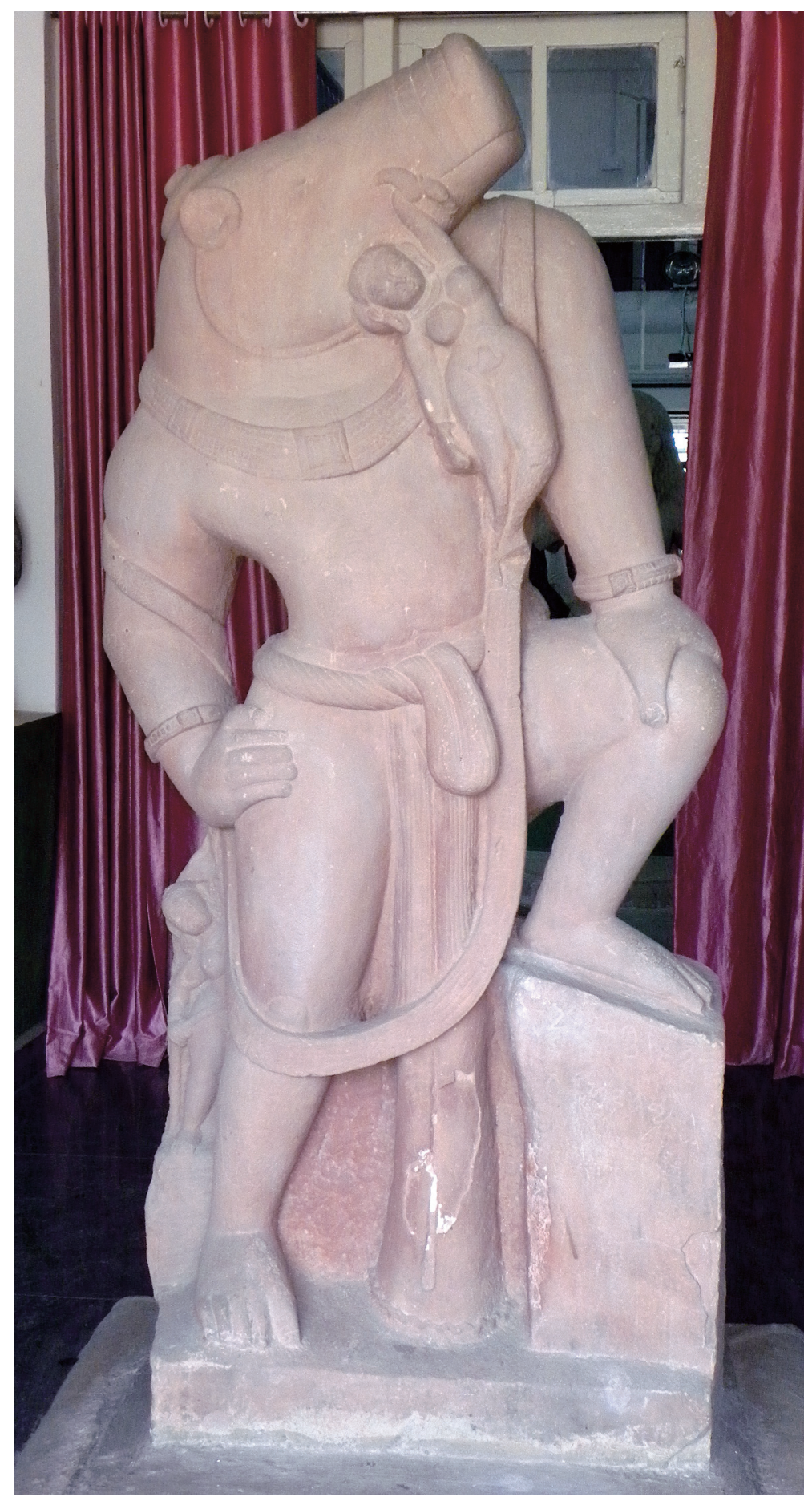

Viṣnu's manifestation as the Man-Boar, Naravarāha

(Eran, Madhya Pradesh, now at the Sagar University Museum) 


\title{
The Skandapurāṇa
}

\author{
VOLUME V Adhyāyas 96-112
}

The Varāha Cycle and the Andhaka Cycle Continued

\author{
Critical Edition \\ with an Introduction \\ $\&$ \\ Annotated English Synopsis \\ by
}

Peter C. Bisschop and Yuko Yokochi

in cooperation with Sanne Dokter-Mersch and Judit Törzsök

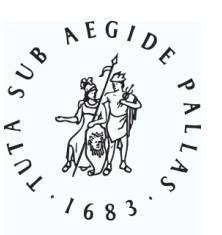

B R I L L

LEIDEN | BOSTON 
This is an open access title distributed under the terms of the CC BY-NC 4.o license, which permits any non-commercial use, distribution, and reproduction in any medium, provided the original author(s) and source are credited. Further information and the complete license text can be found at https://creativecommons.org/licenses/by-nc/4.0/

The terms of the cc license apply only to the original material. The use of material from other sources (indicated by a reference) such as diagrams, illustrations, photos and text samples may require further permission from the respective copyright holder.

\section{Photograph frontispiece: Peter Bisschop}

This book has been realised thanks to the financial support of the Japan Society for the Promotion of Sciences (JSPS) and the Netherlands Organisation of Scientific Research (NWo).

Thanks to generous support of the J. Gonda Fund Foundation the e-book version of this volume is available in Open Access.

The Library of Congress Cataloging-in-Publication Data is available online at https://lccn.loc.gov/2001415230

ISS N 1566-7642

ISBN 978-90-04-45930-4 (hardback)

ISBN 978-90-04-46103-1 (e-book)

Copyright 2021 by Peter C. Bisschop and Yuko Yokochi.

Published by Koninklijke Brill NV, Leiden, The Netherlands.

Koninklijke Brill NV incorporates the imprints Brill, Brill Hes \& De Graaf, Brill Nijhoff, Brill Rodopi, Brill Sense, Hotei Publishing, mentis Verlag, Verlag Ferdinand Schöningh and Wilhelm Fink Verlag. Koninklijke Brill NV reserves the right to protect the publication against unauthorized use.

This book is printed on acid-free paper and produced in a sustainable manner. 


\section{Preface}

We are pleased to present this volume of the critical edition of the Skandapurāna three years after the publication of volume IV. The text included here is closely related in content. The inclusion of the extensive Varāha cycle allows us to return to the subject of the integration of Vaisnava mythology in the Skandapurāna. We hope that scholars working on the history of Vaiṣnavism will take notice of this new material and integrate it into their own studies. The Skandapurāṇa remains a treasure trove for the study of Brahmanical Hinduism.

The last two chapters contain Devi's instructions to the goddesses about donations, fasts and penances, which have been cited extensively by the medieval Dharmanibandhas. We address the nature of these citations in the introduction, which adds to our understanding of the transmission of the text as well as the composition of the Dharmanibandhas. The second half of chapter 112 provides an opportunity to look ahead at later chapters in the text and examine how the different myth cycles fit together.

Several meetings were held at Leiden University and Kyoto University to discuss drafts of the edition and synopsis. Some of these meetings were attended by other scholars as well. We would like to thank Diwakar Acharya, Hans Bakker, Elizabeth Cecil, Sanne Dokter-Mersch, Kengo Harimoto, Nirajan Kafle, Yuto Kawamura, Andrey Klebanov, Tomoka Mushiga, Fumi Nakamura, Kiyokazu Okita, Kenji Takahashi, Judit Törzsök, Somdev Vasudeva and Amandine Wattelier-Bricout for their valuable input during these meetings.

The critical edition was produced by Yuko Yokochi, while the English synopsis was prepared by Peter Bisschop. The introduction was written by Peter Bisschop and Yuko Yokochi together. Draft editions of parts of the text were prepared by Sanne Dokter-Mersch (SP 108, SP 109 and SP 110 ) and Judit Törzsök (SP 112.1-72, $\mathrm{SP}_{\mathrm{RA}} 112.1$ and $\mathrm{SP}_{\mathrm{RA}} 112.2$ ) and were subsequently adapted and integrated by Yuko Yokochi. We have also benefitted from the work done by Sanne Dokter-Mersch during the preparation of her $\mathrm{PhD}$ thesis at Leiden University.

Peter Pasedach provided technical support and put the final touches on the TeX files. Kristen De Joseph proofread and corrected the English. We thank them both. 
We are indebted to the Netherlands Organisation of Scientific Research (NWO) and the Japan Society for the Promotion of Science (JSPS) for their financial support of our research. Thanks to the generous support of the J. Gonda Fund Foundation, the e-book version of this volume is available in open-access format. Finally, we wish to thank Albert Hoffstädt and Patricia Radder of Brill Publishers for their care and support.

September 2020,

Peter Bisschop, Leiden Yuko Yokochi, Kyoto 


\title{
Table of Contents
}

\author{
Introduction
}

The Battle Continued . . . . . . . . . . . . . . . . 3

The Varāha Cycle . . . . . . . . . . . . . . . . . . . . . 4

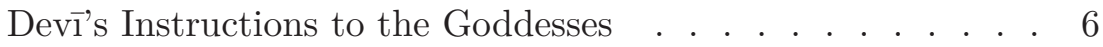

The Andhaka Cycle Continued . . . . . . . . . . . . . . . 8

The Incorporation of Vaișnava Mythology . . . . . . . 9

The Composition of the Second Part of SP $112 \ldots \ldots$

Three Connective Episodes . . . . . . . . . . . . . . . . 16

The Revision of SP 112 in the RA Recension . . . . . . . . 23

Dharmanibandha Citations of Devī's Teachings . . . . 29

EdITORIAL POLICY . . . . . . . . . . . . . . 40

Presentation of the Revision of Adhyāya 112 . . . . . . . . 40

Metrical, Grammatical and Syntactical Anomalies . . . . . 41

\section{Synopsis}

Structure of the Contents of Chapters 96 to $112 \ldots 49$

SyNOPSES OF Chapters 96 to $112 \ldots \ldots$. . . . . . . . 51 


\section{Skandapurāṇa}

Symbols and Abbreviations in the Apparatus . . . . . . . . . . . 101

Sigla of the Manuscripts Used . . . . . . . . . . . . . . . . . . 102

Abbreviations of the Editions Used . . . . . . . . . . . . . . . 103

SkAndapurāna: AdhyĀYas 96 to 112

Adhyāya 96 . . . . . . . . . . . . . . . . . . . . . . . 105

Adhyāya 97 . . . . . . . . . . . . . . . . . . . . 112

Adhyāya 98 . . . . . . . . . . . . . . . . . . . . . . . . 118

Adhyāya 99 . . . . . . . . . . . . . . . . . . . . . . . . . 127

Adhyāya 100 . . . . . . . . . . . . . . . . . . 132

Adhyāya 101 . . . . . . . . . . . . . . . . . . . . . . . 143

Adhyāya 102 . . . . . . . . . . . . . . . . . . . . . . . . 149

Adhyāya 103 . . . . . . . . . . . . . . . . . . . 156

Adhyāya 104 . . . . . . . . . . . . . . . . . . . . . . . 164

Adhyāya 105 . . . . . . . . . . . . . . . . . . . . . 174

Adhyāya 106 . . . . . . . . . . . . . . . . . . . . . . . . 181

Adhyāya 107 . . . . . . . . . . . . . . . . . . . 187

Adhyāya 108 . . . . . . . . . . . . . . . . . . . . . . . 195

Adhyāya 109 . . . . . . . . . . . . . . . . . . . . . . . 201

Adhyāya 110 . . . . . . . . . . . . . . . . . . . . . . . 210

Adhyāya 111 . . . . . . . . . . . . . . . . . . . . . . . 216

Adhyāya 112 . . . . . . . . . . . . . . . . . . . . . 236

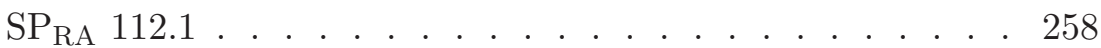

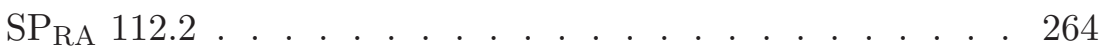

$\mathrm{SP}_{\mathrm{RA}}$ 112.3.................. . . . 267

Bibliography \& Indexes

AbBreviations . . . . . . . . . . . . . . . . . 283

REFERENCES . . . . . . . . . . . . . . . . 284

INDEXES

Index to the Introduction . . . . . . . . . . . . . 291

Index to the Synopsis . . . . . . . . . . . . . . . . . . . 293

Index of Text Passages . . . . . . . . . . . . . . . . . . 299 


\section{Introduction}


Peter Bisschop and Yuko Yokochi - 978-90-04-46103-1 Downloaded from Brill.com04/26/2023 02:09:47PM 


\section{The Battle Continued}

The previous volume culminated in Hiranyākșa's capture of the Earth (Pṛthivi) and his conquest of the entire world (SP 95). Hiranyā̄sṣa had taken over as king of the Daityas after the death of his brother Hiranyakaśipu at the hands of Viṣnu in his manifestation as the Man-Lion (Narasiṃha). A prolonged battle between the Asuras and the Devas ended with Hiraṇyākṣa's victory. The final chapter described his rule in accordance with the dharma and the prospering of his kingdom as a result. The situation of the gods could hardly be more hopeless.

The present volume continues this storyline and tells how Viṣnu manifests in the form of the Boar (Varāha) in order to kill Hiranyākṣa. This Varāha cycle takes up the major part of the text included here (SP 96110). The Skandapurāna expands upon the known version of the Varāha myth by adding a sequel in which Viṣnu holds on to his Boar form and produces a son named Vṛka (SP 109-110). This son ravages the forest of Skanda's dwelling at Gaurīkūṭa. Skanda puts an end to Viṣnu's Boar manifestation and thus causes Viṣnu to return to his natural form.

After the termination of his Varāha manifestation, Viṣnu requests that Siva teach the gods the Pāśupata observance. Devī remains behind on Mt Mandara and instructs the goddesses on the merits of donations and observances (SP 111-112.72). She then explores Mandara's forest with them. Here she encounters a young aśoka tree, which she decides to adopt as her son. At that moment Andhaka and his entourage arrive at Mandara. Andhaka declares his desire for Devī but is warned off by Prahlāda. Next, the Asuras chance upon the Seven Sages (Saptarși), who are visited by the gods Dhātṛ, Vidhātṛ and Kṛtānta. The sages ask them about the future affairs of the Devas and the Asuras.

Of the topics included in this volume, two had already been identified in the synopsis of the Anukramanikā in SP I: 'the slaying of Hiranyākṣa' (SP 2.15c: hiranyākșavadhaś caiva $\rightarrow$ SP 107) and 'the arrival [of Andhaka] at Mandara' (SP 2.21b: mandarāgamanam tathā $\rightarrow$ SP 112.82-92). To this we may add 'Andhaka's catching sight of Devì' (SP 2.17d: devyāś 
cāndhakadarśanam $\rightarrow$ SP 112.82-92). ${ }^{1}$ Moreover, the topic of 'Devī's hundred forms' (SP 2.18b: devyāś ca śatarūpatā) seems to have inspired a revision of $\mathrm{SP} 112$ in the $\mathrm{RA}$ recension. ${ }^{2}$

\section{The Varāha Cycle}

The Varāha cycle starts in SP 96 with a description of Hiranyākṣa's glorious rule. Agni is expelled and a new Agni is installed in his place. The Mantras and Yajña follow the new Agni. The gods no longer receive their offerings and are in a despondent state. Brahmā advises them to bide their time and take up residence in the bodies of Hiraṇākșa's subjects through yoga. When four yugas have passed, Hiranyākṣa notices what is going on. He starts slaying his own people and dries up all the waters by means of yoga. ${ }^{3}$

The next chapter (SP 97) sees the gods once again looking for Brahmā's help. He tells them that the power of Hiranyākș̣a's tapas has run out and that they should beseech Viṣnu to take up the form of the 'ManBoar' (Naravarāha). Brahmā refers to a set of conditions that recalls the Narasimha myth: he cannot be killed by a man, a god or an animal, nor on earth, in fire, in the sky or in the worlds (SP 97.9-10). A structural link with the earlier Narasimha cycle (SP 70-71) is thus established, further highlighted by the identification of the Boar manifestation as a hybrid (Naravarāha). ${ }^{4}$ The gods follow Brahmā's advice and proceed to Mt Śveta, where they praise Viṣnu with a lengthy hymn (SP 97.15-30). Viṣnu is pleased and promises to slay the Daitya, but he calls for the gods' help since he cannot do it on his own. This request sets the tone for the rest of the narrative, in which Viṣnu structurally comes across as dependent and not in control.

SP 98 tells of the fashioning of the Boar's body by the gods. All the gods infuse him with their power and take up residence in his limbs. The Boar rises up with his massive body. An important simile compares his form to the one Madhusūdana took up in the past when he lifted up the Earth as Svayambhu (SP 98.20), thus distinguishing between the earlier cosmogonic form and the present Daitya-slaying form. Siva is asked to strengthen Viṣnu with his tejas. He promises the gods that Viṣnu will

1 Alternatively, this may be taken the other way around as 'Devì's catching sight of Andhaka' (cf. SP I, 62: 'Devì's vision of Andhaka'). Both Andhaka episodes are narrated once again in more detail in $\mathrm{SP}_{\mathrm{Bh}}$ 130.2-41 (see below, p. 20), to which the Anukramanikā may by extension also be considered to refer.

2 See below, p. 28.

3 This prequel to the Varāha cycle is not known from any other source.

4 The only other text to refer to Viṣnu's Varāha form in this way is the Viṣnudharmottarapurāna (VDhP 1.53.13-14). See n. 137 on p. 53. 
slay the Daitya after his tejas has entered him. Brahmā performs an elaborate rite of protection and Varāha sets out for the great Ocean. A lengthy description of Varāha's journey through the Ocean follows (SP 99), in which he encounters, among others, the Nāga Ananta. A Daitya serving as a sea guard catches sight of him and hastens back to the city to inform Hiraṇyākṣa of the coming of Varāha.

SP 100 starts with a description of bad omens in Hiranyākșa's city. Prahlāda tells Hiraṇyākṣa about a dream he has had in which a man-boar seized Hirạ̣yākșa. The latter tells Prahlāda that he himself had a dream in which Siva told him to give up his kingship. The Asuras are having an argument about what to do when a Dānava arrives, in haste, introducing himself as Nala the seaguard. He informs Hiranyākșa about the arrival of the Boar. Prahlāda remarks that this is no ordinary boar, but Vị̣nu in disguise. Hiraṇyākṣa expresses delight at the arrival of his brother's killer and instructs the Daityas and Dānavas to find him.

The Daityas and Dānavas find the Boar and ask him why he has come (SP 101). Varāha feigns ignorance, but they attack him. Varāha slays them all. One Asura manages to escape and returns back to Hiranyākșa's capital (Aśmakapura) to inform the king of what has happened (SP 102). Next, Vipracitti, Prahlāda and others are dispatched to fight the Boar. In the meantime Varāha has reached Aśmakapura. He circumambulates the city anticlockwise and breaks the southern gate, a clear portent of Hiraṇākșa's upcoming death. The Asuras at the gate start attacking him. Varāha tells the Asuras to put up a just fight (dharmayuddha), but Prahlāda expresses his disagreement. They all attack the Boar (SP 103). Varāha comes out victorious and scares away the Daityas and Dānavas. The next chapter (SP 104) sees them attack once more, but Varāha once again conquers them all. Vipracitti and Varāha engage in combat with each other and Varāha hurls Vipracitti atop Hiraṇyākṣa's palace. Hiranyākssa wants to know who could have possibly done this and Vipracitti tells him about the Boar, begging Hiraṇyākṣa to leave the city. Hiraṇyākṣa wants to hear nothing of it and prepares himself to fight.

The description of the fight between Varāha and Hiranyākṣa takes up three chapters (SP 105-107). Hiranyākșa sets out in full armour and encounters Varāha not far from the city (SP 105). He paralyses him with a volley of arrows and the gods have to revive Varāha with mantras. Varāha tries to attack Hiranyā̄kṣa's chariot, but he is bound with snakes and struck harshly by the Daityas. Garuda releases him from the snakes. Attacking Hiraṇākșa once more, Varāha is struck in the heart and falls to the ground. This time he is strengthened by the sages and the gods, who fill him with their tapas. Varāha and Hiranyākṣa provoke each other and fight once again (SP 106). Varāha destroys Hiraṇyākṣa's chariot, but 
the latter hits him with the weapon of stupification (mohanāstra), which is removed with mantras by the gods. More fighting follows, until Hiraṇyākșa hurls a spear, reciting 'homage to Rudra!' The spear strikes Varāha in the heart, leaving him as good as dead (SP 107). This time Siva himself revives Varāha with his tejas. Varāha tears out the spear and strikes Hiranyākṣa in the heart with it. The two end up abandoning their weapons and begin a long wrestling match. When, after many thousands of years, Hiraṇyākṣa is weakened, a voice from the sky instructs Varāha to strike the Daitya with the cakra of Maheśvara. Varāha calls to mind the cakra, which appears before him in all its majesty. He hurls the cakra at Hiraṇyākṣa and decapitates him.

Having killed Hiranyākssa, Varāha goes in search of the Earth (SP 108). He finds her held captive under the Śankkha mountain. After freeing her, he re-establishes her in her proper place, and hands over the three worlds to Indra. With this, Varāha's job should be over, but he expresses a desire to enjoy his Boar form a little longer. The gods agree and go home. Varāha has a party with Vedic Apsarases who have taken on the form of female boars.

The last two chapters of the Varāha cycle form a sequel to the myth of the manifestation of Varāha. A son named Vṛka is born (SP 109). This son is a menace and ravages the forest of Kārttikeya near Gaurīkutta on the Himavat. A Ganapa of Skanda called Kokavaktra holds him to account and takes him captive. Meanwhile Skanda returns from a visit to Śiva on Mandara and is shown the prisoner. He orders him to be tortured in public. Nārada sends word to Varāha, who goes there in anger. Fighting with Skanda, he ends up being struck in the heart by his spear (SP 110). He leaves behind his Boar body and becomes Viṣnu again. Heading for Siva's abode, Viṣnu praises him and requests that the god teach him the Pāśsupata observance. Śiva promises to do so and goes to Mt Meru, taking leave of Pārvatī.

\section{Devī's Instructions to the Goddesses}

While Śiva is away teaching the Pāśupata observance to the gods, Pārvatī remains behind on Mt Mandara. There she is approached by the Mothers of the World (lokasya mātarah). They ask her about dharma. Devī first instructs them in the dharma of making donations (SP 111). In the next chapter (SP 112), she teaches the goddesses about the merits of fasting. Both donating (dāna) and fasting (upavāsa) are taught from the perspective of a male agent. In the final part of her instruction, Devī addresses the question of what a woman can do. Starting from the principle that a woman's duties lie with her husband, she tells the 
goddesses that a woman can perform the dharma as well, but only if her husband allows her (SP 112.67-72). ${ }^{5}$ Both chapters have been quoted extensively in a number of medieval Dharmanibandhas. These citations provide much insight into the nature and transmission of the text. ${ }^{6}$

There are two issues relating to the audience of Devi's instructions on donation in SP 111 that reveal the early stage of the text's redaction process. At the beginning of the chapter, we are told that the goddesses attended on Devī when Deva had gone to heaven, and asked her about dharma. Devī starts to instruct the goddesses at SP 111.9. Thus it is clear that Devi is the speaker, while the goddesses are the addressees of the following teaching. However, the goddesses are addressed with the feminine vocative plural only at SP $111.9 \mathrm{~b}$ (suvratạh), and then again near the end of the chapter, at SP 111.94d (devatāh), ${ }^{7} \mathrm{SP} 111.95 \mathrm{c}$ (devyah) and SP

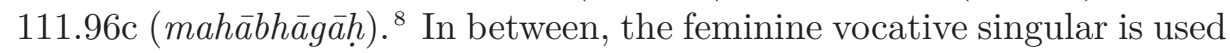
frequently, indicating that it is a singular goddess who is the addressee of the teaching. This is the case not only in the available manuscripts of the $\mathrm{S}$ recension - significantly $\mathrm{R}, \mathbf{A}$ and $\mathrm{SP}_{\mathrm{Bh}}$ have changed these readings into a vocative plural or replaced it with another word-but also in some of the quotations in the Dharmanibandhas. ${ }^{9}$ Furthermore, the use of the second-person imperative singular (śrṇu and śrṇuṣva) likewise indicates that just one goddess was the original recipient of instruction. These imperative singulars not only occur in the $\mathrm{S}$ manuscripts, but also frequently in $\mathrm{R}$ and $\mathbf{A}$, and receive support from the Dharmanibandha testimonia. ${ }^{10}$ Thus, except for the beginning and end, which incorporate the chapter in the Skandapurāna's narrative, the addressee of the instruction in SP 111

5 This teaching is in line with other statements about a woman's duty in the text. Cf., e.g., SP 52.21-25 and $\mathrm{SP}_{\mathrm{Bh}}$ 158.80-87. Following this section, $\mathrm{R}$ and $\mathbf{A}$ insert a long passage about the observance for women (strîvrata). See below, p. $23 \mathrm{f}$.

6 See below, p. $29 \mathrm{f}$.

7 Some of the vocatives (devatāh, suvratāh and mahābhāgāh) could of course also be the masculine vocative plural, but the context requires taking them as a feminine.

8 In SP 111.91d the fem.voc.pl. suvrata $h$ appears in all available manuscripts except $\mathrm{A}_{7}$ (the verse is omitted in $\mathrm{A}_{7}$ ). We have, however, emended it to suvratah (masc.nom.sg.) based on the reading in the Dānasāgara and the fact that the fem.voc.sg. appears in SP 111.92.

9 The fem.voc.sg. is used in SP 111.16c (devi), SP 111.16d (śubhe), SP 111.26b (śubhānane, supported by DS), SP 111.27b (devi), SP 111.30b (śucismite), SP 111.36c (devi), SP 111.41c (devi, supported by DS), SP 111.43b (śubhe), SP 111.57c (devi, supported by AYS, DK, DS and HeDKh), SP 111.64c (devi) and SP 111.92c (devi).

10 The imperative singular śrṇu occurs in SP 111.22d (in all manuscripts, supported by DK, DS, KR and DKK), SP 111.33d (in all manuscripts) and SP 111.60b (in all manuscripts, DK and HeDKh). The middle imperative singular śrnusvva (actually tac chṛnuṣva) is used in SP $111.37 \mathrm{~d}$ in $\mathrm{S}_{2} \mathrm{~S}_{3}$ (tac chṛnudhva in $\mathrm{S}_{1}$ ), while $\mathrm{R}$ and $\mathbf{A}$ have the imperative plural, tac chrnudhvam. 
is a single goddess. ${ }^{11}$ This strongly suggests that the original instruction came from an external source and was incorporated here, with the beginning and end added in order to smoothly connect it with the immediate context. We are not able to identify this external source; it may not have been a written source but part of an oral tradition. However, the setting in which someone teaches dharma to a goddess reminds us of many such instructions of Śiva to Pārvatī. Although the instruction of dāna here is purely Brahmanical, with no specific Śaiva elements, a possible source would be a text like the Sivadharma. ${ }^{12}$

There is one more issue relating to the addressee in this chapter. This concerns SP 111.78c, in which Vyāsa is the one addressed, in a reading supported by $\mathrm{S}_{2} \mathrm{~S}_{3}$ and $\mathbf{A} .{ }^{13}$ This vocative occurs in a passage that describes in detail the individual parts of a donated cow as consisting of all cosmic divinities (SP 111.69cd-79). This recalls a similar description of the bull when he became Śiva's vehicle (SP 33.116-134) and of Varāha when his form was produced by all the gods (SP 98.1-18). No feminine vocative singular appears in this passage. It seems likely that this part was composed separately by one of the authors of our text, referring to the Skandapurāna's usual addressee Vyāsa, and that it was inserted here during the process of redaction.

\section{The Andhaka Cycle Continued}

After Devī has finished her instruction, the Mothers (Mātṛs) propose to explore Mandara's forest. When Devī encounters a young aśoka tree with its blossoms bending down toward her, she decides to adopt the tree as her son, if Deva allows her when he returns (SP 112.73-81). Devì's submissive attitude is in line with the conclusion of her own teaching, in which she had stressed the need for women to get the approval of their husband in the performance of dharma. The adoption ceremony of the aśoka tree itself is taken up again only much later in the text, in $\mathrm{SP}_{\mathrm{Bh}}$ 158-162.

The scene is crudely interrupted by the arrival of Andhaka and his forces, who have come to Mandara from Pātāla. Andhaka stares at De-

11 Note that this does not apply to SP 112, where Devī continues to instruct the goddesses and where the plural is used throughout.

12 The two earliest texts of the Śivadharma, which eventually grew into a corpus of eight texts as found in palm-leaf manuscripts surviving from Nepal, are the Śivadharmaśāstra and the Śivadharmottara. There may, however, have been more texts like this dedicated to specifiying the rules and regulations of lay worship of Śiva. See Bisschop 2018, 1-27, for an introduction to the corpus and to the Śivadharmaśāstra in particular.

$13 \mathrm{~S}_{1}$ is not available for this passage, while $\mathrm{R}$ has devyah and the Dānasāgara quotation has madhye. 
$v \overline{1}$, but he is warned by Prahlāda that she is none other than the wife of Siva and that he should bow down to her. While not explicitly stated, this warning serves as a portend of Andhaka's downfall, for he had earlier received a boon that he could only be killed if he would not bow down to the Mother of the World (SP 74.23). ${ }^{14}$

Devī disappears and the Daityas start wandering around Mandara. They spot the Seven Sages (Saptarși) at a waterfall and eavesdrop upon them. The sages notice their arrival and decide to go elsewhere (SP 112.99-102). At this moment, somewhat out of the blue, the gods Dhātr, Vidhātr and Kṛtānta arrive. ${ }^{15}$ Welcomed by the sages, they report that they have come from Brahmaloka. They tell the sages about their visit to Kaśyapa at the request of Brahmā. There Dhātṛ had informed Kaśyapa about the future affairs of the Devas and Asuras, which Kaśyapa was concerned about, being the ancestor of both sides. The sages express their desire to hear about this as well and Kṛtānta is charged with telling it. With the announcement that he will narrate it all to them the volume comes to an end.

\section{The Incorporation of Vaișnava Mythology}

In the Introduction to SP IV, we have briefly touched upon the question of how Vaiṣnava mythology is incorporated into the Skandapurāna. ${ }^{16}$ The authors of the text have taken great effort to integrate and expand upon several of the most celebrated myths of Viṣnu's manifestations, and they have done so in a systematic manner. To understand the position of some of this material in the text as a whole, it is necessary to look beyond the confines of the present volume.

The first thing to note about Viṣnu's manifestations is their order of narration. While the usual order of the prādurbhāva lists includes Varāha before Narasimuha, ${ }^{17}$ in the Skandapurāna the order is reversed. This is because the dynastic line of the Daitya kings is the main principle guiding the narration of events (Table 1). As in the eighteen-day battle of

14 Cf. also $\mathrm{SP}_{\mathrm{Bh}}$ 130.23, where Prahlāda reminds Andhaka of the conditions of the boon that he has received. This forms part of a much more elaborate description of the fight between Andhaka and Pārvatī, likewise set on Mandara. It is not clear to what extent these two episodes refer to the same event; this may very well reflect different layers of textual composition. See below, p. 20.

15 It is not clear from the text if the Asuras are still present or if the sages have already moved elsewhere. This is rather important in view of what Kṛtānta has to say about the future affairs of the Suras and Asuras in the chapters that follow.

16 SP IV, 6-7.

17 See Brinkhaus 1992 and 1993. 
the Mahābhārata, the Skandapurāna's narrative is structured around the successive leaders of the opposing army. In the case of the Mahābhārata, these are the four generals of the Kaurava army, whose names provide the titles of the epic's four battle books. ${ }^{18}$ In the case of the Purāna, the leaders are the Daitya kings.

Table 1: The Daitya dynasty

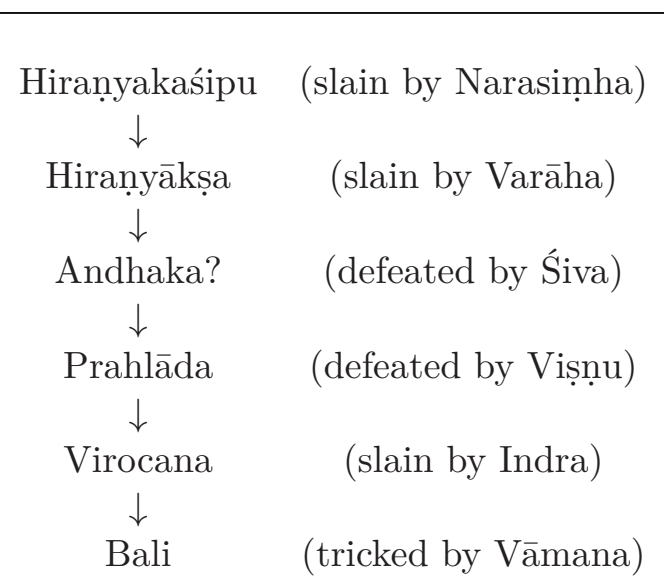

The conflict between the Devas and the Asuras starts with the first Daitya king, Hiranyakaśipu, the eldest son of Kaśyapa and Diti. He is crowned king of the Daityas but seizes Indra's position. As a consequence he gets killed by Viṣnu in the form of Narasiṃha (SP 70-71). Hiraṇyakaśipu's younger brother, Hiraṇyākṣa, takes over, plotting revenge, and defeats the gods. He is slain by Viṣnu in the form of Varāha (SP 73-108).

There is some ambiguity as to who is the next Daitya king: Prahlāda or Andhaka. The one who is explicitly identified as such is Prahlāda, Hiranyakaśipu's son $\left(\mathrm{SP}_{\mathrm{Bh}}\right.$ 113-115). ${ }^{19}$ His defeat at the hand of Viṣnu is linked to the Amṛtamanthana myth, in which Viṣnu steals the nectar of immortality (amrta) in the form of the bewitching woman Mohini. Defeated by Viṣnu after waging many battles, Prahlāda finally hands over the rule of the Daityas to his son Virocana $\left(\mathrm{SP}_{\mathrm{Bh}} 116.1-13\right) .{ }^{20}$ Virocana gets killed in the Aṭi-Baka battle ( $\mathrm{SP}_{\mathrm{Bh}}$ 116.1-13ab). Viṣnu does not

18 Bhịṣmaparvan (MBh 6); Droṇaparvan (MBh 7); Karṇaparvan (MBh 8); Śalyaparvan (MBh 9).

$19 \mathrm{SP}_{\mathrm{Bh}}$ 113.2: bhaviṣyaty asurānām tu hiranyakaśipoh sutah | indro mahābalo vidvān prahlādo 'surapungavah $\|$.

20 Prahlāda's defeat in battle by Viṣnu is announced in $\mathrm{SP}_{\mathrm{Bh}}$ 113.3. According to $\mathrm{SP}_{\mathrm{Bh}} 115.49 \mathrm{~cd}-50 \mathrm{ab}$, he left the battlefield with the Dānavas after he was defeated by Viṣnu. $\mathrm{SP}_{\mathrm{Bh}}$ 116.1-2 states that he handed over rule to Virocana after engaging in hundreds of battles. For the stealing of the amrta by Mohinī, see $\mathrm{SP}_{\mathrm{Bh}} 113.55-$ 65 . 
play a role in this battle; instead, Virocana is slain by Indra $\left(\mathrm{SP}_{\mathrm{Bh}} 116.3 \mathrm{~d}\right.$ : mahendrena). Following Virocana's death, his son Bali is consecrated king. He conquers the three worlds but is tricked by Viṣnu, in the form of Vāmana, who returns the kingship to the gods by taking his celebrated three strides ( $\mathrm{SP}_{\mathrm{Bh}}$ 116.13-117.20). After this there are yet more Devāsura wars, but there is no more mention of a dynastic succession of Daitya kings. ${ }^{21}$

The position of Andhaka in this dynasty is somewhat obscure. After the death of Hiranyākṣa the line seems, at first sight, to return again to that of the elder brother, through Hiranyakaśipu's son Prahlāda. ${ }^{22}$ Andhaka, on the other hand, being the son of Hiranyākșa, would also be a possible claimant to the throne. ${ }^{23}$ While no mention is made of his installation as king of the Daityas, there are some indications that Andhaka took over before Prahlāda. For a start, when Prahlāda is introduced as king of the Daityas in $\mathrm{SP}_{\mathrm{Bh}}$ 113.2, Krrtānta, who is speaking to the Seven Sages, uses the future tense (bhavisyati). This suggests that somebody else must have been ruler at the time. It makes sense that this is Andha$\mathrm{ka}$, introduced in the preceding chapter as arriving at Mt Mandara in the company of many Daityas, including Prahlāda, who warned him about Pārvatī. Moreover, later in the text, when the Andhaka cycle is resumed ( $\left.\mathrm{SP}_{\mathrm{Bh}} 130\right)$, Andhaka is referred to twice as king of the Daityas. ${ }^{24}$ Significantly, in the speech that follows, Prahlāda addresses him three times as king of the Dānavas. ${ }^{25}$ In $\mathrm{SP}_{\mathrm{Bh}}$ 116.86, in a speech of Bali to Prahlāda, he

21 Up to this point, the SP has followed the lineage of Daityas taught in the Vamśa part of the Purānapañcalakșaṇa (PPL 165.66-70ab). According to PPL 165.70cd, Bali had one hundred sons, the eldest of whom was Bāna, but there is no mention of his rule in our text. The war recounted after the defeat of Bali in the SP is the Tārakāmaya war, in which the Asura leaders are Tāraka and Maya, two Dānavas. There is no mention of a Daitya king. At the time of the Tārakāmaya war, the Saimhikeyas were slain by Jāmadagnya $\left(\mathrm{SP}_{\mathrm{Bh}} 121.37-64\right)$, but he is not identified as an avatāra of Viṣnu as in other Purāṇas. The slaying of the Saiṃhikeyas is followed by the killing of Kālanemi by Keśava ( $\left.\mathrm{SP}_{\mathrm{Bh}} 122.1-13\right)$. This ends the Tārakāmaya war. After this the text continues with the Dhvaja war.

22 There are different traditions about the succession in other early texts. Compare, for example, ViP 1.20.32, where Prahlāda takes over after Hiraṇyakaśipu has been slain by Narasiṃha: pitary uparatim nīte narasiṃhasvarūpin̄ā | viṣnunā so 'pi daityānām maitreyābhūt patis tatah \|. According to HV App. 1 No.42B 1l. 3334, Bali takes over after Hiranyakaśipu has been slain: tam drștvā nārasiṃhena hiraṇakaśipum hatam | daityā devavadhārthāya balim indrạ̣ pracakrire \|.

23 Their natural rivalry as potential heirs to the throne may explain some of the animosity between Prahlāda and Andhaka. They are often found to be in disagreement about the course of action to be adopted. The following argument about Andhaka's position in the dynasty draws on Dokter-Mersch, forthc.

$24 \mathrm{SP}_{\mathrm{Bh}}$ 130.2a, 130.5a: daityendra.

$25 \mathrm{SP}_{\mathrm{Bh}}$ 130.8a: dānavendra; $\mathrm{SP}_{\mathrm{Bh}}$ 130.12c: dānavānām adhipati; $\mathrm{SP}_{\mathrm{Bh}}$ 130.13b: dānaveśvara. Also, in the rest of this same chapter, Andhaka is referred to by such an appellation: $\mathrm{SP}_{\mathrm{Bh}}$ 130.30b: dānaveśvara; $\mathrm{SP}_{\mathrm{Bh}}$ 130.33c, 130.39a: dānavendra. 
states that neither king ( rājan) Hiraṇyakaśipu, nor Hirạ̣yākṣa, nor his son (tatsuta) Andhaka attained complete happiness. In the next verse $\left(\mathrm{SP}_{\mathrm{Bh}}\right.$ 116.87) he refers to Prahlāda as his grandfather (pitāmaha). Finally, in $\mathrm{SP}_{\mathrm{Bh}} 172$, where Prahlāda is king of the Daityas, his strength is compared to that of other famous Daityas of the past. Here Andhaka is mentioned in the same line as the Daitya kings Hiraṇyakaśipu and Hiraṇyākṣa. ${ }^{26}$ All of this hints at Andhaka's position in between Hiranyākșa and Prahlāda. Prahlāda would then have taken over as king after Andhaka was impaled and burned on Siva's śula, an event that is narrated much later in the text $\left(\mathrm{SP}_{\mathrm{Bh}} 155\right)$. It is quite likely that the ambiguities surrounding Andhaka's position as king of the Daityas are the result of Andhaka's insertion into the lineage of the Daityas. ${ }^{27}$

Returning to the subject of Viṣnu's manifestations, three of the abovementioned episodes concern bodily manifestations of Viṣnu: Narasiṃha, Varāha and Vāmana. The defeat of Prahlāda by Viṣnu himself, Virocana by Indra and Andhaka by Śiva do not fit into this scheme. The three myths concerned with Viṣnu's manifestations, by contrast, share a common structure that is unique to the Skandapurāna. The first two are hybrid forms and their hybridity is emphasized. In both cases, Viṣnu is not willing to give up his body after he has accomplished the task of slaying the Daitya king. Śiva forces him to abandon his Narasimha form by trampling him in his own Śarabha manifestation (SP 71.48-72), while Śiva's son Kārttikeya causes Viṣnu to give up his Varāha form by striking him with his spear (SP 110.10-15). The final manifestation of Vāmana is a special case, but once more involves a situation in which the manifestation continues to exist after he has accomplished his task. Viṣnu naturally cannot hang on to the Vāmana form because of the parameters of the myth that involve the dwarf's expansion to cosmic dimensions. Instead, a unique episode has been added in which an Asuric Evil (Pāpmā) enters Viṣnu due to his excessive pride and the abandonment of his svadharma. This turns him into a dwarf again ( $\mathrm{SP}_{\mathrm{Bh}}$ 117.28-31). A purificatory pilgrimage is required to release him from $\sin \left(\mathrm{SP}_{\mathrm{Bh}} 118-121\right)$. At the very end, Viṣnu performs the mahāvrata and after twelve years reaches union with Siva,

The use of danavendra is ambiguous though: is it the equivalent to daityendra here? Note that Hiranyākșa is sometimes referred to as a dānava as well. The text is not consistent in this regard (see SP IV, 79, n. 223).

$26 \mathrm{SP}_{\mathrm{Bh}}$ 172.50-51.

27 Andhaka does not yet figure in the Daitya lineage in the Purānapañcalakṣana. According to PPL 166.72-73ab, Hiraṇyākșa had five sons: Utkara, Śakuni, Bhūtasaṃtāpana, Mahānābha and Kālanābha. There is no mention of Andhaka as a son of Hiranyākṣa. The Skandapurāna is the first text to give an account of his life story. See SP IV, 9, and Yokochi forthc., for a comprehensive account of the structure of the Skandapurāna and the insertion of the Andhaka cycle in the text. 
being granted half of his body. He thus becomes Viṣnuśaṃkara ( $\mathrm{SP}_{\mathrm{Bh}}$ 121.16-20).

Two narrative lines come together in this intricate plot: on the one hand the theme of the dynastic succession of the Daitya kings, and on the other hand the motif of Viṣu's manifestations. The line of the Daitya kings comes to an end with Viṣnu's manifestation as Vāmana and the return of the three worlds to Indra through Vị̣nu's three giant steps. Each of the three manifestation myths includes an episode about an afterlife that is in need of termination. ${ }^{28}$ Through this plot structure, the authors of the Skandapurāṇa have furnished Viṣnu with a unique trajectory, in which he reaches his final destiny by being granted half of Śiva's body. This happens after his performance of the mahâvrata. This 'great observance' is nothing other than the Pāśupata observance. ${ }^{29}$ In other words, Viṣnu has been turned into a true Siva devotee and reaches the goal that is the ultimate destiny of the Pāśupata liberation seekers: union with Siva (śivasāyujya).

To a contemporary audience, the granting of half of Siva's body to Viṣnu would no doubt have brought up the image of Harihara, a wellknown icon at the time. ${ }^{30}$ The Skandapurāna provides this icon with a remarkable theological interpretation, through the elaborate narrative structure of Viṣnu's manifestations culminating in his union with Śiva. ${ }^{31}$

Other allusions to Viṣnu's iconography are in evidence in the Varāha cycle, the subject of the present volume, as well. Thus, Varāha's body

28 It may be observed that the three manifestation myths are distributed across different myth cycles. The Narasimna myth is in the Skanda cycle, the Varāha myth in the Varāha cycle within the Andhaka cycle, and the Vāmana myth in the Devāsura war cycle. The three myths thus function as connective knots that tie the different myth cycles together.

$29 \mathrm{SP}_{\mathrm{Bh}}$ 121.18-20: sa cātha krtarakṣas tam sarvadharmāvaham śubham | yogam yantram vratam caiva paramaiśvaryasādhanam \| yat tat pāśspatam divyaṃ vidhānam sārvakāmikam | tac cīrtvā dvādaśa samāh paramaiśvaryam āptavān || tasya devah svayam śūlì tuștạ prekṣya tathāvidham | śarīrārdham dadau tasmai tad abhüd viṣnuśaṃkaram $\|$. For $121.18 \mathrm{a}, \mathrm{S}_{2}$ and $\mathrm{S}_{3}$ more or less read pañcārtham krtarakșantam, while $\mathrm{S}_{1}$ has sañcārthakrtarakșantat; the text can be emended to pañcārtham krtarakșam tat. On the Pāśupata mahāvrata, see also Bakker 2014, $152-153$.

30 On the iconography of Harihara, see Adiceam 1966, Agrawala 1970 and Lavy 2003. Particularly interesting in connection with the SP's integration of Harihara with Viṣu's manifestations is a Gupta-period pillar from Kutari (Allahabad district), now in the Allahabad Museum. Its four sides depict, respectively, Harihara, Varāha, Vāsudeva(?) and Vāmana. See Chandra 1970, 90-91, plates LXVIII and LXIX.

31 Significantly, $\mathrm{SP}_{\mathrm{Bh}} 121.21$ concludes with a phalaśruti and an enjoinment to worship 'Śivavișnu': ya imam śrṇuyān martyah sadā parvasu parvasu | arcayec chivavișnum ca sa gacchet paramām gatim $\|$. The inclusion of this phalaśruti highlights the significance of this episode in the composition of the text. 
is explicitly identified as the Naravarāha 'Man-Boar' (SP 97.11). This recalls the popular imagery of Varāha represented as a man with a boar's head, most famously the Gupta-period Varāha of Cave 6 at Udayagiri. ${ }^{32}$ The Skandapurāna graphically describes how Varāha carries the Earth 'like an elephant with a lotus plant dangling from his tusk' (SP 108.14). This simile brings to mind, in addition to the image from Udayagiri, the standing Varāha from nearby Eran, in which the tender Earth is shown hanging from Varāha's tusk by her arm. ${ }^{33}$ The Skandapurāna also uniquely refers to the argha offering made by the Ocean before Varāha dives in to rescue the Earth. The image of the personified Ocean holding a water vessel in his hands can be seen on the side walls of the Varāha relief at Udayagiri and may well be linked to this episode. ${ }^{34}$ Overall, the narration of the Skandapurāna is strikingly visual. ${ }^{35}$

The Varāha cycle also contains some tantalizing references to what appear to be historical place names and deities. A striking example is the name Nandivardhana 'Increasing Joy', which is uniquely used as an appellation of Varāha in the Skandapurāṇa. It occurs altogether twentytwo times in the Varāha cycle, a clear marker of its significance. The use of this epithet becomes all the more intriguing in combination with the narrative line of Varāha heading out to Hiranyākșa's capital, which is called Aśmakapura 'City of Stone'. This juxtaposition conjures up the name of the capital of the Eastern Vākātakas, Nandivardhana (present Nagardhan), and their latent enemies, the Aśmakas. ${ }^{36}$ One of the famous icons from the Vākātaka kingdom is the enshrined theriomorphic Varāha on Rāmagiri (Ramtek). ${ }^{37}$ Could there perhaps be a veiled allusion to this? On the other hand, Varāha in the Skandapurāṇa has the form of a man-boar, which is not known from the Vākātaka realm. Another, somewhat comparable case is Varāha's fight with a Gaṇa of Kārttikeya by name of Kokavaktra 'Wolf-faced'. Two deities named Śvetavarāhasvāmin and Kokāmukhasvāmin are known from the late fifth-century Dāmodarpur copperplates from Bengal. ${ }^{38}$ It is uncertain to what extent the authors of the text used these names simply because they happened to be available to them, or if they used them strategically with a more specific purpose in mind.

Further insight into the text's frame of reference for Viṣnu is provided by the gods' hymn of praise (stotra) in SP 97.15-30. The string of epithets

32 Williams 1982, 43-46, plate 37.

33 Frontispiece. See also Williams 1982, 91, plates 126, 127.

34 See n. 175 on p. 59.

35 See also Dokter-Mersch 2020.

36 See Bakker 1997, 35-39.

37 See n. 197 on p. 65.

38 See n. 257 on p. 79. 
included in this eulogy provides a rich overview of the various identities, roles and narratives associated with his divine persona. These include his various embodiments - not only the manifestations treated above, but also, e.g., Kṛṣnadvaipāyana, Rāma (Dāśarathi) and Rāma (Jāmadagnya), Dattātreya, Dāmodara and Kapila - celebrated deeds performed in the past, such as the slaying of Śakuni, Dhundhu, Madhu, Kaitabha and others, as well as references to his physical appearance, the various weapons held in his hands and more abstract notions associated with the god (e.g., sacrifice, yoga and truth). ${ }^{39}$ Of particular interest, in view of the composition of the text, are several unique epithets that express Viṣu's dependence on Śiva (e.g., mahādevapriya 'dear to Mahādeva', rudrārdharūpa 'having the form of half of Rudra', maheśvaragana 'the Gana of Maheśvara' and rudradattavara 'who received a boon from Rudra'). These epithets fit within the larger paradigm that emphasizes Viṣnu's devotion and dependence, while at the same time allowing him to perform the grand deeds for which he is recognized.

How should we interpret this intensive engagement with Viṣnu's persona in the text? The conflict between the Devas and Asuras has long been identified as the central theme of Vedic and post-Vedic mythology, ${ }^{40}$ but the kind of full-scale narration of this conflict as we find it in the Skandapurāna, through the lengthy description of a series of battles between the Devas and each of the successive Daitya leaders, had not been done before. The Purāna breaks new ground by retelling a number of earlier myths and integrating them into an overarching and comprehensive model. In doing so, the authors of the Skandapurāna focused in particular on the role of Viṣnu, who is consistently portrayed as the slayer of demons (daityaghna), fighting on behalf of the gods. ${ }^{41}$

While there is nothing new about this role of Viṣnu in itself, it is in the integration of his successive manifestations within the larger narrative frame of the succession of Daitya kings that the Skandapurāna presents a new model for viewing the role of Viṣnu's manifestations and thereby of Viṣnu himself. The incorporation and appropriation of narratives detailing the exploits of Vị̣nu's manifestations in a Śaiva text may hint at religious competition, but the Skandapurāna's engagement with these narratives first of all reflects a strategic awareness of the cultural importance of these myths. In order to capture the audience's attention and present their case, the authors had to engage with and address the narratives and

39 For further details, see the notes in the synopsis ad loc. A detailed analysis of the various epithets is given in Dokter-Mersch, forthc.

40 See e.g. Brown 1942, Kuiper 1975 and Doniger O'Flaherty 1976, 57-93.

41 See SP 71.72, where Śiva, after he has slain Narasimpha in the form of the Śarabha, grants Viṣnu the boon of being a slayer of demons and tells him to return to his original state. 
gods that mattered most in the Brahmanical milieu in which they were operating. Effectively, what they have done is to explain how, while Vișnu is certainly engaged in combatting Asuras, he is put to the task and made successful in it by Siva. The one who ultimately controls it all, the transcendent director behind the scenes, is Siva, husband of Pārvatī, the master of everyone and everything.

\section{The Composition of the Second Part of SP 112}

The second half of SP 112 (SP 112.73-115) in many ways constitutes the most complex part of the text included in this volume and requires special attention. In this section we first of all discuss the three episodes included in this part of the text and how they provide insight into the composition and architecture of the Skandapurāna. As will be shown, they serve as connective episodes that introduce a very large part of the remainder of the text, taking the reader all the way up to $\mathrm{SP}_{\mathrm{Bh}}$ 163, where the Skanda cycle will be resumed. Next, we address the significant changes that have been introduced in the RA redaction of this part of the text.

\section{Three Connective Episodes}

The second part of SP 112 consists of three independent episodes, though narrated in sequence (see Table 2 on p. 24 for a tabular overview).

Episode A (SP 112.73-81): After receiving Devì's instructions on dharma, the goddesses are satisfied and invite her for a walk around the forest of the Mandara mountain. As they take in the beautiful scenery, Devī sees a young aśoka tree in blossom and decides to adopt it as her son with permission from Deva upon his return. The story is resumed in $\mathrm{SP}_{\mathrm{Bh}}$ 158; the ritual of the adoption of the tree as her son is narrated in $\mathrm{SP}_{\mathrm{Bh}}$ 158-162.

Episode B (SP 112.82-92): Ill omens occur, followed by the arrival of Andhaka and his retinue at Mandara. Andhaka finds Devī surrounded by the goddesses and stares at her without paying respect. Prahlāda warns him, saying that she is Umā, the consort of Deva. Devī disappears together with the goddesses. The extensive Andhaka myth proper is narrated in $\mathrm{SP}_{\mathrm{Bh}}$ 130-157.

Episode C (SP 112.93-115): Wandering around Mandara, Andhaka spots some sages in conversation. Prahlāda tells him that they are the 
Seven Sages (Saptarși) and proposes eavesdropping upon them. The sages become aware of their presence and decide to move elsewhere, reproaching the Asuras' greed for kingship. Just then, Dhātṛ, Vidhātr and Kṛtānta arrive. They report that they have paid a visit to Kaśyapa, at the command of Brahmā, and told him about the future affairs of the Devas and Asuras, and that Brahmā subsequently sent them to Mandara to see Devī. The Seven Sages request that the trio tell them about these future affairs as well as their message to Devi. Hereafter, Kṛtānta starts his narration, which forms the subject of $\mathrm{SP}_{\mathrm{Bh}}$ 113-129. We refer to these future affairs of the Devas and Asuras as the Devāsura war cycle. ${ }^{42}$ The second question, regarding their message to Devī, is not followed up in the subsequent part.

As can be observed from the above, all three episodes function as preludes to the narratives told after this chapter, in the reverse order: Episode $\mathrm{C}$ is connected with the immediately following narration $\left(\mathrm{SP}_{\mathrm{Bh}} 113-129\right)$, Episode B with the subsequent Andhaka myth ( $\mathrm{SP}_{\mathrm{Bh}}$ 130-157) and Episode A with the story of the aśoka tree's adoption as a son $\left(\mathrm{SP}_{\mathrm{Bh}}\right.$ 158-162). Thus, the second half of SP 112 figures as a sort of showcase of what will be narrated after this chapter and before the resumption of the Skanda cycle in $\mathrm{SP}_{\mathrm{Bh}} 163$, the cycle that was suspended at the end of SP 72 .

A closer look, however, reveals that the relationship of each episode with its corresponding main narrative is quite complex. First of all, Episode $\mathrm{C}$ is well connected with the immediately following Devāsura war cycle, but Krtānta is mentioned only once as the narrator of this cycle, in $\mathrm{SP}_{\mathrm{Bh}}$ 113.1, when Vyāsa asks Sanatkumāra to tell him what Kṛtānta told the sages. Moreover, the appearance of the Seven Sages and the arrival of Dhātṛ, Vidhātṛ and Kṛtānta are very abrupt, and there is no intrinsic connection with the preceding Episode B. The only connection relates to the content of their talk, for the Asuras' presence triggers their conversation about the nature of the Asuras' enmity with the Devas. This could

42 Many battles between the Devas and the Asuras are related in the text, for example, the lengthy one leading up to Hiranyākṣa's victory covering SP 78-95. On the other hand, we refer to $\mathrm{SP}_{\mathrm{Bh}} 113-129$ as 'the Devāsura war cycle' because a succession of seven wars between the Devas and the Asuras forms its basic structure and it thus constitutes a myth cycle proper. The Devāsura wars treated in these chapters are the following: 1. the Amrtamanthana war $\left(\mathrm{SP}_{\mathrm{Bh}} 113-115\right)$; 2. the Ātībaka war ( $\left.\mathrm{SP}_{\mathrm{Bh}} 116.1-13 \mathrm{ab}\right)$; 3. the Vāmana war ( $\mathrm{SP}_{\mathrm{Bh}} 116.13 \mathrm{~cd}-$ $121.22) ; 4$. the Tārakāmaya war $\left(\mathrm{SP}_{\mathrm{Bh}} 121.23-122.16\right) ; 5$. the Dhvaja war $\left(\mathrm{SP}_{\mathrm{Bh}}\right.$ $125)$; 6. the Hālāhala war ( $\left.\mathrm{SP}_{\mathrm{Bh}} 129.1-18\right)$; and 7. the Andhakāraka war ( $\mathrm{SP}_{\mathrm{Bh}}$ 129.19-46). This Devāsura war cycle may well have been inspired by the listing of twelve Devāsura wars in PPL 489.71-85: Nārasiṃha, Vāmana, Vārāha, Amṛtamanthana, Tārakāmaya, Ạ̣̄̂vaka, Traipura, Andhakāra, Dhvaja, Vārtra, Hālāhala and Kolāhala. See Yokochi forthc. 
trigger the reader's interest in the various wars between the Devas and the Asuras.

What is intriguing here, and potentially confusing, is that the embedded Devāsura war cycle concerns future events. In the case of the embedding of one narrative into another narrative frame, the embedded narrative usually relates to what happened before, a past event, but here the narrative is explicitly connected with the future. ${ }^{43}$ Thus, the temporal relationship, in terms of narration, between the events told in the Andhaka cycle and those in the Devāsura war cycle is accounted for and made clear. Therefore, it seems likely that Episode $\mathrm{C}$ was composed independently and incorporated here in order to link the preceding narrative with the Devāsura war cycle that follows, as well as to explain to the reader the temporal relationship of the events narrated in the two cycles. In conclusion, we can identify the embedding of a narrative of future events within a higher narrative frame as one of the unique narrative methods employed in the process of redacting the Skandapurāna. ${ }^{44}$

Episode A appears to be a real prelude to the story of Devi's adoption of the aśoka tree as her son, narrated in $\mathrm{SP}_{\mathrm{Bh}}$ 158-162. First of all, the event related in Episode A, viz. Umā's discovery of a young aśoka tree

43 SP 112.109b and SP 112.112b mention bhavisyam, and SP 112.115b yathābhavișyam, which we take as a noun, not an adverb.

44 The Devāsura war cycle is in fact not the only case in the Skandapurāna in which a future event is embedded. The Andhaka cycle (SP 73-157, which includes the Varāha and the Devāsura war cycle within it) is mostly a future affair from the perspective of the Skanda cycle, in which it is embedded, because Skanda, though not yet born by the end of SP 72, features in SP 109-110, and the Ganas called Skandas, Viśākhas, Śākhas and Naigameśas, as well as Skanda himself, join the battle between the Ganas and Andhaka's demon army narrated in the Andhaka cycle. Viśākha, Śākha and Naigameśa are manifestations of Skanda. Skandas (plural) are mentioned in $\mathrm{SP}_{\mathrm{Bh}}$ 130.67cd-69ab, Viśākhas in $\mathrm{SP}_{\mathrm{Bh}}$ 130.69cd-71ab, Śākhas in $\mathrm{SP}_{\mathrm{Bh}}$ 130.71cd-73ab, Naigameśas in $\mathrm{SP}_{\mathrm{Bh}} 130.73 \mathrm{~cd}-75 \mathrm{ab}$, and the single Skanda with his retinue in $\mathrm{SP}_{\mathrm{Bh}}$ 130.80. Each of them is mentioned on occasion, as the battle takes place, in the subsequent chapters. The fact that these events lie in the future from the perspective of the narrative at hand is, however, not made explicit and it may rather be due to confusion at the time when the Andhaka cycle was redacted and embedded in the Skanda cycle. In SP 72.130, the gods ask Śiva to stop Andhaka from continuing to practice severe asceticism (tapas), using the present tense, and Śiva promises that he will kill him in the next verse. If we follow this indication, Andhaka's tapas, narrated in SP 74, takes place before Skanda's birth. However, as pointed out in SP IV (p. 9 and p. 53, n. 116), this passage, or rather the last part of SP 72 (SP 72.127-140), of which it forms part, is secondary. It is likely that the Andhaka cycle was originally composed independently of the Skanda cycle, and in the Andhaka cycle Skanda is assumed to be there as Śiva's son. The secondary passage, SP 72.127-140, which was added in order to link both cycles, has led to a confusion of their temporal relationship. In the case of Episode $\mathrm{C}$, on the other hand, we are not only told that the next narrative concerns the future, but also why these future events can be told at this moment in time. 
and her resolve to adopt it as her son with Śiva's permission, is told by her to Siva in $\mathrm{SP}_{\mathrm{Bh}}$ 158.70-72. Her account exactly corresponds to the content of Episode A, except for the detail that milk flowed out from Umā's breasts when she saw the tree $\left(\mathrm{SP}_{\mathrm{Bh}}\right.$ 158.72). Secondly, Episode $\mathrm{A}$ and the main narrative share a unique epithet of Umā, Devadevi. ${ }^{45}$ Thus it seems that Episode A and the corresponding main narrative were composed as a coherent story by the same author.

Here we encounter a problem. Episode A is incorporated in the Andhaka cycle, and the corresponding main story, $\mathrm{SP}_{\mathrm{Bh}} 158-162$, is told immediately after it, in one and the same sequence. Umā is, however, said to be aputrā 'without a son' on several occasions in the story of the aśoka tree, ${ }^{46}$ while $\mathrm{SP}_{\mathrm{Bh}} 158.74$ and $\mathrm{SP}_{\mathrm{Bh}} 162.127$ refer to the gods' preventing her from having a son, ${ }^{47}$ which clearly refers to their request that Siva not have a son, the eventual Skanda, from Umā herself (SP 72.89-92). Skanda, however, features in the Andhaka cycle, so that this statement of Umā being childless contradicts the story line of the Andhaka cycle. ${ }^{48}$ The allusion to the gods' intervention suggests that this aśoka-tree story is closely associated with the Skanda cycle and was originally included between the start of the Skanda cycle (SP 72.1-126) and the main Skanda myth in $\mathrm{SP}_{\mathrm{Bh}}$ 163-165. Thus the location of Episode A here does not fit very well with the temporal sequence of the immediate context. It may have been included here because Siva's absence, which is a precondition of Episode A, is mentioned at the end of SP 100 (SP 100.30-31). In addition, the dharma of women (strìdharma) related by Devī to Deva in $\mathrm{SP}_{\mathrm{Bh}} 158.80-87$ is similar in content to $\mathrm{SP} 112.67-72 \mathrm{ab}$, in the last part of Devi's instruction to the goddesses. It seems to indicate that part of this teaching was composed in tandem with Episode A and the main story of the adoption of the aśoka tree, expanded upon later during redaction, incorporating material from an external source. ${ }^{49}$

45 The epithet occurs at SP 112.79a, SP 112.84c, SP $\mathrm{Bh}_{158.69 a}, \mathrm{SP}_{\mathrm{Bh}} 169.26 \mathrm{~d}$ and $\mathrm{SP}_{\mathrm{Bh}}$ 171.34b. Its occurrence in SP 112.84c in Episode B may have been influenced by the preceding Episode A (see the argument below regarding Episode B). We are not certain why the epithet also appears later on, in $\mathrm{SP}_{\mathrm{Bh}} 169$ and 171.

$46 \mathrm{SP}_{\mathrm{Bh}}$ 158.63a, $\mathrm{SP}_{\mathrm{Bh}} 158.74 \mathrm{c}$ and $\mathrm{SP}_{\mathrm{Bh}}$ 162.69a. Episode A does not mention that she is aputrā, but the expanded version in the $\mathrm{RA}$ recension refers to it $\left(\mathrm{SP}_{\mathrm{RA}}\right.$ 112.3.16a).

$47 \mathrm{SP}_{\mathrm{Bh}}$ 158.74: devaih putraphale kșipte sa hi me tarupotakah | tuștiprado hy aputrāyāh putrako bhavitānagha \|; $\mathrm{SP}_{\mathrm{Bh}}$ 162.127: devair yac cāpi mușitam iștaputraphalaṃ purā | tan me sarvam vyapagatam prāpyāśokataruṃ sutam \|.

48 See n. 44 on p. 18.

49 See p. 8 above. Moreover, the teaching that a good son (satputra) delivers his ancestors from hell, found in $\mathrm{SP}_{\mathrm{Bh}} 158$ and $\mathrm{SP}_{\mathrm{Bh}}$ 162, suggests a connection between the story of the aśoka tree's adoption and the Naraka cycle of SP 35-52. 
The relationship between Episode B and the corresponding main narrative is the most problematic. The introductory portion of the battle between Andhaka's army and Śiva's Gaṇas, featuring in $\mathrm{SP}_{\mathrm{Bh}}$ 130.2-41, can be summarized as follows.

While Andhaka is wandering around Mt Mandara with his retinue, after having conquered all the gods, he encounters Devì by chance and desires her to be his wife, totally obsessed with her. Prahlāda warns him that he will destroy all the Asuras if he disrespects the Mother of the World and consort of Deva. But Andhaka refuses to listen and tries to touch her. When Devī registers his lustful intentions she orders her Ganas, headed by Somanandin, to attack him. Andhaka defeats them. Then Devī herself assaults him with bow and arrows. When he counterattacks her, she wields the trident. At that moment Deva interferes and tells her that he is the one who should punish Andhaka. Devī disappears and Deva orders Nandin to gather the Ganas.

This introduction partly overlaps with the content of Episode B (Andhaka's lust for Devī and Prahlāda's warning) and partly contradicts it (Andhaka's fight with her Gaṇas and herself before her disappearance). Therefore, it may well be that Episode B was composed independently of the main Andhaka myth, in the form of an abridged version of the introduction, in order to give a glimpse of what would be narrated later.

The reference to this introductory portion of the Andhaka myth in the 'table of contents' (Anukramaṇikā) of SP 2 further complicates matters. The topic of Andhaka's catching sight of Devī (or of Devì's catching sight of Andhaka) is mentioned in SP 2.17d (devyāś cāndhakadarśanam) and Deva's arrival is mentioned in SP 2.19a (devasyāgamanam). Thus the topics mentioned in between, in SP 2.18, would most probably refer to the events in this portion. The following four topics are listed in SP 2.18: the encounter between Nandin (Śailādi) and the Daitya(s) (śailādidaityasammmardo), Devì's taking on of a hundred of forms (devyāś ca śatarūpatā), Devī's granting of boons (āryāvarapradānam ca), probably to Nandin, and the praise of Nandin (śailädistava eva ca), which is either a eulogy to him or a eulogy to Devī by him. None of these elements are found in Episode B or in the corresponding passage of the RA recension ( $\mathrm{SP}_{\mathrm{RA}}$ 112.3.17-56), nor in the introductory portion in $\mathrm{SP}_{\mathrm{Bh}} 130$. In the end this may not be all that surprising, because the Anukramanikāa, in general, does not correspond exactly to the contents of the Skandapurāna; it seems to be rather a sort of blueprint for the entire composition. ${ }^{50}$

50 Törzsök 2004, 26-28. In her words (p. 27f.), 'the anukramanikā represents a theoretical list of subjects which the writer(s) or redactor(s) of the anukramanik $\bar{a}$ 
Attention should now be drawn to the Vāmanapurāna. This Purāna shares many topics with the Skandapurāṇa, such as the Skandapurāṇa's main storyline, comprising Śiva's marriages with Sat̄̄ and Umā, Skanda's birth and his conquest of Tāraka, Umā's change of complexion and the birth of Kauśikī-Vindhyavāsinī ${ }^{51}$ and finally the Andhaka myth. Furthermore, some topics of the Vāmanapurāna find a parallel with material found only in the RA recension. ${ }^{52}$ A detailed comparison of both Purānas would require a separate study. Here it should suffice to notice that the Skandapurāna, probably in an early form or predecessor of the RA recension, was one of the important sources for the Vāmanapurāna. ${ }^{53}$

The Andhaka myth of the Vāmanapurāna is narrated in a very similar manner as in the Skandapurāna, though much more briefly. VmP 33.1547 corresponds to the separate prelude, Episode B, in the Skandapurāna. The main story of the battle between Andhaka and Siva is narrated in $\mathrm{VmP} 37-44,{ }^{54}$ which does not include the introduction, except for the repeated warning by Prahlāda. As a consequence the prelude is more easily connected with the main story. The story of the prelude, VmP $33.15-47$, runs as follows.

Andhaka comes to Mt Mandara with his retinue and catches sight of Devī, staring at her in fascination. Prahlāda warns him, explaining who she is, but Andhaka gets angry and rushes to her with his army. Nandin obstructs them but he is hit by Andhaka's blow. On seeing this, Devī manifests a hundred forms (goddesses). ${ }^{55}$ When they assail him, Andhaka does not counterattack them, thinking that they are only young women, and is struck to the ground. Seeing him fallen, Devī disappears with her hundred forms. The Asuras, enraged, attack Nandin, who defeats them and returns to Devī. She sends out her manifestations ( $m \bar{u} r t i)$ all over the world to take up an abode on earth as they like. Andhaka goes back to the underworld, brooding over her.

would have ideally included in the purāna, but which has never corresponded to any stage of the actual text.'

51 The ensuing fight between Vindhyavāsin̄̄ and the demon brothers Sumbha and Nisumbha in VmP 29-30, on the other hand, is modelled after the Devīmāhātmya rather than the Skandapurāna.

52 Yokochi 2004, 92-94. One noteworthy instance is Vināyaka's birth, for which see Törzsök 2004, 19-24.

53 See also Bakker 2021, for various parallels between the Mahākapāla myth of Kurukșetra in the SP and the VmP's Saromāhātmya.

54 This contains a sub-narrative of king Dạda in VmP 37.19-40.19, told by Prahlāda as a warning to Andhaka, which has no parallel in the SP.

55 VmP 33.34: śailādiṃ patitam dṛsțā dhāvamānam tathāndhakam | śatarūpābhavad gaurī bhayāt tasya durātmanah \|. 
As this summary shows, two topics mentioned in the Anukramanikā of the Skandapurāna are found here: 1) the fight between Nandin and the demons, and 2) Devì's taking on of a hundred forms. The topics of Devì's granting of boons and the praise of Nandin, however, are not included. How should we interpret this phenomenon? One possible scenario would be that the Anukramaṇikā of the Skandapurāṇa exerted some influence on the composition of the Vāmanapurāṇa, just as it did on the RA recension. ${ }^{56}$ Another option, which may be more likely, is as follows. A version of the Andhaka myth, including all the motifs mentioned in the Anukramanikā, was known among the Paurānikas when the redaction of the Skandapurāṇa took place, and the Anukramaṇikā was composed as a sort of blueprint. The composers of the Vāmanapurāna may well have known this version and incorporated some motifs from it as a separate prelude in their own telling of the myth. The composers of the Andhaka myth of the Skandapurāna, on the other hand, may have preferred to narrate the introduction in a briefer manner, even if they were aware of a richer version as suggested by the Anukramanikā, possibly because they intended to bring into focus the battle between Andhaka's army and Siva's Gaṇas, which takes up many chapters in the Skandapurāna's version of the Andhaka myth. Thus the difference between the topics listed in SP 2.18 and the three versions of the actual narrative -Episode B, the introduction to the Andhaka myth in $\mathrm{SP}_{\mathrm{Bh}}$ 130, and the corresponding story in $\mathrm{VmP} 33$ - demonstrates how the composers of each version dealt with the material in accordance with their own aims and the requirements of its position in the work at hand.

To summarize the argument advanced above, Episode A was probably composed together with the main story of the aśoka tree's adoption narrated in $\mathrm{SP}_{\mathrm{Bh}}$ 158-162 to form its prelude. Furthermore, both Episode A and the main story appear to have been closely associated with the Skanda cycle originally. Their current connection with the Andhaka cycle is probably the result of the process of tying the different parts together. Episode B, on the other hand, was composed independently from the main Andhaka myth, and probably inserted in its current position in order to give a glimpse of the upcoming Andhaka myth. Episode C, finally, was also introduced here, not just to link the immediately following Devāsura war cycle with the Andhaka cycle, but also to make the temporal relationship between both cycles clear. Although the relationship of each

56 The Anukramanikā most probably triggered the addition of some material at the time of the major revision that led to the RA recension, but continued to do so afterwards as well. Topics mentioned in it but not included in the main text of an earlier form of the SP gave rise to the composition of new material. See Törzsök 2004, 26-28, for the addition of the story of Śiva's ashes; for the addition of SPA 112.1, see the discussion below, p. 28. 
episode with the corresponding main narrative may be different, the three episodes in sequence function as a preview to prepare the reader for all that comes after, before the main storyline resumes much later with the Skanda cycle. The second half of SP 112, consisting of three brief and highly diverse episodes, may look confusing at first glance, but it provides good insight into the editorial techniques involved in the process of redacting the Skandapurāṇa.

\section{The Revision of SP 112 in the RA Recension}

The second half of Adhyāya 112 also offers valuable insight into the production and transmission of the RA recension of the Skandapurāna. At the end of Devì's instruction to the goddesses in Adhyāya 112, the RA recension diverges radically from the S recension. After SP 112.72, the RA recension adds two more pādas, a closing verse in a longer metre, and a colophon that indicates the end of the conversation between Umā and the goddesses. ${ }^{57}$ This is followed by two additional chapters, which have been edited and presented in our edition as $\mathrm{SP}_{\mathrm{RA}} 112.1$ and $\mathrm{SP}_{\mathrm{RA}}$ 112.2. Of these additional chapters, neither the last portion of $\mathrm{SP}_{\mathrm{RA}} 112.1$ (112.1.40colophon) nor any of $\mathrm{SP}_{\mathrm{RA}} 112.2$ are found in the $\mathrm{A}$ manuscripts. It is uncertain whether these part have been lost in the A recension or if they were added later in the $\mathrm{R}$ recension. Hereafter, the $\mathrm{RA}$ recension resumes the storyline found in the S recension at SP 112.73, although the text of the $\mathrm{RA}$ recension is much expanded. This part is printed in our edition as $\mathrm{SP}_{\mathrm{RA}}$ 112.3. Near the end of the chapter, at SP 112.106ab, which corresponds to $\mathrm{SP}_{\mathrm{RA}} 112.3 .87 \mathrm{~cd}$, the $\mathrm{S}$ recension and the $\mathrm{RA}$ recension meet again and more or less share the same text up to the end. Table 2 gives an overview of the relationship between the different recensions of Adhyāya 112. The second part of this chapter, SP $112.73-115$, is divided into three segments in accordance with the content. ${ }^{58}$

The question arises as to whether the accretion and expansion in the $\mathrm{R}$ and $\mathrm{A}$ recensions were done simultaneously or at different times. A first clue to answer this question may be found in the expansion of $\mathrm{SP}_{\mathrm{RA}}$ 112.3. As has been observed elsewhere, the major revision that brought the ancestor of the RA recension into being is marked by a special group of epithets referring to Vyāsa as 'the son of Kālī' (Kāleya, Kālinandana,

57 The title of the preceding part as given in the colophon is probably umāsāvitryādisamvāada, following the reading in $\mathrm{R}$. The variants in the A manuscripts seem to be corrupted from this. See the apparatus of SP 112.72 .

See the summary above, p. 16. 
Table 2: Adhyāya 112 in the S, R and A Recensions

\begin{tabular}{|c|c|c|c|}
\hline Content & S Recension & R Recension & A Recension \\
\hline $\begin{array}{l}\text { Devī's instruction of ekabhakta } \\
\text { etc. to the goddesses }\end{array}$ & SP $112.1-72$ & \multicolumn{2}{|c|}{$\begin{array}{l}\text { SP } 112.1-72 \text { with } 6 \text { additional } \\
\text { pādas and colophon }\end{array}$} \\
\hline $\begin{array}{l}\text { strīvrata (Śatarūpā tells Devī } \\
\text { about Brahmā's instruction } \\
\text { to Sāvitrī) }\end{array}$ & - & $\begin{array}{l}\mathrm{SP}_{\mathrm{RA}} 112.1 .1-49 \\
\text { with colophon }\end{array}$ & $\mathrm{SP}_{\mathrm{RA}} 112.1 .1-39$ \\
\hline $\begin{array}{l}\text { devīśokaparihāra (Mālinī shows } \\
\text { Devī the beauty of the forest } \\
\text { to console her) }\end{array}$ & - & $\begin{array}{l}\mathrm{SP}_{\mathrm{RA}} 112.2 .1-25 \\
\text { with colophon }\end{array}$ & - \\
\hline $\begin{array}{l}\text { Devī walks with the goddesses } \\
\text { on Mandara and finds an aśoka } \\
\text { tree } \rightarrow \text { SP } 158-162\end{array}$ & $\begin{array}{l}\text { SP } 112.73-81 \\
\text { (9 vs.) }\end{array}$ & \multicolumn{2}{|c|}{$\begin{array}{c}\mathrm{SP}_{\mathrm{RA}} 112.3 .1-16 \\
\text { (16 vs.) }\end{array}$} \\
\hline $\begin{array}{l}\text { Ill omens, appearance of } \\
\text { Andhaka with his demons, his } \\
\text { lust for Devi, and Prahlāda's } \\
\text { warning } \rightarrow \text { Andhaka myth } \\
\text { (SP 130-157) }\end{array}$ & $\begin{array}{l}\text { SP } 112.82-92 \\
\text { (11 vs.) }\end{array}$ & \multicolumn{2}{|c|}{$\begin{array}{l}\mathrm{SP}_{\mathrm{RA}}{ }^{112.3 .17-56} \\
\text { (40 vs.) }\end{array}$} \\
\hline $\begin{array}{l}\text { Seven sages in conversation, } \\
\text { arrival of Dhātr, Vidhātr and } \\
\text { Krrtānta, and the question } \\
\text { about the future events of the } \\
\text { Devas and Asuras } \rightarrow \text { Devāsura } \\
\text { war cycle (SP } 113-129 \text { ) }\end{array}$ & $\begin{array}{l}\text { SP } 112.93-115 \\
\quad(23 \text { vs.) } \\
\text { with colophon }\end{array}$ & \multicolumn{2}{|c|}{$\begin{array}{c}\mathrm{SP}_{\mathrm{RA}} 112.3 .57-97 \\
\text { (41 vs.) } \\
\text { with colophon }\end{array}$} \\
\hline
\end{tabular}

Kālija etc.). ${ }^{59}$ These epithets occur five times in $\mathrm{SP}_{\mathrm{RA}} 112.3,{ }^{60}$ which strongly suggests that $\mathrm{SP}_{\mathrm{RA}} 112.3$ was composed at the time of the major revision, although some passages may have been added or changed later.

Do the new colophon after SP 112.72 and the additional material found in $\mathrm{SP}_{\mathrm{RA}} 112.1$ and $\mathrm{SP}_{\mathrm{RA}} 112.2$ also go back to the major revision? To answer this question, we need to examine the colophons in the $\mathrm{R}$ and $\mathrm{A}$ recensions. The first additional colophon, after SP 112.72, is shared by both recensions, as mentioned above, but the Sanskrit numbering of the chapter as ekādaśottaraśato dhyāyah 'the 111th chapter' is found only in the A recension. ${ }^{61}$ The two colophons at the end of $\mathrm{SP}_{\mathrm{RA}} 112.1$ and $\mathrm{SP}_{\mathrm{RA}}$ 112.2 are found only in $\mathrm{R}$ and without any title name; the text from $\mathrm{SP}_{\mathrm{RA}}$ 112.1.40 to the end of $\mathrm{SP}_{\mathrm{RA}}$ 112.2, including the two colophons, is not preserved in the A recension. In the last colophon at the end of Adhyāya 112, A has another chapter numbering, identifying it as dvādaśottaraśatatamo dhyāyah 'the 112th chapter', while its title, saptarșisamāgama or sapta-

59 Bisschop 2006, 7-8. For the major revision of the RA recension, see Harimoto 2004, 41-43 (Fig.1 provides a good overview).

60 They are Kālinandana (112.3.19d; 112.3.38d), Kāleya (112.3.20c, only in A; 112.3.41a) and Kālija (112.3.48d, only in A).

61 This should in fact be the 112th chapter (dvādaśottaraśato dhyāyah). This reduction of one number in the chapter numbering starts at the colophon of chapter 70 and is probably due to an error in counting there. The Arabic numbers found in the colophons in some of the A manuscripts are neglected here because it is likely that they were added after the hyparchetype of the A recension. 
rșisamāgamana, is shared by the $\mathrm{R}$ and $\mathrm{A}$ recensions. Thus, according to its chapter numbering, the A recension divides Adhyāya 112 into two chapters, while the $\mathrm{R}$ recension divides it into four chapters. Was this chapter numbering in the colophons made in the hyparchetype of the $\mathrm{A}$ recension or even earlier? The hyparchetype of the A recension did not have the text from $\mathrm{SP}_{\mathrm{RA}}$ 112.1.40 to the end of $\mathrm{SP}_{\mathrm{RA}} 112.2$, so it would have been natural to number the remaining two colophons in this way. However, evidence from other parts of the text suggests that the chapter numbering of the A recension was made prior to the hyparchetype.

Colophons containing chapter numbering in Sanskrit are occasionally found in the A recension. The colophon of Adhyāya 70 refers to it as the 69th chapter (ekonasaptatitamo 'dhyāyah); here the 69th for the 70th is probably due to a mere error. Some portions of the succeeding chapters, including the colophons of Adhyāyas 93, 98 and 103, are lost in the A recension, probably due to the loss of a folio or some verses in the hyparchetype of the A recension. ${ }^{62}$ According to the colophon of Adhyāya 104 in the A recension, this is the 103rd chapter, and the colophons of the successive chapters, SP 105-111, have the Sanskrit chapter numbering of the actual chapter number minus one. This means that the Sanskrit chapter numberings in the colophons were written before the hyparchetype of the A recension, because the loss of text including some colophons in the hyparchetype did not affect the numbering. Taking into account that adding colophons is more common in intentional modification than reducing colophons, it is plausible that the RA recension originally divided SP 112 into two chapters by adding a new colophon after SP 112.72, and that it was subsequently divided into four chapters in the $\mathrm{R}$ recension alone through the addition of two more colophons. The fact that the two early colophons (one after SP 112.72 and the other at the end of the chapter) share almost the same title in $\mathrm{R}$ and $\mathrm{A}$, while the other two, later colophons (at the end of $\mathrm{SP}_{\mathrm{RA}} 112.1$ and $\mathrm{SP}_{\mathrm{RA}}$ 112.2) found only in $\mathrm{R}$ do not have any title, lends further support to this conclusion.

Moreover, we may assume that the division of SP 112 into two chapters goes back to the major revision of the RA recension, because the content of SP 112 is clearly divided at SP 112.72, which is where Devi's instruction (continued from the previous chapter) ends. It would have been natural, therefore, to divide the chapter here when the second part was expanded. If this is the case, was the division of SP 112 into two chapters and the accretion of $\mathrm{SP}_{\mathrm{RA}} 112.1$ and/or $\mathrm{SP}_{\mathrm{RA}} 112.2$ done at the same time?

There are several reasons to answer this question negatively. First, although it rests only on negative evidence, we have not yet found any

62 SP 93.20c-94.18d, SP 98.47-colophon and SP 103.39e-194.11b are lost in the A recension. 
quotations from $\mathrm{SP}_{\mathrm{RA}} 112.1$ in the Dharmanibandha literature. Secondly, since the subject of $\mathrm{SP}_{\mathrm{RA}} 112.1$ is the observance for women (strivvrata), if this part had existed when SP 112 was divided into two chapters, it would have been more reasonable context-wise to place the new colophon after this part, rather than before it. But the strongest reason is the following. The RA recension adds two pādas after SP 112.72, before the closing verse and the new colophon. In these two pādas, Devī asks the goddesses what else they would like to hear. ${ }^{63}$ This question offers a segue into SP 112.73 74 , in which the goddesses reply that Devī has already told the dharma of great merit sufficiently, after which they invite her to take a walk in the forest. At the beginning of $\mathrm{SP}_{\mathrm{RA}}$ 112.1, however, Devī asks Sāvitrī to tell her the observance for women, which is not compatible with Devì's question in the two additional pādas after SP 112.72. This is also the case for the beginning of $\mathrm{SP}_{\mathrm{RA}} 112.2$, which connects smoothly with the end of $\mathrm{SP}_{\mathrm{RA}} 112.1$ but not with the additional two pādas after SP 112.72. Thus, it is unlikely that $\mathrm{SP}_{\mathrm{RA}} 112.1$ and/or $\mathrm{SP}_{\mathrm{RA}} 112.2$ were inserted at the same time that the two additional pādas, accompanied by the closing verse and colophon were, added after SP 112.72.

Nor does the current beginning of $\mathrm{SP}_{\mathrm{RA}} 112.3$ connect smoothly with the question in the two additional pādas. As mentioned above, the question seems to anticipate a reply like the one found in SP 112.73-74, so it may be supposed that, when the text after SP 112.73 was expanded into the current $\mathrm{SP}_{\mathrm{RA}} 112.3$, the beginning would have been closer to the $\mathrm{S}$ recension and would have had a passage similar to SP 112.73-74. A clue to the later revision of this part is provided by the presence of one of the special epithets of Vyāsa, Kālinandana, in $\mathrm{SP}_{\mathrm{RA}}$ 112.2.24b. Furthermore, pāda d in the same verse refers to Śailādi (i.e. Nandin) as a companion of the goddesses. Nandin was mentioned as their companion in SP $112.78 \mathrm{~d}^{64}$ and in $\mathrm{SP}_{\mathrm{RA}}$ 112.3.20b and $\mathrm{SP}_{\mathrm{RA}}$ 112.3.23-24, while another Gạ̣a, Bhṛngiriti, features in $\mathrm{SP}_{\mathrm{RA}}$ 112.2.7-8, where he seems to be confused with Nandin. These two points suggest that $\mathrm{SP}_{\mathrm{RA}}$ 112.2.24 belongs to the text of the major revision. This means that this verse was most probably included at the beginning of $\mathrm{SP}_{\mathrm{RA}} 112.3$ when the text after SP 112.73 was expanded, with a new colophon added before it. Later, when the new material in $\mathrm{SP}_{\mathrm{RA}} 112.1$ and/or $\mathrm{SP}_{\mathrm{RA}} 112.2$ was inserted, the beginning of $\mathrm{SP}_{\mathrm{RA}} 112.3$ was revised in order to make it fit into the new context, and the verse was moved to the end of the additional material.

63 This is based on the reading in $\mathbf{A}$. The variant in $\mathrm{R}$ looks corrupt, but can be emended to ato bravimi kiñcānyac chrotum icchatha sobhanāh, which makes it similar in meaning to $\mathbf{A}$.

64 See n. 307 on p. 90. 
To sum up, we may hypothesize the following three stages from the major revision to the present $\mathrm{R}$ and $\mathrm{A}$ recensions.

Stage 1: At the time of the major revision, the second half of SP 112 (112.73-115) was expanded and a new colophon was placed after SP 112.72, along with two additional pādas and one closing verse in a longer metre. As a result, SP 112 was divided into two chapters. $\mathrm{SP}_{\mathrm{RA}} 112.3$ represents more or less the expanded text, corresponding to SP 112.73-115, but the beginning was probably closer to the surviving text of the $\mathrm{S}$ recension. It would have included a passage similar to SP 112.73-74 and $\mathrm{SP}_{\mathrm{RA}}$ 112.2.24.

Stage 2: Between the major revision and the hyparchetype of the $\mathrm{R}$ and $\mathrm{A}$ recensions, entirely new material was incorporated after the colophon added in Stage 1. This material would have contained most of $\mathrm{SP}_{\mathrm{RA}}$ 112.1.1-39 as well as something more, since $\mathrm{SP}_{\mathrm{RA}}$ 112.1.39 occurs in the middle of Brahmā's speech to Satarūpā. At the least, some extra verses ending their conversation and resuming the storyline of the conversation between Devi and the goddesses on Mandara would have been necessary. Part of this is preserved in the $\mathrm{R}$ recension in $\mathrm{SP}_{\mathrm{RA}}$ 112.1.40-112.2.25, but another part of it is lost. ${ }^{65}$ The beginning of $\mathrm{SP}_{\mathrm{RA}} 112.3$ was modified accordingly.

Stage 3: Some more material, along with the two new colophons (at the end of $\mathrm{SP}_{\mathrm{RA}} 112.1$ and $\mathrm{SP}_{\mathrm{RA}}$ 112.2), was added in the $\mathrm{R}$ recension after the split of the $\mathrm{R}$ and the $\mathrm{A}$ recensions. As a result, Adhyāya 112 was divided into four chapters in the $\mathrm{R}$ recension. In the hyparchetype of the A recension, on the other hand, some verses were lost after $\mathrm{SP}_{\mathrm{RA}}$ 112.1.39. ${ }^{66}$

65 It is not impossible that most of $\mathrm{SP}_{\mathrm{RA}} 112.1$ and $\mathrm{SP}_{\mathrm{RA}} 112.2$ was added at this stage, excluding both the two colophons at the end of SPRA 112.1 and $\mathrm{SP}_{\mathrm{RA}}$ 112.2 as well as the closing verses before the colophons ( $\mathrm{SP}_{\mathrm{RA}} 112.1 .50$ and $\mathrm{SP}_{\mathrm{RA}}$ 112.2.25). But we suppose that only the material about the strivrata was inserted at this stage, and that the part with the motif of Umā's depression due to her separation from Śiva and her consolation by the goddesses ( $\mathrm{SP}_{\mathrm{RA}}$ 112.1.49cd112.2.23) was a further addition, made in the next stage. There are two reasons for this: firstly, the addition of two more colophons without any addition or expansion of the text in the next stage is unlikely; and secondly, the Mandara forest is depicted not only in $\mathrm{SP}_{\mathrm{RA}} 112.2$ but also in $\mathrm{SP}_{\mathrm{RA}}$ 112.3.2-8, and these two passages are somewhat redundant, though the verbal expression in both passages is very different.

66 This does not mean that there is no loss of verses in the $\mathrm{R}$ recension or no additions in the A recension. $\mathrm{SP}_{\mathrm{RA}}$ 112.1.6-7, which is missing in $\mathrm{R}$, may have been added in the hyparchetype of the A recension, and some pādas that resume the main story of Umā and the goddesses were clearly lost in the $\mathrm{R}$ recension ( $\mathrm{SP}_{\mathrm{RA}}$ 112.2.49ab). But here we are dealing with the modification of the text on a larger scale. 
A significant outcome of the above analysis is that the modification of the text-not only minor changes of formulation, but also major changes such as the accretion of new material and the expansion and revision of an earlier text - continued even after the major revision in the transmission of both recensions. This can serve as an illustration of how a Purāna may undergo continuous changes during its various stages of transmission over time. More specifically, it cautions us to be careful in dealing with passages found only in the $\mathrm{R}$ and A recensions, for while some parts may be ascribed to the major revision, others may have been added at a later time.

Finally, an intriguing point concerning the relationship between the Anukramanikā (SP 2) and the RA recension must be noted. It has already been pointed out elsewhere that several subjects mentioned in the Anukramanikā are not treated in the $\mathrm{S}$ recension but are found only in the RA recension. ${ }^{67}$ In adding new material, the redactors of the text at the time of the major revision appear to have taken up several of the untreated subjects from the Anukramanikā. This is also the case in $\mathrm{SP}_{\mathrm{RA}}$ 112.1. The topics mentioned in the Anukramanikā are not always listed systematically in their order of appearance in the text, and so they can be difficult to identify. Nevertheless, the subject of Devì's taking on a hundred forms (devyāś ca śatarūpatā), referred to in SP 2.18b, is most probably related to the Andhaka myth, because SP 2.17d refers to Andhaka's catching sight of Devī (devyāśs cāndhakadarśanam). ${ }^{68}$ The author of $\mathrm{SP}_{\mathrm{RA}} 112.1$ seems to have been inspired by SP $2.18 \mathrm{~b}$ and introduced Śatarūpā, the only daughter of Brahmā, in the newly added section. However, it is highly unlikely that the topic originally intended in SP 2.18b was the appearance of the goddess Śatarūpā, for this episode of Umā's multiplication of herself into a hundred forms, while not featuring in our Skandapurāṇa, is known from the version of the Andhaka myth told in the Vāmanapurāna. It was no doubt this episode that the author of the Anukramanikā had in mind. ${ }^{69}$ The word śatarūpata, however, was sufficient to trigger the invention of a new framework, namely the conversation between Brahmā and his daughter Śatarūpā, which served to introduce the additional material of the strīvrata. Thus, the Anukramanikā included in SP 2 not only exerted an influence upon the major revision, but also continued to do so in the transmission of the text afterwards.

67 SP I, 43f.; Harimoto 2004, 45f.; Törzsök 2004, $26 f$.

68 Furthermore, SP 2.18a, SP 2.18cd and SP 2.19ab also seem to refer to episodes belonging to the beginning of the Andhaka myth, though not all of them are narrated in our text. See above, p. 20.

For the Vāmanapurāṇa, see above, p. 21. 


\section{Dharmanibandha Citations of Devì's Teachings}

Devī's teachings to the goddesses in SP 111 and SP 112.1-72 are quoted extensively in several Dharmanibandha works. Before embarking on a discussion of these citations, the other citations by Dharmanibandha authors may be summarized in brief. The Adbhutasāgara of Ballālasena and his son Lakșmanasena quotes five passages from the text included in this volume: SP 100.3ab and SP 100.3cd, SP 107.3cd-4, SP 107.27, and the set of SP 107.28ab, SP 107.29ab and SP 107.30ab. Furthermore, mention should be made of two quotations from SP 78, which were not listed as testimonia in our edition of SP IV. ${ }^{70}$ The quotations that these two royal authors have collected from the Skandapurāna are from different parts of the text, wherever ill omens are related before or in the midst of battles. This indicates that Ballālasena and Lakșmaṇasena, or the scholars who worked under their names, were very familiar with the content of the text.

In addition, we would like to add one more quotation from the descriptions of hells, cited in the Niyatakālakāṇda of Lakșmīdhara's Kṛtyakalpataru, that was not incorporated as testimony in SP II B. The citation consists of SP 47.14ab and SP 49.9cd. ${ }^{71}$

Regarding the Dharmanibandha citations of Devi's teachings to the goddesses in SP 111 and SP 112.1-72, except for the passages that embed the teaching into the main narrative and those that concern ritual procedures, most of her teachings are cited either under the subject of donation (dāna), in the case of SP 111.11-94 and SP 112.49-50, or that of religious observance (vrata), in the case of SP 112.2-37. Of the eight Dharmanibandha works identified as testimonia in our edition, ${ }^{72}$ five have already been discussed in the Prolegomena of SP I: the Dānakāṇda (DK) and Vratakāṇda (VK) of the Kṛtyakalpataru of Lakṣmīdhara, the Dānasāgara (DS) of Ballālasena, Aparārka's commentary on the Yājñavalkyasmṛti (AYS), the Kṛtyaratnākara (KR) of Caṇdeśvara, and the Dānakhaṇda (HeDKh) and Vratakhaṇda (HeVKh) of Hemādri's Caturvarga-

70 SP $78.7 \mathrm{~cd}$ is quoted on p. 378 and SP $78.8 \mathrm{ab}$ on p. 480 of the Adbhutasāgara, with the variant śakranandana for śaktinandana. The quotation of SP 78.8ab is preceded by three unidentified pādas on p. 479.

71 Both hemistiches are quoted together on p. 463 of the edition of the Niyatakālakāṇda (kapilā yasya goșthe syād anagner brāhmaṇasya ca | sa yāti dustaram ghoram narakam tat tamomayam $\|$ ). The second hemistich was not identified as $49.9 \mathrm{~cd}$ in the Prolegomena of SP I (p. 7, n. 22).

72 There may be more testimonia but, if so, it is more likely that they would have quoted the text indirectly through one of the earlier works mentioned here. The argument advanced in the following pages supports our earlier assumption that Candeśvara, in the 14th century, was the last Dharmanibandha author who had direct access to the Skandapurāna. 
cintāmani. ${ }^{73}$ For this volume, three more testimonia have been identified. ${ }^{74}$ The oldest and most important addition is the Samayapradipa (SaPra) of Śrīdatta Upādhyāya, who flourished in Mithilā before Caṇdeśvara. ${ }^{75}$ The second addition is the Dānavivekoddyota (DVU), one of the sections of the Madanaratnapradipa, which is an extensive digest on dharma composed under the patronage of King Madanasimphadeva in or near Delhi in the first half of the 15 th century. ${ }^{76}$ The last one, the Dānakriyākaumudī (DKK) of Govindānanda Kavikan̉kaṇācārya, though lateit is ascribed to the first half of the 16 th century ${ }^{77}$ - is interesting because of Govindānanda's location, Bengal, which is where the oldest two manuscripts of the $\mathrm{R}$ and $\mathrm{A}$ recensions come from.

In this section, we first investigate the interrelationship of these eight authors, particularly the question of whether they quoted from the text directly or indirectly through each other's works. Next we consider if the first-hand citations provide testimony as witnesses to the modifications that the text of the Skandapurāṇa was undergoing during its transmission.

First, however, in order to illustrate the interdependence of the eight Dharmanibandhas with respect to their citations of Devi's teachings in the Skandapurāna, we list here the individual passages and their citations.

SP 111:

1-10: No testimony

11-15: DS

16-21: No testimony

22-23: DK, DS, DKK, KR, HeDKh

24: DS, DKK, KR

25: DS, DKK

26: DS

27-29: No testimony

30-32 (except for 31cd): DK, HeDKh

33-35: No testimony

36: DK, HeDKh

37ab, 38ab, 39ab: DK

73 SP I, Prolegomena, pp. 6-13.

74 We thank Amandine Wattelier-Bricout for providing information on the additional testimonia.

75 Kane I, 759-763. According to Kane, Śrīdatta probably composed his works in Mithilā between 1275-1310 AD. One of the works referred to by Śrīdatta is Lakșmīdhara's Krrtyakalpataru, while, conversely, his Samayapradippa is mentioned by Caṇdeśvara in the Kṛtyaratnākara (Kane I, 762).

76 Kane I, 804-809. The Madanaratnapradipa refers to the Krtyakalpataru, the Kṛtyaratnākara and Hemādri (Kane I, 808).

77 For the date, location and works of Govindānanda Kavikañkaṇācārya, see Kane I, $882-889$. 
37cd, 38cd, 39cd: No testimony

40-41: DS

42-44: DK, HeDKh, DVU, DS, KR

45-48: DS, DKK, KR

49: DS (twice), KR

50-51: DS, KR

52: DS, DKK, KR

53: DK, HeDKh, DVU, DS, KR (twice)

54: DS, KR

55-56: KR

57: AYS, DK, HeDKh, DVU, DS, DKK, KR

58: DK, DS (twice), DKK (twice), KR

59: KR

60-66: DK, HeDKh (66abcd also in DVU)

67-68: AYS, DK, HeDKh, DS

69-79 (except for 77bc): DS

80-86: AYS, DK, HeDKh, DS (84 and 85cd only in DS)

87: DK, HeDKh, DS

88-93: DS

94: DS, DKK

95-96: No testimony

SP 112.1-72:

1: No testimony

2-12: VK, KR (3cd, 6 and 12 also in SaPra; 4cd and 10 only in KR; 7 only in VK)

13-18: VK, SaPra (16cd and 17 only in SaPra)

19: VK, HeVKh, SaPra

20-26, 28, 30, 32, 34: VK, HeVKh

35abcd, 36, 37ef: VK, HeVKh, SaPra

27, 29, 31, 33, 35ef and 37abcd: No testimony

38-48: No testimony

49-50 : AYS, DK, HeDKh (twice)

51-72: No testimony

From this list, the relationships between these Dharmanibandha works become more or less clear. First, the Dānakriyākaumudī quotes SP 111.2225, SP 111.45-48, SP 111.52, SP 111.57-58 and SP 111.94, which are all quoted by the Dānasāgara. Although some of the same verses are also quoted by Lakṣmīdhara and Caṇdeśvara, taking into account the place of composition of the Dānakriyākaumud̄̄ it seems very likely that Govindānanda used the Dānasāgara of Ballālasena for these citations. This 
conclusion is supported by the fact that SP 111.58 is quoted twice in both works, once together with SP 111.57 and once independently. Because the $\mathrm{R}$ and $\mathrm{A}$ recensions have been transmitted in Bengal, the possibility that Govindānanda consulted a Skandapurāna manuscript directly cannot be excluded, ${ }^{78}$ but there is no strong evidence for this, at least not in these chapters.

Next, the case of Aparārka deserves attention because he is a contemporary of Lakșmīdhara, although the two authors were active in different regions of the subcontinent: 'Aparārka appears to be the nom de plume of the Silāhāra king of Aparāditya (or a group of pandits under his auspices), who ruled in the Konkan between AD 1110-1140 and maintained contacts with Kashmir; he was thus a contemporary of Lakșmīdhara, who worked at the court of the Gāhadavāla king of Vārānasi, Govindacandra (Kane I, 663-669).' ${ }^{79}$ From Devī's teachings, Aparārka quotes SP 111.57, SP 111.67-68, SP 111.80-83, SP 111.85ab, SP $111.86^{80}$ and SP 112.49-50 in his commentary on the Yãjñavalkyasmṛti, all of which are also quoted by Lakṣmīdhara in the Dānakāṇ̣a of his Kṛtyakalpataru. Attention should be drawn to SP 111.80cd, where Aparārka and Lakșmīdhara both share a reading entirely different from that of the Skandapurāna. ${ }^{81}$ Because neither this reading nor anything resembling it is found in any of our SP manuscripts, it is very unlikely that Aparārka and Lakșmīdhara independently consulted an SP manuscript that by chance had this reading; it is more probable that one borrowed it from the other. ${ }^{82}$ Lakșmindhara quotes extensively from the Skandapurāna on several subjects and it is

78 In SP $111.47 \mathrm{c}$, the DKK has a reading (sarvakāmasamrddhah san) very close to that of the A recension (sarvakāmasamrddhah sa), compared to the variants found in the other SP manuscripts and the citations in the DS and the KR, but this is too little to lead to any substantial conclusion.

79 SP I, Prolegomena, 6-7. For Aparārka, see Kane I, 713-723. For the date and location of Lakșmīdhara, see now also Brick 2015, 5-11; according to him, Lakșmīdhara would have been based at Kanauj. It seems more likely, however, that he would have worked at Vārāṇas̄in, as his Tīrthavivecanakāṇda provides detailed information on the many sacred sites in Vārāṇas̄i and not on Kanauj. Govindacandra's reign commenced after 1109 and ended before 1168 AD.

80 SP 111.83, SP 111.85ab and SP 111.86 are quoted in a sequence with attribution to the Matsyapurāna. But this quotation comes immediately after that of SP 111.80-82 and some words in SP 111.80-82 are glossed after SP 111.86. Therefore it is almost certain that the line matsyapurāne before the quotation of SP 111.83 is a secondary, mistaken addition made after the composition of the AYV.

81 The AYS and DK read mrdubandhena badhnīyād antahślakșnena rajjunā | 'One should tie [the cow] with a rope that is bound softly and smooth inside (i.e. on the side of the rope attached to the cow's neck).'

82 The possibility that the reading in the AYS is the result of contamination under the influence of the DK during transmission can be excluded, because Aparārka comments on the word rajjun $\bar{a}$ after quoting SP 111.86 (p. 296: rajjunā rajjvetyarthah). 
evident that he had direct access to the text; by contrast, Aparārka's quotations from the Skandapurāna are few in number - in fact, only the above-mentioned ones from SP 111 and SP 112. Thus, Aparārka most probably quoted them from Lakṣmīdhara's Dānakāṇda without consulting a manuscript of the Skandapurāna directly. ${ }^{83}$

The next work, in chronological order, is the Samayapradīpa. Śrīdatta quotes SP 112.3cd, SP 112.6, SP 112.12, SP 112.13-19, SP 112.35abcd, SP 112.36 and SP 112.37ef. All these citations, with the exception of SP 112.16cd-17, are also quoted by Lakșmīdhara in the Vratakānda, and the omission of this passage in the edition of the Vratakanda is very likely due to eyeskip. ${ }^{84}$ Even so, in view of his time and place, Śrīdatta might have been able to utilize a manuscript of the Skandapurāna. In this regard, it is worth noting that the order of SP 112.13 and SP 112.14 is inverted in the RA recension and the Samayapradipa compared to the order in the $\mathrm{S}$ recension and the Vratakānda. This could suggest that the author of the Samayapradīpa directly consulted a manuscript of the Skandapurāna closer to the RA recension than that used by Lakșmìdhara. In this case too, however, it is difficult to determine, because the inverted order (14 followed by 13) is more logical and the inversion could have taken place independently. Since the Krtyakalpataru is mentioned in the Samayapradīpa, it is certain that Śrīdatta relied on Lakṣmīdhara's work for his composition. Whether he also consulted the Skandapurāna directly or not cannot be concluded on the basis of the small number of citations from SP 112.

The dependence of Hemādri's Caturvargacintāmaṇi on Lakṣmīdhara's Kṛtyakalpataru has already been discussed in the Prolegomena of SP I. ${ }^{85}$ As has been pointed out there, the extensive quotations from SP 111 and SP 112 in the Dānakhaṇua of the Caturvargacintāmaṇi are all found in the Dānakāṇda of the Kṛtyakalpataru. Those from SP 112 in the Vratakhanda of the Caturvargacintāmaṇi are also found, without exception, in the Vratakānda of the Krtyakalpataru. There are several clues that Hemādri borrowed these from Lakṣmīdhara. For example, SP 111.31cd

83 In SP 112.50d, though just a minor variant, both the AYS and the DK have edhate for aśnute. Furthermore, in SP 111.85a, the variants found in the DK and the AYS are closer to each other than to the other readings. For different opinions on the date of the Krtyakalpataru and its relationship with another commentary on the Yājñavalkyasmṛti, Vijñāneśvara's Mitākșara, see Brick 2015, 7-11. The likelihood that Aparārka borrowed quotations from the DK may make some contribution to this debate, though the relationship between Aparārka's commentary and the Mitākșara is also the subject of controversy. According to Derrett (1973, 50), Aparārka's commentary 'has an affinity with the Kṛtyakalpataru, which its author(s) may have used.'

84 SP 112.16c and SP 112.18a both begin with sa tena karmaña.

85 SP I, $10 f$. 
is omitted in both works, ${ }^{86}$ while the above-mentioned distinctive reading of SP $111.80 \mathrm{~cd}$ in the AYS and the DK is also shared by the Dānakhanda. A similar situation applies for SP 112.21cd, where an entirely different reading is shared by the Vratakānda and the Vratakhanda. ${ }^{87} \mathrm{In}$ SP 112.24b, the Vratakānda and the Vratakhanda both repeat the reading of SP 112.23b. ${ }^{88}$ Thus, as far as concerns the citations of SP 111 and SP 112, we can safely conclude that Hemādri borrowed them from Lakșmīdhara's earlier work. However, there is one small clue that suggests that Hemādri may have used a source other than the Kṛtyakalpataru. Hemādri quotes SP 112.49-50 twice in his Dānakhaṇda, once on p. 600 and another time on p. 868 of the edition. The second citation is more or less identical with that of Lakșmīdhara (DK 14.1.37-38), but the first one deviates from it, and its variants show correspondences with the readings found in $\mathrm{R}$ and/or the $\mathrm{S}$ manuscripts. ${ }^{89}$ Though a trivial point, this suggests that Hemādri may have quoted the passage on p. 600 from a source other than the Dānakāṇda. This hypothesis receives further support from several considerably longer passages quoted from Adhyāyas 158 and 162 in the Dānakhaṇụa that are not found in the Dānakāṇ̦a, nor in any other early extant Dharmanibandha. ${ }^{90}$ Hence, one might conclude that Hemādri consulted the Skandapurāna directly. However, it seems very unlikely to us, for the attributions to the Skandapurāna in the Caturvargacintāmaṇi are imprecise, moderately speaking. ${ }^{91}$ This would not have been the case if

86 This omission is shared with the $\mathrm{R}$ and $\mathrm{A}$ recensions.

87 Interestingly, this reading, common to both the $\mathrm{VK}$ and the HeVKh, is almost identical to SP $112.56 \mathrm{~cd}$, which is not cited in either work.

88 There are other shared minor variants in both texts for SP 111.30d, SP 111.32ab, SP 111.36c, SP 111.62d, SP 111.63cd (this is close to the reading in $\mathrm{S}_{1}$ ), SP 111.65b, SP 111.66f, SP 111.85a, SP 112.19, SP 112.26b and one of the two occurrences of SP 112.50d.

89 For tarpayitva in SP $112.50 \mathrm{a}$ - a reading that the DK and the HeDKh share on p. 868 of the edition - the HeDKh reads tārayitvā on p. 600 , which is the reading of R. More importantly, for SP 112.50d, the HeDKh has aśnute on p.600, which is shared by all the available manuscripts (verses $49-50$ are missing in the A recension), while the DK, the SaPra and the citation of the HeDKh on p. 868 read edhate.

90 In addition to $\mathrm{SP}_{\mathrm{Bh}}$ 158.44cd-45ab, $\mathrm{SP}_{\mathrm{Bh}}$ 158.47ab, $\mathrm{SP}_{\mathrm{Bh}}$ 158.65, $\mathrm{SP}_{\mathrm{Bh}}$ 158.68, $\mathrm{SP}_{\mathrm{Bh}}$ 162.57-64ab and $\mathrm{SP}_{\mathrm{Bh}}$ 162.67-68 (SPI, 11, notes 38 and 39; 'p. 1053' in n. 39 should be 'p. 1052'), $\mathrm{SP}_{\mathrm{Bh}} 158.44 \mathrm{ab}, \mathrm{SP}_{\mathrm{Bh}} 158.49-50, \mathrm{SP}_{\mathrm{Bh}} 158.54$ and $\mathrm{SP}_{\mathrm{Bh}}$ 158.56-57 are also quoted in the Dānakhanda (44ab preceded by eight unidentified pādas on p. 1050 and the others on p. 21) but not in the Dānakāṇda. For the Dharmanibandha citations from these two chapters, see also Wattelier-Bricout 2019. An edition and study of these chapters is under preparation for her doctoral thesis (Sorbonne Nouvelle, Paris 3).

91 In the Dānakhaṇda, there are a number of passages attributed to the Skandapurāna that actually contain quotations from other sources. A telling example concerns chapters 100 (rasadhenudānam), 102 (śarkarādhenudānam), 103 (madhu- 
he had had an understanding of the overall shape and content of the Skandapurāna. From this we may conclude that Hemādri did not know the text himself, but that he had access to some passages through a source other than the Dānakānda. This source may have been a lost Dharmanibandha, or a collection of dharma-related passages copied from various Purānas. If he used something like the latter in compiling his extensive work, it could explain the widespread misattributions of citations in the Caturvargacintāmani. ${ }^{92}$

The Dānavivekoddyota of the Madanaratnapradipa quotes SP 111.4244, SP 111.53, SP 111.57 and SP 111.66abcd, all of which are also found in Lakṣmīdhara's Dānakāṇḍa and Hemādri's Dānakhạ̣ḍ. Since the Madanaratnapradīpa refers to both works as its sources, it is safe to conclude that the Dānavivekoddyota borrowed these citations from either of the two works. Comparison of the readings of the quotations in the three works reveals that the Dānakhaṇda was the primary source of the Dānavivekoddyota. ${ }^{93}$

The last work to be examined is the Kṛtyaratnākara of Caṇdeśvara. The relationship between the works of Caṇdeśvara and Lakṣmìdhara,

dhenudānam), 104 (kșīradhenudānam) and 105 (dadhidhenudānam) of the Varāhapurāna. These five chapters are quoted in their entirety with attribution to the Skandapurāṇa (HeDKh pp.423-431). Even more intriguing are the eleven or twelve passages (one of them only partly identified) quoted from the Sivadharmottara (three from chapter 3, four from chapter 4, two from chapter 7, and three from chapter 12) and attributed to the Skandapurāna. On the other hand, a quotation attributed to the Sivadharmottara is actually found in chapter 10 of the Śivadharmaśāstra. There may have been confusion between the Skandapurāṇa and the Śivadharmottara because both texts share similar traits, being targeted at lay Śaiva devotees and closely associated with the Pāśupatas. All the same, the attributions of the Skandapurāna in the Caturvargacintāmaṇi are unreliable. Some of the wrong attributions seem to have made their way from the Caturvargacintāmaṇi to later Dharmanibandhas, such as the Madanaratnapradīpa. This misattribution may apply not only to the Skandapurāna but also to other Purānas.

92 Such a collection may have been made by the people who worked under him, or it was already transmitted in a form available at the time. For what such a work might look like, compare the many misattributions to Purānas in an anonymous collection of Vārānasīmāhātmyas in a 12th-century palm-leaf manuscript from Vārānasī, now in the collection of the Kaiser Library in Kathmandu (Bisschop 2016, 113-115).

93 Though a minor point, both the DVU and the HeDKh read prabhur for yakșo in SP 111.44d. In SP 111.53bcd, the DVU has a very different reading from that of the SP and all the other quotations. This might mean that the DVU had access to another source, but this cannot be determined without a proper critical edition of the text. The DVU seems to have borrowed from the HeDKh several quotations along with their misattribution to the Skandapurāna, e.g. VarP 103-105 and some passages from the Sivadharmottara, the latter as mentioned in n. 91 on p. 34 . For the dependence of the DVU on the HeDKh, see also Wattelier-Bricout 2019, 104, n. 32 . 
as well as Ballālasena, and the question of whether or not Caṇdeśvara had direct access to the Skandapurāna have already been discussed from various angles by Törzsök (2004) and Harimoto (2004, 2006). ${ }^{94}$ Both agree on the principal conclusion that Candeśvara consulted the Skandapurāṇa while also utilizing both of his predecessors' works. ${ }^{95}$ The citations from SP 111 and SP 112 support this conclusion. Of the citations in the Krrtyaratnākara, those that are not found in the Dānakạnḍa or the Vratakāṇda are SP 111.24, SP 111.45-52, SP 111.54-56 and SP 111.59. From among these, SP 111.24, SP 111.45-52 and SP 111.54 are quoted by Ballālasena in the Dānasāgara, so the remaining unique citations in the Kṛtyaratnākara are only SP $111.55-56$ and SP $111.59 .{ }^{96}$ In the Dānasāgara, however, the citations of SP 111.24, SP 111.45-52 and SP 111.54 are divided into six passages in accordance with the subjects dealt with and distributed across the text; on the other hand, the Kṛtyaratnākara quotes SP 111.2224 and SP $111.42-59$ in one sequence. ${ }^{97}$ This would have been impossible if Caṇdeśvara had not had the original text of the Skandapurāna at his disposal. ${ }^{98}$ Alternatively, it might be assumed that the Dānakāṇ̣a, which quotes SP 111.22-23, SP 111.42-44, SP 111.53 and SP 111.57-58 in one sequence (DK 19.62-69), originally had a longer citation that included all the citations in the Krrtyaratnākara, but that some of the verses were lost during the transmission of the Dānakānda. The likelihood of this hypothesis has been significantly reduced by the publication of the critical edition of the Dānakānda by David Brick (2015). ${ }^{99}$

94 See also SP IV, 13-18. Kengo Harimoto kindly shared his unpublished research report on the same subject based on SP 111 and SP 112, to which we owe some of the following observations.

95 Caṇdeśvara used the Samayapradīpa as well.

96 In addition, in the quotation of SP $112.2-12$ in the VK and the KR, SP 112.4cd and SP 112.10 are missing in the VK and SP 112.7 in the KR. Since SP 112.2-12 states the rewards of the practice of ekabhakta-vrata in each month from Mārgaśira to Kārttika and since the VK quotes the passage in one sequence, the loss of SP 112.4cd and SP 112.10 is certainly secondary. Hence, this case is not considered here.

97 SP 111.53 is cited twice in the wrong place, first after SP 111.44 and secondly after SP 111.48. The first misplacement is probably due to the influence of the DK, in which SP 111.53 is cited immediately after SP 111.44. The second one may either stem from a manuscript of the SP that Caṇdeśvara was able to consult or may have taken place independently during the transmission of the KR. In the second occurrence, the KR reads atmānam instead of assanam, thus changing the offering of a seat to the offering of the donor himself. Whether this represents an intentional change on the part of Candeśvara in order to avoid repetition of the same verse or a secondary one by a scribe cannot be determined in the absence of a critical edition.

98 Harimoto 2006, 26.

99 Harimoto (2006) also reached a negative conclusion on the hypothesis of an original version of the Krtyakalpataru that would have contained more complete citations, 
Different from the case of Hemādri, who was attached to the Yādava court of Devagiri in the south, Candeśvara was based in Mithilā, which formed part of northeastern India (including Nepal). Here the Skandapurāna was well known, at least by the end of the 12th century; all three recensions have been transmitted in the area. Furthermore, the attributions to the Skandapurāṇa in the Kṛtyaratnākara are very precise. Of the 17 citations of the Skandapurāna, all but one are identified in our Skandapurāṇa, including text found only in the RA recension. ${ }^{100}$ This suggests that Candéśvara was well acquainted with the Skandapurāṇa. In conclusion, it is most likely that Candeśvara had direct access to one or more manuscripts of the Skandapurāna.

So far we have identified with some certainty three works as firsthand testimonia: the Dānakāṇda and the Vratakānḍa of Lakṣmīdhara's Kṛtyakalpataru, Ballālasena's Dānasāgara and Cạ̣deśvara's Kṛtyaratnākara. ${ }^{101}$ Can these three sources, as witnesses to the text, tell us more about the historical development of the Skandapurāna? Previous studies have already demonstrated that all of them had access to some version of the text that was brought into being by the major revision that gave rise to the RA recension. Thus they are witnesses to an early stage in the formation of the RA recension. ${ }^{102}$ The same also follows from the comparison of Lakșmīdhara's and Candeśvara's citations in two respects: the readings of both authors, when available, are generally closer to each other than to the $\mathrm{R}$ or $\mathrm{A}$ recension, and these shared readings are in several cases closer to the $\mathrm{S}$ recension than to the $\mathrm{R}$ and $\mathrm{A}$ recensions. ${ }^{103}$ The citations from SP 111 and SP 112 more or less confirm both points.

after examing an old manuscript of the Śrāddhakāṇda dated April 5, 1176 AD. If the date of this manuscript is correct, on which Harimoto expresses some doubt, it would be very close to the time of composition of the text.

100 The only unidentified citation (p. 405 of the edition) has a variant reading attributing it to the Padmapurāna, which is probably original.

101 As mentioned above, there is a fair possibility that Śrīdatta Upādhyāya may also have consulted the SP directly, in view of the date and location of composition of the Samayapradīpa. However, because its citations are limited in number and all are also quoted in the Vratakạṇda, we do not include it in the following argument.

102 That all three Dharmanibandha authors quote some parts or verses found only in the RA recension and that they thus seem 'to have access to a version of SP that was closer in at least some important respects to our $\mathrm{R}$ and $\mathrm{A}$ recensions than to the Nepalese recension (p. 9)' was already pointed out in SP I, 7-9, 12f. Bisschop (2002) first established that Lakșmīdhara consulted the text of the SP following its major revision. For an overview of the position of the major revision in the historical development and transmission of the SP, see Harimoto 2004.

103 See Törzsök 2004, Harimoto 2004 and 2006, and SP IV, 13-18 on this and the following argument. An early version of the RA recension is also reflected in the passages borrowed from the SP by the Avantyakhaṇda of the SkP (Yokochi 2004). 
The omission of some passages may demonstrate more clearly that the three testimonia represent a middle stage between the $\mathrm{S}$ recension and the extant $\mathrm{R}$ and A recensions. For example, the omission of SP 111.31cd is shared by RA and the Dānakāṇta, and that of SP 111.75bc (preserved not only in the $\mathrm{S}$ recension, but also in $\mathrm{R}$ ) by $\mathbf{A}$ and the Dānasāgara, while SP $111.14 \mathrm{~cd}-15$ and SP $111.84 \mathrm{~cd}$ are preserved in the Dānasāgara though missing in RA. Furthermore, while SP 111.24ab is fairly corrupt in RA, the text found in the $\mathrm{S}$ recension is well preserved in the Dānasāgara and the Kṛtyaratnākara. As for the terms of address to a single goddess in the main part of SP 111, the words expressing a fem.voc.sg. are mostly changed to the fem.voc.pl. or replaced by other words in the RA recension. In some cases the testimonia agree in this with the RA recension but in others they retain the vocative singular. ${ }^{104}$ In SP $111.58 \mathrm{~d}$ all three share their reading with the $\mathrm{S}$ recension (bhuvi jāyate) against RA (jāyate bhuvi). Among the three testimonia, as will be argued below, the Dānasāgara is the closest to the RA recension. Even so, in addition to the above-mentioned cases, there are a few instances in which the Dānasāgara (as well as the Krtyaratnākara) shares the reading with the S recension against the RA recension. ${ }^{105}$ The citations in the Krtyakalpataru often have the reading of the $\mathrm{S}$ recension, sometimes in conjunction with those of the Krrtyaratnākara or Samayapradīpa. In SP 111.80b, SP 111.82d, SP 111.82f and SP 111.86c, the Dānakānd has he reading of the S recension, while the Dānasāgara by and large agrees with the RA recension. In SP 112.8a and SP 112.9a, the shared readings of the Vratakānda and the Krrtyaratnākara correspond to the $\mathrm{S}$ recension against RA, ${ }^{106}$ and in SP 112.14c and SP 112.15c, the Vratakāṇta, the Samayapradīpa and the S recension share their reading against RA. ${ }^{107}$ Concerning the order of verses of SP 112.13-14, as mentioned above, the RA recension and the Samayapradīpa invert the order, which is more logical, but the Vratakāṇda retains the order found in the $\mathrm{S}$ recension. As for the readings shared with the RA recension against the $\mathrm{S}$ recension, we may refer to SP 111.83d (bhayāt

104 In SP 111.36c devyo (for devi) is more or less shared by RA and DK; in SP 111.43b śubham (for śubhe) is attested in R, DK, KR and DS; in SP 111.92c devyo (for devi) is shared by RA and DS. The fem.voc.sg., however, is retained in the DS for SP 111.26b and SP 111.41c, and in the DK and DS for SP 111.57c (see n. 9 on p. 7).

105 E.g., in SP 111.24d dhanadhānyavān for dhanavān sukh̄̄ in RA, and in SP 111.48d bhogavān for bhagavān in RA.

106 The readings āṣäham ... māsam (SP 112.8a) and śrāvane ... māse (SP 112.9a) are shared by VK, KR and the $\mathrm{S}$ recension, while RA have ạsạḍe ... māsi and śrāvañạ ... māsam.

107 In SP 112.14c, VK, SaPra and the S recension have pārthivasamo for pārthivo mahān in RA; in $112.15 \mathrm{c}, \mathrm{VK}$, SaPra and the $\mathrm{S}$ recension have sa suvarnānām for aśvamedhānām in $\mathrm{R}$ (missing in $\mathbf{A}$ ). 
in DK and DS), SP 112.7c (śrestho in VK), SP 112.9b (tathaivācarate in VK and KR) and SP 112.26a (yo bhunkte in VK). SP 112.26b is a special case, in which we consider labhet supported by RA and the Vratakānda to preserve a reading closer to the original than the $\mathrm{S}$ recension's bhavet.

As for more particular matters, such as whether the variations between the readings of Lakșmīdhara and Caṇdeśvara reflect some development or modification in the RA recension, however, nothing definite can be said. ${ }^{108}$ Rather, it may be next to impossible for several reasons. Concerning the Dharmanibandhas, occasional variant readings are reported in the citations in the available editions of each work. That there must actually be many more is shown by Brick's critical edition of the Dānakāṇda. ${ }^{109}$ Furthermore, the Dharmanibandha authors, at least Lakșmìdhara and Candeśvara, sometimes intentionally changed the readings of the citations; ${ }^{110}$ thus, the readings of the citations do not necessarily reflect the source texts from which they were quoted. Concerning the Skandapurāna, as argued by Yokochi in the Introduction to SP III, ${ }^{111}$ the manuscripts of the text soon after the major revision may have represented various degrees of contamination, between the older form of the text before the revision, which would have been closer to the $\mathrm{S}$ recension, and the newly revised form of the text, which became the ancestor of the RA recension. In other words, the distribution of variant readings may not be diachronic but synchronic. Moreover, the date of composition of each Dharmanibandha work may not correspond to the historical stage of the text quoted, at least with respect to minor changes of reading; a manuscript of the Skandapurāṇa consulted by Caṇdeśvara could actually have been older than one at Lakșmīdhara's disposal.

Nevertheless, we can add one observation on the basis of the citations from SP 111 and SP 112 in the three mentioned works: the readings in the Dānasāgara on the whole seem to be comparatively closer to those of the $\mathrm{R}$ and $\mathrm{A}$ recensions. ${ }^{112}$ This most probably has a spatial rather

108 For example, in SP IV, 16, we state that '[t]he citations of the Kaumudimahotsava, however, suggest that concerning some minor points, the text cited by Lakșīdhara is sometimes slightly closer to the S recension than the one cited by Candeśvara.' The same cannot be verified in the citations from SP 111 and SP 112 .

109 See Brick 2015, 249, regarding Aiyangar's earlier edition: '[m] ost importantly in this regard, they (= his manuscript collations) omit the majority of all variant readings.' In cases where one of the variants cited in the available editions is close to the reading of a manuscript of the SP, we have reported this in the register of testimonia in the apparatus of our edition.

110 For some instances in the Kaumudimahotsava, see SP IV, $15 \mathrm{f}$. The reading suśobhanam in the DK instead of śucismite, a feminine vocative referring to the narrative setting, in SP 111.30b is an example of intentional omission of a narrative element in the source text. On this phenomenon in general, see De Simini 2015.

111 SP III, $53 \mathrm{f}$.

112 For instance, SP 111.40c (bhog $\bar{\imath}$ in R and DS for bhāg $\bar{\imath}$ ), SP 111.74b (niyamā in A 
than a temporal explanation. The Dānasāgara was composed in Bengal, where the RA recension was transmitted, leading to the hyparchetype of the $\mathrm{R}$ and $\mathrm{A}$ recensions and surviving in the two oldest extant manuscripts of both recensions $\left(\mathrm{R}\right.$ and $\left.\mathrm{A}_{7}\right)$. It is possible, therefore, that the Dānasāgara and the two recensions share some readings that reflect a regional version of the RA recension, a version in terms of occasional minor variant readings.

\section{Editorial Policy}

The critical edition follows the model and principles established in the previous volumes of the Skandapurāna. ${ }^{113}$ There is, however, one major difference, and this concerns the text after SP 112.72 .

\section{Presentation of the Revision of Adhyāya 112}

As discussed above, the RA recension has revised the text of Adhyāya 112 and introduced entirely new material after SP 112.72. This material has been edited separately and is presented after the main text as $\mathrm{SP}_{\mathrm{RA}}$ 112.1 and $\mathrm{SP}_{\mathrm{RA}}$ 112.2. For SP 112.73-115, the situation is slightly more complex. In this case, the RA recension shows textual correspondences with the $\mathrm{S}$ recension, but with major expansions. To allow for consecutive reading of the revised text of the RA recension, this part of the RA recension has been edited separately as well ( $\mathrm{SP}_{\mathrm{RA}}$ 112.3). Passages that

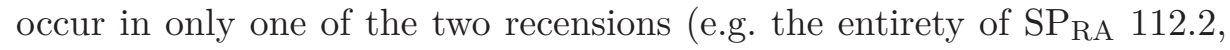
which is only present in $\mathrm{R}$ ) are printed in a smaller font.

The main text of SP 112.73-115 has been constituted on the basis of the $\mathrm{S}$ recension, but for those verses that have a parallel in $\mathrm{R}$ and of $\mathrm{A}$ the variants are given as usual in the apparatus of the critical edition. The verses that have been added in the RA recension, on the other hand, are identified in the $\mathrm{R}$ and $\mathrm{A}$ registers with reference to the verse numbers of

and DS for yamāni; R has yamaś ca), SP 111.75c (rec is included in the compound in $\mathbf{A}$ and DS), SP $111.77 \mathrm{bc}$ (omitted in $\mathbf{A}$ and DS, though preserved in R), SP 111.80b (sarvalokanamaskrtām in RA and DS for sarvair hastadvayena tu), SP 111.82d (sarvalokābhayāya ca in DS, sarvalokodbhavāya ca in R, and sarvalokahitāya ca in A for sarvadevanamaskrtām), SP 111.82f (śubhāya gām in R and DS, śubhāya tām in A for śubhām iti), SP 111.86c (dhanavān rūpavāmśs caiva in RA and DS for rūpavān dhanavāmiś caiva) and SP 111.93b (-m acetanam in A and DS for - $m$ acetasam; $\mathrm{R}$ has viketanam).

113 See SP IV, 24, n. 57-58, for a comprehensive overview of references to the relevant sections relating to editorial principles in the previous volumes. 
the edition of $\mathrm{SP}_{\mathrm{RA}}$ 112.3. Correspondingly, the apparatus to the edition of $\mathrm{SP}_{\mathrm{RA}} 112.3$ includes a layer with references to the underlying parallels in the main text. This allows the reader to easily identify where and how the text of the RA recension has been expanded. The apparatus of both editions includes the text constituted in the editio princeps of Bhattarāī, who has conflated the text of the different recensions. ${ }^{114}$ When a reading of Bhatțarāi follows the reading of the $\mathrm{S}$ recension, this is indicated in the apparatus of $\mathrm{SP}_{\mathrm{RA}} 112.3$ with a sign indicating derivation $(<)$.

The preparation of a critical edition of text on the basis of the $R$ and A recensions alone confronts the editor with major challenges due to the text's poor state of transmission. ${ }^{115}$ Although the goal of our edition in this case has been to reconstruct the hyparchetype of the RA recension to the extent that this is possible, we have often been forced to adopt readings that are simply the most intelligible or those that we think point in the right direction. Unintelligible text placed between crux marks sometimes follows the reading of $\mathrm{R}$ and sometimes that of $\mathrm{A}$, depending upon which reading we consider most likely to be closer to the original. The choice between two equally possible readings is often arbitrary. The reader will also encounter comparatively more emendations and conjectures in the edition of the $\mathrm{RA}$ recension. The situation in $\mathrm{SP}_{\mathrm{RA}} 112.2$ is different, because this part only survives in the $\mathrm{R}$ recension.

The synopsis of the text of the RA recension differs somewhat from that of the main text. On the whole, we have kept it briefer and refrained from commenting upon every textual problem, of which there are many. The many descriptive portions that characterize the text of the RA recension, including a large number of similes, have only been summarized concisely. The main aim of the synopsis of the RA recension is to give the reader general guidance on how we have understood the text and to draw attention to some of its characteristic features.

\section{Metrical, Grammatical and Syntactical Anomalies}

The text edited in this volume again shows numerous deviations from 'standard' (Pāṇinian) Sanskrit. These have been listed and categorized below in accordance with the principles of presentation adopted earlier (see the references in SP IV, 25-29). While not laying a claim to being exhaustive, we hope that eventually these lists will be of use for writing a grammar of the Skandapurāna. References are to the verse numbers of the main text of the critical edition, except for those followed by RA

114 For his edition, Bhattarāā used $S_{1}$ and $S_{2}$ of the $S$ recension and $A_{3}$ of the $A$ recension.

115 See Bisschop 2006, for a similar situation and the challenges involved. 
between square brackets. These refer to the three additional editions of the second half of chapter 112 in the $\mathrm{RA}$ recension $\left(\mathrm{SP}_{\mathrm{RA}} 112.1, \mathrm{SP}_{\mathrm{RA}}\right.$ 112.2, $\left.\mathrm{SP}_{\mathrm{RA}} 112.3\right)$.

1. Metre

- hypermetrical reading: bhagavan varāharūpasya 109.25a; ${ }^{116}$ prapitāmahāinśs ca lokeșu 111.28c. ${ }^{117}$

- irregular ma-Vipulā: apaśyan saptarșīn siddhān 112.94c.

- $-r$ - metrically treated as -ri-: ${ }^{\circ}$ samrddham $111.47 \mathrm{c}$.

- -ri- metrically treated as - $r$-: triloka $112.2 .11 \mathrm{c}[\mathrm{RA}]$.

2. Sandhi

In addition to double sandhi and lack of sandhi or irregular sandhi between pādas, all of which are quite common in the text, the following deviations from the rules of sandhi occur.

- - a+e- becomes -e-: evetya 97.14a.

- -au+a- becomes -au with elision of $a-:{ }^{\circ}$ sau 'sureśvarah 103.16b.

- $-a s+\bar{a}$ - becomes -o with elision of $\bar{a}$-: so 'pyāyitas $105.37 \mathrm{a}$; so 'pyāyita $107.7 \mathrm{a}$; so 'hvayed $109.29 \mathrm{~d}$; ${ }^{118}$ tvatto 'tmanas $109.37 \mathrm{c}$; tato 'tmānam 112.41c.

- $r$ - at the beginning of a word treated as ri-: 'sau rṣi $i^{\circ} 108.34 \mathrm{a}$; sevyamāno rșibhis $98.51 \mathrm{a}$; sarvai rșibhih 105.41b.

- lack of sandhi in a pāda: tvayā ume 112.2.13d[RA]; devadeve adhisthite (conj.) 112.3.15b[RA].

- double sandhi within a compound: apsaropagìtena $111.32 \mathrm{c}$.

- hiatus-breaking m: hata-m-ity 97.43e; śvāpada-m-ity 100.38b; māsa-m-eka $a^{\circ} 112.10 \mathrm{ab} ; \quad$ divi-m-ūrjitah 112.56d; tulā-m-api $112.1 .23 \mathrm{~b}[\mathrm{RA}]$.

- hiatus-breaking $r$ : megheșu-r-ati ${ }^{\circ} 112.2 .25 \mathrm{~d}[\mathrm{RA}]$.

- avagraha at the beginning of a pāda: 'ndajaiś 112.2.9b[RA].

3. Nouns, pronouns and adjectives

- a-stem formation: duștacetasāh $96.30 \mathrm{~b}$; jalaukasaih $99.9 \mathrm{~d}$; brahmasadam 112.38a (acc.).

- -in for -i: śaurine 97.26d; baddhaprștheșudh̄̄ 105.1c.

116 Here bhaga makes one guru syllable.

117 Here prapi makes one guru syllable.

118 Alternatively, this may be irregular sandhi of so before a voiced consonant. 
$--i$ for $-i n$ : ${ }^{\circ} d v \bar{a} r i m$ 102.2a.

$--i$ for $-\bar{\imath}$ : patnayo (fem.nom.pl.) 111.6c

- ${ }^{\circ}$ rājan at the end of a compound: daityarājānam 100.53c, 107.23a, 107.24c.

$-{ }^{\circ} \bar{a} t m a$ at the end of compound: jitātma $\bar{a}[s]$ (fem.nom.pl., conj.) 112.2.23a[RA].

- nominative plural for accusative plural: appo 104.3c; patnyah 104.57c; devadundubhayo 108.28c; ${ }^{\circ}$ kotyah 111.46a; gāvo 112.46b; añjalayah (conj.) 112.3.10c[RA]; sakhyaś $112.3 .20 \mathrm{c}[\mathrm{RA}]$; kathayanto 112.3.62b[RA].

- genitive for dative: vipracitteś (with $\sqrt{ } k$ șip) 103.36e.

- dative for genitive: tubhyam in the meaning of genitive (m.c.) 109.35a. ${ }^{119}$

- case change of enclitics of personal pronouns: te in the meaning of accusative 101.14c, 109.12d; me in the meaning of instrumental 110.21b.

- masculine for feminine: caran (pr.pt.) for caratī 112.1.3c[RA].

- masculine for neuter: imam deśam 101.11c; indriyān (acc.pl.) 104.7d; tam for tat(?) 107.24a; tam āpatantam (subj. cakra, acc.) 107.33a; dahann iva (subj. cakra) 107.35 $\mathrm{d}^{120}$; tam ... upayāntam (subj. cakra, acc.) 107.36a; rūpam ... imam 112.3.11a[RA].

- neuter for masculine: yamāni 111.74b; idam dharmam 112.68b.

- feminine for masculine: balim ... śubhām 100.60d.

- devata as a masculine noun: devataih 100.19b, 104.40b, 105.40b; te devatāh 105.39a; devatān 112.3.93a[RA]. ${ }^{121}$

- pataye (masc.dat.sg.) for patye $112.70 \mathrm{c}$ in the meaning of a husband.

- svayambhus (masc.nom.sg.) for svayaṃbhūs 98.20a.

- lakșmī (fem.nom.sg.) for lakṣmīh/lakșmīś 98.9b, 111.4c.

- anumatī (fem.nom.sg.) for anumatih 111.5d.

- kuhū (fem.nom.sg.) for kuhūh 111.5c.

- tiryak (masc.nom.sg.) for tiryan் (conj.) 100.34a.

119 Cf. mahyam instead of mama (m.c.) 28.43a (SP II A, 208); GES 10.3.4, p. 332.

120 See SP III, 21 and SP IV, 28, for similar cases of the construction of a pr.pt. with iva.

121 This usage is very common in the text (see SP III, 68; SP IV, 26). 
- mūrdhnan- for mūrdhan-: mūrdhnany (loc.sg.) 103.30d. ${ }^{122}$

- trsțtup for triștup (m.c.) 111.75a.

- śivipista- as an orthographic variant for śipivista- $97.23 \mathrm{a} ;{ }^{123}$ tripiștapa- for triviștapa-111.11d, 111.96d.

- avasavyam for apasavyam 102.32c. ${ }^{124}$

- apāhasta for apahasta $107.13 \mathrm{c}$.

- añjan̄ for $\bar{a} \tilde{n} j a n \bar{\imath} 112.1 .24 \mathrm{a}[\mathrm{RA}]$.

- sar̄̄ṣpām for sarīsrpānāam 112.3.38d[RA]

- danudaitya $a^{\circ}$ for dānavadaitya ${ }^{\circ} 102.16 a$; ditidānavāh for daityadānavāh 103.17b. ${ }^{125}$

- yathāśaktyā for yathāśakti 111.93c, 112.1.47d[RA].

- bhinnakrama compound: sarittadāgāvațaśuṣkapalvalam for śuṣkasarittad̄āāvatapalvalam $96.34 \mathrm{c}$.

- rare vocabulary: kampana as the name of a weapon $101.26 \mathrm{~b}$; kșipana 'throwing' 104.27d (attested in combination with prefix pra-, ut- or ni-); praverita 'cast, hurled' (denominative from vera/vela? Cf. GES, p.6) 104.55b; vrști used for rsțti(?) in śaravrsțtitomarair 102.38 a ( $-v$ - may be used to break hiatus).

4. Irregular taddhita formation

- gānāpatyam for gānapatyam 112.57d.

- taddhita without vrddhi of the first syllable: maheśvaram for māheśvaram 106.14b; sarvakāmikam for sārvakāmikam 110.28b; rudrān ... gaṇān for raudrān ... gan̄ān 112.43c; devāsuram for daivāsuram 112.108c.

5. Verbal forms, inflections and derivatives

- change of class: upāsanta for upāsata (II $\rightarrow$ I) 96.26c; upāsate for upāste (II $\rightarrow$ I) 112.1.43b[RA]; naśantu for naśyantu (IV $\rightarrow$ I) $100.45 \mathrm{c}, 104.46 \mathrm{a}$; anvacinvata for anvacinuta $(\mathrm{V} \rightarrow \mathrm{I}) 108.6 \mathrm{~d}$, 108.7d; samāsarjat for samāsrjat (conj.; VI $\rightarrow$ I) 107.38a; akurvatām for akurutām (VIII $\rightarrow$ I) 107.14a; akurvanta for akurvata $(\mathrm{VIII} \rightarrow \mathrm{I})$ 96.2c, 96.3c, 109.47c; snāyet for snāyāt (II $\rightarrow$ IV) 112.42a; upayujyanti for upayuñjanti (VII $\rightarrow$ IV) 111.38b; ghnata for hata (II $\rightarrow$ VI) 101.18b, 101.19b.

122 Cf. SP IV, 26.

123 Cf. SP II B, 45, n. 107.

124 avasavya-also occurs in $27.67 \mathrm{c}$ and $87.36 \mathrm{c}$.

125 Cf. AiGr II.2, $118 \mathrm{f}$. 
- secondary ending for primary ending in indicative present: tișthāma 96.21c, 97.3f; prapaśyāma 97.3e; jīvāma 100.21c; manyadhvam 103.6a; abhidravata 101.7b; ghnata 101.18b, 101.19b.

- sama- for sam- as preverb: samayojaya (m.c.) 112.2.6d[RA] (samabhāvayantam for saṃbhāvayantam in 85.31b).

- future imperative (or secondary ending for primary ending): kariṣyāma 99.21d, 102.14d; paśyāma 100.31e; jeșyāma 110.28c; vetsyata 101.21a.

- change to seț stem: nayișyati for neșyati 100.25d, 100.26d; nayișyāma for neșyama(h) 101.14c.

- present used with imperative meaning: samtyajāmo $103.8 \mathrm{c} ;$ jān $\bar{\imath}-$ mah 112.3.68a[RA].

- future used with optative meaning: yotsyate 100.19b.

- causative without causative meaning: 'vartayanta 96.26a; yodhayāma $103.8 \mathrm{~d}$; dāpayet $111.62 \mathrm{~b}$; pradāpayet $112.46 \mathrm{~d}$.

- jagàma used with causative meaning: 99.27c.

- parasmaipada for àtmanepada: 'tvarat 99.26b; jāyati 111.13d; āsevet (conj.) 112.63c.

- passive with parasmaipada ending: dṛ́yanti 100.48a; stūyati $112.2 .11 \mathrm{~b}[\mathrm{RA}]$.

- irregular form of àtmanepada present participle: cālayāno 98.23b; kṣobhayāno 99.9b; pūjayānam 99.22a; nādayāno 103.39e, 109.4c; dārayānau 103.43c; drāvayāṇam 104.12a; drāvayāṇo 104.16d, 105.33b; cūrnaayāno 104.20c; krodhayāno 106.8d; ādaśānam 107.43a; saṃdaśānam 107.43b; bhīṣayāno 108.6c.

- augmentless imperfect: pūjayat 99.20b; samnnahyanta 102.18c; 'vacūrnayad 102.34d; saṃcodayat 105.10a; sampracodayat 105.11b; avekșata 105.20c; paribhramat 106.1d; avalokayata $106.2 \mathrm{~b}$; avekșanta 108.10c; upatișthanta 108.24a; praveśayat (m.c.) 109.21d; yātayanta 109.32d; pravepata (m.c.) 109.44b; utsrjat 110.3c; anvaveksata $112.85 \mathrm{~d}$; abhipaśyata $112.3 .17 \mathrm{~d}[\mathrm{RA}]$.

- irregular placement of augment: apraișit 104.9d; vyanivartata $110.7 \mathrm{~d}$.

- aorist with augment in prohibition: mā pramādam ag $\bar{a}$ daitya 102.4a.

- imperfect for present(?): aveștayat 112.2.18b[RA].

- perfect for present(?): papau 112.2.12d[RA]. 
- absolutive I for II: proktvā for procya 98.50a.

- absolutive II for I: aganya for aganayitvā 110.11a. ${ }^{126}$

- absolutive in the meaning of infinitive: gatvā 104.55d.

- $\sqrt{ }$ pru $\rightarrow \sqrt{ }$ plu: plavate $103.26 \mathrm{~b} ;$ pluta 106.2a. ${ }^{127}$

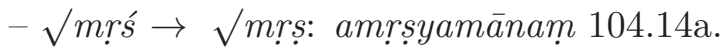

- 'tikrāmate for 'tikrāmati or 'tikramate 97.13d.

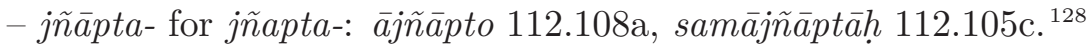

6. Syntax

- lack of concord in gender: tān̄iritān ... a ayudhāni 104.4ab; etāmiś cānyāmśs ca subahūn ... nimittāni bhayadāni 105.20; śūla (masc./neut.) referred to by tat (acc.) in 106.32a and tam (acc.) in 106.33a. ${ }^{129}$

- lack of concord in number: abhāsata for a plural subject (conj.) 112.1.50b[RA].

- absolutive and participle directly connected: ${ }^{130}$ nihatya ... avapāsitīan 101.3ab; samāásāsyotthitam 104.24a; nivṛttam ... cakram akrtvā kāryam ... 110.8ab; krtvāñjalim ... avasthitam 112.79f; vitatya ... vyavasthitam $112.2 .15 \mathrm{c}[\mathrm{RA}]$; śrutvā vyākulasya $112.3 .56 \mathrm{ab}[\mathrm{RA}]$.

- nominative sentence inside a list of names in genitive plural: viśvedevāś ca ye kecit sādhyās tathaiva ca 112.11ab.

- irregular syntax in compound: ... karacaranaih svamuktaśastrair damștrābhir nakhamukhadāritās ... 101.30ab (all the instrumentals and nakhamukha ${ }^{\circ}$ within the compound are connected with ${ }^{\circ} d \bar{a} r i t \bar{a} s$ as the second member of the compound); silammanimayāñ chubrāñ

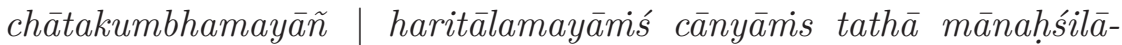
calān | 109.5abcd (all the adjectives and mānahśsila ${ }^{\circ}$ within the compound qualify ${ }^{\circ}$ acalān as the second member of the compound); tilapātrāṇi ... krṣnānām for pātrāṇi krṣnānām tilānām 112.49.

126 The negative prefix is treated as a preverb. Cf. GES 9.7.2 (b).

127 Cf. SP III, $72 f$.

128 The form jiñapta- also occurs in SP 33.114a, 33.115f, 63.13a, 70.8a and 70.19a.

129 Cf. tam referring to the same śūla in 107.1a (acc.) and 107.10a (acc.); tat in 107.32a may be in the meaning of tatas.

130 This syntax of the absolutive or gerund can be found in various genres of Sanskrit literature (Speijer 1886, $\S 380.2$ ), but it is not in accordance with its principal usage. We include it here to draw the reader's attention to this syntactical feature and provide some instances. 
Synopsis 
Peter Bisschop and Yuko Yokochi - 978-90-04-46103-1 Downloaded from Brill.com04/26/2023 02:09:47PM 


\section{Structure of the Contents of Chapters 96-112}

\section{SP 96-110: The VarĀHa Cycle}

1.1 Viṣnu's adoption of the form of the Boar (Varāha) to slay Hiraṇyākṣa.

* SP 96: While Hiranyākș̣a is ruling the triple world, the gods enter his subjects through yoga. Hiraṇyākṣa notices them and starts slaying his own people.

* SP 97: Brahmā tells the gods that Hiranyākṣa's time has come. They go to Viṣnu and request that he take on the form of a Boar, Varāha.

* SP 98: The gods fashion the Boar's body and enter it. He sets out for the Ocean.

* SP 99: Varāha makes his way through the Ocean and reaches Rasātala, where a sea guard sees him.

* SP 100: Hiranyākṣ̣a and Prahlāda share their bad dreams with each other. A guard informs them about the arrival of a terrific boar. Hiranyākșa orders that he be found.

* SP 101: The Asuras find the Boar, but he defeats them all.

* SP 102: One Asura escapes and reports back to Hiranyākșa. Vipracitti and the others are sent to slay the Boar. They start fighting.

* SP 103: Vipracitti and Prahlāda fight with Varāha, but he triumphs over them.

* SP 104: Vipracitti has another duel with Varāha and is hurled onto Hiraṇyākṣa's palace. Hiraṇyākṣa prepares himself to fight.

* SP 105: Hiraṇyākṣa sets out to fight with Varāha. He pierces Varāha in the heart with an arrow. The gods revive him.

* SP 106: Hiraṇyākṣa and Varāha continue to fight. Hiraṇyākṣa invokes Rudra and hurls a spear at Varāha. 
* SP 107: The spear hits Varāha in the heart. He is revived by the tejas of Maheśvara. Hiraṇyākṣa and Varāha have a long wrestling match. A voice instructs Varāha to slay Hiraṇyākṣa with Maheśvara's cakra. Varāha decapitates him.

* SP 108: Varāha finds the Earth held captive under the Śankkha mountain. He re-establishes the Earth and returns the three worlds to Indra. Viṣnu holds on to his Boar form and enjoys the company of female boars.

1.2 SP 109-110: Kārttikeya's harassment of Varāha's son Vṛka and his defeat of Varāha.

* SP 109: Varāha has a son called Vṛka. He destroys Kārttikeya's forest near Gaurīkutța. He is taken captive and tortured. Nārada informs Varāha.

* SP 110.1-15: Varāha arrives and starts to fight. Kārttikeya strikes a spear in his heart. Viṣnu abandons his Boar body and proceeds to Siva to praise him. He requests that Siva teach him the Pāśupata observance. Śiva leaves for heaven to teach the observance.

2 SP 111-112.72: Devì's Instructions to the Goddesses

2.1 SP 111: On Mt Mandara, Devī instructs the goddesses on donations.

2.2 SP 112.1-72: Devī instructs the goddesses on fasts and penances.

\section{SP 112.73-115: Continuation of the AndhaKa CyCle}

- SP 112.73-81: Devī explores the forest on Mt Mandara together with the goddesses. She decides to adopt a young aśoka tree as her son.

- SP 112.82-92: Andhaka arrives at Mt Mandara. He desires Devī, but Prahlāda warns him off.

- SP 112.93-102: The Asuras wander around Mt Mandara and eavesdrop on the Seven Sages. The sages decide to go away.

- SP 112.103-115: Dhātṛ, Vidhātṛ and Kṛtānta arrive. They report that Dhātr had told Kaśyapa about the future affairs of the Devas and Asuras. The sages want to hear this as well. Kṛtānta is charged with telling it. 


\section{Skandapurāṇa 96}

When Hiranyākṣa installs a new Agni, the Mantras and Yajña start serving the Daityas. The gods become despondent. Brahmā encourages them. They should wait until Hiraṇyākṣa's tapas runs out; then Viṣnu will slay him. In the meantime they should dwell in the bodies of Hiranyākșa's subjects through yoga. They do so for a long time, until Hiranyākșa notices them and starts slaying his own people. He also dries up all the waters and vegetation. (105)

1 Vyāsa asks what the banished gods did when the lord of the Daityas (Hiranyākșa) was ruling the triple world, the Earth was bound and his subjects were happy. Sanatkumāra tells him.

4 The Daitya expells Agni and appoints another in his place. Thereupon the Mantras follow the new Agni and dedicate the sacrifical portions to the Daityas and Dānavas. When Yajña himself also starts serving the Daityas, all the gods are as good as dead. They have little strength and are without joy. Deprived of their kingdom, the gods are like snakes burned by mantras, like mountains crushed by thunderbolts, etc. They worry and lament.

10 When Pitāmaha sees the gods in this state, he addresses them from his vimāna. ${ }^{131}$ 'Why are you so distressed? I will give you the power of tapas and yoga! It is not proper for you to remain as though you are impotent. You should leave behind misery, and resort to my yoga and your own. Just as darkness is improper for the sun, heat for the moon, goodness for a bad person, lack of virtue for somebody from a good family, so too is this improper for the gods. You should not give way to grief on facing misfortune. You will regain your kingdom. Right now Hiraṇyākṣa is furnished with great yogic power and cannot be slain. ${ }^{132}$ You must bide your time. Viṣnu will slay the lord of the Daityas in battle after his tapas has run out.'

20 The gods bow down to the Creator and tell him that their abodes have been taken. Where can they stay? Pitāmaha responds. 'I am aware that your abodes have been taken. You must dwell in the bodies of all [the king's] subjects ${ }^{133}$ through yoga. The Earth, though bound by snakes, ${ }^{134}$ will nourish you with what is drunk and eaten by them.'

131 The expression vimānenārkavarnena in SP 96.10c is a stock phrase found in SP 112.13c, SP 112.62c, MBh 13.78.24c and HV 31.35c, among others.

132 The compound mahāyogabalopeta ${ }^{\circ}$ (SP 96.18a) occurs frequently in the text and is also well attested in other Purāṇas. In even pādas, the usual phrase is mah $\bar{a}$ -

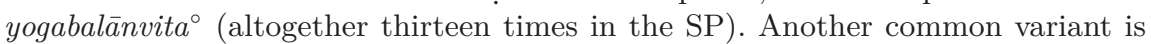
tapoyogabalopeta ${ }^{\circ}$-balānvita ${ }^{\circ}$ (e.g. 98.28d below).

133 Hiranyākșa rules the triple world, so his subjects ( $p r a j \bar{a})$ include the Asuras as well as all other creatures.

134 See SP 95.13. 
25 The gods do as they are told by Brahmā. They dwell there for four yugas. Then Hiraṇyākṣa sees the gods abiding in his subjects through yoga and he gets angry at them. He kills every person in whom he sees a god is dwelling. Observing that he is always engaged in protecting his subjects from fear, and that the ungrateful ones who nourish his enemies with food and drink deserve punishment, he becomes exceptionally cruel and slays all his subjects wherever they are.

32 Then the Dānava dries up all ponds and rivers through yoga. ${ }^{135} \mathrm{He}$ destroys the plants and crops, and lets the trees and creepers wither. The world resembles the back of a tortoise. With the varnas, aśramas and dharmas eliminated, deprived of cattle, birds and men, the world appears as if it has been destroyed by the fire of time at the end of a yuga. ${ }^{136}$

\section{Skandapurāṇa 97}

The gods go and see Brahmā. He tells them that the time of the Daitya has come. They should go and ask Viṣnu to take on the form of the Man-Boar, which will ensure the death of Hiraṇyākṣa. The gods go to Viṣnu and praise him extensively. Viṣnu assures them that he will slay Hiranyākșa in the form of the Boar. The gods rejoice. $($ p. 112)

1 Seeing the world in this state, the gods go to the world of Virāj (Brahmā) to see Pitāmaha once more. After bowing down repeatedly, they tell him about the Daitya's deed. They are unable to engage in battle with him and they cannot find a place to stay.

4 Brahmā speaks to the gods. 'You must not be afraid of the great yogin. The fruit of the Daitya's tapas has run out. The time of his death is imminent. Hence you must all go with me and beseech Viṣnu. You are powerless now, but Viṣnu is capable and will kill the Daitya. In the past, when he (the Daitya) was born, a bodiless voice prophesied that he could not be killed by a man, nor a god, nor an animal, not on earth, nor in fire,

$135 \mathrm{SP} 96.32 \mathrm{ab} \approx \mathrm{SP} 95.26 \mathrm{ab}$. The situation described in this passage stands in direct contrast to the time when Hiraṇyākṣa began his reign (SP 95.21-31) and includes some verbal echoes of the passage describing this event.

136 The metre of SP 96.34 is Upajāti (Jagatī), and that of SP 96.35, Vamśastha. 
nor in the sky, nor in the worlds. ${ }^{137}$ The righteous Daitya lord is invincible to all beings, but he can be slain with difficulty, when Viṣnu has taken on the form of the Boar (Varāha) - neither divine, nor human, nor animal; it is the form of the Man-Boar (Naravarāha) - and enters the nether region (Pātāla) — neither earth, nor sky, nor fire, nor the world; it is appropriate in all respects. ${ }^{, 138}$

13 The gods are delighted and agree that they should go. They all proceed to Mt Śveta, where they praise Viṣnu reverentially. ${ }^{139}$

15 'Obeisance to the destroyer of all enemies; the destroyer of Dānavas; the invincible god Vaikunthha; he who shakes off rajas; truth; the Sādhya; the store of great virtue; Yama; victory; the son of Aditi; Nara and Nārāyaṇa; the benevolent one; Viṣnu; having the form of a dwarf (Vāmana); Kṛ̣ṇadvaipāyana; ${ }^{140}$ Rāma (Dāśarathi); Rāma (Jāmadagnya); ${ }^{141}$ Dattātreya; ${ }^{142}$ the Man-Lion (Narasiṃha); the supporter; the slayer of Śakuni; ${ }^{143}$ Dāmodara; practising tapas in water; ${ }^{144}$ fond of lying on a snake (Śeșa); having

137 These conditions are not found in any of the other versions of the Varāha myth, with the exception of VDhP 1.53.13-14: tiryarimanuṣyadevānām avadhyah sa surāntakah | brahmano varadānena tasmāt tasya vadhepsayā $\|$ nrvarāho bhavișyāmi na devo na ca mānuṣah| tiryagrūpena caivāham ghātayiṣyāmi tam tatah \| (read tiryagrūpo na?). The Viṣnudharmottara is also the only other text that refers to this specific form as the Man-Boar (Nṛvarāha), a hybrid form that satisfies the conditions set. The formulation of the conditions here is clearly inspired by the earlier Narasimha episode (SP 70.30-32), where it forms an intrinsic element of the narrative in other versions as well.

138 The syntax of this passage is far from straightforward. 11a and 12a continue from verse 7 , while verses 8-10 form a parenthetical clause explaining the preconditions for Hiranyākșa's death. 11bcd is a sort of commentary or elaborate explanation of $11 \mathrm{a}$, and $12 \mathrm{bcd}$ of $12 \mathrm{a}$

139 Perhaps Śvetaparvata 'the White Mountain' is named as the residence of Viṣnu because of its association with Śvetadvippa 'the White Island', the paradisical continent of Nārāyaṇa (Rönnow 1929, Oberlies 1997). Several passages in the text indicate that Varāha's body is white; see n. 167 on p. 57.

140 The Nārāyaṇiyya regards Kṛṣnadvaipāyana Vyāsa as an incarnation of Nārāyaṇa: MBh 12.334.9, MBh 12.337.3-5 and MBh 12.337.42-44. This tradition is followed in the Purānas (Saindon 2004-05).

141 The reading of SP 97.16a is uncertain. We have adopted Bhattarāī's conjecture, referring to the two Rāmas. For the two Rāmas (Jāmadagnya and Dāśaratha) as manifestations of Viṣnu-Nārāyaṇa, see e.g. MBh 12.326.77-81 and HV 31.100-142. The reading of $\mathbf{A}(n \bar{a} g \bar{a} y a)$ would rather refer to Balarāma.

142 An early reference to Dattātreya as a prādurbhāva of Viṣnu can be found in HV 31.93-100ab.

143 'Śakuni' refers to the ogress Pūtanā, who was slain by Kṛ̣na. See HV 50.20-50.

144 Followed by the image of Viṣnu lying on Śșa, this may suggest Viṣnu's yogic sleep on the cosmic ocean, but in origin the reference is rather to Siva. Cf. tapyamānāya salile (MBh 7.5.4a) and salile tapyamānāya (SP 7.16a, $\left.\mathrm{SP}_{\mathrm{Bh}} 122.36 \mathrm{c}\right)$, all in hymns addressed to Śiva. This no doubt refers to the Sthāṇu myth, which starts with Siva performing tapas in water (MBh 10.17.11). On this see also Shulman 1986. 
the form of Kapila; ${ }^{145}$ the great person (Purusa); having the form of a cloud; ${ }^{146}$ dear to Mahādeva; having the form of half of Rudra; having the form of Umā; ${ }^{147}$ with a discus and a hammer in his hands; the Gana of Maheśvara; Śivipișta; ${ }^{148}$ bearer of the śrīvatsa; the slayer of Dhundhu (Dhundhumāra); ${ }^{149}$ the slayer of Madhu and Kaitabha; the four-armed; the dark-coloured one; wearing the kaustubha jewel; positioned in the sky with his three strides; wearing a yellow garment; the destroyer of cities; ${ }^{150}$ bearing a terrific club and sword; the yogin; the sacrificer; the killer of the wife of Bhrgu; ${ }^{151}$ having the form of a bull; ${ }^{152}$ the best of the Adityas; the intelligent one; the restrained one; Śauri; ${ }^{153}$ the friend of the Vṛșnis; the slayer of Aśvagrīva; ${ }^{154}$ the killer of Asuras; with the Sārnga bow; the destroyer of Saubha and Sālva; ${ }^{155}$ having a lotus-navel; knowing the true path of brahman; victory; ${ }^{156}$ Śarva; who received a boon from Rudra; ${ }^{157}$ the lord of all; establishing the dharma when it perishes; the excellent person (Purușa); the hundred-armed! Thanks to your grace we transcend hardships, O Purusottama! Don't you know that we have all been robbed of our kingdoms by Hiraṇyākṣa? O Vaikụ̣ṭha, destroy him!'

145 For the Sāṃkhya teacher Kapila as a form of Viṣnu, see MBh 12.326.64.

146 This refers to Viṣnu as Yajña, who in the past was granted the form of a cloud (SP 31.38-46).

147 'Half of Rudra' indicates Harihara, but the reference to 'the form of Umā' is not clear; perhaps it is an allusion to Ardhanārīśvara or to Viṣnu's female manifestation as Mohinī. The word $u m \bar{a}$ can also mean a flax flower, in which case it could refer to Viṣnu's blue skin.

148 For Śivipișța (or Śipivișța), see SP I, 86, n. 79.

149 The slayer of the demon Dhundhu, the son of Madhu and Kaitabha, was King Kuvalāśva, who had been given yogic power by Viṣnu. His story is told in MBh 3.192-195.

150 Perhaps Kṛṣna's destruction of Vārāṇasī is meant. See SP II A, 26-27, with reference to ViP 5.24 (a typo for ViP 5.34) and BhāgP 10.66.

151 The reference is to Rām. 1.24.18, which tells how Viṣnu killed Bhṛgu's wife, the mother of Śukra (kâvyamātr), when she desired to rid the world of Indra:

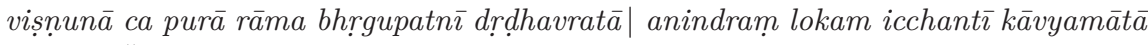
niṣu ditā\|.

152 The bull refers to Viṣnu as Dharma. For the identification of the bull with Dharma, see SP II B, 65, n. 210.

153 The text actually has śârine (confusion between $-i$ and - $i n$ ending).

154 This obviously does not refer to the avatāra Hayagrīva 'Horse-Necked', but to the demon of the same name. A brief allusion to Viṣnu's killing of Hayagrīva occurs in MBh 5.128.49 and Rām. 4.41.22. According to BhāgP 8.24, Viṣnu rescued the Vedas from the demon Hayagrivva in his Matsya avatāra. See also Jaiswal 1985.

155 Sālva (or Śālva) was the ruler of the city of Saubha, which was destroyed by Kṛ̣na, together with its king, after the latter had attacked Dvārakā (MBh 3.15-23).

156 Because of loss of a folio in $\mathrm{S}_{1}$ and $\mathrm{S}_{3}$, the textual basis for SP $97.28 \mathrm{~cd}-42 \mathrm{ab}$ consists only of $\mathrm{R}$ and $\mathbf{A}$.

157 This probably refers to SP 71.72, where Viṣnu is given the boon of being a slayer of demons (daityaghna). 
31 A man who constantly recites this praise of Viṣnu with devotion is released from all sin. When he dies, he is worshipped in all the worlds by all the gods for fourteen times ten million years. One who recites this praise is released from sin; he is freed from suffering.

34 The Bhagavat (Vị̣nu) responds. 'The wicked Daitya has to be killed after you enter the Boar form. ${ }^{158}$ It is not possible for me to slay the powerful and righteous Daityendra on my own. I will slay the Daityendra after assuming the form of Varāha, increasing joy (nandivardhana), ${ }^{159}$ consisting of all the gods. In that form it is possible to bring back the Earth from him/it (Pātāla). I will slay the Dānava for your sake, just like a Śarabha slays a lion. ${ }^{160}$ Purandara (Indra) will be the consecrated sacrificer (dīkșita), Bṛhaspati the Hotṛ, Brahmā the Brahman priest, Yama the Prasthātṛ, Varuṇa the Udgātṛ, Hiraṇyanayana (Hirạ̣yākṣa) the sacrificial animal (paśu), and I myself will be the butcher (Śamitṛ). ${ }^{161}[\ldots]^{162}$

43 Once the gods have heard his speech, they consider the Daityendra already to have been slain. They cry out: 'The Daitya has been slain, just like his mighty elder brother before him by Narasiṃha!' ${ }^{163}$

158 The manuscript situation of this passage is poor and the readings of $\mathrm{R}$ and $\mathbf{A}$ diverge. We have followed the reading of $\mathrm{R}$. A has a different syntactic structure. Here Viṣnu tells the gods that the Daitya is doomed and that they should prepare the body of a mortal and a boar, thus referring to the Naravarāha form. We have also considered the possibility that SP 97.35 may originally have been placed after SP 97.30 and would have rather formed the end of the gods' speech to Viṣnu. It is conceivable that the śrutiphala of 31-33 was inserted at some stage in the transmission, which may have created the confusion.

159 The adjective nandivardhana here qualifies the form ( $r \bar{u} p a$ ) of Varāha. Later, however, starting at SP 98.19b, the text appears to use Nandivardhana 'Increasing Joy' as an epithet of Varāha. It is used with reference to Varāha throughout the rest of the Varāha cycle (twenty-two times until chapter 112) and is unique to the SP. For the possible historical background, see n. 197 on p. 65.

160 The simile is pregnant with meaning, since Viṣnu was overpowered by Śiva in the form of a Śarabha to defeat his former Man-Lion manifestation (SP 71.48-73).

161 For a similar idea, involving some of the same priestly roles and comparable imagery, see SP 84.1-7.

162 SP 97.42 is incomplete. It involves comparing the battle between Viṣnu and Hiranyākșa to that of two rutting elephants for a female elephant (vāsitā), implying here the goddess Earth, who has been taken captive by Hiranyākṣa.

163 The metre of SP 97.44 is Upajāti, a combination of Triștubh (ab) and Jagatī (cd). In $\mathrm{R}$ and $\mathbf{A}$, as well as $\mathrm{SP}_{\mathrm{Bh}}$, the verse has been turned into a Jagatī. 


\section{Skandapurāṇa 98}

The gods fashion the Boar's body from the seven worlds and each of them occupies one of his limbs. The sages energize the Boar's body. Viṣnu declares that he will slay Hiranyākṣa and liberate the Earth. Brahmā warns him that the Daitya is strong. The gods request that Śiva strengthen Viṣnu with his energy. Brahmā performs a protection rite, asking Śiva in his many aspects to protect Viṣnu during the battle. Varāha sets out for the Ocean. (118)

1 The gods prepare his form [i.e. his boar form], with Brahmā as the creator. They fashion his body from the seven worlds. ${ }^{164}$ The mountains become his bones; the rivers, his veins; the seven oceans, his blood; the three gunas, the three humours; the plants, his faeces; dharma, his semen; the clouds, his urine. The seven winds enter his abdomen; Brahmā, his head; Rudra, his skull; Dharma, his forehead; Vāyu, his nose; the sun and the moon, his eyes; the directions, his ears; the stars, his eyebrows; day and night, his eyelids; the submarine fire, his mouth; earth and sky, his lips; the snakes, his teeth; the four weapons, his fangs; ${ }^{165}$ lightning, his tongue; space, his palate; Umā, his neck; the thunderbolt, his shoulders; the Ādityas, his cheeks; the Rudras, his hands; fame, fortune, success, glory, victory, splendour, strength, beauty, action and inaction, his fingers; all the weapons, his nails; Yamadaṇda, Kāladaṇda, Mṛtyudaṇda and Rudradạ̣da, his arms and feet; the Sādhyas, his chest; Soma, his heart; the great elements, his belly; Aditi, his navel; Prajāpati, his penis; Mitra, his anus; the Vasus, his ribs; Dharma, his back; Mṛtyu, Kāla and Yama, his palms and soles; the Aśvins, his tail; the pitrs, his joints; fate, the noose of time, death, quarrel and disease, his sight; Yakșas, Rākșasas, Gandharvas and Pannagas, his skin; the chants, the Vedas and the oblations, the pores of his skin; the gifts, the yamas and niyamas, the Mothers, the local deities, the domestic animals and birds, his bristles; the Viśvedevas, the

164 Viṣnu in the form of the Boar is generally considered to be a sacrificial boar (yajñavarāha), and the limbs of his body are identified with sacrificial elements. See, e.g, HV 31.21-27, HV App. 1 No. 42 1l. 165-178, ViP 1.4.32-34; for a study and overview, Agrawala 1963. This is no doubt related to the idea that Viṣnu is the sacrifice (Gonda 1969, 77-80). The present passage rather involves an identification of the Boar's limbs with the entire cosmos (saptalokamaya), paying particular attention to the position of the gods. This is connected with Viṣnu's earlier request that the gods strengthen him because he could not slay Hiranyākṣa on his own (SP 97.35-37). See also Bakker 2014, 246, n. 703, which does not, however, properly distinguish between the cosmic boar described here and the sacrificial boar described in other texts.

165 This refers to the four mantra weapons: the Pāśupata weapon, the discus (cakra), the staff of Brahmā and the head of Brahmā. For the Pāśupata weapon and the head of Brahmā, see Bakker \& Bisschop 2016, 248-252. 
paws of his feet; the Bhrgus and Angirases, his nails. ${ }^{166}$ The sages occupy all the spaces between his bristles.

19 In this way, Varāha Nandivardhana comes into being; he touches both heaven and earth. In the past, the Slayer of Madhu (Madhusūdana) shone forth in that form, when he was about to lift up the Earth as Svayambhu. ${ }^{167}$ The sages activate Varāha's energy (tejas) with their tapas. Viṣnu blazes up like the fire at the end of time. Roaring loudly, he tells the sages that he will slay the Daitya. He will enter Rasātala and liberate the Earth, place her in her proper place and return the kingdom to the gods. Now they should repeat 'to victory!' and 'to Śiva!'

26 Brahmā warns him to muster his strength, since the Daitya is very strong. He should make a great effort and slay the Daitya king with complete selfcomposure. The former Hiranyakaśipu is not comparable to him.

29 The gods and sages bow down to Govrșadhvaja and ask him to strengthen Viṣnu with his tejas. ${ }^{168}$ The Bhagavat (Śiva) promises that he (Viṣnu) will slay the Daitya instantly, after Śarva's tejas has entered Hari. ${ }^{169}$ Thereupon Brahmā performs the rite of protection.

33 Brahmā requests Vidhātṛ; Dhātṛ; Rudra; Kāpālin; Tālaketu; the lord of smell, taste, sight, touch, sound and all organs; Nilalohita; the great yogin; the lord of the seed, the seed's place and consciousness, to protect him. The lord of action and inaction; the knower of time; the goal of dharma and adharma; the one who bestows fruits on agents; activator of the gunas; indifferent to actions; the agent of the observance; the knower of the actions of agents; for whom the object of the instruments comes about without instruments; ${ }^{170}$ the knower of all; protector of all; the ruler for

166 The reading nakhāh $(\mathrm{R})$ is uncertain. The Boar's nails have already been mentioned in $9 \mathrm{f}$, but there the reference was to the fingernails. Here it is the toenails that must be intended.

167 A distinction is made here between the earlier cosmogonic Varāha form, originally associated with Prajāpati (e.g. TaiSa 7.1.5.1), and Viṣnu's present Asura-slaying Varāha form. Cf. also SP 108.15, where this earlier form is instead referred to as Brahmā. The present passage rather follows the Vaiṣnava tradition that identifies the cosmogonic boar with Viṣnu. The simile added in 20ef ('like Mt Himavat, shining with herbs at night') calls to mind the description of the Himavat in Kumārasambhava 1.43 and indicates that the Boar's body is white. On Śvetavarāha ('White Boar'), see Bakker 2014, 246, n. 703, with references.

168 For the theme of strengthening with tejas, which is a recurring topic in the SP's narration of the Varāhā myth, see Hara 1987, 136: 'a god given "tejas" by a more powerful god becomes stronger.' See also Magnone 2009.

169 This refers ahead to the apotheosis of the fight with Hiranyākșa in SP 107 (see n. 243 on p. 76). Note that Siva uses the phrase śārvam tejas with reference to himself.

170 Cf. PS 1.25-26: vikaranadharmitvam ca. 
whom there is nothing that is not governed; who has hands and feet everywhere, eyes and heads everywhere and ears everywhere; ${ }^{171}$ omnipresent; imperishable; whose lordship is undecaying, innate and uncreated; the creator of all beings and the tattvas; the maker and eradicator of samsāra; the one whom the Sāmkhyas and the yogins who are learned in the scriptures do not know; who is always contented; deluding the creatures with māyā; by whom all tattvas starting with puruṣa are woven and warped; who is not pervaded; without knowing whom there is no release; by whom all the world is bound; by whom he (Brahmā) was made Prajāpati in the past: ${ }^{172}$ by whom he (Vị̣nu) was created as both Yajña and Viṣnu - let Him grant power and energy, distinction in speech and recollection of the weapon; let Deva provide complete protection during his fight. He (Brahmā) has properly performed the protection; now he (Viṣnu) should destroy the Daitya!

47 Next the sages and gods praise him, and all the various creatures declare 'victory!' Divine drums resound in the sky. Showers of flowers descend upon Varāha. After declaring 'success!' and bowing to Rudra, he sets out for Varuna's abode, repeating the victorious Rudra $[$ mantra $] .{ }^{173}$ Accompanied by the sages etc. he proceeds to the great Ocean. ${ }^{174}$

\section{Skandapurāṇa 99}

Varāha reaches the Ocean, who welcomes him with great respect. He dives in, scaring all kinds of water creatures along the way. He visits various places, ending in the city of Śeșa, whom he requests not to constitute an obstacle. When he reaches Rasātala, a sea guard Daitya sees the strange sight and hurries to inform Hiraṇyākṣa. ( $\quad$ p. 127)

1 Varāha sets out and reaches the Ocean. The latter beholds Nandivardhana, roaring, reclining, dancing and leaping, skilled in fighting, traversing

171 SP 98.40 draws upon a verse from the Bhagavadgītā: sarvatahpānipādāntam sarvatokșiśiromukham| sarvatahśrutimal loke sarvam āvṛtya tișthati \| (MBh 6.35.13).

172 This is a reference to SP 3.22, where Śiva grants Brahmā prajāpatitva.

173 The verb $\sqrt{ }$ jap with the plural accusative Rudra (rudrān) occurs at SP 21.2c, SP 35.16c, SP 51.12e and SP 51.18d. See also SP I, 98, n. 119.

174 The metre of SP 98.51 is Vamśasthavila. 
the earth in manifold circles. ${ }^{175}$ The Ocean welcomes him with an offering of guest water. After accepting it for victory and having honoured the Ocean, he (Varāha) enters the Ocean, leaving behind all creatures.

7 He dives in playfully. Submerging very deep, he descends out of sight. The water creatures behold him as he stirs up the Ocean. Frightening various kinds of whales, Makaras, shellfish, and other fish with the forms of different creatures, he goes along on his way. Some fish descend on him and sniff him in curiosity before disappearing again en masse.

14 He makes a circumambulation around the submarine fire (Hayaśiras) and instantly proceeds to Bhogavatī via Maināka. ${ }^{176}$ He goes to the city of Varuna; makes a circumambulation around the elephant Parjanya; visits the city of Surabhī, where he sees the nectar-yielding cow; drinks the milk at lake Kșiroda and spends the night there worshipped by the foam-drinkers. Then he proceeds to the cities of Kaǹka, Vāsuki and Takṣaka, and reaches the city of Śeșa, called Ramaṇā. ${ }^{177}$

20 Ananta receives him with guest water and addresses him with great respect, saying that, if he wants, they can accomplish the business for the gods together. ${ }^{178}$ The Destroyer of Madhu requests that he not constitute an obstacle: the opportunity for the Daitya's defeat should not be missed.

175 The passage is unsmooth. We conjecture loss of two pādas after SP 99.4ab, which would have made reference to the embodied form of the Ocean. The Ocean probably appears as embodied here in order to offer argha to Varāha. An early visual representation of this moment in the narrative, which does not occur in any other text known to us, may be seen at the bottom of the side walls of the famous Varāha relief from Udayagiri, depicting a male figure in the Ocean's waves with a water vessel in his hands. See Harle 1974, 10, plate 13; Williams 1982, 43-45, plate 37, fig. 5. Similar passages describing a natural phenomenon that appears embodied (mūrtimat) in front of Deva or Devī are found in SP 13.73 (Seasons), SP 59.3 (Gaurīśikhara) and SP 69.37 (Gaurīśsikhara).

176 The description of Varāha's journey towards Pātāla is not found in other versions of the Varāha myth, but some parallels for the geography can be found in the tale of Mātali's journey to the Nāgaloka (MBh 5.95-103). It includes, among other things, descriptions of the abode of Varuna (5.96); the world of the elephants, where the city of Pātāla and the abode of Hayaśiras is located (5.97); the city of the Daityas, called Hiranyapura (5.98); the world of the Garuḍas (5.99); Rasātala, where Surabhī and the foam-drinkers live (5.100); and Bhogavatī, where various Nāgas, including Śeșa, Takșaka and Vāsuki, live (5.101).

177 This name for the city of Śesa is not known from other sources.

178 Verse 21 is found after $22 \mathrm{~d}$ in all manuscripts. We have relocated it here because the verb upa- $\sqrt{ }$ mantr in $20 \mathrm{~d}$ introduces Ananta's speech. In its original position, the verse would be Ananta's answer to Viṣnu's request, but without indication of a change of speaker. The reference to Ananta in this passage brings to mind the iconography of the image of Varāha standing on a Nāga whose hands are folded in humble veneration. See Dokter-Mersch 2020. 
23 Leaving the Nāga, he reaches Rasātala. There, a sea guard Daitya sees him heading for the city of Hiranyākṣa and gazes at the minute gods in his limbs. The Asura is perplexed by his form and does not dare to approach him. Hurrying to inform Hiranyākșa, he speeds to the city ahead of Varāha. In his desire to reach the lord of the Daityas (Ditijas), he brings Varāha himself to the Daitya (Hiraṇyākṣa), just like the wind carrying the garland brought death. ${ }^{179}$

\section{Skandapurāṇa 100}

Bad omens appear in Hiraṇyākșa's city. Prahlāda informs him about a dream in which a man-boar seizes Hiraṇākșa. Hiranyākṣa says that he had a dream in which he was forced to give up his kingship. The Asuras debate whether anything can be done to prevent this from happening. They are interrupted by the arrival of a Dānava who reports that a terrific boar consisting of all the gods is heading for the city. Prahlāda says that this must be a form of Viṣnu. Hiranyākṣa expresses his satisfaction at the chance to avenge his brother's killer. He commands ten thousand Kimkaras to find him. ( $)$ p. 132)

1 Terrible omens appear in Hiranyākșa's city: the watchtowers collapse, the images of the gods laugh, ${ }^{180}$ jackals howl in the houses and assembly halls, there is a sudden terrifying noise, trees are uprooted without wind, ${ }^{181}$ the sun is covered by a kabandha and a fight is seen there [i.e. at the sun]. ${ }^{182}$

4 The Daitya king addresses the Asuras, saying that these omens are not without cause. The gods who have been robbed of their kingdoms will not remain inactive: resolving to something, they are now heading for battle.

179 The metre of SP 99.27 is Upajāti, a combination of Upendravajrā (pāda a) and Vamśastha (pādas bcd). As so often in these concluding verses, the syntax is not very smooth. We take jagāma in a causative sense. The simile contains a terse, but remarkable reference to an episode from Aja's life as narrated in Raghuvamśa 8.33-37, where a divine garland attached to the lute of Nārada is caught by the wind and ends up killing Aja's wife, Indumatī, when it falls on her breast. We owe the conjecture pracyutadāmamālyavān to Csaba Dezső.

180 For the laughing of images as an omen, cf. AVPariś 70c.29.3.

181 Ballālasena quotes the first two lines of verse 3 separately in the Adbhutasāgara (respectively on p. 485 and p. 445 of the printed edition).

182 For the omens of the kabandha and the fight (between two men), see SP IV, 69, n. 179 (where 'SP 78.8ab' should be corrected to 'SP 78.8cd'). 
7 Hearing this, Prahlāda bows down before his father and speaks. 'I am your son and you are my father by law; ${ }^{183}$ your judgement does not depend on the likes of me. And yet, desiring your undecaying kingship, I will say something in my childishness. Please listen. Last night, in a dream, I saw someone with a human and a boar form defeat you. May you act appropriately, so that this will not happen!'

11 Hiraṇyākṣa answers. 'Without a doubt, you are virtuous and you have seen it correctly. Today, in a dream, I visited the dwelling of Tryambaka (Śiva). Govrșadhvaja informed me that the time of my kingship is over and that I should return my royal insignia to Sahasrākṣa (Indra): the crown, the necklace, the armlets, the sword, the golden medallion, the bracelets, the royal seal ${ }^{184}$ and the fine upper garment. After removing them, he gave them to Śakra. The Bhagavat then told me to dwell in his proximity and not in my kingdom. ${ }^{185}$ Although what I have seen will certainly come to pass, still you should not be afraid because of me.'

18 The Daityas respond. 'This is false! Dreams are reported to be false. ${ }^{186}$ Joining Andhaka, who alone can fight the gods and is unconquerable, we will fight without distress. You (Hiranyākșa) should not fight! The lives of the Daityas and Dānavas depend upon you. Or, we will leave the city and enter the great Ocean.'

22 Hiranyākṣa laughs. 'Nobody can change what has been ordained by the creator and destroyer. If he has ordained my death, then death would kill me even if I were to sit down without fighting. Try and find that place where death will not take me! ${ }^{187}$ Alternatively, if he has not ordained my death, then death will not take me while I am fighting. How can someone like me do what is condemned by the wise: to protect oneself and hand one's child over to death? How can I who have killed many enemies on my own turn my back to them [i.e. my enemies]?'

29 Vipracitti says that they will strive to make sure that none of the gods return after they have been destroyed.

30 Hiranyākṣa responds. 'The gods, knowing themselves to be immortal, understand that they will regain their kingdom in the end, and so they always disperse. We, however, are not immortal. Once we are destroyed,

183 Prahlāda is actually the son of Hiranyakaśipu (cf. PPL 214.8-9), but with the death of his father he has become Hiranyākṣa's lawful son.

184 We take śāsana in the sense of 'royal seal'.

185 'His proximity' (tatsamīpa) implies Hiranyākșa's death.

186 We take the Daityas' argument to be that dreams in general are false, but it is also possible to take it with reference to the individual dreams of Prahlāda and Hiraṇyākṣa.

187 A rhetorical challenge. Such a place does not exist. 
we have no more hope of life. You should not think of fleeing. My mind is fixed on battle. Let us die in battle in a good fight!'

33 While they are speaking like this, a Dānava appears, out of breath, like an animal frightened by a lion in the jungle. Looking in all directions, he addresses the door guardian. 'O master of the assembly, inform the king that I, Nala the sea guard, have arrived! I will quickly relate something untimely'

37 The door guardian laughs at him and tells him not to be frightened: 'There is no lion or other beast of prey here, not even cows.' The Asura (Nala) gets angry and makes a great noise. They inform the king that the Asura has seen something. They ask the king to comfort the Daitya (Nala) ${ }^{188}$ and petition him to ensure the welfare of the Dānavas.

42 The king of the Dānavas tells him (Nala) to let go of his fear. He should report all that he has seen. Thereupon the Dānava bows down before the king and tells him the following.

45 'Victory to the king! May all enemies perish! At your command I patrol the ocean's ends with my men day by day. Today I saw a boar-shaped form $(v \bar{a} r \bar{h} h a)$ resembling the peak of Mt Meru, blazing like fire. In his limbs all the gods and sages could be seen in miniscule form. Your Majesty is very powerful, but he is even more terrifying! His likeness has not been seen or heard of before. Struck by the sight, I fell down to the ground in fright. ${ }^{189}$ My companions all dropped dead because of the boar's force. He is heading towards the city, stirring up the earth, disturbing the oceans and robbing the water creatures of their lives.'

53 On hearing this, Prahlāda addresses the Daitya king. 'The boar comprised of all the gods is no ordinary boar. Therefore you should take action so that it does not bewilder us and take over. It is clear that this is the Boar form of the bearer of the discus and the plough [i.e. Viṣnu], conceived by Brahmā. It is because you cannot be slain by any of the gods that they have created this māya .

58 Hiraṇyākṣa turns to the Daityas and Danujas. 'My heart's desire has been fulfilled today ${ }^{190}$ if my brother's killer has arrived. Today I will cut him to pieces and serve him as a bali offering to Paśupati! Today I will chop the

188 Earlier, in verse 33, Nala was called a Dānava. As in other parts of the text, the terms Daitya and Dānava are used interchangeably.

189 In SP 99.25, it was said that the demon could not move because of the Boar's tejas.

190 Note the repeated use of adya in this speech, which indicates Hiranyākṣa's excitement at the prospect of avenging the murder of his brother. 
head off his body and give it to Rudra! ${ }^{191}$ In the former battle I did not encounter Keśava, but now, approaching him, I will bring him to Yama's abode! Today, after I have killed him, all the gods will be turned into slaves!'

64 He then commands the Daityas and Dānavas, as well as ten thousand Kimkara Dānavas, to find out who he is. They accept his command with delight and depart in full armour. The sons of the Dānavas and Daityas set out noisily and excitedly. ${ }^{192}$

\section{Skandapurāṇa 101}

The Daityas and Dānavas find the Boar and surround him. They ask him why he has come. The Boar responds that he is looking for his lost wife. The Dānavas express disbelief and attack him, whereupon the Boar declares that he will kill them all. They attack him with many weapons, but he defeats them all. (的 p. 143)

1 The armed Daityas and Dānavas head for the Boar (Varāha). Carried off by the one with the appearance of a boar, the Asuras resemble sacrificial animals. He leads away the Daityas, who have been struck and fettered by fate and death, like sacrificial animals. After travelling for eight yojanas, they behold the Boar who has traversed the Ocean's waters. Drawing their bows, they surround him.

6 The Boar addresses them. ${ }^{193}$ 'Why are you attacking me? I have not done anything wrong and I am not your enemy.'

8 Encircling him, the sons of Diti ask him: 'Who are you, having crossed the ocean in the form of a boar? Why have you come here? Where are you heading?'

10 Resounding like a thundercloud, the Boar responds. 'I am just a boar. I have come to this place to wander. My wife has been taken by another and I am distraught. ${ }^{194}$ I am thinking about catching him.'

191 The phrase śirah kāyāt sakundalam in SP 100.60b (= SP 91.9b) derives from the Dronaparvan (cf. MBh 7.15.37b, MBh 7.30.22b, MBh 7.30.25b).

192 The metre of SP 100.67 is Upajāti, a combination of Trișțubh (ab) and Jagatī (cd).

193 The phrase tān appatata evātha (SP 101.6c) is also found in SP 80.33a, SP 81.19a and SP 86.9a. For other variants of this stock phrase, see SP IV, 21.

194 In a veiled way, Varāha is speaking the truth. Viṣnu's wife is the Earth (Bhū), who has been taken captive by Hiraṇyākṣa. 
13 The Dānavas reply. 'This is is the abode of the Daityas and not a place for you. Why have you arrived here, without respecting the Dānavas? We will slay you today and bring you to the lord of the Daityas!' Thereupon, they all attack him.

16 Again the divine Boar speaks to the Daityas, even as he is being attacked. 'I have not done anything wrong to you and I am not planning to either. Why are you striking me with weapons? There is no hostility between us. Or, if it is my meat that you are after, try and kill me with all your might. I have no fear of you! I have only to stretch out my hands and I will kill you instantly. Today you shall learn the power of animals! I will destroy your arrogance for having defeated the gods!'

22 Thereupon the Bhagavat (Varāha) stretches his arms ${ }^{195}$ and rises like the sun. The Dānavas attack him in anger. Like a storm struck by clouds, like Garutman by snakes etc., Varāha pays no attention. As he is being attacked by various kinds of weapons, he disappears from view and they are delighted.

28 While the Dānavas are shouting with joy, Varāha steps forth from the pile of weapons and crushes their heads. He tears them to pieces with his arms, feet and fangs, and slaughters others with the weapons they had released. Utterly destroyed by them, they are like heaps of riches enjoyed by many. ${ }^{196}$

\section{Skandapurāṇa 102}

One of the Asuras manages to escape and reports back to Hiraṇākṣa in Aśmakapura. Vipracitti and the others request that the king command them to slay the Boar. He approves. All the Dānavas set out. Varāha arrives at Aśmakapura and breaks the door

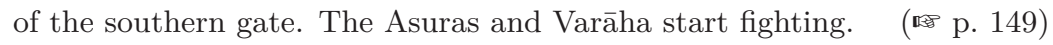

195 The arms of Varāha are compared to Indra's flag pole (SP 101.22b). Similes referring to Indra's flag pole (śakraketu, indraketu, indradhvaja) occur multiple times in the battle episodes. For an analysis of such similes in the two Sanskrit epics, see Brockington 1995.

196 The metre of SP 101.30 is Praharșiṇī. 
1 Seeing them all slain, one Asura escapes to Aśmakapura. ${ }^{197}$ Wild-haired, covered with dust and blood, he tells the door guardian to inform the king ${ }^{198}$ that the Asuras who had gone to find the animal (mrgendra) have all been slain. ${ }^{199}$ He should not underestimate the animal or bide his time. The Boar is great and cannot be killed by the Dānavas.

5 When he hears this news, Hiranyākșa rises from his seat in anger, roaring like a thundercloud and blazing like a fire enveloped in smoke.

7 Vipracitti and the Daityas bow down and tell him that he is the king of all Daityas - he does not have to exert himself while they are around. They will slay the Boar, and after cutting him up, they will bring him his meat! They are capable of slaying the Adityas, the Rudras, the Vasus, the Aśvins etc., and punishing wicked beings at any time. He should not leave. The king need only command them and they will do it. He should only act if they are incapable. If the king goes after the animal himself, it will be said that the Daityas are powerless.

17 Thereupon, the king of the Daityas (Hiranyākṣa) issues orders to them all. The Daityas accept his command, and prepare and mount their vehicles: Prahlāda, Anuhlāda, Śini, Bāṣkala, Jambha, Kujambha, Vātāpin, Ilvala, Virocana, Bali, Bāṇa, Vāta, Śambhu, Kāśyapa, Śambara, Mahāmāya, Kālaśambara, Pradīpta, Asiloman, Silika, ${ }^{200}$ Śarabha, Śalabha, Dhundhu, Mūka, Śatodara, Hradodara, Tāra, Tāraka, Maya, Hāla, Ajaka, Namuci, Vyamsa, Kārtasvana, Kubha, ${ }^{201}$ Ilvaka, Pilvaka, Vipāka, Pāka, Hastin, Duryodhana, Vipracitti, Hayagrīva, Mura, Naraka, Kụ̣da, Śakuni, Vṛṣaparvan, Śataketu, Mahārava, Makara, Rāhu, Svarbhānu, Kāla, Virādha, Kabandha, Dundubhi, Śatadundubhi, Sālva, Druma, Mayūragrīva, Kālanemin, Meghanāda, Andhaka, Mahiṣa, Ānanda, Śamaka, Āṭi and Baka.

197 'City of Stone', the name of Hiranyākșa's capital. See SP IV, 59, n. 142. The combination of the elements Nandivardhana and Aśmakapura in this myth brings to mind the names of the old capital of the Eastern Vākāṭakas, Nandivardhana (present-day Nagardhan: Bakker 1997, 84-85), and their enemies, the Aśmakas. Without suggesting a direct connection between the myth and the historical past, it seems likely that the combination of these two names would have rung a bell for the learned audience at the time. The worship of Varāha by the Vākātakas is evinced by the enshrined theriomorphic Varāha on Rāmagiri (present-day Ramtek Hill: Bakker 1997, 138-139).

198 After this, $\mathrm{R}$ and $\mathbf{A}$ insert an extra line to indicate that the speech is delivered to the king by the door guardian.

199 The words mrga, mrgendra and mrgapati are used with reference to Varāha throughout these chapters. We have rendered these references in the synopsis with 'animal'.

200 The name Silika is not known from any other source.

201 The name Kubha is conjectured on the basis of the parallel kārtasvanah kubhah at $\mathrm{SP}_{\mathrm{Bh}} 122.17 \mathrm{~b}, 138.3 \mathrm{~b}$ and $154.3 \mathrm{~b}$; moreover, Kubha is also mentioned at SP $83.5 \mathrm{c}$ and $\mathrm{SP}_{\mathrm{Bh}} 143.13 \mathrm{~b}$. 
Then all the Dānavas, skilled in weapons and tested in battle, set out on chariots, horses, elephants and by foot to slay the Boar. ${ }^{202}$

30 Nandivardhana is praised by the sages inhabiting his body. After he has killed all the Kiṃkaras, he reaches Aśmakapura, thundering like a cloud at the end of a yuga. The lord circumambulates the town anticlockwise and arrives at the southern gate. ${ }^{203}$ The Dānavas at the gate make a hallooing sound, by which the city is alarmed. He breaks and pulverises the śataghn $\bar{\imath}$ projectiles, the panel of the door, the cudgels and the kālacakra engines. ${ }^{204}$

35 The Dānavas come and shower the animal with a rain of missiles. Struck by the spears, lances and javelins, he exits the gate and withdraws to open ground. Taking him to be defeated, the Asuras follow him from behind and cut him with weapons, but steered by the gods, he springs up and fights the sons of Diti. ${ }^{205}$

\section{Skandapurāṇa 103}

Varāha tells the Dānavas to put up a just fight. Andhaka agrees, but Prahlāda retorts that they should not give up their own conduct. He covers Varāha with arrows; Varāha engages in battle with him. Andhaka and others pierce him with arrows. Varāha grabs the clubs of Andhaka and Vipracitti, and performs various moves. As they fight, he jumps into the air and topples the two Daityas from the sky. He crushes the Asura army. Overcome with shame, the Asuras once again surround him. (156)

1 Varāha addresses the Dānavas, who have reached the open ground. 'Don't you have any shame in fighting me, an animal, violently in battle? Or rather, you have no power, and it is false that you have conquered the gods. You are many and powerful, while I am just a single forest animal; your mind is not intent on a just fight (dharmayuddha). I do not have a weapon to fight with you who bear weapons. Abandon your weapons and fight with me one by one, in accordance with the rules (nyāya)!'

202 A remarkable comparison follows: 'just like the gods go to slay a demon'.

203 The circumambulation in anticlockwise direction and the arrival of Varāha at the southern gate portends the death of Hiranyākșa.

204 The identity of some of these weapons remains elusive, but they are clearly weapons used at the defensive walls. Several of them are listed in Arthaśāstra 2.3.34, in a passage on the construction of a fort. On yantras (siege engines or ballistae) and śataghn̄̄s (projectiles) in this context, see Singh 1965, 112-115, and Newid 1986 , 19-22.

205 The metre of SP 102.38 is Vamśastha. 
7 Andhaka tells the Dānavas that the animal is right. ${ }^{206}$ They should leave their weapons behind and fight one by one.

9 Prahlāda says that the just fight proposed by the animal is unwise. Such a fight is recommended between equals, but animals are always slain with weapons; this is the proper conduct (dharma). How can they abandon their own conduct (svadharma) and adopt that of animals? They must kill the vile animal without hesitation. Some wretched god is hoping to deceive them. Where is it seen or heard that animals should fight with men arm to arm? This is that wicked Viṣnu, resorting to deceit $(m \bar{a} y \bar{a})$ because he has no power of his own!

16 Thereupon the Asura lord (Prahlāda) showers him (Varāha) with many arrows. Andhaka, Vipracitti and all the Daityas and Dānavas do the same.

18 Heavily pierced by the Dānavas, the god looks like the Himavat covered with sunrays. Shaking off the arrows, he advances towards Prahlāda with ease. He instantly destroys his chariot and charioteer with his tusks and hands. Jumping down from the chariot, he strikes the Daitya in the head with his flag pole. Prahlāda jumps up and hits him in the chest with a club. The god abandons the chariot and returns to his original position.

24 Andhaka, Vipracitti, Śambara and Kālaśambara pierce Nandivardhana with arrows shaped like venomous snakes. ${ }^{207}$ As he is being pierced, he moves about in circles. He leaps like a lion; bearing the arrows, he lies flat on the ground, like a tiger; shaking off the arrows, he rises with a single foot, like a bull; like a bird, he draws circles in the sky; then, like a mountain, he stands still. ${ }^{208}$

29 After performing various moves (mārga) like this, he seizes the chariots of Vipracitti and Andhaka. Swinging them around, he hurls them to the ground, shatters them, and beats both Daityas in the head. The two raise their clubs and simultaneously hit Varāha in the head. He grabs the two clubs from their outstretched hands in anger.

206 For the formulaic phrase yugāntāmbudavan nidan ('resounding like a thundercloud at the end of a yuga') in 7d, see SP IV, 20-21.

207 The phrase śarair āśivișākārais in SP 103.24c is well attested: SP 79.28c, SP 80.19c, SP 80.24c, SP 87.1c, SP 91.24c. In addition, the variant śarair āșivișopamais occurs in even pādas, in $\mathrm{SP} 106.20 \mathrm{~b}$ and $\mathrm{SP}_{\mathrm{Bh}}$ 154.42d. Except for the last instance, its usage is thus limited to the part dealing with Hiranyākṣa's battles with the gods (SP 70-108), yielding further evidence for a separate authorship of this part of the text (cf. SP IV, 18-23). For the phrase śarair samnataparvabhih ('with arrows with a smooth shaft') in SP 103.25b, see SP IV, 21, and Brockington 2000, 343. These phrases attest to the influence of the battle books of the Mahābhārata.

208 For a similar list of moves, see SP 106.1-5. 
33 Then Janārdana (Viṣnu), skilled with the club, ${ }^{209}$ performs various circling manoeuvres (mandala): ${ }^{210}$ throwing, discharging, running, turning round, turning back etc. Whirling around, Nandivardhana casts one club at Andhaka and another at Vipracitti. The two Dānavas sidestep the two clubs and dash towards Varāha. As they attack, Varāha strikes Andhaka with his fist and Vipracitti with his foot. Andhaka grabs his fist and Vipracitti his foot, saying 'you are done for!' Seized by them, he quickly jumps into the air. Lifting up the two Daityas, he looks like Garutman carrying the elephant and tortoise for dinner. ${ }^{211}$ He shakes his arms and foot and shakes off the two Daityas. The two Dānavas fall to the ground, like two bolts of lightning crashing from the sky.

44 Varāha crushes the chariots of all the Daityas. He seizes one by the railing and hurls it into the ocean; another he pulverises by stamping it with his foot. Dashing chariot against chariot, foot soldier against foot soldier and elephant against elephant, ${ }^{212}$ he leads them to Yama's abode.

47 The Daityas and Dānavas run away, but return, overcome with shame. The Asura lords look each other in the face; filled with shame, they once again surround the god in the body of a boar. ${ }^{213}$

\section{Skandapurāṇa 104}

The Dānavas attack Varāha, but he defeats them all. Vipracitti and Varāha fight a duel, which ends in Vipracitti being hurled onto Hiranyākṣa's palace. Hiranyākṣa asks him who on earth did this. Vipracitti tells him that the boar is no ordinary boar, but a product of Viṣnu's sorcery. He begs him to leave the city. Hiraṇyākṣa refuses, for he wants to slay his brother's killer. He prepares himself for the fight. ( p. 164)

209 The expression gadāviśāradah samyak (33c) is repeated in 36a.

210 The club fight between Ajaikapād and Kālanemi (SP 87.27-38) has some similar descriptions. Cf. also SP III, p. 29, n. 296, for references to various wrestling moves found in the Mahābhārata, which include parivṛtta and nivrtta.

211 This refers to the story of the two brothers Supratīka and Vibhāvasu, who cursed each other to become an elephant and a tortoise and were eaten by Garuda. See MBh 1.25.10-1.26.26.

212 The same image is used in SP 93.19.

213 The metre of SP 103.48 is Upajāti. 
1 The angry Dānavas violently stab the animal with weapons. They attack the Boar (Varāha) like deer a tiger, like elephants a youthful lion. He enters the Ocean and drinks up its water, like the fire at the Mare's Face (Vadavāmukha). Opening his big mouth, he also swallows the weapons of the Daityas. He then speeds to the Dānavas, like a lion towards elephants, like a śarabha towards lions, etc. The protector of the world (Lokapa) races towards the Dānavas, just like the distracted mind runs after the senses. On reaching them, he drives them away, like Rudra chasing cattle. ${ }^{214}$ Some he sends to Yama's abode with his feet, others with his hands, others still with his tusk. Striking Śambara and Kālaśambara with his palm, Naraka with his foot, Hayagrīva with his fist, and Namuci and Mahāmāya with his chest, he causes them to fall to the ground.

12 Vipracitti beats Varāha's chest with his fist; Varāha strikes Vipracitti in the side. Hit by Varāha, Vipracitti strikes him in the chest with a sword. Varāha ignores the blow and beats him in the head with his fist. Sent spinning by the blow, the Daitya drops to the ground. ${ }^{215}$ The animal approaches Vipracitti and grabs him by the foot. Whirling him round and roaring repeatedly, Nandivardhana hurls him towards the city. Being thrown by him, the Dānava lord (Vipracitti) looks like a solitary rain cloud. He crashes into the palace of Hiranyākșa. ${ }^{216}$ He collides with its watchtower, like a bolt of lightning striking the highest mountain.

21 Lured by the noise, Hiraṇyākṣa himself hastily appears and sees the Dānava chief, who is momentarily unconscious from the blow. The king revives him with cold water, fans and jewels. After he has been revived and is seated on a throne, the king questions the Daitya.

25 'Who lifted Himavat or the Earth with its oceans, which Viśvakarman could do only with a great army? Who loosed Mandara? Who conquered death? Who threw you? Who on earth is so powerful? The feat of throwing you is like lifting the Earth, loosing Mandara, and imprisoning death! Who lifted you aloft in battle, you who are comparable to Rudra, Indra and Death (Mrtyu)? Who has this power? Who has such power of arms spoken of in the three worlds? Tell me!'

214 This refers to the Vedic Rudra, who is feared for slaying cattle. Cf. VāP 26.134ef (jaghāna haihayān kruddho rudrah paśugañān iva) for the same simile. The compound mahājaladanisvana ('rumbling like a great rain cloud') in SP $104.8 \mathrm{~b}$ also occurs in SP 77.66c, SP 90.26d, MBh 8.8.36b, MBh 8.15.33b and HV App. 1 No. 42B 1.1762. Cf. further tadā jaladanisvanah in SP 101.10d.

215 For the phrase papāta bhūmau vegena vātāhata iva drumah in SP 104.15cd, cf. $\mathrm{SP}_{\mathrm{Bh}}$ 154.16cd (sahasā bhūmau for bhūmau vegena) and $\mathrm{MBh} 11.1 .9 \mathrm{~cd}$ (papāta bhuvi durdharșo vātāhata iva drumaḥ).

216 SP 104.19a $\approx$ SP 100.50c. 
30 Sighing deeply and looking about repeatedly, Vipracitti speaks. 'This [power] - beyond men, gods and demons - has never been seen nor heard of before. Nobody has the kind of power that the Boar (Varāha) has. While he was cut in battle with many weapons, he did not experience suffering or pain, nor did he lose consciousness. Whatever discomfort he may feel when bitten by a mosquito, he does not experience even that when he is smitten by the Daityas and Dānavas, how much less fear them. He goes after them like a lion goes after small deer. He is neither an animal, nor a god, nor a demon: some sort of misfortune of the sons of Diti has come! I was beaten in the head by him, seized and hurled into your palace. I don't know where the other Dānavas and Daityas are. I think they have all been slain. He is invulnerable and we are weak; after hearing this, do what is beneficial for the sons of Diti! All the sages and gods can be seen in his body. I think it is sorcery prepared against you. Turn your mind away from battle and do what is beneficial for the Daityas! He is powerful and the Daityas are weak; he is immortal and we are mortal; he is unconquerable and the Daityas have been conquered. Do not send us into battle! Let us abandon Aśmakapura and withdraw to the Ocean's water. Do not look down on the animal, thinking he is only an animal; in the past, you thought the same of Narasimha. ${ }^{217}$ As long as you survive, so long shall the Asuras stay alive. The sons of Diti and Danu should not perish; let us leave the city!'

47 Hiranyākșa responds. 'No doubt the animal who lifted you aloft is a great being. Today I have enjoyed kingship for four thousand divine years, and the fifth [cycle of a thousand years] has come. The gods are still ruined. Why, then, having ruled without rival, should I be afraid, and enter and dwell in the water, like a serpent? If Viṣnu has taken on the form of the Boar (Varāha), that is my business; do not fear, lord of the Dānavas! I have undecaying power and I am more powerful than him. What concern should I, who can kill an elephant, a lion and a śarabha, have for this animal, who out of fear of me has abandoned his own form and turned into an animal? The Boar challenges me, steered by all the gods because of fear of me, and so victory is mine. For he has hurled you forth as a messenger, hastening towards his own death. I will not rest today until I have killed my brother's killer!'

57 Thereupon he instructs his charioteer to prepare the chariot. He enters his residence to comfort his wives. Blessed by them, the son of Diti looks at them all and takes up his armour. ${ }^{218}$

217 When Narasiṃha destroyed his park, Hiraṇyākṣa’s elder brother Hiraṇyakaśipu wanted to present the lion to the queen as a pet.

218 The metre of SP 104.58 is Upajāti. 


\section{Skandapurāṇa 105}

Hiranyākșa sets out on his chariot. Leaving the city, he sees many bad omens. When he catches sight of Varāha, he shoots arrows at him. Varāha is paralysed, but the gods heal him with mantras. He attacks Hiranyākșa's chariot, but the latter ties him up with snakes. Garuḍa releases Varāha from the snakes. Varāha attacks once more, but Hiranyākșa pierces his heart with an arrow. Varāha falls to the ground, but the sages revive him. The gods and sages strengthen him with their tapas. ( p. 174)

1 Hiranyākṣa takes up his bow and arrows, and puts on protective armour. He has a yellow beard, four tusks, pointed ears, a mighty jaw, arms reaching to his knees, long eyes, the proportions of a fig tree, [the marks of] a lotus and a conch on his hands, a wheel and a fish on his feet, web-like hands, web-like feet, a horse's penis, ${ }^{219}$ eyes like the morning sun, and is dark like a heap of collyrium. He sets out with a frown on his face.

5 At the gate, he inspects the chariot prepared by the charioteer. Measuring a thousand nalvas, it is furnished with ten thousand divine horses and provided with a skull staff as a flag pole. ${ }^{220}$ He mounts the chariot, while the Dānavas shout 'victory!' ${ }^{221}$ Standing on the chariot, he shines like a sapphire placed on a golden vessel. His diadem looks like a forest fire on a peak of Mt Collyrium. ${ }^{222}$

10 He commands the charioteer to set out, just like a disease commands an ailing person to die. ${ }^{223}$ The charioteer commands the horses, just like Yama, commanded by the creator (Dhātṛ), commands the lives of men. The

219 Several of the items in this description of the king feature in the list of the thirtytwo marks of a great man (mahāpurușa). The listing of such marks is not limited to Buddhism, but representative of a shared tradition of royal ideology in ancient India. See Zysk 2016, 160-172, 195-205, with references to earlier scholarly literature and relevant sources. For 'a horse's penis', the Buddhist lists typically have 'a penis concealed in a sheath' (Zysk 2016, 198). See, however, Mahāvastu p. 305, 1. 10, which indicates that it conveys the same idea: kośavastiguhyamedhram hayarājasya yādrśam; Levman 2005, 37, for the same attribute in the Gandavyūhasūtra; and Powers 2009, 13, for the explanation of the Buddha's attribute by Buddhaghosa.

220 Compare the description of Hiraṇyākșa's chariot in SP 77.58-59. For the skull staff serving as his flag pole, see SP 77.65.

221 SP 105.7cd includes a comparison with the sun on his chariot, just as in the first description of Hiraṇyākṣa's chariot (SP 77.61cd).

222 Comparisons with Añjanagiri/Añjanācala, or a heap of collyrium, to indicate a dark complexion are common in the text. Cf., e.g., SP 40.2b, SP $105.4 \mathrm{~b}$ and $\mathrm{SP}_{\mathrm{Bh}}$ 152.4a.

223 SP 105.10cd-12 is only found in $\mathrm{S}_{3}$. The unique similes in this passage make an original impression, and it is possible that the passage was dropped due to eyeskip from gamanam prati to samyamanam prati (ten pādas, roughly the length of one line in an old palm-leaf manuscript). 
swift horses carry the chariot to victory, just like dharma and adharma carry a dead man to Yama's abode (Samyamana).

13 Vipracitti is positioned on his side, just like a comet and its reflection in the sky. ${ }^{224}$ Hiranyākșa leaves Aśmakapura to the sound of conches and drums. All the Asuras accompany him, in front, at the rear and at his sides, like the planets accompanying the sun. ${ }^{225}$

16 As he sets out from the city, the Daitya lord observes omens foreboding danger, but he disregards them. A black snake crosses his path; a redfaced vulture alights on his flag pole; another vulture circles above his chariot; the flag pole is broken; the left side of his body trembles; the horses do not neigh; the elephants are free from rut. The Daitya sees many such fear-inspiring omens.

21 Not far from the city, the Dānava beholds the animal, fighting fearlessly. Drawing his great bow, the mighty Daitya ${ }^{226}$ comes charging on his chariot. Scaring away the sons of Diti, Varāha runs up towards Suvarṇākṣa (Hiraṇyākṣa). The Dānava pierces all his joints with many pointed arrows. ${ }^{227}$ Pierced by the arrows the animal no longer moves.

26 When the gods see him paralysed, they remove the arrowheads from him with special mantras. Then the animal again speeds forth towards the son of Diti (Ditija). Struck by arrows, he reaches the Daitya's chariot and tries to seize it, but the charioteer turns the chariot round. The Daitya binds the animal, whose hands are outstretched, with the snake weapon; ${ }^{228}$ he falls to the ground.

224 We follow Bhatțarāi in the relocation of SP 105.13cd. The original displacement, which must have happened at an early stage of transmission, can be explained by eyeskip between avasthitah in $13 \mathrm{~b}$ and $13 \mathrm{~d}$. A scribe may have added $13 \mathrm{~cd}$ in the margins, which were then inserted in the wrong place in a subsequent copy of the text. We have also considered keeping the current pādas $13 \mathrm{~cd}$ where they are in the manuscripts (i.e. after 15) and rather placing 13ab before them. A third and more radical option would be to place the current verse 13 (which already involves relocation of two pādas) after verse 14 . The presence of tasya in 13a is much smoother when 13 is placed after 14 . This would yield the most logical order of presentation: first, a verse describing Hiraṇyākṣa setting out from Aśmakapura (current 14), followed by a verse describing his closest companion, Vipracitti, at his side (current 13), again followed by a verse describing all the Asuras surrounding the chariot (current 15). This order of presentation would also be more or less equivalent to the earlier description of Hiranyākṣa setting out for Amarāvatī in SP 77.67-72. It would, however, involve more relocation of pādas.

225 SP 105.15 is reminiscent of SP 77.72, which, however, has the moon instead of the sun.

226 Again, the terms Daitya and Dānava are used interchangeably.

227 For the formulaic phrase tasyāpatata evāśu in 24a, see SP IV, 21.

228 Presumably a mantra weapon is intended. 
31 On seeing that he (Varāha) has fallen, the Daityas strike him harshly, but Garutman quickly releases Nandivardhana from the snakes. Once released, he jumps up, driving the sons of Diti away, and quickly attacks Hiranyākșa's chariot. As he is advancing, the Daitya pierces him in the heart with an arrow. ${ }^{229}$ The animal faints and falls to the ground. ${ }^{230}$

36 All the assembled gods cry out, the sages praise him, and the sun loses its light, but he is braced by the sages. Regaining consciousness, he asks the gods to reinforce him, for he cannot overcome the Daitya with so little strength. Thereupon, the gods and sages fill him with their tapas. Strengthened by them, his body looks like death, time and fire at the end of a yuga. ${ }^{231}$ Praised by the gods and sages, shining like seven suns, he looks like Devadeva about to consume the worlds. ${ }^{232}$

\section{Skandapurāṇa 106}

Varāha performs various manoeuvres. Hiraṇākșa and Varāha provoke each other, boasting of their powers. As they start fighting again, Hiraṇyākṣa uses mantras. Reciting 'homage to Rudra!', Hiranyākșa hurls his spear at Varāha, frightening the gods. (霹 p. 181)

1 The god (Varāha) performs various manoeuvres: ${ }^{233}$ he jumps like a lion, he approaches like an elephant, he swallows weapons, he slays Dānavas with trees and rocks, he moves about in the air like the king of birds (Garuḍa), he laughs in anger like the crack of a thunderbolt, he suddenly makes his appearance after making himself small.

5 Hiraṇyākṣa addresses him loudly. 'You will not escape! I will kill you and present you as a bali offering to Rudra! The fruit of your treacherous killing of my elder brother has come about!'

229 For the stock phrase śarenānataparvaña (SP 105.34b), see SP IV, 21, n. 51.

230 The simile in SP 105.35cd, 'he fell down on the ground, like Śakra's flag pole at the end of [his] festival', is shared with SP 109.20cd. Cf. also SP 76.46cd and SP $87.21 \mathrm{~cd}$.

231 Similes featuring the expression yugāntāgni- (SP 150.40c) are popular in the battle descriptions (e.g. SP 73.49d, SP 73.72d $=\mathrm{SP} 110.6 \mathrm{~b}=\mathrm{SP}_{\mathrm{Bh}} 114.76 \mathrm{~b}, \mathrm{SP} 80.15 \mathrm{~d}$, SP 98.22d, SP 107.30c).

232 The metre of SP 105.41 is Upajāti.

233 Cf. SP 103.25-28. 
8 Viṣnu responds. 'I have killed the Daitya (Hiranyakaśipu) in the form of a man-lion (Narasimha). Now your death is certain! Whether you go to the sky, the nether region, the mountain or the ocean, you will not escape! Whatever power, asceticism or magic you have, I will blow it all away from your body, together with your life!'

12 Hiranyākṣa returns. 'When I paralysed you with arrows, the gods revived you with mantras. When you were bound by the [snake] weapon, the king of birds released you. When you passed out, the gods revived you. I will slay you again! What power do you have - except for the boon of Maheśvara - even to touch me with your hand? You come to me in battle, resorting to a body consisting of the worlds and steered by them (the gods), while I am furnished with my own tapas and power. And yet you, together with the gods, are unable to fight or attack me. The difference between the two of us is massive indeed. If one is of high birth, wise and intent upon the path of the good, he can give up the battle, knowing himself to be defeated [by a stronger opponent]. Who but you would endure the shame of becoming an animal? Daityas don't do this! You are not made to be my death, but I am made to be yours. The Siddhas and Cāranas here will behold the difference between the two of us as we fight!'

20 Hiraṇyākṣa strikes Varāha with arrows that are like venomous snakes. Though injured by him, Varāha seizes his chariot. Taking it by the railing, he hurls it along with its charioteer and horses. The horses' halters are broken and the chariot falls apart. Hiranyākșa proceeds on foot with his bow, and hits the animal with the weapon of stupefaction (mohanasstra). ${ }^{234}$ The stupefaction enters Nandivardhana, but the gods remove it again with the power of mantras.

26 The Daitya lord attacks with many kinds of mantras, but he does not cause him (Varāha) any pain. Laughing, Varāha uproots a tree ${ }^{235}$ and strikes the Daitya in the head. Because of the blow, the Daitya's bow slips from his hand together with the set of five arrows. The Daityas and Dānavas wail and they hit Varāha with many weapons. He opens his mouth and devours all the weapons.

31 In anger, Hirạ̣yākṣa seizes his spear, reciting 'homage to Rudra!' He hurls the spear, resembling the fire at the end of a yuga, at Varāha. When the Suras and Siddhas see it flying, they cry out loud. ${ }^{236}$

234 Presumably, this is a mantra weapon, recited along with the shooting of the arrow.

235 The phrase vrkșam utpātya vegena in SP 106.27c also occurs in SP $71.42 \mathrm{c}$ and SP 110.10c.

236 The metre of SP 106.33 is Upajāti. Pādas ab are nearly identical with SP 85.31a and c, which are likewise in Upajāti. 


\section{Skandapurāṇa 107}

The spear hits Varāha in the heart and he falls down. Revived again by the tejas of Maheśvara, he pulls out the spear and sends it hurtling back to Hiraṇyākṣa. Hiranyyākṣa then takes up his sword, but Varāha strikes it away from him. The two start wrestling for a very long period of time. When Hiranyākșa's strength finally weakens, a voice instructs Varāha to kill Hiraṇyākṣa with the cakra of Maheśvara. He calls the cakra to mind and hurls it at Hiranyākșa. The latter tries to ward it off with magic, but it decapitates him. ( p. 187)

1 As he is occupied with all the Daityas, the animal (Varāha) does not notice the approaching spear. Struck in the heart, the son of Aditi falls down, apparently dead. ${ }^{237}$ Invisible beings wail, the oceans overflow, the sun loses its light, there is a battle between the planets, and celestial vehicles fall. ${ }^{238}$

5 The sages mutter prayers and Brahmā calls to mind Mahādeva. Then all returns to normal and Varāha rises up. The divine tejas of Maheśvara enters Madhusūdana. Tearing out the spear, Mādhava resembles a thousand fires. He strikes the Daitya in the heart with it, like Guha (Skanda) the Krauñca mountain. The mighty Asura feels no pain, like a wise man facing difficulty.

10 Tearing out the spear and casting it aside, he pulls out his sword and strikes Varāha in the head. Nandivardhana feels no pain, engulfed with blood. He looks like the Himavat, colourful with minerals. ${ }^{239}$ With the back of his hand, ${ }^{240}$ he strikes the sword from the Daitya's hand.

14 Thereupon, the two skilled in wrestling fight like two angry elephants, like two buffaloes, like two lions, etc. They fight each other with 'hook grips', 'rope grips' ${ }^{241}$ throws, slaps, fists, feet, nails, tusks etc. The battle lasts for eighteen plus fourteen [divine] days plus a thousand human years, until the Daitya becomes weak.

237 Cf. HV App. 1 No. 42 1l.594-595, where Varāha is likewise struck in the heart by Hiraṇyākṣa's spear.

238 Several lines from this chapter are quoted in the Adbhutasāgara. See the apparatus for details. Ballālasena's attributions (skandapurāne varāhaparājayanimittam, skandapurāne hiranyākșavadhanimittam, etc.) indicate that he knew the context of these lines in the SP.

239 The simile once again reminds us that the Boar's body is white. See n. 167 on p. 57.

240 The Nepalese manuscripts consistently have apāhasta for apahasta 'back of the hand'.

241 Since Varāha and Hirạ̣yākṣa have now started wrestling, they do not hold any weapons, but the special motions of their hands are compared to weapons. 
20 On noticing that the Daitya has weakened, a bodiless voice addresses Varāha from the sky, ${ }^{242}$ telling him that he cannot slay the mighty Daitya like this. The cruel one has been weakened by Maheśvara's tejas; ${ }^{243}$ his time has come. Vaikuṇtha must kill the Daitya king with the cakra of Maheśvara. ${ }^{244}$

24 On hearing this, Nandivardhana lets go of the Daitya king after kicking him in the chest. The Daitya resembles the sun who has been swallowed and released by Rāhu.

26 Looking at the radiant Daitya, the Bhagavat calls the cakra to mind, paying homage to Pinākin. All the directions glow like a firepit, there is a tremendous noise, Siddhas fall to the ground, fear enters the gods, the sages pray for well-being, the oceans dry up, snakes and birds perish, the Daityas and Dānavas enter the city, and meteors fall from the sky at the arrival of the cakra, the wheel of death. The great cakra, having razor-sharp edges, born from the water, ${ }^{245}$ and killing the water creatures, reaches the hand of Varāha to the sound of a hundred bolts of lightning. Beholding its arrival, all beings fall to the ground and none can see anything.

34 Then the god, taking on a magnificent form that pervades the three worlds, hurls the cakra at the Dānava. Resembling the doomsday fire and splitting the sky, it swiftly approaches the Dānava. He strikes it with many missiles as it approaches, but the great cakra reduces them to ashes. Thereupon, he (Hiranyāksṣa) unleashes magic $(m \bar{a} y \bar{a})$ : relating to fire, earth, wind and water, blinding, deluding, paralysing, blocking, crushing and other kinds. ${ }^{246}$ The cakra destroys them all. When it reaches his head, it uproots his head like a mountain. The massive head falls down like the tall peak of Meru. ${ }^{247}$ It no longer shines, just like the disc of the moon at the end of

242 For the motif of the bodiless voice from the sky, see above, SP 97.8. It remains unclear to whom this voice belongs. Hopkins 1915, 67, discusses the same motif in the Sanskrit epics.

243 The implication is that it is not so much Varāha himself who has weakened Hiranyākșa while wrestling, but the tejas of Maheśvara that had revived him earlier (verses 6-7 above). There seems to be a slight inconsistency in the text, since Siva had prophesised that Varāha would instantly slay Hiranyākṣa the moment his tejas would enter him (SP 98.30). This obviously leaves out the intervening period of the long-lasting wrestling match.

244 According to SP 68.10, Viṣnu had received the Sudarśana cakra from Śamkara on Mt Svarnākșa. $\mathrm{SP}_{\mathrm{Bh}}$ 122.11cd (see the following footnote) relates that he wielded the cakra fashioned by Rudra.

$245 \mathrm{SP}_{\mathrm{Bh}} 122.11 \mathrm{~cd}$, in a passage where Viṣnu is about to kill Kālanemin, likewise refers to the cakra as abja: cakram tad abjam sasmāra yat tad rudrena nirmitam.

246 Several of the kinds of magic listed here are well known from other sources. See Goudriaan 1978, 251-412, on the satkarmāni.

247 Cf. HV App. 1 No. 42 1l.599-602, where Varāha likewise decapitates Hiraṇyākṣa 
the night. Biting its lips and teeth, the head falls down like an overgrown mountain peak. ${ }^{248}$

\section{Skandapurāṇa 108}

The gods and sages celebrate, but the Asuras are afraid. Varāha searches for the Earth and finds her held captive under the Śankha mountain. He hurls the mountain into the Ocean and re-establishes the Earth in her proper place, returning the three worlds to Indra. The sages and gods request that Viṣnu resume his former form, but Varāha replies that he wants to enjoy the Boar form a little longer. The gods return to their abodes. Varāha enjoys himself with Apsarases in the form of female boars every day. $($ p. 195)

1 After the Daitya (Hiraṇyākṣa) has been slain, all the gods and sages celebrate. Flowers fall from the sky and invisible drums resound. The world returns back to normal. The cakra disappears, and the gods, sages and people become calm and see that the Daitya has been slain. The Asuras shut the gates and stand guard at the ramparts, afraid for and protective of their lives.

6 The Bhagavat (Varāha) searches for the Earth (Pṛthivī), frightening the Asuras. He searches outside and tears up trees; he uproots mountains, crushes the divine parks, and destroys the tanks. Then he goes southward, roaring like a thundercloud when he reaches Mt Śankha. In fear, the Asuras, stationed behind the ramparts, observe the animal running into all directions. He uproots the Sankkha mountain and finds the Earth bound and guarded by the Dānavas. He hurls the mountain into the Ocean and slays all the Dānavas guarding her. After driving away the Nāgas ${ }^{249}$ and seizing the Earth, he departs, meeting the [surviving] Daityas and taking the jewels with him. ${ }^{250}$

with the cakra, and the decapitated head falling down is compared to the peak of Meru struck by Indra's thunderbolt.

248 The metre of SP 107.41-43 is Upajāti.

249 The Nāgas had served as ropes for tying the Earth under the Śankha mountain (SP 95.13).

250 For the motif of taking the enemy's jewels as a sign of victory, see SP 93.33. 
14 As he carries the Earth, clinging to his tusk, he looks like an elephant with a lotus plant dangling from his tusk. ${ }^{251}$ Carrying her through the Ocean, he resembles Brahmā, who carried the Earth (Vasudhā) in the form of the Boar (Varāha) at an earlier age. ${ }^{252}$ After he has crossed the Ocean, Nandivardhana re-establishes the Earth (Mahī) in her own place. Then Madhusūdana hands over the three worlds to Śakra, and affirms their friendship. He declares that he will slaughter any other Asuras that may become his (Indra's) enemy.

19 All the sages and gods ask him to resume his former form. Varāha replies that he has not yet enjoyed the pleasure (rati) appropriate to his present form. He will delight in it for a while, before becoming a god again. The gods make a circumambulation and return to their abodes.

23 When the gods have gone, Nandivardhana starts amusing himself. Thousands of beautiful Vedic Apsarases serve him as female animals ( $m r g \bar{\imath})$ and he dallies with them. Nandivardhana amuses himself like a rutting elephant in a forest with female elephants. He delights on the bank of the Ocean like another Airāvata. The Siddhas and sages in the sky rain down flowers upon him; others praise and circumambulate him. All play divine drums continuously. Apsarases dance in front of Varāha and Gandharvas play music and sing, pleasing him. The gods, Yakșas, Yātudhānas etc., all the princes and congregations come and behold the feast of Varāha. The joyous (nandivardhana) feast of Varāha takes place every day. It is frequented by sages, gods, Siddhas, Gandharvas etc. ${ }^{253}$

251 This simile is strongly suggestive of early material representations of Varāha lifting the Earth, where she is depicted as a woman hanging from the Boar's tusk by her arm. A particularly striking example is the Gupta-period Naravarāha from Eran (Madhya Pradesh), currently in the Harisingh Gour Archaeological Museum of Sagar University (Harle 1974, 12, plate 26: 'one of the finest of all Indian sculptures'). Cf. also MkP 4.54: bhūtvā purā varāheṇa tuṇdeñāpo nirasya ca | ekaȳa damștrayotkhātā nalin̄̄va vasuṃdharā $\|$.

252 SP 108.14b (vahan bhāti mrgeśvarah) $=108.15 b$. The two verses form a pair, with 14 focusing on the Earth and 15 on the Boar. For the distinction between the cosmogonic boar form of Brahmā and the demon-slaying boar form of Viṣnu, see n. 167 on p. 57. For further discussion, see Brinkhaus 1992 and Dokter-Mersch forthc.

253 The metre of SP 108.34 is Upajāti. 


\section{Skandapurāṇa 109}

Varāha has a son called Vṛka. He arrives at Kārttikeya's dwelling near Gaurīkūṭa and destroys its forest. Kārttikeya's Ganapa Kokavaktra tries to calm him down, but to no avail. Vṛka is taken captive. Kārttikeya arrives and Kokavaktra shows Vṛka to him. Skanda tells him that Vṛka should be punished. Nārada sees this and informs Varāha that his son is being tortured. The latter sets out for Gaurīsikhara amidst ominous portents. ( p. 201)

1 After enjoying himself for a long time, Varāha has a son called Vṛka with his wife Citralekhā. ${ }^{254}$ Vṛka constantly roams the earth, killing living beings. He reaches the abode of Kārttikeya on the Himavat near Gaurīkutta. ${ }^{255}$ Unwitting, he tears up all kinds of magical trees and digs up the hills with precious stones and minerals. ${ }^{256}$ He ravages Kārttikeya's forest.

7 Attracted by the noise, a Ganapa of Skanda called Kokavaktra comes out. ${ }^{257}$ Observing the big, handsome cub, Kokavaktra addresses him with a smile. 'Whose son are you? Don't you know that this is Skanda's home, beloved by the gods and worshipped by the Gaṇeśas? Kumāra has gone to Mandara and he has instructed me to protect it. I am pleased with your form and power; if you stop, I will repair what has been broken. I will speak up for you so that the god will not be angry, and make you a Pravara. ${ }^{258}$

15 Vṛka retorts to Kokavadana that he is afraid neither of Kumāra nor of him. Kumāra and his Ganeśvaras do not have the power that he has. They should show their strength. He will utterly destroy the forest. Thereupon, he tears up a tree and throws it at Kokavaktra. Laughing, Kokāsya takes up the tree and strikes Vṛka in the head with it. Destabilized by the blow, Vṛka drops to the ground, unconscious. Kokāsya laughs, ties him up with

254 Citralekhā, a well-known Apsaras, must be one of the Apsarases who turned into female boars $(m r g \bar{\imath})$. She is not known as the wife of Varāha from other sources.

255 On the possible location of this mountain peak, see Bisschop 2006, 184-185, and SP III, 5-6, n. 9. Gaurīkūța, also called Gaurīśikhara, is named after Devī, who performed tapas there to be fair-coloured (gaur̄̄). Its Māhātmya is given in SP 69 .

256 For SP 109.5cd, cf. SP 28.16ab and SP 34.23ab.

257 The name of the Gaṇa Kokavaktra/Kokamukha 'Wolf-faced', in combination with a story about Varāha, has led several scholars to speculate about a possible connection with the deities Śvetavarāhasvāmin and Kokāmukhasvāmin mentioned in the Dāmodarpur copperplates from Bengal (Sircar 1971, 275ff.). See Granoff 2004, 135-136; Bakker 2014, 245-246; and Kropman 2019, 115-116. Copperplate 5 mentions that these two deities, imported to Koṭivarșa, had their original home in Nepal (himavacchikhare).

258 Kokavaktra addresses Vṛka as sūkareśvara, which indicates that he is a boar just like his father. For 'Pravara' (more or less the equivalent of a Gana), see SP II B, 75 , n. 262. 
ropes and leads him to the dwelling. When his fellow animals see Vṛka taken captive, they flee in fear for their lives.

23 At this moment, Kārttikeya arrives on his peacock, surrounded by Gaṇapas. Kokavaktra updates him and shows him Vṛka taken captive. He tells him that Vrrka is known to be the son of the one who in his Varāha form killed Hiranyākșa. Since he, together with his companions, destroyed the forest, he (Kokavaktra) tied him up with nooses. He (Skanda) should now deal with him.

27 Skanda replies that he cannot let him go, for the word of his release would reach the rest of the world. Deva will for sure say that he is frightened, inasmuch as he has released the son of Varāha, who has behaved badly. Sthāṇu has told him that he should show no mercy on Varāha's body when he challenges him in battle. ${ }^{259}$ He has given him the samvartik $\bar{a}$ spear, which destroys all weapons. The villain (Vṛka) should be seized quickly and bound with force in public.

32 Thereupon Skanda's Gaṇanāyakas tie him up and torture him outside. He wails like a man in hell.

34 Nārada sees this and informs Varāha that his son Vṛka is being tortured by Kārttikeya's servants. Because of his childish nature, Skanda does not bend to the god who strives for the good of the world; holding himself to be more powerful, he has captured his son. He should go and release him!

39 After hearing Nārada's speech, Varāha roars in anger and a destructive fire shoots forth from his eyes. Rising up from his seat, he sets out for the Peak of Gaurī. Causing the earth to tremble, he proceeds unimpeded while seeing ominous portents. A snake cuts his path, and when his tusk fells a tree it drops on the ground. Blood flows from his mouth, his heart quivers, while he has an apprehension that blocks his speed. Opposing winds blow and he falls with his chest to the ground. Thinking about his son, he starts sweating heavily. He proceeds on his way, disregarding the portents. Observing the scene, the gods prepare worship in heaven. He goes to Gaurīśikhara, accompanied by Siddhas, Yakṣas etc. ${ }^{260}$

259 Apparently, Skanda has already been warned about Vṛka and Varāha on his visit to Mt Mandara.

260 The metre of SP 109.48 is Upajāti. 


\section{Skandapurāṇa 110}

Kārttikeya teases Vṛka. Varāha arrives and starts fighting. His cakra has no effect on Kokāmukha, so he abandons it. Kārttikeya strikes him in the heart with the samvartikā spear. Viṣnu gives up his Boar body through yoga. He goes to Śiva and praises him. Siva is pleased and grants him a boon. Viṣnu requests that he teach the gods the Pāśupata observance. ( p. 210)

1 Kumāra leaves his dwelling to play with the Ganapas. He brings Vṛka and sets him free, laughing, but then he catches him again, releases him and catches him yet again. While he is playing thus, Varāha arrives. He seizes a rock and hurls it at Kārttikeya. Kokāmukha captures it in flight. ${ }^{261}$ Thereupon the lord (Viṣnu) hurls his cakra at the Gạ̣a (Kokamukha), but it does not reach him and returns [to Viṣnu]. Viṣnu rejects the cakra with contempt and the cakra quickly returns home. ${ }^{262}$

10 When the cakra has gone, Nandivardhana pulls out a tree and strikes Kumāra with it. The Fire-born One (Analātmaja) pays no attention, but hurls the samvartika spear in anger. Burning and roaring, the spear advances to kill Varāha. Nandivardhana strikes the spear mid-air with many kinds of weapons. The spear reduces them all to ashes and penetrates his heart. He then abandons his body through yoga and takes on another one.

16 When the best of the gods has taken on his old body, he goes to Bhava's mansion, accompanied by all the gods. There he sees Mahādeva seated on a golden throne, with Pārvatī by his side and surrounded by many Gaṇas who are dancing and singing. On seeing Śamkara, Viṣnu starts praising him with hymns and speaks sweetly.

21 'I have slain Hiranyākssa, after taking on the Varāha form, strengthened by your tejas. You are the eternal cause of creation and destruction; by you all the world is pervaded; thanks to your grace I, Brahmā, Śakra and all the other gods are worshipped in the world. When you are pleased, we all are pleased, but when you are angry, our destruction is nigh.'

25 Śamkara says that he is pleased with Viṣnu's devotion and his endeavour for the gods - he may choose a boon! Vị̣nu requests that he teach [them] the Pāśupata observance, by which they may slay the Daiteyas and be free

261 The metre of SP 110.5 is Upājāti. Kokāmukha is metri causa for Kokamukha. Pāda a has several close parallels in the text: SP 85.31a, SP 106.33a and $\mathrm{SP}_{\mathrm{Bh}}$ 136.17a.

262 Presumably, the cakra returns to Maheśvara, for it was earlier referred to as Maheśvara's cakra (SP 107.24). 
from suffering and grief. ${ }^{263}$ Deva promises to tell them the secret Pāśupata observance, by which they will attain their desires. Having spoken thus, Devadeveśa goes to heaven and takes leave of Devī. Sarva, mounting the bull, goes to Mt Sumeru to teach the observance. ${ }^{264}$

\section{Skandapurāṇa 111}

The Mothers of the World approach Devī and ask her to instruct them in dharma. Devī teaches them about various kinds of donations, such as the gift of food, that of water and that of a cow. She explains in detail how the gods are present in all the body parts of the cow. ( p. 216)

1 Vyāsa wants to know what Mahādevī did after Mahādeva had gone to heaven. Sanatkumāra tells him that the Mothers of the World approached her: ${ }^{265}$ Mālinī, the daughter of Bharata (Agni); ${ }^{266}$ Subhāvatī, the daughter of Parjanya; Sāvitrī; Gāyatrī; Durgā; Śr̄̄; Kīrti; Lakṣmī; Dhṛti; Prajñā; Khyāti; Diti; Danu; Aditi; Siṃhikā; Khaśā; Rākā; Kuhū; Sinīvālī; Anumatī; Gañgā, Sarasvatī and other holy rivers; and the wives of sages, gods, Yakșas, Rakṣases, Uragas, Khagas and Gandharvas. They all pay homage to Pārvatī and ask her about dharma: 'By what dharma or tapas does one obtain abundant and undecaying merit?' Devī promises to relate it, for their benefit and that of the worlds. ${ }^{267}$

263 The phrase yadi tușțo 'si no deva yadi deyo varaś ca nah in SP 110.27ab is a common stock phrase in the text. See SP I, 30 (with reference to variants).

264 The metre of SP 110.31 is Puspitāgrā.

265 Some of the Mothers listed here also appear in LiP 1.103.4-7, in a list of Mothers attending Siva's wedding.

266 Bharata is another name for Agni.

267 As befits the setting of the instruction, Pārvatī addresses the goddesses as a group (suvratāh). In the following passage, however, the vocative singular is used in the S manuscripts (devi: 16c, 27b, 28e etc.). This suggests that the original teaching may rather have involved the instruction of Pārvatī by Śiva. The text seems to have been adopted from another source, without having been redacted properly. The S manuscripts return to the plural only later on in the chapter (starting with devatāh in $94 \mathrm{~d}$ ). Furthermore, in 78c, the addressee is Vyāsa (see note ad loc.). $\mathrm{R}, \mathbf{A}$ and $\mathrm{SP}_{\mathrm{Bh}}$ have, each in their own way, removed the vocatives singular and replaced them with vocatives plural. In the next chapter, where Devi continues the instruction, the vocative plural is used consistently throughout. See also Introduction, p. 7. 
10 There is no higher gift than the gift of food. ${ }^{268}$ It is supreme because beings are produced from food. He who gives food to a Brahmin obtains all desires and is worshipped in heaven (Tripistapa). He obtains an aerial vehicle that shines like the sun. When he becomes a human being again, he is reborn with a handsome appearance and to a rich family. A man who gives daily, according to his capability, attains the world of Prajāpati. He who gives proper food to a Brahmin only once, enjoys it a hundred- or a thousandfold in the worlds [hereafter] and becomes happy in the present. But he who gives food that is unclean and held in disregard, receives the same food in great amounts, while he is being tortured by Rākșasas in hell. When he is reborn as a human again, he becomes a wealthy mleccha and feasts like a god. ${ }^{269}$ There is nothing higher than food. Food is Prajāpati, which is the year, which is the sacrifice, and in sacrifice everything is established. ${ }^{270}$ All beings are produced from it. Therefore food is taught to be supreme. There is no higher gift than the gift of food. It is praised because beings are produced from food. ${ }^{271}$

22 Next follows the fruit of one who gives cool and fragrant water to Brahmins. Ascending on a vehicle shining like the sun, he goes to the world of Varuna. Having lived there for eighty thousand years like a god, he is reborn rich to an eminent family. He who gives a vessel full of water to a Brahmin enjoys water and goes to heaven. He who gives vessels filled to the brim becomes a vessel of enjoyment and saves his ancestors from danger. He who creates a water tank saves his various ancestors ${ }^{272}$ and traverses the sky for six million years like a god. When he returns to the human world he becomes rich and is born as a royal personage, a donor and sacrificer. A man who digs a well and gives it to Brahmins, decorating it with eight flags, a flag pole, a victory banner and flowers, rescues his ancestors and goes to the world of Varuna.

268 Parts of the opening verse of this section, praising the gift of food, have parallels in other texts (e.g., MBh 6.25.14a (= BhG 3.14a), MtP 83.43c, BdP 2.16.52a and VDhP 3.315.1c). Extensive parts of this chapter are quoted by several Dharmanibandha authors, including Aparārka (Commentary on the Yājñavalkyasmṛti), Lakṣmīdhara (Dānakāṇ̣a), Ballālasena (Dānasāgara), Hemādri (Dānakhạ̣ụa), Caṇdeśvara (Kṛtyaratnākara) and Govindānanda (Dānakriyākaumud̄̄). For details, see the register of testimonia in the edition and our discussion in the Introduction (p. 29).

269 The logic seems to be that although the gift of food leads to the enjoyment of food, the man experiences hell and is reborn among the mlecchas because the food he gave was impure.

270 This homology goes back to the Satapathabrāhmaṇa; cf. Gonda 1984, 89.

271 SP 111.21abc repeats SP 111.10abc.

272 SP $111.28 \mathrm{c}$ is hypermetrical (the first two syllables are counted as one guru). 
33 Next follows the fruit of one who gives gold, ${ }^{273}$ land, sesame or jewels to all beings. He reaches Indra's world on a big vehicle and rejoices like a god. Descending from there, he is reborn as a king in an eminent family.

36 A man who plants a tree rescues his ancestors on the path of the moon. If he gives it to Brahmins and buys it back again, he rescues his ancestors for as many thousands of years as there are flowers and fruits of that tree enjoyed by living beings, and when he dies, he attains Soma's world. He who gives fruit to Brahmins becomes blessed with fruit. He who gives wood to Brahmins in winter gains Agni's world.

42 He who gives a golden vessel adorned with jewels rejoices in heaven on a vehicle with hundreds of Apsarases; if he gives a silver vessel, he reaches the position of the Gandharvas and rejoices with Urvaśí; if a copper vessel, he becomes a Yakṣa of Yakṣarāja (Kubera).

45 He who gives a house provided with all pleasures attains the world of Brahmā. After he has dwelt there for forty million years, he is reborn as a rich and generous householder.

47 He who gives herbs and grain attains Soma's world. ${ }^{274}$ After he has stayed there for seven thousand years, he is reborn as a rich man.

49 He who gives a fertile field enjoys a field as a man and attains the world of Prajāpati. ${ }^{275}$ He who gives land to a Brahmin traverses all the worlds on a radiant vehicle for many thousands of years. On becoming a human being again, the earth yields all he desires.

52 He who gives a garment to a Brahmin lives happily in Vairāja (i.e., the world of Virāj) for ten million years. He who gives a seat to a Brahmin obtains a kingdom and reaches heaven. He who gives a bed obtains many loving wives. He who gives a girl to a Brahmin lives in the world of the ancestors ( pitr) for one million years. When he is reborn again on earth, he obtains devoted wives and offspring.

57 He who gives a horse speckled with gold attains the world of the Gandharvas. ${ }^{276}$ He who gives a chariot, a horse, an elephant, a female slave, a

273 Two types of gold are mentioned: hiranya and heman. The first may refer to raw gold and the second to fashioned gold. Cf. Meulenbeld 1999, IB: 178, n. 563, with reference to the Carakasaṃitā.

274 The unmetrical reading adopted in 47c presumes that ${ }^{\circ}$ samrddham would have been pronounced ${ }^{\circ}$ samriddham. The different variants may have arisen from different attempts to repair this.

275 The implicit meaning may be that a man ( pumān) enjoys a woman's body ( $k s ̣ e t r a)$ and begets offspring ( rajā) on her.

276 After verse 57, the Dānakriyākaumud̄̄ consecutively quotes six more pādas attributed to the Skandapurāṇa: yāvanti tasya lomāni tāvadvarșaśatāni ca | śvetañ ca datvā viprāya phalam daśagunam labhet | vadavāyāh pradānena śvetatulyam phalam smrtam | (DKK p. 83). 
girl and a house, along with land, is reborn on earth as a king. The earth turns into a cow, yielding all desires.

60 Next follows the fruit of one who gives a 'water cow' (jaladhenu): a water shed, a hostel, a tank or a well. ${ }^{277}$ He should fill water pots adorned with garlands, and worship Brahmins, provide bowls of sesame seeds along with food to their satisfaction, pay an abundant fee (daksing $\bar{a})$, and make them touch the $[\mathrm{cow}] .{ }^{278}$ He should say: 'Let these cool and auspicious waters gratify my ancestors! Let the ancestors be desire-givers!' After he has thus given the cow and bought her back again, he should bring her to the water shed. He should bathe and give bowls of sesame seeds, a pair of garments, gold and fruit to the Brahmins. 'Cows produce ghee; ghee is rooted in the earth; ghee is fire and the gods; may ghee be given to me!' 279 One who has given thus, according to these rules, attains Brahmā's world.

67 If a man gives, in addition to a milk vessel, a cow with calf, decorated with golden horns and silver hooves, dressed in a linen cloth, etc. ${ }^{280}$ having gratified the Brahmins, then the gods enter the cow's limbs at the time of the donation: ${ }^{281}$ Brahmā, the top; ${ }^{282}$ Sakra, the bottom; Candra and Aditya, the eyes; Vāyu, the nose; Vahni, the mouth; Soma, the tongue; the directions, the ears; the Rudras, the head; the Lokapālas, the feet; ${ }^{283}$ the mountains, the bones; the seven oceans, the stomach; the Adityas, the neck; ${ }^{284}$ Gangā, the dewlap; the Vasus, the flank; Prajāpati, the generative organ; the bathing places, the urine; Śr̄̄, the feces; the Nāgas, the entrails; the Sādhyas and all the worlds, the tail; the Mantras, sacrifices, gifts, observances, R̦̣is, asterisms, planets, stars, Gāyatrī, Triṣtubh, Jagatī, Pañkti, Anuṣtubh, Rcc, Yajus, Sāmans, Ātharvaṇa, the Mothers of the World, clouds, rain, Dharma, Nārāyaṇa, Bhūtas and rivers, the pores

277 The gift of the water cow, which is one among several donations of 'cows' made of different substances, is attested in a range of sources, including AVPariś 9.3.2, MBh 13.70.36-41, VDh 88.1-12, VarP 100 and VDhP 3.309. See also Brick 2015, 143-152. The connection with different water structures as prescribed in the SP does not, however, seem to be attested elsewhere. Brick interprets this passage differently and connects krtvā in $61 \mathrm{a}$ with $60 \mathrm{~cd}$.

278 The water pots represent the cow. See Brick 2015, 149, n. 10. The Brahmins bless the 'cow' by touching the water pots.

279 Cf. VDh 87.15: ghrtam agnir ghrtam somas tanmayāh sarvadevatāh | ghṛtam prayacchatā dattā bhavanty akhiladevatāh \|

280 For the golden horns and silver hooves, see, e.g., Yājñavalkyasmṛti 1.204.

281 The presence of the gods in the various limbs that make up the cow recalls the creation of the body of Viṣnu as the Boar (SP 98.1-18) and the earlier story of Vrșabha (SP 33.116-129).

282 The following passage, connecting the various parts of the cow's body with different deities, is quoted only in the Dānasāgara.

283 The dual pādayor used here may be an authorial error. The reference should equate the four feet with the four Lokapālas.

284 The interpretation of tapanāh (suns, i.e. the Ādityas?) is uncertain. 
of her skin; Yakṣas, Rākṣasas, Piśācas, Pakșins, sacrifices and fees, Apsarases, Gandharvas and other great beings, the horns; ${ }^{285}$ the fruits and destinations of gifts and sacrifices, the calf, which consists of all the gods.

80 With both hands, he should give the Brahmins the cow inhabited by all the gods. He should give kuśa grass, suvarna seeds, ${ }^{286}$ sesame seeds and white mustard, along with water, ${ }^{287}$ while reciting: 'I present the dairy cow consisting of all the gods to the imperishable cause of all the worlds!' ${ }^{288}$ When he has thus given away the cow, she will save him wherever he is reborn, and she will yield his wishes and grant him all worlds and all knowledge. He will rejoice in all worlds in her company, and when he is reborn, he will have recourse to her. Born together with her, he will have a thousand cows, be rich, and have many sons.

87 He who gives a two-facing dairy cow, ${ }^{289}$ according to the above-mentioned rule, will remember his former births. If he gives a cow to Brahmins, in whatever way, ${ }^{290}$ the cow will save him from hell.

89 He who gives a black antelope's skin to a celibate ascetic attains the fruit of [giving] the earth and reaches yoga. ${ }^{291}$ He who provides a habitation for yogins attains the fruit of an Aśvamedha, Aptoryāma, Pauṇdarīka and Gosahasra, ${ }^{292}$ and after attaining the highest recollection, acquires yoga. He who gives a water jar to a Brahmin reaches constancy in dharma. He who rescues a diseased and destitute sage is released from the sin of killing

285 The vocative addressing Vyāsa instead of Devī, in 78c, is unexpected. See Introduction, p. 8.

286 We are unsure about the referent of suvarna here.

287 Presumably, this refers to the water contained in the pots, which is poured into the hands of the donee.

288 The dative in the mantra probably refers to Brahman, of which the Brahmin is the earthly representative. The Śabdakalpadruma, s.v. sodaśadānam, cites a mantra, attributed to the Śuddhitattva (of Raghunandana), to accompany the gift of a cow. Its last verse shows striking correspondences with the present mantra: sarvalokanimittāya sarvalokam api sthirām | prayacchāmi mahābhāgām akșayāya sukhāya ca $\|$.

289 The term ubhayatomukh $\bar{\imath}$ refers to a pregnant cow: her own face faces forward, while that of the calf faces backward. See Kane II, 879-880.

290 This meaning of yathätatham is not recorded in the dictionaries.

291 After verse 89, the Dānasāgara consecutively quotes one more verse attributed to the Skandapurāna: sasamudraguhā tena saśailavanakānanā | caturantā bhaved dattā prthivō nātra saṃśayah | (DS p. 529). This verse is not found in our text but occurs (with small variations) in several other texts, including ViS 87.9, VDh 46.17, MtP 205.5 and MBh 14 App. 1 No. 4 ll. 1929-30.

292 The Aptoryāma is one of the seven types of Soma sacrifices (Kane II, 1206), and the Paundarīka is a variant of the Agnicayana involving the gift of ten thousand horses (Knipe 2015, 225-226). The Gosahasra is one of the mahādannas (see e.g. AVPariś 16). 
a Brahmin. He who gives gold to a poor Brahmin acquires the fruit of ten Aśvamedhas. ${ }^{293}$ He who gives all these gifts becomes a world emperor.

96 He who hears this, who gives according to his capability, and who recites it goes to heaven (Tripiștapa). ${ }^{294}$

\section{Skandapurāṇa 112}

Devī instructs the goddesses in various kinds of fasts and their fruits. She also teaches them the general paradigm for fasts, as well as different kinds of penance. All these fasts are prescribed for men, but women can also perform them if their husband gives them permission.

After the instruction, Devī and the Mothers go and see the forest of Mt Mandara. Devī sees a young aśoka tree and decides to adopt him as her son. At this moment, Andhaka arrives. Stunned by the sight of Devī, he does not pay obeisance to her. Prahlāda warns him that this is Umā, the wife of Śiva. Devī disappears and the Asuras wander around Mandara. They see the Seven Sages and decide to eavesdrop on them. The sages talk about the Asuras, who have been destroyed because of their violation of dharma. Dhātṛ, Vidhātṛ and Kṛtānta arrive from Brahmaloka. They report that Dhātṛ had told Kaśyapa about the future affairs of the Devas and Asuras. The sages want to know about this as well and Kṛtānta is charged with narrating it. ( p. 236)

1 Devi tells the goddesses that she will explain how, without donation, one acquires the same merit (dharma) through fasting (upavāsa). ${ }^{295}$

2 By eating once a day during the month of Mārgaśira, one obtains cows; ${ }^{296}$ during Pauṣa, one obtains many virtuous sons; during Māgha, one obtains dear wives; during Phālguna, one reaches affection of one's wives; during

293 Before verse 94, the Dānasāgara quotes one more verse: brāhmaṇasya viśuddhasya suvarnam yah prayacchati | suvarṇānām śatam tena dattam bhavati niścayah | (DS p. 419).

294 In contrast to the other chapters in this volume, the final verse of this chapter is written in the same metre as the rest of the chapter.

295 Like the previous chapter, this chapter is quoted extensively by several Dharmanibandha authors: Aparārka (Commentary on the Yājñavalkyasmṛti), Lakșmīdhara (Dānakāṇda, Vratakāṇda), Caṇ̣eśvara (Kṛtyaratnākara), Śrīdatta (Samayapradīpa) and Hemādri (Dānakhạ̣ḍa, Vratakhạ̣ḍa). See the Introduction, p. $29 \mathrm{f}$, and the apparatus of the edition for details.

296 Here starts the section on ekabhakta, a vrata that involves eating only once a day (cf. Kane V, 100-101). See also MBh 13.109.17-29, which may be a kind of model for this section. 
Caitra, one is reborn with a handsome appearance and to a rich family; ${ }^{297}$ during Vaiśākha, a man reaches eminence, [becoming] wealthy and respected; during Jyeșthamūla, he becomes the eldest (jyeștha) brother and acquires much wealth; during Așādha, one becomes a minister to a king and attains rich pleasures; during Śrāvana, one becomes a commander of an army and is born strong; during Bhādrapada, one is born rich; during Áśvayuja, one's merchandise, agriculture and cattle thrive; and during Kārttika, one obtains the result of a horse sacrifice and is exalted in the world of Vahni (Agni).

13 He who eats once a day for as long as he lives goes to the world of Śakra; doing this for a year, he comes to rule the earth like Mahendra. ${ }^{298}$

15 He who fasts for one day and one night attains the fruit of [giving] ten pieces of gold; ${ }^{299}$ he who fasts once a month becomes purified, virtuous and wise; he who fasts on the 14th and 8th of each fortnight for a full year does not go to hell and will not see Yama; he who fasts for three days each month reaches the world of Kubera and finds supreme happiness.

20 He who eats with restraint after the 4th day [of fasting] reaches the position of the Gandharvas and delights in heaven like Śakra; after the 5th, the world of Vāyu; after the 6th, the world of Varuna; after the 7th, the world of Aditya; after the 8th, the world of Viṣnu. If he eats with restraint after the 9 th day, one roams with the Vasus; after the 10th, one attains the fruit of a ten-day sacrifice, becomes equal to the Aśvins, shining like the sun, and upon becoming human again, attains ten wives and undiminishing gold, and does not die at the wrong time; after the 11th, one attains the fruit of an eleven-day sacrifice, and acquires the position of a Gana of Rudra for 108 years, after which he becomes a Brahmin and is reborn on earth as a sacrificer; after the 12th, one attains [the fruit of] a twelve-day sacrifice and reaches the world of Sakra, after which he is reborn on earth as a king, a royal personage or a rich man; after the 13th, one enters the abode of Bhṛu, ${ }^{300}$ and when he becomes human again, he is reborn to a wealthy family; after fourteen days, one reaches the world of the Tusitas and becomes a Gaṇapati.

35 He who fasts for half a month becomes the equal of Devarāja (Indra) in heaven and is reborn on earth as a great king. He who fasts for a month will be surrounded by Apsarases on a celestial vehicle, worshipped like a

297 SP $112.5 \mathrm{~cd} \approx \mathrm{SP} 111.13 \mathrm{~cd}$.

298 The order of these two verses is reversed in $\mathrm{SP}_{\mathrm{RA}}$ (and in the testimony of the Samayapradipa), which is indeed more logical.

299 Here starts a new section on fasting (upavāsa/ksapana).

300 The abode of Bhṛu (bhārgavam sthānam) is not known from any other source, but it is clear that it should be some divine world. Perhaps Bhṛu here refers to Śukra, i.e. Venus. 
god, and reaches eternal happiness. He dwells for many myriads of years in all the [divine] worlds. Upon reaching the residence of Brahmā, he is honoured by Brahmā and dwells in Brahmā's world like Brahmā. When he returns again [to earth], he becomes a superior Brahmin and attains yoga. After becoming a supreme yogi, he becomes a Gaṇapati of Śambhu.

40 Now they should hear the meritorious precept (vidhi) of all fasts (upava$s a)$. The wise one should fast after he has had himself consecrated. He should bathe at the three junctures and offer oblations. Restrained, reciting the Gāyatrī, the purificatory (pavitra) [mantras] and the collections (gana) of Rudras, ${ }^{301}$ sleeping on the bare ground strewn with kuśa grass, avoiding women and Sūdras, he should eat, free from sorrow and envy. He should feed Brahmins on all days during his fast. At the completion of his fast, he should honour a hundred or a thousand Brahmins according to his capability, give sacrificial food, cows and clothes, and provide each [Brahmin] with a bowl of sesame seeds and gold. He will get a fruit hard to obtain by other observances.

47 If he releases a dark bull, or a different kind, the man will gratify his ancestors. ${ }^{302}$ He will delight in heaven for as many thousands of years as there are hairs on the bull. He who gives bowls of black sesame seeds ${ }^{303}$ to Brahmins on the day of the new moon will gratify his ancestors, attain the world of the ancestors (pitr), and find long-lasting happiness.

51 The precept of fasting has been told; now they should hear the precept of the Cāndrāyaṇa [penance]. The one who performs the Cāndrāyaṇa as taught ${ }^{304}$ will reach the world of Soma and become equal to Soma. He who performs the Prājāpatya, once or many times, will be honoured like Prajāpati in his (Prajāpati's) world. He who performs the Sāmtapana penance (krcchra) rescues himself from difficulty ( $k r c c h r a)$ and goes to the world of Agni. He who performs the Mahāsāmtapana becomes omniscient and attains the world of Brahmā. He who performs the Tulāpuruṣaka is released from all sin and goes to heaven. With the Atikrcchra, a man proceeds to the abode of Śarva; with the Krcchrātikrcchra, he attains the

301 Rudra mantras are referred to elsewhere in the text as well. Cf. SP I, 98, n. 119. The reference may be to the Śatarudriya or to the repeated japa of 'Rudra'.

302 On the release of a bull (vrṣotsarga) as a Śrāddha rite, see Kane IV, 539-542. As described in the sources assembled by Kane, following the death of a man, a bull should be driven away together with four cows. Nobody should be allowed to seize or use the bull. In our text, the release of a bull is presented as part of the upavāsavidhi. See also Einoo 2004.

303 Cf. the comment of Lakșmīdhara and Hemādri after the quotation of verses 49 and 50: krṣnāāàn tilānām iti śeșah.

304 In fact, no description of the Cāndrāyaṇa has been given. Perhaps the intended meaning is 'as prescribed in the Dharmaśāstra'. For the various penances described in this paragraph, see the glossary of prāyaścittas in Kane IV, 130-152. 
position of a Ganapati. But if he performs all the penances, he attains whatever he desires. He who is devoted to whichever penance becomes successful because of it and reaches divinity.

60 A man who lives on milk for a year and consumes barley prepared with cow's urine, oil cake, fruits or food that is not pungent and does not contain salt attains the fruit of a horse sacrifice and reaches the world of Brahmā. Freed of all sin and bonds, he travels on a radiant vehicle like Brahmā.

63 He who performs these various [fasts] for as long as he lives attains the worlds he desires, liberation or supernatural power. All these donations and austerities are prescribed without mantras for Ś $\bar{u} d r a s ;{ }^{305}$ thus Prajāpati has declared. They do not attain sin.

67 For women, a husband is god and is held to be the highest dharma. If she is allowed by him and performs this dharma, she will acquire its fruit. But if she performs it without being allowed by him, she will not obtain its fruit, but the fruit of an unfaithful wife. However, if she is allowed by him, performs the dharma, and grants it to her husband, her merit will be endless. She will acquire whatever she longs for in this world or the next, and be reborn as a beloved wife. Her husband will be under her control; she will be dear to him and bear sons. ${ }^{306}$

73 The Mothers of the World honour Mahādevī and tell her that she has told the dharma by which one gains a very great result. Now they will explore the mountain's forest with its many birds and flowers. Thereupon Devī sets out with the Devamātṛs to see the divine forest of Mt Mandara. As she wanders around and beholds its peaks, waterfalls, lakes and ponds, and seeing Nandin standing at her side, ${ }^{307}$ the Mountain Daughter (Giri-

305 Śūdras are excluded from the Veda, so they have no access to the mantras. However, as indicated here, they can perform these fasts without mantras and still gain merit. Cf. MaS 10.127 (referring to Ś̄̄dras): dharmepsavas tu dharmajñāh satām ṿ̛ttam anuṣthitāḥ | mantravarjaṃ na duṣyanti praśaṃsām prāpnuvanti ca $\|$.

306 After SP 112.72, the $\mathrm{R}$ and A recensions have two more pādas, followed by a closing verse and a chapter colophon, after which there is a long passage on the observance for women (strīvrata) as told by Brahmā to Śatarūpā ( $S_{\mathrm{RA}}$ 112.1). This is followed by a passage, only attested in R, in which Mālinī tries to cheer up Pārvatī by pointing out the beauties of the forest ( $\left.S_{R A} 112.2\right)$. After this, the $R$ and $\mathrm{A}$ recensions continue to have a very different and expanded text, although practically all verses from the $\mathrm{S}$ recension are paralleled here and the passage in general follows the same storyline $\left(\mathrm{SP}_{\mathrm{RA}} 112.3\right)$. All three recensions are more or less the same again from SP 112.103 until the end. See the Introduction and $\mathrm{SP}_{\mathrm{RA}}$ 112.1-3 for details.

307 The connection between pādas abc and pāda d in verse 78 is unsmooth, with the reference to Nandin appearing out of the blue. A similar phrase occurs in $\mathrm{SP}_{\mathrm{Bh}}$ 159.2c (pārśvastham nandinam tatra), which is striking because it forms part of the continued aśoka tree episode. There Siva instructs Nandin to make the proper 
$\mathrm{j} \overline{\mathrm{a}})$ is pleased. Thereupon Devadevi ${ }^{308}$ sees a blossoming young aśoka tree making an añjali with hundreds of reddish buds. She experiences great delight and declares that the tree shall be her son. If Svayambhū (Śiva) allows her upon his return, she shall adopt the aśoka tree as her son. ${ }^{309}$

82 A terrifying omen occurs. A great wind uproots the mountain's trees. Andhaka reaches Mandara, coming from Pātāla, in the company of thousands of Daityas and Dānavas. ${ }^{310}$ He beholds Devadevī, attended by her friends. The stupefied Daitya does not make obeisance, but only gazes at her. ${ }^{311}$

86 When Prahlāda sees him staring at the Mountain's Daughter, he addresses him. 'This is Himavat's Daughter, the Mother of the World, known all over as Umā! The one whose son Brahmā became, ${ }^{312}$ who grants boons to us and to the gods, who permeates all living beings, by whom this world is supported - she is the wife of that god, Parameśa! She is capable of burning, withdrawing or throwing this world into hell in an instant. Why, foolish Daitya, do you not make obeisance to her?' As the enemy of the gods is speaking properly (dharmayukta) in this way, Devī disappears, along with the goddesses.

93 The Daityapas start wandering around the great mountain. They see the Seven Sages (Saptarși) at a waterfall. Andhaka asks Prahlāda who they are and why they have come together there.

arrangements so that Pārvatī can adopt the tree. It is conceivable that these parts belonged together at an earlier stage in the text's composition.

308 This epithet of the Goddess, introduced here for the first time in the text and reoccurring below (SP 112.84c), is used once more much later in the text, when the narration of the aśoka tree's adoption ceremony is resumed $\left(\mathrm{SP}_{\mathrm{Bh}} 158.69 \mathrm{a}\right)$, thus connecting the two passages.

309 The ceremony of the aśoka tree's adoption by Devī forms the subject of $\mathrm{SP}_{\mathrm{Bh}}$ 158-162. In $\mathrm{SP}_{\mathrm{Bh}}$ 158.69-71, Devī tells Śiva that while he was away and she was walking around Mt Mandara, she saw a young aśoka tree that she desired to adopt as her son. In the ensuing dialogue, she asks Śiva for permission, reiterating the above teaching that a woman can only gain merit through actions that are allowed by her husband. SPRA 112.3.16 adds the significant detail that the tree will remove Devì's grief at not having a son. This conforms to the story told in $\mathrm{SP}_{\mathrm{Bh}} 158$, which mentions Devī's not having a son (aputrā) two times (158.63a, 158.74c). See Introduction, p. 19.

310 The $\mathrm{R}$ and $\mathrm{A}$ recensions include a long list of the Asuras that accompany Andhaka ( $\mathrm{SP}_{\mathrm{RA}}$ 112.3.27-35).

311 This seals Andhaka's fate, for he had earlier received a boon from Brahmā that he would only die if he would not bow down before the Mother of the World (SP $74.23)$.

312 This is a reference to SP 3.4-9. $\mathrm{SP}_{\mathrm{RA}} 112.3 .50$ expands upon this reference by also including Śiva's granting Brahmā the office of demiurge (prājāpatya) and his becoming Brahmā's son as a boon. 
96 Prahlāda tells Andhaka that these are the Seven Sages: Bhṛgu, Atri, Marīci, Viśvāmitra, Añgiras, Bharadvāja and Vasiștha. They have not come to Mandara for no reason; he suggests that the Daityapas should eavesdrop on them.

99 The sages speak to each other. 'This place is not pure. Let us go elsewhere, for the wicked Daityas have arrived. They who violate the dharma have all been destroyed. If they had not violated the dharma for the sake of kingship, the enemies of the gods would not have been destroyed. If they would have remained satisfied with their own kingdom, they would be worshipped like the gods.'

103 As they are talking about the Asuras in this way, Dhātṛ, Vidhātṛ and Kṛtānta arrive. After the sages have honoured them in the proper manner, they ask them from where they have come.

105 Vidhātṛ ${ }^{313}$ responds. 'At the instruction of Brahmā, we went today from Brahmaloka to Kaśyapa. Then Dhātṛ reminded the Prajāpati Kaśyapa of what he had told Brahmā [earlier]: namely, that both the Devas and Asuras, being his sons, are dear to him and that he (Brahmā) should make sure that there is no enmity between them. Having been ordered by Brahmā, he (Dhātṛ) promises to tell him (Kaśyapa) what happens between the Devas and Asuras, about their mutual friendship, the production of the Amrta and the rule of their kingdom. At his request, the best of sages (Dhātṛ) then told Kaśyapa about the future (bhavișya) deeds of the Devas and Asuras. After all was reported to him, we were sent here by Brahmā to see the blessed Daughter of Himagiri.'

111 The sages ask them about the future (bhavisya) affairs of the Devas and Asuras. They also want to know what they have spoken to Devī. ${ }^{314}$

114 The three supreme deities tell Kṛtānta that he should relate it. ${ }^{315}$ Thereupon he tells them about the future of the Suras and Asuras, as well as the reason why the Suras and the Asuras are victorious respectively, as had been determined by Vidhātṛ (Brahmā) before. ${ }^{316}$

313 We conjecture Vidhātṛ as the speaker because Dhātṛ is mentioned in the speech that follows.

314 This second request is not followed up.

315 In other words, Dhātṛ, Vidhātṛ and Kṛtānta decide that Kṛtānta should speak on their behalf.

316 The metre of SP 112.115 is Upajāti, a combination of Jagatī (acd) and Triștubh (b). The following chapters tell of seven Devāsura wars. See n. 42 on p. 17. 


\section{Skandapurāṇa $\left(\mathrm{SP}_{\mathrm{RA}}\right) 112.1$}

After SP 112.72, R and A have six additional pādas in which Devī asks the goddesses what else they would like to hear (see the apparatus of the edition of the main text). This is followed by a chapter colophon, after which starts a new section in $\mathrm{R}$ and A.

Devī asks Sāvitrī about the observance for women (strīvrata). Sāvitrī reports what Brahmā once taught Śatarūpā. Brahmā instructs Śatarūpā in the dharma of women, which is founded on devotion to their husband, and teaches various observances. After this instruction, Satarūpā starts practising the dharma. Devī is left thinking about herself. ( p. 258)

1 Devī (Himavatputrī) asks Sāvitrī, the wife of Brahmā and mother of the Vedas, about the observance for women and its fruit. Sāvitrī responds by telling what Śatarūpā, the only daughter of Brahmā, ${ }^{317}$ once asked him.

5 Śatarūpā asks Brahmā about the rules of dharma for women: how will she be dear to her husband, obtain many good sons, be beloved by her mother- and father-in-law, gain a suitable husband, etc. ${ }^{318}$

9 Brahmā tells her the great dharma of women. The basis is for women to obey their husband. In all activity, she should obtain her husband's consent. Even an unmarried girl should not act independently. ${ }^{319}$ A widow should strive to obtain the world of her husband. If she does otherwise, she will go to the terrible Raurava hell.

15 The fast of women ends after three nights; any more than that is for men.

16 If she refrains from pungent or salty food each month, her body and that of her husband will become beautiful; [if she refrains] in Mārgaśiras, the head [will become beautiful]; in Pauṣa, the neck; in Māgha, the chest; in Phālguna, the arms and hands; in Caitra, the waist; in Vaiśākha, the buttocks; in Jyaiștha, the thighs; in Așậhha, the ankles; in Śrāvaṇa, the shanks; in Bhādrapada, the feet; in Aśvayuja, the back; and in Kārttika, the speech.

22 She who abstains from salt for a year should, at the end of the year, make an image of a couple from salt and sugar, seeds and juices, and place it in

317 For the birth of Śatarūpā from Brahmā, see PPL 114.7-9. The insertion of Brahmā's teaching of Śatarūpā seems to have been inspired by the item devyās ca śatarūpatā (SP 2.18b) in the Anukramanikā. It is likely, however, that the author of the Anukramanikā rather intended to refer to an episode involving the multiplication of Devī into hundreds of goddesses to fight Andhaka and his army. See Introduction, p. 28.

318 Verses 6 and 7, which are only attested in A, make a secondary impression. Śatarūpā's main question concerns gaining a suitable husband and being dear to her husband.

319 Verse 12 is problematic, but appears to say that an unmarried girl should ask her father, brother or mother's father. 
an earthern vessel. She should offer a collyrium box, an eyeliner pencil, a makeup brush etc., and give various kinds of edibles, sweets, fragrances, two pairs of cloths and a seat to the [couple] at the rise of the full moon in Kārttika, while observing a fast for three nights, and distribute gold and silver as daksinga ${ }^{320}$ She will obtain beauty and have a handsome husband.

30 A woman who upholds the observance of eating non-cooked food experiences no suffering; she who performs the lion observance controls her husband, having shoulders like a lion; she who performs the observance of Yama does not see Yama; ${ }^{321}$ she who worships Kāma, eating only once at night, obtains a handsome husband and pleasure; she who eats a handful of rice each day obtains a handsome husband and many sons.

35 She should perform these observances for a year and at the end gratify many Brahmins. Having made images of these observances with flour, she should let the Brahmins touch them. ${ }^{322}$ Then she will attain her wish. A Brahmin woman should dedicate [the images of] the observances to her husband, but there is no such rule for the other classes.

38 She who eats her husband's leftovers for a year will not have a different husband in the next life. If she is devoted to her husband and worships him like a god, what need is there for tapas? The vows, pleased with her mindset, will give her all she desires. ${ }^{323}$

41 She who performs the moon's ordinance (candrakalpa) on the eighth day obtains a gentle (saumya) husband. By practising these monthly obser-

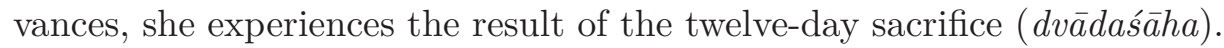
She who worships Kālarātrī in Bhādrapada will not see the night of death ( $k \bar{a}$ larātra); she who practises the rain observance on the first day of raining will be dear to her husband like rain to people; she who practises the observance of much offspring will have sons and grandsons.

46 'There is no higher dharma than devotion to one's husband (pativrata). You should practise it diligently'. Then Śatarūpā bowed down [to Brahmā] and practised the dharma.

320 The passage is obscure and we are not sure about several of the items listed. The image of the couple made of salt, to which various items associated with beauty are presented, seems to represent the completed vrata and its result.

321 For the Yamavrata, see e.g. VDhP 3.87, but note that there it is not a woman's vow.

322 The earlier vow of abstaining from salt for a year seems to provide the model for the present passage, which involves making images of the vows one has performed. Note that the word vrata is used as a masculine noun, perhaps indicating its personified form.

323 The A recension omits the rest of the chapter from verse 40. 
49 Thereupon she (Devī) thinks about herself and stands still once again. ${ }^{324}$ Her friends gaze at Śivā, who looks dark as night, in wonder. ${ }^{325}$

\section{Skandapurāṇa $\left(\mathrm{SP}_{\mathrm{RA}}\right) 112.2$}

This passage follows after $\mathrm{SP}_{\mathrm{RA}}$ 112.1, but is only attested in $\mathrm{R}$.

Mālinī tells Devī not to grieve. The worlds suffer because of her. Devī says that there is no need for them to grieve, for Bhṛngiriți is there. Mālin̄̄ tries to cheer her up by drawing attention to various trees and birds. In the end, she makes Devī and her friends laugh. ( p. 264)

1 Mālin̄i, the daughter of Agni, ${ }^{326}$ tells Devī (Himavattanayā) not to grieve. Her husband will come soon and certainly also suffers from seperation from her. Prabhāvatīi ${ }^{327}$ agrees with Mālin̄̄ and adds that the worlds suffer with her grief, since she is the support of the worlds.

7 Devī replies that they should not grieve for her, seeing that Bhṛngiriți, who is always dear to Íśvara, is there. ${ }^{328}$ Thereupon Bhṛngiritị emerges from the house. She leaves with her friends.

9 Mālinī draws Devī's attention to various trees in the forest. ${ }^{329}$ One with its birds looks like Rudra surrounded by Ganas, another like Devapati attended by Suras, Siddhas and Cāraṇas, yet another like Purandara praised by sages. One bird drinks the nectar of the flowers like a lover, another one with its female companion looks like Rudra with Umā, yet

324 The change of subject is unsmooth. We conjecture loss of two pādas or more, taking us back to the main narrative frame.

325 The metre of $\mathrm{SP}_{\mathrm{RA}}$ 112.1.50 is Upajāti, a combination of Jagatī (acd) and Tristubh (b).

326 Agni's daughter Mālin̄̄ was mentioned in SP 111.3ab.

327 Prabhāvatī was not listed among the Mothers in SP 111.2-7.

328 Verses 7-8 use the singular, and so we take nandin 'gladdening' as an adjective qualifying Bhṛngiriți. Because the Gạ̣as Bhṛngiriți and Nandin are frequently mentioned together, one might have expected a dual. Note, however, that Nandin (referred to as Śailādi) accompanies Devī and the goddesses in the forest ( $\mathrm{SP}_{\mathrm{RA}}$ 112.2.24) and is present when Devī sees the aśoka tree ( $\left.\mathrm{SP}_{\mathrm{RA}} 112.3 .20-24\right)$. It is possible that there was some confusion about his identity.

329 Except for verse 9, Mālinı̄’s speech is in Vaṃsastha metre. 
another intoxicated with flowers, looks like Purandara. ${ }^{330}$ She also points out a peacock, a tall tree, ${ }^{331}$ a creeper and another tree. She likens the latter to Maheśvara tormented by love for her.

20 Hearing this, Devī laughs and strikes [Mālinī] with a lotus, saying that she has provoked her even while she is in pain. Thereupon her friends say that Mālinī only said what she did to make her laugh, and they praise Mālinī for it. Laughing, they walk to another spot together with Śailādi (Nandin). ${ }^{332}$ They reach the forest, free from grief. ${ }^{333}$

\section{Skandapurāṇa $\left(\mathrm{SP}_{\mathrm{RA}}\right) 112.3$}

Instead of SP 112.73-115, R and A have a much expanded text. The text of S and $\mathrm{A}$ has been conflated in $\mathrm{SP}_{\mathrm{Bh}}$. There is more attention to detail in the text of $\mathrm{R}$ and A, but the storyline corresponds more or less to that of $\mathrm{S}$, while individual verses are shared.

Śubhāvatī points out the beauties of Mandara's forest to Devī. She draws attention to a young aśoka tree, which Devī desires to adopt as her son. Bad omens appear and Devī asks Nandin to dispel her fear. Andhaka arrives in the company of many Daityas. He sees Pārvatī and desires to have her as his wife. Prahlāda warns him that she is the wife of Śiva. The Mothers disappear and the Asuras wander around Mandara. They see the Seven Sages and decide to eavesdrop on them. The sages talk about the Asuras, who have been destroyed because of their violation of dharma. Dhātṛ, Vidhātṛ and Kṛtānta arrive from Brahmaloka. They report that Dhātr had told Kaśyapa about the future affairs of the Devas and Asuras. The sages want to know about this as well. Kṛtānta starts telling them. ( p. 267)

330 The extended simile in verse 14 refers to a time in the past $(p u r \bar{a})$ when, at the sacrifice of King Marutta, Indra was so intoxicated with Soma that he stumbled and fell down. The story of Marutta's sacrifice is found in MBh 14.4-10. For Marutta's offering of Soma to Indra, see MBh 14.10.21.

331 The comparison to a single, hoisted Indra flag pole in verse 16 suggests a tall tree. The subject of verse 17 is unclear, but gitabhassitam perhaps again suggests something with birds.

332 The presence of Vyāsa's epithets Kālinandana and Kāleya in SPA 112.2.24b, $\mathrm{SP}_{\mathrm{RA}}$ 112.3.19d and $\mathrm{SP}_{\mathrm{RA}}$ 112.3.20c confirms that these passages follow the major revision of $\mathrm{R}$ and A. See Introduction, p. 23.

333 The metre of $\mathrm{SP}_{\mathrm{RA}} 112.2 .25$ is Upajāti. 
1 Subhāvatī, the daughter of Meru, ${ }^{334}$ speaks. She points out the beauties of the forest of Mandara to Devī, including pleasure parks, waterfalls etc. She also identifies some of its peaks. ${ }^{335}$

9 Śubhāvatī remarks on an aśoka tree making añjalis with its blossoms. She invites Śarvāṇ̄ to have a look. With its hand-like sprouts, it looks like a child dancing before his mother. She suggests it is the favourite abode of the forest deity.

14 The Mountain Daughter takes a look at the tree and desires it to be her son. She will ask Śiva's permission upon his return. The tree will remove her pain at not having a son. ${ }^{336}$

17 Moving along to another place, she observes various bad omens. A mountain peak falls down without any apparent cause; meteors drop from the sky; her right eye trembles. ${ }^{337}$ She asks Śailādi (Nandin) to dispel her fear. He tells her that she is the wife of Vṛsadhvaja and the mother of the gods; how can she have fear?

24 As they speak, Andhaka arrives at Mandara, coming from Pātāla. The Daityas who accompany him are listed by name: Prahlāda, Anuhlāda, Śibi, Bāṣkali etc. ${ }^{338}$

38 They make a tremendous noise. Andhaka sees Pārvatī with her friends. Possessed by Kali, fate, death and passion, he asks the Dānavas who she is. He needs her to be his wife. Otherwise, what kind of a lord is he? Prahlāda warns him that this is Umā, the wife of Śiva. 'The one whose son Brahmā became, who granted Brahmā the office of demiurge (Prajāpati), who became Brahmā's son as a boon, ${ }^{339}$ who when pleased gives boons to the demons and gods, who creates and destroys everything by yoga, who

334 Note that according to SP 111.3cd, Śubhāvatī is the daughter of Parjanya.

335 The speech of Śubhāvatī includes various similes, not all of which are clear. In verse 2 , a pleasure park, which is sarvartusampannam, is compared to the eloquent speech of a sage (i.e., it is like a Mahākāvya including the depiction of all seasons?). In verse 3, a waterfall is said to be like the appropriate speech of wise people (i.e., they deliver their speech in a flow?).

336 This suggests that Skanda has not been born yet, despite the fact that Devi finds satisfaction in the birth of Skanda in SP 72.140 and that Skanda appears in the Varāha myth (SP 109), whose events precede the present episode. See Introduction, n. 44 on p. 18.

337 For the omen of the right eye, we follow the reading of $\mathrm{R}$. In the case of women, the (in)auspicious side of the body is reversed, and so it is the trembling of the right eye rather than the left eye that is held to be inauspicious.

338 Most of the Daityas listed here are known from other passages in the SP, but there are also some unknown and doubtful ones, while there are quite some variations between the readings of $\mathrm{R}$ and $\mathrm{A}$.

339 The reference to SP 3.4-9 in SP 112.88 has been expanded. The addition of such text-internal cross references is characteristic of the revision in $\mathrm{R}$ and $\mathrm{A}$ in general. See Bisschop 2016, 10-11. 
supports the world with his eight bodies - she is the wife of him, Rudra! She is capable of burning, destroying or throwing this world into hell in an instant. She cannot be obtained by you!' While Andhaka is troubled by Prahlāda's words, the Mothers disappear.

57 The Asuras wander around Mandara with its many sights and see the Seven Sages (Saptarsii) at a waterfall, seated on a stone slab, conversing about dharma. The Asuras wonder who they are and Prahlāda tells them that these are the Seven Sages: Bhṛgu, Atri, Marīci, Viśvāmitra, Angiras, Bharadvāja and Vasiștha. He proposes that they eavesdrop on them.

70 The sages say that the place is impure because of the presence of the Asuras and that Bhavānī has also left. They remark that the Asuras are wretched because of their violation of dharma. Angiras, Atri and Bhrgu continue to discuss the interdependence of dharma and kingship. They conclude that the Asuras' downfall is due to adharma.

83 Dhātṛ, Vidhātṛ and Kṛtānta arrive. They sit down on the rocks. Dhātr says that they have come from Brahmaloka and reports what he had told Kaśyapa there regarding the hostility and future of the Devas and Asuras. ${ }^{340}$ They have come to Mandara to see Himavat's Daughter. The sages want to know about the future affairs of the Devas and Asuras too, and also what they have told Devī. Kṛtānta starts telling them. ${ }^{341}$

340 The subject in the reported dialogue between Dhātṛ and Kaśyapa has been changed in comparison to the $\mathrm{S}$ recension. Here Dhātr directly reports his conversation with Kaśyapa to the sages, while in the S recension Vidhātṛ (our conjecture for Dhātṛ; see n. 313 on p. 92) reports the dialogue between Dhātṛ and Kaśyapa.

341 The metre of $\mathrm{SP}_{\mathrm{RA}}$ 112.3.97 is Upajāti. This concluding verse is identical with SP 112.115 . 
Skandapurāṇa

Adhyāyas 96-112 
Peter Bisschop and Yuko Yokochi - 978-90-04-46103-1 Downloaded from Brill.com04/26/2023 02:09:47PM 


\section{Symbols and Abbreviations in the Apparatus}

\langle\rangle In the layer of apparatus recording lacunae, these brackets enclose references (by $p \bar{a} d a$ letter and raised syllable number) to illegible or lost syllables in the Nepalese manuscripts.

In the registers with variants, they enclose syllables of a manuscript reading that have been cancelled.

( ) In the layer of apparatus recording lacunae, these parentheses enclose references (by $p \bar{a} d a$ letter and raised syllable number) to poorly legible syllables in the Nepalese manuscripts.

In the registers with variants, they are used in reporting a manuscript reading to enclose syllables that are uncertain. They are also used after a siglum to enclose comments in English.

In the main, lowest register, only when a lemma is long, they are used to enclose the siglum of a manuscript that supports the lemma except for minor differences. The minor differences in the manuscript reading are recorded separately in a layer of apparatus devoted to the readings of the recension to which it belongs.

$\leftarrow \rightarrow$ Used within the layer of apparatus recording lacunae to indicate that a lacuna extends beyond the verse boundary.

++ Enclose syllables of a manuscript reading that have been added (usually in the margin, occasionally between lines).

\{ \} Enclose variants of individual manuscripts reported within a larger variant of the group to save space (cf. SP I, 52).

- Used to separate different lemmas within the same $p \bar{a} d a$.

$\sqcup$ Represents a gap left open by a scribe.

... Used to represent illegible or lost syllables in a manuscript reading when the illegible or lost portion extends beyond the lemma.

\pm Used only in the layer of apparatus devoted to the readings of the Ambikākhaṇda recension, to indicate that trivial individual variants within a larger variant have been suppressed.

_ _ Used to represent illegible or lost syllables that should be assumed to be metrically light, heavy or indifferent.

* After a siglum, denotes the second occurrence of a line that is repeated.

$\begin{array}{ll}\text { conj. } & \text { conjecture } \\ \text { ac } & \text { before correction } \\ \text { f. } & \text { folio } \\ \text { r } & \text { recto } \\ \text { om. } & \text { omit(s) } \\ \text { sec. } & \text { second }\end{array}$

em. emendation

pc after correction

col. colophon

$\mathrm{v} \quad$ verso

i.m. in the margin

m.c. metri causa 


\section{Sigla of the Manuscripts Used}

$\mathrm{S}_{1} \quad$ National Archives, Kathmandu, MS 2-229. Rotographs preserved in the Bodleian Library, Oxford, as MS Max Müller, Rotogr. 34. Described in Shastri 1905, 141-146; Gambier Parry 1930, 22-25 (No. 22); Bṛhatsūcīpatram vol. 8, 278; Bhatțarāì 1988, prastāvanā p. 37. Microfilmed by the NGMPP on reel No. B 11/4. Palm leaf, early Nepalese 'Licchavi' script. Bhatțarāı's siglum kha. This manuscript is dated 234 (AD 810/811). For further description see SP I, 32.

$\mathrm{S}_{2} \quad$ National Archives, Kathmandu, MS 1-831. Described in Bṛhatsūcīpatram vol. 8, 292; Bhatțarāı 1988, prastāvanā p. 36. Microfilmed by the NGMPP on reel B 12/3. Palm leaf, early Nepalese 'Licchavi' script. Bhatțarāì's siglum $k a$. Undated. For further description see SP I, 33.

$\mathrm{S}_{3} \quad$ Bodleian Library, Oxford, MS Sansk.a.14 (R). Palm leaf, early Nepalese 'Licchavi' script. This manuscript was acquired by the Bodleian Library in 1992; it is not listed in any printed catalogue, and was not used by Bhatțarāi. Undated. For further description see SP I, 33f.

R Asiatic Society, Calcutta, MS G-3909. Paper, an early Bengali script. Described in Shastri 1928, 568-572. Dated Śaka 1604 (AD 1682). Not used by Bhatțarāi. For further description see SP I, 34f.

$\mathrm{A}_{2} \quad$ India Office Library MS 662-663. Described in Eggeling 1899, 1321b-1323a. Paper, Devanāgarī script. Not used by Bhațțarāi. See SP I, 35. On the occasional spare use of this manuscript, see SP III, 61.

$\mathrm{A}_{3} \quad$ Asiatic Society, Calcutta, MS G-972. Described in Mitra 1882, 117-121; Shastri 1928, 579 (see also the Preface p. clxxviii); Bhațtarā̄ 1988, prastāvan̄a p. 37. Paper, Devanāgarī script. This is the only A manuscript used (or mentioned) by Bhatțarāi (his siglum gha). See SP I, 35.

$\mathrm{A}_{4} \quad$ Sanskrit College, Varanasi, Ms 14311. Paper, Devanāgarī script. Described in The Pandit vol. 4, supplement (February 1, 1870), p. l; Catalogue of the Sanskrit College Library n.d., 237; 1957, 10. Not used by Bhatțarāī. See SP I, 35 .

$\mathrm{A}_{7} \quad$ Dhakka University Library, MS 3376. Paper, an early Bengali script. Mentioned in the New Catalogus Catalogorum I, 362. Not used by Bhatțarā. See SP II A, 10f.

A We use this siglum to denote the above-mentioned Ambikākhanda manuscripts as a group, or a reading unanimously shared by them all. See SP III, $62 \mathrm{f}$. 


\section{Abbreviations of the Editions Used}

Bh The editio princeps of the Skandapurāṇa by Kṛ̣ṇaprasāda Bhatțarāà. See Skandapurāna in References.

AYS Aparārka's commentary on the Yājñavalkyasmṛti. See Aparārka in References.

DK Dānakāṇ̣a of the Kṛtyakalpataru of Lakșmīdhara. See Lakṣmīdhara in References.

DKK Dānakriyākaumudī of Govindānanda Kavikañkanācārya. See Govindānanda in References.

DS Dānasāgara of Ballālasena. See Ballālasena in References.

DVU Dānavivekoddyota of the Madanapradīpa of Madanasiṃhadeva. See Madanasiṃhadeva in References.

HeDKh Dānakhạ̣ḍa of the Caturvargacintāmaṇi of Hemādri. See Hemādri in References.

HeVKh Vratakhanḍa of the Caturvargacintāmaṇi of Hemādri. See Hemādri in References.

KR Kṛtyaratnākara of Caṇḍeśvara. See Caṇḍeśvara in References.

SaPra Samayapradīpa of Śrīdatta Upādhyāya. See Śrīdatta Upādhyāya in References.

VK Vratakāṇta of the Kṛtyakalpataru of Lakșmīdhara. See Lakṣmīdhara in References. 
Peter Bisschop and Yuko Yokochi - 978-90-04-46103-1 Downloaded from Brill.com04/26/2023 02:09:47PM 
षण्नवतितमो डध्यायः ।

\section{व्यास उवाच।}

तथा राजनि दैत्येन्द्रे त्रैलोक्याधिपतौ शुभे।

धरणयां चैव बद्धायां सुखितासु प्रजासु च॥ ?॥

स्थानेम्यश्चयाविता देवा ह्यप्रतिष्ठा महाबलाः।

किमकुर्वन्त दुःखार्ता एतन्नः शंस सर्वशः॥ २॥

सनत्कुमार उवाच।

शृणु धर्मक्र देवानामवस्था या बभूव ह।

यदकुर्वन्त दुःखार्तास्तच्च सवं यथातथम्॥ ३॥

हव्यवाहो ऊग्निरभवद्देवानां भागवर्धनः।

तं निरस्य तदा दैत्यो वह्निमन्यं चकार ह॥ ४॥

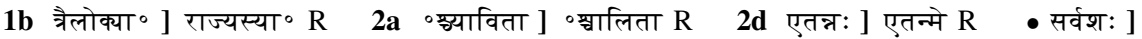

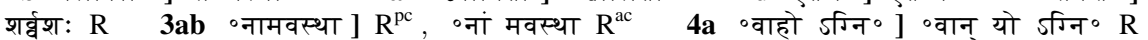
$4 \mathrm{c}$ तदा दैत्यो ] स दैत्येन्द्रो $\mathrm{R} 4 \mathrm{~d}$ ॰मन्यं चकार ह ] ॰मल्पाइ्चकार स: $\mathrm{R}$

$1 c$ धरण्यां ] $\mathrm{A}_{3} \mathrm{~A}_{4}$, धरन्याज् $\mathrm{A}_{7} 1 \mathrm{~d}$ सुखितासु ] स्वार्थितासु $\mathrm{A}_{3} \mathrm{~A}_{4}$, स्वान्विताषु $\mathrm{A}_{7}$ 2a ०भयप्रयाविता ] $\mathrm{A}_{3} \mathrm{~A}_{4}$, ०भ्यः चाविता $\mathrm{A}_{7} \quad \mathbf{2 a b}$ देवा ह्यप्रतिष्ठा ] देवाः $\left\{{ }^{\circ}\right.$ वा $\left.\mathrm{A}_{3} \mathrm{~A}_{4}\right\}$ प्रतिष्ठाप्य $\mathrm{A}$ 2c ॰ कुर्वन्त ] $\mathrm{A}_{4} \mathrm{~A}_{7}$, ०कुर्वत $\mathrm{A}_{3}$ 2d एतन्नः ] एतन्मे $\mathbf{A}$ - शंस] $\mathrm{A}_{3}$, संश $\mathrm{A}_{4}$, शंश $\mathrm{A}_{7} 3 \mathbf{3}$ शृणु ] $\mathrm{A}_{3} \mathrm{~A}_{4}$, शृनुध्वं $\mathrm{A}_{7}$ (unmetrical) $3 \mathbf{a b}$ देवानाम० ] $\mathrm{A}_{3} \mathrm{~A}_{4}$, देवाणां अ० $\mathrm{A}_{7} \quad 3 \mathbf{c}$ ०कुर्वन्त ]

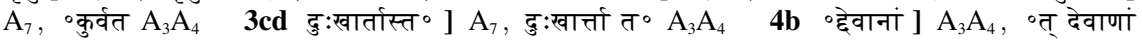
$\mathrm{A}_{7} \mathbf{4 c}$ तं निरस्य ] तत्रिशम्य $\mathrm{A}$ - दैत्यो ] $\mathrm{A}_{3} \mathrm{~A}_{4}$, दैत्येन्द्रो $\mathrm{A}_{7}$ (unmetrical) $4 d$ ममन्यं च०] ०मन्यश्च्च० $\mathrm{A}_{7}$, ०मेतच्च $\mathrm{A}_{3} \mathrm{~A}_{4}$

Manuscripts available for this chapter: $\mathrm{S}_{1}$ photos $3.28 \mathrm{~b}\left(\mathrm{f} .150^{\mathrm{r}}\right), 3.29 \mathrm{a}\left(\mathrm{f} .150^{\mathrm{v}}\right)$ and $3.29 \mathrm{~b}\left(\mathrm{f} .151^{\mathrm{r}}\right.$ ); $\mathrm{S}_{3}$ f. $150^{\mathrm{v}}-151^{\mathrm{v}} ; \mathrm{R}$ f. $168^{\mathrm{r}}-169^{\mathrm{r}} ; \mathrm{A}_{3}$ f. $99^{\mathrm{v}}-100^{\mathrm{r}} ; \mathrm{A}_{4}$ f. $142^{\mathrm{r}}-143^{\mathrm{r}} ; \mathrm{A}_{7}$ f. $140^{\mathrm{r}}-141^{\mathrm{r}}$.

$3\left(c^{7}-d^{3}\right) S_{1} \quad 4\left(b^{1}\right) S_{1}$

$1 a$ दैत्येन्द्रे ] $S_{3} R A B h$, दैत्येन्द्रा $S_{1}$ 1c धरण्यां ] $S_{1} R A_{3} A_{4} B h$, धरण्यं $S_{3}$ 2a स्थानेम्य०] $S_{3}$ $\mathrm{RABh}$, स्थानेत्य॰ $S_{1}$ - ० ख्युाविता ] $\mathrm{S}_{1}^{\mathrm{pc}} \mathrm{A}_{3} \mathrm{~A}_{4} \mathrm{Bh}$, ०धाधिता $\mathrm{S}_{1}^{\mathrm{ac}}$, ० श्चाविता $\mathrm{S}_{3} \quad 2 \mathrm{~b}$ ०प्रतिष्ठा ] $\mathrm{S}_{1} \mathrm{~S}_{3}^{\mathrm{pc}} \mathrm{RBh}$, ०प्रतिषा $\mathrm{S}_{3}^{\text {ac }}$ (unmetrical) - महाबलाः ] $\mathrm{S}_{1} \mathrm{RABh}$, महाबला $\mathrm{S}_{3}$ 2c ०कुर्वन्त ] $\mathrm{S}_{1}$ $\mathrm{S}_{3} \mathrm{RA}_{4} \mathrm{~A}_{7}$, ०कुर्वत $\mathrm{Bh}$ 2d एतत्रः ] $\mathrm{S}_{1} \mathrm{~S}_{3}^{\mathrm{pc}}$, एतनः $\mathrm{S}_{3}^{\mathrm{ac}}$, एतन्मे $\mathrm{Bh} \bullet$ सर्वशः ] $\mathrm{S}_{1} \mathrm{ABh}$, सर्वश $\mathrm{S}_{3}$ 3a शृणु धर्मज्ञ ] $\mathrm{S}_{3} \mathrm{RA}_{3} \mathrm{~A}_{4}$, शृणुष्व धर्म्म $\mathrm{S}_{1}$, शृणुष्व धर्म $\mathrm{Bh}$ (Bh adds (?)) 3ab ०नामवस्था ] $\mathrm{R}^{\mathrm{pc}} \mathrm{A}_{3} \mathrm{~A}_{4} \mathrm{Bh}$, ०नां मवस्था $\mathrm{S}_{1} \mathrm{~S}_{3} \quad 3 \mathrm{c}$ यदकुर्वन्त ] $\mathrm{S}_{1}^{\mathrm{pc}} \mathrm{RA}_{7}$, (स्व)दकुर्वन्त $\mathrm{S}_{1}^{\mathrm{ac}}$, यदुकुर्वन्त $\mathrm{S}_{3}$, यदकुर्वत $\mathrm{Bh} \quad 3 \mathrm{~cd}$ दुःखार्तास्तच्च ] $\mathrm{S}_{1} \mathrm{RA}_{7}$, दुःखात्ता त च $\mathrm{S}_{3}^{\mathrm{pc}}$, दुःखात्त त च $\mathrm{S}_{3}^{\mathrm{ac}}$, दुःखार्तास्तत्र $\mathrm{Bh}$ (conj.?) 3d सर्व ] $\mathrm{S}_{3} \mathrm{RA}$, (स)र्व $\mathrm{S}_{1}$ (anusvāra possibly lost), सर्वे Bh (conj.?) • यथातथम् ] $\mathrm{S}_{3} \mathrm{RA}$, यथाक्रमम् $\mathrm{S}_{1} \mathrm{Bh}$ 4a ०रभवद् ] $\mathrm{S}_{1} \mathrm{RABh}$, ०रभव $\mathrm{S}_{3} \quad \mathbf{4 b}$ ०नां भाग॰] $\mathrm{S}_{1}^{\mathrm{pc}} \mathrm{S}_{3} \mathrm{RA}_{3} \mathrm{~A}_{4} \mathrm{Bh}$, ०नाम्भाश० $\mathrm{S}_{1}^{\mathrm{ac}} 4 \mathrm{c}$ दैत्यो ] $\mathrm{S}_{3} \mathrm{~A}_{3} \mathrm{~A}_{4} \mathrm{Bh}$, दैत्या $\mathrm{S}_{1}$ 
तस्मिन्कर्मणि विप्रेन्द्र मन्त्रास्तदनुगाभवन्।

दैत्यदानवभागानां वक्तार: शुभसाधकाः ॥ $y \|$

ततो यक्ञः स्वयं दैत्यानुपतस्थे महात्मनः।

यड़े गते च दैत्येन्द्रान्देवाः सर्वे मृता इव॥ ६॥

अभवन्नष्टसंज्ञाश्च मन्दवीर्यपराकमाः।

नि:श्रीकाश्च निरुद्योगा निरानन्दा निरुत्सुकाः॥ ७॥

मन्त्रदग्धा यथा सर्पा वज्रपिष्टा इवाचलाः।

गरुत्मताभिसंदष्टा भुजगा इव निर्विषाः।

विहीनाद्रिर्यथा वृक्षा बान्धवैर्वापि योषितः ॥५॥

तथा ते देवता व्यास हृतराज्या हृतश्रियः।

चिन्तयन्ति हुदा चैव शुष्यन्ति विलपन्ति च॥ ९॥

अथ देवः स्वयंभूस्ताग्ड्रात्वा देवांस्तथाविधान्।

विमानेनार्कवर्णेन प्रोवाचेद पितामहः ॥ १०॥

5a ॰न्कर्मणि ] ॰न् कम्म्माणि R 5d वक्तार: शुभसाधका: ] भोक्तार: सारका: R (unmetrical) $6 \mathrm{~b}$ महात्मनः ] महामना: $R$ 6c गते च दैत्यन्द्रान् ] शास्ते च दैत्येन्द्रा $R$ 7d निरुत्सुका: ] अनुत्सुका: $R \quad 8 b$ पिष्टा ] वपृष्टा $R \quad 8 \mathrm{c}$ ०संदष्टा ] ०संकृष्टा $R \quad 8 e$ विहीनाद्धि॰ ] विहीनायु० $R$ 9a देवता ] दानवैर् $R \quad 9 b$ हततश्रियः ] हताश्रया: $R \quad 10 \mathrm{ab}$ देव: स्वयंभूस्ताभ्ज्ञा० ] देवस्तु तान्दृप्तान् ज्ञा० $\mathrm{R} 10 \mathrm{~d}$ प्रोवाचेदं ] आगत्याह $\mathrm{R}$

5a ॰न्कर्मणि ] $\mathrm{A}_{3} \mathrm{~A}_{7}$, ०न्कर्माणि $\mathrm{A}_{4}$ 5b ॰भवन् ] $\mathrm{A}_{3}$, ॰भवत् $\mathrm{A}_{4} \mathrm{~A}_{7} \quad \mathbf{5 c}$ ॰भागानां ] ॰भक्तानां A 5d ०साधका: ] ॰दायका: $A$ 6b ननुपतस्थे ] ॰ नवतस्थे $\mathrm{A}_{3}$, ०न् वतस्थे $\mathrm{A}_{4}$ (unmetrical), ${ }^{\circ}$ न् त्वतस्थैव $\mathrm{A}_{7} \bullet$ महात्मनः ] महाबलः $\left\{{ }^{\circ} \mathrm{A}_{7}\right\} \mathbf{A}$ 7 ab ०संज्ञाश्च मन्द०] विज्ञाना मंद० $\{\circ$ स्मन्द० $\left.\mathrm{A}_{7}\right\} \mathrm{A} 7 \mathbf{7}$ निरानन्दा निरुत्सुका: ] $\mathrm{A}_{3} \mathrm{~A}_{4}$, निरात्क्दा नितत्सुका: $\mathrm{A}_{7}$ 8e विहीनाद्रि०] विशाखाभि० $\mathrm{A} 8 \mathrm{f}$ योषितः ] $\mathrm{A}_{3} \mathrm{~A}_{4}$, शोषितः $\mathrm{A}_{7} \quad 9 \mathrm{~b}$ हृतराज्या हृत ${ }^{\circ} \mathrm{A}_{3}$, कृतराज्या हृत $\mathrm{A}_{4}$, कृत् राह्या कृत ${ }^{\circ} \mathrm{A}_{7}$ (unmetrical) 9d शुष्यन्ति ] मुह्यन्ति $\mathbf{A} 10 \mathrm{a}$ अथ ] तथा $\mathbf{A}$ - स्वयंभू॰ ] $\mathrm{A}_{3}$, स्वयंभु० $\mathrm{A}_{4} \mathrm{~A}_{7}$

$7\left(c^{7}, d^{8}\right) S_{1} \quad \mathbf{9}\left(c^{6}-c^{7}\right) S_{1} \quad \mathbf{1 0}\left(c^{1}\right) S_{1}$

5a तस्मिन् ] $\mathrm{S}_{1}^{\mathrm{pc}} \mathrm{S}_{3} \mathrm{RABh}$, कस्मिं $\mathrm{S}_{1}^{\mathrm{ac}}$ - विप्रेन्द्र ] $\mathrm{S}_{1} \mathrm{RABh}$, विप्रेन्द्रे $\mathrm{S}_{3} \quad \mathbf{5 b}$ ॰भवन् ] $\mathrm{RA}_{3} \mathrm{Bh}$, ॰भवत् $\mathrm{S}_{1} \mathrm{~S}_{3} \quad 6 \mathbf{6 a b}$ दैत्यानु० $] \mathrm{S}_{1} R B h$, दैत्यो नु॰ $\mathrm{S}_{3} \quad \mathbf{6 b}$ ०पतस्थे ] $\mathrm{S}_{3} R B h$ (em.?), ०पपस्थे $\mathrm{S}_{1}$ - महात्मनः ] $\mathrm{S}_{1}^{\mathrm{pc} B h}$, महात्मना $\mathrm{S}_{1}^{\mathrm{ac}} \mathrm{S}_{3}$ 6cd दैत्येन्द्रान्देवा: ] $\mathrm{ABh}$, दैत्येन्द्रा देवास् $\mathrm{S}_{1}$, दैत्येन्द्रा देवा $S_{3} 7 \mathbf{a}$ ०संज्ञाश्च ] $S_{1} R B h$, ०सज्ञाश्च $S_{3} \quad 7 b$ मन्दवीर्य०] $S_{1}^{\text {pc }} S_{3} R A_{3} A_{4} B h$, म(न्दी)र्य० $S_{1}^{\text {ac }}$ (unmetrical) 7d निरानन्दा ] $\mathrm{S}_{3} \mathrm{RA}_{3} \mathrm{~A}_{4}$, निराक्रन्दा $\mathrm{S}_{1} \mathrm{Bh}$ - निरुत्सुका: ] $\mathrm{A}_{3} \mathrm{~A}_{4}$, समुत्सु(का) $\mathrm{S}_{1}$, निरुत्सका $\mathrm{S}_{3}$, समुत्सुका: $\mathrm{Bh}$ (em.?) 8a सर्पा ] RABh, सर्वा $S_{1}^{\mathrm{pc}} S_{3}$, (श) $S_{1}^{\text {ac }}$ (unmetrical) 8b इवाचला: ] RA, इव च वाचला: $S_{1}$ (unmetrical), इवाचला $S_{3}$, यथाचला: Bh (conj.) 8c गरुत्मता॰ ] $\mathrm{S}_{1} \mathrm{RABh}$, गरुत्माता॰ $\mathrm{S}_{3}$ • संदष्टा ] $\mathrm{S}_{1}^{\mathrm{pc}} \mathrm{S}_{3} \mathrm{~A}$, ०सन्दाष्टा $\mathrm{S}_{1}^{\mathrm{ac}}$, ०सन्दष्टा: Bh (em.?) 8d भुजगा ] $S_{3} R A$, पन्नगा $S_{1} B h$ - निर्विषाः ] $S_{1} R A B h$, निर्विषा $S_{3}^{p c}$, निर्विशा $S_{3}^{\text {ac }}$ 8e विहीनाद्रि० ] $\mathrm{S}_{3} \mathrm{Bh}$ (conj.?), विहीनाभि॰ $\mathrm{S}_{1} \quad \mathbf{8 f}$ ०र्वापि योषितः ] $\mathrm{S}_{1}^{\mathrm{pc}} \mathrm{S}_{3} \mathrm{RA}_{3} \mathrm{~A}_{4} \mathrm{Bh}$, ०र्वपि योषिता $\mathrm{S}_{1}^{\mathrm{ac}}$ 9a देवता ] $\mathrm{S}_{1} \mathrm{~S}_{3} \mathrm{~A}$, दैवता $\mathrm{Bh}$ (conj.) $9 \mathrm{~b}$ हततराज्या ] $\mathrm{S}_{1} \mathrm{RA}_{3} \mathrm{Bh}$, हितराज्या $\mathrm{S}_{3} \quad 9 \mathrm{c}$ हदा चैव ] $\mathrm{S}_{3} \mathrm{RABh}$, हत(ताश्चै)व $\mathrm{S}_{1} \quad 10 \mathrm{~b}$ ०विधान् $] \mathrm{S}_{3} \mathrm{RABh}$, ०विधा+: $+\mathrm{S}_{1} \quad 10 \mathrm{c}$ ननार्क॰] $\mathrm{S}_{1}^{\mathrm{pc}} \mathrm{S}_{3} \mathrm{RABh}$, ०नार्ण० $\mathrm{S}_{1}^{\mathrm{ac}} \mathbf{1 0 d} \circ$ तामहः ] RABh, ०तामह $\mathrm{S}_{1} \mathrm{~S}_{3}$ 
भो देवा नष्टसंज्ञा: स्थ किमर्थं दुःखिता भृशम्।

तपोयोगबलं वो उद्य ददानि सुरपुंगवाः ॥ ?? ॥

यूयं लोकस्य कर्तारो हर्तारश्चैव सर्वशः।

न युक्त भवतामेतत्क्रीववत्स्थातुमद्य वै॥ ?२॥

स्वं च योगं मदीयं च त्यत्का दुःखं महाबलाः।

प्रतिपद्यत मा शोके स्वयं देवा: प्रवर्तत॥ १३॥

न तमो भास्कराद्युकं न सोमादुष्णता यथा।

नाग्नेस्तुषारश्च यथा नामृतं भुजगादपि॥ १४॥

नासाधो: साधुभावश्च न कुलीनादशोभनम्।

नाधर्मों नियमेम्यश्च न वेदेम्यश्च दुर्मतिः॥ १४ ॥

तथा न युक्त युष्माकमिदं देवा महात्मनाम्।

आपत्सु न विषीदन्ति ये केचित्तेजसि स्थिताः ॥ १६॥

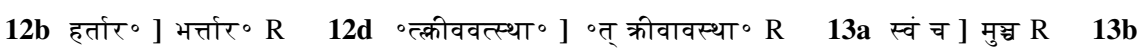
महाबलाः ] महाबलं $R \quad 14 \mathrm{~b}$ ०मादुष्णता यथा ] ॰मादुष्टता तथा $R \quad 14 \mathrm{c}$ ० ख्य ] ०स्तु $R \quad 15 \mathrm{a}$ नासाधो: साधुभावश्च ] न साधोः साधुताहश्च $R \quad 15 d$ वेदे॰ ] देवे० $R$ 16d स्थिता: ] स्थिता $R$

$11 \mathrm{a}$ ०संज्ञाः स्थ ] ०संज्ञाः $\left\{0\right.$ ज्ञा $\left.\mathrm{A}_{4} \mathrm{~A}_{7}\right\}$ स्थः $\mathrm{A} 11 \mathrm{~b}$ भृशम् ] $\mathrm{A}_{3} \mathrm{~A}_{7}$, भूशं $\mathrm{A}_{4}$ 11d ददानि] दाना $\mathrm{A}_{3} \mathrm{~A}_{4}$ (unmetrical), नानानि $\mathrm{A}_{7} 12 \mathrm{a}$ लोकस्य ] वो लोक॰ $\mathrm{A}_{3} \mathrm{~A}_{4}$, वै लोक॰ $\mathrm{A}_{7} \quad 12 \mathrm{~b}$ ० स्चैव ]

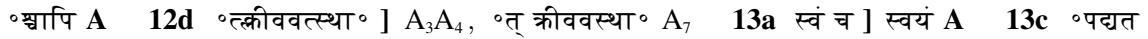
मा शोके] ॰पद्यन्त मा शोक: $A$ 13d देवा: प्रवर्तत ] देवाः $\left\{{ }^{\circ}\right.$ वा $\left.\mathrm{A}_{3} \mathrm{~A}_{4}\right\}$ प्रवर्त्तते $\mathrm{A}$ 14b न सोमादुष्णता यथा ] सोमे वै क्रिष्टता तथा $\mathrm{A}_{3} \mathrm{~A}_{4}$, सोमो कृह्टता तथा $\mathrm{A}_{7} 14 \mathbf{c d}$ ] om. $\mathrm{A}$ 15a नासाधो: ] $\mathrm{A}_{3} \mathrm{~A}_{4}$, नासाधो $\mathrm{A}_{7} 16 \mathrm{ab}$ युक्त युष्माकमिद देवा] युष्माकमिदं देवानां च $\mathrm{A} 16 \mathrm{c}$ विषीदन्ति] $\mathrm{A}_{3}$, विशीदन्ति $\mathrm{A}_{4} \mathrm{~A}_{7} \quad 16 d$ ०त्तेजसि ] $\mathrm{A}_{3} \mathrm{~A}_{4}$, ०त्तेजसे $\mathrm{A}_{7}$

$\mathbf{1 1}\left(b^{7}-b^{8}, c^{6}\right) S_{1} \quad 12\left(c^{6}-c^{7}, d^{4}\right) S_{1} \quad 13\left(c^{1}, d^{4}-d^{7}\right) S_{1} \quad 14\left(a^{8}, b^{3}\right) S_{1}$

$11 \mathrm{a}$ ०संज्ञा: स्थ ] $\mathrm{R}$, ०संज्ञा थे $\mathrm{S}_{1}$, ०सज्ञा स्थः $\mathrm{S}_{3}$, ०संज्ञा स्थ $\mathrm{Bh}$ (typo?, em.?) $11 \mathrm{~b}$ ०ता भृशम् ] $\mathrm{RA}_{3} \mathrm{~A}_{7} \mathrm{Bh}$, ०ता(भव)न् $\mathrm{S}_{1}^{\mathrm{pc}}$, ०तो (न्तशः) $\mathrm{S}_{1}^{\mathrm{ac}}$, ०ता भृशः $\mathrm{S}_{3}$ 11c ०बलं] $\mathrm{S}_{1}^{\mathrm{pc}} \mathrm{RABh}$, ०बलो $S_{1}^{\text {ac }}$, ०बल $S_{3}$ (unmetrical) 11d ददानि ] $S_{1} S_{3} R$, ददामि Bh (conj.?) • ०पुंगवा: ] $\mathrm{S}_{1}^{\mathrm{pc}} \mathrm{S}_{3} \mathrm{RABh}$, ०पुड्गवा $\mathrm{S}_{1}^{\mathrm{ac}} \quad \mathbf{1 2 b}$ हर्तारस्चैव ] $\mathrm{S}_{1}^{\mathrm{pc}} \mathrm{S}_{3} \mathrm{Bh}$, हर्ता च चैव $\mathrm{S}_{1}^{\mathrm{ac}}$ 12c न युक्त ] $\mathrm{S}_{1}^{\mathrm{pc}} \mathrm{S}_{3}$

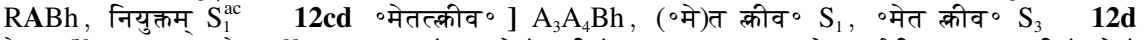
वै ] $S_{1}^{\text {pc }} S_{3} R A B h$, वै: $S_{1}^{\text {ac }}$ 13a स्वं च योगं मदीयं च] $S_{3}$, स्तथा यो धर्म्मदीयश्च $S_{1}$, स्वीयं योगं मदीयच्च Bh (conj.) 13b ०बला: ] $S_{3} A B h$, ०बला $S_{1}$ 13d ०वाः प्रवर्तत ] $S_{3} R B h$ (em.?), ( वा प्रवर्त्त)तः $S_{1}$ 14a तमो ] $S_{1} R A B h$, तेमो $S_{3}$ - ०द्युक्त ] RABh, ०द्यु(क्ष) $S_{1}$ (tops lost), ॰ द्युका $\mathrm{S}_{3} 14 \mathbf{b}$ ॰मादुष्णता ] $\mathrm{S}_{3} \mathrm{Bh}$ (conj.?), (॰मा) स्रष्णता $\mathrm{S}_{1} 14 \mathbf{c}$ नाग्नेस्तुषारश्च यथा ] $\mathrm{S}_{3}$, नाग्ने तुषारश्च यथा $S_{1}$, नाग्नेर्यथा तुषारश्च $B h$ (conj.) 15a नासाधो: ] $A_{3} A_{4} B h$, नासाधो $S_{1} S_{3}$

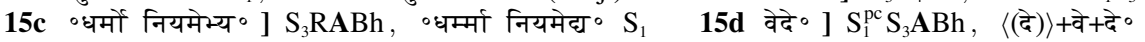
$\mathrm{S}_{1}$ • दुर्मतिः ] RABh, दुर्म्मतिं $\mathrm{S}_{1}$, दुर्न्मति $\mathrm{S}_{3} \quad \mathbf{1 6 a b}$ युष्माकमिदं देवा ] RBh (cf. A), युष्माक इमन्देवा $\mathrm{S}_{1}$, युष्माभिमिमन्देव $\mathrm{S}_{3} 16 \mathrm{c}$ न ] $\mathrm{S}_{3} \mathrm{RABh}$, च $\mathrm{S}_{1}$ • विषीदन्ति ] $\mathrm{S}_{3} \mathrm{RA}_{3} B h$, विसीदन्ति $\mathrm{S}_{1} 16 \mathrm{~d}$ ०त्तेजसि ] $\mathrm{S}_{3} \mathrm{RA}_{3} \mathrm{~A}_{4}$, ०त्तेजसा $\mathrm{S}_{1} \mathrm{Bh}$ - स्थिता: ] $\mathrm{ABh}$, स्थिता $\mathrm{S}_{1} \mathrm{~S}_{3}$ 
ते यूयमापदं प्राप्य न शोकं कर्तुमर्हथ।

मा भवन्तो उवसीदन्तु राज्यं भूयो भविष्यति॥ १७॥

महायोगबलोपेतो हिरण्याक्षो उद्य देवताः।

अशक्यो हन्तुमल्पेन तेजसा दितिनन्दनः॥ ?५॥

प्रतीक्षन्तु भवन्तो उस्य तपसः क्षयमव्ययाः।

क्षीणे तपसि दैत्येन्द्र युद्धे विष्णुर्वधिष्यति॥ १९॥

सनत्कुमार उवाच।

त एवं ब्रह्मणा प्रोका लब्धयोगा: सुरेश्वरा:।

प्रणम्य सर्वभूतानां स्रष्टारमिदमब्रुवन्॥ २०॥

हृतानि नो महायोग स्थानानि दितिनन्दनै:।

क्ष तिष्ठाम वयं ब्रूहि दिश न: स्थानमव्ययम्॥ २?॥

पितामह उवाच।

हृतानि सर्वस्थानानि युष्माकं विदितं मया।

शृणुध्वं यत्र वस्तव्यं युष्माभिर्योगमायया॥ २२॥

$17 \mathrm{c}$ उवसीदन्तु ] विषीदन्तु $\mathrm{R} 18 \mathrm{~b}$ देवता: ] $\mathrm{R}^{\mathrm{pc}}$, देवता $\mathrm{R}^{\mathrm{ac}} 18 \mathrm{~d}$ दितिनन्दनः ] ०दितिनन्दना: $R \quad 19 a$ उस्य ] द्य $R$ 20d स्रष्टार॰ ] ग्रष्टार॰ $R$ - ०मब्रुवन् ] $R^{\mathrm{pc}}$, ०मब्रवीत् $R^{\mathrm{ac}} 21 \mathrm{~b}$ ॰नन्दनै: ] $\mathrm{R}^{\mathrm{pc}}$, ॰नन्दना $\mathrm{R}^{\mathrm{ac}} \quad$ 21d न: ] च $\mathrm{R} \quad 22 \mathrm{a}$ ०स्थानानि ] ॰नामानि $\mathrm{R}$ 22b मया ] $\mathrm{R}^{\mathrm{ac}}$, मम $\mathrm{R}^{\mathrm{pc}} \quad$ 22d युष्माभि॰] युष्मभि० $\mathrm{R}$

$17 \mathrm{a}$ ते ] $\mathrm{A}_{3} \mathrm{~A}_{4}$, ये $\mathrm{A}_{7} \quad 17 \mathrm{c}$ उवसीदन्तु ] वसीदन्त $\mathrm{A} \quad 18 \mathrm{~b}$ उद्य ] थ $\mathrm{A} \quad 18 \mathrm{c}$ ०मल्पेन ] ०मन्येन $A \quad 19 a$ प्रतीक्षन्तु ] प्रतीक्षन्तो $A$ - उस्य ] $\mathrm{A}_{3} \mathrm{~A}_{4}$, ष्य $\mathrm{A}_{7} 19 \mathrm{~d}$ युद्धे विष्णुर्वधिष्यति ] युधि विष्णुर्वधिष्यति $\mathrm{A}_{3} \mathrm{~A}_{4}$, युधिर्वृधिर्भविष्यति $\mathrm{A}_{7} \quad 20 \mathrm{~b}$ ०योगा: ] $\mathrm{A}_{3} \mathrm{~A}_{4}$, ०योगा $\mathrm{A}_{7}$ 20d ०मब्रुवन् ] ममब्रवीत् $A$ 21a हृतानि ] कृतानि $A$ 21b ननन्दनै: ] ०नन्दनः $A$ 21c तिष्ठाम ] तिष्ठामो $A$ - ब्रूहि ] $\mathrm{A}_{3}$, ब्रुहि $\mathrm{A}_{4} \mathrm{~A}_{7}$ (unmetrical) 21d न: ] व: $\mathbf{A}$ 22a हततानि ] कृतानि $\mathbf{A} 22 \mathbf{b}$ मया ] मम $\mathbf{A}$

$\mathbf{1 8}\left(c^{7}\right) S_{1} \quad \mathbf{1 9}\left(b^{7}\right) S_{1} \quad 20\left(b^{3}\right) S_{1},\left(c^{1}\right) S_{3} \quad 21\left(d^{1}\right) S_{1} \quad 22\left(b^{1}\right) S_{1}$

17a ते ] $\mathrm{RA}_{3} \mathrm{~A}_{4} \mathrm{Bh}$, ये $\mathrm{S}_{1} \mathrm{~S}_{3}$ - ०मापदं प्राप्य ] $\mathrm{S}_{3} \mathrm{RABh}$, ०मापम्प्राप्ययस्य $\mathrm{S}_{1}$ (unmetrical) $18 \mathrm{~b}$ देवता: ] $R^{\mathrm{pc}} \mathrm{ABh}$, देवता $S_{1} S_{3} \quad 18 \mathrm{c}$ अशक्यो ] $S_{3} R A B h$, अशक्ये $S_{1} \quad 18 d$ ॰नन्दनः ] $S_{1}^{\mathrm{pc}} \mathrm{S}_{3} \mathrm{ABh}$, ०नन्दन $\mathrm{S}_{1}^{\mathrm{ac}} \quad$ 19a उस्य $] \mathrm{S}_{1} \mathrm{~S}_{3}^{\mathrm{pc}} \mathrm{A}_{3} \mathrm{~A}_{4} \mathrm{Bh}$, ब्य $\mathrm{S}_{3}^{\mathrm{ac}} \quad 19 \mathrm{~b}$ तपस: ] $\mathrm{S}_{1} \mathrm{~S}_{3}^{\mathrm{pc}} \mathrm{RABh}$, तपय: $S_{3}^{\text {ac }}$ - ०मव्यया: ] RABh, ०म(व्य)या $S_{1}$, ०मव्ययं $S_{3}$ 19c दैत्येन्द्र ] $S_{3} R A B h$, दैत्येन्द्रे $\mathrm{S}_{1} \quad 19 \mathrm{~d}$ युद्धे विष्णुर्वधिष्यति ] $\mathrm{RBh}(\mathrm{em}$.$) , युद्धे विर्ष्णुर्वधिष्यति \mathrm{S}_{1}^{\mathrm{pc}}$, युद्धेर्विष्ण्णुर्भविष्यति $\mathrm{S}_{1}^{\mathrm{ac}}$, युद्धे दैत्य $\left\{\right.$ ०त्यं $\left.S_{3}^{\text {pc }}\right\}$ र्वधिष्यति $S_{3} \quad 20 a$ एवं ] $S_{1} R A B h$, एव $S_{3}$ - प्रोका ] $S_{3} R A B h$, प्रोक्त $S_{1} 20 b$ ०योगा: सुरेश्वरा: ] $\mathrm{S}_{3} \mathrm{RA}_{3} \mathrm{~A}_{4} \mathrm{Bh}$, (०यो)गा सुरेश्वरा $\mathrm{S}_{1} \quad 20 \mathrm{~d}$ ०मब्रुवन् ] $\mathrm{S}_{3} \mathrm{R}^{\mathrm{pc}} \mathrm{Bh}$ (conj.), ०मब्रवीत् $\mathrm{S}_{1}$ 21d दिश नः ] $\mathrm{S}_{3} B h$ (em.?), (दि)शः न $\mathrm{S}_{1} 22$ पितामह उवाच ] $\mathrm{S}_{3} \mathrm{RA}$ (पिताम उ in $\mathrm{S}_{3}$ ), ब्रह्माण उ $\mathrm{S}_{1}$, ब्रह्मोवाच $\mathrm{Bh}\left(\mathrm{em}\right.$. ?) $22 \mathrm{~b}$ विदितं मया ] $\mathrm{S}_{3} \mathrm{R}^{\mathrm{ac}}$, विदितस्य मे+: $+\mathrm{S}_{1}$, विदितन्च मे $\mathrm{Bh}$ (conj.) 22c वस्तव्यं ] $S_{3} R A B h$, वक्तव्यं $S_{1}$ 
यूयं सर्वशरीरेषु योगाद्वसत सत्तमाः।

प्रजानां सर्वतो देवास्ततो वृत्तिमवाप्स्यथ॥ २३॥

तेषामशितपीतैश्च संस्कारैश्च पृथग्विधैः।

पृथिवी नागबद्धापि युष्मानाप्याययिष्यति॥ २४॥

सनत्कुमार उवाच।

त एवमुका देवेन देवा: सर्वे सवासवाः।

तथा चक्रुर्यथोवाच ब्रह्मा लोकपितामहः ॥ २४ ॥

ते उवर्तयन्त सततं तत्रस्थाः सुरसत्तमाः।

चतुर्युगमुपासन्त लोकधातुर्मते स्थिताः॥ र६॥

अथ योगाद्विरण्याक्षः प्रजासु समवस्थितान्।

सुरानपश्यद्योगात्मा चुकोप स च तान्प्रति॥ २७॥

यस्मिन्यस्मिन्नपश्यच्च सुरं स समवस्थितम्।

अवधीत्तं तमम्येत्य तदा दानवसत्तमः॥ २५॥

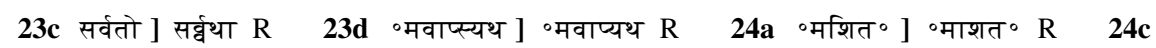
नाग॰] नाश॰ $R \quad 26 a$ उवर्तयन्त ] वर्त्तयन्तः $R \quad 26 \mathrm{c}$ ॰मुपासन्त ] ॰मुपासन्तो $R$ 26d लोक॰ ] लोल॰ $\mathrm{R} 27 \mathrm{~b}$ समव०] सम० $\mathrm{R}$ (unmetrical) $27 \mathrm{c}$ ०नपश्यद् ] ॰न्मन्यत $\mathrm{R} 2 \mathrm{27d}$ स च] च स $\mathrm{R} 28 \mathrm{a}$ ०न्नश्यच्च] ॰नपश्यत् $\mathrm{R}^{\mathrm{pc}}$ (unmetrical), ॰नपश्यत $\mathrm{R}^{\mathrm{ac}}$ (unmetrical) $28 \mathrm{~b}$ सुरं स समव॰ ] स सुरस्च सम॰ $R \quad 28 c$ अवर्धत्तं ] अवधात्तं $R \quad 28 d$ तदा ] तन्तु $R$

23a सर्वशरीरेषु ] सर्वे शरीरे मे $\mathbf{A} 23 \mathbf{b}$ योगाद्व०] $\mathrm{A}_{3}$, योगात्व॰ $\mathrm{A}_{4}$, योगन्व॰ $\mathrm{A}_{7} \quad 24 \mathbf{a}$ ०मशित०] ०मपित० $A \quad 24 c$ नागबद्धापि ] चावकल्पैग्च $A \quad 24 d$ ०प्याययिष्यति ] $A_{3}$, ०प्यायिष्य [० स्य० $\left.\mathrm{A}_{7}\right\}$ ति $\mathrm{A}_{4} \mathrm{~A}_{7}$ (unmetrical) 25a त ] $\mathrm{A}_{3} \mathrm{~A}_{4}$, om. $\mathrm{A}_{7}$ (unmetrical) 25b सवासवा: ] $\mathrm{A}_{3} \mathrm{~A}_{4}$, शवा: शवा: $A_{7} 25 d$ ०पितामहः ] $A_{3} A_{4}$, ०पितामह $A_{7}$ 26a उवर्तयन्त ] $A_{7}$, वर्त्तयंतः $A_{3} A_{4}$ 26b तत्रस्था: ] $\mathrm{A}_{7}$, तत्रस्था $\mathrm{A}_{3} \mathrm{~A}_{4} 27 \mathbf{b}$ समव॰] समुप॰ $A$ 28a ०न्नपश्यच्च ] ०न्नपश्यन्त $\mathrm{A}_{7}$, ०न् म $\left\{\mathrm{A}_{4}\right\}$ पश्चाच $\mathrm{A}_{3} \mathrm{~A}_{4} \quad \mathbf{2 8 b}$ सुरं स समवस्थितम् ] स सुरान्समव $\left\{{ }^{\circ}\right.$ मुप॰ $\left.\mathrm{A}_{3}\right\}$ स्थितान् $\mathbf{A} \mathbf{2 8 c}$ अवधीत्तं तम॰ $]$ अब्रवीत्तान्सम ${ }^{\circ} \mathrm{A}_{3} \mathrm{~A}_{4}$, अब्रवीत्त समा॰ $\mathrm{A}_{7}$

$\mathbf{2 3}\left\langle\mathrm{c}^{8}-\mathrm{d}^{7}\right\rangle\left(\mathrm{d}^{8}\right) \mathrm{S}_{3} \quad \mathbf{2 4}\left(\mathrm{a}^{3}-\mathrm{a}^{4}\right)\left\langle\mathrm{a}^{5}\right\rangle\left(\mathrm{a}^{6}-\mathrm{a}^{7}, \mathrm{~d}^{1}-\mathrm{d}^{2}\right) \mathrm{S}_{1},\left(\mathrm{a}^{8}-\mathrm{b}^{2}, \mathrm{c}^{1}-\mathrm{c}^{3}, \mathrm{~d}^{1}-\mathrm{d}^{2}\right) \mathrm{S}_{3} \quad \mathbf{2 6}\left(\mathrm{c}^{1}\right) \mathrm{S}_{1} \quad \mathbf{2 7}\left(\mathrm{a}^{8}-\right.$ $\left.b^{2}, b^{8}-c^{1}, d^{1}\right) S_{1},\left(a^{1}-a^{5}\right)\left\langle a^{6}-a^{7}\right\rangle\left(a^{8}-b^{2}\right)\left\langle b^{3}\right\rangle\left(b^{4}-c^{3}, c^{6}-c^{8}\right) S_{3}$

23a सर्व०] $S_{1} S_{3} R$, सर्वे $B h \quad 23 b$ ०द्वससत ] $S_{3} R A_{3}$, ०द्वेसव $S_{1}$, ०द् विशत $B h$ (conj.) • सत्तमा: ] RABh, सत्तमा $S_{1} S_{3} 23 c$ प्रजानां ] $S_{1} R A B h$, पूजानां $S_{3}$ 24d ०प्याययिष्यति ] $S_{3}$ $\mathrm{RA}_{3} \mathrm{Bh}$, व्यायमिष्यति $\mathrm{S}_{1}$ 25a त एवमुक्ता ] $\mathrm{S}_{3} \mathrm{RA}_{3} \mathrm{~A}_{4} \mathrm{Bh}$, तदेवमुत्का $\mathrm{S}_{1}$ 25b देवा: सर्वे] $\mathrm{RABh}$, सर्वे देवा $\mathrm{S}_{1}$, देवा सर्वे $\mathrm{S}_{3}$ - सवासवा: ] $\mathrm{S}_{1}^{\mathrm{pc}} \mathrm{S}_{3} \mathrm{RA}_{3} \mathrm{~A}_{4} \mathrm{Bh}$, सवासवा $\mathrm{S}_{1}^{\mathrm{ac}} 25 \mathrm{c}$ कक्रुर्यथो॰ ] $S_{3} R A B h$, ०कुु थो॰ $S_{1}$ (unmetrical) 25cd ०वाच ब्रह्मा ] $S_{1} R A B h$, ०वाचा ब्रह्म $S_{3}$ 25d पितामहः ] $\mathrm{RA}_{3} \mathrm{~A}_{4} \mathrm{Bh}$, ०पितामह $\mathrm{S}_{1} \mathrm{~S}_{3} \quad \mathbf{2 6 b}$ तत्रस्था: ] $\mathrm{RA}_{7} \mathrm{Bh}$ (em.?), तत्रस्था $\mathrm{S}_{1} \mathrm{~S}_{3}$ 26c ०मुपासन्त ] $\mathrm{S}_{1} \mathrm{~S}_{3} \mathrm{~A}$, ०मुपासन्तो Bh (conj.) 26d ०धातुर् ] RABh, ०धातु $\mathrm{S}_{1} \mathrm{~S}_{3}$ - स्थिता: ] RABh, स्थिता $S_{1} S_{3}$ 27a ०द्विरण्याक्षः ] RABh, ०द्विरण्या(क्ष) $S_{1}, f-c-\left(\right.$ क्ष) $S_{3} \quad 27 b$ समवस्थितान् ] $S_{1}$, (समवस्थिता) $S_{3}$, समवास्थितान् Bh (typo?) 27d चुकोप ] $S_{3} R A$, (चु)कोप $\mathrm{S}_{1}$, चुक्रोध $\mathrm{Bh}$ (conj.) - स च] $\mathrm{S}_{1} \mathrm{~S}_{3} \mathrm{~A}$, च स $\mathrm{Bh}$ (conj.) - तान्प्रति ] $\mathrm{S}_{3} R A B h$, तां प्रतिः $S_{1} \quad 28 a$ ननपश्यच ] $S_{1} B h$, ०नपश्य च $S_{3}$ (unmetrical) 28b स ] $S_{1} B h$, om. $S_{3}$ (unmetrical) $28 \mathrm{c}$ ॰ धीत्तं तम० $\mathrm{S}_{1}^{\mathrm{pc}} \mathrm{Bh}$, ०धी तन्तम॰ $\mathrm{S}_{1}^{\mathrm{ac}}$, ०धीत्तन्तद॰ $\mathrm{S}_{3}$ 
अहं प्रजा: सदोद्युको रक्षामि सततं भयात्।

ममैव ता दुराचारा विद्विषो वर्धयन्त्युत॥ २९॥

कृतझा: स्वामिघातिन्यो दुष्पूरा दुष्टचेतसाः।

मम शत्रूनिमान्दुष्टानन्नपानादिभि: सदा।

आप्याययन्ति दुर्वृत्ता दण्डार्हा मे मतास्ततः॥ ३०॥

एवं निश्चिन्त्य दैत्येन्द्रो नैर्घृण्यं परमं गतः।

यत्र तत्र गता: सर्वा: प्रजा: सर्वत्र सो उवधीत्॥ ३१॥

पल्वलानि तडागानि नदीप्रस्रवणानि च।

सर्वाण्येव तदा योगादशोषयत दानवः॥ ३२॥

औषध्यो उकृष्टपच्याश्च या ह्यासंस्तस्य सुत्रत।

व्यनाशयत्स ताश्चापि वृक्षवल्बीरशोषयत्॥ ३३॥

29a सदोद्युको ] सदोयुक्तो $R 29 \mathrm{c}$ ममैव ता ] ममैवैते $R 30 \mathrm{~b}$ दुष्पूरा दुष्टचेतसाः ] दुष्पुरा दुष्टचेतना: $R 30 c$ शत्रूनि॰ ] शक्रूनि॰ $R$ 30f मे] स्थ $R 31 a$ निश्चिन्त्य ] निश्चित्य $R$ 31b नैर्घृण्यं ] नैपुण्यं $\mathrm{R} 31 \mathrm{c}$ यत्र तत्र गताः सर्वा: ] तत्र यत्र मृताः सर्व्व $\mathrm{R} 31 \mathrm{~d}$ उवधीत् ] उब्रवीत् $\mathrm{R}$ 32a पल्वलानि ] पत्ललानि $R \quad 32 \mathrm{c}$ तदा ] तमो॰ $R \quad 33 \mathrm{a}$ औषध्यो ] ओषध्यो $R \quad 33 b$ या ह्यासंस्तस्य ] यास्यामभ्यस्य $\mathrm{R}$

29a प्रजा: ] $\mathrm{A}_{3} \mathrm{~A}_{4}$, प्रदा: $\mathrm{A}_{7}$ - सदोद्युक्तो] सदोयुक्तो $\mathrm{A}_{7}$, सदा युक्तो $\mathrm{A}_{3} \mathrm{~A}_{4}$ 29c ममैव ता ] तानेव च $\mathrm{A}_{3} \mathrm{~A}_{4}$, त एव च $\mathrm{A}_{7} \quad 30 \mathbf{a}-31 \mathbf{b}$ ] om. $\mathbf{A}$ 31c गता: सर्वा: ] गतान् सर्वान् $\mathbf{A}$ 31d उवधीत् ] ब्रवीत् $A$ 32b ०प्रस्रवणानि ] ॰ श्चु पुष्कराणि $\mathrm{A}_{3} \mathrm{~A}_{4}$, ०श्च पुस्करानि $\mathrm{A}_{7} 32 \mathrm{c}$ सर्वाण्ये॰] सर्वान्ये० $\mathrm{A}_{3} \mathrm{~A}_{7}$, सर्वोण्ये० $\mathrm{A}_{4} 32 \mathrm{~d}$ ०दशोषयत ] ०दपो $\left\{\circ\right.$ यो॰ $\left.\mathrm{A}_{3}\right\}$ थयत $\mathrm{A}$ 33a औषध्यो] ओषध्यो $A$ - इकृष्ट॰] $\mathrm{A}_{3} \mathrm{~A}_{4}$, हृष्ट० $\mathrm{A}_{7}$ - ०पच्याग्च ] $\mathrm{A}_{3} \mathrm{~A}_{7}$, ०पच्या स $\mathrm{A}_{4}$ 33b सुत्रत ] $\mathrm{A}_{3}$, सुत्रत $\mathrm{A}_{4}$, सुत्रतः $\mathrm{A}_{7} 33 \mathrm{c}$ व्यनाशयत्स ताश्चापि ] वाल्नी $\left\{\circ\right.$ ल्वी॰ $\mathrm{A}_{4}$, ०ली॰ $\left.\mathrm{A}_{7}\right\}$ सूयंय $\left\{\circ\right.$ प० $\left.\mathrm{A}_{4}\right\}$ तांश्चापि A 33d ०वल्ली०] $\mathrm{A}_{3} \mathrm{~A}_{7}$, ०वल्वी॰ $\mathrm{A}_{4}$

$29\left(c^{2}, d^{7}\right) S_{1} \quad 30\left(b^{1}-b^{2}\right) S_{1},\left(b^{5}, c^{2}-c^{4}, c^{7}-d^{2}, d^{5}, d^{8}, e^{5}\right)\left\langle e^{6}\right\rangle\left(e^{7}, f^{1}, f^{7}\right) S_{3} \quad 31\left(b^{2}\right) S_{3} \quad 33\left\langle a^{7}-\right.$ $\left.a^{8}\right\rangle\left(b^{1}, d^{2}\right) S_{1},\left(a^{5}\right)\left\langle c^{1}\right\rangle\left(c^{2}-c^{3}, c^{5}\right)\left\langle c^{6}-c^{7}\right\rangle\left(d^{1}-d^{2}, d^{6}\right) S_{3}$

29a प्रजाः ] $\mathrm{RA}_{3} \mathrm{~A}_{4} B h$, प्रजा $\mathrm{S}_{1}$, प्रज $\mathrm{S}_{3}$ 29d वर्धयन्त्युत ] $\mathrm{S}_{1} R A B h$, वद्धयन्त्युतः $S_{3}$ 30b ०चेतसा: ] em., ०चेतसा $S_{1} S_{3}$ (visarga possibly lost in $S_{1}$ ), ०चेतस: $B h$ (em.) 30cd शत्रूनिमान्दुष्टान॰ ] em. (cf. R), शत्रुनिमान्दृष्टान॰ $S_{1}$, (शत्रु)निमा(न्दुषान्न॰) $S_{3}$ (lower parts faint), शत्रूनिमा दुष्टान० Bh (conj.) 30d ०पानादिभिः ] $S_{1} R B h$, ०पाना(दि)भि $S_{3}$ (unmetrical) 30e आप्याययन्ति ] $S_{1}^{\text {pc }} S_{3} R B h$, आ(क्षा)ययन्ति $S_{1}^{\text {ac }}$ - दुर्वृत्ता ] $S_{1} R B h, ~-($ द्व $)$ ता $S_{3}$ 30f दण्डाहा ] $S_{1} R B h$, (द)ण्डहा $S_{3}$ - मतास्ततः ] $S_{3} R$, ततस्ततः $S_{1}$, ततस्तु ताः $B h$ (conj.) 31ab ] $\left(S_{3}\right)(R)$, om. $\mathrm{S}_{1}$ (an insertion mark before 31c; inserted pādas possibly lost i.m.), Bh conjectures loss of two pādas 31a निश्चिन्त्य ] em., निचिन्त्य $S_{3}$ • दैत्येन्द्रो ] $R$, दैन्द्रो $S_{3}$ (unmetrical) 31b नैर्घृण्यं ] em., नै(घृ)ण्यं $S_{3} \quad 31 c$ गताः ] em. $B h$ (silently), गता $S_{1} S_{3}$ • सर्वा: ] $S_{3} B h$ (em.), सर्वे $S_{1}$ 31d प्रजा: ] RABh, प्रजा $S_{1} S_{3}$ - उवधीत् ] $S_{1}^{\text {pc }} S_{3} B h$, वधी $S_{1}^{\text {ac }}$ 32b नदीप्रस्रव०] $\mathrm{S}_{1}^{\mathrm{pc}} \mathrm{S}_{3} \mathrm{R}$, नदीप्रव० $\mathrm{S}_{1}^{\mathrm{ac}}$ (unmetrical), नदी: प्रस्रव $\mathrm{Bh}$ (conj.?) 32c सर्वाण्ये०] $\mathrm{S}_{3} \mathrm{RBh}$ (em.?), सवाण्ये० $S_{1}$ 32cd योगाद० $S_{1}^{\text {pc }} S_{3} R A B h$, यो(य)द० $S_{1}^{\text {ac }}$ 32d दानव: ] $S_{3} R A B h$, दानवा $S_{1}$ 33a औषध्यो] $\mathrm{S}_{1} \mathrm{~S}_{3}$, ओषध्यो $\mathrm{Bh}$ - इकृष्ट०] $\mathrm{S}_{1} \mathrm{RA}_{3} \mathrm{~A}_{4} \mathrm{Bh}$, कृ(ष्ण०) $\mathrm{S}_{3}$ • ०पच्याग्च ] $\mathrm{RA}_{3} \mathrm{~A}_{7}$ $\mathrm{Bh}$, ०प - $\simeq S_{1}$, ०पक्षाश्च $S_{3} 33 \mathbf{b}$ सुत्रत ] $\mathrm{RA}_{3} B h$, सुत्रतः $S_{1}$, सुत्रतः $S_{3} 33 \mathbf{c}$ व्यनाशयत्स ] $\mathrm{RBh}$ (em.?), व्यनाशयं स $\mathrm{S}_{1}, \simeq$ (नाश)य(स) $\mathrm{S}_{3}$ • ताश्चापि ] RBh (em.?), तश्चापि $\mathrm{S}_{1}, \quad$ - पि $\mathrm{S}_{3} 33 \mathrm{~d}$ ॰वल्नी॰ $\mathrm{S}_{1} \mathrm{RA}_{3} \mathrm{~A}_{7} \mathrm{Bh}$, ०वली॰ $\mathrm{S}_{3}$ (unmetrical) • ०रशोषयत् ] $\mathrm{S}_{1} \mathrm{~S}_{3} \mathrm{RA}$, ०रपोथयत् $\mathrm{Bh}$ (conj.) 


\title{
तन्नष्टवृक्षक्षुपवल्निपल्नवं तथौषधीप्रस्रवणोदकाशयम् । सरित्तडागावटशुष्कपल्वलं जगद्वभौ कच्छ,पपृष्टसंनिभम्॥ ३४॥ प्रनट्टवर्णाश्रमधर्मसंयमं विनष्टघोषत्रजपक्षिमानुषम्। द्विपाश्वपश्वादिगणैर्विनादितं युगान्तकालाग्निसुदगधवज्जगत् ॥ ३४ ॥
}

\author{
इति स्कन्दपुराणे षण्नवतितमो डध्यायः॥ ९६॥
}

\footnotetext{
34a ववृक्षक्षुपवत्रिपत्लवं ] ॰वश्निक्षुपवृक्षपल्ववं $\mathrm{R} \quad 34 \mathrm{~b}$ ०काशयम् ] ०काश्रयम् $\mathrm{R} \quad 34 \mathrm{c}$ ॰पल्वलं ]

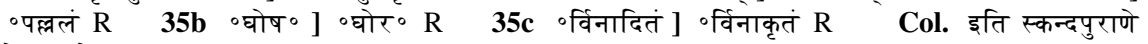
रेवाखण्डे इध्याय: $\mathrm{R}$
}

34a ०वल्लि॰ $\mathrm{A}_{3} \mathrm{~A}_{4}$, ०वनि॰ $\mathrm{A}_{7}$ (unmetrical) 34b तथौषधी॰] तथौ $\left\{\right.$ थो० $\left.\mathrm{A}_{4}\right\}$ षधि॰ $\mathrm{A} \quad 34 \mathbf{c}$ ०शुष्कपल्वलं ] ॰शुक्क $\left\{{ }^{\circ}\right.$ ल्क $\left.\mathrm{A}_{4}\right\}$ पत्नवं $\mathrm{A}_{3} \mathrm{~A}_{4}$, ०सुश्कपलं $\mathrm{A}_{7}$ (unmetrical) 34d ] यच्छ,मो कच्छुपपद्मसत्निभं $\mathrm{A}_{3} \mathrm{~A}_{4}$ (unmetrical), जगच्च सर्व्वं चुकुभे दिगन्तं $\mathrm{A}_{7} 35 \mathbf{a}$ प्रनष्ट०] प्रणष्ट० $\mathbf{A} \bullet$ वर्णा०] ०वदा० $\mathrm{A}_{3} \mathrm{~A}_{4}$ (unmetrical), ०दा॰ $\mathrm{A}_{7}$ (unmetrical) 35b ०व्रज०] $\mathrm{A}_{7}$, ०ब्रज० $\mathrm{A}_{3} \mathrm{~A}_{4}$ ० ०पक्षिमानुषम् ] ०धर्मसंयमं $A \quad 35 c$ ०पश्वादि॰] ०पत्यादि॰ $A$ ०र्विनादितं ] $\mathrm{A}_{3} \mathrm{~A}_{4}$, ०र्विणादित $\mathrm{A}_{7}$ 35d ०सुदगध०] ०मुदग्र० $\mathbf{A}$ - ववज्जगत् ] $\mathrm{A}_{3} \mathrm{~A}_{4}$, ०यज्जगदिति $\mathrm{A}_{7}$ (unmetrical) Col. इति स्कन्दपुराणे एकाशीतिसाहस्रचां संहिताया $\left\{\right.$ इति स्कंद॰ $\left.\mathrm{A}_{4}\right\}$ मम्बिकाखण्डे हिरण्याक्षाज्ञाध्याय: $\mathbf{A} \pm$

34 $\left(\mathrm{a}^{1}, \mathrm{a}^{11}\right) \mathrm{S}_{3} \quad \mathbf{3 5}\left\langle\mathrm{a}^{4}\right\rangle\left(\mathrm{c}^{2}-\mathrm{c}^{5}, \mathrm{~d}^{8}-\mathrm{d}^{9}\right)\left\langle\mathrm{d}^{10}\right\rangle \mathrm{S}_{1}$

34a ववल्लिपल्नवं ] $\mathrm{S}_{1} \mathrm{~A}_{3} \mathrm{~A}_{4} \mathrm{Bh}$, ववलिप(ल्व)वं $\mathrm{S}_{3}$ (unmetrical) 34b तथौ॰ ] $\mathrm{S}_{1} \mathrm{~S}_{3} \mathrm{RA}_{3} \mathrm{~A}_{7}$, तृणौ॰ $\mathrm{Bh}$ (conj.) - ०णोदकाशयम् ] ABh, ०णोदनाशयम् $S_{1}$, ०णदकाशयत् $S_{3}$ (unmetrical) $\mathbf{3 4 c}$ ०गावट॰] $S_{3} R A B h$, ०गावत॰ $S_{1}$ 34d जगद् ] $S_{3} R B h$ (conj.?), गजं $S_{1}$ • कच्छप ० ] $S_{1} R A$ $\mathrm{A}_{4} \mathrm{Bh}$, कछाप $\mathrm{S}_{3}$ (unmetrical) • ०पृष्ठ॰] RBh (em.?), ०पृष्ट० $\mathrm{S}_{1} \mathrm{~S}_{3}$ • ०संनिभम् ] $\mathrm{S}_{1} \mathrm{~S}_{3}^{\mathrm{pc}} \mathrm{RA}_{3}$ $\mathrm{A}_{4} \mathrm{Bh}$, ०सनिभं $\mathrm{S}_{3}^{\mathrm{ac}}$ (unmetrical) 35a प्रनष्ट०] $\mathrm{S}_{1} \mathrm{~S}_{3} \mathrm{R}$, प्रणष्ट० $\mathrm{Bh}$ 35b विनष्ट०] $\mathrm{S}_{1} \mathrm{RABh}$, विन० $\mathrm{S}_{3}$ (unmetrical) • ०व्रज०] $\mathrm{S}_{3} \mathrm{RA}_{7} \mathrm{Bh}$, ०ब्रज० $\mathrm{S}_{1} \quad 35 \mathrm{c}$ द्विपाग्व०] $\mathrm{RABh}$, द्वि(पाश्चे०) $S_{1}$, द्विषाग्व० $S_{3}$ - ०पश्वादि॰] $S_{3} R$, - -ादि॰ $S_{1}$ (first aksara has subscript य and second subscript व्), ०पत्यादि॰ $\mathrm{Bh} \bullet$ ०गणैर् ] $\mathrm{S}_{1} \mathrm{RABh}$, ०गणे $\mathrm{S}_{3}$ - ०नादितं ] $\mathrm{S}_{3} \mathrm{~A}_{3} \mathrm{~A}_{4} \mathrm{Bh}$, ०नादित $S_{1}$ 35d ०कालाग्नि॰] $S_{3} R A B h$, ०कालानि॰ $S_{1}$ • ०सुदग्ध०] $S_{1} S_{3} R$, ०मुदग्र० $B h$ ० ०वज्जगत् ] $\mathrm{RA}_{3} \mathrm{~A}_{4} \mathrm{Bh}$, -ज्जगदिति $\mathrm{S}_{1}$ (इति part of col.), ०व जगत् $\mathrm{S}_{3}$ (unmetrical) Col. $\odot ॥$ स्कन्दपु (रा)णे ब्रह्मणे वाक्ये आध्यायः १५२ (in letter numerals)॥ $\odot \mathrm{S}_{1}, \odot ॥ \asymp($ न्दपुराणे) नामाध्यायः ९६ (in letter numerals)॥ $\odot \mathrm{S}_{3}$, इति स्कन्दपुराणे ब्रह्मणो वाक्यं नाम षण्नवतितमोध्याय: Bh 
सत्तनवतितमो ऽध्यायः ।

सनत्कुमार उवाच।

तथाभूतं जगद्दृष्ट्रा देवास्ते दुःखपीडिताः।

वैराजं लोकमासाद्य भूयो उपश्यन्पितामहम्॥ ? ॥

ते सर्वे समुपागम्य प्रणम्य च पुनः पुनः।

ऊचुस्ते कर्म दैत्यस्य सर्व एव सुदुः खिताः।

निवेद्य च पुनर्देवमूचुस्ते लोककारणम्॥ २॥

भगवन्ह्तरराज्याश्च दुर्बलाश्च तथा विभो।

असमर्था वयं तस्य स्थातुं दैत्यस्य संयुगे।

न तत्स्थानं प्रपश्याम यत्र तिष्ठाम विज्वराः ॥ ३॥

सनत्कुमार उवाच।

तेषां तद्वचनं श्रुत्वा भीतानां त्रिदिवौकसाम्।

उवाच भगवान्ब्रह्मा सर्वानेव दिवौकसः ॥ ४ ॥

न भेतव्यं सुरास्तस्य योगिन: सुमहात्मनः।

समाप्त तपसः सर्वं फलं दैत्यस्य तस्य तत् $॥$ ४॥

$1 a$ तथाभूतं ] तथाविधं $R \quad 1 d$ इपश्यन् ] प्येनं $R \quad 2 b c$ ] om. $R \quad$ 2e च ] om. R (unmetrical) $3 b$ तथा ] तदा $R$ 3e ०पश्याम ] ०पश्यामो $R$ 3f विज्वरा: ] विद्वरा: $R$ 5a भेतव्यं ] तेतरां $\mathrm{R}$

1c वैराजं लोक॰] देवा अलोक॰ $\mathrm{A}_{3} \mathrm{~A}_{4}$, देवा लोक्य० $\mathrm{A}_{7}$ (unmetrical) 2c दैत्यस्य ] $\mathrm{A}_{3} \mathrm{~A}_{4}$, दैत्येन्द्र $\mathrm{A}_{7} \quad 3 \mathbf{a}$ वन्हृतराज्याश्च ] ०वन्नो $\left\{\circ\right.$ न्वो $\left.\mathrm{A}_{4}\right\}$ हृतं राज्यं $\left\{{ }^{\circ}\right.$ ह्यं $\left.\mathrm{A}_{7}\right\} \mathbf{A}$ 3b विभो] $\mathrm{A}_{3} \mathrm{~A}_{4}$, विभो: $\mathrm{A}_{7} 3 \mathrm{3d}$ स्थातुं दैत्यस्य संयुगे ] संयुगे स्थातुमग्रतः $\mathbf{A}$ 3e-5b ] om. $\mathbf{A}$ 5c Before this $\mathbf{A}$ adds ब्रह्मोवाच। 5d तस्य ] $\mathrm{A}_{3} \mathrm{~A}_{4},\langle$ स $\rangle+\left(\right.$ द्य) $+\mathrm{A}_{7}$ (unmetrical)

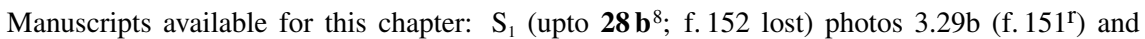
3.30a (f. $151^{\mathrm{v}}$ ); $\mathrm{S}_{3}$ (upto $\mathbf{5} \mathbf{d}^{2}$ and from $\mathbf{4 2 \mathbf { f } ^ { 7 }}$; f. 152 lost) f. $151^{\mathrm{v}}$ and $153^{\mathrm{r}}$; R f. $169^{\mathrm{r}}-170^{\mathrm{v}} ; \mathrm{A}_{3}$ f. $100^{\mathrm{r}}-101^{\mathrm{r}} ; \mathrm{A}_{4}$ f. $143^{\mathrm{r}}-144^{\mathrm{r}} ; \mathrm{A}_{7}$ f. $141^{\mathrm{r}}-142^{\mathrm{v}}$.

$\mathbf{3}\left(a^{3}\right) S_{1},\left(a^{1}, a^{5}-a^{7}, b^{2}-b^{6}\right) S_{3} \quad 4\left(c^{6}-c^{7}\right) S_{1},\left(a^{3}, d^{5}\right) S_{3} \quad \mathbf{5}\left(a^{5}, b^{1}, b^{5}-b^{6}, c^{2}-c^{4}, c^{8}\right)\left\langle d^{3}-d^{8} \rightarrow\right\rangle S_{3}$ (one folio lost after this)

1 a जगद् ] $S_{1} R A B h$, जग $S_{3}$ (unmetrical) 1 b ०पीडिता: ] $S_{1} R A B h$, ०पीडिता $S_{3}$ 1c वैराजं ] $S_{1} R B h$, वैराज० $S_{3}$ 1d उपश्यन् ] $S_{3} A B h$, पश्यम् $S_{1}$ 2c ०स्ते ] $S_{1} A B h$ (in a note Bh suggests ०स्तत्), ०स्तत् $S_{3}$ • दैत्यस्य ] $S_{3} A_{3} A_{4} B h$, दैव्यस्य $S_{1}$ 2d सर्व एव] $S_{1} S_{3} R A$, सर्वमेव $\mathrm{Bh}$ (conj.) 2e पुनर् ] $\mathrm{S}_{1} \mathrm{RABh}$, पुन $\mathrm{S}_{3}$ (unmetrical) $3 \mathbf{b}$ विभो ] $\mathrm{S}_{1}^{\mathrm{pc}} \mathrm{S}_{3} \mathrm{RA}_{3} \mathrm{~A}_{4} \mathrm{Bh}$, विभो: $S_{1}^{\text {ac }} 3 \mathrm{e}$ तत् $] \mathrm{R}$, स $\mathrm{S}_{1} \mathrm{~S}_{3}$, च $\mathrm{Bh}$ (conj.) - ०पश्याम $\mathrm{S}_{3}$, ०पश्याद्य $S_{1}$, ०पश्यामो $\mathrm{Bh}$ (conj.) 3f तिष्टाम ] $S_{1}^{\mathrm{pc}} S_{3} R B h$, तिःष्ठाम $S_{1}^{\mathrm{ac}}$ - विज्वरा: ] $S_{1}^{\mathrm{pc}} S_{3} B h$, विज्वरा $S_{1}^{\text {ac }} 4 \mathbf{a}$ ॰द्वचनं ] $S_{1} R B h$, ॰द्वचन $S_{3}$ 4c ०न्ब्रह्मा ] $S_{1} R B h$, ०न्ब्रह्म $S_{3}$ 4d दिवौकस: ] RBh (em.?), दिवौकसाम् $S_{1}$, (दि)वौकसां $S_{3} \quad 5 b$ योगिन: ] $S_{1} R B h$, (यो)गिन $S_{3}$ (unmetrical) $5 \mathbf{c}$ ०तं तपस: ] $\mathrm{S}_{1} \mathrm{RABh},\left({ }^{\circ}\right.$ पन्त)पस $\mathrm{S}_{3}$ (unmetrical) 5d तस्य तत् $] \mathrm{RA}_{3} \mathrm{~A}_{4} \mathrm{Bh}$, तस्य त $\mathrm{S}_{1}^{\mathrm{pc}}$, (व)स्यत $\mathrm{S}_{1}^{\mathrm{ac}}$ 
कालस्तस्याभिसंप्राप्तो जीवितान्तकरः सुराः।

तस्मात्सर्वे मया सार्ध यात विष्णुं प्रयाचत॥ ६॥

भवन्तो निर्बला ह्यद्य अशक्तास्तस्य बाधने।

विष्णुः शक्तः स तं दैत्यं जीविताच्च्यावयिष्यति॥ ७॥

पूर्व हि जाते तस्मिस्तु वागुवाचाशरीरिणी।

नायं वध्यो मनुष्यस्य न देवस्य कथंचन॥ ५॥

नापि तिर्यक्षु जातस्य न भूमौ न च तेजसि।

नाकाशे नापि लोकेषु महात्मायं भविष्यति॥ ९॥

स एष देवा दैत्येशो महात्मा धार्मिकस्तथा।

अवध्यः सर्वभूतानां वध्यो दुःखाद्भविष्यति॥ १०॥

वाराहं रूपमास्थाय न देवत्वं न मानुषम्।

न च तिर्यक्षु तज्जातं नरवाराहमस्ति वै॥ १? ॥

पाताले च प्रविश्यैव नासौ भूर्नापि खं हि तत्।

न तेजो नापि लोको उसौ सर्वतो युक्तमेव तत्॥ १२॥

$6 a$ ०स्तस्याभि॰] ०स्तस्यापि $R \quad 6 b$ सुरा:] सुता: $R \quad 6 c$ ०त्सर्वे ] ॰त्सर्व्व $R \quad 7 c$ शक्तः स तं] शक्रसमं $R \quad 7 d$ ०च्यावयिष्यति ] ॰चानयिष्यति $R \quad 8 a$ हि जाते ] जातेति $R$ 9a तिर्यक्षु जातस्य ] तिर्य्यग्वधस्तस्य $\mathrm{R} \quad 9 \mathrm{~d}$ महात्मायं ] महात्मानं $\mathrm{R} \quad 10$ ] om. $\mathrm{R} \quad 11 \mathrm{~b}$ देवत्वं न ] दैवं तन्न $\mathrm{R}$

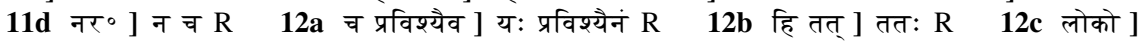
कालो $R$ 12d सर्वतो युक्तमेव ] सविता युक्त एव $R$

6a ०स्तस्याभि॰] $\mathrm{A}_{3}$, ०स्ते स्याभि॰ $\mathrm{A}_{4}$, ०स्तस्तभि॰ $\mathrm{A}_{7} \mathbf{6 b}$ सुरा: ] $\mathrm{A}_{3}$, सुरा $\mathrm{A}_{4}$, शुभा: $\mathrm{A}_{7} \mathbf{6 d}$ यात ] $\mathrm{A}_{3} \mathrm{~A}_{7}$, घात $\mathrm{A}_{4}$ 7a निर्बला ह्यद्य ] निर्बला $\left\{\circ 0\right.$ णा० $\left.\mathrm{A}_{7}\right\}$ त्यन्त $\mathbf{A} \quad \mathbf{7 b}$ बाधने ] $\mathrm{A}_{3} \mathrm{~A}_{4}$, बाधमे $\mathrm{A}_{7} \quad \mathbf{7 d}$ ०च्यावयिष्यति ] ०चाल $\left\{{ }^{\circ}{ }^{\circ} \mathrm{A}_{7}\right\}$ यिष्यति $A$ 8a पूर्वं $\mathrm{A}_{3} \mathrm{~A}_{7}$, पूर्व $\mathrm{A}_{4}$ (unmetrical) $8 \mathbf{b}$ ॰शरीरिणी] $\mathrm{A}_{4}$, ०शरीणी $\mathrm{A}_{3}$ (unmetrical), ०शरिरिणां $\mathrm{A}_{7}$ (unmetrical) 9a नापि तिर्यक्षु जातस्य ] न पितृय $\left\{\circ\right.$ र्य० $\left.A_{7}\right\}$ क्षराजस्य $A$ 9c लोकेषु ] लोकेशो $A$ 10a देवा दैत्येशो ] दैत्यो देवेशो $A 10 b$ ०स्तथा ] ०स्तदा $A 11 b$ देवत्वं न] दैवं न तु $A$ 11c तिर्यक्षु ] $\mathrm{A}_{3} \mathrm{~A}_{4}$, तिर्यकक्षु $\mathrm{A}_{7}$ (unmetrical) 11d नरवाराहमस्ति ] न वाराहमिहास्ति $\mathrm{A}_{7}$, नरावाहसिहास्ति $\mathrm{A}_{3} \mathrm{~A}_{4}$ 12ab च प्रविश्यैव नासौ भूर्नापि खं ] यस्चैव वला सो भून्नापि हसं $\left\{\circ\right.$ पि खं $\mathrm{A}_{7}$ (unmetrical) $\} \mathrm{A}$ 12c तेजो नापि ] तेजा नासि $\mathrm{A}_{7}$, तं जानाति $\mathrm{A}_{3} \mathrm{~A}_{4}$

$7\left\langle c^{1}\right\rangle\left(c^{2}, c^{6}, d^{4}\right) S_{1} \quad \mathbf{8}\left(c^{1}, c^{3}\right) S_{1} \quad \mathbf{1 0}\left(b^{1}-b^{5}\right)\left\langle b^{6}-c^{2}\right\rangle\left(c^{3}\right)\left\langle c^{4}\right\rangle\left(c^{5}-c^{8}\right) S_{1} \quad \mathbf{1 1}\left(c^{4}\right) S_{1} \quad \mathbf{1 2}\left(d^{2}\right) S_{1}$

$6 \mathbf{6}$ ०स्तस्याभि॰] $\mathrm{A}_{3} \mathrm{Bh}$, ०स्तस्याति॰ $\mathrm{S}_{1}$ - ०संप्राप्तो ] $\mathrm{S}_{1}^{\mathrm{pc}} \mathrm{RABh}$, ०सम्प्राप्ते $\mathrm{S}_{1}^{\mathrm{ac}}$ 6d यात ] $\mathrm{S}_{1}^{\mathrm{pc}} \mathrm{RA}_{3} \mathrm{~A}_{7} \mathrm{Bh}$, या(च) $\mathrm{S}_{1}^{\mathrm{ac}}$ - प्रयाचत ] $\mathrm{S}_{1}^{\mathrm{pc}} \mathrm{RABh}$, प्रयाचत: $\mathrm{S}_{1}^{\mathrm{ac}}$ 7a भवन्तो ] $\mathrm{S}_{1}^{\mathrm{ac}}$ ?RABh, सर्वन्तो $S_{1}^{\mathrm{pc}}$ - ह्यद्य ] RBh (conj.?), हतत्य $\mathrm{S}_{1} \quad \mathbf{7 b}$ बाधने ] $\mathrm{RA}_{3} \mathrm{~A}_{4} \mathrm{Bh}$, माधने $\mathrm{S}_{1} \quad \mathbf{7 c}$ विष्णु: ] $\mathrm{RABh}, \simeq$ (ष) $\mathrm{S}_{1}$ (lower parts lost) $\mathbf{7 d}$ ०ताच्च्यावयिष्यति ] $\mathrm{S}_{1}^{\mathrm{pc}} \mathrm{Bh}$, ०ता+(त्)+ च्यावयिष्यति $\mathrm{S}_{1}$ $8 \mathbf{a}$ पूं ] $\mathrm{RA}_{3} \mathrm{~A}_{7} \mathrm{Bh}$, पूर्वो $\mathrm{S}_{1} \mathbf{8 b}$ ॰चाशरीरिणी ] $\mathrm{S}_{1}^{\mathrm{pc}} \mathrm{RA}_{4} \mathrm{Bh}$, ०च शरीरिणी $\mathrm{S}_{1}^{\mathrm{ac}} \quad \mathbf{8 c}$ वध्यो ] $\mathrm{S}_{1}^{\mathrm{ac}} \mathrm{RABh}$, (ब)न्ध्यो $\mathrm{S}_{1}^{\mathrm{pc}} \quad 10 \mathrm{a}$ दैत्येशो ] em. Bh (silently), दैत्येषा $\mathrm{S}_{1} \quad \mathbf{1 0 b}$ धार्मिक॰] $\mathbf{A B h}$, (धर्मि) $\cdots S_{1}$ - ०स्तथा ] conj., ०स्तदा $B h \quad 10 d$ वध्यो ] $A B h$, बध्यो $S_{1} 11 b$ देवत्वं न] $\mathrm{S}_{1}$, दैवं नापि $\mathrm{Bh}$ (conj.) 11c तिर्यक्षु $\mathrm{S}_{1}^{\mathrm{pc}} \mathrm{RA}_{3} \mathrm{~A}_{4} \mathrm{Bh}$, तिक्षु $\mathrm{S}_{1}^{\mathrm{ac}}$ (unmetrical) - तज्जातं ] $S_{1}^{\text {pc } R A B h, ~-~-~ त ं ~} S_{1}^{a c}$ 11d वै ] $S_{1}^{p c} R A B h$, वै: $S_{1}^{a c} \quad$ 12a च ] conj. Bh (silently), व $S_{1}$ $12 b$ नासौ ] RBh (em.?), नासो $S_{1}$ • तत् ] $A B h$, तम् $S_{1} \quad 12 c$ नापि ] RBh (conj.?), वापि $\mathrm{S}_{1}$ 12d युक्तमेव ] A, मुक्तमेव $\mathrm{S}_{1} \mathrm{Bh}$ 
सनत्कुमार उवाच।

ततस्ते हृषिता: सर्वे प्रणम्य च पितामहम्।

ऊचुर्गच्छाम देवेश कालो डतिकामते हि नः॥ १३॥

ततस्ते सर्व एवेत्य श्वेतं पर्वतसत्तमम्।

विष्णुं सहिष्णुं जिष्णुं च दानवायुतमर्दनम्।

अस्तुवन्वाग्भिरिष्टाभिः प्रणम्य बहुमानतः॥ १४॥

नमः सर्वरिपुछाय दानवान्तकराय च।

नमो ऊजिताय देवाय वैकुण्ठाय महात्मने ॥ १४ ॥

नमो निर्धूतरजसे नमः सत्याय चैव ह।

नमः साध्याय देवाय नमो धाम्ने सुवेधसे॥ १६॥

नमो यमाय देवाय जयाय च नमो नमः।

नमश्चादितिपुत्राय नरनारायणाय च॥ १७॥

नमः सुमतये चैव नमश्चैवास्तु विष्णवे।

नमो वामनरूपाय कृष्णद्वैपायनाय च॥ १५॥

नमो रामाय रामाय दत्तात्रेयाय वै नमः।

नमस्ते नरसिंहाय धात्रे चैव नमो नमः॥ १९॥

नमः शकुनिहन्त्रे च नमो दामोदराय च।

सलिले तप्यमानाय नागशय्याप्रियाय च॥ २०॥

$13 \mathrm{~b}$ च पिता॰ ] प्रपिता० $\mathrm{R} \quad 13 \mathrm{c}$ ऊचुर्ग॰] $\mathrm{R}^{\mathrm{ac}}$, ऊचु+(स्)+कर्ग॰ $\mathrm{R} \quad 13 \mathrm{~d}$ ॰ कामते हि न: ] क मतो हि स: $R \quad 14 a$ एवेत्य ] एवैत्य $R \quad 14 b$ क्तम्तम् ] ममुत्तमक् $R \quad 16 b$ ह ] हि $R \quad 16 d$ सुवेधसे ] सुरेधिने $R \quad 17$ ] om. $R \quad 18 d$ च ] नम: $R$ (unmetrical) 19a रामाय रामाय ] वामाय रामाय $\mathrm{R} \quad 20 \mathrm{a}$ शकुनि॰] शत्रुनि॰ $\mathrm{R}$

$13 \mathrm{c}$ देवेश ] देवेशं $A \quad 13 \mathrm{~d}$ कामते हि ] कामतीह $\mathrm{A} \quad 14 \mathrm{~b}$ श्वेतं ] $\mathrm{A}_{3} \mathrm{~A}_{4}$, श्रेतं $\mathrm{A}_{7}$ - पर्वतसत्तमम् ] परममुत्तमं $\mathrm{A} 14 \mathrm{f}$ बहुमानतः ] बहुशो ल $\left\{\right.$ न्त $\left.{ }^{\circ} \mathrm{A}_{3}\right\}$ ता: $\mathbf{A} 15 \mathrm{c}$ नमो ] तमो॰ $\mathrm{A} 16 \mathrm{~b}$ ह ] हि $\mathrm{A} \quad 16 \mathrm{c}$ देवाय ] वेदाय $\mathrm{A} \quad 16 \mathrm{~d}$ सु० ] च $\mathrm{A} \quad 17$ ] om. $\mathrm{A} \quad 18 \mathrm{a}$ सुमतये ] स्वरतये $\mathrm{A}_{3} \mathrm{~A}_{4}$, शुरतये $\mathrm{A}_{7} 19 \mathrm{a}$ रामाय रामाय] रामाय नागाय $A$ 19c नर॰] नार॰ $A$ 19d धात्रे चैव ] ऋतवे च $\mathbf{A}$ - After this $\mathbf{A}$ has two pādas reading नमः साध्याय वेदाय चक्रिणे वै नमो नमः। (cf. 16c) 20a शकुनि॰ ] शत्रुनि॰ $\mathrm{A}_{3} \mathrm{~A}_{4}$, शक्रुनि॰ $\mathrm{A}_{7}$ 20c सलिले] मलिने $\mathrm{A}_{3} \mathrm{~A}_{4}$, मनिले $\mathrm{A}_{7}$ 20d ०शय्या०] $\mathrm{A}_{3} \mathrm{~A}_{4}$, ०सय्या० $\mathrm{A}_{7}$

13(speaker indication $\left.1-a^{4}\right)\left\langle a^{5}-a^{8}\right\rangle\left(b^{1}\right)\left\langle b^{2}-b^{5}\right\rangle\left(c^{1}-c^{2}\right) S_{1} \quad 17\left(c^{3}\right) S_{1} \quad 18\left\langle d^{8}\right\rangle S_{1}$

$13 d$ क्रामते ] $S_{1}$, क्रमते $B h(e m$.$) - न: ] A B h$, व: $S_{1}$ 14a एवेत्य ] $S_{1} A$, एवैत्य $B h$ (em.?) 14b श्वेतं ] $\mathrm{RA}_{3} \mathrm{~A}_{4} \mathrm{Bh}$, श्वेत॰ $\mathrm{S}_{1} 14 \mathrm{e}$ अस्तुवन् ] $\mathrm{RABh}$, अड्रुतं $\mathrm{S}_{1}^{\mathrm{pc}}$, अ(द्वत्व) $\mathrm{S}_{1}^{\mathrm{ac}}$ $16 \mathbf{a}$ ०रजसे ] $\mathrm{S}_{1} \mathrm{RA}$, ०रजमे $\mathrm{Bh}$ (typo) $16 \mathbf{b}$ ह ] em., ह: $\mathrm{S}_{1}$, हि $\mathrm{Bh}$ 19a रामाय रामाय ] conj. Bh (silently), रागाय रामाय $S_{1}$ 19d धात्रे ] RBh (em.?), धात्रै $S_{1}$ - After this Bh has two pādas reading नमः साध्याय वेदाय चक्रिणे वै नमो नमः। $20 \mathrm{a}$ हहन्त्रे] $\mathrm{RABh}$, हनन्ते $\mathrm{S}_{1}$ 20d ०शय्या॰] $\mathrm{S}_{1}^{\mathrm{pc}} \mathrm{RA}_{3} \mathrm{~A}_{4} \mathrm{Bh}$, ०शय्यां $\mathrm{S}_{1}^{\mathrm{ac}}$ 
नमः कपिलरूपाय महते पुरुषाय च।

नमो जीमूतरूपाय महादेवप्रियाय च॥ २?॥

नमो रुद्रार्धरूपाय तथोमारूपिणे नमः।

चक्रमुद्ररहस्ताय महेश्वरगणाय च॥ २२॥

शिविपिष्टाय च सदा नमः ग्रीवत्सधारिणे।

धुन्धुमाराय शूराय मधुकैटभघातिने॥ २३॥

चतुर्भुजाय कृष्णाय रत्नकौस्तुभधारिणे।

त्रिविक्रमवियत्स्थाय पीतवस्त्रसुवाससे॥ २४॥

नमः पुरविघाताय गदाखड्रोग्रधारिणे।

योगिने यजमानाय भृगुपत्नीप्रमाथिने ॥ २४ ॥

वृषरूपाय सततं आदित्यानां वराय च।

चेकितानाय दान्ताय शौरिणे वृष्णिबन्धवे॥ २६॥

पुराम्वग्रीवनाशाय तथैवासुरसूदिने ।

नमस्ते शार्ड्रधनुषे सौभसाल्वविघातिने॥ २७॥

नमस्ते पद्मनाभाय ब्रह्मसत्पथदर्शिने ।

नमो जयाय शर्वाय रुद्धदत्तवराय च ॥ २६॥

नमः सर्वेय्वरायैव नष्टधर्मप्रवर्तिने ।

पुरुषाय वरेण्याय नमस्ते शतबाहवे।

तव प्रसादात्कृच्छान्वे तरामः पुरुषोत्तम॥ २९.॥

$24 b$ रत्न०] चक्र० $R \quad 25 b$ वड्गोग्रधारिणे] ०खड़ाय पाणये $R \quad 26 b$ आदित्यानां वराय ] आदित्याराधनाय $R \quad 26 c$ चेकितानाय ] केचित्तनोग्र० $R \quad 26 d$ ०बन्धवे ] ०रूपिणे $R \quad 27 a$ पुराश्य॰ ] पुरा सु॰ $\mathrm{R} \quad$ - ०नाशाय ] ॰नाम्ने च $\mathrm{R}^{\mathrm{pc}}$, ०नामाय $\mathrm{R}^{\mathrm{ac}} \quad 27 \mathrm{c}$ ०धनुषे] ०धनुषा $\mathrm{R} \quad 27 \mathrm{~d}$ सौभसाल्वविघातिने ] शौरशत्रुनिपातिने $R \quad$ 28-29 ] om. $R$

21ab ] om. A 22a रुद्रार्ध०] रतार्द्ध॰ A 22b तथोमारूपिणे नमः ] तथा दामोदराय च $\mathbf{A} 23$ ] om. A $24 c$ ०वियत्स्थाय ] ०वियस्थाय $A$ 24d ॰वस्त्र॰] ॰वास:० A 25a पुरवि॰] पुरुष० A 25c यजमानाय] $A_{7}$, जयमानाय $A_{3} A_{4}$ 26ab ] om. $A$ 26d शौरिणे] $A_{3}$, सौरिणे $A_{4} A_{7}$ - वृष्णि॰] $\mathrm{A}_{3} \mathrm{~A}_{4}^{\mathrm{pc}}$, वृष्टि॰ $\mathrm{A}_{4}^{\mathrm{ac}} \mathrm{A}_{7}$ - ॰बन्धवे ] ॰बान्धवे $\mathbf{A}$ 27a पुराम्व॰ ] पुरा सु॰ $\mathrm{A}_{3}$, परा सु॰ $\mathrm{A}_{4}$, पुराश्च $\mathrm{A}_{7} 27 \mathrm{~b}$ ॰वासुर॰] ॰वाम्बर॰ $A$ 27d सौभसाल्व॰] सौभसालु॰ $\mathrm{A}_{7}$, शौभसानु॰ $\mathrm{A}_{3} \mathrm{~A}_{4} 28 \mathrm{~b}$ ०सत्पथदर्शिने ] ०देहप्रदेशिने $\mathrm{A} \quad 28 \mathrm{c}$ जयाय ] $\mathrm{A}_{3} \mathrm{~A}_{4}$, जय॰ $\mathrm{A}_{7}$ (unmetrical) • शर्वाय ] $\mathrm{A}_{3}$, सर्वाय $\mathrm{A}_{4} \mathrm{~A}_{7} \quad 29 \mathrm{a}$ ०यैव ] $\mathrm{A}_{3} \mathrm{~A}_{4}$, ०यै च $\mathrm{A}_{7} 29 \mathrm{e}$ ०सादात्कृच्छान्वै ] $\mathrm{A}_{4}$, ०सादात्कृच्छ्रन्वै $\mathrm{A}_{3}$, ०साद: कृत्त्रान्वै $\mathrm{A}_{7}$ 29f तरामः ] चरामः $\mathrm{A}_{4} \mathrm{~A}_{7}$, न्वरामः $\mathrm{A}_{3}$ - ०षोत्तम ] $\mathrm{A}_{3} \mathrm{~A}_{4}$, ०षोत्तम: $A_{7}$

$\mathbf{2 1}\left(\mathrm{d}^{7}\right) \mathrm{S}_{1} \quad \mathbf{2 4}\left(\mathrm{b}^{2}, \mathrm{~b}^{4}\right)\left\langle\mathrm{b}^{5}\right\rangle\left(\mathrm{b}^{6}\right) \mathrm{S}_{1} \quad \mathbf{2 5}\left(\mathrm{d}^{2}-\mathrm{d}^{4}\right) \mathrm{S}_{1} \quad \mathbf{2 7}\left(\mathrm{c}^{4}\right) \mathrm{S}_{1} \quad \mathbf{2 8}\left\langle\mathrm{b}^{2}-\mathrm{b}^{4}, \mathrm{c}^{1}-\mathrm{d}^{8} \rightarrow\right\rangle \mathrm{S}_{1}$ (one folio lost after this)

23a शिविपिष्टाय ] $S_{1}^{\mathrm{pc}} R$, शिविविष्टाय $\mathrm{S}_{1}^{\mathrm{ac}}$, शिपिविष्टाय $\mathrm{Bh}$ (em.?) 23b नमः ] RBh (em.?), नमो $\mathrm{S}_{1}$ 24c-25b ] om. $\mathrm{S}_{1} \quad \mathbf{2 4 d}{ }^{\circ}$ वस्त्र॰ ] $\mathrm{R}$, ०वास: $\mathrm{Bh}$ 25a पुरवि॰] $\mathrm{R}$, पुरुष॰ $\mathrm{Bh}$ 26ab सततं आ॰ ] $S_{1} R$, सततमा॰ $B h \quad 26 d$ शौरिणे ] $R A_{3} B h$, गौरिणे $S_{1}$ • ०बन्धवे ] em. $B h$ (silently), ०बान्धवे $S_{1} \quad 27$ a पुराश्य॰ ] $S_{1}$, मुराश्य॰ Bh (conj.) 27d ॰साल्व॰] $S_{1}$, ॰शाल्व॰

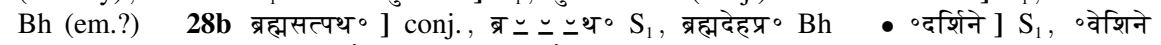
$\mathrm{Bh}$ (conj.) 29e वत्कृच्छ्रान्वै ] $\mathrm{A}_{4}$, वत्कृच्छ्र वै $\mathrm{Bh}$ (em.?) 29f तरामः ] conj. Bh (silently) 
हतराज्या वयं सर्वे न त्वं वेत्सि महाभुज।

हिरण्याक्षेण वैकुण्ठ तं नाशय नमो उस्तु ते॥ ३०॥

सनत्कुमार उवाच।

य इदं वैष्णवं स्तोत्रं भत्तया परमया युतः।

कीर्तयेत्सततं मर्त्यः सर्वपापै: प्रमुच्यते॥ ३? ॥

मृतश्च सर्वलोकेषु वर्षकोटिं चतुर्दश।

पूजितः सर्वदेवैग्च्च मोदते नात्र संशयः॥ ३२॥

कीर्तयत्येव य इदं पापेम्यो विप्रमुच्यते ।

स मृत्युलोकमप्राप्य चरते दुः खवर्जितः॥ ३३॥

सनत्कुमार उवाच।

तेषां तद्वचनं ग्रुत्वा भगवान्स जगत्पतिः।

उवाच सुरशार्दूलानिदं संपूजयंस्तदा॥ ३४॥

हतः स दैत्यो दुर्बुद्धिर्देवद्विड्विघ्नकारकः।

क्रियतां रूपमभ्येत्य वाराहं मा विचार्यताम्॥ ३४ ॥

महात्मा स च दैत्येन्द्रो बलवान्धार्मिकश्च ह।

न च शक्यो मयैकेन हन्तुं सत्यं ब्रवीमि वः॥ ३६॥

सर्वदेवमयं रूपं वाराहं नन्दिवर्धनम्।

तत्समास्थाय हन्तास्मि दैत्येन्द्रं तं महाबलम्॥ ३७॥

तेन रूपेण सर्वेषां युष्माकं देवसत्तमाः।

महीं शक्यं पुनस्तस्मादिहानयितुमोजसा॥ ३५॥

युष्मदर्थ तमद्याहं दानवं धर्मपालिनम्।

वधिष्यामि यथा सिंहं शरभः सुमहाबलः॥ ३९॥

32a मृतश्च ] मृतस्य $\mathrm{R} 32 \mathrm{~b}$ ०कोटिं चतुर्दश ] ०सेति चतुर्गमः $\mathrm{R}$ 33a कीर्तयत्येव ] की+र्त्त+यन्नेव $R 33 c$ मृत्युलोकम॰ ] सत्यलोकमा० $R 33$ चरते दुःख० ] वातदुःखवि॰ $R$ - After this $R$ has col. reading इति स्कन्दपुराणे रेवाखण्डे डध्यायः। 34cd ॰शार्दूलानि॰ $]$ ॰शार्दूलमि॰ $R$ 35a हतः ] इतः $\mathrm{R} 35 \mathrm{~b}$ ०रेवद्विडवि॰] ०र्देवविद्वि॰ $\mathrm{R}^{\mathrm{ac}}$, ०र्देवारिर्द्वि॰ $\mathrm{R}^{\mathrm{pc}} \quad 35 \mathrm{~d}$ मा ] $\mathrm{R}^{\mathrm{pc}}$, वा $\mathrm{R}^{\mathrm{ac}}$ $36 \mathrm{a}$ स च ] च स $\mathrm{R} 33 \mathrm{c}$ तत् ] तं $\mathrm{R} 37 \mathrm{~d}$ तं ] om. $\mathrm{R}$ (unmetrical) 38c महीं ] न हि $\mathrm{R}$ 38d ॰नयितुमो॰ ] न्नयिमो॰ R (unmetrical)

30d नमो उस्तु ते ] महाभुज $\left\{\circ ज: \mathrm{A}_{4}\right\} \mathrm{A}$ 31d ०पापै: प्र०] $\mathrm{A}_{3} \mathrm{~A}_{4}$, ०पापैर्वि॰ $\mathrm{A}_{7} \quad 32 \mathrm{~b}$ ०र्दश ] $\mathrm{A}_{3} \mathrm{~A}_{4}$, ०र्गुन: $\mathrm{A}_{7} \quad 33 \mathbf{a}$ इदं ] इम $\mathbf{A} \quad 33 \mathbf{b}$ पापेम्यो वि॰ $]$ प्राणिभ्यो पि $\left\{\right.$ वि० $\left.\mathrm{A}_{7}\right\} \mathbf{A}$ 34ab ] om. $A$ 34d ०यंस्तदा ] ०यत्सदा $A_{3}$, ०यन्सदा $A_{4}$, ०यं सदा $A_{7}$ 35a हतः ] इतः $A$ 35b ०र्देवद्विड्विघ्नकारकः ] ०रेद $\left\{\right.$ दे० $\left.\mathrm{A}_{7}\right\}$ वान् द्वेष्टि सहायवान् $A$ 35cd ] क्रियतां मर्त्य $\left\{\right.$ मत्य० $\mathrm{A}_{3}$, मत्स० $\left.\mathrm{A}_{4}\right\}$ रूपं मे वाराहं $\left\{{ }^{\circ}\right.$ ह $\left.\mathrm{A}_{3} \mathrm{~A}_{7}\right\}$ मां विधार्यतां $\mathbf{A} 36 \mathbf{d}$ व: ] ते $\mathbf{A} \quad 37 \mathbf{a}$ सर्व०] सर्वं $\mathbf{A} \quad 37 \mathbf{b}$ वाराहं ] $\mathrm{A}_{4} \mathrm{~A}_{7}$, वराहं $\mathrm{A}_{3} \quad 38 \mathrm{~b}$ युष्माकं ] अस्माकं $\mathrm{A} \quad$ - ${ }^{\circ}$ सत्तमा: ] $\mathrm{A}_{3} \mathrm{~A}_{4}$, ०शत्तमं $\mathrm{A}_{7} \quad 38 \mathrm{c}-40 \mathrm{~d}$ ] om. A

30d नमो उस्तु ते ] $\mathrm{R}$, महाभुज $\mathrm{Bh} \quad 32 \mathrm{~b}$ चतुर्दश ] $\mathrm{A}_{3} \mathrm{~A}_{4} \mathrm{Bh} \quad 33 \mathbf{a}$ इदं ] $\mathrm{R}$, इमं $\mathrm{Bh} \quad 33 \mathbf{b}$ पापेम्यो ] $\mathrm{R}$, प्राणिभ्यो $\mathrm{Bh}$ 34ab ] $\mathrm{R}$, Bh conjectures loss of two pādas. 34d ०्यंस्तदा ] $\mathrm{R}$, ०यन्सदा $\mathrm{Bh}$ (em.?) 35a हतः ] conj., इतः $\mathrm{Bh} \quad 35 \mathbf{b}$ ०र्देवद्विड्वि॰ ] conj., ०र्देवान् द्वेष्टि $\mathrm{Bh}$ - घकारक: ] $\mathrm{R}$, सहायवान् $\mathrm{Bh} 35 \mathrm{c}$ रूपमम्येत्य ] $\mathrm{R}$, मर्त्यरूपं मे $\mathrm{Bh}(\mathrm{em} . ?)$ 35d मा ] $\mathrm{R}^{\mathrm{pc}}$, मां $\mathrm{Bh}$ - विचार्यताम ] $\mathrm{R}$, विधार्यताम् $\mathrm{Bh} 38 \mathrm{ab}$ ०षां युष्माकं ] $\mathrm{R}$, ०षामस्माक $\mathrm{Bh}$ 38c-40d ] (R), om. Bh 38c महीं ] conj. 38d ०नयितुमो॰] conj. 
राजास्माकमयं श्रेष्टः सहस्राक्षः पुरंदरः।

दीक्षितो दैत्ययड़ेन होता त्वस्य बृहस्पतिः॥४०॥

ब्रह्मा ब्रह्मत्वमापत्रः प्रस्थाता यम इत्यपि।

उद्भाता वरुणश्चात्र हिरण्यनयनः पशुः।

शमिताहं सुर श्रेष्ठाः पशोस्तस्य महात्मनः॥ ४१ ॥

अद्य पश्यन्तु भूतानि मम तस्यैव चोभयो:।

अरणये वासिताहेतोर्मत्तयोर्गजयोरिव॥ ४२॥

तस्य तद्वचनं श्रुत्वा गर्जितं च महात्मनः।

हर्षोत्फुल्लेक्षणा: सर्वे निरीक्षन्तः परस्परम्।

मेनिरे हत-म्-इत्येव दैत्येन्द्रं सुमहाबलम्॥ ४३॥

तेषां तदोत्फुल्नकुशेशयाभवक्रेक्षणानां हृषितो रवो अूत्।

हतः स दैत्यो नरसिंहरूपिणा यथा पुरा तस्य गुरुर्महाबलः॥ ४४॥

\section{इति स्कन्दपुराणे सप्तनवतितमो उध्यायः॥ ९७॥}

$41 \mathrm{~b}$ प्रस्थाता ] प्रस्तोता $\mathrm{R}$ - इत्यपि ] हान्न्यपि $\mathrm{R} 44 \mathrm{c}$ वरुण०] वैरिण० $\mathrm{R}$ 42cd ] om. $\mathrm{R}$ $42 \mathrm{e}$ अरणये ] अरण्य० $\mathrm{R} 43 \mathrm{~b}$ गर्जितं च] गर्जितस्य $\mathrm{R} \quad 43 \mathrm{~d}$ निरीक्षन्तः ] निरीक्षन्त $\mathrm{R} \quad 43 \mathrm{e}$ ०त्येव ] त्येवं $\mathrm{R}$ 44a तदोत्फुल्लकुशेशयाभ०] तदोफुल्लकुटाशयप्रभुं $\mathrm{R}$ 44b ] वक्रेक्षणं हासरुचावभासकम् R 44d ०र्महाबलः ] ०र्महात्मन: $R$ Col. om. $R$

41b इत्यपि ] हत्यपि $\mathrm{A}_{3} \mathrm{~A}_{4}$, हात्यपि $\mathrm{A}_{7} 41 \mathrm{c}$ वरुणश्चात्र ] तत्र वरुणो $\mathrm{A}$ 41d हिरण्यनयनः ]

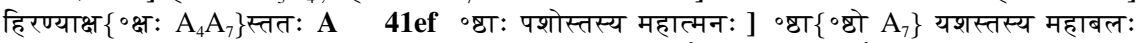
A 42a अद्य पश्यन्तु ] $\mathrm{A}_{3} \mathrm{~A}_{4}$, अथर्वणन्तु $\mathrm{A}_{7}$ 42b तस्यैव] $\mathrm{A}_{3} \mathrm{~A}_{4}$, तथैव $\mathrm{A}_{7}$ 42cd] om. $A$ 43d निरीक्षन्तः ] निरीक्षन्त $A$ 43e हत-म्-इ॰ ] हत इ० $A$ 44a तदोत्फुल्न०] तदुत्फुल्भ० $\mathrm{A}_{7}$, तत्वतफुल्न $\mathrm{A}_{3} \mathrm{~A}_{4}$ (unmetrical) - ० कुशेशयाभ ${ }^{\circ}$ ॰ कुशे $\left\{\circ\right.$ कुशो॰ $\mathrm{A}_{3}$, ०देशे॰ $\left.\mathrm{A}_{7}\right\}$ शयप्रभं $\mathbf{A}$ 44b ] चक्रेक्षणं तारुराभव $\left\{\right.$ तरुराभ $\left.\mathrm{A}_{7}\right\}$ भाषक $\mathrm{A}$ (unmetrical) $44 \mathrm{c} \circ$ रूपिणा ] $\mathrm{A}_{3} \mathrm{~A}_{4}$, ०रुपिणा $\mathrm{A}_{7}$ (unmetrical) Col. इति स्कन्दपुराणे एकाशीतिसाहस्रचां संहिताया $\left\{\right.$ इति स्कंद॰ $\left.\mathrm{A}_{4}\right\}$ मम्बिकाखण्डे हिरण्याक्षवधोपाय: $\mathrm{A} \pm$

$\mathbf{4 2}\left\langle\leftarrow \mathrm{a}^{1}-\mathrm{f}^{6}\right\rangle \mathrm{S}_{3} \quad \mathbf{4 4}\left(\mathrm{c}^{9}\right) \mathrm{S}_{3}$

41b इत्यपि ] conj. Bh (silently) 41c वरुणश्चात्र ] conj., तत्र वरुणो Bh 41d हिरण्यनयन: ] $\mathrm{R}$, हिरण्याक्षस्तत: $\mathrm{Bh}$ 41ef ०्ठाः पशोस्तस्य महात्मनः ] $\mathrm{R}$, ०्ठा यशस्तस्य महाबलः $\mathrm{Bh}$ 42cd ] Bh conjectures loss of two pādas. 43c ० त्फुल्लेक्षणा: ] $\mathrm{RABh}$, ०त्फुलेक्षणा $\mathrm{S}_{3}$ 43d निरीक्षन्तः ] conj. Bh (silently), निरीक्षन्त $S_{3} 43 \mathrm{e}$ हत-म्-इ॰] $\mathrm{S}_{3} \mathrm{R}$, हत इ॰ $\mathrm{Bh} 44 \mathbf{a}$ तदोत्फुल्न $] \mathrm{em}$., सदोत्फुल॰ $\mathrm{S}_{3}$ (unmetrical), तदुत्फुत््न $\mathrm{Bh}$ (conj.?) • ०शयाभ॰] $\mathrm{S}_{3}$, ॰शयप्रभं $\mathrm{Bh}$ 44b ] conj., ०वेक्रेक्षणाना हषीद्रवो भूत् $\mathrm{S}_{3}$ (unmetrical), वक्रेक्षणं चारुतरावभासकम् $\mathrm{Bh}$ (conj.?) $44 \mathrm{c}$ हतः ] RABh, हत $\mathrm{S}_{3}$ (unmetrical) • नरसिंह॰] RABh, नरसिं(ङ्ह॰) $\mathrm{S}_{3}^{\mathrm{pc}}$, ररसिंह॰ $\mathrm{S}_{3}^{\mathrm{ac}}$ • रूपिणा ] $\mathrm{RA}_{3} \mathrm{~A}_{4} \mathrm{Bh}$, ०रूपिणो $\mathrm{S}_{3}$ 44d ०र्महाबलः ] $\mathrm{ABh}$, ०र्महाबल इति $\mathrm{S}_{3}$ (इति part of col.) Col. ॥ स्कन्दपुराणे नामाध्यायः ९७ (in letter numerals)॥ $S_{3}$, इति स्कन्दपुराणे हिरण्याक्षवधोपायो नाम सप्तनवतितमोध्याय: $\mathrm{Bh}$ 
अष्टनवतितमो ऽध्यायः।

\author{
सनत्कुमार उवाच। \\ अथ ते सुरशार्दूलास्तस्य रूपं प्रचक्रिरे। \\ विश्वकर्माणमादाय ब्रह्माणं लोककारणम्। \\ सत्तलोकमयं तस्य शरीरं चक्रुरीश्वराः॥ ?॥ \\ अस्थीनि पर्वताः सर्वे नद्यो नाडयश्च तस्य तु। \\ रुधिरं चार्णवाः सप्त कफपित्तानिता गुणाः ॥ २॥ \\ पुरीषं चाप्यौषधयो धर्मों रेतः कृतः स तु। \\ मूत्रं तस्याभवन्मेघा वायवः सत्त कोष्ठगाः॥ ३॥ \\ शिरस्तस्याभवद्वद्मा रुद्रो मुर्धानमाश्रितः। \\ ललाटं तस्य धर्मों अभून्नासिका वायुरात्मवान्॥ ४॥ \\ सूर्याचन्द्रमसौ नेत्रे श्रोत्रे चापि दिशो अवन्। \\ भ्रुवौ तस्याभवंस्तारा अहोरात्रं च वर्त्मनी ॥ $y \|$
}
1c ॰मादाय ] ॰माहूय $R \quad 2 b$ नाङ्यश्च तस्य तु ] नाभ्यस्तु सर्व्वशः $R \quad 3 a$ चाप्यौ॰] चास्यौ॰ $R$ $3 c$ मूत्रं ] मृतं $R$ - ०न्मेघा ] ०न् मेदा $R$ 3d सत्त ] om. $R$ (unmetrical) 4a ०स्याभवद् ] ०स्य च ते $\mathrm{R} 4 \mathrm{~b}$ ०माश्रितः ] ०मास्थित: $\mathrm{R} 4 \mathrm{~cd}$ ] ललाटे तस्य च यमो भूर्नासिका वात्मवान् $\mathrm{R}$ (unmetrical) $5 d$ वर्त्मनी ] पक्षिणी R

1cd ] om. $\mathbf{A} 2 \mathbf{b}$ नद्यो] वशा $\mathrm{A}_{3} \mathrm{~A}_{4}$, वसा $\mathrm{A}_{7} \quad 2 \mathbf{c}$ चार्णवा:] चान्तरा: $\mathbf{A}$ 2d गुणा:] गुणं $\mathrm{A}_{3} \mathrm{~A}_{4}$, गुन: $\mathrm{A}_{7} \quad 3 \mathbf{a}$ ०प्यौषधयो ] ०प्योषधयो $\mathrm{A}_{3} \mathrm{~A}_{4}$, ०पि ओषधयो $\mathrm{A}_{7}$ (unmetrical) $3 \mathbf{b}$ रेतः ] $\mathrm{A}_{7}$, चेतः $\mathrm{A}_{3} \mathrm{~A}_{4}$ - कृतः स] कृतो स्य $\mathrm{A}_{3} \mathrm{~A}_{4}$, कृतस्य $\mathrm{A}_{7} \quad 3 \mathbf{c}$ नन्मेघा ] ०न्मेघ $\mathbf{A} 4 \mathbf{a}$ ०स्याभवद्वह्मा ] ०स्या $\left\{\circ\right.$ स्य $\left.\mathrm{A}_{7}\right\}$ भवन्साध्या $\mathrm{A} 4 \mathbf{b}$ ०माश्रितः ] मास्थितः $\mathrm{A} \mathbf{4 c}$ ललाटं] ललाटे A $4 d$ वायु०] $\mathrm{A}_{4} \mathrm{~A}_{7}$, यु० $\mathrm{A}_{3}$ (unmetrical) $\mathbf{5 b}$ चापि] तस्य $\mathrm{A}_{3} \mathrm{~A}_{4}$, तस्या $\mathrm{A}_{7} \mathbf{5 c}$ भ्रुवौ तस्याभवंस्तारा ] भ्रुवोस्तस्यातरन्प्राणा \{ वन् प्राणे $\left.\mathrm{A}_{7}\right\} \quad \mathrm{A}$ 5d वर्त्मनी ] पक्षिणी $\mathrm{A}_{3} \mathrm{~A}_{4}$, पक्षणी $\mathrm{A}_{7}$

Manuscripts available for this chapter: $S_{1}$ (from $\mathbf{1 0} \mathbf{c}^{1}$; f. 152 lost) photos $3.31 \mathrm{~b}$ (f. $153^{\mathrm{r}}$ ), 3.32a (f. $153^{\mathrm{v}}$ ) and $3.32 \mathrm{~b}\left(\mathrm{f} .154^{\mathrm{r}}\right.$ ); $\mathrm{S}_{3}$ f. $153^{\mathrm{r}}-154^{\mathrm{v}} ; \mathrm{R}$ f. $170^{\mathrm{v}}-172^{\mathrm{r}} ; \mathrm{A}_{3}$ f. $101^{\mathrm{r}}-101^{\mathrm{v}} ; \mathrm{A}_{4}$ f. $144^{\mathrm{r}}-145^{\mathrm{r}}$; $\mathrm{A}_{7}$ f. $142^{\mathrm{V}}-143^{\mathrm{V}}$ (A upto $\mathbf{4 6}$ ).

1cd ] $S_{3}(R), B h$ conjectures loss of two pādas. If ०रीश्वरा: ] RABh, ०रीश्वरात् $S_{3}$ 2a पर्वता: ] RABh, पर्वता $S_{3} 2 c$ चार्णवा: ] $R$, चार्णवा $S_{3}$, चाब्धयः Bh (conj.) 3a ०व्यौषधयो ] $\mathrm{S}_{3}$, ०प्योषधयो $\mathrm{Bh} 3 \mathrm{~b}$ कृतः स ] $\mathrm{R}$, कृत स $\mathrm{S}_{3}$ (unmetrical), कृतोस्य $\mathrm{Bh}$ 3d कोष्ठगा: ] RABh, कोष्टगा: $S_{3} \quad 4 a$ ०भवद्रह्मा ] $S_{3}$, ०भवन् साध्या Bh $4 b$ ०माश्रितः ] $S_{3}$, ०मास्थित: $B h$ $4 \mathbf{c}$ ललाटं ] $S_{3}$, ललाटे $B h$ 4cd अून्ना०] $A B h$, भू ना॰ $S_{3} 4 d$ ०रात्मवान् ] $A B h$, ०रात्मना $\mathrm{S}_{3} 5 \mathbf{a}$ सूर्या॰] RABh, सूर्य॰ $\mathrm{S}_{3} \mathbf{5 b}$ चापि ] $\mathrm{S}_{3} \mathrm{R}$, तस्य $\mathrm{Bh} \bullet$ अवन् ] $\mathrm{RABh}$, भवत् $\mathrm{S}_{3}$ 5c भ्रुवौ त०] $S_{3} R$, भ्रुवोस्त॰ $B h$ • वस्त्तारा ] $S_{3} R$, ०वन् प्राणा $B h$ (em.?) 5d वर्त्मनी ] em., वर्त्मनों $\mathrm{S}_{3}$, पक्ष्मणी $\mathrm{Bh}$ (conj.) 
आस्यं तस्याग्निरभवद्वडवामुखसंस्थितः।

ओष्टौ भूरन्तरिक्षं च दन्ताश्च भुजगाभवन्॥ ६॥

चत्वार्यस्त्राणि दंष्ट्राश्च कृतानि सुमहान्ति वै।

अस्त्रं पाशुपतं पूर्व द्वितीयं चऋमेव च।

ब्रह्मदण्डं तृतीयं च चतुर्थं ब्रह्मणः शिरः॥ ७॥

जिह्वा तस्याभवद्विद्युत्तालुः खं सर्वमुच्यते।

ग्रीवा तस्याभवच्चोमा वज्रं स्कन्धे अवत्सितम्।

गण्डे चापि तथादित्या हस्तौ रुद्रैश्च निर्मितौ॥ ५॥

अड्कुल्यस्तस्य कीर्तिश्च लक्ष्मी सिद्धिरथापि च।

यशो जयश्च द्वावेतौ श्रीरूर्जा कान्तिरेव च।

प्रवृत्तिश्च निवृत्तिश्च नखाश्चास्त्राणि सर्वशः॥ ९॥

यमदण्ड: कालदण्डो मृत्युदण्डस्तथापर:।

रुद्रदण्डश्च चत्वारो बाहुपादा: कृता बभुः॥ १०॥

$6 \mathrm{a}$ आस्यं ] अड़े $\mathrm{R} \quad 6 \mathrm{c}$ ०रन्तरिक्षं च] ०रन्तरीक्षच्व $\mathrm{R} \quad 7 \mathrm{a}$ ०र्यस्त्राणि दंष्ट्राश्च ] ०र्यस्थीनि दंट्टाद्य

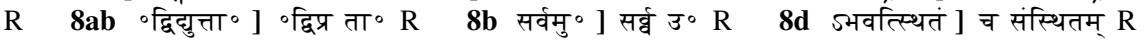
$8 e$ गण्डे ] अण्डे $R$ - थथादित्या ] ०था दैत्या $R$ 8f रुद्रैश्च ] रुद्रस्य $R \quad 9 b$ लक्ष्मी ] लक्ष्मी: $R$ 9d ग्रीरूर्जा ] जीवश्च $\mathrm{R}$ 9f ०खाश्चास्त्राणि ] ०खाः शस्त्राणि $\mathrm{R}$

6a तस्याग्नि०] तदग्नि० $A$ b ०संस्थितः ] ०संस्थिता $\mathrm{A}_{3}$, ०संस्थिता: $\mathrm{A}_{4} \mathrm{~A}_{7} 6 \mathbf{c}$ ओष्ठौ भूरन्तरिक्षं च] ओष्टे भूदन्तरीक्षग्च $\mathrm{A}_{7}$, ओष्टे भवदतररिक्षं च $\mathrm{A}_{3}$ (unmetrical), तुष्टो भूवदंतरीक्षं च $\mathrm{A}_{4}$ (unmetrical) $7 \mathbf{b}$ ॰महान्ति ] ॰महानि $\mathbf{A} 7 \mathbf{7}$ ०दण्डं ] $\mathrm{A}_{7}$, ${ }^{\circ}$ दत्तं $\mathrm{A}_{3} \mathrm{~A}_{4}$ - तृतीयं च ] कृतायस्क $\mathrm{A}_{3} \mathrm{~A}_{4}$, कृतां यस्कां $\left.\mathrm{A}_{7} \quad \mathbf{8 a b}\right]$ om. $\mathbf{A}$, instead of this, $\mathbf{A}$ has two pādas reading रुददण्डा $\left\{{ }^{\circ}\right.$ दत्ता ${ }^{\circ} \mathrm{A}_{3} \mathrm{~A}_{4}$ \}? चत्वारो बहिःपादा $\left\{{ }^{\circ}\right.$ दो $\left.\mathrm{A}_{7}\right\}$ कृता भुवः। (cf. $10 \mathrm{~cd}$ ) $8 \mathbf{c}$ ०च्चोमा ] ०च्छोमो $\mathbf{A} 8 \mathbf{8 d}$ वज्रं ] रुद्र $\mathbf{A}$ - अवत्सितं ] च संस्थितं $\mathbf{A} 9 \mathbf{b}$ लक्ष्मी ] $\mathrm{A}_{3} \mathrm{~A}_{7}$, लक्ष्मीं $\mathrm{A}_{4}$ - ०रथापि ] ०स्तथैव $\mathbf{A}$ 9cd ] om. A 9e प्रवृत्तिश्च निवृत्तिश्च ] $\mathrm{A}_{4}$, प्रवृर्तिश्र निवृर्तिश्च $\mathrm{A}_{7}$, प्रवृत्तिश्च $\mathrm{A}_{3}$ (unmetrical) 10a ०दण्डो ] $\mathrm{A}_{3} \mathrm{~A}_{4}$, ०दण्डा $\mathrm{A}_{7} 10 \mathrm{~b}$ ०थापर: ] ०थैव च $\mathbf{A} \quad 10 \mathrm{~d}$ ०पादा: ] ०पादा $\mathrm{A}$ - बभुः ] वतु $\mathrm{A}_{3} \mathrm{~A}_{4}$, ०स्य तु $\mathrm{A}_{7}$

$\mathbf{1 0}\left\langle\leftarrow \mathrm{a}^{1}-\mathrm{b}^{8}\right\rangle\left(\mathrm{d}^{2}\right)\left\langle\mathrm{d}^{3}\right\rangle \mathrm{S}_{1},\left(\mathrm{~d}^{7}\right) \mathrm{S}_{3}$

6a ०रभवद् ] RABh, ०रभव $S_{3} \quad 6 b$ ०संस्थितः ] R, ०संस्थितं $S_{3}$, ०संस्थिता $B h \quad 6 c$ ओष्टौ] $\mathrm{R}$, ओष्टौ $\mathrm{S}_{3}$, ओष्टे $\mathrm{Bh} \bullet$ भूर॰] $\mathrm{S}_{3} \mathrm{R}$, भूद॰ $\mathrm{Bh}$ (conj.?) 6d ॰भवन् ] $\mathrm{RABh}$, ०भवत् $\mathrm{S}_{3}$ 7f ब्रह्मणः ] RABh, ब्रह्मणा: $S_{3} \quad 8$ ab ] $S_{3}(R)$, om. $B h \quad 8 b$ ०तालुः ] $S_{3}^{p c}$, ${ }^{\circ}$ तालु $S_{3}^{\text {ac }} \quad 8 c$ ग्रीवा त० ] RABh, ग्रीवान्त॰ $S_{3}$ • ०वच्चोमा ] $R$, ०व चोमा $S_{3}$, ०वत्सोमो Bh (conj.?) 8d वज्रं ] $S_{3} R$, रुद्र: $B h$ (em.?) - अवत्स्थितं ] $S_{3}$, च संस्थितः $B h$ (em.?) 9a अडुल्यस्त॰] $\mathrm{RABh}$, अंगुल्यास्त॰ $\mathrm{S}_{3}$ 9b लक्ष्मी ] $\mathrm{S}_{3} \mathrm{~A}_{3} \mathrm{~A}_{7}$, लक्ष्मी: $\mathrm{Bh}$ (em.?) • ०रथापि ] $\mathrm{S}_{3} \mathrm{R}$, ०स्तथैव $\mathrm{Bh} 9 \mathrm{~cd}]\left(\mathrm{S}_{3}\right), \mathrm{om} . \mathrm{Bh} 9 \mathrm{~d}$ ०रूर्जा ] em., ०रुर्जा $\mathrm{S}_{3}$ 9e प्रवृत्तिश्च निवृत्तिश्च ] $\mathrm{S}_{3} \mathrm{RA}_{4},--$ - - प्रवृत्तिश्च $\mathrm{Bh}$ (in a note Bh suggests प्रवृत्तिश्च निवृत्तिश्च) $10 \mathrm{a}$ ०दण्डो ] $\mathrm{S}_{3}^{\mathrm{pc}} \mathrm{RA}_{3} \mathrm{~A}_{4} \mathrm{Bh}$, ०दण्डो: $S_{3}^{\text {ac }} 10 b$ ०थापर: ] $S_{3} R$, ०थैव च $B h \quad 10 c$ ०दण्डग्य ] $S_{1} R A B h$, ०दण्डाग्च $S_{3} 10 d$ ०पादा: ] $\mathrm{RBh}\left(\mathrm{em}\right.$. ?), $\simeq$ दा $\mathrm{S}_{1}$, ०पादा $\mathrm{S}_{3}$ - कृता बभुः $] \mathrm{S}_{3}^{\mathrm{ac}}$ ? R, कृता ब्रभुः $\mathrm{S}_{1}$, कृता (च)तुः $\mathrm{S}_{3}^{\mathrm{pc}}$, कृता: प्रभो: $\mathrm{Bh}$ (conj., in a note $\mathrm{Bh}$ reads प्रभु: in $\mathrm{S}_{1}$ ) 
साध्या देवा उरस्तस्य हृदयं सोम इत्यपि।

उदरं तस्य भूतानि महान्ति ऋषिसत्तम॥ १? ॥

नाभिस्तस्याभवन्माता अदितिर्ब्रह्मसत्तम।

शिम्नं प्रजापतिस्तस्य मित्रो डपाने ऽभवत्स्थितः॥ १२॥

वसवस्तस्य पार्श्वेषु तथा धर्मश्च पृष्ठतः।

मृत्युः कालो यमश्चैव हस्तपादतलाश्रिताः ।

अश्विनौ तस्य लाड़ूलं पितरः संधिषु स्थिताः॥ ?३॥

नियति: कालपाशश्च कृतान्तकलहावपि।

व्याधयश्चापि ये केचिद्टृष्टि तस्य समाश्रिताः॥ १४॥

यक्षाश्च राक्षसाग्चैव गन्धर्वाः पन्नगै: सह।

सर्वे त्वचं समाश्रित्य त्वग्भूता: समवस्थिताः ॥ १५ ॥

तथा सर्वाणि छन्दांसि वेदा इष्टय एव च।

रोमकूपेषु सर्वाणि तानि तस्थुः पृथक्पृथक्॥ १६॥

दानानि नियमाश्चैव यमा: सर्वाश्च मातर:।

स्थानाभिमानिनो देवा: पशव: पक्षिणश्च ह।

सर्वे रोमाणि तस्यासन्वराहस्य महात्मनः॥ १७॥

$11 \mathrm{a}$ उरस्त०] उरुस्त० $R \quad 11 b$ इत्यपि ] हत्यपि $R \quad 11 d$ महान्ति ऋषि॰] महाधनंषि $R$ 12ab ] om. $R \quad 12 c$ शिम्नं] शिशु: $R \quad 12 d-13 a$ ] om. $R \quad 13 \mathrm{e}$ लाड़ूलं ] लाड़ूले $R \quad 15 c$ समाश्रित्य ]

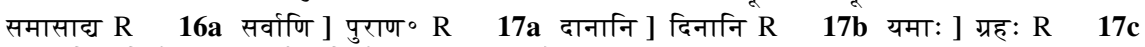
स्थानाभिमानिनो ] स्थानानीमानि ते $\mathrm{R} \quad 17 \mathrm{e}$ सर्वे ] सर्व० $\mathrm{R}$

11a-13b ] om. A 13d-15a ] om. A 15c सर्वे त्वचं ] तत्र सर्वे A 15d त्वग्भूता:] त्वंबुदा $\mathrm{A}_{3} \mathrm{~A}_{4}$, द्वम्बुता: $\mathrm{A}_{7} 17 \mathrm{~b}$ यमा: ] समा: $\mathrm{A}$ - मातर: ] नातय: $\mathrm{A}_{3}$, नातप: $\mathrm{A}_{4}$, नाडय: $\mathrm{A}_{7} 17 \mathrm{c}$ स्थानाभिमानिनो देवा: ] स्थानमानानि देवाश्च $\left\{\circ\right.$ वा चे $\left.\mathrm{A}_{7}\right\} \mathrm{A} \quad 17 \mathrm{e}$ रोमाणि ] रोमानि $\mathrm{A}_{7}$, रमाणि $\mathrm{A}_{3} \mathrm{~A}_{4}$

$12\left\langle d^{3}-d^{4}\right\rangle\left(d^{5}-d^{7}\right) S_{3} \quad 13\left(d^{1}-d^{2}\right) S_{1} \quad 15\left(a^{1}-a^{2}, c^{6}-c^{7}\right)\left\langle c^{8}-d^{1}\right\rangle\left(d^{2}\right) S_{1} \quad 16\left(a^{6}-a^{7}, c^{4}\right) S_{1}$

11c उदरं त॰ ] $\mathrm{S}_{3}^{\mathrm{pc}} \mathrm{RBh}$ (em.?), उदरस्त॰ $\mathrm{S}_{1}$, उद/न्तोरन्त॰ $\mathrm{S}_{3}$ 11d ॰सत्तम ] RBh (conj.),

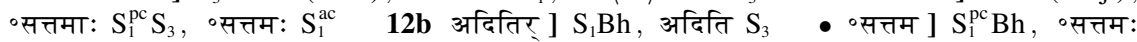
$S_{1}^{\text {ac }} S_{3} 12 d$ ०वत्सितः ] $S_{1}^{\text {pc } B h}$, ०वस्थितः $S_{1}^{\text {ac }}$, (वत्स्थि)ता $S_{3}$ 13b पृष्टतः ] $S_{1} R B h$, पृष्टतः $S_{3} 13 c$ मृत्युः ] $S_{3} R A B h$, मृत्यु $S_{1}$ 13d ०श्रिता: ] $S_{1} R B h$, ०श्रिता $S_{3}$ 13f संधिषु ] $S_{1} R$ $\mathrm{Bh}$, संन्धिषु $\mathrm{S}_{3}$ - स्थिता: ] RBh (em.?), स्थिता $\mathrm{S}_{1} \mathrm{~S}_{3}$ 14a नियतिः ] $\mathrm{S}_{1} \mathrm{~S}_{3}^{\mathrm{pc}} \mathrm{RBh}$, नियति $\mathrm{S}_{3}^{\mathrm{ac}}$ (unmetrical) - ०पाशश्च ] $S_{3} R B h$ (conj.), ०पाड़ग्यच $S_{1}$ 14b कृतान्त॰ ] $S_{1} R B h$, कृतान्तः $S_{3}$ 14 cd ॰चिदृष्टिं तस्य ] RBh (em.?), ०चिदृष्टिन्तस्या $S_{1}$, ०चिदृष्टिन्तस्य $S_{3}$ 14d ०श्रिता: ] $S_{1} R B h$, ०स्थिता: $S_{3} \quad 15 a$ राक्षसाग्चै॰ $S_{1} R B h$, राक्षसा चै० $S_{3} \quad 15 b$ गन्धर्वा: पन्नगै: सह ] RABh, यमा सर्वा $\left\{\right.$ ०र्पा० $\left.S_{1}^{\text {ac }}\right\}$ ग्च मातरा: $S_{1}$ (cf. 17b), गन्धर्वा पन्नगै सह $S_{3}$ 15d त्वग्भूता: ] $R, \simeq\left(\right.$ ग्भू)ता $S_{1}$ (upper part of ग्भू lost), त्वग्भूता $S_{3}$, संहता: $B h$ (conj.) - ०स्थिता: ] $S_{3} R A B h$, ०स्थिता $S_{1}$ $16 c$ कक पेषु $] S_{1} S_{3}^{\text {pc }} R A B h$, ०कुपाषु $S_{3}^{\text {ac }}$ 16d तस्थुः ] $S_{3} R A B h$, तस्थु $S_{1}$ 17b यमा: ] em.

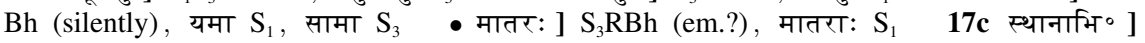
$\mathrm{S}_{3} \mathrm{Bh}$ (conj.?), स्थानानि $\mathrm{S}_{1}$ • देवा: ] $\mathrm{S}_{3} \mathrm{RBh}$ (em.?), देवा $\mathrm{S}_{1}$ 
अडुल्यस्तस्य पादाभ्यां विश्वेदेवाभवंस्तदा।

भृगवो ऽड्गिरसश्चैव देवास्तस्याभवन्नखा:।

रोमान्तरेषु ऋषयः सर्वेष्वड़ेषु संस्थिताः ॥ १५॥

एवं समभवद्यास वराहो नन्दिवर्धनः।

स भाति तेन रूपेण द्यां भुवं चापि संस्पृशन्॥ १९॥

पुरा स्वयंभुर्भगवानुद्धरिष्यन्महीमिमाम्।

स रेजे तेन रूपेण दीत्रिमान्मधुसूदनः।

निशायामौषधीदीप्तो हिमवानिव पर्वतः॥ २०॥

ततस्तमृषयः सर्वे तपसा महता तदा।

स्वेन स्वेनाभिसंप्राप्य तेजस्तस्याभ्यदीपयन् ॥ २? ॥

स विष्णुस्तेजसा तेषामृषीणां परमौजसाम्।

संप्रजज्वाल कालान्ते युगान्ताग्निरिवापरः॥ २२॥

नादं कृत्वा च सुमहचालयानो महीतलम्।

उवाच तानृषीन्सर्वान्हन्मि दैत्यं सुरद्विषम्॥ २३॥

$18 \mathrm{a}$ पादाभ्यां ] पादाभ्या $R \quad 18 \mathrm{c}$ डड़िस ${ }^{\circ}$ ] दिवस० $R \quad 19 \mathrm{a}$ ०द्यास ] ॰द्यास $R \quad 20 \mathrm{a}$ स्वयंभु॰ ] स्वयम्भू॰ $R \quad 20 \mathrm{c}$ स रेजे] रराज $R$ 21d ०स्तस्याभ्य॰] ०स्तस्य व्य॰ $R \quad$ 23ab नादं कृत्वा च सुमहच्चा०] नादान् कृत्वा सुमहांश्चा० $R$ (unmetrical)

18ab ] om. A 18d देवास्तस्याभवन्नखा:] नीललोहित एव च $\mathrm{A}$ (cf. 35d) $18 \mathrm{f}$ सर्वेष्वड़ेषु ] सर्वे

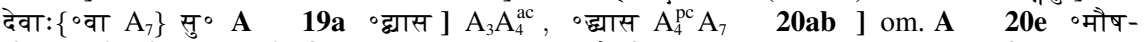
धी॰ ] ०मोषधी० $\mathrm{A}_{3}$, ०मोषधि॰ $\mathrm{A}_{4}$ (unmetrical), ०मौषधि० $\mathrm{A}_{7}$ (unmetrical) 20f ०वानिव पर्वतः ] ॰वत्पर्वतो यथा A 21cd ॰ प्राप्य तेजस्तस्याभ्य॰] ॰ प्राप्यस्तेजस्तस्याद्य $A$ 22b ॰मौजसाम् ] $A_{7}$, ०मोजसां $\mathrm{A}_{3} \mathrm{~A}_{4} 22 \mathrm{c}$ संप्र०] स प्र० $\mathbf{A}$ • कालान्ते ] कान्तेषु $\mathbf{A} 23 \mathrm{~b}$ ०यानो महीतलम् ] $\mathrm{A}_{3} \mathrm{~A}_{4}$, $\circ$ यामो महीतले $\mathrm{A}_{7}$

$\mathbf{1 8}\left(\mathrm{f}^{5}\right) \mathrm{S}_{1} \quad \mathbf{2 0}\left(\mathrm{e}^{4}-\mathrm{e}^{5}\right) \mathrm{S}_{1} \quad \mathbf{2 1}\left(\mathrm{b}^{6}\right) \mathrm{S}_{1} \quad \mathbf{2 2}\left(\mathrm{b}^{4}\right) \mathrm{S}_{1} \quad \mathbf{2 3}\left\langle\mathrm{c}^{1}-\mathrm{c}^{5}\right\rangle\left(\mathrm{c}^{6}-\mathrm{d}^{2}\right) \mathrm{S}_{1}$

$18 \mathrm{a}$ अडुलुल्यस्तस्य ] $\mathrm{S}_{1}^{\mathrm{pc}} \mathrm{RBh}$, अडुलुल्यस्य $\mathrm{S}_{1}^{\mathrm{ac}}$ (unmetrical), अंगुल्यास्तस्य $\mathrm{S}_{3}$ - पादाम्यां] $\mathrm{S}_{3} \mathrm{Bh}$ (em.?), पादाभ्या $S_{1} \quad 18 b$ ॰वंस्तदा ] $S_{1} R$, ववन्त्युतः $S_{3}$, ०वंस्तथा Bh (conj.) 18d ०वन्नखा: ] $R$, ०वस्तदा: $S_{1}$, ०वंस्तुथा $S_{3}$, ०वंस्तदा $B h$ (em.?) 18e ऋषयः ] $S_{1} S_{3} R A$, शृषय: Bh (typo) $18 f$ संस्थिताः ] $S_{1} R A B h$, संस्थिता $S_{3} 19 d$ भुवं चा॰ ] $S_{1} R A B h$, ०भुवंश्चा० $S_{3}$ • संस्पृशन् ] $S_{3}$ $\mathrm{RABh}$, संस्पृशम् $\mathrm{S}_{1} \quad \mathbf{2 0 a}$ स्वयंभुर ] $\mathrm{S}_{1}$, स्वयंभु $\mathrm{S}_{3}$, स्वयंभूर $\mathrm{Bh}(\mathrm{em} . ?) \quad \mathbf{2 0 a b}$ वानुद्धरिष्यन् ] $\mathrm{RBh}$ (em.?), ०वानु $\left\{\left({ }^{\circ}{ }^{\circ}\right) \mathrm{S}_{1}^{\mathrm{ac}}\right\}$ द्धरिष्य $\mathrm{S}_{1}$, ०वां नुद्धरिष्यन् $\mathrm{S}_{3} \quad \mathbf{2 0 b} \circ$ मिमाम् ] RBh (em.?), ०मिमान $S_{1}$, ०मिव $S_{3}$ 20e ०यामौषधीदीतो ] $S_{3} R$, ०यां (मोष)दीप्तो हि $S_{1}$ (upper parts of मोष lost), ०यां संप्रदीतो हि $\mathrm{Bh}$ (conj.?) $20 \mathrm{f}$ ०निव पर्वतः ] $\mathrm{S}_{3} \mathrm{RBh}$ (conj.?), ०नित पर्वत $\mathrm{S}_{1}^{\mathrm{pc}}$, ०नित (स)र्वत $S_{1}^{\mathrm{ac}}$ 21a ०मृषय:] $\mathrm{S}_{1} \mathrm{RABh}$, ०मृषय $\mathrm{S}_{3}$ (unmetrical) 21d ०स्याभ्यदीपयन् ] $\mathrm{S}_{3} \mathrm{Bh}$ (conj.?), ०स्यापि दीपयत् $\mathrm{S}_{1}$ 22ab तेषामृषीणां] $\mathrm{S}_{1}^{\mathrm{pc}} \mathrm{RABh}$, (ति)षामृषीणा(म्) $\mathrm{S}_{1}^{\mathrm{ac}}$, तेशां ऋषीणा $S_{3} 22 b$ ॰मौजसाम् ] $S_{1} R A_{7} B h$, ०मौजसा $S_{3}$ 22c ०जज्वाल] $S_{3} R A B h$, ०जज्वल $S_{1}$ 23ab सुमहचा०] $\mathrm{S}_{1} \mathrm{ABh}$, सुमह चा० $\mathrm{S}_{3}$ 23b महीतलम् $] \mathrm{S}_{3} \mathrm{RA}_{3} \mathrm{~A}_{4} \mathrm{Bh}$, महीमिमाम् $\mathrm{S}_{1}$ 23cd ॰न्सर्वान्हन्मि ] RABh, (न्सर्वा) हन्मि $\mathrm{S}_{1}$, ०न्सर्वान्हर्मि $\mathrm{S}_{3}$ 
हत्वा तं दैत्यराजं वै सिंहं शरभराडिव।

मोचयिष्ये महीं विप्रा: प्रविश्याद्य रसातलम्॥ २४॥

स्वस्थाने स्थापयित्वा च दत्वा राज्यं दिवौकसाम्।

जपध्वं विजयायाद्य शिवाय च तपोधनाः ॥ २४॥

सनत्कुमार उवाच।

तस्य तद्वचनं श्रुत्वा ब्रह्मा लोकपितामहः।

उवाच बलमाधत्स्व दैत्यो उसौ सुमहाबलः॥ २६॥

आस्थाय यत्नं सुमहदप्रमत्तः सुरेश्वर।

जहि तं दैत्यराजं वै कृच्छ्रमेतन्मतं मम॥ २७॥

न तस्य सदृशो दैत्यो हिरण्यकशिपु: पुरा।

महाबलो उयं दैत्येन्द्रस्तपोयोगबलान्वितः॥ २५॥

ततो देवस्तदा व्यास भगवान्गोवृषध्वजः ।

सुरै: सब्रह्मकैस्तत्र ऋषिभिश्च तपोधनै:॥ २९॥

उक्तः प्रणम्य देवेशो विष्णुमाप्यायय प्रभो।

तेजसा स्वेन सर्वेश यथा हन्यात्सुरद्विषम्॥ ३०॥

$24 b$ सिंहं ] सिहं $\mathrm{R} 24 \mathrm{c}$ मोचयिष्ये ] योचयिष्ये $\mathrm{R} 2 \mathrm{24d}$ प्रविश्याद्य ] प्रविगाह्य $\mathrm{R} 25 \mathrm{c}$ जपध्वं ] यजध्वं $R$ - ०जयायाद्य ] $R^{\mathrm{pc}}$, ०जयामो द्य $\mathrm{R}^{\mathrm{ac}}$ 26a तस्य] तस्यै $\mathrm{R}$ 27ab ] आस्थाय युद्धं सुमदप्रमत्तं नरेग्वर $\mathrm{R}$ (unmetrical) $29 \mathrm{c}$ सुरै: सब्र०] असुरैर्र० $\mathrm{R} 30 \mathrm{~b}$ ०माप्यायय प्रभो ] ॰माप्याय तं प्रभुम् $\mathrm{R} 30 \mathrm{c}$ सर्वेश ] सर्वेण $\mathrm{R}$

24b शरभ०] $\mathrm{A}_{4}$, सरभ० $\mathrm{A}_{3} \mathrm{~A}_{7} \quad 24 \mathrm{c}$ विप्रा: ] $\mathrm{A}_{4} \mathrm{~A}_{7}$, विप्र: $\mathrm{A}_{3}$ 24d ०विश्याद्य रसातलम् ] विश्य च $\left\{\circ\right.$ श्याश्च $\left.\mathrm{A}_{7}\right\}$ महीतलं $A$ 25a स्वस्थाने ] स्वे स्थाने $\mathbf{A} 25 \mathrm{c}$ जपध्वं] जयध्वं $\mathbf{A} 26 \mathrm{~b}$ ०पितामहः ] $\mathrm{A}_{3} \mathrm{~A}_{4}$, ०पितामह $\mathrm{A}_{7} \quad 26 \mathrm{c}$ बलमाधत्स्व ] $\mathrm{A}_{4} \mathrm{~A}_{7}$, वनमाधत्स $\mathrm{A}_{3}$ 27ab सुमहदप्रमत्तः सुरेश्वर ] देवानां समं प्रभुसुरेश्वर: $\mathrm{A}_{3}$, देवानां $\left\{\circ\right.$ णां $\left.\mathrm{A}_{7}\right\}$ समापि प्रभुरीश्वर: $\mathrm{A}_{4} \mathrm{~A}_{7}$ 27d कृच्छ्र० ] $\mathrm{A}_{3} \mathrm{~A}_{7}$, कृच्छः $A_{4} 28 b$ पुरा ] $A_{3} A_{4}$, पुराः $A_{7}$ 29a देवस्त॰ ] $A_{7}$, देव त॰ $A_{3} A_{4} \quad 30 b$ ०माप्यायय ] $\circ$ मा $\left\{\circ\right.$ ना० $\left.\mathrm{A}_{7}\right\}$ प्याययन्, $\mathrm{A} \quad 30 \mathrm{c}$ सर्वेश ] सर्वेण $\mathrm{A}_{3} \mathrm{~A}_{4}$, सर्वेन $\mathrm{A}_{7}$

$\mathbf{2 6}\left\langle\mathrm{c}^{1}-\mathrm{d}^{1}\right\rangle\left(\mathrm{d}^{2}-\mathrm{d}^{8}\right) \mathrm{S}_{1} \quad \mathbf{2 7}\left(\mathrm{a}^{1}-\mathrm{a}^{2}\right) \mathrm{S}_{1} \quad \mathbf{2 9}\left(\mathrm{c}^{2}, \mathrm{c}^{4}-\mathrm{c}^{6}\right)\left\langle\mathrm{c}^{7}-\mathrm{c}^{8}\right\rangle\left(\mathrm{d}^{5}-\mathrm{d}^{6}\right) \mathrm{S}_{1}$

$24 \mathrm{~b}$ सिंहं ] $\mathrm{S}_{1} \mathrm{ABh}$, सिंहा $\mathrm{S}_{3} 24 \mathrm{c}$ महीं विप्रा: ] $\mathrm{RA}_{4} \mathrm{~A}_{7}$, महीं विप्रां $\mathrm{S}_{1}$, महीम्विप्र $\mathrm{S}_{3}$, महीं विग्नां $\mathrm{Bh}$ (conj.) 25a स्वस्थाने] $S_{1} R B h$, स्वे च्छाने $S_{3} \quad 25 \mathrm{c}$ जजयायाद्य] $R^{\mathrm{pc}} \mathrm{ABh}$, जजयास्याद्य $S_{1}$, ०जयायाध्वं $S_{3}$ 25d तपोधना: ] $S_{1} R A B h$, तपोधना $S_{3}$ 26a 'व्दूचनं ] $S_{1}^{p c} S_{3} R A B h$, ०द्वचंनं $\mathrm{S}_{1}^{\mathrm{ac}}$ (unmetrical) 26b ब्रह्मा ] $\mathrm{S}_{1} \mathrm{RABh}$, ब्रह्म $\mathrm{S}_{3}$ - ०पितामहः ] $\mathrm{S}_{1} \mathrm{RA}_{3} \mathrm{~A}_{4} \mathrm{Bh}$, ०पितामह $\mathrm{S}_{3}$ $27 \mathbf{a b}$ यतं सुमहद॰ $] \mathrm{em}$. Bh (silently), यत सुमहद $S_{1}$ (anusvāra possibly lost), सुमहद्यत्नं म० $\mathrm{S}_{3} \quad 27 \mathrm{~b}$ ०प्रमत्तः ] $\mathrm{S}_{3} \mathrm{Bh}$ (conj.?), ०प्रमत्तं $\mathrm{S}_{1}$ - सुरेश्वर ] conj. Bh (silently), सुरेश्वर: $\mathrm{S}_{1} \mathrm{~S}_{3}$ 27d कृच्छ्रमेत॰ ] $\mathrm{S}_{1}^{\mathrm{pc}} \mathrm{RA}_{3} \mathrm{~A}_{7} \mathrm{Bh}$, कृच्छ्र(वे)त॰ $\mathrm{S}_{1}^{\mathrm{ac}}$, कृत्स्नमेत॰ $\mathrm{S}_{3}$ • ०तं मम ] $\mathrm{S}_{1}^{\mathrm{pc}} \mathrm{S}_{3} \mathrm{RABh}$, ०तम्मय $\mathrm{S}_{1}^{\mathrm{ac}} 28 \mathrm{~b}$ पुरा ] $\mathrm{S}_{3} \mathrm{RA}_{3} \mathrm{~A}_{4} \mathrm{Bh}$, सुरा: $\mathrm{S}_{1}$ 28cd ॰त्येन्द्रस्त्त $\mathrm{S}_{3}^{\mathrm{pc}} \mathrm{RABh}$, ०त्येन्द्रं त॰ $\mathrm{S}_{1}$, ॰त्येन्द्रस्त० $S_{3}^{\text {ac }}$ 28d ०बलान्वितः ] $S_{3} R A$, ०समन्वितः $S_{1} B h$ 29a देवस्त॰] $S_{3} R A_{7} B h$ (em.?), देवास्त॰ $S_{1} \quad 29 \mathrm{c}$ सुरै: ] $\mathrm{S}_{1} \mathrm{~S}_{3}^{\mathrm{pc}} \mathrm{ABh}$, सुरै $\mathrm{S}_{3}^{\mathrm{ac}} \quad 30 \mathrm{a}$ उक्तः ] $\mathrm{S}_{3}^{\mathrm{pc}} \mathrm{RABh}$, उक्त $\mathrm{S}_{1} \mathrm{~S}_{3}^{\mathrm{ac}}$ • देवेशो ] $\mathrm{S}_{1} \mathrm{~S}_{3}^{\mathrm{pc}} \mathrm{RABh}$, देवो सो $\mathrm{S}_{3}^{\mathrm{ac}} 30 \mathrm{~b}$ ०माप्यायय ] $\mathrm{S}_{1} \mathrm{~S}_{3}^{\mathrm{pc}} \mathrm{Bh}$, ०माप्याय $\mathrm{S}_{3}^{\mathrm{ac}}$ (unmetrical) • प्रभो ] $S_{3}^{\text {ac }} A B h$, प्रभो: $S_{1} S_{3}^{\text {pc }}$ 30c सर्वेश ] $S_{1} B h$, सर्वेशो $S_{3}$ 30d हन्यात् ] $S_{1} S_{3}^{\text {pc }} R A B h$, हन्यां $S_{3}^{\text {ac }}$ 


\section{भगवानुवाच।}

तस्मिन्काले सुरेशानं शावं तेजो उ्ययं हरिम्।

प्रवेक्ष्यति ततो दैत्यं क्षिप्रमेव निहंस्यति॥ ३? ॥

ततो ब्रह्मा स्वयं तस्य रक्षां चक्रे महात्मनः।

यथावत्तां निबोधाद्य गदतो मे शुचित्रत॥ ३२॥

ब्रह्मोवाच।

रक्षतु त्वां विधाता च धाता च ऋषिसत्तमः।

रुद्दः स्रष्टा च सर्वेषां मर्माणि तव युध्यतः॥ ३३॥

कापाली तालकेतुश्च गन्धाधिपतिरेव च।

रसस्याधिपतिश्चैव सूक्ष्मरूपश्च रक्षतु॥ ३८॥

स्पर्शवेत्ता च यः सूक्ष्मो नादवांग्च महामनाः।

इन्द्रियाधिपतिश्चैव नीललोहित एव च॥ ३४ ॥

31 भगवानुवाच ] om. $R$ 31a सुरेशानं ] सुरेशेन $R \quad 31 b$ शार्वं ] सर्व्व० $R \quad 31 \mathrm{c}$ वेक्ष्यति ] ववक्ष्यति $R \quad 31 d$ ०हंस्यति ] ॰हंस्यसि $R \quad 32 c$ यथावत्तां नि॰] तथा च तत्रि॰ $R \quad 33 b$ धाता च ऋषिसत्तमः ] ऋषिभिश्च ततस्ततः $R$ 34a कापाली] कपाली $R$ 34d ० श्चु] ०स्तु $R$ 35a स्पर्शवेत्ता च य: ] स्वणिरे तापस: $\mathrm{R} \quad 35 \mathrm{~b}$ नादवांश्च ] रागवेत्ता $\mathrm{R}$

31 भगवा०] $\mathrm{A}_{4} \mathrm{~A}_{7}$, श्रीभगवा० $\mathrm{A}_{3} 31 \mathrm{a}$ सुरेशानं ] सुरेशानां $\mathrm{A}_{3} \mathrm{~A}_{4}$, सुरेशान $\mathrm{A}_{7} \quad 31 \mathbf{b}$ शार्वं] सर्व $\mathbf{A}$ - उ्ययं हरिम् ] महद्धरिं $\mathbf{A} 31 \mathrm{c}$ ववेक्ष्यति ] ववेक्षति $\mathrm{A}_{7}$, ०वेशेष्यति $\mathrm{A}_{3}$ (unmetrical), ०विष्येष्यति $\mathrm{A}_{4}$ (unmetrical) 31d ०व निहंस्यति ] ०व $\left\{\right.$ वा० $\left.\mathrm{A}_{7}\right\}$ हनिष्यति $\mathbf{A} 32 \mathbf{b}$ महात्मनः ] महायशा: $\left\{\circ\right.$ सा: $\left.\mathrm{A}_{7}\right\} \mathbf{A} \quad 32 \mathrm{c}$ ०तां निबोधाद्य ] ०त्तन्नि $\left\{{ }^{\circ}\right.$ त्त नि० $\left.\mathrm{A}_{7}\right\}$ बोधार्य $\left\{\right.$ ०्य $\left.\mathrm{A}_{4}\right\} \mathbf{A}$ 32d शुचित्रत ] $A_{3}$, शुचिब्रत $A_{4}$, शुचिर्व्रत $A_{7} \quad 33 a$ रक्षतु ] $A_{3} A_{7}$, रक्षंतु $A_{4} \quad 33 b$ धाता च ] $A_{4} A_{7} A_{2}$ (f. $245^{\mathrm{r}}$ ), om. $\mathrm{A}_{3}$ (unmetrical) - ऋषिसत्तमः ] ऋषिभिस्ततः $A$ 33d मर्माणि] $\mathrm{A}_{4}$, मर्मान $\mathrm{A}_{3}$, धर्माण $\mathrm{A}_{7} 34 \mathbf{a}$ तालकेतु $\left.{ }^{\circ}\right]$ का $\left\{\right.$ को॰ $\left.\mathrm{A}_{7}^{\mathrm{pc}}\right\}$ लकेतु ${ }^{\circ} \mathrm{A}$ 34d सूक्ष्मरूपश्च ] सूक्ष्मारूपस्तु $\mathrm{A}_{3} \mathrm{~A}_{4}$, सूक्ष्वारुपास्तु $\mathrm{A}_{7}$ (unmetrical) - रक्षतु $] \mathrm{A}_{3} \mathrm{~A}_{4}$, रक्षति $\mathrm{A}_{7} \quad \mathbf{3 5 b}$ नादवांश्च महामनाः ] दानवाश्च्च महाबला: A

$33\left(c^{1}\right) S_{1}$

$31 \mathbf{a}$ सुरेशानं ] $S_{3}$, सुरेशानां $S_{1}$, सुरेशाना: $B h$ (conj.) $31 b$ शार्वं] $S_{3}^{p c}$, सर्व० $S_{1}$ こ वं $S_{3}^{a c}$, सर्वे $B h$ (conj.) - उव्ययं ] R, ०मयं $S_{1} B h$, प्ययं $S_{3}$ • हरिम् $] S_{1} R B h$, हरि+:+ $S_{3}$ 31c व वेक्ष्यति ] em., ०वेक्षति $S_{1}$, ०वेक्ष्याति $S_{3}^{\mathrm{pc}}$, ववक्ष्या(नि) $S_{3}^{\mathrm{ac}}$, ०वेक्ष्यन्ति Bh (conj.) 32a Before this $B h$ adds सनत्कुमार उवाच। 32b महात्मन: ] $S_{1} R B h$, महामना: $S_{3}$ 32d गदतो ] $S_{1} S_{3} R A$, वदतो $\mathrm{Bh}$ (conj.?) - ॰व्रत ] $\mathrm{RA}_{3} \mathrm{Bh}$, ॰व्रत $\mathrm{S}_{1}$, ॰व्रतः $\mathrm{S}_{3} 33$ ब्रह्मोवाच ] $\mathrm{S}_{1} \mathrm{RABh}$, ब्रह्म उ $\mathrm{S}_{3} 33 \mathrm{a}$ रक्षतु ] $\mathrm{S}_{1} \mathrm{~S}_{3} \mathrm{RA}_{3} \mathrm{~A}_{7}$, रक्षन्तु $\mathrm{Bh}$ (conj.?) • त्वां] $\mathrm{S}_{3}^{\mathrm{pc}} \mathrm{RABh}$, त्वा $\mathrm{S}_{1} \mathrm{~S}_{3}^{\mathrm{ac}}$ 33b च ऋषिसत्तमः ] em., चमृषिसत्तम $S_{1}$, च ऋषिसत्तम $S_{3} B h$ (em.?) 33d मर्माणि ] $S_{3} R_{4}$, कर्माणि $\mathrm{S}_{1} \mathrm{Bh} 34 \mathbf{a}$ कापाली] $\mathrm{S}_{1} \mathrm{~S}_{3} \mathrm{~A}$, कपाली $\mathrm{Bh}$ (em.?) 34d रक्षतु ] $\mathrm{S}_{1}^{\mathrm{ac}} \mathrm{S}_{3} \mathrm{RA}_{3} \mathrm{~A}_{4} \mathrm{Bh}$, रक्षतु: $\mathrm{S}_{1}^{\mathrm{pc}}$ 35a वेत्ता ] $\mathrm{S}_{3} \mathrm{ABh}$, ०वेता $\mathrm{S}_{1} \quad 35 \mathbf{b}$ नादवांश्च ] $\mathrm{S}_{3} \mathrm{Bh}$ (conj.?), नादतांश्च $\mathrm{S}_{1}$ - महामनाः ] $\mathrm{RBh}$ (conj.?), महात्मना $\mathrm{S}_{1}$, महामना $\mathrm{S}_{3}$ 
रक्षतु त्वां महायोगी बीजाधिपतिरेव च।

बीजाधिष्ठानपालश्च चेतनापतिरेव च॥ ३६॥

प्रवृत्तेश्च निवृत्तेश्च कालवेत्ता च यः प्रभुः।

धर्माधर्मगतिश्चैव कर्तृणां फलदः प्रभुः॥ ३७॥

गुणानां वृत्तिदो यश्च अनपेक्षश्च कर्मसु।

नियमस्य च यः कर्ता कर्मवेत्ता च कर्मिणाम्।

विना च करणैर्यस्य करणार्थः प्रवर्तते॥ ३५॥

सर्वज्ञः सर्वगोपश्च अधिष्ठाता च यः स्वयम्।

येन नाधिष्टितं किंचित्कर्थंचिन्नापि विद्यते॥ ३९ ॥

सर्वतःपाणिपादान्तः सर्वतोक्षिशिरोमुखः।

सर्वतः श्रुतिमान्यश्च सर्वतोगतिरव्ययः ।

ऐश्वर्यमक्षयं यस्य सहजं चाकृतं तथा॥ ४०॥

यः स्रष्टा सर्वभूतानां तत्त्वानां च महायशा:।

संसारस्यास्य यः कर्ता तथा चैव निवर्तकः ॥ ४९॥

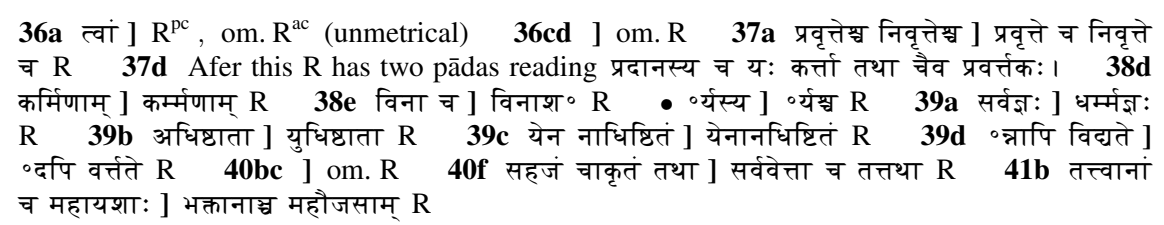

36b बीजाधि॰] राजाधि॰ $\mathbf{A} 36 \mathbf{c}$ बीजाधि०] $\mathrm{A}_{3} \mathrm{~A}_{4}$, राजाधि॰ $\mathrm{A}_{7} 37 \mathbf{a}$ प्रवृत्तेश्च निवृत्तेश्च ] प्रवृत्तिश्च निवृत्तिश्च $\mathbf{A} \pm \quad 37 \mathbf{c d}$ ] Insead of this, $\mathbf{A}$ has two pādas reading प्रधानस्य च यः कर्ता तथा चैव प्रवर्त्तकः $38 \mathrm{~d}$ कर्मिणाम् ] यः प्रभुः A 38e-39d ] om. A 40a ०पादान्तः सर्वतोक्षि०]

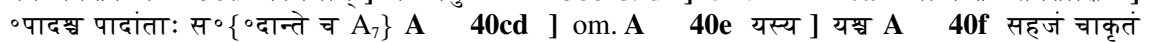
तथा ] सहस्राकृतयस्तथा $\mathbf{A} \pm 41 \mathrm{c}$ ०स्यास्य यः कर्ता ] ०स्यापकर्ता च $\mathbf{A}$

36 $\left(c^{1}\right) S_{1} \quad 38\left(d^{3}-d^{4}\right) S_{1} \quad 40\left(c^{4}-c^{5}\right)\left\langle c^{6}-c^{7}\right\rangle\left(c^{8}\right)\left\langle f^{2}-f^{3}\right\rangle\left(f^{4}\right) S_{1}$

36a त्वां] $S_{3}^{\mathrm{pc}} R^{\mathrm{pc}} A B h$, त्वा $S_{1} S_{3}^{\mathrm{ac}}$ - महायोगी ] $\mathrm{S}_{1} \mathrm{RABh}$, महामायो $S_{3}$ 36c ०पालग्च ] $\mathrm{S}_{3}$ $A$, ०मालश्च $S_{1} B h \quad 36 d$ ०पतिरे॰ $S_{1}^{\mathrm{pc}} S_{3} A B h$, ०पविरे॰ $S_{1}^{\text {ac }}$ 37d कर्तृणां ] $S_{1} R B h$, कतृणां $S_{3}$ 38a गुणानां ] $S_{1} R A B h$, गुणाना $S_{3} 38 d$ ०वेत्ता ] $S_{1} R A B h$, ०वेता $S_{3}$ • कर्मिणाम् ] $S_{1}^{p c} S_{3}$, कर्म्मणां $S_{1}^{a c}$, कर्मणां $B h \quad 38 e$ ०र्यस्य $] S_{1} S_{3}$, वर्यश्च Bh (conj.) $38 f$ करणार्थः ] $S_{3} R$, करणार्त्थम् $\mathrm{S}_{1}$, करणार्थ $\mathrm{Bh}$ 39a ०गोपश्च ] $\mathrm{S}_{1} \mathrm{~S}_{3} \mathrm{R}$, ०गो यश्च $\mathrm{Bh}$ (conj.) 39b अधिष्ठाता ] $\mathrm{S}_{1} B \mathrm{Bh}$, अधिप्टाता $\mathrm{S}_{3} \quad 39 d$ ०न्नापि ] conj. $\mathrm{Bh}$, ०दपि $\mathrm{S}_{1} \mathrm{~S}_{3} \quad$ 40a ०पादान्तः ] RBh (em.?), ०पादान्त $\mathrm{S}_{1} \mathrm{~S}_{3}$ 40c ॰मान्यश्च ] $S_{3}, \quad--$ (श्च) $S_{1}$, ॰मांश्चैव Bh (conj.?) 40e ०यं यस्य ] RBh (conj.), ०यन्तस्य $\mathrm{S}_{1} \mathrm{~S}_{3} 40 \mathrm{f}$ सहजं चाकृतं तथा ] $\mathrm{S}_{3}$, स $\simeq$ (च्च) कृतन्तथा $\mathrm{S}_{1}$ (upper part of च्च lost), सहस्राकृतयस्तथा $\mathrm{Bh} 41 \mathrm{~b}$ महायशा: ] $\mathrm{S}_{1} \mathrm{ABh}$, महायशा $\mathrm{S}_{3}$ 41d तथा चैव ] $\mathrm{S}_{1} \mathrm{~S}_{3} \mathrm{RA}$, तथैव च Bh (conj.) निवर्तक: ] $S_{3} R A B h,+$ नि+र्तक: $S_{1}$ (unmetrical) 
यं सांख्या नाभिजानन्ति योगिनो विदितागमाः।

तुष्टो यो ज्ञायते नित्यं मायया मोहयन्प्रजाः ॥ ४२॥

ओतप्रोतानि येन स्म तत्त्वानि सुमहात्मना।

पुरुषादीनि सर्वाणि यो व्याप्तश्च न केनचित् ॥ ४३॥

यमज्ञात्वा न मोक्षो उस्ति येन बद्धमिद् जगत्।

येनाहं सर्वलोकानां कृतः पूर्वं प्रजापतिः।

त्वं यज्ञश्चैव विष्णुश्च येन सृष्टः पुरातनः॥ ४४॥

स ते बलं च सुमहदूर्ज तेजश्च यच्छुतु।

अकाहलत्वं सर्वत्र स्मृतिं चास्त्रे महामनाः ॥ ४४॥

रक्षां च सर्वशो देवो युध्यतस्ते प्रयच्छ, ।

कृतरक्षो मया सम्यग्गच्छ दैत्यं विनाशय॥ ४६॥

$43 \mathrm{~b}$ ॰महात्मना ] ॰महात्मन: $\mathrm{R}$ 43d यो व्याप्तश्च न ] योगिव्याप्तस्य $\mathrm{R}$ 44d ॰ पतिः ] $\mathrm{R}^{\mathrm{pc}}$, ०पति $R^{\mathrm{ac}} \quad 44 \mathrm{f}$ पुरातनः ] प्रजापतिः $\mathrm{R} \quad 45 \mathrm{~b}$ ०दूर्ज ] ॰दूर्ज्ज $\mathrm{R} \quad 45 \mathrm{c}$ अकाहलत्वं ] अकालदत्तं $\mathrm{R}$ 45d स्मृतिं चास्त्रे महामना:] स्मृतिमांस्ते महात्मन: $\mathrm{R}$

42a यं सांख्या ] ससांख्या $\mathrm{A}_{7}$, ससां $\mathrm{A}_{3}$ (unmetrical), सहसा $\mathrm{A}_{4}$ 42b विदितागमा:] विदिता: समा: $\mathrm{A} 42 \mathrm{~d}$ ॰न्प्रजा: ] $\mathrm{A}_{3} \mathrm{~A}_{4}$, ०न् प्रजा $\mathrm{A}_{7}$ 43a ओतप्रोतानि ] हतप्रोतानि $\mathrm{A}_{7}$, हतप्रोतास्मि $\mathrm{A}_{3} \mathrm{~A}_{4} 43 \mathrm{~b}$ तत्त्वानि सुमहात्मना $]$ तेनासि सु $\left\{\right.$ तनानिषु $\left.\mathrm{A}_{7}\right\}$ महाबला: $\mathbf{A}$ 43d व्यात्तश्च न ] न प्राप्तश्च

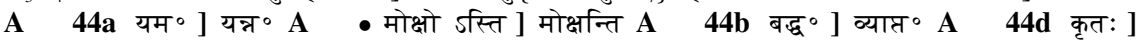
कृत० A $44 \mathrm{e}$ त्वं यज्ञश्चैव विष्णुश्च ] त्वं यज्ञश्चैव रिश्च $\mathrm{A}_{3}$ (unmetrical), त्वं यज्ञश्च वरिष्टश्च $\mathrm{A}_{4}$, यज्ञश्चैव वरिष्ठश्च $\mathrm{A}_{7} 45$ ] स बलं च बलं चैव महदु $\left\{{ }^{\circ}\right.$ द्रा० $\mathrm{A}_{3}$, ० द्वा० $\left.\mathrm{A}_{4}\right\}$ ज्यं च यच्छाति। आ $\left\{\right.$ अ० $\left.\mathrm{A}_{7}\right\}$ कारं यस्य वै दृष्ट्रा वित्रस्यति महाबल: $\mathrm{A} \pm$ 46ab ] om. A

$42\left(a^{4}, c^{2}\right) S_{1} \quad 43\left(a^{7}-b^{1}, b^{8}\right) S_{1} \quad 45\left\langle b^{1}-b^{2}\right\rangle\left(b^{3}-b^{6}\right) S_{3} \quad 46\left(b^{1}-b^{3}\right) S_{1}$

42a सांख्या नाभि॰ $] \mathrm{S}_{1}^{\mathrm{pc}} \mathrm{S}_{3} \mathrm{RBh}$, संख्या(न्ना)भि॰ $\mathrm{S}_{1}^{\mathrm{ac}} \quad 42 \mathrm{c}$ तुष्टो यो ज्ञायते ] $\mathrm{S}_{3} \mathrm{RA}$, तु(ष्ट)यो ज्ञातयो $\mathrm{S}_{1}$, तुष्टयो ज्ञातयो $\mathrm{Bh}$ 42d ०यन्प्रजा: ] $\mathrm{S}_{3} \mathrm{RA}_{3} \mathrm{~A}_{4} \mathrm{Bh}$, ०यं प्रजा $\mathrm{S}_{1}$ 43a ओतप्रोतानि ] $\mathrm{S}_{1}^{\mathrm{pc}} \mathrm{S}_{3} \mathrm{R}$ $\mathrm{Bh}$, रुतप्रोक्तानि $\mathrm{S}_{1}^{\mathrm{ac}}$ - येन स्म ] $\mathrm{S}_{1}^{\mathrm{ac}} \mathrm{S}_{3} \mathrm{RA}$, ये (तस्म) $\mathrm{S}_{1}^{\mathrm{pc}}$ (upper part of तस्म lost), चैतस्मिन् $\mathrm{Bh}$ (conj., in a note Bh reads ये तस्मिन् in $S_{1}$ ) $\quad \mathbf{4 3 b}$ ०महात्मना ] $S_{1} S_{3}$, ०महात्मनि Bh (conj.) $44 d$ ०पति: ] $R^{\mathrm{pc}} A B h$, ०पति $S_{1} S_{3} \quad 44 e$ विष्णुश्च ] $S_{1} S_{3}^{\text {pc }} R B h$, विष्णु $S_{3}^{\text {ac }}$ (unmetrical) $44 f$ सृत्ट: ] $\mathrm{S}_{3} \mathrm{RA}$, सृष्टा $\mathrm{S}_{1}$, सृष्टा: Bh (em.?, in a note Bh suggests सृष्टौ) - पुरातनः ] $\mathrm{S}_{3} \mathbf{A}$, पुरातन $\mathrm{S}_{1}^{\mathrm{pc}} \mathrm{Bh}$, षुरातन $S_{1}^{\text {ac }} \quad 45 b$ यच्छतु $] S_{3} R B h(e m . ?)$, यच्छतु : $S_{1} \quad 45 c$ अकाहलत्वं ] $S_{3}$, अकामालब्ध $S_{1}$, अकामलब्धां $\mathrm{Bh}$ (conj.?) 45d महामना: ] conj. Bh (silently), महात्मना+: $+\mathrm{S}_{1}$, महामना $\mathrm{S}_{3}$ 46a सर्वशो ] $\mathrm{S}_{1} \mathrm{~S}_{3} \mathrm{R}$, सर्वगो $\mathrm{Bh}$ (conj.?) $46 \mathrm{~b}$ ०यच्छतु ] $\mathrm{S}_{3} \mathrm{RBh}\left(\mathrm{em}\right.$. ?), ०यच्छतु $\mathrm{S}_{1}$ 46c ० रक्षो ] $\mathrm{S}_{3} \mathrm{RABh}$, ०रक्षा $\mathrm{S}_{1}$ 
सनत्कुमार उवाच।

ततस्तं स्तुतिभिर्विप्रास्तस्य रोमान्तरस्थिताः।

अस्तुवन्वाग्भिरिष्टाभिर्देवाश्च बहुमानतः।

सर्वाणि च जयेत्यूचुर्भूतानि विविधानि च॥ ४७॥

अनाहतास्तदा व्योम्नि देवदुन्दुभयः शुभाः।

विनेदुस्तत्र दिव्याश्च वराहो यत्र सो भवत्॥ ४५॥

सुरभीणां च पुष्पाणां वराहोपरि सर्वतः।

वृष्टयः पेतुरत्यर्थं देवानां हर्षवर्धनाः॥ ४९॥

ततः सिद्धिरिति प्रोत्का कृत्वा रुद्राय वै नमः।

जपअयावहं रुद्रं प्रययौ वरुणालयम्॥ पू०॥

स सेव्यमानो ऋषिभिस्तपोधनैस्तथा शकुन्तैर्बहुभिर्जयावहै:।

मृगैश्च दिव्यैर्बहुभि: प्रदक्षिणैर्जयाय देव: प्रययौ महार्णवम्॥ ४२?॥

इति स्कन्दपुराणे इष्टनवतितमो उध्यायः ॥९५॥

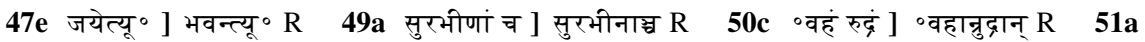
सेव्यमानो ] सेव्यमान $R$ (unmetrical) Col. इति स्कन्दपुराणे रेवाखण्डे इध्याय: $R$

47-col. ] om. A

$47\left(d^{7}\right) S_{1},\left(a^{7}\right) S_{3} \quad 48\left(a^{4}-a^{6}, c^{8}-d^{1}\right) S_{1} \quad 51\left(a^{5}-a^{7}, d^{5}\right) S_{1}$

47a ततस्तं ] $S_{1}^{\mathrm{pc}} \mathrm{S}_{3} \mathrm{RBh}$, तत(क) $\mathrm{S}_{1}^{\mathrm{ac}} \quad$ 47ab ०र्विप्रास्त०] $\mathrm{RBh}(\mathrm{em} . ?)$, ०र्विप्रा त० $\mathrm{S}_{1}$, ( ०र्वि)प्रा त० $\mathrm{S}_{3} \quad 47 \mathrm{~b}$ ०स्थिता: ] $\mathrm{RBh}(\mathrm{em} . ?)$, ०स्थिता $\mathrm{S}_{1} \mathrm{~S}_{3} \quad 47 \mathrm{c}$ ०वन्वाग्भि० ] $\mathrm{S}_{1}^{\mathrm{pc}} \mathrm{S}_{3} \mathrm{RBh}$, ०वं वागि० $S_{1}^{\text {ac }}$ ०रिष्टाभिर् ] $S_{1} R B h$, ०रिष्टाभि $S_{3}$ 47d ०मानतः ] $S_{3} R B h$ (em.?), ०मा(न)त $S_{1}$ 47ef ] $\left(\mathrm{S}_{1}\right) \mathrm{Bh}$, om. $\mathrm{S}_{3}$ 47e सर्वाणि ] $\mathrm{S}_{1}^{\mathrm{pc}} \mathrm{RBh}$, (अ)र्वाणि $\mathrm{S}_{1}^{\mathrm{ac}}$ - ०त्यूचुर् ] em. Bh (silently), ॰त्यूचु $S_{1} \quad 48 \mathbf{a}$ ०तास्तदा ] $S_{3} R$, (॰ता त) - $\Gamma S_{1}$, ०तास्ततो Bh (conj.?) 48b ०भयः शुभाः ] $\mathrm{S}_{1} \mathrm{RBh}$, ०भय शुभा $\mathrm{S}_{3}$ (unmetrical) $48 \mathrm{c}$ दिव्याग्च ] $\mathrm{S}_{3} \mathrm{RBh}$ (em.?), दिव्यां(श्च) $\mathrm{S}_{1}$ 49b सवतः ] $S_{1} S_{3}^{p c} R B h$, सर्वशः $S_{3}^{\text {ac }} \quad 49 d$ ०वर्धना: ] $S_{1} S_{3}^{p c} R B h$, ०वर्द्धना $S_{3}^{\text {ac }}$ 50a ततः ] $S_{1} R B h$, तत $S_{3}$ - प्रोत्का ] $S_{1} S_{3} R$, प्रोच्य $B h(e m) \quad$.$50 b कृत्वा रुद्राय वै नमः ] S_{1} R B h$, देवानां हर्षवद्धना $\mathrm{S}_{3}$ (cf. 49d) 50d प्रययौ] $\mathrm{S}_{1} \mathrm{~S}_{3} \mathrm{R}$, स ययौ $\mathrm{Bh}$ (conj.) 51a ऋषिभि॰] $\mathrm{S}_{1} \mathrm{~S}_{3} \mathrm{R}$, मुनिभि॰ $\mathrm{Bh}$ (conj.?) 51b ०र्बहुभिर् ] $S_{1} R B h$, ०बहुभि $S_{3}$ (unmetrical) 51c दिव्यैर् ] $S_{1} R B h$, दिव्यै $S_{3}$ - प्रदक्षिणै॰] $\mathrm{S}_{3} \mathrm{RBh}$ (em.?), प्रदक्षिणी॰ $\mathrm{S}_{1}$ 51d महार्णवम् ] $\mathrm{S}_{3} \mathrm{RBh}$, महार्ण्णवमिति $\mathrm{S}_{1}$ (इति part of col.) Col. $\odot \|$ स्कन्दपुराणे वरुणालयगमने आध्याय: शू८ (in letter numerals)॥ $\odot S_{1}$, $\odot ॥$ स्कन्दपुराणे नामाध्याय: ९५ (in letter numerals)॥ $\odot \mathrm{S}_{3}$, इति स्कन्दपुराणे वराहस्य वरुणालयगमनं नामाष्टनवतितमोध्याय: $\mathrm{Bh}$ 
एकोनशततमो डध्यायः।

सनत्कुमार उवाच।

स संप्रयातो धर्मात्मा नर्दमानो यथा घनः।

सर्वलोकमयो देवो वराहो नन्दिवर्धनः।

अपश्यत्सागरं चैव संप्राप्यातिमहाबलः ॥ १ ॥

नर्दमानं यथा मेघं लीयमानं मृगेन्द्रवत्।

नर्तकीमिव नृत्यन्तं वल्गन्तं चैव योधवत्॥ २॥

मण्डलैर्बहुभिश्चित्रैश्चरन्तं वसुधां तथा।

नियुद्धकुशलं यद्वद्धदायुद्धविशारदम्॥ ३॥

तदा तं बहुधा चित्रमपश्यन्नन्दिवर्धनम्।

$$
\text { ॥ }
$$

स तमर्घेण देवेशं सर्वलोकमयं विभुम्।

पूजयामास देवाश्च ऋषयो ये च संगता: ॥ $y \|$

1b नर्दमानो यथा घनः ] सह सिद्धैर्म्महात्मभि: $\mathrm{R}$ 1f संप्राप्याति॰ ] श्रीमान् स तु $\mathrm{R}$ 2c नर्तकीमिव ] नर्त्तकानिव $\mathrm{R}$ 2d After this $\mathrm{R}$ has two pādas reading फलपुष्पोपहारांग्च कुर्व्वन्तमिव चान्यतः। $3 b$ वसुधां तथा ] वसुधातले $R \quad 3 c$ यद्वद् ] युद्धे $R \quad 5 a$ तदा तं ] चरन्तं $R \quad 5 b$ ०पश्यन्नन्दिवर्धनम् ] ०पश्यंश्चापि सड़्ता: $R \quad 5 \mathrm{~cd}$ ] om. $R \quad 6 a$ स तमर्घेण ] देवर्षयो थ $R \quad 6 c$ ममास ] ॰मासुर् $R$

$1 a$ ॰प्रयातो ] ॰ प्राप्रो ति॰ $A$ 1b घन: ] $\mathrm{A}_{3}$, मनः $\mathrm{A}_{4} \mathrm{~A}_{7}$ 1e अपश्यत् ] $\mathrm{A}_{3} \mathrm{~A}_{4}$, अपश्य $\mathrm{A}_{7}$ if ०प्राप्याति॰ ] प्राप्येति $A$ 2a मेघं ] $\mathrm{A}_{3} \mathrm{~A}_{4}$, मेघ $\mathrm{A}_{7} \quad 2 \mathrm{~b}$ लीयमानं ] नीयमानं $\mathrm{A} \quad 2 \mathrm{2d}$ नृत्यन्तं वल्गन्तं चैव ] नर्दन्ती स्वर्गं तं चैव $\left\{\right.$ तत्रैव $\left.\mathrm{A}_{4}\right\} \mathbf{A} \quad \mathbf{2 d}$ After this $\mathbf{A}$ has two pādas reading फलपुष्पो-

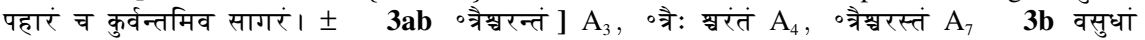
तथा ] वसुधातलं $\mathbf{A} \quad 3 \mathbf{c}-\mathbf{4 d}$ ] om. $\mathrm{A} \quad \mathbf{6 c}$ देवाश्च ] $\mathrm{A}_{3} \mathrm{~A}_{7}$, देवांश्च $\mathrm{A}_{4}$

Manuscripts available for this chapter: $S_{1}$ photos $3.32 \mathrm{~b}$ (f. $154^{\mathrm{r}}$ ), $3.33 \mathrm{a}\left(\mathrm{f} .154^{\mathrm{v}}\right.$ ) and $3.33 \mathrm{~b}\left(\mathrm{f} .155^{\mathrm{r}}\right.$ ); $\mathrm{S}_{3}$ f. $154^{\mathrm{v}}-155^{\mathrm{r}} ; \mathrm{R}$ f. $172^{\mathrm{r}}-172^{\mathrm{v}} ; \mathrm{A}_{3}$ f. $101^{\mathrm{v}}-102^{\mathrm{r}} ; \mathrm{A}_{4}$ f. $145^{\mathrm{r}}-145^{\mathrm{v}} ; \mathrm{A}_{7}$ f. $143^{\mathrm{v}}-144^{\mathrm{r}}$.

$2\left(a^{3}\right) S_{1}$

1e अपश्यत् ] $\mathrm{S}_{3} \mathrm{RA}_{3} \mathrm{~A}_{4} \mathrm{Bh}$, अपश्य $\mathrm{S}_{1}$ 1f ०प्राप्याति॰] $\mathrm{S}_{1} \mathrm{Bh}$, ०प्राप्य ति॰ $\mathrm{S}_{3}$ - ॰महाबलः ] $\mathrm{S}_{3} \mathrm{RA}$, ०बलस्तदा: $\mathrm{S}_{1}$, ०बलस्तदा Bh (em.?) 2a यथा ] $\mathrm{S}_{1}^{\mathrm{pc}} \mathrm{S}_{3} \mathrm{RABh}$, मथा $\mathrm{S}_{1}^{\mathrm{ac}}$ • मेघं ] $\mathrm{S}_{1} \mathrm{R}$ $\mathrm{A}_{3} \mathrm{~A}_{4} \mathrm{Bh}$, मेघ $\mathrm{S}_{3} \quad$ 2b मृगेन्द्र॰ $] \mathrm{S}_{1} \mathrm{RABh}$, नगेन्द्र॰ $\mathrm{S}_{3}$ 2c नृत्यन्तं ] $\mathrm{S}_{1} \mathrm{RBh}$, नृत्यन्तं $\mathrm{S}_{3} \quad \mathbf{2 d}$ वल्गन्तं ] $S_{1} R$, वल्गान्तं $S_{3}$, बल्गन्तं $B h \quad 3 a$ मण्डलैर ] $S_{1} R A B h$, मण्डले $S_{3}$ 3ab ० श्चित्रैश्चरन्तं ]

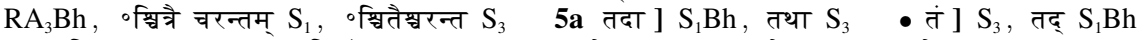
5 ab चित्रम॰] $S_{1} R B h$, ०चित्तं म॰ $S_{3} \quad 5 b$ ०वर्धनम् ] $S_{3}$, ०वर्द्धन: $S_{1}$, ०वर्धन: Bh 5cd ] Loss of two pādas conjectured, om. $S_{1} S_{3} B h$ 6c देवाश्च ] $S_{3} R_{3} A_{7}$, देवांग्च $S_{1} B h$ 
स जयाय प्रगृह्यैनमनुमान्य महोदधिम्।

निवर्त्य सर्वभूतानि प्रविवेश महार्णवम्॥ ६॥

विगाहमानः सकीडमर्णवं विबभौ विभुः।

सरः सुमहदासाद्य यथा मत्तो महागजः॥ ७॥

संप्रविश्य सुदूरं च सो उदृश्यः समपद्यत।

भूमिलेखावृतः सूर्यों यथा संपूर्णमण्डलः॥ ५॥

ततो उन्तर्जलमाविश्य क्षोभयानो महार्णवम्।

जलचन्द्रकवद्यास अदृश्यत जलौकसै:॥ १॥

तिमींस्तिमिंगिलांग्यैव तिमिंगिलगिलानपि ।

तथा वै तद्निलानन्यान्हस्तिनो गर्दभानपि॥ १०॥

मकरांग्चैव शड्वांश्च तथैवाश्वमुखानपि।

तथा वै पक्षिसंकाशान्मानुषानपि चापरान्॥ ?? ॥

$7 \mathrm{a}$ स जयाय ] जयाय स $\mathrm{R} \quad 7 \mathrm{c}$ निवर्त्य ] निर्व्वत्त्य R $8 \mathrm{ab}$ सक्रीडमर्णवं विबभौ] संक्रीडं तत्रैवं विभ-

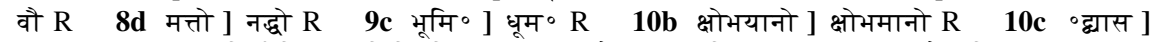

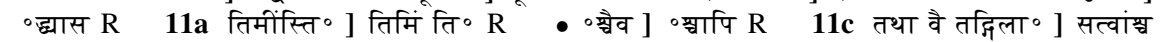
विविधा० $\mathrm{R}$ 12ab ] om. R

$7 \mathbf{a}$ ०गृह्यैन ${ }^{3} \mathrm{~A}_{3} \mathrm{~A}_{4}$, ०गृह्येन $\mathrm{A}_{7} \quad 7 \mathrm{c}$ निवर्त्य ] निर्वृत्य $\mathrm{A}_{3}$, निर्वत्यै $\mathrm{A}_{4}$, निवृर्त्तः $\mathrm{A}_{7}$ - ०भूतानि ] $\mathrm{A}_{4} \mathrm{~A}_{7}$, ०भूतानां $\mathrm{A}_{3} \quad 8 \mathbf{a b}$ ] om. $\mathbf{A} \quad \mathbf{8 c}$ सर: ] दूरं $\mathbf{A}$ - ०दासाद्य ] $\mathrm{A}_{3} \mathrm{~A}_{4}$, ०दास्याद्य $\left.\mathrm{A}_{7} 9 \mathrm{ab}\right]$ सं $\left\{\right.$ स $\left.\mathrm{A}_{4}\right\}$ प्रविश्य बभूवं च सो दृश्यत्सुमहाद्युति: $\mathrm{A}_{3} \mathrm{~A}_{4}$, संप्रविश्यम्वश्यार्णवं देवश्चादृश्यो भून्महाद्युति: $A_{7}$ (unmetrical) $9 \mathrm{c}$ भूमि॰ ] धूम० $A$ 10c ०द्यास ] $\mathrm{A}_{3} \mathrm{~A}_{4}$, ०द्यास $\mathrm{A}_{7} \mathbf{1 0 d}$ जलौकसै: ] जलौकस: $\left\{\circ\right.$ शः $\left.\mathrm{A}_{7}\right\} \mathbf{A}$ 11a तिमोंस्तिमिंगिला० ] तिमिस्तिमिंगिला० $\circ \circ$ मिगिणा० $\left.\mathrm{A}_{4}\right\} \mathbf{A}$ 11b-11a $]$ om. A $12 \mathrm{~b}$ तथैवाग्वमुखा॰ $]$ सत्वांश्चास्वे मुखा॰ $\mathrm{A}_{3}$, सत्वा $\left\{{ }^{\circ}\right.$ त्वां॰ $\left.\mathrm{A}_{4}^{\mathrm{ac}}\right\}$ श्चारो मुखा० $\mathrm{A}_{4}$, सत्वांग्चातम्वबा(हु)खा० $\mathrm{A}_{7}$ (unmetrical) $\mathbf{1 2 d} \circ$ नपि चापरान् ] ॰न् महिषान् खगान् $\left\{{ }^{\circ}\right.$ मान् $\left.\mathrm{A}_{3}\right\}$ $\mathbf{A}$

$\mathbf{8}\left\langle\mathrm{b}^{8}\right\rangle\left(\mathrm{c}^{1}\right) \mathrm{S}_{1} \quad \mathbf{1 0}\left(\mathrm{d}^{8}\right) \mathrm{S}_{1} \quad \mathbf{1 1}\left(\mathrm{a}^{1}-\mathrm{a}^{7}\right)\left\langle\mathrm{a}^{8}\right\rangle \mathrm{S}_{1}$

7a ०गृह्यैन०] $\mathrm{S}_{3} \mathrm{RA}_{3} \mathrm{~A}_{4} \mathrm{Bh}$, ०गृह्लेन $\mathrm{S}_{1} \quad \mathbf{7 b}$ महोदधिम् ] $\mathrm{S}_{3} \mathrm{RABh}$, महोदधि $\mathrm{S}_{1} \quad 8 \mathbf{a}$ ०गाहमान: ] $\mathrm{S}_{3} \mathrm{RBh}$ (em.?), ०गाहमान $\mathrm{S}_{1} \quad \mathbf{8 a b}$ सक्रीडम०] em. Bh (silently), सक्रीडमा० $\mathrm{S}_{1}$, सक्रीडा आ० $S_{3} 8 \mathbf{b}$ विबभौ ] $S_{1} B h$, विबभो $S_{3}$ • विभुः ] $S_{3}^{\text {pc }} R B h$ (conj.?), वि $S_{1}$, विभु $S_{3}^{\text {ac }} \mathbf{8 c}$ ०दासाद्य] $\mathrm{S}_{1} \mathrm{~S}_{3}^{\mathrm{pc}} \mathrm{RA}_{3} \mathrm{~A}_{4} \mathrm{Bh}$, ०दासाद $\mathrm{S}_{3}^{\mathrm{ac}}$ 9a ०प्रविश्य ] $\mathrm{S}_{1} \mathrm{RABh}$, क्रपश्य $\mathrm{S}_{3}$ 9b सो उद्श्यः ] RBh (em.?), सो दृश्य $S_{1}$, सौद्यश्य $S_{3}$ - ०पद्यत ] $S_{3} R B h$ (em.?), ०पद्यतः $S_{1}$ 9c भूमि॰ ] $S_{1} B h$, भूमी॰ $S_{3}$ • ववृतः सूर्यों ] RABh, ०वृतः सूर्य $S_{1}$, ववृत सूर्यों $S_{3}$ (unmetrical) $10 a$ ततो उन्त० ] $S_{1}^{\mathrm{pc}} S_{3} R A B h$, ततो न० $S_{1}^{\text {ac }} \quad 10 b$ महार्णवम् ] $S_{1} R A B h$, महाण्णव: $S_{3}$ 10c ०कवद्यास ] $\mathrm{S}_{3} \mathrm{~A}_{3} \mathrm{~A}_{4} \mathrm{Bh}$, ०कवत्व्यास $\mathrm{S}_{1}^{\mathrm{pc}}$, ०कर व्यास $\mathrm{S}_{1}^{\mathrm{ac}}$ 10d जलौकसै: ] $\mathrm{S}_{3} \mathrm{R}$, स लोक(पै): $\mathrm{S}_{1}$, स लोकपै: $\mathrm{Bh} 11 \mathrm{a}$ तिमींस्तिमिंगिलांग्च्चेव ] em., (तिमान्तमिड्भला) - $-\mathrm{S}_{1}$ (upper parts lost, last

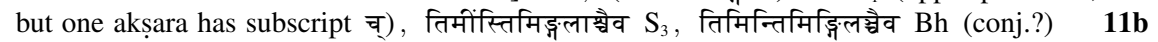
तिमिंगिल॰ $] S_{1} S_{3} R$, तिमिड्डल ${ }^{\circ} B h$ (typo?) 11c-11b ] om. $S_{3}$ 11c तथा वै ] $S_{1}$, तथैव $B h$ (conj.) - तद्रिलान०] $\mathrm{S}_{1}^{\mathrm{pc}} \mathrm{Bh}$, तद्रिलन० $\mathrm{S}_{1}^{\mathrm{ac}}$ (unmetrical) 11d हस्तिनो गर्दभानपि ] $\mathrm{R}$, गर्दभां हस्तिनो न्यपि $\mathrm{S}_{1}$, गर्दभान् हस्तिनो ह्यपि $\mathrm{Bh}$ (conj.?) $\quad$ 12a शड्वांश्च ] em. Bh (silently), शंखाश्च $\mathrm{S}_{1}$ $12 \mathrm{c}$ वै पक्षि॰ ] $\mathrm{S}_{1} \mathrm{RABh}$, नैक्षि॰ $\mathrm{S}_{3}$ (unmetrical) - ०संकाशान् ] RABh, ०संकाशा $\mathrm{S}_{1}$, ०सकाशं $\mathrm{S}_{3}$ (unmetrical) $12 \mathrm{~d}$ चापरान् ] $\mathrm{RBh}(\mathrm{em} . ?)$, चापराम् $\mathrm{S}_{1}$, चापरात् $\mathrm{S}_{3}$ 
रथचक्रकारांश्च सिंहव्याघ्रमुखानपि ।

शरभर्क्षविडालास्यान्मत्स्यान्बहुविधांस्तथा।

त्रासयन्स महातेजा जगाम सुमहाबलः॥ ?२॥

कुतूहलात्समाविश्य केचिदाध्राय चैव हि।

नश्यन्ति मत्स्या दीत्तास्याः शतशो डथ सहस्रशः॥ १३॥

स प्रदक्षिणमावृत्य दिव्यं हयशिरः शुभम्।

क्षणान्मैनाकमध्येन गत्वा भोगवतीमपि॥ १६॥

वरुणस्य पुरीं गत्वा पयोनाथस्य धीमतः।

पर्जन्यं दिग्गजं प्राप्य कृत्वा चापि प्रदक्षिणम् ॥ १४ ॥

सुरभीपुरमासाद्य गां दृष्ट्रा चैव सुप्रभाम्।

या क्षरन्ती सदा व्यास सुधाममृतमेव च॥ ?६॥

क्षीरोद तत्सरो दिव्यं फेनपा यत्र ते द्विजाः।

तस्मिन्सरसि तत्पीत्वा पयो उमृतसमप्रभम्।

पूजितः फेनपै: सम्यक्तां रात्रिं तत्र सो उवसत्॥ १७॥

उषित्वा तत्र सो उगच्छत्कड़क्स्य पुरमव्ययम्।

वासुकेश्च पुरं प्राप्य तक्षकस्य च धीमतः॥ १५ ॥

$13 \mathrm{c}$ ०विडालास्यान् ] ०विडालाख्यान् $\mathrm{R} 13 \mathrm{f}$ जगाम सु० ] गजानपि $\mathrm{R} 14 \mathrm{~cd}$ ] दर्शनात्तस्य दीत्या च नमस्यन्ति सहस्रश: $R \quad 15 \mathrm{c}$ क्षणान् ] क्षणं $R \quad{ }^{\circ}$ ०मध्येन ] ०मध्ये च $R$ 16c पर्जन्यं ] पास्वल्यं $\mathrm{R}^{\mathrm{pc}}, \sqcup$ ल्यं $\mathrm{R}^{\mathrm{ac}} 17 \mathrm{a}$ ०पुर०॰] ${ }^{\circ}$ तीर० $\mathrm{R} \quad 17 \mathrm{~b}$ गां ] गा $\mathrm{R}$ • सुप्रभाम् ] सुप्रभा: $\mathrm{R} 17 \mathrm{c}$ क्षरन्ती ] क्षरन्ति $R \quad 17 d$ सुधाम॰ ] दिव्य ${ }^{\circ}{ }^{\circ}$ • च ] हि $R \quad 18 a$ तत्सरो ] तत्सरं $R \quad 18 c$ ॰न्सरसि तत् ] ॰न् वारि सितं $R \quad 19 b$ वत्कड्कस्य ] ०त् कर्कोट $R^{\circ}$

13ab ] om. A $13 \mathrm{~cd}$ ] om. $\mathrm{A}_{7} 13 \mathrm{~cd}$ ०विडालास्यान्मत्स्यान् ] विनाशस्यास्सस्यान् $\mathrm{A}_{3} \mathrm{~A}_{4}$ $13 \mathrm{e}$ त्रासयन्स ] त्रास $\left\{\circ\right.$ श० $\left.\mathrm{A}_{7}\right\}$ नस्व० $\mathrm{A} 14 \mathbf{a}$ कुतूहलात् ] $\mathrm{A}_{3} \mathrm{~A}_{4}$, कुतूहलः $\mathrm{A}_{7} 14 \mathbf{b}$ ०दाप्राय ] ॰दाघाय $\mathrm{A}_{7}$, ०दाद्याय $\mathrm{A}_{3}$, ०दाव्वाय $\mathrm{A}_{4} 14 \mathrm{c}$ मत्स्या दीप्तास्या: ] दीप्तास्ते $\left\{{ }^{\circ}\right.$ तस्ताण् $\left.\mathrm{A}_{7}\right\}$ सर्वे $\mathrm{A}$ $15 \mathrm{c}-17 \mathrm{~d}$ ] om. A 18e पूजितः फेनपै: ] पूजितासन् ततः $\mathrm{A}_{3} \mathrm{~A}_{4}$, पूजिता सतता $\mathrm{A}_{7}$ 19a सो उगच्छत् ] वै व्यास $\mathbf{A}$

$15\left(c^{7}\right) S_{3} \quad 16\left(c^{8}-d^{1}\right) S_{1} \quad 19\left(b^{3}-b^{4}\right) S_{1}$

$13 \mathrm{c}$ शरभर्क्षवि॰] $\mathrm{RA}_{3} \mathrm{~A}_{4} \mathrm{Bh}$, शरभक्षवि॰ $\mathrm{S}_{1}^{\mathrm{ac}}$, शरभक्षान्वि॰ $\mathrm{S}_{1}^{\mathrm{pc}}$, शरभाक्षवि॰ $\mathrm{S}_{3} 13 \mathrm{~cd}$ ०लास्यान्मत्स्यान् ] $S_{1}^{\mathrm{pc}} \mathrm{Bh}$, ०लांन्स्यां मत्स्या $\mathrm{S}_{1}^{\mathrm{ac}}$, ॰लास्यान्मत्स्याम् $\mathrm{S}_{3} \quad 13 \mathrm{e}$ त्रासयन्स ] $\mathrm{S}_{3} \mathrm{R}$, त्रासयन्सु॰ $\mathrm{S}_{1}$, भ्रामयन्सु॰ $\mathrm{Bh}$ (conj.?) $\mathbf{1 3 f}$ ०महाबलः ] $\mathrm{S}_{1}^{\mathrm{pc}} \mathrm{RABh}$, ${ }^{\circ}$ महाबल $\mathrm{S}_{1}^{\mathrm{ac}}$, ${ }^{\circ}$ महाबला: $\mathrm{S}_{3} \quad \mathbf{1 4 a}$ कुतूहलात्समा॰ ] $\mathrm{S}_{1} \mathrm{RA}_{3} \mathrm{~A}_{4}$, कूतूहलां समा० $\mathrm{S}_{3}$, कुतूहलात्तमा॰ $\mathrm{Bh}$ (conj.) 14c नश्यन्ति ] $\mathrm{S}_{3} \mathrm{~A}$, दशन्ति $S_{1} B h$ - दीप्तास्या: ] em. Bh (silently), दीप्तास्या $S_{1} S_{3}$ 15a प्रदक्षिण॰] $S_{1} R A B h$, प्रदक्षिणा॰ $S_{3} \quad 15 \mathrm{c}$ न्मैनाकमध्येन ] $\mathrm{S}_{1} \mathrm{~S}_{3}^{\mathrm{pc} B h}$, न्मैनामम(थ)न $\mathrm{S}_{3}^{\mathrm{ac}}$ 16a पुरीं ] $\mathrm{S}_{1} R B h$, पुरी

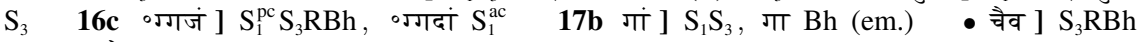
(em.?), दैव $S_{1}$ - सुप्रभाम् ] $S_{1} S_{3}$, सुप्रभा: Bh (em.) 17c या ] $S_{1} S_{3} R$, या: Bh (em.?) • क्षरन्ती ] conj. (cf. MBh 5.100.2a), क्षरन्ति $\mathrm{S}_{1} \mathrm{Bh}$, क्षरति $\mathrm{S}_{3}$ (unmetrical) $\mathbf{1 8 b}$ फेनपा ] $\mathrm{S}_{1}^{\mathrm{pc}} \mathrm{S}_{3} \mathrm{R}$ $\mathrm{Bh}$, (द)न(या) $\mathrm{S}_{1}^{\mathrm{ac}}$ - द्विजाः ] $\mathrm{S}_{1}^{\mathrm{pc}} \mathrm{RBh}$, द्विजा $\mathrm{S}_{1}^{\mathrm{ac}}$, द्विजां $\mathrm{S}_{3} \quad \mathbf{1 8 d}$ पयो ] $\mathrm{S}_{3} \mathrm{R}$, यशो $\mathrm{S}_{1}^{\mathrm{pc}} \mathrm{Bh}$, (प)शो $S_{1}^{\text {ac }} \quad 18$ e फेनपै: ] $S_{1} R B h$, फेनपै $S_{3}$ 18ef ०म्यक्तां रात्रिं ] RABh, ०म्यका रांत्रि $S_{1}$, ॰म्य तां रात्रिं $S_{3} \quad 18 f$ सो ] $S_{1} R A B h$, तो $S_{3} \quad 19 c$ पुरं ] $S_{1} R A B h$, पुरी $S_{3} \quad$ 19d धीमतः ] $\mathrm{S}_{1}^{\mathrm{pc}} \mathrm{S}_{3} \mathrm{RABh}$, धीमत $\mathrm{S}_{1}^{\mathrm{ac}}$ 
ततः शेषस्य देवेशो विदितां रमणामिति।

रम्यां मनोज्ञां दिव्यां च स्वर्गादपि तां वराम्॥ ?९॥

श्रुत्वानन्तश्च तं राजा अर्घेण च स पूजयत्।

प्रणम्य बहुमानाच्च उपामन्त्रयदव्ययः ॥ २०॥

महत्कार्यमिदं देव कर्तव्यं त्रिदिवौकसाम्।

भूयो वयं त्वया सार्धं करिष्याम यदीच्छुसि॥ २? ॥

तं पूजयानं मधुहा प्रीत्या परमया युतः।

उवाच लोककार्यस्य न विघं कर्तुमर्हसि।

मा च कालो उयमुद्युको दैत्यस्य न भवेदिति॥ २२॥

सनत्कुमार उवाच।

ततो विसृज्य तं नागं रसातलमुपागमत्।

तत्र सागरको दैत्य: सुप्रभो ऽन्तर्जलेचर:॥ २३॥

अपश्यत्तं तदायान्तं हिरण्याक्षपुरं प्रति।

गात्रेषु देवान्सूक्ष्मांग्च वराहस्यान्ववैक्षत॥ २४॥

20b विदितां रमणामिति ] विदित्वा रमणीं पुरीम् $\mathrm{R} 2 \mathrm{20d}$ स्वर्गादपि ] प्रययावपि $\mathrm{R}^{\mathrm{pc}}$, प्राददापि $\mathrm{R}^{\mathrm{ac}}$ $21 b$ अर्घेण च स] सुखेन सम० $\mathrm{R} 21 \mathrm{~d}$ ०मन्त्रय०] ०मन्त्रयय० $\mathrm{R} 22$ ] $R$ has this after $22 \mathrm{~d}$. $22 c$ क्यो वयं त्वया ] ०यः काम्ये तदा $R$ 22d करिष्याम ] गमिष्यामि $R$ 23a मधुहा ] मधुहं $R$ 23d After this $R$ has 21. 23e कालो उयमुद्युक्तो] कालात्ययो देव $R$ 23f न भवेदिति ] मरणे भवेत् $\mathrm{R} 24 \mathrm{~b}$ ०मुपागमत् ] $\mathrm{R}^{\mathrm{pc}}$, ॰मगात् पुन: $\mathrm{R}^{\mathrm{ac}} 24 \mathrm{c}$ सागरको] सागरगो $\mathrm{R}$ 25a अपश्यत्तं ] अपश्यत $\mathrm{R}$

$20 \mathrm{ab}$ देवेशो विदितां रमणामिति ] देवो सौ विदतां $\left\{{ }^{\circ}\right.$ ता $\left.\mathrm{A}_{4}\right\}$ रमनीमिति $\mathrm{A}_{3} \mathrm{~A}_{4}$, देवेशौ न्यवसत् कामचारतः $\left.\mathrm{A}_{7} 20 \mathrm{~cd}\right]$ om. $\mathrm{A}_{7} \quad 20 \mathrm{c}$ रम्यां मनोज्ञां दिव्यां ] सा मनो $\left\{\right.$ शर्मणो॰ $\left.\mathrm{A}_{4}\right\}$ ज्ञा च दिव्या $\mathrm{A}_{3} \mathrm{~A}_{4} \quad 20 \mathrm{~d}$ वराम् ] वरं $\mathrm{A}_{3}$, बरं $\mathrm{A}_{4} \quad 21 \mathrm{ab}$ राजा अर्घेण च स] ज्ञात्वा अर्घ्येण [अर्घेन $\mathrm{A}_{4}$, अर्घ्येन $\left.\mathrm{A}_{7}\right\}$ सम॰ $\mathbf{A}$ 21c ०मानाच्च ] $\mathrm{A}_{3} \mathrm{~A}_{4}$, ${ }^{\circ}$ मानाग्च $\mathrm{A}_{7} 22$ ] $\mathbf{A}$ has this after 22d. 22d यदीच्छसि ] यदिच्छसि $\mathrm{A}_{3} \mathrm{~A}_{4}$, यदास्यसि $\mathrm{A}_{7}$ 23c लोक॰ ] देव $A$ 23d न ] मा $\mathbf{A}$ - After this $\mathrm{A}_{3} \mathrm{~A}_{4}$ have 21 and $\mathrm{A}_{7}$ does $24 \mathrm{ab}$ and 21. 23ef ] om. $\mathbf{A} 24$ सनत्कुमार उवाच] om. $\mathrm{A}_{7}$ 24c तत्र ] तत: $\mathbf{A}$ 24d ०र्जलेचर: ] ०र्जले $\left\{\circ\right.$ ने० $\left.\mathrm{A}_{4}\right\}$ श्वर: $A$ 25ab ] $\mathrm{A}_{7}$ has this after $22 \mathrm{~d}$ and repeats it here. 25a अपश्यत्तं ] $\mathrm{A}_{3} \mathrm{~A}_{4}$, अपश्यन्तं $\mathrm{A}_{7}$, अपश्य त्वं $\mathrm{A}_{7}^{*} \mathbf{2 5 b}$ ०पुरं ] ०रथं $\mathbf{A A}_{7}^{*} \quad \mathbf{2 5 c}$ ०वान्सूक्ष्मांग्च ] ०वांश्चिक्षेप A 25d वराहस्यान्ववैक्षत ] वाराहस्य न्यवेक्षतः $A_{7}$, परावाहस्य नेक्षतः $A_{3} A_{4}$

$\overline{21\left(c^{4}-c^{5}, c^{8}-d^{2}\right) S_{1}} \quad 23\left(e^{2}\right) S_{1} \quad 24\left(c^{1}\right) S_{1}$

20a ततः ] $S_{3} R A$, तत्त् $S_{1}$, तत्र Bh $20 b$ विदितां रमणामिति ] $S_{3}$, विदितामरतामिति: $S_{1}$, विन्दतामरतामिति $B h$ (conj.) 20c दिव्यां च ] $\mathrm{S}_{3} R B h$ (em.?), दिव्यांश्च $S_{1}$ 21a तं ] $S_{3} R A B h$, तां $S_{1} 21 b$ च स ] $S_{1} S_{3}$, सम॰ $B$ • पूजयत् ] $S_{3} R A B h$, पूजयम् $S_{1}$ 21c ०मानाच्च ] $R_{3}$ $\mathrm{A}_{4} \mathrm{Bh}$, ०माना こ $\mathrm{S}_{1}$ (last akșara has subscript च्), ०मानाश्च $\mathrm{S}_{3} \quad \mathbf{2 2}$ ] Relocation of these four pādas here conjectured, $S_{1} S_{3} B h$ have this after 22d. 22b कर्तव्यं त्रि॰] $S_{1} R A B h$, कर्त्तृव्यन्तृ ${ }^{\circ}$ $\mathrm{S}_{3} 22 \mathrm{c}$ सार्ध] $\mathrm{S}_{1} \mathrm{RABh}$, सार्द्ध $\mathrm{S}_{3}$ 23d विघं ] $\mathrm{S}_{1} \mathrm{RABh}$, विर्घ $\mathrm{S}_{3}$ (unmetrical) - After this $S_{1} S_{3} B h$ have 21. 23e ॰मुद्युक्तो] $S_{3} B h$ (conj.?), ०मुद्युद्यो $S_{1}$ 24a तं नागं ] $S_{1}^{p c} S_{3} R A$ $\mathrm{Bh}$, त-गं $\mathrm{S}_{1}^{\mathrm{ac}} \mathbf{2 4 c}$ सागरको] $\mathrm{S}_{1} \mathrm{~S}_{3} \mathrm{~A}$, सागरपो Bh (conj.) • दैत्य: ] $\mathrm{S}_{1} R A B h$, दैत्य $\mathrm{S}_{3}$ 25a अपश्यत्तं ] $\mathrm{S}_{3} \mathrm{~A}_{3} \mathrm{~A}_{4} \mathrm{Bh}$, अपश्यन्त $\mathrm{S}_{1}$ 25b हिरण्याक्ष०] $\mathrm{S}_{3} \mathrm{RAA}_{7}^{*} \mathrm{Bh}$, हिरण्डाक्ष० $\mathrm{S}_{1} \mathbf{2 5 d}$ ०न्ववैक्षत ] $\mathrm{RBh}(\mathrm{em} . ?)$, न्ववेक्षत $\langle:\rangle \mathrm{S}_{1}$, ॰न्ववैक्षतः $\mathrm{S}_{3}$ 
विस्मितश्चास्य रूपेण भयान्नैनमुपागमत् ।

तेजसा चापि विष्टब्धो दुरात्मा तस्य सो उसुरः॥ २४ ॥

आविवेदयिषुस्तस्मै हिरणयाक्षाय सो उत्वरत्।

चक्क वेगं प्रति पुरं वराहस्य तदाग्रतः॥ २६॥

स यातुकामो दितिजाधिराजं वराहरूपं तमनन्तमन्तकम्।

जगाम दैत्याय स जीवितान्तकं यथानिलः प्रच्युतदाममाल्यवान्॥ २७॥

इति स्कन्दपुराण एकोनशततमो ऽध्यायः॥९९॥

27a आविवे॰] प्रविवे॰ $R \quad 27 b$ सो उत्वरत् ] सत्वरं $R \quad 27 c$ चक्रे वेगं प्रति ] चक्रिरे संप्रति $R$ $28 \mathrm{a}$ यातु ${ }^{\circ}$ ] हन्तु ${ }^{\circ} \mathrm{R} 28 \mathrm{~b}$ ०रूपं तमनन्तमन्तकम् ] ०रूपेण अनन्ततेजाः $R \quad 28 \mathrm{c}$ जीवितान्तक ] जीवितान्तको $\mathrm{R} 28 \mathrm{~d}$ प्रच्युतदाम॰ ] पूज्यतमो हि $\mathrm{R}$ Col. om. $\mathrm{R}$

26b भयान्नैन०] भयन्नैव $A \quad 26 c$ विष्टब्धो ] विष्टध्रो $\mathrm{A}_{7}$, रिष्टश्नो $\mathrm{A}_{3} \mathrm{~A}_{4} \quad 27 \mathbf{a}$ ०वेदयिषु०] $\mathrm{A}_{3} \mathrm{~A}_{7}$, वेदपिषु॰ $\mathrm{A}_{4} 27 \mathbf{b}$ सो ऊत्वरत् ] सोत्तरं $A$ 27d वराहस्य ] $\mathrm{A}_{7}$, वाराहस्य $\mathrm{A}_{3} \mathrm{~A}_{4}$ 28a यातु॰] हन्तु० $\mathrm{A} 28 \mathrm{~b}$ ०मन्तकम् ] ०रासुरं $\mathrm{A} 28 \mathrm{c}$ स जीवितान्तक ] जीवान्तको $\mathbf{A}$ (unmetrical) $28 \mathrm{~d}$ प्रच्युतदाममाल्यवान् ] प्रत्युत मान्यवान् $\mathbf{A}$ (unmetrical) संहिताया $\left\{\right.$ इति स्कंद० $\left.\mathrm{A}_{4}\right\}$ मम्बिकाखण्डे वराहगमनाध्याय: $\mathrm{A} \pm$

Col. इति स्कन्दपुराणे एकाशीतिसाहस्त्यां

$27\left(a^{7}, d^{4}\right)\left\langle d^{5}\right\rangle S_{1},\left\langle d^{4}-d^{5}\right\rangle\left(d^{6}-d^{7}\right) S_{3}$

26a विस्मितश्चा०] $S_{3} R A$, तस्मिन्तच्चा० $S_{1} B h \quad 26 b$ भयान्नै०] $S_{1} R B h$, भया नै० $S_{3} \quad 26 c$ चापि विष्टब्धो ] $S_{1}^{\text {pc }} S_{3} R B h$, चाविष्टब्धो $S_{1}^{\text {ac }}$ (unmetrical) 27a आविवेदयिषुस्तस्मै ] $S_{3} A_{3} A_{7}$, आविवेदयिष(न्त)स्मै $\mathrm{S}_{1}^{\mathrm{pc}}$, आविवेदयि(ष्या)स्मै हि $\mathrm{S}_{1}^{\mathrm{ac}}$ (unmetrical), आवेदयिष्यन्तस्मै हि Bh (conj.?) $27 \mathbf{b}$ सो उत्वरत् ] em., सो त्वरन् $S_{1}$, सो द्वरं $S_{3}$, सत्वरम् $B h$ (conj.) $28 c$ जीवितान्तकं ] $S_{1} S_{3}$, जीवितान्तं Bh (conj.?) 28d प्रच्युत॰ ] conj., प्रद्युत॰ $S_{1} B h$, प्रत्युत $S_{3}$ • ०दाम॰] $S_{1}^{\text {ac }}$ ?, ०दान॰ $S_{1}^{p c}$ $\mathrm{S}_{3} \mathrm{Bh}$, - माल्यवान् ] $\mathrm{RBh}$, ०माल्यवानिति $\mathrm{S}_{1} \mathrm{~S}_{3}$ (इति part of col.) Col. $\odot \|$ स्कन्दपुराणे सागरप्रवेशे आध्याय शूप (in letter numerals)॥ $\odot \mathrm{S}_{1}, \odot \|$ स्कन्दपुराणे नामाध्यायः ९९ (in letter numerals)॥ $\odot \mathrm{S}_{3}$, इति स्कन्दपुराणे वराहस्य सागरप्रवेशो नामैकोनशततमोध्याय: $\mathrm{Bh}$ 
शततमो डध्यायः ।

सनत्कुमार उवाच।

तस्मिन्भये समापन्ने विनाशभयसूचकाः।

हिरण्याक्षपुरे घोरा उत्पाता ह्यभवस्तदा॥ ? ॥

अट्टालका विशीर्यन्ते देवतार्चा हसन्ति च।

शिवा नदन्ति दैत्यानां गृहेषु च सभासु च॥ २॥

अकस्माचाभवत्तत्र पौराणां भैरवो रव:।

पादपाश्च विना वातं पतन्त्युन्मूलिता भुवि।

भास्करश्च कबन्धान्धो युद्धं चाप्यत्र दृश्यते॥ ३॥

सनत्कुमार उवाच।

एतान्यन्यानि च तदा निमित्तानि महान्ति च।

संतक्ष्य राजा दैत्यानामसुरानिदमब्रवीत्॥ ४॥

निमित्तान्यभिलक्ष्यन्ते महान्त्यसुरपुंगवाः।

नैव तान्यनिमित्तानि दृश्यते च भयं महत् ॥ $y \|$

3ab $=$ AS p. $485 \quad 3 \mathbf{c d}=$ AS p. 445

$1 a$ समापन्ने ] समुत्पन्ने $R \quad 2 a$ अट्टालका ] अट्टालिका $R \quad 2 b$ देवतार्चा ] देवताश्च $R \quad 3 a b$ ॰भवतत्र पौराणां भैरवो रव: ] अभवस्तत्र प्रजानां भैरवा रवा: $\mathrm{R} \quad 4 \mathrm{a}$ च तदा] घोराणि $\mathrm{R}$ 5cd ] एतानि हि निमित्तानि दृश्यन्ते भयवन्ति हि $\mathrm{R}$

$1 d$ ह्यभवं०] $\mathrm{A}_{7}$, अभवं॰ $\mathrm{A}_{3}$, सुभवं० $\mathrm{A}_{4} \quad 2 \mathrm{~b}$ देवतार्चा ] प्रतिमा च $\mathbf{A} \quad \mathbf{2 d}$ गृहेषु ] $\mathrm{A}_{3} \mathrm{~A}_{4}$, गुहेषु $\mathrm{A}_{7} \bullet$ सभासु ] $\mathrm{A}_{3}$, सभाशु $\mathrm{A}_{4}$, सभाषु $\mathrm{A}_{7} \mathbf{3 a}$ अकस्माच्चा०] अधस्ताच्चा० $\left\{\right.$ श्चा० $\left.\mathrm{A}_{7}\right\} \mathrm{A}^{3} \mathbf{3 d}$ ०न्मूलिता ] ॰न्मीलिता $\mathrm{A}_{3}$, ०न्मिलिता $\mathrm{A}_{4} \mathrm{~A}_{7}$ 3e भास्करश्च ] भास्कराश्च $\mathrm{A}$ - कबन्धान्धो ] कवंधांवो $\mathrm{A}_{3} \mathrm{~A}_{4}$, कबन्धाश्च $\mathrm{A}_{7} \quad 4 a b$ l om. $A$ 4cd दैत्यानाम०] दैत्यांश्च अ० $A$ a ab ०न्यभिलक्ष्यन्ते महान्त्य०] ०न्य $\left\{\circ\right.$ त्य॰ $\left.\mathrm{A}_{4}\right\}$ त्र रक्षंते सहस्त्य॰ $\mathrm{A}_{3} \mathrm{~A}_{4}$, ०न्यत्र रक्ष्यन्ते ऋहन्त्य: $\mathrm{A}_{7}$ 5cd ] एतानि हि निमित्तानि दृश्यन्ते भयवन्ति च $\mathbf{A}$

Manuscripts available for this chapter: $S_{1}$ photos $3.33 \mathrm{~b}$ (f. $155^{\mathrm{r}}$ ), 3.34a (f. $155^{\mathrm{v}}$ ), $3.34 \mathrm{~b}$ (f. $156^{\mathrm{r}}$ ), $3.35 \mathrm{a}\left(\mathrm{f} .156^{\mathrm{v}}\right.$ ) and $3.35 \mathrm{~b}\left(\right.$ f. $\left.157^{\mathrm{r}}\right) ; \mathrm{S}_{3}$ f. $155^{\mathrm{r}}-157^{\mathrm{r}}$; R f. $172^{\mathrm{v}}-174^{\mathrm{r}} ; \mathrm{A}_{3}$ f. $102^{\mathrm{r}}-103^{\mathrm{v}} ; \mathrm{A}_{4}$ f. $145^{\mathrm{v}}-$ $147^{\mathrm{r}} ; \mathrm{A}_{7}$ f. $144^{\mathrm{r}}-146^{\mathrm{r}}$.

$\mathbf{1}\left\langle\mathrm{c}^{7}-\mathrm{c}^{8}\right\rangle\left(\mathrm{d}^{1}-\mathrm{d}^{2}\right) \mathrm{S}_{3} \quad \mathbf{3}\left(\mathrm{e}^{3}\right) \mathrm{S}_{1}$

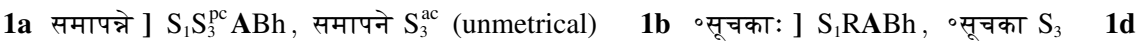
उत्पाता ] $\mathrm{S}_{1}^{\mathrm{pc}} \mathrm{S}_{3} \mathrm{RABh}$, उत्पातो $\mathrm{S}_{1}^{\mathrm{ac}}$ - ०वंस्तदा ] RABh, ०वन्तदा: $\mathrm{S}_{1}$, ॰वन्तद $\mathrm{S}_{3} 2 \mathrm{~b}$ देवतार्चा ] $S_{3}$, देवताचा $S_{1}$, देवताश्चा० $B h(e m . ?)$ हसन्ति च ] $S_{3} R A$, ०हसत्रिव $S_{1} B h$ 2d गृहेषु ] $\mathrm{S}_{1} \mathrm{~S}_{3}^{\mathrm{pc}} \mathrm{RA}_{3} \mathrm{~A}_{4} \mathrm{Bh}$, (शृ)हेषु $\mathrm{S}_{3}^{\mathrm{ac}} \quad$ 3a अकस्माच्चा॰] $\mathrm{S}_{1} \mathrm{RBh}$, अकस्मा च $\mathrm{S}_{3} \quad \mathbf{3 b}$ पौराणां ] $\mathrm{S}_{3} \mathrm{ABh}$, पौरणोम् $\mathrm{S}_{1}^{\mathrm{pc}}$, पौरणाम् $\mathrm{S}_{1}^{\mathrm{ac}}$ 3d ॰तन्त्युन्मूलिता ] $\mathrm{RBh}$ (em.?), ॰तन्त्यून्मूलिता $\mathrm{S}_{1}$, ॰तन्त्यु $\left\{{ }^{\circ}\right.$ त्यु॰ $\left.\mathrm{S}_{3}^{\mathrm{pc}}\right\}$ न्मूलता $\mathrm{S}_{3}$ 3e भास्करश्च ] $\mathrm{S}_{3} \mathrm{RBh}(\mathrm{em}$.$) , भास्क(रा)श्च \mathrm{S}_{1}$ • कबन्धान्धो $\mathrm{S}_{1} \mathrm{R}$,

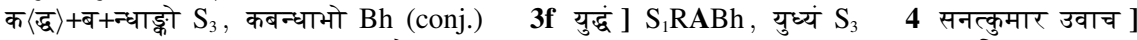
$\mathrm{S}_{3} \mathrm{RABh}$ (सन उ in $\mathrm{S}_{3}$ ), सनकुमारोवाच $S_{1}$ 4a तदा ] $S_{1} B h$, दता $S_{3}$ 4b महान्ति] $S_{1} R B h$ महन्ति $\mathrm{S}_{3} \quad 4 \mathbf{c}-6 \mathbf{b}$ ] om. $\mathrm{S}_{3}$ 4d ०सुरानि॰] $\mathrm{S}_{1}^{\mathrm{pc}} \mathrm{RABh}$, ०सुरामि॰ $\mathrm{S}_{1}^{\mathrm{ac}} \quad \mathbf{5 a}$ न्यभिलक्ष्यन्ते ] $\mathrm{RBh}$ (conj.), ॰न्यपि लक्ष्येत $S_{1} \quad \mathbf{5 c}$ तान्य०] conj. Bh, तानि $S_{1}$ • ०निमित्तानि ] $S_{1}^{\text {pc }} R A B h$, निमित्तांनि $\mathrm{S}_{1}^{\mathrm{ac}}$ 
हृतराज्याश्च देवेशा न ते स्थास्यन्ति निष्क्रियाः।

नूनं ते किंचिदाश्रित्य कुर्वन्ति समरं प्रति॥ ६॥

सनत्कुमार उवाच।

तस्य तद्वचनं श्रुत्वा प्रह्लादो उसुरसत्तमः।

प्रणम्य पितरं सम्यगिदं वचनमब्रवीत्॥ ७॥

प्रह्लाद उवाच।

सुतो इह तव दैत्येन्द्र पिता त्वं मम धर्मतः।

न तवास्मद्विधे बुद्धिराधेया दैत्यसत्तम॥ $५ ॥$

तथापि तु वयं प्रीत्या इच्छुन्तो राज्यमक्षयम्।

वक्ष्यामो बालभावेन तन्नः संस्मर्तुमहैसि॥ ॥

अद्य रात्रौ मया स्वप्ने दृष्टो उसौ नररूपवान्।

वराहरूपी संगत्य भवन्तं निगृहीतवान्।

न तथा तद्यथा स्याद्धि तथा त्वं सम्यगाचर॥ १०॥

हिरण्याक्ष उवाच।

एवमेतन्न संदेहो भवान्धर्मरतः सदा।

दृष्टवांस्तद्यथातत्त्वमेवमेतन्न संशयः ॥ १?॥

अहमद्य गतः स्वप्ने त्यम्बकस्य निवेशनम्।

नतं च मामिदं प्राह भगवान्गोवृषध्वजः ॥ ?२॥

8cd तवास्मद्विधे बुद्धिराधेया ] चाप्यस्मद्विधो बुद्धिः सन्धेया R 9b राज्यमक्षयम् ] वाक्यमक्षニम् R 9d

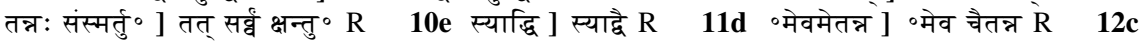
प्राह ] तात $\mathrm{R}$

6ab ] om. $\mathbf{A}$ 6c नूनं ते ] $\mathrm{A}_{3} \mathrm{~A}_{4}$, नृणन्ते $\mathrm{A}_{7}$ - ०दाश्रित्य ] ०दासृज्य $\mathrm{A}_{3} \mathrm{~A}_{4}$, ०दासृह्य $\mathrm{A}_{7} \quad \mathbf{7 b}$ उसुरसत्तमः ] मुनिसत्तम $\left\{{ }^{\circ}\right.$ म: $\left.\mathrm{A}_{7}\right\} \mathbf{A} 8 \mathbf{a}$ सुतो ] अतो $\mathbf{A} 8 \mathbf{b}$ मम ] तव $\mathbf{A} 8 \mathbf{c}-9 \mathbf{b}$ ] om. $\mathbf{A}$ $9 \mathrm{~d}$ तन्नः संस्मर्तु॰] तत्सर्वं क्षन्तु ${ }^{\circ} \mathrm{A} 10 \mathrm{c}$ ०रूपी ] ०रूपं $\mathrm{A}$ 10ef ] om. A 11cd ०तत्त्वमेव॰ ] $\mathrm{A}_{3} \mathrm{~A}_{4}$, तत्र मेरु॰ $\mathrm{A}_{7} \quad 11 \mathrm{~d}$ ०मेतन्न ] ॰मेव न $\mathbf{A} \quad 12 \mathrm{c}$ नतं च] नतस्य $\mathbf{A}$ • मामिदं ] $\mathrm{A}_{3} \mathrm{~A}_{4}$, मादिदं $\mathrm{A}_{7} \mathbf{1 2 d}$ ०वान्गो॰] ॰वान्मे $\mathrm{A}$

6a देवेशा ] RBh (em.?), देवेसा $S_{1}$ 6b निष्क्रिया: ] $S_{1}^{\text {pc }} R B h$, निष्क्रया: $S_{1}^{\text {ac }}$ 6c-7b ] $S_{3}$ has this after $9 \mathrm{~b}$. 6c नूनं ते ] $\mathrm{S}_{3} \mathrm{RA}_{3} \mathrm{~A}_{4} \mathrm{Bh}$, नूनन्तो $\mathrm{S}_{1}^{\mathrm{pc}}$, नुनन्तो $\mathrm{S}_{1}^{\mathrm{ac}}$ 6d समरं ] $\mathrm{S}_{1} \mathrm{RABh}$, समर $\mathrm{S}_{3} \quad 8 \mathbf{a}$ सुतो ] $\mathrm{S}_{1} R B h$, ततो $\mathrm{S}_{3}$ - दैत्येन्द्र $] \mathrm{S}_{1}^{\mathrm{pc}} \mathrm{S}_{3} \mathrm{RABh}$, देत्येन्द्र $\mathrm{S}_{1}^{\mathrm{ac}} \quad \mathbf{8 b}$ धर्मतः ] $\mathrm{S}_{1}^{\mathrm{pc}} \mathrm{S}_{3} \mathrm{R}$ $\mathrm{ABh}$, धर्म्मत $\mathrm{S}_{1}^{\mathrm{ac}} \mathbf{8 c}$ तवा०] $\mathrm{S}_{1} \mathrm{Bh}$, तदा॰ $\mathrm{S}_{3}$ • ०द्विधे ] em., ०द्विथे $\mathrm{S}_{1}$, ०द्विधै $\mathrm{S}_{3}$, ०द्विधैर् $\mathrm{Bh}(\mathrm{em} . ?) \quad 8 d$ ०सत्तम ] $S_{1}^{\mathrm{pc}} R B h$, ०सत्तम: $S_{1}^{\text {ac }} S_{3} \quad 9$ b राज्य॰] $S_{1} B h$, राज० $S_{3}$ 9c-10b ] om. $S_{3}$, instead of this $S_{3}$ has $6 c-7 b$. 9d तन्न: ] $S_{1}$, तन्न Bh (conj.) $10 b$ ०रूपवान् ] RABh, ०रूपवाम् $\left.\mathrm{S}_{1} \quad 10 \mathrm{~cd}\right] \mathrm{om} . \mathrm{S}_{1} \quad 10 \mathrm{c}$ ०रूपी ] $\mathrm{S}_{3} \mathrm{R}$, ०रूपं $\mathrm{Bh} \quad 10 \mathrm{e}$ स्याद्धि ] $\mathrm{S}_{1}^{\mathrm{pc}} \mathrm{S}_{3} \mathrm{Bh}$, स्या(धि) $S_{1}^{\text {ac }} \quad 10 f$ ०गाचर ] $S_{1}^{\text {pc }} S_{3} R B h$, ०गाचर: $S_{1}^{\text {ac }}$ 11a एवमे॰ $] S_{1} S_{3}^{p c} R A B h$, एतमे॰ $S_{3}^{\text {ac }} \quad 11 b$ भवान्धर्मरतः सदा ] $S_{3}^{\mathrm{pc}} R A$, भगवान्धर्म्मतस्सदा $S_{1}$, भवान्धर्मरत सदा $S_{3}^{\text {ac }}$ (unmetrical), भवान्यद्धर्मतस्तदा $\mathrm{Bh}$ (conj.) 11c दृष्टवांस्त॰ ] $\mathrm{S}_{1} \mathrm{RABh}$, दृष्टचान्त॰ $\mathrm{S}_{3} 11 \mathrm{~cd}$ ॰तत्त्वमे॰ $] \mathrm{S}_{1} \mathrm{RA}_{3} \mathrm{~A}_{4} \mathrm{Bh}$, नस्त्वं ए॰ $S_{3} \quad 11 d$ मेतन्न $] S_{1} B h$, ०मेत न $S_{3}$ 12a गतः $S_{3} R A B h$, तत: $S_{1}$ 12b निवेशनम् ] $S_{3} R A$, निवेशने $S_{1} B h \quad 12 c$ नतं च मा॰ ] $S_{3} R$, नतम्ममा॰ $S_{1}^{p c}$ (च written above म्म), (त)तम्मया० $\mathrm{S}_{1}^{\mathrm{ac}}$, ततः स मा० $\mathrm{Bh}$ (conj.) - ०मिदं ] $\mathrm{S}_{1} \mathrm{RA}_{3} \mathrm{~A}_{4} \mathrm{Bh}$, ०मिद $\mathrm{S}_{3}$ 
एतावझ्कवतो दैत्य राज्यमिन्द्रत्वमेव च।

यच्छेमां त्वं श्रियं पुत्र सहस्राक्षाय सुप्रभाम्॥ १३॥

शनैराद्धिद्य मुत्कैव मुकुटं हारमेव च।

केयूरे चाड़्दे चैव खड्गं रुचकमेव च॥ १४॥

कटके शासनं चैव दुकूलं च तथोत्तम् ।

अनिच्छ,तो मे संगृह्य शक्राय प्रददौ तदा॥ १४ ॥

ततो मां भगवानाह मत्समीपे त्वया सदा।

काल्यं प्रभृति वस्तव्यं दिव्ये राज्ये न दैत्यप॥ १६॥

यदेतद्धि मया दृष्ट नैतन्मिथ्या भविष्यति।

सर्वथा नास्ति दैत्यानां मयैकेन भयं त्विह॥ १७॥

सनत्कुमार उवाच।

तस्य तद्वचनं श्रुत्वा दैत्या: सर्वे तदाब्रुवन्।

मिथ्यैतत्स्वप्नगतयो मिथ्या राजन्प्रकीर्तिताः ॥ १५॥

अन्धको उसहितो उस्माभिर्योत्स्यते देवतै: सह।

यो उवध्यः सर्वभातानां बलवानजितश्च ह॥ ??॥

13c-14b ] om. R 14c केयूरे चाड़्दे ] केयूरमड़गगद्् $R$ (unmetrical) 14d-15a ] om. $R$ $15 \mathrm{~d}$ शक्राय प्रददौ तदा ] +प्रददौ+ प्रददौतराम $R \quad 16 \mathrm{~b}$ मत्समीपे ] तत्समीपे $\mathrm{R} 16 \mathrm{c}$ काल्यं ] कले: $R \quad 16 d$ दिव्ये राज्ये] किन्ते राज्यं $R \quad 17 c$ नास्ति ] स्वस्ति $R \quad 18 c$ ०त्स्वप्रगतयो ] ०त्सुप्रमतयो $R$ 18d राजन्प्रकीर्तिता: ] राज्यं प्रकीर्त्तितम् $R$ 19a अन्धको उस॰] अन्धकः स० $R$ 19b देवतै: ] दैवतै: $\mathrm{R} \quad 19 \mathrm{~d}$ ०नजितश्च ह ] ०न् गज्जिज्जतय्च +ह+ $\mathrm{R}$

$13 \mathrm{c}$ यच्छेमां त्वं श्रियं ] यच्छेमं $\left\{{ }^{\circ}\right.$ म $\left.\mathrm{A}_{3}\right\}$ त्वं $\left\{\right.$ लं $\left.\mathrm{A}_{7}\right\}$ प्रियं $\mathrm{A} \quad 13 \mathrm{~d}$ सहस्रा० $] \mathrm{A}_{3} \mathrm{~A}_{4}$, सहश्रा० $\mathrm{A}_{7}$ - सुप्रभाम् ] सूतया $A$ 14a-16b ] om. $A$ 16c काल्यं ] कस्य $A$ 16d दिव्ये] किं ते $A$ 17b नैतन् ] $\mathrm{A}_{3} \mathrm{~A}_{4}$, मे तन् $\mathrm{A}_{7} 17 \mathrm{c}$ नास्ति ] स्वस्ति $\mathrm{A}_{3} \mathrm{~A}_{4}$, सस्ति $\mathrm{A}_{7} 17 \mathrm{~d}$ भयं त्विह ] भवत्विह $\mathrm{A}_{3} \mathrm{~A}_{4}$, भवन्निह $\mathrm{A}_{7} 18 \mathrm{~b}$ दैत्या: ] $\mathrm{A}_{4} \mathrm{~A}_{7}$, दैत्या $\mathrm{A}_{3} 19 \mathrm{a}$ अन्धको उस०] अन्धकः स० $\mathrm{A}_{4} \mathrm{~A}_{7}$, अन्धकस० $\mathrm{A}_{3}$ (unmetrical) $19 \mathrm{~b}$ ०योत्स्यते ] $\mathrm{A}_{3} \mathrm{~A}_{4}$, ०योष्यन्ते $\mathrm{A}_{7}$ • देवतैः ] दैवतैः $\mathrm{A}$

$13\left(d^{3}\right) S_{1} \quad 18\left(b^{4}\right) S_{1} \quad 19\left(d^{1}\right) S_{1}$

13a एतावद् ] $S_{3} R A B h$, एताव $S_{1} 13 c$ यच्छेमां ] $S_{3} B h$ (conj.), यच्छैमां $S_{1}$ - त्वं श्रियं ] $\mathrm{S}_{3}$, त्वम्प्रियम् $\mathrm{S}_{1}$, त्वं प्रियां $\mathrm{Bh}$ (conj.) 13d सहस्राक्षाय ] $\mathrm{S}_{3} \mathrm{~A}_{3} \mathrm{~A}_{4}$, सह(य)क्षाय $\mathrm{S}_{1}$, सहयक्षाय $\mathrm{Bh}$ 14a शनैराछ्छिद्य मुत्कैव ] $S_{3}$, क्षिप्रमेतां प्रयच्छाद्य $S_{1} B h \quad 14 b$ च ] $S_{1}^{\text {pc }} S_{3} B h$, om. $S_{1}^{\text {ac }}$ (unmetrical) $14 \mathrm{c}$ केयूरे चाड़द्ये] $S_{3}$, केयूराड़्दकज् $S_{1}$, केयूराड़्दकं $B h \quad 14 d$ खड्गं ] em. Bh (silently), खन्ग

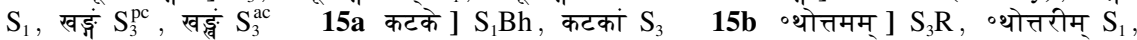
०थोतरीम् Bh (typo) 15c अनिच्छतो ] $S_{3} R B h$ (em.), अनिच्छते $S_{1}$ 16a मां] $S_{3} R B h$, मा $S_{1} \quad 16 \mathbf{b}$ सदा ] $S_{1}^{\mathrm{pc}} S_{3} R B h$, स(ह) $S_{1}^{\text {ac }} 16 \mathbf{c}$ काल्यं] $S_{1} S_{3}$, कल्यं Bh (em.) • वस्तव्यं ] $S_{3}$ $\mathrm{RABh}$, वक्तव्यं $S_{1}$ 16d दिव्ये राज्ये न] $S_{1} S_{3}$, किन्ते राज्येन $B h$ - दैत्यप ] $S_{3} R A B h$, दैत्यप: $\mathrm{S}_{1} \quad \mathbf{1 7 b}$ नैतन् ] $\mathrm{S}_{3} \mathrm{RA}_{3} \mathrm{~A}_{4}$, नैत $\mathrm{S}_{1}$, न तन् $\mathrm{Bh}$ (conj.) - भविष्यति ] $\mathrm{S}_{1} \mathrm{~S}_{3}^{\mathrm{pc}} \mathrm{RABh}$, भविष्य $\mathrm{S}_{3}^{\mathrm{ac}}$ (unmetrical) 17d भयं त्विह ] $\mathrm{R}$, भवन्ति ह $\mathrm{S}_{1}$, भवत्विह $\mathrm{S}_{3}$, भवं त्विह $\mathrm{Bh}$ (conj.) $18 \mathrm{~b}$ दैत्या: ] $\mathrm{RA}_{4} \mathrm{~A}_{7} \mathrm{Bh}$ (em.?), दैत्या $\mathrm{S}_{1} \mathrm{~S}_{3}$ - ०दाब्रुवन् ] $\mathrm{S}_{3} \mathrm{RABh}$, ०दाब्रुवम् $\mathrm{S}_{1}$ 18d ०कीर्तिता: ] $\mathrm{S}_{1} \mathrm{ABh}$, ०कीर्तिता $\mathrm{S}_{3} 19 \mathrm{a}$ अन्धको उस॰ $\mathrm{S}_{1} \mathrm{~S}_{3}$, अन्धक: स० $\mathrm{Bh}(\mathrm{em} . ?) \quad 19 b$ वोत्स्यते ] $\mathrm{S}_{1} \mathrm{RA}_{3} \mathrm{~A}_{4} \mathrm{Bh}$, ०योप्यते $\mathrm{S}_{3}$ • देवतै: $\mathrm{S}_{1} \mathrm{~S}_{3}$, दैवतै: $\mathrm{Bh}$ 19d बलवा॰] $\mathrm{S}_{1}^{\mathrm{pc}} \mathrm{S}_{3} \mathrm{RABh}$, मलवा० $\mathrm{S}_{1}^{\mathrm{ac}}$ 
तमाश्रित्य वयं सर्वे योत्स्यामो विज्वराः सुखम्।

मा युध्यतु भवान्सार्ध सुरै: सुरबलार्दनः॥ २०॥

त्वयि प्राणा: स्थिता: सर्वे दैत्यानां दानवै: सह।

त्वयि जीवति जीवाम त्वं चेन्नासि कुतो वयम्।

त्यत्का वा स्वपुरं सर्वे प्रविशाम महोदधिम्॥ २? ॥

सनत्कुमार उवाच।

तेषां तद्वचनं श्रुत्वा हिरण्याक्षो महासुरः।

प्रहस्य तानिदं सम्यगुवाच वदतां वरः॥ २२॥

स्रष्टायं सर्वभूतानां दाता हर्ता तथैव च।

विहित तेन यत्पूर्वं तत्कुर्यात्को ऽन्यथा पुनः॥ २३॥

यदि मृत्युरवश्यं मे विहितस्तेन दानवा:।

अयुध्यमानमासीनमेत्यासौ मां हनिष्यति॥ २४॥

वीक्षध्वं तन्मम स्थानं सर्व एवासुरोत्तमाः।

यत्र तिष्ठन्तमभ्येत्य न मां मृत्युर्नयिष्यति॥ २४॥

20b विज्वरा: सुखम् ] विगतज्वरा: $R \quad 20 c$ युध्यतु ] युध्यत $R \quad 20 d$ ०लार्दनः ] ०लार्दन R $21 b$ दानवै: सह ] दानवेश्वरर $\langle:\rangle \mathrm{R} 21 \mathrm{~cd}$ जीवाम त्वं चेन्नासि ] जीवामो त्वश्चेच्छुसि $\mathrm{R} \quad 21 \mathrm{e}$ वा स्व०] राज्यं $R 21 f$ ०विशाम महोदधिम् ] ०विशामो महेग्वरम् $R \quad$ 22d वदतां वर: ] मधुरं वच: $R$ After this $R$ has हिरण्याक्ष उवाच । 23ab ] om. $R$ 23c विहितं तेन यत् ] धात्रा यद्विहितं $R$ 24ab मे विहित० ] +विहित $+R$ (unmetrical) 25b सर्व एवा०] भवन्तो ह्य० $R$ 25c यत्र ] यद० $R$ - ०मक्येत्य ] ०मव्यग्रं R 25d ०र्नयिष्यति ] ०र्न नेष्यति $R$

20ab ] om. $A$ 20c मा युध्यतु ] स $\left\{\right.$ सा $\left.\mathrm{A}_{7}\right\}$ युध्यते $A$ 20d ०लार्दन: ] $\mathrm{A}_{4} \mathrm{~A}_{7}$, ०लार्दन $\mathrm{A}_{3}$ 21c जीवाम ] $\mathrm{A}_{3} \mathrm{~A}_{4}$, जीवामः $\mathrm{A}_{7}$ 21d चेन्नासि कुतो ] चेन्नासी \{चे नासी॰ $\mathrm{A}_{4}$, चे नाशी॰ $\left.\mathrm{A}_{7}\right\}$ द्रता A 21e वा स्व॰] $A_{3}$, वा सु० $A_{7}$, वाल ${ }^{\circ} A_{4}$ 21f प्रविशाम ] $A_{3}$, प्रविवेश $A_{4}$, प्रविवेशामो $\mathrm{A}_{7}$ (unmetrical) 23a स्रष्टायं ] $\mathrm{A}_{3} \mathrm{~A}_{4}$, सृष्टायां $\mathrm{A}_{7}$ - ०भूतानां ] ॰देवानां $\left\{\circ\right.$ णां $\left.\mathrm{A}_{7}\right\} \mathbf{A}$ 23cd ] om. $\mathrm{A} 24 \mathrm{~b}$ विहितस्ते॰] $\mathrm{A}_{7}$, विहितास्ते॰ $\mathrm{A}_{3} \mathrm{~A}_{4}$ 24cd ०नमेत्यासौ] ०नं मन्ये $\left\{\circ\right.$ न्यो $\left.\mathrm{A}_{7}\right\}$ सौ A 24d हनिष्यति ] $\mathrm{A}_{3} \mathrm{~A}_{4}$, हनिष्यसि $\mathrm{A}_{7} 25 \mathrm{ab}$ ०न्मम स्थानं सर्व एवासुरोत्तमा: ] न्महत्स्थानं तिष्ठाम्यागत्य तत्र वै $\mathrm{A} \pm \mathbf{2 5 d}$ मृत्युर्नयि॰] $\mathrm{A}_{3} \mathrm{~A}_{7}$, मृत्युनंयि॰ $\mathrm{A}_{4}$

$25\left(a^{6}\right) S_{1}$

20b विज्वरा: सुखम् ] em. Bh (silently), विज्वरा सुखम् $S_{1}$, देवतै सह $S_{3} \quad 20$ युध्यतु ] $S_{1}^{\text {pc }} S_{3} B h$, युद्यत $\mathrm{S}_{1}^{\mathrm{ac}} \bullet{ }^{\circ}$ न्सार्धं ] $\mathrm{S}_{1} \mathrm{RABh}$, ॰न्सार्द्ध $\mathrm{S}_{3} 20 \mathrm{~d}$ सुरै: सु॰ ] RABh, शरैस्सु॰ $\mathrm{S}_{1}$, सुरै सु॰ $\mathrm{S}_{3}$ - ०लार्दनः ] $\mathrm{S}_{1} \mathrm{~S}_{3} \mathrm{~A}_{4} \mathrm{~A}_{7}$, ०लार्दन $\mathrm{Bh}$ 21a स्थिता:] $\mathrm{S}_{1} \mathrm{RABh}$, स्थिता $\mathrm{S}_{3}$ 21b दानवै: ] $\mathrm{S}_{1} \mathrm{ABh}$, दानवै $\mathrm{S}_{3}$ 21c जीवाम $] \mathrm{S}_{1} \mathrm{~S}_{3} \mathrm{~A}_{3} \mathrm{~A}_{4}$, जीवामस् $\mathrm{Bh}$ (em.?) 21d त्वं चेन्नासि ] em. $\mathrm{Bh}$, त्वस्चे नास्ति $S_{1}$, त्वं चे नास्ति $S_{3}$ • वयम् ] $S_{3} R A B h$, भयम् $S_{1}$ 21e वा स्व०] $S_{3} A_{3}$, वान्य॰ $S_{1}$, वाद्य Bh (conj.) 21f महोदधिम् ] $S_{1} A B h$, महोदधि $S_{3}$ 22b हिरण्याक्षो] $S_{1} R A B h$, हिरण्याक्षो $\mathrm{S}_{3} 22 \mathrm{c}$ तानिदं ] $\mathrm{S}_{3} \mathrm{RABh}$, तागिदं $\mathrm{S}_{1}$ 22d वर: ] $\mathrm{S}_{3} \mathrm{ABh}$, बर: $\mathrm{S}_{1}$ 23a स्रष्टायं ] $\mathrm{S}_{1} \mathrm{~A}_{3} \mathrm{~A}_{4}$, स्रष्टा य: $S_{3}^{\text {pc }} B h$ (conj.?), स्रष्टाय $S_{3}^{\text {ac }}$ 23d उन्यथा ] $S_{1}^{\text {pc }} S_{3} R B h$, (स्य)था $S_{1}^{\text {ac }}$ 24b दानवा: ] $\mathrm{S}_{1}^{\mathrm{pc}} \mathrm{S}_{3} \mathrm{RABh}$, दानवा $\mathrm{S}_{1}^{\mathrm{ac}}$ 24d ०मेत्यासौ] $\mathrm{S}_{3} \mathrm{RBh}(\mathrm{em} . ?)$, ०मेत्य सौ $\mathrm{S}_{1}$ - मां] $\mathrm{S}_{1} \mathrm{~S}_{3} \mathrm{RA}$, मा $\mathrm{Bh}$ (typo?) - हनिष्यति ] $\mathrm{S}_{3} \mathrm{RA}_{3} \mathrm{~A}_{4}$, वधिष्यति: $\mathrm{S}_{1}$, वधिष्यति $\mathrm{Bh}$ (em.?) 25a ०न्मम ] $\mathrm{S}_{1}^{\mathrm{pc}} \mathrm{S}_{3} \mathrm{RBh}$, ॰न्म(रु॰) $\mathrm{S}_{1}^{\mathrm{ac}} \quad \mathbf{2 5 b}$ एवासुरो॰] $\mathrm{S}_{1}^{\mathrm{pc} B h}$, एव सुरो॰ $\mathrm{S}_{1}^{\mathrm{ac}} \mathrm{S}_{3}$ 25d मां] $\mathrm{S}_{3}^{\mathrm{pc}} \mathrm{RA}$, मा $\mathrm{S}_{1} \mathrm{~S}_{3}^{\mathrm{ac}} \mathrm{Bh} \bullet$ मृत्युर् $] \mathrm{S}_{1} \mathrm{RA}_{3} \mathrm{~A}_{7} \mathrm{Bh}$, मृत्यु $\mathrm{S}_{3}$ 
अथवा नैव मृत्युर्मे विहितस्तेन दानवाः।

युध्यमानं यथापूर्व नैव मां स नयिष्यति॥ २६॥

मादृशः कथमेवैतत्कुर्यात्सद्विर्विगर्हितम्।

बाले मृत्युं समावेश्य ततश्चात्माभिरक्षणम्॥ २७॥

रणे रिपूणां कदनं कृत्वैकश्चाप्यनेकशः।

पृष्टं दद्यात्पुनस्तेषां मादृशो दानवेश्वराः॥ २५॥

विप्रचित्तिरुवाच।

देवा ह्यनेकशः सर्वे जिता नष्टाश्च सर्वशः।

पुनश्चायान्ति न यथा तथा सर्वे यतामहे॥ २९॥

हिरण्याक्ष उवाच।

अमरं देवता ज्ञात्वा स्वमात्मानं सुदुर्बलाः।

जीवन्तः सुचिरेणापि भूयो लप्यामहे वयम्।

राज्यमेवं विजानन्तो विपलायन्ति नित्यशः॥ ३०॥

अस्माकममरत्वं तु नैवास्त्यसुरोत्तमा:।

नष्टानामप्यतो उस्माकं जीविताशा न विद्यते ।

तस्यामसत्यां पश्याम यत्प्राप्तं तद्धि नो वरम्॥ ३? ॥

26d नैव ] न हि $\mathrm{R}$ - नयिष्यति ] हनिष्यति $\mathrm{R} \quad 27 \mathrm{~d}$ ० श्चात्माभि०] ० ग्राभि० $\mathrm{R}$ (unmetrical) $28 \mathrm{ab}]$ रणे रिपून् समाहत्य एकैकग्चाप्यनेश: $R$ (unmetrical) $28 d$ मादृशो] सदृश्यो $R 29$ विप्रचित्तिरुवाच ] om. $R \quad 30 \mathrm{a}$ अमरं देवता ] अमरत्वं सुरा $R \quad 30 \mathrm{~b}$ स्वमात्मानं ] आत्मानग्र $R \quad 30 \mathrm{c}$ $\circ$ णापि ] ०णा $R$ (unmetrical) 30e राज्य०] वाक्य० $R$ 30f विपलायन्ति ] विफला यान्ति $R$ $31 \mathrm{ab}$ तु नैवा०] हि न वा० $\mathrm{R} 31 \mathrm{e}$ तस्यामसत्यां पश्याम ] तस्मादन्यं न पश्यामो $\mathrm{R}$

26d स नयि०] $\mathrm{A}_{3} \mathrm{~A}_{4}$, समयि॰ $\mathrm{A}_{7}$ 27c-29speaker indication ] om. $\mathrm{A}$ 29c यथा ] $\mathrm{A}_{3}$ $\mathrm{A}_{4}$, तथा $\mathrm{A}_{7} 30$ हिरण्याक्ष ] सुवर्णाक्ष $\mathbf{A} 30 \mathrm{a}$ देवता ] दैवतं $\mathrm{A} 30 \mathrm{~b}$ स्वमात्मानं ] $\mathrm{A}_{4} \mathrm{~A}_{7}$, त्वत्मानं $\mathrm{A}_{3}$ (unmetrical) $\bullet$ सु० ] न $\mathbf{A}$ 30e राज्यमेवं ] वाह्यमानं $\mathbf{A}$ 30f विपलायन्ति ] $\mathrm{A}_{3}$, विपुलायंति $\mathrm{A}_{4}$, विपलायान्ति $\mathrm{A}_{7} \quad 31 \mathrm{ab}$ तु नैवास्त्य॰ ] च नैवाभ्य॰ $\mathrm{A}$ 31d जीविताशा न ] जीवितानान्न $\left\{{ }^{\circ}\right.$ नु $\left.\mathrm{A}_{7}\right\} \quad \mathrm{A}_{3} \mathrm{~A}_{7}$, जीवितं नात्र $\mathrm{A}_{4}$ 31e तस्यामसत्यां पश्याम ] तस्मादन्यन्न पश्यामो $\mathbf{A} \pm$

26 $\left(b^{7}-b^{8}, d^{4}\right) S_{1} \quad 27\left(b^{5}\right) S_{1} \quad 29\left(c^{2}-c^{3}\right) S_{3} \quad 31\left(a^{8}\right) S_{1},\left(a^{8}\right) S_{3}$

26a मृत्युर्मे ] RABh, मृत्युन्मे $S_{1}$, मृत्यु मे $S_{3}$ (unmetrical) $26 c$ युध्यमानं ] $S_{1}^{\mathrm{pc}} S_{3} R A B h$, युध्यमानां $S_{1}^{\text {ac }}$ 26d मां स नयि॰] $S_{3} A_{3} A_{4} B h$, मा(म)न्नयि॰ $S_{1}$ 27a ०मेवैतत् ] $S_{1}^{\text {pc }} S_{3} R A B h$, ०मेवैत $\mathrm{S}_{1}^{\mathrm{ac}} \quad 27 \mathrm{~b}$ ०त्सद्रिर ] $\mathrm{S}_{1} \mathrm{RABh}$, ०त्सद्रि $\mathrm{S}_{3} \quad 27 \mathrm{c}$ बाले ] $\mathrm{S}_{1}^{\mathrm{ac}} \mathrm{S}_{3} \mathrm{RBh}$, बाल $\mathrm{S}_{1}^{\mathrm{pc}}$ - समावेश्य ] $\mathrm{RBh}$ (conj.), समाविश्य $\mathrm{S}_{1} \mathrm{~S}_{3}^{\mathrm{pc}}$, समा(श्रित्य) $\mathrm{S}_{3}^{\mathrm{ac}}$ 27d ० श्चात्माभिरक्षणम् ] $\mathrm{S}_{1}^{\mathrm{pc}} \mathrm{S}_{3}$, ०श्चात्मारं रक्षणम् $S_{1}^{\mathrm{ac}}$, ०श्चात्मान्तरेक्षणम् $\mathrm{Bh}$ (conj.?) $\mathbf{2 8 b}$ ॰त्वैकश्चा॰] $S_{1}^{\mathrm{pc}} \mathrm{S}_{3} \mathrm{Bh}$, ०त्वैतश्चा॰ $S_{1}^{\mathrm{ac}} \mathbf{2 8 c}$ पृष्टं दद्यात् ] $S_{1} R B h$, पृष्टन्द द्यात्+ $S_{3}$ 29a ०नेकशः ] $S_{1} R A B h$, ०नेकश $S_{3}$ (unmetrical) 29c यथा ] $\mathrm{S}_{3} \mathrm{RA}_{3} \mathrm{~A}_{4} \mathrm{Bh}$, तथा $\mathrm{S}_{1} 30$ हिरण्याक्ष ] $\mathrm{S}_{1} \mathrm{RBh}$, सुवर्णा $S_{3} \quad \mathbf{3 0 a}$ अमरं ] $\mathrm{S}_{1} \mathrm{~S}_{3}^{\mathrm{pc}} \mathrm{ABh}$, अमर $\mathrm{S}_{3}^{\mathrm{ac}}$ (unmetrical) 30b ॰मात्मानं ] $\mathrm{S}_{1} \mathrm{~S}_{3}^{\mathrm{pc}} \mathrm{A}_{4} \mathrm{~A}_{7} \mathrm{Bh}$, ॰मात्मान $\mathrm{S}_{3}^{\mathrm{ac}}$ - ॰दुर्बलाः ] $\mathrm{S}_{3} R \mathbf{A}$, ॰ दुर्त्नभां $\mathrm{S}_{1}$, ॰दुर्लभम् $\mathrm{Bh}\left(\mathrm{em}\right.$.) 30c जीवन्तः ] $\mathrm{S}_{1}^{\mathrm{pc}} \mathrm{S}_{3} \mathrm{RABh}$, जीवन्त $\mathrm{S}_{1}^{\mathrm{ac}}$ 30d लप्स्यामहे ] $\mathrm{S}_{3} \mathrm{RABh}$, लफ्स्योमहे $\mathrm{S}_{1} \quad 31 \mathrm{ab}$ ०त्वं तु नैवा॰ $] \mathrm{S}_{1}^{\mathrm{pc}} \mathrm{Bh}$, ॰त्वन्त नैवा॰ $\mathrm{S}_{1}^{\mathrm{ac}}$, ०त्वं (तं) नैवा॰ $\mathrm{S}_{3}^{\mathrm{pc}}$, ॰त्वं $\asymp$ वा० $\mathrm{S}_{3}^{\mathrm{ac}}$ (unmetrical) 31c ०मप्यतो] $\mathrm{S}_{1} \mathrm{~S}_{3}^{\mathrm{pc}} \mathrm{RABh}$, ०माप्यतो $\mathrm{S}_{3}^{\mathrm{ac}}$ 31e ०मसत्यां ]

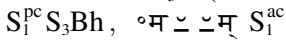


मा कृथा नशने बुद्धिं युद्धे बुद्धिः स्थिरा मम।

सुयुद्धेन रणे प्राणा यान्तु मा क्कीववद्धि नः॥ ३२॥

सनत्कुमार उवाच।

तेषामेवं तु वदतां सभायां सुरविद्विषाम्।

वेगश्वासाभिसंरब्धो दानवः प्रत्यदृश्यत॥ ३३॥

तिर्यक्संत्रासित इव मृगराजेन निर्जने ।

करीव सिंहपातेन गरुडेनेव पन्नगः॥३४॥

तदा स बद्धमुष्टिश्च दिशः सर्वा विलोकयन्।

वेगेन निश्वसन्गत्वा द्वारि द्वा:स्थमभाषत॥ ३४ ॥

दानव उवाच।

आवेदय सभापाल राक्षे प्राप्रो नलः स्वयम्।

सागरारक्षिकः क्षिप्रमकालं शीघ्रमुच्यते ॥ ३६॥

ततः प्रहस्य तं द्वाःस्थः सभापालेति भाषितः।

उवाच मा भीर्भवतु कुतो भयमिहासुर॥ ३७॥

नेह सिंहो उस्ति चोरो वा नान्यः श्वापद-म्-इत्यपि।

न गावः पशवो ऊन्ये वा भयं त्यज समाश्वस ॥ ३६॥

32a नशने ] नाशने $R \quad 32 d$ क्रीववद्धि न: ] भीरुबुद्धितः $R \quad 34 a$ तिर्यक् ] सम्यक् $R \quad 34 c$ ०पातेन ] ॰ पोतेन $R \quad 35 a$ तदा ] तथा $R \quad 35 c$ निश्वसन्गत्वा ] निःस्वरान् कृत्वा $R$ 36 राजे ] राजन् $\mathrm{R}$ - नलः ] वण: $\mathrm{R}^{\mathrm{pc}}$ (or रण:), वन: $\mathrm{R}^{\mathrm{ac}}$ 36c सागरारक्षिक:] सागरं प्रेक्षकं $\mathrm{R}$ 36d ०मकालं शीघ्रमुच्यते ] ॰मासनं पीदमुच्यतां $R \quad 37 b$ ०पालेति भाषितः ] ०पालप्रभाषिणम् $R \quad 37 c$ मा भीर्भवतु ] भीर्न ते भूय: $\mathrm{R} \quad 38 \mathrm{ab}$ ] न सिंहो न वराहो वा नान्य: श्रापदमित्यवै $\mathrm{R}^{\mathrm{ac}}$, नरसिंहो वराहो वा नान्यत् ग्वापदमित्यवै $\mathrm{R}^{\mathrm{pc}} \quad 38 \mathrm{c}$ न गावः ] शार्दूल: $\mathrm{R}$

32a नशने ] नाशने $A$ 32d कीववद्धि न: ] की $\left\{\right.$ की० $\left.A_{7}\right\}$ वबुद्धितः $A$ 33b सभायां] सभयो $A$ $33 \mathbf{c}$ ०श्वासाभि॰ ] ० ग्चास्याभि॰ $A$ - ०संरब्धो ] ०संरंभो $\mathrm{A}_{4}$, ०संरंभा $\mathrm{A}_{3}$, ०संरम्भात् $\mathrm{A}_{7}$ 34a38b ] om. A

32a कृथा ] $S_{1} R A B h$, वृथा $S_{3}$ - नशने ] $S_{3}$, नाशने $S_{1} B h$ 32b स्थिरा ] $S_{3} R A$, स्थिता $S_{1}^{p c}$ $\mathrm{Bh}$, स्थितो $\mathrm{S}_{1}^{\mathrm{ac}}$ • मम ] $\mathrm{S}_{3} R A B h$, मम: $\mathrm{S}_{1} \quad 32 \mathrm{c}$ ०युद्धेन ] $\mathrm{S}_{3} R A B h$, ०युद्धे तु $\mathrm{S}_{1}$ • प्राणा ] $\mathrm{RABh}$, प्राणां $\mathrm{S}_{1} \mathrm{~S}_{3}$ 32d क्रीव०] $\mathrm{S}_{1} \mathrm{~S}_{3} \mathrm{~A}_{3} \mathrm{~A}_{4}$, क्रीब ${ }^{\mathrm{Bh}}$ - ०वद्धि नः ] $\mathrm{S}_{1}^{\mathrm{acc}} \mathrm{S}_{3} \mathrm{Bh}$, ०वर्द्धिन: $\mathrm{S}_{1}^{\mathrm{pc}}$ 33a तेषामे॰ ] $S_{1} R A B h$, तेषां मे॰ $S_{3}$ 33d दानव: ] $S_{1}^{\text {pc }} S_{3} R A B h$, दानव $S_{1}^{\text {ac }}$ • ०दृश्यत ] $S_{3}$ RABh, ०दृश्यतः $S_{1}$ 34a तिर्यक् ] conj., सम्यक् $S_{1} S_{3} B h \quad 34 c$ ०पातेन ] $S_{3}$, ०पादेन $S_{1} B h$ 35a तदा ] $S_{1} B h$, तथा $S_{3} \quad 35 \mathbf{b}$ सर्वा ] $S_{1} S_{3}^{\mathrm{ac}} R B h$, सर्वां $S_{3}^{\mathrm{pc}}$ 35c निश्वसन्गत्वा ] $S_{1}^{\mathrm{pc}} S_{3}^{\mathrm{pc}}$, निश्वसं गद्वा $S_{1}^{\mathrm{ac}}$, निश्यस -(वा) $\mathrm{S}_{3}^{\mathrm{ac}}$, निः ग्वसन् गत्वा $\mathrm{Bh}\left(\mathrm{em}\right.$. ?) $35 \mathrm{~d}$ द्वारि द्वाःस्थ०] $\mathrm{S}_{1} \mathrm{~S}_{3}^{\mathrm{pc}} \mathrm{RBh}$, रि द्वास्था॰ $\mathrm{S}_{3}^{\mathrm{ac}}$ (unmetrical) - ०भाषत ] $\mathrm{S}_{1} \mathrm{RBh}$, ०भाषतः $\mathrm{S}_{3}$ 36c सागरारक्षिक:] $\mathrm{S}_{1}^{\mathrm{pc}} \mathrm{Bh}$, सागरारक्षि(क्ष) $\mathrm{S}_{1}^{\mathrm{ac}}$, सागराक्षिक: $\mathrm{S}_{3}$ (unmetrical) 37a द्वाःस्थः ] $\mathrm{S}_{1}^{\mathrm{pc}} \mathrm{RBh}$, द्वास्थं $\mathrm{S}_{1}^{\mathrm{ac}}$, द्वास्थ $\mathrm{S}_{3}$ 37b ०पालेति भाषितः ] $S_{3}$, ०पालेति भाषितम् $S_{1}$, ०पालोभिभाष्य तं Bh (conj.) 37d भयमिहासुर ] $\mathrm{R}$, भय महासुर: $\mathrm{S}_{1} \mathrm{~S}_{3}$, भीस्ते महासुर $\mathrm{Bh}$ (conj.) $38 \mathrm{~b}$ नान्यः श्रा० $] \mathrm{S}_{1} \mathrm{R}^{\mathrm{ac}} \mathrm{Bh}$, नान्यच्छ्वा० $\mathrm{S}_{3}$ - ०पद-म्-इ॰] $\mathrm{S}_{1} \mathrm{~S}_{3} \mathrm{R}$, ०पद इ० $\mathrm{Bh}(\mathrm{em} . ?) \quad 38 \mathrm{c}$ गाव: $\mathrm{S}_{1}^{\mathrm{pc}} \mathrm{S}_{3} \mathrm{ABh}$, गाव $\mathrm{S}_{1}^{\mathrm{ac}} \mathbf{3 8 d}$ समाश्वस ] $S_{3} R A B h$, समाश्वस: $S_{1}$ 
स तथा तेन संप्रोकः शान्तश्चासुरपुंगवः।

कुद्धः शब्द तदा चके महान्तं नादयन्दिशः॥ ३९॥

ते उभिगम्य तदा व्यास राजानं दानवेश्वरम्।

ऊचुरेष किमप्यद्य दृष्टं कथयते डसुरः॥ ४०॥

स राजा सम्यगाश्वास्य दैत्यमेनं महायशाः।

दानवानां हितार्थाय पृच्छुस्व दितिनन्दनः ॥ ४१॥

तेषां स राजा विप्रेन्द्र दानवानां महाबलः।

श्रुत्वा तं दानवं व्यास इदं वचनमब्रवीत् ॥ ४२॥

भयं नश्यतु ते दैत्य मत्समीपे उभिवर्ततः।

ब्रूहि सर्व यथादृष्टं समाश्वस्य यथातथम्॥ ४३॥

सनत्कुमार उवाच।

ततः स दानवो व्यास राजानं विगतज्वर:।

प्रणम्य प्राअलिर्वाक्यमिदं सम्यगुवाच ह॥ ४४॥

नित्यं जयतु नो राजा दानवानां सुखावहः।

नशन्तु विद्विषः सर्वे ये उस्माकमहितावहाः ॥ ४४॥

39ab संप्रोक्तः शान्तश्चा०] संगम्य प्रोक्तव्यो $5^{\circ} \mathrm{R}$ 39d ०यन्दिशः ] ०यन्नमुम् $\mathrm{R} \quad 40 \mathrm{a}$ ते ऽिगम्य ] ग्रुत्वा सर्वे $\mathrm{R} 40 \mathrm{c}$ रेष ] ०रेव $\mathrm{R} 40 \mathrm{~d}$ कथयते ] कथय सो $\mathrm{R} 41 \mathrm{~b} \circ$ मेनं ] मेवं $\mathrm{R}$ 41d ॰नन्दनः ] ॰नन्दनम् $R$ 43b मत्समीपे ऊभिवर्ततः ] मत्समं यो भिवर्त्तित: $R$ 43c सर्वं ] शंस $R 43 d$ यथातथम् ] यथा तथा $R \quad 44$ सनत्कुमार उवाच ] om. $R \quad 44 c$ प्राअलि॰] चाअलि॰ $R$ 45a जयतु ] जयति $\mathrm{R} \quad 45 \mathrm{c}$ नशन्तु ] नश्यन्तु $\mathrm{R}^{\mathrm{pc}}$, नश्यन्ति $\mathrm{R}^{\mathrm{ac}}$

39a संप्रोकः ] $\mathrm{A}_{3} \mathrm{~A}_{4}$, संप्राप्रो $\mathrm{A}_{7}$ 39b शान्त० ] प्राप्त $A$ 40c ० प्यद्य ] वप्यत्य $\mathrm{A}_{3} \mathrm{~A}_{7}$, ० प्यन्य $\mathrm{A}_{4} 40 \mathrm{~d}$ ०ते उसुर: ] ०तेस्वर: $\mathrm{A}_{4}$, ०तेश्वर: $\mathrm{A}_{3} \mathrm{~A}_{7} 41 \mathrm{a}$ स ] तं $\mathrm{A}$ - गगाम्वास्य ] गाहूय $\mathrm{A}$ 41d पृच्छस्व ] च्छस्व $\mathrm{A}_{3}$ (unmetrical), प्रयच्छस्व $\mathrm{A}_{4} \mathrm{~A}_{7}$ (unmetrical) • ०नन्दनः ] $\mathrm{A}_{4} \mathrm{~A}_{7}$, ०नंदन $\mathrm{A}_{3}$ 43ab ] om. $A$ 43c ब्रूहि ] $\mathrm{A}_{3}$, ब्रुहि $\mathrm{A}_{4} \mathrm{~A}_{7}$ 43d यथातथम् ] यथायथं $\mathrm{A}$ 45a जयतु ] यजतु $A$ 45b सुखावहः ] $\mathrm{A}_{3} \mathrm{~A}_{4}$, सुखावह $\mathrm{A}_{7} 45 \mathrm{c}$ नशन्तु ] नश्यन्तु $\mathrm{A}$

$39\left(c^{3}-c^{6}, d^{3}\right) S_{3} \quad 42\left(d^{3}-d^{4}\right) S_{3}$

39a संप्रोकः ] $S_{1}^{\text {pc }} A_{3} A_{4}$, सम्प्रोक्ता $S_{1}^{\text {ac }}$, सः प्रोक्तः $S_{3}$, संप्रोको Bh (conj.) 39b शान्त॰] $S_{1} B h$, शान्ता० $S_{3}$ - ०सुरपुंगवः ] RA, ०सुरसत्तम: $S_{1} B h$, ०सुपुङ्भव: $S_{3}$ (unmetrical) 39c कुद्धः ] $\mathrm{S}_{1} \mathrm{RABh}$, क्रुद्ध $\mathrm{S}_{3}$ - चक्के] $\mathrm{S}_{1}^{\mathrm{pc}} \mathrm{S}_{3} \mathrm{RABh}$, चक्र $\mathrm{S}_{1}^{\mathrm{ac}}$ 39d ०न्त नादयन्दिशः ] $\mathrm{S}_{1}^{\mathrm{pc}}$ (sec. hand) $\mathrm{S}_{3} \mathrm{ABh}$, नन्तन्नादयानिव $\mathrm{S}_{1}^{\text {ac }}$ - After this Bh conjectures loss of two pādas. 40a व्यास ] $S_{1} R A B h$, व्यासं $S_{3} \quad 40 c$ ०प्यद्य] $S_{1} S_{3}^{p c} R B h$, ०व्य(त्र) $S_{3}^{\text {ac }}$ 41a राजा ] $S_{1} R A$, राजं $S_{3}$,

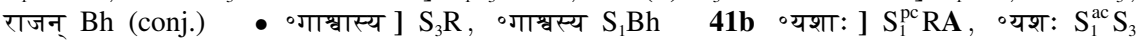
$\mathrm{Bh} 41 \mathrm{~d}$ ०स्व दिति॰] $\mathrm{S}_{1}^{\mathrm{pc}} \mathrm{S}_{3} \mathrm{RABh}$, ०स्वादिति॰ $\mathrm{S}_{1}^{\mathrm{ac}}$ - ०नन्दनः ] $\mathrm{S}_{1}^{\mathrm{pc}} \mathrm{S}_{3} \mathrm{~A}_{4} \mathrm{~A}_{7}$, ०नन्दन $\mathrm{S}_{1}^{\mathrm{ac}} \mathrm{Bh}$ 42a ०षां स राजा ] $S_{1} R A B h$, ०षान्तदा तु $S_{3} \quad$ 43a ०यं नश्यतु ते ] $S_{3} R$, ०यन्न शक्रुते $S_{1}$, ०यं न शक्तुते $\mathrm{Bh} 43 \mathrm{~b}$ ऊभवर्ततः ] $\mathrm{S}_{3}$, तिवर्त्तते $\mathrm{S}_{1}$, भिवर्तितुम् $\mathrm{Bh}$ (conj.) 43c सर्वं] $\mathrm{S}_{3} \mathrm{ABh}$, सर्वे $\mathrm{S}_{1}$ 43d यथातथम् $\mathrm{S}_{1} \mathrm{~S}_{3}$, तथातथम् Bh (typo?) 44a ततः ] $\mathrm{S}_{1} \mathrm{RABh}$, तत $\mathrm{S}_{3}$ (unmetrical) 44b ०ज्वर: ] $S_{1} R A B h$, कज्वरं $S_{3}$ 44c प्राअलिर ] $S_{1} A B h$, प्रांजलि $S_{3}$ (unmetrical) 45b सुखावहः ] $\mathrm{S}_{1}^{\mathrm{pc}} \mathrm{S}_{3} \mathrm{RA}_{3} \mathrm{~A}_{4} \mathrm{Bh}$, सुखावह $\mathrm{S}_{1}^{\mathrm{ac}} \quad 45 \mathrm{c}$ नशन्तु $] \mathrm{S}_{3}$, नाशन्तु $\mathrm{S}_{1}$, नश्यन्तु $\mathrm{Bh}$ 45d ०कमहिता० ] $\mathrm{S}_{1}^{\mathrm{pc}} \mathrm{S}_{3} \mathrm{RABh}$, ०कम्महिता० $\mathrm{S}_{1}^{\mathrm{ac}}$ 
अहं तवाइ्तया राजन्विचरामि दिने दिने।

सागरान्तं महाराज पुरुषै: सह संगतः॥ ४६॥

सो उद्य पश्याम्यहं तत्र वाराहं दैत्यपुंगव।

मेरुशृड्रप्रतीकाशं ज्वलन्तमिव पावकम्॥ ४७॥

तस्य गात्रेषु दृश्यन्ति सूक्ष्मरूपधराः स्थिताः।

सर्वे सुरा महाराज ऋषयश्च तपोधनाः॥ ४५॥

महाबलस्त्वं राजेन्द्र देवानां भयदः सदा।

त्वत्तो उपि सुमहान्भीमस्तादृग्रुपो न विद्यते ।

न दृष्टो न श्रुतो वापि वपुषा दैत्यपुंगव॥ ४९॥

अहं तेनाहतो दृष्ट्या न्यपतं भूतले भृशम्।

स्रस्तहाराम्बरो मीतः कुलिशेनेव ताडितः ॥ पू०॥

ये ममानुचराश्चासन्दानवा मीमविक्रमाः।

ते सर्वे तस्य वेगेन पतिता गतजीविताः ॥ पू? ॥

$46 \mathrm{c}$ सागरान्तं ] सागरान्ते $\mathrm{R} 48 \mathrm{a}$ गात्रेषु दृश्यन्ति ] मद्ये च दृश्यन्ते $\mathrm{R} \quad 49 \mathrm{a}$ ०बलस्त्वं रा०]

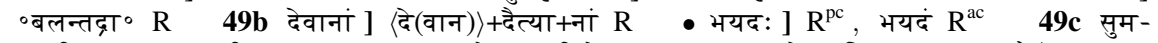
हान्भीम० ] स महाभीम० $\mathrm{R}$ 49d ०ग्रूपो ] ०ग्वीरो $\mathrm{R}$ 49ef ग्रुतो वापि वपुषा ] ग्रुत स्चैवं वपुष्मान् $\mathrm{R} 50 \mathrm{a}$ दृष्ट्या ] दृष्टो $\mathrm{R}^{\mathrm{pc}}$, दृष्टा $\mathrm{R}^{\mathrm{ac}} 50 \mathrm{~b}$ न्यपतं] न्यपतद् $\mathrm{R}$ 51ab ममानुचराश्चासन्दानवा ] समर्थवरा ह्यासन् समर्था $R$ 51c तस्य ] गत० $R$

46c सागरान्तं ] सागरान्तो $\mathrm{A}_{3} \mathrm{~A}_{4} \mathrm{~A}_{7}^{\mathrm{ac}}$, सागरान्ते $\mathrm{A}_{7}^{\mathrm{pc}} \quad 47 \mathrm{c}-49 \mathrm{f}$ ] om. $\mathrm{A}$ 50a तेनाहतो दृष्ट्या ] तवाहतो $\left\{{ }^{\circ}\right.$ नो $\mathrm{A}_{3}$ \} दृष्ट्रा $\mathbf{A} \quad \mathbf{5 0 b}$ न्यपतं ] $\mathrm{A}_{3} \mathrm{~A}_{7}$, न्ययतं $\mathrm{A}_{4} \quad$ 50c स्तस्तहाराम्बरो ] त्रस्तो महा \{हाम ${ }^{\circ}$ $\mathrm{A}_{7}$ \}सुरो $\mathrm{A}$ - भीतः ] $\mathrm{A}_{3} \mathrm{~A}_{4}$, तीतः $\mathrm{A}_{7}$ 51ab ० श्चासन्दानवा ] $\mathrm{A}_{3} \mathrm{~A}_{4}$, ०स्यासन् नादवा $\mathrm{A}_{7}$

$49\left(c^{2}, f^{2}\right) S_{1},\left(d^{7}\right) S_{3}$

46a ०वाज्ञाया ] RABh, ०वाज्ञाया $S_{1}$, ०वाज्ञाय $S_{3}$ • राजन्] $S_{3} R A$, सर्व $S_{1} B h$ 46d पुरुषै: ] $\mathrm{S}_{1}^{\mathrm{pc}} \mathrm{RABh}$, पुरुषै $\mathrm{S}_{1}^{\mathrm{ac}} \mathrm{S}_{3}$ - सह संगतः ] $\mathrm{S}_{1}^{\mathrm{pc}} \mathrm{RABh}$, सिंहसड़्तः $\mathrm{S}_{1}^{\mathrm{ac}}$, स स गतः $\mathrm{S}_{3}$ (unmetrical) $47 \mathrm{ab}$ ०हं तत्र वाराहं दैत्यपुंगव ] $\mathrm{S}_{1} R A$, ०हन्देत्य वाराहन्तत्र पुंगव: $\mathrm{S}_{3}$, ०हं तत्र वराहं दैत्यपुड्गव $\mathrm{Bh}$ (em.) 48a दृश्यन्ति ] $S_{1} S_{3}$, दृश्यन्ते $B h(e m) \quad$.$48 b स्थिता: ] S_{1}^{\text {pc }} S_{3} R B h$, स्थिता $S_{1}^{\text {ac }} 49 a$ ०स्त्वं ] $\mathrm{S}_{1} \mathrm{Bh}$, ०स्तं $\mathrm{S}_{3} \quad 49 \mathrm{c}$ त्वत्तो] $\mathrm{S}_{3} \mathrm{RBh}$ (conj.?), त+(त्)+त्वो $\mathrm{S}_{1}$ 49cd ॰न्भीमस्ता॰] em. $\mathrm{Bh}$ (silently), ॰न्भीम ता॰ $\mathrm{S}_{1}$, ॰न्भीमास्ता॰ $\mathrm{S}_{3}$ 49d ॰दृगूपो न $\mathrm{S}_{3}$, ॰दृत्नैवेह $\mathrm{S}_{1}$, ॰दृड् नैवेह $\mathrm{Bh}$ (em.?) 49e श्रुतो] $\mathrm{S}_{1}^{\mathrm{pc}} \mathrm{S}_{3} B \mathrm{Bh}$, श्रुते $\mathrm{S}_{1}^{\mathrm{ac}} \quad$ 49f वपुषा ] $\mathrm{S}_{3} B \mathrm{Bh}$ (conj., in a note Bh reads मधुषा in $S_{1}$ ), व(पु)सा $S_{1}^{\mathrm{pc}}$, म(ब्र)सा $S_{1}^{\mathrm{ac}} \quad$ • ०पुंगव ] RBh (em.?), ॰पुड़्व: $\mathrm{S}_{1} \mathrm{~S}_{3}$ 50a दृष्ट्या ] $\mathrm{S}_{1} \mathrm{Bh}$, दृष्ट्रा $\mathrm{S}_{3} \quad \mathbf{5 0 b}$ न्यपतं भूतले ] $\mathrm{A}_{3} \mathrm{~A}_{7} \mathrm{Bh}$, न्यपतड्ूूतल $\mathrm{S}_{1}^{\mathrm{pc}}$ (unmetrical), (॰भ्य)पड़ूूित(ले) $\mathrm{S}_{1}^{\mathrm{ac}}$, न्यपतड्डूतले $\mathrm{S}_{3}$ - भृशम् ] $\mathrm{S}_{3} \mathrm{RABh}$, भृषम् $\mathrm{S}_{1}$ 50c भीतः ] $\mathrm{S}_{1} \mathrm{RA}_{3} \mathrm{~A}_{4} B h$, भीत $\mathrm{S}_{3}$ 50d ०नेव ] $\mathrm{S}_{3} \mathrm{RABh}$, ०ैैव $\mathrm{S}_{1} \mathbf{5 1 b}$ ॰न्दानवा ] $\mathrm{S}_{1} \mathrm{~A}_{3} \mathrm{~A}_{4} \mathrm{Bh}$, ०न्दानवाम् $\mathrm{S}_{3}$ • ०विक्रमा: ] $\mathrm{S}_{3} \mathrm{RABh}$, ०विक्रमा $S_{1}$ 51d गतजीविता: ] $S_{1} R A B h$, गजीविता $S_{3}$ (unmetrical) 
स एषो ऽ्येति राजेन्द्र तवैव नगरं प्रति।

चालयन्वसुधां सर्वां क्षोभयन्सागरांस्तथा।

जलेचरांश्च दैत्येन्द्र जीवितैर्विप्रयोजयन् ॥ $y$ २॥

सनत्कुमार उवाच।

तस्य तद्वचनं श्रुत्वा प्रह्लादो उसुरसत्तमः

उवाच दैत्यराजानमिदं वचनकोविद:॥ $y$ ३॥

प्रह्लाद उवाच।

यादृशं तद्वराहस्य तस्य रूपं त्वया श्रुतम्।

सर्वदेवमयं राजन्वराहो उप्राकृतो मतः ॥ $4 \vee \|$

तस्मात्तथा विधातव्यं यथा नो न स मोहयेत्।

अधितिष्टेत दैत्येन्द्र माचिरं तद्विधीयताम् $४$ पू $॥$

सुव्यक्त ब्रह्मणा तस्य चकलाड़्लधारिणः।

सर्वदेवमयं रूपं वाराहमिदमीहितम्॥ पू६॥

52a राजेन्द्र ] दैत्येन्द्र $R \quad 52 \mathrm{e}$ दैत्येन्द्र ] दैत्येन्द्रान् $R \quad 54 \mathrm{a}$ ०शं तद्वराहस्य ] ०शन्तु वराहत्वं $R$ $54 b$ त्वया श्रुतम् ] प्रचक्ष्यते $R \quad 54 d$ ॰न्वराहो उप्राकृतो मतः ] ॰न्नसौ प्रकृतसम्भव: $R \quad 55 b$ नो न ] न च $R \quad 55 \mathrm{c}$ अधितिष्टेत ] यावन्नायाति $R \quad 55 \mathrm{~d}$ माचिरं तद् ] तावत् कालं $R \quad 56 \mathrm{a}$ सुव्यक्त ] अव्यक्त $\mathrm{R}$ • ब्रह्मणा त० ] ब्रह्मणस्त० $\mathrm{R}$

52b तवैव ] तथैव $\mathbf{A}$ - नगरं ] $\mathrm{A}_{3}$, न परं $\mathrm{A}_{4} \mathrm{~A}_{7} \quad \mathbf{5 2 c}$ ॰न्वसुधां सर्वां ] ॰न्नसुरान् सर्वान् $\mathbf{A} 52 \mathrm{e}$ दैत्येन्द्र ] राजेन्द्र $A$ 52f ०योजयन् ] ०याजयन् $A_{7}$, ०भाजयन् $A_{3} A_{4} 53 d$ ०कोविद: ] ०चोदितः A 54a वशं तद् ] ०शं तु $A_{3} A_{4}$, ०शन्त $A_{7} \quad 54 b$ त्वया श्रुतम् ] प्रचक्षते $A_{3} A_{4}$, प्रवक्षते $A_{7} 54 d$ ॰हो उप्राकृतो मतः ] ${ }^{\circ}$ हः प्रकृतो मम $\left\{{ }^{\circ}\right.$ मः $\left.\mathrm{A}_{3}^{\mathrm{ac}}\right\}$ A $55 \mathbf{a}$ तस्मात् ] $\mathrm{A}_{3} \mathrm{~A}_{7}$, तस्मा $\mathrm{A}_{4} \quad \mathbf{5 5 b}$ यथा नो न ] यथानेन $\mathrm{A}_{3} \mathrm{~A}_{4}$, यथा नो ग्रु $\mathrm{A}_{7}$ - मोहयेत् ] $\mathrm{A}_{4} \mathrm{~A}_{7}$, मोहयत् $\mathrm{A}_{3} \quad 55 \mathrm{c}$ अधितिष्ठेत ] यावन्नायाति $\mathrm{A}_{7}$, यान्न याति $\mathrm{A}_{3} \mathrm{~A}_{4}$ (unmetrical) $56 \mathrm{a}$ सुव्यक्त ] अव्यक्त $\mathbf{A} 56 \mathbf{b}$ चकाड़्र००] रूपं च चक्र० A (unmetrical) 56d ०मिदमीहितम् ] ०मिदमोहितं $\mathrm{A}_{4}$, ०मिह मोहितं $\mathrm{A}_{3}$, ०मिदमाहितं $\mathrm{A}_{7}$

$\mathbf{5 5}\left(\mathrm{a}^{8}\right)\left\langle\mathrm{c}^{1}\right\rangle\left(\mathrm{c}^{2}-\mathrm{c}^{8}\right) \mathrm{S}_{1}$

52b नगरं ] $S_{1} R_{3} B h$, नगराम् $S_{3}$ 52c सर्वां] $S_{3} R B h$ (em.?), सर्वा $S_{1}$ 52d क्षोभयन् ] $S_{1}$ $\mathrm{RABh}$, क्षोभयान् $\mathrm{S}_{3} \mathbf{5 2 f}$ वितैर्वि॰] $\mathrm{S}_{1} \mathrm{RABh}$, ०वितै वि॰ $\mathrm{S}_{3}$ • ०योजयन् ] RBh (em.), ०योजयत् $S_{1} S_{3} \quad 53 a$ ॰द्वचनं] $S_{1} R A B h$, ॰दूचन $S_{3} \quad 53 b$ प्रह्लादो ] $S_{1} R A B h$, प्रहादो $S_{3}$ ०सत्तमः ] $S_{3} R A B h$, ०सत्तम $S_{1}$ 53d ०कोविद: ] $S_{3} R$, ०मब्रवीत् $S_{1}$, ०मर्थवत् Bh (conj.?, in a note Bh suggests कोविद:) 54 प्रह्लाद ] $S_{1} R A B h$, प्रहाद $S_{3} \mathbf{5 4 b}$ त्वया ] $S_{1} S_{3}$, मया $B h$ (conj.?) • श्रुतम् ] $S_{1}^{\text {pc }} S_{3} B h$, ( च्यु)त $S_{1}^{\text {ac }} \quad \mathbf{5 4 c}$ राजन् $] S_{1} R A B h$, राज $S_{3} \quad 54 d$ उप्राकृतो मतः ] $\mathrm{S}_{1} \mathrm{Bh}$, नन्दिवर्द्धन: $\mathrm{S}_{3} \quad \mathbf{5 5 a}$ तस्मात्तथा $] \mathrm{S}_{3} \mathrm{RA}_{3} \mathrm{~A}_{7}$, तस्मा त्वया $\mathrm{S}_{1}$, तस्मात्त्वया $\mathrm{Bh} \mathbf{5 5 b}$ मोहयेत् ] $\mathrm{S}_{3} \mathrm{RA}_{4} \mathrm{~A}_{7} \mathrm{Bh}(\mathrm{em} . ?)$, मोहयेन् $\mathrm{S}_{1}^{\mathrm{pc}}$, मोहयन् $\mathrm{S}_{1}^{\mathrm{ac}} \quad \mathbf{5 5 c}$ अधितिष्ठेत ] $\mathrm{S}_{3}, \simeq$ (धि) $\mathrm{f} \simeq$ (ष्ठेत) $\mathrm{S}_{1}$ (lower parts lost), विनिश्चित्य च $\mathrm{Bh}$ (conj.?) 55d ०चिरं तद् $] \mathrm{S}_{1}^{\mathrm{pc}} \mathrm{S}_{3} \mathrm{ABh}$, ०चिरन्त $\mathrm{S}_{1}^{\mathrm{ac}}$ 56a सुव्यक्त ] $S_{1} B h$, अव्यक्त $S_{3}$ - ब्रह्मणा ] $S_{1}^{\mathrm{pc}} S_{3} A B h$, ब्राह्मणा $S_{1}^{\mathrm{ac}} \quad \mathbf{5 6 b}$ धधारिणः ] RABh, ०धारिणम् $\mathrm{S}_{1} \mathrm{~S}_{3}$ 56c सर्व०] $\mathrm{S}_{3} \mathrm{RABh}$, सर्वे $\mathrm{S}_{1}$ 
भवानवध्यः सर्वेषां देवानां दानवेश्वर:।

अशक्तैस्तैरियं माया सृष्टा वै न तदन्यथा॥ पू७॥

सनत्कुमार उवाच।

तस्य तद्वचनं श्रुत्वा हिरण्याक्षः प्रतापवान्।

उवाच दैत्यान्दनुजानिदं वचनमर्थवत् ॥ $\Sigma_{\zeta} \|$

हिरण्याक्ष उवाच।

यद्यद्य म्रातृहन्ता मे इहायाति दुरात्मवान्।

पूर्णः स्यादद्य सुचिराद्यो मे ह्वि मनोरथः ॥ पू९॥

अद्याहं तं दुरात्मानं म्रातृहन्तारमाहवे।

छित्वा छित्वा करिष्यामि बलिं पशुपते: शुभाम्॥ ६०॥

अद्य तस्य विचित्राक्षं शिर: कायात्सकुण्डलम्।

उत्कृत्य दैत्या दास्यामि रुद्राय परमात्मने॥ ६?॥

मया नासादितः पूर्वं तस्मिन्युद्धे स केशवः।

अद्याहं तं समासाद्य नेष्यामि यमसादनम्॥ ६२॥

अद्य तस्मिन्हते सर्वे निराशा भयविह्तलाः।

ममैव कार्यतां गत्वा देवा यास्यन्ति दासताम्॥ ६३॥

57a ०नवध्य: ] ०न् वध्यो न $R \quad 57 \mathrm{~b}$ ०वेश्वर: ] ०वेश्वर $\mathrm{R} \quad 59 \mathrm{a}$ यद्यद्य ] अद्य स $\mathrm{R} \quad 60 \mathrm{~cd}$ छित्वा करिष्यामि बलिं ] हरिष्यामि बलिं प्रभो: $R$ 60d शुभाम् ] शुभम् $R$ 61ab विचित्राक्षं शिर: कायात्स०] विचित्राक्षीणि शिरश्च+ग्च+ल० $\mathrm{R}$ (unmetrical) $61 \mathrm{c}$ दैत्या ] दित्या $\mathrm{R} 62$ ] om. $R$

57a ०नवध्य: ] $\mathrm{A}_{3} \mathrm{~A}_{4}$, ०न् वध्यः $\mathrm{A}_{7}$ (unmetrical) $58 \mathrm{c}$ उवाच दैत्यान्दनुजा०] प्रह्लादाद्यांस्तदा सवा० $A \pm 58 d$ ०मर्थवत् ] ०मब्रवीत् $A \quad 59$ हिरण्याक्ष ] सुवर्णाक्ष $A$ 59a यद्यद्य ] यद्यसौ $A$ 59c सुचिराद् ] स चिराद् $\mathrm{A}_{3}$, स चिरा $\mathrm{A}_{4} \mathrm{~A}_{7}$ 61c उत्कृत्य ] उद्धृत्य $A$ - दैत्या ] $\mathrm{A}_{3} \mathrm{~A}_{4}$, दैत्य $\mathrm{A}_{7} 62 \mathrm{~b}$ केशव:] $\mathrm{A}_{3}$, केसर: $\mathrm{A}_{4}$, केश्वर: $\mathrm{A}_{7} 63$ ] om. $\mathrm{A}$

$\mathbf{5 7}\left(c^{3}-c^{4}\right) S_{1} \quad \mathbf{5 8}\left(b^{4}\right) S_{1} \quad \mathbf{5 9}\left(c^{2}\right) S_{1} \quad \mathbf{6 0}\left(a^{8}\right) S_{1}$

57a ०नवध्य: ] $\mathrm{S}_{1} \mathrm{~A}_{3} \mathrm{~A}_{4} \mathrm{Bh}$, ०नवद्य $\mathrm{S}_{3} \quad$ 57b ०वेश्वर: ] $\mathrm{S}_{1}^{\mathrm{pc}} \mathrm{S}_{3} \mathrm{~A}$, ०वेश्वरा: $\mathrm{S}_{1}^{\mathrm{ac}}$, ०वेश्वर $\mathrm{Bh}$ (em.) 57d तदन्यथा ] $S_{1}^{\mathrm{pc}} \mathrm{S}_{3} \mathrm{RABh}$, त(द्य)था $\mathrm{S}_{1}^{\text {ac }}$ (unmetrical) 58b हिरण्याक्षः ] RABh, हिरण्या $+($ क्ष $)+S_{1}$, हिरण्याक्ष $S_{3}$ 58cd दैत्यान्दनुजानि॰] $S_{1} R B h$, दैत्या दनुजामि॰ $S_{3} \quad$ 59a यद्यद्य ] $S_{3}$, यद्यस्य $S_{1}$, यद्येष Bh (conj.) - भ्रातृ॰ ] $S_{1} R A B h$, प्रातृ $S_{3}$ 60d शुभाम् ] $S_{1} S_{3} A$, शुभम् $\mathrm{Bh}$ (em.) 61c दैत्या] $\mathrm{S}_{1}^{\mathrm{ac}} \mathrm{A}_{3} \mathrm{~A}_{4} \mathrm{Bh}$, दैत्य $\mathrm{S}_{1}^{\mathrm{pc}} \mathrm{S}_{3}$ 62a मया ] $\mathrm{S}_{1}^{\mathrm{pc}} \mathrm{S}_{3} \mathrm{ABh}$, माया $\mathrm{S}_{1}^{\mathrm{ac}}$ 63a अद्य] $\mathrm{S}_{1} \mathrm{~S}_{3} \mathrm{R}$, अथ $\mathrm{Bh}$ (conj.?) • तस्मिन् ] $\mathrm{S}_{1}^{\mathrm{pc}} \mathrm{S}_{3} \mathrm{RBh}$, (वस्मै) $\mathrm{S}_{1}^{\mathrm{ac}}$ 63c ०व कार्य॰] $\mathrm{S}_{1} \mathrm{~S}_{3} \mathrm{R}$, ०वाकार्य॰ Bh (conj.) 
सनत्कुमार उवाच।

ततः स दानवाम्छूरान्दैत्यांश्च सुमहाबलान्।

उवाच नाम्ना विख्यातान्किकरान्नाम दानवान्॥ ६४॥

दश तानि सहस्राणि गच्छुध्वं तं महाबलाः।

जानीत को उयमित्येवं ततो यास्याम्यहं स्वयम्॥ ६४॥

ते तथोका महामाया हृष्टाः सर्वे विनिर्गताः।

बद्धगोधाड्रुलित्राणाः संनद्धास्तु पदातयः ॥ ६६॥

ते हेमचित्राम्बरहारसूत्रा महाबला दानवदैत्यपुत्राः।

विनादयन्तो बहुधातिकोपिता यथैव नागा: सविषा विनिर्ययुः॥ ६७॥

इति स्कन्दपुराणे शततमो ऽध्यायः ॥ १००॥

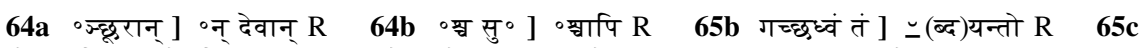

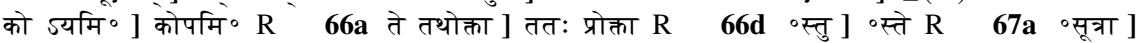
॰ भूषिता $R \quad 67 c$ विनादयन्तो ] विनायन्तो $R$ (unmetrical)

Col. om. R

66b हृष्टा: ] $A_{4}$, हृष्टा $A_{3} A_{7} \quad 66 c-67 b$ ] om. $A_{4} \quad 67 a$ हेम०] तीव $A_{3} A_{7} \quad 67 c$ ०कोपिता ] रोषिता A 67d सविषा ] सरितो A Col. इति स्कन्दपुराणे एकाशीतिसाहस्रचां संहिताया $\{$ इति स्कंद० $\left.\mathrm{A}_{4}\right\}$ मम्बिकाखण्डे उसुरागमो ध्याय: $\mathbf{A} \pm$

$\mathbf{6 4}\left(d^{2}\right) S_{1} \quad \mathbf{6 6}\left(b^{3}-b^{4}, d^{8}\right) S_{1}$

64 सनत्कुमार ] $S_{3} R A B h$ (सन in $S_{3}$ ), नस $S_{1} \quad 64 a$ ततः ] $S_{1} R A B h$, तत $S_{3}$ (unmetrical) 64b सु॰ ] $S_{3} A B h$, स $S_{1} 64 c$ उवाच ] $S_{1} R A B h$, उवाचा $S_{3}$ 64cd विख्यातान्किकरान् ] $S_{1}^{\text {pc }} R A B h$, विख्या/तः (कि) $\rangle+$ तां कि(ङ्क) +रान् $S_{1}$, विख्यातं किंकरा $S_{3} 65 \mathbf{c}$ को उयमि॰] $S_{3} A B h$, कायमि॰ $S_{1}^{p c}$, $\simeq($ क्षा $)$ मि॰ $\mathrm{S}_{1}^{\mathrm{ac}} \bullet$ ०त्येवं ] $\mathrm{S}_{1} \mathrm{RABh}$, ०त्येव $\mathrm{S}_{3}$ 66b हृष्टा: ] $\mathrm{RA}_{4} \mathrm{Bh}(\mathrm{em} . ?)$, हृष्टा $\mathrm{S}_{1} \mathrm{~S}_{3}$ $\mathrm{S}_{3} \quad 66 \mathrm{c}$ व्राणा: ] $\mathrm{RA}_{3} \mathrm{~A}_{7} \mathrm{Bh}$, ॰त्राणां $\mathrm{S}_{1}$, ०त्राणा $\mathrm{S}_{3}$ 67a हहारसत्रा ] $\mathrm{A}_{3} \mathrm{~A}_{7} \mathrm{Bh}$, ०हेमचित्ता $S_{1}$, ०सूत्र $S_{3}$ (unmetrical) 67b ०पुत्रा: ] $S_{1} R_{3} A_{7} B h$, ०पुत्रा $S_{3}$ 67c ०धाति॰] $S_{1}^{p c} S_{3} R A$ $\mathrm{Bh}$, ०धा(धि०) $\mathrm{S}_{1}^{\mathrm{ac}}$ 67d नागा:] $\mathrm{S}_{1}^{\mathrm{pc}} \mathrm{RABh}$, नागा $\mathrm{S}_{1}^{\mathrm{ac}} \mathrm{S}_{3}$ - ०नर्ययुः ] $\mathrm{S}_{3} R A B h$, ०निर्ययु इति $\mathrm{S}_{1}$ (इति part of col.) Col. $\odot ॥$ स्कन्दपुराणे किड्करादेशने आध्याय शूर (in letter numerals)॥ $\odot \mathrm{S}_{1}, \odot \|$ स्कन्दपुराणे नामाध्याय: १०० (in letter numerals)॥ $\mathrm{S}_{3}$, इति स्कन्दपुराणे किड़करादेशनं नाम शततमोध्याय: $\mathrm{Bh}$ 
एकोत्तरशतो डध्याय:।

सनत्कुमार उवाच।

ते उभिनिर्गत्य वेगेन दंशिता दैत्यदानवाः।

वराहं प्रति संजग्मुर्मृगाः सिंहमिवातुराः ॥ ? ॥

ते वराहदृशा तेन नीयमानासुरेश्वरा:।

आभान्ति व्यास संबद्धाः प्रोक्षिताः पशवो यथा॥ २॥

तान्निहत्य कृतान्तेन मृत्युना चावपाशितान्।

निनाय स तदा दैत्यान्पशूनिव यथा नरः॥ ३॥

गत्वा ते योजनान्यष्टौ उत्तीर्णं सागराम्भसः।

वराहं ददृशुः सर्वे सिंह क्षुद्रमृगा इव॥ ४॥

ते मुहूर्तं निरीक्ष्यैन परिवत्रुः समन्ततः।

विस्फारयन्तश्चापानि संकुद्धा दैत्यदानवा: $\|y\|$

$1 b$ दंशिता ] दीपिता $R \quad 1 c$ वराहं ] वाराहं $R \quad 2 a$ ०दृशा ] ०द्विषा $R \quad 2 b$ नीयमानासुरेग्वरा: ] प्रेषयमाणा दिते: सुता: $R \quad 3 a$ तात्रिहत्य ] तान्विपद्य $R \quad 3 b$ चावपाशितान् ] चैव पालितान् $R$ $3 d$ न्पशूनिव ] ॰नपत्यानि $R$ • नर: ] नरा: $R \quad 4 a b$ न्यष्टौ उत्तीर्णं ] ॰न्यक्टौ +वु+उत्तीर्णा: $R$ (unmetrical) $4 c$ वराहं ] वाराहं $\mathrm{R} 4 \mathrm{~d}$ सिंहं ] सिहं $\mathrm{R} 5 \mathrm{c}$ ० स्फारयन्त $\left.{ }^{\circ}\right] \mathrm{R}^{\mathrm{ac}}$, ० स्फोरयन्त् $\mathrm{R}^{\mathrm{pc}}$ - ० श्चापानि ] ० ग्चास्यानि $\mathrm{R}$

1c प्रति सं०] संप्रति $\mathbf{A} 2 \mathrm{ab}$ ] om. A $2 \mathrm{c}$ आभान्ति ] आयान्ति $\mathbf{A}$ - संबद्धाः ] सन्नद्धाः $\mathbf{A}$ 3a तात्रि॰ ] तत्रि॰ $\mathbf{A} 3 \mathbf{b}$ मृत्युना चाव $\left.{ }^{\circ}\right]$ मृत्युपाशेन $\mathbf{A} 3 \mathbf{c}$ निनाय ] $\mathrm{A}_{7}$, निलाय $\mathrm{A}_{3} \mathrm{~A}_{4} 3 \mathbf{d}$ $\circ$ न्पशिनिव यथा नर: ] ॰न मसनिव यथानलः $\left\{{ }^{\circ}\right.$ नः $\left.\mathrm{A}_{7}\right\} \mathrm{A} \quad \mathbf{4 b}$ उत्तीर्णं] तत्तीरं $\mathrm{A}_{3} \mathrm{~A}_{7}$, ततीरं $\mathrm{A}_{4} \mathbf{5 a}$ मुहूत्त ] $\mathrm{A}_{3} \mathrm{~A}_{4}$, मूहूत्तं $\mathrm{A}_{7}$ ○ ०रीक्ष्यैनं ] $\mathrm{A}_{3}$, ०रीक्षैनं $\mathrm{A}_{4} \mathrm{~A}_{7}$ 5c विस्फार० ] $\mathrm{A}_{3} \mathrm{~A}_{4}$, विष्फार० $\mathrm{A}_{7}$

Manuscripts available for this chapter: $S_{1}$ photos $3.35 \mathrm{~b}$ (f. $157^{\mathrm{r}}$ ), 3.36a (f. $157^{\mathrm{v}}$ ) and $3.36 \mathrm{~b}\left(\mathrm{f}^{\mathrm{s} .} 158^{\mathrm{r}}\right.$ ); $\mathrm{S}_{3}$ f. $157^{\mathrm{r}}-158^{\mathrm{r}}$; R f. $174^{\mathrm{v}}-175^{\mathrm{r}} ; \mathrm{A}_{3}$ f. $103^{\mathrm{v}}-104^{\mathrm{r}} ; \mathrm{A}_{4}$ f. $147^{\mathrm{r}}-147^{\mathrm{v}} ; \mathrm{A}_{7}$ f. $146^{\mathrm{r}}-147^{\mathrm{r}}$.

$2\left(c^{4}-c^{5}\right) S_{1} \quad 4\left\langle a^{7}\right\rangle\left(a^{8}\right)\left\langle b^{1}\right\rangle\left(b^{2}-b^{3}\right) S_{3}$

1 सनत्कुमार उवाच ] $S_{1}^{\text {pc }} S_{3} R A B h$, om. $S_{1}^{\text {ac }}$ 1b दंशिता ] $S_{3} A B h$, दंसिता $S_{1}$ 1d ०र्मृगा: सिंहमि॰ $] S_{3} R A B h$, ०र्मृ $\left\{\circ\right.$ म्मु॰ $\left.S_{1}^{a c}\right\}$ गा सिंहानि॰ $S_{1}$ 2c व्यास संबद्धा: $S_{3} R$, (भ्याग)मम्बद्धा: $S_{1}^{\mathrm{pc}}$, व्यासमम्बद्धा $S_{1}^{\text {ac }}$, व्यास सन्नद्धा: $B h \quad 2 d$ प्रोक्षिताः ] RABh, प्रोक्षिता $S_{1} S_{3}$ 3a तात्रि॰] $S_{3} B h$ (em.?), ता नि॰ $S_{1} \quad 3 b$ ०पाशितान् ] $S_{3} A B h$, ०पाशिताम् $S_{1}$ 3c निनाय स ] $S_{1} S_{3}^{p c} R_{7} B h$, निनासय $S_{3}^{\text {ac }}$ 4b उत्तीर्ण ] $S_{1} B h, \simeq$ (त्तीर्णा) $S_{3}$ 4d सिंहं ] $S_{1} A B h$, सिंहा $S_{3}$ 5a मुहूर्तं ] $\mathrm{RA}_{3} \mathrm{~A}_{4} \mathrm{Bh}$, मूहूर्त्तन् $\mathrm{S}_{1}$, मूहूर्त्त $\mathrm{S}_{3}$ - ०रीक्ष्यैन ] $\mathrm{RA}_{3}$, ०रीक्ष्यैव $\mathrm{S}_{1} \mathrm{Bh}$, ०रिक्ष्यैन $\mathrm{S}_{3} \mathbf{5 b}$ परिवत्रुः ] $R A$, परिबभुस् $S_{1} B h$, परवव्तु: $S_{3} 5 c$ ०स्फारयन्तश्चा०] $S_{1} R^{a c} A_{3} A_{4} B h$, ०स्फारय+न्त+ चा॰ $S_{3}$ 
तानापतत एवाथ निरीक्ष्य स समन्ततः।

वराहेन्द्रस्तदा दैत्यान्प्राहेदं सुमहाबलः॥ ६॥

वराह उवाच।

किं मा यूयं दितेः पुत्रा अभिद्रवत सर्वशः।

दूषयामि न व: किंचिदसुह्रन्न च वो ह्यहम्॥ ७॥

अथैवंवादिनं दैत्या वराहं तं सुविस्मिता:।

पप्रच्छुः परिवार्यैव सर्वे दितिसुतास्तदा॥ ५॥

कस्त्वं वराहरूपीह तीर्त्वा सागरमूर्जितः।

इहागतः किमर्थं वा क्ष वा गन्तव्यमित्युत॥ ९॥

तेषां तद्वचनं श्रुत्वा वराहो उसौ महामना:।

उवाच दानवान्सर्वांस्तदा जलदनिस्वनः॥ १०॥

वराहो इहं यथा दैत्यास्तादृग्रूपं च पश्यत।

प्रचारार्थमिम देशमागतो ऽस्मि न संशयः ॥ १? ॥

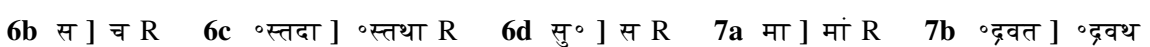
$R$ 7d ०दसुह्त्र च वो] ०दनुकूलचरो $R \quad 8 a$ अथैवं०] अथैन $R \quad 8 c$ पप्रच्छुः ] पपृच्छु: $R$

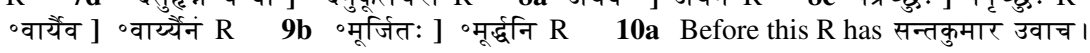

6b निरीक्ष्य स] निरीक्षंत $\left\{{ }^{\circ}\right.$ त: $\left.\mathrm{A}_{4}\right\} \mathbf{A}$ 6c ०स्तदा ] ०स्तथा $\mathbf{A}$ 6d ०महाबलः ] ममहाबला: $\mathbf{A}$ 7a मा ] मां $A$ 7c दूषयामि न व: ] भूयो यामि नर: $A$ 7d ०दसुह्त्र च वो ] ०दसु $\left\{{ }^{\circ}{ }^{\circ} \mathrm{A}_{3}\right.$ $\left.\mathrm{A}_{4}\right\}$ कृत्न तथा $\mathbf{A} \mathbf{8 b}$ तं] तु $\mathbf{A} \quad \mathbf{8 c}$ पप्रच्छुः ] पप्रच्छ $\mathrm{A}_{3}$, पपृच्छ $\mathrm{A}_{4}$, पपृच्छः: $\mathrm{A}_{7} \mathbf{8 d}$ सर्वे दितिसुतास्तदा ] दितिपुत्रास्तदा च तं \{नं $\left.\mathrm{A}_{4}\right\} \mathbf{A}$ 9a कस्त्वं ] कथं $\mathbf{A} \quad 9 \mathbf{b}$ तीत्व्वा ] तीर्ण: $\mathbf{A}$ ०मूर्जितः ] $\mathrm{A}_{7}$, ${ }^{\circ}$ मूर्छितः $\mathrm{A}_{3} \mathrm{~A}_{4}$ 9d क्ष वा गन्तव्यमित्युत ] क्ष गन्तव्यमितः पुनः $\mathrm{A}$ 10a Before this $\mathbf{A}$ has सन्तकुमार उवाच। $\bullet$ तेषां ] $\mathrm{A}_{4} \mathrm{~A}_{7}$, तस्य $\mathrm{A}_{3} \quad 10 \mathrm{~b}$ महामना: ] महाबला: $\mathbf{A}$ 11ab दैत्यास्ता०] $\mathrm{A}_{3} \mathrm{~A}_{4}$, दैत्यः ता॰ $\mathrm{A}_{7} 11 \mathrm{~b}$ पश्यत ] दृश्यते $\mathrm{A}$ 11c ०मिमं ] मिदं $\mathrm{A}$ 11d ०मागतो ] ०मायातो $\mathrm{A}_{4} \mathrm{~A}_{7}$, ${ }^{\circ}$ मयातो $\mathrm{A}_{3}$

7 $\left(a^{3}\right) S_{1},\left\langle\right.$ speaker indication- $\left.a^{6}\right\rangle\left(a^{7}-b^{2}\right) S_{3} \quad \mathbf{1 0}\left\langle a^{1}-a^{3}\right\rangle\left(a^{4}-a^{8}, c^{5}, c^{7}\right) S_{1} \quad \mathbf{1 1}\left(a^{6}\right) S_{1}$

6a ०पतत ] $S_{3} R A B h$, ०पतन $S_{1}^{p c}$, ०पतन्त $S_{1}^{\text {ac }}$ 6b निरीक्ष्य ] $S_{1}^{\text {pc }} S_{3} R B h$, निरीक्ष $S_{1}^{\text {ac }}$ 6d ०न्प्राहेदं ] $S_{1} R A B h$, ०न्प्राहेदं $S_{3} \quad 7 a$ दितेः ] RABh, दितै: $S_{1} \quad 7 b$ ०द्रवत ] $S_{1} S_{3} A$, ०द्रवथ $B h$ (em.) - सर्वशः ] $\mathrm{S}_{1} \mathrm{RABh}$, सर्व: $\mathrm{S}_{3}$ (unmetrical) 7d ॰दसुह्न्न ] $\mathrm{S}_{3} B h$ (em.?), ०दन्सुह्न्न $\mathrm{S}_{1}$ $8 \mathbf{a}$ अथैवं०] $A B h$, अथैन $S_{1}$, तथैवं० $S_{3} 8$ b वराहं ] $S_{3} R A B h$, वाराहन् $S_{1}$ ० विस्मिता: ] $S_{1}^{\mathrm{pc}} S_{3} R A B h$, ०विस्मिता $S_{1}^{\mathrm{ac}} \quad 8 \mathrm{c}$ पप्रच्छुः ] $\mathrm{S}_{1} \mathrm{Bh}$, प्रप्रच्छु $S_{3}^{\mathrm{pc}}$, प्रपच्छु $S_{3}^{\mathrm{ac}}$ 8d सर्वे दिति॰] $\mathrm{S}_{1} \mathrm{~S}_{3}^{\mathrm{pc}} \mathrm{RBh}$, सर्वदेति॰ $\mathrm{S}_{3}^{\mathrm{ac}} 9 \mathrm{~b}$ तीत्वा ] $\mathrm{S}_{1} \mathrm{RBh}$, त्रीत्वा $\mathrm{S}_{3}$ • मूर्जितः ] $\mathrm{S}_{3} \mathrm{~A}_{7}$, ०मूर्जिज्जतम् $\mathrm{S}_{1}$, ० मूर्जिम् Bh (typo, unmetrical) 9c-12b ] om. $S_{3} \quad 9 c$ इहागतः ] $S_{1}^{\text {pc }} R A B h$, इहागता $S_{1}^{\text {ac }}$ 9d ०मित्युत ] RBh (conj.?), ०मिच्युत $\langle:\rangle \mathrm{S}_{1} \quad \mathbf{1 0 b}$ महामना: ] RBh (em.?), महामना $\mathrm{S}_{1}^{\mathrm{pc}}$, महा(त्म)ना $S_{1}^{\text {ac }} \quad 10 \mathrm{c}$ उवाच] $S_{1}^{\text {pc }} R A B h$, उवा(द) $S_{1}^{\text {ac }} \quad 10 d$ जलद ${ }^{\circ} S_{1}^{\text {pc }} R A B h$, जलन० $S_{1}^{\text {ac }}$ $11 \mathrm{a}$ इहं यथा ] $\mathrm{S}_{1}^{\mathrm{pc}} \mathrm{RABh}$, हन्य(था) $\mathrm{S}_{1}^{\mathrm{ac}} \quad 11 \mathrm{ab}$ दैत्यास्ता॰ $] \mathrm{S}_{1}^{\mathrm{pc}} \mathrm{RA}_{3} \mathrm{~A}_{4} \mathrm{Bh}$, दैत्यस्ता $\mathrm{S}_{1}^{\mathrm{ac}} \quad 11 \mathrm{c}$ ॰मिमं ] $\mathrm{RBh}$ (em.), ०मिदन् $\mathrm{S}_{1}$ 
हृतभार्यों इहमन्येन विमना दैत्यपुंगवाः।

पर्यटंस्तस्य दुष्टस्य चिन्तयामि परिग्रहम् ॥ ?२॥

दानवा ऊचुः।

नायं प्रचारो युष्माकं दैत्यानामयमालयः।

अनादृत्य कथं दैत्यानिमं देशमुपागतः ॥ १३॥

वयं त्वाद्य वधिष्यामः सर्वे मृगकुलाधम।

हत्वा च ते नयिष्याम सर्वे दैत्येश्वरं प्रति॥ १४॥

ततस्ते दानवा: सर्वे तमायुधवरैर्भृशम्।

निजघु़ः: पर्वतं यद्वन्मेघा वृष्ट्या समुन्नताः ॥ १५ ॥

बलवान्सो ऊपि देवात्मा वराहः सुमहाबलः।

वध्यमानो ऽपि तान्देत्यानिदं वचनमब्रवीत् ॥ १६॥

न ह्यत्र भवतां किंचिदल्पमप्यसुरोत्तमाः।

अपराधं चकाराहं न करिष्ये करोमि वा॥ १७॥

12d चिन्तयामि परिग्रहम् ] चिन्तयानः सुनिग्रहम् $R \quad 13 b$ ०मालयः ] ॰माशय: $R \quad 13 d$ ०निमं देश० ] ०निद कूल० $R \quad 14 \mathrm{a}$ वयं त्वाद्य वधिष्यामः ] वयन्त्ववय वधिष्यामि $R \quad 14 \mathrm{~b}$ ०कुलाधम ] ०कुलाधमम् $R \quad 14 c$ हत्वा च ते नयिष्याम ] रुद्धा च त्वां नयिष्याम: $R \quad 15 d$ न्मेघा ] ॰न्मेघ॰ $R$ $16 \mathrm{a}$ देवात्मा ] देवानां $R \quad 17 \mathrm{a}$ ह्यत्र ] क्षुद्रा $R \quad 17 \mathrm{ab}$ किंचिदल्प॰] कश्चिदन्य॰ $R^{p c}$, किश्चिदन्य॰ $\mathrm{R}^{\mathrm{ac}} \quad 17 \mathrm{c}$ अपराधं ] अपचारं $\mathrm{R}$

12 ] om. $\mathrm{A} 13$ ऊचुः ] $\mathrm{A}_{3} \mathrm{~A}_{4}$, उचुः $\mathrm{A}_{7}$ 13a प्रचारो ] प्रचारे $\mathrm{A} \quad 13 \mathrm{~b}$ ०नामयमा॰] ॰नां अधमा० $A$ 13cd ] om. $A$ 14a त्वाद्य ] चाद्य $A$ - वधिष्याम: ] $A_{7}$, वधिष्याम $\mathrm{A}_{3} \mathrm{~A}_{4}$ 14b ०कुलाधम ] ०गणाधम $\mathrm{A}_{3}$, ०गणांधम $\mathrm{A}_{4}$, ०गणाधमः $\mathrm{A}_{7} 14 \mathrm{c}$ च ते नयिष्याम ] त्वां च \{ताच्च $\left.\mathrm{A}_{7}\right\}$ नयिष्याम: $A \quad 14 d^{3}-15 a^{8}$ ] om. $A_{4}$ (unmetrical) $15 d$ ०न्मेघा ] ०त् मेघो $A$ 16a बलवान्सो डपि देवात्मा ] अनाहत्य बलं सो पि $\left\{\right.$ सापि $\left.\mathrm{A}_{7}\right\} \mathrm{A} \quad 17 \mathrm{~b}$ ०दल्प०] ०दन्य० $\mathrm{A}_{3} \mathrm{~A}_{4}$, ०दन्या॰ $\mathrm{A}_{7}$

$12\left(a^{1}-a^{4}\right) S_{1} \quad 13\left\langle b^{4}-b^{5}\right\rangle S_{3}$

13 दानवा ऊचुः ] $\mathrm{RA}_{3} \mathrm{~A}_{4} \mathrm{Bh}$, दानव ऊ $\mathrm{S}_{1}$ (retraced), दानवा उ $\mathrm{S}_{3} \quad 13 d$ ०निमं ] $\mathrm{S}_{1} \mathrm{~S}_{3}^{\mathrm{pc}} \mathrm{Bh}$, ०निदं $\mathrm{S}_{3}^{\mathrm{ac}}$ - ०मुपागतः ] $\mathrm{S}_{1} \mathrm{RBh}$, ०मिहागत: $\mathrm{S}_{3}$ 14a वधिष्याम: ] $\mathrm{S}_{1} \mathrm{~A}_{7} \mathrm{Bh}$, वधिष्यामि $\mathrm{S}_{3}$ 14b ०कुलाधम ] em. Bh (silently), ॰कुलाधम: $\mathrm{S}_{1} \mathrm{~S}_{3} \quad \mathbf{1 4 c}$ ते ] $\mathrm{S}_{1} \mathrm{~S}_{3}$, त्वां $\mathrm{Bh}$ (em.) • नयिष्याम ] $\mathrm{S}_{1} \mathrm{~S}_{3}^{\mathrm{pc}}$, नयिष्यामि $\mathrm{S}_{3}^{\mathrm{ac}}$, हि नेष्यामः $\mathrm{Bh}$ (conj.) 15a दानवा:] $\mathrm{S}_{1} \mathrm{RA}_{3} \mathrm{~A}_{7} \mathrm{Bh}$, दानवा $\mathrm{S}_{3}$ 15c निजघुः ] $S_{1}^{\text {pc }} R A B h$, निजघु $\langle$ प $\rangle+:+S_{1}$, निर्जघुः $S_{3}^{\text {pc }}$, निर्जर्धु: $S_{3}^{\text {ac }}$ 15d ०न्मेघा ] $S_{3} B h(e m . ?)$, न्मेघ॰ $S_{1}$ - समुन्नता: ] $S_{1} S_{3} R A$, समुद्धता: Bh (conj.) $16 \mathbf{b}$ ०महाबलः ] $S_{1} R A B h$, ०माहाबल: $S_{3}$ (unmetrical) $16 \mathbf{c}$ वध्यमानो ] $S_{3} R A B h$, बद्यमानो $S_{1}^{p c}$, बद्यामानो $S_{1}^{\text {ac }} \quad 17 b$ ०दल्पम०] $\mathrm{S}_{1}^{\mathrm{pc}} \mathrm{S}_{3} \mathrm{Bh}, \quad \circ$ (प)म० $\mathrm{S}_{1}^{\mathrm{ac}}$ 
किमर्थं मां शितै: शस्त्रैर्घत सर्वे यथा परम्।

न हि नो वैरमस्तीह न च कार्यं मया हि वः॥ ?५॥

अथ मांसेन कृत्यं वो ततो मा घ्त दानवाः।

यथाप्राणं शितैः शस्त्रैर्युष्मत्तो न हि मे भयम्॥ १९॥

एतौ करौ प्रसार्याहं संस्थितो दितिनन्दनाः।

यदा भवन्तः स्थास्यन्ति तदा हन्तास्मि वः सकृत्॥ २०॥

अद्य वेत्स्यत दैतेया मृगाणामपि यद्वलम्।

मत्ता यूयं सुराज्जित्वा तन्मदं नाशयामि वः॥ २? ॥

सनत्कुमार उवाच।

ततः स भगवान्व्यास शक्रध्वजनिभौ भुजौ।

प्रसार्य तस्थावुद्यन्वै भगवानिव भास्करः॥ २२॥

ते उपि तद्वचनं ग्रुत्वा दानवा: कोधमूर्छिताः।

निजघुर्भृशमायस्ता नानाशस्त्रास्त्रपाणयः॥ २३॥

$18 \mathrm{c}-19 \mathrm{~b}$ ] om. $\mathrm{R} 19 \mathrm{~d}$ ०र्युष्मत्तो न ] ०रायुधैर्न $\mathrm{R} 21 \mathrm{a}$ अद्य वेत्स्यत ] अन्तरीक्षे डथ $\mathrm{R} 21 \mathrm{~b}$ ॰मपि ] ॰मिव $R \quad 21 d$ तन्मदं ] तं मद $R \quad 23 c$ ॰मायस्ता ] ॰मायत्ता $R$

18a शितै: ] सितै: $A \quad 18 b$ ०र्द्रत ] $A_{3}$, ०र्श्रतः $A_{4} A_{7} 18 d$ मया हि ] ममाहि $A$ 19ab कृत्यं वो ततो मा ] कृत्य [०त्या० $\left.A_{4}\right\}$ र्था मां वै नि॰ $A \quad 19 c$ ०प्राणं ] पाशं $A_{3} A_{4}$, पापं $A_{7}$ - शितै: ] $\mathrm{A}_{3}$, सितै: $\mathrm{A}_{4} \mathrm{~A}_{7} 19 \mathrm{~cd}$ ०स्त्रै्युष्मत्तो ] $\mathrm{A}_{3}$, ०स्त्रै: पुष्यंतो $\mathrm{A}_{4}$, ०स्त्रै: पुष्पन्तो $\mathrm{A}_{7} 20 \mathrm{c}$ स्थास्यन्ति ] $\mathrm{A}_{3} \mathrm{~A}_{4}$, स्थाष्यन्ति $\mathrm{A}_{7}$ 21a वेत्स्यत ] वीक्षत $\mathrm{A}$ - दैतेया ] $\mathrm{A}_{3} \mathrm{~A}_{7}$, देतेया $\mathrm{A}_{4}$ 21b यद्वलम् ] यद्वली $A$ 21c ०सित्वा ] ०न् च्छित्वा $A$ 22b भुजौ] च तौ $A$ 22c तस्थावुद्यन्वै] $\mathrm{A}_{3} \mathrm{~A}_{4}$, स्थावुभौ $\mathrm{A}_{7}$ (unmetrical) 23a ऊपि] च $\mathbf{A}$ 23b दानवा: ] $\mathrm{A}_{3} \mathrm{~A}_{4}$, दानवा $\mathrm{A}_{7}$ 23c निजघु० $\mathrm{A}_{7}$, निर्जघgु० $\mathrm{A}_{3} \mathrm{~A}_{4}$ - ॰मायस्ता ] $\mathrm{A}_{3}$, ॰मायस्या $\mathrm{A}_{4}$, ०मायस्था $\mathrm{A}_{7}$

18a किमर्थं मां ] $S_{3} R A B h$, किमर्थ मा $S_{1} 18 \mathbf{b}$ ०र्घत ] $S_{1} R A_{3} B h$, ०र्घन: $S_{3}$ - यथा परम् ] $\mathrm{S}_{1}^{\mathrm{pc}} \mathrm{S}_{3} \mathrm{RABh}$, यथामरम् $\mathrm{S}_{1}^{\mathrm{ac}} \mathbf{1 8 c}$ हि नो ] $\mathrm{S}_{3} \mathrm{~A}$, हितो $\mathrm{S}_{1}$, हि वो Bh (conj.) 18d कार्यं] $\mathrm{S}_{1} \mathrm{ABh}$, कायां $\mathrm{S}_{3} \quad$ 19ab वो ततो ] $\mathrm{S}_{1} \mathrm{~S}_{3}$, वस्ततो Bh (em.?) 19b मा ] $\mathrm{S}_{1} \mathrm{~S}_{3}$, मां Bh (em.) - घ्नत दानवा: ] $S_{1}^{\mathrm{pc}} \mathrm{S}_{3} \mathrm{ABh}$, घात मानवा: $S_{1}^{\mathrm{ac}}$ 19d न हि ] $\mathrm{S}_{3} \mathrm{~A}$, न च $\mathrm{S}_{1}^{\mathrm{pc}} \mathrm{Bh}$, न्न च $\mathrm{S}_{1}^{\mathrm{ac}}$ 20c स्थास्यन्ति ] $\mathrm{S}_{1}^{\mathrm{pc}} \mathrm{S}_{3} \mathrm{RA}_{3} \mathrm{~A}_{4} \mathrm{Bh}$, स्थास्यान्ति $\mathrm{S}_{1}^{\mathrm{ac}}$ 21a वेत्स्यत ] $\mathrm{S}_{1}$, वैक्षत $\mathrm{S}_{3}$, वेत्स्यथ $\mathrm{Bh}(\mathrm{em}$.) • दैतेया ] $\mathrm{S}_{3} \mathrm{RA}_{3} \mathrm{~A}_{7} \mathrm{Bh}$, दैत्येया $\mathrm{S}_{1} 21 \mathbf{b}$ ०मपि ] $\mathrm{S}_{3} \mathrm{~A}$, ०मिव $\mathrm{S}_{1}$, ०मिह $\mathrm{Bh}$ (conj.) 21c मत्ता ] $\mathrm{S}_{1}^{\mathrm{pc}} \mathrm{S}_{3} \mathrm{RABh}$, मत्ता $\mathrm{S}_{1}^{\mathrm{ac}}$ - सुरास्जि॰] $\mathrm{S}_{1}^{\mathrm{pc}} \mathrm{S}_{3} \mathrm{RBh}$, सुरा जि॰ $\mathrm{S}_{1}^{\mathrm{ac}}$ 21d तन्मदं ] $\mathrm{S}_{1} \mathrm{~A}$, तर्मद $\mathrm{S}_{3}$, तं मदं $\mathrm{Bh}$ (conj.?) $22 \mathrm{~b}$ भुजौ] $\mathrm{R}$, शुभौ $\mathrm{S}_{1}$, भुजै $\mathrm{S}_{3}$, करौ $\mathrm{Bh}$ (conj.) $22 \mathrm{c}$ ववुद्यन्वै ] $\mathrm{S}_{1} \mathrm{~S}_{3}$ $\mathrm{RA}_{3} \mathrm{~A}_{4}$, ०वुद्यंचौ $\mathrm{Bh}$ (conj.) 22d भास्कर: ] $\mathrm{S}_{3} \mathrm{RA}$, शंकर: $\mathrm{S}_{1} \mathrm{Bh}$ 23b दानवा:] $\mathrm{RA}_{3} \mathrm{~A}_{4} \mathrm{Bh}$, दानवा $S_{1} S_{3} \quad 23 c$ निजघु $\left.{ }^{\circ}\right] S_{1} R_{7} B h$, निर्जघु ${ }^{\circ} S_{3}$ • ०मायस्ता ] $S_{1} A_{3} B h$, ०मायत्ता $S_{3}$ 
मेघैरिव महावायुर्गरुत्मान्भुजगैरिव ।

मृगैरिव यथा व्याप्रः शशै: सिंहशिशुर्यथा। हविषेवानलो दीप्रो गजो गोमायुभिर्यथा॥ २४॥ तथा स भगवान्व्यास वराहो नन्दिवर्धनः। तैरर्द्यमानो उगणयंस्तस्थावचलसंनिभः॥ २४॥ स यदा तै: शरैश्चैव गदामुसलकम्पनैः।

भिन्दिपालैर्भुसुण्डीभिः करवालैरयोमुखैः ॥ २६॥ एतैश्चान्यैश्च बहुभिर्वध्यमानो मृगेश्वरः। अदृश्यो विबभौ सर्वे तदा ते हर्षिता भृशम्॥ २७॥ सनत्कुमार उवाच। तेषां निनदतां व्यास वराहो नन्दिवर्धनः। शस्त्रकूटाद्विनिष्क्रम्य शिरांसि समपोथयत्॥ २५॥ कराभ्यां चरणाभ्यां च दंष्ट्राभिश्च विदारयन्। तन्मुक्तैरायुधैश्चापि चिच्छेदान्यान्ररास च॥ २९॥

24a महावायु॰ ] महाराहु॰ $R \quad 24 \mathrm{~cd}$ ] मेघैरिव यथा सूर्य्यः शनै: सिंहशिशुस्तदा $R \quad 24 \mathrm{e}$ हविषेवा० ] प्रविवेशा० $R \quad 24 f$ गोमायुभिर् ] गोमायुना $R \quad 25 a$ स] च $R \quad 25 c-28 b$ ] om. $R$

24a ०न्भुजगै०] $\mathrm{A}_{3} \mathrm{~A}_{4}$, ०न्तुजगै० $\mathrm{A}_{7} \quad 24 \mathbf{c}-\mathbf{f}$ ] om. $\mathrm{A}$ 25a तथा ] यथा $\mathrm{A}$ • व्यास ] विष्णुर् $A \quad 25 c$ तैरर्द्यमानो डगणयन् ] अर्दमानो [अर्द्धमाणो $\left.\mathrm{A}_{7}\right\}$ न गणयत् $A$ 25d ०स्थावचल॰ ] $\mathrm{A}_{3}$, ०स्थावचन० $\mathrm{A}_{7}$, ०स्थौ वचन० $\mathrm{A}_{4} \quad 26 \mathbf{a}$ यदा ] तदा $\mathrm{A} 26 \mathbf{b}$ ०मुसल० ] $\mathrm{A}_{4}$, ${ }^{\circ}$ मुषल॰ $\mathrm{A}_{3} \mathrm{~A}_{7} \bullet$ ०कम्पनै: ] $\mathrm{A}_{3} \mathrm{~A}_{4}$, ०कम्पलै: $\mathrm{A}_{7} 26 \mathrm{c}$ ०र्भुसुण्डीभि: ] ०र्भुशुं $\left\{{ }^{\circ}\right.$ शं० $\left.\mathrm{A}_{4}\right\}$ डीभिः $\mathrm{A}_{3} \mathrm{~A}_{4}$, ०र्भुषुभीत्ति: $\mathrm{A}_{7}$ (unmetrical) 27c अदृश्यो वि॰] अदृश्यथ $\mathrm{A}_{3} \mathrm{~A}_{4}$, अदृश्याथ $\mathrm{A}_{7} 28 \mathrm{c}$ शस्त्र०] अस्त्र० $A$ ०कूटाद्विनि॰ ] $\mathrm{A}_{3}$, ०कूटान् विनि॰ $\mathrm{A}_{4}$, ०कूटानवि॰ $\mathrm{A}_{7}$ 28d शिरांसि ] $\mathrm{A}_{3} \mathrm{~A}_{4}$, शिरांशि $\mathrm{A}_{7} 29 \mathrm{~b}$ दंष्ट्राभि॰ $\mathrm{A}_{3} \mathrm{~A}_{4}$, दंष्काभि० $\mathrm{A}_{7} 29 \mathrm{~d}$ ०दान्यात्ररास च ] ॰दान्यान् $\left\{\right.$ ल्यान् $\mathrm{A}_{3}$, ०न्तान् $\left.\mathrm{A}_{7}\right\}$ महासुरान् A

$28\left(c^{3}\right) S_{1}$

24ab ववयुर्गरुत्मान्भुजगैरिव ] $\mathrm{S}_{1} \mathrm{~A}_{3} \mathrm{~A}_{4} \mathrm{Bh}$, ०वायु शशैः सिड्हशिशुर्यथा $\mathrm{S}_{3} \quad 24 \mathrm{c}$ मृगैरिव यथा व्याघ्र: ] $S_{1}^{\mathrm{pc}} \mathrm{Bh}$, मृगैरिव यथा व्याघ्र $S_{1}^{\mathrm{ac}}$, मेघैरिव यथा वायुर $\mathrm{S}_{3}$ (cf. 24a) 24d शशैः सिंहशिशुर्यथा ] conj. (cf. $R$ and $24 b$ in $S_{3}$ ), शशैरिव यथा हरि: $S_{1} B h$, गरुत्मा भुजगैरिव $S_{3}$ (cf. 24b) $24 f$ गजो ] $S_{3} R B h$ (em.?), गजा $S_{1} \quad 25 c$ ०रर्द्यमानो ] $S_{1} B h$, ०रद्यमानो $S_{3} \quad 25 d$ ०संनिभः ] $S_{1} S_{3}^{p c}$ $\mathrm{ABh}$, ०सनिभ: $S_{3}^{\mathrm{ac}}$ (unmetrical) $26 \mathbf{a}$ तै: ] $\mathrm{S}_{1} \mathrm{ABh}$, तै $\mathrm{S}_{3} \quad \mathbf{2 6} \mathbf{b}{ }^{\circ}$ मुसल० $] \mathrm{S}_{1} \mathrm{~S}_{3} \mathrm{~A}_{4}$, ०मुशल० $\mathrm{Bh}$ (em.?) - ०कम्पनै: ] $\mathrm{S}_{3} \mathrm{~A}_{3} \mathrm{~A}_{4}$, ०पट्टसै: $\mathrm{S}_{1}$, ०पट्टिशै: $\mathrm{Bh}(\mathrm{em}$.$) 26c ०र्भुसुण्डीभिः ] \mathrm{S}_{1}$, ०र्भुसुण्ढीभि $S_{3}$, ०र्भुशुण्डीभि: $B h \quad 26 d$ ०मुखै: ] $S_{1}^{p c} S_{3} A B h$, ०मुखै $S_{1}^{\text {ac }}$ 27ab ०भिर्वध्य ० $S_{1}^{p c}$ $\mathrm{S}_{3} \mathrm{ABh}$, ०भिः (ब)ध्य॰ $\mathrm{S}_{1}^{\mathrm{ac}} \quad 27 \mathrm{~cd}$ सर्वे त॰ $] \mathrm{ABh}$, सर्व त० $\mathrm{S}_{1}$, सर्वस्त० $\mathrm{S}_{3}$ 27d हर्षिता] $\mathrm{S}_{1} \mathrm{ABh}$, हृषिता $\mathrm{S}_{3} \quad 28 \mathrm{a}$ तेषां ] $\mathrm{S}_{1} \mathrm{ABh}$, तेषा $\mathrm{S}_{3} \quad 28 \mathrm{c}$ ०कूटाद्वि॰ $\mathrm{S}_{3} R A_{3} B h$, ०कूटान्वि॰ $S_{1}$ 28d शिरांसि सम० ${ }^{\circ} S_{1} R_{3} A_{4} B h$, शिरस्वास्थिम॰ $S_{3}$ • ०पोथयत् ] $S_{3} R A B h$, ०पोथयन् $S_{1}$ 29b दंष्ट्राभि॰ ] $\mathrm{S}_{1} \mathrm{RA}_{3} \mathrm{~A}_{4} \mathrm{Bh}$, दृष्ट्राभि॰ $\mathrm{S}_{3}$ - विदारयन् ] $\mathrm{S}_{3} \mathrm{RA}$, विदारयत् $\mathrm{S}_{1}$, व्यदारयत् $\mathrm{Bh}(\mathrm{em}$., in a note Bh suggests विदारयन्) 29c तन्मुक्तै] $S_{1} R A B h$, तर्मुक्तै $S_{3} \bullet$ श्चापि ] $S_{3} R A$, श्चैव $\mathrm{S}_{1} \mathrm{Bh} \quad 29 \mathrm{~d}$ ॰दान्यान्] $\mathrm{S}_{3} \mathrm{RA}_{4} \mathrm{Bh}$ (em.?), ॰दान्या $\mathrm{S}_{1}$ 


\section{ते सर्वे करचरणैः स्वमुक्तशस्त्रैद्देंट्राभिर्नखमुखदारितास्तथैव। संक्षीणा बहुभिरिवोपभुज्यमाना द्रव्याणामतिनिचयाः सदा महान्तः॥ ३०॥}

इति स्कन्दपुराण एकोत्तरशतो डध्यायः ॥ १०१॥

30a ॰चरणै: स्वमुक्तशस्त्रैर ] चरणैर्युक्तशस्त्रा $R$ (unmetrical) $30 \mathrm{~b}$ ०र्नखमुख॰] ॰र्मुखवि॰ $R$ (unmetrical) 30d ॰मतिनिचया: सदा ] ॰मतिचयास्ते $\mathrm{R}$ (unmetrical) Col. इति स्कन्दपुराणे रेवाखण्डे इध्याय: $\mathrm{R}$

30a ०चरणै: स्वमुक्त०] वचरणैश्च्च युक्त॰ $\mathbf{A}$ (or मुक्त॰ in $\mathrm{A}_{7}$ ) 30b ] $\mathrm{A}_{3} \mathrm{~A}_{4}$, ०दंष्क्राभिर्न्नखदारितस्तथैव च $A_{7}$ (unmetrical) $30 \mathrm{c}$ ०रिवोप॰ ] ०रथोप॰ $A$ 30d ०मतिनिचया: सदा ] ॰मतिनिचया यया $\mathrm{A}_{3} \mathrm{~A}_{4}$, ०मभिनिचया यथा $\mathrm{A}_{7}$ Col. इति स्कन्दपुराणे एकाशीतिसाहस्रचां संहिताया इइति स्कंद० $\left.\mathrm{A}_{4}\right\}$ मम्बिकाखण्डे वराहहर्षो $\left\{\right.$ वराहर्षो $\left.\mathrm{A}_{7}\right\}$ नामाध्याय: $\mathrm{A} \pm$

30a ॰चरणै: स्व०] $\mathrm{S}_{3}$, ॰चरणैर्वि॰ $\mathrm{S}_{1}$, ॰चणैर्वि॰ Bh (typo, unmetrical) 30b ०र्दंष्ट्राभिर्नखमुख॰] $\mathrm{S}_{1} \mathrm{~A}_{3} \mathrm{~A}_{4}$, ० हैंष्टाभि मुख॰ $\mathrm{S}_{3}$ (unmetrical), ०दंष्ट्राभिर्मखमुख॰ $\mathrm{Bh}$ (typo?) • ०दारिता॰] $\mathrm{S}_{3} \mathrm{RA}_{3}$ $\mathrm{A}_{4} \mathrm{Bh}$, ०रादिता० $\mathrm{S}_{1}$ 30c संक्षीणा ] $\mathrm{S}_{1} \mathrm{RABh}$, सक्षीण $\mathrm{S}_{3}$ (unmetrical) 30d ०मतिनिचया: ] em., ०मतिनिचया $S_{1}$, ०मतिनिच $\langle(स)\rangle+$ या $+S_{3}$, ०मिव निचया: Bh (conj.) • महान्तः ] RABh, महान्तेति $\mathrm{S}_{1}^{\mathrm{pc}}$ (इति part of col.), महानेति $\mathrm{S}_{1}^{\text {ac }}$ (इति part of col.), महान्तं $\mathrm{S}_{3} \quad$ Col. $\odot ॥$ स्कन्दपुराणे किड्करयुद्धे आध्यायः शै६ (in letter numerals)॥ $\odot \mathrm{S}_{1}, \odot$ ॥ स्कन्दपुराणे नामाध्यायः १०१ (in letter numerals)॥ $\odot \mathrm{S}_{3}$, इति स्कन्दपुराणे किड्करयुद्धे एकोत्तरशततमोध्याय: $\mathrm{Bh}$ 
द्युत्तरशतो इध्यायः ।

सनत्कुमार उवाच।

अथ तात्रिहतान्सर्वान्वराहेणाभिवीक्ष्य तु।

एक: कृच्छ्राद्विनिर्मुको ह्यश्मकं पुरमागमत्॥ ? ॥

स गत्वा तत्सभाद्वारिमिदं वचनमब्रवीत्।

मुक्तकेशो रजोध्वस्तो रुधिरेणाभिसंत्रुतः ॥ ॥

निवेदयत भो दैत्या दानवेन्द्राय धीमते।

ये ते गता मृगेन्द्र तं द्रष्टुं ह्यसुरपुंगवाः।

ते हतास्तेन विक्रम्य सर्व एव दिते: सुताः ॥ ॥

मा प्रमादमगा दैत्य मावमस्था मृगेश्वरम्।

मा च कालं प्रतीक्षध्वं मृगं तं मा विजानत।

महानसौ न संदेहो जेतुं शक्यो न दानवै:॥ ४॥

$1 \mathrm{~b}$ वराहेणाभिवीक्ष्य तु ] कुमारेणाभिवीक्षि $\left\{{ }^{\circ}\right.$ क्ष० $\left.\mathrm{R}^{\mathrm{ac}}\right\}$ तः $\mathrm{R} 1 \mathrm{~cd}{ }^{\circ}$ को ह्यश्मकं पुरमागमत् ] ${ }^{\circ}$ क् कथस्चित् परमागतः $R$ 2a ०द्वारि॰] ॰द्वार॰ $R$ 2d ०संत्रुतः ] ०संयुतः $R$ 3b After this $R$ has two pādas reading द्वास्थो निवेदयदाइे प्रविश्य हि तमाज्ञा। $3 \mathrm{c}$ मृगेन्द्र तं] मृगेन्द्रत्वं $\mathrm{R} 3 \mathrm{3d}$ द्टुं ह्य०] दर्टुच्चा० $\mathrm{R} \quad \mathbf{4 a}$ ०मगा ] ०मगाद् R

$1 b$ वराहेणाभिवीक्ष्य ] $\mathrm{A}_{3}$, वराहेनाभिवी $\left\{\circ\right.$ री॰ $\left.\mathrm{A}_{4}\right\}$ क्ष $\mathrm{A}_{4} \mathrm{~A}_{7}$ 1c एक: ] $\mathrm{A}_{3} \mathrm{~A}_{4}$, एक $\mathrm{A}_{7}$ 1cd ०को

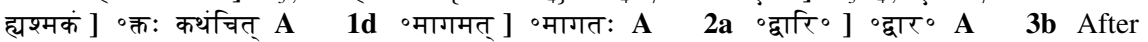
this $\mathbf{A}$ has two pādas reading द्वास्थो निवेदयत्प्राज्ञ प्रेरिताहातदायुधा: $\mathrm{A}_{3} \mathrm{~A}_{4}$, द्वारस्थो निवेदयात् प्राज्ञ प्रेरितात्तदायुधा: $\mathrm{A}_{7}$ (unmetrical) 3d दृष्टुं ] $\mathrm{A}_{3}$, दृष्टुं $\mathrm{A}_{4}$, दृष्णु $\mathrm{A}_{7} \mathbf{4 a}$ प्रमादमगा ] प्रसा \{०शा० $\left.\mathrm{A}_{7}\right\}$ दमपा $\left\{\circ\right.$ पाद् $\left.\mathrm{A}_{3}\right\} \mathbf{A} \quad \mathbf{4 b}$ मृगेश्वरम् ] ह्य $\left\{\right.$ न्व० $\left.\mathrm{A}_{7}\right\}$ गोचरं $\mathbf{A} \quad \mathbf{4 d}$ मा विजानत ] न विजानता $\left\{{ }^{\circ}\right.$ ता $\left.\mathrm{A}_{7}\right\} \mathbf{A}$

Manuscripts available for this chapter: $S_{1}$ photos $3.36 \mathrm{~b}\left(\right.$ f. $\left.158^{\mathrm{r}}\right), 4.2 \mathrm{a}\left(\mathrm{f} .158^{\mathrm{v}}\right.$ ) and $4.2 \mathrm{~b}\left(\mathrm{f} .159^{\mathrm{r}}\right.$ ); $\mathrm{S}_{3}$ f. $158^{\mathrm{r}}-159^{\mathrm{r}} ; \mathrm{R}$ f. $175^{\mathrm{r}}-176^{\mathrm{r}} ; \mathrm{A}_{3}$ f. $104^{\mathrm{r}}-105^{\mathrm{r}} ; \mathrm{A}_{4}$ f. $147^{\mathrm{v}}-148^{\mathrm{v}} ; \mathrm{A}_{7}$ f. $147^{\mathrm{r}}-148^{\mathrm{v}}$.

1 सन्तकुमार उवाच ] $\mathrm{S}_{1} \mathrm{RABh}$, om. $\mathrm{S}_{3}$ 1a अथ तात्रि॰ $] \mathrm{S}_{1}^{\mathrm{pc}} \mathrm{S}_{3} \mathrm{RABh}$, अथा तत्रि॰ $\mathrm{S}_{1}^{\mathrm{ac}} \mathbf{1 b}$ वराहेणा॰ $\mathrm{S}_{3} \mathrm{~A}_{3} \mathrm{Bh}$, वराहेना॰ $\mathrm{S}_{1}$ - ०वीक्ष्य ] $\mathrm{S}_{1}^{\mathrm{pc}} \mathrm{S}_{3} \mathrm{~A}_{3} \mathrm{Bh}$, ०वीक्ष $\mathrm{S}_{1}^{\mathrm{ac}}$ 1c एक: ] $\mathrm{S}_{1}^{\mathrm{pc}} \mathrm{S}_{3} \mathrm{RA}_{3}$ $\mathrm{A}_{4} \mathrm{Bh}$, एक $\mathrm{S}_{1}^{\mathrm{ac}} \mathbf{1 d} \circ{ }^{\circ}$ मागमत् ] $\mathrm{S}_{3}$, ०माविशम् $\mathrm{S}_{1}$, ${ }^{\circ}$ माविशत् $\mathrm{Bh}$ (em.?) 2a गत्वा तत् $\mathrm{S}_{3} \mathrm{RABh}$, गत्वा तं $\mathrm{S}_{1}^{\mathrm{pc}}$, ग(च्छ) तं $\mathrm{S}_{1}^{\mathrm{ac}} \quad \mathbf{2 a}{ }^{\circ}$ द्वारि॰ $] \mathrm{S}_{1} \mathrm{~S}_{3}^{\mathrm{pc}}$, ०द्वार॰ $\mathrm{S}_{3}^{\mathrm{ac}} \mathrm{Bh} \quad 2 \mathrm{2d}$ ०भिसंत्रुतः ] $\mathrm{S}_{3} \mathrm{ABh}$, ०ि स प्रुतः $\mathrm{S}_{1} \quad \mathbf{3 a}$ भो दैत्या ] $\mathrm{S}_{3} \mathrm{RABh}$, ता दैत्यो $\mathrm{S}_{1}$ 3b After this Bh has two pādas reading द्वाःस्थो न्यवेदयद्राज्ञे प्रेरितः सोद्यतायुधः। (conj.?) $3 c$ गता ] $S_{3} R A B h$, गत्वा $S_{1}$ 3d दृष्टुं ] $S_{1} R A_{3} B h$, दृष्टु $S_{3}$ - ०पुंगवा:] $S_{3} R A$, ०सत्तमा $S_{1}$, ०सत्तमा: Bh (em.?) 4a प्रमादमगा दैत्य $] \mathrm{S}_{3}$, प्रमादमगा $\left\{{ }^{\circ}\right.$ शा $\left.\mathrm{S}_{1}^{\mathrm{ac}}\right\}$ दैत्या $\mathrm{S}_{1}$, गा: प्रमादं दैत्येन्द्र $\mathrm{Bh}$ (conj.) $4 \mathbf{b}$ मावमंस्था ] $\mathrm{S}_{1} \mathrm{RABh}$, मावमस्था $\mathrm{S}_{3}$ - मृगेश्वररम् ] $\mathrm{S}_{1}^{\mathrm{pc}} \mathrm{S}_{3} \mathrm{RBh}$, मृगेश्वरां $\mathrm{S}_{1}^{\mathrm{ac}} \mathbf{4 c}$ कालं ] $\mathrm{S}_{3} \mathrm{RABh}$, काल $\mathrm{S}_{1}$ 4d विजानत ] $S_{3} R B h(e m$.$) , विजानतत् S_{1}$ 
सनत्कुमार उवाच।

तस्य तद्वचनं श्रुत्वा हिरणयाक्षो महासुरः।

स्वयमेवाभिसंकुद्ध उत्पपात तदासनात् $\|y\|$

सेन्द्रकेतुरिवोत्तस्थौ पयोद इव चोन्नदन्।

भृकुटीदूषितमुखः सधूमो उग्निरिव ज्वलन्॥ ६॥

अथोत्थितं तदा दैत्या विप्रचित्तिश्च दानवः।

प्रणम्योचुस्तदा दैत्यमिदं श्रक्ष्णपदाक्षरम्॥ ७॥

त्वं राजा सर्वदैत्यानां भूतानां च जयावहः।

तिष्टत्स्वस्मासु नोद्यन्तुं स्वयमेव त्वमर्हसि॥ ५॥

वयं तं सह देवैश्च ये च तस्याभिरक्षिणः।

हत्वा मांसं महाराज छित्वा तस्यानयामहे॥ १॥

आदित्यानां सरुद्राणां वसूनामश्विनोरपि।

भृगूणां पितृभिः सार्ध तथैवाड़्रिरसामपि॥ १०॥

$5 c$ मेवाभि॰ ] ०मेवाथ $R \quad 5 d$ तदासनात् ] च दानव: $R \quad 6 c$ ०दूषित० ] ॰भूषित० $R$ 7bc ] om. $R \quad 7 d$ ०मिदं ] इदं $R \quad 8 b$ जयावह: ] $R^{\mathrm{pc}}$, जयावह $\mathrm{R}^{\mathrm{ac}} \quad \mathbf{8 c}$ ०स्मासु नोद्यन्तुं ] ०स्मासु नो गन्तुं $\mathrm{R}^{\mathrm{pc}}$, ०स्मा - - $न$ न्तुं $\mathrm{R}^{\mathrm{ac}} \quad 9 \mathrm{c}$ मांसं ] मीस $\mathrm{R} \quad 9 \mathrm{~d}$ छित्वा ] जित्वा $\mathrm{R} \quad 10 \mathrm{a}$ आदित्या-

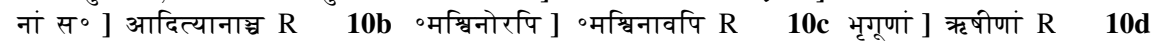
॰वाड़िर्रसामपि ] ॰वा(प्स)रसामपि $\mathrm{R}^{\mathrm{pc}}$, ०वासरसावपि $\mathrm{R}^{\mathrm{ac}}$

$5 \mathbf{c}$ ०संक्रुद्ध ] ०संप्राप्त $A \quad 6 a$ सेन्द्र०] इन्द्र० $A$ - ०वोत्तस्थौ ] $\mathrm{A}_{3} \mathrm{~A}_{4}$, ०वोत्तस्मा $\mathrm{A}_{7} 6 \mathbf{b}$ चोन्नदन् ] $\mathrm{A}_{3}$, चोन्नदत् $\mathrm{A}_{4} \mathrm{~A}_{7}$ 6c ०दूषित०] ०भीषित० $A$ 6d ०व ज्वलन् ] $\mathrm{A}_{3} \mathrm{~A}_{4}$, ०वोज्वलन् $\mathrm{A}_{7}$ 7b दानव: ] $\mathrm{A}_{3}$, दानवा: $\mathrm{A}_{4} \mathrm{~A}_{7}$ 7d श्रक्ष्णपदाक्षरम् ] सूक्ष्मपदाक्षरात् $\left\{\right.$ रान् $\mathrm{A}_{4}$, ०रत् $\left.\mathrm{A}_{7}\right\} \mathbf{A} \mathbf{8 a b}$ ०दैत्यानां भूतानां च जयावहः ] ०भूतानां दैत्यानां चाभयावहः $\left\{\right.$ ०ह $\left.\mathrm{A}_{7}\right\} \mathbf{A} 8 \mathrm{cc}$ तिष्ठत्स्वस्मासु नोद्यन्तुं ] तिष्ट $\left\{{ }^{\circ}\right.$ ट्ट $\mathrm{A}_{4}$ \}त्स्वस्वासु राजेंद्र $\mathrm{A}_{3} \mathrm{~A}_{4}$, तिष्ट उस्मासु गेजेन्द्र $\mathrm{A}_{7}$ (unmetrical) 9a देवैश्च ] दैवैश्च $\mathrm{A}_{4}$, ०दैवश्च $\mathrm{A}_{7}$, दैत्यैग्र $\mathrm{A}_{3} \quad 9 \mathrm{~b}$ तस्याभि०] $\mathrm{A}_{3} \mathrm{~A}_{4}$, तस्यापि $\mathrm{A}_{7}$ 9d छित्वा ] $\mathrm{A}_{7}$, स्थित्वा $\mathrm{A}_{3} \mathrm{~A}_{4}$ - ०स्यानयामहे ] ०स्यान $\left\{{ }^{\circ}{ }^{\circ} \mathrm{A}_{3} \mathrm{~A}_{4}\right\}$ याम्यहं $\left\{{ }^{\circ}\right.$ ह $\left.\mathrm{A}_{7}\right\} \quad \mathrm{A} \quad 10 \mathrm{~b}$ वसूनामश्विनोरपि ] वसूनामश्विनावपि $\mathrm{A}_{3} \mathrm{~A}_{4}$, वसुनस्वेनावपि $\mathrm{A}_{7}$ (unmetrical) $10 \mathrm{c}$ भृगूणां ] $\mathrm{A}_{3}^{\mathrm{pc}}$, भृगुणां $\mathrm{A}_{3}^{\mathrm{ac}} \mathrm{A}_{4}$, भृशुणां $\mathrm{A}_{7}$ - सार्धं ] $\mathrm{A}_{3} \mathrm{~A}_{4}$, सासार्द्ध $\mathrm{A}_{7}$ (unmetrical)

5b हिरण्याक्षो ] RABh, हिरण्या+क्षा+ $S_{1}$, हिरण्याक्ष्यो $S_{3}$ 5cd ॰क्रुद्ध उ०] $S_{1} R B h$, ०क्रुद्धरु० $S_{3}$ 5d तदासनात् ] $\mathrm{ABh}$, सदासनात् $S_{1}^{\mathrm{pc}}$, सदसनात् $S_{1}^{\mathrm{ac}}$ (unmetrical), तदासरात् $S_{3} \quad 6 \mathbf{a}{ }^{\circ}$ केतुरि॰] $\mathrm{S}_{1} \mathrm{RABh}$, केकुरि॰ $\mathrm{S}_{3}$ - ०वोत्तस्थौ] $\mathrm{S}_{3} \mathrm{RA}_{3} \mathrm{~A}_{4} \mathrm{Bh}$, ०वोर्त्तस्थौ $\mathrm{S}_{1}$ 6b पयोद इव ] $\mathrm{S}_{1}^{\mathrm{pc}} \mathrm{S}_{3} \mathrm{RA}$ $\mathrm{Bh}$, पयोदा इ $\mathrm{S}_{1}^{\mathrm{ac}}$ (unmetrical) - चोन्नदन् ] $\mathrm{RA}_{3} \mathrm{Bh}$, चोन्नदम् $\mathrm{S}_{1}$, चोन्नदत् $\mathrm{S}_{3}^{\mathrm{pc}}$, चोनदत् $\mathrm{S}_{3}^{\mathrm{ac}}$ 6c ॰मुखः ] $S_{1}^{\mathrm{pc}} \mathrm{S}_{3} \mathrm{RABh}$, ॰मुख $\mathrm{S}_{1}^{\mathrm{ac}}$ 6d ०व ज्वलन् ] $\mathrm{S}_{3} \mathrm{RA}_{3} \mathrm{~A}_{4} \mathrm{Bh}$, ०वोज्वलन् $\mathrm{S}_{1}^{\mathrm{pc}}$, ०वोज्वलम् $S_{1}^{\text {ac }} 7 \mathbf{a}$ अथोत्थितं ] $S_{1} R A B h$, अथोच्छितं $S_{3}$ - तदा ] $S_{1} S_{3} R A$, ततो Bh (conj.) • दैत्या ] $\mathrm{S}_{3} \mathrm{RABh}$, दैत्यो $\mathrm{S}_{1} \quad$ 7b दानव: ] $\mathrm{S}_{3} \mathrm{~A}_{3} \mathrm{Bh}$, दानव $\mathrm{S}_{1}$ 7cd दैत्यमि॰] $\mathrm{S}_{3} \mathrm{ABh}$, दैत्य इ० $\mathrm{S}_{1}^{\mathrm{pc}}$, दैत्या इ॰ $S_{1}^{\text {ac }}$ 7d श्रक्ष्ण०] RBh (em.?), श्रक्ष॰ $S_{1}$, सूक्ष्म० $S_{3}$ 8a राजा ] $S_{1} R A B h$, राज $\mathrm{S}_{3} \quad \mathbf{8 b}$ जयावह:] $\mathrm{S}_{1}^{\mathrm{pc}} \mathrm{R}^{\mathrm{pc}} \mathrm{Bh}$, जयावहम् $\mathrm{S}_{1}^{\mathrm{ac}}$, भयावह: $\mathrm{S}_{3} \quad \mathbf{8 c}$ तिष्ठत्स्वस्मासु ] RBh (em.?), तिष्टेस्वास्मासु $S_{1}$, तित्टस्वस्मासु $S_{3} 9 b$ तस्याभि०] $S_{1}^{\text {pc }} S_{3} R_{3} A_{4} B h$, तस्य भि० $S_{1}^{\text {ac }} 10 b$ ०मश्विनोरपि ] $\mathrm{S}_{3} \mathrm{Bh}(\mathrm{em}$.$) , ०मश्विनौरपि \mathrm{S}_{1} \quad \mathbf{1 0 c}$ भृगूणां ] $\mathrm{S}_{1}^{\mathrm{pc}} \mathrm{S}_{3} \mathrm{~A}_{3}^{\mathrm{pc}} \mathrm{Bh}$, (भग्र)णां $\mathrm{S}_{1}^{\mathrm{ac}}$ • ०भिः सार्ध ] $\mathrm{RA}_{3} \mathrm{~A}_{4} \mathrm{Bh}$, ०भिस्साद्ध $\mathrm{S}_{1}$, ०भि सार्द्ध $\mathrm{S}_{3}$ 
विश्वेदेवाश्च ये केचित्साध्या देवास्तथैव च।

यक्षाणां राक्षसानां च पिशाचानां महोरगैः॥ १?॥ गन्धर्वपक्षिणां चैव मानुषानां च दानव।

उद्युकानां समृत्यूनां लोकपालैः सहैव च॥ १२॥

शक्ता निवारणे दैत्या वधे चैव दुरात्मनाम्।

निग्रहे च यथाकालं स्वयं मा त्वमितो गमः।

हतमस्माभिरुद्युक्तः पश्याद्य दितिनन्दन ॥ १३॥

आज्ञापयति नो यत्र राजा स्वामी प्रजेग्वरः।

तद्वयं शिरसा सर्वे करिष्याम न संशयः॥१४॥

यदशक्ता वयं कार्यं सर्वे उप्यसुरपुंगव।

कर्तुं तस्य भवान्कर्ता मा नः पश्य परानिव॥ १४ ॥

मृगार्थे दनुदैत्यानां स्वयं राजा महाबलः।

निर्गतो नास्ति दैत्यानां वक्ष्यन्ते बलमित्युत॥ १६॥

$11 \mathrm{c}$ राक्षसानां च] रक्षसाख्वैव $R$ 11d महोरगै: ] महोरगा: $R$ 12b मानुषाणां च ] सर्पानास्चैव $R 13 d$ स्वयं मा त्वमितो गम: ] स्वयमात्ममितो गत: $R$ 13ef ०रुद्युक्तः पश्याद्य दिति $\left.{ }^{\circ}\right]$ ०रित्युक्तः पश्याम्यदिति $R \quad 14 d$ करिष्याम ] करिष्यामो $R \quad 15 a$ यदशका ] यदुका $R$ (unmetrical) 15c$16 b$ ] om. $R \quad 16 c$ निर्गतो नास्ति ] निर्गता मास्ति $R \quad 16 d$ वक्ष्यन्ते बलमित्युत ] वीक्षन्ते बलमच्युत $\mathrm{R}$

11a केचित् ] $\mathrm{A}_{4} \mathrm{~A}_{7}$, चित् $\mathrm{A}_{3}$ (unmetrical) 11d पिशाचानां ] $\mathrm{A}_{4}$, पिशाचाना $\mathrm{A}_{3} \mathrm{~A}_{7}$ 12a-14b ] om. $A$ 14c तद्वयं] $A_{7}$, तत्वयं $\mathrm{A}_{3} \mathrm{~A}_{4} 14 \mathrm{~d}$ करिष्याम] करिष्यामो $A$ 15a यदशक्ता ] यद्युका तु $A$ 15b ०पुंगव ] ॰पुंगवा: $A$ 15d परानिव] $\mathrm{A}_{7}$, पुरानिव $\mathrm{A}_{3} \mathrm{~A}_{4} \quad 16 \mathrm{a}$ दनु०] चैव $\mathrm{A}$ $16 d$ वक्ष्यन्ते बलमित्युत ] वक्षंत वनमित्यतः $\mathrm{A}_{7}$, वंधंत वनिमित्यतः $\mathrm{A}_{4}$, वंधं तव निमित्ततः $\mathrm{A}_{3}$

$11\left(d^{4}\right) S_{1},\left(d^{4}\right) S_{3} \quad 13\left(a^{1}-a^{2}\right) S_{1} \quad 14\left\langle c^{1}\right\rangle\left(c^{2}-c^{5}\right) S_{3}$

$11 \mathrm{a}$ केचित् ] $\mathrm{S}_{3} \mathrm{RA}_{4} \mathrm{~A}_{7} \mathrm{Bh}$ (em.?), केचि $\mathrm{S}_{1}$ 11d पिशाचानां महोरगै: ] $\mathrm{S}_{1}^{\mathrm{pc}} \mathrm{A}_{4}$, (र्वशो)च सम(रे ग) $\mathrm{S}_{1}^{\mathrm{ac}}$, महोर(गै): $\mathrm{S}_{3}$ (unmetrical), पिशाचानां सहोरगै: $\mathrm{Bh}$ (conj.) $\mathbf{1 2 b}$ मानुषाणां च] $\mathrm{S}_{3}$, मानुष्याणास्च $S_{1}$, मनुष्यानास्च Bh (em.?) - दानव ] RBh (em.?), दानव: $S_{1} S_{3}$ 13a शक्ता ] $\mathrm{S}_{1}^{\mathrm{ac}} ? \mathrm{~S}_{3} \mathrm{RBh}$, (शाका) $\mathrm{S}_{1}^{\mathrm{pc}}$ - निवारणे ] $\mathrm{S}_{1} \mathrm{RBh}$, निवारणै $\mathrm{S}_{3}$ 13d गमः ] $\mathrm{S}_{3} B$ h (conj.), गतः $\mathrm{S}_{1} \quad 13 \mathrm{e}$ ०रुद्युक्तः ] $\mathrm{S}_{1}^{\mathrm{pc} B h}$, ०रुद्युको $\mathrm{S}_{1}^{\mathrm{ac}}$, ०रुद्युक्त $\mathrm{S}_{3}$ 13f पश्याद्य] $\mathrm{S}_{3} B h$ (em.?), बश्याद्य $\mathrm{S}_{1}$ - ०नन्दन ] $S_{1}^{\mathrm{pc} R B h, ~ ० न न ् द न: ~} S_{1}^{\mathrm{ac}} S_{3} \quad$ 14a नो ] $S_{1} R B h$, भो $S_{3}$ 14b राजा ] $S_{1} R B h$, राज $S_{3}$ - प्रजेश्वर: ] $S_{3} R B h(e m . ?)$, प्रजेश्वर $S_{1} \quad 15 b$ उप्यसुर० ] $S_{1}^{\mathrm{pc}} S_{3} R A B h$, प्यंसुर॰ $S_{1}^{a c}$ - ०पुंगव ] RBh (em.?), ०पुड्रव: $S_{1} S_{3} \quad 15 d$ न: ] $S_{3} A B h$, न $S_{1} \quad 16 d$ मित्युत ] em. Bh (silently), मित्युत: $\mathrm{S}_{1} \mathrm{~S}_{3}$ 


\section{सनत्कुमार उवाच।}

ततः स राजा दैत्यानां सर्वानेव समादिशत्।

काले जलधरानिन्द्रो यथा भिन्नाअनत्विषः॥ १७॥

आज्ञां तस्य गृहीत्वैव ते ऊपि दैत्या मुदान्विताः।

संनह्यन्त महामाया वाहनानि च भेजिरे॥ १५ ॥

प्रह्लादश्चानुह्लादश्च शिनिर्बाष्कल एव च।

जम्भः कुजम्भो वातापी इल्वलो डथ विरोचनः॥ १९॥

बलिर्बाणश्च वातश्च शम्भुः काश्यप एव च।

शम्बरश्च महामायः कालशम्बर एव च॥ २०॥

प्रदीप्तश्चासिलोमा च सिलिकश्चैव दानवः।

शरभः शलभश्चैव धुन्धुर्मूकश्च दानवः॥ २? ॥

शतोदरश्च विख्यातस्तथैवान्यो हूदोदर:।

तारश्च तारकश्चैव मयो हालश्च विश्रुतः॥ २२॥

अजको नमुचिश्चैव व्यंसः कार्तस्वनः कुभः।

इल्वक: पिल्वकश्चैव विपाक: पाक एव च॥ २३॥

19b शिनिर्बाष्कल ए०] शिविर्बास्कलिरे॰ $R \quad 19 c-20 b$ ] om. $R \quad 20 d$ काल॰] सन: $R \quad 21 b$ सिलिक०] शिनिक० $R$ 21cd ] om. $R$ 22d हालश्च ] हानश्च $R$ 23a अजको] आजको $R$ 23b व्यंस: ] व्यस्व: $R$ • ०स्वन: कुभः ] ०स्वर: शुभ: $R$

17d भिन्नाअनत्विषः ] भिन्नांजनो दिशः $\mathrm{A}_{3} \mathrm{~A}_{4}$, भिद्यत् न्नाजलो दिशः $\mathrm{A}_{7}$ (unmetrical) 18cd ] om. A 19b शिनिर्बाष्कल ए० ] शिविर्बाष्क $\left\{{ }^{\circ}\right.$ क्षु० $\left.\mathrm{A}_{7}\right\}$ लिरे॰ $A$ 19cd ] om. A 20b शम्भुः काश्यप ] शुम्भः कश्यप A 20c-25b ] om. A

$17\left(a^{4}-b^{2}\right)\left\langle b^{3}-b^{8}\right\rangle S_{1} \quad 19\left(a^{2}\right) S_{1}$

17b समादिशत् ] RABh, समादिश $S_{3} 17 d$ भिन्नाजन०] $S_{1} R B h$, भिन्नांजना॰ $S_{3}^{p c}$, भिनांजना०

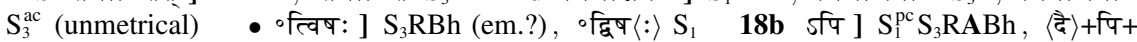
$S_{1}$ - मुदान्विताः ] RABh, मुदान्विता $S_{1} S_{3}$ 18c महामाया ] $S_{3} R$, महाकाया $S_{1} B h$ 19a

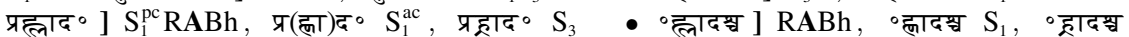
$\mathrm{S}_{3} \quad 19 \mathrm{~b}$ शिनि॰ ] $\mathrm{S}_{1}^{\mathrm{pc}} \mathrm{S}_{3} \mathrm{Bh}$, 〈नि $\rangle+$ शि+नि॰ $\mathrm{S}_{1}$ 19c जम्भः कुजम्भो ] $\mathrm{S}_{1}^{\mathrm{pc}} \mathrm{S}_{3} \mathrm{Bh}$, जम्भकुजम्भ $\mathrm{S}_{1}^{\mathrm{ac}}$ (unmetrical) 20b शम्भुः ] $\mathrm{S}_{3} \mathrm{Bh}\left(\mathrm{em}\right.$. ?), शम्भु $\mathrm{S}_{1}$ - काश्यप ] $\mathrm{S}_{1}^{\mathrm{pc}} \mathrm{S}_{3}$, का $\simeq$ प $\mathrm{S}_{1}^{\mathrm{ac}}$, कश्यप $\mathrm{Bh} 20 \mathrm{c}$ महामाय:] $\mathrm{R}$, महाकाया $\mathrm{S}_{1}$, महामाय $\mathrm{S}_{3}$, महाकाय: $\mathrm{Bh}(\mathrm{em} . ?)$ 21b सिलिक०] $\mathrm{S}_{3}$, सिलिता॰ $\mathrm{S}_{1}$, शिलिता॰ $\mathrm{Bh}\left(\mathrm{em}\right.$. ?) - दानवः ] $\mathrm{S}_{3} \mathrm{R}$, दानवा: $\mathrm{S}_{1} \mathrm{Bh}$ 21c शरभः ] $\mathrm{S}_{1}^{\mathrm{pc}} \mathrm{S}_{3}$ $\mathrm{Bh}$, शरभ $\mathrm{S}_{1}^{\text {ac }}$ (unmetrical) 22d हालग्च ] $S_{3}$, बालग्च $S_{1}$, कालग्च Bh (conj.?) 23b व्यंस: ] $\mathrm{S}_{3} \mathrm{Bh}$ (em.?), व्यंस $\mathrm{S}_{1}$ • कार्तस्वनः ] $\mathrm{S}_{1} \mathrm{Bh}$, कर्त्तास्वनः $\mathrm{S}_{3}^{\mathrm{pc}}$, कर्त्तास्वर: $\mathrm{S}_{3}^{\mathrm{ac}}$ • कुभः ] conj., शु (चि〉भ: $S_{1}$, स्वभ: $S_{3}$, शुभ: $B h \quad 23 c$ इल्वक: पिल्वक॰] $S_{3} R$, इल्वल+:+ बिल्वल० $S_{1}$, इल्वको विल्वक॰ Bh (conj.) 23d विपाक: ] $S_{3} R B h$ (conj.?), पिपाक+: $+S_{1}$ 
हस्ती दुर्योधनश्चैव विप्रचित्तिश्च दानवः।

हयग्रीवो मुर श्चैव नरक: कुण्ड एव च॥ २४॥

शकुनिर्वृषपर्वा च शतकेतुर्महारवः।

मकरश्चैव राहुश्च स्वर्भानुः काल एव च॥ २४॥

विराधश्च कबन्धश्च दुन्दुभिः शतदुन्दुभिः।

साल्वो दूमश्च द्वावेतौ मयूरग्रीव एव च॥ २६॥

कालनेमी मेघनादो महावीर्यः स चान्धकः।

महिषानन्दशमका आटिश्च बक एव च॥ २७॥

ततो दानवशार्दूला महामाया महाबलाः।

सर्वे महास्त्रविदुषो लब्धलक्षाश्च संयुगे॥ २५॥

रथैर्हयैर्गजै स्चैव तथैवान्ये पदातयः।

जग्मुर्वराहं तं व्यास हन्तुं देवा इवासुरम्॥ २९॥

स चापि हि महातेजा वराहो नन्दिवर्धनः।

स्तूयमानस्तथात्मस्थैर्मुनिभिर्वेगवान्बली॥ ३०॥

हत्वा तान्किंकरान्सर्वानश्मकं पुरमागमत्।

गर्जमानो यथा मेघो युगान्ते वृष्टिसर्जनः॥ ३? ॥

24a-26b ] om. R 26cd ] दुमो मयूरकश्चैव वाली सुग्रीव एव च $R \quad 27 a$ नेमी महानादो ] नेमिम्महावीय्यो R $27 \mathrm{~cd}$ ०शमका आटिश्च बक ए०] ${ }^{\circ}$ संवाह आन्धकश्चानुरे० $\mathrm{R} \quad 28 \mathrm{a}$ ततो दानवशार्दूला ] एते प्रचलिता दैत्या $R \quad 28 d$ लब्ध०] शिक्ष० $R \quad 29 \mathrm{ab}$ हरयैर्गजैस्चैव तथैवान्ये ] ${ }^{\circ}$ हारैवैद्वाजिभिश्च तथा$\begin{array}{lll}\text { न्ये ये } \mathrm{R} 29 \mathrm{~cd}] \text { मेनिरे तं हतं व्यास शार्दूल इव शूकरम् } \mathrm{R} & 30 \mathrm{a} \text { हि ] च } \mathrm{R} & 30 \mathrm{c} \text { ०स्तथात्मस्थैर् ] }\end{array}$ ०स्तदा तस्थौ $\mathrm{R} 31 \mathrm{~b}$ ०नश्मकं पुरमागमत् ] ०न् दैत्यस्य वरमासितः $\mathrm{R}$

25cd ] om. $\mathrm{A}_{3} \mathrm{~A}_{4}$ 26a विराध०] $\mathrm{A}_{4}$, विवाध॰ $\mathrm{A}_{3}$, विनाध० $\mathrm{A}_{7}$ 26b After this $\mathbf{A}$ has 103.4a-17d ${ }^{3}$, preceded by two additional pādas and a speaker indication. $26 \mathbf{c}-\mathbf{2 7 d ^ { 3 }}$ ] om. A 28d ०लक्षाश्च ] ०वल्काश्च $\mathrm{A}_{3} \mathrm{~A}_{4}$, ०बन्धाश्च $\mathrm{A}_{7} 29 \mathrm{~d}$ देवा इवासुरम् ] देवान्सवासवान् $\mathrm{A} 30 \mathrm{c}$ ०थात्मस्थैर् ] $\mathrm{A}_{3} \mathrm{~A}_{4}$, ०थात्मस्थै $\mathrm{A}_{7} \quad 31 \mathrm{~b}$ ०नश्मकं ] ०न् दैत्यस्य $\mathbf{A}$

27 $\left(b^{7}\right) S_{1} \quad 31\left(c^{2}-c^{3}\right) S_{1}$

24d कुण्ड ] $S_{1} B h$, कुण्ठ $S_{3} 25 b$ शतकेतुर् ] $S_{1} B h$, शतकेतु $S_{3} \quad 25 c$ मकर०] $S_{3} A_{7}$, मरक॰ $\mathrm{S}_{1} \mathrm{Bh} 26 \mathrm{a}$ विराध०] $\mathrm{S}_{1} \mathrm{~A}_{4} \mathrm{Bh}$, विरध० $\mathrm{S}_{3} 26 \mathbf{c}$ साल्वो ] $\mathrm{S}_{1} \mathrm{~S}_{3}$, शाल्वो $\mathrm{Bh}$ (em.?) $27 \mathbf{b}$ चान्धक: ] $S_{3} R B h(e m$.$) , वा(न्ध)क: S_{1}^{\text {pc }}$, वा $\sim$ क: $S_{1}^{\text {ac }}$ 27d आटिश्च ] conj., वाटिश्च $S_{1} S_{3} B h$

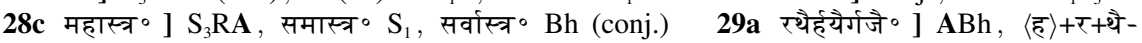
हयै ग $\left\{\right.$ ०र्ग० $\left.\mathrm{S}_{1}^{\mathrm{ac}}\right\}$ जै० $\mathrm{S}_{1}$, रथै गजै हयै० $\mathrm{S}_{3} \quad 29 \mathrm{~b}$ ०वान्ये $] \mathrm{S}_{1}^{\mathrm{ac}} \mathrm{ABh}$, ०वान्यैर् $\mathrm{S}_{1}^{\mathrm{pc}}$, वान्यो $\mathrm{S}_{3}$ 29c जग्मुर्] $S_{1} A B h$, जग्मु $S_{3}$ (unmetrical) 29d हन्तुं] $S_{1} A B h$, हन्तु $S_{3}$ 30a महातेजा ] $\mathrm{S}_{1} \mathrm{RABh}$, महातेज $\mathrm{S}_{3} \quad 30 \mathrm{c}$ ०थात्मस्थैर् ] $\mathrm{S}_{3} \mathrm{~A}_{3} \mathrm{~A}_{4} \mathrm{Bh}$, ०थान्मस्थै $\mathrm{S}_{1}$ 30d ०र्वेगवान् ] $\mathrm{S}_{3} \mathrm{RA}$, ०र्वागवां $S_{1}$, ०र्भगवान् Bh (conj.?) 31a तान् ] $S_{1}^{\text {pc }} S_{3} R A B h$, नां $S_{1}^{\text {ac }}$ 31b न्मक्मक ] $S_{3} B h$ (conj.), ॰नस्माकं $S_{1}$ 31c मेघो] $S_{1} R A B h$, मेघा $S_{3}$ 31d युगान्ते ] $S_{3} R A B h$, युगान्तो $S_{1}$ - वृष्टिसर्जन: ] $S_{1} R A B h$, वृष्टिर्वर्षण: $S_{3}$ (unmetrical) 
स गत्वा तं तदा व्यास पुरं लोकमयः प्रभुः ।

अवसव्यं परावृत्य दक्षिणं द्वारमागमत्॥ ३२॥

दक्षिणद्वारिभिस्तत्र दानवैर्बहुभिर्भृशम्।

कृतो हलहलाशब्दो नगरं येन कोपितम्॥ ३३॥

सो उपि भित्त्वा शतछीश्च कवाटं कूटमुद्रान्।

कालचक्राणि यन्त्राणि सो उवचूर्णयदव्ययः ॥ ३४॥

अथाजग्मुर्भृशाविष्टास्ते दानवमहारथाः।

शस्त्रवर्षणण चोग्रेण छादयन्तो मृगेश्वरम्॥ ३४ ॥

स शक्तितोमरशतैर्भिन्दिपालैश्च ताडितः।

द्वारं त्यत्काभिनिर्गम्य समां भूमिमपाश्रितः ॥ ३६॥

ते उपि तं भग्नमित्येव विजानन्तो उसुरास्तथा।

पृष्टतो ऽनुययुर्व्यास तक्षयन्तो वरायुधैः॥ ३७॥

32a गत्वा तं तदा ] तु गत्वा पुनर् $R \quad 32 b$ लोकमयः ] दैत्यपते: $R \quad 32 c$ अवसव्यं ] अथ संव्या $R$ $32 d$ मागमत् ] ०मागतः $R$ 33c हलहला०] हनहना० $R$ 33d येन कोपितम् ] तेन कम्पितम् $R$ 34a भित्त्वा ] भड्कवा $R \quad 34 b$ कवाटं ] कपाटं $R \quad \bullet$ मुद्धरान् ] ${ }^{\circ}$ मुद्धरम $R^{\mathrm{pc}}$ (unmetrical), मुद्धरम् $\mathrm{R}^{\mathrm{ac}} 34 \mathrm{c}$ काल॰ ] न स $\mathrm{R}$ • यन्त्राणि] मन्दानि $\mathrm{R}$ 34d उवचूर्णय॰] प्यचूर्णय ० $\mathrm{R} 35 \mathrm{~b}$ ०महारथा: ] ॰महाबला: $R \quad 35 \mathrm{c}$ शस्त्र॰ ] शर॰ $R \quad 36 \mathrm{a}$ स ] सु॰ $\mathrm{R} 36 \mathrm{~b}$ ० पालैश्च ] ०पालै: स $R$ 36d समां भूमिमपाश्रितः ] समभूमिगतस्ततः $R$ 37a भग्नमित्येव ] भस्ममित्येवं $R$ 37b ॰स्तथा ] ॰स्तदा $R$ 37d तक्षयन्तो] धक्षयन्तो $R^{\mathrm{pc}}$, रक्षयन्तो $\mathrm{R}^{\mathrm{ac}}$

32b लोकमयः ] लोकमयं $A \quad 32 \mathrm{c}$ अव०] अथ $\mathrm{A} \quad 33 \mathrm{a}$ दक्षिण॰] $\mathrm{A}_{3}$, दक्षिणं $\mathrm{A}_{4} \mathrm{~A}_{7} \quad 33 \mathrm{c}$ हलहला० ] हलाहलो $\mathrm{A}_{3} \mathrm{~A}_{4}$, हनाहना० $\mathrm{A}_{7} \quad 33 \mathbf{d}$ कोपितम् ] क्षोभितं $\mathrm{A} \quad 34 \mathbf{a}$ भित्त्वा ] गत्वा शतघ्रीय्च ] शतघीस्तु $\mathrm{A}_{3} \mathrm{~A}_{4}$, शतघीन्तु $\mathrm{A}_{7} 3 \mathrm{3} \mathrm{b}$ कवाटं ] कवटात् $\mathrm{A}_{3}$, कवटान् $\mathrm{A}_{4}$, कवचान् $\mathrm{A}_{7} \mathbf{3 4 c}$ यन्त्राणि ] मन्त्रांश्च $A$ 34d उवचूर्णय॰] प्यचूर्णयय $\mathrm{A}_{7}$, प्यच्छंतुय॰ $\mathrm{A}_{3} \mathrm{~A}_{4}$ 35a अथाजग्मु॰] अथाजघु० $A$ 35b दानवमहारथा: ] दानवा महाबला: $A$ 36a स ] $\mathrm{A}_{4} \mathrm{~A}_{7}$, श $\mathrm{A}_{3} \bullet{ }^{\circ}$ तोमरशतैर् ] $\circ$ तोमरैश्चुक्रै $\left\{\circ\right.$ कै $\left.\mathrm{A}_{7}\right\} \quad \mathbf{A}$ 36cd ] द्वारं $\left\{\circ \mathrm{A}_{3}\right\}$ त्यत्का $\left\{\circ\right.$ का $\left.\mathrm{A}_{7}\right\}$ समां भूमिं निर्गत्य समुपस्थितः $A$ 37 $a^{\circ}$ त्येव ] ०त्येवं $A$ 37c पृष्ठतो ] $A_{3}$, पृष्टतो $\mathrm{A}_{4} \mathrm{~A}_{7} 37 \mathbf{d}$ तक्षयन्तो ] भक्षयन्तो $A$ वरायुधै: ] वराग्रवै: $\mathrm{A}_{3} \mathrm{~A}_{4}$, वराग्रमै: $\mathrm{A}_{7}$

$32\left\langle\mathrm{c}^{1}\right\rangle\left(\mathrm{c}^{2}-\mathrm{c}^{3}\right) \mathrm{S}_{1}$

32a तं तदा ] $\mathrm{S}_{1} \mathrm{~S}_{3} \mathrm{~A}$ (तन्त॰ or तत्त॰ in $\mathrm{S}_{1}$ ), तत्तदा $\mathrm{Bh}$ 32b लोकमयः ] em. Bh (silently), लोकमयं $S_{1}$, लोहमयं $S_{3} \quad 32 \mathrm{c}$ अवसव्यं ] $S_{3}, \simeq$ (वस)व्यम् $S_{1}$ (upper parts of वस or पस lost), अपसव्यं $\mathrm{Bh}$ (conj.?) 32d ०मागमत् ] $\mathrm{S}_{1} \mathrm{ABh}$, ०मागत $S_{3} \quad 33 \mathbf{b}$ दानवैर ] $S_{1} R A B h$, दानवै $\mathrm{S}_{3}$ - ०र्भृशम् ] $\mathrm{S}_{3} \mathrm{RABh}$, ०वृतम् $\mathrm{S}_{1}$ 33c हलहला॰] $\mathrm{S}_{3}$, हलाहला॰ $\mathrm{S}_{1} \mathrm{Bh}$ 34a सो ऊपि ] $\mathrm{S}_{3} \mathrm{RA}$, यो हि $\mathrm{S}_{1} \mathrm{Bh}$ - शतघीश्च ] $\mathrm{S}_{1} \mathrm{RBh}$, शतघी च $\mathrm{S}_{3} \quad \mathbf{3 4 b}$ कवाटं ] $\mathrm{S}_{1} B h$, कपाटं $S_{3}$ 34c यन्त्राणि ] $\mathrm{S}_{1} \mathrm{Bh}$, यत्राणि $\mathrm{S}_{3}$ 34d उवचूर्णय॰] $\mathrm{S}_{1} \mathrm{~S}_{3}$, वाचूर्णय॰ $\mathrm{Bh}$ (em.) 35a अथाजग्मु॰] $\mathrm{S}_{1} \mathrm{RBh}$, तथाजघुल $\mathrm{S}_{3} \quad 35 \mathrm{~b}$ ०महारथा: ] $\mathrm{S}_{1} \mathrm{Bh}$, ०महारथा $\mathrm{S}_{3}$ 35d मृगेश्वरम् ] $\mathrm{S}_{1}^{\mathrm{pc}} \mathrm{S}_{3} \mathrm{RABh}$, मुगेश्वरम् $S_{1}^{\text {ac }} 36 \mathbf{a}$ स शक्तितो॰ $\mathrm{S}_{3} \mathrm{~A}_{4} \mathrm{~A}_{7}$, अशक्तिन्तो॰ $\mathrm{S}_{1}$, अथ तैस्तो॰ $\mathrm{Bh}$ (conj.) $36 \mathbf{a b}$

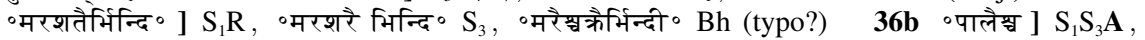
०पापालैग्य $\mathrm{Bh}$ (typo, unmetrical) $36 \mathrm{c}$ ०रं त्यत्काभि॰] $\mathrm{S}_{3} \mathrm{R}$, ०रन्त्यक्तानि $\mathrm{S}_{1}$, ०रं त्यत्का वि० $\mathrm{Bh}$ (conj.) 36d ॰मपाश्रितः ] $\mathrm{S}_{1} \mathrm{~S}_{3}$, ०मुपाश्रितः Bh (conj.?) 37b ०स्तथा ] $\mathrm{S}_{1}^{\text {ac }} \mathrm{S}_{3} \mathrm{~A}$, ०स्तदा $\mathrm{S}_{1}^{\mathrm{pc}} \mathrm{Bh} 37 \mathrm{c}$ पृष्ठतो ] $\mathrm{S}_{1} \mathrm{RA}_{3} \mathrm{Bh}$, पृष्टतो $\mathrm{S}_{3}$ 
स तक्ष्यमाणः शरवृष्टितोमरैर्महागदाभिर्मुसलैरयोमुखैः ।

तदाभिनिःसृत्य दितेः सुतानसावयोधयद्देवगणैरधिष्टितः॥ ३५॥

इति स्कन्दपुराणे द्वुत्तरशतो डध्यायः॥ १०२॥

$38 \mathrm{a}$ तक्ष्यमाणः ] धक्ष्यमाणः $\mathrm{R} 38 \mathrm{~b}$ ०र्मुसलै०] ०र्मुषलै० $\mathrm{R} 38 \mathrm{~cd}$ दितेः सुतानसावयोधयद् ] स तान्दितेः सुतानपोथयद् $R$ - ०रधिष्टितः ] ०रभिस्तुतः $R$ Col. इति स्कन्दपुराणे रेवाखण्डे इध्यायः $\mathrm{R}$

38a तक्ष्यमाणः ] भक्षमानः A $38 \mathrm{~b}$ ०म्मुसलै०] ०र्मुषलै० $\mathrm{A} \quad 38 \mathrm{c}$ ०निःसृत्य ] ०निसृत्य $\mathrm{A}_{3} \mathrm{~A}_{4}$ (unmetrical), ०निःसृह्य $\mathrm{A}_{7} \bullet$ सुतानसा॰ ] सुतालसा॰ $\mathrm{A}_{3} \mathrm{~A}_{4}$, सुतानासा॰ $\mathrm{A}_{7}$ (unmetrical) 38d ०वयोधयद् ] ०वपोथयद् $\mathrm{A}_{7}$, ०वयोथयद् $\mathrm{A}_{3} \mathrm{~A}_{4}$ - ०रधिष्टितः ] $\mathrm{A}_{3} \mathrm{~A}_{4}$, ०रधिष्टितः $\mathrm{A}_{7}$ Col. इति स्कन्दपुराणे एकाशीतिसाहस्रचां संहिताया $\left\{\right.$ इति स्कंद॰ $\left.\mathrm{A}_{4}\right\}$ मम्बिकाखण्डे $\mathbf{A}$

$38\left(a^{1}\right) S_{3}$

38a स ] $\mathrm{S}_{1} \mathrm{~S}_{3}^{\mathrm{pc}} \mathrm{RABh}$, त $\mathrm{S}_{3}^{\mathrm{ac}}$ • तक्ष्यमाणः ] $\mathrm{S}_{1}^{\mathrm{pc}} \mathrm{S}_{3} \mathrm{Bh}$, तक्ष्यमाण $\mathrm{S}_{1}^{\mathrm{ac}}$ (unmetrical) • ०तोमरैर् ] $\mathrm{S}_{1} \mathrm{RABh}$, ०तोमरै $\mathrm{S}_{3} \quad \mathbf{3 8 b}$ ०र्मुसलै॰] $\mathrm{S}_{1} \mathrm{~S}_{3}$, ०र्मुशलै॰ $\mathrm{Bh}(\mathrm{em} . ?) \quad 38 \mathbf{c}$ ॰निःसृत्य ] $\mathrm{RBh}$ (em.?), ०निसृत्य $S_{1} S_{3}$ (unmetrical) - दितेः ] $\mathbf{A B h}$, दिते $S_{1} S_{3} \quad 38 d$ ०वयोधयद् ] $S_{1} B h$, ०वयोधय $\mathrm{S}_{3}$ (unmetrical) - ०रधिष्टितः ] $\mathrm{A}_{3} \mathrm{~A}_{4} \mathrm{Bh}$, ०रधिष्टितेति $\mathrm{S}_{1}$ (इति part of col.), ०रधिष्टितः $\mathrm{S}_{3}$

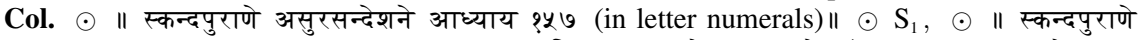
नामाध्याय: १०२ (in letter numerals)॥ $\odot \mathrm{S}_{3}$, इति स्कन्दपुराणे असुरसन्देशनं नाम द्युत्तरशततमोध्याय: $\mathrm{Bh}$ 
त्युत्तरशतो उध्यायः।

\author{
सनत्कुमार उवाच। \\ अथ व्यास समां भूमिं संप्राप्तान्दानवर्षभान्। \\ उवाच सर्वान्गम्भीरं मृगान्सिंह इवाजने॥ ? ॥ \\ भवन्तो दानवा: सर्वे दैत्याश्च सुमहाबलाः। \\ मया मृगेण समरे युध्यतां तु पुनर्भृशम्॥ २॥ \\ न लज्जा समरे उस्त्यद्य युष्माकं दानवेश्वराः। \\ अथवा न बलं वो उस्ति मिथ्या देवा हि वो जिताः ॥ ॥ \\ बहवो बलवन्तश्च मृगश्चाहं वनेचर:। \\ न मन्ये धर्मयुद्धे वो मतिर्दानवसत्तमाः॥ ४॥ \\ न ममास्ति धनुः किंचित्र शस्त्रं च तथाविधम्। \\ सशस्त्रैर्बहुभिर्येन युध्येयमसुरेश्वरा: $y \|$
}

$1 b$ संप्राप्तान् ] संप्राप्तो $\mathrm{R} \quad 1 \mathrm{~cd}$ ॰न्गम्भीरं मृ॰] ॰न् स भीरुर्मृ॰ $\mathrm{R} \quad 2 \mathrm{~b}$ दैत्याश्च ] दैत्याद्या: $\mathrm{R} 2 \mathrm{c}$ समरे ] व: सार्द्ध $R 2 d$ ०तां तु ] ०ताग्र $R$ 3a उस्त्यद्य ] उत्यर्थं $R$ 3d हि वो जिता: ] विनिज्जिता: $R \quad 5 a$ धनुः ] बल $R \quad 5 b$ ॰न्न शस्त्रं च तथाविधम् ] ॰्वससतस्तु तथा वनम् $R$ sd युध्येयम॰] नियुद्ये अ० $\mathrm{R}$

$1 a$ भूमिं ] $\mathrm{A}_{3} \mathrm{~A}_{4}$, भूमीं $\mathrm{A}_{7} 1 \mathrm{~b}$ संप्राप्तान् ] संप्रापं $\mathrm{A}_{7}$, प्राप्तां $\mathrm{A}_{3} \mathrm{~A}_{4}$ (unmetrical) 1c उवाच सवान् ] सर्वानुवाच $\mathbf{A} \quad \mathbf{1 d} \circ$ वाजने ] ०वाजिरे $\mathbf{A} \quad \mathbf{2 c}$ मया मृगेण ] मायामृगेन $\left\{\circ{ }^{\circ} \mathrm{A}_{7}^{\mathrm{pc}}\right\} \mathbf{A} \quad \mathbf{2 d}$ ०तां तु ] $\mathrm{A}_{7}$, ०तां त $\mathrm{A}_{3} \mathrm{~A}_{4}$ 3a उस्त्यद्य] म्येत्य $\mathbf{A} \quad 3 \mathbf{c}$ न बलं ] बल $\left\{{ }^{\circ}\right.$ न० $\left.\mathrm{A}_{7}\right\}$ वत्यो $\mathbf{A}$ 3d हि वो जिता: ] जिता इति $\mathbf{A} \quad \mathbf{4 a - 1 7 d ^ { 3 }}$ ] $\mathbf{A}$ has this after $102.26 \mathrm{~b}$, preceded by two additional pādas with a speaker indication reading: तानागतान्समालोक्य वराहो वाक्यमब्रवीत्। वराह उवाच। \pm $4 a$ बहवो ] भवन्तो $A 4 b$ वनेचर: ] $\mathrm{A}_{3} \mathrm{~A}_{4}$, बलेचर: $\mathrm{A}_{7} \quad$ 4cd वो मतिर् ] वो $\left\{\right.$ वा $\left.\mathrm{A}_{3} \mathrm{~A}_{4}\right\}$ मतिं $\mathrm{A}$ $5 \mathbf{a b} \circ$ चित्र शस्त्रं च] ०चित् $\left\{\circ\right.$ चि $\left.\mathrm{A}_{7}\right\}$ शस्त्रं वापि $\mathbf{A} 5 \mathrm{c}$ सशस्त्रै॰] समस्तै॰ $\mathrm{A} 5 \mathrm{~d}$ युध्येयम०] युद्धेयम॰ $\mathrm{A}_{3} \mathrm{~A}_{4}$, स्ववेयेम॰ $\mathrm{A}_{7}$ - $०$ सुरेश्वरा: ] $\mathrm{A}_{4} \mathrm{~A}_{7}$, ० सुरेश्वर: $\mathrm{A}_{3}$

Manuscripts available for this chapter: $S_{1}$ photos $4.2 \mathrm{~b}$ (f. $159^{\mathrm{r}}$ ), $4.3 \mathrm{a}\left(\mathrm{f} .159^{\mathrm{v}}\right), 4.3 \mathrm{~b}$ (f. $160^{\mathrm{r}}$ ) and $4.4 \mathrm{a}\left(\mathrm{f} .160^{\mathrm{v}}\right.$, largely retraced); $\mathrm{S}_{3}$ f. $159^{\mathrm{r}}-160^{\mathrm{v}} ; \mathrm{R}$ f. $176^{\mathrm{r}}-177^{\mathrm{r}} ; \mathrm{A}_{3}$ f. $104^{\mathrm{v}}-105^{\mathrm{v}} ; \mathrm{A}_{4}$ f. $148^{\mathrm{r}}-149^{\mathrm{r}}$; $\mathrm{A}_{7}$ f. $147^{\mathrm{v}}-149^{\mathrm{r}}$ (A upto 39d).

$1 \mathrm{a}$ समां ] $\mathrm{S}_{1}^{\mathrm{pc}} \mathrm{S}_{3} \mathrm{RABh}$, मां $\mathrm{S}_{1}^{\mathrm{ac}}$ (unmetrical) • भूमिं ] $\mathrm{S}_{1} \mathrm{RA}_{3} \mathrm{~A}_{4} \mathrm{Bh}$, भूमि $\mathrm{S}_{3} \quad \mathbf{1 b}$ संप्राप्तान् ] $\mathrm{S}_{1} \mathrm{Bh}$, स प्राप्तां $\mathrm{S}_{3}$ - ववर्षभान् ] $\mathrm{S}_{3} \mathrm{RABh}$, ०वर्षभाम् $\mathrm{S}_{1}$ 1c ॰वान्गम्भीरं ] em. Bh (cf. A), ०वां गम्भीरां $S_{1} S_{3}$ 1d मृगान् ] $S_{1}^{p c} A B h$, मृगा $S_{1}^{a c} S_{3}$ 2a दानवा: ] $S_{1}^{\text {pc }} R A B h$, दानवा $S_{1}^{\text {ac }} S_{3}$ 2d युध्यतां ] $S_{1} R A B h$, युद्धतां $S_{3}$ 3a लज्जा ] $S_{1} R A B h$, लज्ज $S_{3}$ - उस्त्यद्य ] $S_{3}$, त्यज्य $S_{1}$, म्येत्य $B h$ 3c उस्ति ] $S_{1} R A B h$, द्य $S_{3}$ 3d देवा ] $S_{3} R A B h$, देवो $S_{1}$ - जिता: ] $S_{1} B h$, जित: $\mathrm{S}_{3} \quad 4 \mathrm{~b}$ मृगश्चाहं वनेचर: ] $\mathrm{S}_{3} \mathrm{RA}_{3} \mathrm{~A}_{4} \mathrm{Bh}$, मृगाश्चाहं वनेश्वरा: $\mathrm{S}_{1} \quad 4 \mathbf{c}$ ०युद्धे $] \mathrm{S}_{3} \mathrm{RABh}$, ०युद्वो $S_{1} \quad 4 d$ मतिर् ] $S_{1} R B h$, मति $S_{3} \quad 5 a$ Before this $S_{1}$ adds सन उ। and $S_{3}$ वारा उ। • धनुः ] $S_{1} \mathbf{A B h}$, धनु $S_{3}$ (unmetrical) $\mathbf{5 b}$ तथाविधम् ] $S_{1} \mathbf{A B h}$, ताथाविधम् $S_{3}^{\text {pc }}$ (unmetrical), ताथावि(त)म् $S_{3}^{\text {ac }}$ (unmetrical) 5c सशस्त्रैर् ] $S_{1} R B h$, सशस्त्रै $S_{3}$ • भिर्येन ] $S_{3} R A B h$, भिर्येण $\mathrm{S}_{1} \quad$ 5d युध्येयम॰ ] em., युद्धेभम॰ $\mathrm{S}_{1}$, युध्ययम $\mathrm{S}_{3}$ (unmetrical), युद्धेयम ${ }^{\circ} \mathrm{Bh} \bullet{ }^{\circ}$ सुरेश्वरा: ] $\mathrm{S}_{1} \mathrm{~S}_{3}^{\mathrm{pc}} \mathrm{RA}_{4} \mathrm{~A}_{7} \mathrm{Bh}$, ०सुरेसुरा: $\mathrm{S}_{3}^{\mathrm{ac}}$ 
ते यूयं यदि मन्यध्वं शस्त्राणि त्यजताधुना।

मया चैकैकशः सर्वे युध्यध्वं न्यायमास्थिताः॥ ६॥

सनत्कुमार उवाच।

तस्य तद्वचनं श्रुत्वा सो डन्धको दानवेश्वरः।

उवाच सर्वान्दैत्येन्द्रान्युगान्ताम्बुदवन्नदन्॥ ७॥

एवमेतद्याथाहायं मृगो उसुरमहारथाः।

संत्यजामो उद्य शस्त्राणि योधयामैकशस्ततः॥ ५॥

प्रह्नाद उवाच।

अबुद्धिरेषा दैत्येन्द्रा यथाहायं मृगाधमः।

समानानां समैः सार्धमेतद्युद्धं प्रशस्यते॥ ९॥

न मृगाणां च शस्त्राणि न बाहुबलमित्युत।

वध्यन्ते च सदा शस्त्रैरेष धर्मः सतां मतः॥ १०॥

ते वयं कथमुत्सृज्य स्वधर्म दानवेश्वराः।

मृगधर्मं समास्थाय युध्येम पशवो यथा॥ ?? ॥

6d ॰मास्थिता: ] ॰मात्रिता: $R \quad 7 c$ सर्वान्दैत्येन्द्रान् ] सर्वदैत्येन्द्रान् $R \quad 8 a$ ॰द्यथाहायं ] ॰द्यथान्यायं $\mathrm{R} 8 \mathrm{~d}$ योधयामैक॰] योधयानेक॰ $\mathrm{R} 9 \mathrm{ab}$ दैत्येन्द्रा यथाहायं मृगाधमः ] दैत्येन्द्र यथाकालं मृगाधम $R \quad 10 b$ बाहुबल०] वा स्वबल $R$ 10c सदा ] तदा $R$ 11d युध्येम] युध्याम: $R$

6b शस्त्राणि ] $\mathrm{A}_{7}$, शस्त्रानि $\mathrm{A}_{3} \mathrm{~A}_{4}$ - त्यजताधुना ] त्यज \{ ०्य० $\mathrm{A}_{3} \mathrm{~A}_{4}$ \}ताधमा: $\mathbf{A} 7 \mathbf{b}$ दानवेश्वर: ] $\mathrm{A}_{7}$, दानवो सुर: $\mathrm{A}_{3} \mathrm{~A}_{4} \quad 7 \mathrm{c}$ सर्वान्दैत्येन्द्रान् ] $\mathrm{A}_{3} \mathrm{~A}_{4}$, दैत्यान् सर्वेन्द्रान् $\mathrm{A}_{7} \quad \mathbf{8 b}$ मृगो उसुर०] मृगेश्वर० $\mathrm{A}_{3} \mathrm{~A}_{4}$, मृगेश्वरो $\mathrm{A}_{7}$ (unmetrical) - ०महारथा: ] $\mathrm{A}_{3} \mathrm{~A}_{4}$, महात्मवान् $\mathrm{A}_{7}$ 8d योधयामैकशस्ततः ] योधयै $\left\{\circ\right.$ यैनै० $\mathrm{A}_{7}$ (unmetrical) $\}$ कैकशः शुभः $\left\{\circ\right.$ मे $\left.^{\mathrm{A}_{4}}\right\} \mathbf{A} \quad 9 \mathbf{a}$ अबुद्धिरेषा ] कुबुद्धिरे $\left\{\circ\right.$ रै० $\left.\mathrm{A}_{7}\right\}$ षा $\mathbf{A}$

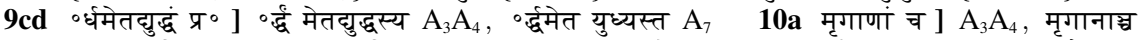
$A_{7} 10 b$ मित्युत ] $A_{3} A_{7}$, ०मित्युत: $A_{4} 10 \mathrm{c}$ वध्यन्ते ] $A_{3} A_{7}$, बध्यंते $A_{4}$ • सदा ] शरै: $A_{3}$ $\mathrm{A}_{4}$, शुरै: $\mathrm{A}_{7} \mathbf{1 0 d}^{3}-\mathbf{1 1 b}^{1}$ ] om. $\mathrm{A}_{7}$ (unmetrical) 10d सतां मतः ] सनातनः $\mathrm{A}_{3} \mathrm{~A}_{4}$ 11cd ] om. A

$\mathbf{8}\left(\mathrm{c}^{2}\right) \mathrm{S}_{1} \quad \mathbf{1 1}\left\langle\mathrm{a}^{5}\right\rangle\left(\mathrm{a}^{6}-\mathrm{b}^{1}, \mathrm{~b}^{3}, \mathrm{~b}^{7}\right) \mathrm{S}_{3}$

6a यूयं ] $S_{1} R A B h$, यूय $S_{3}$ 6b शस्त्राणि ] $S_{1} R A_{7} B h$, शस्त्रोणि $S_{3}$ • त्यजता॰] $S_{3} R A_{7} B h$ (em.?), त्यजतो $S_{1}$ 6d ०मास्थिता: ] $S_{1}^{\mathrm{pc}} S_{3} A B h$, ०मास्थिता $S_{1}^{\mathrm{ac}}$ 7b दानवेग्वर: ] $S_{1}^{\mathrm{pc}} \mathrm{S}_{3} \mathrm{RA}_{7}$ $\mathrm{Bh}$, दानवेश्वरा: $\mathrm{S}_{1}^{\mathrm{ac}}$ 7c सर्वान्दैत्येन्द्रान् ] $\mathrm{S}_{1} \mathrm{~A}_{3} \mathrm{~A}_{4} \mathrm{Bh}$, सर्वा दैत्येन्द्रा $\mathrm{S}_{3}$ 7d ०वन्नदन् ] $\mathrm{S}_{1}^{\mathrm{pc}} \mathrm{RABh}$, ॰वन्नदम् $S_{1}^{\mathrm{ac}}$, ॰वन्नदत् $\mathrm{S}_{3}^{\mathrm{pc}}$, ॰वनदत् $\mathrm{S}_{3}^{\mathrm{ac}}$ (unmetrical) $\mathbf{8 a}$ ॰थाहायं ] $\mathrm{S}_{1} \mathrm{ABh}$, ०थाहायां $\mathrm{S}_{3} \mathbf{8 b}$ मृगो डसुर० ] $\mathrm{S}_{1}^{\mathrm{pc}} \mathrm{RBh}$, (स)गो सुर० $\mathrm{S}_{1}^{\mathrm{ac}}$, मृगेश्वर० $\mathrm{S}_{3}$ - ०महारथा: ] $\mathrm{S}_{1} \mathrm{RA}_{3} \mathrm{~A}_{4} \mathrm{Bh}$, ०महारथा $\mathrm{S}_{3}$ $8 c$ संत्यजामो ] $S_{1} R A$, सन्त्यजमो $S_{3}$ (unmetrical), सन्त्यजामा॰ Bh (em.) 8d योधयामैक॰ ] $\mathrm{S}_{3}$, योधामेकैक॰ $\mathrm{S}_{1}$, योधामैकैक॰ $\mathrm{Bh}$ (em.?) - ०स्ततः ] $\mathrm{S}_{3} \mathrm{R}$, ०स्तथा $\mathrm{S}_{1} \mathrm{Bh} 9$ प्रह्लाद $] \mathrm{S}_{1} \mathrm{R}$ $\mathrm{ABh}$, प्रहा $\mathrm{S}_{3} \quad 9 \mathbf{a}$ अबुद्धिरेषा ] $\mathrm{S}_{1}^{\mathrm{pc}} \mathrm{S}_{3} \mathrm{RBh}$, अबुचेषाय $\mathrm{S}_{1}^{\mathrm{ac}} \quad 9 \mathbf{b}$ मृगाधमः ] $\mathrm{S}_{1}^{\mathrm{pc}} \mathrm{S}_{3} \mathrm{ABh}$, मृगाधम $\mathrm{S}_{1}^{\mathrm{ac}} \quad 9 \mathrm{c}$ समै: ] RABh, समै $\mathrm{S}_{1} \mathrm{~S}_{3} \quad 10 \mathrm{a}$ मृगाणां ] $\mathrm{S}_{1} \mathrm{RA}_{3} \mathrm{~A}_{4} \mathrm{Bh}$, मृगाणा $\mathrm{S}_{3} \quad 10 \mathrm{~b}$ मित्युत ] $\mathrm{S}_{1} \mathrm{RA}_{3} \mathrm{~A}_{7} \mathrm{Bh}$, ०मित्युतः $\mathrm{S}_{3} \quad 10 \mathrm{c}$ वध्यन्ते ] $\mathrm{S}_{3} \mathrm{RA}_{3} \mathrm{~A}_{7} \mathrm{Bh}$, बद्यन्ते $\mathrm{S}_{1}$ 10d धर्म: ] $\mathrm{S}_{1}^{\mathrm{pc}} \mathrm{S}_{3} \mathrm{RA}_{3} \mathrm{~A}_{4}$ $\mathrm{Bh}$, धर्म्म $\mathrm{S}_{1}^{\mathrm{ac}}$ - मतः ] $\mathrm{S}_{1} \mathrm{RBh}$, मम $\mathrm{S}_{3}$ 11c धधर्मं ] $\mathrm{S}_{3} \mathrm{RBh}$ (em.?), ०धर्म्म $\mathrm{S}_{1}$ (anusvāra possibly lost) 11d युध्येम ] $S_{1}^{\text {ac }} S_{3} B h$, युद्येया $S_{1}^{\text {pc }}$ (retraced) 
मृगाधमो उयं दुर्वृत्त अवध्यो नास्मदादिभिः।

घतैनं मा विचारो वो मृगे भवतु सर्वशः॥ १२॥

मायामास्थाय दुष्टात्मा को उप्ययं सुरपांसनः।

अस्मान्वज्चयितुं दैत्याः का द्क्तेत सुदुरात्मवान् ॥ १३॥

क्ष वः श्रुतं वा दृष्टं वा मृगाणामसुरेश्वराः।

मनुष्यवद्वाहुयुद्धं पुरुषै: सह संयुगे॥ १४॥

एष विष्णुर्दुराचारो दुरात्मा दैत्यकण्टकः।

अशक्तः स्वेन वीर्येण मायामास्थाय संस्थितः॥ १४ ॥

ततस्तं बलवान्क्रुद्धो धनुषासौ उसुरेश्वरः।

शरैरवाकिरद्यास बहुभिर्विररास च॥ १६॥

अन्धको विप्रचित्तिश्च सर्वे च दितिदानवाः।

अवाकिरन्छरैस्तीक्षणैः शतशो ऽथ सहस्रशः॥ १७॥

12 ] om. $R \quad 13 b$ उप्ययं ] प्येष $R \quad \bullet$ ०पांसन: ] ॰पांशुल: $R \quad 13 \mathrm{c}$ ॰न्वस्चयितुं ] ॰न् विध्वंसितुं $R \quad 13 d$ सु॰ ] च $R \quad 14 a$ क्ष वः ग्रुतं वा दृष्टं वा ] न श्रुतम्वापि दुष्टात्मा $R \quad 14 c$ द्वाहु॰] ${ }^{\circ}$ त्कुरुते R (unmetrical) $15 \mathrm{ab}$ ] om. $R \quad 16 \mathrm{~b}$ धनुषासौ] धनुषा सो $R \quad 16 \mathrm{~d}$ बहुभिर्वि॰] बहुभिस्तै $R$ 17a विप्रचित्तिश्च ] विप्रचित्त्याद्या: $R \quad 17 b$ च दिति॰ ] दैत्याश्च $R \quad 17 \mathrm{c}$ ०किरन्छरैस्तीक्ष्णः: ] ०किच्छ रैस्तीक्ष्णै $\mathrm{R}$

12a दुर्वृत्त ] $\mathrm{A}_{3} \mathrm{~A}_{4}$, दुवृत्त्त $\mathrm{A}_{7}$ 12cd ] om. $\mathrm{A} \quad 13 \mathrm{~b}$ को उप्ययं सुर०] को यं स्वर्गण० $\left\{\circ{ }^{\circ} \mathrm{A}_{3} \mathrm{~A}_{7}\right\}$ A 13c ०न्वज्चयितुं] $\mathrm{A}_{4} \mathrm{~A}_{7}$, ०न्वंचयितु $\mathrm{A}_{3}$ (unmetrical) $14 \mathbf{a}$ क्ष वः] कुतः $A$ 14b मृगाणा॰] मृगाना॰ $A$ 15d संस्थितः ] $\mathrm{A}_{7}$, संस्थितं $\mathrm{A}_{3} \mathrm{~A}_{4}$ 16a ०स्तं ब॰] ०स्तान्ब॰ $\mathrm{A}_{3}$, ०स्तौ ब॰ $\mathrm{A}_{4}$, ०स्त्वं ब॰ $\mathrm{A}_{7} \quad 16 \mathrm{~b}$ धनुषासौ] धनुषा सो $\mathrm{A} \quad 16 \mathrm{~d}$ ०र्विररास च] ०र्विररास $\left\{{ }^{\circ}\right.$ म $\left.\mathrm{A}_{4} \mathrm{~A}_{7}\right\}$ ह $\mathrm{A}$ 17b दिति॰] $\mathrm{A}_{4} \mathrm{~A}_{7}$, दैत्य॰ $\mathrm{A}_{3}$ (unmetrical) 17c ०किर्छरैस्ती०] $\mathrm{A}_{4}$, ०किरत् शरैस्ती० $\mathrm{A}_{3}$, ०करत् सरै ती॰ $\mathrm{A}_{7}$ 17d डथ सहस्रशः ] om. A (instead $\mathbf{A}$ has बक एव च, resuming 102.27d)

$12\left(a^{1}-d^{8}\right) S_{1} \quad 13\left(b^{3}, b^{6}\right) S_{1}$

12a मृगाधमो ] $S_{1}$ (retraced)ABh, मृगाधिमो $S_{3}$ - द्वुर्वृत ] $A_{3} A_{4} B h$, (दुवृत्ता) $S_{1}$ (upper parts lost, retraced), दुद्दृत्त: $S_{3}$ 12c घतैनं मा ] $S_{3}$, (घतनम्मा) $S_{1}$ (upper parts lost, retraced), - - मा Bh - विचारो वो ] $S_{1}$ (retraced)Bh, विचारे व: $S_{3}$ 13c ०तुं दैत्या: ] $R_{4} A_{7} B h$ (em.?), ॰तुन्दैत्या $S_{1}$, ०तु दैत्या $S_{3}$ (unmetrical) 13d काद्ध्रते ] $S_{3} R A B h$, काक्षते $S_{1}$ • ०रात्मवान् ] $S_{3} R A B h$, ०रात्मवाम् $S_{1} 14 a$ क्ष व: ] em., क्ष च $S_{1} B h$, क व: $S_{3}$ वा दृष्टं वा ] $S_{1} A B h$, क्ष

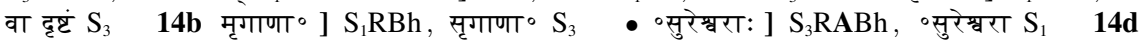
संयुगे ] $S_{1} R A B h$, सयुगे $S_{3}$ (unmetrical) 15a विष्णुर ] $S_{1}^{\mathrm{pc}} S_{3} A B h$, विष्णु $S_{1}^{\text {ac }} \quad 16 \mathbf{a}$ Before this $\mathrm{Bh}$ adds सनत्कुमार उवाच । बलवान् ] $\mathrm{S}_{1} \mathrm{RA}_{4} \mathrm{~A}_{7} \mathrm{Bh}$, बलवा $\mathrm{S}_{3} \mathbf{1 6 b}$ धनुषासौ] $\mathrm{S}_{3}$, धनुषो सौ $\mathrm{S}_{1}$, धनुषा सो $\mathrm{Bh} \quad \mathbf{1 6 c}$ ०रवाकिरद् ] RABh, ०रवाकिरं $\mathrm{S}_{1}$, ०रवाकिर $\mathrm{S}_{3}$ 16d बहुभिर् ] $\mathrm{S}_{1} \mathrm{ABh}$, बहुभि $\mathrm{S}_{3}$ (unmetrical) $17 \mathrm{~b}$ च दितिदानवा: ] $\mathrm{S}_{1} \mathrm{~A}_{4} \mathrm{~A}_{7}$, च दितिनन्दना $\mathrm{S}_{3}$, ते दैत्यदानवा: $\mathrm{Bh}$ (conj.?) $17 \mathrm{c}$ ०किरम्छः $] \mathrm{S}_{1} \mathrm{~A}_{4} \mathrm{Bh}$, ०किरच्छ $\mathrm{S}_{3}$ ० ०स्तीक्ष्णै: ] $\mathrm{S}_{3}^{\mathrm{pc}} \mathrm{A}_{3} \mathrm{~A}_{4} \mathrm{Bh}$, ०स्तीक्ष्णै $\mathrm{S}_{1} \mathrm{~S}_{3}^{\mathrm{ac}}$ 
अथ देवः सुसंख्धो विद्धस्तैर्दानवैर्भृशम्।

शुशुभे भास्करकरै: संबद्धो हिमवानिव॥ १५ ॥

स वेगं बलवान्कृत्वा विधुन्वानः शराभ्छितान् ।

सलीलं प्रययौ देवः प्रह्लादं प्रति दानवम्॥ १९ ॥

स गत्वा तस्य सहसा सारथिं रथमेव च।

दंष्ट्राभिश्च कराभ्यां च नामशेषं चकार ह॥ २०॥

ततो रथादवप्रुत्य हन्यमानो उपि दानवैः।

रथध्वजेन तं दैत्यं मूर्धि देवो ऊभिजघ्रिवान् ॥ २? ॥

प्रह्लादो उपि ततोत्पत्य गदया भीमरूपया।

आजघानोरसि कुद्धो विघ्नो धर्मं यथास्थितम्॥ २२॥

स तेनाभिहतो देवो मुत्का तस्य रथं तदा।

तमेव देशमायातो पूर्व यत्राभवत्स्थितः॥ २३॥

ततो उन्धको विप्रचित्तिः शम्बरः कालशम्बरः।

शरैराशीविषाकारैर्बिभिदुर्नन्दिवर्धनम्॥ २४॥

$18 d$ संबद्धो ] संयुक्तो $R \quad 19 b$ विधुन्वानः शराम्छितान् ] विधूय सततं क्षुरान् $\left\{\right.$ रम् $\left.R^{\mathrm{ac}}\right\} R$ 19c

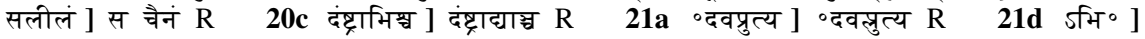
ऽपि $R \quad 22 a$ ततोत्पत्य ] तदोत्पत्य $R \quad 23 a$ देवो ] $R^{p c}$, दैत्यो $R^{a c} 23 b$ मुत्का त०] मुक्तस्त् $\mathrm{R} 23 \mathrm{c}$ ०मायातो ] ॰मायात: $\mathrm{R} 2 \mathrm{23d}$ यत्राभवत् ] यत्राहवे $\mathrm{R} 2 \mathrm{24cd}$ ०कारैर्बि॰ ] ०कारै बि० $\mathrm{R}$

18a A has this immediately after $3 \mathrm{~d}$, placing $4 \mathrm{a}-17 \mathrm{~d}^{3}$ after $102.27 \mathrm{~b}$. • अथ देव: सु० ] वराहो ह्यति॰ $A 18 \mathrm{~b}$ विद्धस्तैर् ] विदुर्गे $A 18 \mathrm{c}$ भास्करकरै: ] भास्कराकारै: $A$ 18d संबद्धो ] समृद्धो $\mathrm{A}_{3} \mathrm{~A}_{4} \mathrm{~A}_{7}^{\mathrm{ac}}$, समूद्धो $\mathrm{A}_{7}^{\mathrm{pc}} 19 \mathrm{a}$ बलवान् ] बलवत् $\mathrm{A} 19 \mathrm{~b}$ शराभ्छितान् ] $\mathrm{A}_{3} \mathrm{~A}_{7}$, शरान् सितान् $\mathrm{A}_{4}$ $19 \mathrm{c}$ सलीलं] सलीलः $\mathrm{A}_{3} \mathrm{~A}_{4}$, सनीलः $\mathrm{A}_{7} 20 \mathrm{c}$ दंष्टाभि॰ $\mathrm{A}_{4}$, दष्ट्राभि० $\mathrm{A}_{3}$, दंष्क्राभि॰ $\mathrm{A}_{7} 21 \mathrm{a}$ ॰दवप्रत्य ] ॰दवप्तुत्य $A$ 21d ऽभि०] $\mathrm{A}_{7}$, पि $\mathrm{A}_{3} \mathrm{~A}_{4}$ 22a ततोत्पत्य ] ततो भ्येत्य $\mathrm{A}_{4} \mathrm{~A}_{7}$, तरो दैत्य $\mathrm{A}_{3} 22 \mathrm{~d}$ धर्मं यथास्थितम् ] धर्मे यथा स्थितः $A$ 23ab देवो मुत्का ] दैत्यो मूर्धा $\left\{0\right.$ 의 $\left.\mathrm{A}_{3}\right\} A$ 23cd ] om. A 24ab ०चित्ति: शम्बर:] ०चित्ति ससुर: $\mathrm{A}_{3} \mathrm{~A}_{7}$, ०चित्तिरसुर: $\mathrm{A}_{4}$ 24b ०शम्बर: ] $\mathrm{A}_{4}$, ०सम्वर: $\mathrm{A}_{3} \mathrm{~A}_{7}$ 24d ०र्बिभिदुर्नन्दिवर्धनम् ] ०र्विविधैर्नन्दिवर्द्धनः $A$

19( $\left(a^{4}\right) S_{1}$

18a देव: ] $S_{3} R B h$ (em.?), देव $S_{1}$ - ०संरब्धो ] $S_{1} S_{3} R A$, ०संरब्धैर् Bh (conj.?) $18 b$ ०द्धस्तैर्दानवैर् ] RBh (conj.?), ॰ ध्वस्तैर्दानवैर $S_{1}$, ०द्धस्त्त दानवै $S_{3} \quad 18 c$ भास्करकरै: ] RBh (conj.?), भास्कराकारै $S_{1}$, भास्करकरै $S_{3} \quad 18 d$ संबद्धो ] $S_{3}$, संबिद्धो $S_{1}$, संविद्धो Bh 19a बलवान् ] $S_{3} R$, $\langle$ ले $\rangle+\left(\right.$ व)+लवत् $S_{1}$, बलवत् Bh $19 b$ विधुन्वान: ] $S_{1} A B h$, विधून्वान: $S_{3}$ • शराक्छितान् ] $A_{3} A_{7}$ $\mathrm{Bh}$, गरास्थिवाम् $S_{1}$, शरात्थितां $S_{3}$ 19d प्रह्लादं ] $S_{1} R A B h$, प्रहाद $S_{3}$ • दानवम् ] $S_{1} R A B h$, दानवान् $S_{3} 20 \mathrm{c}$ दंष्ट्राभिश्च ] $S_{1} A_{4} B h$, द्रष्टाभि च $S_{3}$ 20d ०शेषं च०] $S_{3} R A B h$, शेषास्च० $S_{1}$ 21a ततो ] $S_{1}^{\mathrm{pc}} \mathrm{S}_{3} \mathrm{RABh}$, (ते)तो $\mathrm{S}_{1}^{\mathrm{ac}}$ - ०दवप्रुत्य ] $\mathrm{S}_{1} \mathrm{~S}_{3}$, ०दवत्रुत्य $\mathrm{Bh}$ 21b हन्यमानो ] $\mathrm{S}_{1}^{\mathrm{pc}}$ $\mathrm{S}_{3} \mathrm{RABh}$, (रू)न्यमानो $\mathrm{S}_{1}^{\mathrm{ac}} 22 \mathrm{a}$ प्रह्लादो ] $\mathrm{S}_{1}^{\mathrm{pc}} \mathrm{RABh}$, प्र(ह्वा)दो $\mathrm{S}_{1}^{\mathrm{ac}}$, प्रहादो $\mathrm{S}_{3}$ 22c कुद्धो ] $S_{3} R A$, क्रुद्ध $S_{1} B h$ 22d धर्मं यथा॰ ] $S_{3} R$, धम्म्मपथा॰ $S_{1}$, धर्मे यथा $B h$ 23a ${ }^{\circ}$ हो ] $S_{3} R A B h$, ०हता $S_{1} 23 c$ ०मायातो ] $S_{1} S_{3}$, ०मायातः Bh (em.?) 23d ०भवत्स्थितः ] $S_{3} B h(e m . ?)$, ०भव स्थिता: $S_{1}$ 24a विप्रचित्तिः ] $S_{3} R B h$ (em.?), विप्रचित्ति $S_{1}$ 24cd ०कारैर्बि०] $S_{1} A B h$, ०कारै

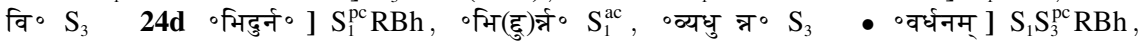
०वर्द्धन: $\mathrm{S}_{3}^{\mathrm{ac}}$ 
स भिन्नस्तैस्तदा व्यास शरै: संनतपर्वभिः।

भिद्यमानश्च बहुधा मण्डलानि चचार ह॥ २४॥

कदाचित्सिहवच्चापि प्रवते नर्दते उपि च।

शार्दूलवत्कदाचिच्च भूमावात्मानमाहवे॥ र६॥

वितत्य स महावीर्यस्तिष्ठते सायकान्सहन्।

पादेन तत उत्थाय अवकीर्य वृषो यथा॥ २७॥

पक्षिवत्स तदाकाशे मण्डलानि मृगेश्वर:।

भ्रमित्वा निश्चलस्तस्थौ वराहः पर्वतो यथा॥ २५॥

एवं बहुविधान्मार्गान्विचरित्वा महाबलः।

वेगेनैव कराभ्यां स रथौ जग्राह नादयन्।

विप्रचित्तेश्च बलवानन्धकस्य च सुप्रभः॥ २९॥

म्रामयित्वा मुहूर्तं च सहाश्वै: सह सायकै:।

भूमावुत्क्षिप्य चिक्षेप बभअ च पुनः पदा।

रथे स्थितौ च तौ दैत्यौ पुनर्मूर्ध्रन्यताडयत्॥ ३०॥

$25 \mathrm{~d}$ चचार ] चकार $\mathrm{R} 26 \mathrm{~cd}$ ०चिच्च भूमावात्मानमा०] ०चित्स भ्रममाणो महा॰ $\mathrm{R} 27 \mathrm{a}$ स ] सु० $\mathrm{R} 27 \mathrm{~b}$ ॰न्सहन्] ० न् हसन् $\mathrm{R} 27 \mathrm{~cd}$ तत उत्थाय अवकीर्य ] तं समुत्थाय अवतीर्य $\mathrm{R} 28 \mathrm{c}$ निश्चलस्तस्थौ ] निश्चलं हस्तौ $\mathrm{R} 29 \mathrm{~d}$ रथौ ] रथं $\mathrm{R} 30 \mathrm{~b}$ सहाग्यै: सह सायकै: ] सहयै: सवरायुधै: $R 30 d$ पदा ] सदा $R$ 30ef ] उभावपि तदा दैत्यौ वराह: पर्वतो यथा $R$ (cf. 28d for pāda f)

25c बहुधा ] $\mathrm{A}_{7}$, बहु $\mathrm{A}_{3}$ (unmetrical), बहुभिर् $\mathrm{A}_{4}$ 25d चचार] चकार $\mathbf{A}$ 26c शार्दूलवत् ] $\mathrm{A}_{3} \mathrm{~A}_{4}$, शार्दूलग्च $\mathrm{A}_{7} 27 \mathbf{b}$ सायकान्सहन् ] सा $\left\{\right.$ शा० $\left.\mathrm{A}_{7}\right\}$ यकास $\left\{\circ\right.$ श० $\left.\mathrm{A}_{4} \mathrm{~A}_{7}\right\}$ न: $\mathbf{A} 28 \mathbf{b}$ मृगेश्वर: ] $\mathrm{A}_{3} \mathrm{~A}_{7}$, मृगेश्वरा: $\mathrm{A}_{4} \quad 28 \mathrm{c}$ भ्रमित्वा ] $\mathrm{A}_{7}^{\mathrm{pc}}$, भूमित्वा $\mathrm{A}_{3} \mathrm{~A}_{4} \mathrm{~A}_{7}^{\mathrm{ac}} \quad 29 \mathrm{a}$ एवं बहु॰ ] एवमुक्ता \{०कान् $\mathrm{A}_{7}^{\mathrm{pc}}$, ०त्का $\left.\mathrm{A}_{4}\right\} \mathrm{A} \quad 29 \mathrm{~d}$ रथौ] $\mathrm{A}_{3} \mathrm{~A}_{7}$, रथं $\mathrm{A}_{4}$ 29e विप्रचित्तेश्च्च] विप्रचित्तिश्च $\mathrm{A}$ 29ef ०वानन्धकस्य ] $\mathrm{A}_{3} \mathrm{~A}_{4}$, वान् उन्धक(स्यै)व $\mathrm{A}_{7}^{\mathrm{pc}}$, ०वान् न्धकारस्य $\mathrm{A}_{7}^{\mathrm{ac}}$ 29f सुप्रभः ] सुप्रभौ $\mathrm{A}$ 30a-d ]

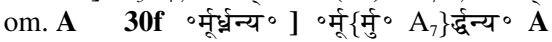

$26\left(b^{1}\right) S_{3} \quad 28\left(c^{3}\right) S_{1} \quad 29\left(d^{4}\right) S_{3} \quad 30\left(a^{8}\right) S_{1}$

25a भिन्नस्तै॰] $S_{1}^{\mathrm{pc}} S_{3} R A$, भित्नस्ते $S_{1}^{\text {ac }}$, विद्धस्तै $B h$ (conj.?) $25 \mathbf{b}$ शरैः ] $S_{1}^{\mathrm{pc}} R A B h$, शरै $S_{1}^{\mathrm{ac}}$ $\mathrm{S}_{3}$ - संनतपर्व०] $\mathrm{S}_{3} \mathrm{RABh}$, सत्रतर्पर्व० $\mathrm{S}_{1}$ (unmetrical) 25c बहुधा ] $\mathrm{S}_{1}^{\mathrm{pc}} \mathrm{S}_{3} \mathrm{RA}_{7} \mathrm{Bh}$, बहु(णि) $S_{1}^{\mathrm{ac}} 26 \mathbf{a}$ ०वच्चापि ] $\mathrm{S}_{1} R A B h$, ०व चापि $\mathrm{S}_{3}$ (unmetrical) $26 \mathbf{b}$ प्रवते ] $S_{1}^{\mathrm{pc}} \mathrm{RABh}$, (पू)वते $\mathrm{S}_{1}^{\mathrm{ac}} \mathrm{S}_{3}^{\mathrm{ac}}$, (पु)वते $\mathrm{S}_{3}^{\mathrm{pc}} 26 \mathrm{c}$ शार्दूलवत्क॰ $\mathrm{S}_{1} \mathrm{RA}_{3} \mathrm{~A}_{4} \mathrm{Bh}$, शादूलवड्कः $\mathrm{S}_{3}$ • ०चिच्च ] $\mathrm{ABh}$, ०चिच्छ $S_{1}$, ०च च $S_{3}$ (unmetrical) 26d ०माहवे] $S_{1}^{\mathrm{pc}} S_{3} A B h$, ०मा - वे $S_{1}^{\mathrm{ac}} \quad \mathbf{2 7} \mathbf{a b}$ ०वीर्यस्ति॰] $\mathrm{RABh}$, ०वीर्य ति॰ $\mathrm{S}_{1} \mathrm{~S}_{3} \quad \mathbf{2 7 b}$ ०ते सायकान्सहन् ] $\mathrm{S}_{3} \mathrm{Bh}$ (em.?), ०तिस्सायकां सहम् $\mathrm{S}_{1}$ 27c पादेन ] $S_{1}^{\mathrm{pc}} \mathrm{S}_{3} \mathrm{RABh}$, पदेन $\mathrm{S}_{1}^{\mathrm{ac}} \quad \mathbf{2 7 d}$ अवकीर्य ] $\mathrm{S}_{1}^{\mathrm{pc}} \mathrm{ABh}$, अवतीर्य $\mathrm{S}_{1}^{\mathrm{ac}}$, त्यवकीर्य $\mathrm{S}_{3}^{\mathrm{pc}}$, त्यककीर्य $\mathrm{S}_{3}^{\mathrm{ac}} 28 \mathrm{~b}$ मृगेश्वर: ] $\mathrm{S}_{1}^{\mathrm{pc}} \mathrm{S}_{3} \mathrm{RA}_{3} \mathrm{~A}_{7} \mathrm{Bh}$, गेश्वर: $\mathrm{S}_{1}^{\mathrm{ac}}$ (unmetrical) 28d वराह: ] $\mathrm{S}_{1}^{\mathrm{pc}} \mathrm{S}_{3} \mathrm{RABh}$, वराह $S_{1}^{\mathrm{ac}}$ (unmetrical) 29a ०विधान् ] $S_{1}^{\mathrm{pc}} \mathrm{RABh}$, वविधा $S_{1}^{\mathrm{ac}} S_{3}$ 29d रथौ] $\mathrm{A}_{3} \mathrm{~A}_{7} B \mathrm{Bh}$, रथो $\mathrm{S}_{1} \mathrm{~S}_{3}$ • जग्राह ] $\mathrm{S}_{1} \mathrm{~S}_{3}^{\mathrm{pc}} \mathrm{RABh}$, जगाह $\mathrm{S}_{3}^{\mathrm{ac}}$ - नादयन् ] $\mathrm{S}_{1}^{\mathrm{pc}} \mathrm{S}_{3} \mathrm{RABh}$, नादयम् $\mathrm{S}_{1}^{\mathrm{ac}}$ 29e विप्रचित्ते॰] $\mathrm{S}_{1}^{\mathrm{pc}} \mathrm{S}_{3} \mathrm{RBh}$, 〈प्र〉+वि+प्रचित्ते $\mathrm{S}_{1}$ 29ef ॰वानन्धकस्य ] $\mathrm{S}_{3} \mathrm{RA}_{3} \mathrm{~A}_{4} \mathrm{Bh}$, ०वां नन्दकस्य $\mathrm{S}_{1}^{\mathrm{pc}}$, ०वां नन्दक乞 $S_{1}^{\text {ac }}$ 29f सुप्रभः ] $S_{1} R B h$, सुप्रभो $S_{3} \quad 30 a$ मुहूर्तं च ] $S_{3}^{p c} R$, मुहूर्त्त(ग्रु) $S_{1}^{p c}$, मुहूर्त्तश्च $\mathrm{S}_{1}^{\mathrm{ac}}$, मुहूर्त्त च $\mathrm{S}_{3}^{\mathrm{ac}}$ (unmetrical), मुहूर्त तौ $\mathrm{Bh}$ (conj.?) $\mathbf{3 0 b}$ सहाग्ये: ] $\mathrm{S}_{3} \mathrm{Bh}$ (em.?), सहाग्ये $\mathrm{S}_{1}$ - सायकै: ] $\mathrm{S}_{1} \mathrm{~S}_{3}$, ०सारथी Bh (conj.) 30c ॰वुत्क्ष्प्य ] $\mathrm{S}_{3} R B h(\mathrm{em} . ?)$, ०वुक्षिप्य $\mathrm{S}_{1}$ 30d ०न: पदा ] $S_{1} B h$, ०नस्तदा $S_{3} \quad 30 e$ रथे ] $S_{3} A$, रथी $S_{1}$, रथा० Bh (conj.?) 30f पुनर्मूर्धन्य॰] $S_{1}$, पुन मूर्ध्यन्य॰ $\mathrm{S}_{3}^{\mathrm{pc}}$, पुन मूर्ध्यन्य॰ $\mathrm{S}_{3}^{\mathrm{ac}}$, पुनर्मूर्धन्य॰ $\mathrm{Bh}$ 
तौ हतावतिसंक्रुद्धौ गदे चोद्यम्य वेगितौ।

वराहं मूर्धि युगपत्समाहत्य विनेदतुः॥ ३?॥

ताभ्यां स बलवान्क्रुद्धो हस्ताभ्यां रक्तलोचनः।

गदे जग्राह यत्ताक्यां बलादेव मृगेश्वरः ॥ ३२॥

ततो उचरन्मण्डलानि विविधानि जनार्दनः।

गदाविशारदः सम्यग्विचित्राणि बहुनि च॥ ३३॥

आक्षित्रमथ विक्षित्रमवाक्षित्रं च मण्डलम्।

उत्क्षिप्रमथ निक्षित्रं विसृष्टं धावितं तथा॥ ३४॥

परावृत्तं निवृत्तं च अर्धचन्द्रमथापि च।

विष्टब्धं चोद्यतं चैव हंसोड़्रमणमेव च॥ ३४॥

गदाविशारद: सम्यग्रमित्वा मण्डलानि च।

गदामुपरि चिक्षेप सो उन्धकाय विनादयन्।

अपरां विप्रचित्तेश्च बलवान्नन्दिवर्धनः॥ ३६॥

ते गदे तौ महावेगौ दानवौ सुदुरासदौ।

वस्चयित्वा रणे भूयो वराहं प्रति दानवौ।

आधावितौ यथा देशमुत्पातौ वेगिताविव॥ ३७॥

$31 \mathrm{a}$ हतावति॰ ] हवपि $\mathrm{R}$ (unmetrical) $31 \mathrm{~b}$ गदे ] गदां $\mathrm{R} \quad 32 \mathrm{a}$ ताभ्यां ] द्वयो: $\mathrm{R}$ 32c यताभ्यां ] हस्ताभ्यां $R \quad 33 \mathrm{a}$ ततो इचरन्] ततश्चरन् $R \quad 33 b$ जनार्दन: ] जनेश्वर: $R \quad 33 \mathrm{c}$ गदा० ] सदा $R$ 33d ०ग्विचित्राणि ] क विभ्राणश्च $R$ 34d धावित ] धारितन् $R$ 35d हंसोड्रमण०] सो इध्वभ्रमण० $R$ 36 च ] स: $R$ 36 ef ] om. $R$ 37a ते गदे तौ] तौ गच्छन्तौ $R$ 37ef देशमुत्पातौ वेगिताविव ] श्येनपोतौ च वेगितौ द्विज $\mathrm{R}$

$31 \mathrm{a}$ ०वति॰] ०विति $\mathbf{A} 31 \mathrm{~b}$ गदे चो॰] गदामु० $\mathbf{A}$ - वेगितौ] $\mathrm{A}_{7}^{\mathrm{ac}}$, वेगिनौ $\mathrm{A}_{3} \mathrm{~A}_{4} \mathrm{~A}_{7}^{\mathrm{pc}} 32 \mathrm{a}$ स बलवान् ] बलवान् सं॰ $\mathbf{A}$ (unmetrical) $32 \mathrm{c}$ यत्ताभ्यां ] दन्ताभ्यां $\mathbf{A}$ 33a उचरन्] म्बरे $\mathrm{A}_{4} \mathrm{~A}_{7}$, वरे $\mathrm{A}_{3}$ 34ab ] om. A 34d ०ष्टं धावितं त०] ०ष्टं नाचितत्त० $\mathrm{A}_{3} \mathrm{~A}_{4} \mathrm{~A}_{7}^{\mathrm{ac}}$, ० प्टमाचितन्त० $\mathrm{A}_{7}^{\mathrm{pc}}$ 35a परावृत्तं ] $\mathrm{A}_{4} \mathrm{~A}_{7}$, परावृतं $\mathrm{A}_{3} 35 \mathrm{c}$ चोद्यतं ] चोद्धतं $\mathrm{A} 35 \mathrm{~d}$ हंसोड़्रमण॰ ] वासार्थं भ्रम॰ ${ }^{\circ}$ भूम॰ $\mathrm{A}_{4}$, भूमि॰ $\left.\mathrm{A}_{3}\right\}$ A 36e-37b ] om. $\mathbf{A} 37 \mathbf{d}$ वराहं ] वाराहं $\mathbf{A}$ 37e आधावितौ] सुवारितौ A $37 \mathbf{f} \circ$ मुत्पातौ] सु $\left\{\right.$ सू० $\left.\mathrm{A}_{3}\right\}$ तौ तौ $\mathbf{A}$ • ०विव ] विह $\mathbf{A}$

32 $\left(a^{2}, a^{5}-a^{6}, a^{8}-b^{3}, b^{8}-c^{1}, d^{3}\right) S_{1} \quad 37\left(e^{8}\right) S_{3}$

31b वेगितौ] $S_{1} R_{7}^{a c} B h$, चौदितौ $S_{3}$ 31c वराहं ] $S_{3} R A B h$, वराह $S_{1}$ - युगपत् ] $S_{1}^{\mathrm{pc}} S_{3} R$ $\mathrm{ABh}$, युगप $S_{1}^{\text {ac }}$ 31d विनेदतु: ] $S_{1}^{\text {pc }} S_{3} R A B h$, पिविनेदतु: $S_{1}^{\text {ac }}$ (unmetrical) 32d बलादेव ] $\mathrm{S}_{1}^{\mathrm{ac}} \mathrm{S}_{3} \mathrm{RABh}$, बला(द्दे)व $\mathrm{S}_{1}^{\mathrm{pc}} \quad$ 33a इचरन्] $\mathrm{S}_{1} \mathrm{Bh}$, ररन् $\mathrm{S}_{3}$ 33d बहूनि च ] $S_{3} R \mathbf{A}$, बहून्यपि $\mathrm{S}_{1} \mathrm{Bh} \quad 34 \mathrm{a}$ आक्षित्र०] $\mathrm{S}_{1} \mathrm{RBh}$, अक्षित्र $\mathrm{S}_{3} \quad \mathbf{3 4 c}$ निक्षितं ] $\mathrm{S}_{3} \mathrm{RA}$, विक्षितं $\mathrm{S}_{1} \mathrm{Bh}$ 35a परावृत्त निवृत्तं च ] $\mathrm{RA}_{4} \mathrm{~A}_{7} \mathrm{Bh}$ (em.?), बरावृत्तन्निष्टन्तम्च $\mathrm{S}_{1}$, परावृत्तनिवृत्तं च $\mathrm{S}_{3}$ 35c विश्टब्धं ] $\mathrm{RABh}$, विष्टब्ध $\mathrm{S}_{1} \mathrm{~S}_{3} 35 \mathrm{~d}$ हंसोड्रमणमे॰] em., हंसोभ्रमण ए॰ $\mathrm{S}_{1}$, हन्सोभ्रमणमे॰ $\mathrm{S}_{3}$, हंसोड्रमितमे॰ $\mathrm{Bh}$ (conj.) 36b च] $S_{3} A$, स $S_{1}$, स: Bh (em.?) 36d उन्धकाय ] $S_{1} S_{3} R A$, न्धकस्य Bh (conj.) - ॰ नादयन् ] $S_{1} R A B h$, ०नादयत् $S_{3}$ 36f बलवान् ] $S_{1} S_{3}^{\text {pc } B h, ~ ब ल व ा ~} S_{3}^{\text {ac }}$ 37a गदे ] $S_{1}^{\text {pc }} S_{3} B h$, शदे $\mathrm{S}_{1}^{\mathrm{ac}}$ - महावेगौ] $\mathrm{S}_{3} \mathrm{R}$, महावेगे $\mathrm{S}_{1} \mathrm{Bh} \quad 37 \mathrm{~b}$ ०रासदौ] $\mathrm{S}_{1}^{\mathrm{pc}} \mathrm{S}_{3} \mathrm{RBh}$, ०रासदै: $\mathrm{S}_{1}^{\mathrm{ac}} \quad 37 \mathrm{c}$ वस्चयित्वा ] $\mathrm{S}_{1} \mathrm{RABh}$, वचयित्वा $\mathrm{S}_{3}$ 37e देश०] $\mathrm{S}_{1} \mathrm{~S}_{3}^{\mathrm{pc}} \mathrm{ABh}$, दे(व०) $\mathrm{S}_{3}^{\mathrm{ac}}$ 37f ०विव] $\mathrm{S}_{1} \mathrm{Bh}$, ०विह $\mathrm{S}_{3}$ 
तयोरापततोरेव वराहो उसौ महाबलः।

मुष्टिनान्धकमाहत्य विप्रचित्तिं पदावधीत्॥ ३५॥

अन्धकस्तस्य मुष्टिं तं विप्रचित्तिः पदं च ह।

कुद्धौ जगृहतुर्देत्यौ हतस्त्वमितिवादिनौ।

नादयानौ यथाकाले कृष्णाविव बलाहकौ॥ ३९ ॥

स गृहीतस्तदा ताभ्यां महात्मा सुरसत्तमः।

उत्पपात वियद्वेगात्पक्षिराडिव काश्यपः॥ ४०॥

वियत्स्थो विबभौ दैत्यावुद्वहन्स मृगेश्वरः।

गरुत्मानिव पक्षीशो भक्षार्थं गजकच्छ,पौ॥ ४? ॥

विनद्य स तदाकाशे विधूय च करौ बली।

पादं चैवाभिचिक्षेप तौ दैत्यौ भुजगाविव॥ ४२॥

तौ क्षिप्रौ पेततुर्व्यास दानवौ युद्धदुर्मदौ।

दारयानौ महीं घोरावशनी खाच्च्युताविव॥ ४३॥

असावपि च देवेशो वराहो नन्दिवर्धनः।

रथान्वै सर्वदैत्यानां चूर्णयामास वीर्यवान्॥ ४४॥

38a तयोरा॰] $\mathrm{R}^{\mathrm{pc}}$, ततोरा॰ $\mathrm{R}^{\mathrm{ac}} \quad 38 \mathrm{~d}$ पदावधीत् ] तदाहनत् $\mathrm{R} \quad 39 \mathrm{a}-\mathrm{d}$ ] om. $\mathrm{R} \quad 40 \mathrm{c}$ क्देगात् ] ${ }^{\circ}$ ताभ्यां $\mathrm{R} \quad 41 \mathrm{ab}$ वियत्स्थो विबभौ दैत्यावुद्वहन् ] वियत्स्था $\left\{{ }^{\circ}\right.$ त्स्थो $\left.\mathrm{R}^{\mathrm{ac}}\right\}$ विव तौ दैत्यौ वृत्तहा $\mathrm{R}$ 42ab ] om. $R \quad 42 \mathrm{c}$ पादं चैवाभि०] पादेनैवाति॰ $R \quad 43 \mathrm{~b}$ ०दुर्मदौ] ०निर्म्मदौ $R \quad 43 \mathrm{~cd}$ महीं घोरावशनी ] महाघोराववनिं $\mathrm{R} 43 \mathrm{~d}$ खाच्च्युता॰ ] $\mathrm{R}^{\mathrm{pc}}$, खा च्युता॰ $\mathrm{R}^{\mathrm{ac}} \quad 44 \mathrm{c}$ ०न्वै सर्व॰] ॰न्रथै: स $\mathrm{R}$ - ०दैत्यानां ] $\mathrm{R}^{\mathrm{pc}}$, (दे)वानां $\mathrm{R}^{\mathrm{ac}}$

$38 \mathrm{a}$ तयोरा॰ ] ततोरा॰ $\mathrm{A}_{3} \mathrm{~A}_{7}$, ततो स $\mathrm{A}_{4} \quad 38 \mathrm{ab}{ }^{\circ}$ तोरेव वराहो ] ${ }^{\circ}$ तो व्यास वाराहो $\mathbf{A} 38 \mathrm{~d}$ पदावधीत् ] पदाहनत् $A$ 39ab ] om. $A$ 39c क्रुद्धौ] $A_{3}$, कुद्धो $A_{4} A_{7}$ 39e-104.11b ] om. A

38 $\left(d^{4}-d^{6}\right) S_{3} \quad 41\left(c^{2}-c^{3}\right) S_{3} \quad \mathbf{4 2}\left(d^{4}\right) S_{1} \quad 43\left(c^{1}-c^{2}, c^{4}, d^{5}\right) S_{1} \quad 44\left\langle d^{3}-d^{8}\right\rangle S_{3}$

38a ०पततोरेव ] $\mathrm{S}_{3} R B h$ (em.?), ०पततेरेव $S_{1} \quad 38 b$ महाबलः ] $S_{1} S_{3}^{\text {pc }} R A B h$, मुहाबलः $S_{3}^{\text {ac }}$ 38d ०चित्तिं पदावधीत् ] $S_{1} B h$, ०चि(त्ति पदा)वधीम् $S_{3}$ 39a अन्धकस्त्र ] $S_{3} B h$ (em.?), अन्धकन्त० $S_{1} \quad 39 b$ विप्रचित्तिः ] $S_{3} B h$ (em.?), विप्रचित्ति $S_{1}$ 39c कुद्धौ ] $S_{3} A_{3} B h$, कुद्धो $S_{1}$ • जगृहतुर् ] $S_{1} A B h$, जगृहतु $S_{3}$ (unmetrical) 39e नादयानौ] $S_{1}^{\text {pc }} S_{3} R B h$, नादया (न्तौ) $S_{1}^{\text {ac }}$ 40c द्वेगात् ] $S_{1}^{\text {pc }} S_{3} B h$, ${ }^{\circ}$ द्वेगा $S_{1}^{a c}$ 41a वियत्स्थो ] $R^{\text {ac }} B h\left(e m\right.$.), वियस्थौ $S_{1}$, वियस्थो $S_{3}$ 41c गरुत्मानिव ] $\mathrm{S}_{1}^{\mathrm{pc}} \mathrm{S}_{3} \mathrm{RBh}$, गरुत्मा (चै)व $\mathrm{S}_{1}^{\mathrm{ac}} \quad$ 41d भक्षार्थ ] $\mathrm{S}_{1} \mathrm{RBh}$, भक्षार्थ $\mathrm{S}_{3}$ 42a ०दाकाशे] $\mathrm{S}_{1}^{\mathrm{pc}} \mathrm{S}_{3} \mathrm{Bh}$, ०दाकाशै $\mathrm{S}_{1}^{\mathrm{ac}} \quad \mathbf{4 2 b}$ बली ] $\mathrm{S}_{1} \mathrm{~S}_{3}^{\mathrm{pc}} \mathrm{Bh}$, ब(ती) $\mathrm{S}_{3}^{\mathrm{ac}} \quad 42 \mathrm{c}$ पादं चैवा०] $\mathrm{S}_{1} \mathrm{Bh}$, पादेनैवा० $S_{3}^{\mathrm{pc}}$, पाद (चै)व $S_{3}^{\mathrm{ac}} 42 \mathrm{~d}$ दैत्यौ] $\mathrm{S}_{1} \mathrm{~S}_{3}^{\mathrm{pc}} \mathrm{RBh}$, देत्यौ $\mathrm{S}_{3}^{\mathrm{ac}}$ - भुजगा० ] $\mathrm{S}_{1}^{\mathrm{pc}} \mathrm{S}_{3} \mathrm{RBh}$, स्वजगा० $\mathrm{S}_{1}^{\mathrm{ac}} \quad$ 43a पेततुर ] $\mathrm{R}$, प्रेक्षतु $\mathrm{S}_{1}$, पेततु $\mathrm{S}_{3}$, प्रेक्ष्य तु $\mathrm{Bh}(\mathrm{em}.) \quad \mathbf{4 3 b}$ ॰दुर्मदौ ] $\mathrm{S}_{3} B h$ (conj.?) ॰दुम्म्मतौ $\mathrm{S}_{1} \quad$ 43c दारयानौ ] $\mathrm{S}_{3} \mathrm{R}$, (दीव)या(नौ) $\mathrm{S}_{1}^{\mathrm{pc}}$, (दाव)या(तौ) $\mathrm{S}_{1}^{\mathrm{ac}}$, अभियातौ $\mathrm{Bh}$ (conj.?) - महीं ] em. Bh (silently), मही $\mathrm{S}_{1} \mathrm{~S}_{3} \quad \mathbf{4 3 d}$ खाच्च्युता $\left.{ }^{\circ}\right] \mathrm{S}_{1}^{\mathrm{pc}} \mathrm{R}^{\mathrm{pc}} \mathrm{Bh}$, खा (च्यु)ता॰ $\mathrm{S}_{1}^{\mathrm{ac}}$, खा च्युता॰ $\mathrm{S}_{3}$ - ०वि ] $\mathrm{S}_{1}^{\mathrm{ac}} \mathrm{S}_{3} \mathrm{RBh}$, ०विदं $\mathrm{S}_{1}^{\mathrm{pc}}$ 
गृहीत्वा कूबरे कंचित्स चिक्षेप महार्णवम्।

कंचित्पदा समाहत्य पांसुसायुज्यमानयत् ॥ ४४ ॥

कंचिद्रथं रथेनैव पदातिं च पदातिना।

गजं गजेन चाहत्य स निन्ये यमसादनम्॥ ४६॥

सनत्कुमार उवाच।

ते डथ विद्राविता: सर्वे लज्जां परमिकां गताः।

दैत्यदानवशार्दूला विनिवृत्ता यथाबलाः ॥ ४७॥

एकेन सर्वे विजितासुरेन्द्राः परस्परं वीक्ष्य मुखानि शूराः।

त्रीडान्वितास्तं पुनरेव देवं वराहदेहं परिवार्य तस्थुः॥ ४५॥

इति स्कन्दपुराणे न्युत्तरशतो ऽध्यायः॥ १०३॥

45ab कंचित्स चिक्षेप महार्णवम् ] कांश्चिच्चिक्षेप स महार्ण्णवे $R \quad 45 \mathrm{~cd}$ ] om. $R$ 47d यथाबला: ] यथाचला: $R \quad 48 \mathrm{ab}$ ] om. $R \quad 48 \mathrm{c}$ ०स्तं ] ०स्ते $R \quad 48 \mathrm{~d}$ वराहदेहं ] महावराहं $\mathrm{R}$ Col. इति स्कन्दपुराणे रेवाखण्डे डध्याय: $R$

$46\left(a^{7}-b^{2}\right)\left\langle b^{6}\right\rangle\left(c^{2}\right) S_{1} \quad 47\left(a^{2}\right) S_{1},\left(d^{1}-d^{4}\right)\left\langle d^{5}-d^{7}\right\rangle\left(d^{8}\right) S_{3} \quad 48\left(a^{2}, b^{4}, c^{1}, c^{11}-d^{3}\right)\left\langle d^{4}-d^{10}\right\rangle\left(d^{11}\right)$ $\left\langle d^{12}\right.$ ?-middle of colophon $\rangle S_{1},\left(a^{1}-a^{4}\right) S_{3}$

45b ॰त्स चि॰] em., ०त्सो चि॰ $\mathrm{S}_{1} \mathrm{~S}_{3}$, ०त्सोच्चि॰ $\mathrm{Bh}$ (conj.?) • महार्णवम् ] $\mathrm{S}_{1} \mathrm{~S}_{3}$, महार्णवे $\mathrm{Bh}$ (conj.) 45c ॰त्पदा ] $S_{3} B h$ (em.?), ॰त्पादा $S_{1}$ 45d पांसु॰] $S_{1} S_{3}$, पांशु॰ $B h$ (em.?) 46d स] $\mathrm{RBh}$ (em.?), सो $\mathrm{S}_{1}$ (retraced) $\mathrm{S}_{3}$ 47a ते डथ ] $\mathrm{S}_{1}$ (retraced) $\mathrm{S}_{3} \mathrm{R}$, तेपि Bh (conj.?) - ॰द्दाविता: ] RBh (em.?), ॰द्राविता $\mathrm{S}_{1} \mathrm{~S}_{3}$ 47b लज्जां ] $\mathrm{RBh}$ (em.?), लज्जा $\mathrm{S}_{1}$ (retraced), लजां $\mathrm{S}_{3}$ - परमिकां ] $\mathrm{S}_{3} \mathrm{RBh}$ (em.?), बरमिका $\mathrm{S}_{1}$ (retraced) • गता: ] RBh (em.?), गता $\mathrm{S}_{1}$ (retraced) $\mathrm{S}_{3}$ 47d यथाबला: ] em. Bh (silently), यथाबला $\mathrm{S}_{1}$ (retraced), $\cdots: \mathrm{S}_{3}$ 48a एकेन ] $\mathrm{S}_{1}$ (retraced)Bh, (एतेन) $\mathrm{S}_{3}$ (upper parts lost) - ०सुरेन्द्रा: ] em. Bh (silently), ०सुरेंद्रा $\mathrm{S}_{1}$ (retraced), ॰सुरेन्द्रा $\mathrm{S}_{3} \quad \mathbf{4 8 b}$ शूरा: ] em. Bh (silently), शूरा $\mathrm{S}_{1}$ (retraced) $\mathrm{S}_{3} \quad \mathbf{4 8 c}$ त्रीडा॰] $\mathrm{S}_{1}$ (retraced)RBh, कीडा० $\mathrm{S}_{3}$ • ०स्तं ] $\mathrm{S}_{3}$, ०स्त $\mathrm{S}_{1}$ (tops lost, retraced), ०स्ते Bh (conj.?) 48d वराहदेहं ] $S_{3}$, (वराह) $\cdots S_{1}$, वराह-- Bh • परिवार्य तस्थुः ] R, $\cdots$ (स्थु) $\cdots S_{1}$ (upper parts lost, retraced), परिवार्य तस्थुरिति $S_{3}$ (इति part of col.), ----- ति Bh (conj.?) Col. ... वराहयुद्धे आध्यायः १५५ (in letter numerals)॥ $\odot \mathrm{S}_{1}, \odot \|$ स्कन्दपुराणे नामाध्यायः १०४ (in letter numerals)॥ $\mathrm{S}_{3}$, इति स्कन्दपुराणे वराहयुद्धे श्युत्तरशततमोध्याय: Bh 
चतुरुत्तरशतो डध्यायः।

सनत्कुमार उवाच।

अथ ते तं मृगं व्यास दानवा भीमगर्जनाः।

आयुधै: समभिक्रुद्धास्ततक्षुस्त तदा भृशम्॥ ? ॥

ते मृगा इव शार्दूल सिंहपोतं गजा इव।

आजघुद्रानवाः ऋुद्वा वराहं शस्त्रवृष्टिभिः॥ २॥

स चापि मृगशार्दूल उपविश्य महोदधौ।

आपो उपिबत्समाविश्य वह्निवद्वडवामुखे॥ ३॥

तथा तानीरितान्देत्यैरायुधानि सहस्रशः ।

व्यादाय सुमहद्वक्त जग्रास च ररास च॥ ४॥

ग्रसित्वा तानि सर्वाणि शस्त्राणि स महाबलः।

दानवान्प्रति संचक्र वेगं सिन्धुरिवापर:॥ $y \|$

$1 c$ आयुधै: ] असुरै: $\mathrm{R} \quad 1 \mathrm{~cd}$ ॰ कुद्धास्ततक्षुस्तं त॰] ॰ कुद्धा वार्य्य तस्थुस्त० $\mathrm{R} 3 \mathrm{~b}$ उपविश्य महोदधौ] प्रविश्य हि महोदधिम् $R \quad 3 c$ आपो उपिबत् ] स योगीव $R \quad 4 a$ तथा तानीरितान्दैत्यै० ] तथेरितानि दैत्येन्द्रै० $R \quad 4 d$ जग्रास] जग्राह $R \quad 5 a$ ग्रसित्वा तानि ] असिधाराणि $R \quad 5 b$ शस्त्राणि स ] स शस्त्राणि $\mathrm{R}$

Manuscripts available for this chapter: $S_{1}$ photos $4.4 \mathrm{a}$ (f. $160^{\mathrm{v}}$, largely retraced), $2.34 \mathrm{a}\left(\mathrm{f} .161^{\mathrm{r}}\right.$, largely retraced), $2.33 \mathrm{~b}\left(\right.$ f. $161^{\mathrm{v}}$ ), and $4.4 \mathrm{~b}\left(\right.$ f. $162^{\mathrm{r}}$ ); $\mathrm{S}_{3}$ f. $160^{\mathrm{v}}-162^{\mathrm{r}} ; \mathrm{R}$ f. $177^{\mathrm{r}}-178^{\mathrm{v}} ; \mathrm{A}_{3}$ f. $105^{\mathrm{v}}-$ $106^{\mathrm{r}} ; \mathrm{A}_{4}$ f. $149^{\mathrm{r}}-150^{\mathrm{r}} ; \mathrm{A}_{7}$ f. $149^{\mathrm{r}}-150^{\mathrm{v}}$ (A from 11c).

$2\left(a^{6}, a^{8}\right) S_{3} \quad 3\left(b^{1}-b^{2}, b^{8}\right) S_{1}$

1 सनत्कुमार उवाच ] $\mathrm{S}_{1} \mathrm{~S}_{3}^{\mathrm{pc}} \mathrm{RBh}$ (सन उ in $\mathrm{S}_{1} \mathrm{~S}_{3}^{\mathrm{pc}}$ ), om. $\mathrm{S}_{3}^{\mathrm{ac}}$ 1b ०गर्जना: ] $\mathrm{S}_{1}$ (retraced)RBh, ॰गर्जना $S_{3} \quad 1 c$ आयुधै: ] $S_{1}$ (retraced)Bh, आयुधै $S_{3} \quad 1 c d$ ॰ कुद्धास्ततक्षुस्तं त० ] conj., ०कुद्धो तक्षतस्तं त॰ $S_{1}$, ॰ क्रुद्धास्तक्षतस्तं त॰ $S_{3}$, ॰ क्रुद्धाः संततक्षुस्त॰ $B h$ (conj., in a note Bh reads ततक्षुस्तं in $\mathrm{S}_{1}$ ) $2 \mathbf{a}$ शार्दूलं ] $\mathrm{S}_{1} \mathrm{RBh}$, (शा)दू(ल) $\mathrm{S}_{3} \quad \mathbf{2 b}$ गजा इव] $\mathrm{S}_{1} \mathrm{RBh}$, गजाविव $\mathrm{S}_{3} \quad \mathbf{2 c}$ आजघुर्दानवा: ] $\mathrm{RBh}$ (conj.?), आजग्मुर्दानवा $\mathrm{S}_{1}$, आजघु दानवा $\mathrm{S}_{3} \mathbf{3 b}$ महोदधौ] $\mathrm{S}_{3}$, महोद(धे) $\mathrm{S}_{1}$ (right part and tops lost, retraced), महोदधिम् Bh (em.?) $\quad 3 c$ आपो $] \mathrm{S}_{1} \mathrm{~S}_{3}$, अपो Bh (em.?) 3d वह्निवद्वडवा० ] RBh, वह्निवद्वडवा० $S_{1}$, वह्निस्ता वडवा॰ $S_{3} \bullet \circ$ मुखे ] $S_{3} R$, ॰मुख: $S_{1}$ (retraced), ॰ मुखम् $\mathrm{Bh}$ (conj.?) $\quad \mathbf{4 a}$ तथा तानीरितान्देत्यै० $\mathrm{S}_{3}$, तथा तानीरिता दैत्यौ॰ $\mathrm{S}_{1}$, तथेरितानि तैर्देत्यै० $\mathrm{Bh}$ (conj.?) 4c व्यादाय ] $\mathrm{S}_{1} \mathrm{~S}_{3}^{\mathrm{pc}} \mathrm{RBh}$, व्याद(व्य) $\mathrm{S}_{3}^{\mathrm{ac}}$ - ॰द्वक्रं ] $\mathrm{S}_{1}^{\mathrm{pc}} \mathrm{RBh}$, ०द्व(क्षं) $\mathrm{S}_{1}^{\mathrm{ac}}$, ०द्वक्र $\mathrm{S}_{3} 4 \mathbf{d}$ जग्रास] $\mathrm{S}_{1} \mathrm{Bh}$, जग्राह $\mathrm{S}_{3} \quad \mathbf{5 b}$ स ] $\mathrm{S}_{3} \mathrm{Bh}$ (conj.), सु॰ $\mathrm{S}_{1}$ 5d वेगं सिन्धुरिवापरः ] $\mathrm{S}_{1} \mathrm{RBh}$, वेग सिन्धुमिवापरं $\mathrm{S}_{3}$ 
गजान्प्रति यथा सिंहः सिंहान्छरभराडिव।

गरुत्मान्भुजगान्यद्वच्छार्दूलग्च मृगानिव।

मेघवृन्दान्यथा वायुः कपोतानिव पक्षिराट्॥ ६॥

तथा स भगवान्व्यास दानवान्प्रति लोकपः।

वेगं चक्रे यथा क्षिप्रमिन्द्रियान्प्रति वै मनः॥ ७॥

आसाद्य च स तान्देत्यान्महाजलदनिस्वनः।

सर्वान्विद्रावयामास रुद्र: पशुगणानिव॥ ५॥

कंचित्पद्यां सुसंक्रुद्धो हस्ताभ्यामपरानपि।

अपरान्दंट्र्रया तत्र ह्यप्रैषीद्यमसादनम्॥ ९॥

तलेन शम्बरं भूमौ कालशम्बरमेव च।

नरक पादघातेन हयग्रीवं च मुष्टिना॥ १०॥

उरसा नमुचिं चापि महामायं च सुत्रत।

आहत्याहत्य संकुद्धः पातयामास देवपः॥ १? ॥

$6 \mathbf{b}$ ॰्छरभ०] ० न्छरभरभ० $\mathrm{R}$ (unmetrical) $7 \mathbf{a}$ तथा ] तदा $\mathrm{R} \quad 7 \mathbf{b}$ लोकप: ] लोलुप: $\mathrm{R}$ 7cd क्षिप्रमि०] वह्निरि॰ $R \quad 8 a$ आसाद्य च स तान् ] आस्वाद्य $\langle$ च $\rangle$ भगवान् $R$ 9a कंचित् ] $R^{\mathrm{pc}}$, (क्ष) चित् $\left.R^{\mathrm{ac}} \quad 9 \mathrm{~cd}\right]$ om. $\mathrm{R} \quad 10 \mathrm{a}$ शम्बरं भूमौ] सम्बरं भूय: $\mathrm{R} \quad 10 \mathrm{~b}$ ॰शम्बर॰] ०सम्बर॰ $\mathrm{R}$

11d देवप: ] दैत्यपान् $\mathrm{A}_{4} \mathrm{~A}_{7}$, दैपान् $\mathrm{A}_{3}$ (unmetrical)

$\mathbf{6}\left(d^{7}\right) S_{1} \quad 7\left(d^{2}\right) S_{1}$

6a गजान् ] $S_{1} R B h$, गजा $S_{3}$ - सिंह: ] $S_{1}^{\mathrm{pc} R B h}$, सिंह $S_{1}^{\mathrm{ac}}$, सिंहा $S_{3}$ 6b सिंहान्छः ] $R B h$ $(\mathrm{em} . ?)$, सिंहा श॰ $\mathrm{S}_{1}$, सिहा श॰ $\mathrm{S}_{3}$ 6c गरुत्मान् ] $\mathrm{RBh}(\mathrm{em} . ?),\langle($ रु $)\rangle+\pi+$ रुत्मा $\mathrm{S}_{1}$ (retraced), गरुत्मा $S_{3}^{\mathrm{pc}}$, गभत्मा $\mathrm{S}_{3}^{\mathrm{ac}}$ 6d मृगानिव ] $\mathrm{S}_{3} \mathrm{RBh}(\mathrm{em} . ?)$, मृगा(ज्छि) व $\mathrm{S}_{1}$ (retraced, unmetrical) 6e ॰वृन्दान् ] $S_{3} R$, ०वृन्द $S_{1}$ (retraced), ॰वृन्दं Bh (em.?) • वायुः ] RBh (em.?), वायु $\mathrm{S}_{1}$ (retraced) $S_{3}$ 7c वेगं ] $\mathrm{S}_{1} \mathrm{RBh}$, वेग $\mathrm{S}_{3}$ • क्षित्र ${ }^{\circ} \mathrm{S}_{3}$, क्षिप्र० $\mathrm{S}_{1} \mathrm{Bh}$ 7d ०मिन्द्रियान्प्र०] $\mathrm{em}$, ०मि(न्द्रि)यं प्र० $\mathrm{S}_{1}$, ०मिन्द्रियाम्प्र० $\mathrm{S}_{3}$, ०मिन्द्रियं प्र० $\mathrm{Bh} \quad$ 8a च] $\mathrm{S}_{3} \mathrm{R}^{\mathrm{ac}} \mathrm{Bh}$ (conj.?), तं $\mathrm{S}_{1}$ - तान्देत्यान् ] $S_{3} B h$ (em.?), तान्देत्या $S_{1} \quad 8 b$ ०निस्वन: ] $S_{1} S_{3} R$, ०निःस्वन: Bh (em.?) 8d ०गणानिव ] $S_{1}^{\mathrm{ac}} \mathrm{S}_{3} \mathrm{RBh}$, गगणानि च $\mathrm{S}_{1}^{\mathrm{pc}}$ 9a कंचित् ] $\mathrm{S}_{3} \mathrm{R}^{\mathrm{pc}}$, किस्चित् $\mathrm{S}_{1}$, कांश्चित् $\mathrm{Bh}$ (conj.?) - ॰संक्रुद्धो ] RBh (em.?), ॰संक्रुद्धा $S_{1}$ (retraced), ०सक्रुद्धौ $S_{3}$ 9b हस्ताभ्याम॰ ] $S_{1} R B h$, हस्ताभ्यान॰ $S_{3}$ • ०नपि ] $S_{3} R$, ०निति $S_{1}$ (retraced)Bh 9c अपरान्दंष्ट्रया त० ] $S_{1}^{\text {pc }}$ (retraced), अपरान्द्रंट्रया त॰ $\mathrm{S}_{1}^{\mathrm{ac}}$, अपरां द्रष्टया त॰ $\mathrm{S}_{3}$, दंष्ट्राभिश्चापरांस्त॰ $\mathrm{Bh}$ (conj.) 9d ह्यप्रैषीद् ] $\mathrm{S}_{1}^{\mathrm{ac}} \mathrm{S}_{3}$, ह्यप्रेषीद् $S_{1}^{p c}$ (retraced), स प्रैषीद् $B h$ (conj.) $\quad \mathbf{1 0 a}$ तलेन ] $S_{1}^{p c}$ (retraced) $S_{3} R$, तथा $\simeq S_{1}^{a c}$, तुण्डेन $\mathrm{Bh}$ (conj.) 10d मुष्टिना ] $\mathrm{S}_{3} \mathrm{RBh}\left(\mathrm{em}\right.$. ?), मुष्टिना: $\mathrm{S}_{1}$ (retraced) $11 b$ सुत्रत ] $\mathrm{R}$, शम्बर: $\mathrm{S}_{1}$ (retraced), सुत्रत: $S_{3}$, सत्वर: $B h$ (conj.) 11c संक्रुद्ध: ] $S_{3} R A B h$, संक्रुद्ध $S_{1}$ 
तांस्तथा द्रावयाणं च गर्जमानं च सिंहवत्।

विप्रचित्तिर्वराहं तं मुष्टिनोरस्यताडयत्।

विप्रचित्ति जघानोग्रं पार्श्वदेशे स मुष्टिना॥ ?२॥

स आहतो वराहेण वराहं ऋोधमूह्छितः।

पुनर्जघान खड्गेन वक्षस्येनं विनादयन् ॥ १३॥

अमृष्यमाणस्तं घातं वराहः स महाबलः।

मुष्टिना मूर्धि तं दैत्यं वज्राभेन व्यताडयत् ॥ १४॥

स दैत्यस्तेन घातेन भ्रमित्वा चऋवत्तदा।

पपात भूमौ वेगेन वाताहत इव द्रमः ॥ १५ ॥

पतितं तं तदाम्येत्य विप्रचित्तिं मृगेश्वर:।

पादे जग्राह देवेशो द्रावयाणो दितेः सुतान्॥ ?६॥

म्रामयित्वा ततश्चैन नर्दित्वा चासकृद्वूली।

पुरं प्रति विचिक्षेप महात्मा नन्दिवर्धनः॥ १७॥

12a तांस्तथा द्रावयाणं च ] तन्तथा द्वावयामास $R \quad 12 \mathrm{~d}$ ॰नोरस्य॰ $] \mathrm{R}^{\mathrm{ac}}$, ॰नोरस्या॰ $\mathrm{R}^{\mathrm{pc}} 13 \mathrm{a}$ वराहेण ] $\mathrm{R}^{\mathrm{pc}}$, वराहेन $\mathrm{R}^{\mathrm{ac}} \quad 13 \mathrm{~b}$ वराहं ] वराह: $\mathrm{R} \quad 16 \mathrm{~d}$ दावयाणो ] दारयाणो $\mathrm{R} \quad 17 \mathrm{~b}$ 'द्वली ] ॰ड़शम् $\mathrm{R}$

12a तांस्तथा द्रावयाणं ] तं तथा प्राद्रवन्तं $\mathrm{A} 12 \mathrm{~b}$ सिंहवत् ] $\mathrm{A}_{7}^{\mathrm{pc}}$, संहवत् $\mathrm{A}_{7}^{\mathrm{ac}}$, संहरत् $\mathrm{A}_{3} \mathrm{~A}_{4} 12 \mathrm{c}$ विप्रचित्तिर्वराहं तं ] विप्रचित्तिं $\left\{{ }^{\circ}\right.$ त्त $\left.\mathrm{A}_{4}\right\}$ वराहस्तं $\mathrm{A} \quad 12 \mathrm{e}-14 \mathrm{~d}$ ] om. A $\mathbf{A}$ 15d वाताहत इव ] $\mathrm{A}_{3}$, वाता इव हत० $\mathrm{A}_{4} \mathrm{~A}_{7} \quad 16 \mathrm{a}$ ०दाम्येत्य ] ०दालक्ष्य $\left\{\circ\right.$ क्ष $\left.\mathrm{A}_{4}\right\} \quad \mathrm{A} \quad 16 \mathrm{c}$ पादे ] पदे $\mathrm{A}_{3} \mathrm{~A}_{4}$, पाद $\mathrm{A}_{7} 16 \mathrm{~d}$ द्रावयाणो ] द्रावमाना $\left\{\circ\right.$ णान् $\left.\mathrm{A}_{7}\right\} \mathbf{A} \quad 17 \mathbf{a b} \circ$ त्वा ततश्चैनं नर्दित्वा चा०] ${ }^{\circ}$ त्वाथ मर्दित्वा गर्जि $\{\circ$ कि $०$ $\left.\mathrm{A}_{3}\right\}$ त्वाथ $\mathbf{A}$

$15\left(c^{4}, d^{1}-d^{5}\right) S_{1} \quad 16\left(a^{2}\right)\left\langle a^{3}\right\rangle\left(a^{4}-a^{5}, a^{7}-b^{1}\right)\left\langle c^{1}-c^{4}\right\rangle\left(c^{5}-d^{4}\right) S_{1}$

12a द्रावयाणं च] em., द्रावयानस्च $S_{1} B h$, द्रावयानं च $S_{3}$ 12c विप्रचित्तिर् ] $S_{1}$ (retraced)RBh, विप्रचित्ति $S_{3} \quad 12 d$ ०ताडयत् ] $S_{3} R A B h$, ०ताडयम् $S_{1}$ (retraced) 12e विप्रचित्ति ] $S_{1}$ (retraced) $\mathrm{RBh}$, विप्रचित्ति $\mathrm{S}_{3} 12 \mathrm{f}$ पार्श्वदेशे स ] $\mathrm{S}_{1}^{\mathrm{ac}}$ (retraced)RBh, पार्श्वदेशो स $\mathrm{S}_{1}^{\mathrm{pc}}$ (retraced), पाश्वदेशेषु $\mathrm{S}_{3}$ - मुष्टिना ] $S_{1}^{\text {pc }}$ (retraced) $S_{3} R B h$, मुष्टिना: $S_{1}^{\text {ac }}$ (retraced) 13a आहतो ] $S_{3} R B h$ (em.?), आहता $S_{1}$ (retraced) • वराहेण ] $S_{1}$ (retraced) $R^{\mathrm{pc}} B h$, वराहेन $S_{3} \quad 13 c$ पुनर् ] $S_{1}$ (retraced)R $\mathrm{Bh}$, पुन $\mathrm{S}_{3}$ (unmetrical) $\quad$ खड्गेन $] \mathrm{S}_{1}^{\mathrm{pc}}$ (retraced) $\mathrm{S}_{3}^{\mathrm{pc}} \mathrm{RBh}$, ख(ने) $\mathrm{S}_{1}^{\mathrm{ac}}$ (unmetrical), खडेन $\mathrm{S}_{3}^{\mathrm{ac}}$ (unmetrical) 13d वक्षस्येनं ] $\mathrm{RBh}\left(\mathrm{em}\right.$. ?), वक्षस्यैनं $\mathrm{S}_{1} \mathrm{~S}_{3}$ • ॰ नादयन् ] $\mathrm{RBh}$ (em.?), ०नादयत् $\mathrm{S}_{1} \mathrm{~S}_{3} \quad 14 \mathrm{a}$ ०माणस्तं ] $\mathrm{S}_{3} \mathrm{RBh}$ (em.?), ॰माणंस्तं $\mathrm{S}_{1}$ 14b वराह: ] $\mathrm{S}_{1}^{\mathrm{pc}} \mathrm{S}_{3} \mathrm{RBh}$, वराह $\mathrm{S}_{1}^{\mathrm{ac}}$ - स ] $S_{3} R$, सु॰ $S_{1} B h \quad 14 c$ तं दैत्यं ] $S_{1}^{\text {ac }} S_{3} R B h$, तहैत्यं $S_{1}^{\text {pc }}$ (retraced) 14d ०ताडयत् ] $\mathrm{S}_{3} \mathrm{RBh}$ (em.?), ॰ताडयन् $S_{1}$ 15d इव] $S_{1}^{\text {pc }} S_{3} R_{3} B h$, इवा $S_{1}^{\text {ac }}$ 16a ०दाभ्येत्य ] $S_{1} R B h$, ०दाभेत्य $S_{3} 16 b$ ०चित्तिं मृगेश्वर: ] RA, ०चित्तिं प्रजेश्वरं $\left\{\right.$ ०र: $\left.S_{1}^{a c}\right\} S_{1}$ (retraced), ०चित्तिर्मृगेश्वर: $S_{3}$, ०चित्तिं प्रजेग्वर: $B h \quad 16 c$ पादे जग्राह $] S_{3} R, \cdots$ (ह) $S_{1}$ (retraced), जग्राह पद्यां $B h$ (conj.) 16d द्रावयाणो ] em., (द्रावमाना) $S_{1}$ (upper parts lost, retraced), द्रावयानो $S_{3}$, द्रावमाणं $\mathrm{Bh}$ (conj.) - दिते: ] $\mathrm{S}_{1}^{\mathrm{pc}}$ (retraced) $\mathrm{S}_{3} \mathrm{RA}_{3} \mathrm{~A}_{4} \mathrm{Bh}$, दिते $\mathrm{S}_{1}^{\mathrm{ac}}$ (retraced) - सुतान् ] $\mathrm{S}_{1} \mathrm{~S}_{3} \mathrm{RA}$, सुतम् $\mathrm{Bh}$ (conj.) 17a ०श्चैन ] $\mathrm{RBh}$ (conj.), ०श्चेव $\mathrm{S}_{1}$ (tops lost, retraced), ०श्चैव $\mathrm{S}_{3} \quad \mathbf{1 7 b}$ नर्दित्वा चा॰] $\mathrm{RBh}\left(\mathrm{em}\right.$. ?), नद्दित्वा चा॰ $\mathrm{S}_{1}$ (tops lost, retraced), नदित्वा च $\mathrm{S}_{3} \quad \mathbf{1 7 d}$ ०वर्धन: ] $\mathrm{S}_{1}($ retraced $) \mathrm{S}_{3}^{\mathrm{pc}} \mathrm{RABh}$, oवर्द्धन $\mathrm{S}_{3}^{\mathrm{ac}}$ 
स तेन क्षिप्रो विबभौ दानवाधिपतिर्बली।

सबलाकतडिज्ज्वालः परिच्छित्र इवाम्बुदः ॥ ?५ ॥

स्रस्तहाराम्बरधर श्च्युतमाल्यविभूषणः।

पपातोपरि वेगेन हिरण्याक्षस्य वेश्मनि॥ १९॥

सोच्चमट्टालक तस्य विमानमिव संस्थितम्।

चूर्णयानो उपतद्वास पर्वतेन्द्रमिवाशनिः॥ २०॥

महता चास्य शब्देन हिरण्याक्षः स्वयं तदा।

वेगेनागत्य ददृशे दानवेन्द्रं दितेः सुतः॥ २? ॥

सो ऽपि दानवशार्दूलो वराहेणावताडितः।

तेन चैव निघातेन मुहुर्तमभवज्जड:॥ २२॥

तं समाश्वासयद्राजा तदा शीतेन वारिणा।

तालवृन्त्रेश्च बहुभिर्मणिभिश्च दितेः सुतः ॥ २३॥

समाश्वस्योत्थितं चैव उपविष्टं वरासने।

राजा पप्रच्छ, तं दैत्यं परं विस्मयमागतः॥ २४ ॥

18cd ०कतडिज्ज्वालः परिच्छित्न ] ०कावलिद्योतत्परिच्छुद R 19ab ०धरश्चयुतमाल्यविभूषणः ] ०वरग्र्युमालो विभीषण: $R$ (unmetrical) 19d वेश्मनि ] धीमत: $R \quad 20 a$ सोच्चमट्टालकं ] उच्चमण्डनकन् $R \quad 20 b$ मिव ] ०मति॰ $R \quad 20 \mathrm{c}$ चूर्णयानो उपतद् ] चूर्णायामास तद् $R \quad 20 d$ पर्वतेन्द्रमिवाशनि: ] पर्वतेन हिमाचल: $R \quad 21 b$ ०क्षः स्वयं तदा ] ०क्षस्तदा भृशम् $R \quad 21 \mathrm{c}$ वेगेनागत्य ददृशे ] दृष्ट्वाननुगतो भूत्वा $R 21 d$ सुतः ] सुतम् $R 22 b$ ०णाव॰ ] ०णाभि॰ $R \quad 22 c$ तेन चैव नि॰ ] तेनैव विनि॰ $R$ $23 b$ तदा शीतेन ] तदानीं तेन $R \quad 23 d$ ०र्मणिभि॰] ०र्मालाभि॰ $R \quad 24 a b$ ] om. $R$

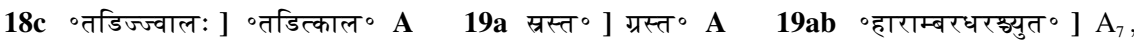
$\circ$ हारायु $\left\{{ }^{\circ}{ }^{\circ} \mathrm{A}_{4}\right\}$ रधराश्चुत० $\mathrm{A}_{3} \mathrm{~A}_{4}$ 19d वेश्मनि ] वेश्मन: $\mathrm{A} \quad 20 \mathrm{c}$ चूर्णयानो ] चूर्णमानो $\left\{\circ 0 \mathrm{~A}_{7}\right\}$ A $21 \mathrm{~cd}$ ॰नागत्य ददृशे दानवेन्द्र ] ॰ नाहत्य $\left\{\circ\right.$ न्य $\left.\mathrm{A}_{4}\right\}$ बहुभिर्दानवेन्द्रो $\mathbf{A} 22 \mathrm{~b}$ वराहेणा॰ ] $\mathrm{A}_{7}^{\mathrm{pc}}$, वराहेना० $\mathrm{A}_{3} \mathrm{~A}_{4} \mathrm{~A}_{7}^{\mathrm{ac}}$ - ${ }^{\circ}$ ताडितः ] ०पीडितः $A \quad 22 \mathrm{c}$ चैव निघातेन] दैत्यनिपातेन $A$ 22d ०वज्जड: ] ०वद्यतः $\mathrm{A}_{3} \mathrm{~A}_{4}$, ०वद्धतः $\mathrm{A}_{7} \quad 23 \mathrm{c}$ तालवृन्तै॰] वालवृंतै॰ $\mathrm{A}_{3}$, तालवृन्दै० $\mathrm{A}_{4} \mathrm{~A}_{7} \quad 23 \mathrm{~cd}$ ०भिर्मणि॰] $\mathrm{A}_{3}$, ०भि: र्मणि॰ $\mathrm{A}_{4}$, ०भिम्माला० $\mathrm{A}_{7}$ 24ab समाश्वस्योत्थितं चैव उपविष्टं ] आश्वास्योत्थापयच्चैव उपविष्टो $A \quad 24 c$ पप्रच्छ ] $A_{3}$, पपृच्छ $A_{4} A_{7}$

$18\left(\mathrm{c}^{6}, \mathrm{~d}^{7}-\mathrm{d}^{8}\right) \quad 19\left(\mathrm{a}^{5}-\mathrm{a}^{6}, \mathrm{c}^{1}, \mathrm{~d}^{7}\right) \mathrm{S}_{1}$

18a तेन क्षिप्रो ] $\mathrm{S}_{1} \mathrm{~S}_{3} R A$, क्षिप्तस्तेन $\mathrm{Bh}$ (conj.) $18 \mathrm{c}$ ०तडिज्ज्वालः ] $\mathrm{S}_{3}$, ०त(डि)ज्वाल॰ $\mathrm{S}_{1}^{\mathrm{ac}}$, ${ }^{\circ}$ त(ठि)ज्वाल॰ $S_{1}^{\mathrm{pc}}$ (retraced), ०तडिज्ज्वाल॰ $\mathrm{Bh} \mathbf{1 8 d}$ परिच्छि,्न ] $S_{1}\left(\right.$ retraced) $S_{3}^{\mathrm{pc}} \mathbf{A B h}$, परिच्छिद $S_{3}^{\text {ac }}$ 19ab ०धरश्चुत्त० $S_{1}$ (retraced) $A_{7} B h$, ०धरच्युत॰ $S_{3}$ 19b ०भूषणः ] $S_{3} A B h$, ॰ भूषण $S_{1}$ (retraced) 19c वेगेन ] RABh, वेगेण $S_{1} S_{3}$ 19d वेश्मनि ] $S_{1}$ (retraced), वेशनि $S_{3}$, वेश्ममनि Bh (typo, unmetrical) 20a सोच्च ] $\mathbf{A}$, सौध० $S_{1}^{\mathrm{pc}} B$, सौ(च॰) $S_{1}^{\mathrm{ac}}$, सोच॰ $S_{3} 20 d$ ०वाशनिः ] $S_{3} A B h$, ०वाशनि $S_{1}$ (retraced) 21a चास्य ] $S_{1}^{\mathrm{pc}} S_{3} R A$, स्य $S_{1}^{\text {ac }}$ (unmetrical), तस्य Bh (conj.?) 21b ०यं तदा ] $S_{3} A B h$, ०यन्तथा $S_{1}$ (retraced) 21c ददृशे ] $S_{1} B h$, ददृशो $S_{3}$ 21d दानवेन्द्रं ] $S_{1}^{\text {ac }} R B h$, दानवेन्द्र: $S_{1}^{p c}$, दानवेन्द्र $S_{3}$ - सुतः ] $S_{1}^{\text {ac }} S_{3} A B h$, सुतं $S_{1}^{p c} \quad 22 a$ ०शार्दूलो ] $\mathrm{S}_{3} \mathrm{RABh},{ }^{\circ}$ शार्दूला $\mathrm{S}_{1} \quad \mathbf{2 2 b}$ वराहेणा॰ ] $\mathrm{RA}_{7}^{\mathrm{pc}} \mathrm{Bh}\left(\mathrm{em}\right.$. ?), वराहेना॰ $\mathrm{S}_{1} \mathrm{~S}_{3}$ • ${ }^{\circ}$ ताडितः ] $\mathrm{S}_{1} \mathrm{~S}_{3} \mathrm{R}$, ०पीडितः $\mathrm{Bh}$ 22c निघातेन ] $\mathrm{S}_{3} \mathrm{R}$, विघातेन $\mathrm{S}_{1} B h$ 22d भवज्जड: ] $\mathrm{S}_{1}$ (retraced)R $\mathrm{Bh}$, ०भव जता: $\mathrm{S}_{3}$ (unmetrical) 23c बहुभिर् ] $\mathrm{S}_{1}$ (retraced)RA $\mathrm{R}_{3} \mathrm{~A}_{7} \mathrm{Bh}$, बहुभि $\mathrm{S}_{3}$ 23d दिते: ] $\mathrm{S}_{1} \mathrm{RABh}$, दिते $\mathrm{S}_{3}$ 24a समाग्वस्यो॰] $\mathrm{S}_{3} \mathrm{Bh}$ (conj.), समाग्वासो॰ $\mathrm{S}_{1}$ 24b उपविष्टं ] $\mathrm{S}_{1} \mathrm{Bh}$, उपविष्ट च $\mathrm{S}_{3}$ (unmetrical) $24 \mathrm{c}$ पप्रच्छ, ] $\mathrm{S}_{1}$ (retraced)RA $\mathrm{A}_{3} \mathrm{Bh}$, प्रपच्छ, $\mathrm{S}_{3}$ 
हिरण्याक्ष उवाच।

केनाद्य हिमवान्देत्य पृथिवी वा ससागरा।

महाबलैर्महादैत्य तुलिता विश्वकर्मणा॥ २४ ॥

केनाद्य मन्दरः स्तस्तो मृत्युः केन पराजितः।

केन त्वं दानवेशान क्षित्रः को बलवान्भुवि॥ २६॥

पृथिव्यास्तुलनं यादृझ्मन्दरस्य च चालनम्।

मृत्योग्च बन्धनं तादृक्तवेदं क्षिपणं मतम्॥ २७॥

रुद्रेन्द्रमृत्युप्रतिमो लोकपालभयंकरः।

केन त्वं तुलितः संख्ये बलवानबलो यथा॥ २५॥

कस्येदं बलमक्षय्यं केन बाह्वोर्बलं महत्।

र्यापितं त्रिषु लोकेषु दानवेश्वर कथ्यताम्॥ २९॥

सनत्कुमार उवाच।

तस्य तद्वचनं श्रुत्वा दानवः स महाबलः।

तमाह दीर्घ निश्वस्य निरीक्ष्य च पुनः पुनः॥ ३०॥

25 हिरण्याक्ष उवाच] om. $\mathrm{R} 25 \mathrm{c}$ ०बलैर्महादैत्य ] ०बल सदैत्येन $\mathrm{R} 25 \mathrm{~d}$ तुलिता ] $\mathrm{R}^{\mathrm{ac}}$, तुलितो $\mathrm{R}^{\mathrm{pc}} 26 \mathrm{a}$ केनाद्य ] केन स्यान् $\mathrm{R}$ - ०र: स्रस्तो ] ०रो ग्रस्तो $\mathrm{R}$ 26d क्षित्रः को बलवान् ] क्षित्रस्त्वबलवद् $\mathrm{R}$ 27a ०स्तुलनं ] ० ग्चालनं $\mathrm{R}$ 27cd ] मृत्योग्च चालनं यादृक् तादृक् च $\left\{\right.$ चि $\left.\mathrm{R}^{\mathrm{ac}}\right\}$ क्षेपनन्तव $R$ 28d वानबलो ] ववान् चलो $R$ (unmetrical) 29b केन] कस्य $R$ 30c निग्वस्य ] नि:ग्वस्य $\mathrm{R}$

25a हिमवान् ] हि महा ${ }^{A} 25 \mathrm{~b}$ पृथिवी वा ] पृथिवीयं A $25 \mathrm{~cd}$ ०बलैर्महादैत्य तुलिता ] ०ब [० च० $\left.\mathrm{A}_{7}\right\}$ लेन दैत्येश भूषिता $\mathrm{A} 26 \mathrm{a}$ ०र: स्रस्तो ] ०रो ग्रस्तो $\mathrm{A} 27 \mathrm{~cd}$ तादृक्तवेद क्षिपणं ] यादृक् तादृक् विक्षेपणं $\left\{\circ{ }^{\circ} \mathrm{A}_{7}\right\} \quad \mathrm{A}_{3} \mathrm{~A}_{7}$, यादृक् विक्षेपणं $\mathrm{A}_{4}$ (unmetrical) $28 \mathrm{~d}$ ०वानबलो] ॰वानचलो $\mathbf{A}$ 29a ममक्षय्यं ] $A_{3} A_{7}$, ०मक्षज्यं $A_{4} 29 b$ केन बाह्वोर्ब०] कस्य वक्षोब॰ $A$ 29c ख्यापित ] $A_{7}$, व्यापितं $\mathrm{A}_{3}$, क्षापितं $\mathrm{A}_{4} \quad 30 \mathrm{c}-\mathbf{3 2 d}$ ] om. $\mathbf{A}$

$\mathbf{2 6}\left(c^{1}-c^{3}\right) S_{1}$

$25 \mathrm{c}$ बबलैर्महादैत्य ] $S_{1}$, ०बलै महादैत्य $S_{3}$, ०बलेन सहसा Bh (conj.) 25d ०कर्मणा ] $S_{1}^{\mathrm{pc}} S_{3} R A$ $\mathrm{Bh}$, कर्माणा: $S_{1}^{\text {ac }}$ 26a ०र: स्रस्तो ] em. Bh (silently), ०रो स्रस्तो $S_{1}$ (retraced), ०रो ग्रस्तो $\mathrm{S}_{3} 26 \mathbf{b}$ पराजितः ] $\mathrm{S}_{3} \mathrm{RABh}$, पराजिता: $\mathrm{S}_{1}$ (retraced) 27c बन्धनं ] $A$, मरणन् $\mathrm{S}_{1}$, वधनं $\mathrm{S}_{3}$, मरणं $\mathrm{Bh}$ 27d ॰कवेदं ] $\mathrm{S}_{1} \mathrm{Bh}$, ०कवैद $\mathrm{S}_{3}$ - क्षिपणं मतम् $] \mathrm{S}_{3}$, क्षिपणम्महत् $\mathrm{S}_{1}$, क्षेपणं महत् $B$ h (em.) $28 b$ व्भयंकर: ] $S_{3} R A B h$, भयक्कर $S_{1}$ (retraced) 28c संख्ये ] RABh, संखे $\mathrm{S}_{1}$ (retraced) $\mathrm{S}_{3}$ 29a ०मक्षय्यं ] $\mathrm{S}_{3} \mathrm{RA}_{3} \mathrm{~A}_{7} \mathrm{Bh}$, ०मक्षेय्यं $\mathrm{S}_{1}^{\mathrm{pc}}$ (retraced), ०मक्षै(य) $\mathrm{S}_{1}^{\mathrm{ac}} \quad \mathbf{2 9 b}$ ०बलं महत् ] $\mathrm{S}_{1}$ (retraced)RBh, ${ }^{\circ}$ महद्वलं $S_{3}$ 29c र्यापितं ] $S_{1}$ (retraced)RA $A_{7} B h$, ख्यापित $S_{3}$ 30a ०द्वचनं ] $\mathrm{S}_{1}$ (retraced)RABh, ०द्वचन $\mathrm{S}_{3}$ 30c निश्वस्य ] $\mathrm{S}_{1} \mathrm{~S}_{3}$, नि:म्वस्य Bh (em.?) 30d च पुन: ] $\mathrm{S}_{1} \mathrm{RBh}$, च पुन $\mathrm{S}_{3}$ (unmetrical) 
विप्रचित्तिरुवाच ।

अमानुषमिदं राजन्नतिदेवं तथापि च।

अतिदैत्यं च दैत्येन्द्र न दृष्ट न श्रुतं क्षचित्॥ ३?॥

वराहस्य बलं यादृड्न तादृक्षस्यचित्क्राचित् ।

न हि तुल्यं प्रपश्यामि तस्य राजन्महात्मनः॥ ३२॥

अस्त्रै: शस्त्रैश्च बहुभिस्तक्ष्यमाणस्य संयुगे।

नार्तिर्न दुःखं दैत्येन्द्र न च संज्ञा प्रहीयते॥ ३३॥

भवेत्तस्याभिदष्टस्य मशकेनाप्यनिर्वृतिः।

न दैत्यदानवै राजन्निघ्नस्य भयमित्युत ॥ ३४॥

यथा क्षुद्रमृगान्सिंहो मण्डूकानिव चोरगः।

तथा स कालयामास सर्वान्दैत्येन्द्रदानवान् ॥ ३४ ॥

न तं मृगमहं मन्ये न देवं नापि चासुर्,

को उप्यसौ दितिपुत्राणामनयः समुपस्थितः ॥ ३६॥

$31 \mathrm{~b}$ ०न्नतिदेवं तथापि ] ०न् त्रिदिवेयं तथैव $\mathrm{R} \quad 31 \mathrm{c}$ अति॰ ] आति॰ $\mathrm{R} \quad 32 \mathrm{c}$ तुल्यं प्र०] तुल्यश्च $R \quad 33 b$ ०स्तक्ष्यमाणस्य ] ०स्तक्ष्यमाणश्च $R \quad 33 c$ नार्तिर्न दुःखं ] न हि दुःखश्व $R$ 34ab ] om. $R 34 d$ ०त्रिघ्नस्य ] ०न् निघ्नतो $R \quad 35 b$ मण्डूकानिव ] मण्डूकमिव $R 35$ कालया०] ताडया० $\mathrm{R} 36 \mathrm{~d}$ ०मनयः ] ०मनर्थ: $\mathrm{R}$

33a अस्त्रै: ] $\mathrm{A}_{4} \mathrm{~A}_{7}$, अस्त्रै $\mathrm{A}_{3} \quad 33 \mathbf{b}$ ०स्तक्ष्यमाणस्य ] ०स्तस्य मानश्च $\left\{\circ\right.$ नं च $\left.\mathrm{A}_{4}\right\} \quad \mathbf{A} \quad 33 \mathbf{c}$ नार्तिर्न दुःखं ] आर्ति $\left\{{ }^{\circ}\right.$ त्ति $\left.\mathrm{A}_{7}\right\}$ दुःखस्य $\mathrm{A} 33 \mathrm{~d}$ प्रहीयते ] प्रलीयते $\mathrm{A} 34 \mathrm{a}$ भवेत्तस्या० ] यथैतस्या० A 34b मशकेनाप्य॰] $\mathrm{A}_{4}$, मसकेनाप्य० $\mathrm{A}_{7}$, मम केनाथ $\mathrm{A}_{3} 34 \mathrm{c}$ न दैत्यदानवै ] नादैश्च दानवो $\mathrm{A}$ 34d ०न्निघ्नस्य ] ०न् युतोश्च $\mathrm{A}_{3} \mathrm{~A}_{7}$, ०न् युजोश्च $\mathrm{A}_{4} \quad 35 \mathbf{b}$ चोरग: ] $\mathrm{A}_{3} \mathrm{~A}_{4}$, चौरग: $\mathrm{A}_{7} \quad 35 \mathbf{c}-\mathbf{3 7 d}$ ] om. A

31 $\left(b^{1}, d^{1}, d^{4}\right) S_{1} \quad 32\left(a^{6}, b^{1}-b^{2}, c^{1}, c^{5}\right) S_{1} \quad 33\left(b^{4}-b^{5}\right) S_{1} \quad 34\left(b^{5}\right)\left\langle b^{6}\right\rangle S_{1} \quad 36\left(a^{6}, a^{8}\right) S_{1}$, $\left\langle\mathrm{a}^{1}\right\rangle\left(\mathrm{a}^{2}-\mathrm{a}^{4}, \mathrm{a}^{6}, \mathrm{~b}^{3}\right) \mathrm{S}_{3}$

31 विप्रचित्तिरुवाच ] $R B h$ (em.?), विप्रचित्ति उ $S_{1}$ (retraced), विप्रचित्त उ $S_{3}$ 31a ०मिदं ] $S_{1} R$ $\mathrm{Bh}$, ०मिद $\mathrm{S}_{3}$ (unmetrical) 31ab राजन्नतिदेवं ] em. Bh (silently), राज(न)तिदेवं $\mathrm{S}_{1}$ (retraced), राजनतिदैवन् $S_{3} \quad 31 c$ अतिदैत्यं च] conj. Bh (silently), नतिदैत्यम्च $S_{1}$ (retraced), नतिदैत्य च $\mathrm{S}_{3} \quad 31 \mathrm{~d}$ न दृष्टं न ग्रुतं क्वचित् $] \mathrm{S}_{3} \mathrm{RBh}$ (conj.), (न) दृष्टम् (ग्रु)तं न क्वचित् $\mathrm{S}_{1}^{\mathrm{pc}}$ (retraced), (न दृष्ट न श्रुतं क्षचित्) $S_{1}^{\text {ac }}$ (unmetrical) 32ab यादृङ्न् ] $S_{3} R B h$ (em.?), यादृ (क्) $S_{1}^{\text {pc }}$ (retraced), यादृ (क) $\mathrm{S}_{1}^{\text {ac }} \quad 32 \mathrm{~b}$ तादृक्षस्यचित् ] $\mathrm{R}$, (ता)दृक्च क्षचित् $\mathrm{S}_{1}$, तादृक्कस्यचिक् $\mathrm{S}_{3}$, च तादृक् क्षचित् $\mathrm{Bh}$ (conj.?) 32d ॰हात्मन: ] $S_{1}$ (retraced)RBh, ०हात्मान: $S_{3}$ (unmetrical) 33a अस्त्रै: ] $\mathrm{S}_{3} \mathrm{RA}_{4} \mathrm{~A}_{7} \mathrm{Bh}$ (em.?), अस्त्रै $\mathrm{S}_{1}$ • शस्त्रैश्च] $\mathrm{S}_{1} \mathrm{RABh}$, शस्त्रै च $\mathrm{S}_{3}$ • बहुभि॰] $\mathrm{S}_{1}^{\mathrm{ac}} \mathrm{S}_{3} \mathrm{RABh}$, बहुश० $S_{1}^{p c} \quad 33 b$ ०स्तक्ष्यमाणस्य ] $S_{3} B h$ (conj.), ०स्तक्ष्यमा(णग्च) $S_{1} \quad 33 c$ नार्तिर्न दुःखं ] em. $\mathrm{Bh}$ (silently), नार्त्ति नन्दुःखं $\mathrm{S}_{1}$, नार्त्ति न्न दुःखं $\mathrm{S}_{3} \quad$ 34a भवेत्तस्याभि॰] $\mathrm{S}_{3} \mathrm{Bh}$ (conj.), भवेस्तस्यापि $S_{1}$ 34b ०निर्वृतिः ] $A B h,-$-वृति $S_{1}$, ०निर्वृति $S_{3}$ 34d भय०] $S_{1}^{\text {pc }} S_{3} R A B h$, भ० $S_{1}^{\text {ac }}$ (unmetrical) - मित्युत ] $S_{1}^{\mathrm{pc}} R A B h$, ०मित्युतः $S_{1}^{\mathrm{ac}} S_{3}$ 35a ०मृगान् ] $S_{1} R A B h$, ०मृगा $S_{3}$ $35 \mathbf{b}$ चोरग:] $\mathrm{S}_{3} \mathrm{RA}_{3} \mathrm{~A}_{4}$, वोरग: $\mathrm{S}_{1} \mathrm{Bh} \quad 35 \mathrm{c}$ कालया० ] $\mathrm{S}_{3}$, कलया० $\mathrm{S}_{1}^{\mathrm{pc}} \mathrm{Bh}$, कलयो $\mathrm{S}_{1}^{\mathrm{ac}}$ 35d सर्वान् ] $S_{1} R B h$, सर्वा $S_{3}$ 36a तं ] $S_{3} R B h$ (conj.?), ते $S_{1}$ • ०महं मन्ये ] $S_{3} R B h$ (conj.?), ०म+(ह)+म्म(ध्ये) $\mathrm{S}_{1} \quad 36 \mathrm{~b}$ नापि ] $\mathrm{S}_{1}^{\mathrm{ac}} ? \mathrm{~S}_{3} \mathrm{RBh}$, नास्ति $\mathrm{S}_{1}^{\mathrm{pc}}$ - चासुरम् ] $\mathrm{S}_{1}^{\mathrm{pc}} \mathrm{S}_{3} \mathrm{RBh}$, चासुम् $\mathrm{S}_{1}^{\mathrm{ac}}$ (unmetrical) 36cd ०णामनय: ] em. Bh (silently), ०णां मनय: $\mathrm{S}_{1} \mathrm{~S}_{3}$ 
तेनास्मि मुष्टिना मूर्धि ताडितो भूतलं गतः।

गृहीत्वा सहसा क्षित्रः पतितस्त्वनृहोपरि॥ ३७॥

दानवानां सदैत्यानामितरेषां च दानव।

न जाने समवस्थानं मन्ये ते सर्वशो हताः॥ ३५॥

अवध्यः स महातेजा बलवान्दुर्बला वयम्।

श्रुत्वैतद्धितिपुत्राणां हितं यत्तत्समाचर॥ ३९ ॥

तस्याओ मुनयः सर्वे दृश्यन्ते सह देवतैः।

कृत्या सेति मतं मे उद्य तव हेतोर्विनिर्मिता॥ ४०॥

मनश्च तव दैत्येन्द्र युद्धाय कृतनिश्चयम्।

विनिवर्तय तचैव दैत्यानां हितमाचर॥ ४?॥

बलवान्सो उबला दैत्या वयं मर्त्या: स चामरः।

अजय्यो उसौ जिता दैत्या मा नो युद्धेन योजय॥ ४२॥

$37 \mathrm{ab}$ ] om. $\mathrm{R} 38 \mathrm{c}$ समव॰] समर० $\mathrm{R} 38 \mathrm{~d}$ ते सर्वशो हता: ] इहं सर्व्वमाहतम् $\mathrm{R}$ 39a महातेजा ] महाराज $R \quad 39 \mathrm{c}$ श्रुत्वैतद् ] प्रीत्यैतद् $R \quad 40 \mathrm{~b}$ दृश्यन्ते ] भूषन्ते $R \quad \bullet$ देवतै: ] दैवतै: $R$ 42 ] om. R

$38 \mathbf{a b} \circ$ नामितरेषां च ] $\mathrm{A}_{7}$ (॰नां इ॰), ०नां हतशेषाश्च $\mathrm{A}_{3} \mathrm{~A}_{4} \quad 38 \mathrm{~b}$ दानव ] दानवा: $\mathrm{A} \quad 38 \mathrm{c}$ समव० ] $\mathrm{A}_{7}$, समर० $\mathrm{A}_{3} \mathrm{~A}_{4} 38 \mathrm{~d}$ ते सर्वशो हता:] हं सर्वथा कृतं $\mathbf{A} 39 \mathrm{c}$ श्रुत्वैतद् ] ग्रुत्वैव $\mathbf{A}$ $40 \mathrm{~b}$ देवतै: ] दैवतै: $A \quad 40 \mathrm{c}$ कृत्या सेति मतं ] कृत्या इति स तं $\mathrm{A}_{3} \mathrm{~A}_{4}$, कृत्वा इति मतं $\mathrm{A}_{7} 40 \mathrm{~d}$ हेतोर्वि॰ $] \mathrm{A}_{4} \mathrm{~A}_{7}$, हेतो वि॰ $\mathrm{A}_{3}$ 41a मनश्च ] मतिश्च $A$ 41b ०निश्चुयम् ] निश्चया $A$ 41c विनिवर्तय तच्चैव ] निवर्त्तस्वेति \{निवर्त्तस्वति $\mathrm{A}_{4}$, विवर्ण अति॰ $\left.\mathrm{A}_{7}\right\}$ युद्धाद्वै $\mathbf{A}$ 42ab ] बलवान्सो बलान् दैत्या $\left\{\right.$ बला+त्+ दैत्याः $\left.\mathrm{A}_{7}\right\}$ कार्यं $\left\{0\right.$ र्य० $\left.\mathrm{A}_{4}\right\}$ मन्यं समाचरन् $\mathbf{A}$ 42c अजय्यो उसौ ] अजय्यो सो $\mathrm{A}_{3}$, अजम्यो सो $\mathrm{A}_{4}$, अजय्यों सौ $\mathrm{A}_{7}$ - जिता दैत्या ] हि तान् दैत्यान् $\mathbf{A}$ 42d नो युद्धेन] नो $\left\{\right.$ लो $\left.\mathrm{A}_{7}\right\}$ युद्धे नि॰ $\left\{\right.$ ति॰ $\left.\mathrm{A}_{4}\right\} \mathbf{A}$

$39\left\langle\mathrm{a}^{1}\right\rangle\left(\mathrm{a}^{2}\right) \mathrm{S}_{1}$

37a तेनास्मि ] $\mathrm{S}_{1} \mathrm{Bh}$, तेनास्मिन् $\mathrm{S}_{3} \quad 37 \mathrm{c}$ ०सा क्षिप्तः ] $\mathrm{S}_{1}^{\mathrm{pc}} \mathrm{S}_{3} \mathrm{R}$, ०सा क्षित्र $\mathrm{S}_{1}^{\mathrm{ac}}$, ०सोत्क्षित्रः $\mathrm{Bh}$ (conj.) 37d ॰तस्त्वदृहो॰ ] $S_{1} R B h$, ०तो स्मिन्गृहो॰ $S_{3}$ 38a दानवानां स० ] $S_{1}^{\text {pc }} S_{3} R A B h$, दानवारम॰ $S_{1}^{\mathrm{ac}} \quad 38 \mathbf{a b}$ नामितरेषां ] $\mathrm{S}_{1} \mathrm{RA}_{7} \mathrm{Bh}$, ०नां मितरेषा $\mathrm{S}_{3} \quad \mathbf{3 8 b}$ दानव ] $\mathrm{S}_{1}^{\mathrm{pc}} \mathrm{RBh}$, दानव: $\mathrm{S}_{1}^{\mathrm{ac}}$, दानवा: $\mathrm{S}_{3} \quad 38 \mathrm{c}$ समवस्थानं ] $\mathrm{S}_{3} \mathrm{~A}_{7} \mathrm{Bh}$ (em.?), समवत्स्थानं $\mathrm{S}_{1}$ 38d मन्ये ] $\mathrm{S}_{1}^{\mathrm{pc}} \mathrm{S}_{3} \mathrm{RA}$ $\mathrm{Bh}$, मत्ये $\mathrm{S}_{1}^{\mathrm{ac}}$ - हता: ] $\mathrm{S}_{3} \mathrm{Bh}(\mathrm{em} . ?)$, हता $\mathrm{S}_{1} \quad 39 \mathrm{~b}$ ॰न्दुर्बला ] $\mathrm{S}_{1}^{\mathrm{pc}} \mathrm{S}_{3} \mathrm{RABh}$, ०न्दुर्ब(लो) $\mathrm{S}_{1}^{\mathrm{ac}}$

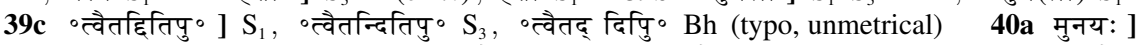
$\mathrm{S}_{3} \mathrm{RABh}$, मुनय $\mathrm{S}_{1}$ (unmetrical) - सर्वे ] $\mathrm{S}_{1}^{\mathrm{pc}} \mathrm{S}_{3} \mathrm{RABh}$, वे $\mathrm{S}_{1}^{\mathrm{ac}}$ (unmetrical) 40b दृश्यन्ते ] $\mathrm{S}_{3} \mathrm{ABh}$, दृश्यते $\mathrm{S}_{1}$ • देवतै: ] $\mathrm{S}_{1} \mathrm{~S}_{3}$, दैवतै: $\mathrm{Bh} \quad 40 \mathrm{~d}$ हेतोर्वि॰] $\mathrm{RA}_{4} \mathrm{~A}_{7} \mathrm{Bh}\left(\mathrm{em}\right.$. ?), हेतो प० $\mathrm{S}_{1}$ (प possibly corrected to य i.m.), हेतो वि॰ $S_{3} \quad \mathbf{4 1 b}$ निश्चयम् ] $S_{1} R B h$, ०निश्चयः $S_{3}$ 41c तच्चैव ] $\mathrm{RBh}$ (em.?), तश्चैव $\mathrm{S}_{1}$, त चैव $\mathrm{S}_{3}$ (unmetrical) 41d ०माचर ] $\mathrm{S}_{3} \mathrm{RABh}$, ०माचर: $\mathrm{S}_{1}$ 42a ॰वान्सो ] $S_{1} A B h$, ०वान्सौ $S_{3} \quad$ 42b वयं मत्त्या: ] em. Bh (silently), वयम्म्मत्त्या $S_{1}$, वय मत्या $\mathrm{S}_{3} 42 \mathrm{c}$ अजय्यो] $\mathrm{S}_{1} \mathrm{~A}_{3} \mathrm{Bh}$, अजयो $\mathrm{S}_{3}$ 42d मा नो ] $\mathrm{S}_{3} \mathrm{~A}_{3} \mathrm{~A}_{4} \mathrm{Bh}$, मानं $\mathrm{S}_{1}$ - योजय ] $\mathrm{ABh}$, मोजय: $\mathrm{S}_{1}$, योजय: $\mathrm{S}_{3}$ 
हित्वाश्मकपुरं सर्वे समुद्राम्भः समास्थिताः।

तिष्टाम राजन्मा युद्धे तेन सार्ध मनः कृथाः॥ ४३॥

मावमंस्था मृगं दैत्य मृगो उसाविति सर्वशः।

नरसिंहो उप्यभूत्पूर्व मृगस्तद्विदितं हि वः॥४४॥

यावत्त्वं ध्रियसे दैत्य दानवानां सुखावह।

तावत्सर्वे उसुरा जीवा भविष्यन्ति न संशयः॥ ४४॥

मा नशन्तु दितेः पुत्रा दनोग्चैव सुबालिशाः।

अपयाम पुरादस्मादसुरेश्वर सर्वशः॥ ४६॥

सनत्कुमार उवाच।

तस्य तद्वचनं ग्रुत्वा हिरण्याक्षः प्रतापवान्।

उवाच दानवेशानं भीतं तस्य महात्मनः॥ ४७॥

असंशयं महात्मासौ मृगो दानवसत्तम।

येन मन्दरकल्पस्त्वं तुलितः सुमहाबलः ॥ ५५॥

43a हित्वाश्मकपुरं ] हित्वा पुरं वयं $R \quad 43 b$ समुद्राम्भः समास्थिता: ] समुद्रान्तः समाश्रिता: $R$ 44b मृगो उसाविति सर्वशः ] मृगस्यास्य पलायताम् $\mathrm{R} 4 \mathbf{4 4 d}$ मृगस्तद्विदितं हि व: ] मृगः स विदितो हि ते $\mathrm{R}$ 45a यावत्त्वं ] यावत्सु $R \quad 45 \mathrm{~cd}$ ] om. $R$ 46a नशन्तु ] नश्यन्तु $R$ 46b दनोग्चैव सु० ] दनो: पुत्रा अ० $\mathrm{R} 46 \mathrm{~cd}$ ] अपयामः सुरात्सर्व्वात्तदस्मादसुरेश्वर $\mathrm{R} 47$ सनत्कुमार उवाच ] om. $\mathrm{R} 48 \mathrm{~b}$ ०सत्तम ] $\mathrm{R}^{\mathrm{pc}}$, ०सत्तम: $\mathrm{R}^{\mathrm{ac}} 48 \mathrm{c}$ येन मन्दर॰ ] यो डयमन्ध $+($ क $)+{ }^{\circ} \mathrm{R} \quad 48 \mathrm{~d}$ सु० ] स $\mathrm{R}$

43a हित्वाश्मक॰] हित्वा स्वकं $A 43 b$ समुद्राम्भः समास्थिता: ] समुद्रान्तः समाहिता: $A$ 44ab ] om. A 44c उप्यभूत् ] ह्यभूत् $A$ 44d मृगस्तद्विदितं हि व: ] मृगो भूत्वाधि ${ }^{\circ}$ त्वा उहि॰ $\mathrm{A}_{7}^{\mathrm{pc}}$, ०ताधि॰ $\mathrm{A}_{3}$ \}तं हि न: $\mathbf{A} 45 \mathbf{a}$ यावत्त्वं ] $\mathrm{A}_{4}$, याच त्वं $\mathrm{A}_{3}$, यावद्धं $\mathrm{A}_{7}$ - ध्रियसे ] ब्रुया $\mathrm{A}_{3}$ (unmetrical), उपा $\mathrm{A}_{4}$ (unmetrical), ब्रूयते $\mathrm{A}_{7} 45 \mathbf{b}$ सुखावह ] सुखावह: $\mathbf{A} 45 \mathbf{c}{ }^{\circ}$ त्सर्वे] ${ }^{\circ}$ तु ते $\mathrm{A}_{3} \mathrm{~A}_{7}^{\mathrm{pc}}$, ${ }^{\circ}$ तु तै: $\mathrm{A}_{4}$, ${ }^{\circ}$ त्तः $\mathrm{A}_{7}^{\mathrm{ac}}$ - जीवा ] भीता $\mathrm{A}$ 46a नशन्तु ] नास्यमु $\mathrm{A}_{3} \mathrm{~A}_{4}$, नस्येयुर् $\mathrm{A}_{7}$ 46b दनोश्चैव ] दानवाश्च $A$ - ०बालिशा: ] $A_{3}$, ०बालिशा $A_{4}$, ०बानिशां $A_{7} 46 c$ अपयाम पुरादस्मा० ] अपयामः पुराद्य $\left\{\circ\right.$ रा य० $\left.\mathrm{A}_{4} \mathrm{~A}_{7}\right\}$ स्मा० $\mathrm{A} 47$ सनत्कुमार उवाच ] om. $\mathrm{A} 47 \mathrm{c}$ दानवेशानं ] दानवेश तं $\mathrm{A} 48 \mathrm{~b}$ ०सत्तम ] ०सत्तमः $\mathrm{A} 48 \mathrm{~d}$ तुलितः सु० ] तुलितो सि $\mathrm{A}$ - ममहाबलः ] $\mathrm{A}_{3}$, महाबल $\mathrm{A}_{4} \mathrm{~A}_{7}$

$45\left(a^{2}\right) S_{1} \quad 47\left\langle a^{1}-a^{5}\right\rangle\left(a^{6}-b^{5}\right) S_{1}$

43a हित्वाश्मक०] $S_{1} S_{3}$, हित्वाश्मकं Bh (em., in a note Bh reads हित्वास्माकं in $S_{1}$ ) $43 b$ समुद्राम्भः समास्थिताः ] $S_{3}$, समुद्रास्तम्भमास्थिता $S_{1}$, समुद्रस्तम्भमाश्रिताः Bh (conj.?) 43c राजन्मा ] $\mathrm{S}_{3} \mathrm{RABh}$, राजम्मा $\mathrm{S}_{1}$ - युद्धे $] \mathrm{S}_{1} \mathrm{~S}_{3} \mathrm{RA}$, युद्ध $\mathrm{Bh}$ (conj.?) 43d तेन ] $\mathrm{S}_{3} \mathrm{RABh}$, न ते $\mathrm{S}_{1}$ सार्ध मनः कृथा: ] RA, साकम्पुनः कृशा $S_{1}$, सार्द्ध मनः कृथा $S_{3}$, साकं पुनः कृथा: $B h(\mathrm{em}$.$) 44a$ मावमंस्था ] $\mathrm{S}_{3} \mathrm{RBh}\left(\mathrm{em}\right.$. ?), मावयंस्था $\mathrm{S}_{1}$ 44d ०द्विदितं हि व: ] $\mathrm{S}_{3}$, ०द्विनिवृंहितः $\mathrm{S}_{1}$, ०द्विनिबृंहितः $\mathrm{Bh}$ - After this Bh conjectures loss of two pādas. 45a ध्रियसे ] $S_{3} R B h$ (em.?), धृयसे $S_{1}$ $45 b$ सुखावह ] $S_{3} R$, सुखावह: $S_{1} B h \quad 45 d$ भविष्यन्ति ] $S_{1} A B h$, भविष्यति $S_{3}$ 46a नशन्तु ] $S_{3}$, नुशन्तु $S_{1}$, रुशन्तु $B h$ (conj.) $46 b$ दनोग्चैव ] $S_{1} B h$, दन्येग्चैव $S_{3}$ - ०बालिशा: ] $S_{1} S_{3}^{\text {pc }} R A_{3} B h$, ०बालि(षा): $S_{3}^{a c}$ 47b हिरण्याक्ष: ] RABh, (हिरण्याक्ष) $S_{1}$ (lower parts lost), हिरण्याक्ष $S_{3}$ प्रताप॰ ] $S_{1} S_{3}^{\text {pc }} R A B h$, प्रताव $S_{3}^{\mathrm{ac}}$ 47d भीतं ] $S_{3} R A B h$, भीमन् $S_{1}$ • तस्य ] $S_{1} S_{3} R A$, तस्मान् $\mathrm{Bh}$ (conj.) $48 \mathrm{a}$ असंशयं ] $\mathrm{S}_{3} \mathrm{RABh}$, असंशय $\mathrm{S}_{1} \quad \mathbf{4 8 b}$ ०सत्तम ] $\mathrm{R}^{\mathrm{pc}} \mathrm{Bh}(\mathrm{em} . ?)$, ०सत्तमः $\mathrm{S}_{1} \mathrm{~S}_{3} \quad 48 \mathrm{c}$ ०स्त्वं ] $\mathrm{S}_{1}^{\mathrm{pc}} \mathrm{S}_{3} \mathrm{RABh}$, (॰स्व) $\mathrm{S}_{1}^{\mathrm{ac}}$ 48d तुलितः ] RBh (em.?), भुलितो $\mathrm{S}_{1}$, तुलितो $\mathrm{S}_{3}$ 
अद्य वर्षसहस्राणि दिव्यान्यसुरपुंगव।

चत्वारि भुअ्तो राज्यं गतानि सुमहान्ति मे॥ ४९॥

पश्चुमं चानुसंप्राप्त तावद्देवाश्च नाशिताः।

सबला बहुभिघोरै: संग्रामैरबला इव॥ $y \circ \|$

सो हहं तथा बलोपेतो भुत्का सर्वमकण्टकम्।

भीतः प्रविश्य सलिलं कथं स्थास्ये भुजंगवत्॥ पू?॥

मृगरूपी स विष्णुग्च वाराहं रूपमास्थितः।

यदि स्यात्तच्च कृत्यं मे दानवेश्वर मा भयम्।

ममापि बलमक्षय्यं तस्माच्च बलवानहम्॥ पूर॥

यो मे भयात्परित्यज्य स्वं रूपं मृगतां गतः।

यो हन्याद्धस्तिनं संख्ये सिंहं शरभमेव च।

तस्य कास्था भवेद्देत्य मृगे ह्यस्मिन्महाबल ॥ प३३॥

49b दिव्यान्यसुरपुंगव ] जला $\left\{{ }^{\circ}\right.$ ना० $\left.\mathrm{R}^{\mathrm{ac}}\right\}$ न्यसुरपुड़्वा: $\mathrm{R} \quad 49 \mathrm{c}$ भुझतो ] भुज्यते $\mathrm{R} \quad 50 \mathrm{a}$ पझ्चमं चा-

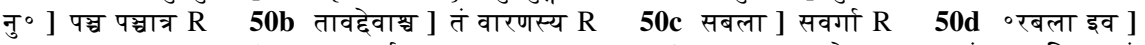
०रबला: कृता: $R \quad 51 b$ भुत्का सर्व० ] भुद्ध्ध राज्य० $R \quad 52 \mathrm{~cd}$ ] यदस्य मे उग्रतः सत्यं जानामि मरणं हि तम् $\mathrm{R} \quad 53 \mathrm{e}$ कास्था ] संस्थो $\mathrm{R}$

49ab ] om. A 49c c d ] $\mathrm{A}_{4}$ repeats this after $51 \mathrm{~b}^{2} \quad$ 49cd राज्यं गतानि ] राज्यशतानि $\mathbf{A A}_{4}^{*}$ $50 \mathrm{a}$ चानु० ${ }^{\text {] }}$ चात्र $\mathrm{A} \quad 50 \mathrm{~b}$ तावद्देवा॰ ] तव देवा० $\mathrm{A}_{3} \mathrm{~A}_{4}$, हावदेवा॰ $\mathrm{A}_{7}$ • नाशिता: ] $\mathrm{A}_{3} \mathrm{~A}_{7}$, नासिता: $\mathrm{A}_{4} 50 \mathrm{~d}$ ०रबला इव ] ०रबला: कृता: $\mathrm{A}_{7}$, ०रुवला कृता $\mathrm{A}_{3} \mathrm{~A}_{4}$ 51a-b ${ }^{2}$ ] $\mathrm{A}_{4}$ repeats this after inserting $49 \mathrm{c}^{7}-50 \mathrm{~b}$ (50ab cancelled). 51a तथा बलोपेतो] प्राप्तबलो $\left\{{ }^{\circ}\right.$ नो $\left.\mathrm{A}_{7}\right\}$ राज्यो $\mathrm{AA}_{4}^{*} \mathbf{5 1 b}$ भुत्का ] $\mathrm{A}_{3}$, नक्ता $\mathrm{A}_{4}$, नुत्का $\mathrm{A}_{4}^{*}$, लब्धा $\mathrm{A}_{7}$ - सर्व॰] राज्य॰ $\mathbf{A}$ 52a मृगरूपी ] मृगरूप: $\mathrm{A} 52 \mathrm{~b}$ वाराहं ] $\mathrm{A}_{7}^{\mathrm{pc}}$, वराहं $\mathrm{A}_{3} \mathrm{~A}_{4}$, नवा(त्व) $\left.\mathrm{A}_{7}^{\mathrm{ac}} \quad \mathbf{5 2 c d}\right]$ ममाग्रतो यदि स्यात्तु जानामि सवलं $\left\{\circ{ }^{\circ} \mathrm{A}_{7}\right\}$ हि तं $\mathbf{A} \pm \mathbf{5 3} \mathbf{c}$ यो हन्याद्धस्तिनं ] सो हं तथा बलं $\mathbf{A} 53 \mathrm{~d}$ शरभ०] $\mathrm{A}_{4}$, सरभ० $\mathrm{A}_{3} \mathrm{~A}_{7}$ 53e भवेद्] ] वधे $\mathbf{A} 53 \mathrm{f}$ मृगे] मृगो $\mathbf{A}$ - ०बल] ०बल: $\mathbf{A}$

$\mathbf{4 9}\left\langle\mathrm{c}^{7}\right\rangle\left(\mathrm{c}^{8}, \mathrm{~d}^{4}\right) \mathrm{S}_{1} \quad \mathbf{5 0}\left(\mathrm{a}^{1}, \mathrm{a}^{3}\right) \mathrm{S}_{1} \quad \mathbf{5 1}\left(\mathrm{a}^{6}, \mathrm{~b}^{4}, \mathrm{c}^{1}-\mathrm{c}^{4}, \mathrm{c}^{8}, \mathrm{~d}^{2}\right) \mathrm{S}_{1} \quad \mathbf{5 3}\left(\mathrm{c}^{6}-\mathrm{c}^{7}\right) \mathrm{S}_{1}$

49b ०पुंगव ] em. Bh (silently), ०पुंगव: $S_{1}$, ०पुड़व: $S_{3}$ 49c चत्वारि ] $S_{3} R A B h$, चत्वारिम् $S_{1}$

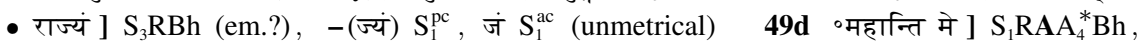

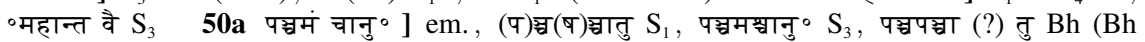
possibly read this in $S_{1}$ ) $\quad \mathbf{5 0 a b}$ व्राप्तं तावद् ] em. Bh (silently), ॰प्राप्तन्तावन् $S_{1}$, ॰ प्राप्तेस्ताव $S_{3}$ 50b नाशिता: ] $R_{3} A_{7} B h$, नाशिता $S_{1} S_{3}$ 50c सबला ] $S_{3} A B h$, सबाला $S_{1}$ 50cd ०भिघोरै: संग्रामै॰ ] RABh, ०भि: घोरै संग्रामे॰ $S_{1}$, ०भि घोरै: सग्रामै॰ $S_{3}$ (unmetrical) 51b सर्व०] $S_{1}$ $\mathrm{S}_{3}$, राज्य॰Bh 51c भीतः ] $\mathrm{S}_{3} \mathrm{RABh}$, (भात) $\mathrm{S}_{1}$ (upper parts lost) 51d स्थास्ये] $\mathrm{S}_{1} \mathrm{RABh}$, स्थाप्ये $\mathrm{S}_{3} \quad \mathbf{5 2 b}$ वाराहं ] $\mathrm{RA}_{7}^{\mathrm{pc} B h}(\mathrm{em}$.$) , वराहं \mathrm{S}_{1} \mathrm{~S}_{3}$ • ०मास्थितः ] $\mathrm{S}_{1} \mathrm{RABh}$, ०मास्थितं $\mathrm{S}_{3}$ 52c ०त्तच ] $S_{1} B h$, ०त्त च $S_{3} \quad 52 e$ ममक्षय्यं ] $S_{3} R A B h$, ०मक्षय्य $S_{1}$ 52f तस्माच्च ] RABh, तस्माश्च $S_{1}$, तस्मा च $S_{3}$ - ववानहम् ] $S_{3} R A B h$, वाहनम् $S_{1} \quad 53 c$ संख्ये ] $S_{3} R A B h$, - खे $S_{1}$ 53e भवेद्] RBh (em.?), भवे $S_{1} S_{3}$ 53f ०बल ] $S_{1} R B h$, ॰बल: $S_{3}$ 
मझ्नयात्स वराहश्च सर्वदेवैरधिष्टितः।

मामाह्वयति दैत्येन्द्र जय एव ततो हि मे॥ $y<\|$

भवानेव हि मे दैत्य तेन दूतः प्रवेरितः।

त्वरता मृत्युलोक तु गत्वा दानवपुंगव ॥ पू $॥$

अद्य तं म्रातृहन्तारं दानवानां भयंकरम्।

अहत्वा न निवर्तिष्ये शपे सत्येन दानव॥ $y ६ ॥$

सूतं ततः समादिश्य रथं सज्जमचीकरत्।

समाश्वासयितुं पत्न्यः प्रविवेश पुनर्गृहान् ॥ $\mathrm{Q} ७ ॥$

स तत्र ताभिः कृतमड़्लस्तदा दितेः सुतस्ताश्च निरीक्ष्य सर्वशः।

जग्राह सवं रणयोग्यमुज्वलं महाबलः शत्रुनिवारणक्षमम् ॥ पू ॥

\section{इति स्कन्दपुराणे चतुरुत्तरशतो डध्यायः॥ १०४॥}

54b ०रधिष्टितः ] $\mathrm{R}^{\mathrm{pc}}$, ०रधिष्टितः $\mathrm{R}^{\mathrm{ac}} \quad 54 \mathrm{c}$ मामा० ] समा० $\mathrm{R} \quad 55 \mathrm{~b}$ प्रवेरितः ] प्रदेशितः $\mathrm{R}$ $55 \mathrm{c}$ त्वरता मृत्युलोक तु ] त्वरतां मृत्युकालो यं $R \quad 56 \mathrm{c}$ अहत्वा ] आहत्वा $R \quad 56 \mathrm{~d}$ शपे सत्येन] शापसव्येन $R \quad 57 b$ रथं सज्जमचीकरत् ] सज्जं रथमचीकर: $R \quad 57 \mathrm{c}$ पत्न्यः ] पत्नीं $R^{\mathrm{pc}}$, पत्नी $\mathrm{R}^{\mathrm{ac}}$ $57 \mathrm{~d}$ ०र्गृहान् ] ०र्गृहम् $\mathrm{R} \quad 58 \mathrm{a}$ ॰मड़्लस्तदा ] ॰मड़्लाभिर् $\mathrm{R} 58 \mathrm{~b}$ सुतस्ताश्च ] $\mathrm{R}^{\mathrm{pc}}$, सुतन्ताश्च $\mathrm{R}^{\mathrm{ac}}$ - सर्वशः ] सर्व्वा: $\mathrm{R} \quad 58 \mathrm{c}$ सर्वं ] शस्त्रं $\mathrm{R} \quad 58 \mathrm{~d}$ ०निवारणक्षमम् ] ०निवर्हणश्च $\mathrm{R}$ Col. इति स्कन्दपुराणे रेवाखण्डे चतुरुत्तरशताध्याय: $R$

54ab ] मम तस्य वराहस्य चैत $\left\{\right.$ चेत: $\mathrm{A}_{4}$, चैतं $\mathrm{A}_{7}^{\mathrm{pc}}$, चैत: $\left.\mathrm{A}_{7}^{\mathrm{ac}}\right\}$ सर्वेरधिष्टि $\left\{\circ\right.$ ष्टि॰ $\left.\mathrm{A}_{4} \mathrm{~A}_{7}\right\}$ तः $\left.\mathrm{A} \quad \mathbf{5 4 c d}\right]$ om. A $55 b$ दूतः प्रवेरितः ] भूतः प्रचोदितः $A$ 55c त्वरता ] त्वरितो $A$ 55d गत्वा दानवपुंगव ] गं $\left\{\right.$ गा० $\left.\mathrm{A}_{7}\right\}$ तुमिच्छुति दानवः $\left\{{ }^{\circ}\right.$ व $\left.\mathrm{A}_{3}^{\mathrm{pc}}\right\} \mathbf{A} \quad \mathbf{5 6 d}$ शपे ] $\mathrm{A}_{7}$, शाप॰ $\mathrm{A}_{3} \mathrm{~A}_{4} \quad 57 \mathrm{c}$ समाश्वास० ] समाश्वाश० $\mathrm{A}_{7}^{\mathrm{pc}}$, समासाद० $\mathrm{A}_{3} \mathrm{~A}_{4}$, समास्थाद० $\mathrm{A}_{7}^{\mathrm{ac}} \bullet$ पत्न्य:] पत्नीं $A$ 57d ०र्गृहान् ] ०र्गृहं $\mathbf{A}$ 58b ०स्ताश्च ] $A_{7}$, ०स्ताच्च $A_{3}$, ०स्ताशु $A_{4}$ • निरीक्ष्य ] $A_{3} A_{7}$, निरीक्ष $A_{4}$ 58d महाबलः ] $A_{3}$ $\mathrm{A}_{4}$, महाबला: $\mathrm{A}_{7}$ - शत्रु० ] शस्त्र॰ $A$ - ०क्षमम् ] ०क्षम: $\mathrm{A}_{3} \mathrm{~A}_{4}$, ०क्ष: $\mathrm{A}_{7}$ Col. इति $\{$ इति ग्री॰ $\left.\mathrm{A}_{7}\right\}$ स्कन्दपुराणे एकाशीतिसाहस्रचां संहिताया $\left\{\right.$ इति स्कंद॰ $\left.\mathrm{A}_{4}\right\}$ मम्बिकाखण्डे उत्रि $\left\{\right.$ त्रे॰ $\left.\mathrm{A}_{3} \mathrm{~A}_{7}\right\}$ रुत्तरशतं $\mathbf{A} \pm$

$\mathbf{5 7}\left(\mathrm{b}^{4}, \mathrm{c}^{8}\right) \mathrm{S}_{1}$

54b ०रधिष्टितः ] $\mathrm{S}_{1} \mathrm{R}^{\mathrm{pc}} \mathrm{A}_{3} \mathrm{Bh}$, ०रधिष्टितः $\mathrm{S}_{3} \quad \mathbf{5 4 c}$ मामा० ] $\mathrm{S}_{3} \mathrm{Bh}$ (conj., in a note Bh suggests समा०), ममा० $S_{1} 54$ जय एव $] S_{1} R B h$, जयमेव $S_{3} \quad 55 b$ प्रवेरितः ] $S_{1} S_{3},----B h$ (conj.) 55d ॰पुंगव ] $S_{1} R B h$, पपुझ्गव: $S_{3} \quad 56 a$ अद्य तं ] $S_{3} R A$, यद्यहम् $S_{1}$, यदहं Bh (conj.?) 56d शपे] $A_{7} B h$ (em.?), शपेत् $S_{1} S_{3}$ - दानव ] $S_{1} R A B h$, दाव $S_{3}^{p c}$ (unmetrical), दान $S_{3}^{\text {ac }}$ (unmetrical) 57a Before this Bh adds सनत्कुमार उवाच। 57b सज्जम॰ ] $S_{1} S_{3}^{\mathrm{pc}} \mathbf{A B h}$, सजम० $\mathrm{S}_{3}^{\mathrm{ac}}$ - ॰चीकरत् ] $S_{1}^{\mathrm{pc}} S_{3}^{\mathrm{pc}} \mathrm{ABh}$, ॰चीकरम् $\mathrm{S}_{1}^{\mathrm{ac}}$, ॰ची(तरं) $S_{3}^{\mathrm{ac}} \quad 57 \mathrm{c}$ ॰तुं पत्न्यः ] $S_{3}$, ०तुम्म(न्य) $\mathrm{S}_{1}^{\mathrm{pc}}$, ॰तुम्म(ल्न्य) $\mathrm{S}_{1}^{\mathrm{ac}}$, ०तुं पत्नी: $\mathrm{Bh}$ (em.) 57d प्रविवेश ] $\mathrm{S}_{1} \mathrm{~S}_{3} \mathrm{RA}$, स विवेश $\mathrm{Bh}$ (conj.) • ०र्गृहान् ] $S_{1} B h$, ०र्गृहात् $S_{3}^{\text {pc }}$, ०र्गृहत् $S_{3}^{\text {ac }} \quad \mathbf{5 8 a}$ तत्र $] S_{1} S_{3}^{\text {pc }} R A B h$, तत्रा $S_{3}^{\text {ac }} \quad \mathbf{5 8 b}$ ०ते: सुतस्ताश्च ] $\mathrm{S}_{3}^{\mathrm{pc}} \mathrm{R}^{\mathrm{pc}} \mathrm{A}_{7}$, ०तेस्सुतांस्तांश्च $\mathrm{S}_{1}$, ०तेः सुतास्ताश्च $\mathrm{S}_{3}^{\mathrm{ac}}$, ०तेः सुतांस्तांश्च $\mathrm{Bh} \bullet$ निरीक्ष्य सर्वशः ] $\mathrm{S}_{3} \mathrm{~A}_{3} \mathrm{~A}_{7} \mathrm{Bh}$, निरीक्ष सर्व: $\mathrm{S}_{1} \quad \mathbf{5 8 c}$ जग्राह ] $\mathrm{S}_{3} \mathrm{RA}$, गृहाण $\mathrm{S}_{1} \mathrm{Bh}$ 58d महाबलः ] $\mathrm{S}_{3} \mathrm{RA}_{3} \mathrm{~A}_{4} \mathrm{Bh}$, महाबल $\mathrm{S}_{1}$ - ०क्षमम् ] $\mathrm{S}_{3} \mathrm{Bh}$, ०क्षममिति $\mathrm{S}_{1}$ (इति part of col.) Col. $\odot$ ॥ स्कन्दपुराणे विप्रचित्तिपातने आध्याय: १९९ (in letter numerals)॥ $\odot \mathrm{S}_{1}, \odot ॥$ स्कन्दपुराणे नामाध्यायः १०६ (in letter numerals)॥ $\odot \mathrm{S}_{3}$, इति स्कन्दपुराणे विप्रचित्तिपातने चतुरुत्तरशततमोध्याय: $\mathrm{Bh}$ 
पश्चोत्तरशतो डध्यायः।

सनत्कुमार उवाच।

स धन्वी कवची भूत्वा बद्धगोधाड़ुलित्रवान्।

बद्वपृष्टेषुधी चैव शरी खड्गी महाबलः॥ ?॥

हरिश्मश्रुश्चतुर्देष्ट्रः शड्कुकरों महाहनुः।

आजानुबाहुर्दीर्घाक्षो न्यग्रोधपरिमण्डलः ॥ ॥

हस्तयो: पद्मशंखौ च चक्रमत्यौ च पादयोः।

दधानो जालहस्तश्च जालपादो उश्वमेहनः॥ ३॥

बालादित्यनिभाक्षश्च अभनाचलसंनिभः।

स निर्ययौ तदा व्यास भृकुटीभूषिताननः॥ ४॥

द्वार्यपश्यच्च सूतेन रथं समुपकल्पित्म ।

सहस्रनल्वमात्रं च हयैर्दिव्यै: समन्वितम् $y \|$

सहस्रैर्दशभिर्व्यास सर्वोपकरणान्वितम्।

खट्वाड्गेन च संयुक्त ध्वजेनादित्यवर्चसा॥ ६॥

1c ०धी चैव ] ०धीश्चैव $R \quad 2$ ] om. R 3cd ] महामनुर्जनुपदो जलहस्तो महाबल: $R \quad 4 a$ बालादित्य॰] लोलादित्य० $R \quad 5 a$ द्वार्यपश्यच्च सूतेन ] अवेदयत्तु स्नेहेन $R \quad 6 a$ वरशभि०] ०र्बहुभि॰ $R$ 6cd ] खट्वाड़्मुत्तमं युक्त व्यजनं सूर्य्यवर्च्चसम् $R$

$1 c$ पपृष्टेषु॰ ] $\mathrm{A}_{3} \mathrm{~A}_{7}$, ॰पृष्टेषु॰ $\mathrm{A}_{4} \quad 1 d$ शरी खड़ी ] शरांश्र्म $\mathrm{A}_{3} \mathrm{~A}_{7}$, शरां धर्म $\mathrm{A}_{4}$ 2cd ] om. $\mathbf{A} 3 \mathbf{b} \circ$ मत्स्यौ च ] ०मस्यै च $\left\{\right.$ व $\left.\mathrm{A}_{3}\right\} \mathbf{A} 3 \mathbf{c d}$ ] महाहनुर्जाल $\left\{{ }^{\circ}{ }^{\circ} \mathrm{A}_{3}\right.$, ०न० $\left.\mathrm{A}_{4}\right\}$ पादो जाल $\left\{\circ{ }^{\circ} \circ\right.$ $\mathrm{A}_{3} \mathrm{~A}_{4}$ \}हस्तः समेहलः $A \quad 4 a$ ०निभाक्षश्च ] ०निभेक्षश्च $A$ 4d ०भूषिता०] ०भीषिता० $A$ 5a द्वार्यपश्यच्च ] द्रात्पश्य [०त्यश्य॰ $\mathrm{A}_{3}$, ०त्पश्यं० $\left.\mathrm{A}_{4}\right\}$ ति $\mathbf{A}$ 6ab ] om. $\mathrm{A}_{3}$, instead $\mathrm{A}_{2}$ is used (f. $258^{\mathrm{r}}$ ). 6c खट्वाड़ेन ] $\mathrm{A}_{7}$, खट्टांगेन $\mathrm{A}_{3} \mathrm{~A}_{4}$

Manuscripts available for this chapter: $S_{1}$ photos $4.4 \mathrm{~b}\left(\mathrm{f} .162^{\mathrm{r}}\right.$ ), $4.5 \mathrm{a}\left(\mathrm{f} .162^{\mathrm{v}}\right)$, and $4.5 \mathrm{~b}\left(\mathrm{f} .163^{\mathrm{r}}\right.$ ); $\mathrm{S}_{2}\left(\right.$ from $20 \mathbf{d}^{8}$ ) exposure 113 (f. $148^{\mathrm{r}}$ ); $\mathrm{S}_{3}$ f. $162^{\mathrm{r}}-163^{\mathrm{r}} ; \mathrm{R}$ f. $178^{\mathrm{v}}-179^{\mathrm{v}}$ (lower left corner of $\mathrm{f} .179$ is cut off and lost in triangular shape); $A_{3}$ f. $106^{\mathrm{r}}-107^{\mathrm{r}} ; \mathrm{A}_{4}$ f. $150^{\mathrm{r}}-151^{\mathrm{r}} ; \mathrm{A}_{7}$ f. $150^{\mathrm{v}}-151^{\mathrm{v}}$.

$\begin{array}{llll}\mathbf{3}\left(d^{8}\right) S_{3} & \mathbf{4}\left(b^{1}-b^{4}\right) S_{1} & 5\left(a^{1}\right) S_{1} & 6\end{array}\left(d^{6}-d^{8}\right) S_{1}$

$1 b$ ॰गोधाड़ुलि॰] $S_{3} R A B h$, ॰गोड़ुनल ॰ $S_{1}$ (unmetrical) 1c ॰पृष्टेषु॰] $S_{1} R A_{3} A_{7} B h$, ॰पृष्टेषु॰ $S_{3}$

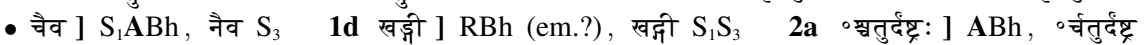

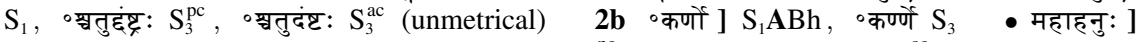
$\mathrm{ABh}$, महाहनु $\mathrm{S}_{1}$, महाबलः $\mathrm{S}_{3} \mathbf{2 c}$ आजानु० $\mathrm{S}_{3}^{\mathrm{pc}} \mathrm{Bh}(\mathrm{em} . ?)$, अजानु ${ }^{\circ} \mathrm{S}_{1} \mathrm{~S}_{3}^{\mathrm{ac}}$ • बाहुर् ] $\mathrm{S}_{1}$

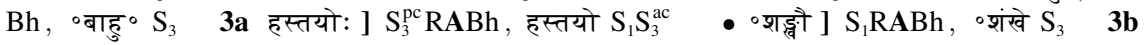
॰मत्स्यौ च ] $\mathrm{S}_{3} \mathrm{RBh}\left(\mathrm{em}\right.$. ?), ${ }^{\circ}$ मत्स्योग्च $\mathrm{S}_{1}$ 3cd दधानो जालहस्तश्च जालपादो ] $\mathrm{S}_{1} \mathrm{Bh}$, महाहनुजालहस्तजालपादो $\mathrm{S}_{3}^{\mathrm{pc}}$ (unmetrical), महाहनुजलहस्तजलपादो $\mathrm{S}_{3}^{\mathrm{ac}}$ (unmetrical) 3d इश्वमेहनः ] $\mathrm{S}_{3}$, न्धमेहन: $S_{1}$, ल्पमेहन: $B h$ (conj.?) $4 \mathbf{a}$ बालादित्य॰] $\mathbf{A B h}$, बालादित्या॰ $S_{1}$, लोलादित्य॰ $S_{3}^{\mathrm{pc}}$, लोलदित्य॰ $S_{3}^{a c}$ 4b ०संनिभ: ] $S_{1} S_{3}^{p c} R A B h$, ०सनिभ: $S_{3}^{\text {ac }}$ (unmetrical) 4d ०भूषिता०] $S_{1} R$ $\mathrm{Bh}$, ०दूषिता० $\mathrm{S}_{3} \quad \mathbf{5 a}$ ०पश्यच्च] $\mathrm{S}_{1} B$, ०पश्य च $S_{3}$ 5b रथं] $S_{1} R A B h$, रथ $S_{3}$ (unmetrical) $5 \mathbf{c}$ ममात्रं च] $\mathrm{S}_{3} \mathrm{RABh}$, ०मात्थग्च $\mathrm{S}_{1}$ 6a ०स्रैर्दशभिर् $] \mathrm{S}_{1} \mathrm{~S}_{3}^{\mathrm{pc}} \mathbf{A B h}$, ०स्रै दशभि $\mathrm{S}_{3}^{\mathrm{ac}}$ 
आरुरोह जयेत्युको दानवैर्बहुभिस्तदा।

दिवाकरो रथं यद्वद्गगवांस्तेजसां पतिः॥ ७॥

विबभौ स तदारूढो रथस्थो दितिनन्दनः।

सौवर्ण भाजने यद्वदिन्द्रनीलं समर्पितम्॥ $५ \|$

किरीटं त्वाबभौ तस्य शिरःस्थं सुमहाद्युति।

यथाअनगिरे: शृड़े दावागिनः समवस्थितः॥९॥

संचोदयच्च यन्तारं स दैत्यो गमनं प्रति।

यथातुरतरं व्यास व्याधिर्वे मरणं प्रति॥ १०॥

यन्ता प्रचोदितस्तेन तस्याश्वान्संप्रचोदयत्।

धात्रा प्रचोदितो यद्वज्जीवितानि नृणां यमः ॥ १? ॥

जवनास्ते तदा जैत्रमूहुस्तं स्यन्दनं हयाः।

धर्माधर्मों नरं यद्वन्मृतं संयमनं प्रति॥ १२॥

तस्य पार्श्वे अवद्यास विप्रचित्तिरवस्थितः।

केतोरिव यथा व्योम्नि प्रतिकेतुरवस्थितः ॥ १३॥

7a जयेत्युक्तो ] हयैर्युको $R \quad 8 a$ तदारूढो ] तदारूपै $R \quad 9 a$ किरीटं त्वा०] किरी+ट+सु $R$ 9cd शृड्रे दावाग्निः समवस्थितः ] शृड्धं दावानलमवस्थितम् $R$ 10c-12d ] om. $R$ 13cd ] $R$ has this after $15 \mathrm{~d}$. $13 \mathrm{c}$ यथा व्योम्नि ] यथान्यो हि $\mathrm{R}$

7a ०त्युको ] ०त्युत्का A 7b ०स्तदा ] ०स्तथा A 8ab ] Instead of this, $\mathbf{A}$ has 13a and 15d. 8c भाजने ] $\mathrm{A}_{4} \mathrm{~A}_{7} \mathrm{~A}_{2}$ (f. $258^{\mathrm{r}}$ ), om. $\mathrm{A}_{3}$ (unmetrical) 8d ०नीलं समर्पितम् ] ०नीलसमन्वितं $\mathbf{A}$ $9 \mathrm{a}$ त्वा० ] चा० $\mathrm{A}$ - तस्य] यस्य $\mathrm{A} 9 \mathrm{~b}$ शिरःस्थं सु० ] शिरःसंस्थं $\mathrm{A} 9 \mathrm{c}$ ०गिरे: शृड़े] ०गररेर्मध्ये $A$ 9d दावाग्निः ] $\mathrm{A}_{4} \mathrm{~A}_{7}$, दावाग्नि $\mathrm{A}_{3}$ - समवस्थितः ] समुपस्थितः $\mathbf{A}$ 10a सं०] स $\mathbf{A} 10 \mathbf{b}$ गमनं ] $\mathrm{A}_{3} \mathrm{~A}_{4}$, समरं $\mathrm{A}_{7}$ 10c-12d ] om. $\mathbf{A}$ 13a ] $\mathbf{A}$ has this instead of $8 \mathrm{a}$ and repeats it here. 13b ] om. A 13cd ] A has this after 15d. 13d ०रवस्थितः ] ०रिव स्थितः A

$7\left(b^{6}\right)\left\langle b^{7}\right\rangle\left(b^{8}\right)\left\langle c^{1}-c^{4}\right\rangle\left(c^{5}-c^{6}, d^{1}, d^{4}-d^{7}\right) S_{1} \quad 8\left(a^{1}-a^{3}\right)\left\langle a^{4}\right\rangle\left(a^{5}, a^{7}-a^{8}, b^{3}-b^{5}, c^{3}\right) S_{1} \quad 9\left(a^{4}, d^{8}\right) S_{1}$ $10\left(a^{5}-a^{8}\right)\left\langle b^{1}-b^{8}\right\rangle S_{1} \quad 13\left(c^{1}\right) S_{1},\left(b^{1}-b^{2}\right) S_{3}$

7a वत्युक्तो ] $S_{3} B h$ (em.), ०त्युक्ता $S_{1}$ 7b दानवैर ] $S_{1} R A B h$, दानवै $S_{3}$ 7c रथं ] $S_{1} S_{3}^{p c} R A$ $\mathrm{Bh}$, रथ $\mathrm{S}_{3}^{\mathrm{ac}}$ (unmetrical) $\mathbf{7 d}$ ०सां पतिः ] $\mathrm{S}_{3}^{\mathrm{pc}} \mathrm{RABh},\left({ }^{\circ}\right.$ साम्प)तिम् $\mathrm{S}_{1}$, ०सां प्रति $\mathrm{S}_{3}^{\mathrm{ac}} \mathbf{8 b}$ रथस्थो ] $S_{3} R$, रथट $S_{1}$ (last akșara has subscript थ), रथं तं Bh (conj.?) 8c सौवर्णे ] $S_{1} R A B h$, सौवर्ण० $\mathrm{S}_{3} \quad 8 d$ ०दिन्द्रनीलं ] $\mathrm{RBh}(\mathrm{em} . ?)$, ०दिन्द्रनील० $\mathrm{S}_{1} \mathrm{~S}_{3}$ 9a किरीटं त्वा०] $\mathrm{S}_{1}^{\mathrm{ac}}$ ?, किरीट(घा०) $\mathrm{S}_{1}^{\mathrm{pc}}$, किरीट त्वा० $\mathrm{S}_{3}$, किरीटस्त्वा० $\mathrm{Bh}$ (em.?) 9b शिर:स्थं ] $\mathrm{S}_{1} \mathrm{R}$, शिरस्थ $\mathrm{S}_{3}$, शिरस्थः Bh (em.?) • ०महाद्युति ] RA, ०महाद्युति: $S_{1} S_{3} B h \quad 9 c$ यथाअन०] $S_{1} R A B h$, यथाजन॰ $S_{3}$ - ०गिरे: ] $\mathrm{S}_{3} \mathrm{RBh}$ (em.?), ०गहे $\mathrm{S}_{1}$ 9d दावाग्नि: ] $\mathrm{A}_{4} \mathrm{~A}_{7} \mathrm{Bh}$ (em.?), दावाग्नि $\mathrm{S}_{1} \mathrm{~S}_{3}$ 10a संचोदयच्च ] $S_{1} R B h$, अचोदय च $S_{3}$ 10c-12d ] $\left(S_{3}\right)$, om. $S_{1} B h$ 10d व्याधिर्] em., व्याधि $\mathrm{S}_{3} \quad 11 \mathrm{ab}$ ०स्तेन तस्या॰ ] em., ०स्तेनस्तस्या॰ $\mathrm{S}_{3} \quad 11 \mathrm{~b}$ ॰ चोदयत् ] em., ॰चोदयन् $\mathrm{S}_{3}$ 11 cd यद्वज्जी॰] $S_{3}^{\mathrm{pc}}$, यद्व जी॰ $S_{3}^{\mathrm{ac}}$ 11d नृणां ] $S_{3}^{\mathrm{pc}}$, तृणं $S_{3}^{\mathrm{ac}}$ 12b ॰मूहुस्तं ] em., ०मुहुस्तं $S_{3}$ - हया: ] $S_{3}^{\mathrm{pc}}$, हया $\mathrm{S}_{3}^{\mathrm{ac}} \quad 12 \mathrm{c}$ ०धर्मों नरं ] $\mathrm{S}_{3}^{\mathrm{pc}}$, ०धमों नर $\mathrm{S}_{3}^{\mathrm{ac}}$ (unmetrical) • यद्वन् ] em., यद्व $\mathrm{S}_{3} 12 \mathrm{~d}$ संयमनं ] conj., संयनं $\mathrm{S}_{3}$ (unmetrical) 13cd ] Bh conjectures the relocation of these two pādas here, while $S_{1}$ and $S_{3}$ have it after $15 \mathrm{~d}$. 


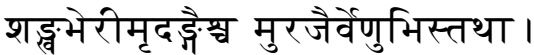

वाद्यमानैर्ययौ राजा हिरण्याक्षो इश्मकात्पुरात्॥ १४॥

अग्रतः पृष्टतश्चैव पार्श्वयोरुभयोरपि।

जग्मुः सर्वे उसुरा व्यास भास्करस्य यथा ग्रहाः ॥ १५ ॥

निर्गच्छुमानः स्वपुराच्छुकुन्तान्भयशंसिन :

अपश्यद्वास दैत्येन्द्रो न च तानकरोद्धृदि॥ १६॥

अच्छिनत्तस्य पन्थानं भुजंग: कृष्णदेहवान्।

गृध्रश्च रक्तवक्रो उस्य निलिल्ये ध्वजमूर्धनि॥ १७॥

गृध्रश्चकायते चास्य रथोपरि च गच्छुतः।

ध्वजश्चाभज्यत महात्रथस्य सुमहाप्रभः॥ ?५॥

वामं चाड़ं स्फुरत्यस्य शरीरस्य मुहुर्मुहुः।

हेषन्ते न हया दीना हस्तिनो विमदाभवन्॥ १९॥

14c राजा ] दैत्यो $R \quad 14 d$ ०क्षो इश्मकात् ] ०क्षः स्वकात् $R$ 15d After this R has 13cd. 16ab ॰ पुराच्छकुन्तान् ] ॰पुराद्यात्रायां $R$ 16c-18d ] om. $R$ 19c न हया दीना ] च हयादीनि $R$ 19d ०दाभवन् ] ०दा ब $\simeq$ : R

14a-15c ] om. A 15d ] A has this instead of $8 b$ and repeats it here. - After this $\mathbf{A}$ has $13 \mathrm{~cd}$. 16ab ०पुराच्छकुन्तान् ] ॰पुरात् शत्रू $\left\{{ }^{\circ}\right.$ त्रु $\mathrm{A}_{4}$, ${ }^{\circ}$ कू० $\left.\mathrm{A}_{7}\right\}$ णां $\mathbf{A} \mathbf{1 6 d} \circ$ करोद्दृदि ] $\mathrm{A}_{3}$ $\mathrm{A}_{7}$, ०करो हृदि $\mathrm{A}_{4} \quad 17 \mathrm{~b}$ भुजंग: ] भुजग: $\mathrm{A}_{3} \mathrm{~A}_{4}$, भजग: $\mathrm{A}_{7} \quad 17 \mathrm{c}$ वक्तो ] ०वह्नो $\mathrm{A}_{3} \mathrm{~A}_{4}$, ०वर्णो $\mathrm{A}_{7} 17 \mathrm{~d}$ निलिल्ये] विनिन्ये $\mathrm{A}_{3} \mathrm{~A}_{7}$, विनित्ये $\mathrm{A}_{4} \quad 18 \mathrm{a}$ गृध्रश्चक्रायते ] गृध्रो वत्रायते \{वन्द्रामते $\left.\mathrm{A}_{7}\right\}$ A $18 \mathrm{~cd}]$ तक्षतेव $\left\{\right.$ च $\left.\mathrm{A}_{4}\right\}$ ध्वजो मूलाद्रथस्य तु महाप्रभुः $\mathbf{A}$ 19cd ] om. $\mathbf{A}$

$17\left(d^{2}-d^{3}\right) S_{3} \quad 18\left(b^{8}\right) S_{1} \quad 19\left(d^{8}\right) R$

$14 b$ मुरजैर् ] $S_{1} R B h$, मुरजै $S_{3}$ - ०स्तथा ] $S_{1}^{a c} S_{3} R B h$, ०स्तदा $S_{1}^{p c} \quad 14 c$ वाद्यमानैर ] $S_{3} R B h$ (em.?), वाद्यमाने $S_{1}^{\mathrm{pc}}$, वाद्यामाने $S_{1}^{\mathrm{ac}} \quad \mathbf{1 4 d}$ ०क्षो इश्मकात् ] em. Bh (silently), ०क्षो श्मका $S_{1}$, ॰क्षः स्वकात् $S_{3} 15 a$ अग्रतः ] $S_{3} R B h$ (em.?), अग्रत $S_{1}$ (unmetrical) • पृष्ठत॰ ] $S_{1} R B h$, पृष्टत० $S_{3} \quad 15 b$ पार्श्श्ययो॰] $S_{1} R B h$, पाश्वयो॰ $S_{3} \quad$ 15d After this $S_{1}$ and $S_{3}$ have 13cd. 16a ॰मानः स्व॰] $\mathrm{S}_{1} \mathrm{~S}_{3} \mathrm{RA}$, ०मानश्च Bh (conj.?) 16ab ॰पुराच्छकुन्तान्भय॰] $\mathrm{S}_{3}^{\mathrm{pc}} \mathrm{Bh}$ (conj.?), ॰पुरा शकुन्तभ $+\langle$ व $\rangle$ य $+^{\circ} \mathrm{S}_{1}$, ०पुच्छकुन्तां भय॰ $\mathrm{S}_{3}^{\mathrm{ac}}$ (unmetrical) 16d ०करोद्धदि ] $\mathrm{S}_{3}^{\mathrm{pc}} \mathrm{A}_{3} \mathrm{~A}_{7} \mathrm{Bh}$, ${ }^{\circ}$ करो-

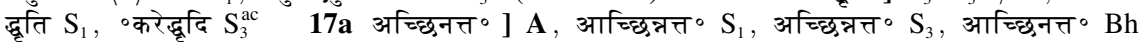
(em.?) - पन्थानं ] $S_{3} A B h$, पुच्छानम् $S_{1} \quad 17 b$ भुजंग: ] $S_{1} B h$, भुजग: $S_{3} \quad 17 c$ रक्त॰] $S_{1}^{p c}$ $\mathrm{S}_{3} \mathrm{ABh}$, रक्र० $\mathrm{S}_{1}^{\mathrm{ac}}$ - ववक्रो उस्य ] $\mathrm{S}_{3}^{\mathrm{pc}} \mathrm{Bh}(\mathrm{em} . ?)$, ववक्तोश्च $\mathrm{S}_{1}$, ववक्तो स्य $\mathrm{S}_{3}^{\mathrm{ac}}$ 17d निलिल्ये] $\mathrm{S}_{1} \mathrm{~S}_{3}^{\mathrm{ac}} \mathrm{Bh}$, नि(शिश्य) $\mathrm{S}_{3}^{\mathrm{pc}}$ 18a गृध्रश्चक्रायते ] em. Bh (silently), गृद्ध चकायते $\mathrm{S}_{1}$, गृद्ध चकायते $\mathrm{S}_{3} \quad 18 \mathrm{~b}$ रथोपरि च] $\mathrm{S}_{3} \mathrm{~A}$, यथोपरि च $\mathrm{S}_{1}$, रथस्योपरि $\mathrm{Bh}$ (conj.) 18c ०श्चाभज्यत ] $\mathrm{S}_{1} B \mathrm{Bh}$, ० ग्र्च भज्यत $\mathrm{S}_{3}$ - महान्] $\mathrm{S}_{3} \mathrm{Bh}$ (em.?), महा॰ $\mathrm{S}_{1} \quad$ 19a वामं चाड़ं ] RABh, वामं वाड्गं $\mathrm{S}_{1}$, वामं चागं $S_{3}^{\mathrm{pc}}$, वाम चाग $\mathrm{S}_{3}^{\mathrm{ac}}$ - स्फुरत्यस्य ] $\mathrm{S}_{1}^{\mathrm{pc}} \mathrm{RABh}$, स्फुर(न्त) स्य $S_{1}^{\mathrm{ac}}$, स्फुरत्तस्य $S_{3} 19 \mathrm{c}$ न ] $S_{1} B h$, च $S_{3}$ - दीना ] em. Bh (silently), दीनां $S_{1}$, दीनं $S_{3}$ 19d ०दाभवन् ] em. Bh (silently), ॰दाभवत् $\mathrm{S}_{1}$, ०दा बभु: $\mathrm{S}_{3}$ 
एतांश्चान्यांश्च सुबहून्स दैत्यो मुनिसत्तम।

अवेक्षत निमित्तानि भयदान्यात्मनो उसकृत्॥ २०॥

नातिदूरे स निर्गम्य नगरस्य मृगेश्वरम्।

अपश्यद्दानवः संख्ये युध्यमानमभीतवत्॥ २?॥

सो उपि दैत्यवर: श्रीमान्कोधात्संरक्तोचनः।

विस्फारयन्महाचापं रथेनाम्यपतद्वली। २२॥

वराहो उपि महाबाहुर्विद्राव्य दितिनन्दनान्।

सुवर्णाक्षं प्रति रुषा वेगेनैवाम्यधावत॥ २३॥

तस्यापतत एवाशु दानवः सुमहाबलः।

सर्वसंधिषु तीक्ष्णाग्रांश्चखान सुबहूग्छुरान्॥ २४॥

सायकैस्तैर्विनिर्भित्रः सर्वसंधिषु सुत्रत।

न चचाल मृगेन्द्रो डसौ विष्टब्धः समतिष्ठत॥ २४॥

20c अवेक्षत ] अवैक्षत $R 20 d$ भयदान्यात्मनो उसकृत् ] भयदास्त्रासिनो ऽभन् $R$ 21a स ] च $R$ $21 b$ नगरस्य ] नगरे स $R \quad 22 b$ कोधात्सं०] कोधसं० $R \quad 22 c$ न्महाचापं ] न्महच्चापं $R$ 22d रथेनाभ्य० ] रथेनास्या० $R \quad 23 b$ ०र्विद्राव्य दितिनन्दनान् ] ०र्विदित्वा दितिनन्दनम् $R \quad 24 c d$ ] om. R $25 \mathrm{ab}$ ०निर्भिन्नः सर्वसन्धिषु ] ०भिन्नस्तु स सिद्धैरिर R

20a एतांग्चा॰] $\mathrm{A}_{4} \mathrm{~A}_{7}$, एतां चा॰ $\mathrm{A}_{3}$ • सुबहन् ] $\mathrm{A}_{4} \mathrm{~A}_{7}$, सुबहुन् $\mathrm{A}_{3} \quad 20 \mathrm{~b}$ ०सत्तम ] $\mathrm{A}_{4} \mathrm{~A}_{7}$, ०सत्तमः $A_{3} 20 \mathrm{c}$ अवेक्षत ] अवैक्षत $A$ 20d ०नो उसकृत् ] ०नः सकृत् $A$ 21a नातिदूरे स ] स्यन्दनेनाभि॰ $\mathbf{2 1 b}$ नगरस्य ] नगरात्स $A$ - मृगेश्वरम् ] $\mathrm{A}_{3} \mathrm{~A}_{7}$, मृगेश्वर: $\mathrm{A}_{4} 22 \mathrm{c}$ ०न्महाचापं ] ०न्महच्चापं $A$ 23b ०र्विद्राव्य दितिनन्दनान् ] ०रिदित्वा दितिनन्दनं $A$ 23c रुषा ] स च $A$ 24a एवाशु ] एवासौ $A$ 24b सुमहाबलः ] कोधमूह्छितः A 24cd ०ग्रांश्चाखान सु०] ०ग्रान् निचखान $A$ 25a ०निर्भित्रः ] $\mathrm{A}_{3} \mathrm{~A}_{7}$, ०निभिन्नः $\mathrm{A}_{4}$ (unmetrical) $25 \mathbf{b}$ सुत्रत ] $\mathrm{A}_{3} \mathrm{~A}_{7}$, मुत्रत $\mathrm{A}_{4}$ 25d विष्टब्धः ] $\mathrm{A}_{3} \mathrm{~A}_{7}$, विष्टध्व: $\mathrm{A}_{4}$ - समतिष्ठत ] समपद्यत $\mathbf{A}$

$\mathbf{2 0}\left\langle\leftarrow \mathrm{a}^{1}-\mathrm{d}^{7}\right\rangle\left(\mathrm{d}^{8}\right) \mathrm{S}_{2} \quad \mathbf{2 1}\left(\mathrm{b}^{3}-\mathrm{b}^{5}\right) \mathrm{S}_{1} \quad \mathbf{2 2}\left\langle\mathrm{c}^{1}-\mathrm{c}^{3}\right\rangle\left(\mathrm{c}^{4}\right) \mathrm{R} \quad \mathbf{2 3}\left(\mathrm{a}^{6}-\mathrm{a}^{7}\right) \mathrm{S}_{1},\left(\mathrm{a}^{7}-\mathrm{b}^{1}, \mathrm{~b}^{3}, \mathrm{~d}^{3}-\mathrm{d}^{8}\right) \mathrm{S}_{2}$ $\mathbf{2 4}\left\langle a^{1}\right\rangle\left(a^{2}\right)\left\langle a^{3}-a^{6}\right\rangle\left(a^{7}-a^{8}\right) S_{2} \quad 25\left\langle a^{1}\right\rangle\left(a^{2}-a^{4}, c^{8}\right) S_{1},\left\langle c^{1}-c^{7}\right\rangle R$

20a एतांश्चान्यांश्च $] \mathrm{S}_{3} \mathrm{RA}_{4} \mathrm{~A}_{7}$, एतांस्यान्यांश्च $\mathrm{S}_{1}$, एतान्यन्यानि $\mathrm{Bh}$ (conj.) 20ab सुबहून्स] $\mathrm{S}_{1}$ $\mathrm{RA}_{4} \mathrm{~A}_{7}$, सुबहु स $\mathrm{S}_{3}$, च बहुनि $\mathrm{Bh}$ (conj.) $20 \mathrm{~b}$ ०सत्तम $] \mathrm{S}_{1} \mathrm{RA}_{4} \mathrm{~A}_{7} \mathrm{Bh}$, ०सत्तम: $\mathrm{S}_{3} 20 \mathrm{c}$ अवेक्षत नि॰ ] $S_{3}$, अवेक्षतत्रि॰ $S_{1}$, सोवैक्षत नि॰ $B h$ (conj.) 20d भयदान्या॰] $S_{3} A B h$, भयदाना० $\mathrm{S}_{1}$ 21a नाति॰] $\mathrm{S}_{2} \mathrm{~S}_{3} R B h$, तानि $\mathrm{S}_{1}$ • निर्गम्य ] $\mathrm{S}_{2} \mathrm{~S}_{3} R A$, निर्गत्य $\mathrm{S}_{1}$, निर्गत्य $\mathrm{Bh}$ 21b मृगेश्वरम् ] $S_{1} R_{3} A_{7} B h$, महेग्वरम् $S_{2}$, महेश्वरं $S_{3} \quad 21 \mathrm{c}$ अपश्यद्दानवः ] $R A B h$, अपश्यद्दानवो $\mathrm{S}_{1} \mathrm{~S}_{2}$, अपश्य दानवो $\mathrm{S}_{3}$ - संख्ये ] $\mathrm{S}_{3} \mathrm{RABh}$, संखे $\mathrm{S}_{1}$, सखे $\mathrm{S}_{2}$ (unmetrical, anusvāra possibly lost) 22a श्रीमान ] $\mathrm{S}_{1} \mathrm{RABh}$, श्रीमा $\mathrm{S}_{2} \mathrm{~S}_{3} \quad 22 \mathrm{~b}$ कोधात्सं॰ ] $\mathrm{S}_{2} \mathrm{~A}$, कोधसं॰ $\mathrm{S}_{1} B h$, कोधात्स $\mathrm{S}_{3}$ (unmetrical) 22c ०स्फारयन्म०] $S_{2} S_{3} A B h$, ०स्फारयम्म० $S_{1}$ 22d रथेनाभ्यपत०] $S_{2} S_{3} A B h$, रथे चाभ्यद्रव० $S_{1} \quad 23 \mathbf{a}$ महाबाहुर् ] $S_{2} R A B h$, म(हाबा)हु $S_{1}$, महाबाहु $S_{3} \quad 23 b$ ॰द्राव्य ] $S_{1} S_{2}^{p c}$ $\mathrm{S}_{3} \mathrm{Bh}$, ०द्या(व्य) $\mathrm{S}_{2}^{\text {ac }}$ - ०नन्दनान् ] $\mathrm{S}_{3} \mathrm{Bh}$ (em.?), ॰नन्दनात् $\mathrm{S}_{1}$, ०नन्दनाम् $\mathrm{S}_{2}$ 23c सुवर्णाक्षं ] $\mathrm{S}_{1} \mathrm{~S}_{2} \mathrm{~S}_{3}^{\text {pc }} \mathrm{RABh}$, सुवर्णाक्ष $\mathrm{S}_{3}^{\text {ac }} \quad \mathbf{2 4 a b}$ एवाशु दा॰ $\mathrm{S}_{1} \mathrm{~S}_{3} \mathrm{RBh}$, -(वाशु)द्दा॰ $\mathrm{S}_{2}$ (tops lost) $24 \mathrm{c}$ ॰सन्धिषु तीक्ष्णा॰ ] $\mathrm{S}_{2} \mathrm{~S}_{3} \mathrm{ABh}$, ०सन्धिप्रतीक्षा॰ $\mathrm{S}_{1}$ 24cd ॰ग्रांश्चखान सु॰] $\mathrm{S}_{2}$, ॰ग्रं दानवस्सु॰ $\mathrm{S}_{1}$, ०ग्राश्चखान सु॰ $\mathrm{S}_{3}$, ०ग्रान्निचखान $\mathrm{Bh} \mathbf{2 4 d}$ ०बहम्छरान् ] $\mathrm{S}_{1} \mathrm{ABh}$, ०बहन्छरान् $\mathrm{S}_{2}^{\mathrm{pc}}$, ०बहन्छिरान् $\mathrm{S}_{2}^{\mathrm{ac}}$, ०बहनन्थरान् $\mathrm{S}_{3}^{\mathrm{pc}}$, ०बहन्थिरान् $\mathrm{S}_{3}^{\mathrm{ac}} \quad 25 \mathrm{a}$ ०कैस्तैर्वि॰ $] \mathrm{S}_{1} \mathrm{~S}_{3}^{\mathrm{pc}} \mathrm{RABh}$, ०कैस्त्रैर्वि॰ $\mathrm{S}_{2}$, ०कैस्तै वि॰ $\mathrm{S}_{3}^{\mathrm{ac}}$ - ०निर्भित्नः ] $\mathrm{S}_{1} \mathrm{~S}_{2}^{\mathrm{pc}} \mathrm{A}_{3} \mathrm{~A}_{7} \mathrm{Bh}$, ०निर्भित्र $\mathrm{S}_{2}^{\mathrm{ac}} \mathrm{S}_{3}^{\mathrm{pc}}$, ०निभिन्न $\mathrm{S}_{3}^{\mathrm{ac}}$ (unmetrical) 25b सुत्रत ] $S_{2}^{\text {pc }} R_{A_{3}} A_{7} B h$, सुत्रत $S_{1}$, सुत्रतः $S_{2}^{\text {ac }} S_{3} \quad 25 d$ विष्टब्धः ] $S_{2} R A_{3} A_{7} B h$, विष्टब्ध $S_{1}$, विष्ठब्धः $S_{3}$ ०तिष्ठत ] $\mathrm{S}_{1} \mathrm{~S}_{2} \mathrm{RBh}$, ०तिष्टत $\mathrm{S}_{3}$ 
तं स्तम्भितं तदा व्यास दृष्ट्वा देवा महाबलम्।

विशल्यकरणैर्मन्त्रैर्विशल्यमभिचक्रिरे॥ २६॥

स विशल्यस्तदा देवै: कृतो मृगपतिर्महान्।

पुनर्वेगं महत्कृत्वा जगाम दितिजं प्रति॥ २७॥

स वध्यमानो बहुभिः शरैर्मृगपतिर्महान्।

दैत्येन्द्ररथमासाद्य इयेष रथमव्ययः ॥ २५॥

ग्रहीतुं नादयन्व्यास बहुधा विश्वरूपधृक्।

यन्ता च मण्डलं कृत्वा म्रामयामास तं रथम्॥ २९॥

प्रसारितकरं दैत्यो मृगं तं सुमहाबलम्।

बबन्धास्त्रेण नागानां स बद्धो न्यपतड्दुवि॥ ३०॥

पतितं तं च दैत्येन्द्रा विविधायुधपाणयः।

विजघुर्भृशमायस्ता बहुधा ऋोधमूह्छिताः॥ ३? ॥

तं बद्धं वध्यमानं च पतितं नन्दिवर्धनम्।

गरुत्मान्भुजगेन्द्रेम्यः क्षिप्रमेव व्यमोचयत्॥ ३२॥

$26 a$ स्तम्भितं ] कुण्ठितं $R \quad 27 c$ महत्कृत्वा ] स कृत्वा तु $R$ 27d दितिजं प्रति ] दितिजा ... $R$ 28c ०मासाद्य ] ०मास्थाय R 28d ०मव्यय: ] ॰मन्यदा $R \quad 29 a$ ०न्व्यास ] ०न् सर्व्व R 30a ०करं ]

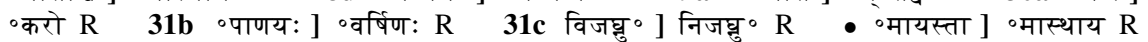
31d बहुधा ] चक्षुषा $R \quad 32 c$ न्भुजगेन्द्रेम्यः ] न्म भुजगेन्द्रांश्च $R$

26b देवा ] देवं $A$ 26cd ०र्मन्त्रैर्विशल्य॰] $\mathrm{A}_{3} \mathrm{~A}_{7}$, ०र्मत्रैर्विशल॰ $\mathrm{A}_{4}$ (unmetrical) 28 ] om. $\mathrm{A}$ 29a ग्रहीतुं ] $A_{7}$, गृहीतं $A_{3}$, गृहीतुं $A_{4} 29 c$ यन्ता च ] यत्नतो $A \quad 30 d$ स बद्धो ] $A_{4}$, सबन्धो $\mathrm{A}_{3} \mathrm{~A}_{7}$ 31c विजघु ${ }^{\circ}$ ] निजघु ${ }^{\circ} \mathrm{A}$ - ${ }^{\circ}$ मायस्ता ] $\mathrm{A}_{3}$, ०मायस्था $\mathrm{A}_{4} \mathrm{~A}_{7}$ 32a बद्धं ] सुरा $\mathrm{A}_{3} \mathrm{~A}_{7}$, शूरा $\mathrm{A}_{4} \quad 32 \mathrm{c}$ गरुत्मान् $] \mathrm{A}_{3} \mathrm{~A}_{7}$, गरुत्वान् $\mathrm{A}_{4}$

27 $\left(b^{8}\right) S_{2},\left\langle d^{7}-d^{8} \rightarrow\right\rangle R \quad 28\left(a^{1}, a^{5}\right) S_{1},\left\langle\leftarrow a^{1}-a^{7}\right\rangle R \quad 30\left(b^{3}, d^{5}-d^{8}\right) S_{1},\left\langle b^{5}-c^{7}\right\rangle\left(c^{8}\right) R \quad 32\left(d^{5}\right)$ $\mathrm{S}_{1},\left\langle\mathrm{~d}^{2}-\mathrm{d}^{8} \rightarrow\right\rangle \mathrm{R}$

26a स्तम्भितं ] $\mathrm{S}_{2} \mathrm{~S}_{3} \mathrm{ABh}$, स्तम्भिदन् $\mathrm{S}_{1} \quad 26 \mathrm{c}$ ककरणैर्मन्त्रैर् ] $\mathrm{S}_{2} \mathrm{RA}_{3} \mathrm{~A}_{7} \mathrm{Bh}$, ककरणैर्मन्त्र $\mathrm{S}_{1}$, ककरणै मन्त्रै $\mathrm{S}_{3} 26 d$ ॰श्यमभि॰ $\mathrm{S}_{2} \mathrm{~S}_{3} \mathrm{RA}_{3} \mathrm{~A}_{7} \mathrm{Bh}$, ०शल्य स वि० $\mathrm{S}_{1}$ 27a स विशल्य॰] $\mathrm{S}_{2} \mathrm{~S}_{3} \mathrm{RABh}$, सेवैशल्य॰ $S_{1}$ - देवै: ] $S_{1} R A B h$, देवै $S_{2} S_{3}$ 27c पुनर् ] $S_{1} S_{2} R A B h$, पुन $S_{3}$ महत् ] $S_{1} S_{2}$ $\mathbf{A B h}$, महा $\mathrm{S}_{3} \quad 28 \mathbf{a}$ वध्यमानो ] $\mathrm{S}_{2} \mathrm{~S}_{3} B h$, बद्यमा(नो) $\mathrm{S}_{1}$ 28ab ०भिः शरैर्मृगपतिर ] $\mathrm{S}_{1} \mathrm{~S}_{2} R B h$, ०भि शरै मृगपति $\mathrm{S}_{3}$ (unmetrical) $28 \mathrm{c}$ दैत्येन्द्र $] \mathrm{S}_{2} \mathrm{~S}_{3} R B h$, दैत्येन $\mathrm{S}_{1}$ 28d इयेष ] $\mathrm{S}_{2} \mathrm{~S}_{3} R B h$, ईषेष $S_{1}$ - ०मव्ययः ] $S_{1} B h$, ०मव्ययम् $S_{2} S_{3}$ 29a ०तुं नादयन् ] $S_{2} S_{3} R_{A} A_{4} A_{7} B h$, ०तुन्नादयद् $S_{1}$ 29c यन्ता ] $\mathrm{S}_{2} \mathrm{~S}_{3} R B h$, मन्ता $\mathrm{S}_{1}$ 31c विजघुरा $] \mathrm{S}_{1} \mathrm{~S}_{2}^{\mathrm{pc}} \mathrm{Bh}$, विजघु $\mathrm{S}_{2}^{\text {ac }} \mathrm{S}_{3}$ 31d ॰मूर्छिता: ]

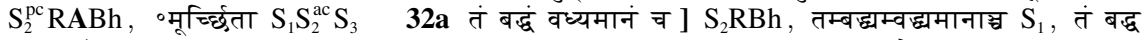
वद्यमानं च $\mathrm{S}_{3} \quad 32 \mathrm{c}$ गरुत्मान् ] $\mathrm{S}_{1} \mathrm{~S}_{2}^{\mathrm{pc}} \mathrm{RA}_{3} \mathrm{~A}_{7} \mathrm{Bh}$, गरुत्मा $\mathrm{S}_{2}^{\mathrm{ac}} \mathrm{S}_{3}$ 32d ०मेव व्य॰] $\mathrm{S}_{2} \mathrm{~S}_{3} \mathrm{ABh}$, $\circ$ मेत (द्वा०) $\mathrm{S}_{1}$ (upper part of द्वा lost) 
मुक्तश्च स तदोत्पत्य द्रावयाणो दितेः सुतान्।

हिरण्याक्षरथं तुर्णमम्यधावन्महायशाः॥ ३३॥

तं धावन्तं पुनर्देत्य: शरेणानतपर्वणा।

विव्याध हृदये व्यास नर्दमानो यथाम्बुदः॥ ३४॥

मृगेश्वरश्च भिन्नो उसौ हृदये मोहमास्थितः।

पपात भूमौ निर्वृत्ते शऋध्वज इवोत्सवे॥ ३४॥

ततो हाहाकृतं सर्वे: समूढैर्देवपुंगवै:।

ऋषयस्तुष्टुवुश्चैनं भास्करश्चाप्रभो अवत्॥ ३६॥

अथ सो उप्यायितस्तत्र ऋषिभिर्ब्रह्मवित्तमै:।

प्रतिलभ्य तदा संज्ञामिदं वचनमब्रवीत्॥ ३७॥

आप्याययध्वं मां क्षिप्रं मूढो उह सर्वशः सुराः।

नाल्पवीर्येण शक्यो उयं दैत्यो योधयितुं रणे॥ ३५॥

ततस्ते देवता: सर्वे ऋषयश्च तपोधनाः।

तपसा स्वेन तं देवं सर्व एवाभ्यपूरयन्॥ ३९॥

$33 b$ द्रावयाणो दितेः सुतान् ] द्रावयानो दिशश्च तान् $R \quad 33 d$ ०न्महायशा: ] ०न्महौजसा $R$ 34a तं धावन्तं पुनर्देत्यः ] तमायान्तं रणद्देत्य: $R \quad 35 \mathrm{a}$ मृगेश्वरश्च ] मृगेश्वरस्य $R \quad 35 \mathrm{~b}$ हृदये] हृदयं $\mathrm{R} 36 \mathrm{~b}$ समूढै॰ ] संमूढै॰ $\mathrm{R} 36 \mathrm{c}$ ऋषयस्तु ${ }^{\circ}$ ] भाषयस्तु ${ }^{\circ} \mathrm{R} 36 \mathrm{~d}$ ०रश्चाप्रभो ] ०र: सुप्रप्रभो $\mathrm{R}^{\mathrm{pc}}$ (unmetrical), ०र अप्रप्रभो $\mathrm{R}^{\mathrm{ac}}$ (unmetrical) $37 \mathbf{a b}$ ] om. $\mathrm{R} \quad 37 \mathrm{c}$ तदा ] ततः $\mathrm{R} \quad 38 \mathrm{a}$ मां क्षिप्रं ] क्षिप्रं मां $R \quad 39 a$ ततस्ते ] ततश्च $R \quad 39 c$ तपसा स्वेन ] बलैग्चैव हि $R \quad 39 d$ ०पूरयन् ] ०पूजयत् R

33b द्रावयाणो ] द्रावयानो $\mathrm{A} \quad 34 \mathrm{a}$ पुनर्देत्यः ] पुनर्देत्यं $\mathrm{A}_{7}$, महादेत्यः $\mathrm{A}_{3} \mathrm{~A}_{4}$ 35c निर्वृत्ते ] $\mathrm{A}_{4} \mathrm{~A}_{7}$, निर्वृते $\mathrm{A}_{3}$ (unmetrical) 35d-37a ] om. $A$ 37b ०वित्तमै: ] ०सत्तम $\mathrm{A}_{3}$, ०सत्तम: $\mathrm{A}_{4} \mathrm{~A}_{7} 37 \mathbf{c}$ प्रतिलम्य ] प्रतिपद्य $\mathrm{A} \quad 38 \mathrm{a}$ आप्याययध्वं ] आप्याययत $\mathrm{A}_{3}$, आप्यापयत $\mathrm{A}_{4}$, आप्याययतु $\mathrm{A}_{7} \mathbf{3 8 b}$ मूढो इहं ] मृतो यं $\mathrm{A}_{3} \mathrm{~A}_{4}$, मृगो यं $\mathrm{A}_{7} \quad 38 \mathrm{c}$ डयं] $\mathrm{A}_{3}$, हं $\mathrm{A}_{4} \mathrm{~A}_{7} \quad 39 \mathrm{~d}$ ०पूरयन् ] $\mathrm{A}_{7}$, वपूरयत् $\mathrm{A}_{3}$, ०पूरन् $\mathrm{A}_{4}$ (unmetrical)

$33\left(b^{6}-b^{8}\right) S_{1},\left\langle\leftarrow a^{1}-a^{6}\right\rangle\left(a^{7}\right) R \quad 35\left\langle c^{1}-d^{6}\right\rangle\left(d^{7}\right) R \quad 36\left(d^{8}\right) S_{1} \quad 38\left(c^{8}\right) S_{1},\left\langle c^{6}-d^{8}\right\rangle R$

33a स तदोत्पत्य ] $A B h$, पतततोत्पत्य $S_{1}$ (unmetrical), स तदोत्पत्या $S_{2} S_{3}$ 33b द्रावयाणो ] em. Bh (silently), द्रावयानो $\mathrm{S}_{1} \mathrm{~S}_{2} \mathrm{~S}_{3}$ • दितेः सुतान् ] $\mathrm{S}_{2} \mathrm{~S}_{3} \mathrm{ABh}$, दि(ते सुता)म् $\mathrm{S}_{1}$ 33cd ०रथं

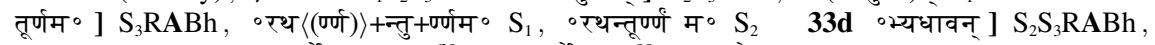
॰भ्यथावन् $S_{1} \quad 34 a$ पुनर्देत्य: ] $S_{1} S_{2}^{p c} B h$, पुनर्देत्य $S_{2}^{a c}$, पुन दैत्य $S_{3}$ (unmetrical) 34b ०णानतपर्वणा ] $\mathrm{S}_{2} \mathrm{~S}_{3} \mathrm{RABh}$, ०ण $\left\{\circ 0{ }^{\circ} \mathrm{S}_{1}^{\mathrm{ac}}\right\}$ नतपर्वणा: $\mathrm{S}_{1}$ 34c व्यास $] \mathrm{S}_{1} \mathrm{~S}_{2}^{\mathrm{pc}} \mathrm{S}_{3} \mathrm{RABh}$, (ध्या)स $\mathrm{S}_{2}^{\mathrm{ac}}$ 34d नर्दमानो] $S_{2} S_{3} R A B h$, नदम्बानो $S_{1} \quad 35 a$ वग्च भिन्नो ] $S_{2} A B h$, ०गतियों $S_{1}$, ०ग्च भिनो $S_{3}$ (unmetrical) 35b ०मास्थितः ] $S_{1}^{\text {pc }} S_{2} S_{3} R A B h$, ०मास्थित $S_{1}^{\text {ac }}$ 35c पपात ] $S_{2} S_{3} A B h$, आपात $\mathrm{S}_{1}$ - निर्वृत्ते ] $\mathrm{S}_{1} \mathrm{~S}_{2} \mathrm{~A}_{4} \mathrm{~A}_{7} \mathrm{Bh}$, निवृत्ते $\mathrm{S}_{3}$ 36a ०कृतं ] $\mathrm{S}_{1} \mathrm{RBh}$, ककृत: $\mathrm{S}_{2} \mathrm{~S}_{3}$ 36ab सर्वे: समूढैर्देव०] conj., सर्वे मम दैत्येव $\mathrm{S}_{1}$, सर्वेस्समूहैर्द्धव० $\mathrm{S}_{2}$, सर्वे समूहै देव० $\mathrm{S}_{3}$, सर्वे: समेतैर्देव० Bh (conj.) $36 \mathrm{c}$ ०स्तुष्टुवु $\left.{ }^{\circ}\right] \mathrm{S}_{1} \mathrm{~S}_{2} \mathrm{RBh}$, ०स्तुष्टवु $\mathrm{S}_{3}$ - ० श्चैन ] $\mathrm{S}_{2}^{\mathrm{ac}} \mathrm{RBh}$, ० श्चैव $\mathrm{S}_{1} \mathrm{~S}_{3}^{\mathrm{ac}}$, ० श्चैन $\mathrm{S}_{2}^{\mathrm{pc}} \mathrm{S}_{3}^{\mathrm{pc}} 37 \mathrm{a}$ अथ सो ] $\mathrm{S}_{2} \mathrm{~S}_{3} \mathrm{Bh}$, अथासौ $\mathrm{S}_{1}$ 37b ऋषिभिर् ] $\mathrm{S}_{2} \mathrm{ABh}$, ऋषिभि: $\mathrm{S}_{1}$, ऋषिभि $\mathrm{S}_{3}$ 38a मां ] $\mathrm{S}_{2} \mathrm{~S}_{3}^{\mathrm{pc}} \mathrm{ABh}$, मा $\mathrm{S}_{1} \mathrm{~S}_{3}^{\mathrm{ac}}$ 38d योधयितुं ] $\mathrm{S}_{1} \mathrm{~S}_{2} \mathrm{ABh}$, योधयितु $\mathrm{S}_{3}$ (unmetrical) 39a देवता: ] $\mathrm{RA}$, देवता $\mathrm{S}_{1} \mathrm{~S}_{2} \mathrm{~S}_{3}$, दैवतास् $\mathrm{Bh}$ (em.) 39c स्वेन ] $\mathrm{S}_{1} \mathrm{~S}_{3}^{\mathrm{pc}} \mathbf{A B h}$, सेन $\mathrm{S}_{2} \mathrm{~S}_{3}^{\text {ac }}$ 39d ०पूरयन् ] $\mathrm{S}_{1} \mathrm{~A}_{7} \mathrm{Bh}$, ०पूजयत् $\mathrm{S}_{2} \mathrm{~S}_{3}$ 
तस्य त्वाप्याय्यमानस्य ऋषिभिर्देवतैश्च ह।

बभौ रूपं युगान्ताग्निकालमृत्युसमप्रभम्॥ ४०॥

स दीप्यमानो विबभौ महात्मा देवैश्च सर्वे ऋषिभि: स्तुतश्च।

दीप्तस्तदा भास्करसप्तकल्पो लोकान्दहिष्यन्निव देवदेवः॥ ४?॥

इति स्कन्दपुराणे पझ्चोत्तरशतो डध्यायः ॥ १०४॥

40a तस्य त्वाप्याय्यमानस्य ] स तदाप्यायमानश्च $R \quad 40 \mathrm{~b}$ ०र्देवतैश्च ह ] ०र्देवतैः सह $\mathrm{R} \quad 40 \mathrm{c}$ रूपं युगान्ताग्नि०] युगान्ताग्निनिभ: $R \quad 40 d$ ०प्रभम् ] ०प्रभः $R \quad 41 a$ स दीप्यमानो ] संदीप्य... $R$ 41c दीत्तस्तदा ] दीप्रो यथा $R$

Col. इति स्कन्दपुराणे रेवाखण्डे डध्याय: $R$

40a त्वाप्याय्यमानस्य ] त्वापर्य्यमानस्य $\mathrm{A}_{7}$, द्वापर्यमाणस्य $\mathrm{A}_{3} \mathrm{~A}_{4} \quad 40 \mathrm{~b}$ ०र्देवतैश्च ह ] ०र्दे $\left\{\circ\right.$ दें $\left.\mathrm{A}_{7}\right\}$ वतै:

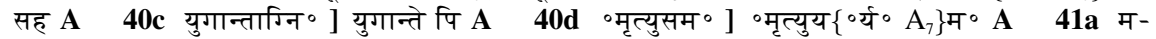
हात्मा ] वराहो $\mathrm{A} 41 \mathrm{~b}$ सर्वे ऋषि०] $\mathrm{A}_{4}$, सर्वेर्कषष० $\mathrm{A}_{3} \mathrm{~A}_{7}$ • स्तुतश्च ] $\mathrm{A}_{3} \mathrm{~A}_{4}$, स्तुताश्च $\mathrm{A}_{7}$ 41c दीप्तस्तदा ] दीप्रो यथा $\mathrm{A}$ 41d ०न्दहिष्यत्रिव ] $\mathrm{A}_{4} \mathrm{~A}_{7}^{\mathrm{pc}}$, ०न्दहिष्यनिव $\mathrm{A}_{3} \mathrm{~A}_{7}^{\mathrm{ac}}$ (unmetrical) Col. इति स्कन्दपुराणे एकाशीतिसाहस्रचां संहिताया $\left\{\right.$ इति स्कंद $\left.{ }^{\circ} \mathrm{A}_{4}\right\}$ मम्बिकाखण्डे चत्वार्यधिकशततमो $\left\{\circ\right.$ शतो $\left.\mathrm{A}_{7}\right\}$ ध्याय: A

$41\left\langle a^{4}-a^{11}\right\rangle\left(b^{1}-b^{2}\right) R$

40a त्वाप्याय्यमानस्य ] $\mathrm{S}_{2} \mathrm{~S}_{3}$, त्वाप्यायमानस्य $\mathrm{S}_{1} \mathrm{Bh} \quad 40 \mathrm{~b}$ ०भिर्देवतैग्च ] $\mathrm{S}_{1} \mathrm{~S}_{2}$, ०भि देव+तै+श्च $\mathrm{S}_{3}$, ०िर्देवतैश्च $B h$ (em.) 41a दीप्यमानो ] $S_{1} S_{2} A B h$, दीप्यमाने $S_{3} \quad 41 b$ सर्वे ऋषि०] $S_{1} S_{2} S_{3} R_{4}$, सर्वैर्क्षषि॰ $\mathrm{Bh}$ - स्तुतश्च ] $\mathrm{S}_{2} \mathrm{~S}_{3} \mathrm{RA}_{3} \mathrm{~A}_{4} \mathrm{Bh}$, स्तुतैश्च $\mathrm{S}_{1}$ 41c भास्कर॰] $\mathrm{S}_{1} \mathrm{~S}_{2} \mathrm{~S}_{3}^{\mathrm{pc}} \mathrm{RABh}$, भास्क॰ $\mathrm{S}_{3}^{\mathrm{ac}}$ (unmetrical) - ०कल्पो ] $\mathrm{S}_{1} \mathrm{RABh}$, ०कल्प+:+। $\mathrm{S}_{2}$, ०कल्प $\mathrm{S}_{3}$ 41d ०न्दहिष्यन्निव ] $\mathrm{S}_{1} \mathrm{~S}_{2}$ $\mathrm{RA}_{4} \mathrm{~A}_{7}^{\mathrm{pc}} \mathrm{Bh}$, ०न्दहिष्यन्तिव $\mathrm{S}_{3}$ - देवदेव: ] $\mathrm{RABh}$, देवदेवेति $\mathrm{S}_{1} \mathrm{~S}_{2} \mathrm{~S}_{3}$ (इति part of col.) Col. $\odot ॥$ स्कन्दपुराणे वराहाप्यायने आध्याय: १६० (in letter numerals)॥ $\odot \mathrm{S}_{1}$, स्कन्दपुराणे पझ्चोत्तरशतो ध्याय $\mathrm{S}_{2}, \odot \|$ स्कन्दपुराणे नामाध्याय: १०७ (in letter numerals)॥ $\odot \mathrm{S}_{3}$ 
षडुत्तरशतो डध्यायः ।

सनत्कुमार उवाच।

स तथाप्यायितो देवो बलवान्भास्करद्युतिः।

चित्रं बहु च शीघ्रं च मण्डलानि परिभ्रमत्॥ १॥

प्रुतादि सिंहवत्कृत्वा अवलोकयतासकृत्।

पृष्ठतश्चाग्रतश्चापि पुनर्गजवदाचरत्॥ २॥

पुनर्व्यात्ताननो भूत्वा शस्त्राणि ग्रसते रिपोः।

पुनर्वृक्षैः शिलाभिश्च दानवान्स न्यसूदयत्॥ ३॥

पुनराकाशगो भूत्वा पक्षिराडिव सो अ्रमत्।

पुनर्जहास संकुद्ध अशनीपातसंनिभम्।

पुनश्च सूक्ष्ममात्मानं कृत्वा तस्थावथाग्रतः॥ ४ ॥

$1 c$ बहु च शीघ्रं च] बहुरुचः शीघ्रं $R \quad 1 d$ ०भ्रमत् ] ॰्रमन् $R \quad 2 d$ पुनर्गजवदाचरत् ] मण्डलानि चकार स: $\mathrm{R} 3 \mathrm{~b}$ शस्त्राणि ग्रसते ] अस्त्राणि ग्रसतो $\mathrm{R} \quad 3 \mathrm{c}$ ०वृक्षैः ] ०वृक्षै $\mathrm{R}$ (visarga possibly

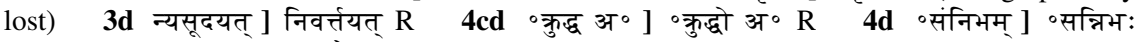
$\mathrm{R} 4 \mathrm{f}$ तस्थावथाग्रतः ] तस्थौ पुनश्च स: $\mathrm{R}$

$1 c$ चित्रं बहु च] चित्र $\left\{{ }^{\circ} \circ \mathrm{A}_{3}\right\}$ वर्णश्च $\mathbf{A} \quad 1 d$ ॰भ्रमत् ] ॰भ्रमन् $\mathbf{A} \quad 2 \mathrm{a}$ प्रुतादि ] म्रुतानि $\mathbf{A} 2 \mathrm{c}$ पृष्टत० ] $\mathrm{A}_{7}$, पृष्टतं $\mathrm{A}_{3} \mathrm{~A}_{4} \quad \mathbf{2 d}$ ॰दाचरत् ] ॰दाचरन् $\mathbf{A} \quad \mathbf{3 b}$ ग्रसते रिपो: ] श्व \{स्व० $\mathrm{A}_{3}$, ब्व० $\mathrm{A}_{4}$ \}सते हि स: $\mathbf{A} 3 d$ दानवान्स न्यसूदयत् ] दानवास्त्राण्यचूर्णयत् $\mathbf{A} 4 \mathbf{b}$ सो अ्रमत् ] चो वों० $\left.\mathrm{A}_{4}\right\}$ इ्रमन् $\mathrm{A} 4 \mathbf{c d} \circ$ क्रुद्ध अशनीपातसंनिभम् ] ॰क्रुद्धो अशनिप्रतिमस्वनं $\left\{{ }^{\circ}\right.$ म $^{\left.\mathrm{A}_{7}\right\}} \mathbf{A}$ 4e पुनश्च सूक्ष्ममा॰ ] पुनः सूक्ष्म $\left\{{ }^{\circ}\right.$ क्ष० $\left.\mathrm{A}_{3}\right\}$ मिवा० $\mathbf{A}$ 4f तस्थावथा०] तस्थौ तद॰ $\mathbf{A}$

Manuscripts available for this chapter: $S_{1}$ photos $4.5 \mathrm{~b}$ (f. $163^{\mathrm{r}}$ ), $4.6 \mathrm{a}$ (f. $163^{\mathrm{v}}$, largely retraced), $4.7 \mathrm{~b}$ (f. $164^{\mathrm{r}}$, largely retraced) and $4.8 \mathrm{a}\left(\right.$ (f. $164^{\mathrm{v}}$ ); $\mathrm{S}_{2}$ exposures $113-114 \mathrm{~b}$ (f. $148^{\mathrm{r}}-149^{\mathrm{r}}$ ); $\mathrm{S}_{3}$ f. $163^{\mathrm{r}}-164^{\mathrm{r}}$; R f. $179^{\mathrm{v}}-180^{\mathrm{v}}$ (lower left corners of f. 179 and 180 are cut off in triangular shape; the fragment of f. 179 is lost but that of f. 180 is almost intact); $A_{3}$ f. $107^{\mathrm{r}}-107^{\mathrm{v}} ; \mathrm{A}_{4}$ f. $151^{\mathrm{r}}-151^{\mathrm{v}}$; $\mathrm{A}_{7}$ f. $151^{\mathrm{v}}-152^{\mathrm{v}}$.

$\mathbf{1}\left(\right.$ speaker indication $\left.1-\mathrm{b}^{5}, \mathrm{c}^{4}, \mathrm{c}^{7}-\mathrm{c}^{8}, \mathrm{~d}^{2}\right) \mathrm{S}_{1},\left(\mathrm{c}^{2}\right) \mathrm{S}_{2},\left\langle\mathrm{~b}^{2}-\mathrm{b}^{6}\right\rangle\left(\mathrm{b}^{7}\right) \mathrm{R} \quad \mathbf{2}\left(\mathrm{a}^{1}-\mathrm{a}^{2}, \mathrm{c}^{8}-\mathrm{d}^{8}\right) \mathrm{S}_{1} \quad \mathbf{3}\left\langle\mathrm{c}^{5}-\right.$ $\left.\mathrm{c}^{6}\right\rangle\left(\mathrm{c}^{7}\right) \mathrm{R}$

1 a देवो ] $S_{1} R A$ (lower half lost in $S_{1}$ ), व्यास $S_{2} S_{3} B h \quad 1 b$ वद्युति: ] $S_{2} R A B h$, ०द्युति $S_{1} S_{3}$ 1c चित्रं ] $\mathrm{S}_{1} \mathrm{~S}_{2} \mathrm{~S}_{3}^{\text {pc }} \mathrm{RBh}$, चित्रं च $\mathrm{S}_{3}^{\text {ac }}$ (unmetrical) 2a प्रुतादि $] \mathrm{S}_{1} \mathrm{~S}_{2} \mathrm{~S}_{3} \mathrm{R}$, प्रुतानि $\mathrm{Bh} 2 \mathbf{2 b}$ ॰ लोकयतास० ] RA, ०लोकयतो स० $\mathrm{S}_{1} \mathrm{~S}_{2} \mathrm{~S}_{3}$, ०्लोकयते स० $\mathrm{Bh}$ (conj.) $2 \mathrm{c}$ पृष्टत० $] \mathrm{S}_{1}^{\mathrm{ac}} \mathrm{S}_{2} \mathrm{RA}_{7}$ $\mathrm{Bh}$, पृष्टत० $\mathrm{S}_{1}^{\mathrm{pc}} \mathrm{S}_{3}$ - ० ग्चापि ] $\mathrm{S}_{2} \mathrm{~S}_{3} \mathrm{RABh}$, (० ग्चेव) $\mathrm{S}_{1}$ (upper parts lost, retraced) 2d पुनर्ग०] $\mathrm{S}_{1}$ (retraced) $\mathrm{S}_{2} \mathrm{ABh}$ (upper parts lost in $\mathrm{S}_{1}$ ), पुन ग० $\mathrm{S}_{3}$ (unmetrical) • ०दाचरत् ] $\mathrm{S}_{1}$ (retraced) $\mathrm{S}_{3} \mathrm{Bh}$, ०दाचरन् $\mathrm{S}_{2}$ 3b रिपो: ] $\mathrm{S}_{2} \mathrm{~S}_{3} R B h$, रिपो $\mathrm{S}_{1}$ (retraced) 3c oवृक्षै: ] $\mathrm{S}_{2} \mathrm{~S}_{3} \mathrm{ABh}$, ०वृक्षै $\mathrm{S}_{1}$ (retraced) 3d न्यसूदयत् ] $\mathrm{S}_{1}$ (retraced) $\mathrm{S}_{2} \mathrm{~S}_{3}^{\mathrm{pc}} \mathrm{Bh}$, न्य/दू/सूदयत् $\mathrm{S}_{3}$ 4a ०राकाशगो ] $\mathrm{S}_{1}^{\mathrm{pc}} \mathrm{S}_{2} \mathrm{~S}_{3}$ $\mathrm{RABh}$, ०राकामो $\mathrm{S}_{1}^{\mathrm{ac}}$ (unmetrical) $4 \mathrm{c}$ पुनर् ] $\mathrm{S}_{1} \mathrm{~S}_{2} \mathrm{RABh}$, पुन $\mathrm{S}_{3}$ (unmetrical) 4cd ०क्रुद्ध अ॰] $\mathrm{S}_{1}$, ॰क्रुद्धर॰ $\mathrm{S}_{2} \mathrm{~S}_{3}$, ॰कुद्धो ह्य॰ $\mathrm{Bh}$ (conj.) $4 \mathrm{~d}$ ०संनिभम् ] $\mathrm{S}_{1} \mathrm{~S}_{2} \mathrm{~S}_{3}^{\mathrm{pc}} \mathrm{Bh}$, ०सनिभम् $\mathrm{S}_{3}^{\mathrm{ac}}$ (unmetrical) 
एवं तं वल्गमानं च नर्दमानं च दानवः।

उवाच भृकुटीवक्रो हिर्याक्षो उभिनादयन्॥ $y \|$

भो क्षुद्रमृग दुर्बुद्धे न त्वं मोक्षमवाप्यसि।

हत्वा त्वाहं प्रदास्यामि रुद्राय बलिमोजसा॥ ६॥

त्वया हतश्छुम्मना मे भ्राता ज्येष्टो दुरात्मना।

तस्याद्य कर्मणः प्राप्तं फलं दुष्टात्मनस्तव॥ ७॥

सनत्कुमार उवाच।

तस्य तद्वचनं श्रुत्वा हिरण्याक्षस्य संयुगे।

उवाच भगवान्विष्णुः ऋोधयानो दितेः सुतम्॥ $५ \|$

हतो डसौ नरसिंहेन मया दैत्य: प्रतापवान्।

विक्रम्य संयुगे तद्वूद्यवो ऽपि वधो ध्रुवः॥ १॥

यदि त्वं गच्छुसे खं वा पातालं वाप्यतो उपरम्।

पर्वतं वोदधिं वापि न तथापि विमोक्ष्यसे॥ १०॥

$5 \mathrm{ab}$ ] एवन्तु नर्द्दमानग्च वन्दमानग्च दानव: $R \quad 5 d$ ऊभिनादयन्] विनादयन् $R \quad 6 a$ भो] भो: $R$ $6 \mathrm{~b}$ मोक्ष० ] क्षोभ $^{\circ} \mathrm{R} \quad 6 \mathrm{c}$ त्वाहं ] त्वां सं० $\mathrm{R} \quad 7 \mathrm{ab}$ हतश्छुम्मना मे भ्राता ] हतः पुरा भ्राता मम $\mathrm{R}$ 7b दुरात्मना ] महाबल: $R \quad 8$ सनत्कुमार उवाच ] om. $R \quad 9 d$ वधो ध्रुव: ] भवो ध्रुवम् $R \quad 10 a$ खं वा ] मूढ $R \quad 10 b$ वाप्यतो ] वाप्यत: $R \quad 10 \mathrm{c}$ पर्वतं वोदधिं वापि ] पर्वतम्चोदधिश्चापि $R$

5a एवं तं वल्गमानं ] नदन्तं बलवन्तं $A$ 5c उवाच भृकुटी॰ ] भ्रुकुटिभ्रकुटा॰ $\mathrm{A}_{3}$, भ्रकुटीभ्रकुटा॰ $\mathrm{A}_{4}$, भृकुटीभृकुटी० $\mathrm{A}_{7}$ - ॰वक्रो ] $\mathrm{A}_{3}$, ॰वक्रो $\mathrm{A}_{4} \mathrm{~A}_{7}$ 5d ऊभिनादयन् ] भ्यभाषत $\mathbf{A} \quad \mathbf{6 a}$ दुर्बुद्धे ] $\mathrm{A}_{3} \mathrm{~A}_{7}$, दुर्बुर्द्धे $\mathrm{A}_{4} \quad \mathbf{7 a}$ ०श्छुमना ] ० श्चामुना $\mathrm{A} \quad \mathbf{7 b}$ ज्येष्ठो ] $\mathrm{A}_{3} \mathrm{~A}_{7}$, ज्येष्टो $\mathrm{A}_{4} \bullet$ दुरात्मना ] महाबल: $A$ 7cd ] om. $A$ 8cd ०न्विष्णुः को॰ ] $\mathrm{A}_{3} \mathrm{~A}_{7}$, ०न् विष्णुक्रो॰ $\mathrm{A}_{4} \quad 9 \mathrm{a}$ हतो ] ततो $\mathrm{A}$ 9cd ] om. $\mathrm{A} 10 \mathrm{a}$ गच्छुसे खं ] $\mathrm{A}_{7}$, गच्छुसे ष $\mathrm{A}_{4}$ (unmetrical), गच्छशेषं $\mathrm{A}_{3} \quad 10 \mathrm{~b}$ वाप्यतो ] वाप्यतः $\mathrm{A} 10 \mathrm{c}$ वोदधिं ] चोदधिं $\mathrm{A} \operatorname{10d}$ विमोक्ष्यसे ] विमोक्षसे $\mathrm{A}$

$5\left\langle a^{1}\right\rangle\left(a^{2}\right) R \quad 6\left(a^{7}\right) S_{1} \quad 10\left(d^{3}\right)\left\langle d^{4}\right\rangle S_{1}$

5a एवं तं] $\mathrm{S}_{1}$ (retraced)Bh, रवन्तं $\mathrm{S}_{2} \mathrm{~S}_{3}$ • वल्गमानं च ] $\mathrm{S}_{1}^{\mathrm{ac}}$ ? $\mathrm{S}_{2} \mathrm{~S}_{3} \mathrm{Bh}$, वल्गमानश्च $\mathrm{S}_{1}^{\mathrm{pc}}$ (retraced) 5b नर्दमानं ] $S_{1}$ (retraced) $S_{2} A B h$, नदमान $S_{3}$ 5d ऊभिनादयन् ] $S_{3} B h$ (em.), निनादयन् $S_{1}$ (retraced), भिनादयत् $\mathrm{S}_{2} \mathbf{6 a}$ दुर्बुद्धे $] \mathrm{S}_{1}$ (retraced) $\mathrm{S}_{2} \mathrm{RA}_{3} \mathrm{~A}_{7} \mathrm{Bh}$, दुबुद्धे $\mathrm{S}_{3}$ (unmetrical) $\mathbf{6 c}$ त्वाहं ] $\mathrm{S}_{1} \mathrm{ABh}$, चाहं $\mathrm{S}_{2} \mathrm{~S}_{3}$ 6d ०मोजसा ] RABh, ०मौजसा $\mathrm{S}_{1} \mathrm{~S}_{2} \mathrm{~S}_{3}$ 7a हतश्छ॰ ] $\mathrm{S}_{2} \mathrm{~S}_{3} \mathrm{Bh}$, हत च्छ॰ $S_{1}$ (retraced) $7 b$ भ्राता ] $S_{1} S_{3} A B h$, भ्रात्रा $S_{2}$ - ज्येष्टो ] $S_{1} S_{2} R A_{3} A_{7} B h$, जेष्टा $S_{3}$ 7c कर्मण: ] $S_{2} S_{3} R B h$, कर्म्मण $S_{1}$ 8b हिरण्याक्षस्य ] $S_{2} S_{3} R A B h$, हिरण्यक्षस्य $S_{1}$ (retraced) 8c ०न्विष्णुः ] $S_{2} S_{3} R A_{3} A_{7} B h$, नन्विष्णु $S_{1}$ (retraced) 8d सुतम् ] $S_{1} R A B h$, सुतान् $S_{2} S_{3} 9 b$ दैत्य: ] $S_{2} R A B h$, दैत्य $S_{1} S_{3}$ 9c विक्रम्य ] $S_{1} S_{2} R B h$, विक्रम्य $S_{3}$ - तद्वद् ] $S_{2} S_{3} R B h$, यद्वद् $S_{1}$ 9d वधो ध्रुवः ] $\mathrm{S}_{2} \mathrm{~S}_{3} \mathrm{Bh}$, ध्रुवं बध: $\mathrm{S}_{1} 10 \mathrm{~b}$ ०लं वाप्यतो ] $\mathrm{S}_{1}$, ०लम्वाव्यतो $\mathrm{S}_{2} \mathrm{~S}_{3}$, ०लं वाप्यतः $\mathrm{Bh} 10 \mathrm{c}$ ०धिं वापि ] $\mathrm{S}_{1} \mathrm{ABh}$, ०धिर्वापि $\mathrm{S}_{2}^{\mathrm{pc}}$, ०धि वापि $\mathrm{S}_{2}^{\mathrm{ac}} \mathrm{S}_{3}$ (unmetrical) 10d तथापि ] $\mathrm{S}_{2} \mathrm{~S}_{3} \mathrm{RABh}$, त(स्था) $\simeq \mathrm{S}_{1}$ - विमोक्ष्यसे ] $\mathrm{S}_{2} \mathrm{~S}_{3} \mathrm{RBh}$, विमोक्षसे $\mathrm{S}_{1}$ (retraced) 
यत्ते बलं तपो यच्च या च माया तवासुर।

तत्सवं निर्धमाम्यद्य तव देहात्सजीवितम्॥ ?? ॥

हिरण्याक्ष उवाच।

त्वं मया शरविष्टब्धो देवैर्मन्त्रैर्विमोक्षितः।

बद्धं चास्त्रेण भूयस्त्वां पक्षिराजो ह्यमोचयत्॥ ?२॥

भूयो मृतश्च दुर्बुद्धे देवैरुज्जीवितो भवान्।

भूयस्त्वाहं वधिष्यामि सिंहो मृगमिवाजने॥ ?३॥

तव का शक्तिरद्येह महेश्वरमृते वरम्।

मां स्प्रष्टुमपि हस्तेन नरस्येव हुताशनम्॥ १४॥

त्वं लोकमयमास्थाय शरीरं तैरधिष्टितम्।

सर्वेराप्यायितश्चैव संयुगे मामुपागतः ।

अहं तु स्वेन तपसा बत्लेन च समन्वितः ॥ १४॥

11c निर्धमाम्य॰] निर्दहाम्य्य $\mathrm{R} 11 \mathrm{~d}$ देहात्स०] देहात्म॰ $\mathrm{R}^{\mathrm{ac}}$, देहात्तु $\mathrm{R}^{\mathrm{pc}} 12 \mathrm{~d}$ ह्यमोचयत् ] व्यमोचयत् $R \quad 14 \mathrm{ab}$ ०रद्येह महेग्वरमृते वरम् ] ०रस्त्यत्र मयि दर्शिष्यतां खलु $\mathrm{R} 14 \mathrm{c}$ मां स्प्रष्टुमपि ] मा गच्छ, मम $R \quad 14 d$ नरस्येव ] निरस्येव $R \quad 15 c$ ०राप्यायित०] ०रप्यर्पित $R$

$11 \mathrm{~b}$ या ] $\mathrm{A}_{3} \mathrm{~A}_{7}$, पा $\mathrm{A}_{4}$ - तवासुर ] पुराधम $\mathrm{A}_{3} \mathrm{~A}_{4}$, ०सुराधम $\mathrm{A}_{7}$ 11c निर्धमाम्य॰] निर्दहाम्य० A $12 \mathrm{a}$ मया ] पुरा $\mathrm{A}$ - विष्टब्धो] $\mathrm{A}_{3} \mathrm{~A}_{4}$, ०विष्ध (ब्वो) $\mathrm{A}_{7}^{\mathrm{pc}}$, ०विष्ध्य(ध्वो) $\mathrm{A}_{7}^{\mathrm{ac}} 12 \mathrm{c}$ बद्ध चास्त्रेण ] वज्रं $\left\{\circ\right.$ ज्र० $\left.\mathrm{A}_{3}\right\}$ शस्त्रेण $A$ 12d ह्य॰] व्य॰ $\mathrm{A}_{3}$, द्य $\mathrm{A}_{4}$, भ्य० $\mathrm{A}_{7} 13 \mathrm{~b} \circ$ रुज्जीवितो ] ०रि जीवितो $\mathrm{A}$ (unmetrical) $13 \mathrm{c}$ ०हं वधिष्यामि ] ०हं म्व $\left\{{ }^{\circ}\right.$ हं यु० $\mathrm{A}_{3}$, ०ह यु० $\left.\mathrm{A}_{4}\right\}$ धिष्यामि $\mathbf{A}$ $13 \mathrm{~d}$ ०वाजने ] $\mathrm{A}_{7}^{\mathrm{pc}}$, ०वाजले $\mathrm{A}_{3} \mathrm{~A}_{4} \mathrm{~A}_{7}^{\mathrm{ac}} 14 \mathrm{a}$ ०रदोह ] ०रद्यी $\circ^{\circ}$ दो० $\left.\mathrm{A}_{7}\right\}$ व $\mathrm{A} 14 \mathbf{b}$ वरम् ] विभुं A $14 \mathrm{c}$ स्प्रष्टु॰ ] पृष्टु० $A$ 14d नरस्येव ] नन $\left\{{ }^{\circ}{ }^{\circ} A_{7}^{\mathrm{pc}}\right\}$ स्येव $A$ 15b शरीरं तैर०] शरीरस्तैर० $\mathrm{A}_{7}$, शरीरस्तेव॰ $\mathrm{A}_{3}$, शरीरं स्तेव॰ $\mathrm{A}_{4} 15 \mathrm{c}$ सर्वेरा॰ ] $\mathrm{A}_{7}$, सर्वे वा॰ $\mathrm{A}_{3} \mathrm{~A}_{4} \quad 15 \mathrm{~d}$ मामुपा॰] $\mathrm{A}_{4} \mathrm{~A}_{7}$, मा $\mathrm{A}_{3}$ (unmetrical) 15ef ] om. $\mathbf{A}$

$11\left(a^{3}\right) S_{1} \quad 12\left(c^{6}\right) S_{1} \quad 13\left(b^{4}, b^{7}, d^{6}\right)\left\langle d^{7}-d^{8}\right\rangle S_{1} \quad 15\left(d^{6}\right) S_{1}$

$11 \mathrm{a}$ यत्ते ] $\mathrm{S}_{1}$ (retraced) $\mathrm{S}_{2} R A B h$, यत्ने $\mathrm{S}_{3}$ - यच्च ] $\mathrm{S}_{1}$ (retraced) $\mathrm{S}_{2} \mathrm{RABh}$, य च $\mathrm{S}_{3}$ (unmetrical) $11 b$ या च ] $\mathrm{RA}_{3} \mathrm{~A}_{7} \mathrm{Bh}$, यच्च $\mathrm{S}_{1}$ (retraced), यश्च $\mathrm{S}_{2} \mathrm{~S}_{3}$ - माया तवासुर ] $\mathrm{S}_{2}^{\mathrm{pc}} \mathrm{RBh}$, मायन्तधासुर: $S_{1}$ (retraced), माया तवासुर: $S_{2}^{\text {ac }} S_{3} 11 \mathrm{c}$ ०र्धमाम्य०] $S_{1}^{\text {pc }} S_{2}^{\text {ac }} S_{3} B h$, ०र्धयाम्य० $S_{1}^{\text {ac }}$, ०र्द्ध $\langle$ मा $\rangle$ म्य० $\mathrm{S}_{2}$ (unmetrical, no corrected akșara i.m.) $\quad$ 12a विष्टब्धो ] $\mathrm{S}_{1} \mathrm{~S}_{2} \mathrm{RA}_{3} \mathrm{~A}_{4} \mathrm{Bh}$, ०विष्टम्बो $\mathrm{S}_{3} \quad \mathbf{1 2 b}$ ०र्मन्त्रैर ] $\mathrm{S}_{1} \mathrm{~S}_{2} \mathrm{RABh}$, ०र्मन्त्रै $\mathrm{S}_{3}$ - ०मोक्षितः ] $\mathrm{S}_{2} \mathrm{~S}_{3} \mathrm{RABh}$, ०मोक्षित $\mathrm{S}_{1}$ 12c बद्धं चास्त्रेण ] $\mathrm{RBh}(\mathrm{em} . ?)$, बद्धश्चास्त्रेण $\mathrm{S}_{1}$, बद्ध चास्त्रण $\mathrm{S}_{2}$, बद्ध चास्त्रेण $\mathrm{S}_{3}$ - ०स्त्वां ] $\mathrm{S}_{2} \mathrm{~S}_{3} \mathrm{RABh}$, ०स्त्वा $S_{1} 12 d$ ह्यमोचयत् ] $S_{1} S_{2}$, ह्यमोचयेत् $S_{3}$, व्यमोचयत् Bh 13a मृतश्च ] $S_{1} S_{2} S_{3} R A$, मृतस्त्वं $\mathrm{Bh}$ (conj.?) 13b देवैरुज्जीवितो] $\mathrm{S}_{1} \mathrm{RBh}$, देवैर्हि ज्जीवितो $\mathrm{S}_{2}$, देवै हि जीवितो $\mathrm{S}_{3}$ (unmetrical) $13 c$ वधिष्यामि ] $S_{1}$ (retraced) $S_{2} R B h$, चधिष्यामि $S_{3} \quad 14 a$ ०रद्येह $] S_{2} S_{3} B h$, ०रद्यें $S_{1}$ (retraced) $14 b$ मृते ] $S_{2} S_{3} A B h$, ${ }^{\circ}$ मृतो $S_{1}$ (retraced) $14 c$ स्प्रष्टु॰ ] $S_{2} S_{3} B h$, प्रष्टु॰ $S_{1}$ (retraced) 14d हुताशनम् ] $\mathrm{S}_{1}^{\mathrm{pc}} \mathrm{S}_{2} \mathrm{~S}_{3} \mathrm{RABh}$, हताशनम् $\mathrm{S}_{1}^{\mathrm{ac}}$ (unmetrical) $15 \mathrm{c}$ ०तश्चैव ] $\mathrm{S}_{1} \mathrm{RABh}$, ०तंग्चैव $\mathrm{S}_{2} \mathrm{~S}_{3}$ 15d मामुपा०] $\mathrm{S}_{1} \mathrm{~S}_{2} \mathrm{~S}_{3}^{\mathrm{pc}} \mathrm{RA}_{4} \mathrm{~A}_{7} \mathrm{Bh}$, (स)मुपा० $\mathrm{S}_{3}^{\mathrm{ac}}$ 
न च मां त्वं तथाप्यद्य शक्तः सिंहं यथा मृगः।

योद्दुं वाप्यभिसर्तुं वा सह देवैर्दुरात्मवान्।

नन्वावयोरेतदेव ह्यन्तरं सुमहत्तरम्॥ १६॥

यः स्यात्कुलीनो विद्वान्वा सतां मार्गे च संस्थितः।

सो डनेैव जितं मत्वा आत्मानं संयुगं त्यजेत् ॥ १७॥

निर्घृणस्त्यक्तज्जश्च छिद्रघाती दुरात्मवान्।

त्वदन्यः को भवेत्तिर्यड्नैतहैत्येषु विद्यते॥ १५ ॥

न त्वं मम कृतो मृत्युरहं तु तव संयुगे।

एते सिद्धाः प्रपश्यन्तु चारणाश्च सहस्रशः।

आवयोरन्तरं संख्ये बहुधा युध्यमानयोः ॥ १९॥

सनत्कुमार उवाच।

एवमुत्का हिरण्याक्षः शरैराशीविषोपमै:।

जघे वराहं संक्रुद्धो वज्राशनिसमत्विषम्॥ २०॥

सो डथ तेनार्द्यमानो ऽपि वराहः सुमहाबलः।

गत्वा वेगेन संक्रुद्धो रथं जग्राह नादयन्॥ २? ॥

$16 \mathrm{c}$ वाप्यभिसर्तुं वा ] वाप्यथ संधातुं $\mathrm{R} 16 \mathrm{f}$ ॰महत्तरम् ] ॰महद्वरम् $\mathrm{R} \quad 17 \mathrm{ab}$ यः स्यात्कुलीनो विद्वान्वा सतां ] य स्या कुलीनो विज्ञात्मा सत्य० $R \quad 17 \mathrm{c}$ डनेनैव जितं ] डन्येनैव जितो $R \quad 17 \mathrm{~d}$ संयुगं ] संयुगे $R \quad 18 \mathrm{a}$ निर्घृण०] निर्गुण० $R \quad 18 \mathrm{c}$ त्वदन्यः ] त्वमन्य: $R \quad 18 d$ विद्यते ] दृश्यते $R$ 19d

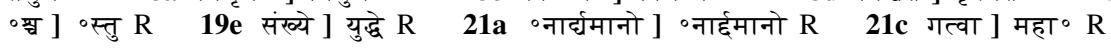

$16 \mathrm{c}$ वाप्यभिसतुं वा ] चाप्यभिसंस्थातुं $A$ 16d ०र्दुरार्त्मवान् ] ०र्दुराकृते $A$ 16ef ] om. $A$ 17a य: स्यात्कुलीनो विद्वान्वा ] यश्चाकुलीनो वित्रास्य: $\mathrm{A}_{3} \mathrm{~A}_{4}$, यथा कुलीनो विन्नास्य: $\mathrm{A}_{7}$ 17b संस्थितः ] $\mathrm{A}_{3} \mathrm{~A}_{4}$, संस्थिता: $\mathrm{A}_{7} 17 \mathrm{c}$ जेनैव ] न्येनैव $A$ 17d आत्मानं ] अनात्मा $A$ 18ab ] om. $A$ $18 \mathrm{~cd}$ ०त्तिर्यड्नै०] $\mathrm{A}_{3}$, ०तीर्यक् नै० $\mathrm{A}_{4} \mathrm{~A}_{7} 18 \mathrm{~d}$ ०तहैत्येषु विद्यते ] तत्रित्येषु दृश्यते $\mathrm{A}$ 20d ०त्विषम् ] ॰प्रभं A $21 \mathrm{a}$ नार्द्यमानो ] ननार्द्रमानो $A$

16 $\left(b^{7}, c^{2}\right) S_{1},\left(c^{7}\right) S_{3} \quad 17\left\langle c^{1}-c^{4}\right\rangle\left(c^{5}-c^{8}, d^{3}-d^{4}\right) S_{1},\left(a^{2}\right) S_{2} \quad 18\left(a^{2}\right) S_{1},\left\langle a^{1}\right\rangle\left(a^{2}\right) S_{2} \quad 19\left(b^{3}\right) S_{2}$ $20\left(b^{1}-b^{4}\right)\left\langle b^{5}-b^{6}\right\rangle\left(b^{7}\right) S_{2} \quad 21\left(c^{6}\right) S_{2}$

$16 \mathbf{a}$ मां ] $\mathrm{S}_{2} \mathrm{RABh}$, मा $\mathrm{S}_{1} \mathrm{~S}_{3} \quad 16 \mathrm{~b}$ सिंहं ] $\mathrm{S}_{2} \mathrm{~S}_{3} \mathrm{RABh}$, सिंहो $\mathrm{S}_{1}$ (retraced) 16c योद्धुं वा०] $\mathrm{S}_{1}$ (retraced) $\mathrm{S}_{3}^{\mathrm{pc}} \mathrm{RBh}$, योद्दुम्ना $\mathrm{S}_{2} \mathrm{~S}_{3}^{\mathrm{ac}}$ - ० व्यभिसतुं वा ] $\mathrm{S}_{2} \mathrm{Bh}$, ०व्यहिहन्तुं वा $\mathrm{S}_{1}$ (retraced), ०प्यभिसतुर्वा $S_{3}^{\text {ac }}$ (unmetrical), ०व्यभिस(न्त्व)र्वा $S_{3}^{p c}$ 16d देवैर् $S_{2} S_{3} R A B h$, देवै $S_{1}$ (retraced) $16 e$ नन्वावयो॰ $\mathrm{S}_{2} S_{3}^{\mathrm{pc}} R$, न त्वावयो॰ $S_{1}$ (retraced)Bh, नन्वाचयो॰ $S_{3}^{\text {ac }} 16 f$ महत्तरम् ] $\mathrm{S}_{1}$ (retraced)Bh, ॰महद्वरम् $\mathrm{S}_{2}$, ${ }^{\circ}$ महद्वरं $\mathrm{S}_{3} \quad \mathbf{1 7 a}$ यः स्यात् ] $\mathrm{S}_{1}$ (retraced) $\mathrm{S}_{2}^{\mathrm{ac}} \mathrm{Bh}$, य (स्वा)त् $\mathrm{S}_{2}^{\mathrm{pc}}$, स स्यात् $S_{3}^{\text {pc }}$, य स्यां $S_{3}^{\text {ac }} 17 \mathrm{~b}$ संस्थितः ] $S_{2} S_{3} R_{2} A_{3} A_{4} B h$, संस्थिता: $S_{1}$ (retraced) 17c डनेनैव ] $S_{2}^{\text {pc }} S_{3} B h$, नैनैव $S_{2}^{a c}$ - जितं ] $S_{1} S_{2} A B h$ (upper parts lost in $S_{1}$ ), जित $S_{3}$ (unmetrical) 17d संयुगं ] $\mathrm{S}_{1} \mathrm{~S}_{2} \mathrm{~S}_{3}^{\mathrm{pc}} \mathrm{ABh}$, संयुगे $\mathrm{S}_{3}^{\mathrm{ac}} 18 \mathrm{a}$ ०लज्जश्च ] $\mathrm{S}_{1} \mathrm{~S}_{2} \mathrm{RBh}$, ०लजश्च $\mathrm{S}_{3}$ (unmetrical) 18cd ०त्तिर्यड्नै०] $\mathrm{RA}_{3} \mathrm{Bh}$, ०त्तिर्यों नै० $\mathrm{S}_{1}$, ०त्तिर्यो नै० $\mathrm{S}_{2} \mathrm{~S}_{3} \quad \mathbf{1 8 d}$ ०तहैत्येषु $] \mathrm{S}_{1} R$, ०तहैत्यस्य $\mathrm{S}_{2} \mathrm{~S}_{3}^{\mathrm{pc}} \mathrm{Bh}$, ०त दैत्यस्य $S_{3}^{\mathrm{ac}} \quad 19 \mathrm{a}$ न $] \mathrm{S}_{1}^{\mathrm{pc}} \mathrm{S}_{2} \mathrm{~S}_{3} \mathrm{RABh}$, न च $\mathrm{S}_{1}^{\mathrm{ac}}$ (unmetrical) 19c सिद्धा: ] RABh, सिद्वा $\mathrm{S}_{1} \mathrm{~S}_{2} \mathrm{~S}_{3} \quad 19 \mathrm{e}$ संख्ये ] $\mathrm{ABh}$, संखे $\mathrm{S}_{1}$ (retraced) $\mathrm{S}_{2} \mathrm{~S}_{3} \quad 19 \mathrm{f}$ ०मानयो: ] $\mathrm{S}_{1}$ (retraced) $\mathrm{S}_{2} \mathrm{RABh}$, ०माभयो: $\mathrm{S}_{3} 20$ सनत्कुमार उवाच ] $\mathrm{S}_{2} \mathrm{~S}_{3} \mathrm{RABh}$ (सन उ in $\mathrm{S}_{2} \mathrm{~S}_{3}$ ), om. $\mathrm{S}_{1}$ (akșaras possibly lost i.m.) 20a मुत्का ] $S_{1}$ (retraced) $S_{3} R A B h$, ०मुक्त $S_{2}$ - हिरण्याक्षः ] $S_{2} S_{3} R A B h$, हिरणयाक्ष $S_{1}$ 20d ०त्विषम् ] $\mathrm{S}_{2} \mathrm{~S}_{3} R B h$, ०त्विषत् $\mathrm{S}_{1} \quad 21 b$ वराह: ] $\mathrm{S}_{2} \mathrm{~S}_{3} \mathrm{RABh}$, वराह $\mathrm{S}_{1}$ 
गृहीत्वा कूबरे चापि आक्षिप्योत्क्षिप्य वेगवत्।

साम्यं ससारथिं देवश्चिक्षेप च ररास च॥ २२॥

तस्य त्वाक्षेपविक्षेपैश्छि,न्नयोक्रा बभुर्हयाः।

उड्रान्तो रथमुख्यश्च विसंधिः समपद्यत॥ २३॥

हिरण्याक्षो रथं त्यत्का पदातिर्धनुषा तदा।

मृगेन्द्र मोहनास्त्रेण बलवानक्यताडयत्॥ २४॥

मोहः समाविशच्चैव तं देवं नन्दिवर्धनम्।

देवैर्मन्त्रप्रभावेन नष्टमोहः पुनः कृतः॥ २४॥

एष मन्न्रैर्बहुविधैर्देत्येन्द्रो हि रुषान्वितः।

आजघान न चाप्येनं रुजा स समयोजयत्॥ २६॥

अथैनं स महातेजा वराहः प्रहसत्रिव।

वृक्षमुत्पाट्य वेगेन दैत्यं मूर्धि व्यताडयत्॥ २७॥

तस्य तेन प्रहारेण दैत्यस्याभिहतस्य ह।

धनुः पपात वेगेन हस्ताद्वाणश्च पश्चकः॥ २५॥

$22 b$ आक्षिप्योत्क्षिप्य वेगवत् ] उत्क्षप्योत्क्ष्प्य वेगवान् $\mathrm{R} \quad 22 \mathrm{c}$ साम्यं ] साग्रं $\mathrm{R} \quad 22 \mathrm{~d}$ ०श्चिक्षेप ] मश्चिक्षे R (unmetrical) 23a तस्य त्वा० ] तस्या० $\mathrm{R}$ (unmetrical) 23ab ०पैश्छित्र०] ०पै: क्षुणण० $\mathrm{R} 23 \mathrm{~b}$ बभुर्हया: ] व श्चतुर्हया: $\mathrm{R} 23 \mathrm{~cd}$ ] उड्रान्ता रथयन्त्रस्य विसन्धिं समपश्यत $\mathrm{R}$ 24a रथं त्यत्का ] रथाध्यक्षः $R 24 \mathrm{~b}$ ०र्धनुषा ] ०र्बहुधा $\mathrm{R}$ 25ab ] मोहं समाविश(स्चै)व स देवो नन्दिवर्द्धनः $R \quad 25 \mathrm{c}$ ०प्रभावेन] ॰ प्रभावेण $\mathrm{R} \quad 26 \mathrm{~b}$ ०र्देत्येन्द्रो हि ] ०र्देत्येन्द्रं तं $\mathrm{R} \quad 26 \mathrm{c}$ न] स $\mathrm{R}$ $26 d$ रुजा स समयोजयत् ] ररास च पुनः पुन: $R \quad 27 d$ मूर्धि ] मूर्द्धि $R \quad 28 b$ दैत्यस्याभिहतस्य ह ]

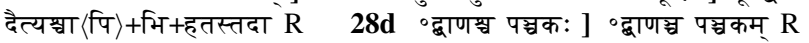

22c साम्यं ] $\mathrm{A}_{3} \mathrm{~A}_{4}$, सा $\left\langle\right.$ ग्रं $\mathrm{A}_{7}$ (unmetrical, no corrected akṣara i.m.) - ससारथिं ] ससादिनं $A 22 d$ ररास ] ननाद $A$ 23a त्वा०] चा० $A$ 23ab ०क्षेपविक्षेपैश्चित्न० ] $A_{7}$, ०क्षेपविक्षेपै: शिशु॰ $A_{3}$, क्षेपै शिशु० $A_{4}$ (unmetrical) $23 b$ कक्रा बभुर्हया: ] $A_{3} A_{7}$, ०त्का वभुर्हया $A_{4} 23 \mathbf{c}$ उड्रान्तो ] $\mathrm{A}_{3} \mathrm{~A}_{7}$, उड्रांभो $\mathrm{A}_{4}$ 24b पदाति॰] गदाभि॰ $\mathbf{A}$ • तदा ] तथा $\mathbf{A}$ 25ab ] om. $\mathbf{A}$ $25 \mathbf{c}$ ०प्रभावेन ] ०प्रभावैश्च $\mathbf{A} 25 \mathrm{~d}$ नष्टमोहः ] प्रष्ट ०ष्ट० $\left.\mathrm{A}_{7}\right\}$ मोह $\mathbf{A}$ - कृतः ] $\mathrm{A}_{3}$, कृथ $\mathrm{A}_{7}$, पृथ $\mathrm{A}_{4} 26 \mathrm{ab}$ धधर्देत्येन्द्रो हि रुषान्वितः ] ०धैर्दे $\left\{\circ\right.$ धै दै० $\left.\mathrm{A}_{4}\right\}$ त्येन्द्र रुषितान्वितः $\mathrm{A} 26 \mathrm{c}$ न चा०] $]$ चा॰ $\mathrm{A}_{3} \mathrm{~A}_{4}$, स गो $\mathrm{A}_{7}^{\mathrm{ac}}$, मृगो $\mathrm{A}_{7}^{\mathrm{pc}} 26 \mathbf{d}$ रुजा स ] राजा च $\mathbf{A} 27 \mathbf{a}$ स ] सु० $\mathbf{A} 27 \mathbf{d}$ मूर्धि

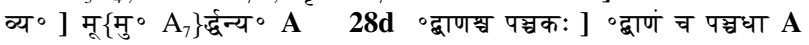

$22\left(c^{2}\right) S_{2},\left(d^{5}\right) S_{3} \quad 23\left(b^{3}-c^{3}\right\rangle S_{2} \quad 25\left(b^{7}\right) S_{1},\left(a^{7}\right) R \quad 26\left(c^{6}-c^{8}\right) S_{2} \quad 27\left(c^{2}\right) R$

22b आक्षिप्योत्क्षिप्य ] $S_{2} A B h$, आक्षित्रोक्षित्र० $S_{1}$, आक्षिप्योक्षिप्य $S_{3}$ 22d ररास च] $S_{1} S_{2} R B h$, $+\left(\right.$ स)+ केशव $\mathrm{S}_{3} \quad$ 23ab ०विक्षेपैश्छि॰ ] $\mathrm{A}_{7} \mathrm{Bh}(\mathrm{em} . ?)$, ०चिक्षेपै च्छि॰ $\mathrm{S}_{1}$, ०विक्षेपै च्छि० $\mathrm{S}_{2} \mathrm{~S}_{3}$ 23b ${ }^{\circ}$ क्रा बभुर्हया: ] $\mathrm{S}_{1}^{\mathrm{pc}} \mathrm{A}_{3} \mathrm{~A}_{7}$, ${ }^{\circ}$ क्रा चतुर्हया: $\mathrm{S}_{1}^{\mathrm{ac}}$, ${ }^{\circ}$ क्रा बभुर्हया $\mathrm{S}_{3}$, ${ }^{\circ}$ क्राश्च्च ते हया: $\mathrm{Bh}$ (conj.) $23 \mathrm{c}$ उड्रान्तो ] $\mathrm{S}_{1} \mathrm{~A}_{3} \mathrm{~A}_{7}$, उड्डान्ता $\mathrm{S}_{3} \mathrm{Bh}$ (em.?) 23d विसंधि: ] $\mathrm{S}_{2} \mathrm{~S}_{3} \mathrm{ABh}$, विसन्धि $\mathrm{S}_{1}$ 24b पदातिर् ] $\mathrm{S}_{2} \mathrm{~S}_{3} \mathrm{RBh}$, पदाति $\mathrm{S}_{1} \quad$ 25ab ०विशच्चैव तं देवं ] $\mathrm{S}_{1} \mathrm{~S}_{2} \mathrm{Bh}$, ०विशश्चैव त देव $\mathrm{S}_{3}$ (unmetrical) $25 \mathrm{c}$ देवै०] $\mathrm{S}_{1}^{\mathrm{pc}} \mathrm{S}_{2} \mathrm{~S}_{3} \mathrm{RABh}$, दैवै० $\mathrm{S}_{1}^{\mathrm{ac}}$ - ०प्रभावेन ] $\mathrm{S}_{1} \mathrm{~S}_{2} \mathrm{~S}_{3}$, ०प्रभावेण $\mathrm{Bh}$ (em.?) 25d ०मोह:] $\mathrm{S}_{2} \mathrm{RBh}$, ०मोह $\mathrm{S}_{1} \mathrm{~S}_{3} \quad 26 \mathrm{a}$ मन्त्रैर ] $\mathrm{S}_{1} \mathrm{~S}_{2} \mathrm{RA}$, मन्त्रै $\mathrm{S}_{3}$, शस्त्रैर् $\mathrm{Bh}$ (conj.) 26ab ध धैर्देत्येन्द्रो ] conj. $B h$, धैर्देत्येन्द्र $S_{1} S_{2}$, ०धै दैत्येन्द्र $S_{3}$ 26b रुषान्वितः ] $S_{2} S_{3} R B h$, रुषान्विता: $S_{1}$ 27a महातेजा ] $S_{1} S_{2} R A B h$, महातेज $S_{3} \quad 27 b$ वराह: ] $S_{2} S_{3} R A B h$, वराह $S_{1}$ 27c वृक्ष०] $S_{1} S_{2} R A$ $\mathrm{Bh}$, वृक्ष्य० $\mathrm{S}_{3}$ 27d व्यताडयत् ] $\mathrm{S}_{2} \mathrm{~S}_{3} \mathrm{RBh}$, न्यपातयत् $\mathrm{S}_{1}$ 28d हस्ताद्वाणश्च ] em. (cf. RA), हस्तावापश्च $\mathrm{S}_{1}$, हस्तावापश्च $\mathrm{S}_{2} \mathrm{Bh}$, हस्ताचापश्च $\mathrm{S}_{3}$ 
ततो हाहाकृतं दैत्यैर्दानवैश्च सुदु :खितैः।

शस्त्रैश्च बहुभिः क्रुद्धा वराहं समताडयन्॥ २९ ॥

स हन्यमानस्तैर्देत्यैव्यादाय सुमहाबलः।

मुखं सर्वाणि शस्त्राणि जग्रास च ररास च॥ ३०॥

तं तथाविकृतं दृष्ट्रा हिरण्याक्षः प्रतापवान्।

शूलं जग्राह संक्रुद्धः कृत्वा रुद्राय वै नमः॥ ३? ॥

तद्युगान्तानलप्रख्यं महाशूलमतिप्रभम्।

चिक्षेप दैत्यः संक्रुद्धो वराहाय महास्वनम्॥ ३२॥

तमापतन्तं बहुधा नदन्तं ज्वालास्फुलिड्राश्च समुद्विर्तन्तम्।

दृष्ट्रा सुराः सिद्धगणाश्च सर्वे हाहेति चक्रुर्भयमूढचित्ताः॥ ३३॥

इति स्कन्दपुराणे षडुत्तरशतो डध्यायः॥ १०६॥

29c शस्त्रैश्च बहुभिः क्रुद्धा ] अस्त्रैश्च बा $\left\{\right.$ ब० $\left.\mathrm{R}^{\mathrm{ac}}\right\}$ हुभिः कृत्वा $\mathrm{R} \quad 30 \mathrm{~b}$ ॰र्व्यादाय ] ०र्व्यनदन् $\mathrm{R}$ 30cd मुखं सर्वाणि शस्त्राणि जग्रास ] मुखे शस्त्राणि सर्वाणि जग्राह $R \quad 32 b$ ०मति॰ ] ०सम॰ $R \quad 32 d$ महास्वनम् ] महास्वन: $R \quad 33 b$ ०स्फुलिड़ाग्च ] ०स्फुलिड़ाग्च $R$ Col. इति स्कन्दपुराणे रेवाखण्डे डध्याय: R

29c शस्त्रैश्च्च ] अस्त्रैश्च $A$ - क्रुद्धा ] क्रुद्धो $A$ 29d वराहं ] $\mathrm{A}_{3}$, वाराहं $\mathrm{A}_{4} \mathrm{~A}_{7}$ - ॰ताडयन् ] $\mathrm{A}_{4}$ $\mathrm{A}_{7}$, ०ताडयत् $\mathrm{A}_{3}$ 30cd मुखं सर्वाणि शस्त्राणि जग्रास ] मुखै: शस्त्राणि सर्वाणि जग्राह $\mathrm{A}$ 31c संक्रुद्ध: ] $\mathrm{A}_{3} \mathrm{~A}_{7}$, संक्रुद्ध $\mathrm{A}_{4}$ 32a तद् ] $\mathrm{A}_{3} \mathrm{~A}_{4}$, तं $\mathrm{A}_{7}$ 32d महास्वनम् ] महात्मने $\mathbf{A} 33 \mathbf{b}$

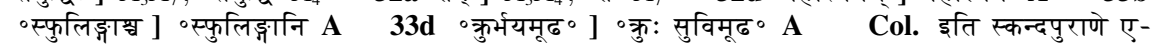
काशीतिसाहस्रचां संहिताया $\left\{\right.$ इति स्कंद॰ $\left.\mathrm{A}_{4}\right\}$ मम्बिकाखण्डे पझ्चोत्तरशतो ध्यायः $\mathbf{A}$

$30\left(a^{7}\right) R$

29a दैत्यैर ] $\mathrm{S}_{1} \mathrm{~S}_{2} \mathrm{RABh}$, दैत्यै $\mathrm{S}_{3} \quad 29 \mathrm{c}$ कुद्धा ] $\mathrm{S}_{1} \mathrm{~S}_{2}^{\mathrm{pc}} \mathrm{S}_{3} \mathrm{Bh}$, कुद्धो $\mathrm{S}_{2}^{\mathrm{ac}}$ 29d ०ताडयन् ] $\mathrm{RA}_{4} \mathrm{~A}_{7}$ $\mathrm{Bh}(\mathrm{em} . ?)$, ०ताडयत् $\mathrm{S}_{1} \mathrm{~S}_{2} \mathrm{~S}_{3} \quad \mathbf{3 0 a b}$ ०स्तैर्देत्यैर्या०] $\mathrm{S}_{1} \mathrm{~S}_{2} \mathrm{~A}$, ०स्तै देवो व्या॰ $\mathrm{S}_{3}^{\mathrm{pc}}$, ०स्तै देवौ व्या॰ $\mathrm{S}_{3}^{\mathrm{ac}}$, ०स्तैर्देत्यैर्व्य० $\mathrm{Bh}$ (typo) 30c मुखं ] $\mathrm{S}_{1} \mathrm{Bh}$, मुखे $\mathrm{S}_{2} \mathrm{~S}_{3}$ 30d जग्रास ] $\mathrm{S}_{1} \mathrm{Bh}$, जग्राह $\mathrm{S}_{2} \mathrm{~S}_{3}$ $31 \mathrm{a}$ तं तथावि॰] $\mathrm{S}_{1} \mathrm{~S}_{2} \mathrm{RA}$, तन्तथापि $\mathrm{S}_{3}$, तत्तथा वि॰ $\mathrm{Bh}(\mathrm{em} . ?)$ 31b हिरण्याक्षः ] $\mathrm{S}_{2} \mathrm{~S}_{3}^{\mathrm{pc}} \mathrm{RA}$ $\mathrm{Bh}$, हिरणयाक्ष $\mathrm{S}_{1} \mathrm{~S}_{3}^{\mathrm{ac}} \quad 31 \mathrm{c}$ संक्रुद्ध: ] $\mathrm{S}_{1} \mathrm{~S}_{2}^{\mathrm{pc}} \mathrm{S}_{3} \mathrm{RA}_{3} \mathrm{~A}_{7} \mathrm{Bh}$, संक्रुद्धो $\mathrm{S}_{2}^{\mathrm{ac}}$ 32c दैत्य:] $\mathrm{S}_{2} \mathrm{~S}_{3} \mathrm{RABh}$, दैत्य $\mathrm{S}_{1} \quad 33 \mathrm{~b}$ ज्वाला० $\mathrm{S}_{1} \mathrm{~S}_{2} \mathrm{~S}_{3} \mathrm{RA}$, ज्वाला: $\mathrm{Bh}(\mathrm{em} . ?)$ समुद्निरन्तं ] $\mathrm{S}_{1} \mathrm{~S}_{2} \mathrm{RABh}$, समुद्निरं । (तं) $\mathrm{S}_{3}$ (unmetrical) 33c सुरा: ] $\mathrm{S}_{2}^{\mathrm{pc}} \mathrm{RABh}$, सुरा $\mathrm{S}_{1} \mathrm{~S}_{2}^{\mathrm{ac}} \mathrm{S}_{3}$ 33d ०चित्ता: ] RABh, ०चित्ता इति $\mathrm{S}_{1} \mathrm{~S}_{2} \mathrm{~S}_{3}$ (इति part of col.) Col. $\odot \|$ स्कन्दपुराणे (त्रि)शूलाक्षेपणे आध्यायः १६१ (in letter numerals) ॥ $\odot \mathrm{S}_{1}$, स्कन्दपुराणे षडोत्तरशतो ध्याय:॥ $\mathrm{S}_{2}$, ॥ स्कन्दपुराणे नामाध्याय। ९०६ (in letter numerals) ॥ $\odot \mathrm{S}_{3}$, इति स्कन्दपुराणे त्रिशूलाक्षेपणे षडुत्तरशततमोध्याय: $\mathrm{Bh}$ 


\title{
सप्तोत्तरशतो उध्याय:।
}

\author{
सनत्कुमार उवाच। \\ तमापतन्तं वेगेन न शूलं दृष्टवान्मृगः। \\ दैत्यै: सर्वे: समासकः सर्वप्राणिभयंकरम्॥ १॥ \\ अलक्षितेन तेनासौ शुलेनादितिनन्दनः। \\ विभिन्नो ह्दयये व्यास मृतकल्प: पपात च॥ २॥ \\ ततो हाहाकृतं भूतैरदृश्यैर्मुनिसत्तम। \\ उद्वेला: सागराश्चासन्भास्करश्चाप्रभो अवत्॥ ३॥ \\ उल्का: पेतुश्च सर्वत्र म्नानमाल्या: सुराभवन्। \\ ग्रहाणामभवद्युद्धं विमानानि च पेतिरे॥ 6 ॥
}

3cd AS p. 711: उद्वेषा नागराश्चासन् भास्करश्चाप्रभो अवत्।

4ab AS p. 712: उल्का: पेतुग्च सर्वत्र भूमिरल्पसुराऽवत्। $\quad \mathbf{4 c d}=$ AS p. 712

$1 b$ ०न्मृग: ] ०न् यत: $R \quad 1 c$ ०सक्त: ] व्युक्त $R 2 b$ ०नादिति॰ ] ०न दिति॰ $R \quad 2 d$ च ] स: $\mathrm{R} 3 \mathrm{~b}$ ०रदृश्यै०] ०रुद्विग्नै० $\mathrm{R} \quad 3 \mathrm{c}$ ०राश्चासन् ] ०रा ह्यासन् $\mathrm{R} \quad 4 \mathrm{~b}$ म्लानमाल्याः ] म्रियमाना: $\mathrm{R}^{\mathrm{pc}}, \check{\simeq} \simeq \check{\simeq}: \mathrm{R}^{\mathrm{ac}}$

1b न शूलं दृष्टवान्मृगः ] शूलं दृष्ट्रा मृगस्तदा $A$ 1c ०सक्तः ] $A_{4}$, ०शक्तः $A_{3} A_{7}$ 2a तेनासौ] तेनास्मिन् $\mathbf{A} 2 \mathbf{2 b}$ ०नादिति॰ ] ०न दिति॰ $\mathbf{A}$ • ०नन्दनः ] $\mathrm{A}_{3}$, ०नन्दनाः $\mathrm{A}_{4} \mathrm{~A}_{7}$ 2c विभित्रो हृदये ] विभिन्नो हृदयो $\mathrm{A}_{7}$, विभित्नह्दययो $\mathrm{A}_{3} \mathrm{~A}_{4} \quad 3 \mathbf{b}$ ०सत्तम ] ०सत्तमै: $\mathbf{A} \quad 3 \mathbf{c}$ उद्वेलाः ] $\mathrm{A}_{7}^{\mathrm{pc}}$, तत्वेना $\mathrm{A}_{3} \mathrm{~A}_{4}$, तत्वेना: $\mathrm{A}_{7}^{\mathrm{ac}} \quad 4 \mathbf{a}$ उल्का: पेतु श्च सर्वत्र ] उल्का निपेतुश्च तदा $\mathbf{A} 4 \mathbf{b}$ ०माल्याः ] ०सस्या: $\mathrm{A}_{7}^{\mathrm{pc}}$, ०सस्यो $\mathrm{A}_{3} \mathrm{~A}_{4} \mathrm{~A}_{7}^{\mathrm{ac}} \quad \mathbf{4 d}$ पेतिरे ] $\mathrm{A}_{3} \mathrm{~A}_{7}$, येतिरे $\mathrm{A}_{4}$

Manuscripts available for this chapter: $S_{1}$ photos $4.8 \mathrm{a}\left(\mathrm{f} .164^{\mathrm{v}}\right.$ ), $4.6 \mathrm{~b}\left(\mathrm{f} .165^{\mathrm{r}}\right.$ ) and $4.7 \mathrm{a}\left(\mathrm{f} .165^{\mathrm{v}}\right.$ ); $\mathrm{S}_{2}$ exposures $114 \mathrm{~b}-115 \mathrm{~b}$ (f. $149^{\mathrm{r}}-150^{\mathrm{r}}$ ); $\mathrm{S}_{3}$ f. $164^{\mathrm{r}}-165^{\mathrm{v}}$; $\mathrm{R} \mathrm{f.} 180^{\mathrm{v}}-181^{\mathrm{r}}$ (lower left corner of f. 180 is cut off in triangular shape, but the fragment is almost intact); $A_{3}$ f. $107^{\mathrm{v}}-108^{\mathrm{v}} ; \mathrm{A}_{4}$ f. $151^{\mathrm{v}}-152^{\mathrm{v}}$; A f. $152^{\mathrm{v}}-153^{\mathrm{v}}$

$\mathbf{2}\left(\mathrm{b}^{1}, \mathrm{~b}^{6}-\mathrm{b}^{7}\right) \mathrm{S}_{1} \quad \mathbf{3}\left(\mathrm{d}^{7}\right) \mathrm{S}_{3},\left(\mathrm{a}^{1}\right) \mathrm{R}$

$1 \mathrm{ab}$ वेगेन न ] $\mathrm{S}_{3} \mathrm{RBh}$ (conj.), वेगेन त्रि॰ $\mathrm{S}_{1}$, तं स्वेन तं $\mathrm{S}_{2} \quad$ 1c दैत्यैः सर्वे: ] RA, दैत्ये सर्वे $\mathrm{S}_{1}$, दैत्यः सर्वे $\mathrm{S}_{2} \mathrm{~S}_{3}$, दैत्यसन्धे $\mathrm{Bh}$ (conj.?, in a note Bh suggests दैत्यसंघै:) 1d ०भयंकरम ] RABh, ०भयड़:: $S_{1}$, ०भयंकर: $S_{2} S_{3}$ 2b ०नन्दन: ] $S_{2} S_{3} R_{3} B h$, (०तद्ध)न: $S_{1}$ 2c विभित्रो ] $S_{2} R_{7} B h$, विच्छित्रो $S_{1}$, विभिनो $S_{3}$ 2d ०कल्पः ] $S_{1}^{\text {pc }} S_{2} S_{3} R A B h$, ०कल्प $S_{1}^{\text {ac }}$ • च ] $S_{2} S_{3} A$, ह $\mathrm{S}_{1} \mathrm{Bh} \quad \mathbf{3 b}$ ०रदृश्यैर ] $\mathrm{S}_{1} \mathrm{~S}_{2}^{\mathrm{pc}} \mathrm{ABh}$, ०र $\langle$ श्यै $\rangle+$ दृश्यै+र $\mathrm{S}_{2}$, ०रदृश्यै $\mathrm{S}_{3}$ - ०सत्तम ] $\mathrm{S}_{1} \mathrm{~S}_{2}^{\mathrm{pc}} \mathrm{RBh}$, ०सत्तमः $\mathrm{S}_{2}^{\mathrm{ac}} \mathrm{S}_{3} \quad 3 \mathrm{c}$ उद्वेला: ] RA $\mathrm{RA}_{7}^{\mathrm{pc}} \mathrm{Bh}\left(\mathrm{em}\right.$. ?), उद्वेला $\mathrm{S}_{1} \mathrm{~S}_{2} \mathrm{~S}_{3}$ - ०श्चासन् ] $\mathrm{S}_{2} \mathrm{~S}_{3} \mathrm{ABh}$, ०श्चास $\mathrm{S}_{1}$ 3d ०प्रभो ऽवत् ] $S_{1} S_{2} S_{3}^{\mathrm{pc}} R A B h$, ०प्रभास्वरत् $S_{3}^{\text {ac }}$ 4ab ] om. $S_{1}^{\text {ac }}$ ( $S_{1}$ erases $4 \mathrm{c}-6 \mathrm{~b}$ and writes $4 \mathrm{a}-5 \mathrm{~d}$ by first hand over it; variants in the erased are not recorded.) $\quad 4 a$ उल्का: ] $\mathrm{S}_{2}^{\mathrm{pc}} \mathrm{RBh}$, उल्के $\mathrm{S}_{1}^{\mathrm{pc}}$, उल्का $\mathrm{S}_{2}^{\mathrm{ac}} \mathrm{S}_{3} \quad 4 \mathrm{~b}$ ॰माल्या: ] $\mathrm{S}_{2}^{\mathrm{pc} B h}$, ०माल्य $\mathrm{S}_{1}^{\mathrm{pc}}$, ॰माल्यां $\mathrm{S}_{2}^{\mathrm{ac}} \mathrm{S}_{3}$ • सुराभवन् ] RABh, सुराभवत् $S_{1}^{\text {pc }} S_{2} S_{3}^{\text {pc }}$, सुभाभवत् $S_{3}^{\text {ac }}$ 4d पेतिरे ] $S_{2} R_{3} A_{7} B h$, पेदिरे $S_{1}$, पेतिर $S_{3}$ 
जजपुर्मुनयः सर्वे वराहे पतिते तदा।

महादेवं नमस्कृत्य ब्रह्मा सस्मार तं तदा॥ $y \|$

ततो वितिमिरं सर्वमभवत्पूर्ववच्छुभम्।

प्रकृतिस्थं जगचाभूद्वराहश्चोदतिष्टत।

तेजो माहेश्वरं दिव्यं विवेश मधुसूदनम्॥ ६॥

सो उप्यायिततनुस्तेन शूलं निष्कृष्य माधवः।

सहस्रानलसंकाशो बभूव स महाबलः॥ ७॥

ततस्तेनैव शूलेन तं दैत्यं देवनन्दनः।

जघान हृदये ऋद्धः ऋ ॠं शक्तया यथा गुहः ॥ ॥

स भिन्नह्दयसस्तेन वराहेण महासुरः।

नार्तिमानभवद्वास कृच्छ़्रे विद्वानिव स्थितः॥ १॥

मध्येभित्न: स तं शूलं निष्कृष्य च विसृज्य च।

खड्ड निष्कृष्य वेगेन वराहं मूर्ध्यत्यताडयत्॥ १०॥

स तेन सुप्रहारेण वराहो नन्दिवर्धनः।

नार्तिमानभवद्यास बभूव रुधिरत्तुतः ॥ ??॥

5a जजपु $\left.{ }^{\circ}\right]$ जज्वलु ${ }^{\circ}$ 5d ब्रह्मा सस्मार तं ] ब्रह्माणं स्तावयेत् $R$ • After this R has two pādas reading शिवेनापीक्षितो व्यास वराहः स समूच्च्छुतः। $6 a$ ततो वि॰ ] हतो ऽपि $R \quad 6 b$ वच्छुभम् ]

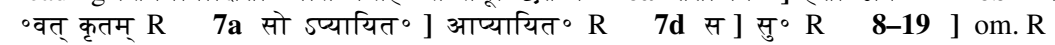

5a जजपुर्मु॰] जजल्पुर्मु॰ $\mathrm{A}_{3}$, जजल्पुः मु॰ $\mathrm{A}_{4}$, जज्ज(हु)र्मु॰ $\mathrm{A}_{7}^{\mathrm{pc}}$, जज्ज(प्सु): मु॰ $\mathrm{A}_{7}^{\mathrm{ac}} 5 \mathrm{5d}$ सस्मार तं] संस्कारयत् $\mathrm{A} \quad \mathbf{6 c}$ प्रकृतिस्थं ] $\mathrm{A}_{4} \mathrm{~A}_{7}$, प्रकृतिस्थ $\mathrm{A}_{3}$ 6e माहेग्वरं ] $\mathrm{A}_{7}^{\mathrm{pc}}$, महे प्वरं $\mathrm{A}_{3} \mathrm{~A}_{4} \mathrm{~A}_{7}^{\mathrm{ac}}$ $7 \mathbf{a b}$ शूलं निष्कृष्य ] शूलात्रिष्क $\left\{\right.$ ०स्क्र० $\left.\mathrm{A}_{4}\right\}$ म्य $\mathbf{A}$ 7b माधव:] $\mathrm{A}_{7}^{\mathrm{pc}}$, वाधमः $\mathrm{A}_{7}^{\mathrm{ac}}$, वाधन: $\mathrm{A}_{3} \mathrm{~A}_{4}$

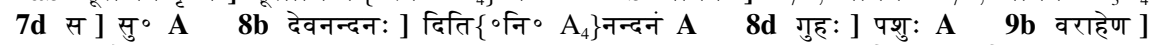
$\mathrm{A}_{4}$, वराहेन $\mathrm{A}_{3} \mathrm{~A}_{7}$ 9c-11b ] om. $\mathrm{A}_{3} \mathrm{~A}_{4} \mathrm{~A}_{7}^{\mathrm{ac}}\left(\mathrm{A}_{7}^{\mathrm{pc}}\right.$ written i.m.) 10b निष्कृष्य ] नि(स्कृत्य) $\mathrm{A}_{7}^{\mathrm{pc}}$ $10 \mathrm{c}$ निष्कृष्य ] विकृ(ष्य) $\mathrm{A}_{7}^{\mathrm{pc}}$ 11d रुधिर०] वरवि॰ $A$

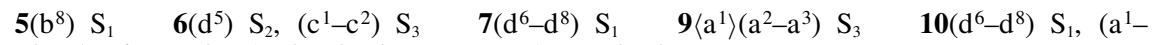
$\left.a^{4}\right)\left\langle a^{5}\right\rangle\left(a^{6}\right)\left\langle a^{7}-a^{8}\right\rangle\left(b^{1}-b^{2}\right)\left\langle b^{3}-b^{8}\right\rangle S_{2} \quad \mathbf{1 1}\left\langle a^{1}-a^{7}\right\rangle\left(a^{8}-b^{2}\right) S_{1}$

5a जजपुर् ] $S_{1} S_{2} B h$, जर्जप $S_{3}$ (unmetrical) 5b तदा ] $S_{1} S_{2}^{p c} S_{3}^{p c} R A B h$, नदा $S_{2}^{\text {ac }} S_{3}^{\text {ac }}$ 5d ब्रह्मा सस्मार तं तदा ] $\mathrm{S}_{2}^{\mathrm{pc}}$, ब्रह्माणं स्मरतन्तथा $\mathrm{S}_{1}$, ब्रह्म $\left\{{ }^{\circ}\right.$ हुं $\left.\mathrm{S}_{3}^{\mathrm{pc}}\right\}$ सस्मार तन्तदा $\mathrm{S}_{2}^{\mathrm{ac}} \mathrm{S}_{3}$, ब्रह्मा संस्मार तं तदा $\mathrm{Bh}$ (typo) 6ab सर्वम॰] $\mathrm{S}_{1} \mathrm{RABh}$, सर्व म० $\mathrm{S}_{2} \mathrm{~S}_{3}$ 6cd प्रकृतिस्थं जगचाभूद्वराह॰ ] $\mathrm{RA}_{4} \mathrm{~A}_{7}$, प्रकृतिस्थं जगचाभू वराह॰ $\mathrm{S}_{1}$, महादेवं नमस्कृत्य वाराह॰ $\mathrm{S}_{2} \mathrm{Bh}(\mathrm{cf} .5 \mathrm{c}$ ), (महा)देवं नमस्कृत्य वाराह॰ $S_{3}$ (cf. 5c) 6d ० ग्रोदतिष्ठत ] $S_{1} S_{2}^{\text {ac }} S_{3} R A B h, ~ \circ$ श्रो(प)तिष्टत $S_{2}^{\text {pc }}$ 6e माहेश्वरं ] $S_{1}^{\text {pc }} S_{2}$ $R A_{7}^{\mathrm{pc}} B h$, महेग्वरन् $S_{1}^{\mathrm{ac}} S_{3} \quad 7 b$ निष्कृष्य ] $S_{1} R B h$, निष्कृत्य $S_{2} S_{3}$ • माधवः ] $S_{1}^{p c} S_{2} S_{3} R A_{7}^{p c} B h$, माधव $\mathrm{S}_{1}^{\mathrm{ac}} 7 \mathrm{c}$ सहस्रानल॰ $\mathrm{S}_{2} \mathrm{~S}_{3}^{\mathrm{pc}} \mathrm{RA}$, सहसानल॰ $\mathrm{S}_{1} \mathrm{Bh}$, सहस्रान॰ $\mathrm{S}_{3}^{\text {ac }}$ (unmetrical) 8c क्रुद्व: ] $S_{1}^{\text {pc }} S_{2} S_{3} A B h$, कुः: $S_{1}^{\text {ac }}$ (unmetrical) 8d कौस्चं ] $S_{2} A B h$, कोम्च $S_{1} S_{3}$ 9a स भिन्नह्दय० ] $\mathrm{S}_{2} \mathrm{ABh}$, संभिन्नह्य ० $\mathrm{S}_{1}$ (unmetrical), $\simeq \mathrm{f}\left(\right.$ (न्न)ह्हदय॰ $\mathrm{S}_{3}$ 9b वराहेण $] \mathrm{S}_{1} \mathrm{~S}_{2}^{\mathrm{pc}} \mathrm{S}_{3}^{\mathrm{pc}} \mathrm{A}_{4} \mathrm{Bh}$, वराहेणेण

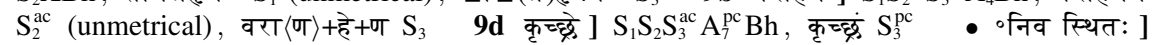
$\mathrm{S}_{1}^{\mathrm{ac}} \mathrm{S}_{2} \mathrm{~S}_{3} \mathrm{~A}_{7}^{\mathrm{pc}} \mathrm{Bh}$, ०नवस्थितः $\mathrm{S}_{1}^{\mathrm{pc}} \quad \mathbf{1 0 a}$ ०भित्र: ] $\mathrm{A}_{7}^{\mathrm{pc}}$, ०भिन्नं $\mathrm{S}_{1} \mathrm{Bh}$, (०भिन्न) $\mathrm{S}_{2}$, ०भिंनं $\mathrm{S}_{3}^{\mathrm{pc}}$, ०भिन $\mathrm{S}_{3}^{\mathrm{ac}}$ - तं शूलं ] $\mathrm{S}_{3} \mathrm{~A}_{7}^{\mathrm{pc}}$, ते शूल $\mathrm{S}_{1},($ तं $)-\simeq \mathrm{S}_{2}$, तच्छूल $\mathrm{Bh}(\mathrm{em} . ?) \quad 10 \mathrm{c}$ खड्रं $] \mathrm{A}_{7}^{\mathrm{pc}} \mathrm{Bh}$

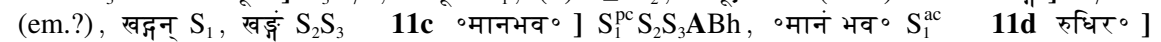
$\mathrm{S}_{2} \mathrm{~S}_{3}^{\mathrm{pc}}$, रुधिरा॰ $\mathrm{S}_{1} \mathrm{Bh}$, (धुलि)र॰ $\mathrm{S}_{3}^{\mathrm{ac}}$ 


\author{
नानाधातुविचित्रो डसौ हिमवानिव पर्वतः। \\ बभौ वराहो देवात्मा सर्वासुरविमर्दनः॥ ?२॥ \\ पुनराहन्तुकामस्य तस्य दैत्यस्य सुत्रत। \\ अपाहस्तप्रहारेण खड़ं हस्तादपातयत्॥ ?३॥ \\ अकुर्वतां ततो युद्ध नियुद्धकुशलावुभौ। \\ तौ गजाविव संक्रुद्धौ महिषाविव दर्पितौ॥ ?० ॥ \\ सिंहाविव च नर्दन्तौ संकुद्धौ वृषभाविव। \\ शरभाविव चायस्तौ शार्दूलाविव निर्घृणौ॥ १४॥ \\ परस्परमयुध्येतां परस्परजयैषिणौ। \\ अड्कुशशर्हस्तयोक्तैश्च क्षेपणैरपसर्पणै:। \\ मण्डलैश्च पुनश्चित्रै: कर्षणैरपकर्षणै:॥ १६॥ \\ तत्रैश्च मुष्टिभिश्चैव भुजै: सचरणैरपि। \\ नखैश्च दशनैश्चैव तथान्यैश्च महाबलौ॥ १७॥ \\ तयोरेवमभूद्युद्धमुभयोर्देवदैत्ययो:। \\ अहानि दश चाष्टौ च तथान्यानि चतुर्दश ॥ ?५॥ \\ अन्यत्सहस्रमेवासीद्वर्षाणां तच्च मानुषम्। \\ एष कालो भवेत्तत्र ततो दैत्यो उबलो अवत्। १९ ॥
}

$13 \mathrm{~b}$ सुत्रत ] $\mathrm{A}_{4} \mathrm{~A}_{7}$, सुत्रत $\mathrm{A}_{4} 13 \mathrm{c}$ अपाहस्त॰ ] अहं दृष्ट॰ $\mathrm{A} 13 \mathrm{~d}$ ॰ दपातयत् $]$ ददपो $\{\circ$ यो॰ $\left.\mathrm{A}_{3}\right\}$ थयत् $\mathrm{A} \quad 14 \mathrm{c}-16 \mathrm{~b}$ ] om. $\mathrm{A}_{7} \quad 15 \mathrm{a}$ सिंहाविव च ] तौ सिंहाविव $\mathrm{A}_{3} \mathrm{~A}_{4} \quad 15 \mathrm{c}$ चायस्तौ] $\mathrm{A}_{3}$, चायस्थौ $\mathrm{A}_{4} \quad 16 \mathrm{c}$ अडुक्रुरस्तयोक्तैश्च ] अंशयोर्हस्तयोग्चैव $\mathrm{A} \quad 16 \mathrm{~d}$ ०णैरपसर्पणै: ] ०णरुर $\left\{\right.$ रू० $\left.\mathrm{A}_{3} \mathrm{~A}_{7}\right\}$ पसर्पिणौ $\mathrm{A} \quad 16 \mathrm{e}$ ०श्चित्रै: ] $\mathrm{A}_{7}^{\mathrm{pc}}$, ०श्चित्र $\mathrm{A}_{3} \mathrm{~A}_{4} \mathrm{~A}_{7}^{\mathrm{ac}} 16 \mathrm{f}$ ०णैरप०] ०णैरुप० $\mathrm{A}_{4} \mathrm{~A}_{7}$, ०णै रूप० $\mathrm{A}_{3}$ $17 \mathrm{c}$ दशनै०] $\mathrm{A}_{3}$, दर्शनै० $\mathrm{A}_{4} \mathrm{~A}_{7} \quad 17 \mathrm{~d}$ महाबलौ] महाबलै: $\mathrm{A} 18 \mathrm{~d}$ तथान्यानि ] तथाहानि $\mathrm{A}$ $19 \mathrm{~b}$ तच्च ] चाति ${ }^{\circ} A$ 19c भवेत्त० ] भवत्त० $A$ 19d दैत्यो डबलो] दैत्यबलो $A$

$13\left(d^{2}, d^{7}\right) S_{1} \quad 15\left(b^{7}, c^{5}, c^{8}, d^{2}, d^{5}\right)\left\langle d^{6}-d^{8} \rightarrow\right\rangle S_{1} \quad 16\left\langle\leftarrow a^{1}-b^{7}\right\rangle\left(b^{8}-c^{2}\right)\left\langle c^{3}\right\rangle\left(c^{4}-d^{8}\right)\left\langle e^{1}-e^{6}\right\rangle\left(e^{7}-\right.$ $\left.\mathrm{e}^{8}\right)\left\langle\mathrm{f}^{1}-\mathrm{f}^{2}\right\rangle\left(\mathrm{f}^{3}-\mathrm{f}^{8}\right) \mathrm{S}_{1} \quad 17\left(\mathrm{a}^{2}, \mathrm{a}^{7}, \mathrm{~b}^{1}-\mathrm{b}^{2}\right) \mathrm{S}_{1} \quad 18\left(\mathrm{a}^{7}-\mathrm{b}^{7}\right)\left\langle\mathrm{b}^{8}\right\rangle \mathrm{S}_{1} \quad \mathbf{1 9}\left(\mathrm{b}^{8}, \mathrm{c}^{6}\right)\left\langle\mathrm{c}^{7}\right\rangle\left(\mathrm{d}^{5}\right) \mathrm{S}_{1}$

$12 \mathbf{b}$ ०वानिव ] $\mathrm{S}_{1} \mathrm{~S}_{2} \mathrm{~S}_{3} \mathrm{~A}$, ०वानव $\mathrm{Bh}$ (typo) 13a पुनराह॰] $\mathrm{S}_{1} \mathrm{~S}_{2} \mathrm{~S}_{3}^{\mathrm{pc}} \mathrm{ABh}$, पुनवराह॰ $\mathrm{S}_{3}^{\mathrm{ac}}$ (unmetrical) $13 \mathbf{b}$ सुत्रत ] $S_{2}^{\text {pc }} A_{3} A_{7} B h$, सुब्रत $S_{1}$, सुत्रतः $S_{2}^{\text {ac }} S_{3} 13 \mathbf{c}$ अपाहस्त० $S_{1} S_{2} S_{3}$, अपहस्त॰ $\mathrm{Bh}$ (em.?) 13d खड्डं ] $\mathrm{S}_{2} \mathrm{~S}_{3} \mathrm{ABh}$, ख(न्न) $\mathrm{S}_{1} \quad \mathbf{1 4 a}$ अकुर्वतां ] $\mathrm{S}_{1}^{\mathrm{pc}} \mathrm{S}_{2}^{\mathrm{ac}} \mathrm{S}_{3} \mathrm{~A}$, अकुर्वतो $\mathrm{S}_{1}^{\mathrm{ac}}$, अकुर्वातान् $\mathrm{S}_{2}^{\mathrm{pc}}$, अकुर्वातां $\mathrm{Bh} 14 \mathrm{~b}$ ०लाबुभौ] $\mathrm{S}_{2} \mathrm{~S}_{3} \mathrm{ABh}$, ल्लाबुभौ $\mathrm{S}_{1}$ 14d महिषाविव ] $\mathrm{S}_{1} \mathrm{~S}_{2}^{\mathrm{pc}} \mathrm{S}_{3}^{\mathrm{pc}} \mathrm{A}_{3} \mathrm{~A}_{4} \mathrm{Bh}$, महिषानिव $\mathrm{S}_{2}^{\mathrm{ac}} \mathrm{S}_{3}^{\mathrm{ac}} \quad 15 \mathrm{c}$ चायस्तौ] $\mathrm{S}_{1} \mathrm{~A}_{3} \mathrm{Bh}$, चायत्तौ $\mathrm{S}_{2} \mathrm{~S}_{3} \quad 15 \mathrm{~d}$ निर्घृणौ] $\mathrm{S}_{2} \mathrm{~A}_{3} \mathrm{~A}_{4} \mathrm{Bh}$, निघृणौ $\mathrm{S}_{3}$ (unmetrical) $16 \mathrm{~b}$ ०जयैषिणौ ] $\mathrm{S}_{2} \mathrm{~S}_{3}^{\mathrm{pc}} \mathrm{A}_{3} \mathrm{~A}_{4} \mathrm{Bh}, \cdots$ (णा) $\mathrm{S}_{1}$ (upper parts lost), ०जयैषिणो $S_{3}^{\mathrm{ac}} 16 \mathrm{c}$ हरस्तः $\mathrm{S}_{1} \mathrm{~S}_{2}^{\mathrm{pc}} \mathrm{S}_{3} \mathrm{ABh}$, ०हस्त्र० $\mathrm{S}_{2}^{\mathrm{ac}} 16 \mathrm{e}$ मण्डलैश्च ] $\mathrm{S}_{2} \mathrm{~S}_{3} \mathrm{~A}$, मण्लैग्च $\mathrm{Bh}$ (typo, unmetrical) - ०श्चित्रै: ] $\mathrm{S}_{2} \mathrm{~A}_{7}^{\mathrm{pc}} \mathrm{Bh}, \mathrm{f}-\left(\right.$ त्ते) $\mathrm{S}_{1}$ (upper parts lost), ०श्चित्रै $\mathrm{S}_{3}$

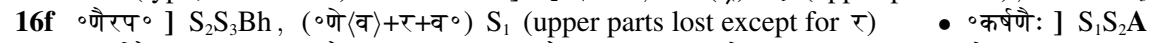
$\mathrm{Bh}$, ०कर्षणै $\mathrm{S}_{3} \quad 17 \mathbf{b}$ भुजै: ] $\mathrm{S}_{1} \mathrm{~S}_{2} \mathrm{ABh}$, भुजै $\mathrm{S}_{3} \quad 18 \mathrm{a}$ ०रेवमभू॰] $\mathrm{S}_{1} \mathrm{ABh}$, ०रेववभू॰ $\mathrm{S}_{2} \mathrm{~S}_{3}^{\mathrm{ac}}$, रेवं वभू॰ $S_{3}^{\mathrm{pc}} \quad \mathbf{1 8 b}{ }^{\circ}$ मुभयोर्दे॰] $\mathrm{S}_{2} \mathrm{ABh},\left({ }^{\circ}\right.$ मुभयाद $\left.{ }^{\circ}\right) \mathrm{S}_{1}$ (upper parts lost), ॰मुभयो दे॰ $\mathrm{S}_{3}$ $18 d$ चतुर्दश ] $A B h$, चतुर्दश: $S_{1} S_{3}$, चतुर्द्र+श: $+S_{2} \quad 19 a$ ०मेवासीद् ] $S_{1}^{p c} A B h$, ०मेवासी $S_{1}^{\text {ac }} S_{2} S_{3}$ $19 \mathrm{~b}$ ०णां तच्च ] $\mathrm{S}_{1} \mathrm{~S}_{2} \mathrm{~S}_{3}^{\mathrm{pc} B h}$, ०णान्त च $\mathrm{S}_{3}^{\mathrm{ac}} 19 \mathrm{c}$ भवेत्त $] \mathrm{S}_{2} \mathrm{~S}_{3}$, भ(वे) $-\mathrm{S}_{1}$, भवत्त॰ $B$ h $19 d$ दैत्यो ऽबलो ] $\mathrm{S}_{1}^{\mathrm{pc}} \mathrm{S}_{2} \mathrm{~S}_{3} \mathrm{Bh}$ (दैत्यो $+5+$ बलो in $\mathrm{S}_{2} \mathrm{~S}_{3}$ ), दैत्यो $\left\langle(\right.$ ल) $\rangle+($ ब $)+$ लो $\mathrm{S}_{1}$ 


\section{तं हीयमानमालक्ष्य्य दैत्याधिपतिमर्जितम् ।}

आकाशे वागुवाचेदमशरीरातिसुस्वरा॥ २०॥

शृणु देव वराहेद श्रुत्वा चैव समाचर।

अशक्यो उयं त्वया ह्येवं हन्तुं दैत्यो महाबलः॥ २?॥

अबलो उयं कृतः करो ध्रुवं माहेश्वरेण हि।

तेजसा पश्य चैवैनमेष कालो उस्य वर्तते। २२॥

मुत्कैनं दैत्यराजानं चक्रेण विनिसूदय।

माहेश्वरेण वैकुण्ठ ततो मृत्युमवाप्स्यति॥ २३॥

सनत्कुमार उवाच।

ततस्तमभिसंश्रुत्य भगवान्नन्दिवर्धन :।

मुमोच दैत्यराजानं पादेनाहत्य वक्षसि॥ २४॥

स मुक्तस्तेन देवेन विबभौ दैत्यपुंगवः।

भुक्तमुको यथा सूर्यः सैंहिकेयेन राहुणा॥ २४॥

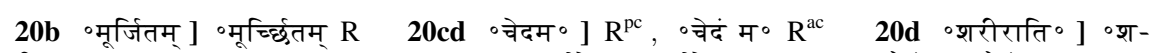
रीरा च $R \quad 21 \mathrm{ab}$ ] om. $R \quad 22 d$ उस्य वर्तते ] भ्यवर्त्तते $R \quad 23 a$ मुत्कैनं ] युत्कैनं $R \quad 23 \mathrm{c}$ वैकुण्ठ ] वै साक्षात् $R \quad 25 \mathrm{ab}$ देवेन विबभौ ] विबभौ संयुगे $R \quad 25 \mathrm{~cd}$ सूर्यः सैंहिकेयेन ] सूर्य्यश्च्च्द्र: पर्व्वणि $\mathrm{R}$

$20 \mathrm{~b}$ ॰मूर्जितम् ] $\mathrm{A}_{3} \mathrm{~A}_{7}^{\mathrm{pc}}$, ${ }^{\circ}$ मुर्जितं $\mathrm{A}_{4} \mathrm{~A}_{7}^{\mathrm{ac}} 20 \mathrm{~cd}$ ॰गुवाचेदम॰] $\mathrm{A}_{7}$, ॰गुवाचेदं म॰ $\mathrm{A}_{3}$, ०गुराचेदम॰ $\mathrm{A}_{4} 20 \mathrm{~d}$ ॰शरीराति॰] ॰ शरीरा च $\mathrm{A}$ - ०सुस्वरा ] $\mathrm{A}_{7}$, सस्वरा $\mathrm{A}_{3} \mathrm{~A}_{4}$ 21c अशक्यो ] असह्यो $A 21 d$ हन्तुं दैत्यो] दैत्यो हन्तुं $A \quad 22 b$ माहेश्वरेण ] महेश्वरेण $\left\{{ }^{\circ}{ }^{-} A_{3}\right\} A$ 22c पश्य ] तस्य $A$ $22 \mathrm{~cd}$ चैवैनमे॰ ] $\mathrm{A}_{3} \mathrm{~A}_{7}$, चैवेनं ए० $\mathrm{A}_{4} \quad 23 \mathrm{a}$ मुत्कैनं ] युद्धैनं $\mathrm{A} \quad 23 \mathrm{c}$ माहेप्वरेण वैकुण्ठ ] महेग्वरेण कार्ण्णोन $A$ 23d ततो ] $A_{7}$, त्रतो $A_{3}$, त्रातो $A_{4} 24 a$ संग्रुत्य ] ०संगम्य $A$ 25a देवेन] कालेन A 25d सैंहिकेयेन ] $\mathrm{A}_{3} \mathrm{~A}_{7}$, सैंहिकेयेण $\mathrm{A}_{4}$ - राहुणा ] $\mathrm{A}_{3} \mathrm{~A}_{4}$, राहुना $\mathrm{A}_{7}$

$\mathbf{2 0}\left(d^{1}-d^{5}\right) S_{1} \quad \mathbf{2 3}\left(d^{3}-d^{5}\right) S_{1} \quad \mathbf{2 4}\left(b^{7}, c^{8}, d^{4}\right) S_{1}$, (speaker indication 1$) S_{2} \quad \mathbf{2 5}\left(b^{7}-c^{3}\right) S_{1}$

20b ०मूर्जितम् ] $\mathrm{S}_{1} \mathrm{~A}_{3} \mathrm{~A}_{7}^{\mathrm{pc}} \mathrm{Bh}$, ०मूर्जित: $\mathrm{S}_{2} \mathrm{~S}_{3}$ 20c आकाशे ] $\mathrm{S}_{1}^{\mathrm{pc}} \mathrm{S}_{2} \mathrm{~S}_{3} \mathrm{RABh}$, आहाशे $\mathrm{S}_{1}^{\mathrm{ac}}$ 20cd वागुवाचेदम० ] $\mathrm{S}_{1}^{\mathrm{pc}} \mathrm{R}^{\mathrm{pc}} \mathrm{A}_{7} \mathrm{Bh}$, वागुकेवाचेद $\mathrm{S}_{1}^{\mathrm{ac}}$, वागुवाचेदं म० $\mathrm{S}_{2} \mathrm{~S}_{3} \quad 20 \mathrm{~d}$ ०सुस्वरा ] $\mathrm{RA}_{7}$, ${ }^{\circ}$ सस्वरा+: $+S_{1}$, ०सुस्वना $S_{2} S_{3} B h$ 21a वराहेद ] $S_{1}^{\text {pc }} S_{2} S_{3} A B h$, वराहदं $S_{1}^{\text {ac }}$ (unmetrical) 21c अशक्यो उयं ] $S_{2} R B h$, अशक्तो यं $S_{1}$, अशक्यो य $S_{3}$ - ह्येवं $S_{2} S_{3} R A B h$, ह्येव $S_{1}$ 21d हन्तुं ] $\mathrm{S}_{1} \mathrm{~S}_{2} \mathrm{RABh}$, हन्तु $\mathrm{S}_{3}$ 22a क्रिरो $\mathrm{S}_{1} \mathrm{~S}_{2} \mathrm{RABh}$, कूरो $\mathrm{S}_{3}$ 22b ध्रुवं ] $\mathrm{S}_{1} R A B h$, ध्रुव $\mathrm{S}_{2} \mathrm{~S}_{3}$ $22 \mathrm{c}$ तेजसा ] $\mathrm{S}_{2} \mathrm{~S}_{3} R A B h$, तेजसात् $S_{1}$ 22cd चैवैनमे०] $S_{3} R_{3} A_{7} B h$, +ते+नैनमे० $S_{1}$, चैवैन मे० $\mathrm{S}_{2} 23 \mathrm{a}$ मुत्कैन ] $\mathrm{S}_{2} \mathrm{~S}_{3} \mathrm{Bh}$, मुक्त्र्व $\mathrm{S}_{1}^{\mathrm{pc}}$, मुक्तै(न) $\mathrm{S}_{1}^{\mathrm{ac}} 23 \mathrm{c}$ ०रेण वै०] $\mathrm{S}_{1} \mathrm{~S}_{2} \mathrm{~S}_{3}^{\mathrm{pc}} \mathrm{RBh}$, ०रेणै(व) $\mathrm{S}_{3}^{\text {ac }} 24 \mathrm{~b}$ भगवान्] $\mathrm{S}_{2} \mathrm{~S}_{3} \mathrm{RABh}$, भगवा $\mathrm{S}_{1}$ 24c मुमोच ] $\mathrm{S}_{1} \mathrm{~S}_{3} \mathrm{RABh}$, मुमोच्य $\mathrm{S}_{2}$ - ०राजानं ] $\mathrm{S}_{1} \mathrm{~S}_{2} \mathrm{~S}_{3}^{\mathrm{pc}} \mathrm{RABh}$, ०राजान $\mathrm{S}_{3}^{\mathrm{ac}}$ 24d पादेनाहत्य ] $\mathrm{S}_{2} \mathrm{~S}_{3} \mathrm{RABh}$, पादेना(प)त्य $\mathrm{S}_{1}^{\mathrm{pc}}$, पादेन (अ्र)त्य $\mathrm{S}_{1}^{\mathrm{ac}} \quad$ 25a देवेन ] $\mathrm{S}_{2} \mathrm{~S}_{3} \mathrm{Bh}$, दैवेन $\mathrm{S}_{1} \quad$ 25b ०पुंगव: ] $\mathrm{S}_{1}^{\mathrm{pc}} \mathrm{S}_{2} \mathrm{~S}_{3} \mathrm{RABh}$, पु $\simeq \simeq \mathrm{S}_{1}^{\mathrm{ac}} \quad$ 25c यथा ] $\mathrm{S}_{1} \mathrm{~S}_{2}^{\mathrm{pc}} \mathrm{S}_{3} \mathrm{RABh}$, (पे)था $\mathrm{S}_{2}^{\mathrm{ac}} 25 \mathrm{~cd}$ सूर्यः सैंहिकेयेन $] \mathrm{S}_{2}^{\mathrm{pc}} \mathrm{A}_{3} \mathrm{~A}_{7} \mathrm{Bh}$, सूर्यस्सै $\left\{\right.$ सै॰ $\left.\mathrm{S}_{1}^{\mathrm{ac}}\right\}$ डिंकेयेन $\mathrm{S}_{1}$, सूर्य सैड्हिकेयेन $\mathrm{S}_{2}^{\mathrm{ac}}$, सूर्य+:+ सैहिकेयेण $\mathrm{S}_{3} \quad 25 \mathrm{~d}$ राहुणा ] $\mathrm{S}_{2} \mathrm{~S}_{3} \mathrm{RA}_{3} \mathrm{~A}_{4} \mathrm{Bh}$, राहुना $\langle:\rangle \mathrm{S}_{1}$ 
भगवानपि दीप्यन्तं श्रिया दैत्यं समीक्ष्य तम्।

सस्मार तत्तदा चकं नमस्कृत्वा पिनाकिने॥ २६॥

ततः सर्वा दिशो व्यास वह्निकुण्डनिभा बभुः।

शब्दश्च सुमहानासीद्युगान्ताम्बुदसंनिभः॥ २७॥

सिद्धा: पेतुश्च मेदिन्यां देवांग्च भयमाविशत्।

स्वस्त्यस्तु सर्वभूतानामित्यूचुर्मुनयस्तदा॥ २५॥

सागराश्चावशुष्यन्ति विनेशुर्नागपक्षिणः।

दैत्याश्च दानवाश्चैव सर्वे ते विविशुः पुरम्॥ २९॥

भयत्रस्तानि भूतानि उल्का: पेतुर्नभस्तलात्।

आगच्छुति युगान्ताग्निकालचके सुभास्वरे॥ ३०॥

27ab AS p.702: ततः सर्वा दिशो व्याप्रा वह्निकुण्डनिभा भुवि। $27 \mathbf{c d}=\mathrm{AS}$ p.702 28ab AS p. 710: सिद्धा: पेतुरथादित्याद् देवाश्च भयमाविशन्। 29ab AS p. 710: सागराश्च चुक्षुभिरे विरेजुर्नगपक्षिणः॥ 30ab = AS p. 710

$26 a$ दीप्यन्तं ] चायान्तं $R \quad 26 b$ दैत्यं ] दीत्तं $R \quad 26 c$ तत्तदा चक्रं] तन्तदा +व्यास+ $R \quad 27 \mathrm{c}$ ० ग्रु सुमहा ${ }^{\circ}$ ] ०स्तु स महा ${ }^{\circ} \mathrm{R} 28 \mathrm{a}$ सिद्धा: पेतुश्च ] सिद्धा यत्र तु $\mathrm{R} 28 \mathrm{~b}$ देवांश्च भयमाविशत् ] देवाश्र भयमाविशन् $R \quad 28 \mathrm{c}$ स्वस्त्यस्तु ] सूर्य्यस्तु $R \quad 28 d$ ०मित्यूचुर ] ॰मुवाच $R \quad 29 \mathrm{ab}$ ०शुष्यन्ति विनेशु० ] ॰शुष्यन्त विनेदु॰ $R \quad 29 \mathrm{~cd}$ ०वाश्चैव सर्वे ते ] ॰वाः सर्वे ते पुनर् $R \quad 30 \mathrm{~b}$ ०र्नभस्तलात् ] $\circ$ र्नभःस्थलात् $R \quad 30 c$ युगान्ताग्नि॰] युगान्ताग्नौ $R \quad 30 d$ सुभास्वरे ] सुभासुरे $R$

26b समीक्ष्य तम् ] समीक्षत $\mathrm{A}_{7}$, समीक्षतः $\mathrm{A}_{3} \mathrm{~A}_{4}$ 26cd चक्र नमस्कृत्वा पिनाकिने ] चैतन्नमस्कृत्य पिनाकिनं $\left\{\circ\right.$ नां $\left.\mathrm{A}_{7}\right\} \quad A \quad$ 27b ०कुण्डनिभा बभुः ] ०तुण्डानिभावतु $\mathrm{A}_{3} \mathrm{~A}_{4}, \quad \circ$ तु $\langle($ डा $)\rangle / \mathrm{f}\langle($ अ्र $)\rangle$ वतु $\mathrm{A}_{7}$ (unmetrical, no corrected akșara i.m.) 28a सिद्धा: ] $\mathrm{A}_{4}$, सेद्धा: $\mathrm{A}_{3}$, सिद्धः $\mathrm{A}_{7}$ - मेदिन्यां ] मे $\left\{\right.$ ये $\left.\mathrm{A}_{3}\right\}$ दैत्य० $\mathrm{A}_{3} \mathrm{~A}_{4} \mathrm{~A}_{7}^{\mathrm{ac}}$, खाद्देत्य॰ $\mathrm{A}_{7}^{\mathrm{pc}} \quad \mathbf{2 8 b}$ ०माविशत् ] ${ }^{\circ}$ मादिशन् $\mathbf{A}$ 28cd ] om. $\mathbf{A}$ 29b विनेशु०] निनेशु० $\mathrm{A}_{3} \mathrm{~A}_{4}$, निनिशु० $\mathrm{A}_{7}$ 29d सर्वे ते विविशुः पुरम् ] सर्वतो विक्कवाभवन् $A$ 30a भयत्रस्तानि ] त्रस्तानि सर्व० $A$ 30b उल्का: ] $A_{7}$, उल्का $A_{3}$, उत्का $A_{4} 30 \mathrm{c}$ आगच्छुति ] आगच्छत $\mathrm{A} 30 \mathrm{~d}$ ॰चके सुभास्वरे] ॰चक्रेषु भास्करे $\mathrm{A}$

27 $\left(c^{2}\right) S_{1} \quad 28\left(b^{3}, c^{1}\right) S_{2} \quad 29\left(a^{4}-a^{6}\right) S_{1},\left(c^{5}-c^{8}, d^{5}\right)\left\langle d^{6}-d^{7}\right\rangle\left(d^{8}\right) S_{2} \quad 30\left(b^{4}, b^{7}, c^{1}\right)\left\langle c^{2}-c^{3}\right\rangle\left(c^{4}-c^{8}\right)$ $\mathrm{S}_{1},\left\langle\mathrm{a}^{1}\right\rangle\left(\mathrm{a}^{2}\right) \mathrm{S}_{2}$

26b समीक्ष्य ] $\mathrm{S}_{2} \mathrm{~S}_{3} \mathrm{RBh}$, समीक्ष $\mathrm{S}_{1}$ 26c सस्मार ] $\mathrm{S}_{2} \mathrm{~S}_{3} \mathrm{RABh}$, संस्मार $\mathrm{S}_{1}$ 26d नमस्कृत्वा पिनाकिने ] $S_{1} S_{2} S_{3} R$, नमस्कृत्य पिनाकिनम् Bh 27a ततः ] $S_{1} S_{2} R A B h$, तत $S_{3}$ 27b ०कुण्ड०] $\mathrm{S}_{2} \mathrm{~S}_{3} \mathrm{R}$, ॰ कुण्ठ॰ $\mathrm{S}_{1}$, ॰ कुण्डा॰ Bh (typo) 27c सुमहा॰ ] $\mathrm{S}_{1} \mathrm{~S}_{2} \mathrm{~S}_{3} \mathrm{~A}$, मुमहा ${ }^{\circ} \mathrm{Bh}$ (typo) 27d ०गान्ताम्बुद॰ ] $S_{1} S_{2} R A B h$, ०गान्ताबुद $S_{3}$ • ०संनिभः ] $S_{2} S_{3}^{\text {pc }} R A B h$, ०वन्नदम् $S_{1}$, ०सनिभः $S_{3}^{\text {ac }}$ (unmetrical) 28a सिद्धा: ] $\mathrm{S}_{1}^{\mathrm{pc}} \mathrm{S}_{2} \mathrm{~S}_{3}^{\mathrm{pc}} \mathrm{A}_{4} \mathrm{Bh}$, सिद्धा $\mathrm{S}_{1}^{\mathrm{ac}}$, सिद्धः $\mathrm{S}_{3}^{\mathrm{ac}}$ - मेदिन्यां ] $\mathrm{S}_{1} \mathrm{~S}_{2} R B \mathrm{Rh}$, मेदित्यां $S_{3}^{\mathrm{pc}}$, मेदिव्यां $S_{3}^{\mathrm{ac}} 28 \mathrm{~b}$ देवांश्च ] $\mathrm{S}_{1} \mathrm{~S}_{2} \mathrm{ABh}$, दैवाश्च $\mathrm{S}_{3}^{\mathrm{pc}}$, देवाश्च $S_{3}^{\mathrm{ac}}$ - ०माविशत् ] $\mathrm{S}_{1} B h$, ०माविशन् $\mathrm{S}_{2} \mathrm{~S}_{3} \quad$ 28cd ॰नामित्यूचुर्मुनय॰] $\mathrm{S}_{3} \mathrm{Bh}$ (em.?), ०नामित्यूचूर्मभय॰ $\mathrm{S}_{1}^{\mathrm{pc}}$, ०नां मृत्युこ (त्म)भय० $S_{1}^{\mathrm{ac}}$, ०नां मित्यूचुर्मुनय० $S_{2} 28 d$ ०स्तदा ] $S_{2} S_{3} R B h$, ०स्सदा $S_{1}$ 29a ०श्चावशुष्यन्ति ] $S_{3} A$, ( ०र्यार्व शु)ष्यन्ति $S_{1}^{\mathrm{pc}}$, (०रुपकृ)ष्यन्ति $S_{1}^{\mathrm{ac}}$, ० ग्चाप+:+ शुष्यन्ति $\mathrm{S}_{2}$, ॰श्च व्यशुष्यन्त Bh (conj.?) 29b विनेशुर् ] $S_{2} B h$, विवेशुर $S_{1}$, विनेशु $S_{3}$ (unmetrical) 29d ०विशुः पुरम् ] $S_{3} R$, ०विशुः परम् $S_{1}$, (०वि) - $\check{\cup} \mathrm{S}_{2}$, वविशुर्विलम् Bh (conj.) 30b उल्का: ] $\mathrm{S}_{2} \mathrm{~S}_{3} \mathrm{RA}_{7} \mathrm{Bh}$, उल्का $\mathrm{S}_{1}^{\mathrm{ac}}$, उल्क: $\mathrm{S}_{1}^{\mathrm{pc}}$ पेतुर् ] $\mathrm{S}_{2} \mathrm{RABh}$, पे(तु) $\mathrm{S}_{1}$, पेतु $\mathrm{S}_{3} \quad 30 \mathrm{~d}$ ॰काल॰ ] $\mathrm{S}_{1} \mathrm{~S}_{2} \mathrm{~S}_{3} \mathrm{RA}$, ०कल्पे Bh (conj.?) 


\author{
क्षुरान्तं तन्महाचक्ज्जं जलचरान्तकम्। \\ दुर्निरीक्ष्यं सर्वघाति अभेद्यमविघाति च॥ ३? ॥ \\ तथाप्रतिहतं दिव्यं मोहनं सर्वदेहिनाम्। \\ करमागाद्वराहस्य शताशनिसमस्वनम्॥ ३२॥ \\ तमापतन्तं संवीक्ष्य सर्वभूतानि सर्वतः। \\ पेतुर्भूमौ महाघोरमपश्यन्न च किंचन॥ ३३॥ \\ सो उपि देवस्तदा कृत्वा रूपं सुमहदव्ययम्। \\ त्रैलोक्यव्यापि चिक्षेप दानवं प्रति नादयन्॥ ३४॥ \\ तद्युगान्तानलप्रख्यं क्षुरान्तं स्फोटयन्नभः। \\ जगाम दानवं क्षिप्रं दिशः सर्वा दहत्रिव॥ ३४॥
}

$31 \mathrm{~b}$ ममब्जं जलचरान्तकम् ] ममब्जजालग्च मध्यतः $R$ 31c सर्वघाति ] हि जन्तूनां $R$ 31d-32a ] $R$ repeats this after 32a. 31d अभेद्यमविघाति ] सर्व्वसत्वावघाति $R R^{*}$ 32a After this $R$ repeats 31d and 32a. 32d ०स्वनम् ] ०प्रभम् $R$ 33b सर्वतः ] $\mathrm{R}^{\mathrm{pc}}$, सर्वशः $\mathrm{R}^{\mathrm{ac}} 33 \mathrm{c}$ पेतुर्भूमौ] युद्धभूमौ $R \quad 34 b$ रूपं सुमहदव्ययम् ] स्वरूपं सुमहड्जयम् $R \quad 35 c$ क्षिप्रं ] सर्व्व $R$

31a तन् ] तु $\mathbf{A} 31 \mathbf{b}$ ०मब्जं जलचरान्तकम् ] ${ }^{\circ}$ म $\left\{{ }^{\circ}{ }^{\circ} \mathrm{A}_{3} \mathrm{~A}_{4}\right\}$ रजालं च मध्यतः $\mathbf{A}$ 31cd ] दुरिरीक्षं च जन्तूनां सर्वसत्वविघातिन: $A$ 32a तथा० ] यथा० $A$ - दिव्यं ] $\mathrm{A}_{4}$, दिव्ये $\mathrm{A}_{3} \mathrm{~A}_{7} 32 \mathrm{~d}$ शताशनि॰ ] सतांस $\left\{\circ\right.$ श० $\left.\mathrm{A}_{4}\right\}$ नि॰ $\mathrm{A}_{3} \mathrm{~A}_{4} \mathrm{~A}_{7}^{\mathrm{ac}}$, तस्याशनि॰ $\mathrm{A}_{7}^{\mathrm{pc}}$, उल्काशनि॰ $\mathrm{A}_{7}^{\mathrm{pc}}$ (उल्का i.m. possibly cancelled) $34 \mathrm{~b}$ ०दव्ययम् ] $\mathrm{A}_{3}$, ०दव्यय: $\mathrm{A}_{4} \mathrm{~A}_{7} 34 \mathrm{c}$ त्रेलोक्यव्यापि ] त्रिलोचन $\mathrm{A}_{3}$ (unmetrical), त्रिलोचनस्तु $\mathrm{A}_{4}$, त्रिलोचनश्च $\mathrm{A}_{7}$ 35d दहत्रिव ] $\mathrm{A}_{3} \mathrm{~A}_{4},+$ +अ+दह्य+त+ $\mathrm{A}_{7}$

$31\left(b^{2}, d^{1}-d^{4}\right) S_{2} \quad 32\left(c^{1}-c^{2}\right)\left\langle c^{5}\right\rangle\left(c^{6}\right)\left\langle d^{1}\right\rangle S_{1} \quad 33\left\langle a^{1}\right\rangle\left(a^{2}-a^{8}, b^{3}, b^{5}-b^{6}, b^{8}, c^{2}-c^{4}\right)\left\langle c^{5}-c^{6}\right\rangle\left(c^{7}-\right.$ $\left.\mathrm{d}^{1}\right)\left\langle\mathrm{d}^{2}\right\rangle\left(\mathrm{d}^{3}\right)\left\langle\mathrm{d}^{4}\right\rangle\left(\mathrm{d}^{5}-\mathrm{d}^{8}\right) \mathrm{S}_{1} \quad \mathbf{3 4}\left(\mathrm{a}^{1}-\mathrm{a}^{2}, \mathrm{a}^{5}-\mathrm{a}^{7}, \mathrm{~b}^{1}, \mathrm{c}^{6}-\mathrm{c}^{8}, \mathrm{~d}^{4}-\mathrm{d}^{5}\right)\left\langle\mathrm{d}^{6}-\mathrm{d}^{8}\right\rangle \mathrm{S}_{1} \quad \mathbf{3 5}\left(\mathrm{a}^{1}-\mathrm{a}^{2}, \mathrm{c}^{8}\right.$, $\left.d^{4}\right)\left\langle d^{5}\right\rangle\left(d^{6}-d^{7}\right) S_{1}$

$31 \mathrm{a}$ क्षुरान्तं तन्म॰ $] \mathrm{RBh}(\mathrm{em} . ?)$, क्षुरान्तन्तम्म॰ $\mathrm{S}_{1}$, क्षुरा $\left\{\circ\right.$ श॰ $\left.\mathrm{S}_{2}^{\mathrm{ac}}\right\}$ न्तन्तं म॰ $\mathrm{S}_{2}$, क्षुरन्तन्तं म॰ $\mathrm{S}_{3} 31 \mathrm{ab}$ चक्रमब्ज जल०] em., ०चक्रमब्जम्बल० $\mathrm{S}_{1}$, ०चक्र म(ब्ज)ज्जल० $\mathrm{S}_{2}$, ॰चक्र मब्जजल० $\mathrm{S}_{3}$ (unmetrical, or ॰जाल॰), ०चक्र मज्जज्जल॰ Bh (conj.?, in a note Bh suggests गर्जज्जल॰) 31b ॰ चरान्तकम् ] $\mathrm{S}_{1} \mathrm{~S}_{3} \mathrm{Bh}$, ०चरान्तकन् $\mathrm{S}_{2}$ 31c ॰घाति ] $\mathrm{S}_{1} \mathrm{Bh}$, ॰घाती $\mathrm{S}_{2} \mathrm{~S}_{3}$ 31d ॰ भेद्यमविघाति ] $\mathrm{S}_{1} \mathrm{~S}_{2} \mathrm{~S}_{3}$, भेद्यं प्रतिघाति $\mathrm{Bh}$ (conj.) 32cd ] om. $\mathrm{S}_{2}^{\mathrm{ac}}$ ( $\mathrm{S}_{2}^{\mathrm{pc}}$ written i.m.) 32c ${ }^{\circ}$ मागाद्व $\left.{ }^{\circ}\right]$ $\mathrm{S}_{3} \mathrm{RABh}$, ०मागा $\mathrm{S}_{1}$, ${ }^{\circ}$ मागात्व॰ $\mathrm{S}_{2}^{\mathrm{pc}} \quad 33 \mathbf{a}$ तमा० $] \mathrm{S}_{2} \mathrm{~S}_{3} \mathrm{RA}, \simeq\left(\right.$ मा०) $\mathrm{S}_{1}$ (retraced), तदा॰ $\mathrm{Bh}$ (em.) 33b सर्वतः ] $\mathrm{S}_{2} \mathrm{~S}_{3} \mathrm{R}^{\mathrm{pc}} \mathrm{ABh}$, (स)र्व(श): $\mathrm{S}_{1}$ (retraced) 33c पेतुर् ] $\mathrm{S}_{1}$ (retraced) $\mathrm{S}_{2} \mathrm{~A}$

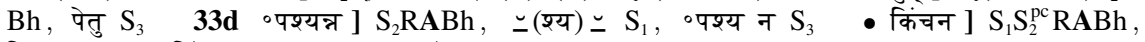
किश्चन: $S_{2}^{\text {ac }}$, किंचन: $S_{3}$ 34b रूपं ] $S_{1} S_{2} A B h$, रूप $S_{3}$ (unmetrical) - ०दव्ययम् ] $S_{1} S_{2} A_{3}$ $\mathrm{Bh}$, ०दव्यं $\mathrm{S}_{3}$ (unmetrical) 34c त्रैलोक्यव्यापि ] $\mathrm{S}_{1} \mathrm{~S}_{2} \mathrm{RBh}$, त्रैलोक्या 〈वि $\rangle+$ व्या+पि $\mathrm{S}_{3}$ - चिक्षेप ] $\mathrm{S}_{1} \mathrm{~S}_{2} \mathrm{~S}_{3}^{\mathrm{pc}} \mathrm{RABh}$, विक्षे $\mathrm{S}_{3}^{\mathrm{ac}}$ (unmetrical) 34d नादयन् ] RABh, नादयत् $\mathrm{S}_{2} \mathrm{~S}_{3}$ 35a तद्युगा०] $\mathrm{S}_{1}^{\mathrm{pc}} \mathrm{S}_{2} \mathrm{~S}_{3} \mathrm{RABh}$, (नम)गा॰ $\mathrm{S}_{1}^{\mathrm{ac}}$ - ०प्रख्यं ] $\mathrm{S}_{2} \mathrm{RABh}$, ०प्रर्य $\mathrm{S}_{1} \mathrm{~S}_{3}$ 35b क्षुरान्तं ] $\mathrm{S}_{1} \mathrm{~S}_{2}^{\mathrm{pc}} \mathrm{RABh}$, क्षुरन्त $\mathrm{S}_{2}^{\text {ac }}$, क्षुरन्त $\mathrm{S}_{3}$ - स्फोटयन्नभः ] $\mathrm{S}_{2} \mathrm{~S}_{3} \mathrm{RABh}$, स्फोटसत्रिभ: $\mathrm{S}_{1}$ 35c दानवं ] $\mathrm{S}_{1} \mathrm{~S}_{2}^{\mathrm{pc}} \mathrm{S}_{3} R A$ $\mathrm{Bh}$, दानवां $\mathrm{S}_{2}^{\mathrm{ac}}$ - क्षिप्रं ] $\mathrm{S}_{1} \mathrm{~S}_{2} \mathrm{~S}_{3}^{\mathrm{pc}} \mathrm{ABh}$, (प्रक्ष्यं) $\mathrm{S}_{3}^{\mathrm{ac}}$ 35d सर्वा ] $\mathrm{S}_{1} \mathrm{~S}_{2} \mathrm{~S}_{3}^{\mathrm{pc}} \mathrm{RABh}$, सर्वां $\mathrm{S}_{3}^{\mathrm{ac}}$ - दहत्निव ] $\mathrm{S}_{2} \mathrm{RA}_{3} \mathrm{~A}_{4} \mathrm{Bh}$, $\sim$ (हत्रि)व $\mathrm{S}_{1}$, दहनिव $\mathrm{S}_{3}$ (unmetrical) 


\section{तं स दानवशार्दूल उपयान्तं महारवम्। \\ जघानास्त्रैर्बहुविधैरव्यथः शक्तिनन्दन॥ ३६॥ \\ तच्च तानि महाचऋमस्त्राण्यनलसंनिभम्। \\ चकार भस्मसाद्यास जगाम च विनादयत्॥ ३७॥ \\ अथ मायां समासर्जत्तेजसीं पार्थिवामपि। \\ वायव्यां वारुणीं चैव तामसीमिन्द्रियात्मिकाम्॥ ३५॥ \\ तथैवोत्पातिकीं मायां मोहनीं स्तम्भनीमपि। \\ निवर्तनीं जम्भनीं च चकारान्याश्च संयुगे॥ ३९ ॥ \\ ता: सर्वास्तत्तदा चक्र महड्दीममनाशयत्। \\ गत्वा तस्य शिर: कायादुन्ममाथ यथाचलम्॥ ४०॥}

36b उपयान्तं महारवम् ] उपायान्तं महाबलम् $R \quad 37 a$ तच्च ] तस्य $R \quad 37 d$ ॰नादयत् ] ॰नादयन्

$R \quad 38 a b$ समासर्जत्तेजसीं पार्थिवामपि ] स मायावी तेजसीयात्मिकामयी $R \quad 38 c$ वायव्यां] वायवीं $R$ 39a व्वोत्पातिकीं ] ॰वोत्पत्तिकां $R \quad 39 b$ मोहनों ] मोहिनी॰ $R$ • ॰मपि ] ॰मयीम् $R$ 39c निवर्तनीं जम्भनीं च ] निबन्धनीं जृम्भनीक्चैव $R$ (unmetrical) 39d ०रान्याश्च ] ०रान्यानि R 40ab ] ताः सर्व्वा निगृहीत्वा तु तच्चक्र भीमदर्शनम् $R \quad 40 d$ ॰दुन्ममाथ यथाचलम् ] ॰दुन्ममन्थ महाबलम् $R$

36-37 ] om. $\mathrm{A}_{7}$ 36a स दानव॰] सदा नर॰ $\mathrm{A}_{3} \mathrm{~A}_{4}$ 36 b उपयान्तं ] उपायांतं $\mathrm{A}_{3} \mathrm{~A}_{4}$ 36d ०रव्यथः शक्तिनन्दन ] ०रव्यग्रो दितिनंदनः $\mathrm{A}_{3} \mathrm{~A}_{4}$ 37d ०नादयत् ] ०नादयन् $\mathrm{A}_{3} \mathrm{~A}_{4}$ 38ab ] अथ मायांत संयुज्य ते $\left\{\right.$ तै $\left.\mathrm{A}_{4}\right\}$ जसीं पार्थिवीमपि $\mathrm{A}_{3} \mathrm{~A}_{4}$, +ततो दैत्यश्च सहसा+ तेजसीं पार्थिवीमपि $\mathrm{A}_{7} 38 \mathrm{c}$ वायव्यां ] वायवीं $\mathrm{A}_{3}$, वायवी० $\mathrm{A}_{4} \mathrm{~A}_{7} \quad 38 d$ ०मिन्द्रियात्मिकाम् ] ०मित्रियात्मिक $\mathrm{A}_{7}^{\mathrm{pc}}$, ०मित्रियार्थिक $\mathrm{A}_{3}^{\mathrm{ac}} \mathrm{A}_{7}^{\mathrm{ac}}$, ०मित्रिपार्थिक $\mathrm{A}_{3}^{\mathrm{pc}} \mathrm{A}_{4} \quad 39 \mathrm{a}$ ०वोत्पातिकीं ] ०व योगिनां $\mathbf{A} \quad 39 \mathrm{c}$ ०नीं जम्भनीं च ] $\mathrm{A}_{7}$, ०निं जंभनिं च $\mathrm{A}_{3}$, ०निजभनिचं $\mathrm{A}_{4}$ (unmetrical) 39d ०रान्याश्च्च] $\mathrm{A}_{3} \mathrm{~A}_{7}$, ०र न्याश्च $\mathrm{A}_{4} \quad$ 40ab ] ता: सर्वा नि $\left\{\right.$ णि० $\left.\mathrm{A}_{3} \mathrm{~A}_{4}\right\}$ गृहीत्वा तु तच्चक्क भीमनादवत् $\mathbf{A} 40 \mathrm{c}$ गत्वा ] भित्वा $\mathbf{A} \bullet$ शिर: ] $\mathrm{A}_{3} \mathrm{~A}_{7}$, शिव: $\mathrm{A}_{4}$

$39\left(d^{4}\right) S_{1}$

36a तं स ] $\mathrm{S}_{1} \mathrm{RA}_{3} \mathrm{~A}_{4}$, स तन् $\mathrm{S}_{2}$, स तं $\mathrm{S}_{3}^{\mathrm{pc}}$, स नं $\mathrm{S}_{3}^{\mathrm{ac}}$, तत् स $\mathrm{Bh}\left(\mathrm{em}\right.$. ?) $\bullet$ वार्दूल ] $\mathrm{S}_{1} \mathrm{~S}_{2} \mathrm{RA}_{3}$ $\mathrm{A}_{4} \mathrm{Bh}$, ०शादूल $\mathrm{S}_{3} \quad 36 \mathrm{~b}$ उपयान्तं ] $\mathrm{S}_{1} \mathrm{~S}_{2} \mathrm{~S}_{3}^{\mathrm{pc}} \mathrm{Bh}$, उपयात $\mathrm{S}_{3}^{\mathrm{ac}}$ 36c ०नास्त्रैर ] $\mathrm{S}_{1} \mathrm{~S}_{2} \mathrm{RA}_{3} \mathrm{~A}_{4} \mathrm{Bh}$, ॰ नास्त्रै $S_{3} \quad 36 d$ ०रव्यथः ] $S_{2} S_{3} R B h$, ०रव्यथ $S_{1}$ (unmetrical) • शक्ति॰] $S_{1} S_{3} R B h$, शक्ति॰ $\mathrm{S}_{2}$ - ननन्दन ] $\mathrm{S}_{2}^{\mathrm{pc}} \mathrm{RBh}$, ०नन्धन $\mathrm{S}_{1}$, ॰नन्दन: $\mathrm{S}_{2}^{\mathrm{ac}} \mathrm{S}_{3}$ 37a तच्च $] \mathrm{S}_{1} \mathrm{~S}_{2} \mathrm{~S}_{3}^{\mathrm{pc}} \mathrm{A}_{3} \mathrm{~A}_{4} B \mathrm{Bh}$, त च $\mathrm{S}_{3}^{\mathrm{ac}}$ - तानि ] $S_{1}^{\text {pc }} S_{2} S_{3} R_{3} A_{4} B h$, नानि $S_{1}^{\text {ac }} \quad 37 b$ ०णयनलसंनिभम् ] $\mathrm{S}_{1} \mathrm{~S}_{2} \mathrm{~S}_{3}^{\text {pc }} \mathrm{RA}_{3} \mathrm{~A}_{4} B h$, ०णयललसनिभम् $\mathrm{S}_{3}^{\mathrm{ac}}$ (unmetrical) 37c भस्मसाद् ] $\mathrm{S}_{1}^{\mathrm{pc}} \mathrm{S}_{3}^{\mathrm{pc}} \mathrm{RA}_{3} \mathrm{~A}_{4} \mathrm{Bh}$, भस्मसा $\mathrm{S}_{1}^{\mathrm{ac}} \mathrm{S}_{2} \mathrm{~S}_{3}^{\mathrm{ac}}$ 37d ननादयत् ] $\mathrm{S}_{2} \mathrm{~S}_{3}$, ०नादयन् $\mathrm{S}_{1} \mathrm{Bh}$ 38ab मायां समासर्जत्तेजसीं ] conj., माया $\left\{{ }^{\circ}\right.$ मा० $\left.\mathrm{S}_{1}^{\mathrm{ac}}\right\}$ मसार्ज्यन्ते तेजस्वी $\mathrm{S}_{1}$, माया समावब्जत्तेजसीम् $\mathrm{S}_{2}$ (or ॰ ब्जन्ते०), माया समावब्जा तेजसीं $\mathrm{S}_{3}$ (or ॰ ब्ज), मायां समसृजत् तैजसीं $\mathrm{Bh}$ (conj.) 38b पार्थिवामपि ] em., पार्थिवानपि $\mathrm{S}_{1} \mathrm{~S}_{2} \mathrm{~S}_{3}$, पार्थिवीमपि $\mathrm{Bh} 38 \mathrm{c}$ वायव्यां ]

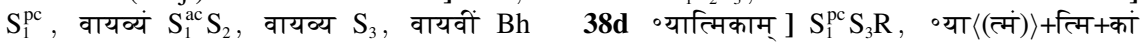
$\mathrm{S}_{1}$, ०यात्मकां $\mathrm{S}_{2} \mathrm{Bh}$ 39a ०वोत्पातिकीं ] $\mathrm{S}_{2} \mathrm{~S}_{3}^{\mathrm{pc}}$, ०वोत्पातिकीन् $\mathrm{S}_{1}$, ०वोत्पताकि $\mathrm{S}_{3}^{\mathrm{ac}}$ (unmetrical), ०वोत्पातकीं Bh (em.?) 39b मोहनों ] $A B h$, मोहनी॰ $\mathrm{S}_{1} \mathrm{~S}_{2} \mathrm{~S}_{3}$ (anusvāra possibly lost in $\mathrm{S}_{1}$ ) • स्तम्भनी॰ ] $\mathrm{S}_{1}^{\mathrm{pc}} \mathrm{S}_{2} \mathrm{~S}_{3} \mathrm{RABh}$, स्तम्भ॰ $\mathrm{S}_{1}^{\mathrm{ac}}$ (unmetrical) 39c निवर्त॰ $\mathrm{S}_{2} \mathrm{~S}_{3} \mathrm{ABh}$, निर्वर्त्त॰ $\mathrm{S}_{1}$ • ०नीं जम्भनीं ] $\mathrm{S}_{1} \mathrm{~S}_{2} \mathrm{~A}_{7} \mathrm{Bh}$, ०नी जम्भनी $\mathrm{S}_{3} \quad 39 \mathrm{~d}$ ०रान्याश्च ] $\mathrm{A}_{3} \mathrm{~A}_{7} \mathrm{Bh}$, ०रा(पा)च्च $\mathrm{S}_{1}^{\mathrm{pc}}$, ० रा(न्या)च्च $\mathrm{S}_{1}^{\mathrm{ac}}$, ०रान्यांग्च $\mathrm{S}_{2} \mathrm{~S}_{3}$ - संयुगे ] $\mathrm{S}_{1} \mathrm{~S}_{2} \mathrm{RABh}$, सयुगे $\mathrm{S}_{3}$ (unmetrical) 40a ता: सर्वास्तत्तदा ] em. $\mathrm{Bh}$, ता सर्वास्त्रन्तदा $\mathrm{S}_{1}$, तां सर्वान्तत्तदा $\mathrm{S}_{2}$, तां सर्वां तत्तदा $\mathrm{S}_{3}^{\mathrm{pc}}$, ता सर्वनत्तदा $\mathrm{S}_{3}^{\mathrm{ac}} \quad \mathbf{4 0 b}$ महद्रीममनाशयत् ] conj., सुमहड़ीमनादवत् $\mathrm{S}_{1}$, सुमहड़ीम नादयत् $\mathrm{S}_{2} \mathrm{~S}_{3}$, नाशयद् भीमनादवत् Bh (conj.) 40c शिर: ] $\mathrm{S}_{1} \mathrm{~S}_{2} \mathrm{~S}_{3}^{\mathrm{pc}} \mathrm{RA}_{3} \mathrm{~A}_{7} \mathrm{Bh}$, शिर $\mathrm{S}_{3}^{\mathrm{ac}}$ (unmetrical) 


\title{
तत्तेन कृत्तं सुमहच्छिरो डग्यं व्यात्ताननागिन्रतिमोग्रनेत्रम् ।

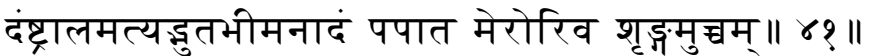 रथाड़निष्पीतवपुर्विरागं न भाति तद्वक्रमतीव दीनम्। निशाप्रहाणौ विनिवृत्तरश्मि बिम्बं यथा चन्द्रमसो विशोभम्॥ ४२॥ तद्धन्तपड्किच्छुदमादशानं मुहुश्च दन्तान्यपि संदशानम्। पपात दैत्यस्य शिरो निकृत्तं यथा गिरे: शृड़्मतिप्रवृद्धम्॥ ४३॥
}

\author{
इति स्कन्दपुराणे सप्रोत्तरशतो डध्याय:॥ १०७॥
}

41a सुमहच्छिरो उग्यं] शिरमुग्ररूपं $R \quad 41 b$ ] व्या $\left\{\right.$ व्य॰ $R^{a c}$ \}त्तास्यमग्निप्रतिमझ्च नेत्रम् $R \quad 41 c$

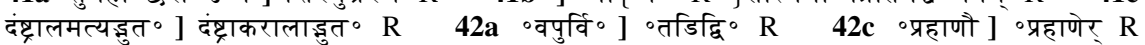
42d ०रश्मि बिम्बं] ०रश्मिरयं $R$ 43ab ] तद्तन्तयुक्त च्छदमानमालमुद्यम्य दन्तावलिमादधानम् $R$ Col. इति स्कन्दपुराणे रेवाखण्डे इध्याय: $\mathrm{R}$

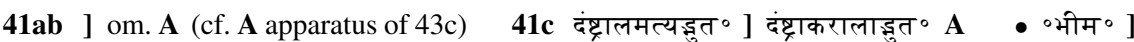
$\mathrm{A}_{7}$, ०भीत० $\mathrm{A}_{3} \mathrm{~A}_{4}$ 42a ] रथात्रिष्टीतवसहिरागं $\mathrm{A}_{3} \mathrm{~A}_{4}$ (unmetrical), रथा(स्थिष्टी)तवससंरागं $\mathrm{A}_{7}^{\mathrm{ac}}$ (unmetrical), रथा(स्थि)हीनं वससंविरागं $\mathrm{A}_{7}^{\mathrm{pc}} \mathbf{4 2 b}$ तद्वक्र० ${ }^{\circ} \mathrm{A}_{7}^{\mathrm{ac}}$ ?, तद्वकु० $\mathrm{A}_{3} \mathrm{~A}_{4}$, तद्वहू॰ $\mathrm{A}_{7}^{\mathrm{pc}}$

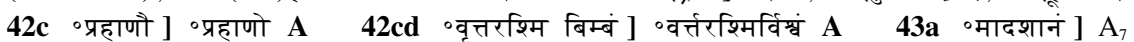
॰मादशाल $\mathrm{A}_{3} \mathrm{~A}_{4} \quad 43 \mathrm{~b}$ ] om. $\mathrm{A} \quad 43 \mathrm{c}$ After this $\mathrm{A}$ has one pāda reading सुमहच्छिरो $\left\{{ }^{\circ}\right.$ वो॰ $\left.\mathrm{A}_{4}\right\}$ ग्रं क्या $\left\{\right.$ वा० $\mathrm{A}_{3}$, व्य० $\left.\mathrm{A}_{7}\right\}$ त्तास्यमग्नि $\left\{\right.$ ०िनर $\left.\mathrm{A}_{7}\right\} \mathbf{A}$ (unmetrical, cf. 41ab) Col. इति इइति ग्री॰ $\left.\mathrm{A}_{3} \mathrm{~A}_{7}\right\}$ स्कन्दपुराणे एकाशीतिसाहस्रचां संहितायामम्बिकाखण्डे षडुत्तरशततमो ध्यायः $\mathbf{A}$

$41\left(c^{5}, d^{4}\right) S_{1},\left(a^{9}\right) S_{3} \quad 42\left(a^{4}, a^{8}-a^{9}\right) S_{1} \quad 43\left(c^{6}-c^{8}, c^{11}\right) S_{3}$

41a कृत्तं ] $\mathrm{S}_{1}^{\mathrm{pc}} \mathrm{S}_{2} \mathrm{~S}_{3} \mathrm{RBh}$, कृतं $\mathrm{S}_{1}^{\mathrm{ac}}$ (unmetrical) - ०च्छिरो डग्यं ] $\mathrm{S}_{2} \mathrm{~S}_{3} B h$, ०न्छिरोग्रं $\mathrm{S}_{1}$ 41b व्यात्ताननाग्नि॰ ] em. Bh (silently), व्याप्ताननागिन० $S_{1}$, व्यात्तानमग्नि॰ $S_{2}^{\text {ac }} S_{3}$, संध्मातमग्नि॰ $S_{2}^{p c}$ 41c दंष्ट्राल॰] $\mathrm{S}_{1}^{\mathrm{pc}} \mathrm{S}_{2} \mathrm{Bh}$, दंष्ट्रा॰ $\mathrm{S}_{1}^{\mathrm{ac}}$ (unmetrical), दाष्टाल॰ $\mathrm{S}_{3} \bullet{ }^{\circ}$ मत्यड़ुतभीम॰ $\mathrm{S}_{1}^{\mathrm{pc}} \mathrm{S}_{2} \mathrm{~S}_{3}^{\mathrm{pc}} \mathrm{Bh}$,

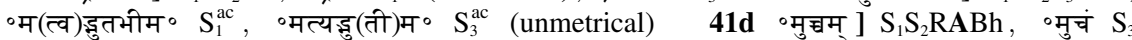
(unmetrical) 42a ०निष्पीत० ] $S_{1}^{\text {ac }} S_{2} S_{3} R B h$, ( न दि)ष्पीत० $S_{1}^{\text {pc }}$ (retraced) • ०वपुर्वि॰] $S_{2} B h$, ०व(पु वि) $\mathrm{S}_{1}^{\text {ac }}$ (upper part of वि lost, unmetrical), ०व(कृ०) $\mathrm{S}_{1}^{\mathrm{pc}}$ (unmetrical), ०वपु वि॰ $\mathrm{S}_{3}$ (unmetrical) 42b भाति ] $\mathrm{S}_{2} \mathrm{~S}_{3} \mathrm{RABh}$, भावि $\mathrm{S}_{1}$ - ०मतीव ] $\mathrm{S}_{1} \mathrm{~S}_{2} \mathrm{~S}_{3}^{\mathrm{pc}} \mathrm{RABh}$, ०मीतीव $\mathrm{S}_{3}^{\mathrm{ac}}$ (unmetrical) 42c ०प्रहाणौ] $S_{1}$, ०प्रहाणो $S_{2} S_{3}$, ०प्रहाणे Bh (conj.) • ०रश्मि बिम्बं] $S_{1} S_{3}$ $\mathrm{Bh}$, ०रश्मिर्बिम्बं $\mathrm{S}_{2}$ 42d विशोभम् $] \mathrm{S}_{2} \mathrm{~S}_{3} \mathrm{RABh}$, हि शोभम् $\mathrm{S}_{1}$ 43a तद्नन्त० ] $\mathrm{S}_{1} \mathrm{~S}_{2} \mathrm{RABh}$, त दन्त॰ $\mathrm{S}_{3}$ • ॰मादशानं ] $\mathrm{S}_{1} \mathrm{~S}_{2}^{\mathrm{ac}} \mathrm{S}_{3} \mathrm{~A}_{7} \mathrm{Bh}$, ०मादधानं $\mathrm{S}_{2}^{\mathrm{pc}} \quad \mathbf{4 3 b}$ दन्तान्यपि ] $\mathrm{S}_{1} \mathrm{~S}_{2} \mathrm{~S}_{3}^{\mathrm{pc}}$, दण्डन्यपि $\mathrm{S}_{3}^{\mathrm{ac}}$, दन्तानपि $\mathrm{Bh}(\mathrm{em}$.$\left.) - संदशानम् \right] \mathrm{S}_{1} \mathrm{~S}_{2}^{\mathrm{ac}} \mathrm{S}_{3} \mathrm{Bh}$, सन्दधानं $\mathrm{S}_{2}^{\mathrm{pc}}$ 43d गिरे: ] $\mathrm{S}_{2} \mathrm{RABh}$, गिरे $\mathrm{S}_{1} \mathrm{~S}_{3}$ - ववृद्धम् ] RABh, ॰वृद्धमिति $\mathrm{S}_{1} \mathrm{~S}_{2} \mathrm{~S}_{3}$ (इति part of col.) Col. $\odot \|$ स्कन्दपुराणे हिरण्यावधे (आ)ध्यायः १६? (in letter numerals)॥ $\odot \mathrm{S}_{1}$, स्कन्दपुराणे (सत्तोत्तरशतो द्याय)॥ $\mathrm{S}_{2}^{\mathrm{ac}}$, स्कन्दपुराणे हिरण्याक्षवधे सप्तोत्तरशतो द्यायः ॥ $\mathrm{S}_{2}^{\mathrm{pc}}, \odot \|$ स्कन्दपुराणे हिरण्याक्षवधे द्यायः १०९. (in letter numerals)॥ $\odot \mathrm{S}_{3}$, इति स्कन्दपुराणे हिरण्याक्षवधे सप्तोत्तरशतोध्याय: $\mathrm{Bh}$ 
अष्टोत्तरशतो डध्यायः।

सनत्कुमार उवाच।

तस्मिन्विनिहते दैत्ये सुराः सर्वे उभितुष्टुवुः।

ऋषयश्च तपोयुकाः पुष्पवृष्ट्यश्च पेतिरे॥ ?॥

देवदुन्दुभयो नेदुरदृश्या: सुमहास्वनाः।

भूतानां चाभवच्छुर्म प्रकृतिस्थं जगद्वभौ॥ २॥

जगामादृश्यतां चकं ततः स्वस्था बभुः सुराः।

ऋषयश्चैव लोकाश्च दैत्यं च ददृशुर्हतम्॥ ३॥

असुरापि हि ते सर्वे पुरद्वाराणि सर्वशः।

पिधाय यत्नात्संनद्धाः प्राकारेष्ववतस्थिरे॥ $6 ॥$

ते भीता मुक्तकेशाश्च रजोध्वस्ता भयार्दिता:।

जीवितं संपरीप्सन्तः स्थिता: प्राकारगास्तदा॥ $y \|$

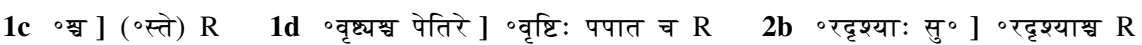
$2 c$ वच्छर्म ] ०वत् कान्ति: $R 3 b$ स्वस्था ] सुस्था $R$ 4a असुरापि हि ] असुराश्चापि $R \quad 4 b$ पुरद्वाराणि ] दुद्रवुश्चैव $\mathrm{R}^{\mathrm{pc}}, \simeq($ द्व $) \simeq \asymp($ स्थ $) \mathrm{R}^{\mathrm{ac}} \quad 4 \mathrm{c}$ ०त्संनद्धाः ] ॰द्वान्नद्धाः $\mathrm{R} \quad 4 \mathrm{~d}$ ॰ ब्ववतस्थिरे ] ॰षु रणात्तततः R (unmetrical) $5 c$ संपरीप्सन्तः ] परिलप्स्यन्तः $R \quad 5 d$ ०गास्तदा ] ०संस्थिताः $R$

$1 d$ ०वृष्ट्यश्च पेतिरे ] ॰वृष्टिं पपातिरे $A \quad 2 b$ ॰महास्वना: ] $A_{7}$, ०महात्मना $\mathrm{A}_{3} \mathrm{~A}_{4} \quad 2 c$ ०नां चाभवच्छर्म ] नामभवच्चर्म $A 3 b$ स्वस्था ] सुस्था $A$ 3d दैत्यं च] तं दैत्यं $A$ a $4 a$ असुरापि हि ] असुरा अपि $\mathrm{A} 4 \mathrm{c}$ पिधाय ] $\mathrm{A}_{3} \mathrm{~A}_{7}^{\mathrm{pc}}$, विधाय $\mathrm{A}_{4}$, 〈वि $\rangle$ पिधाय $\mathrm{A}_{7}$ - यत्नात् ] यत्ता: $\mathrm{A}_{3}$, यत्ता $\mathrm{A}_{4} \mathrm{~A}_{7} \quad 4 d$ प्राकारेष्ववतस्थिरे ] $\mathrm{A}_{7}$, प्रविकारेष्ववस्थिरे $\mathrm{A}_{3} \mathrm{~A}_{4}$ 5a भीता ] $\mathrm{A}_{4} \mathrm{~A}_{7}$, भिता $\mathrm{A}_{3} \mathbf{5 b}$ रजो॰ ] $A_{7}$, राजा० $A_{3} A_{4} 5 c$ संपरीप्सन्तः ] स्वं परीप्सन्तः $A$ 5d स्थिताः प्राकारगास्तदा ] प्राकारांत $\left\{\circ\right.$ रान्तः० $\left.\mathbf{A}_{7}\right\}$ स्थितास्तदा $\mathbf{A} \pm$

Manuscripts available for this chapter: $S_{1}$ photos $4.7 \mathrm{a}\left(\right.$ f. $165^{\mathrm{v}}$ ), $4.8 \mathrm{~b}\left(\right.$ f. $166^{\mathrm{r}}$ ) and $4.9 \mathrm{a}\left(\right.$ f. $166^{\mathrm{v}}$ ); $\mathrm{S}_{2}$ exposures $115 \mathrm{~b}-116 \mathrm{~b}$ (f. $150^{\mathrm{r}}-151^{\mathrm{r}}$ ); $\mathrm{S}_{3}$ f. $165^{\mathrm{v}}-166^{\mathrm{v}} ; \mathrm{R}$ f. $181^{\mathrm{v}}-182^{\mathrm{r}} ; \mathrm{A}_{3}$ f. $108^{\mathrm{v}}-109^{\mathrm{r}} ; \mathrm{A}_{4}$ f. $152^{\mathrm{v}}-153^{\mathrm{v}} ; \mathrm{A}_{7}$ f. $153^{\mathrm{v}}-154^{\mathrm{v}}$. $\mathbf{3}\left(\mathrm{b}^{3}-\mathrm{b}^{4}\right) \mathrm{S}_{1} \quad \mathbf{4}\left\langle\mathrm{a}^{1}-\mathrm{a}^{2}\right\rangle\left(\mathrm{c}^{1}\right) \mathrm{S}_{1} \quad \mathbf{5}\left(\mathrm{a}^{7}\right) \mathrm{S}_{1}$

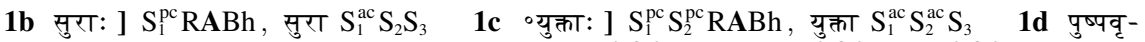
क्यश्च ] $\mathrm{S}_{2}^{\mathrm{pc}} \mathrm{S}_{3} \mathrm{Bh}$, पुष्पवृष्ट्याश्च $\mathrm{S}_{1}$, प्रष्पवृष्ट्यश्च $\mathrm{S}_{2}^{\mathrm{ac}}$ - पेतिरे ] $\mathrm{S}_{2} \mathrm{~S}_{3} B h$, यदिरे $\mathrm{S}_{1}^{\mathrm{pc}}$, पेदिरे $\mathrm{S}_{1}^{\mathrm{ac}} 2 \mathrm{c}$ ॰नां चाभवच्छ॰] $S_{2} S_{3} B h$, ॰नास्च भवच्छ, $S_{1}$ 2d जगद्व $] S_{1} S_{2} R A B h$, जगाद्व० $S_{3}$ 3ab जगामादृश्यतां चक्र ततः ] $S_{1} S_{2} R A B h$, जगाम दृश्यता चक्र तत+: $+S_{3}$ 3b बभु: ] $S_{2} S_{3} R A$, ०भवन् $\mathrm{S}_{1} \mathrm{Bh}$ - सुरा: ] $\mathrm{S}_{1} \mathrm{~S}_{2} \mathrm{~S}_{3}^{\mathrm{pc}} \mathrm{RABh}$, स्वरा: $\mathrm{S}_{3}^{\mathrm{ac}}$ 3d च ] $\mathrm{S}_{1} \mathrm{~S}_{2} \mathrm{~S}_{3} \mathrm{R}$, तं $\mathrm{Bh}$ (conj.) • ददृशुर ] $\mathrm{S}_{1} \mathrm{~S}_{2} \mathrm{RABh}$, ददृशु $\mathrm{S}_{3}$ (unmetrical) $4 a$ असुरापि हि ] $\mathrm{S}_{2} \mathrm{~S}_{3}, \simeq \simeq$ रापि हि $\mathrm{S}_{1}$, असुरा अपि $\mathrm{Bh}$ - ते स० $] S_{1} R A B h$, तेस्स० $S_{2}^{p c}$, तैस्स॰ $S_{2}^{\mathrm{ac}}$, तै स० $S_{3} 4 \mathbf{b}$ पुर० $] S_{1}^{\mathrm{pc}} S_{2} S_{3} A B h$, पुरा॰ $S_{1}^{\mathrm{ac}}$

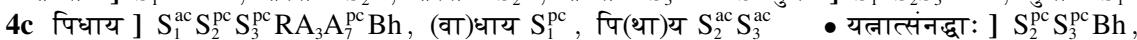
यत्ना+:+ सन्नद्धा: $\mathrm{S}_{1}$, यत्नात्सन्नद्धा $\mathrm{S}_{2}^{\mathrm{ac}} \mathrm{S}_{3}^{\mathrm{ac}} \quad \mathbf{4 d}$ प्राकारेष्व०] $\mathrm{S}_{2}^{\mathrm{pc}} \mathrm{S}_{3} \mathrm{~A}_{7}$, प्राकारेस्व॰ $\mathrm{S}_{1}$, प्राकारे (स्व०) $\mathrm{S}_{2}^{\mathrm{ac}}$, प्राकरेष्व $\mathrm{Bh}$ (typo) $5 \mathbf{a}$ भीता ] $\mathrm{S}_{1} \mathrm{RA}_{4} \mathrm{~A}_{7} \mathrm{Bh}$, भीत० $\mathrm{S}_{2} \mathrm{~S}_{3}$ 5b रजो॰] $\mathrm{S}_{1}^{\mathrm{pc}} \mathrm{S}_{2} \mathrm{~S}_{3} \mathrm{RA}_{7} \mathrm{Bh}$, राजो॰ $S_{1}^{\mathrm{ac}}$ - भयार्दिता: ] $\mathrm{S}_{1} \mathrm{~S}_{2}^{\mathrm{pc}} \mathrm{RABh}$, भयार्दिता $\mathrm{S}_{2}^{\mathrm{ac}} \mathrm{S}_{3}^{\mathrm{pc}}$, भयार्दिता $\mathrm{S}_{3}^{\mathrm{ac}}$ 5c जीवितं ] $\mathrm{S}_{1} \mathrm{~S}_{2} \mathrm{R}$ $\mathrm{ABh}$, जीवित $\mathrm{S}_{3}$ (unmetrical) - संपरीप्सन्तः ] $\mathrm{S}_{1} \mathrm{~S}_{2}^{\mathrm{pc}} \mathrm{Bh}$, सम्परीप्सन्त $\mathrm{S}_{2}^{\mathrm{ac}}$, सपरीप्सन्त $\mathrm{S}_{3} 5 \mathbf{5 d}$ स्थिता: ] $\mathrm{S}_{1} \mathrm{~S}_{2}^{\mathrm{pc}} \mathrm{RBh}$, स्थिता $\mathrm{S}_{2}^{\mathrm{ac}} \mathrm{S}_{3}$

- ०स्तदा ] $\mathrm{S}_{2} \mathrm{~S}_{3} \mathrm{~A}_{3} \mathrm{~A}_{7}^{\mathrm{pc}} \mathrm{Bh}$, ०स्तथा $\mathrm{S}_{1}$ 
भगवानपि दीप्तार्चि विषेद्ध इवानलः।

भीषयानो उसुरान्सर्वान्पृथिवीमन्वचिन्वत॥ ६॥

स बहि: सर्वतो ऊन्विष्य उत्पार्य च महीरुहान्।

प्रणष्टामिव गां गोपः समन्तादन्वचिन्वत॥ ७॥

पर्वतान्स तदोत्पार्य देवोद्यानान्यचूर्णयत्।

आरामान्स तडागानि बभअ्ज च ररास च॥ ५॥

ततो दक्षिणतो गत्वा मुहूर्त देवसत्तमः।

शड्द्वं पर्वतमासाद्य ननर्द जलदो यथा॥ ॥

असुरापि हि ते भीताः प्राकारान्तरसंस्थिताः।

अवेक्षन्त मृगेन्द्र तं धावन्तं सर्वतोदिशः॥ १०॥

सो उपि देवस्तदा शड्द्वमुत्पार्य नगमुत्तमम्।

अपश्यत्पृथिवीं बद्धां रक्ष्यमाणां च दानवैः॥ १? ॥

सागराम्भसि विक्षिप्य शड्व्रं तं पर्वतोत्तम्।

अवधीद्दानवान्सर्वान्मेदिन्या ये उभिरक्षिणः॥ ?२॥

6b ०हंविषेद्ध इवानल: ] ०हंविषेवो $\left\{\circ\right.$ व $\left.\mathrm{R}^{\mathrm{ac}}\right\}$ ज्वलानल: $\mathrm{R}$ 6d ०चिन्वत ] ०चिन्तत $\mathrm{R}$ 7c गां गोप: ] गाड़्रेय $\mathrm{R}$ 7d ०चिन्वत ] ०चिन्तत $\mathrm{R} \quad 8 \mathrm{c}$ तडागानि ] तडागांश्च $\mathrm{R} \quad 9 \mathrm{a}$ ततो ] त्रतो $\mathrm{R}^{\mathrm{pc}}$, $\simeq$ तो $R^{\mathrm{ac}} \quad 9 \mathrm{c}$ शड्द्वं] शड्द्व० $\mathrm{R} \quad 10 \mathrm{a}$ असुरापि हि ] असुराश्चापि $\mathrm{R} \quad 10 \mathrm{~b}$ ०संस्थिता: ] ०मास्थिता: $\mathrm{R}$

6a दीप्रार्चिर् ] $\mathrm{A}_{3} \mathrm{~A}_{7}$, दीप्रार्चि $\mathrm{A}_{4}$ 6b ०षेद्ध ] $\mathrm{A}_{3} \mathrm{~A}_{4}$, ०षे(त्म) $\mathrm{A}_{7}$ - इवानलः ] विरोचनः $\mathrm{A}_{3} \mathrm{~A}_{4}$ $\mathrm{A}_{7}^{\mathrm{ac}}$, विवाचलः $\mathrm{A}_{7}^{\mathrm{pc}}$ 6d ०मन्वचिन्वत ] ०मनुचिन्तत $\mathrm{A}_{3} \mathrm{~A}_{7}$, ०मनुचिन्तत् $\mathrm{A}_{4}$ (unmetrical) $7 \mathbf{a}$ स बहिः सर्वतो ऊन्विष्य ] सर्वतोत्क्षप्य वेगेन $A$ 7 7 प्रणष्टामिव ] प्रणप्टानि च $A$ गोपः ] गौद्यः $\mathrm{A}_{3}$, गौघ: $\mathrm{A}_{4} \mathrm{~A}_{7}$ 7d ॰दन्वचिन्वत ] ॰दनुचिन्तयत् $\mathrm{A} \quad \mathbf{8 b}$ देवोद्यानान्य०] देवो $\left\{\circ\right.$ व० $\left.\mathrm{A}_{4}\right\}$ द्वाराण्य० A $8 c$ आरामान् ] अवसान $A$ 8d ररास] ननाद $A$ 9c शड्वं ] $A_{3} A_{7}^{a c}$, शखं $A_{4}$, शङ्वं० $A_{7}^{p c}$ $10 \mathrm{a}$ असुरापि हि ] असुरा अंपि $\mathrm{A} 10 \mathrm{~b}$ ०संस्थिता: ] ०मास्थिता: $\left\{{ }^{\circ}\right.$ तः $\left.\mathrm{A}_{4} \mathrm{~A}_{7}^{\mathrm{ac}}\right\} \mathrm{A} \quad 10 \mathrm{c}$ अवेक्षन्त ] अवेक्षत $A 11 b$ नगमुत्तमम् ] नगसत्तमं $A$ 11d रक्ष्यमाणं ] रक्षमाणं $A$ 12b पर्वतोत्तमम् ] स मृगोत्तमं $\left\{\circ\right.$ मः $\left.\mathrm{A}_{7}^{\mathrm{pc}}\right\} \mathbf{A}$

$\mathbf{6}\left(d^{3}-d^{8}\right) S_{2} \quad 7\left(a^{8}, b^{6}\right) S_{1},\left(a^{1}-a^{3}\right) S_{2},\left(b^{8}\right) S_{3} \quad \mathbf{8}\left(d^{1}-d^{7}\right)\left\langle d^{8}\right\rangle S_{1} \quad \mathbf{9}\left(d^{8}\right) S_{2} \quad \mathbf{1 0}\left\langle b^{1}-b^{3}\right\rangle S_{2}$ $11\left(d^{6}-d^{8}\right) S_{1}$

6a दीप्रार्चिर्] $\mathrm{S}_{1}^{\mathrm{pc}} \mathrm{S}_{2} \mathrm{RA}_{3} \mathrm{~A}_{7} \mathrm{Bh}$, दीपार्चिर $\mathrm{S}_{1}^{\mathrm{ac}}$, दीप्रार्चि $\mathrm{S}_{3}$ 6b ०षेद्ध ] $\mathrm{S}_{2} \mathrm{~S}_{3} \mathrm{~A}_{3} \mathrm{~A}_{4} \mathrm{Bh}$, ०षाक्त $\mathrm{S}_{1}$ 6d ०चिन्वत ] $S_{1} B h$, (०चिन्वतः) $S_{2}$, ०चिन्वत: $S_{3} \quad 7 b$ उत्पाट्य ] $S_{1} S_{2} R A B h$, उत्पाव्या $S_{3}$ • महीरुहान् ] $\mathrm{S}_{1} \mathrm{~S}_{2} \mathrm{RABh}$, महीरु(जा)न् $\mathrm{S}_{3}^{\mathrm{pc}}$, महीरुहं $\mathrm{S}_{3}^{\mathrm{ac}} \quad 7 \mathrm{c}$ प्रणष्टामि॰] $\mathrm{S}_{2} \mathrm{RBh}$, प्रनष्टा इ॰ $\mathrm{S}_{1}$, प्रनष्टामि० $S_{3}$ - गां गोपः ] $S_{2}^{\mathrm{pc}} B h$, गाड़ोपा: $S_{1}$, गां गोप $S_{2}^{\mathrm{ac}} S_{3}^{\mathrm{pc}}$, गा गोप $\mathrm{S}_{3}^{\mathrm{ac}} \mathbf{7 d}$ ०दन्वचिन्वत ] $S_{1} S_{2}^{\text {pc } B h}$, ०दन्वचिन्वतः $S_{2}^{\text {ac }} S_{3}^{\text {ac }}$, ॰दंन्वचिन्वतः $S_{3}^{\text {pc }}$ 8a तदो॰ ] $S_{2} S_{3} R A B h$, ततो॰ $\mathrm{S}_{1} \quad \mathbf{8 b}$ देवो॰ $] \mathrm{S}_{2} \mathrm{~S}_{3} \mathrm{RA}_{3} \mathrm{~A}_{7}$, दैत्यो॰ $\mathrm{S}_{1} \mathrm{Bh}$ - ॰चूर्णयत् $\mathrm{S}_{1} \mathrm{~S}_{2}^{\mathrm{pc}} \mathrm{RABh}$, ॰चूण्ण्णयम् $\mathrm{S}_{2}^{\mathrm{ac}}$, ॰चूण्णयं $S_{3} \quad 8 c$ आरामान् ] $S_{2} R B h$, आराम: $S_{1}$, आरामं $S_{3}$ 9a ततो ] $S_{1} S_{2} S_{3}^{p c} A B h$, भतो $S_{3}^{a c}$

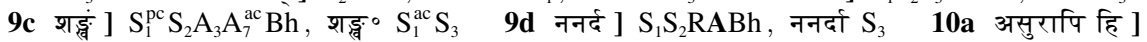
$\mathrm{S}_{1} \mathrm{~S}_{2} \mathrm{~S}_{3}$, असुरा ह्यपि $\mathrm{Bh}$ (conj.) - भीता: ] $\mathrm{S}_{1} \mathrm{~S}_{2}^{\mathrm{pc}} \mathrm{RABh}$, भीता $\mathrm{S}_{2}^{\mathrm{ac}} \mathrm{S}_{3} \quad 10 \mathrm{~b}$ ०संस्थिता: ] $\mathrm{S}_{1}$ $\mathrm{S}_{2} \mathrm{Bh}$, ०सस्थिता+: $+\mathrm{S}_{3} \quad 10 \mathrm{c}$ अवेक्षन्त ] $\mathrm{S}_{1} \mathrm{R}$, अवैक्षन्त $\mathrm{S}_{2} \mathrm{~S}_{3} B h$ मृगेन्द्रं तं ] $\mathrm{S}_{2} \mathrm{RABh}$, मृगे नूनं $S_{1}$, मृगेन्द्रन्त $S_{3} \quad 11 a$ देवस्त॰ $S_{1} S_{2}^{p c} S_{3} R A B h$, देव त॰ $S_{2}^{\text {ac }}$ • शड्व्व० ] $S_{1} S_{3} R A B h$, संख॰ $\mathrm{S}_{2} 11 \mathrm{~b}$ नगमुत्तमम् ] $\mathrm{S}_{1} \mathrm{~S}_{2}^{\mathrm{pc}} \mathrm{RBh}$, नगसत्तम: $\mathrm{S}_{2}^{\mathrm{ac}} \mathrm{S}_{3}$ 11c पृथिवीं बद्धां ] $\mathrm{S}_{3} \mathrm{RABh}$, पृथिवी बद्धा $\mathrm{S}_{1}$ (anusvāras possibly lost), पृथिवीद्यद्धां $S_{2} \quad 11 d$ रक्ष्यमाणां च ] $S_{2} R B h$, रक्ष्यमाणग्च $S_{1}$, रक्ष्यमाणा च $S_{3} 12 b$ शड्व्वं तं ] $S_{1} R A B h$, सङ्वन्तं $S_{2}$, शड्द्वन्त $S_{3} \quad 12 c$ अवधीद् ] $S_{1} S_{2} R A B h$, अवधी $S_{3}$ 
ततो विद्राव्य नागेन्द्रान्प्रगृह्य पृथिवीं बलात् ।

जगाम दैत्यान्संदृश्य रतान्यादाय सर्वशः॥ १३॥

स तां दंष्ट्राड़ुरे लग्नां वहन्भाति मृगेश्वरः।

विषाणलग्नां लम्बन्तीं मृणालीं गजराडिव॥ १६॥

स तां सागरमध्येन वहन्भाति मृगेश्वरः।

वराहरूपी कालान्ते ब्रह्मेव वसुधां पुरा॥ १४ ॥

स सागरं तमुत्तीर्य भगवान्नन्दिवर्धनः।

स्वे स्थाने स्थापयामास महीं तां पुनरेव हि॥ १६॥

ततः शक्राय लोकांस्त्रीनदात्स मधुसूदनः।

उवाच राजा त्वं नो उद्य मित्रं चाहं तवानघ॥ १७॥

ये उन्ये उपि ते उरयः केचिझ्ञविष्यन्त्यसुरेश्वराः।

तेषामपि वधं घोरं करिष्यामि न संशयः॥ १६॥

ततस्तमृषयः सर्वे देवताश्च सवासवाः।

ऊचुः स्वां मूर्तिमास्थाय यथा पूर्वं तथा भव॥ १९॥

$13 \mathrm{c}$ ०न्संदृश्य ] ०न् संकृत्त्य $\mathrm{R} 13 \mathrm{~d}$ रतान्यादाय ] वक्रेणादाय $\mathrm{R}^{\mathrm{pc}}$, वक्राण्यादाय $\mathrm{R}^{\mathrm{ac}} 14 \mathrm{~d}$ मृणालीं ] मृगाणां $R$ 15c ०रूपी ] ०रूप: $R$ 16a तमुत्तीर्य ] समुत्तीर्य $R \quad 17 \mathrm{ab}$ ततः शक्राय लोकांस्त्रीनदात्स ] स शक्राय ददौ लोकांस्त्रींस्तदा $R \quad 18 \mathbf{a b}$ ] अन्ये ऊपि ते उरयो यत्र भविष्यन्ति सुरेश्वर $\mathrm{R} 19 \mathrm{~b} \circ$ श्र्व ] $\mathrm{R}^{\mathrm{ac}}$, ०श्चैव $\mathrm{R}^{\mathrm{pc}}$ (unmetrical) $19 \mathrm{c}$ ऊचुः स्वां मूर्ति॰] ऊचुस्तां वृत्ति॰ $\mathrm{R}$

13a विद्राव्य नागेन्द्रान् ] विद्रावनागेंद्र $\left\{\right.$ गेन्द्रान् $\left.\mathrm{A}_{7}\right\} \mathrm{A} \quad 13 \mathrm{c}$ ०न्संदृश्य ] ०न्संह्तत्य $\mathrm{A} \quad 14 \mathbf{a b}$ लग्नां वहन्भाति ] कृत्वा मेदिनों तां $\mathbf{A} 14 \mathbf{c}$ ०लग्नां लम्बन्तीं ] ०लग्न $\left\{\right.$ ०ग्ना० $\left.\mathrm{A}_{7}^{\mathrm{pc}}\right\}$ कमुन्वन्तीं $\mathbf{A}$ (unmetrical) $14 \mathrm{~d}$ मृणालीं] मृगाणां $\mathrm{A} 15 \mathrm{~b}$ वहन्भाति ] $\mathrm{A}_{7}^{\mathrm{pc}}$, वहतताति $\mathrm{A}_{3}$, वहताति $\mathrm{A}_{4}$, वह(न्ना)ति $\mathrm{A}_{7}^{\mathrm{ac}} 16 \mathbf{a}$ सागरं तमु॰ ] सागरान्तमु॰ $\mathbf{A} 16 \mathrm{~b}$ भगवान् ] $\mathrm{A}_{3} \mathrm{~A}_{7}$, भगवा $\mathrm{A}_{4} \quad 16 \mathrm{c}$ स्वे ] $\mathrm{A}_{3} \mathrm{~A}_{7}$, स्व॰ $\mathrm{A}_{4}$ $17 \mathbf{a b}$ ०स्त्रीनदात् ] $\mathrm{A}_{7}$, ०स्त्रीं नादात् $\mathrm{A}_{3} \mathrm{~A}_{4} 17 \mathrm{c}$ उवाच ] सुरेश $\mathbf{A}$ - त्वं नो उद्य] $\mathrm{A}_{7}$, त्वान्नाद्य

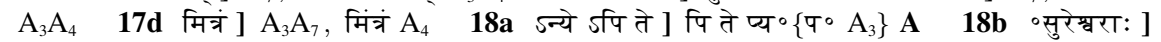
$\mathrm{A}_{3} \mathrm{~A}_{7}$, ०सुरेम्वंरा: $\mathrm{A}_{4}$ 19d भव ] $\mathrm{A}_{4}$, भव: $\mathrm{A}_{3}$, भव+त्+ $\mathrm{A}_{7}$

$13\left(a^{5}\right) S_{1} \quad 15\left(d^{7}\right) S_{1} \quad 17\left(b^{1}-b^{2}\right) S_{1}$

13ab नागेन्द्रान् ] $\mathrm{S}_{1} \mathrm{RA}_{7} \mathrm{Bh}$, नागेन्द्राम् $\mathrm{S}_{2} \mathrm{~S}_{3} \quad 13 \mathrm{c}$ ॰न्संदृश्य ] $\mathrm{S}_{1} \mathrm{~S}_{2}$, ॰न्सदृश्य $\mathrm{S}_{3}$, ०न् संधृष्य $\mathrm{Bh}$ (conj.) 13d रतान्या॰] $S_{2} S_{3}^{\text {pc }} \mathbf{A}$, रत्नाभ्या॰ $S_{1}$, रनान्या॰ $S_{3}^{\text {ac }}$, रत्नान्य $B$ B (typo) 14a तां दंष्ट्राड़ुरे ] RABh, तान्दंष्टान्तरे $S_{1}$, तान्दंष्टाड़ुरा॰ $S_{2}$, तां द्रष्टांकुरा॰ $S_{3}$ 14ab लग्नां वहन् ] $S_{2} R B h$, लग्नो बहद् $S_{1}$, लग्नां वहद् $S_{3} \quad 14 c$ लम्बन्तीं ] $S_{1} S_{3} R B h$, लम्बन्ती $S_{2}$ 14d मृणालीं ] $S_{1} S_{3} B h$, मृंणालीङ् $S_{2} 15 b$ वहन्भा० $] S_{2} R_{7}^{p c} B h$, वहड़ा० $S_{1}$, वह भा० $S_{3}$ 15d ब्रह्मेव ] $S_{1} S_{2} R A B h$, ब्रह्मे थ $\mathrm{S}_{3} 16 \mathrm{~b}$ भगवान् ] $\mathrm{S}_{1} \mathrm{~S}_{2} \mathrm{RA}_{3} \mathrm{~A}_{7} \mathrm{Bh}$, भगवा $\mathrm{S}_{3} 16 \mathrm{c}$ स्वे ] $\mathrm{S}_{1} \mathrm{~S}_{2} \mathrm{~S}_{3} \mathrm{RA}_{3} \mathrm{~A}_{7}$, स्व० $\mathrm{Bh}(\mathrm{em}$. ?) $17 \mathbf{a b}$ ०स्त्रीनदात् ] $\mathrm{S}_{1} \mathrm{~S}_{2}^{\mathrm{ac}} \mathrm{S}_{3} \mathrm{~A}_{7} \mathrm{Bh}$, ०स्त्रीन्नदात् $\mathrm{S}_{2}^{\mathrm{pc}} 17 \mathrm{c}$ राजा $] \mathrm{S}_{1} \mathrm{~S}_{2} \mathrm{RABh}$, राज $\mathrm{S}_{3} 17 \mathrm{~d}$ मित्रं चा॰] $\mathrm{S}_{1} \mathrm{RA}_{3} \mathrm{~A}_{7} \mathrm{Bh}$, मित्रश्चा० $\mathrm{S}_{2} \mathrm{~S}_{3}$ - ०वानघ ] $\mathrm{S}_{1}^{\mathrm{pc}} \mathrm{S}_{2} \mathrm{~S}_{3} \mathrm{RABh}$, ०वानघ: $\mathrm{S}_{1}^{\mathrm{ac}} \quad$ 18a ये ] $\mathrm{S}_{2} \mathrm{~S}_{3} \mathrm{ABh}$, य $\mathrm{S}_{1} \mathbf{1 8 b}$ न्त्यसुरेश्वरा: ] $\mathrm{S}_{1}^{\mathrm{pc}} \mathrm{S}_{2}^{\mathrm{pc}} \mathrm{S}_{3} \mathrm{~A}_{3} \mathrm{~A}_{7} \mathrm{Bh}$, ०न्त्यसुरेश्वसुरेश्वरा: $\mathrm{S}_{1}^{\mathrm{ac}}$ (unmetrical), ०न्ति सुरेग्वरा: $S_{2}^{\text {ac }} 19 \mathrm{c}$ मूर्ति॰ $\mathrm{S}_{1} \mathrm{~S}_{2} \mathrm{ABh}$, मूत्ति॰ $\mathrm{S}_{3}$ 
वराह उवाच।

इयं मूर्तिर्मया देवा: प्राप्ता परमवर्चस:।

न चानया रतिः काचित्प्राप्ता मे सदृशी भुवि॥ २०॥

सो इहं कंचिद्विह्तत्येह कालं मूर्त्यानया सुखम्।

भविष्यामि पुनर्देवः सत्यमेतद्रवीमि वः॥ २१॥

सनत्कुमार उवाच।

तस्य तद्वचननं श्रुत्वा सर्वे देवा: सवासवाः।

प्रदक्षिणमुपावृत्य जग्मुः स्थानानि सर्वशः ॥ २॥

गतेषु देवसंघेषु भगवान्नन्दिवर्धनः।

विजहार सुखं तत्र हत्वा दानवपुंगवम्॥ २३॥

तस्य तत्रोपतिष्ठन्त मृग्यो भूत्वा सहस्रशः ।

वैदिको उप्सरसः शुभ्रास्ताभिः सह रराम सः॥ २४॥

स ताभिर्विचरन्देवो महात्मा नन्दिवर्धनः।

रेमे मत्तो महानागो यथारण्ये करेणुभि:॥ २४॥

20a इयं मूर्तिर् ] इमां मूर्तिं $R \quad 20 \mathrm{~b}$ प्राप्ता ] प्राप्ता: $R \quad 21 \mathrm{a}$ कंचिद्विहत्येह ] किस्चिद्विकृत्याहं $R$ 23a ०संघेषु ] ०संहेषु $R$ 23d ०पुंगवम् ] ०सत्तमम् $R$ 24ab ०तिष्टन्त मृग्यो ] विष्टन्तम्वशा $R$ 24cd ] देविक्यो उप्सरसो रम्या: स्त्रीभिः सह राम ह $\mathrm{R}$

20 वराह उवाच] om. $\mathrm{A} \quad 20 \mathrm{a}$ इयं ] इमां $\mathrm{A}_{3} \mathrm{~A}_{4} \mathrm{~A}_{7}^{\mathrm{ac}}$, इयां $\mathrm{A}_{7}^{\mathrm{pc}}$ - मूर्तिर् ] $\mathrm{A}_{7}$, मूर्त्ति $\mathrm{A}_{3}$, मूर्ति $\mathrm{A}_{4} 20 \mathrm{~b}$ प्राप्ता ] $\mathrm{A}_{3}^{\mathrm{ac}}$, प्राप्ता: $\mathrm{A}_{3}^{\mathrm{pc}} \mathrm{A}_{4} \mathrm{~A}_{7} \quad 20 \mathrm{c}$ चानया रतिः काचित् ] चालयावतिसरित् $\mathrm{A}$ 20d सदृशी ] सदृशं $A$ 21ab ] सो हं क्षचिद्वितत्येह को न मृत्योवया सुखं $\mathrm{A} \pm$ 21c पुनर् ] $\mathrm{A}_{4} \mathrm{~A}_{7}$, पुन $\mathrm{A}_{3}$ (unmetrical) 22b देवा:] $\mathrm{A}_{3} \mathrm{~A}_{7}$, देवा $\mathrm{A}_{4}$ 23c-25b ] om. $\mathrm{A}_{7}^{\mathrm{ac}}, \mathrm{A}_{7}^{\mathrm{pc}}$ written i.m. 24ab ०तिष्ठन्त मृग्यो ] ०तिष्टन्ति मृगा $\left\{\right.$ गोो $\left.\mathrm{A}_{7}^{\mathrm{pc}}\right\} \mathbf{A} \quad \mathbf{2 4 d}$ स: ] $\mathrm{A}_{4} \mathrm{~A}_{7}^{\mathrm{pc}}$, ह $\mathrm{A}_{3}$ 25a ०र्विचरन् ] ०र्विहरन् $\mathbf{A}$ 25b महात्मा नन्दि॰] महानन्दिवि॰ $\mathbf{A}$ - After this $\mathrm{A}_{7}^{\mathrm{pc}}$ adds ग्रीरामः

$20\left(b^{2}\right) S_{1},\left(a^{2}\right) S_{2} \quad 23\left(c^{6}-c^{8}\right)\left\langle d^{1}\right\rangle\left(d^{2}-d^{3}\right) S_{1} \quad 24\left(a^{3}, c^{4}\right) S_{1} \quad 25\left\langle d^{3}\right\rangle\left(d^{4}\right) S_{2}$

20 वराह उवाच ] $\mathrm{S}_{1}^{\mathrm{pc}} \mathrm{S}_{2} \mathrm{~S}_{3} R B h$, om. $\mathrm{S}_{1}^{\mathrm{ac}} \quad$ 20a इयं ] $\mathrm{S}_{1}^{\mathrm{pc}} \mathrm{S}_{2}^{\mathrm{pc}} \mathrm{Bh}$, इमे $\mathrm{S}_{1}^{\mathrm{ac}} \mathrm{S}_{2}^{\mathrm{ac}} \mathrm{S}_{3}$ • मूर्तिर् $] \mathrm{S}_{1} \mathrm{~A}_{7}$ $\mathrm{Bh}$, मूर्ति $\mathrm{S}_{2} \mathrm{~S}_{3}$ - देवा: ] $\mathrm{S}_{1} \mathrm{~S}_{2}^{\mathrm{pc}} \mathrm{RABh}$, देवा $\mathrm{S}_{2}^{\mathrm{ac}} \mathrm{S}_{3} \quad 20 \mathrm{~b}$ प्राप्ता $] \mathrm{S}_{2} \mathrm{~S}_{3} \mathrm{~A}_{3}^{\mathrm{ac}} \mathrm{Bh}$, प्रा(ता): $\mathrm{S}_{1}$ • ०वर्चसः ] $\mathrm{S}_{1} \mathrm{~S}_{2} \mathrm{~S}_{3} \mathrm{RA}$, ०वर्चसा Bh (em.) 20c रतिः ] $\mathrm{S}_{1}^{\mathrm{pc}} \mathrm{S}_{2} \mathrm{~S}_{3} \mathrm{RBh}$, रति $\mathrm{S}_{1}^{\mathrm{ac}}$ (unmetrical) 20d ०त्प्राप्ता ] $\mathrm{S}_{1}^{\mathrm{pc}} \mathrm{S}_{2} \mathrm{~S}_{3} \mathrm{RABh}$, ०त्प्राप्त $\mathrm{S}_{1}^{\mathrm{ac}}$ - सदृशी ] $\mathrm{S}_{2} \mathrm{~S}_{3} \mathrm{RBh}$, सदृशा $\mathrm{S}_{1}$ 21a कंचिद् ] $\mathrm{S}_{2} \mathrm{~S}_{3} \mathrm{Bh}$, किश्चिद् $\mathrm{S}_{1} 21 \mathrm{~b}$ कालं मूत्र्या॰ $\mathrm{S}_{1} \mathrm{~S}_{2} \mathrm{~S}_{3}^{\mathrm{pc}} \mathrm{RBh}$, काल मूत्या० $\mathrm{S}_{3}^{\mathrm{ac}}$ 21c पुनर्देव: ] $\mathrm{S}_{1} \mathrm{RA}_{4} \mathrm{~A}_{7} \mathrm{Bh}$, पुनर्द्रेवा+: $+\mathrm{S}_{2}$, पुन देव: $\mathrm{S}_{3}^{\mathrm{pc}}$ (unmetrical), पुन देवा $\mathrm{S}_{3}^{\mathrm{ac}}$ (unmetrical) 22b देवा: ] $\mathrm{S}_{2} \mathrm{~S}_{3} \mathrm{RA}_{3}$ $\mathrm{A}_{7} \mathrm{Bh}$, देवा $\mathrm{S}_{1}$ 23b भगवान् ] $\mathrm{S}_{1} \mathrm{~S}_{2} \mathrm{RABh}$, भगवा $\mathrm{S}_{3}$ 24a तत्रो॰ ] $\mathrm{S}_{1}^{\mathrm{pc}} \mathrm{S}_{2} \mathrm{~S}_{3} \mathrm{RABh}$ ニ ニ त्रो॰ $\mathrm{S}_{1}^{\mathrm{ac}}$ - ०तिष्टन्त ] $\mathrm{S}_{1}^{\mathrm{ac}} \mathrm{S}_{2}^{\mathrm{ac}} \mathrm{S}_{3} \mathrm{Bh}$, ०तिष्टन्तः $\mathrm{S}_{1}^{\mathrm{pc}}$, ०तिष्टन्तो $\mathrm{S}_{2}^{\mathrm{pc}}$ 24cd शुभ्रास्ताभिः ] $\mathrm{S}_{1} \mathrm{~S}_{2} \mathrm{~S}_{3}^{\mathrm{pc}} \mathrm{A}$ $\mathrm{Bh}$, शुभास्ताभि $\mathrm{S}_{3}^{\mathrm{ac}}$ 24d स: ] $\mathrm{S}_{1} \mathrm{~A}_{4} \mathrm{~A}_{7}^{\mathrm{pc}} \mathrm{Bh}$, च $\mathrm{S}_{2} \mathrm{~S}_{3}$ 25a ताभिर्वि॰] $\mathrm{S}_{1} \mathrm{~S}_{2} \mathrm{RABh}$, ताभि वि॰ $\mathrm{S}_{3}$ 
स सिंह इव सिंहीभिः शार्दूल इव चोत्नदन्।

रराम सागरानूपे ऐरावत इवापरः॥ २६॥

रममाणस्य सिद्धाश्च ऋषयश्च तपोधनाः।

पुष्पाणां रुचिरा वृष्टीः पातयन्ति वियत्सिताः ॥ २७॥

तुष्टुवुश्चापरे नित्यं चक्रुश्चैनं प्रदक्षिणम्।

देवदुन्दुभयो नित्यं सर्व एव न्यवादयन्॥ २५॥

नृत्यन्त्यप्सरसश्चापि वराहस्याग्रतस्तदा।

वादयन्ति च गन्धर्वा गायन्ति च महात्मनः॥ २९ ॥

रमयन्तो वराहं तं देवाश्चेन्द्रपुरोगमाः।

यक्षा: पुण्यजना ये च तथा देवजनाश्च ये॥३०॥

यातुधानाश्च ये केचिद्रह्मधानाश्च सर्वशः।

मनुष्याः पशवश्चैव ऋषयश्चैव सर्वशः॥ ३? ॥

$26 \mathrm{~b}$ चोन्नदन् ] चोद्वहन् $\mathrm{R} 26 \mathrm{c}$ सागरानूपे ] सागराम्भःस्थ $\mathrm{R} 27 \mathrm{a}$ रममाणस्य ] रममाणाश्च $\mathrm{R}$ 27c पुष्पाणां रुचिरा वृष्टी: ] ऋष्याणां रुचिरां वृष्टिं $R \quad 28 \mathrm{a}$ ०श्चापरे ] ० श्चाप्सरो $\mathrm{R} 28 \mathrm{~b}$ ०ख्चैनं] ० श्चैव $R \quad 28 d$ एव न्यवादयन् ] एवाभ्यनादयन् $R \quad 29 b$ ०स्याग्रतस्त॰ ] ०स्यायतस्त॰ $R$ 29c च ] om. $R$ (unmetrical) 30a रमयन्तो] शमयन्तो $R \quad 30 d$ देव॰] पुण्य॰ $R \quad 31 a$ केचिद् ] केचि R $31 b$ सर्वशः ] चापरे $\mathrm{R}$

26b चोन्नदन् ] $\mathrm{A}_{4} \mathrm{~A}_{7}$, चोन्नदम् $\mathrm{A}_{3}$ 26c-28d ] om. A 29a नृत्यन्त्य॰ ] $\mathrm{A}_{7}^{\mathrm{pc}}$, नृत्यंश्चा० ${ }^{\circ}$ चा॰ $\left.\mathrm{A}_{4}\right\} \quad \mathrm{A}_{3} \mathrm{~A}_{4} \mathrm{~A}_{7}^{\mathrm{ac}}$ - व श्चापि ] ०स्तत्र $\mathrm{A} \quad 30 \mathrm{a}$ रमयन्तो] नमयन्तो $\mathrm{A}_{3} \mathrm{~A}_{4}$, नामयन्तो $\mathrm{A}_{7} 30 \mathrm{~d}$

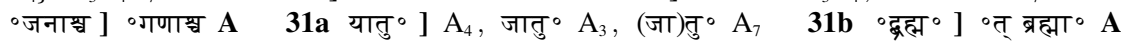

26( $\left(d^{3}, d^{7}-d^{8}\right) S_{1},\left(b^{7}\right) S_{3} \quad 27\left(b^{4}, d^{4}\right) S_{1},\left(c^{2}, d^{5}-d^{7}\right) S_{2} \quad 28\left(a^{4}\right)\left\langle a^{6}\right\rangle\left(a^{7}-a^{8}\right)\left\langle b^{1}\right\rangle\left(c^{4}\right) S_{1} \quad 29\left(c^{4}\right.$, $\left.\mathrm{c}^{8}\right) \mathrm{S}_{1} \quad \mathbf{3 0}\left(\mathrm{a}^{4}-\mathrm{a}^{6}, \mathrm{c}^{1}, \mathrm{~d}^{3}-\mathrm{d}^{4}, \mathrm{~d}^{8}\right) \mathrm{S}_{2} \quad 31\left(\mathrm{~d}^{1}\right)\left\langle\mathrm{d}^{2}\right\rangle\left(\mathrm{d}^{3}\right) \mathrm{S}_{1}^{\mathrm{pc}},\left(\mathrm{c}^{7}, \mathrm{~d}^{2}-\mathrm{d}^{3}\right) \mathrm{S}_{2}$

26a सिंह ] $S_{1} S_{2} R A B h$, सिंहा $S_{3}$ - सिंहीभि: ] $S_{1}^{\text {pc }} S_{2} R A B h$, सिंहाभि $S_{1}^{\mathrm{ac}}$, सिंहीभि $S_{3} 26 \mathbf{b}$ चोत्रदन् ] $\mathrm{S}_{1}^{\mathrm{pc}} \mathrm{S}_{2} \mathrm{~A}_{4} \mathrm{~A}_{7}$, चोत्रदम् $\mathrm{S}_{1}^{\mathrm{ac}}$, चोनदन् $\mathrm{S}_{3}^{\mathrm{pc}}$, चोदन $\mathrm{S}_{3}^{\mathrm{ac}}$, चोन्नदन् Bh (typo, unmetrical) 26c रराम] $S_{2} S_{3} R B h$, ररांम $S_{1} \quad 26 c d$ सागरानूपे $] S_{1}^{\text {pc }} S_{2} S_{3} B h$, साग-रूपे $S_{1}^{\text {ac }}$ 27a रममा-

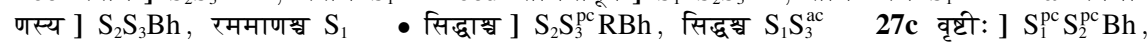
वृष्टी $S_{1}^{\text {ac }} S_{2}^{\text {ac }} S_{3}$ 27d वियत्सिता: ] $S_{2}^{p c} R B h$, वियस्थिता: $S_{1}$, (वियत्सिथ)ता $S_{2}^{a c}$, वियस्थिता $S_{3}$ $28 \mathrm{a}$ तुष्टुवुश्चा०] $S_{1} S_{2} R$, तुष्टुवु चा॰ $S_{3}$, तष्टुवुश्चा॰ $B h$ (typo) $28 b$ ०श्चैनं ] $S_{2} S_{3} B h$, ०श्चेन $S_{1}^{p c}$ (tops lost), ० श्चेव $S_{1}^{\text {ac }}$ (tops lost) 28d सर्व ] $S_{2} S_{3} R B h$, सव $S_{1}$ • एव न्यवादयन् ] em., एव न्यवादयत् $S_{1}$, एवानुवादयन् $S_{2} S_{3}$, एवान्ववादयन् $B h(e m . ?)$ 29a नृत्यन्त्य॰ ] $S_{1}^{p c} S_{2} S_{3} R A_{7}^{p c} B h$, नित्यन्त्य॰ $S_{1}^{\mathrm{ac}} \bullet$ ०सश्चांपि ] $\mathrm{S}_{1} \mathrm{R}$, ०सश्चास्य $\mathrm{S}_{2}^{\mathrm{pc}} \mathrm{Bh}$, ०साश्चास्य $\mathrm{S}_{2}^{\mathrm{acc}} \mathrm{S}_{3} \quad 29 \mathrm{~b}$ ०स्याग्रतस्तदा ] $\mathrm{S}_{1}^{\mathrm{pc}} \mathrm{S}_{2} \mathrm{~S}_{3} \mathrm{ABh}$, ०स्याग्रस्तदा $\mathrm{S}_{1}^{\mathrm{ac}}$ (unmetrical) 29c वादयन्ति च ] $\mathrm{S}_{1}^{\mathrm{pc}} \mathrm{S}_{2}^{\mathrm{pc}} \mathrm{S}_{3} \mathrm{ABh}$, वादय (न्ति) $\mathrm{S}_{1}^{\mathrm{ac}}$ (unmetrical), वदयन्ति च $\mathrm{S}_{2}^{\text {ac }} \quad \mathbf{3 0 a}$ रमयन्तो] $\mathrm{S}_{3} \mathrm{Bh}\left(\mathrm{em}\right.$.), रामयन्तो $\mathrm{S}_{1}$, रंमय(न्तो) $\mathrm{S}_{2}$ 30c यक्षा: ] $\mathrm{S}_{2} R A B h$, यक्षा $\mathrm{S}_{1}$, यक्ष: $\mathrm{S}_{3}$ - ०जना ] $\mathrm{S}_{1} \mathrm{~S}_{2} \mathrm{~S}_{3} \mathrm{RA}$, ०जनना Bh (typo, unmetrical) 31b ध धानाश्च ] $S_{2} S_{3} R A B h$, ०दानाश्च $S_{1}$ 31cd ] om. $S_{1}^{\text {ac }}, S_{1}^{\text {pc }}$ written i.m. 31c मनुष्या: ] $\mathrm{RABh}$, मनुष्या $\mathrm{S}_{1}^{\mathrm{pc}} \mathrm{S}_{2} \mathrm{~S}_{3}$ - ० श्चैव $] \mathrm{S}_{2} \mathrm{~S}_{3} \mathrm{RABh}$, ०श्चेव $\mathrm{S}_{1}^{\mathrm{pc}}$ 
राजन्या: क्षत्रिया: सर्वे निकायाग्चैव सर्वशः।

तत्राजग्मुर्निरीक्षन्तो वराहस्योत्सवं शुभम्।

बह्वाश्चर्यसमाकीर्णं बह्तालक्ष्यं सदैव च॥ ३२॥

एवं तस्याभवद्यास वराहस्य महात्मनः।

उत्सवः सुमहान्दिव्यः प्रत्यहं नन्दिवर्धनः॥ ३३॥

तस्योत्सवो उसौ ऋषिसंघजुष्टः सदा सुरै: सिद्धजनैश्च जुष्टः।

गन्धर्वयक्षोरगराक्षसैश्च विद्याधरैश्चैव सहाप्सरोभिः॥ ३४॥

इति स्कन्दपुराणे इत्टोत्तरशतो इध्यायः ॥ १०५॥

32ab ] om. R 32cd ] तत्रा/गत्य〉 निरीक्षन्ते देवाराधनमुत्तमम् R (unmetrical) 32f बह्वालक्ष्यं ] बहुलक्ष $R$ 33a एवं ] एतत् $R$ 33d नन्दिवर्धन: ] कालरूपिण: $R$ 34a ऋषिसंघ॰] ऋषिसंह॰ $\mathrm{R} 34 \mathrm{~d}$ ० श्चैव सहा॰] ० श्चापि सदा॰ $\mathrm{R}$ Col. इति स्कन्दपुराणे रेवाखण्डे डध्याय: $\mathrm{R}$

32b निकायाग्चै०] नियाकाश्चै॰ $A \quad 32 c$ ०जग्मुर ] $\mathrm{A}_{3} \mathrm{~A}_{7}$, ०जग्मु $\mathrm{A}_{4}$ 32ef ] वद्धाचार्यसमाकीण $\left\{\right.$ णणं $\left.\mathrm{A}_{4}\right\}$ वद्दालक्षं ०क्ष्यं $\left.\mathrm{A}_{7}\right\}$ सदैव च $\mathbf{A} 33 \mathbf{c}$ सु० $] \mathrm{A}_{4}$, स $\mathrm{A}_{3} \mathrm{~A}_{7}$ - ०न्दिव्य:] ०न्देवा: $\mathbf{A}$ 34a उसौ ऋषि॰] सावृषि॰ $\mathbf{A} 34 \mathbf{b}$ सदा सुरै: ] सुरासुरै: $\mathbf{A} \bullet$ सिद्ध०] $\mathrm{A}_{3} \mathrm{~A}_{4}^{\mathrm{ac}}$, सिद्धि॰ $\mathrm{A}_{4}^{\mathrm{pc}}$ $\mathrm{A}_{7} 34 \mathrm{c}$ गन्धर्वयक्षोरग॰] गन्धर्वो $\left\{\circ\right.$ व्वा $\left.\mathrm{A}_{3}\right\}$ रग॰ $\mathrm{A}$ (unmetrical) $34 \mathrm{~d}$ सहा॰ ] $\mathrm{A}_{3}$, महा० $\mathrm{A}_{4} \mathrm{~A}_{7}$ Col. इति $\left\{\right.$ इति श्री॰ $\left.\mathrm{A}_{4} \mathrm{~A}_{7}\right\}$ स्कन्दपुराणे एकाशीतिसाहस्रचां संहितायामम्बिकाखण्डे वराहोत्सवो नाम सत्रोत्तरशतं $\mathbf{A} \pm$

32 $\left(\mathrm{f}^{1}-\mathrm{f}^{2}\right)\left\langle\mathrm{f}^{3}\right\rangle \mathrm{S}_{1},\left\langle\mathrm{~d}^{3}\right\rangle\left(\mathrm{d}^{4}\right) \mathrm{S}_{3} \quad \mathbf{3 4}\left(\mathrm{d}^{12}\right) \mathrm{S}_{1},\left(\mathrm{~d}^{11}\right) \mathrm{S}_{3}$

32a राजन्या: ] $\mathrm{S}_{1} \mathrm{~S}_{2} \mathrm{~S}_{3}^{\mathrm{pc}} \mathrm{ABh}$, राजन्या $\mathrm{S}_{3}^{\mathrm{ac}}$ - क्षत्रिया: ] $\mathrm{S}_{1} \mathrm{~S}_{2}^{\mathrm{pc}} A B \mathrm{Bh}$, क्षत्रिया $\mathrm{S}_{2}^{\mathrm{ac}} \mathrm{S}_{3}$ 32c तत्राजग्मुर् ] $\mathrm{S}_{1} \mathrm{~S}_{2} \mathrm{~A}_{3} \mathrm{~A}_{7} \mathrm{Bh}$, तत्र जग्मु $\mathrm{S}_{3}$ - ०रीक्षन्तो ] $\mathrm{S}_{1} \mathrm{~S}_{3} \mathrm{ABh}$, ०रीक्ष्यन्तो $\mathrm{S}_{2}$ 32d ०स्योत्सवं शुभम् ] $A B h$, ०स्योत्तमं शुभम् $S_{1}$, ०स्योत्सवश्शुभं $S_{2}^{p c}$, ०स्योत्सवश्शुभः $S_{2}^{\mathrm{ac}}$, ( ०स्यो)त्सव शुभः $S_{3}$ 32e ०समाकीर्ण ] $S_{2} R_{4} B h$, ०समाकीर्ण० $S_{1}$ (anusvāra possibly lost), ०समाकीर्ण्ण॰ $S_{3}^{\text {pc }}$, ०समाकीर्ण० $S_{3}^{\text {ac }} \quad 33 \mathrm{a}$ ०स्याभवद्या० $] S_{1} S_{3} R A B h$, ०स्याड्शवद्या० $S_{2}$ 33c उत्सवः ] $S_{1} S_{2} R A B h$, उत्सव $\mathrm{S}_{3}$ - ०महान्दिव्यः ] $\mathrm{S}_{1} \mathrm{~S}_{2}^{\mathrm{pc}} \mathrm{RBh}$, ०महान्दिव्य $\mathrm{S}_{2}^{\mathrm{ac}}$, ०महादिव्यं $\mathrm{S}_{3}$ 34a तस्योत्सवो ] $\mathrm{S}_{1} \mathrm{~S}_{2} \mathrm{~S}_{3} \mathrm{RA}$, तस्योत्सोवो $\mathrm{Bh}$ (typo, unmetrical) • उसौ] $\mathrm{S}_{1}^{\mathrm{pc}} \mathrm{S}_{2} \mathrm{~S}_{3} \mathrm{RBh}$, om. $\mathrm{S}_{1}^{\mathrm{ac}}$ (unmetrical) • ०जुष्ट: ] $\mathrm{S}_{1}^{\mathrm{pc}} \mathrm{S}_{2} \mathrm{RABh}$, ${ }^{\text {जुष्ट }} \mathrm{S}_{1}^{\mathrm{ac}} \mathrm{S}_{3}$ (unmetrical) 34b ] $\mathrm{S}_{1}^{\mathrm{pc}} \mathrm{RBh}$ (जुष्टम् corrected to जुष्ट: in $S_{1}^{\mathrm{pc}}$ ), गन्धर्वयक्षोरगराक्षसैग्च $\mathrm{S}_{1}^{\mathrm{ac}}$ (cf. $34 \mathrm{c}$ ), सदा सुरै सिद्धजनैस्च जुष्टो $\left\{\right.$ युष्ट $\left.\mathrm{S}_{2}^{\mathrm{acc}}\right\} \mathrm{S}_{2}$, सदा सुरै सिद्धजनैश्च जुष्ट $\mathrm{S}_{3} \quad 34 \mathrm{c}$ ०राक्षसैख्च ] $\mathrm{S}_{1}^{\mathrm{pc}} \mathrm{S}_{2} \mathrm{~S}_{3} \mathrm{RABh}$, ०राक्षसाश्च $\mathrm{S}_{1}^{\mathrm{ac}}$ 34d ०धरैस्चै०] $\mathrm{S}_{1} \mathrm{~S}_{2}^{\mathrm{pc}} \mathrm{S}_{3} \mathrm{ABh}$, धधरास्चै० $\mathrm{S}_{2}^{\mathrm{ac}}$ - सहाप्सरोभि: ] $\mathrm{S}_{2} \mathrm{~S}_{3} \mathrm{~A}_{3} \mathrm{Bh}$, सहाप्सरोभि(रि)ति $\mathrm{S}_{1}$ (इति part of col.) Col. $\odot ॥$ स्कन्दपुराणे वराहोत्सवे आध्याय १६ $~$ (in letter numerals) $\cdots \mathrm{S}_{1}$, स्कन्दपुराणे +नन्दिवराहा(र्चती) नाम+ अष्टोत्तरशतो ध्यायः ॥ $\mathrm{S}_{2}$, $\odot ॥$ स्कन्दपुराणे नामाध्यायः १९० (in letter numerals)॥ $\odot \mathrm{S}_{3}$, इति स्कन्दपुराणे वराहोत्सवे अष्टोत्तरशतो ध्याय: $\mathrm{Bh}$ 
नवोत्तरशतो डध्यायः।

सनत्कुमार उवाच।

तस्य कालेन महता रमतः शक्तिनन्दन।

भार्यायां चित्रलेखायां वृको नामाभवत्सुतः ॥ १॥

स वृको बलवान्नित्यं विचरन्पृथिवीमिमाम्।

नर्दमानो उवधीब्लोके भूतानि शतशो महान्॥ २॥

अथाससाद शैलेन्द्र हिमवन्तं महागिरिम्।

गौरीकूटसमीपे च कार्त्तिकेयालयं शुभम्॥ ३॥

तमजानंस्तदाम्येत्य बलेनाविनयेन च।

नादयानो दुमान्छुभ्रान्रत्नहेमिभूषितान्।

सर्वर्तुपुष्पफलदान्सर्वकामप्रदानपि॥ ४॥

$2 \mathrm{a}$ वृको ] एको $\mathrm{R} \quad 3 \mathrm{~d}$ ०यालयं ] ॰यवनं $\mathrm{R}^{\mathrm{pc}}$, ०यनवं $\mathrm{R}^{\mathrm{ac}} \quad 4 \mathrm{~b}$ च] ह $\mathrm{R} \quad 4 \mathrm{c}$ नादयानो ] भअयानो $\mathrm{R} \quad 4 \mathrm{~cd}$ ०न्छुभ्रात्रत० ] ॰न्भग्नान्वने $\mathrm{R}$

$1 b$ रमतः ] रमता $\mathbf{A}$ - शक्ति॰ ] शक्र० $\mathbf{A} 2 \mathrm{~d}$ शतशो महान् ] तत्रसुस्तदा $\mathbf{A}$ - After this $\mathbf{A}$ adds 2 pādas reading तेन शब्देन लोकेशा: कल्पिता: शतशो भवन् । $\pm \quad 3 c$ गौरी॰] गिरि॰ $\mathbf{A} 4 \mathbf{a}$ तमजानंस्त॰ ] अवजानंस्तस्त॰ $\mathrm{A}_{3}$ (unmetrical), अवजालंस्त॰ $\mathrm{A}_{4}$, अवजानंस्त॰ $\mathrm{A}_{7} \mathbf{4 c}$ नादयानो दुमान्छु॰ ] नादयान् गन्धमान् शु॰ $\mathrm{A}_{3}$, नादयेनां धमान् शु॰ $\mathrm{A}_{4}$, नादयाना ऋमान् शु॰ $\mathrm{A}_{7} \mathbf{4 d}$ न्नत्नहेम० ] ०न्हेमरत्न० $\mathbf{A}$

Manuscripts available for this chapter: $S_{1}$ photos $4.9 \mathrm{a}\left(\right.$ f. $\left.166^{\mathrm{v}}\right), 4.10 \mathrm{a}\left(\mathrm{f} .167^{\mathrm{r}}\right), 4.9 \mathrm{~b}\left(\right.$ f. $167^{\mathrm{v}}$ ) and $4.10 \mathrm{~b}$ (f. $168^{\mathrm{r}}$ ); $\mathrm{S}_{2}$ exposures $116 \mathrm{~b}-117 \mathrm{~b}$ (f. $151^{\mathrm{r}}-152^{\mathrm{r}}$ ); $\mathrm{S}_{3}$ f. $166^{\mathrm{v}}-168^{\mathrm{r}} ; \mathrm{R}$ f. $182^{\mathrm{r}}-183^{\mathrm{v}} ; \mathrm{A}_{3}$ f. $109^{\mathrm{r}}-110^{\mathrm{r}} ; \mathrm{A}_{4}$ f. $153^{\mathrm{v}}-155^{\mathrm{r}} ; \mathrm{A}_{7}$ f. $154^{\mathrm{v}}-156^{\mathrm{r}}$.

$4\left(e^{5}\right) S_{1}$

1 सनत्कुमार उवाच ] $S_{1}^{\text {pc }} S_{2} S_{3} R A B h$ (सन उ in $S_{1}^{p c} S_{2} S_{3}$ ), om. $S_{1}^{\text {ac }}$ 1b शक्ति॰ ] $S_{1} S_{2} R B h$, शक्ति॰ $\mathrm{S}_{3} \bullet$ ०नन्दन ] RABh, ०नन्दन: $\mathrm{S}_{1} \mathrm{~S}_{2} \mathrm{~S}_{3}$ 1c भार्यायां ] $\mathrm{S}_{1}^{\mathrm{pc}} \mathrm{S}_{2} \mathrm{~S}_{3} \mathrm{RABh}$, भार्य(य:) $\mathrm{S}_{1}^{\text {ac }}$ • चित्र॰] $\mathrm{S}_{1}^{\mathrm{pc}} \mathrm{S}_{2} \mathrm{~S}_{3} \mathrm{RABh}, \mathrm{f}-$ त्र० $\mathrm{S}_{1}^{\mathrm{ac}}$ 1d ०माभवत्सुतः ] $\mathrm{S}_{2}^{\mathrm{pc}} \mathrm{S}_{3}^{\mathrm{pc}} \mathrm{RABh}$, ०मभवत्सुतः $\mathrm{S}_{2}^{\mathrm{ac}} \mathrm{S}_{3}^{\mathrm{ac}}$, ०माभवं शु 〈मः $\rangle+त ः+S_{1}$ 2a बलवान् ] $S_{1} S_{2} R A B h$, बलवा $S_{3}$ 2c उवधील्लोके] $S_{1}^{\text {pc }} S_{2} R A B h$, वधी लोके $\mathrm{S}_{1}^{\mathrm{ac}} \mathrm{S}_{3}$ 2d भूतानि ] $\mathrm{S}_{2} \mathrm{~S}_{3}$ RABh, भूत्वाभि॰ $\mathrm{S}_{1}$ 3b हिमवन्तं ] $\mathrm{S}_{1} \mathrm{~S}_{2}$ RABh, हिमवन्त $\mathrm{S}_{3}$

० गिरिम् ] $\mathrm{S}_{2} \mathrm{~S}_{3} \mathrm{RABh}$, गिरिन् $\mathrm{S}_{1}$ 3d कार्त्तिकेयालयं ] $\mathrm{S}_{2}^{\mathrm{pc}} \mathrm{S}_{3} \mathrm{ABh}$, कार्त्तिकेयाल $\mathrm{S}_{1}$ (unmetrical, insertion mark after ल; akșara i.m. possibly lost), कार्त्तिक(स्या)लयं $S_{2}^{\text {ac }}$ 4a ०मजानंस्त०] $\mathrm{S}_{1} \mathrm{~S}_{2}^{\mathrm{pc}} \mathrm{RBh}$, ॰मजानांस्त॰ $\mathrm{S}_{2}^{\mathrm{ac}}$, ॰मजानस्त $\mathrm{S}_{3}$ • ०दाम्येत्य $] \mathrm{S}_{2} \mathrm{~S}_{3} \mathrm{RABh}$, ०दाभेत्य $\mathrm{S}_{1} 4 \mathrm{~b}$ ०नाविनयेन ] $\mathrm{S}_{2} \mathrm{~S}_{3} \mathrm{RABh}$, ०नाविजयेन $\mathrm{S}_{1} \quad 4 \mathrm{c}$ नादयानो] $\mathrm{S}_{1}^{\mathrm{ac}} \mathrm{S}_{2} \mathrm{~S}_{3} \mathrm{Bh}$, नोदयानो $\mathrm{S}_{1}^{\mathrm{pc}}$ 4cd दुमान्छुभ्रान्रत्न ] $\mathrm{S}_{1} \mathrm{Bh}$, दुमान्छुभ्रात्र $\left\{\circ\right.$ त्र० $\left.\mathrm{S}_{2}^{\mathrm{pc}}\right\}$ न $\mathrm{S}_{2}$, दुमाच्छुभ्रा रत्न $\mathrm{S}_{3}$ 4d ॰ भूषितान् ] $\mathrm{RABh}$, ॰भूषिताम् $\mathrm{S}_{1} \mathrm{~S}_{2} \mathrm{~S}_{3} \quad 4 \mathrm{e}$ ॰पुष्पफलदान् ] $\mathrm{S}_{2} \mathrm{RABh}$, ०क(फ)लां पुष्पां $\mathrm{S}_{1}$, ॰पुष्पफलदा $\mathrm{S}_{3}$ 


\section{शिलामणिमयाज्छुभ्राज्छात कुम्भमयाज्छुभान् ।}

हरितालमयांश्चान्यांस्तथा मानःशिलाचलान्।

\section{उत्पाट्योत्पाट्य वेगेन बभज्ज रुषितो यथा॥ $y \|$}

स गर्जमानः सततं गजो मत्त इवापरः।

बभझ्ज तद्वनं शुभ्रं कार्त्तिकेयस्य धीमतः॥ ६॥

तस्य गर्जितशब्देन वनभड्गस्वनेन च।

स्कन्दस्य गणपः शूरो निर्जगाम निशामयन्॥ ७॥

कोकवक्त इति ख्यातो दृढं स्कन्दस्य वत्नभः।

महात्मा बलसंपन्नो गत्वा वृकमवैक्षत ॥ ५॥

स तं दृष्ट्रा महाकायं तरुणं प्रियदर्शनम्।

जीमूतमिव नर्दन्तं किंचित्प्रकुपिताननम्।

उवाच वचनं हृष्टः कोकवक्रो हसत्रिव॥ ९॥

$5 d$ मानःशिलाचलान् ] मणिमयाछ्छुभान् $R$ 6b गजो मत्त ] गजोत्तम $R \quad 7 c$ गणप: ] तु गणः $R$ 7d निशामयन् ] महावनम् $R \quad 8 a$ कोक॰] काक॰ $R \quad 9 e$ हृष्ट: ] वीर: $R$ 9f कोक॰] ]काक० $R$

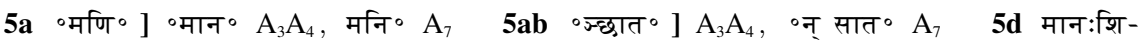
लाचलान् ] मनःशिलामयान् $\mathbf{A} \quad \mathbf{6 a}$ गर्जमान: ] सर्ज $\left\{0\right.$ जर्ज० $\left.\mathrm{A}_{7}\right\}$ मान: $\mathbf{A}$ 6b गजो मत्त ] $\mathrm{A}_{4} \mathrm{~A}_{7}$, गजमत्त $\mathrm{A}_{3} \quad \mathbf{6 c}$ तद्वनं] $\mathrm{A}_{3} \mathrm{~A}_{7}$, तद्वलं $\mathrm{A}_{4} \quad \mathbf{7 b}$ वन०] वचन० $\mathrm{A}_{3}$ (unmetrical), बल॰ $\mathrm{A}_{4} \mathrm{~A}_{7}$ 8a कोकवक्र ] काकवल्क $\mathrm{A}_{3} \mathrm{~A}_{4}$, काकेव(क्क) $\mathrm{A}_{7}^{\mathrm{pc}}$, काकेव(क्र) $\mathrm{A}_{7}^{\mathrm{ac}} \quad \mathbf{8 b}$ वल्लभः ] $\mathrm{A}_{3} \mathrm{~A}_{7}$, ववल्लभः $\mathrm{A}_{4}$

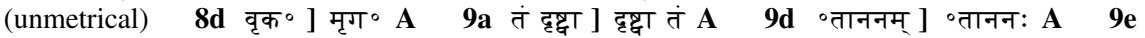
वचनं ] $\mathrm{A}_{3} \mathrm{~A}_{7}$, वनं $\mathrm{A}_{4}$ (unmetrical) $9 \mathrm{f}$ कोकवक्रो ] काकवल्को $\mathrm{A}_{3} \mathrm{~A}_{4}$, काकव(क्को) $\mathrm{A}_{7}^{\mathrm{pc}}$, काकव(क्रो) $\mathrm{A}_{7}^{\mathrm{ac}}$

$\mathbf{6}\left(\mathrm{a}^{1}-\mathrm{a}^{3}\right) \mathrm{S}_{1} \quad \mathbf{8}\left(\mathrm{c}^{6}, \mathrm{~d}^{7}-\mathrm{d}^{8}\right) \mathrm{S}_{1} \quad \mathbf{9}\left(\mathrm{c}^{4}, \mathrm{e}^{7}-\mathrm{e}^{8}\right) \mathrm{S}_{1}$

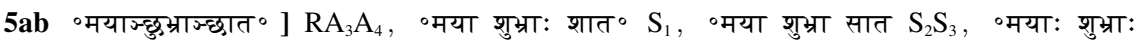
शात॰ $\mathrm{Bh}(\mathrm{em} . ?) \quad \mathbf{5 b}$ ०मयान्छुभान् ] RA, ${ }^{\circ}$ मयास्तथा $\mathrm{S}_{1} \mathrm{Bh}$, ${ }^{\circ}$ मया शुभा $\mathrm{S}_{2} \mathrm{~S}_{3} \quad \mathbf{5 c d}$ ०मयांश्चान्यांस्त॰ ] $S_{1} R A$, मयाश्चान्यास्त॰ $S_{2} B h$, मयाश्चान्या त० $S_{3}$ 5d मानः०] $S_{2} S_{3} B h$, मानं० $S_{1}$ ०शिलाचलान् ] em., ०शिलाबलान् $S_{1}$, ०शिलाचला $S_{2}$, ०शिलातला $S_{3}$, ०शिलोपालान् Bh (typo, em.?) 5e ०ट्योत्पाव्य ] $S_{1}^{\text {pc }} S_{2} S_{3} R A B h$, ०ट्योत्प $S_{1}^{\text {ac }}$ (unmetrical) 5f बभअ ] $S_{1} S_{2}^{p c} S_{3} R A B h$, ब $\left\langle\right.$ ज्जे+भ+ज $\mathrm{S}_{2}$ - रुषितो ] $\mathrm{S}_{2} \mathrm{~S}_{3} \mathrm{RA}$, रूषितो $\mathrm{S}_{1} \mathrm{Bh}$ 6b गजो मत्त ] $\mathrm{S}_{3}^{\mathrm{pc}} \mathrm{A}_{4} \mathrm{~A}_{7} \mathrm{Bh}$ (em.), गजोत्तम $\mathrm{S}_{1}$, गजोन्मत्त $\mathrm{S}_{2}$, गजोत्तमत्त $\mathrm{S}_{3}^{\mathrm{ac}}$ (unmetrical) $\mathbf{6 c}$ तद्वनं ] $\mathrm{S}_{1} \mathrm{RA}_{3} \mathrm{~A}_{7} \mathrm{Bh}$, सौ द्वं ततः $\mathrm{S}_{2}^{\mathrm{pc}}$ (unmetrical), द्वं $\sim$ नं $S_{2}^{\text {ac }}$, द्वनं $S_{3}$ (unmetrical) - शुं्रं] $S_{1} S_{2} R A B h$, शुभ्र $S_{3}$ 6d कार्तिकेयस्य ] $\mathrm{S}_{1} \mathrm{~S}_{2} \mathrm{~S}_{3} \mathrm{RA}$, कार्तिकेस्य Bh (typo, unmetrical) $\mathbf{7 a}$ तस्य $] \mathrm{S}_{1} \mathrm{~S}_{2}^{\mathrm{pc}} \mathrm{S}_{3} \mathrm{RABh}$, तस्या $\mathrm{S}_{2}^{\mathrm{ac}} \mathbf{7 b}$ च ] $S_{1} S_{2} R A B h$, व $S_{3}$ 7c गणप: ] $S_{2} S_{3} A B h$, स गण: $S_{1}$ 7d निशामयन् ] $S_{1} A$, स मन्दिरं $\mathrm{S}_{2} \mathrm{~S}_{3}^{\mathrm{ac}}$, स मन्दिरात् $\mathrm{S}_{3}^{\mathrm{pc}} \mathrm{Bh}$ (em.) 8a ख्यातो ] $\mathrm{S}_{1} \mathrm{~S}_{2} \mathrm{~S}_{3} \mathrm{RA}$, ख्यतो Bh (typo, unmetrical) $\mathbf{8 b}$ दृढं ] $\mathrm{S}_{1} \mathrm{~S}_{2} \mathrm{RABh}$, दृढ $\mathrm{S}_{3}$ - वल्नभः ] $\mathrm{S}_{2} \mathrm{~S}_{3}^{\mathrm{pc}} \mathrm{RA}_{3} \mathrm{~A}_{7} \mathrm{Bh}$, बल्लभः $\mathrm{S}_{1}$, वलभः $\mathrm{S}_{3}^{\text {ac }}$ (unmetrical) $8 \mathrm{c}$ ०संपन्नो ] $\mathrm{S}_{1} \mathrm{~S}_{2} \mathrm{RABh}$, ०संपनो $\mathrm{S}_{3}$ (unmetrical) 9c जीमूतमिव ] $\mathrm{S}_{2} \mathrm{RABh}$, जामूत(मे)व $\mathrm{S}_{1}^{\text {pc }}$ (tops lost), जामूत(मि)व $S_{1}^{\text {ac }}$ (tops lost), जीमूर्त्तमिव $S_{3}$ - नर्दन्तं ] $S_{2}^{\text {pc }} R A B h$, नर्द्धन्त $S_{1}$ (tops lost), नर्द्दन्तो) $\mathrm{S}_{2}^{\mathrm{ac}}$, नर्द्धन्तो $\mathrm{S}_{3}$ 9d ०ताननम् ] $\mathrm{S}_{1} \mathrm{RBh}$, ०तानन: $\mathrm{S}_{2} \mathrm{~S}_{3}$ 9e वचनं हृष्ट: ] $\mathrm{S}_{1} \mathrm{~A}_{3} \mathrm{~A}_{7} \mathrm{Bh}$, वचनन्दृष्ट $\mathrm{S}_{2}$, वचन दृष्ट $\mathrm{S}_{3}$ 
कस्य त्वमिह संप्राप्तो बालो देवगृहं शुभम्।

न जानीषे किमेतच स्कन्दस्य सुमहात्मनः॥ १०॥

वेश्म देवै: सगन्धर्वे: सयक्षोरगपन्नगै:।

कृतं दयितमत्यर्थं गणेशैश्चापि पूजितम्॥ १? ॥

कुमारो मन्दरं यातः सर्वे: सह गणेश्वरै:।

रक्षार्थं मामिह स्थाप्य वारयामि ततो हि ते॥ ?२॥

तुष्टो उस्मि तव रूपेण बलेन वपुषा तथा।

उपारमस्व तेन त्वां ब्रवीमि सुमहाबल।

अहं करिष्ये यद्नग्नं तथैव पुनरेव हि॥ १३॥

वक्ष्ये देवं च तं सम्यत्कदर्थं सूकरेश्वर।

यथा न कुप्यते तुभ्यं प्रवरं त्वां करोति च॥ १४॥

सनत्कुमार उवाच।

तस्य तद्वचनं श्रुत्वा वृकः संरक्कोचनः।

उवाच कोकवदनमिदं मृगपतिस्तदा॥ १९ ॥

$10 \mathrm{a}$ कस्य त्व॰ ] वध्यत्व ${ }^{\circ} \mathrm{R} 10 \mathrm{~d}$ सु $\left.{ }^{\circ}\right]$ तु $\mathrm{R} 11 \mathrm{a}$ देवै: सगन्धर्वे: ] सदेवैर्गन्धर्वे: $\mathrm{R}$ 12a मन्दरं ] मन्दिरं $R \quad 13 \mathrm{e}$ यद्जग्नं ] यड्जड्रं $R \quad 14 \mathrm{ab}$ ] रक्षो देवं गुहं सम्यगुदखिद्यकरेश्वरम् $\mathrm{R}^{\mathrm{ac}}$, वक्ष्यं देवगृहं सम्यग्वदस्वाद्य मृगेश्वर $\mathrm{R}^{\mathrm{pc}}$ (i.m.) $14 \mathrm{~d}$ प्रवरं त्वां करोति ] प्रवरस्तत्करोतु $\mathrm{R}^{\mathrm{pc}}$, प्रवरं तत्करोति $\mathrm{R}^{\mathrm{ac}}$ 15a ] Before this $\mathrm{R}$ adds $18 \mathrm{a}-\mathrm{d}$. 15c कोक॰] काक॰ $\mathrm{R}$ 15d ० पति॰ ] सुत० $\mathrm{R}$

$10 \mathrm{c}$ जानीषे] $\mathrm{A}_{3}$, जानीमे $\mathrm{A}_{4}$, जानीसे $\mathrm{A}_{7} 11 \mathrm{a}$ वेश्म ] $\mathrm{A}_{3} \mathrm{~A}_{4}$, वैश्म $\mathrm{A}_{7}$ • सगन्धर्वे: ] $\mathrm{A}_{3} \mathrm{~A}_{7}$, सगंधर्वे $\mathrm{A}_{4} 11 \mathrm{c}$ दयितम० ] च दिवम० $\mathrm{A}$ 12b सर्वे: सह गणेश्वरै: ] ससर्वेर्गणपेश्वरै: $\mathrm{A} 12 \mathrm{c}$ रक्षार्थ ] $\mathrm{A}_{3} \mathrm{~A}_{7}$, रक्षार्थ $\mathrm{A}_{4} \quad 13 \mathrm{c}$ उपारमस्व ] $\mathrm{A}_{7}$, उमावमसु $\mathrm{A}_{3} \mathrm{~A}_{4} \quad 13 \mathrm{~d}$ ०बल ] बबल $\mathrm{A}$ 14a च तं ] गुहं $\mathrm{A} \quad 14 \mathrm{ab}$ ॰क्कदर्थ ] $\mathrm{A}_{7}$, ०क् तदर्थ $\mathrm{A}_{3} \mathrm{~A}_{4}$ • सूकरे॰] शूकरे॰ $\mathrm{A}_{3} \mathrm{~A}_{4}$, शुकरे॰ $\mathrm{A}_{7} 14 \mathrm{c}$ यथा ] तथा $A$ कुप्यते ] कुध्यते $\mathrm{A}_{3} \mathrm{~A}_{7}$, कृध्यते $\mathrm{A}_{4}$ 14d प्रवरं त्वां ] प्रसादस्ते $\mathrm{A}$ 15-17 ] om. A

$13\left\langle\mathrm{c}^{1}\right\rangle\left(\mathrm{c}^{2}-\mathrm{c}^{4}, \mathrm{c}^{8}\right) \mathrm{S}_{2} \quad \mathbf{1 5}\left(\mathrm{d}^{8}\right) \mathrm{S}_{2}$

10a त्वमिह ] $\mathrm{S}_{2} \mathrm{~S}_{3} \mathrm{RABh}$, त्वयिह $\mathrm{S}_{1} \quad 10 \mathrm{c}$ ०मेतच ] $\mathrm{S}_{1} \mathrm{~S}_{2} \mathrm{RA}$, ॰मेत च $\mathrm{S}_{3}$ (unmetrical), ॰मेतत्त्वं $\mathrm{Bh}$ (conj.) 11a वेश्म देवै: ] $\mathrm{A}_{3} \mathrm{~A}_{4} \mathrm{Bh}$, वेश्म दैवै+: $+\mathrm{S}_{1}$, वेश्मन्दैवैस् $\mathrm{S}_{2}$, वेश्मं देवै $\mathrm{S}_{3}$ - ०गन्धवे: ] $\mathrm{S}_{1} \mathrm{~S}_{2} \mathrm{~A}_{3} \mathrm{~A}_{7} \mathrm{Bh}$, ०गन्धर्वे $\mathrm{S}_{3} \quad$ 11b ०पन्नगै: ] $\mathrm{S}_{1} \mathrm{~S}_{2} \mathrm{~S}_{3}^{\mathrm{pc}} \mathrm{RA}$, ०पनगै: $\mathrm{S}_{3}^{\text {ac }}$ (unmetrical), ०किन्नरै: $\mathrm{Bh}$ (conj.) $11 \mathrm{~cd}$ ०मत्यर्थं गणेशैश्चापि $] \mathrm{S}_{1} \mathrm{RA}$, ०मत्य/मत्यर्थड्गणैश्चापि सु॰ $\mathrm{S}_{2}$, ०मत्यर्थ गणैश्चापि सु॰ $\mathrm{S}_{3}$, ॰मत्यर्थ गणैश्चापि सु॰ $\mathrm{Bh}$ 12ab ] $\mathrm{S}_{3}$ writes this over the two pādas cancelled, possibly $14 \mathrm{~cd}$. 12b सर्वे:] $\mathrm{S}_{1} \mathrm{~S}_{2} R B h$, सर्वे $\mathrm{S}_{3}^{\mathrm{pc}} 12 \mathrm{c}$ रक्षार्थं $\mathrm{S}_{1} \mathrm{~S}_{2} \mathrm{RA}_{3} \mathrm{~A}_{7} B \mathrm{Bh}$, रक्षार्थ $\mathrm{S}_{3}$ - स्थाप्य ] $\mathrm{S}_{2} \mathrm{~S}_{3} \mathrm{RABh}$, प्राप्तो $\mathrm{S}_{1} \quad$ 12d वारयामि ] $\mathrm{S}_{1} \mathrm{RABh}$, वरयामि $\mathrm{S}_{2} \mathrm{~S}_{3}$ - हि ] $\mathrm{S}_{1} \mathrm{~S}_{2}^{\mathrm{pc}} \mathrm{S}_{3} \mathrm{RABh}$, ह $\mathrm{S}_{2}^{\text {ac }} \quad 13 \mathbf{a}$ उस्मि ] $\mathrm{S}_{1} R A B h$, स्मिन् $\mathrm{S}_{2} \mathrm{~S}_{3} \quad 13 \mathbf{b}$ वपुषा ] $\mathrm{S}_{1} \mathrm{RABh}$, पुरुषा $\mathrm{S}_{2} \mathrm{~S}_{3} \quad 13 \mathbf{c}$ त्वां] $\mathrm{S}_{2}$

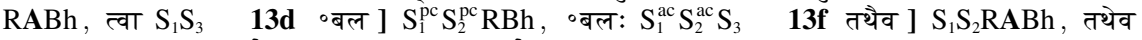
$\mathrm{S}_{3} \quad$ 14ab सम्यत्कदर्थं] $S_{2} A_{7} B h$, सम्यक्तवार्थ $S_{1}$ ( म्यक्तवा० retraced), सम्यक्षदर्थ $S_{3}^{\text {pc }}$, सम्यत्कदर्थ $\mathrm{S}_{3}^{\mathrm{ac}} \bullet$ सूकरेश्वर ] $\mathrm{S}_{1}^{\mathrm{pc}} \mathrm{S}_{2}^{\mathrm{pc}}$, सूकरे म्वर: $\mathrm{S}_{1}^{\mathrm{ac}} \mathrm{S}_{2}^{\mathrm{ac}} \mathrm{S}_{3}$, शूकरेम्वर $\mathrm{Bh} 14 \mathrm{c}$ तुम्यं ] $\mathrm{S}_{1} \mathrm{~S}_{2} \mathrm{RABh}$, तुम्य $\mathrm{S}_{3}$ $14 d$ प्रवरं त्वां] $S_{3}^{\mathrm{pc}}$, प्रवरं त्वा $\mathrm{S}_{1} \mathrm{~S}_{3}^{\mathrm{ac}}$, प्रवरन्तं $\mathrm{S}_{2}$, प्रसादं ते $\mathrm{Bh}(\mathrm{em}$.$) 15d ०स्तदा ] \mathrm{S}_{3} \mathrm{RBh}$ (conj.?), ०स्तथा $S_{1}$, ०स्त(था) $S_{2}$ 


\section{न बिभेमि कुमारस्य तव वा पापचेतसः।}

बले मम कुमारो उसौ न तुल्यः सगणेश्वरः ॥ १६॥

यद्वो बलं च दर्पं च तत्कुरुध्वमशड्किताः।

नामावशेषमेतद्वः कर्ताहं वनमन्तशः॥ १७॥

सनत्कुमार उवाच।

ततः स वृक्षमुत्पाट्य हैम वैड्रूयपत्रवम्।

कोकवक्राय चिक्षेप ननाद च यथा वृषः॥ १५ ॥

ततः प्रहस्य कोकास्यस्तमेवोद्धह्य पादपम् ।

वृकं तं तेन संकुद्धः शिरस्यभिजघान ह॥ १९ ॥

स तेन सुप्रहारेण भ्रमित्वा मण्डलं वृकः।

पपात भूमौ नि:संज्रो यथा शक्वजो महान्॥ २०॥

ततस्तं पतितं दृष्ट्रा कोकास्यः प्रहसंस्तदा ।

बबन्ध पाशैर्बहुभिर्वेश्म चैव प्रवेशयत् ॥ २? ॥

तं बद्ध पतितं दृष्ट्रा सहायास्तस्य ते मृगाः।

प्रदुताः सहसा सर्वे भयार्ता जीवितैषिणः॥ २२॥

$16 \mathrm{~b}$ वा पाप॰ ] वाक्याप॰ $\mathrm{R} \quad 16 \mathrm{c}$ बले मम $]$ बलेन मे $\mathrm{R} \quad 17 \mathrm{a}$ यद्वो ] यत्ते $\mathrm{R} \quad 17 \mathrm{~b}$ तत्कुरुध्वमशड्किता: ] तत् कुरु त्वमशड्कितः $R \quad 17 c$ नामावशेषमेतद्व: ] न मे वेगसमं तद्व: $R \quad 17 d$ वनमन्तशः ] बलवत्तर: $\mathrm{R}$ 18a-d ] $\mathrm{R}$ has this before $15 \mathrm{a}$ and repeats it here. $18 \mathbf{a}$ ततः स वृक्षमु $\left.{ }^{\circ}\right] \mathrm{R}^{*}$, स तु वृक्षं समु० $\mathrm{R} \quad 18 \mathrm{~b}$ हैम वैडूर्य॰] हेमवैदूर्य्य० $\mathrm{RR}^{*} \quad 18 \mathrm{c}$ कोक॰] काक॰ $\mathrm{RR}^{*} 19 \mathrm{a}$ कोकास्य॰] काकास्य ${ }^{\circ} \quad 19 b$ वोद्हु्य ] वोद्दृत्य $R \quad 19 \mathrm{c}$ तं ] स $R \quad 20 d$ यथा ] य यथा $R$ (unmetrical) $21 b$ कोकास्य: ] काकास्य: $R \quad 21 d$ चैव ] तच्च $R \quad 22 a$ तं बद्धुं पतितं ] पतितं संयतं $R$

$18 \mathrm{~b}$ हैमं वैर्र्य०] हेमवैदूर्य० $\mathrm{A}_{3} \mathrm{~A}_{7}$, हेमवैर्ड्य० $\mathrm{A}_{4} \quad 18 \mathrm{c}$ कोकवक्ताय ] काकवल्काय $\mathrm{A}_{3} \mathrm{~A}_{4}$, काकवक्राय $\mathrm{A}_{7} 19 \mathrm{ab}$ कोकास्यस्त॰ ] काकस्य त्व० $\mathrm{A}_{3} \mathrm{~A}_{4}$, काकास्यस्त॰ $\mathrm{A}_{7} 19 \mathrm{~b}$ ममेवोदृह्य ] मेव गृह्य $A$ (unmetrical) - पादपम् ] पावक: $\mathrm{A}_{3} \mathrm{~A}_{4} \mathrm{~A}_{7}^{\mathrm{ac}}$ ?, पा(ह्नव): $\mathrm{A}_{7}^{\mathrm{pc}} 19 \mathrm{c}$ वृक तं तेन संक्रुद्धः ] आचयं \{क्षं $\left.\mathrm{A}_{4}\right\}$ तं तेन शूर: $\mathrm{A}_{3} \mathrm{~A}_{4}$, आयान्तं शूकर: तेन $\mathrm{A}_{7}^{\mathrm{pc}}$, आयन्तं तेन च शूर: $\mathrm{A}_{7}^{\mathrm{ac}} 20 \mathrm{c}$ निःसंज्ञो ] निःशंको $\mathrm{A}_{3}$, निशंको $\mathrm{A}_{4}$, निःसड़ो $\mathrm{A}_{7}$ 21b कोकास्य: ] काकस्य $\mathrm{A}_{3} \mathrm{~A}_{4} \mathrm{~A}_{7}^{\mathrm{ac}}$, काकास्य: $\mathrm{A}_{7}^{\mathrm{pc}}$ - ०संस्तदा ] ०सत्रिव $\mathbf{A} 22 \mathrm{~b}$ ०स्तस्य ते] $\mathrm{A}_{3} \mathrm{~A}_{4}$, ०स्तप्यते $\mathrm{A}_{7}$

$\begin{array}{llll}16\left(a^{6}-a^{8}\right) S_{2} & 18\left(d^{6}\right) S_{1} & 19\left(b^{1}\right) S_{1} \quad 22\left(d^{3}\right) S_{1}\end{array}$

17a दर्प च ] $\mathrm{S}_{1} \mathrm{~S}_{2} \mathrm{~S}_{3} \mathrm{R}$, दर्पश्च Bh (em.) 17d ०मन्तशः ] $\mathrm{S}_{2}^{\mathrm{ac}} \mathrm{S}_{3}$, ॰मुत्तमम् $\mathrm{S}_{1}^{\mathrm{pc}}$, ०मुत्तमः $\mathrm{S}_{1}^{\mathrm{ac}} \mathrm{S}_{2}^{\mathrm{pc}}$, ०मन्ततः Bh (conj.?) 18a ततः $S_{1} S_{2} R^{*} A B h$, तत $S_{3}$ (unmetrical) $18 b$ हैमं ] $S_{2} B h$, हेमं $\mathrm{S}_{1} \mathrm{~S}_{3}$ - वैडूर्यपत्लवम् ] $\mathrm{S}_{1} \mathrm{~S}_{2} \mathrm{~A}_{4}$, वैड्रूयपलवं $\mathrm{S}_{3}$ (unmetrical), वैदूर्यपत्रवम् $\mathrm{Bh} 18 \mathrm{c}$ चिक्षेप ] $\mathrm{S}_{2} \mathrm{~S}_{3} \mathrm{RR}^{*} \mathrm{ABh}$, विक्षेप $\mathrm{S}_{1} \quad \mathbf{1 8 d}$ वृषः ] $\mathrm{S}_{1}^{\mathrm{pc}} \mathrm{S}_{2} \mathrm{~S}_{3} \mathrm{RR}^{*} \mathrm{ABh}$, वृष $\mathrm{S}_{1}^{\mathrm{ac}}$ 19ab कोकास्यस्त॰ ] $\mathrm{S}_{1}^{\mathrm{pc}}$ $\mathrm{S}_{2} \mathrm{~S}_{3}^{\mathrm{pc}} \mathrm{Bh}$, कोकास्य (त)॰ $\mathrm{S}_{1}^{\mathrm{ac}}$, कोकस्यस्त० $\mathrm{S}_{3}^{\mathrm{ac}} 19 \mathrm{c}$ संक्रुद्धः] $\mathrm{S}_{1}^{\mathrm{pc}} \mathrm{S}_{2} \mathrm{~S}_{3} R B \mathrm{Rh}$, संक्रुद्ध $\mathrm{S}_{1}^{\mathrm{ac}} 20 \mathrm{~b}$ वृक: ] $S_{1} R A$, मृग: $S_{2} S_{3} B h$ 20c निःसंजो ] $S_{1} S_{2} R B h$, निसज्ञो $S_{3}$ 20d यथा ] $S_{2} S_{3} R A B h$, य वा $S_{1}$ 21a पतितं ] $S_{1} S_{2} R A B h$, पतित $S_{3}$ (unmetrical) 21b कोकास्य: ] $S_{1}^{\mathrm{pc}} S_{2}^{\mathrm{pc}} B h$, कोकास्य $\mathrm{S}_{1}^{\mathrm{ac}} \mathrm{S}_{2}^{\mathrm{ac}} \mathrm{S}_{3}$ - प्रहसंस्त॰ ] $\mathrm{S}_{1} \mathrm{~S}_{2} \mathrm{RBh}$, प्रहसस्त॰ $\mathrm{S}_{3}$ 21cd पाशैर्बहुभिर्वेश्म चै॰] RABh, पाशैर्बहुभिर्वेश्मस्चै० $S_{1}$, पाशैर्बहुभिर्वेश्मस्चै० $S_{2}$, पाशै बहुभि वेश्मं चै० $S_{3}$ 22a तं बद्धं ] $S_{1} S_{2} A B h$, तम्बद्ध $S_{3}$ 22c प्रदुताः ] $S_{1}^{\mathrm{pc}} R \mathbf{A}$, प्रदुता $S_{1}^{\mathrm{ac}} \mathrm{S}_{2} \mathrm{~S}_{3} B h$ (typo?) 22d भयार्ता ] $S_{1}^{\mathrm{pc}} \mathrm{S}_{2} \mathrm{~S}_{3} R A B h$, भया(ती) $\mathrm{S}_{1}^{\mathrm{ac}}$ 
अथागात्तेन कालेन गणपैर्बहुभिर्वृतः

कार्तिकेयो मयूरेण कूजमानेन सानुगः॥ २३॥

तस्य तत्कथयामास कोकवक्रो गणेश्वरः।

वृकं च दर्शयामास पाशैर्बद्ध महाबलम्॥ २४॥

कोकवक्त उवाच।

भगवन्वराहरूपस्य सुतः श्रीमान्वृक: किल।

हिरणयाक्षो हतो येन दानवो देवकण्टकः २ २ ॥

बभआ्जायं सुदुष्टात्मा सहितो ऊन्यैर्वनं तव।

ततः पाशैर्मया बद्धः क्रियतामस्य यत्परम्॥ २६॥

स्कन्द उवाच।

नायं शक्यो मयाद्येह मोकुं मृगकुलाधमः।

मुक्ते वक्तव्यता लोके भविष्यति न संशयः॥ २७॥

देवो मां वक्ष्यते व्यकं स्कन्दो भीतो न संशयः।

यो मुमोच सुतं तस्य वराहस्य कृतागसम्॥ २५॥

23a अथागात्तेन ] तथागात्तत्र $R \quad 23 d$ कूजमानेन सानुगः ] कूजता पितृमन्दिरात् $R$ 24b कोक॰ ] काक॰ $R \quad 25$ कोकवक्त ] ककास्य $R 25 \mathrm{a}$ ०वन्वराह॰] ॰वन काम॰ $R$ 26a बभआयं सु॰] बभज्ञ एष $R \quad 27 \mathrm{a}$ ०याद्येह ] ०या ह्येव $\mathrm{R} \quad 27 \mathrm{~b}$ ०कुलाधमः ] ०कुलाधमम् $\mathrm{R}$ 28a व्यक्त ] नित्यं $\mathrm{R} 28 \mathrm{c}$ यो] यन् $\mathrm{R} 2 \mathrm{28d}$ कृतागसम् ] कृताशनम् $\mathrm{R}$

24b कोकवक्रो] काकवल्को $\mathrm{A}_{3} \mathrm{~A}_{4}$, काकवक्रो $\mathrm{A}_{7}$ 24d ०बलम् ] ०बलः $A$ कोकवक्र उवाच ] काकवल्क $\left\{{ }^{\circ}\right.$ क् $\left.\mathrm{A}_{7}\right\}$ उवाच $\mathrm{A}_{3} \mathrm{~A}_{7}$, काकवल्कौवाच $\mathrm{A}_{4}$ 25a भगवन् ] $\mathrm{A}_{3} \mathrm{~A}_{4}$ (hypermetrical), भवन् $\mathrm{A}_{7}$ $25 b$ सुतः ] तस्य $A$ - किल ] सुतः $A$ 25d दानवो ] दैत्यपो $A_{3} A_{7}$, दैत्ययो $A_{4}$ 26a सु० ] स $\mathrm{A} 26 \mathrm{~b}$ ०र्वनं] $\mathrm{A}_{3}$, ०र्बलं $\mathrm{A}_{4} \mathrm{~A}_{7} \quad 26 \mathrm{c}$ बद्ध:] $\mathrm{A}_{3} \mathrm{~A}_{7}$, बद्ध $\mathrm{A}_{4}$ 26d यत्परम ] $\mathrm{A}_{3} \mathrm{~A}_{4}$, तत्परं $\mathrm{A}_{7} 27 \mathrm{a}$ ०याद्येह ] या त्वेह $\mathrm{A} \quad 27 \mathrm{~b}$ मृग॰ ] स्यात्तु $\mathrm{A} \quad 27 \mathrm{c}$ मुक्ते वक्तव्यता ] मुक्तेन $\left\{{ }^{\circ}\right.$ व $\left.\mathrm{A}_{4}\right\}$ तु व्यथा $\mathrm{A}_{3} \mathrm{~A}_{4}$, मुक्ते वक्तव्य/त)था $\mathrm{A}_{7} \quad \mathbf{2 8 a}$ देवो मां ] देवानां $\mathrm{A}_{3} \mathrm{~A}_{7}^{\mathrm{ac}}$, देवा मां $\mathrm{A}_{4} \mathrm{~A}_{7}^{\mathrm{pc}}$ - वक्ष्यते व्यक्त ] व $\left\{\right.$ र० $\left.^{\circ} \mathrm{A}_{4}\right\}$ क्षते नूनं $\mathbf{A} \quad \mathbf{2 8 c}$ यो] यत् $\mathbf{A}$ - सुतं ] $\mathrm{A}_{7}$, युतं $\mathrm{A}_{3} \mathrm{~A}_{4} \quad \mathbf{2 8 d}$ कृतागसम् ] $\mathrm{A}_{7}$ ?, कृतागमं $\mathrm{A}_{3} \mathrm{~A}_{4}$

$24\left(d^{2}-d^{3}\right) S_{1} \quad 27\left(b^{8}\right) S_{1}$

23a कालेन ] $\mathrm{S}_{1}^{\mathrm{pc}} \mathrm{S}_{2} \mathrm{~S}_{3} \mathrm{RABh}$, कालैन $\mathrm{S}_{1}^{\mathrm{ac}} \quad \mathbf{2 3 b}$ गणपैर ] $\mathrm{S}_{1} \mathrm{~S}_{2} \mathrm{RABh}$, गणेपै $\mathrm{S}_{3} \quad$ 24d पाशैर् ] $\mathrm{S}_{1} \mathrm{~S}_{2} \mathrm{RABh}$, पाशै $\mathrm{S}_{3} \quad 25 \mathrm{a}$ भगवन् ] $\mathrm{S}_{1} \mathrm{~S}_{3} \mathrm{RA}_{3} \mathrm{~A}_{4} \mathrm{Bh}$ (hypermetrical except $\mathrm{R}$ ), भगवान् $\mathrm{S}_{2}$ (hypermetrical) 25b सुतः ] $S_{1}^{\text {pc }} S_{2} S_{3} R B h$, सुत $S_{1}^{\text {ac }}$ - किल ] $S_{2} S_{3} R B h$, किलः $S_{1}$ 25d ०कण्टक: ] $\mathrm{S}_{2} \mathrm{~S}_{3} \mathrm{RABh}$, ०कण्ट: $\mathrm{S}_{1}$ (unmetrical) 26a बभझायं ] $\mathrm{S}_{1}^{\mathrm{pc}} \mathrm{S}_{2} \mathrm{ABh}$, बभअयं $\mathrm{S}_{1}^{\mathrm{ac}}$, बभंजयं $\mathrm{S}_{3}$ - ॰दुष्टात्मा ] $\mathrm{S}_{2} \mathrm{~S}_{3} \mathrm{RABh}$, ॰दृष्टात्मा $\mathrm{S}_{1} \quad$ 26b जन्यैर्वनं तव ] $\mathrm{S}_{2}^{\mathrm{pc}} \mathrm{S}_{3} R \mathrm{~A}_{3} B h$, न्दैर्वनन्तव $S_{1}$, न्यैर्वनन्ततः $S_{2}^{\text {ac }} 26 c$ पाशैर ] $S_{1} S_{2} R A B h$, पाशै $S_{3}$ - बद्धः ] $S_{1} S_{2}^{p c} R_{2} A_{3} A_{7} B h$, बद्ध $S_{2}^{a c}$ $\mathrm{S}_{3} 26 \mathrm{~d}$ ०तामस्य] $\mathrm{S}_{1}^{\mathrm{pc}} \mathrm{S}_{2} \mathrm{~S}_{3} \mathrm{RABh}$, ०तां मस्य $\mathrm{S}_{1}^{\mathrm{ac}}$ 27c वक्तव्यता ] $\mathrm{S}_{1} \mathrm{~S}_{2} \mathrm{~S}_{3}^{\mathrm{pc}} \mathrm{RBh}$, वक्तव्यतां $\mathrm{S}_{3}^{\mathrm{ac}}$ 27d संशय:] $\mathrm{S}_{1} \mathrm{~S}_{2} \mathrm{~S}_{3} \mathrm{RA}$, संशय $\mathrm{Bh}$ (typo) 28a मां ] $\mathrm{S}_{2} \mathrm{~S}_{3} \mathrm{RA}_{4} \mathrm{~A}_{7}^{\mathrm{pc}} \mathrm{Bh}$, मा $\mathrm{S}_{1}$ वक्ष्यते ] $\mathrm{S}_{2} \mathrm{~S}_{3} \mathrm{RBh}$, लक्ष्यते $\mathrm{S}_{1} \quad \mathbf{2 8 d}$ कृतागसम् ] $\mathrm{S}_{1}^{\mathrm{pc}} \mathrm{S}_{2} \mathrm{~S}_{3} \mathrm{~A}_{7}$ ? Bh, कृतागमम् $\mathrm{S}_{1}^{\mathrm{ac}}$ 
उक्तो गतश्चाहमद्य स्थाणुना परमात्मना।

मा क्षमेथा वराहस्य तनुं त्वां सो इह्वयेद्युधि॥ २९॥

इयं च मम तेनाद्य शक्तिर्दत्तातिभास्वरा।

संवर्तिकेति विख्याता सर्वास्त्रबलनाशनी॥ ३०॥

सो उयं दुरात्मा दुर्वृत्तः सर्वलोकप्रबाधकः।

गृह्यतां बध्यतां चैव क्षिप्रमाविष्कृतं बलात्॥ ३१॥

सनत्कुमार उवाच।

तत एनं बहि: सर्वे स्कन्दस्य गणनायका:।

बद्वा बहुविधै: पाशैर्यातयन्त सहस्रशः॥ ३२॥

स यात्यमानो दुःखार्तो विललाप यथा नर:।

निरयस्थो दुराचार: कर्मभिः स्वै: सुपाशितः॥ ३३॥

तं यात्यमानं संदृश्य नारद: सुमहातपाः।

गत्वा न्यवेदयत्तस्य वराहस्यामितात्मनः॥ ३४॥

29a उक्तो ] उत्का $R$ - गतश्चा०] गतस्त्वा० $R \quad 29 c$ मा क्षमेथा ] मोक्षसेथा $R$ 29d तनुं ] यदि $\mathrm{R}$ - उह्वयेद् ] उवयेद् $\mathrm{R} \quad 30 \mathrm{~b}$ ०र्दत्तातिभास्वरा ] ०र्दुर्गा $\left\{\simeq \simeq \mathrm{R}^{\mathrm{ac}}\right\}$ भिभासुरा $\mathrm{R} \quad 30 \mathrm{~d}$ ०नाशनी ] ॰नाशिनी $R$ 31b सर्व॰ ] सुर॰ $R \quad 31 d$ ०माविष्कृतं ] ॰माकृष्यतां $R \quad 32-38$ ] om. $R^{\mathrm{ac}}, \mathrm{R}^{\mathrm{pc}}$ written i.m. 32cd ०शैर्यातयन्त ] शशै: पातयन्तः $R^{p c}$ 33a यात्यमानो ] पात्यमानो $R^{p c}$ 33d ०पाशितः ] ०पूरितः $\mathrm{R}^{\mathrm{pc}} \quad 34 \mathrm{a}$ यात्यमानं ] पात्यमानं $\mathrm{R}^{\mathrm{pc}}$ 34d ०स्यामितात्मनः ] ०स्य महात्मनः $\mathrm{R}^{\mathrm{pc}}$

29a ०श्चाहमद्य॰] ० ग्रु हेमश्च $A$ 29c मा क्षमेथा ] मोक्षयेथा $A_{3} A_{4}$, मोक्षमेथा $A_{7}$ 29d तनुं त्वां सो इह्बयेद्युधि ] युधे हिंसा ह्व $\left\{\right.$ है $\left.^{\circ} \mathrm{A}_{4}\right\}$ येद्यदि $\mathbf{A} 30 \mathrm{~b}{ }^{\circ}$ द्तत्तातिभास्वरा ] ०र्दत्ता हि भासुरा $\mathbf{A} 30 \mathbf{c}$ संवर्तिकेति ] संवर्त्तकेति $\mathbf{A}$ 30d ०नाशनी ] ०नाशिनी $\mathbf{A} 31 \mathrm{~b}$ ०प्रबाधकः ] $\mathrm{A}_{7}^{\mathrm{pc}}$, ०प्रधारक: $\mathrm{A}_{3} \mathrm{~A}_{4}$,

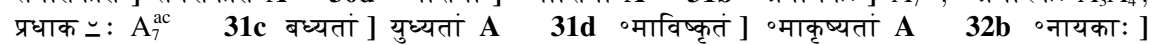
$\mathrm{A}_{3} \mathrm{~A}_{7}$, ०नायक: $\mathrm{A}_{4} \quad 32 \mathrm{c}$ बद्वा ] बद्धा $A$ 32d ०र्यातयन्त ] ॰र्घातयन्तः $A$ 33a यात्यमानो ] मार्यमानो $\left\{\circ\right.$ णो $\left.\mathrm{A}_{4}\right\} \mathrm{A}$ - दु :खार्तों ] $\mathrm{A}_{4} \mathrm{~A}_{7}$, दुखार्तों $\mathrm{A}_{3}$ 33cd-34 ] om. $\mathbf{A}$

$29\left(c^{3}, d^{3}\right) S_{1} \quad 32\left(d^{4}\right) S_{1} \quad 33\left(c^{5}\right) S_{2},\left(c^{7}-c^{8}, d^{2}\right) S_{3}$

29c क्षमेथा ] $S_{1}^{\mathrm{pc}} \mathrm{S}_{2} \mathrm{~S}_{3} \mathrm{Bh}$, क्षयेथा $\mathrm{S}_{1}^{\mathrm{ac}} \quad 29 \mathrm{~d}$ तनुं त्वां सो] $\mathrm{S}_{3}$, तनु(त्का) सो $\mathrm{S}_{1}^{\mathrm{pc}}$, तनु - सो $\mathrm{S}_{1}^{\mathrm{ac}}$, तनुं त्वसो $S_{2}^{p c}$, तनुं त्वा सो $S_{2}^{a c}$, तनुं त्वासौ $\mathrm{Bh}\left(\mathrm{em}\right.$.) - ०द्युधि $\mathrm{S}_{1} \mathrm{~S}_{2} \mathrm{~S}_{3} \mathrm{R}$, वद्यदि $\mathrm{Bh} 30 \mathrm{a}$ इयं च ] $\mathrm{S}_{2} \mathrm{~S}_{3} \mathrm{RABh}$, इमच्च $\mathrm{S}_{1} \mathbf{3 0 b}$ शक्तिर् ] $\mathrm{S}_{1} \mathrm{~S}_{2} \mathrm{RABh}$, शक्ति $\mathrm{S}_{3}$ • ०भास्वरा ] $\mathrm{S}_{1} \mathrm{~S}_{2} \mathrm{~S}_{3}^{\mathrm{pc}} \mathrm{Bh}$, ( ०दा)स्वरा $S_{3}^{\text {ac }}$ 30c संवर्तिकेति ] $S_{2} S_{3} R B h$, संवर्त्तकेति $S_{1}$ 31a सो ] $S_{2} S_{3} R A B h$, यो $S_{1}$ दुरात्मा ] $S_{1}^{\text {pc }} S_{2} S_{3} R A B h$, दुरात्म $S_{1}^{a c} 31 b$ ०लोक॰] $S_{1} S_{2} R A B h$, ०लोकक॰ $S_{3}$ (unmetrical) 31c ०तां बध्यतां ] $S_{1} S_{2} R$, ०ताम्बद्यता $S_{3}$, ०तां वध्यतां $B h$ 31d ०माविष्कृतं ] $S_{2} B h$, ०माविष्कृतां $\mathrm{S}_{1}$, ०माविष्कृत $\mathrm{S}_{3}$ (unmetrical) 32a बहि: $\mathrm{S}_{1} \mathrm{~S}_{2} \mathrm{R}^{\mathrm{pc}} \mathrm{ABh}$, बहि $\mathrm{S}_{3}$ (unmetrical) 32b ०नायका: ] $\mathrm{S}_{2} \mathrm{~S}_{3} \mathrm{R}^{\mathrm{pc}} \mathrm{A}_{3} \mathrm{~A}_{7} \mathrm{Bh}$, नायका $\mathrm{S}_{1}$ 32cd पारैर्यातयन्त स० $\mathrm{S}_{1} \mathrm{Bh}$, पाशैर्यातन्तस्स॰ $\mathrm{S}_{2}$, पाशै यातयन्त स० $\mathrm{S}_{3} \quad$ 33a दुःखातों] $\mathrm{S}_{1} \mathrm{~S}_{2} \mathrm{R}^{\mathrm{pc}} \mathrm{A}_{4} \mathrm{~A}_{7} \mathrm{Bh}$, दुःखार्ता $\mathrm{S}_{3}$ 33d स्वै: ] $\mathrm{S}_{1} \mathrm{~S}_{2} \mathrm{R}^{\mathrm{pc}} \mathrm{Bh}$, स्वै $\mathrm{S}_{3}$ - ०पाशितः ] $\mathrm{S}_{2} \mathrm{~S}_{3} B h$, ०पातित: $S_{1} \quad$ 34a यात्यमानं ] $\mathrm{S}_{1} S_{2}^{\text {pc }} S_{3} B h$, यात्यमानां $S_{2}^{\text {ac }}$ 34b ०महातपा: ] $\mathrm{S}_{1} \mathrm{~S}_{2}^{\mathrm{pc}} \mathrm{R}^{\mathrm{pc}} \mathrm{Bh}$, ०महातपा $\mathrm{S}_{2}^{\mathrm{ac}} \mathrm{S}_{3} \quad 34 \mathrm{c}$ न्यवेदयत् ] $\mathrm{S}_{2} \mathrm{~S}_{3} \mathrm{R}^{\mathrm{pc}} \mathrm{Bh}$, निवेदयत् $\mathrm{S}_{1}$ 
एष पुत्रो वृकस्तुम्यं बद्धः पाशैर्नेकशः।

यात्यते कार्त्तिकेयस्य किंकरैद्दुष्कृती यथा॥ ३४ ॥

न नाम तव देवस्य लोकार्थायोद्यतस्य च।

करोति संनतिं स्कन्दो बालभावात्रिरानमः॥ ३६॥

अथवा स्वबलं स्कन्दो मन्यते बलवत्तरम्।

त्वत्तो उत्मनस्ततः पुत्रं तव पाशैर्बबन्ध है। ३७॥

तद्यावदेव तं नासौ प्रमापयति देवप।

तावदेव भवान्गत्वा विमोचयतु माचिरम्॥ ३५॥

सनत्कुमार उवाच।

नारदस्य वचः श्रुत्वा वराहो नन्दिवर्धनः।

जीमूत इव कालान्ते ननाद रुषिताननः॥ ३९॥

तस्य ऋधधत्तदा वह्निर्नेत्राभ्यामतिदीत्रिमान्।

निश्चक्राम जगत्सर्वं संहरत्रिव तेजसा॥ ४०॥

$35 \mathrm{c}$ यात्यते ] पात्यते $\mathrm{R}^{\mathrm{pc}} \quad 36 \mathrm{~b}$ लोकार्थायोद्यतस्य ] लोकस्याप्युद्यतस्य $\mathrm{R}^{\mathrm{pc}} \quad 36 \mathrm{c}$ करोति ] अकरोत् $\mathrm{R}^{\mathrm{pc}} \quad 36 \mathrm{~d}$ ०त्रिरानमः ] ०त्रिरामयः $\mathrm{R}^{\mathrm{pc}} \quad 37 \mathrm{ab}$ ] om. $\mathrm{R}^{\mathrm{pc}} \quad 37 \mathrm{~cd}$ त्वत्तो उत्मनस्ततः पुत्रं तव ] दुरात्मानं तव सुतं येन $\mathrm{R}^{\mathrm{pc}} \quad 38 \mathrm{a}$ ०देव ] ०देवं $\mathrm{R}^{\mathrm{pc}} \quad 38 \mathrm{~d}$ विमोचयतु ] विलम्बयतु $\mathrm{R}^{\mathrm{pc}} 39 \mathrm{c}$ कालान्ते ] कल्पान्ते $R \quad 40 b$ ०र्नेत्राम्याम॰ ] ०र्गत्वा तान ${ }^{\circ}$

35a Before this $\mathbf{A}$ adds नारद उवाच। व वकस्तु०] $\mathrm{A}_{3} \mathrm{~A}_{4}$, वृकोस्तु ${ }^{\circ} \mathrm{A}_{7} 35 \mathbf{b}$ ०रनेकशः ] ०रनेकधा $A \quad 35 c$ यात्यते ] आर्द्यते $A \quad 35 d$ किंकरैर ] $A_{7}$, किकरैर $A_{3}$, किंकरे $A_{4} 36 a$ नाम ] $\mathrm{A}_{7}$, नाय $\mathrm{A}_{3}$, नाप $\mathrm{A}_{4} 36 \mathrm{~b}$ लोका॰ ] कोका० $\mathbf{A} 36 \mathrm{c}$ करोति ] अकरोत् $\mathrm{A}$ - संनतिं ] सयति $\mathrm{A}_{3}$, सपति $\mathrm{A}_{4}$, सयतिं $\mathrm{A}_{7} 36 \mathrm{~d}$ ०त्रिरानमः ] ०न्निरात्मवान् $\mathbf{A} 37 \mathbf{a}$ अथवा स्वबलं ] अथास्य भुवनं A $37 \mathrm{~cd}$ उत्मनस्ततः पुत्रं तव ] न्यूनं तव सुतं येन $\mathbf{A} 38 \mathbf{a b}]$ तस्मादन $\left\{\right.$ तस्मा+त्+दल $\left.\mathrm{A}_{7}\right\}$ वरश्चासौ न नाशयति देवय: $\left\{\circ \mathrm{प:} \mathrm{A}_{7}\right\} \mathrm{A} \quad 38 \mathrm{c}$ ०न्गत्वा ] ॰न्स त्वान् स त्वा $\mathrm{A}_{3}$ (unmetrical), ०न्स त्वा $\mathrm{A}_{4} \mathrm{~A}_{7}$ $38 d$ विमोचयतु ] $\mathrm{A}_{7}$, तं विमोचय $\mathrm{A}_{3} \mathrm{~A}_{4} \quad 39 \mathrm{c}$ कालान्ते ] घर्मान्ते $\mathrm{A}$

36 $\left(d^{1}-d^{5}\right) S_{2} \quad 38\left(d^{2}\right) S_{1},\left(a^{8}\right) S_{2} \quad 39\left(c^{1}\right) S_{1}$

35a वृकस्तु॰ ${ }^{\circ} \mathrm{S}_{1} \mathrm{~S}_{2} \mathrm{R}^{\mathrm{pc}} \mathrm{A}_{3} \mathrm{~A}_{4} \mathrm{Bh}$, वृक तु॰ $\mathrm{S}_{3} \quad 35 \mathrm{~b}$ बद्धः ] $\mathrm{S}_{2} \mathrm{~S}_{3}^{\mathrm{pc}} \mathrm{R}^{\mathrm{pc}} \mathrm{ABh}$, बन्धः $\mathrm{S}_{1}$, बद्ध $\mathrm{S}_{3}^{\mathrm{ac}}$ 35d किंकरै ] $S_{1} S_{2} R^{p c} A_{7} B h$, किड्कै $S_{3} \quad 36 b$ लोकार्थायो॰ ] $S_{2} S_{3} B h$, लोकार्थीयो॰ $S_{1}$ • च ] $\mathrm{S}_{2} \mathrm{~S}_{3} \mathrm{R}^{\mathrm{pc}} \mathrm{ABh}$, ह $\mathrm{S}_{1} \quad 36 \mathrm{c}$ संनतिं ] $\mathrm{S}_{1} \mathrm{R}^{\mathrm{pc}} \mathrm{Bh}$, सन्नति $\mathrm{S}_{2}$, सन्ततिं $\mathrm{S}_{3}^{\mathrm{pc}}$, सन्नति $\mathrm{S}_{3}^{\mathrm{ac}}$ 36d ०न्निरानमः ] $S_{2} S_{3}^{\text {pc }}$, ०त्रिरामन: $S_{1}$, निरानमः $S_{3}^{\text {ac }}$, ॰च रोषतः Bh (conj.) 37a स्वबलं ] $S_{1} S_{3}$, स्वबल $\mathrm{S}_{2}$, स्वमलं Bh (conj.) 37b बलवत्तरम्] $\mathrm{S}_{1} \mathrm{~S}_{2}^{\mathrm{pc}} \mathrm{S}_{3} \mathrm{ABh}$, बलत्तरम् $\mathrm{S}_{2}^{\text {ac }}$ (unmetrical) 37c त्वतो ] $\mathrm{S}_{2} \mathrm{~S}_{3} \mathrm{ABh}$, तत्वो $\mathrm{S}_{1}$ 37ed पुत्रं तव $] \mathrm{S}_{1} \mathrm{Bh}$, पुत्रंस्तव $\mathrm{S}_{2}$, पुत्रस्तव $\mathrm{S}_{3}^{\mathrm{pc}}$, पुत्रस्तंव $\mathrm{S}_{3}^{\mathrm{ac}} \quad 37 \mathrm{~d}$ पाशैर ] $S_{1} S_{2} R^{p c} A B h$, पाशै $S_{3} \quad 38 a$ तं नासौ ] $S_{1} S_{2} S_{3}^{p c} R^{p c} B h$, तनासौ $S_{3}^{\text {ac }}$ (unmetrical) $38 b$ देवप ] $\mathrm{S}_{2}^{\mathrm{ac}} \mathrm{S}_{3} \mathrm{R}^{\mathrm{pc}} \mathrm{Bh}$, देवप: $\mathrm{S}_{1} \mathrm{~S}_{2}^{\mathrm{pc}}$ 38d विमोचयतु ] $\mathrm{S}_{2} \mathrm{~S}_{3} \mathrm{~A}_{7} \mathrm{Bh}$, वि(मो)चयितु $\mathrm{S}_{1}$ 38d ०चिरम् ] $\mathrm{S}_{1} \mathrm{~S}_{3} \mathrm{RABh}$, ०चिरन् $\mathrm{S}_{2}$ 39c जीमूत ] $\mathrm{S}_{1} \mathrm{~S}_{2}^{\text {pc }} \mathrm{S}_{3} \mathrm{RABh}$, जीत $\mathrm{S}_{2}^{\mathrm{ac}}$ (unmetrical) कालान्ते ] $\mathrm{S}_{1}^{\mathrm{pc}} \mathrm{S}_{2} \mathrm{~S}_{3} \mathrm{Bh}$, कान्त $\mathrm{S}_{1}^{\mathrm{ac}}$ (unmetrical) 39d ननाद $] \mathrm{S}_{2} \mathrm{~S}_{3} \mathrm{RABh}$, ननार $\langle$ दः $\rangle \mathrm{S}_{1}$ - रुषिता०] $\mathrm{S}_{1} \mathrm{~S}_{2} \mathrm{~S}_{3} \mathrm{RA}$, रूषिता० $\mathrm{Bh}$ (conj.?) 40a वह्निर ] $\mathrm{S}_{1} \mathrm{~S}_{2} \mathrm{RABh}$, वह्नि $\mathrm{S}_{3} \quad 40 \mathrm{~b}$ ०दीत्रिमान् ] $\mathrm{S}_{2} \mathrm{~S}_{3} \mathrm{R}$ $\mathrm{ABh}$, ॰दीप्तवान् $\mathrm{S}_{1}$ 40d संहरत्रि॰ $\mathrm{S}_{1}^{\mathrm{pc}} \mathrm{S}_{2} \mathrm{~S}_{3}^{\mathrm{pc}} \mathrm{RABh}$, संहर(न्ति) $\mathrm{S}_{1}^{\mathrm{ac}}$, संहरनि॰ $\mathrm{S}_{3}^{\mathrm{ac}}$ (unmetrical) 
उत्थाय चासनाह्देवः सहसैवानिरीक्षणः।

प्रतस्थे शिखरं दिव्यं गौर्या मृगपतिः स्वयम्॥ ४१॥

स कम्पयन्महों सर्वां स्तूयमानो महात्मभिः।

उत्पातान्भयदान्पश्यअगामाविनिवारितः ॥ ४२॥

गच्छुतस्तस्य देवस्य पन्थानं भुजगो उच्छिनत्।

दंश्र्रा च वृक्षमापात्य पपात धरणीतले॥ ४३॥

रुधिरं चास्रवद्वक्राद्धद्यं च प्रवेपत।

भयं चास्याभवत्तत्र वेगो येनाभिहन्यते॥ ४४॥

वायवः प्रतिलोमाश्च उरसा चापतद्रुवि।

स्वेदश्चास्य प्रियं स्मृत्वा तदात्यर्थमजायत॥ $४ Y \|$

एतांश्चान्यांश्च बहुश उत्पातान्भयसूचकान्।

अनादृत्य मृगेन्द्रो उसौ जगामैव महाबलः॥ ४६॥

$41 \mathrm{a}$ नाद्देव: ] ॰नात् क्रूर: $\mathrm{R} 41 \mathrm{~b}$ सहसैवानि॰ ] सहसैव नि० $\mathrm{R} 41 \mathrm{c}$ प्रतस्थे शिखरं ] प्रतापण्णिखरं $\mathrm{R} 41 \mathrm{~d}$ गौर्या ] गर्जन् $\mathrm{R} 42 \mathrm{a}$ स कम्पयन्महीं सर्वां ] अरद्वयन्निव महीं $\mathrm{R}$ 42d ०माविनि॰ ]

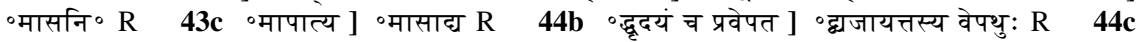
०त्तत्र ] ०त्तस्य $\mathrm{R} 45 \mathrm{~b}$ उरसा चापतड्डु॰] रजसो चापतन्भु॰ $\mathrm{R}^{\mathrm{pc}}$, रजसा चापतड्डु० $\mathrm{R}^{\mathrm{ac}} 45 \mathrm{~cd}$ ] om. $\mathrm{R}^{\mathrm{pc}}$, स्नेहश्चास्य प्रियं श्रुत्वा तदाकृत्नमहाय च $\mathrm{R}^{\mathrm{ac}} \quad 46 \mathrm{a}$ बहुश] बहुधा $\mathrm{R} \quad 46 \mathrm{c}$ अनादृत्य ] अनाहतो $\mathrm{R} \quad 46 \mathrm{~d}$ मैैव ] ॰मैवं $\mathrm{R}$

$41 \mathrm{a}$ ०द्देव: ] ॰देव $A 41 \mathrm{~b}$ सहसैवानिरी॰] सहसा दुर्निरी॰ $A 42 \mathrm{c}$ ०न्भयदान् ] न्म शतशः $A$ $42 \mathrm{~d}$ ०माविनि॰] $\mathrm{A}_{3} \mathrm{~A}_{7}$, ०म विनि॰ $\mathrm{A}_{4} 43 \mathrm{c}$ ०मापात्य ] ०मासाद्य $\mathrm{A} \quad 44 \mathrm{a}$ ०द्वृक्राद्धृ० ] $\mathrm{A}_{3} \mathrm{~A}_{7}^{\mathrm{pc}}$, वद्वक्ता है० $\mathrm{A}_{4} \mathrm{~A}_{7}^{\mathrm{ac}} \quad$ 44b प्रवेपत ] प्रवेपते $\mathrm{A}_{3} \mathrm{~A}_{7}$, प्रवेयते $\mathrm{A}_{4} \quad$ 44d येनाभि॰] येन वि॰ $A \quad 45 b$ उरसा चापतड़्ध० ] तव सापपतत भु॰ $\mathrm{A}_{3} \mathrm{~A}_{4}$, तव $+\simeq$ +पपतत भु० $\mathrm{A}_{7} 45 \mathrm{c}$ स्वेदश्चा० ] स्नेहश्चा० $\mathrm{A}_{3} \mathrm{~A}_{7}$, स्नेहंग्चा० $\mathrm{A}_{4} \quad 45 \mathrm{~d}$ ॰दात्यर्थ०] $\mathrm{A}_{7}$, ०दात्यथ॰ $\mathrm{A}_{3} \mathrm{~A}_{4}$ 46b ०तान्भयसूचकान् ] ॰तानड़ुतान् स्वकान् $\mathrm{A}_{3} \mathrm{~A}_{4}$, ${ }^{\circ}$ तान् भूतलांशुकान् $\mathrm{A}_{7} \quad \mathbf{4 6 c}$ अनादृत्य ] अनाहत्य $A$

$41\left(a^{7}-a^{8}\right) S_{1} \quad 42\left(b^{8}\right) S_{1} \quad 43\left(a^{6}, b^{1}-c^{1}, d^{6}-d^{8}\right) S_{1} \quad 46\left(d^{6}\right) S_{1}$

41a चासनाद्देव:] $S_{1} S_{2}^{p c} B h$, चासनाद्देव $S_{2}^{a c}$, वासनादेव $S_{3} 41 b$ सहसैवानिरी०] $S_{1}$, सहसैवान्निरी॰ $\mathrm{S}_{2}$, सहसैवांनिरी॰ $\mathrm{S}_{3}$, सहसैवोन्निरी॰Bh (em.) 41d गौर्या ] $\mathrm{S}_{1} \mathrm{ABh}$, गोय्या $\mathrm{S}_{2} \mathrm{~S}_{3}$ •

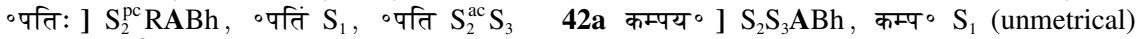

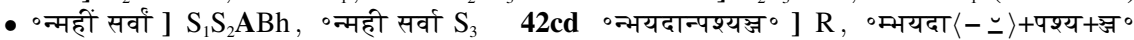
$\mathrm{S}_{1}$, ॰नुत्थितान्पश्यन्ज॰ $\mathrm{S}_{2}$, ०नुच्छितान्पश्य ज० $\mathrm{S}_{3}^{\mathrm{pc}}$, ॰नुच्छतान्पश्य ज० $\mathrm{S}_{3}^{\mathrm{ac}}$, ॰नुत्थितान् पश्यन् ज० $\mathrm{Bh} 42 \mathrm{~d}$ ०माविनि॰ $] \mathrm{S}_{1} \mathrm{~A}_{3} \mathrm{~A}_{7} \mathrm{Bh}$, ०म विनि॰ $\mathrm{S}_{2} \mathrm{~S}_{3}$ 43a गच्छतस्त० ] $\mathrm{S}_{2} \mathrm{RABh}$, गच्छन्त्ते त० $S_{1}$, गच्छुत+त+ $S_{3}$ 43b पन्थानं ] $S_{3} R A B h$, (पन्थाना) $S_{1}$ (anusvāra possibly lost), पन्थानां $\mathrm{S}_{2}$ - उच्छिनत् ] $\mathrm{S}_{2} \mathrm{~S}_{3} R A B h$, (च्छिता)न् $\mathrm{S}_{1}$ (tops lost) 43c दंष्ट्रा ] $\mathrm{S}_{1} \mathrm{~S}_{2} \mathrm{RABh}$, दंष्टा $\mathrm{S}_{3}$

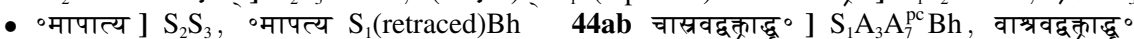
$\mathrm{S}_{2}$, चास्रवद्वक्रा है० $\mathrm{S}_{3} \quad \mathbf{4 4 b}$ च प्रवेपत ] $\mathrm{Bh}(\mathrm{em} . ?)$, चाप्रवेपत $\mathrm{S}_{1}^{\mathrm{pc}}$, चाप्रवेपतः $\mathrm{S}_{1}^{\mathrm{ac}}$, च प्रवेपतः $\mathrm{S}_{2} \mathrm{~S}_{3} \quad 44 \mathrm{c}$ भयं ] $\mathrm{S}_{1} \mathrm{~S}_{2} \mathrm{RABh}$, भय $\mathrm{S}_{3}$ 44d येना०] $\mathrm{S}_{2} \mathrm{~S}_{3} \mathrm{RBh}$, येता॰ $\mathrm{S}_{1}$ 45a ०लोमाश्च ] $\mathrm{S}_{2} \mathrm{~S}_{3} \mathrm{RABh}$, ०लोमाच्च $\mathrm{S}_{1} \quad 45 \mathrm{c}$ स्वेदश्चा॰ ] conj., स्वेहश्चा० $\mathrm{S}_{1}$, स्नेहश्चा० $\mathrm{S}_{2} \mathrm{Bh}$, स्वेह चा॰ $\mathrm{S}_{3}^{\mathrm{pc}}$ ?, सेह चा॰ $S_{3}^{\mathrm{ac}}$ ? - प्रियं ] $S_{3} R^{\mathrm{ac}} A$, प्रियां $S_{1} S_{2} B h \quad 45 d$ तदा० $S_{1} S_{2}^{p c} S_{3} R^{a c} A B h$, त- $\Gamma^{\circ} S_{2}^{a c}$

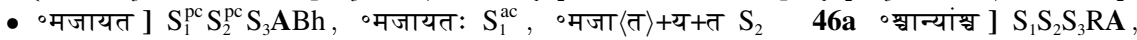
॰ श्चान्यान् सु॰ $B h$ (conj.) $46 \mathrm{~b}$ उत्पातान् $] S_{1}^{p c} S_{2} R A B h$, उत्पाताम् $S_{1}^{\text {ac }}$, उत्पाता $S_{3}$ • सूचकान् ] $\mathrm{S}_{1} \mathrm{RBh}$, ०सूचकाम् $\mathrm{S}_{2}$, सूचकां $\mathrm{S}_{3}$ 46c मृगेन्द्रो ] $\mathrm{S}_{1} \mathrm{~S}_{2} \mathrm{RABh}$, मृगेद्रो $\mathrm{S}_{3}$ 46d जगामैव ] $\mathrm{S}_{1}^{\mathrm{pc}} \mathrm{S}_{2} \mathrm{~S}_{3} \mathrm{ABh}$, ニ गामैव $\mathrm{S}_{1}^{\mathrm{ac}}$ 
तं प्रस्थितमभिप्रेक्ष्य निमित्तानि च सुत्रत।

पूजां सज्जामकुर्वन्त देवलोके दिवौकसः॥ ४७॥

स सिद्धसंघैरनुगम्यमानो यक्षैश्च गन्धर्वमहोरगैग्ये।

रक्षोगणैश्चारणकिंनरैस्च जगाम गौरीशिखरं महात्मा॥ ४५॥

इति स्कन्दपुराणे नवोत्तरशतो ऽध्यायः॥ १०९ ॥

47c सज्जा०] सर्वा० $\mathrm{R}^{\mathrm{pc}}$, संज्ञा० $\mathrm{R}^{\mathrm{ac}} \quad 48 \mathrm{c}$ रक्षोगणैग्चारण०] विद्याधरैश्चोरग॰ $\mathrm{R}$ Col. इति स्कन्दपुराणे रेवाखण्डे डध्याय: $\mathrm{R}$

47c सज्जामकुर्वन्त ] च समकुवंस्तु $\mathrm{A}_{3} \mathrm{~A}_{4}$, च समकुर्वन्त $\mathrm{A}_{7} \quad 47 \mathrm{~d}$ देव॰ ] तदा $\mathrm{A} \quad 48 \mathrm{c}$ ०णैश्चारणकिन्नरैश्च ] ०णै: किन्नरचारणैश्च $A$ 48d महात्मा ] महाबलः $A$ Col. इति [इति श्री० $\mathrm{A}_{4}$, ओं॥ इति श्री॰ $\mathrm{A}_{7}$ \}स्कन्दपुराणे एकाशीतिसाहस्रचां संहितायामम्बिकाखण्डे वराहप्रयाणो नाम शतमष्टोत्तरं $\mathbf{A}$

$\mathbf{4 7}\left(b^{7}\right)\left\langle b^{8}\right\rangle S_{2}$

47b निमित्तानि ] $\mathrm{S}_{1} \mathrm{~S}_{2} \mathrm{RABh}$, निमितानि $\mathrm{S}_{3}$ - सुव्रत ] RABh, सुब्रत $\mathrm{S}_{1}$, सु(व्र) $\simeq \mathrm{S}_{2}$, सुत्रतः $\mathrm{S}_{3} 47 \mathrm{c}$ सज्जा० ] $\mathrm{S}_{1} \mathrm{~S}_{2} \mathrm{Bh}$, सजा० $\mathrm{S}_{3}$ - ०मकुर्वन्त ] $\mathrm{S}_{1} \mathrm{~S}_{2} \mathrm{~S}_{3} \mathrm{RA}_{7}$, ०मकुर्वन्ते $\mathrm{Bh}(\mathrm{em}$.$) 47d$ देवलोके] $\mathrm{S}_{1} \mathrm{~S}_{2} \mathrm{~S}_{3} \mathrm{R}$, देलवोके $\mathrm{Bh}$ (typo) 48c रक्षो॰ $\mathrm{S}_{1} \mathrm{~S}_{2} \mathrm{~S}_{3}^{\mathrm{pc}} \mathrm{ABh}$, रक्षोय॰ $\mathrm{S}_{3}^{\text {ac }}$ (unmetrical) - किंनरैख्च ] $S_{1} S_{2} R B h$, किनरैश्च $S_{3}$ (unmetrical) 48d महात्मा ] $S_{2} S_{3} R B h$, महात्मा इति $S_{1}$ (इति part of col.) Col. $\odot \|$ स्कन्दपुराणे वृकबन्धे आध्याय १६३ (in letter numerals)॥ $\odot \mathrm{S}_{1}$, स्कन्दपुराणे नवोत्तरशतो ध्यायः॥ $\mathrm{S}_{2}, \odot \|$ स्कन्दपुराणे नामाध्यायः १९१ (in letter numerals)॥ $\mathrm{S}_{3}$, इति स्कन्दपुराणे वृकबन्धो नाम नवोत्तरशतो ध्याय: $\mathrm{Bh}$ 
दशोत्तरशतो डध्यायः

सनत्कुमार उवाच।

विनिर्गम्य कुमारो उपि रम्यात्स्वभवनात्तदा।

रराम गणपै: सार्ध कीडनैर्बहुभिः शुभैः ॥ १॥

आनयामास तं चापि वराहस्य सुतं प्रभुः।

वृकं विमुच्य पाशैश्च उत्ससर्ज हसन्विभुः॥ २॥

उत्सृष्टं धावमानं च पुनर्जग्राह वेगितम्।

पुनरेवोत्सृजचैन जग्राह च पुनः पुनः।

एवं रराम तेनासौ वराहो अ्यागमच्च तम्॥ ३॥

शिलां गृहीत्वा महतीं संक्रुद्धो उन्तकसंनिभः।

चिक्षेप कार्त्तिकेयाय नादयअलदो यथा॥ $४ \|$

तामापतन्तीं बहुधा नदन्तीं विहायसा मृत्युसमानरूपाम्।

जग्राह वेगेन महातिवेगां कोकामुखः प्रज्वलितामिवोल्काम् ॥ $y \|$

$1 b$ भवनात् ] भभवनात् $R \quad 1 d$ कीडनैर् ] कीडन्तं $R \quad 2 c$ पाशैश्च ] पाशैस्तु $R \quad 3 a$ धावमानं च ] नादमानग्च $R$ 3b वेगितम् ] वेगित: $R \quad 3 c$ ०वोत्सृजचै०] ०वोत्सृजग्चै॰ $R$ 3f भ्यागमच्च तम् ]

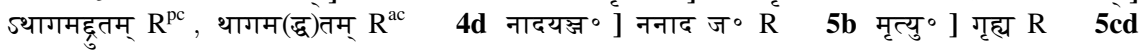
वेगेन महतीवेगां कोकामुखः ] वेगान्महतो ऽतिवेगां लोको $\left\{{ }^{\circ}\right.$ का $\left.{ }^{\circ} \mathrm{R}^{\mathrm{ac}}\right\}$ न्मुख॰ $\mathrm{R}$

$1 b$ रम्यात् ] $\mathrm{A}_{3} \mathrm{~A}_{4}$, रम्यां+त्+ $\mathrm{A}_{7}$ 1c गणपै: ] स गणै: $\mathrm{A}$ 1d कीडनैर ] $\mathrm{A}_{3} \mathrm{~A}_{7}$, कीडनै:र् $\mathrm{A}_{4}$ 2b प्रभुः ] $\mathrm{A}_{7}$, प्रभुं $\mathrm{A}_{3} \mathrm{~A}_{4}$ 2d हसन्विभुः ] हसत्रिव $\mathbf{A} \quad 3 \mathbf{b}$ वेगितम् ] वेगिनं $\mathbf{A} \quad 3 \mathbf{c}$ ०वोत्सृजचै० ] ववासृजच्चै० $A \quad 4 c$ कार्त्तिकेयाय ] $\mathrm{A}_{3} \mathrm{~A}_{7}$, कात्तिकेयाय $\mathrm{A}_{4} \quad \mathbf{5 a}$ नदन्तीं ] $\mathrm{A}_{4} \mathrm{~A}_{7}$, नदती $\mathrm{A}_{3}$ 5c ०वेगां ] ०वेगं $\mathbf{A} 5 d$ कोकामुखः ] $\mathrm{A}_{4}$, कोकामुख $\mathrm{A}_{3} \mathrm{~A}_{7}$ - ०वोल्काम् ] $\mathrm{A}_{7}^{\mathrm{ac}}$, ०वोक्षां $\mathrm{A}_{3} \mathrm{~A}_{4}$, $\circ$ वो-ं $\mathrm{A}_{7}^{\mathrm{pc}}$

Manuscripts available for this chapter: $S_{1}$ photos $4.10 \mathrm{~b}$ (f. $168^{\mathrm{r}}$ ), $4.11 \mathrm{a}\left(\mathrm{f} .168^{\mathrm{v}}\right) ; \mathrm{S}_{2}$ exposures $117 \mathrm{~b}-118 \mathrm{~b}$ (f. $152^{\mathrm{r}}-153^{\mathrm{r}}$ ); $\mathrm{S}_{3}$ f. $168^{\mathrm{r}}-168^{\mathrm{v}} ; \mathrm{R}$ f. $183^{\mathrm{v}}-184^{\mathrm{r}} ; \mathrm{A}_{3}$ f. $110^{\mathrm{r}}-110^{\mathrm{v}} ; \mathrm{A}_{4}$ f. $155^{\mathrm{r}}-156^{\mathrm{r}} ; \mathrm{A}_{7}$ f. $156^{\mathrm{r}}-157^{\mathrm{r}}$.

$3\left(\mathrm{f}^{8}\right) \mathrm{S}_{2}$

1a विनिर्गम्य ] $\mathrm{S}_{1} \mathrm{RABh}$, विनिगम्य $\mathrm{S}_{2} \mathrm{~S}_{3}$ 1b रम्यात् ] $\mathrm{S}_{1}^{\mathrm{pc}} \mathrm{S}_{2} \mathrm{RA}_{3} \mathrm{~A}_{4} \mathrm{Bh}$, रम्यत् $\mathrm{S}_{1}^{\mathrm{ac}}$, रम्या $\mathrm{S}_{3}$ $1 c$ गणपै: सा० ] $\mathrm{S}_{1} \mathrm{RBh}$, गणवैस्सा० $\mathrm{S}_{2}$, गणवै सा० $\mathrm{S}_{3}$ 1d कीडनैर ] $\mathrm{S}_{2} \mathrm{~A}_{3} \mathrm{~A}_{7} \mathrm{Bh}$, कीडतैर $\mathrm{S}_{1}$, कीडनै $S_{3}$ 2a तं चा०] $S_{1} R A B h$, तचा० $S_{2}$, त चा० $S_{3}$ (unmetrical) 2 b वराहस्य ] $S_{1} S_{2}^{\text {pc }}$ $\mathrm{S}_{3} \mathrm{RABh}$, वहाहस्य $\mathrm{S}_{2}^{\mathrm{ac}}$ 2cd पाशेश्च उ०] $\mathrm{S}_{1} A$, पाशैश्चुरु० $\mathrm{S}_{2} \mathrm{~S}_{3}$, पाशेम्य उ० $B$ (conj.) $2 d$ ०सन्विभुः ] $\mathrm{S}_{2} \mathrm{~S}_{3} \mathrm{RBh}$, ०सं प्रभुः $\mathrm{S}_{1}$ 3a धावमानं च ] $\mathrm{S}_{1}^{\mathrm{pc}} \mathrm{S}_{2} \mathrm{~S}_{3} \mathrm{ABh}$, वावमानग्च $\mathrm{S}_{1}^{\mathrm{ac}}$ 3b पुनर् ] $\mathrm{S}_{1} \mathrm{~S}_{2} \mathrm{RABh}$, पुन $\mathrm{S}_{3}$ - वेगितम् ] $\mathrm{S}_{1}^{\mathrm{pc}} \mathrm{S}_{2} \mathrm{~S}_{3} \mathrm{Bh}$, वे(ति)तम् $\mathrm{S}_{1}^{\text {ac }}$ 3c ०वोत्सृजच्चैं ] $\mathrm{S}_{2} \mathrm{Bh}$, ०वोत्सृजचैव $S_{1}$, ०वोत्सृज चैन $S_{3}$ (unmetrical) 3d जग्राह ] $S_{1} S_{2}^{\text {pc }} S_{3} R A B h$, ज(वा)ह $S_{2}^{\text {ac }}$ • पुनः पुनः ] $\mathrm{S}_{1} \mathrm{~S}_{2} \mathrm{~S}_{3}^{\mathrm{pc}} \mathrm{RABh}$, पुन पुन: $\mathrm{S}_{3}^{\mathrm{ac}}$ (unmetrical) $3 \mathrm{f}$ वराहो ] $\mathrm{S}_{1} \mathrm{~S}_{2} \mathrm{RABh}$, वराहे $\mathrm{S}_{3}$ - अ्यागमच्च तम् ] $\mathrm{S}_{2} \mathrm{ABh}$, भ्यागतन्धतम् $\mathrm{S}_{1}$, भ्यागम च तं $\mathrm{S}_{3}$ (unmetrical) 4 a शिलां ] $\mathrm{S}_{1} \mathrm{~S}_{2} \mathrm{RABh}$, शिला $\mathrm{S}_{3}$ - महतीं ] $\mathrm{S}_{1} \mathrm{~S}_{2} \mathrm{RABh}$, महती $\mathrm{S}_{3}$ 4b संक्रुद्धो ] $\mathrm{S}_{1} \mathrm{~S}_{2} \mathrm{RABh}$, सक्रुद्धो $\mathrm{S}_{3}$ 4c कार्त्तिकेयाय ] $\mathrm{S}_{2} \mathrm{~S}_{3} \mathrm{RA}_{3} \mathrm{~A}_{7} \mathrm{Bh}$, कार्त्तिकेयम्च $\mathrm{S}_{1}$ 5a तामा०] $\mathrm{S}_{1} \mathrm{RABh}$, तमा० $\mathrm{S}_{2} \mathrm{~S}_{3}$ 5a बहुधा] $\mathrm{S}_{1}^{\mathrm{pc}} \mathrm{S}_{2} \mathrm{~S}_{3} \mathrm{RA}$ $\mathrm{Bh}$, बहु(वा) $\mathrm{S}_{1}^{\mathrm{ac}}$ - नदन्तीं ] $\mathrm{S}_{2} \mathrm{~S}_{3} \mathrm{RA}_{4} \mathrm{~A}_{7} \mathrm{Bh}$, नदन्ती $\mathrm{S}_{1} \quad \mathbf{5 b}$ ०रूपाम् ] $\mathrm{S}_{1} \mathrm{~S}_{2} \mathrm{RABh}$, ०रूपा $\mathrm{S}_{3}$ 5d ०ज्वलितामि॰] RABh, ०ज्वलितां मि॰ $S_{1}$, ॰ज्वलितानि॰ $S_{2} S_{3}$ • ०वोल्काम् $] S_{2} S_{3} R A_{7}^{a c} B h$, $\circ$ वोल्कान् $\mathrm{S}_{1}$ 
ततश्चकं सहस्रारं युगान्ताग्निसमप्रभम्।

शिलाग्रहणव्यग्राय गणाय व्यसृजत्प्रभुः ॥ ६॥

तदन्तकप्रतीकाशं चक्र सर्वसुरारिहम्।

विवेश न गणं तूर्ण ततस्तद्यनिवर्तत॥ ७॥

तत्रिवृत्तं पुनश्चक्रमकृत्वा कार्यमुज्ञवलम्।

न जग्राह तदा विष्णुरवमेने च तत्तदा॥ ५॥

तत्तदानर्चितं तेन चक्र दानवघातिना।

विष्णुना प्रययौ क्षिप्रं स्वमेव भवनं प्रति॥ १॥

तस्मिंश्चक्रे तदा याते भगवान्नन्दिवर्धनः।

वृक्षमुत्पाट्य वेगेन कुमारमभिजछिवान् ॥ १०॥

अगण्य तं प्रहारं तु भगवाननलात्मजः ।

शक्ति संवर्तिकां कोधाच्चिक्षेप च ननाद च॥ १?॥

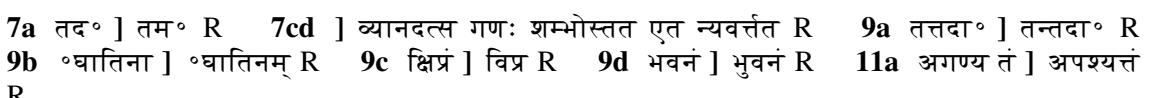
$\mathrm{R}$

$6 \mathrm{a}$ सहस्रारं ] सहस्राक्ष $\mathrm{A} 6 \mathrm{~d}$ गणाय व्य॰] गणपाया० $\mathrm{A} 7 \mathrm{a}$ तद ${ }^{\circ}$ ] तम० $\mathrm{A}$ 7cd ] न विवेश गणं शम्भोस्ततो गत्वा निवर्त्तत $\left\{{ }^{\circ}\right.$ तः $\left.\mathrm{A}_{3}\right\} \mathbf{A} \quad \mathbf{8 a}$ पुनश्चे०] तत्र च० $\mathbf{A}$ 8cd विष्णुरवमेने ] विष्णु वधमेने $\mathrm{A}_{3} \mathrm{~A}_{4}$, विष्णुर्वव $\left\{\circ\right.$ धं $\left.\mathrm{A}_{7}^{\mathrm{ac}}\right\}$ मेने $\mathrm{A}_{7}$ 9a तत्तदानर्चितं तेन ] तत्तदानिश्चितं तेन $\mathrm{A}_{3}$, तत्तंदाश्चितं तेन $\mathrm{A}_{4}$ (unmetrical), तत्तदानर्र्चितस्तेन $\mathrm{A}_{7} \quad 9 \mathrm{~b}$ ०घातिना ] ॰ घातिनं $\mathbf{A} \quad \mathbf{1 0 a}$ याते ] $\mathrm{A}_{7}$, जाते $\mathrm{A}_{3} \mathrm{~A}_{4}$ 10d ०जघ्रिवान्] $\mathrm{A}_{7}^{\mathrm{pc}}$, ०जग्मिवान् $\mathrm{A}_{3} \mathrm{~A}_{4} \mathrm{~A}_{7}^{\mathrm{ac}}$ 11a अगण्य ] $\mathrm{A}_{3} \mathrm{~A}_{7}$, आगत्य $\mathrm{A}_{4} \quad 11 \mathbf{b}$ ०ननलात्मजः ] ०न् शैलजात्मजः $A$ 11cd कोधाच्चि॰] $\mathrm{A}_{3} \mathrm{~A}_{7}$, कोधात् वि० $\mathrm{A}_{4}$

$\mathbf{6}\left(c^{1}-c^{6}\right) S_{2} \quad 7\left\langle a^{1}-a^{3}\right\rangle\left(a^{4}\right) S_{1} \quad 9\left(d^{8}\right) S_{1}$

6a ततश्च्चक्र ] $S_{1} S_{2} S_{3}^{\text {pc }} R A B h$, (तश्चश्च्तततश्चक्क $S_{3}$ • सहस्रारं ] $S_{1} S_{2} R B h$, सहसार $S_{3}$ (unmetrical) 6c शिलाग्रहणव्यग्राय ] $S_{2} S_{3} R A$, शिलाग्रहणदक्षाय $S_{1}^{\mathrm{pc}}$, शिलाग्रहण: $\simeq \simeq \simeq S_{1}^{\mathrm{ac}}$, विनायकस्याव्यग्राय $\mathrm{Bh}$ (conj.?) 6d व्यसृज॰] $\mathrm{S}_{1} \mathrm{~S}_{2} \mathrm{RBh}$, च्यसृज॰ $\mathrm{S}_{3} \quad \mathbf{7 a}$ तद॰ ] em. Bh, तम॰ $\mathrm{S}_{2} \mathrm{~S}_{3} \mathbf{7 b}$ ०सुरारिहम् ] RABh, ॰सुरारिणुत् $S_{1}$, ॰सुरारिघम् $S_{2}$, ०सुरारिघं $S_{3} \quad 7 c$ न ] conj., स० $S_{1} S_{2} S_{3}^{p c}$ $\mathrm{Bh}$, सस० $\mathrm{S}_{3}^{\mathrm{ac}}$ (unmetrical) $\mathbf{7 c d}$ गणं तूर्णं] em., गगणन्तुर्णन् $\mathrm{S}_{1}$, ०गणस्तूर्णन् $\mathrm{S}_{2}$, गगणस्तूर्ण $\mathrm{S}_{3}$, गगणस्तूर्ण $\mathrm{Bh}$ 7d ॰द्यानिवर्तत ] $\mathrm{S}_{2} \mathrm{~S}_{3}$, ०द्वातिवर्त्तत $\langle:\rangle \mathrm{S}_{1}$, ०द्विन्यवर्तत Bh (em.?) 8a त-

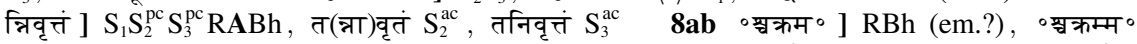
$S_{1}$, ०श्चुक्र म० $S_{2} S_{3}$ 9b चक्र] $S_{1} S_{2} R A B h$, चक्र $S_{3}$ 9d स्वमे॰ $S_{1}^{\text {pc }} S_{2} S_{3} R A B h$, स्वयमे॰ $\mathrm{S}_{1}^{\text {ac }}$ (unmetrical) - भवनं प्रति ] $\mathrm{S}_{1} \mathrm{~S}_{3} \mathrm{ABh}$, भवम्प्रम्प्रति $\mathrm{S}_{2}$ (unmetrical) $10 \mathrm{~b}$ भगवान् ] $\mathrm{S}_{1} \mathrm{~S}_{2}$ $\mathrm{S}_{3}^{\mathrm{pc}} \mathrm{RABh}$, भगवा $\mathrm{S}_{3}^{\mathrm{ac}} \quad 11 \mathrm{a}$ अगण्य $] \mathrm{S}_{1}^{\mathrm{pc}} \mathrm{S}_{2} \mathrm{~S}_{3} \mathrm{~A}_{3} \mathrm{~A}_{7} \mathrm{Bh}$, अरण्य $\mathrm{S}_{1}^{\mathrm{ac}}$ • तं ] $\mathrm{S}_{1} \mathrm{~S}_{2} \mathrm{RABh}$, त $\mathrm{S}_{3}$ $11 c$ शक्ति ] $S_{1} S_{2} R A B h$, शक्ति $S_{3}$ संवर्तिकां ] RABh, सम्वर्षिकां $S_{1}$, सम्वर्त्तकां $S_{2}$, सम्वर्त्तक $S_{3}$ $11 \mathrm{~cd}$ कोधाच्चि०] $\mathrm{S}_{1} \mathrm{~S}_{2} \mathrm{RA}_{3} \mathrm{~A}_{7} \mathrm{Bh}$, कोधा चि॰ $\mathrm{S}_{3}$ 
सा दहन्तीव तेजांसि नदन्ती बहुधा तदा।

हन्तुं वराहं प्रययौ शक्तिर्विद्युदिवाशुगा॥ ?२॥

तामापतन्तों वेगेन भगवान्नन्दिवर्धनः।

जघानास्त्रैर्बहुविधैर्नादयन्सिहराडिव ॥ १३॥

तानि सा भस्मसात्कृत्वा शक्ति: संवर्तिका शुभा।

विवेश हृदयं तस्य कामिनीव दृढ प्रिया॥ १४॥

स तया भित्रह्द्यो योगेन परमेण है।

योगीव देहं संत्यज्य देहेनान्येन तस्थिवान् ॥ १४ ॥

सो उन्यदेहं समास्थाय पौराणं सुरसत्तमः ।

देवै: सर्वे: परिवृतो जगाम भवमन्दिरम्॥ १६॥

तत्रापश्यन्महादेवं जटामुकुटधारिणम्।

चन्द्रल्नखांशुजालौघनिरस्ततिमिरोत्करम्॥ १७॥

12a सा दहन्ती॰ ] सादयन्ती॰ $R \quad 14 a$ तानि सा ] तमस्त्रं $R^{p c}$, अनिशं $R^{a c} 15 a$ तया ] तय $R \quad 15 d$ तस्थिवान् ] भक्तिमान् $R \quad 16 a$ इन्यद्देहं ] उन्यं देहं $R \quad 16 b$ पौराणं ] यौवनं $R$ 17d ०निरस्त॰ ] ०निभं सु० $\mathrm{R}$

12a सा दहन्तीव ] सादयंति च $\mathrm{A}_{3} \mathrm{~A}_{4}$, सा दहन्ती च $\mathrm{A}_{7}$ 13a ॰मापतन्तीं ] $\mathrm{A}_{3} \mathrm{~A}_{7}$, ०मापतंति $\mathrm{A}_{4}$ 14b संवर्तिका ] $\mathrm{A}_{3} \mathrm{~A}_{4}$, शम्वर्तिकां $\mathrm{A}_{7} \quad 14 \mathrm{~d}$ दृढं प्रिया ] दृढप्रियं $\mathrm{A}_{3} \mathrm{~A}_{7}$, दृढं प्रियं $\mathrm{A}_{4} \quad 15 \mathrm{c}$ देहं ] $\mathrm{A}_{3} \mathrm{~A}_{7}$, देह $\mathrm{A}_{4}$ 15d देहेना०] $\mathrm{A}_{3}$, देहिना० $\mathrm{A}_{4} \mathrm{~A}_{7}$ ० तस्थिवान् ] संस्थितः $\mathrm{A}$ 16a सो इन्यदेहं ] योग्यदेहं $A 16 \mathrm{~b}$ पौराणं ] पौराणां $A$ - सुरसत्तमः ] सुरसत्तम $A$ 16c परिवृतो ] $\mathrm{A}_{3} \mathrm{~A}_{7}$, परिवृतै $\mathrm{A}_{4}$

$12\left(b^{1}-b^{6}\right)\left\langle b^{7}-d^{1}\right\rangle\left(d^{2}-d^{4}\right) S_{1} \quad 15\left(a^{1}-a^{8}\right)\left\langle b^{1}-c^{1}\right\rangle S_{1} \quad 16\left(b^{8}\right) S_{1} \quad 17\left(d^{4}\right) S_{1},\left\langle c^{8}-d^{2}\right\rangle\left(d^{3}-d^{4}\right) S_{3}$

12a दहन्ती॰ ] $\mathrm{S}_{2} \mathrm{~S}_{3} \mathrm{~A}_{7} \mathrm{Bh}$, दहन्ति $\mathrm{S}_{1} \quad 12 \mathrm{c}$ हन्तुं ] $\mathrm{S}_{2} \mathrm{RABh}$, हन्तु $\mathrm{S}_{3}$ 12d शक्तिर्विद्युदि॰] $\mathrm{RA}$, (क्तिवद्यु)दि॰ $\mathrm{S}_{1}$ (upper part lost), शक्तिर्दिव इ० $\mathrm{S}_{2}^{\mathrm{pc}}$ (sec. hand), शक्ति(र्विद्यु) $\mathrm{f} \mathrm{S}_{2}^{\mathrm{ac}}$, शक्तिविद्युदि $\mathrm{S}_{3}$, शक्तिर्दिव्य इ॰ $\mathrm{Bh}$ (conj.?) - ०वाशुगा ] RA, ०वाशुभा $\mathrm{S}_{1}$ (tops lost), ०वाशुगः $\mathrm{S}_{2} \mathrm{~S}_{3} \mathrm{Bh} 13 \mathrm{a}$ तामापतन्तीं ] $\mathrm{S}_{1} \mathrm{~S}_{2} \mathrm{RA}_{3} \mathrm{~A}_{7}$, तमापतन्ती $\mathrm{S}_{3}$, तामापमन्तीं Bh (typo) 13b भगवान् ] $\mathrm{S}_{1} \mathrm{~S}_{2} \mathrm{RABh}$, भगवा $\mathrm{S}_{3} \quad 13 \mathrm{c}$ ०नास्त्रैर् ] $\mathrm{S}_{1} \mathrm{~S}_{2} \mathrm{RABh}$, ०नास्त्र $\mathrm{S}_{3} \quad$ 13cd ०विधैर्नादयन् ] $\mathrm{S}_{2}^{\mathrm{pc}} \mathrm{RA}$ $\mathrm{Bh}$, ०विधैन्न्नादयं $\mathrm{S}_{1}$, ०विधैर्न्नादय $\mathrm{S}_{2}^{\mathrm{ac}}$, ०विधै नादयन् $\mathrm{S}_{3} \quad \mathbf{1 4 a}$ तानि सा ] $\mathrm{S}_{1} \mathrm{~S}_{3} \mathrm{ABh}$, तानिस्सा $\mathrm{S}_{2}$ - भस्मसात् ] $S_{2}^{\text {pc }} R A B h$, भस्मसा $S_{1} S_{2}^{\text {ac }} S_{3}$ 14b शक्ति: ] $S_{1} S_{2} R A B h$, शक्ति $S_{3}$ - संवर्तिका ] $\mathrm{S}_{2} \mathrm{~S}_{3} \mathrm{RA}_{3} \mathrm{~A}_{4} \mathrm{Bh}$, संवर्त्तका $\mathrm{S}_{1}$ 14d दृढं ] $\mathrm{RA}_{4} \mathrm{Bh}$ (em.), दृढ॰ $\mathrm{S}_{1} \mathrm{~S}_{2} \mathrm{~S}_{3}$ (anusvāra possibly lost in $S_{1}$ ) 15a भित्र॰] $S_{1} S_{2} S_{3}^{\text {pc }} R A B h$, भिन० $S_{3}^{\text {ac }}$ (unmetrical) 15c देहं ] $S_{1} S_{2} R A_{3} A_{7} B h$, देह $S_{3}$ - संत्यज्य ] $\mathrm{S}_{2} \mathrm{~S}_{3} R A$, सन्त्यत्का $\mathrm{S}_{1}$, तं त्यत्का $\mathrm{Bh}$ (conj.) 16a उन्यद्देहं ] $\mathrm{S}_{2}^{\mathrm{pc} B h}$, न्यदेह $\mathrm{S}_{1} \mathrm{~S}_{2}^{\mathrm{ac}} \mathrm{S}_{3}$ $16 c$ देवै: स०] $S_{1} R A B h$, दैवैस्स॰ $S_{2}$, देवै स० $S_{3}$ - परिवृतो $] S_{1} S_{2} S_{3}^{p c} R A_{3} A_{7} B h$, परिवृ $S_{3}^{a c}$ (unmetrical) 17a ॰देवं ] $S_{1} S_{2} R A B h$, ०देव $S_{3} 17 \mathbf{b}$ ०मुकुट॰] $S_{2} R A B h$, ०मकुट॰ $S_{1} S_{3} 17 \mathbf{c}$ ०्लेखांशुजालौघ॰] $S_{2} R A B h$, ०लेखाशुआालौघ॰ $S_{1}^{p c}$, लेखाअलौघन्च $S_{1}^{a c}$, ०्लेखाड्शुजलौ $\simeq S_{3} 17 d$ ०निरस्ततिमिरोत्करम् ] $\mathrm{S}_{1}^{\mathrm{pc}} \mathrm{S}_{2}^{\mathrm{pc}} \mathrm{ABh}$, निरस्तमिरोत्करम् $\mathrm{S}_{1}^{\mathrm{ac}}$ (unmetrical), ०निरस्ति(भि)मिरोत्कर $\mathrm{S}_{2}^{\mathrm{ac}}$, $\simeq$ こ(स्तति)मिरोत्कर $S_{3}$ (upper parts of स्तति lost, anusvāra possibly lost) 
भद्रपीठे समासीनं काज्चुने मणिभूषणे।

भ्राजमानं श्रियात्यर्थं पार्वत्या पार्श्वसंस्थया॥ १५ ॥

गणैश्च विविधाकारैर्बहुभिः कामरूपिभिः।

नृत्तगीतप्रियैर्नित्यं समन्तात्परिवारितम् ॥ १९ ॥

तं दृष्ट्रा शंकरं विष्णुः प्रसत्नेनान्तरात्मना।

तुष्टाव विविधै: स्तोत्रैरिदं चोवाच सुस्वरम्॥ २०॥

वाराहं रूपमास्थाय त्वत्तेजोबृंहितेन मे।

रणे विक्रम्य भगवन्हिरण्याक्षो निषूदितः॥ २? ॥

त्वं देव कारणं नित्यं संभूतेः प्रतयस्य च।

त्वया सर्वमिदं व्याप्त जगदव्यक्तमूर्तिना॥ २२॥

त्वत्प्रसादेन देवेश ब्रह्माहं शक्र एव च।

पूज्या: स्म लोके सततं तथैवान्ये दिवौकसः॥ २३॥

त्वयि प्रीते महादेव सर्वे प्रीता वयं प्रभो।

त्वयि कुद्धे च नाशो नो भविता नात्र संशयः॥ २४॥

$18 \mathrm{~b}$ ॰भूषणे ] ॰भूषिते $\mathrm{R} 18 \mathrm{~d}$ पार्वत्या पार्श्वसंस्थया ] पार्वत्याः पार्श्वसंश्रयं $\mathrm{R}$ 19ab ०रैबहुभिः का-

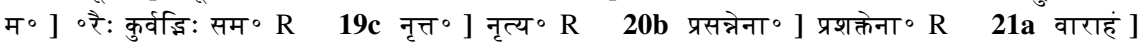
वराह॰ $R 21 b$ त्वत्तेजोबृंहितेन मे ] मया त्वत्तेजसा विभो $R$ 21d निषूदितः ] निसूदितः $R$ 22b

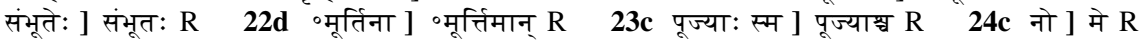

18a भद्रपीठे ] $\mathrm{A}_{3} \mathrm{~A}_{7}$, मद्रपीठे $\mathrm{A}_{4} 18 \mathrm{~b}$ ॰भूषणे ] ॰भूषिते $\mathrm{A} \quad 19 \mathrm{c}$ नृत्त॰ ] नृत्य॰ $\mathrm{A} \quad 20 \mathrm{a}$ तं दृष्ट्रा शंकरं विष्णुः ] त $\left\{\right.$ तं० $\left.\mathrm{A}_{7}\right\}$ तश्च्च शंकरं दृष्ट्वा $\mathrm{A} 20 \mathrm{~d}$ सुस्वरम् ] $\mathrm{A}_{3} \mathrm{~A}_{7}$, सस्वरं $\mathrm{A}_{4} 21 \mathrm{2}$ वाराहं ] $\mathrm{A}_{3} \mathrm{~A}_{4}$, वराहं $\mathrm{A}_{7} \quad 21 \mathrm{~b}$ त्वत्तेजोबृंहितेन मे] मया त्वत्तेजसा विभो $\mathbf{A}$ 21c भगवन् ] $\mathrm{A}_{3} \mathrm{~A}_{7}$, भगवान् $\mathrm{A}_{4} 21 d$ हिरण्याक्षो निषूदितः ] दैत्यो यं विनिसूदितः $A$ 22b संभूतेः ] संभूते $A$ 23c-24b ] om. A

$\mathbf{1 8}\left(b^{6}-b^{7}\right) S_{1} \quad 22\left(b^{6}-b^{7}\right) S_{2} \quad 23\left(d^{7}\right) S_{1},\left(d^{6}\right)\left\langle d^{7}\right\rangle\left(d^{8}\right) S_{2} \quad 24\left(c^{5}\right) S_{1},\left(b^{2}, c^{5}\right) S_{2}$

18a भद्रपीठे ] $\mathrm{S}_{1} \mathrm{RA}_{3} \mathrm{~A}_{7} \mathrm{Bh}$, चन्द्रपीठे $\mathrm{S}_{2} \mathrm{~S}_{3}$ - समासीनं ] $\mathrm{S}_{1} \mathrm{~S}_{2}^{\mathrm{pc}} \mathrm{S}_{3} \mathrm{RABh}$, समासीनां $\mathrm{S}_{2}^{\mathrm{ac}} \mathbf{1 8 b}$ कास्चने ] $\mathrm{S}_{2} \mathrm{~S}_{3} \mathrm{RABh}$, कास्चनैर् $\mathrm{S}_{1}$ - ०भूषणे ] $\mathrm{S}_{1} \mathrm{~S}_{2} \mathrm{~S}_{3}$, ०मूषणे Bh (typo) $18 \mathrm{c}$ ०यात्यर्थ ] $\mathrm{S}_{1} \mathrm{~S}_{2} \mathrm{R}$ $A B h$, ०यात्यर्थ $S_{3} \quad 18 d$ पार्श्व॰] $S_{1} S_{2} S_{3}^{\text {pc }} R A B h$, पाग्व्व $S_{3}^{\text {ac }} \bullet$ ०संस्थया ] $S_{2} S_{3} A B h$, संस्थिया $\mathrm{S}_{1} \quad$ 19b ०बरहुभि: ] $\mathrm{S}_{1} \mathrm{~S}_{3} \mathrm{ABh}$, ०बरहुभि $\mathrm{S}_{2}$ (visarga possibly lost) • ०रूपिभिः ] $\mathrm{S}_{1} \mathrm{~S}_{2}^{\mathrm{pc}} \mathrm{S}_{3} \mathrm{RA}$ $\mathrm{Bh}$, ०रूपभि: $\mathrm{S}_{2}^{\mathrm{ac}} \quad 19 \mathrm{c}$ ०प्रियैर् ] $\mathrm{S}_{1} \mathrm{~S}_{2} \mathrm{~S}_{3}^{\mathrm{pc}} \mathrm{RABh}$, ०प्रयैर् $\mathrm{S}_{3}^{\mathrm{ac}} \quad 20 \mathrm{a}$ तं दृष्द्वा ] $\mathrm{S}_{1} \mathrm{~S}_{3} R B$, तन्दृष्ट्वां $\mathrm{S}_{2} \quad 20 \mathrm{~b}$ प्रसत्नेनान्तरा॰] $\mathrm{S}_{2}^{\mathrm{pc}} \mathrm{S}_{3}^{\mathrm{pc}} \mathrm{RABh}$, प्रसत्नेनान्तारा॰ $\mathrm{S}_{1}$ (unmetrical), प्रसन्नेनन्तरा॰ $\mathrm{S}_{2}^{\mathrm{ac}}$, प्रसनेनान्तरा॰ $S_{3}^{\text {ac }}$ 20c तुष्टाव ] $S_{1}^{\mathrm{pc}} S_{2} S_{3} R A B h$, तुष्टा $S_{1}^{\text {ac }}$ (unmetrical) 20cd स्तोत्रै॰ ] $S_{1} S_{2} R A$ $\mathrm{Bh}$, स्तोस्त्रै॰ $\mathrm{S}_{3} 20 \mathrm{~d}$ सुस्वरम् ] $\mathrm{S}_{1} \mathrm{~S}_{2} \mathrm{RA}_{3} \mathrm{~A}_{7} \mathrm{Bh}$, सुस्वर $\mathrm{S}_{3}$ 21a वाराहं ] $\mathrm{S}_{2} \mathrm{~S}_{3} \mathrm{~A}_{3} \mathrm{~A}_{4} \mathrm{Bh}$, वराहं $\mathrm{S}_{1} 21 \mathrm{~b}$ वबृंहितेन ] $\mathrm{S}_{2} \mathrm{~S}_{3} \mathrm{Bh}$, ०वृंहितेन $\mathrm{S}_{1}$ 21c भगवन् ] $\mathrm{S}_{1} \mathrm{RA}_{3} \mathrm{~A}_{7} \mathrm{Bh}$, भगवान् $\mathrm{S}_{2}$, भगवां $\mathrm{S}_{3}$ 21d निषूदितः ] $S_{2}^{\mathrm{pc}} S_{3} B h$, निसूदितः $S_{1}$, निषू(भि)तः $S_{2}^{\text {ac }}$ 22b संभूतेः ] $S_{2} B h$, संभूते $S_{1}$, संभुतेः $\mathrm{S}_{3} \quad 23 \mathbf{b}$ ब्रह्माहं ] $\mathrm{S}_{2}^{\mathrm{pc}} \mathrm{S}_{3} \mathrm{RABh}$, ब्रह्माण $\mathrm{S}_{1}$, ब्र(हा)हं $\mathrm{S}_{2}^{\mathrm{ac}}$ - शक ए०] $\mathrm{S}_{2} \mathrm{~S}_{3} \mathrm{RABh}$, शकमे० $\mathrm{S}_{1}$

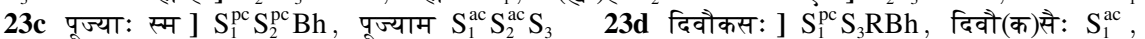
दि(वौ) $+-+\left(\right.$ स): $S_{2} \quad 24 \mathbf{b}$ प्रीता ] $S_{1}^{\text {pc }} S_{2} S_{3} R B h$, प्रीत $S_{1}^{\text {ac }} \quad$ 24c च ] $S_{1} S_{3} R A$, (व) $S_{2}$, वि॰ $B h$ (conj.) 
स्तुवन्तमेवं भगवान्विष्णुं चन्द्रार्धशेखरः।

सहस्रसूर्यतेजस्कः प्रीतः प्रोवाच शंकरः॥ २४॥

भत्ता तुष्टो उस्मि ते विष्णो देवकार्योद्यमेन च।

वरं वरय भद्र ते यस्ते मनसि वर्तते॥ २६॥

विष्णुरुवाच।

यदि तुष्टो उसि नो देव यदि देयो वरश्च नः।

ततः पाशुपतं दिव्यं व्रतमादेष्टुमर्हसि॥ २७॥

यदाश्रित्य वयं सर्वे सशक्रा: सर्वकामिकम्।

युद्धे जेष्याम दैतेयान्दु :खशोकविवर्जिताः॥ २५॥

देव उवाच।

अहं व: कथयिष्यामि गुह्यमेतत्सनातनम्।

व्रतं पाशुपतं दिव्यं येन कामानवाप्स्यथ॥ २९॥

इत्युत्का देवदेवेशो देवानां हितकाम्यया।

ययौ दिवमथामन्त्य देवीं गिरिवरात्मजाम्॥ ३०॥

$25 \mathrm{~b}$ ०न्विष्णुं च०] ०न् विष्णुश्च $\mathrm{R}^{\mathrm{pc}}$, ०न् विष्णु च $\mathrm{R}^{\mathrm{ac}}$ - ०शेखर:] ॰शेखरं $\mathrm{R}$ 25c सहस्र०] सह० $R$ (unmetrical) $25 \mathrm{~cd}$ ०तेजस्क: प्रीतः ] वतेजस्क विष्णुं $R \quad 26 \mathbf{d}$ यस्ते ] यत्ते $R \quad 27 \mathrm{a}$ नो देव ] देवेश $R \quad 28 c$ जेष्याम ] जेष्यामि $R \quad 28 d$ ०विवर्जिता: ] ०विवर्जितः $R^{p c}$, ०विवर्जितां $R^{a c}$ 29 देव ] देवदेव $R$ 29d कामानवाप्स्यथ] सम्मानमाप्स्यथ $R \quad 30 c$ ममामन्त्र्य ] मुपामन्त्य $R$ 30d देवीं ] देवान् $R$

25c ०तेजस्क: ] ०तेजाक्षः $A$ 25d प्रीतः ] $\mathrm{A}_{3} \mathrm{~A}_{7}$, प्रीत $\mathrm{A}_{4} \quad 26 \mathbf{d}$ यस्ते ] यत्ते $\mathbf{A} \quad 27 \mathbf{a}$ तुष्टो ऽसि ] $\mathrm{A}_{3}$, तुष्टो स्मि $\mathrm{A}_{4}$, तुसि $\mathrm{A}_{7}$ (unmetrical) 27c ततः ] तदा $\mathbf{A}$ 27d-29c ] om. $\mathbf{A}$ 29d ०नवाप्स्यथ ] $\mathrm{A}_{3} \mathrm{~A}_{7}^{\mathrm{pc}}$, ०नवाप्सथ $\mathrm{A}_{4} \mathrm{~A}_{7}^{\mathrm{ac}} 30 \mathrm{c}$ ०मथामन्त्र्य ] ०मुपामन्त्र्य $\mathbf{A}$

$\mathbf{2 5}\left(b^{2}, b^{6}, c^{2}\right) S_{2} \quad 29\left(d^{7}\right) S_{1} \quad 30\left(c^{8}, d^{3}, d^{5}-d^{8}\right) S_{1}$

$25 \mathrm{ab}$ मेवं भगवान्विष्णुं च०] $\mathrm{S}_{2}^{\mathrm{pc}} \mathrm{ABh}$, ०मेव भगवां विष्णुन्च० $\mathrm{S}_{1}$, ०मेवम्भ(वतां) वि(ष्णुं) च० $\mathrm{S}_{2}^{\mathrm{ac}}$, ममेव भवतां विष्णु च० $S_{3} \quad 25 \mathrm{~b}$ ०शेखर: ] $S_{1}^{\mathrm{pc}} S_{2}^{\mathrm{pc}} \mathrm{ABh}$, (०ख)खर: $S_{1}^{\mathrm{ac}}$, (०शे)खरन् $\mathrm{S}_{2}^{\mathrm{ac}}$, ०शेखरम् $\mathrm{S}_{3}$ 25d प्रीतः ] $\mathrm{S}_{1}^{\mathrm{pc}} \mathrm{S}_{2} \mathrm{~A}_{3} \mathrm{~A}_{7} \mathrm{Bh}$, प्रीत $\mathrm{S}_{1}^{\mathrm{ac}} \mathrm{S}_{3}$ - शंकर: ] $\mathrm{S}_{1} \mathrm{~S}_{2}^{\mathrm{pc}} \mathrm{RABh}$, शंकरम् $\mathrm{S}_{2}^{\mathrm{ac}}$, शंकरं $\mathrm{S}_{3} 26 \mathrm{~b}$ कायोद्यमेन ] $\mathrm{S}_{1} \mathrm{~S}_{2}^{\mathrm{pc}} \mathrm{S}_{3} \mathrm{RABh}$, कार्योद्यमेव $\mathrm{S}_{2}^{\mathrm{ac}} 27$ विष्णुरुवाच ] $\mathrm{S}_{2} \mathrm{~S}_{3} \mathrm{RABh}$ (विष्णुरु in $S_{2} S_{3}$ ), विष्णु उ $S_{1} \quad$ 27b वरश्च ] $S_{1} S_{2} R A B h$, वरस्व $S_{3}$ 27c ततः पाशुपतं ] $S_{1} R$, यत्तत्पापहरन $\mathrm{S}_{2}^{\mathrm{pc}}$ (ह i.m., sec.hand), यत्तत्पाप(त)न् $\mathrm{S}_{2}^{\text {ac }}$ (unmetrical), यत्तत्पाशुपतन् $\mathrm{S}_{3}$, यत्तत् पापहरं $\mathrm{Bh}$ 27d व्रत० ] $S_{2} S_{3} R B h$, ब्रत० $S_{1}$ 28a यदा० ] $S_{2} S_{3} R B h$, यथा० $S_{1}$ 28b ०शका: ] $S_{1} S_{2} R B h$, ०शक्रा $\mathrm{S}_{3}$ - सर्व०] $\mathrm{S}_{2} \mathrm{~S}_{3} R$, सार्व० $\mathrm{S}_{1} B \mathrm{28c}$ दैतेयान् ] $\mathrm{S}_{1} \mathrm{~S}_{3}^{\mathrm{pc}} \mathrm{RBh}$, दैत्येयां $\mathrm{S}_{2}$, तैतेयां $\mathrm{S}_{3}^{\mathrm{ac}}$ 28d ०विर्जिता: ] $S_{1} B h$, ०विर्जिता $S_{2} S_{3} \quad 29$ देव ] $S_{1}$, देवदेव $S_{2} B h$, देवदे $S_{3}$ 29a अहं व: कथयिष्यामि ] $R$, हन्त वः कथयिष्यामि $S_{1} B h$, अहन्तव $\langle:\rangle$ कयिष्यामि $S_{2}$, हन्त व: कयिष्यामि $S_{3}$ (unmetrical) 29b ०त्सनातनम् ] $\mathrm{S}_{1} \mathrm{~S}_{2} \mathrm{~S}_{3}^{\mathrm{pc}} \mathrm{RBh}$, ०त्सनातन $\mathrm{S}_{3}^{\text {ac }}$ 29c व्रतं ] $\mathrm{S}_{2} \mathrm{~S}_{3} R B h$, ब्रतम् $\mathrm{S}_{1}$

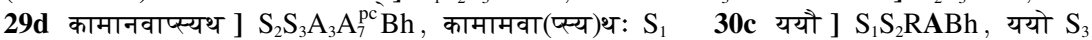




\section{अथ हिमगिरितुल्यचारुमूर्तिं वृषभवरं भगवांस्तदाभिरूढः। \\ सुरगणसहितः प्रभुः सुमेरुं व्रतमुपदेष्टुमना जगाम शर्वः॥ ३१॥}

इति स्कन्दपुराणे दशोत्तरशतो डध्यायः ॥ १९०॥

$31 \mathrm{a}$ ०तुल्य०] ०तुल्यं $\mathrm{R}$ (unmetrical) $31 \mathrm{~b}$ ०दाभिरूढ: ] ०दाधिरूढ: $\mathrm{R}$ 31d शर्व: ] सर्वम् $\mathrm{R}$ Col. इति स्कन्दपुराणे रेवाखण्डे +दशोत्तरशतो+ डध्याय: $\mathrm{R}$

31a ॰तुल्यचारुमूर्तिं ] ॰तुल्यचारुमूर्त्ति॰ ०र्त्तिर् $\left.\mathrm{A}_{7}\right\} \mathrm{A}_{3} \mathrm{~A}_{7}$, ०तुल्यश्चारुर्तिं $\mathrm{A}_{4}$ (unmetrical) $31 \mathbf{b}$ ०दाभिरूढ: ] वदाधिरू 0 रु० $\mathrm{A}_{7}$ (unmetrical)\}ढ: $\mathrm{A}$ 31d ] व्रतसुरमुपदेष्टुं जगाम सर्वशः $\mathrm{A}_{3}$ (unmetrical), व्रतमुपदेष्टु $\left\{\circ\right.$ ट्टुं $\left.\mathrm{A}_{7}\right\}$ जगाम सर्वशः $\mathrm{A}_{4} \mathrm{~A}_{7}$ (unmetrical) Col. इति $\left\{\right.$ इति म्री॰ $\left.\mathrm{A}_{4}\right\}$ स्कन्दपुराणे एकाशीतिसाहस्रचां संहितायामम्बिकाखण्डे नवोत्तरशतं $\mathbf{A}$

$31\left(a^{3}-b^{1}\right)\left\langle b^{6}\right\rangle\left(b^{9}, c^{10}, d^{6}\right) S_{1}$

31a हिमगिरितुल्य॰] $\mathrm{S}_{2} \mathrm{~S}_{3} \mathrm{RABh}$, (गिरिहिमतुल्ये) $\mathrm{S}_{1}$ • ०मूर्तिं ] $\mathrm{S}_{2} \mathrm{RBh}$, ( ०मर्तिर्त) $\mathrm{S}_{1}$ (vowel ऊ possibly lost), ॰मूर्ति $\mathrm{S}_{3} 3 \mathbf{3 b}$ भगवांस्तदाभि॰ $\mathrm{S}_{2}$, + +गवांस्तदाभि॰ $\mathrm{S}_{1}$, भगवान्सदाभि॰ $\mathrm{S}_{3}$, भगवांस्तदाधि० $B$ 31c ०सहितः ] $S_{2} R A B h$, ०महितः $S_{1}$, ०सहितं $S_{3}$ • प्रभुः ] $S_{1} S_{2} R A B h$, प्रभु $\mathrm{S}_{3}$ (unmetrical) 31d व्रत० $\mathrm{S}_{2} \mathrm{~S}_{3} \mathrm{RABh}$, ब्रत० $\mathrm{S}_{1}$ • जगाम $] \mathrm{S}_{1} \mathrm{~S}_{2} \mathrm{~S}_{3}^{\mathrm{pc}} \mathrm{RABh}$, जगम $\mathrm{S}_{3}^{\mathrm{ac}}$ (unmetrical) - शर्व: ] $\mathrm{S}_{3} B$ h, शर्व इति $\mathrm{S}_{1}$ (इति part of col.), सर्व: $\mathrm{S}_{2}$ Col. $\odot \|$ स्कन्दपुराणे वराहरूपसंहारे आध्याय १६६ (in letter numerals)॥ $\odot \mathrm{S}_{1}$, स्कन्दपुराणे दशोत्तरशतो ध्यायः॥ $\mathrm{S}_{2}, \odot$ ॥ स्कन्दपुराणे नामाध्याय: १९२ (in letter numerals)॥ $\odot \mathrm{S}_{3}$, इति स्कन्दपुराणे हिरण्याक्षवधे वराहसंहारे देवदेवस्य देवलोकगमनं नाम दशोत्तरशतो ध्याय: $\mathrm{Bh}$ 
एकादशोत्तरशतो डध्यायः।

\section{व्यास उवाच।}

गते दिवं महादेवे व्रतमादेष्टुमुत्तमम् ।

एकाकिनी महादेवी किं चके तदनन्तरम्॥ ?॥

सनत्कुमार उवाच।

गते तस्मिन्महादेवे देवीं गिरिवरात्मजाम्।

उपतस्थुर्महाभागा देव्यो लोकस्य मातरः॥ २॥

भरतस्य सुताग्नेस्तु मालिनीत्यभिविश्रुता।

शुभावती च देवस्य पर्जन्यस्य सुताव्यया॥ ३॥

सावित्री वेदमाता च गायत्री दुर्गया सह।

श्री: कीर्तिश्चैव लक्क्मी च धृतिः प्रज्ञा तथैव च॥ ४॥

1 व्यास उवाच ] om. R $1 c$ एकाकिनी महादेवी ] एकाकिनीं महादेवीं R $1 d-2 a$ ] om. R $2 b$ देवीं ] गौरीं $R \quad 2 c$ ०भागा ] ०भागां $R \quad 3 a$ सुताग्नेस्तु ] सुताग्नेयी $R \quad 3 c$ शुभावती ] सुतावनी $R$ 3d पर्जन्यस्य ] पर्य्यन्यस्य $R \quad 4 a$ वेद $\left.{ }^{\circ}\right]$ देव॰ $R \quad 4 b$ दुर्गया ] भृड्रया $R \quad 4 c$ लक्ष्मी च ] लक्ष्मीश्च $\mathrm{R}$

2d देव्यो ] $\mathrm{A}_{3} \mathrm{~A}_{7}^{\mathrm{pc}}$, देव्या $\mathrm{A}_{4} \mathrm{~A}_{7}^{\mathrm{ac}}$ 3a भरतस्य सुताग्नेस्तु $]$ तव $\left\{{ }^{\circ}\right.$ च $\left.\mathrm{A}_{3}\right\}$ तस्य सुताग्नेयी $\mathbf{A} 3 \mathbf{c}$ शुभावती ] $\mathrm{A}_{4} \mathrm{~A}_{7}$, सुभावती $\mathrm{A}_{3} 3 \mathbf{d}$ पर्जन्यस्य ] $\mathrm{A}_{3} \mathrm{~A}_{4}$, पर्य्यन्यस्य $\mathrm{A}_{7}$ 4a वेद०] $\mathrm{A}_{3} \mathrm{~A}_{7}$, देव॰ $\mathrm{A}_{4} 4 \mathrm{c}$ लक्ष्मी च] $\mathrm{A}_{4} \mathrm{~A}_{7}$, लक्ष्मीश्च $\mathrm{A}_{3}$ 4d धृतिः ] भूतिः $\mathrm{A}_{3} \mathrm{~A}_{7}$, भूति $\mathrm{A}_{4}$

Manuscripts available for this chapter: $S_{1}$ (upto 68d; f. 171 lost) photos $3.10 \mathrm{~b}$ (f. $169^{\mathrm{r}}$ ), $3.11 \mathrm{a}$ (f. 169 ${ }^{\mathrm{v}}$ ), 2.35a (f. $170^{\mathrm{r}}$ ) and 2.34b (f. 170 ${ }^{\mathrm{v}}$ ); $\mathrm{S}_{2}$ exposures $118 \mathrm{~b}-121 \mathrm{a}\left(\mathrm{f} .153^{\mathrm{r}}-155^{\mathrm{v}}\right) ; \mathrm{S}_{3}$ f. $168^{\mathrm{v}}-$ $171^{\mathrm{v}}$; R f. $184^{\mathrm{r}}-186^{\mathrm{v}} ; \mathrm{A}_{3}$ f. $110^{\mathrm{v}}-112^{\mathrm{v}} ; \mathrm{A}_{4}$ f. $156^{\mathrm{r}}-158^{\mathrm{v}} ; \mathrm{A}_{7}$ f. $157^{\mathrm{r}}-159^{\mathrm{r}}$.

$\mathbf{1}\left\langle\right.$ speaker indicaion- $\left.\mathrm{a}^{4}\right\rangle\left(\mathrm{a}^{5}-\mathrm{b}^{1}, \mathrm{c}^{8}\right) \mathrm{S}_{1} \quad \mathbf{2}\left(\mathrm{d}^{2}\right) \mathrm{S}_{2} \quad \mathbf{3}\left(\mathrm{c}^{1}-\mathrm{c}^{5}\right)\left\langle\mathrm{c}^{6}-\mathrm{c}^{7}\right\rangle\left(\mathrm{c}^{8}\right)\left\langle\mathrm{d}^{1}\right\rangle\left(\mathrm{d}^{2}\right)\left\langle\mathrm{d}^{3}-\mathrm{d}^{8}\right\rangle \mathrm{S}_{1}$

1 व्यास उवाच ] $\mathrm{ABh}$, व्यास $\mathrm{S}_{2}^{\mathrm{pc}}$, सन उ $\mathrm{S}_{2}^{\mathrm{ac}} \mathrm{S}_{3}$ 2a तस्मिन् ] $\mathrm{S}_{1} \mathrm{~S}_{2} \mathrm{~S}_{3} \mathrm{~A}$, दिवं Bh (conj.?) • ॰देवे ] $\mathrm{S}_{1} \mathrm{~S}_{2} \mathrm{~S}_{3}^{\mathrm{pc}} \mathrm{ABh}$, कदेवी $\mathrm{S}_{3}^{\mathrm{ac}}$ 2b देवीं ] $\mathrm{S}_{1} \mathrm{~S}_{2} \mathrm{ABh}$, देवी $\mathrm{S}_{3}$ - ०रात्मजाम् ] $\mathrm{S}_{1}^{\mathrm{pc}} \mathrm{S}_{2} \mathrm{~S}_{3} \mathrm{RABh}$, ०रात्मजात् $S_{1}^{\mathrm{ac}} \quad 2 \mathrm{c}$ उपतस्थुर् ] $\mathrm{S}_{2} \mathrm{RABh}$, उपतस्थु $\mathrm{S}_{1} \mathrm{~S}_{3} \quad$ 2cd ०भागा देव्यो ] $\mathrm{S}_{1} \mathrm{~S}_{2}^{\mathrm{pc}} \mathrm{A}_{3} \mathrm{~A}_{7}^{\mathrm{pc}} \mathrm{Bh}$, ०भाग(त्म्यो) $S_{2}^{\text {ac }}$ (unmetrical), ०भागं देव्यो $S_{3}$ 2d मातर: ] $S_{2}^{\text {pc }} R A B h$, मातरा: $S_{1}$, मातर $S_{2}^{\text {ac }} S_{3}$ 3a भरतस्य ] $\mathrm{S}_{2} \mathrm{~S}_{3} \mathrm{RBh}$, भरथस्य $\mathrm{S}_{1}$ - सुताग्नेस्तु ] $\mathrm{S}_{2} \mathrm{Bh}$, सुराग्ने तु $\mathrm{S}_{1}$, सुताग्ने तु $\mathrm{S}_{3} 3 \mathbf{b}$ ० नीत्यभि॰ ] $S_{1}^{\text {pc }} S_{2} S_{3} R A B h$, ०नीत्यम्भि॰ $S_{1}^{\text {ac }}$ 3c शुभावती ] $S_{1} A_{4} A_{7}$, शुचावती $S_{2} S_{3} B h$ • च देवस्य ] $\mathrm{S}_{2} \mathrm{RABh}$, (व) - - $\simeq \mathrm{S}_{1}$ (last akșara has subscript य्, second and third illegible akṣaras possibly by a second hand), च देवेस्य $S_{3}$ 3d पर्जन्यस्य ] $S_{2} A_{3} A_{4} B h, \simeq \simeq \simeq \simeq S_{1}$ (second akșara has subscipt ज्), पार्जन्यस्य $\mathrm{S}_{3} \quad \mathbf{4 a}$ वेद० ] $\mathrm{S}_{1} \mathrm{~A}_{3} \mathrm{~A}_{7} \mathrm{Bh}$, देव० $\mathrm{S}_{2} \mathrm{~S}_{3}$ 4c श्री: ] $\mathrm{S}_{1} \mathrm{~S}_{2}^{\mathrm{pc}} \mathrm{RABh}$, ग्री $\mathrm{S}_{2}^{\mathrm{ac}} \mathrm{S}_{3}$ - लक्ष्मी च ] $\mathrm{S}_{1} \mathrm{~S}_{2} \mathrm{~S}_{3} \mathrm{~A}_{4} \mathrm{~A}_{7}$, लक्ष्मीश्च $\mathrm{Bh}$ 4d धृतिः ] $\mathrm{S}_{2} \mathrm{~S}_{3} R B h$, धृति $\mathrm{S}_{1}$ 
ख्यातिर्दितिर्दनु ग्चैव अदितिः सिंहिका खशा।

राका कुहु सिनीवाली तथैवानुमती शुभा॥ $y$ ॥

गड़ा सरस्वती चैव तथान्याः सरितः शुभाः।

ऋषीणां पत्नयो याश्च देवानां यक्षरक्षसाम्।

उरगाणां खगानां च गन्धर्वाणां तथैव च॥ ६॥

एताः सर्वास्तथागम्य नमस्कृत्वा च पार्वतीम्।

पप्रच्छुः सर्वधर्मज्ञां धर्मं धर्मार्थसंश्रिताः॥ ७॥

केन धर्मेण देवेशे तपसा वा शुभानने ।

सुमहत्प्राप्यते पुण्यं किं चाक्षख्यं प्रकीर्तितम् ॥ ५॥

देव्युवाच।

युष्माकं तु हितार्थाय लोकानां चैव सुत्रताः।

कथयिष्याम्यहं धर्मं यथावदनुपूर्वशः॥ ९॥

$5 b$ खशा ] तथा R $5 c$ कुहू सिनीवाली ] कुहू: शिनीवाली R $5 d$ तथैवानुमती शुभा ] तथा भानुमती प्रभा $\mathrm{R} 6 \mathrm{c}$ ०णां पत्नयो याश्च ] ०णास्चैव पत्न्यस्तु $\mathrm{R}$ 6f गन्धर्वाणां] गन्धर्व्वणान् $\mathrm{R}$ (unmetrical) $7 \mathrm{ab}$ सर्वास्तथागम्य नमस्कृत्वा ] सभ्यास्तथागत्य नमस्कृत्य $\mathrm{R} 7 \mathrm{c}$ पप्रच्छुः ] पपृच्छु: $\mathrm{R}$ 7cd ०धर्मज्ञां धर्मं ] धर्म्मझ्ञाः सर्व्व० $R \quad 8 a$ देवेशे ] देवो हि $R \quad 8 b$ वा ] च $R \quad 8 d$ किं चाक्षय्यं प्र०] तद्व: कथय $\mathrm{R}$

5a ख्यातिर् ] $\mathrm{A}_{3} \mathrm{~A}_{7}$, ख्याति॰ $\mathrm{A}_{4}$ (unmetrical) $5 \mathbf{b}$ ०का खशा ] ०काथ सा $\mathrm{A}_{4} \mathrm{~A}_{7}$, ०काय सा $\mathrm{A}_{3}$

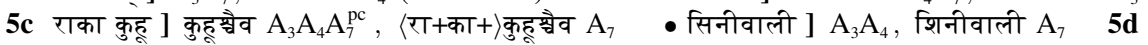
तथैवानुमती ] तथा भानुमती $A \quad 6 b$ तथान्या: ] $A_{3}$, तथान्य $A_{4}$, तथान्या $A_{7}$ - शुभा: ] $A_{3} A_{4}$, शुभा $\mathrm{A}_{7} \quad \mathbf{6 c}$ पत्नयो याश्च्च ] याश्च्च $\left\{\right.$ या च $\left.\mathrm{A}_{4} \mathrm{~A}_{7}^{\mathrm{ac}}\right\}$ पत्न्यो वै $\mathrm{A} \quad \mathbf{6 d}$ ०रक्षसाम् ] ०राक्षस: $\mathrm{A}_{3} \mathrm{~A}_{7}$, ०राक्षसा: $\mathrm{A}_{4}$ 6e उरगाणां] उरगानां $A$ 7c पप्रच्छु: ] $\mathrm{A}_{3} \mathrm{~A}_{7}$, पपृछ, $\mathrm{A}_{4}$ 7cd ०धर्मज्ञां धर्म धमार्थ०] ०धर्मज्ञा धर्मार्थं धर्म० $\mathbf{A} 8 \mathbf{a}$ देवेशे ] धर्म्मे सि $\mathrm{A}_{3}$, धर्मों सि $\mathrm{A}_{4}$, धर्म्मेशि $\mathrm{A}_{7} \quad 8 \mathbf{b}$ शुभानने ] शुभानना $\mathbf{A} \mathbf{8 d}$ चा० ] वा० $\mathbf{A} 9 \mathbf{b}$ सुत्रता: ] $\mathrm{A}_{7}$, सुत्रता $\mathrm{A}_{3} \mathrm{~A}_{4}$

6( $\left(d^{8}\right) S_{1}$

5a ख्यातिर्दितिर् ] $\mathrm{S}_{1} \mathrm{~S}_{2} \mathrm{RA}_{3} \mathrm{~A}_{7} \mathrm{Bh}$, ख्यातिदिति॰ $\mathrm{S}_{3}$ (unmetrical) 5b अदितिः ] $\mathrm{S}_{1} \mathrm{~S}_{2} \mathrm{RABh}$, अदिति॰ $\mathrm{S}_{3}$ (unmetrical) - सिंहिका ] $\mathrm{S}_{2} \mathrm{~S}_{3} \mathrm{RABh}$, सिंहका $\mathrm{S}_{1}$ - खशा ] $\mathrm{S}_{2} \mathrm{~S}_{3} B$ h, खषा $\mathrm{S}_{1} \mathbf{5 c}$ कुहू ] $\mathrm{S}_{1} \mathrm{~S}_{2} \mathrm{~S}_{3}$, कुहू: $\mathrm{Bh}(\mathrm{em} . ?)$ - सिनीवाली ] $\mathrm{S}_{1} \mathrm{~S}_{2} \mathrm{~S}_{3}^{\mathrm{pc}} \mathrm{A}_{3} \mathrm{~A}_{4} \mathrm{Bh}$, पिनीवाली $\mathrm{S}_{3}^{\text {ac }} 5 \mathrm{5}$ ॰वानुमती ] $\mathrm{S}_{1} \mathrm{~S}_{2} \mathrm{~S}_{3}$, ॰वानुमतिः $\mathrm{Bh}\left(\mathrm{em}\right.$.) $\mathbf{6 b}$ तथान्याः सरितः ] $\mathrm{S}_{2} \mathrm{~S}_{3} \mathrm{RA}_{3} \mathrm{Bh}$, तथान्या सरिता: $\mathrm{S}_{1}$ • शुभा: ] $\mathrm{S}_{1} \mathrm{~S}_{2}^{\mathrm{pc}} \mathrm{RA}_{3} \mathrm{~A}_{4} \mathrm{Bh}$, शुभा $\mathrm{S}_{2}^{\mathrm{ac}} \mathrm{S}_{3} \quad \mathbf{6 c}$ ०णां पत्नयो याश्च ] em., ०णां पत्न $\langle$ गा $\rangle+य ो+$ गाश्च $\mathrm{S}_{1}$, ०णाम्पत्न्ययो याश्च $\mathrm{S}_{2} \mathrm{~S}_{3}$, ०णां चैव याः पत्न्यो Bh (conj.) 6d ०रक्षसाम् ] RBh (em.?), ०राक्षसा(म्) $\mathrm{S}_{1}$, ०राक्षसां $\mathrm{S}_{2}$, ०राक्षसा $\mathrm{S}_{3}$ 6e उरगाणां ] $\mathrm{S}_{1} \mathrm{RBh}$, उरगानां $\mathrm{S}_{2} \mathrm{~S}_{3}$ • खगानां च ] $\mathrm{S}_{2} \mathrm{~S}_{3} \mathrm{RABh}$, खगाणाग्च $S_{1}$ 7a एता: ] $S_{2}^{\mathrm{pc}} R A B h$, एतां $S_{1}$, एता $S_{2}^{\mathrm{ac}} S_{3}$ • सर्वास्तथा॰] $S_{2} S_{3}^{\mathrm{pc}} A B h$, सर्वान्तथा० $S_{1}$, सर्वास्तदा० $S_{3}^{\text {ac }} 7 \mathbf{b}$ पार्वतीम् ] $S_{1} S_{2} R A B h$, पार्वती $S_{3}$ 7c पप्रच्छुः ] $S_{1} S_{2} A_{3} A_{7} B h$, प्रप्रच्छु $\mathrm{S}_{3}$ • धर्मज्ञां ] em., ०धर्म्म ज्ञा $\mathrm{S}_{1}$, ०धर्मज्ञा $\mathrm{S}_{2} \mathrm{~S}_{3} B h \quad 8 c$ सुमहत् ] $\mathrm{S}_{1} \mathrm{~S}_{2} \mathrm{~S}_{3} R A$, मुमहत् $\mathrm{Bh}$ (typo) 9 देव्युवाच ] $\mathrm{S}_{2} \mathrm{~S}_{3} \mathrm{RABh}$ (देव्यु in $\mathrm{S}_{2}$ ), देव्य उ $\mathrm{S}_{1}$ 9b सुत्रता: ] $\mathrm{RA}_{7} B \mathrm{Bh}$ (em.?), सुत्रत $\mathrm{S}_{1}$ (right side lost), सुत्रता $\mathrm{S}_{2} \mathrm{~S}_{3}$ 9cd ०म्यहं धर्मं य०] $\mathrm{S}_{2} \mathrm{RABh}$, ०म्यहन्धम्म्मन्य $\mathrm{S}_{1}$, ०मन्धर्म्म य॰ $\mathrm{S}_{3}$ (unmetrical) 9d ०थावदनु०] $\mathrm{S}_{2} \mathrm{~S}_{3} \mathrm{RABh}$, ०थानुवद $\mathrm{S}_{1}$ 
अन्नदानात्परं दानं नैव किंचिद्धि विद्यते।

अन्नाइ्कवन्ति भूतानि तस्मात्तदधिकं स्मृतम्॥ १०॥

अन्नं यस्तु सुसंस्कृत्य प्रयच्छेत द्विजातये।

स सर्वकामानाप्रोति पूज्यते च त्रिपिष्टपे॥ ??॥

मयूरहंसयुक्त च सर्वकामसमृद्विमत्।

विमानं सूर्यसंकाशमन्नदो लभते शुभम्॥ ?२॥

यदि मानुष्यमायाति कदाचित्स नरोत्तमः।

धनधान्यसमाकीर्णे कुले जायति रूपवान्॥ ?३॥

यथाशक्ति तु यो दद्याद्विवसे दिवसे नरः।

स तेन कर्मणाप्नोति प्रजापतिसलोकताम्॥ १४ ॥

कदाचिदपि यो दद्यादन्न विप्राय संस्कृतम्।

तस्यापि तच्छुतुणं सहस्रगुणमेव च।

उपतिष्टति लोकेषु इहापि च सुखी भवेत्॥ १४ ॥

अवधूतमवज्ञातमसत्कृतमथापि च।

अन्नं प्रदद्याद्यो देवि यादृशं तादृशं शुभे॥ १६॥

11ab = DS p. 365. 11cd DS p. 365: सर्वान् कामानवाप्रोति पूज्यते च त्रिपिष्टपे । (var. सर्वकामा०) 12ab DS p. 365: मयूरहंसयुक्तच्च सर्वकामसमृद्धिवत्। $12 \mathrm{~cd}=$ DS p.365 13 DS p. 365: यदि मानुषतां याति कदाचिन्नरसत्तम। धनधान्यसमाकीर्णे कुले जायेत रूपवान्। (var. ०न्नरसत्तमः) 14 DS p. 365: यथाशत्ता तु तद्द्याद्विवसे दिवसे नरः। स तेन कर्मणा प्राप्तः प्रजापतिसलोकताम्। 15ab DS p. 365: कदाचिदपि यो दद्यादन्नं विप्राय सत्कृतम् । (var. संस्कृतं)
15c-f = DS p. 365-66

11c स सर्वकामानाप्रोति ] सर्व्वकामानवाप्रोति $R \quad 11 d$ ०पिष्टपे ] ०विष्टपे $R \quad 12 \mathrm{~cd}$ ०सकाशम०] $\mathrm{R}^{\mathrm{pc}}$, ०संकाशं म॰ $\mathrm{R}^{\mathrm{ac}} \quad 13 \mathrm{~d}$ जायति ] जायेत $\mathrm{R} \quad 14 \mathrm{a}$ ०शक्ति तु यो ] ०स्वशक्तितो $\mathrm{R}$ 14c$16 \mathrm{~b}$ ] om. $\mathrm{R} 16 \mathrm{c}$ अन्नं प्रदद्याद्यो देवि ] श्रद्वयान्नं $\langle$ हि $\rangle+न+$ यो दद्याद् $\mathrm{R} 16 \mathrm{~d}$ शुभे ] भवेत् $\mathrm{R}$

10-20 ] om. A (eyeskip)

$10\left(c^{1}\right) S_{1},\left(a^{5}, b^{3}, c^{5}-c^{6}\right)\left\langle c^{7}-c^{8}\right\rangle S_{2} \quad 11\left(a^{5}\right) S_{1} \quad 12\left(c^{4}-c^{5}\right) S_{1},\left(a^{8}\right) S_{2} \quad 13\left(b^{7}-b^{8}\right) S_{1},\left\langle c^{1}-\right.$ $\left.c^{2}\right\rangle\left(c^{3}-c^{4}, c^{7}-d^{1}\right)\left\langle d^{2}-d^{5}\right\rangle S_{2} \quad 15\left(c^{5}-c^{6}, c^{8}\right) S_{1}$

10a ०दानात् ] $S_{1} S_{2}^{\mathrm{pc} R B h}$, ०दानं $\mathrm{S}_{2}^{\mathrm{ac}} \mathrm{S}_{3} \quad 10 \mathrm{~b}$ किंचिद्धि ] $\mathrm{S}_{1} R B h$, (कि) च्चिश्च $\mathrm{S}_{2}$, किस्चि $\mathrm{S}_{3}$ (unmetrical) 10c अन्नाद् ] $S_{1} S_{2} R B h$, अनाद् $S_{3}$ • भूतानि ] RBh (conj.?), सत्वानि $S_{1}$, (भू) - $-\mathrm{S}_{2}$, भूत्वानि $\mathrm{S}_{3}$ 11c स सर्वकामानाप्रोति ] $\mathrm{S}_{1} \mathrm{~S}_{3} \mathrm{Bh}$, सर्वकामानवाप्रोति $\mathrm{S}_{2}$ 11d ०पिष्टपे ] $\mathrm{S}_{2} \mathrm{~S}_{3}$, ०पिष्टपे $\mathrm{S}_{1}$, ०विष्टपे $\mathrm{Bh}\left(\mathrm{em}\right.$. ?) $12 \mathrm{a}$ वयुक्त च ] $\mathrm{S}_{2} \mathrm{~S}_{3} \mathrm{R}$, ०युक्तेन $\mathrm{S}_{1} \mathrm{Bh} \quad \mathbf{1 2 b}$ ०समृद्धिमत् ] $\mathrm{S}_{2} \mathrm{~S}_{3} \mathrm{R}$, ०समृद्धिना $\left.\mathrm{S}_{1} \mathrm{Bh} \quad 12 \mathrm{~cd}\right] \mathrm{R}^{\mathrm{pc}}$ (cf. DS), विमाने(नार्क)भासेन अन्नदो याति वै दिवम् $\mathrm{S}_{1}$, विमानं सू+र्य+संकाशं मन्नदो लभते शुभम् $\mathrm{S}_{2}$, विमानं सूर्यसंकाशं मनदो लभते शुभं $\mathrm{S}_{3}$, विमानेनार्कभासेन अन्नदो याति वै दिवम् $\mathrm{Bh}$ 13a मानुष्यमा॰] $\mathrm{S}_{2} \mathrm{~S}_{3} R B h$, मानुष्यतां $\mathrm{S}_{1}$ 13cd ०कीर्ण कुले जायति ] $\mathrm{S}_{1} \mathrm{~S}_{3}$, (कीर्ण्ण कु) ニ - $\mathrm{S}_{2}$, ०कीर्णः कुलीनः स्याच्च Bh (conj.) 14a ०शक्ति तु ] em. Bh (silently), ०शक्तिन्तु $\mathrm{S}_{1} \mathrm{~S}_{2}$, ०शक्ति तु $\mathrm{S}_{3}$ • दद्याद् ] $\mathrm{S}_{2}^{\mathrm{pc}} \mathrm{RBh}$, दद्या $\mathrm{S}_{1} \mathrm{~S}_{2}^{\mathrm{ac}} \mathrm{S}_{3} \quad 15 \mathrm{~b}$ ॰दन्न ] $\mathrm{S}_{2} B h$, ०दत्न $\mathrm{S}_{1} \mathrm{~S}_{3}$

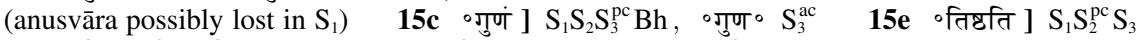
$\mathrm{Bh}$, ०तिष्ठ $\langle($ लो $)\rangle+$ ति $+\mathrm{S}_{2} 15 \mathrm{f}$ च सुखी ] $\mathrm{S}_{1} \mathrm{~S}_{2} \mathrm{~S}_{3}^{\mathrm{pc}} \mathrm{Bh}$, (सुमु)खी $\mathrm{S}_{3}^{\mathrm{ac}} \mathbf{1 6 c}$ अन्नं $] \mathrm{S}_{1} \mathrm{~S}_{2} \mathrm{Bh}$, अन $\mathrm{S}_{3}$ - ॰दद्याद्यो ] $\mathrm{S}_{2}^{\mathrm{pc}} \mathrm{Bh}$, ॰दद्या यो $\mathrm{S}_{1}$, ॰दद्याद्या $\mathrm{S}_{2}^{\mathrm{ac}} \mathrm{S}_{3}$ - देवि ] $\mathrm{S}_{1} \mathrm{~S}_{2} \mathrm{~S}_{3}$, देव्यो Bh (conj.) 16d ॰दृशं शुभे ] em., ०दृशम्भवेत् $S_{1}$, ॰दृश शुभे $S_{2} S_{3}$ (unmetrical), ॰दृशं शुभा: Bh (conj.) 
तस्यापि नरके घोरे यात्यमानस्य राक्षसैः।

उपतिष्टेत बधुधा तृत्रिर्येनास्य जायते॥ १७॥

यदि मानुष्यमायाति कदाचित्स नरः पुनः।

म्लेच्छेषु भोगी भवति रमते च यथामर:॥ ?५॥

अन्नमेवं विशिष्टं हि न तस्मात्परमं भुवि।

अन्नं प्रजापतिः प्रोकं स च संवत्सरो मतः।

संवत्सरश्च यक्रो उसौ यक्षे सर्वं प्रतिष्टितम् ॥ ?९ ॥

तस्माइ्कवन्ति भूतानि स्थावराणि चराणि च।

तस्मादन्नं विशिष्टं तु सर्वेम्य इति वै श्रुतिः॥ २०॥

अन्नदानात्परं दानं नैव किंचिद्धि विद्यते।

अन्नाइवन्त्ति भूतानि तस्मात्तद्वै प्रशस्यते॥ २१॥

सुगन्धा: शीतलाश्चापो रसैर्दिव्यः: समन्विताः।

यः प्रयच्छुति विप्रेभ्यस्तस्य दानफलं शृणु॥ २२॥

22ab = DK 19.62ab, DS p. 343, KR p. 589 and DKK p. 45 (सुगन्धा in DS (typo)); HeDKh p. 989: सुगन्धा: शीतलाश्चापि रसैर्दिव्यै: समन्विताः। (the quotation of 22-23 in HeDKh is attributed to the Padmapurāna) 22cd = DK 19.62cd, DS p. 343 and HeDKh p. 989; KR p. 589 and DKK p. 45 : यः प्रयच्छति विप्रेम्यस्तस्य पुण्यफलं शृणु।

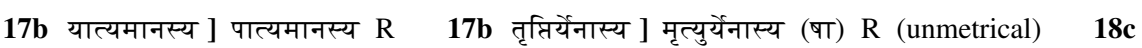
म्लेच्छेषु ] म्लेच्छे च $R \quad 19 a$ मेवं ] ममेव $R \quad 19 b$ न तस्मात् ] तत्तस्मात् $R \quad 19 \mathrm{e}$ संवत्सरश्च ] सम्वत्सरस्य $R \quad 19 f$ यक्षे सर्वं] सर्व यक्षे $R \quad 20 d$ वै ग्रुतिः ] विश्रुतिः $R$ 21d ०त्तद्वै ] ०द्वै तत् $R 22 b$ समन्विता: ] सुगन्धिभि: $R$

21a अन्नदानात् ] अदानात् $\mathrm{A}_{3}$ (unmetrical), अथ दानात् $\mathrm{A}_{4}$, अन्नदान: $\mathrm{A}_{7}$ 21b किंचिद्धि ] किंचिच्च A 21d ॰त्तद्वै] ०चैतत् $\mathrm{A}_{3}$, ०न्नैतत् $\mathrm{A}_{4}$, ०द्वै तत् $\mathrm{A}_{7}$ - ०शस्यते ] $\mathrm{A}_{3} \mathrm{~A}_{4}$, ०शंस्यते $\mathrm{A}_{7}$ 22a सुगन्धा: ] $\mathrm{A}_{3} \mathrm{~A}_{4}$, सुगन्धा $\mathrm{A}_{7}$ - ०लाश्चापो ] ०ला आपो $\mathrm{A}_{3} \mathrm{~A}_{7}$, ०लाश्रयो $\mathrm{A}_{4}$

$17\left\langle c^{1}-c^{4}\right\rangle\left(c^{5}\right)\left\langle c^{6}, d^{1}-d^{4}\right\rangle\left(d^{5}\right)\left\langle d^{6}-d^{7}\right\rangle\left(d^{8}\right) S_{1} \quad 18\left(a^{1}-b^{3}\right)\left\langle b^{4}, c^{1}-c^{4}\right\rangle\left(c^{5}-d^{8}\right) S_{1} \quad 19\left(a^{1}-a^{7}, b^{3}, b^{8}\right)$ $S_{1},\left(a^{6}-a^{8}\right)\left\langle b^{1}\right\rangle\left(b^{2}\right) S_{3} \quad 20\left\langle a^{1}\right\rangle\left(a^{2}\right)\left\langle a^{3}\right\rangle\left(a^{4}-a^{5}, b^{3}, c^{4}\right) S_{1} \quad 21\left(a^{1}-a^{2}\right) S_{1},\left\langle d^{1}-d^{3}\right\rangle\left(d^{4}-d^{5}\right)\left\langle d^{6}\right\rangle S_{3}$

18a मानुष्यमा॰ $] \mathrm{S}_{2} \mathrm{~S}_{3} \mathrm{RBh}$, (मानुष्यபता) $\mathrm{S}_{1}$ (upper parts lost, retraced) $18 \mathbf{b}$ नर: ] $\mathrm{S}_{2} \mathrm{~S}_{3} \mathrm{RBh}$, पुन: $S_{1} \quad 18 \mathrm{c}$ म्लेच्छेषु ] $S_{2} B h$, म्लेच्छे, सु॰ $S_{3} \quad 19 a$ अन्नमेवं ] $S_{2} S_{3}$, (अन्नमेव) $S_{1}$ (upper parts lost), अन्नेमेवं $\mathrm{Bh}$ (typo) $19 \mathrm{~b}$ न तस्मात् ] $\mathrm{S}_{1}$, तस्मान्न $\mathrm{S}_{2} \mathrm{Bh}, \simeq$ (स्मा)न्न $\mathrm{S}_{3}$ 19c अन्नं] $\mathrm{S}_{1}$ $\mathrm{S}_{2} \mathrm{RBh}$, अनं $\mathrm{S}_{3}$ - ०पतिः प्रोक्त ] $\mathrm{S}_{2} \mathrm{~S}_{3} \mathrm{RBh}$, ०पतिप्रोक्त $\mathrm{S}_{1}$ 19f सर्वं ] $\mathrm{S}_{1}^{\text {pc }} \mathrm{S}_{2} \mathrm{Bh}$, संवम् $\mathrm{S}_{1}^{\text {ac }}$, सर्व $\mathrm{S}_{3} 20 \mathrm{c}$ ०दन्न ] $\mathrm{S}_{2} \mathrm{~S}_{3}^{\mathrm{pc}} \mathrm{RBh}$, ०द(न्न) $\mathrm{S}_{1}$, ०दनं $\mathrm{S}_{3}^{\mathrm{ac}}$ - विशिष्ट तु ] $\mathrm{S}_{1} \mathrm{~S}_{2} \mathrm{~S}_{3} \mathrm{R}$, विशिष्टन्तु $\mathrm{Bh}$ (typo) 20d श्रुति: ] $S_{1} S_{2}^{\text {pc }} R B h$, श्रुति $S_{2}^{\text {ac }} S_{3}$ 21a अन्नदानात् ] $S_{1} R B h$, अन्नदानां $S_{2}$, अन्नदानं $\mathrm{S}_{3}^{\mathrm{pc}}$, अनदानं $\mathrm{S}_{3}^{\mathrm{ac}}$ 21ab ०नं नैव ] $\mathrm{S}_{1} \mathrm{~S}_{3} \mathrm{RABh}$, ०नन्नैनं $\mathrm{S}_{2}$ 21cd ] $\mathrm{S}_{1}$ has this after 23cd. $21 c$ अन्नाइवन्ति ] $S_{1} R A B h$, अन्नाइवति $S_{2}$, अनाइ्कवति $S_{3}$ 21d ०शस्यते ] $S_{1} R_{3} A_{4} B h$, ०पश्यते $\mathrm{S}_{2}$, -स्यते $\mathrm{S}_{3}$ 22a सुगन्धा: ] $\mathrm{S}_{2} \mathrm{~S}_{3} \mathrm{RA}_{3} \mathrm{~A}_{4} \mathrm{Bh}$, सुगन्धा $\mathrm{S}_{1}$ 22b रसैर्दिव्यै: स०] $\mathrm{S}_{2} \mathrm{RABh}$, रसै दिव्यैस्स० $S_{1}$, रसै दिव्यै स० $S_{3}$ - ०मन्विता: ] $S_{2} S_{3} A B h$, ०मन्विता $S_{1}$ 22cd विप्रेम्यस्त०] $S_{1} R A B h$, विप्रेम्यो त॰ $S_{2}$, विप्रेम्य त॰ $S_{3} \quad 22 d$ शृणु ] $S_{1} S_{2}^{\text {pc }} R A B h$, शृणु: $S_{2}^{\text {ac }} S_{3}$ 
विमानं सूर्यसंकाशमप्सरोगणनादितम्।

सो ऽधिरुह्य दिवं याति वरुणस्य सलोकताम्॥ २३॥

तत्रासावयुतान्यष्टावुषित्वा देववत्सुखी।

कुले महत्यसंकीर्ण जायते धनधान्यवान्॥ २४॥

अपां तु पूर्णं यो भाण्डं ब्राह्मणाय प्रयच्छाति ।

रसास्तस्योपतिष्टन्ति पूज्यते च दिवं गतः॥ २४॥

भाजनानि च यो दद्यात्सुपूर्णानि शुभानने।

भाजनं स्यात्स भोगानां तारयेच्च पित्न्भयात् ॥ २६॥

तडागं यस्तु कुर्वीत अपां देवि समृद्धिमत्।

गावः पिबन्ति वै यत्र सर्वे जन्तव एव च॥ २७॥

23ab DK 19.63ab, DS p. 343, KR p. 589, DKK p. 45 and HeDKh p. 989: विमानं सूर्यसंकाशमप्सरोगणसेवितम् । 23cd = DK 19.63cd, DS p. 343, KR p. 589, DKK p. 45 and HeDKh p. 989 24ab $=$ DS p. 343 and KR p. 590; DKK p. 45: तत्र वर्षायुतान्यष्टावुषित्वा देववत् सुखी। $\quad$ 24cd = KR p. 590 and DKK p. 45; DS p.343: असड़्रीर्ण कुले शुद्धे जायते धनधान्यवान्। (var. कुले महत्यसंकीर्णे) 25ab DS p. 355: अड्रिस्तु पूर्ण यो भाण्डं ब्राह्मणाय प्रयच्छाति । (var. अपान्तु); DKK p. 45: अपां पूर्ण तु यो भाण्डं ब्राह्मणाय प्रयच्छति। 25cd DS p.355: रमास्तस्योपतिष्ठन्ते पुज्यते च दिवं गतः। (var. वसास्त्त and ०तिष्ठन्ति ); DKK p. 45: रसास्तस्योपतिष्ठन्ति पूज्यते च वियद्गतः। 26 DS p. 355: भाजनानि च यो दद्यादप्पूर्णानि शुभानने। भाजनः स महाभागस्तारयेच्च पित्र्, भयात्।

23d सलोकताम् ] च लोकताम् $R \quad 24 \mathbf{a b}$ ०ट्टावुषित्वा देववत् ] ०ट्टौ वर्षाणां स्थितवान् $R$ 24d धनधान्यवान् ] धनवान् सुखी $R$ 25a तु पूर्ण यो भाण्डं ] पूर्णन्तु भाण्डं यो $R \quad 25 \mathrm{c}$ ०तिष्ठन्ति ] ०तिष्ठन्ते $R \quad 26 b$ ०त्सुपूर्णांनि शुभानने ] ०दापःपूर्णानि शोभना: $R \quad 27 b$ देवि ] पूर्ण्ण $R$

23ab ०संकाशम०] $\mathrm{A}_{3} \mathrm{~A}_{4}$, ०सड़ाशं म० $\mathrm{A}_{7} \quad 23 \mathrm{c}$ उधिरुद्य ] $\mathrm{A}_{3}$, भिरुद्य $\mathrm{A}_{4} \mathrm{~A}_{7} \quad 24 \mathrm{ab}$ तत्रासावयुतान्यष्टावु $\left.{ }^{\circ}\right]$ तत्रासौ वत्सराण्यष्टावु ${ }^{\circ}\left\{{ }^{\circ}\right.$ ट्टा उ० $\left.\mathrm{A}_{4}\right\} \mathrm{A}_{3} \mathrm{~A}_{4}$, तत्र सौवंसूतान्यष्टावु॰ $\mathrm{A}_{7} \quad \mathbf{2 4 b}{ }^{\circ}$ त्सुखी ] ०त्सुखं $\mathrm{A}_{3} \mathrm{~A}_{7}^{\mathrm{pc}}$, ०न्मुखं $\mathrm{A}_{4} \mathrm{~A}_{7}^{\mathrm{ac}} \mathbf{2 4 d}$ धनधान्यवान् ] धनवान् सुखी $\mathbf{A}$ 25a तु पूर्णं ] पूर्ण तु $\mathbf{A}$ $25 \mathrm{~cd}$ ] om. $\mathrm{A}_{7} 25 \mathrm{c}$ रसास्तस्योप॰] रसकुल्योप॰ $\mathrm{A}_{3} \mathrm{~A}_{4}$ 26ab ] om. $\mathrm{A}$ 26c भोगानां] भाग्यानां $\mathrm{A}_{3} \mathrm{~A}_{7}$, भागानां $\mathrm{A}_{4} \quad 26 \mathrm{~d}$ पितॄन्] $\mathrm{A}_{3} \mathrm{~A}_{7}$, पितृन् $\mathrm{A}_{4} \quad 27 \mathbf{b}$ अपां ] $\mathrm{A}_{3} \mathrm{~A}_{7}$, अयां $\mathrm{A}_{4}$ देवि ] देव्य: $A$

23( $\left.c^{1}\right) S_{1} \quad 24\left\langle a^{1}\right\rangle\left(a^{4}, a^{7}\right) S_{1} \quad \mathbf{2 6}\left\langle a^{1}\right\rangle S_{1}$

23ab ०संकाशम॰] $\mathrm{RA}_{3} \mathrm{~A}_{4} \mathrm{Bh}$, ०सड्काशं ह्य० $\mathrm{S}_{1}$, ०संकाशं म० $\mathrm{S}_{2} \mathrm{~S}_{3}$ 23d After this $\mathrm{S}_{1}$ has 21cd. 24ab ०प्टावुषित्वा ] $S_{2} A_{3} A_{7} B h$, ०ट्टौ चोशित्वा $S_{1}$, ०ट्टावुशित्वा $S_{3}$ 24c ०संकीर्णे ] $S_{1} S_{2} S_{3} R A$, ०संकीर्णों Bh (typo?) 25a अपां तु $] \mathrm{S}_{1} \mathrm{~S}_{2} \mathrm{~S}_{3}$, आपान्तु $\mathrm{Bh}$ (typo) • पूर्ण ] $\mathrm{S}_{1} \mathrm{~S}_{2} B$ h, पूर्ण्ण $\mathrm{S}_{3}$ - भाण्डं ] $S_{2} A B h$, भाण्ड $S_{1} S_{3} 25 c$ रसास्त० ] RBh, रसा त॰ $S_{1}$, रसस्त॰ $S_{2} S_{3} 26 b$ ०त्सुपूर्णानि ] $\mathrm{S}_{2} \mathrm{~S}_{3} \mathrm{Bh}$, ०त्स पूर्णांनि $\mathrm{S}_{1}$ - शुभानने ] $\mathrm{S}_{1} \mathrm{~S}_{2} \mathrm{~S}_{3}$, शुभानना: $\mathrm{Bh}$ (conj.) 26c भाजनं ] $\mathrm{S}_{2} \mathrm{~S}_{3} \mathrm{RABh}$, भाजन $\mathrm{S}_{1} \quad$ 26cd ०नां तारयेच्च ] $\mathrm{S}_{1} \mathrm{RABh}$, ०नांस्तारणाच $\mathrm{S}_{2}$, ॰नांस्तारणा च $\mathrm{S}_{3} \quad 26 \mathrm{~d}$ पितॄन्भयात् ] $\mathrm{S}_{2} \mathrm{RA}_{3} \mathrm{~A}_{4} \mathrm{Bh}$, पितॄन्नयात् $\mathrm{S}_{1}$, पितृभयात् $\mathrm{S}_{3}$ (unmetrical) 27b अपां ] $\mathrm{S}_{1} \mathrm{~S}_{2} \mathrm{RA}_{3} \mathrm{~A}_{7} \mathrm{Bh}$, अपा $\mathrm{S}_{3}$ - देवि ] $\mathrm{S}_{1} \mathrm{~S}_{2} \mathrm{~S}_{3}$, देव्य: $\mathrm{Bh} \bullet$ समृद्विमत् ] $\mathrm{S}_{2} \mathrm{~S}_{3} \mathrm{RABh}$, समृद्धिमान् $\mathrm{S}_{1}$ 27c गावः ] $\mathrm{S}_{1}^{\mathrm{pc}} \mathrm{S}_{2} \mathrm{RA}$, गावा $\mathrm{S}_{1}^{\mathrm{ac}}$, गाव $\mathrm{S}_{3}$, अप: Bh (conj.?) • पिबन्ति ] $\mathrm{S}_{2} \mathrm{~S}_{3} \mathrm{RABh}$, पिवन्ति $\mathrm{S}_{1}$ • वै ] $\mathrm{S}_{1} \mathrm{~S}_{2} \mathrm{RABh}$, चै $\mathrm{S}_{3}$ 
तारयित्वा च स पितंस्तथैव च पितामहान्।

प्रपितामहांश्च लोकेषु कामगेषु विहंगमः।

चरते देववद्देवि वर्षायुतशतानि षट्॥ २५॥

पुनश्च मानुषे लोके सर्वरोगविवर्जितः।

भोगी भवति भोगानां राजमात्रश्च जायते।

दाता यज्वा च बलवान्सुप्रभः प्रियदर्शनः॥ २९॥

अवटं यो नरः कुर्यादपां पूर्णं शुचिस्मिते।

दद्याच ब्राह्मणेम्यस्तं भोजयित्वा यथार्थवत् ॥ ३०॥

अष्टाभिः सुविचित्राभिः पताकाभिरलंकृतम्।

ध्वजेन वैजयन्त्या च पुष्पैश्च समलंकृतम् ॥ ३? ॥

स तारयित्वा तु पित्निन्विमानेन नरोत्तमः।

यात्यप्सरोपगीतेन वरुणस्य सलोकताम्॥ ३२॥

30ab DK 20.20ab and HeDKh p. 1002: अवटं यो नर: कुर्यादपां पूर्ण सुशोभनम्। 30cd DK $20.20 \mathrm{~cd}$ : दद्याच्च ब्राह्मणेम्यस्तं भोजयित्वा यथाविधि।; HeDKh p. 1002: दद्यात् सुत्राह्मणेम्यस्तम्भोजयित्वा यथाविधि। 31ab = DK 20.21 ab and HeDKh p. 1002 32ab DK 20.21 cd: पितंस्तारयते पश्चात्तं

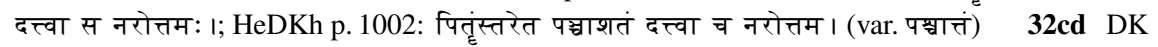
20.21ef and HeDKh p. 1002: यात्यप्सरःसुगीतेन वरुणस्य सलोकताम् ।

$28 \mathrm{a}$ स ] वै $\mathrm{R} 28 \mathrm{c}$ प्रपितामहांश्च ] मातामहांश्र्च $\mathrm{R} \quad 28 \mathrm{e}$ ०वद्देवि ] ०राड्भव्यो $\mathrm{R} 2 \mathrm{29} \mathrm{a}$ मानुषे ] मानुषो $R \quad 29 b$ ०रोग॰ ] ०शोक॰ $R \quad$ 29d राजमात्र०] राजामात्य॰ $R \quad 30 b$ शुचिस्मिते ] शुचिस्मिता: $R$ 30cd ०स्तं भोजयित्वा ] ०स्तु जपित्वा वा $R$ 31cd ] om. $R$

28ab पितृंस्त॰ ] $\mathrm{A}_{3} \mathrm{~A}_{7}$, पितृंस्त॰ $\mathrm{A}_{4} 28 \mathrm{e}$ चरते ] रमते $\mathrm{A}_{7}$, रमंते $\mathrm{A}_{3} \mathrm{~A}_{4}$ • ॰वद्देवि ] ॰वत् देव्या $A$ 29d राजमात्र०] राजामात्य० $A$ 29e दाता यज्वा च बलवान् ] भोक्ता दाता च भगवान् A 30b शुचिस्मिते ] शुचिस्मिता: $A$ 30c दद्याच ] $A_{7}$, दत्वा च $\mathrm{A}_{3} \mathrm{~A}_{4}$ 31a ०विचित्राभि: ] ०पवित्राभि: A 31cd ] om. A 32a स तारयित्वा तु पितॄन् ] तारयित्वा पितॄन् $\left\{\right.$ पितृन् $\left.\mathrm{A}_{4}\right\}$ सर्वान् A

$\mathbf{2 8}\left\langle\mathrm{e}^{1}-\mathrm{e}^{2}\right\rangle \mathrm{S}_{1},\left(\mathrm{a}^{8}\right) \mathrm{S}_{2} \quad \mathbf{3 0}\left(\mathrm{d}^{7}-\mathrm{d}^{8}\right) \mathrm{S}_{1},\left\langle\mathrm{a}^{3}\right\rangle\left(\mathrm{a}^{7}-\mathrm{a}^{8}, \mathrm{~b}^{2}\right) \mathrm{S}_{2} \quad \mathbf{3 1}\left\langle\mathrm{a}^{1}-\mathrm{a}^{2}\right\rangle\left(\mathrm{a}^{3}-\mathrm{a}^{4}\right) \mathrm{S}_{1} \quad \mathbf{3 2}\left(\mathrm{d}^{8}\right) \mathrm{S}_{2}$

28a च ] $S_{2} S_{3} R A B h$, om. $S_{1}$ (unmetrical) 28ab पितॄंस्त॰ $S_{1} S_{2} R_{A} A_{7} B h$, पितॄन्स० $S_{3} \quad \mathbf{2 8 b}$ च ] $S_{2} S_{3} R A B h$, स $S_{1} 28 d$ कामगेषु ] $S_{1} R A$, कामकेषु $S_{2} S_{3}$, कमिकेषु Bh (typo, em. to कामिकेघु?) $28 \mathrm{e}$ ०वट्देवि ] $\mathrm{S}_{1} \mathrm{~S}_{2}^{\mathrm{pc}}$, ०व देवि $\mathrm{S}_{2}^{\mathrm{ac}} \mathrm{S}_{3}$ (unmetrical), ०वट्देव्यो $\mathrm{Bh}$ (em.?) $\mathbf{2 8 f}$ ॰शतानि ] $\mathrm{S}_{1} \mathrm{~S}_{2} \mathrm{~S}_{3} \mathrm{RA}$, ०शातानि Bh (typo, unmetrical) 29d राज॰ ] $\mathrm{S}_{1}^{\mathrm{pc}} \mathrm{S}_{2} \mathrm{~S}_{3} \mathrm{Bh}$, रज॰ $\mathrm{S}_{1}^{\mathrm{ac}}$ 29e यज्वा च ] $S_{2} S_{3} R$, यज्ञाय $S_{1}$, यज्या च Bh (typo) 29f ॰प्रभः ] $S_{1} S_{2} R A B h$, ०प्रभ $S_{3}$ 30a अवटं ] $\mathrm{S}_{1}^{\mathrm{pc}} \mathrm{S}_{3} \mathrm{RABh}$, अ(भ)टं $\mathrm{S}_{1}^{\mathrm{ac}}$, अव+ $\simeq+\mathrm{S}_{2}^{\mathrm{pc}}$, अवं $\mathrm{S}_{2}^{\mathrm{ac}}$ (unmetrical) 30b पूर्ण ] $\mathrm{S}_{1} \mathrm{~S}_{2} \mathrm{RABh}$, पूर्ण्ण $\mathrm{S}_{3}$ - शुचिस्मिते ] $\mathrm{S}_{1}$, समश्नुते $\mathrm{S}_{2} \mathrm{~S}_{3}$, शुचिस्मिता: $\mathrm{Bh}$ 30c दद्याच ] $\mathrm{S}_{2} \mathrm{RA}_{7} \mathrm{Bh}$, दद्याश्च $\mathrm{S}_{1}$, दद्या

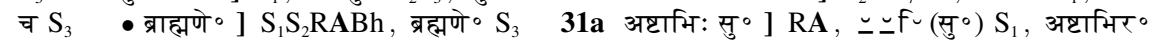
$\mathrm{S}_{2} \mathrm{~S}_{3}$, अष्टाभिश्च Bh (conj.?) - ०विचित्राभिः ] $\mathrm{S}_{1} \mathrm{~S}_{2} \mathrm{RBh}$, ०विचित्राभि $\mathrm{S}_{3}$ 31d पुष्पेय्च ] $\mathrm{S}_{1} \mathrm{Bh}$, पुष्पेश्च $S_{2}$ (tops faint), पुष्पै च $S_{3} \quad 32 c$ त्यप्सरोप॰] $S_{2} S_{3} R A B h$, ०त्यप्सरस० $S_{1}$ 
हिरण्यं हेम भूमिं वा तिलान्रतानि वापि यः।

प्रदद्यात्सर्वभूतेम्यस्तस्य पुण्यफलं शृणु॥ ३३॥

स विमानेन महता सर्वलोकसमन्वितः।

इन्द्रलोके स संप्राप्य मोदते विबुधो यथा॥ ३४ ॥

ततश्चयुतश्च धर्मात्मा सर्वकामसमृद्धिमान्।

कुले महति लोकेशो जायते सुभगश्च ह॥ ३४॥

यस्तु वृक्षं प्रकुरुते छायापुष्पफलोपगम्।

पथि देवि नरः सोम्ये स तारयति वै पितॄन्॥ ३६॥

तथैव दत्त्वा विप्रेम्यो निष्क्रीय च पुनर्नरः।

स यत्फलमवाप्रोति तच्छृणुष्व महाप्रभे॥ ३७॥

यावद्दृक्षस्य पुष्पाणि उपयुज्यन्ति देहिनः।

फलानि चैव भक्ष्यन्ते जन्तुभिः फलितस्य तु॥ ३५॥

36ab = DK 21.27ab and HeDKh p. 1033 36cd DK 21.27cd: पथि देव्यो नर: पापात्संतारयति वै पित्न् ।; HeDKh p. 1033: पथि दिव्ये नर: पापात् सन्तारयति वै पित्न्। 37ab DK 21.28ab: तथैव दत्त्वा विप्रेम्यो निष्क्रीणाति च तत्पुनः। 38ab DK $21.28 \mathrm{~cd}$ : यावत्फलानि पुष्पाणि उपयुअन्ति देहिनः।

33a हेम भूमिं वा ] कास्चनं दिव्यं $\mathrm{R} \quad 33 \mathrm{~b}$ ०त्रत्नानि ] ०नन्नानि $\mathrm{R} \quad$ • यः ] च $\mathrm{R} \quad 33 \mathrm{~d}$ पुण्य०] दान० $R$ 34a स विमानेन महता ] परिमाणेन दिव्येन $R \quad 35 a$ ग ग्युतश्च धर्मात्मा ] ० श्युतश्च धर्म्मत्मा $\mathrm{R} 35 \mathrm{c}$ लोकेशो ] लोकेषु $\mathrm{R} 35 \mathrm{~d}$ ह ] (ह $\rangle+\pi+$ श्च ह $\mathrm{R}$ (unmetrical) $36 \mathrm{a}$ प्रकुरुते ] प्रकुर्वोत $\mathrm{R}$ 36c देवि ] देव्ये $\mathrm{R}$ - सोम्ये ] सौम्य: $\mathrm{R}^{\mathrm{pc}}$, सो ऽपि $\mathrm{R}^{\mathrm{ac}}$ 37b निष्क्रीय च पुनर्नर: ] निष्कुटम्वापि यो नर: $R \quad 37 \mathrm{c}$ स यत्फलम० ${ }^{\circ}$ ] यत्फलं सम॰ $R$ 37d ०ष्व महाप्रभे ] ०ध्वं महाप्रभा: $R$ 38a यावद् ] पर० $R \quad 38 b$ उपयुज्यन्ति ] उपयुह्यन्ति $R \quad 38 c$ अक्ष्यन्ते ] पुष्पाणि $R \quad 38 d$ तु ] च $R$

33b तिलान् $] \mathrm{A}_{4}$, तिकान् $\mathrm{A}_{3}$, तिनान् $\mathrm{A}_{7}$ - वापि यः ] यापि च $\mathrm{A}_{4} \mathrm{~A}_{7}$, यानि च $\mathrm{A}_{3} \mathbf{3 4 c}$

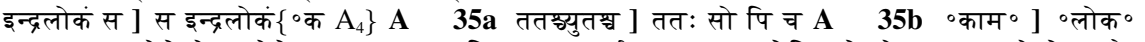
A $35 c$ लोकेशो ] लोकेषु $A 36 c$ पथि ] $A_{7}$, पार्थ $A_{3} A_{4}$ - देवि ] देव्यो $A$ सोम्ये ] सौम्य: $\mathbf{A} 37 \mathbf{b}$ पुनर्नर: ] पुनः पुन: $\mathbf{A} 37 \mathbf{c}$ स यत् ] यद्यत् $\mathrm{A}_{3} \mathrm{~A}_{7}$, यषत् $\mathrm{A}_{4} 37 \mathbf{d}$ ०ष्व महाप्रभे ] धध्वं महाप्रभा: $\mathbf{A}$ 38a पुष्पानि ] छायायां $\mathbf{A} 38 \mathbf{3 b}$ उपयुज्यन्ति ] उय् युज्यंति $\mathrm{A}_{3}$ (unmetrical), उपयुज्यति $\mathrm{A}_{4} \mathrm{~A}_{7} \quad 38 \mathrm{c}$ अक्ष्यन्ते ] भक्षन्ते $\mathrm{A} \quad 38 d$ तु ] च $\mathbf{A}$

$33\left(c^{8}-d^{4}\right)\left\langle d^{5}-d^{8} \rightarrow\right\rangle S_{1} \quad 34\left\langle\leftarrow a^{1}-a^{8}\right\rangle S_{1} \quad 36\left(a^{3}, b^{5}-b^{8}\right)\left\langle c^{1}-c^{7}\right\rangle\left(c^{8}-d^{2}, d^{6}\right) S_{1},\left(a^{3}, c^{2}\right) S_{3}$

33a हिरण्यं ] $S_{1} S_{2} R A B h$, हिरण्य० $S_{3}$ 33b तिलान्रतानि ] $S_{1} A_{4} B h$, तिलां त्रत्नानि $S_{2}$, तिलात्रनानि $S_{3}$ वापि यः ] $S_{1}^{\text {ac }} S_{2} S_{3} B h$, वा पय: $S_{1}^{\text {pc }}$ 33d शृणु ] $S_{2}^{\text {pc }} R A B h$, शृणु: $S_{2}^{\text {ac }} S_{3}$ 34c इन्द्रलोकं स ] $S_{1} R$, इन्द्रस्य लोकं $S_{2} B h$, इन्द्रस्य लोक $S_{3}$ 34d मोदते ] $S_{1} S_{2} R A B h$, मोदतो $S_{3}$

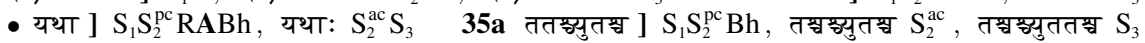
(unmetrical) 35c लोकेशो ] $\mathrm{S}_{1} \mathrm{~S}_{2} \mathrm{~S}_{3}$, लोकेसौ $\mathrm{Bh}$ (conj.?) 35d जायते सु॰ ] $\mathrm{S}_{2} \mathrm{~S}_{3} \mathrm{RABh}$, जायन्ते शु॰ $S_{1} \quad 36 c$ देवि ] $S_{2} S_{3}$, देव्यो $B h$ - सोम्ये ] $S_{2} S_{3} B h,-\left(\right.$ म्या) $S_{1}$ (upper parts lost) 36d तारयति ] $S_{1} S_{2}^{\text {pc }} S_{3} R A B h$, तारयिति $S_{2}^{\text {ac }}$ 37a तथैव ] $S_{1} R A B h$, तथे+व(म्)+ $S_{2}$, तथेव $S_{3}$ 37b पुनर्नर: ] $S_{2} B h$, पुनः पुन: $S_{1}$, पुन नर: $S_{3}$ (unmetrical) 37d तच्छुणुष्व ] $S_{2} S_{3}$, तच्छृणुध्व $\mathrm{S}_{1}$, तछृच्णुध्वं $\mathrm{Bh}$ (typo) - ०प्रभे ] $\mathrm{S}_{1} \mathrm{~S}_{2} \mathrm{~S}_{3}$, ०प्रभा: $\mathrm{Bh}$ 38a पुष्पाणि ] $\mathrm{S}_{1} \mathrm{~S}_{2} R B h$, पुष्पारिण $\mathrm{S}_{3}$ 38b उपयुज्यन्ति ] $\mathrm{S}_{1} \mathrm{~S}_{2} \mathrm{~S}_{3}$, उपयुअन्ति Bh (conj.?) 
तावद्वर्षसहस्राणि तारयित्वा पितॄनपि ।

सोमलोक समासाद्य स मृतः फलमाप्तुयात्॥ ३९ ॥

फलानि यः प्रयच्छेत ब्राह्मणेम्यः समाहितः।

फलानां स तु भागी स्याद्वूहनां सुभगश्च ह॥ ४०॥

काष्ठानि यः प्रयच्छेत हेमन्ते नरसत्तमः।

ब्राह्मणेम्यः सदा देवि सो उग्निलोक समश्नुते ॥ ४? ॥

भाजनं यः प्रयच्छेत हैमं रत्नविभूषितम्।

सो उप्सर:शतसंकीर्णे विमाने दिवि मोदते॥ ४२॥

राजतं यः प्रयच्छेत विप्रेम्यो भाजनं शुभे ।

स गान्धर्वपदं प्राप्य उर्वश्या सह मोदते॥ ४३॥

ताम्रं यो भाजनं दद्याद्वाह्मणेम्यो विशेषतः।

स भवेद्यक्षराजस्य यक्षो बलसमन्वितः॥ ४४॥

\begin{abstract}
39ab DK 21.28ef: तावद्वर्षसहस्राणि संतारयति वै पित्न्। $\quad$ 40ab = DS p. 390 40cd DS p. 390: फलानां तत्र भोगी स्याद्रपेण सुभगश्च ह। $41=$ DS p. $652 \quad$ 42ab DK 19.64ab and HeDkh p 927: भाजनं यः प्रयच्छेत्तु हैम रत्नविभिषितम् ।; DS p. 350 and DVU 3, p. 279: भाजनं यः प्रयच्छेतु हेम रत्नवि-

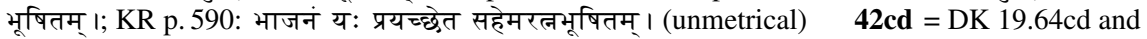

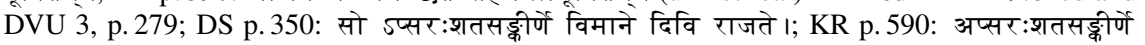
विमाने दिवि मोदते ।; HeDKh p.928: सो उप्सर:शतसंकीर्णविमाने दिवि मोदते। 43ab DK 19.65ab, HeDKh p. 928 and DVU 3, p. 279: राजतं यः प्रयच्छेत्तु विप्रेभ्यो भाजनं शुभम् ।; DS p. 350: राजतं यः प्रयच्छेच्च विप्रेम्यो भाजनं शुभम्। (var. ॰्यच्छेत्तु); KR p. 590: राजतं यः प्रयच्छेत विप्रेम्यो भाजनं शुभम्। 43cd DK 19.65cd, DS p. 350, HeDKh p. 928 and DVU 3, p. 279: स गन्धर्वपद प्राप्य उर्वश्या सह मोदते ।; KR p. 590: स गन्धर्व्वपुरं प्राप्य उर्व्वश्या सह मोदते । 44ab = DK 19.66ab, DS p. 351, KR p. 590, HeDKh p. 928 and DVU 3, p. 279 44cd = DK 19.66cd and KR p. 590; DS p. 351: स भवेद् यक्षो राजस्य पक्षौ बलसमन्वितौ। (var. यक्षराजस्य and यक्षो वरसमन्वितः); HeDKh p. 928 and DVU 3, p. 279: स भवेद् यक्षराजस्य प्रभुर्बलसमन्वितः।
\end{abstract}

40c भागी ] भोगी $R$ 41c देवि ] देव: $R$ 42c सो उप्सरःशतसंकीर्ण ] स नर: शतसंकीण्णों $R$ 43b शुभे ] शुभम् $R \quad 43 \mathrm{c}$ गान्धर्व०] गन्धर्व० $R$

40b-41a ] om. $A$ 41b नरसत्तम: ] च नरोत्तमः $A$ 41c देवि ] देव्य: $A$ 42c ०संकीर्ण ] $\mathrm{A}_{3}^{\mathrm{pc}}$, ०संकीणों $\mathrm{A}_{3}^{\mathrm{ac}} \mathrm{A}_{4} \mathrm{~A}_{7} \quad 42 \mathrm{~d}$ दिवि ] $\mathrm{A}_{3}$, देवि $\mathrm{A}_{4} \mathrm{~A}_{7} 43$ ] om. $\mathrm{A}$ 44cd ०द्यक्षराजस्य यक्षो बल० ] ॰्यस्तु रजसा प्रियो य $\left\{\right.$ व० $\left.\mathrm{A}_{3} \mathrm{~A}_{4}\right\}$ क्ष: $\mathbf{A}$

$39\left(a^{4}-a^{8}, b^{5}-b^{6}\right)\left\langle b^{7}-c^{1}\right\rangle S_{1} \quad 42\left(d^{4}\right) S_{3} \quad 43\left(c^{1}-c^{2}\right) S_{1}$

39c समासाद्य] $S_{1} S_{2} R A B h$, समासत्य $S_{3}$ 39d स मृतः ] $S_{2} S_{3} R A$, सत्कृतः $S_{1}$, सोमृतं Bh (conj.) 40b ब्राह्मणेम्य: ] $S_{1} S_{2} R B h$, ब्राह्मणेभ्य $S_{3} \quad 40 \mathrm{c}$ भागी ] $S_{1}^{\mathrm{pc}} S_{2} S_{3} B h$, भाशी $S_{1}^{\text {ac }}$ 41a काष्टानि ] $\mathrm{S}_{1} \mathrm{~S}_{2} \mathrm{RBh}$, काष्टानि $\mathrm{S}_{3}$ 41c ०भ्यः सदा ] $\mathrm{S}_{1} \mathrm{~S}_{2} \mathrm{~S}_{3} \mathrm{RA}$, ०भ्यस्तदा Bh (conj.?) • देवि ] $\mathrm{S}_{1} \mathrm{~S}_{2} \mathrm{~S}_{3}$, देव्य: $\mathrm{Bh} 42 \mathrm{~b}$ हैमं ] $\mathrm{S}_{2} \mathrm{RABh}$, हेमं $\mathrm{S}_{1}$, हेम० $\mathrm{S}_{3}$ - विभूषितम् ] $\mathrm{S}_{1} \mathrm{~S}_{2}^{\mathrm{pc}} \mathrm{S}_{3} \mathrm{RABh}$, वि/वि>भूषितं $S_{2} 42 d$ मोदते ] $S_{1} S_{2} R A B h$, वोदते $S_{3} \quad 43 b$ भाजनं ] $S_{1}^{\text {pc }} S_{2} S_{3} R B h$, भानं $S_{1}^{\text {ac }}$ (unmetrical) - शुभे ] $\mathrm{S}_{1} \mathrm{~S}_{2} \mathrm{~S}_{3}$, शुभा: $\mathrm{Bh}$ (conj.) 43d उर्वश्या ] $\mathrm{S}_{1} \mathrm{~S}_{3} R B h$, उर्वस्या $\mathrm{S}_{2} \quad 44 \mathrm{a}$ ताम्रं यो भाजनं ] $\mathrm{S}_{1} \mathrm{~S}_{2} \mathrm{RABh}$, ताम्र यो भाजन $\mathrm{S}_{3}$ (unmetrical) $44 \mathrm{c}$ भवेद्यक्ष॰] $\mathrm{S}_{1} \mathrm{RBh}$, भवे 〈क्ष〉यक्ष॰ $\mathrm{S}_{2}$, भवे यक्ष० $\mathrm{S}_{3} \quad 44 d$ ०समन्वितः ] $\mathrm{S}_{2} \mathrm{~S}_{3} \mathrm{RABh}$, ०समन्वित $\mathrm{S}_{1}$ 
गृहं यस्तु प्रयच्छेत सर्वकामसमृद्विमत्।

स लोकं ब्रह्मणः प्राप्य सर्वकामैर्निषेठ्यते॥ $४ ४ ॥$

वर्षकोट्यः स तत्रोष्य चतस्रस्तेन कर्मणा।

गृहमेधी सदादाता भोगवांग्चैव जायते॥ ४६॥

औषधीर्यः प्रयच्छेत धान्यानि विविधानि च।

स सर्वकामसमृद्धं सोमलोकं समश्नुते॥ ४७॥

तत्र वर्षसहस्राणि सत्त स्थित्वा पुनर्नरः।

इह सर्वधनोपेतो भोगवानभिजायते॥ ४५॥

यस्तु क्षेत्रं प्रयच्छेत निष्पन्नं फलवत्पुनः।

स तु क्षेत्रं पुमान्भुत्का प्राजापत्यं समश्नुते॥ ४९॥

45ab = DS p. 444, KR p. 590 and DKK p. 72 45cd = DKK p. 72; DS p. 444: स लोक ब्रह्मण: प्राप्य सर्वकामैर्हि सेव्यते। (var. ०र्निषेव्यते); KR p. 590: स लोके ब्रह्मणः प्रेत्य सर्व्वकामैर्निषेव्यते। 46ab DS p. 444 and KR p. 590: वर्षकोटी: स तत्रोष्य चतस्तस्तेन कर्मणा ।; DKK p. 73: वर्षकोतीर्वसेत्तत्र चतस्रस्तेन कर्म्मणा। 46cd $=$ DS p. 444, KR p. 590 and DKK p.73 47ab DS p.500 and DKK p. 65: ओषधीर्यः प्रयच्छेत धान्यानि विविधानि च ।; KR p. 590: ओषधीर्यः प्रयच्छेत धान्यानि च धनानि च। 47cd DS p. 500: स सर्वकामसंयुक्तः सोमलोकं समश्नुते। (var. ०कालसंवृद्धः); KR p. 590: सर्व्वकामसुसंयुक्तः सोमलोक समश्नुते ।; DKK p. 65: सर्व्वकामसमृद्धः सन् सोमलोक स गच्छति। $48 \mathbf{a b}=$ DS p. 500, KR p. 590 and DKK p. 65 48cd = DS p. 500 and DKK p. 65; KR p. 591: इह लोके धनोपेतो भोगवानभिजायते। 49ab DS p. 328, p. 689 and KR p. 591: यस्तु क्षेत्रं प्रयच्छेत निष्पन्नफलवन्नरः।
49cd = DS p. 689; DS p. 328: स तत्क्षेत्र पुमान् भुत्का प्राजापत्यं समम्नुते । (var. तु for तत्, भूक्ता for भुत्का); KR p. 591: स तु क्षेत्रं पुनर्भुत्का प्राजापत्यं समश्नुते ।

$45 \mathrm{ab}$ ] om. $\mathrm{R} 46 \mathrm{a}$ ककोट्यः स तत्रोष्य ] कोटीश्चतस्रो डद्य $\mathrm{R}$ 47b विविधानि ] च धनानि $\mathrm{R}$ 47c स सर्वकामसमृद्धं ] सर्वकामसुसंयुक्तः $R \quad 48 b$ स्थित्वा ] क्षित्वा $R \quad 48 d$ भोगवानभिजायते ] भग$\begin{array}{llll}\text { वानिह जाया } R \text { (unmetrical) } & 49 \mathrm{a} \text { यस्तु ] यश्च } \mathrm{R} & 49 \mathrm{~b} \text { निष्पन्नं ] निष्पत्न० } \mathrm{R} & 49 \mathrm{c} \text { पुमान्भुत्का ] }\end{array}$ पुनर्भूत्वा $\mathrm{R}$

46a ककोट्य: स ] ०कोटीश्च $A$ - तत्रोष्य ] $\mathrm{A}_{3}$, तत्रास्य $\mathrm{A}_{4}$, तत्रोस्य $\mathrm{A}_{7}$ 47a औषरीर्यः ] एष वीर्यं $\mathrm{A}_{4}$, एष बीजं $\mathrm{A}_{3}$, एकवीर्य्य $\mathrm{A}_{7} \quad 47 \mathrm{c}$ स सर्वकामसमृद्ध $]$ सर्वकामसमृद्धः $\left\{\circ\right.$ द्वं $\left.\mathrm{A}_{4}\right\}$ स $\mathbf{A} 48 d$ भोगवा० ] भगवा० $A$ 49b निष्पन्नं ] निष्पन्न० $\mathrm{A}_{3} \mathrm{~A}_{7}$, निस्पत्र० $\mathrm{A}_{4}$ 49c क्षेत्रं ] $\mathrm{A}_{3} \mathrm{~A}_{4} \mathrm{~A}_{7}^{\mathrm{ac}}$, क्षत्रं $\mathrm{A}_{7}^{\mathrm{pc}}$

$45\left(a^{1}\right) S_{1}$

45c लोकं ब्रह्मणः ] $\mathrm{S}_{2} \mathrm{~S}_{3} \mathrm{RABh}$, लोक ब्राह्मण $\mathrm{S}_{1} \quad 45 \mathrm{~d}$ ०कामैर $] \mathrm{S}_{1} \mathrm{~S}_{2} \mathrm{RABh}$, ०कामै $\mathrm{S}_{3} 46 \mathrm{a}$ वर्षकोट्यः ] $S_{1} S_{2}$, वर्षकोट्य $S_{3}$, सर्वकोटी: $B h$ (typo for वर्षकोटी:?) - तत्रोष्य ] $S_{1}^{\text {pc }} S_{2} A_{3} B h$, तत्रोस्य $\mathrm{S}_{1}^{\mathrm{ac}} \mathrm{S}_{3} \quad 46 \mathrm{c}$ सदा०] $\mathrm{S}_{1} \mathrm{~S}_{2} \mathrm{~S}_{3} \mathrm{RA}$, यदा Bh (typo?) 47a औषधीर्यः ] $S_{2}^{\mathrm{pc}} \mathrm{S}_{3} R$, औषधी य: $\mathrm{S}_{1}$, औषधार्य: $\mathrm{S}_{2}^{\mathrm{ac}}$, ओषधीर्य: $\mathrm{Bh}(\mathrm{em} . ?) \quad 47 \mathrm{c}$ ०समृद्धं ] $\mathrm{S}_{2}^{\mathrm{pc}} \mathrm{S}_{3}$ (unmetrical, read संरिद्धु), ०सम्पूण्णां $\mathrm{S}_{1}$, ०संमृद्धं $\mathrm{S}_{2}^{\mathrm{ac}}$, संमृष्टं $\mathrm{Bh}$ (conj.) 48a तत्र ] $\mathrm{S}_{2} \mathrm{~S}_{3} \mathrm{RABh}$, तत्रं $\mathrm{S}_{1}$ 48c सर्व॰] $\mathrm{S}_{1} \mathrm{~S}_{2} \mathrm{RABh}$, सर्वे $\mathrm{S}_{3}$ - धधनोपेतो ] $\mathrm{S}_{2} \mathrm{~S}_{3} \mathrm{RABh}$, ०नरोपेतो $\mathrm{S}_{1}$ 48d भोगवा०] $\mathrm{S}_{1} \mathrm{~S}_{2} \mathrm{~S}_{3}$, भोगावा॰ $B h$ (typo) 49a क्षेत्रं ] $\mathrm{S}_{1} \mathrm{~S}_{2} \mathrm{~S}_{3}^{\mathrm{pc}} \mathrm{RABh}$, क्षेत्र $\mathrm{S}_{3}^{\mathrm{ac}} \quad 49 \mathrm{~b}$ निष्पन्नं ] $\mathrm{S}_{1} \mathrm{~S}_{2} \mathrm{~S}_{3}^{\mathrm{pc}} \mathrm{Bh}$, निष्पनं $\mathrm{S}_{3}^{\mathrm{ac}}$ 49c क्षेत्रं पुमान्भुत्का ] $\mathrm{A}_{3} \mathrm{~A}_{4} \mathrm{~A}_{7}^{\text {ac }}$ (cf. DS), क्षेत्रम्पुमां भूत्वा $\mathrm{S}_{1}$, क्षेत्रो पुमां भूत्वा $\mathrm{S}_{2}$, क्षेत्रोपमां भूत्वा $\mathrm{S}_{3}$, क्षेत्रपतिर्भूत्वा $\mathrm{Bh}$ (conj.) 
यस्तु भूमिं प्रयच्छेत ब्राह्मणाय महात्मने ।

सर्वलोकेषु स सुखी विमानेन सुवर्चसा।

बहन्यब्दसहस्राणि चरते कामरूपवान् $y \circ \|$

यदि मानुष्यमायाति स नरः कालपर्ययात्।

तत्र कामदुहा तस्य मही भवति सर्वशः ॥ प? ॥

यस्तु वस्त्रं प्रयच्छेत ब्राह्मणाय महायशाः।

स लोकं प्राप्य वैराजं वर्षकोटिं सुखं वसेत् ॥ प२॥

आसनं यः प्रयच्छेत संवीतं ब्राह्मणाय वै।

स राज्यस्थानमाप्नोति स्वर्गं चाप्नोति विज्वरः ॥ $४ ३ ॥$

$\mathbf{5 0 a b}=$ DS p. 328 and KR p. 591 50cd = DS p. 328; KR p. 591: सर्व्वलोकसुखी भूत्वा विमानेन सुव र्चसा । 50ef $=$ DS p. 328 and KR p. 591 51ab = KR p. 591; DS p. 328: यदि मानुष्यमायाति नर: कालविपर्ययात्। 51cd DS p.328: तत्र कामदुघा तस्य मही भवति सर्वतः।; KR p.591: तस्य कामदुघा लोके मही भवति सर्वृतः। 52ab = DS p. 408, KR p. 591 and DKK p. 46 52cd = DS p. 308 and KR p.591; DKK p. 46: स लोक प्राप्य वैराजं वर्षकोटी: सुखं वसेत्। 53ab = HeDKh p.916; DK 19.67ab and KR p. 590: आसनं यः प्रयच्छेत्तु संवीतं ब्राह्मणाय वै ।; DS p. 339: आसनं यः प्रयच्छेच्च सपीठं ब्राह्मणाय वै। (var. ०यच्छेत्तु); KR p.591: आत्मानं यः प्रयच्छेत्तु सम्वीतं ब्राह्मणाय वै।; DVU

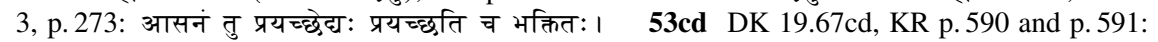
स राज्यस्थानमाप्रोति स्वर्ग प्राप्नोति विज्वर:।; DS p. 339: स राज्यस्थानमाप्रोति स्वर्गमाप्रोति विज्वरः।; HeDKh p. 916: स्वाराज्यं स्थानमाप्रोति तेजस्वी विगतज्वरः ।; DVU 3, p. 273: स दिव्यभोगसंभोगमरोग: सर्वदाश्नुते ।

50b-52a ] om. R 52d ॰कोटिं सुखं ] ॰कोटी: स्वसं R 53d स्वर्गं चा॰ ] स्वर्गमा॰ R

50c सर्व॰] $\mathrm{A}_{3} \mathrm{~A}_{7}$, सर्वे $\mathrm{A}_{4}$ - सुखी ] सुखं $\mathbf{A} 50 \mathrm{~d}$ सुवर्चसा ] सुवर्चस: $\mathbf{A} 51 \mathrm{c}$ कामदुहा ] कामदुघा $\left\{\circ\right.$ द्या $\left.\mathrm{A}_{3}\right\} \mathbf{A} \quad 52 \mathrm{~d}$ ०कोटिं $]$ ०कोटि $\mathrm{A}$ 53a आसनं य: ] निदेनं स $\mathrm{A}_{3} \mathrm{~A}_{4}$, +आसनं+ व: $\mathrm{A}_{7}^{\mathrm{pc}}$, य $\mathrm{A}_{7}^{\mathrm{ac}}$ (unmetrical) 53b वै ] $\mathrm{A}_{7}^{\mathrm{pc}}$, य: $\mathrm{A}_{3} \mathrm{~A}_{4}$, यो $\mathrm{A}_{7}^{\mathrm{ac}} \quad \mathbf{5 3 d}$ स्वर्गं चा० ] स्वर्गं $\left\{\right.$ ग्ग $\left.\mathrm{A}_{4}\right\}$ प्रा० $\mathbf{A}$

$\mathbf{5 1}\left\langle c^{1}-c^{5}\right\rangle\left(c^{6}-d^{2}\right) S_{2} \quad \mathbf{5 3}\left(a^{1}\right) S_{1},\left\langle b^{7}\right\rangle S_{2}$

50a भूमिं ] $\mathrm{S}_{1} \mathrm{~S}_{2} \mathrm{RABh}$, भूमि $\mathrm{S}_{3}$ 50c सर्वलोकेषु स ] $\mathrm{A}_{3} \mathrm{~A}_{7}$, स सर्वलोकेषु $\mathrm{S}_{1} \mathrm{Bh}$, सर्वलोके स $\mathrm{S}_{2}^{\mathrm{ac}} \mathrm{S}_{3}$ (unmetrical), सर्वलोकेसु च $S_{2}^{\mathrm{pc}}$ 50d विमानेन ] $\mathrm{S}_{2} \mathrm{~S}_{3} \mathrm{ABh}$, विमाने $\mathrm{S}_{1}$ (unmetrical) 51a यदि ] $\mathrm{S}_{1} \mathrm{~S}_{2} \mathrm{~S}_{3} \mathrm{~A}$, यद्धि $\mathrm{Bh}$ (typo?) 52b महायशा: ] $\mathrm{S}_{1} \mathrm{~S}_{2}^{\mathrm{pc}} \mathrm{RABh}$, महायशा $\mathrm{S}_{2}^{\mathrm{ac}} \mathrm{S}_{3} \quad$ 52c वैराजं ] $S_{1} S_{2} R A B h$, वैराज $S_{3}$ 52d वर्षकोटिं ] $S_{1} B h$, वषकोटिं $S_{2}$, वर्षकोटी $S_{3}$ - सुखं ] $S_{1} S_{2} A B h$, सुख $S_{3}$ (unmetrical) - वसेत् ] $S_{2} S_{3} R A B h$, वसे $S_{1}$ 53a आसनं य: ] $S_{2} R B h$, (आ)सन य: $S_{1}$ (unmetrical), आसन य $\mathrm{S}_{3}$ (unmetrical) $\mathbf{5 3 b}$ संवीतं ] RABh, सवीतं $\mathrm{S}_{1}$, सम्वीता $\mathrm{S}_{2} \mathrm{~S}_{3} \bullet$ ब्राह्मणाय ] $\mathrm{S}_{1} \mathrm{~S}_{2}^{\mathrm{ac}} \mathrm{S}_{3} \mathrm{RABh}$, ब्राह्मण $\mathrm{S}_{2}^{\mathrm{pc}} \mathbf{5 3 c}$ राज्य॰] $\mathrm{S}_{1} \mathrm{~S}_{2} \mathrm{RABh}$, राज॰ $\mathrm{S}_{3}$ 53d स्वर्गं] $\mathrm{S}_{1} \mathrm{~S}_{2} \mathrm{~A}_{3} \mathrm{~A}_{7} \mathrm{Bh}$, स्वर्ग $\mathrm{S}_{3}$ 
यस्तु शय्यां प्रयच्छेत स्वास्तीर्णां नरसत्तमः।

स तु भार्याः प्रिया दिव्या बह्वीर्भर्ता समश्नुते॥ प४ ॥

यस्तु कन्यां प्रयच्छेत ब्राह्मणाय स्वलंकृताम्।

स गत्वा पितृलोक वै वर्षायुतशतं वसेत् ॥ $y y \|$

इह चापि पुनर्जातः सर्वकामसमन्वितः।

भार्याः प्राप्नोति भक्ताश्च प्रजावांश्चोपजायते ॥ प६६॥

अश्वं यस्तु प्रयच्छेत हेमचित्रं सुलक्षणम्।

स तेन कर्मणा देवि गान्धर्वं लोकमश्नुते ॥ $४$ ७॥

54ab = KR p. 591; DS p. 454: यस्तु शय्यां प्रयच्छेत स्वास्तीर्णां नरसत्तम। 54cd DS p. 454: स हि भार्याः प्रिया दिव्या बह्हीर्भत्ता समश्नुते। (var. बह्नी भक्ता:); KR p. 591: स तु भार्य्यां प्रियां दिव्यां बह्हीं भक्तां समश्नुते। $55=$ KR p. $591 \quad 56 \mathbf{a b}=$ KR p. $591 \quad$ 56cd KR p. 591: भार्य्याः प्राप्रोति भक्ताश्च पूजावांग्चोपजायते। $\quad \mathbf{5 7 a b}=$ AYS p. 372, DS p.551, KR p.591 and DKK p.83; DK 19.68ab: अग्वं यस्तु प्रयच्छेतु हेमचित्रं सुलक्षणम् ।; HeDKh p. 589 and DVU 3, p. 21: अम्वं यस्तु प्रयच्छेद्वै हेमचित्रं सुलक्षणम । $\quad 57 \mathbf{c d}=$ AYS p. 372, DK 19.68cd, DS p. 551 and HeDKh p. 589; KR p. 592: स तेन कर्म्मणा दिव्यो गन्धर्व्व लोकमश्नुते ।; DKK p.83: स तेन कर्म्मणा विप्र गान्धर्व्व लोकमश्नुते। (var. देव for विप्र); DVU 3, p. 21: स तेन कर्मणा चैव गान्धर्वं लोकमश्नुते।

54b स्वास्तीर्णां ] आस्तीर्णं $R \quad 54 c$ स तु भार्याः प्रिया ] सह भार्य्याणिया $R$ 54d ०र्भर्ता ] ०र्भायर्या: $R 55 \mathrm{~b}$ स्वलंकृताम् ] अलंकृताम् $R \quad 55 \mathrm{c}$ ०लोकं] ॰लोकान् $R \quad 56 \mathrm{a}$ पुनर्जातः ] समायुक्तः $R 56 b$ कसमन्वितः ] ०समन्वित $R$ 56c भक्ताश्च ] भक्ता हि $R$ 57c देवि ] दिव्यो $R$

54b स्वास्तीर्णां ] आस्तीर्णां \{ ०ण्णा $\left.\mathrm{A}_{7}\right\} \mathrm{A}$ - ०सत्तमः ] $\mathrm{A}_{7}$, ${ }^{\circ}$ सत्तम $\mathrm{A}_{3} \mathrm{~A}_{4}$ 54c तु भार्या: प्रिया ] च भार्या प्रिया $\mathrm{A}_{3} \mathrm{~A}_{4}$, च भार्यां प्रियां $\mathrm{A}_{7}$ - दिव्या ] देव्या $\mathrm{A}_{3} \mathrm{~A}_{4} \mathrm{~A}_{7}^{\mathrm{ac}}$, देव्यो $\mathrm{A}_{7}^{\mathrm{pc}}$ 54d बह्हीर ] बह्री $\mathrm{A}_{3} \mathrm{~A}_{4}$, बह्वीं $\mathrm{A}_{7}$ 55cd ] om. $A$ 56a ०र्जातः ] $\mathrm{A}_{7}$, ०र्यात: $\mathrm{A}_{3} \mathrm{~A}_{4}$ 56c भार्या:] $\mathrm{A}_{7}^{\mathrm{pc}}$, भाय्या $\mathrm{A}_{3} \mathrm{~A}_{4} \mathrm{~A}_{7}^{\mathrm{ac}}$ 56d प्रजावांश्चो॰] $\mathrm{A}_{7}^{\mathrm{pc}}$, प्रजाया \{ ० यां० $\left.\mathrm{A}_{7}^{\mathrm{ac}}\right\}$ श्रो॰ $\mathrm{A}_{3} \mathrm{~A}_{7}^{\mathrm{ac}}$, प्रयाश्चो॰ $\mathrm{A}_{4}$ (unmetrical) 57b ०चित्रं सु०] ०चित्रस० $A$ - ०लक्षणम् ] $\mathrm{A}_{3}$, ०लक्ष्मणं $\mathrm{A}_{4} \mathrm{~A}_{7}$ 57c देवि ] $\mathrm{A}_{3} \mathrm{~A}_{4} \mathrm{~A}_{7}^{\mathrm{ac}}$, देव्यो $\mathrm{A}_{7}^{\mathrm{pc}} \quad \mathbf{5 7 d}$ गान्धर्वं ] गन्धर्वं $\mathrm{A}$

$\mathbf{5 4}\left(d^{2}\right)\left\langle d^{3}\right\rangle\left(d^{4}\right) S_{1},\left(c^{4}-c^{5}\right)\left\langle c^{6}-c^{8}\right\rangle S_{2},\left(a^{8}-b^{2}, d^{2}, d^{4}\right) S_{3} \quad \mathbf{5 5}\left\langle c^{1}-c^{7}\right\rangle\left(d^{1}-d^{4}\right)\left\langle d^{5}-d^{8}\right\rangle S_{1} \quad \mathbf{5 7}\left(a^{1}\right.$, $\left.a^{4}-a^{6}\right) S_{3}$

54b स्वास्तीर्णां] $S_{1} B h$, स्वस्तीर्णान् $S_{2}$, (स्वस्ती)ण्णन् $S_{3} \quad \mathbf{5 4 c}$ भार्याः ] $S_{2}^{p c} B h$, भार्या $S_{1} S_{3}$, भा (र्या) $\mathrm{S}_{2}^{\mathrm{ac}}$ - दिव्या ] $\mathrm{S}_{1} \mathrm{~S}_{3} R$, देव्यो $\mathrm{Bh}\left(\mathrm{em}\right.$. ?) $54 \mathrm{~d}$ बह्हीर्भर्ता ] em., ब(ह्वी) $\simeq$ (र्ता) $\mathrm{S}_{1}$, बहीर्भक्ता+: $+S_{2}$, ब(ह्वी) भ(र्ता) $S_{3}^{\mathrm{ac}}$, ब(ही) भ(तया) $S_{3}^{\mathrm{pc}}$, बह्वीर्भका: $B h$ 55a कन्यां ] $S_{2} R A B h$, कन्या $S_{1} S_{3}$ - प्रयच्छेत ] $S_{2} S_{3} R A B h$, प्रयच्छुन्ति $S_{1} \mathbf{5 5 b}$ स्वलंकृताम् ] $S_{2} A B h$, सुलकृताम् $S_{1}$ (anusvāra possibly lost, unmetrical), स्वलंकृता $S_{3} \quad 55 c$ गत्वा ] $S_{2}^{\mathrm{pc}} S_{3} R B h$, (स)त्वा $S_{2}^{\text {ac }} \quad \mathbf{5 6 a}$ पुनर् ] $\mathrm{S}_{1} \mathrm{~S}_{2} \mathrm{ABh}$, पुन $\mathrm{S}_{3}$ (unmetrical) $\mathbf{5 6 c}$ भार्या: ] $\mathrm{RA}_{7}^{\mathrm{pc}}$, भार्या $\mathrm{S}_{1} \mathrm{~S}_{2} \mathrm{~S}_{3}$, भर्या: $\mathrm{Bh}$ (typo) भक्ताश्च ] $S_{2} A B h$, भाक्ताश्च $S_{1}$, भक्ता च $S_{3} \quad 56 d$ प्रजावांग्रो॰ ] $S_{1} S_{2} R A_{7}^{\text {pc } B h \text {, प्रजावाश्चो॰ } S_{3}} \mathbf{5 7 b}$ ०चित्रं ] $\mathrm{S}_{1} \mathrm{~S}_{2} \mathrm{RBh}$, ०चित्र० $\mathrm{S}_{3}$ - सु० $\mathrm{S}_{1} \mathrm{RBh}$, स० $\mathrm{S}_{2} \mathrm{~S}_{3}$ 57c देवि ] $\mathrm{S}_{1} \mathrm{~S}_{2} \mathrm{~S}_{3} \mathrm{~A}_{3} \mathrm{~A}_{4} \mathrm{~A}_{7}^{\text {ac }}$, देव्यो Bh (conj.) 57d गान्धवं ] RBh, गान्धर्व० $\mathrm{S}_{1} \mathrm{~S}_{2} \mathrm{~S}_{3}$ (unmetrical) 
रथमश्वं गजं दासीं कन्यां गृहमथापि च।

भूमिं च यः प्रयच्छेत स राजा भुवि जायते॥ रू $\|$

विधिना मन्त्रयुक्तेन तस्य धर्मफलं महत्।

सर्वकामदुहा सास्य धेनुर्भूत्वोपतिष्ठति॥ पू९ ॥

जलधेनुं च यो दद्यात्तस्य दानफलं शृणु।

प्रपां सभां तडागं वा कूपं वापि सुपुष्कलम्॥ ६०॥

कृत्वा कुम्भान्सुसंपूर्णान्गन्धमाल्यैरलंकृतान्।

पुष्पैश्च विविधाकारैरम्यर्च्य द्विजसत्तमान्॥ ६? ॥

भक्ष्यभोज्यै: सुतृप्तानां तिलपात्राणि दापयेत्।

दक्षिणां पुष्कलां दद्यात्तेम्यस्तां स्पर्शयेत्ततः॥ ६२॥

58ab = DS p. 495 and p. 550; DK 19.69ab, KR p. 592 and DKK p. 84: रथमश्वं गजं दासीं कन्यां गृहमथापि वा ।; DKK p. 74: रथमश्वं गजं दासीं शय्यां गृहमथापि वा। $58 c d=$ DS p. 495, KR p. 592 and DKK p. 84; DK 19.69cd and DS p. 550: भूमिं च यः प्रयच्छेतु स राजा भुवि जायते । (var. ०यच्छेत in DS); DKK p. 74: भूमिं वा यः प्रयच्छेत स राजा भुवि जायते। 59 KR p. 592: विधिना मन्त्रयुक्तेन तस्य पुण्यफलं महत् । सर्वकामदुघा भूत्वा धेनुस्तस्योपतिष्ठते । $\quad 60 a b=D K 6.1 .79 \mathrm{ab}$ and HeDKh p. 422 60cd = DK 6.1.79 cd; HeDKh p. 422: प्रपां सत्रं तडागं वा कूपं वापि सुपुष्कलम्। 61ab DK 6.1.79ef and HeDKh p. 422: कृत्वा कुम्भान्सुवर्णांश्च गन्धमाल्यैरलंकृतान् । $\quad$ 61cd = DK 6.1.80ab and HeDKh p. 422 62ab = DK 6.1.80cd and HeDKh p. 422 62cd DK 6.1.80ef and HeDKh p. 422: दक्षिणां पुष्कलां दद्यादेम्यस्त्वाशंसयेत्ततः।

$58 \mathrm{~b}$ च ] वा $R \quad 59 \mathrm{~cd}$ ] सर्व्वकामदुघा भूत्वा धेनुस्तस्योपतिष्टते $R \quad 60 \mathrm{a}$ जलधेनुं च] जलाधारम्च $R 60 \mathrm{c}$ सभां ] शुभां $R$ 60d सुपुष्कलम् ] सुलक्षणम् $R$ 62a ०तृत्तानां] ०सन्तृत्तान् $R$ 62b तिल०] जल॰ $R$ 62d ॰स्तां स्पर्शयेत् ] ०स्तु फलयेत् $R$

$58 \mathrm{~d}$ भुवि जायते ] जायते भुवि $\mathrm{A} 59 \mathrm{~b}$ धर्मफलं महत् ] पुण्यफलं शृणु $\mathrm{A} \quad 59 \mathrm{c}$ ०दुहा सास्य ] ०दुघा तस्य $\mathrm{A} 59 \mathrm{~d}$ धेनुर्भूत्वोप॰ ] विभुत्वमुप॰ $\mathrm{A}_{3} \mathrm{~A}_{4}$, वि(भु)र्भूत्वा(मु)प॰ $\mathrm{A}_{7}^{\mathrm{ac}}$ (unmetrical), (भू)र्भूत्वा ह्युप॰ $\mathrm{A}_{7}^{\mathrm{pc}}$ - ०तिष्टति ] ०तिष्टते $\mathrm{A} \quad 60 \mathrm{~b}$ दान०] पुण्य० $\mathrm{A}$ 60c प्रपां] अपां $\mathrm{A}$ 60d सुपुष्कलम् ] सुदुष्करम् $\mathbf{A}$ 61a कृत्वा ] दत्वा $\mathbf{A}$ 62a अक्ष्यभोज्यै: ] भक्षभोज्यै: $\left\{0\right.$ ज्यै $\left.\mathrm{A}_{4}\right\} \mathrm{A}_{4} \mathrm{~A}_{7}$, भोक्ष्यभाज्यै: $\left.\mathrm{A}_{3} \quad 62 \mathrm{c}-64 \mathrm{~b}\right]$ om. A

$\mathbf{5 8}\left(\mathrm{d}^{7}-\mathrm{d}^{8}\right) \mathrm{S}_{1} \quad \mathbf{6 2}\left(\mathrm{a}^{1}\right) \mathrm{S}_{1}$

58a ०जं दासीं ] $S_{2} S_{3} R A B h$, ०जन्दासी $S_{1} \quad 58 b$ कन्यां ] $S_{1} S_{2} R A B h$, कन्या $S_{3}$ • ०हमथा०] $\mathrm{S}_{1} \mathrm{~S}_{2}^{\mathrm{pc}} \mathrm{S}_{3} \mathrm{RABh},{ }^{\circ} \mathrm{ह}\langle\boldsymbol{2}\rangle++$ +था० $\mathrm{S}_{2} \quad \mathbf{5 8 d}$ After this Bh conjectures loss of two pādas. 59a मन्त्र॰ ] $S_{1} R A B h$, यत्त $S_{2} S_{3} \quad 59 b$ महत् ] $S_{1} R B h$, शृणु $S_{2}^{\text {pc }}$, शृणु: $S_{2}^{\text {ac }} S_{3}$ 59c ०दुहा ] $S_{1} S_{2} S_{3}$, ॰दुघा $\mathrm{Bh} 59 \mathrm{~d}$ धेनुर्भूत्वोप॰] $\mathrm{S}_{1} \mathrm{Bh}$, धेनु भूत्वाव $\mathrm{S}_{2} \mathrm{~S}_{3}$ • ०तिष्टति ] $\mathrm{S}_{1} \mathrm{~S}_{2}^{\mathrm{pc}} \mathrm{S}_{3} \mathrm{Bh}$, ०विष्टति $\mathrm{S}_{2}^{\mathrm{ac}}$ 60b शृणु ] $\mathrm{S}_{1} \mathrm{~S}_{2}^{\mathrm{pc}} \mathrm{RA}$, शृणुः $\mathrm{S}_{2}^{\mathrm{ac}} \mathrm{S}_{3}$, महत् $\mathrm{Bh}$ (conj.?) 60c प्रपां ] $\mathrm{S}_{1}^{\mathrm{pc}} \mathrm{S}_{2} \mathrm{RBh}^{\mathrm{pc}}$, प्रमां $\mathrm{S}_{1}^{\mathrm{ac}}$, प्रपा $\mathrm{S}_{3}$, प्रापां $\mathrm{Bh}^{\mathrm{ac}}$ (typo) - सभां ] $\mathrm{S}_{1} \mathrm{~S}_{2} \mathrm{~S}_{3} \mathrm{~A}$, शुभां $\mathrm{Bh}$ (conj.?) - तडागं ] $\mathrm{S}_{2}^{\mathrm{pc}} \mathrm{S}_{3} \mathrm{RABh}$, तडागां $\mathrm{S}_{1}$, तडागाम् $\mathrm{S}_{2}^{\mathrm{ac}}$ 60d ॰पं वापि ] $\mathrm{S}_{1} \mathrm{~S}_{3} \mathrm{RABh}$, ॰पम्वावि $\mathrm{S}_{2}$ - ॰ पुष्कलम् $] \mathrm{S}_{1} \mathrm{~S}_{2}^{\mathrm{pc}} \mathrm{S}_{3} B \mathrm{Bh}$, ॰ पुष्क $\mathrm{S}_{2}^{\mathrm{ac}}$ (unmetrical) 61a कुम्भान् ] RABh, कुम्भां $\mathrm{S}_{1} \mathrm{~S}_{2} \mathrm{~S}_{3}$ - ०सपूर्णान् ] RABh, ०सम्पूर्णो $\mathrm{S}_{1}$, ०संपूर्णा $S_{2}$, ०सपूर्ण्ण $S_{3}$ (unmetrical) $61 \mathrm{~b}$ ०रलंकृतान् ] RABh, ०रलड़क्ताम् $S_{1}$, ०रलकृताम् $S_{2}$ $\mathrm{S}_{3} \quad 62 \mathrm{a}$ ॰ भोज्यै: ] $\mathrm{S}_{1} \mathrm{~S}_{2} \mathrm{RA}_{7} \mathrm{Bh}$, ॰ भोज्यै $\mathrm{S}_{3}$ - ${ }^{\circ}$ तृतानां ] $\mathrm{S}_{1} \mathrm{~S}_{3} \mathrm{~A}$, ${ }^{\circ}$ तृत्ताना $\mathrm{S}_{2}$, ॰तृत्तांस्तान् $\mathrm{Bh}^{\mathrm{pc}}$ (conj.), ॰ पृत्रांस्तान् $B^{\text {ac }}$ (typo, unmetrical) 62b ०पात्राणि] $S_{2}^{\text {pc }} R A B h$, ०पात्ताय $S_{1}$, ०पत्राणि $\mathrm{S}_{2}^{\mathrm{ac}} \mathrm{S}_{3}$ 62c दक्षिणां] $\mathrm{S}_{2}^{\mathrm{pc}} \mathrm{RBh}$, दक्षिणा $\mathrm{S}_{1} \mathrm{~S}_{3}$, दक्षिणं $\mathrm{S}_{2}^{\mathrm{ac}}$ - पुष्कलां ] $\mathrm{S}_{1} \mathrm{~S}_{2} \mathrm{RBh}$, पुष्कला $\mathrm{S}_{3}$ 62d ०स्तां ] $\mathrm{S}_{1} \mathrm{Bh}$, ०स्ता $\mathrm{S}_{2} \mathrm{~S}_{3}$ 
आपः शिवाश्च सौम्याश्च तर्पयन्तु पित्न्मम ।

कामगाः कामदातारो भवन्त्विति च वै वदेत्॥ ६३॥

एवं दत्त्वा तु तां धेनुं पुनः कीत्वा च वै तदा।

वाहयेत्तां प्रपां देवि ब्रह्मलोकसमर्पणीम्॥ ६४॥

तिलपात्राणि दत्त्वा च तथा वस्त्रयुगं नवम्।

सुवर्णस्य च सांनिध्यं फलानि विविधानि च।

ततो दद्याच्छुचि: स्नातो ब्राह्मणेम्यो यथाविधि॥ ६४॥

घृतं गावः प्रसूयन्ते घृतं भूम्यां प्रतिष्टितम्।

घृतमग्निश्च देवाश्च घृतं मे संप्रदीयताम्।

एवं विधानतो दत्त्वा ब्रह्मलोकमवाप्तुयात् ॥६॥॥

63ab = DK 6.1.81ab; HeDKh p. 422: आप: शिवास्तु सौम्याश्च तर्पयन्तु पित्न्मम। $63 \mathbf{c d} \mathrm{DK}$

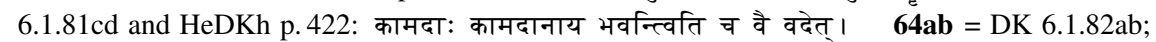
HeDKh p. 422: एवं दत्वा तु तां धेनुं पुनः कृत्वा च वै तदा। 64cd DK 6.1.82cd: वाहयेत्तु प्रपां देवीं ब्रह्मलोकसमर्पिणीम् ।; HeDKh p. 422: आवाहयेत् प्रपां देवीं ब्रह्मलोकसमर्पिणीम्। 65ab DK 6.1.83ab and HeDKh p. 422: तिलपात्राणि दत्वा च तथा वस्त्रयुगं शुभम् । $\quad \mathbf{6 5 c - f}=\mathrm{DK} 6.1 .83 \mathrm{c}-\mathrm{f}$ and HeDKh p. 422 66ab = DK 6.1.84ab, HeDKh p. 414 and DVU 3, p. 127 66cd = HeDKh p. 414; DK 6.1.84cd: घृतमग्निश्च देवाश्च घृतं सम्यक्प्रदीयताम् ।; DVU 3, p. 127: घृतमग्निश्च देवाश्च घृतं मे सम्प्रगृह्यताम्। 66ef DK 6.1.84ef: एवं विधानतो दद्याद्रु्मलोके महीयते ।; HeDKh p. 422: एवं विधानतो दत्त्वा ब्रह्मलोके महीयते ।

63a सौम्याश्च ] सौम्याश्च सौम्याश्च $\mathrm{R}$ (unmetrical) $63 \mathrm{~b}$ तर्पयन्तु ] तर्पयन्ति $\mathrm{R} 63 \mathrm{c}$ कामगा: काम०] कामदा: शम ${ }^{\circ} 63 d$ भवन्त्विति च वै वदेत् ] भवन्तु पितरो मम $R \quad 64 b$ कीत्वा ] कृत्वा $R$ $64 \mathrm{c}$ ०येत्तां प्रपां ] ०येदपगान् $\mathrm{R} \quad 65 \mathrm{a}$ दत्त्वा च] चत्वारि $\mathrm{R} \quad 66 \mathrm{~cd}$ ] om. $\mathrm{R}$

64c प्रपां देवि] पुषां दिव्यां $\mathrm{A}_{3} \mathrm{~A}_{4}$, पु(षा) देव्यो $\mathrm{A}_{7} 64 \mathrm{~d}$ ०समर्पणीम् ] ०समर्पणं $\mathrm{A}_{7}$, ०ससर्पणं $\mathrm{A}_{4}$, ०सर्पणं $\mathrm{A}_{3}$ (unmetrical) $65 \mathrm{a}$ दत्त्वा च] चत्वारि $\mathbf{A} \quad 65 \mathrm{~b}$ ०युगं नवम् ] ग्युगानि च $\mathbf{A} \quad 65 \mathrm{c}$ च सांनिध्यं ] तु आसन्वै $\mathbf{A} 66 \mathrm{~d}$ ॰्रदीयताम् ] ॰ प्रसीदतां $\mathrm{A}$

$65\left\langle a^{1}-a^{2}\right\rangle\left(a^{3}-a^{7}\right) S_{1} \quad 66\left(e^{8}\right) S_{1}$

63a आपः ] $\mathrm{S}_{1} \mathrm{~S}_{2}^{\mathrm{pc}} \mathrm{S}_{3} \mathrm{RBh}$, अप: $\mathrm{S}_{2}^{\mathrm{ac}} \mathbf{6 3 b}$ पितॄन्मम ] $\mathrm{RBh}(\mathrm{em} . ?)$, पितॄम्मम $\mathrm{S}_{1}$, पितॄम्मर्श $\mathrm{S}_{2}^{\mathrm{pc}}$ (unmetrical), पितृम्म(यि) $\mathrm{S}_{2}^{\text {ac }}$, पितृ मम $\mathrm{S}_{3} \quad \mathbf{6 3 c}$ कामगा: ] em. Bh (silently), कामगा $\mathrm{S}_{1} \mathrm{~S}_{2} \mathrm{~S}_{3}$

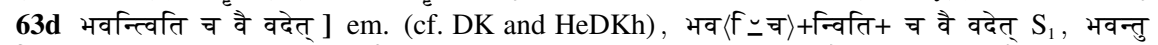
पितर: सदा $\mathrm{S}_{2} \mathrm{~S}_{3} \mathrm{Bh}$ 64b कीत्वा ] $\mathrm{S}_{1} \mathrm{Bh}$, कृत्वा $\mathrm{S}_{2} \mathrm{~S}_{3} \quad \mathbf{6 4 c}$ वाहयेत्तां ] A, वाहयेत्तत् $\mathrm{S}_{1} \mathrm{Bh}$, वाहायेति $S_{2}$, वहायेति $S_{3}$ - ०पां देवि $] S_{1}$, ०पा देवि $S_{2} S_{3}$, ०पां देव्यो Bh (conj.) 65a दत्त्वा

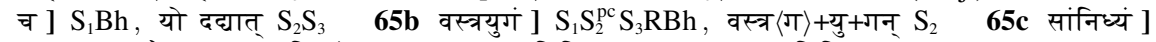
$\mathrm{S}_{2} \mathrm{RBh}$, सत्नैध्य $\mathrm{S}_{1}$, सानिध्यं $\mathrm{S}_{3} \mathbf{6 5 f}$ यथाविधि ] $\mathrm{S}_{1} \mathrm{RABh}$, यथाविधि: $\mathrm{S}_{2} \mathrm{~S}_{3}$ - After this Bh conjectures loss of two pādas. 66a गाव: ] $S_{2} S_{3} R A B h$, गाव $S_{1} \quad 66 \mathbf{b}$ घृतं ] $S_{1} S_{2} R A B h$, घृत $\mathrm{S}_{3} 66 \mathbf{d}$ संप्र० ] $\mathrm{S}_{1} \mathrm{~S}_{2} \mathrm{ABh}$, स प्र० $\mathrm{S}_{3}$ 66e विधानतो ] $\mathrm{S}_{2} \mathrm{~S}_{3} \mathrm{RABh}$, विधाततो $\mathrm{S}_{1}^{\mathrm{pc}}$, विधावतो $\mathrm{S}_{1}^{\mathrm{ac}}$ - दत्त्वा ] $\mathrm{S}_{1}^{\mathrm{pc}} \mathrm{S}_{2} \mathrm{~S}_{3} \mathrm{RABh}$, द $\langle$ ब्र $\rangle+($ त्वा $)+\mathrm{S}_{1}$ 
यो नरो गां प्रयच्छेत सवत्सां कांस्यदोहनीम्।

हेमशृड़ीं रूप्यखुरां दुकूलक्षौमवासिताम्॥ ६७॥

शय्यास्तरणसंपन्नां बहुपुष्पफल्यैर्युताम्।

ब्राह्मणांस्तर्पयित्वा तु गन्धमाल्यैरलंकृताम्॥ ६५ ॥

दानकाले ततस्तस्या: सुरा गात्राणि संश्रिताः।

ब्रह्मा तस्याः स्थितो मूर्धि शक्रो उपानं समाश्रितः॥ ६९ ॥

चन्द्रादित्यौ च नेत्रस्थौ घ्राणे वायुः प्रतिष्टितः।

मुखं तस्याः श्रितो वह्निर्जिह्वां सोमः स्वयं प्रभुः॥ ७०॥

67ab DK 6.2.60ab and DS p. 273: यो नरो गां प्रयच्छेत सवत्सां कांस्यदोहनाम् ।; AYS p. 295 and HeDKh p. 454: यो नरो गां प्रयच्छेत्तु सवत्सां कांस्यदोहनाम् । (HeDKh has 67-68 in the order of 67bc, $67 \mathrm{~d}+68 \mathrm{a}, 68 \mathrm{bc}$ and $67 \mathrm{a}+68 \mathrm{~d}) \quad$ 67cd $=$ HeDKh p. 454; AYS p. 295 and DK 6.2.60cd: हेमशृड़ीं रौप्यखुरां दुकूलक्षौमवासिताम् ।; DS p. 273: हेमशृड्गीं रौप्यखुरां दुकूलक्षौमवाससाम्। $68 \mathbf{a b}=$ AYS p. 295, DK 6.2.61ab, DS p. 273 and HeDKh p. 454 68cd = DK 6.2.61cd and HeDKh p. 454; AYS p. 295: ब्राह्मणं पूजयित्वा तु गन्धमाल्यैरलंकृताम् ।; DS p. 273: ब्राह्मणांस्तर्पयित्वाग्रे गन्धमाल्यैरलड़क्तान्। (var. ०रलड़कता) 69 DS p.273: दानकाले ततस्तस्या: सुरा गात्रेषु संस्थिताः। ब्रह्मा तस्याः स्थितो मूर्धि शक्रो यान समाश्रितः। (var. गात्राणि for गात्रेषु) 70ab DS p. 273: चन्द्रादित्यौ ततो नेत्रे घ्राणे वायुः प्रतिष्टितः। $\quad$ 70cd $=$ DS p. 273

67a यो नरो गां ] गां नरो य: $\mathrm{R} \quad 67 \mathrm{~b}$ कांस्यदोहनीम् ] कांश्यदेहिनीम् $\mathrm{R} \quad 67 \mathrm{~d}$ ०वासिताम् ] ०वासिनीम् $\mathrm{R} 68 \mathrm{a}$ शय्यास्तरण॰] शय्यां तरुण० $\mathrm{R} 69 \mathrm{a}$ ततस्तस्या: ] तु तत्तस्या $\mathrm{R} 69 \mathrm{~b}$ संश्रिता: ] संस्थिता: $R$ 69d After this $R$ has $72 a b$. 70d सोमः स्वयं प्रभुः $]$ सोमो $\left\{{ }^{\circ}{ }^{\circ} \mathrm{R}^{\mathrm{ac}}\right\}$ द्विषां पतिः $\mathrm{R}$

67a गां] $\mathrm{A}_{3}$, गी $\mathrm{A}_{4} \mathrm{~A}_{7} \quad 67 \mathbf{b}$ कांस्य॰ ] $\mathrm{A}_{3}$, कास्य॰ $\mathrm{A}_{4}$, कांश्य॰ $\mathrm{A}_{7}$ • ०दोहीम् ] $\mathrm{A}_{3} \mathrm{~A}_{4} \mathrm{~A}_{7}^{\mathrm{pc}}$, ॰देहिनों $\mathrm{A}_{7}^{\mathrm{ac}} 67 \mathrm{c}$ रूप्य॰] रौप्य॰ $\mathrm{A}$ - ०खुरां ] $\mathrm{A}_{3} \mathrm{~A}_{4}$, ०क्षुरां $\mathrm{A}_{7} 67 \mathrm{~d}$ दुकूल०] $\mathrm{A}_{7}$, बहुल॰ $\mathrm{A}_{3} \mathrm{~A}_{4}$ - वासिताम् ] ॰वाससीं $\mathrm{A}_{7}$, वाससां $\mathrm{A}_{3} \mathrm{~A}_{4} 68 \mathrm{~d}$ गन्ध॰] वस्त्र॰ $\mathbf{A} 69 \mathrm{~b}$ सुरा गात्राणि

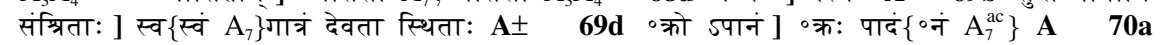
नेत्रस्थौ ] तौ नेत्रे A $70 b$ घ्राणे ] प्राणे $A$ - वायुः ] $A_{3}$, वायौ $\mathrm{A}_{4} \mathrm{~A}_{7}$ - प्रतिष्टितः ] $\mathrm{A}_{3} \mathrm{~A}_{4}$, प्रतिष्टत $\mathrm{A}_{7} \quad 70 \mathrm{~cd}$ वह्निर्जिह्वां ] वहि ह्लाशे $\left\{\right.$ कदे $\left.\mathrm{A}_{7}\right\} \mathrm{A} \quad \mathbf{7 0 d}$ प्रभुः ] $\mathrm{A}_{3}^{\mathrm{ac}}$, प्रभः $\mathrm{A}_{3}^{\mathrm{pc}} \mathrm{A}_{4} \mathrm{~A}_{7}$

$\mathbf{6 8}\left\langle\mathrm{c}^{7}\right\rangle\left(\mathrm{d}^{2}, \mathrm{~d}^{4}-\mathrm{d}^{6}\right)\left\langle\mathrm{d}^{7}\right\rangle\left(\mathrm{d}^{8}\right) \mathrm{S}_{1}$ (after this one folio lost)

67a यो ] $S_{2} S_{3} A B h$, ये $S_{1} \quad 67 \mathbf{b}$ सवत्सां ] $S_{2} S_{3} R A B h$, सवत्सा $S_{1}$ • कांस्य॰] $A_{3} B h$, काम॰ $\mathrm{S}_{1} \mathrm{~S}_{3}$, काड्स० $\mathrm{S}_{2}$ - ०दोहनीम् ] $\mathrm{A}_{3} \mathrm{~A}_{4} \mathrm{~A}_{7}^{\mathrm{pc}} \mathrm{Bh}$, ॰दोहदीम् $\mathrm{S}_{1}$, ॰दोहिनीम् $\mathrm{S}_{2}$, ०दोहिनों $\mathrm{S}_{3} 67 \mathrm{c}$ ०शृद्धीं ] $\mathrm{S}_{2} \mathrm{RABh}$, ०शृड़ी $\mathrm{S}_{1} \mathrm{~S}_{3}$ - रूप्य० ] $\mathrm{RBh}\left(\mathrm{em}\right.$. ?) , रुप्य० $\mathrm{S}_{1}$, रुकम $\mathrm{S}_{2}^{\mathrm{pc}} \mathrm{S}_{3}$, रुग्म० $\mathrm{S}_{2}^{\mathrm{ac}}$ - ०खुरां ] $\mathrm{S}_{2} \mathrm{~S}_{3} \mathrm{RA}_{3} \mathrm{~A}_{4} \mathrm{Bh}$, ०क्षुरां $\mathrm{S}_{1} \quad \mathbf{6 7 d}$ ॰ क्षौम॰] $\mathrm{S}_{1} \mathrm{RABh}$, ०क्षोम॰ $\mathrm{S}_{2} \mathrm{~S}_{3} \quad 68 \mathrm{a}$ ०संपन्नां ] $\mathrm{S}_{1} \mathrm{~S}_{2} \mathrm{RABh},{ }^{\circ}$ सपन्नां $\mathrm{S}_{3}^{\mathrm{pc}}$ (unmetrical), ०सपनं $\mathrm{S}_{3}^{\mathrm{ac}}$ (unmetrical) 68d ०रलंकृताम् ] $\mathrm{S}_{2}^{\mathrm{pc}} \mathrm{RABh}$, (०रलं) (ताम्) $S_{1}$, ०रलंकृतान् $S_{2}^{\text {ac }}$, ०रलकृतां $S_{3}$ (unmetrical) 69a ०काले त० ] $\mathrm{S}_{3}^{\text {pc }} \mathbf{A B h}$, ०काले स्त॰ $\mathrm{S}_{2}$, ०कालेन त० $\mathrm{S}_{3}^{\mathrm{ac}}$ (unmetrical) - ०स्तस्या:] $\mathbf{A B h}$, ०स्तस्या $\mathrm{S}_{2} \mathrm{~S}_{3} \mathbf{6 9 b}$ गात्राणि ] $\mathrm{RBh}$ (conj.), शास्त्राणि $\mathrm{S}_{2} \mathrm{~S}_{3}$ - संश्रिता: ] $\mathrm{S}_{2}^{\mathrm{pc} B h}$, संश्रिता $\mathrm{S}_{2}^{\mathrm{ac}} \mathrm{S}_{3} \quad \mathbf{7 0 b}$ घ्राणे ] $\mathrm{S}_{2} \mathrm{RBh}$, घ्राण $\mathrm{S}_{3}$ - प्रतिष्टितः ] $\mathrm{RA}_{3} \mathrm{~A}_{4} \mathrm{Bh}$, प्रभअनः $\mathrm{S}_{2} \mathrm{~S}_{3}$ 70c मुखं ] $\mathrm{S}_{2} \mathrm{RABh}$, मुख $\mathrm{S}_{3}$ 70cd वह्निर्जिह्नां ] $\mathrm{S}_{2} \mathrm{RBh}$, वा/यु〉जिह्वा $\mathrm{S}_{3}$ (unmetrical) 
कर्णयोस्तु दिशः सर्वाः शिरो रुद्राः समाश्रिताः।

पादयोलोकपालाः स्युः सर्वे उस्थीनि च पर्वताः॥ १९ ॥

समुद्राः सत्त जठरे ग्रीवायां तपनाः श्रिताः।

सास्नां गड़ा सरिच्छ्रेष्टा पार्य्वे तु वसवः शुभाः॥ ७२॥

प्रजापतिरुपस्थं च मूत्रं तीर्थानि सर्वशः।

पुरीषं श्रीरभूत्तस्या नागाश्चान्त्राणि सर्वशः।

साध्या विग्ये डथ लोकाश्च पुच्छुमाश्रित्य संस्थिताः॥ ७३॥

मन्त्रा यज्ञाश्च दानानि यमानि ऋषिभिः सह।

नक्षत्राणि ग्रहास्चैव तारारूपाणि यानि च॥ ७४॥

गायत्री चैव तृष्टुप्च जगती पड्रिरेव च।

अनुष्टुब्युजुस्चैव सामान्याथर्वणं तथा॥ ७४॥

71ab = DS p. 273 71cd DS p. 273: पादयोलोकपालाः स्यु: सर्वास्थीनि च पर्वताः। (var. सर्वे उस्थीनि) 72ab = DS p. 273 72cd DS p. 273: सास्नां गड़ा सरिच्छ्रेष्ठा पार्य्वौ तु वसवः शुभाः। 73ab = DS p. $27473 \mathbf{c d}$ DS p. 274: पुरीषन्तु विभुस्तस्य नासा --- संस्थिताः। $73 \mathbf{e f}=$ DS p. 274 74ab DS p.274: मन्त्रा यड्ञाश्च दानानि नियमा ऋषिभि: सह। $\quad$ 74cd = DS p. 274 75ab DS p.274: गायत्री चैव त्रिष्टुभ् जगती पंक्तिरेव च। (unmetrical, var. तृष्णुप and तिष्ठश्च) 75 cd DS p.274: अनुष्टुभ् ऋग् यजुस्चैव सामान्यथर्वणस्तथा। (var. अनुष्टुप (sic.))

71a ०स्तु ] ० ग्य $\mathrm{R}$ 71d सर्वे उस्थीनि ] सर्व्वस्थीनि $\mathrm{R}$ 72ab ] $\mathrm{R}$ has this after 69 . 72b तपनाः श्रिता: ] तेपनः श्रितः $\left\{{ }^{\circ}\right.$ ता: $\left.R^{\mathrm{ac}}\right\} R$ 72d पार्य्व $]$ पायौ $R \quad$ 73a ०रुपस्थं च ] ०रुपस्थे उस्या $R$ 73c श्रीरभूत्स० $]$ वीरभूस्त० $R$ 73d नागाश्चान्त्राणि सर्वशः ] नागा गात्राणि संस्थिता: $R$ 73e साध्या ] मध्ये $R \quad 74 b$ यमानि ] यमश्च $R \quad 75 c$ अनुष्टुवृग्यजुश्चैव ] अनुष्टुभश्च यज्ञश्च $R \quad 75 d$ ॰न्याथर्वणं त० ] ०न्यथर्व्वनस्त॰ $\mathrm{R}$

71a सर्वा: ] $\mathrm{A}_{3}$, सर्वा $\mathrm{A}_{4} \mathrm{~A}_{7} \quad 71 \mathrm{~b}$ शिरो ] शीर्ष $\mathrm{A}_{3} \mathrm{~A}_{7}^{\mathrm{ac}}$, शिर्षे $\mathrm{A}_{4}$, शिर्ष॰ $\mathrm{A}_{7}^{\mathrm{pc}}$ - रुद्रा:] नेत्रे $\mathrm{A}$ 72c गड़ा ] गड़ां $A$ - च्छ्रेष्टा ] $A_{3} A_{7}$, ०त् श्रेष्टा $A_{4}$ 72d पार्ग्ये ] पादौ $A$ - शुभा: ] $A_{4} A_{7}$, सुभा: $\mathrm{A}_{3} \quad 73 \mathrm{a}$ ०रुपस्थं ] $\mathrm{A}_{4} \mathrm{~A}_{7}$, ०रूपस्यं $\mathrm{A}_{3}$ (unmetrical) 73d नागाश्चान्त्राणि सर्वशः ] नागा चास्त्राणि $\left\{\right.$ ग्चास्थीनि $\left.\mathrm{A}_{7}\right\}$ संस्थिता: $\mathrm{A} \quad \mathbf{7 4 b}$ यमानि ] नियमा $\mathrm{A}_{3} \mathrm{~A}_{4} \mathrm{~A}_{7}^{\mathrm{pc}}$, यमा $\mathrm{A}_{7}^{\mathrm{ac}}$ (unmetrical) 75ab तृष्टुप्च जगती ] दृष्टश्च जगतां $A$ 75c अनुष्टुबृग्य॰ ] $A_{3} A_{4}$, अनुष्टु(यृ)गय॰ $A_{7}$ 75d ०न्याथवरणं त० ] न्य $\left\{\circ\right.$ न्या० $\left.\mathrm{A}_{4}\right\}$ थर्वणस्त॰ $\mathbf{A}$

71a सर्वा: ] $\mathrm{RA}_{3} \mathrm{Bh}$, सर्वा $\mathrm{S}_{2} \mathrm{~S}_{3} \quad 71 \mathrm{~b}$ शिरो ] $\mathrm{S}_{2} \mathrm{~S}_{3} \mathrm{R}$, शिरा $\mathrm{Bh}$ (conj.) - रुद्रा: ] $\mathrm{RBh}$ (em.?), रुद्रा $\mathrm{S}_{2} \mathrm{~S}_{3}$ 71c पादयोर् ] RABh, पादयो $\mathrm{S}_{2} \mathrm{~S}_{3}$ - ०पालाः स्युः ] RA, ०पाला+:+ स्यात् $S_{2}$, ०पाला स्या $S_{3}$, ०पालाश्च $B h$ (conj.) 71d पर्वता: ] $S_{2}^{\mathrm{pc}} R A B h$, पर्वता $S_{2}^{\mathrm{ac}} S_{3} \quad$ 72a समुद्रा: ] $\mathrm{S}_{2} \mathrm{RABh}$, समुद्रा $\mathrm{S}_{3} \mathbf{7 2 b}$ श्रिता: ] $\mathrm{S}_{2}^{\mathrm{pc}} \mathrm{R}^{\mathrm{ac}} \mathrm{ABh}$, श्रिता $\mathrm{S}_{2}^{\mathrm{ac}} \mathrm{S}_{3} \quad \mathbf{7 2 c}$ सास्नां ] $\mathrm{S}_{2}^{\mathrm{pc}} \mathrm{S}_{3} \mathrm{RA}$ $\mathrm{Bh}$, स्नानं $\mathrm{S}_{2}^{\mathrm{ac}}$ - सरिच्छ्रेष्टा ] $\mathrm{RA}_{3} \mathrm{~A}_{7} \mathrm{Bh}$, सरितः श्रेष्टा $\mathrm{S}_{2}^{\mathrm{pc}}$ (unmetrical), सर: श्रेष्टा $\mathrm{S}_{2}^{\mathrm{ac}}$, सर: श्रेष्टा $\mathrm{S}_{3} \quad$ 72d पार्श्ये तु $] \mathrm{S}_{2} \mathrm{~S}_{3}$, पार्श्र्ययोर् $\mathrm{Bh}$ (conj.) - वसवः ] $\mathrm{S}_{2} \mathrm{~S}_{3}^{\mathrm{pc}} \mathrm{RABh}$, भसव: $\mathrm{S}_{3}^{\mathrm{ac}}$ - शुभा: ] $\mathrm{RA}_{4} \mathrm{~A}_{7} \mathrm{Bh}\left(\mathrm{em}\right.$. ?), शुभा $\mathrm{S}_{2} \mathrm{~S}_{3}^{\mathrm{pc}}$, सु(रा) $\mathrm{S}_{3}^{\mathrm{ac}} \quad \mathbf{7 3 a}$ ०रुपस्थं च $] \mathrm{S}_{2} \mathrm{~S}_{3} \mathrm{~A}_{4} \mathrm{~A}_{7}$, ०रुपस्थश्च Bh (typo?) 73b मूत्रं ] RABh, मूर्त्तन् $S_{2} S_{3}$ 73d ० ग्चान्त्राणि ] $S_{2} S_{3}$, ० श्चास्त्राणि $B h$ 73e विश्वे डथ ] $S_{2} R$ $\mathrm{ABh}$, विश्वेष $\mathrm{S}_{3} \mathbf{7 3 f}$ पुच्छ॰ ] RABh, पुंच्छ॰ $\mathrm{S}_{2} \mathrm{~S}_{3}$ - संस्थिताः ] $\mathrm{S}_{2}^{\mathrm{pc}} \mathrm{RABh}$, संस्थिता $\mathrm{S}_{2}^{\mathrm{ac}} \mathrm{S}_{3}$ 74a मन्त्रा ] $S_{2} R A B h$, मन्त्र० $S_{3}$ 74b यमानि ] $S_{2}$, यमा+न+ $S_{3}$ (tops lost of न), यमाश्च $B h$ (conj.) - ऋषिभिः ] $S_{2} R A B h$, ऋषिभि $S_{3}$ (unmetrical) 75a तृष्टुप्च ] $S_{2} S_{3} R$, त्रिष्टुप् च $B h$ (em.?, irregular vipulā) 75b पड़्্ि॰] $\mathrm{RABh}$, पक्ति॰ $\mathrm{S}_{2} \mathrm{~S}_{3}$ 75c अनुट्टुवृग्य०] $\mathrm{A}_{3} \mathrm{~A}_{4} \mathrm{Bh}$ (cf. $\mathrm{DS})$, अनुष्टुप्च य॰ $\mathrm{S}_{2}$, अनष्टुप्च य॰ $\mathrm{S}_{3} \mathbf{7 5 d}$ ॰न्याथर्वणं ] $\mathrm{S}_{2} \mathrm{Bh}$, ॰न्यार्थर्वणन् $\mathrm{S}_{3}$ 
लोकस्य मातरस्चैव मेघा वर्षमथापि च।

धर्मों नारायणश्चैव भूतानि सरितस्तथा।

रोमकूपाणि संश्रित्य तस्या देवा व्यवस्थिताः॥ ७६॥

यक्षाश्च राक्षसाश्चैव पिशाचाः पक्षिभिः सह।

यज्ञाश्च दक्षिणाग्चैव तथा चाप्सरसः शुभाः॥ ७७॥

गन्धर्वाश्च महात्मानो ये चान्ये उप्येवमादयः।

तस्या विषाणयोर्व्यास सर्व एव समाश्रिताः॥ ७६॥

फलानि यज्ञदानानां गतयश्च पृथग्विधाः।

वत्सं समाश्रिताः सर्वे सर्वदेवमयं शुभम्॥ ७९.॥

देवैरध्यासितां तां तु सर्वेह्हस्तद्वयेन तु ।

विप्रेम्यो मन्त्रवद्वस्ते प्रदद्यात्सुसमाहितः॥ ५०॥

76ab DS p. 274: लोकस्य मातर स्चैव मेघावर्षमथापि वा। (var. च) 76cd = DS p. 274 76ef DS p. 274: रोमाणि तस्याः संश्रित्य तस्या देवा व्यवस्थिताः। (var. रूपाणि तस्य) 77 DS p.274: यक्षाश्च राक्षसास्चैव तथा चाप्सरस: शुभा:। (77bc om.) 78ab = DS p. 274 78cd DS p.274: तस्या विषाणयोर्मध्ये सर्व एव समाश्रिताः। 79 = DS p. $274 \quad$ 80ab = AYS p. 295 and DK 6.2.62ab; DS p. 274: देवैरध्यासितां तान्तु सर्वलोकनमस्कृताम् ।; HeDKh p. 454: देवैरध्यासितां तां तु सर्वैस्तद्वद्वयेन तु । 80cd AYS p. 295 and DK 6.2.62cd: मृदुबन्धेन बध्रीयादन्तः श्नक्ष्णेन रज्जुना ।; DS p. 274: विप्रेम्यो मन्त्रमुच्चार्य प्रदद्यात् सुसमाहितः। (var. मन्त्रवद्धसे (sic.)); HeDKh p. 454: मृदुबन्धेन वध्नीयात्ततः श्नक्ष्णेन रज्जुना।

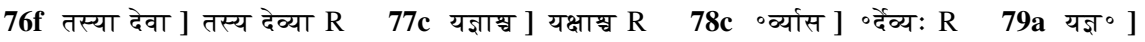
सर्व्व० $\mathrm{R} 80 \mathrm{~b}$ सर्वेहस्तद्वयेन तु ] सर्वलोकनमस्कृताम् $\mathrm{R} \quad 80 \mathrm{c}$ मन्त्रवद्धस्ते ] मन्त्रविद्यश्च $\mathrm{R}$

$76 \mathrm{~b}$ मेघा ] ऋतु० $\mathrm{A} \quad 76 \mathrm{e}$ रोमकूपाणि ] रूपाणि तस्य $\mathrm{A} \quad 76 \mathrm{f}$ तस्या ] तस्यां $\mathrm{A} 77 \mathrm{bc}$ ] om A 79b गतयश्च ] ऋतवश्च $A$ 79d सर्व०] $A_{3} A_{7}$, सर्वे $A_{4} 80 a$ ०रध्यासितां] $A_{3}$, ०रध्याषितान् $\mathrm{A}_{7}$, ०र्वध्यापितां $\mathrm{A}_{4} \quad 80 \mathrm{~b}$ सर्वेर्हस्तद्वयेन तु ] सर्वलोकनमस्कृतां $\mathrm{A} \quad 80 \mathrm{~d}$ ॰त्सुसमा॰] $\mathrm{A}_{7}$, ०त्स समा० $\mathrm{A}_{3} \mathrm{~A}_{4}$

76a मातरश्चै॰] $\mathrm{S}_{2}^{\mathrm{pc}} \mathrm{RABh}$, मातरस्चै॰ $\mathrm{S}_{2}^{\mathrm{ac}}$, मातरं चै॰ $\mathrm{S}_{3} \quad \mathbf{7 6 b}$ च ] $\mathrm{S}_{2} \mathrm{RABh}$, वा $\mathrm{S}_{3}$ 76f तस्या ] em. Bh (silently), तस्य $S_{2} S_{3}$ - ०स्थिता: ] $S_{2} R A B h$, ०स्थिता $S_{3}$ 77b पिशाचा: ] $\mathrm{RBh}$ (em.?), पिशाचा $\mathrm{S}_{2} \mathrm{~S}_{3}$ - पक्षिभि: ] $\mathrm{S}_{2} \mathrm{RBh}$, पक्षिभि $\mathrm{S}_{3}$ (unmetrical) 77c दक्षिणा॰] $\mathrm{S}_{2} \mathrm{RBh}$, दक्षिण॰ $\mathrm{S}_{3}$ 77d तथा चा॰ $\mathrm{S}_{2} \mathrm{RABh}$, तथा॰ $\mathrm{S}_{3}$ (unmetrical) • शुभाः ] $\mathrm{S}_{2}^{\mathrm{pc}} \mathrm{RABh}$, शुभा $\mathrm{S}_{2}^{\mathrm{ac}} \mathrm{S}_{3} \quad 78 \mathrm{a}$ महात्मानो ] $\mathrm{S}_{2}^{\mathrm{pc}} \mathrm{RABh}$, महात्माने $\mathrm{S}_{2}^{\mathrm{ac}} \mathrm{S}_{3} \quad \mathbf{7 8 b}$ ज्येव०] RABh, ध्येव० $\mathrm{S}_{2}$, देव० $S_{3} \quad 78 \mathrm{c}$ व्योर्व्यास ] $S_{2} A B h$, ०यो व्यास $S_{3} \quad 78 d$ समाश्रिता: ] $S_{2}^{\mathrm{pc}} R A B h$, समाश्रिता $S_{2}^{\mathrm{ac}} S_{3}$ 79c समाश्रिता: ] $S_{2} R A B h$, समाश्रिता $S_{3}$ 79d सर्व०] $S_{3} R_{3} A_{7} B h$, सर्वे $S_{2} \quad 80 b$ सर्वैहस्तद्वयेन तु ] $S_{2}$, सर्वे हस्तद्वयेन तु $S_{3}$, सर्वलोकनमस्कृताम् $B h$ 


\author{
कुशान्सुवर्णबीजानि तिलान्सिद्धार्थकांस्तथा। \\ प्रदद्याद्धस्ततो ऽद्ञिस्तु मन्त्रेणानेन सुत्रतः ॥ ५? ॥ \\ सर्वदेवमयीं दोग्ध्रीं सर्वलोकमयीं तथा। \\ सर्वलोकनिमित्ताय सर्वदेवनमस्कृताम्। \\ प्रयच्छामि महासत्वामक्षयाय शुभामिति॥ ५. ॥ \\ एवं स दत्त्वा तां गां तु यत्र यत्र प्रजायते। \\ तत्र तत्र गता सा तं जन्तुं तारयते इक्षया॥ ५३॥ \\ तथा कामदुहा चैव सर्वलोकप्रदा तथा। \\ सर्वज्ञानप्रदा चैव सर्वयज्ञफला तथा॥ ५४॥
}

\begin{abstract}
81ab = AYS p. 295; DK 6.2.63ab: कुशा: सुवर्णं बीजानि तिला: सिद्धार्थकास्तथा ।; DS p. 274: कुशान् सुवर्णबीजांश्च तिलान् सिद्धार्थकांस्तथा। (var. ${ }^{\circ}$ बीजानि); HeDKh p. 454: कुशान् सुवर्णबीजानि तिलाः सिद्धार्थकास्तथा। 81cd AYS p. 295, DK 6.2.63cd, DS p. 274 and HeDKh p. 454: प्रदद्यात्तां ततो उद्रिश्च मन्त्रेणानेन सुत्रत। 82ab = AYS p. 295, DK 6.2.64ab, DS p. 275 and HeDKh p. 454 82cd AYS p. 295 and DK 6.2.64cd: सर्वलोकनिमित्तां गां सर्वदेवनमस्कृताम् ।; DS p. 275: सर्वलोकनिमित्ताय

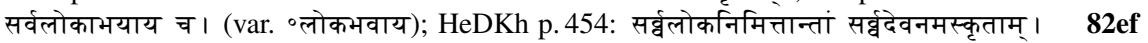
$=$ AYS p. 295, DK 6.2.64ef and HeDKh p. 454; DS p. 275: प्रयच्छामि महाभागामक्षयाय शुभाय गाम् । 83ab = DK 6.2.65ab; AYS p. 295: एवं दत्त्वा तु तां गां तु यत्र यत्र प्रजायते । (the quotations of 83, 85ab and 86 in AYS are attributed to a Matsyapurāṇa); DS p. 275: एवं दत्त्वा स तां गान्तु यत्र यत्राभिजायते।; HeDKh p. 455: एवं स दत्त्वा यो गान्तु यत्र यत्र प्रजायते। 83cd AYS p. 295 and DK 6.2.65cd: तत्र तत्र गता सा तु जन्तुं तारयते भयात् ।; DS p. 275: तत्र तत्र गता सा तु तन्तु तारयते भयात्। (var. जन्तुं for तन्तु); HeDKh p. 455: तत्र तत्र गता सा तान् जन्तूंस्तारयते भयात्। 84 DS p. 275: तथा कामदुघा चैव सर्वलोकप्रदा तथा। सर्वदानफला चैव सर्वयज्ञफला तथा। (var. कामदुहा)
\end{abstract}

$81 \mathrm{a}$ कुशान् ] कुशा $R \quad 81 \mathrm{c}$ ०द्वस्ततो ] ०त्तां ततो $R \quad 81 \mathrm{~d}$ सुत्रतः ] $R^{p c}$, सुत्रत $R^{\mathrm{ac}} 82 \mathrm{~d}$ ०देवनमस्कृताम् ] ०्लोकोड्रवाय च $R \quad 82 f$ शुभामिति ] शुभाय गाम् $R \quad 83 c$ गता सा तं] सभासन्ते $R$ 83d इक्षया ] भयात् $R \quad 84 a$ कदुहा ] ॰दुघा $R \quad 84 b$ तथा ] वरा $R \quad 84 c d$ ] om. $R$

81 ] om. $\mathrm{A}_{7} \quad$ 81a कुशान्सुवर्ण॰] दशां सुवर्णं $\mathrm{A}_{3} \mathrm{~A}_{4} \quad$ 81b तिलान् ] $\mathrm{A}_{3}$, ते तान् $\mathrm{A}_{4}$ • सिद्धार्थकां० ] सिद्धात्रसं० $\mathrm{A}_{3} \mathrm{~A}_{4} \quad 81 \mathrm{c}$ ०द्वस्ततो उद्रिस्तु ] ०त्तात सद्रिश्च $\mathrm{A}_{3} \mathrm{~A}_{4}$ 81d सुत्रतः ] सुत्रत $\mathrm{A}_{3} \mathrm{~A}_{4}$ 82a ०मयीं दोग्ध्रीं ] $\mathrm{A}_{7}$, ०मयीं दोग्धीं $\mathrm{A}_{3}$, ०मयी दोग्ध्रीं $\mathrm{A}_{4}$ 82d ॰देवनमस्कृताम् ] ॰लोकहिताय च $\mathrm{A} 82 \mathrm{f}$ शुभामिति ] शुभाय तां $\mathrm{A} 83 \mathrm{c}$ तं ] $\mathrm{A}_{3} \mathrm{~A}_{7}$, om. $\mathrm{A}_{4}$ (unmetrical) 83d इक्षया ] भयात् A 84a ॰दुहा ] ॰दुघा $\mathrm{A}_{4} \mathrm{~A}_{7}$, ॰दुद्या $\mathrm{A}_{3} \quad \mathbf{8 4 c d}$ ] om. $\mathbf{A}$

81a सुवर्ण॰] $S_{2} S_{3} R$, सुवर्णं Bh $81 b$ तिलान् ] $S_{2} R A_{3} B h$, तिला $S_{3}$ • ०कांस्तथा ] $S_{2} R B h$, ॰ कास्तथा $\mathrm{S}_{3} \quad 81 \mathrm{c}$ ॰द्याद्धस्ततो ] em., ॰द्या 〈हां †घां+स्ततो $\mathrm{S}_{2}$, ॰द्या हस्ततो $\mathrm{S}_{3}$, ॰द्याद् गां ततो $\mathrm{Bh}$ (conj.) 81d सुत्रतः ] $\mathrm{S}_{2} \mathrm{~S}_{3} \mathrm{R}^{\mathrm{pc}}$, सुत्रत $\mathrm{Bh}$ 82a ०मयीं दोग्ध्रीं ] $\mathrm{RA}_{7} \mathrm{Bh}$ (em.?), ०मयीन्दोग्र्रिं $S_{2}$, ०मयी दोगिध $S_{3}$ 82d ०देवनमस्कृताम् ] $\mathrm{S}_{2} \mathrm{~S}_{3}$, ०लोकहिताय च $\mathrm{Bh}$ 82ef ०सत्त्वाम०] $\mathrm{S}_{2} \mathrm{RABh}$ ( ${ }^{\circ}$ त्वां अ० in $\mathrm{S}_{2} \mathrm{~A}$ ), ०सत्वा अ० $\mathrm{S}_{3} \quad 83 \mathrm{a}$ एवं ] $\mathrm{S}_{2} \mathrm{RABh}$, एसं $\mathrm{S}_{3} \quad 83 \mathrm{c}$ सा तं] $\mathrm{S}_{3} \mathrm{~A}_{3} \mathrm{~A}_{7} \mathrm{Bh}$, शान्तं $\mathrm{S}_{2} \quad \mathbf{8 3 d}$ इक्षया ] $\mathrm{S}_{2} \mathrm{~S}_{3}$, भयात् $\mathrm{Bh}$ 84a तथा ] $\mathrm{S}_{2} \mathrm{~S}_{3} \mathrm{RA}$, सर्व॰ Bh (conj.) - कामदुहा ] $S_{2}^{\text {pc }} S_{3} B h$, कदुहा $S_{2}^{\text {ac }}$ (unmetrical) - चैव ] $S_{3} R A B h$, वैव $S_{2}$ 
सवाँल्नोकांस्तया गत्वा रमते च यथामरः।

इह जातश्च तामेव कामगां संप्रपद्यते॥ $5 y \|$

स तया मानुषो जातो गोसहस्री महाबलः।

रूपवान्धनवांश्चैव बहुपुत्रश्च जायते॥ ५६॥

प्रसूयमानां यो गां तु दद्यादुभयतोमुखीम्।

यथोकेन विधानेन स जातिस्मरतां लभेत्॥ ५७॥

यस्तु गां संप्रयच्छेत ब्राह्मणेम्यो यथातथम्।

तमप्यसौ भयाद्धोरात्त्रायते नरकादपि॥ ५. ॥

कृष्णाजिनं तु यो दद्याद्रतिने ब्रह्मचारिणे।

पृथिवीफलमाप्रोति योगश्चास्य प्रवर्तते॥ ५९ ॥

योगिक्यो ब्रह्मचारिम्यो ब्राह्मणेम्यो यतात्मवान्।

यः प्रयच्छेदावसथं सो उश्वमेधफलं लभेत्॥ ९०॥

85ab AYS p. 295: स्वर्गलोक नरो गत्वा रमते च यथामर:।; DK 6.2.66ab: सर्वलोकान्तरे गत्वा रमते च यथामर: ।; DS p. 275: सर्वलोकांस्तथा गत्वा रमते च यथामर:।; HeDKh p. 455: सर्व्वलोकान्तरे गत्वा रमते च यथा नर:। 85cd DS p.275: इह जातश्च तामेव कामगां स प्रपद्यते । 86ab AYS p.296 and DK 6.2.66cd: स तथा मानुषे जातो गोसहस्री महाबलः।; DS p. 275: स तदा मानुषे लोके गोसहस्री महायशाः। (var. सन्तया मानुषो जातो गोसहस्री महाबलः।); HeDKh p. 455: स तथा मानवो जातो गोसहस्री महाबलः। 86cd = AYS p. 296, DK 6.2.66ef and HeDKh p. 455; DS p. 275: धनवान् रूपवांग्चैव बहुपुत्रश्च जायते । 87ab = DS p. 276; DK 6.3.1 ab and HeDKh p. 476: प्रसूयमानां यो गां च दद्यादुभयतोमुखीम्। $\quad$ 87cd $=$ DK 6.3.1cd, DS p. 276 and HeDKh p. $476 \quad \mathbf{8 8}$ DS p. 293: यस्तु गां संप्रयच्छेत ब्राह्मणेक्यो यथा तथा। तमप्यसौ महाघोरात्तायते नरकादपि । $\quad \mathbf{8 9}=$ DS p. $529 \quad \mathbf{9 0}=$ DS p. 450

$85 \mathrm{a}$ सवांब्लोकांस्तया ] सर्वलोकांस्तथा $\mathrm{R} \quad 85 \mathrm{~b}$ रमते च] स रराम $\mathrm{R} 85 \mathrm{~d}$ संप्रपद्यते ] संपद्यते $\mathrm{R}$ (unmetrical) $86 \mathrm{a}$ तया ] तदा $R \quad 86 \mathrm{c}$ रूपवान्धन $\left.{ }^{\circ}\right]$ धनवान् रूप० $R \quad 88 \mathrm{~d}{ }^{\circ}$ त्तायते ] ${ }^{\circ}$ त्ततार $\mathrm{R}$

85a सवाँल्नोकांस्तया ] सर्वलोकांस्तथा A 86a तया] तदा $\mathbf{A} \quad 86 \mathrm{~b}$ गोसहस्री ] गोसहरां ०रं $\left.\mathrm{A}_{4}\right\}$

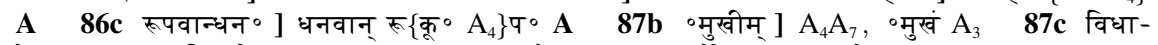
नेन ] $\mathrm{A}_{3} \mathrm{~A}_{7}^{\mathrm{pc}}$, विमानेन $\mathrm{A}_{4} \mathrm{~A}_{7}^{\mathrm{ac}} \quad \mathbf{8 8 c d}$ भयाद्योरात्ता। $]$ भयार्थेक्यस्त्रा॰ $\left\{\right.$ ०्यो त्रा० $\left.\mathrm{A}_{4} \mathrm{~A}_{7}^{\mathrm{ac}}\right\} \mathrm{A} \quad \mathbf{8 9 a}$ तु यो ] $\mathrm{A}_{7}^{\mathrm{ac}}$ ?, ततो $\mathrm{A}_{3} \mathrm{~A}_{4} \mathrm{~A}_{7}^{\mathrm{pc}}$ ? $90 \mathrm{a}$ योगिभ्यो ] योगेक्यो $\mathbf{A} \quad 90 \mathrm{~b}$ यतात्मवान् ] यथात्मवान् $\mathbf{A}$

$\mathbf{8 6}\left(\mathrm{d}^{2}\right) \mathrm{S}_{2},\left(\mathrm{a}^{2}\right) \mathrm{S}_{3}$

85a सवांल्नो॰] $S_{2} B h$, सर्वा लो॰ $S_{3} \quad 85 b$ यथामर: ] $S_{2}^{\mathrm{pc}} S_{3} R A B h$, यथारर: $S_{2}^{\mathrm{ac}} \quad 86 \mathbf{a}$ मानुषो ] $\mathrm{S}_{2} \mathrm{RABh}$, मनुषो $S_{3}$ 86d बहु॰] $S_{2}^{\mathrm{pc}} \mathrm{RABh}$, ब॰ $\mathrm{S}_{2}^{\mathrm{ac}}$ (unmetrical), बपु॰ $S_{3}$ 87-89] om. $\mathrm{S}_{2}$ (an insertion mark after 86, but no insertion i.m.) $\quad \mathbf{8 7 b}$ ॰मुखीम् ] $\mathrm{RA}_{4} \mathrm{~A}_{7} \mathrm{Bh}(\mathrm{em}$. ?), ममुखाम् $\mathrm{S}_{3} \quad 87 \mathrm{~d}$ लभेत् ] RABh, लभे $\mathrm{S}_{3} \quad 88 \mathbf{a}$ गां सं०] RABh, गा सं $\mathrm{S}_{3} \quad 88 \mathrm{c}$ भयाद्वोरात् ] $\mathrm{S}_{3} \mathrm{R}$, भयार्थेम्यस् $\mathrm{Bh} 89 \mathrm{a}$ तु ] $\mathrm{S}_{3} \mathrm{RA}_{7}^{\mathrm{ac}}$ ?, च $\mathrm{Bh}$ (conj.) 
आप्रोर्यामं पौण्डरीकं गोसहस्त्रं च विन्दति।

स्मृतिं च परमां लब्ध्वा योगमाप्रोति सुत्रतः॥ ९?॥

कमण्डलुं तु यो दद्याद्राह्मणाय नरोत्तमः।

स तेन कर्मणा देवि धर्मनित्यत्वमाप्तुते॥ ९२॥

व्याधितं यस्तु विप्रषिं दीनं मूढमचेतसम्।

उद्धरेत यथाशत्ता स मुच्येद्रह्महत्यया॥ ९३॥

यः सुवर्ण प्रयच्छेत दरिद्राय द्विजातये।

दशानामश्वमेधानां फलं प्राप्रोति देवताः॥ ९४॥

यश्चैवेमानि सर्वाणि दानान्युक्तानि कृत्स्नशः।

ददाति युगपद्देव्यः पृथिव्यां सैकराड्भवेत् ॥९ ४॥

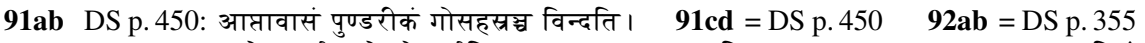
92cd DS p. 355: स तेन कर्मणा देव्यो धर्मनिष्ठत्वमाप्तुयात्। (var. ०नित्यत्व०) 93 DS p. 560: व्याधितं यस्तु विप्रर्षे दीनं मूढमचेतनम्। उद्धरेच्च यथाशत्या स मुच्येद् ब्रह्महत्यया। 94ab DS p.419: सुवर्ण यः प्रयच्छेत्तु दरिद्राय द्विजातये।; DKK p. 52: सुवर्ण यः प्रयच्छेत दरिद्राय द्विजातये। (var. प्रयच्छेतु) 94cd DS p. 419 and DKK p. 52: दशानामश्वमेधानां फलं प्राप्नोति मानवः।

$91 \mathrm{a}$ आप्रोर्यामं पौण्डरीकं ] प्राप्तुयात् पुण्डरीकाख्यं $R$ 91d सुत्रतः ] सुत्रताः $R$ 92c देवि ] देव्यो $R$ 92d ममाप्तुते ] ॰मश्नुते $R$ 93a विप्रर्षि ] विप्रर्षे+र्+ $R \quad 93 \mathrm{~b}$ ०नं मूढमचेतसम् ] ननच्च तु विकेतनम् $R \quad 95 d$ सैकराड् ] स्वैरता $R$

91 ] om. $\mathrm{A}_{7}^{\mathrm{pc}},+$ अ+प्रोर्या $\mathrm{A}_{7}^{\mathrm{ac}}$ (unmetrical) 91a आप्रोर्यामं पौण्डरीकं ] आप्तो $\left\{\circ\right.$ पौ॰ $\left.\mathrm{A}_{3}\right\}$ र्यामपुं $\left\{\circ\right.$ प्पं० $\mathrm{A}_{3}$ \}दरीकं $\mathrm{A}_{3} \mathrm{~A}_{4}$ 91c स्मृतिं च परमां ] स्मृतिश्चाप्सरसां $\mathrm{A}_{3} \mathrm{~A}_{4}$ • लब्ध्वा ] $\mathrm{A}_{4}$, लब्धा $\mathrm{A}_{3}$ 91d सुत्रतः ] सुत्रता: $\mathrm{A}_{3} \mathrm{~A}_{4}$ 92a तु ] च $\mathbf{A}$ 92b ॰द्वाह्मणाय ] $\mathrm{A}_{3} \mathrm{~A}_{7}$, ०त् ब्राणाय $\mathrm{A}_{4}$ (unmetrical) - नरोत्तमः ] $\mathrm{A}_{3}^{\mathrm{ac}}$, नरोत्तम $\mathrm{A}_{3}^{\mathrm{pc}} \mathrm{A}_{4} \mathrm{~A}_{7}$ 92c देवि] दिव्यो $\mathrm{A}_{3} \mathrm{~A}_{4} \mathrm{~A}_{7}^{\mathrm{ac}}$, देव्यो $\mathrm{A}_{7}^{\mathrm{pc}}$ 92d धर्मनित्यत्व० ] धर्मानित्यार्थ० $A_{7}$, धर्मानि $\left\{\circ{ }^{\circ} A_{3}\right.$ त्यर्थ॰ $A_{3} A_{4}$ • माप्तुते ] ०माप्तुयात् $A$ 93a विप्रर्षि ] $\mathrm{A}_{3}$, विप्रर्षि $\mathrm{A}_{4}$, विप्रर्षिर् $\mathrm{A}_{7} \quad 93 \mathrm{~b}$ ०मचेतसम् ] ${ }^{\circ}$ चेतनम् $\mathbf{A} \quad 93 \mathbf{c}$ उद्धरेत ] उद्धरेत्तु $\mathrm{A}_{3} \mathrm{~A}_{4}$, उद्धररे(स्थ) $\rangle \mathrm{A}_{7}$ (unmetrical) $95 \mathbf{b}$ दानान्यु॰] दान्यु॰ $\mathrm{A}_{3}$ (unmetrical), वेदान्यु ${ }^{\circ} \mathrm{A}_{4} \mathrm{~A}_{7}$ - कृत्स्सशः ] सर्वशः $\mathbf{A} 95 \mathbf{d}$ सैकराड्भवेत् ] मुच्यते $\left\{\right.$ मुते $\mathrm{A}_{3}$ (unmetrical $\left.)\right\}$ भयात् $\mathbf{A}$

91a आप्रोर्यामं ] $S_{2}^{\mathrm{pc}} \mathrm{Bh}$, अप्रोर्यामं $\mathrm{S}_{2}^{\mathrm{ac}} \mathrm{S}_{3}$ 91c लब्ध्वा ] $\mathrm{S}_{2} \mathrm{RA}_{4} \mathrm{Bh}$, लब्धा $\mathrm{S}_{3}$ 91d सुत्रतः ] em. (cf. DS), सुत्रता $\mathrm{S}_{2} \mathrm{~S}_{3}^{\mathrm{pc}}$, सुवता $\mathrm{S}_{3}^{\mathrm{ac}}$ (unmetrical), सुत्रता: $\mathrm{Bh} \mathbf{9 2 b}$ द्वाह्मणाय ] $\mathrm{S}_{2}^{\mathrm{pc}} \mathrm{RA}_{3}$ $\mathrm{A}_{7} \mathrm{Bh}$, हद्रह्मणाय $\mathrm{S}_{2}^{\mathrm{ac}} \mathrm{S}_{3}$ 92c देवि $] \mathrm{S}_{2} \mathrm{~S}_{3}$, देव्यो $\mathrm{Bh}(\mathrm{em}$. ?) 92d धर्मनित्य०] RBh (em.), धर्मत्रित्य॰ $S_{2}$, धर्म नित्य॰ $S_{3}$ - ०माप्तुते ] $S_{2} B h$, ०माप्तुयात् $S_{3}$ 93a विप्रर्षि ] $A_{3}$, विप्रर्षि $S_{2}$ $\mathrm{S}_{3}$, विप्रर्षे $\mathrm{Bh}$ (conj.) 93cd ०शत्तया स ] $\mathrm{S}_{2}^{\mathrm{pc}} \mathrm{RABh}$, ०शत्तयात्स $\mathrm{S}_{2}^{\mathrm{ac}} \mathrm{S}_{3}$ 94a सुवर्ण ] $\mathrm{S}_{2} \mathrm{RABh}$, सुवर्ण $S_{3} \quad 94 d$ देवता: ] $S_{2}^{\text {pc }} R A B h$, देवता $S_{2}^{\text {ac }} S_{3} \quad 95 b$ दानान्यु॰ ] RBh (conj.?), दान्यान्यु ${ }^{\circ}$ $\mathrm{S}_{2} \mathrm{~S}_{3} \quad 95 \mathrm{c}$ ०पद्देव्यः ] $\mathrm{S}_{2} \mathrm{RABh}$, ०प देव्य: $\mathrm{S}_{3}$ (unmetrical) 95d पृथिव्यां सैक०] $\mathrm{S}_{3}$, पृथिव्यां स्यैक० $\mathrm{S}_{2}$, स पृथ्व्यामेक॰ Bh (conj.) - ०राड्भवेत् ] em. Bh (silently), ०राट्भवेत् $\mathrm{S}_{2} \mathrm{~S}_{3}$ 
इदं यः शृणुयात्रित्यं दद्याचैव स्वशक्तितः ।

पठेत च महाभागा: सो ऽपि गच्छेत्तिपिष्टपम्॥ ९६॥

इति स्कन्दपुराण एकादशोत्तरशतो डध्यायः ॥ १?? ॥

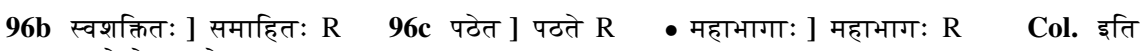
स्कन्दपुराणे रेवाखण्डे उध्याय: $R$

96a इदं यः ] य इदं $\mathrm{A} 96 \mathrm{c}$ पठेत ] पढ्यते $\mathrm{A}$ - महाभागा: ] $\mathrm{A}_{7}^{\mathrm{pc}}$, महाभाग $\mathrm{A}_{3} \mathrm{~A}_{4} \mathrm{~A}_{7}^{\mathrm{ac}}$ 96d पिष्टपम् ] $\mathrm{A}_{4} \mathrm{~A}_{7}$, ०विष्टपं $\mathrm{A}_{3}$ Col. इति $\left\{\right.$ ॥त इति ग्री॰ $\left.\mathrm{A}_{7}\right\}$ स्कन्दपुराणे एकाशीतिसाहस्रयां संहितायामम्बिकाखण्डे दशोत्तरशतं दानाध्याय: $\mathbf{A}$

96ab ०यात्रित्यं दद्याचै०] $\mathrm{S}_{2} \mathrm{RABh}$, ०या नित्यं $\left\{{ }^{\circ}\right.$ त्य $\left.\mathrm{S}_{3}^{\mathrm{ac}}\right\}$ दद्या चै॰ $\mathrm{S}_{3} \quad 96 \mathrm{c}$ महाभागा: $] \mathrm{A}_{7}^{\mathrm{pc}} \mathrm{Bh}$ (em.?), महाभागा $\mathrm{S}_{2} \mathrm{~S}_{3} \quad \mathbf{9 6 d}$ ०पिष्टपम् $] \mathrm{S}_{2} \mathrm{~S}_{3} \mathrm{RA}_{4} \mathrm{~A}_{7}$, ०विष्टपम् Bh Col. स्कन्दपुराणैकादशोत्तरशतो ध्याय:॥ $\mathrm{S}_{2}, \odot$ ॥ स्कन्दपुराणे नामाध्याय: १९३ (in letter numerals)॥ $\odot \mathrm{S}_{3}$, इति स्कन्दपुराणे एकादशोत्तरशतोध्याय: $\mathrm{Bh}$ 
द्वादशोत्तरशतो डध्याय:।

देव्युवाच।

देव्य: शृणुत भूयो उपि यथा दानं विना शुभाः।

अयमेवोपवासेन यथा धर्मों ऽपि लम्यते॥ ? ॥

एकभक्तेन यो देव्यो मासं मार्गशिरं क्षपेत्।

स तेन कर्मणा देव्यो गोमान्भवति नित्यशः॥ २॥

पौषमासेन पुत्रांश्च बहूनाप्नोति धार्मिकान्।

माघमासे च कुर्वाणः स्त्रियः प्राप्नोति वै प्रियाः ॥ ॥

एकभक्त तु कुर्वाणः फाल्गुने मासि नित्यशः।

स्त्रीषु सौभाग्यमाप्नोति स्त्रियश्च परमप्रियाः ॥ ४॥

2ab VK p. 418: एकभक्तेन यो दिव्यं मासं मार्गं क्षपेत च ।; KR p. 444: एकभक्तेन यो दद्यान्मासं मार्ग क्षपेत च। 2cd VK p.418: स तेन कर्मणा युक्तः सौभाग्यं याति सर्वतः।; KR p. 444: स तेन कर्म्मणा युक्तः सुभगो भवति सर्व्वतः। (hypermetrical) $3 \mathbf{a b}=$ VK p.419; KR p. 475: पौषे मासे तु पुत्रांश्च बहूनाप्रोति धार्म्मिकान् । 3cd = VK p. 419; SaPra p. 135: माघमासे तु कुर्वाणः स्त्रियं प्राप्रोति वै प्रियाम् ।; KR p. 491: माघे मासे तु कुर्वाणः स्त्रियः प्राम्नोति वै शुभाः। $\quad$ 4ab =VK p. 419 and KR p. $516 \quad$ 4cd = KR p. 516

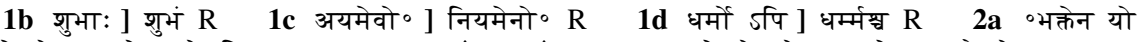
देव्यो ] भभुक्तेन यो दिव्य: $R \quad 2 b$ मासं ] सायं $R \quad 2 c d$ देव्यो गोमान् ] देव्यः सौम्यो $R \quad 3 a$ ${ }^{\circ}$ मासेन ] ॰मासे च $\mathrm{R} \quad 3 \mathrm{c}$ च] तु $\mathrm{R} \quad 4 \mathrm{a}$ वभक्त तु ] वभुक्त $\mathrm{R} 4 \mathrm{c}$ स्त्रीषु ] स्त्रियं $\mathrm{R}^{\mathrm{ac}}$, श्रियं $\mathrm{R}^{\mathrm{pc}}$

1b शुभा: ] शुभं $A \quad 2 a$ देव्यो ] $A_{3}$, देव्या $A_{4} A_{7} \quad 2 b$ ०शिरं क्षपेत् ] ०शिर: क्षिपेत् $A$ 2cd देव्यो गोमान् ] देव्यः $\left\{\circ\right.$ व्या: $\left.\mathrm{A}_{4} \mathrm{~A}_{7}\right\}$ सौम्यो $A$ 3c ०मासे च] ०मासेन $\mathbf{A}$ 3d स्त्रिय: ] $\mathrm{A}_{4} \mathrm{~A}_{7}$, श्रिय: $\mathrm{A}_{3}$ - प्रिया: ] म्रिय: $\mathbf{A}$

Manuscripts available for this chapter: $S_{1}$ (from $\mathbf{6 c}^{1}$; f. 171 lost) photos 8.5 (f. $172^{\mathrm{r}}$, largely faded), 8.4b (f. 172 $), 7.27 \mathrm{a}$ (f. $173^{\mathrm{r}}$ ), 7.26b (f. $173^{\mathrm{v}}$ ), 7.26a (f. $174^{\mathrm{r}}$ ), 7.25b (f. $174^{\mathrm{v}}$ ) and $4.11 \mathrm{~b}\left(\mathrm{f} .175^{\mathrm{r}}\right.$ ); $\mathrm{S}_{2}$ exposures 121a-124a (f. $\left.155^{\mathrm{v}}-158^{\mathrm{v}}\right) ; \mathrm{S}_{3}$ f. $171^{\mathrm{v}}-174^{\mathrm{v}} ; \mathrm{R}$ f. $186^{\mathrm{v}}-193^{\mathrm{v}} ; \mathrm{A}_{3}$ f. $112^{\mathrm{v}}-116^{\mathrm{r}} ; \mathrm{A}_{4}$ f. $158^{\mathrm{v}}-164^{\mathrm{r}} ; \mathrm{A}_{7}$ f. $159^{\mathrm{r}}-165^{\mathrm{r}}$.

$2\left(a^{8}\right) S_{2}$

1 देव्युवाच ] RABh, सनत्कु उ $\mathrm{S}_{2}$, सनत्कुमार उ $\mathrm{S}_{3}$ 1a देव्य: ] $\mathrm{S}_{2} \mathrm{~S}_{3} \mathrm{RA}$, देव्या: Bh (typo?) $1 \mathbf{b}$ शुभा: ] em. Bh (silently), शुभा $\mathrm{S}_{2} \mathrm{~S}_{3}$ 1d धर्मो इपि ] $\mathrm{S}_{2} \mathrm{~S}_{3} \mathrm{~A}$, धर्मोंभि $\mathrm{Bh}$ (conj.) 2a देव्यो ] $S_{2}^{\text {pc }} A_{3} B h$, देव्य $S_{2}^{a c} S_{3}$ 2b मासं ] $S_{3} A B h$, मासे $S_{2}^{\text {pc }}$, मासें $S_{2}^{\text {ac }}$ 2c देव्यो ] em. Bh (silently), देव्या: $S_{2}^{\mathrm{ac}}$, देव्य: $S_{2}^{\mathrm{pc}} S_{3} \quad$ 2d गोमान् ] em. Bh (silently), गोमाद् $\mathrm{S}_{2} \mathrm{~S}_{3} \quad 3 \mathbf{a}$ पौष०] $\mathrm{S}_{2}^{\mathrm{pc}} \mathrm{RABh}$, पौष्य० $\mathrm{S}_{2}^{\mathrm{ac}} \mathrm{S}_{3}$ - पुत्रांग्च ] $\mathrm{S}_{3} \mathrm{RABh}$, पुत्राश्च $\mathrm{S}_{2}$ 3b धार्मिकान् ] $\mathrm{S}_{2} \mathrm{RABh}$, धार्मिक $\mathrm{S}_{3} \quad 3$ cd ०णः स्त्रियः ] $\mathrm{RA}_{4} \mathrm{~A}_{7}$ (cf. VK, SaPra, KR), ०ण भूयः $\mathrm{S}_{2} \mathrm{~S}_{3}$, ०णो भूय: Bh (em.?) 3d प्रिया: ] $\mathrm{RBh}$ (em.), प्रिया $\mathrm{S}_{2} \mathrm{~S}_{3}$ 4a कुर्वाणः ] $\mathrm{S}_{2}^{\mathrm{pc}} \mathrm{RABh}$, कुर्वाण $\mathrm{S}_{2}^{\mathrm{ac}} \mathrm{S}_{3}$ 4d ०प्रिया: ] $\mathrm{RABh}$, ०प्रिया $\mathrm{S}_{2} \mathrm{~S}_{3}$ 


\section{यः क्षपेदेकभक्तेन चैत्रमासं नरोत्तमः।}

धनधान्यसमृद्धे स कुले जायेत रूपवान् $y \|$

वैशाखं यः क्षपेन्मासमेकभक्तेन मानवः

याति स श्रेष्टतां लोके पूजितो धनवानपि॥ ६॥

ज्येष्ठमूलं तु यो मासमेकभक्त समाचरेत्।

भ्रातुणां भवति ज्येष्टो भोगं प्राप्नोति पुष्कलम्॥ ७॥

आषाढं चापि यो मासमेकभक्त समाचरेत्।

स राइो उमात्यतां प्राप्य कामानाप्नोति पुष्कलान्॥ ५ ॥

श्रावणे चापि यो मासे तथा चैवाचरेन्नरः।

सेनापत्यं स संप्राप्य बलवानभिजायते॥ ९ ॥

यस्तु भाद्रपदे मास-म्-एकभकं समाचरेत्।

स तेन कर्मणा देव्यो धनवानभिजायते॥ १०॥

5ab VK p. 419: क्षपयेदेकभक्तेन चैत्रे मासे नरोत्तम।; KR p. 84: क्षपयेदेकभक्तेन चैत्रमासं नरोत्तम। 5 cd VK p. 419 and KR p. 84: धनधान्यसमृद्धे तु कुले जायेत रूपवान्। $\quad$ 6ab = VK p. 419; SaPra p. 136 and KR p. 148: वैशाखं यः क्षिपेन्मासमेकभक्तेन मानवः। (var. क्षयेन् in SaPra) 6cd VK p.419: सा याति श्रेष्ठतां लोके पूजितो धनधान्यवान्। (sic.); SaPra p. 136 and KR p. 148: स याति श्रेष्ठतां लोके पूजितो धनवानपि। 7 VK p.419: ज्येष्टमासे नरो यो वै एकभक्त समाचरेत्। भ्रात्रणां भवति श्रेष्ठो भोगांश्चाप्रोति पुष्कलान्। $\mathbf{8 a b}=$ KR p. 196; VK p.419: आषाढं वापि यो मासमेकभक्त समाचरेत्। 8cd VK p. 419: यात्यसौ मान्यतां प्राप्य कामानाप्रोति पुष्कलान् ।; KR p. 196: राइो उसौ मान्यतां प्राप्य कामानाप्रोति पुष्कलान्। 9ab VK p.419 and KR p.221: श्रावणे वापि यो मासे तथैवाचरते नरः। 9cd = VK p. 419; KR p. 221: सैनापत्यं सम्प्राप्य धनवानभिजायते । (unmetrical) 10ab KR p. 254: यस्तु भादपदे मासि एकभक्त समाचरेत्। $10 \mathrm{~cd}=\mathrm{KR}$ p. 254

$5 \mathrm{c}$ ०समृद्धे स ] ०समृद्धे तु $\mathrm{R} \quad 6 \mathrm{c}$ याति स ] स याति $\mathrm{R} \quad 7 \mathrm{a}$ ज्येष्ठमूलं ] ज्येष्ठे चैव $\mathrm{R} \quad 7 \mathrm{ab}$ मासमे॰ ] मासि ए० $R \quad 7 c$ ज्येष्टो ] ग्रेष्टो $R \quad 7 d$ भोगं प्राप्रोति ] भोगझ्चाप्रोति $R \quad 8 a b$ ] आषाढे चैव यो मासि एकभक्तेन तिष्ठति $R \quad 9 \mathrm{ab}$ ] श्रावणग्चैव यो मासं तथैवाचरते नर: $R \quad 10 \mathrm{ab}$ मास-म्-ए०] मासि ए० $\mathrm{R}$

$5 \mathrm{a}$ क्षपेदे०] क्षिपेदे० $\mathrm{A} 5 \mathrm{~b}$ ०मासं ] ०मासे $\mathrm{A} 5 \mathrm{c}$ ०समृद्धे स ] ०समृद्धेन $\mathrm{A} 5 \mathrm{~d}$ जायेत ] जायति $A$ b मानव:] यो नर: $A \quad 6 c$ श्रेष्ठतां ] ज्येष्ठतां $A_{3} A_{7}$, ज्येष्टतां $A_{4} \quad 7 a$ ज्येष्ठमूलं ] ज्येष्ठ चैव $\mathrm{A}_{3}$, ज्येष्टे चैव $\mathrm{A}_{4} \mathrm{~A}_{7} \quad 7 \mathrm{c}$ ज्येष्टो ] श्रेष्टो $\mathrm{A} \quad 8 \mathrm{a}$ आषाढं ] आषाढे $\mathrm{A} \quad 8 \mathrm{ab}$ मासमे॰] मासि

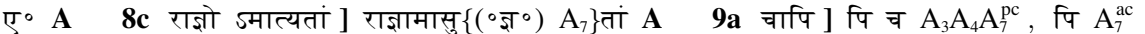
(unmetrical) 9ab मासे तथा चैवाचरेन्] मासं तथैवाचरते $\mathbf{A} 9 \mathrm{c}$ स संप्राप्य ] $\mathrm{A}_{3}$, समं प्राप्य $\mathrm{A}_{4} \mathrm{~A}_{7} 10 \mathrm{a}$ मास-म्-ए॰] मासि ए॰ $\mathrm{A}^{\circ} 10 \mathrm{c}$ देव्यो] $\mathrm{A}_{3}$, देवो $\mathrm{A}_{4}$, देव्या $\mathrm{A}_{7}$ 10d धनवा॰ ] बलवा० $\mathbf{A}$

$\mathbf{6}\left\langle\leftarrow \mathrm{a}^{1}-\mathrm{b}^{8}\right\rangle\left(\mathrm{c}^{1}-\mathrm{c}^{2}\right)\left\langle\mathrm{c}^{3}-\mathrm{d}^{8} \rightarrow\right\rangle \quad \mathrm{S}_{1} \quad \mathbf{7}\left\langle\leftarrow \mathrm{a}^{1}\right\rangle\left(\mathrm{a}^{2}-\mathrm{a}^{7}\right)\left\langle\mathrm{a}^{8}-\mathrm{b}^{1}\right\rangle\left(\mathrm{b}^{2}\right)\left\langle\mathrm{b}^{3}-\mathrm{b}^{4}\right\rangle\left(\mathrm{b}^{5}-\mathrm{b}^{8}\right)\left\langle\mathrm{c}^{1}-\mathrm{c}^{5}\right\rangle\left(\mathrm{c}^{6}-\mathrm{c}^{7}\right)\left\langle\mathrm{c}^{8}\right\rangle$ $\left(\mathrm{d}^{1}-\mathrm{d}^{6}\right)\left\langle\mathrm{d}^{7}\right\rangle\left(\mathrm{d}^{8}\right) \mathrm{S}_{1} \quad \mathbf{8}\left(\mathrm{a}^{1}\right)\left\langle\mathrm{a}^{2}\right\rangle\left(\mathrm{a}^{3}-\mathrm{a}^{4}\right)\left\langle\mathrm{a}^{5}-\mathrm{a}^{8}\right\rangle\left(\mathrm{b}^{1}-\mathrm{b}^{8}\right)\left\langle\mathrm{c}^{1}-\mathrm{d}^{8} \rightarrow\right\rangle \mathrm{S}_{1} \quad \mathbf{9}\left\langle\leftarrow \mathrm{a}^{1}-\mathrm{c}^{1}\right\rangle\left(\mathrm{c}^{2}-\mathrm{c}^{3}, \mathrm{c}^{5}-\mathrm{c}^{8}\right)\left\langle\mathrm{d}^{1}-\right.$ $\left.\mathrm{d}^{2}\right\rangle\left(\mathrm{d}^{3}-\mathrm{d}^{5}\right)\left\langle\mathrm{d}^{6}\right\rangle \mathrm{S}_{1} \quad \mathbf{1 0}\left(\mathrm{a}^{1}-\mathrm{a}^{3}\right)\left\langle\mathrm{c}^{1}\right\rangle\left(\mathrm{c}^{2}-\mathrm{c}^{5}\right)\left\langle\mathrm{d}^{4}\right\rangle\left(\mathrm{d}^{5}-\mathrm{d}^{8}\right) \mathrm{S}_{1}$

$5 \mathbf{c}$ ०समृद्धे स] em. Bh, ०समृद्धेषु $\mathrm{S}_{2} \mathrm{~S}_{3} \quad \mathbf{6 c}$ श्रेष्टतां ] $\mathrm{S}_{2} \mathrm{R}$, श्रेष्टता $\mathrm{S}_{3}$, श्रेष्ठातां $\mathrm{Bh}$ (typo) $7 \mathbf{a}$

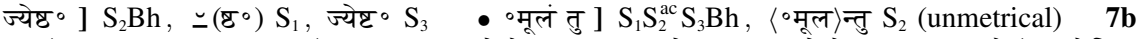
॰भक्त ] $S_{2}^{\text {pc }} S_{3} R A B h$, ०कक्तां $S_{2}^{\text {ac }}$ 7c ज्येष्टो ] $S_{2} B h$, (ज्ये) $\simeq S_{1}$, ज्येष्टो $S_{3}$ 7d भोगं प्राप्रोति ] $\mathrm{S}_{2}^{\mathrm{pc}} \mathrm{ABh}$, (भोगां प्राप्नोति) $\mathrm{S}_{1}$, भोगां प्राप्नोति $\mathrm{S}_{2}^{\mathrm{ac}}$, भोगमाप्नोति $\mathrm{S}_{3} \quad 8 \mathrm{c}$ उमात्यतां ] $\mathrm{S}_{2} \mathrm{R}$ (or मान्य० in $S_{2}$ ), मात्यता $S_{3}$ (or मान्य॰), मान्यतां $B h$ भादपदे ] $\mathrm{S}_{1} \mathrm{RA}$, भाद्रपदं $\mathrm{S}_{2}^{\mathrm{pc}} \mathrm{Bh}$, भद्रपदं $\mathrm{S}_{2}^{\mathrm{ac}} \mathrm{S}_{3}$ 8d पुष्कलान् ] $S_{3} R A B h$, पुष्कलाम् $S_{2} \quad 10 a$ $\mathrm{S}_{1}^{\mathrm{ac}}$

$10 \mathbf{a b}$ मास-म्-एक॰] $\mathrm{S}_{1}^{\mathrm{pc}} \mathrm{S}_{2} \mathrm{~S}_{3} \mathrm{Bh}$, मासे मेक॰ 
यो उपि चाश्वयुजं मासमेकभक्तेन तिष्टति।

वाणिज्यं फलते तस्य कृषिः पशुगणास्तथा॥ १?॥

कार्त्तिक त्वपि यो मासमेकभक्तेन तिष्टति।

सो उश्वमेधफलं प्राप्य वह्निलोके महीयते॥ ?२॥

यः क्षपेदेकभक्तेन यावज्जीवं नरोत्तमः।

विमानेनार्कवर्णेन स गच्छेच्छ,कलोकताम् ॥ १३॥

संवत्सरं तु यः पूर्णमेकभक्तेन तिष्टति।

स पार्थिवसमो भूत्वा महीं पाति महेन्द्रवत् ॥ १४॥

अहोरात्रं तु यो देव्यः कुर्यादेकं नरोत्तमः।

दशानां स सुवर्णानां फलं प्राप्नोति शोभितम् ॥ ?४ ॥

मासे मासे त्वहोरात्रं यः करोति नरोत्तमः।

स तेन कर्मणा शुद्धो विद्वान्भवति धार्मिकः ॥ १६॥

$\mathbf{1 1 a b}=$ KR p. 307; VK p. 419: यो ऽपि चाश्वयुजे मासि चैकभक्तेन तिष्टति । $\quad$ 11cd = VK p. 419; KR p. 308: वाणिज्यं लभते तस्य कृषि: पशुगणास्तथा। 12 =VK p. 419 , SaPra p. 135 and KR p. 406 13ab = VK p. 419; SaPra p. 137: यः क्षिपेदेकभकेन यावज्जीवं नरोत्तमः। (SaPra has 13 after 14) 13cd = VK p. 419 and SaPra p. $137 \quad$ 14ab = SaPra p. 137; VK p. 419: संवत्सरं तु यः पुष्यमेकभक्तेन तिष्टति। 14cd VK p.419 and SaPra p. 137: स पार्थिवसमो भूत्वा महीं याति नरेन्द्रवत्। 15ab VK p.453: अहोरात्रं तु यो देव्याः कुर्यादेक नरोत्तम ।; SaPra p. 137: अहोरात्रं तु यो देव्याः कुर्यादेवं नरोत्तमः। 15cd VK p. 453: दशानां स सुवर्णानां फलमाप्रोति शोभनम् ।; SaPra p. 137: दशानां स सुवर्णानां फलं प्राप्रोति शोभनाम् । (sic.) 16ab =VK p. 453; SaPra p. 137: मासि मासि अहोरात्रं यः करोति नरोत्तमः। 16cd SaPra p.137: स तेन कर्मणा युक्तो विद्वान् भवति धार्मिक:।

$11 \mathrm{ab}$ ॰ युजं मासमे॰ ] ॰ युजे मासि ए॰ $R \quad 11 \mathrm{~b}$ तिष्ठति ] मानव: $R \quad 11 d$ ०गणास्त॰ ] ०गणैस्त॰ $R \quad 12 a$ ०क त्वपि ] ०कम्चापि $R \quad 13 R$ has this after 14. 13d ०च्छक्र०] ॰दुद्र० $R \quad 14 c$ पार्थिवसमो ] पार्थिवो महान् $R$ 14d पाति ] प्रीतिं $R$ - After this $R$ has 13 . 15ab यो देव्य: कुर्यादेक ] यः कुर्याद्देव्य एवं $\left\{{ }^{\circ}\right.$ कं $\left.\mathrm{R}^{\mathrm{ac}}\right\} \mathrm{R} \quad 15 \mathrm{c}$ ०नां स सुवर्णानां ] नामश्वमेधानां $\mathrm{R}$ 15d शोभितम् ] मानव: R

$11 \mathrm{ab}$ ॰ युजं मासमे॰] ॰्युजे मासि ए॰ $A$ 11c फलते ] लभते $A$ 11d वगणास्त॰] वगणस्त॰ $A$ 12a कार्त्तिक ] कार्त्तिके $\mathrm{A}$ 12c इम्वमेध० ] $\mathrm{A}_{3}$, श्वमेधं $\mathrm{A}_{4} \mathrm{~A}_{7}$ 12d वह्निलोके महीयते ] कामानाप्रोति पुष्कलान् $\mathbf{A}$ (cf. 8d) 13ab $\mathbf{A}$ has this after 14. 13a क्षपेदे०] $\mathrm{A}_{3}$, क्षिपेदे० $\mathrm{A}_{4} \mathrm{~A}_{7}$ 13cd ] om. $A$ 14a पूर्ण॰ ] पूर्व॰ $A \quad 14 c$ पार्थिवसमो ] पार्थिवो महान् $A$ 14d महीं ] $\mathrm{A}_{7}$, महिं $\mathrm{A}_{3}$, मही $\mathrm{A}_{4}$ - After this $\mathrm{A}$ has 13ab. 15-16ab ] om. $\mathbf{A}$ 16d विद्वान् ] $\mathrm{A}_{3} \mathrm{~A}_{7}$, विद्य +(न्)+ $\mathrm{A}_{4}$

$\mathbf{1 1}\left(\mathrm{a}^{1}-\mathrm{a}^{5}, \mathrm{~b}^{1}\right)\left\langle\mathrm{b}^{2}-\mathrm{b}^{4}\right\rangle\left(\mathrm{b}^{5}-\mathrm{c}^{1}, \mathrm{c}^{3}-\mathrm{d}^{4}\right)\left\langle\mathrm{d}^{5}-\mathrm{d}^{8} \rightarrow\right\rangle \mathrm{S}_{1} \quad \mathbf{1 2}\left\langle\leftarrow \mathrm{a}^{1}-\mathrm{a}^{8}\right\rangle\left(\mathrm{b}^{1}-\mathrm{b}^{2}, \mathrm{c}^{1}-\mathrm{d}^{1}\right)\left\langle\mathrm{d}^{4}\right\rangle \mathrm{S}_{1},\left\langle\mathrm{a}^{6}-\right.$ $\left.b^{1}\right\rangle\left(b^{2}-b^{8}, c^{6}\right) S_{2} \quad 13\left(a^{2}-a^{5}\right)\left\langle a^{6}\right\rangle\left(a^{7}-a^{8}, b^{4}-c^{6}\right)\left\langle c^{7}-d^{3}\right\rangle\left(d^{4}-d^{5}\right) S_{1} \quad \mathbf{1 4}\left(d^{3}, d^{6}\right)\left\langle d^{7}-d^{8} \rightarrow\right\rangle S_{1}$ $15\left\langle\leftarrow a^{1}-a^{3}\right\rangle\left(a^{4}-a^{5}\right)\left\langle a^{6}\right\rangle\left(a^{7}-b^{7}, c^{3}-c^{4}\right)\left\langle c^{5}\right\rangle\left(c^{6}-c^{8}\right)\left\langle d^{1}\right\rangle\left(d^{2}-d^{3}\right)\left\langle d^{4}-d^{7}\right\rangle\left(d^{8}\right) S_{1},\left(a^{1}-a^{3}\right)\left\langle a^{4}\right\rangle\left(a^{5}\right)\left\langle a^{6}-a^{8}\right\rangle$ $\mathrm{S}_{2} \quad \mathbf{1 6}\left(\mathrm{a}^{1}-\mathrm{a}^{2}, \mathrm{a}^{5}-\mathrm{a}^{8}, \mathrm{~b}^{6}-\mathrm{c}^{1}\right)\left\langle\mathrm{c}^{2}-\mathrm{c}^{4}\right\rangle\left(\mathrm{c}^{5}, \mathrm{c}^{7}\right)\left\langle\mathrm{c}^{8}\right\rangle\left(\mathrm{d}^{2}-\mathrm{d}^{4}\right) \mathrm{S}_{1}$

12b तिष्टति ] $S_{1} S_{2} R A B h$, तिष्टति $S_{3} \quad 13 b$ यावज्जीवं ] $S_{1} S_{2} R A B h$, यावजीवन् $S_{3}^{p c}$, यावजीव $\mathrm{S}_{3}^{\mathrm{ac}} 13 \mathrm{~d}$ स गच्छेच्छकलोकताम् ] $\mathrm{S}_{2}, \cdots\left(\right.$ च्छक लोकताम् $\mathrm{S}_{1}$, स गच्छेच्छकलोकतम् $\mathrm{S}_{3}$, शक्रलोक स गच्छति $B h$ (conj.) 14a य: ] $S_{1}^{\text {pc }} S_{2} S_{3} R A B h$, (या) $S_{1}^{\text {ac }}$ 14b तिष्टति ] $S_{1} S_{2} R A B h$, तिष्टति $\mathrm{S}_{3} 14 \mathrm{~d}$ पाति ] $\mathrm{S}_{1} \mathrm{~S}_{2} \mathrm{ABh}$, पति $\mathrm{S}_{3} \quad 15 \mathrm{a}$ ०त्रं तु यो देव्य: ] em., (०त्र) - (देव्यः) $S_{1}$ (second

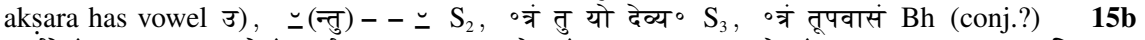
कुर्यादेकं ] $S_{1} S_{2} B h$, ०मेक कुर्या $S_{3} \quad 16 a$ त्वहोरात्रं ] $S_{1} S_{2} S_{3} R$, त्वहोरत्रं Bh (typo) 16d विद्वान् ] $\mathrm{S}_{2} \mathrm{RA}_{3} \mathrm{~A}_{7} \mathrm{Bh}$, वि(द्वा)म् $\mathrm{S}_{1}$, विद्वा $\mathrm{S}_{3}$ 


\section{चतुर्दशीमष्टमीं च उभयो: पक्षयोरपि।}

अहोरात्रं क्षपेद्यस्तु संवत्सरमशेषतः ॥ १७॥

स तेन कर्मणा युक्तः सर्वपापविवर्जितः।

न याति नरकं देव्यो यमं च न स पश्यति॥ १५॥

मासे मासे च यः कुर्यात्तिरात्रक्षपणं बुधः।

कौबेरं लोकमासाद्य स विन्देत्परमं सुखम्॥ १९ ॥

चतुर्थे इहनि यो भुड्के प्रयतात्मा शुचिर्नरः।

गान्धर्वं स पदं प्राप्य मोदते शक्रवृदि॥ २०॥

पश्चमे उहनि यो भुड्के प्रतिमासमतन्द्रितः।

वायुलोक समासाद्य स्वर्गलोकं स गच्छ,ति॥ २१॥

$17 \mathrm{SaPra}$ p. 109: चतुर्दशीमष्टमीं च पक्षयोरुभयोरपि। अहोरात्रं क्षिपेद्यस्तु संवत्सरमशेषतः। $\mathbf{1 8 a b}=$ VK p. 453 and SaPra p. 109 18cd VK p. 453: न याति नरकं सत्यं यमं च न (स) पश्यति।; SaPra p. 109: न याति नरक देवी यमं च स न पश्यति। 19ab $=\mathrm{HeVKh} \mathrm{2,} \mathrm{p.917} \mathrm{(the} \mathrm{quotations} \mathrm{from}$ 19-38 in HeVKh are not attributed to any source); VK p. 453: मासे मासे तु यः कुर्यात्तिरात्रक्षपणं व्रतम ।; SaPra p. 137: मासे मासे तु यः कुर्यात् त्रिरात्रक्षपणं नरः। 19cd VK p. 453: कौबेरलोकमासाद्य स विन्देत्परमं पदम् ।; SaPra p. 137: कौबेरं लोकमासाद्य विन्दते परमं पदम् ।; HeVKh 2, p. 917: कौवेरं लोकमासाद्य स विन्देत् परमं पदम्। $20 \mathbf{a b}=\mathrm{VK}$ p.453; HeVKh 2, p.917: चतुर्थे उहनि यो भुड्के व्रतवांग्च शुचिर्नर:। 20cd =VK p. 453 and HeVKh 2, p. 917 21ab = VK p. 453 and HeVKh 2, p. 917 21cd VK p. 453: स मुक्तः सर्वपापैस्तु स गच्छेद्दिवमूर्जितः।; HeVKh 2, p.918: विमुक्तः सर्व्वपापैग्च स गच्छेद्धिवमूर्जितः। (cf. $56 \mathrm{~cd}$ )

$17 \mathrm{a}$ चतुर्दशीमष्टमीं च ] चतुर्दशी सप्तमी चैव $\mathrm{R} \quad 17 \mathrm{~d}$ संवत्सर॰] संव्वत्सर॰ $\mathrm{R}^{\mathrm{pc}}$, सव्वत्सर॰ $\mathrm{R}^{\mathrm{ac}} 18 \mathrm{a}$ युक्तः ] मुक्त: $R \quad 18 d$ यमं च न स ] यमस्चैव न $R \quad 19 b$ बुधः] नर: $R \quad 20 c$ गान्धर्वं स ] स गान्धर्व्व० $R \quad 21 d$ ०्लोकं स गच्छुति ] ०लोके महीयते $R$

$17 \mathrm{c}$ क्षपेद्य०] $\mathrm{A}_{3}$, क्षिपेद्य॰ $\mathrm{A}_{4} \mathrm{~A}_{7} \quad 19 \mathrm{~b}$ ०क्षपणं ] क्षेपणं $\left\{\circ\right.$ नं $\left.\mathrm{A}_{7}\right\} \quad \mathrm{A} \quad 21 \mathrm{~b}$ ०मासम०] $\mathrm{A}_{3} \mathrm{~A}_{7}$, $\circ$ मासिम० $\mathrm{A}_{4}$ 21d स] च $\mathrm{A}$

$17\left(a^{6}, b^{1}-b^{2}, c^{7}, d^{2}-d^{8}\right) S_{1} \quad 18\left\langle\leftarrow a^{1}-a^{8}\right\rangle\left(b^{1}-b^{5}\right)\left\langle b^{6}\right\rangle\left(b^{7}, c^{1}, c^{4}-c^{5}, c^{7}-d^{1}\right)\left\langle d^{2}-d^{7}\right\rangle\left(d^{8}\right) S_{1} \quad 19\left(a^{1}-\right.$ $\left.a^{6}\right)\left\langle a^{7}-a^{8}\right\rangle\left(b^{1}\right)\left\langle b^{2}-b^{4}\right\rangle\left(b^{5}\right)\left\langle b^{6}-b^{7}\right\rangle\left(b^{8}, c^{2}\right)\left\langle c^{3}\right\rangle\left(c^{4}-c^{6}, c^{8}-d^{3}\right)\left\langle d^{4}\right\rangle\left(d^{5}\right)\left\langle d^{7}-d^{8} \rightarrow\right\rangle S_{1} \quad \mathbf{2 0}\left\langle\leftarrow a^{1}-a^{2}\right\rangle$ $\left(a^{3}-a^{6}, c^{2}-c^{3}, c^{8}-d^{2}, d^{4}-d^{6}\right)\left\langle d^{7}-d^{8} \rightarrow\right\rangle S_{1} \quad 21\left\langle\leftarrow a^{1}-d^{8}\right\rangle S_{1}$

17b उभयो: पक्षयो॰ ] $\mathrm{S}_{1} \mathrm{~S}_{2}^{\mathrm{pc}} \mathrm{S}_{3} \mathrm{RA}$, उभयो पक्षयो॰ $\mathrm{S}_{2}^{\mathrm{ac}}$, पक्षयोरुभयो॰ Bh (conj.) 18a ०णा युक्तः ] $A B h$, ०णाद्युको $S_{2}$, ०णा युक्तो $S_{3} \quad 18 b$ ०विवर्जितः ] $S_{2} R A B h, f \cup-\left(\hat{v ज ् ज}_{)}\right)$: $S_{1}$, ०विवजित: $S_{3}$ (unmetrical) 20b शुचिर्नर: ] $S_{1} S_{2} R A B h$, शुचि न्नर: $S_{3}^{\text {pc }}$, शुचि नर: $S_{3}^{\text {ac }}$ (unmetrical) 20c गान्धर्वं स पदं ] $\mathrm{S}_{2} \mathrm{ABh}$, गा(न्धर्व)सम्पदम् $\mathrm{S}_{1}$, गान्धर्वसंपदं $\mathrm{S}_{3}$ 20d ०वद्विवि ] $\mathrm{S}_{2} \mathrm{RABh},(\circ$ व) $\simeq$ $\mathrm{S}_{1}$, ०व दिवि $\mathrm{S}_{3}$ (unmetrical) $21 \mathrm{~b}{ }^{\circ}$ मासम $\left.{ }^{\circ}\right] \mathrm{S}_{2} \mathrm{~S}_{3}^{\mathrm{pc}} \mathrm{RA}_{3} \mathrm{~A}_{7} \mathrm{Bh}$, ०मास $\left\langle\left(\right.\right.$ त० $\left.\left.^{\circ}\right)\right\rangle+++\mathrm{S}_{3} \quad \mathbf{2 1 c}$ वायुलोकं ] RABh, वायुलोके $\mathrm{S}_{2} \mathrm{~S}_{3}$ 
यो भुड़े दिवसे षष्टे नित्यं नियममास्थितः।

वारुणं लोकमासाद्य सो ऽपि विन्देन्महत्पदम्॥ २२॥

सप्रमे उहनि यो भुड़े जितद्वन्द्वो दृढव्रतः।

आदित्यलोकमासाद्य सो ऽपि विन्देन्महत्पदम्॥ २३॥

अष्टमे चैव यो भुड्र्ते दिवसे मानवः शुचिः।

वैष्णवं लोकमासाद्य स भवेत्परमद्युतिः॥ २४॥

नवमे उहनि यो भुड़े नरो नियममास्थितः।

स वसूनां प्रियो भूत्वा चरते वसुभिः सह॥ २५॥

दशमे उहनि भुत्का तु दशाहस्य फलं लभेत्।

अश्विभ्यां च समो भूत्वा सूर्यवज्ज्वलते सदा॥ २६॥

22ab VK p. 453 and HeVKh 2, p.918: यो भुड़्रे दिवसे षष्टे नित्यं नियमवान् शुचिः। 22cd VK p. 453: वारुणं लोकमासाद्य स याति परमं पदम् ।; HeVKh 2, p. 918: वारुणं लोकमासाद्य स विन्देत्परमं पदम् । 23ab =VK p. 453 and HeVKh 2, p. 918 23cd VK p. 453: आदित्यलोकमाप्रोति सो ऊपि विन्देन्महाव्रतम् ।; HeVKh 2, p. 918: आदित्यलोकमासाद्य सो ऽपि विन्देन्महाग्रियम्। 24ab VK p. 454 and HeVKh 2, p. 918: अष्टमे उहनि यो भुड़े जितद्वन्द्रो दृढव्रतः। (cf. 23ab) $\mathbf{2 4 c d}=$ VK p. 454 and HeVKh 2, p. 918 25ab = HeVKh 2, p. 918; VK p. 454: नवमे डहनि यो भुड़्रे नरो नियमवान् शुचिः। 25cd = VK p. 454 and HeVKh 2, p. 918 26ab VK p. 454 and HeVKh 2, p.918: दशमे उहनि यो भुड्के द्वादशाहफलं लभेत्। 26cd VK p. 454: अश्विभ्यां स समो भूत्वा सूर्यवज्ज्वलते सदा ।; $\mathrm{HeVKh}$ 2, p.918: अस्विभ्यां च समो भूत्वा अव्ययं खेलते तथा।

22b ०मास्थितः ] ॰वान्नर: $R$ 22d सो ऊपि विन्देन्महत्पदम् ] स्वर्गलोके महीयते $R$ (cf. R in 21d) $23 d$ हत्पदम् ] हह्छिवम् $R \quad 24 d$ स भवेत्परमद्युतिः ] सो ऽपि विन्देन्महत्फलम् $R 225 b$ मास्थितः ] वान् स्थितः $R$ 25c वसूनां ] बहूनां $R$ 26a भुत्का तु ] यो भुड्क्ते $R$ 26c च] स $R$ 26d ०वज्ज्वलते सदा ] ०वत्तेजसा दिवि $R$

22a $\mathbf{a}^{4}-\mathbf{2 3 a}^{8}$ ] $\mathrm{A}_{3}$ repeats this after 23a (eyeskip). 22b ०मास्थित: ] $\mathrm{A}_{7}^{\mathrm{pc}}$, ०वत्सितः $\mathrm{A}_{3} \mathrm{~A}_{3}^{*} \mathrm{~A}_{4}$, ०व स्थितः $\mathrm{A}_{7}^{\mathrm{ac}}$ 23a After this $\mathrm{A}_{3}$ repeats $22 \mathrm{a}^{4}-23 \mathrm{a}^{8}$. 23b ${ }^{\circ}$ द्वन्द्वो ] $\mathrm{A}_{3} \mathrm{~A}_{4}$, ०द्वन्दो $\mathrm{A}_{7}$ 23d विन्देन् ] $\mathrm{A}_{3}$, विन्दे $\mathrm{A}_{4} \mathrm{~A}_{7} \quad 24 \mathbf{a}$ भुड़ेत] $\mathrm{A}_{3} \mathrm{~A}_{7}$, भुक्ते $\mathrm{A}_{4} \quad 26 \mathbf{a}$ भुत्का तु ] यो भुंके $\mathbf{A} \quad 26 \mathbf{c}$ अस्विभ्यां च ] आश्रित्यां स $\mathrm{A}_{3} \mathrm{~A}_{4}$, आदित्यांश ${ }^{\circ} \mathrm{A}_{7} \quad$ 26d ०वज्जलते सदा ] ०वत्तेजसाधिक: $A$

$22\left(a^{1}-a^{6}\right)\left\langle a^{7}-a^{8}\right\rangle\left(b^{1}-c^{3}\right)\left\langle c^{4}\right\rangle\left(c^{5}-c^{8}, d^{4}-d^{8}\right) S_{1} \quad 23\left(a^{1}-b^{1}\right)\left\langle b^{2}-b^{8}\right\rangle S_{1} \quad 24\left(a^{2}\right) S_{1} \quad 25\left(d^{2}\right)\left\langle d^{3}-d^{8}\right\rangle$ $\mathrm{S}_{1},\left(\mathrm{~b}^{6}\right) \mathrm{S}_{3} \quad \mathbf{2 6}\left(\mathrm{c}^{3}\right) \mathrm{S}_{2}$

22a षष्टे] $\mathrm{S}_{3} \mathrm{RABh}$, षष्टि $\mathrm{S}_{2} \quad 22 \mathrm{~b}$ ०मास्थितः ] $\mathrm{S}_{2} \mathrm{~S}_{3} \mathrm{~A}_{7}^{\mathrm{pc} B h}$, (०मास्थित) $\mathrm{S}_{1}$ 22c वारुणं] $\mathrm{S}_{1}$ $\mathrm{RAA}_{3}^{*} \mathrm{Bh}$, वरुणं $\mathrm{S}_{2} \mathrm{~S}_{3} 22 \mathrm{2d}$ विन्देन् $] \mathrm{S}_{1} \mathrm{~S}_{2} \mathrm{AA}_{3}^{*} \mathrm{Bh}$, विन्दे $\mathrm{S}_{3}$ - हत्पदम् ] $\mathrm{S}_{1} \mathrm{~S}_{2}^{\mathrm{pc}} \mathrm{S}_{3} \mathrm{AA} \mathrm{A}_{3}^{*} \mathrm{Bh}$, ॰ह(हपं) $\mathrm{S}_{2}^{\mathrm{ac}}$ (unmetrical) 23b ॰द्वन्द्रो ] $\mathrm{S}_{2} \mathrm{RA}_{3} \mathrm{~A}_{4} \mathrm{Bh}$, ॰द्वन्दो $\mathrm{S}_{3}$ 23c ०लोकमा॰] $\mathrm{S}_{1} \mathrm{~S}_{3} \mathrm{RA}$ $\mathrm{Bh}$, ०लोकना० $\mathrm{S}_{2}$ 23d विन्देन् $] \mathrm{S}_{1} \mathrm{~S}_{2} \mathrm{RA}_{3} \mathrm{Bh}$, विन्दे $\mathrm{S}_{3}$ - हत्पदम् $] \mathrm{S}_{2} \mathrm{~S}_{3} \mathrm{ABh}$, हहच्छ्र्यम् $\mathrm{S}_{1}$ $24 a$ चैव ] $S_{1} R A B h$, हनि $S_{2} S_{3}$ - भुड्के ] $S_{1} S_{2} R A_{3} A_{7} B h$, भुक्त $S_{3}$ 24b शुचि: ] $S_{1} S_{2}^{\text {pc } R A B h, ~}$ शुचि $S_{2}^{\text {ac }} S_{3} \quad 24 c$ वैष्णवं ] $S_{1} S_{2} R A B h$, वैष्णव $S_{3} \quad 24 d$ ०द्युतिः ] $S_{2}^{p c} S_{3} A B h$, ०द्युति $S_{1} S_{2}^{a c}$ 25d वसुभि: ] $S_{2} R A B h$, वसुभि $S_{3}$ (unmetrical) $26 \mathbf{b}$ ०लं लभेत् ] RABh, ०लम्भवेत् $S_{1}$, ०लं भवेत् $S_{2} S_{3} 26 c$ अश्विभ्यां ] $S_{1} S_{2}^{\text {pc }} R B h$, अश्विन्याज् $S_{2}^{\text {ac }}$, अश्विन्यां $S_{3}$ 26d ०वज्ञजलते ] $S_{1} B h$, वन्ज्वलते $\mathrm{S}_{2} \mathrm{~S}_{3}$ 
मानुष्यं च पुनः प्राप्य दश भार्या लभेत सः।

सुवर्णमक्षयं चैव न चाकाले म्रियेत सः॥ २७॥

एकादशे तु यो भुड़्ते दिवसे मानवः शुचिः।

एकादश्याः फलं प्राप्य स रुद्रगणतां लभेत् ॥ २५॥

स्थित्वा तत्र शतान्यष्टावतिसौख्यसमन्वितः।

ब्राह्मणत्वमनुप्राप्य यज्वा स इह जायते॥ २९ ॥

द्वादशे दिवसे यस्तु देव्यो भुड्के सदा नर:।

द्वादशाहं स संप्राप्य शऋलोकमवाप्तुयात्॥ ३०॥

तत्रोष्य स सुखं भूय इह जातो नरोत्तमः।

राजा वा राजमात्रो वा धनी वा सुमहान्भवेत्॥ ३? ॥

28ab $=$ HeVKh 2, p. 918; VK p. 454: एकादशे तु यो भुड्के दिवसे मानवः सदा। 28cd VK p. 454: एकादशाहं संप्राप्य स रुद्रगणतां लभेत् ।; $\mathrm{HeVKh} 2$, p. 918 : एकादशाहं संप्राप्य स रुद्रगणतां व्रजेत्। $30 \mathrm{ab}$ VK p. 454 and HeVKh 2, p.918: यो द्वादशे तु दिवसे भुड्के देवि सदा नर:। 30cd VK p. 454 and HeVKh 2, p. 918: द्वादशाहं तु संप्राप्य शक्रोके महीयते ।

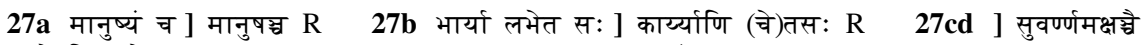
काले प्रियतमे तु स: $R$ (unmetrical) $28 c$ एकादश्या: फलं प्राप्य ] एकादशाहमासाद्य $R$ 29ab ] स्थित्वा तत्र युगान्यष्टाविंशतिं सौख्यमन्वित $R \quad 30 a b$ ] यस्तु द्वादशदिवसे सायं स मानव: $R$ (unmetrical) $30 \mathrm{~d}$ शक्रलोक॰ ] स शक्रत्व $\mathrm{R} 31 \mathrm{a}$ स सुखं ] स सुखी॰ $\mathrm{R}^{\mathrm{pc}}$, स्वसुखी॰ $\mathrm{R}^{\mathrm{ac}} \quad 31 \mathrm{c}$ राजमात्रो ] राजपुत्रो $\mathrm{R} 31 \mathrm{~d}$ धनी वा सु॰ ] धनवान् स $\mathrm{R}$

27a मानुष्यं] मानुषं $A 27 \mathrm{~b}$ लभेत ] लभेच्च $\mathrm{A} 28 \mathrm{c}$ एकादश्या: फलं प्राप्य ] एकादशं समासाद्य A 29a शतान्य॰] युगान्य॰ $A$ 29c ब्राह्मणत्वमनु॰ $] \mathrm{A}_{3}$, ब्राह्मणं स्वमनु० $\mathrm{A}_{4}$, ब्राह्मणं समनु० $\mathrm{A}_{7} 29 \mathrm{~d}$ यज्वा स इह $] \mathrm{A}_{7}$ ?, यजुसे इह $\mathrm{A}_{3}$, यजुशेंद्र प्र० $\mathrm{A}_{4} \quad 30 \mathrm{a}$ द्वादशे दिवसे यस्तु ] यस्तु द्वादशे $\left\{\circ\right.$ श० $\mathrm{A}_{4}$ (unmetrical)\} दिवसे $\mathbf{A} 30 \mathrm{c}$ स संप्राप्य ] समासाद्य $\mathbf{A} 31 \mathbf{a}$ तत्रोष्य ] $\mathrm{A}_{3}$, तत्रास्य $\mathrm{A}_{4}$, तत्रोस्य $\mathrm{A}_{7}$ - सुखं ] सुखी॰ $\mathbf{A} 31 \mathrm{~b}$ जातो ] $\mathrm{A}_{7}^{\mathrm{pc}}$, जाते $\mathrm{A}_{3} \mathrm{~A}_{4} \mathrm{~A}_{7}^{\mathrm{ac}}$ • नरोत्तमः ] $\mathrm{A}_{3}^{\mathrm{ac}} \mathrm{A}_{7}$, नरोत्तम $\mathrm{A}_{3}^{\mathrm{pc}} \mathrm{A}_{4} 31 \mathrm{c}$ राजमात्रो ] राजपुत्रो $\mathbf{A}$ 31d धनी वा ] धनवान् $\mathbf{A}$ • ममहान्भवेत् ] $\mathrm{A}_{3}$, ०महार्णवे $\left\{\circ\right.$ व: $\left.\mathrm{A}_{7}^{\mathrm{pc}}\right\} \mathrm{A}_{4} \mathrm{~A}_{7}$

$\mathbf{2 7}\left(\mathrm{b}^{5}\right) \mathrm{S}_{1} \quad \mathbf{2 8}\left(\mathrm{d}^{6}\right)\left\langle\mathrm{d}^{7}-\mathrm{d}^{8}\right\rangle \mathrm{S}_{1}, \quad \mathbf{3 0}\left(\mathrm{d}^{4}\right) \mathrm{S}_{1} \quad \mathbf{3 1}\left(\mathrm{d}^{8}\right) \mathrm{S}_{1},\left\langle\mathrm{~b}^{2}\right\rangle\left(\mathrm{b}^{3}-\mathrm{b}^{4}\right) \mathrm{S}_{3}$

27a मानुष्यं च ] $\mathrm{S}_{1} \mathrm{~S}_{2}^{\mathrm{pc}} \mathrm{Bh}$, मनुष्यच्च $\mathrm{S}_{2}^{\mathrm{ac}}$, मनुष्यं च $\mathrm{S}_{3}$ 27b भार्या ] $\mathrm{S}_{2} \mathrm{~S}_{3} \mathrm{ABh}$, भार्यां $\mathrm{S}_{1}$ • लभेत ] $\mathrm{S}_{2} \mathrm{~S}_{3} B h,\left(\right.$ फ)लेत $\mathrm{S}_{1}$ - स: ] $\mathrm{S}_{1} \mathrm{RABh}$, स $\mathrm{S}_{2} \mathrm{~S}_{3} \quad$ 27c ०यं चैव ] $\mathrm{S}_{1} \mathrm{ABh}$, वयस्चेव $\mathrm{S}_{2}$, ०यं चेव $S_{3} \quad 27 d$ चाकाले] $A B h$, च काले $S_{1}$, चाकाइं $S_{2}^{p c}$, चाका $\simeq S_{2}^{\text {ac }}$, च काल $S_{3}$ • म्रियेत ] $S_{1}^{\text {pc }} A B h$, प्रियेत $S_{1}^{\text {ac }}$, मृयेत $S_{2} S_{3} \quad 28 b$ शुचि:] $S_{2}^{\text {pc }} S_{3} R A B h$, शुचि $S_{1} S_{2}^{a c} \quad 28 c$ एकादश्या: ] em. Bh (silently), एकादश्या $\mathrm{S}_{1} \mathrm{~S}_{2} \mathrm{~S}_{3} \quad$ 29b ०वतिसौख्य॰] $\mathrm{S}_{2} \mathrm{~S}_{3}^{\mathrm{pc}} \mathrm{ABh}$, वन्तिसौख्य ० $\mathrm{S}_{1}$, ०वतिसौ(स्य॰) $\mathrm{S}_{3}^{\mathrm{ac}}$ • ०समन्वितः ] $\mathrm{S}_{2} \mathrm{~S}_{3} \mathrm{ABh}$, ०समन्वित $\mathrm{S}_{1}$ 29c ब्राह्मण०] $\mathrm{S}_{1}^{\mathrm{pc}} \mathrm{S}_{2} \mathrm{~S}_{3} \mathrm{RA}_{3}$ $\mathrm{Bh}$, ब्रा(हु)ण॰ $\mathrm{S}_{1}^{\mathrm{ac}} 30 \mathrm{a}$ दिवसे यस्तु ] $\mathrm{S}_{2} \mathrm{~S}_{3} \mathrm{Bh}$, चैव दिवसे $\mathrm{S}_{1}$ 30d ०लोकम॰] $\mathrm{S}_{1}^{\mathrm{pc}} \mathrm{S}_{2} \mathrm{~S}_{3} \mathrm{ABh}$, ०लोम॰ $S_{1}^{\text {ac }}$ (unmetrical) 31a तत्रोष्य स $] S_{2} R^{p c} A_{3} B h$, ततो स्य सु॰ $S_{1}$, तत्रोस्य स $S_{3}$ 31c वा ] $\mathrm{S}_{2} \mathrm{~S}_{3} \mathrm{RABh}$, om. $\mathrm{S}_{1}$ (unmetrical) 31d धनी वा ] $\mathrm{S}_{1} \mathrm{~S}_{2}^{\mathrm{pc}}$, धनीवान् $\mathrm{S}_{2}^{\mathrm{ac}} \mathrm{S}_{3}$, धन्वा वा $\mathrm{Bh}$ (conj.?) • ०मान् ] $\mathrm{S}_{1} \mathrm{RA}_{3} \mathrm{Bh}$, ०महा $\mathrm{S}_{2} \mathrm{~S}_{3}$ 
त्रयोदशे तु यो नित्यमश्नाति दिवसे नरः।

विशेत्स भार्गवं स्थानं प्राप्य दिव्यसुखान्वितः ॥ ३२॥

अथ चेन्मानुषो भूयः स नरो जायते शुभः।

धनधान्यसमाकीर्ण जायते स कुले शुभः॥ ३३॥

चतुर्दश तु यो नित्यं दिवसानि क्षपेन्नर:।

तौषितं लोकमासाद्य भवेद्भणपतिर्वर:॥ ३८ ॥

अर्धमासं क्षपेद्यस्तु नित्यमेव ह्यतन्द्रितः।

देवराजेन तुल्यो उसौ भूत्वा स्वर्गे उवतिष्टति।

इह राजा महान्भूमौ भूय एवाभिजायते॥ ३४ ॥

32ab $=$ VK p. 454 and HeVKh 2, p. 918 32cd VK p. 454: वसेत्स भार्गवं स्थानं प्राप्य दिव्यसुखान्वितम् ।; HeVKh 2, p.918: वसेत् स भार्गवस्थानं प्राप्य दिव्यसुखान्वितम्। 34ab VK p. 454: अश्नन् चतुर्दशे नित्यं दिवसांस्तु क्षपेन्नर:।; $\mathrm{HeVKh} 2, \mathrm{p}$.918: चतुर्दशे तु दिवसे नित्यमश्नाति यो नरः। 34cd VK p. 454: तौष्टिक लोकमासाद्य भवेद्गणपतिर्नर:।; HeVKh 2, p.918: स वसदद्रुलोके तु शिवसायुज्यतां व्रजेत् । 35ab = VK p. 454; SaPra p. 137: अर्धमासं क्षिपेद्यस्तु नित्यमेवं ह्यतीन्द्रियः। (var. जितेन्द्रियः, ह्यतन्द्रिय:); HeVKh 2, p. 918: अर्धमासं क्षिपेद्यस्तु नित्यमेव जितेन्द्रयः।। 35cd VK p. 454: देवराजेन तुल्यो उसौ भूत्वा स्वर्गे तु तिष्ठति ।; SaPra p. 137: देवराजेन तुल्यो उसौ भूत्वा स्वर्गे च तिष्ठति ।; $\mathrm{HeVKh}$ 2, p. 918: देवराजेन तुल्यो उसौ भूत्वा स्वर्गं च तिष्ठति।

32ab नित्यम० ] $\mathrm{R}^{\mathrm{pc}}$, नित्यं म० $\mathrm{R}^{\mathrm{ac}} \quad 32 \mathrm{c}$ विशेत्स ] विशेत $\mathrm{R} \quad 33 \mathbf{a}$ चेन् ] तन् $\mathrm{R} \quad 33 \mathbf{b}$ शुभ: ] ततः $R \quad 33 d$ स कुले शुभः ] स शुभे कुले $R \quad 34 a$ चतुर्दश तु ] $R^{p c}$, चतुर्दशाहे $R^{a c} \quad 34 b$ दिवसानि क्षपेन् ] दिवसान् $\left\{{ }^{\circ}\right.$ से $\mathrm{R}^{\mathrm{ac}}$ \} यः क्षिपेन् $\mathrm{R} 3 \mathrm{34c}$ तौषितं ] तुषितं $\mathrm{R}$ 34d भवेद्गणपतिर्वर: ] भार्गवेण पतिम्वर: $R \quad 35 b$ ह्यतन्द्रितः ] जितेन्द्रियः $R$ 35d भूत्वा स्वर्गे डवतिष्ठति ] स्वर्गलोके उवतिष्टते $R$

32cd ॰त्स भार्गवं स्थानं प्राप्य दिव्य॰ ] ०त्स्वर्ग स संप्राप्य दिव्यं वर्ष० $\mathbf{A} 33 \mathrm{a}$ भूयः ] $\mathrm{A}_{7}^{\mathrm{pc}}$, भूय $\mathrm{A}_{3}$ $\mathrm{A}_{4} \mathrm{~A}_{7}^{\mathrm{ac}} 33 \mathrm{~d}$ स कुले शुभः ] सु $\left\{\right.$ स्व० $\left.\mathrm{A}_{4}\right\}$ कुले शुभे $\mathbf{A} 34 \mathbf{a}$ चतुर्दश ] चतुर्दशे $\mathbf{A} 34 \mathbf{b}$ दिवसानि ] दिवसांश्र $\mathrm{A}$ - क्षपेन् ] $\mathrm{A}_{3}$, क्षिपेन् $\mathrm{A}_{4} \mathrm{~A}_{7} 34 \mathrm{c}$ तौषितं ] तोषितं $\mathbf{A} 34 \mathrm{~d}$ भवेद्भणपतिर्वर: ] स [सा $\mathrm{A}_{4}$, सो $\left.\mathrm{A}_{7}\right\}$ विन्देत महत्पदं $\mathrm{A} \quad 35 \mathrm{a}$ क्षपेद् ] $\mathrm{A}_{7}^{\mathrm{pc}}$, क्षिपेद् $\mathrm{A}_{3} \mathrm{~A}_{4} \mathrm{~A}_{7}^{\mathrm{ac}} 35 \mathrm{~b}$ ह्यतन्द्रितः ] जितेन्द्रियः A $35 \mathrm{~cd}$ ] om. A 35 ef ॰न्भूमौ भूय एवा०] ${ }^{\circ}$ न् भूयो भूय नैवा० $\mathrm{A}_{3} \mathrm{~A}_{4} \mathrm{~A}_{7}^{\mathrm{ac}}$, ०न् भूय भूयो नैवा० $\mathrm{A}_{7}^{\mathrm{pc}}$

32 $\left(a^{1}, b^{6}\right) S_{2} \quad 34\left(d^{8}\right) S_{1} \quad 35\left(a^{1}\right) S_{1}$

32ab नित्यम० ${ }^{\circ} \mathrm{S}_{1} \mathrm{R}^{\mathrm{pc}} \mathrm{ABh}$, नित्यं म० $\mathrm{S}_{2} \mathrm{~S}_{3}$ 32c विशेत् $] \mathrm{S}_{1} \mathrm{~S}_{2} \mathrm{~S}_{3} \mathrm{~A}$, वसेत् $\mathrm{Bh}$ (conj.) भार्गवं ] $S_{1} R$, भार्गव० $S_{2} S_{3} B h$ 32d ०सुखान्वितः ] $S_{2} S_{3} R A B h$, ०सुखान्वित $S_{1}$ 33a भूय: ] $\mathrm{S}_{1} \mathrm{~S}_{2} \mathrm{RA}_{7}^{\mathrm{pc}} \mathrm{Bh}$, भूय $\mathrm{S}_{3} \quad 33 \mathbf{b}$ शुभ: ] $\mathrm{S}_{1} \mathbf{A}$, शुभा: $\mathrm{S}_{2} \mathrm{~S}_{3} \mathrm{Bh}$ 33c धन॰] $\mathrm{S}_{1} \mathrm{~S}_{3} \mathrm{RABh}$, धन्य॰ $\mathrm{S}_{2}$ - ककीर्णे] $S_{1} S_{2} R A B h$, ०कीर्ण $S_{3} 33 d$ स कुले ] $S_{1} S_{2} S_{3}$, सत्कुले Bh (conj.) 34b ०पेत्नर: ] $\mathrm{S}_{1} \mathrm{~S}_{2}^{\mathrm{pc}} \mathrm{S}_{3}^{\mathrm{pc}} \mathrm{RABh}$, ०पेन्नर $\mathrm{S}_{2}^{\mathrm{ac}}$, ०पे नर $\mathrm{S}_{3}^{\mathrm{ac}} \quad \mathbf{3 4 c}$ तौषितं ] em. Bh (silently), तुषितां $\mathrm{S}_{1}$, तौषितां

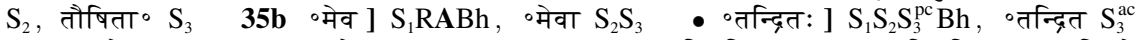
$35 \mathrm{c}$ तुल्यो ] $S_{2}^{\text {pc }} S_{3} R B h$, तुल्ये $S_{1}$, तुल्या $S_{2}^{a c}$ 35d उवतिष्टति ] $S_{1} B h$, च तिष्टति $S_{2}$, च तिष्ठते $\mathrm{S}_{3} \quad 35 \mathrm{e}$ महान् ] $\mathrm{S}_{1} \mathrm{~S}_{2} \mathrm{RABh}$, महा $\mathrm{S}_{3} \quad 35 \mathbf{f}$ एवाभि॰] $\mathrm{S}_{1} \mathrm{~S}_{2} \mathrm{~S}_{3}^{\mathrm{pc}} \mathrm{RBh}$, एवाह $\mathrm{S}_{3}^{\mathrm{ac}}$ 
यस्तु मासं क्षपेद्धीरो जितकोधो जितेन्द्रियः।

विमानेन स दिव्येन अप्सरोभिः समावृतः॥ ३६॥

पूज्यमानो यथा देवः स्तूयमानश्च सर्वशः।

ज्वलनादित्यसंकाशो नित्यं सुखमुपाश्नुते।

सर्वलोकेषु वसते बहून्यब्दायुतानि तु॥ ३७॥

ततो ब्रह्मसदं प्राप्य ब्रह्मणा स सुपूजितः।

ब्रह्मलोके निवसते यथा ब्रह्मा नरोत्तमः॥ ३५॥

अथ चेत्पुनरायाति ब्राह्मणो भवतीश्वरः।

योगं च तत्र लभते येनैश्वर्यं समश्नुते।

योगीशः स ततो भूत्वा शम्भोर्गणपतिर्भवेत्॥ ३९ ॥

सर्वेषां चोपवासानां विधिं परमपुण्यदम्।

देव्य: शृणुध्वं मत्तो ऽन्यं यथावदनुपूर्वशः ॥ ४०॥

स्नातः शुचिरथाचान्तो हुताग्निः सुसमाहितः।

दीक्षयित्वा ततो उत्मानमुपवासं चरेद्धुधः॥ ४१॥

36ab = VK p. 455; SaPra p. 138 and HeVKh 2, p. 919: यस्तु मासं क्षिपेद्वीरो जितक्रोधो जितेन्द्रियः। 36cd VK p. 455: स विमानेन दिव्येन अप्सरोभिः समन्वितः।; SaPra p. 138 and $\mathrm{HeVKh} \mathrm{2,} \mathrm{p.} \mathrm{919:}$ विमानेन स दिव्येन अप्सरोभिः समन्वितः। 37 ef VK p. 455: सर्वलोकेषु वसते बहुन्यब्दयुतानि च । (sic.); SaPra p. 138: सर्वलोकेषु वसते बहुन्यब्दयुगानि तु। (sic.); HeVKh 2, p.919: सर्व्वलोकेषु वसते जन्मान्यप्टायुतानि च। 38ab VK p. 455 and HeVKh 2, p. 919: ततो ब्रह्मासनं प्राप्य ब्रह्मणा च सुपूजितः।; SaPra p. 138: ततो ब्रह्मासनं प्राप्य ब्रह्मणा चानुमोदितः। 38cd VK p.455: ब्रह्मलोके निवसते यथा ब्रह्मा नरोत्तम ।; SaPra p. 138: सर्वलोके निवसते यथा देवो नरोत्तमः।; HeVKh 2, p. 919: ब्रह्मलोके निवसते यथा ब्रह्म नरोत्तमः। (sic.)

$37 b$ ग्च ] ०स्तु $R$ 37e सर्वलोकेषु वसते ] स स्थित्वा स्वर्गलोकेषु $R$ 37f तु ] च $R \quad 38 a$ ब्रह्मसदं ] ब्रह्मपद $R \quad 38 b$ स सु० ] सह $R \quad 38 d$ नरोत्तमः ] सुपूजित: $R \quad 39 a$ अथ चेत् ] अथास्मिन् $R$ $39 \mathrm{~b}$ ०तीश्वर: ] ०तीह स: $\mathrm{R} 33 \mathrm{~cd}$ तत्र लभते येनैश्वर्यं ] लभते तत्र भोगैस्वर्य्यं $\mathrm{R} \quad 39 \mathrm{e}$ ततो ] तदा $R$ 40c शृणुध्वं] शृणुत $R$ 40d यथावदनुपूर्वशः ] यथापूर्वमतिष्ठत $R$ 41a स्नातः शुचिरथा०] स स्नातः शुचिरा० $\mathrm{R} \quad 41 \mathrm{c}$ ततो ] तदा० $\mathrm{R}$

36a यस्तु ] $\mathrm{A}_{7}^{\mathrm{pc}}$, य तु $\mathrm{A}_{7}^{\mathrm{ac}}$, यत्तु $\mathrm{A}_{3} \mathrm{~A}_{4}$ - क्षपेद्धीरो ] क्षिपेद्वी $\left\{\right.$ ०द्वि॰ $\mathrm{A}_{3}$ (unmetrical)\}रो $\mathbf{A} \quad 37 \mathbf{b}$ ० ख्यच ] $\mathrm{A}_{3}$, ०स्तु $\mathrm{A}_{4} \mathrm{~A}_{7} \quad 37 \mathbf{c}-\mathbf{4 3 b}$ ] om. $\mathrm{A}$

$37\left(b^{6}\right)\left\langle b^{7}-c^{1}\right\rangle\left(c^{2}-c^{7}\right) S_{1} \quad 39\left(c^{7}-d^{4}\right)\left\langle d^{5}-d^{8}\right\rangle S_{1} \quad 41\left(a^{1}, a^{3}-a^{4}\right)\left\langle a^{5}-b^{4}\right\rangle\left(b^{5}\right) S_{1}$

36a मासं ] $\mathrm{S}_{1} \mathrm{RABh}$, मासां $\mathrm{S}_{2} \mathrm{~S}_{3}$ 36d अप्सरोभिः ] $\mathrm{S}_{1} \mathrm{~S}_{2} \mathrm{RABh}$, अप्सरोभि $\mathrm{S}_{3}$ 37c ज्वलना०]

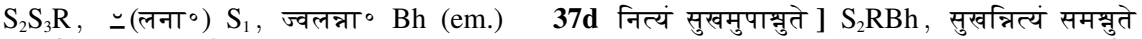
$\mathrm{S}_{1}$, नित्यसुखमुपाश्नुते $\mathrm{S}_{3}$ (unmetrical) $37 \mathrm{f}$ बहून्य॰] $\mathrm{RBh}$, बहून० $\mathrm{S}_{1} \mathrm{~S}_{2}$, बहूना॰ $\mathrm{S}_{3}$ - ०युतानि तु ] $\mathrm{S}_{2} \mathrm{~S}_{3} \mathrm{Bh}$, ०युतान्वितु $\mathrm{S}_{1}^{\mathrm{pc}}$, ०युतान्वित $\mathrm{S}_{1}^{\mathrm{ac}} \mathbf{3 8 b}$ स सु॰] $\mathrm{S}_{2} \mathrm{~S}_{3} \mathrm{Bh}$, सुसु॰ $\mathrm{S}_{1}$ • ०पूजितः ] $\mathrm{S}_{1} \mathrm{RBh}$, ०पूज्यते $\mathrm{S}_{2} \mathrm{~S}_{3} \quad 38 \mathrm{c}$ ब्रह्मलोके $] \mathrm{S}_{1} \mathrm{~S}_{2}^{\mathrm{pc}} \mathrm{S}_{3} \mathrm{RBh}$, ब्रह्मके $\mathrm{S}_{2}^{\mathrm{ac}}$ (unmetrical) 39b ब्राह्मणो ] $\mathrm{S}_{2} \mathrm{~S}_{3} \mathrm{RBh}$, ब्राह्मणा $\mathrm{S}_{1}^{\mathrm{pc}}$, ब्रह्मणा $\mathrm{S}_{1}^{\mathrm{ac}}$ 39d येनैम्वर्यं ] em., (येनैश) $\mathrm{S}_{2} \mathrm{~S}_{3}$, योगैम्वर्यं $\mathrm{Bh}$ (conj.) 39e योगीशः ] $\mathrm{S}_{2} \mathrm{RBh}$, योगीश $\mathrm{S}_{1} \mathrm{~S}_{3}$ • ततो ] $\mathrm{S}_{1}^{\mathrm{pc}} \mathrm{S}_{2} \mathrm{~S}_{3} \mathrm{Bh}$, तततो $\mathrm{S}_{1}^{\text {ac }}$ (unmetrical) 39f शम्भोर $] \mathrm{S}_{1} \mathrm{~S}_{2} \mathrm{RBh}$, शम्भो $S_{3}$ 40c ०ध्वं मत्तो उन्यं ] $\mathrm{S}_{2} B h$, ०ध्वमन्योन्यद् $S_{1}$, ॰ध्व मत्तो न्यं $S_{3} \quad 41 \mathrm{a}$ ॰चान्तो] $S_{2}^{\mathrm{pc}} R B h$, ॰चतो $S_{2}^{\mathrm{ac}}$, ॰चतो $S_{3}$ (unmetrical) $41 \mathrm{~b}$ ०समाहितः ] $\mathrm{S}_{1} \mathrm{RBh}$, ०समीहितः $\mathrm{S}_{2} \mathrm{~S}_{3}$ 41c ततो ] $\mathrm{S}_{1}^{\mathrm{pc}} \mathrm{S}_{2} \mathrm{~S}_{3}$, om. $\mathrm{S}_{1}^{\text {ac }}$ (unmetrical), तथा० $\mathrm{Bh}$ (em.) 41d चरेद्] $\mathrm{S}_{1} \mathrm{~S}_{2} \mathrm{RBh}$, चरे $\mathrm{S}_{3}$ 
स्नायेत्तिषवणं चैव जुहुयादग्निमेव च।

वाग्यतो इकोधनो दान्तो धार्मिक: सत्यवाग्घृणी॥ ४२॥

जपन्स चैव गायत्रों पवित्राणि च नित्यशः।

रुद्रानथ गणान्वापि रात्रौ च स्थण्डिलेशयः।

कुशानास्तीर्य विधिवत्स्त्रीशूद्रै: परिवर्जितः॥ ४३॥

समश्नीयात्ततो देव्यो वीतशोको विमत्सर:।

यावन्त्यहानि तिष्टेत तावद्विप्रांस्तु भोजयेत्॥ ४४॥

ततः पूर्णे तु काले वै ब्राह्मणानां शतं वरम्।

सहस्रमथवा शक्तया पूजयित्वा तु सर्वशः ॥ ४४॥

हविष्यं भोजनं दत्त्वा गावो वासांसि च ऋमात्।

सुवर्ण तिलपात्रं च एकैकस्य प्रदापयेत्।

ततस्तत्फलमाप्नोति यदन्यैर्दुर्लभं व्रतैः॥ ४६॥

वृषभं यस्तु नीलाड़्मुत्सृजेत नरोत्तमः।

अन्यं वापि महाभागा: स पितंस्तारयेन्नरः॥ ४७॥

42a स्नायेत्तिषवणं चैव ] चरेत्तिषरणस्चैस्चैव $R$ (unmetrical) $42 \mathrm{~d}$ ०वाग्घृणी ] ॰वाग्वशी $\mathrm{R} \quad 43 \mathrm{a}$ जपन्स चैव ] जपन्देव० $R$ (unmetrical) $43 b$ नित्यशः ] सर्व्वशः $R \quad 43 c$ गणान्वापि ] गणांश्च्चापि $R$ 43f ०शूद्रै: ] ०तन्त्रै: $R$ (cf. cancelled pādas after 45d) 44b वीतशोको ] रीतिमान् स $R$ 44d यावन्त्यहानि तिष्टेत ] यावत्यहनि तिष्टेत् स $R$ 45d After this $R$ cancels two pādas reading कमादास्तीर्य्य विधिवत् स्त्रीशूद्रै: परिवर्ज्जितः। (cf. 43ef) 46a हविष्यं] हविष्य॰ $R \quad 46 f$ ०र्दुर्लभं] ०र्दुलभं R 47ab ०ड़मुत्सृजेत ] ॰ड़ं समुत्सृज्य R 47c अन्यं वापि महाभागा: ] अन्यत्रापि महाभागः $\mathrm{R} 47 \mathrm{~d}$ पितंस्ता० ] पितृस्ता० $\mathrm{R}$

$43 \mathrm{c}$ ॰नथ गणान्वापि ] ॰नपि गणांश्चापि $\mathrm{A} 43 \mathrm{~d}$ च स्थण्डिलेशयः ] स्थांता [स्थाता $\mathrm{A}_{4}$, (स्नात्वा) $\mathrm{A}_{7}^{\mathrm{pc}}$, (स्थाण्डा) $\left.\mathrm{A}_{7}^{\mathrm{ac}}\right\}$ न संशयः $\mathrm{A}$ 44-46 ] om. $\mathrm{A} \quad \mathbf{4 7 b} \circ$ मुत्सृजेत ] ममुत्सृजेतु $\mathrm{A}$ • नरोत्तमः ] $\mathrm{A}_{4} \mathrm{~A}_{7}^{\mathrm{ac}}$, नरोत्तम $\mathrm{A}_{3}$, नरोत्तमं $\mathrm{A}_{7}^{\mathrm{pc}} \quad 47 \mathrm{c}$ अन्यं वापि ] अन्यद्वापि $\mathbf{A}$

$\mathbf{4 3}\left\langle a^{4}-a^{5}\right\rangle\left(a^{6}\right) S_{2} \quad \mathbf{4 5}\left(b^{5}-b^{8}\right) S_{2} \quad 47\left(b^{8}-c^{1}\right) S_{1},\left(c^{2}, d^{7}\right) S_{2}$

42a स्नायेत्ति॰ $\mathrm{S}_{2} \mathrm{~S}_{3}$, स्नात तृ॰ $\mathrm{S}_{1}$, स्नायात्ति॰ $\mathrm{Bh}(\mathrm{em}$.$) ० ०षवणं चैव ] \mathrm{S}_{2} \mathrm{~S}_{3} \mathrm{Bh}$, ०स्रवणस्चैव $\mathrm{S}_{1}$ 42b जुहुया० ] $S_{1} S_{3} R B h$, जुहूया० $S_{2}$ 42c वाग्यतो] $S_{2} S_{3} R B h$, वाग्दतो $S_{1}$ 42d धार्मिक: ] $\mathrm{S}_{2}^{\mathrm{pc}} \mathrm{RBh}$, धान्मिक: $\mathrm{S}_{1}^{\mathrm{pc}}$, (त)न्मिक: $\mathrm{S}_{1}^{\mathrm{ac}}$, धामिक $\mathrm{S}_{2}^{\mathrm{ac}}$ (unmetrical), धार्मिक $\mathrm{S}_{3}$ (unmetrical) सत्य॰] $S_{1} S_{2}^{\text {pc }} S_{3} R B h$, स(व्य॰) $S_{2}^{a c} \quad 43 a$ जपन्स चैव $] S_{3}$, जपक्ष चैव $S_{1}$, जपन्स $\simeq ~ S_{2}$, जपन्सदैव $\mathrm{Bh}$ (conj.?) - गायत्रों ] $\mathrm{S}_{1}^{\mathrm{pc}} \mathrm{S}_{2} \mathrm{~S}_{3} \mathrm{RBh}$, शायत्त्रीम् $\mathrm{S}_{1}^{\mathrm{ac}}$ 43b पवित्राणि ] $\mathrm{S}_{1} \mathrm{~S}_{2} \mathrm{~S}_{3}^{\mathrm{pc}} \mathrm{RBh}$, पवित्रा $\langle$ च $\rangle+$ णि $+S_{3}$ - नित्यशः ] $S_{1}^{\text {ac }} S_{2} S_{3} B h$, नत्यशः $S_{1}^{\text {pc }}$ 43c गणान्वा॰] $S_{2} S_{3} B h$, गणा वा॰ $\mathrm{S}_{1} \quad$ 43e ०नास्तीर्य ] $\mathrm{S}_{2} \mathrm{~S}_{3} \mathrm{RABh}$, ०न्नस्तीर्य $\mathrm{S}_{1}$ 44a समश्नीया॰] $\mathrm{S}_{2} \mathrm{~S}_{3} \mathrm{RBh}$, सपत्नीया॰ $\mathrm{S}_{1}$ • देव्यो ] $\mathrm{S}_{1} \mathrm{~S}_{2} \mathrm{~S}_{3}^{\mathrm{pc}} \mathrm{RBh}$, देवो $\mathrm{S}_{3}^{\mathrm{ac}} \quad \mathbf{4 4 b}$ वीतशोको ] em. Bh (silently), विकोशो अ० $\mathrm{S}_{1}$, वीतशोक॰ $\mathrm{S}_{2} \mathrm{~S}_{3} \quad 44 \mathrm{c}$ यावन्त्यहानि] em. Bh (silently), यावन्तृहीनि $\mathrm{S}_{1}^{\mathrm{pc}}$, यावन्तृहानि $\mathrm{S}_{1}^{\mathrm{ac}}$, यावन्यहानि $\mathrm{S}_{2}$ $\mathrm{S}_{3} 44$ cd तिष्टेत ता॰] $\mathrm{S}_{2} \mathrm{~S}_{3} \mathrm{Bh}$, तिष्टेतस्ता $\mathrm{S}_{1}$ 44d ॰ द्विप्रांस्तु $] \mathrm{S}_{2} \mathrm{~S}_{3} R B h$, मद्विप्रांश्च $\mathrm{S}_{1}$ 45a काले] $\mathrm{S}_{2} \mathrm{~S}_{3} R B h$, कालो $\mathrm{S}_{1} \quad 45 \mathbf{b}$ ब्राह्मणानां ] $\mathrm{S}_{1} \mathrm{~S}_{2} R B h$, ब्राह्मणाना $\mathrm{S}_{3} \quad$ 46a हविष्यं ] $\mathrm{S}_{2} \mathrm{~S}_{3} \mathrm{Bh}$, हविष्यन् $\mathrm{S}_{1} \quad 46 \mathrm{~b}$ गावो ] $\mathrm{S}_{1} \mathrm{~S}_{2} \mathrm{~S}_{3} \mathrm{R}$, गाश्च $\mathrm{Bh}\left(\mathrm{em}\right.$.) • वासांसि ] $\mathrm{S}_{1} \mathrm{~S}_{2} R B h$, वासाड्शि $\mathrm{S}_{3} 46 \mathrm{c}$ ०पात्रं ] $S_{1} S_{2} R B h$, ०पात्र $S_{3}$ (unmetrical) 46d एकैकस्य ] $S_{2} S_{3} R B h$, ऐकैकस्य $S_{1}$ 46f व्रतै: ] $\mathrm{S}_{2} \mathrm{~S}_{3} \mathrm{RBh}$, ब्रतै: $\mathrm{S}_{1}$ 47b नरोत्तमः ] $\mathrm{S}_{1}^{\mathrm{pc}} \mathrm{S}_{2} \mathrm{~S}_{3} \mathrm{RA}_{4} \mathrm{~A}_{7}^{\mathrm{ac}} \mathrm{Bh}$, नरोत्तम(म्) $\mathrm{S}_{1}^{\mathrm{ac}}$ 47c वापि ] $\mathrm{S}_{1} \mathrm{Bh}$, चापि $\mathrm{S}_{2} \mathrm{~S}_{3}$ - महाभागा: ] $A B h$, महाभागा $\mathrm{S}_{1}$, महाभागान् $\mathrm{S}_{2} \mathrm{~S}_{3}$ 47d ०येन्नर: ] $\mathrm{S}_{1} \mathrm{~S}_{2} \mathrm{RABh}$, ०ये नर: $\mathrm{S}_{3}$ 
यावन्ति तस्य रोमाणि वृषभस्य महात्मनः।

तावन्त्येव सहस्राणि वर्षाणां दिवि मोदते॥ ४५॥

तिलपात्राणि यो दद्याद्विप्रेम्यः शुद्धमानसः।

अमावास्यां समासाद्य कृष्णानां सुसमाहितः॥ ४९॥

स पित्रंस्तर्पयित्वा तु अक्षयं नरपुंगवः।

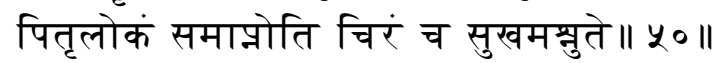

उपवासविधिस्त्वेष कथितो मे सुशोभनाः।

चान्द्रायणविधिं भूयः शृणुध्वं सुसमाहिताः ॥ ४१ ॥

यस्तु चान्द्रायणं कुर्याद्यथोकं सुसमाहितः।

स सोमलोकमासाद्य सोमेन समतां व्रजेत्॥ पर ॥

प्राजापत्यं तु यः कुर्यादेकशो बहुशो ऽपि वा।

प्रजापतिसमो भूत्वा तस्य लोके महीयते ॥ $y$ ३॥

यस्तु सांतपनं कृच्छ्र्ं करोति नरसत्तमः ।

आत्मानमुद्धरेत्कृच्छ्रात्सो ऊग्निलोक च गच्छुति॥ पूष॥

49ab = AYS p. 360 and DK 14.1.37ab; HeDKh p. 600: तिलपात्राणि यो दद्याद्विप्रेभ्यः श्रद्वयान्वितः ।;

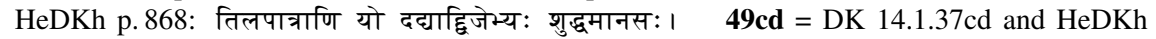
p. 868; AYS p. 360: अमावस्यां तु संप्राप्य कृष्णानां तु समाहितः ।; HeDKh p. 600: अमावास्यां समासाद्य नियतः सुसमाहितः। $50 \mathbf{a b}=\mathrm{HeDKh}$ p. 868; AYS p. 360: पितंंश्च तर्पयित्वा तु अक्षयं नरपुंगवः।; DK 14.1.38ab: स्वपितंस्तर्पयित्वा तु अक्षयं नरपुड्द्वः।; HeDKh p. 600: स पितंस्तारयित्वाशु नरकान्नरपुड्गवः। 50cd AYS p. 360 and HeDKh p. 868: पितृलोक समाप्रोति चिरं च सुखमेधते ।; DK 14.1.38cd: पितृलोक समाप्रोति चिरं स सुखमेधते ।; HeDKh p. 600: पितृलोक समाप्नोति स चिरं सुखमश्नुते।

49b ०द्विप्रेम्यः ] ०द्विप्रेम्य R (unmetrical) 49d कृष्णानां सुसमाहितः ] पूर्ण्ण कृष्णतिलैर्दृढै: $R \quad 50 a$ ०स्तर्पयित्वा ] ०स्तारयित्वा $R$ 50c समाप्रोति ] समासद्य $R$ 51a ०स्त्वेष ] ०स्ते उद्य $R$ 51b ०शोभना: ] ०शोभन: $R$ 51c चान्द्रायणविधिं ] चान्द्रायणादिक $R$ 52d समतां ] समता $R$ 53c56b ] om. R

48a यावन्ति ] यावद्धि $\mathrm{A}_{3} \mathrm{~A}_{4}$, यावद्वै $\mathrm{A}_{7}$ 49-50 ] om. $\mathrm{A} \quad$ 51b ०शोभना: ] $\mathrm{A}_{3} \mathrm{~A}_{7}$, ०शोभन: $\mathrm{A}_{4}$ 51c चान्द्रायणविधिं ] चान्द्रायणादिकं $A$ 51d ०समाहिता: ] $A_{3} A_{7}$, ०समाहितः $A_{4}$ 53-55ab ] om. A

$\mathbf{4 8}\left(\mathrm{a}^{1}\right)\left\langle\mathrm{a}^{2}\right\rangle\left(\mathrm{a}^{3}\right) \mathrm{S}_{2} \quad \mathbf{5 3}\left(\mathrm{b}^{8}\right) \mathrm{S}_{1}$

$48 b$ महात्मनः ] $\mathrm{S}_{2} \mathrm{~S}_{3} \mathrm{RABh}$, महात्मन $\mathrm{S}_{1} \quad 48 \mathrm{c}$ तावन्त्ये०] $\mathrm{S}_{1}^{\mathrm{pc}} \mathrm{S}_{2} \mathrm{~S}_{3} \mathrm{RABh}$, यावन्त्ये० $\mathrm{S}_{1}^{\mathrm{ac}} \quad 49 \mathrm{~b}$

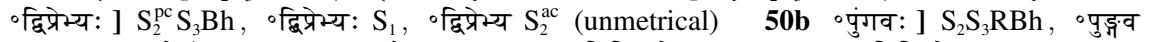
$S_{1} 50 \mathrm{c}$ ०लोक ] $S_{1} S_{2} R B h$, ०लोक $S_{3}$ 51a ०विधिस्त्वेष ] $S_{2} S_{3} A B h$, वविधित्वेष $S_{1}$ 51b सुशोभना: ] $S_{1} S_{2}^{p c} A_{3} A_{7}$, सुशोभना $S_{2}^{a c} S_{3}$, शुभानना: $B h$ (conj.) 51c चान्द्रायण॰] $S_{1}^{p c} B h, ~ \simeq f \simeq 00 。$ $\mathrm{S}_{1}^{\mathrm{ac}}$, चन्द्रायण० $\mathrm{S}_{2} \mathrm{~S}_{3} \quad$ 51d ०समाहिता: ] $\mathrm{S}_{2} \mathrm{~S}_{3} \mathrm{RA}_{3} \mathrm{~A}_{7} \mathrm{Bh}$, ०समाहिता $\mathrm{S}_{1}$ 52ab ] om. $\mathrm{S}_{3}$ 52a चान्द्रायणं ] $S_{1}^{\mathrm{pc}} \mathrm{S}_{2} \mathrm{RABh}$, चन्द्रायणम् $\mathrm{S}_{1}^{\mathrm{ac}} \quad \mathbf{5 2 b}$ ०समाहितः ] $\mathrm{S}_{1}^{\mathrm{pc}} \mathrm{RABh}$, ०समाहित $\mathrm{S}_{1}^{\mathrm{ac}} \mathrm{S}_{2}^{\mathrm{pc}}$, ०स-

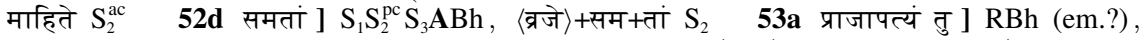
प्राजापत्यश्च $S_{1}$, प्राजापत्यस्तु $S_{2} S_{3}^{p c}$, प्राजपत्यस्तु $S_{3}^{\text {ac }} \quad 54 a$ सांतपनं ] $S_{1} S_{3} B h$, शान्तपनं $S_{2} \quad 54 d$ च गच्छति ] $\mathrm{S}_{2} \mathrm{~S}_{3} \mathrm{Bh}$, समश्नुते $\mathrm{S}_{1}$ 
महासांतपनं यश्च करोति सुमहामनाः।

सर्वज्ञतामवाप्रोति ब्रह्मलोक च विन्दति ॥ $y \mathrm{y} \|$

तुलापुरुषकं यश्च कुरुते द्विजसत्तमः।

स मुक्तः सर्वपापैस्तु गच्छ्रेत दिवि-म्-ऊर्जितः॥ प६६॥

अतिकृच्छ्रेण तु नरः शर्वस्य भवनं व्रजेत्।

कृच्छ्रातिकृच्छ्रेण तथा गाणापत्यमवाप्तुयात् ॥ पै७॥

यस्तु सर्वाणि कृच्छ्राणि कुरुते नरसत्तमः।

स यं प्रार्थयते कामं तमेव समुपाश्नुते॥ पू५॥

यस्य कस्यचिदेवेह कृच्छ्रस्य सुसमाहितः।

स तेन सिद्धो भवति देवत्वं चापि विन्दति॥ पू९॥

पयोभक्षस्तु यो नित्यं नर: संवत्सरं वसेत्।

यावकं चोपयुआ्वानो गोमूत्रेणाभिसंस्कृतम्॥ ६०॥

पिण्याकफलभक्षो वा अक्षारलवणो उपि वा।

सो उश्वमेधफलं प्राप्य ब्रह्मलोक समश्नुते॥ ६?॥

56c मुक्तः ] मुक्त $R \quad 56 d$ गच्छेत दिवि-म्-ऊर्जितः ] गच्छेत्तिदिवपूजित: $R \quad 57 a$ तु ] च $R \quad 57 b$ शर्वस्य ] शक्य $R \quad 57 d$ गाणापत्यमवाप्तुयात् ] गाणपत्यमवाप्यक्यति $R \quad 58 a$ सर्वाणि कृच्छ्राणि ] कृच्छ्राणि सर्वाणि $\mathrm{R} \quad 58 \mathrm{c}$ स यं ] $\mathrm{R}^{\mathrm{pc}}$, (अ)यं $\mathrm{R}^{\mathrm{ac}} \quad 59-61$ ] om. $\mathrm{R}$

56a ०कं यश्च ] ॰दोषं तु $\mathrm{A}_{3} \mathrm{~A}_{4},+{ }^{\circ}$ दो य+स्तु $\mathrm{A}_{7} \quad$ 56b कुरुते द्विजसत्तमः ] द्विजः क्षेत्रादिकापि वा $A$ 56d गच्छेत दिवि-म्-ऊर्जितः ] गच्छेद्धि $\left\{{ }^{\circ}\right.$ दे० $\left.A_{7}\right\}$ वं स चोर्जित: $A$ 57a तु ] च $\mathbf{A} 57 \mathbf{b}$ शर्वस्य ] सर्वस्य $A$ 57d गाणापत्य०] गाणपत्य० $A$ 58a सर्वाणि कृच्छ्क्राणि ] कृच्छ्राणि सर्वाणि $A$ $58 b$ ०सत्तमः ] $\mathrm{A}_{3} \mathrm{~A}_{7}$, ०सत्तम $\mathrm{A}_{4} \quad 58 \mathrm{c}$ स यं] यं यं $\mathbf{A} 58 \mathrm{~d}$ समुपाश्नुते ] $\mathrm{A}_{3} \mathrm{~A}_{4}$, समुपश्नुते $\mathrm{A}_{7}$ 59-60ab ] om. $\mathrm{A}_{4} \quad 59 \mathrm{~b}$ सु॰ ] तु $\mathrm{A}_{3} \mathrm{~A}_{7} \quad 60 \mathrm{~b}$ नर: संवत्सरं वसेत् ] सम्वत्सरमुपश्नुते $\mathrm{A}_{7}$, समुत्सवमुपाश्नुते $\mathrm{A}_{3} 60 \mathrm{c}$ यावकं चोपयुआानो ] नारकं नो \{लो॰ $\mathrm{A}_{7}$ \}पभुजानो $\mathrm{A}$ 61a पिण्याक॰] $\mathrm{A}_{4}$, पिन्याक॰ $\mathrm{A}_{3} \mathrm{~A}_{7}$ • ०भक्षो वा ] ॰माप्रोति $A$ 61c सो उम्व०] अश्व० $A$

$\mathbf{5 6}\left(\mathrm{a}^{6}, \mathrm{~b}^{1}-\mathrm{b}^{2}\right)\left\langle\mathrm{b}^{3}-\mathrm{b}^{8}\right\rangle\left(\mathrm{c}^{1}\right)\left\langle\mathrm{d}^{1}\right\rangle\left(\mathrm{d}^{2}\right) \mathrm{S}_{1}$

55a ०सांतपनं ] $\mathrm{S}_{1} \mathrm{~S}_{3} \mathrm{Bh}$, ०शान्तपनं $\mathrm{S}_{2}$ - यस्च्च ] $\mathrm{S}_{1}^{\mathrm{pc}} \mathrm{S}_{2} \mathrm{~S}_{3} \mathrm{Bh}$, (कृच्छु) $\mathrm{S}_{1}^{\text {ac }} \quad \mathbf{5 5 b}$ ०महामनाः ] em. Bh (silently), ॰महात्मना: $S_{1}$, ॰महात्मना $S_{2}$, ०महामना $S_{3}$ 56a ०पुरुषकं ] $S_{1} S_{2} B h$, ०पुरुषक $S_{3}$ (unmetrical) 56c मुक्तः ] $S_{1} S_{2}^{\text {pc }} A B h$, मुक्त $S_{2}^{\text {ac }} S_{3}$ 56d दिवि-म्-ऊर्जितः ] $S_{1} S_{3}$, दिवि पूर्जितः $S_{2}$, दिवमूर्जितः $B h(e m) \quad$.$57 b व्रजेत् ] S_{2} S_{3} R A B h$, ब्रजेत् $S_{1} \quad$ 57d गाणापत्य॰] em., गणापत्य॰ $\mathrm{S}_{1} \mathrm{~S}_{2}$, गाणांपत्य॰ $\mathrm{S}_{3}$, गाणपत्य॰ $\mathrm{Bh}(\mathrm{em} . ?) \quad \mathbf{5 8 b}$ नरसत्तमः ] $\mathrm{S}_{1} \mathrm{RA}_{3} \mathrm{~A}_{7} \mathrm{Bh}$, स नरोत्तमः $\mathrm{S}_{2} \mathrm{~S}_{3} \quad 58 \mathrm{c}$ यं] $\mathrm{S}_{1} \mathrm{RABh}$, यत् $\mathrm{S}_{2} \mathrm{~S}_{3} \quad \mathbf{5 8 d}$ समुपाश्नुते ] $\mathrm{RA}_{3} \mathrm{~A}_{4} \mathrm{Bh}$, समुपश्नुते $\mathrm{S}_{1} \mathrm{~S}_{2} \mathrm{~S}_{3}$ 59ab ] $\mathrm{S}_{2}^{\mathrm{pc}}$ writes this over cancelled two pādas, possibly 62ab. 59ab ०चिदेवेह कृच्छ्रस्य ] $\mathrm{S}_{1} \mathrm{~S}_{2}^{\mathrm{pc}} \mathrm{S}_{3}$ $\mathrm{A}_{3} \mathrm{~A}_{7}$, ०चिदेतेषां कर्ता स्यात् $\mathrm{Bh}$ (conj.) 59b ०समाहितः ] $\mathrm{A}_{3} \mathrm{~A}_{7} \mathrm{Bh}$, ०समाहित $\mathrm{S}_{1}$, ०समाहिता $\mathrm{S}_{2}^{\mathrm{pc}} \mathrm{S}_{3}$ 59c सिद्धो ] $\mathrm{S}_{1} \mathrm{~S}_{2} \mathrm{~S}_{3} \mathrm{~A}_{3} \mathrm{~A}_{7}$, शुद्धो $\mathrm{Bh}$ (conj.) 59d विन्दति ] $\mathrm{S}_{1} \mathrm{~S}_{2} \mathrm{~S}_{3}^{\mathrm{pc}} \mathrm{A}_{3} \mathrm{~A}_{7} \mathrm{Bh}$, विन्दभि $\mathrm{S}_{3}^{\mathrm{ac}} 60 \mathrm{a}$ यो ] $\mathrm{S}_{2} \mathrm{~S}_{3} \mathrm{~A}_{3} \mathrm{~A}_{7} \mathrm{Bh}$, या $\mathrm{S}_{1}$ 60b नर: ] $\mathrm{S}_{1} \mathrm{~S}_{2} \mathrm{Bh}$, नर $\mathrm{S}_{3}$ • संवत्सरं ] $\mathrm{S}_{2} \mathrm{~S}_{3} \mathrm{Bh}$, सम्वत्संरं $S_{1}$ (unmetrical) 60c यावकं] $S_{1} S_{2} B h$, यावक $S_{3}$ (unmetrical) • ० युझ्ञानो ] $S_{2} S_{3}$ $B h$, ॰भुजानो $S_{1} 60 d$ ०संस्कृतम् ] $S_{1} S_{2} A B h$, ०सस्कृतं $S_{3}$ 61c सो 5ग्य०] $S_{1} S_{2} B h$, सो स्य $S_{3}$ 61d ०लोकं] $\mathrm{S}_{1} \mathrm{~S}_{2} \mathrm{ABh}$, ०लोक $\mathrm{S}_{3}$ 
सर्वपापविनिर्मुक्तो विमुक्तः सर्वबन्धनैः।

विमानेनार्कवर्णेन ब्रह्मवच्चरते च सः॥ ६२॥

यस्त्वेतान्येव सर्वाणि व्यस्तानि नरसत्तमः।

यावदुच्छुवासमासेवेन्महात्मा नष्टकिल्बिषः॥ ६३॥

स लोकान्वा महासत्त्वो यथेष्टान्मोक्षमेव वा।

ऐम्वर्यं वा महत्प्राप्य दीप्यमानो उवतिष्टते॥ ६४॥

एतान्येव च सर्वाणि दानानि च तपांसि च।

विना मन्त्रेण सततं शूद्राणामपि सर्वशः॥ ६४॥

विधीयन्ते न संदेह एवमाह प्रजापतिः।

अमन्त्रास्ते स्मृताः सर्वे शूद्रा विगतकल्मषाः॥ ६६॥

स्त्रीणां तु दैवतं भर्ता न ततो उन्यद्विधीयते ।

स गतिः परमं धाम स धर्मः परमः स्मृतः॥ ६७॥

तेन या त्वभ्यनुज्ञाता इदं धर्म समाचरेत्।

सा फलं तस्य धर्मस्य प्राप्नोति सुसमाहिता॥ ६५॥

$62 \mathrm{~d}$ ब्रह्मवच्चरते च स: ] ब्राह्मणश्चरते दिवि $\mathrm{R} 63 \mathrm{a}$ यस्त्वेतान्येव ] समस्तान्येव $\mathrm{R} 63 \mathrm{c}$ यावदुच्छुवासमासेवेन् ] यावहुःस्थः समासेन $R 63 d$ नष्ट०] गत० $R$ 64a स लोकान्वा ] सर्वलोके $R$ 64b यथेष्टान्मोक्षमेव वा ] यथाष्टमयुगे ह च $\mathrm{R} 64 \mathrm{~cd}$ ] om. $\mathrm{R} 65 \mathrm{c}$ विना मन्त्रेण सततं ] विमानेन तु सर्व्वाणि $R \quad 67 c$ गतिः ] $R^{p c}$, मतिः $R^{a c} \quad 67 d$ स्मृतः ] शुभः $R \quad 68 b$ इदं ] इमं $R \quad 68 c$ फलं ] $\mathrm{R}^{\mathrm{pc}}$ ?, फल्यन् $\mathrm{R}^{\mathrm{ac}}$ ? $68 \mathrm{~d}$ ०समाहिता ] ॰महायशा: $\mathrm{R}$

$62 d$ च स: ] दिवि $A$ 63a यस्त्वेतान्येव ] समस्तान्येव $A$ 63b-65c ] om. $A$ 66c अमन्त्रास्ते ] आमन्त्यस्ते $A 66 d$ ०कल्मषा: ] ०किल्बिषा: $\left\{\circ\right.$ षा $\left.A_{3}\right\} A$ 67b न ततो उन्यद् ] ततो उन्यद् $\mathrm{A}_{3}$ (unmetrical), ततो नान्यद् $\mathrm{A}_{4}$, ततो उन्यन्न $\mathrm{A}_{7} \quad 68 \mathrm{a}$ या त्वभ्यनु॰ $]$ सर्वे भ्य \{त्य॰ $\mathrm{A}_{4}$, ह्य॰ $\left.\mathrm{A}_{3}\right\}$ नु $\mathrm{A} \quad 68 \mathrm{~b}$ इदं धर्मं] इमं धर्मं $\left\{{ }^{\circ} \mathrm{A}_{4}\right\} \mathrm{A} \quad 68 \mathrm{c}$ सा ] $\mathrm{A}_{3} \mathrm{~A}_{7}$, स $\mathrm{A}_{4}$ - फलं] $\mathrm{A}_{3} \mathrm{~A}_{4}$, फल्यं $\mathrm{A}_{7} 68 \mathrm{~d}$ ०समाहिता ] ०महायशा: $\mathrm{A}$

$63\left(c^{4}-c^{5}\right) S_{3} \quad 64\left(a^{3}\right) S_{1} \quad 66\left(c^{1}\right) S_{2},\left(c^{3}\right)\left\langle c^{4}-c^{6}\right\rangle\left(c^{7}-c^{10}\right) S_{3} \quad 67\left\langle d^{1}\right\rangle\left(d^{2}\right) S_{2} \quad 68\left\langle c^{1}-c^{4}\right\rangle\left(c^{5}-\right.$ $\left.\mathrm{d}^{4}\right)\left\langle\mathrm{d}^{5}\right\rangle\left(\mathrm{d}^{6}-\mathrm{d}^{8}\right) \mathrm{S}_{1}$

62b विमुक्तः ] $S_{1} S_{2} R A B h$, विमुक्त $S_{3}$ (unmetrical) 62d ब्रह्मवच्च०] $S_{1} S_{2} A B h$, ब्रह्मव च० $S_{3}$ (unmetrical) • च स: ] $S_{1} B h$, वस: $S_{2} S_{3} \quad 63 a$ ०स्त्वेतान्ये०] $S_{1} S_{2} B h$, ०स्त्वेनान्ये० $S_{3} \quad 63 c$ ०मासेवेन् ] conj., ०या सर्वे $S_{1}^{\mathrm{pc}}$, ०या (मासे) $\mathrm{S}_{1}^{\mathrm{ac}}$, ०मासेवै $\mathrm{S}_{2} \mathrm{~S}_{3}$, ${ }^{\circ}$ माशेते $\mathrm{Bh}$ (conj.?) 64a लोकान्वा ] em. Bh (silently), लो(का) वा $S_{1}^{\text {pc }}$, (लोवाक) $S_{1}^{\text {ac }}$, लोकाम्वा $S_{2}$, लोकम्वा $S_{3}$ 64d दीप्यमानो ] $S_{2} S_{3} B h$, दीव्यमानो $S_{1}$ - उवतिष्टते ] $S_{1}^{\text {pc }} S_{2} S_{3} B h$, भतिष्टते $S_{1}^{\text {ac }}$ 66a विधीयन्ते ] RA, विधीयते $S_{1} B h$, विधीयेत $S_{2} S_{3}$ - संदेह ] $S_{1} S_{2}^{\text {pc }} S_{3} R A$, सन्देहो $S_{2}^{\text {ac }} B h$ (typo?) 66b प्रजापति: ] $\mathrm{S}_{1} \mathrm{~S}_{2} \mathrm{RABh}$, प्रजापति $\mathrm{S}_{3} \quad 66 \mathrm{c}$ अमन्त्रास्ते ] $\mathrm{S}_{1}^{\mathrm{pc}} \mathrm{S}_{2} \mathrm{RBh}$, अमन्त्रा ते $\mathrm{S}_{1}^{\mathrm{ac}}$, अम(न्त्रा $) \simeq \simeq \simeq\left(\right.$ न्त्रस्त) $\mathrm{S}_{3}$ (unmetrical, upper parts of न्त्रस्त lost, verso side starts from the fifth akșara) - स्मृता: ] $S_{1}^{\text {pc }}$ $\mathrm{RABh}$, स्मृता $\mathrm{S}_{1}^{\mathrm{ac}} \mathrm{S}_{2} \mathrm{~S}_{3}$ 66d ०कल्मषा: ] $\mathrm{S}_{1} \mathrm{~S}_{2}^{\mathrm{pc}} \mathrm{RBh}$, ०कल्मषा $\mathrm{S}_{2}^{\mathrm{ac}} \mathrm{S}_{3}$ 67a दैवतं ] $\mathrm{S}_{1} \mathrm{RABh}$, देवता $\mathrm{S}_{2} \mathrm{~S}_{3} \quad$ 67c ०मं धाम $] \mathrm{S}_{1} \mathrm{~S}_{2}^{\mathrm{pc}} \mathrm{RABh}$, ०मन्धाम: $\mathrm{S}_{2}^{\mathrm{ac}} \mathrm{S}_{3}$ 68a तेन ] $\mathrm{S}_{1} R A B h$, येन $\mathrm{S}_{2} \mathrm{~S}_{3}$ - त्वभ्यनु० $] \mathrm{S}_{2} \mathrm{~S}_{3} R B h$, त्वन्यनु० $\mathrm{S}_{1}$ - ज्ञाता ] $\mathrm{S}_{1} \mathrm{~S}_{2} \mathrm{RABh}$, ज्ञातो $\mathrm{S}_{3} \quad 68 \mathrm{~b}$ इदं धर्मं] $\mathrm{S}_{1} \mathrm{~S}_{2}^{\mathrm{ac}}$, इदन्धर्म $\mathrm{S}_{2}^{\mathrm{pc}} \mathrm{S}_{3}$, इमं धर्मं $\mathrm{Bh}$ 68c सा ] $\mathrm{RA}_{3} \mathrm{~A}_{7} \mathrm{Bh}$, स $\mathrm{S}_{2} \mathrm{~S}_{3}$ 
या तु तेनाननुज्ञाता धर्मं कुर्याच्छुचिस्मिताः।

न तत्फलं सा लभते लभते चासतीफलम्॥ ६९ ॥

या तु भर्त्राम्यनुज्ञाता कृत्वा धर्म सुपुष्कलम्।

दद्यात्तु पतये नारी तस्यानन्तं हि तत्फलम्॥ ७०॥

यच्च प्रार्थयते किंचिदिह लोके परत्र वा।

तत्सर्वं प्राप्तुते देव्यः सुभगा चाभिजायते॥ ७१॥

वश्यश्चास्या भवेद्रर्ता प्रिया तस्य च सा तदा।

पुत्रप्रजा च भवति न च दुःखं समश्नुते।

एष धर्मों मयाख्यातो युष्माकं लोकमातरः ॥ ७२॥

69b धर्मं कुर्याच्छुचिस्मिताः ] कुर्य्याद्धर्मानिमानिह $\mathrm{R}$ 69d लभते चासतीफलम् ] सती चाप्यसती भवेत् $R$ 70cd ] पत्युर्दद्यात्तथा नारी तस्यास्तदक्षयं भवेत् $R$ 71a यच्च] यद्यत् $R$ 71b वा] च $R$ 71c प्राप्तुते ] प्राप्तुयाद् $R \quad 72 \mathrm{a}$ वश्यश्चास्या भवेड़्ता ] वश्यो भर्ता भवेच्चास्याः $R$ 72c पुत्रप्रजा ] पुत्रप्रदा $\mathrm{R} \quad \mathbf{7 2 f}$ After this $\mathrm{R}$ has six pādas with colophon reading अतो ब्रवीमि किचुच्यच्छ्छोतुं कथय शोभनाः ॥ अयं हि धर्म्मः सुमहानतिप्रभः सुदुष्करश्चाप्यकृतात्मभिर्व्वराः। न चैवमन्यस्य सतश्च कस्यचित्स धर्म्मिणो वै कथयामि धर्म्मवित् ॥ इति स्कन्दपुराणे रेवाखण्डे उमासावित्यादिसम्वादः॥; subsequently R has a long insertion, for which see $\mathrm{SP}_{\mathrm{RA}} 112.1$ and 112.2.

69a या तु ते॰ ] यावत्ते॰ $A$ 69b धर्म कुर्याच्छुचिस्मिता: ] कुर्य्याद्वर्म्म विभाविनी $A$ 69d लभते चासतीफलम् ] तत्पत्नी सा $\left\{\right.$ चा॰ $\left.\mathrm{A}_{7}\right\}$ सती भवेत् $\mathbf{A}$ 70a भर्राभ्यनु० ] $\mathrm{A}_{7}$, भद्राश्चानु० $\mathrm{A}_{3} \mathrm{~A}_{4}$ 70cd ] पत्युर्दद्याददीनात्मा तस्यास्तु अक्षयं भवेत् $A$ 71a यच्च ] यदि $\mathrm{A}_{3} \mathrm{~A}_{7}$, यद्यत् $\mathrm{A}_{7}^{\mathrm{pc}}$, य(ति) $\mathrm{A}_{7}^{\mathrm{ac}} \mathbf{7 1 b}$ वा ] च $\mathbf{A} \quad 71 \mathrm{c}$ प्राप्तुते ] प्राप्तुयाद् $\mathbf{A}$ 71d सुभगा ] $\mathrm{A}_{7}$, शुभगा $\mathrm{A}_{3} \mathrm{~A}_{4}$ • चाभि०] $\mathrm{A}_{4} \mathrm{~A}_{7}$, चापि $\mathrm{A}_{3}$ 72a वश्यश्चास्या भवेद्रता ] वश्यो भर्ता भवेच्चास्या $\left\{\circ\right.$ स्या: $\left.\mathrm{A}_{7}^{\mathrm{pc}}\right\} \mathrm{A}^{72 \mathrm{c}}$ पुत्रप्रजा ] $\mathrm{A}_{4}$, पुत्र-

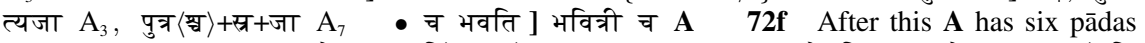
with colophon reading अतो भूयश्च किं त्वन्यं ०न्यत् $\mathrm{A}_{7}$, ०न्य $\left.\mathrm{A}_{4}\right\}$ श्रोतुमिच्छथ शोभनाः॥ अयं हि धर्मः सुमहानतिप्रभः सुदुष्करश्चाप्यकृतात्मभिर्वराः। न चैवमन्यस्य शठस्य कस्यचिदर्भिणो कथयीत धर्मवत् ॥ इति $\left\{\right.$ इति श्री॰ $\left.\mathrm{A}_{4} \mathrm{~A}_{7}\right\}$ स्कन्दपुराणे एकाशीतिसाहस्त्यां संहितायामम्बिकाखण्डे उमासावित्री $\left\{\circ\right.$ त्या: $\mathrm{A}_{7}$, ०न्या $\mathrm{A}_{4}$ \}संवादे एकादशोत्तरशतो $\left\{\right.$ शतोत्तमो $\left.\mathrm{A}_{3}\right\}$ ध्यायः ॥ \pm ; subsequently $\mathbf{A}$ has a long insertion, for which see $\mathrm{SP}_{\mathrm{RA}} 112.1$.

69 $\left(a^{1}-b^{8}\right)\left\langle c^{1}\right\rangle\left(c^{2}-c^{3}\right)\left\langle c^{4}-c^{7}\right\rangle\left(c^{8}-d^{1}\right)\left\langle d^{2}-d^{8} \rightarrow\right\rangle S_{1},\left(b^{1}-b^{8}\right) S_{2},\left(d^{1}-d^{3}\right) S_{3} \quad \mathbf{7 0}\left\langle\leftarrow a^{1}-b^{8}\right\rangle\left(c^{1}-d^{8}\right) S_{1}$ $71\left(a^{1}-a^{4}, a^{7}-b^{8}, c^{4}\right) S_{1}$

69b धर्मं ] em. Bh (silently), (धम्म) $\mathrm{S}_{1}$ (upper parts lost), (धर्म) $\mathrm{S}_{2}$ (tops lost), धर्म्म $\mathrm{S}_{3}$ • कुर्याच्छुचिस्मिता: ] em., (कुर्याच्छुचिस्मित) $\mathrm{S}_{1}$, (कुर्याच्छुचिस्मिता) $\mathrm{S}_{2}$, कुर्याच्छुचिस्मिता $\mathrm{S}_{3}$, किस्चित् समाचरेत् $\mathrm{Bh}$ (conj.) 69d चासती॰ $] \mathrm{S}_{2}^{\mathrm{ac}} \mathrm{S}_{3} \mathrm{~A}_{7}$, च सती $\mathrm{S}_{2}^{\mathrm{pc} B h}$ 70a भर्त्राभ्यनु०] $\mathrm{RA}_{7} \mathrm{Bh}$ (conj.), भर्ता ह्यनु० $\mathrm{S}_{2} \mathrm{~S}_{3} \quad$ 70b धर्मं] $\mathrm{S}_{2} \mathrm{RABh}$, धर्म्म $\mathrm{S}_{3} \quad$ 70c दद्यात्तु $] \mathrm{S}_{1} \mathrm{~S}_{2} B h$, दद्या तु $\mathrm{S}_{3}$ - पतये ] $S_{1} S_{3}$, पतयो $S_{2}^{p c}$, प(र)ये $S_{2}^{\text {ac }}$, पत्युर्या $B h$ (conj.) 70d तस्यानन्त ] $S_{1} B h$, तस्यानन्त्यं $\mathrm{S}_{2} \mathrm{~S}_{3}$ - हि तत्फलम् ] $\mathrm{S}_{2} \mathrm{~S}_{3}$, (हितफल)म् $\mathrm{S}_{1}^{\mathrm{pc}}$ (tops lost, unmetrical), (फलहित)म् $\mathrm{S}_{1}^{\text {ac }}$ (tops lost, unmetrical), भवेत्फलम् Bh (conj.) 71a यच्च $S_{2} B h$, यश्च $S_{1}$, य च $S_{3}$ 71c तत्सर्वं] $\mathrm{S}_{1} \mathrm{~S}_{2}^{\mathrm{pc}} \mathrm{S}_{3} \mathrm{RABh}$, तत्संवा $\mathrm{S}_{1}^{\mathrm{ac}}$ - प्राप्तुते ] $\mathrm{S}_{1} \mathrm{Bh}$, प्राप्यते $\mathrm{S}_{2} \mathrm{~S}_{3}$ - देव्यः ] $\mathrm{S}_{1} \mathrm{~S}_{2}^{\mathrm{pc}} \mathrm{Bh}$, देव्या $\mathrm{S}_{2}^{\mathrm{ac}}$, देव्य $S_{3} \quad 71 d$ ०गा चाभि॰] $S_{3} R_{4} A_{7}$, ०गा चापि $S_{1} B h$, ०गाचाभि० $S_{2} \quad$ 72a ० ग्चास्या ] $S_{2}^{p c} B h$ (em.?), ०ग्चास्य $\mathrm{S}_{1} \mathrm{~S}_{2}^{\mathrm{ac}} \mathrm{S}_{3} \quad$ 72c भवति ] $\mathrm{S}_{1} \mathrm{~S}_{2} \mathrm{~S}_{3} \mathrm{R}$, भति Bh (typo, unmetrical) $72 \mathrm{f}$ ०मातर: ] $\mathrm{S}_{1} \mathrm{~S}_{2}^{\mathrm{pc}} \mathrm{RABh}$, ०मातरम् $\mathrm{S}_{2}^{\mathrm{ac}}$, ०मातरां $\mathrm{S}_{3}$ - After this Bh has six pādas reading अतो भूयश्च किं त्वन्यच्छ्रोतुमिच्छाथ शोभानाः (typo, unmetrical)॥ अयं हि धर्मः सुमहानतिप्रभः सुदुस्करश्चाप्यकृतात्मभिर्वराः। न चैनमन्यस्य शठस्य कस्यचिदधर्मिणो वा कथयीत धर्मवित् ॥ (conj.?) 


\section{सनत्कुमार उवाच।}

ततस्ता: सहिता: सर्वा देव्यो लोकस्य मातरः।

पूर्जयित्वा महादेवीमूचुः संहृष्टचेतसः॥ ७३॥

अहो धर्मस्त्वयाख्यातः सर्वामरनमस्कृते।

यस्य संसेवनात्क्ष्कप्रं प्राप्यते सुमहत्फलम्॥ ७४॥

इतो वीक्षामहे देवि गिरेरस्य वनं शुभम्।

पुष्पजातिसमाकीर्ण बहुपक्षिगणावृतम्॥ ७४ ॥

तत उत्थाय सा देवी सहिता देवमातृभिः।

मन्दरस्य गिरेर्दिव्यं द्रृष्ट तद्वनमुत्तमम्।

विचचार महायोगा चक्षुर्देहसुखावहम्॥ ७६॥

मानःशिलानि शृड़ाणि सौवर्णानि च वीक्षती।

रम्याणि सिततोयानि गिरे: प्रस्रवणानि च॥ ७७॥

सरांस्युत्पलपूर्णानि वापीश्च सुमनोहराः।

तुतोष गिरिजा दृष्ट्वा पार्श्वसंस्थं च नन्दिनम्॥ ७५॥

ततः सा देवदेवी तु विचरन्ती महागिरिम्।

अपश्यद्वालसूर्याभं बालाशोक सुपुष्पितम्।

आताम्रपल्नवशतै : कृत्वाअलिमवस्थितम्॥ ७९॥

73ab-80 ] Instead of this $\mathrm{R}$ has 54 pādas with two speaker indications (see $\mathrm{SP}_{\mathrm{RA}}$ 112.3.1ab-4, $6-14)$.

73 सनत्कुमार उवाच ] om. A 73ab-80 ] Instead of this A has 46 pādas with two speaker indications (see $\mathrm{SP}_{\mathrm{RA}}$ 112.3.1ab-7ab, 10cd-14).

$79\left(d^{4}\right) S_{1}$

73 सनत्कुमार ] $\mathrm{S}_{2} \mathrm{~S}_{3} \mathrm{RBh}$ (सन in $\mathrm{S}_{2}$ ), सना $\mathrm{S}_{1}$ 73a ततस्ता: ] $\mathrm{S}_{1}^{\mathrm{pc}} \mathrm{S}_{2} B h$, ततस्ता $\mathrm{S}_{1}^{\text {ac }} \mathrm{S}_{3}$ सहिता: ] $\mathrm{S}_{1}^{\mathrm{pc}} \mathrm{S}_{2} \mathrm{~S}_{3} \mathrm{Bh}$, सहिता $\mathrm{S}_{1}^{\mathrm{ac}}$ 73b मातर: ] $\mathrm{S}_{1} \mathrm{~S}_{2} \mathrm{~S}_{3}^{\mathrm{pc}} \mathrm{Bh}$, मातर $\mathrm{S}_{3}^{\mathrm{ac}}$ 73d संहृष्ट॰] $\mathrm{S}_{1} \mathrm{~S}_{2}$ $\mathrm{Bh}$, सहृष्ट० $\mathrm{S}_{3}$ (unmetrical) 74d ०त्फलम् $] \mathrm{S}_{1}^{\mathrm{pc}} \mathrm{S}_{2} \mathrm{~S}_{3} \mathrm{Bh},\left({ }^{\circ}\right.$ त्व)लं $\mathrm{S}_{1}^{\mathrm{ac}}$ 75a वीक्षामहे देवि ] $\mathrm{S}_{2} \mathrm{Bh}$, वीक्ष्य महादेवी $\mathrm{S}_{1}^{\mathrm{pc}}$, वीक्ष महादेवी $\mathrm{S}_{1}^{\mathrm{ac}}$, वीक्षमहे देवि $\mathrm{S}_{3} \quad \mathbf{7 6 a}$ तत ] $\mathrm{S}_{1}^{\mathrm{pc}} \mathrm{S}_{2} \mathrm{~S}_{3} \mathrm{Bh}$, ततः $\mathrm{S}_{1}^{\mathrm{ac}}$ - देवी ] $\mathrm{S}_{1} \mathrm{~S}_{2}^{\mathrm{pc}} \mathrm{S}_{3} \mathrm{Bh}$, देवि $\mathrm{S}_{2}^{\mathrm{ac}} \quad \mathbf{7 6 b}$ ०मातृभि: ] $\mathrm{S}_{1} \mathrm{~S}_{2} \mathrm{~S}_{3}^{\mathrm{pc}} \mathrm{Bh}$, ०मातृभि $\mathrm{S}_{3}^{\mathrm{ac}}$ 76c गिरेदिव्यं ] $\mathrm{S}_{1} \mathrm{~S}_{2} \mathrm{Bh}$, गिरे दिव्य $\mathrm{S}_{3}$ 76ef ०योगा चक्षुर्देह॰] $\mathrm{S}_{1}^{\mathrm{pc}}$, ०योगा चक्षुदेव $\mathrm{S}_{1}^{\mathrm{ac}}$, ०योगाचक्षुर्देह॰ $\mathrm{S}_{2}$, ०योगा चक्षुदेह $\mathrm{S}_{3}$, ०योगा चक्षुर्दत्वा $\mathrm{Bh}$ (conj.) $\mathbf{7 6 f}$ ०सुखावहम् ] $\mathrm{S}_{1} \mathrm{~S}_{2} \mathrm{~S}_{3}$, सुखापहम् $\mathrm{Bh}$ (typo?) 77a मान:०] $S_{2} S_{3} B h$, मन:० $S_{1}$ • शृड़ाणि ] $S_{2} B h$, शृड़ानि $S_{1} S_{3}$ 77c रम्यांणि ] $\mathrm{S}_{2} \mathrm{~S}_{3} \mathrm{Bh}$, रम्यानि $\mathrm{S}_{1}$ 77d गिरे: $\mathrm{S}_{1} \mathrm{~S}_{2} \mathrm{~S}_{3}^{\mathrm{pc}} \mathrm{Bh}$, गिरे $\mathrm{S}_{3}^{\mathrm{ac}}$ 78a सरांस्यु॰] $\mathrm{S}_{1} \mathrm{~S}_{2} \mathrm{Bh}$, सराभ्यु॰ $\mathrm{S}_{3}$ • ०पूर्णानि ] $\mathrm{S}_{1} \mathrm{~S}_{2} \mathrm{Bh}$, ०पूण्णानि $\mathrm{S}_{3} \quad \mathbf{7 8 b}$ ॰मनोहरा: ] $\mathrm{S}_{1} \mathrm{Bh}$, ०मनोहरा $\mathrm{S}_{2} \mathrm{~S}_{3}$ 78c तुतोष ] $S_{1}^{\mathrm{pc}} \mathrm{S}_{2} \mathrm{~S}_{3} \mathrm{Bh}$, तुतोश $\mathrm{S}_{1}^{\mathrm{ac}} \mathbf{7 8 d}$ After this Bh has 44 pādas with a speaker indication (see $\mathrm{SP}_{\mathrm{RA}}$ 112.3.1a-7b,10c-14d). 79a तत: ] $\mathrm{S}_{1} \mathrm{~S}_{2}$, तत $\mathrm{S}_{3}$, तथा Bh (conj.) • तु ] $\mathrm{S}_{1} \mathrm{~S}_{2} \mathrm{~S}_{3}$, तं $\mathrm{Bh}$ (conj.) 79b विचरन्ती ] $\mathrm{S}_{1}^{\mathrm{pc}} \mathrm{S}_{2} \mathrm{~S}_{3} \mathrm{Bh}$, धिचरन्ती $\mathrm{S}_{1}^{\text {ac }}$ • महागिरिम् ] $\mathrm{S}_{1} \mathrm{~S}_{2} \mathrm{~S}_{3}$, महागिरौ $\mathrm{Bh}$ (conj.) 79e ०पल्नव०] $S_{1} S_{2} B h$, ०पलव $S_{3}$ (unmetrical) $79 f$ कृत्वा॰] $S_{1} S_{2} B h$, कृता $S_{3}$ - ०मवस्थितम् ] $\mathrm{S}_{2} \mathrm{~S}_{3}^{\mathrm{pc}} \mathrm{Bh}$, ०मुपस्थितम् $\mathrm{S}_{1}$, ०मवस्थित $\mathrm{S}_{3}^{\mathrm{ac}}$ 


\section{तं दृष्ट्रा गिरिजा देवी परां प्रीतिमगान्मुने । \\ एष मे तनयः श्नाघ्यो भविता नन्दिवर्धनः॥ ५०॥ भगवत्यागते ह्येनमनुज्ञाता स्वयम्भुवा। \\ ग्रहीष्यामि प्रियं पुत्रं बालाशोकं सुपादपम्॥ ५? ॥ \\ अथास्मिन्नन्तरे तत्र उत्पातो उतीव भीषणः। \\ वायुवेगो महानासीद्भिरिवृक्षनिपातनः॥ ५२॥ \\ अन्धको ऽपि तदा दैत्य: पातालान्मन्दरं ययौ। \\ प्रह्लादप्रमुखैर्देत्यैद्दानवैश्च सहस्रशः। \\ वृतः श्रीमान्महादैत्यः शक्रो देवगणैरिव॥ ५३॥ \\ सो इन्धकः सुमहावीर्यः सखीभिः सहितां तदा। \\ अपश्यद्देवदेवीं तु वृकः सिंहवधूमिव॥ ५४॥}

81ab ] om. R 81cd ] इयं तेनाभ्यनुज्ञाता ग्रहीष्ये पादपं सुतम् R 82 ] Instead of this R has 36 pādas with three speaker indications (see $\mathrm{SP}_{\mathrm{RA}} 112.3 .16-20 \mathrm{ab}, 21-25 \mathrm{ab}$ ). 83a ऊपि तदा दैत्य: ] नाम दैत्येन्द्र: $R \quad 83 b$ पातालान्मन्दरं ] प्रपातान्मन्दिरं $R \quad 83 c-f$ ] Instead of this $R$ has 52 pādas with a speaker indication (see $\mathrm{SP}_{\mathrm{RA}} 112.3 .26-28,29 \mathrm{~cd}, 30 \mathrm{~cd}-31 \mathrm{ab}, 32 \mathrm{~cd}-39$ ). $\quad$ 84a ०क: सुमहावीर्यः ] क को विचरंस्तत्र R 84b सहितां तदा ] सह पार्वतीम् R 84cd ] अपश्यद्दानव: कूर: स काले ब्राह्मणीमिव $\mathrm{R}$

81 ] आगते पुनरेवेह देवदेवैरतिष्टत $\left\{\right.$ वै अधिष्टिते $\left.\mathrm{A}_{7}\right\}$ । इमं तेनाभ्यनुज्ञाता ग्रहीष्ये पादपं शुभा $\left\{\right.$ सुता $\left.\mathrm{A}_{7}\right\}$ A 82 ] Instead of this $\mathbf{A}$ has 32 pādas with two speaker indications (see $\mathrm{SP}_{\mathrm{RA}}$ 112.3.16-22, 24cd-25ab). $83 \mathbf{a}$ पपि तदा दैत्य: ] नाम दैत्ये $\left\{{ }^{\circ}\right.$ ते॰ $\left.\mathrm{A}_{4}\right\}$ न्द्र: $\mathbf{A} \quad \mathbf{8 3 c}-\mathbf{f}$ ] Instead of this $\mathrm{A}_{3} \mathrm{~A}_{4}$ have 46 pādas and $\mathrm{A}_{7} 58$ pādas, with a speaker indication (see $\mathrm{SP}_{\mathrm{RA}} 112.3 .26-35 \mathrm{~cd}, 36 \mathrm{~cd}-39$ ). 84a कक: सुमहावीर्यः ] क को विचरंस्तत्र $A$ 84b सखीभिः ] $\mathrm{A}_{3} \mathrm{~A}_{7}$, ऋषिभिः $\mathrm{A}_{4}$ - सहितां तदा ] सह पार्वतीं $\mathbf{A} 84 \mathrm{~cd}$ ] अपश्यद्दानवः क्रूर: श्व $\left\{\right.$ स्व० $\left.\mathrm{A}_{7}\right\}$ पाको ब्राह्मणीमिव $\mathbf{A}$

82 $\left(b^{2}-b^{3}\right) S_{1} \quad 84\left(c^{1}-c^{4}\right) S_{1},\left(c^{1}-c^{6}\right) S_{2}$

80a तं ] $\mathrm{S}_{1} \mathrm{~S}_{2} \mathrm{Bh}$, त $\mathrm{S}_{3}$ • देवी ] $\mathrm{S}_{1} \mathrm{~S}_{2}^{\mathrm{pc}} \mathrm{S}_{3} \mathrm{Bh}$, देवीम् $\mathrm{S}_{2}^{\mathrm{ac}} \quad \mathbf{8 0 b}$ ॰मगान्मु॰ $] \mathrm{S}_{1} \mathrm{~S}_{2} \mathrm{Bh}$, ॰ मगार्मु॰ $\mathrm{S}_{3}$ - After this Bh has two pādas (see $\mathrm{SP}_{\mathrm{RA}}$ 112.3.14ef) 80d ०वर्धन: ] $\mathrm{S}_{1} \mathrm{~S}_{3} \mathrm{Bh}$, ववद्धन: $\mathrm{S}_{2}$ 81a भगवत्यागते ] em. Bh (silently), भगवानागते $\mathrm{S}_{1}$, भगवत्यासते $\mathrm{S}_{2} \mathrm{~S}_{3} \quad \mathbf{8 1 b}$ स्वयम्भुवा ] $\mathrm{S}_{2} \mathrm{~S}_{3} \mathrm{Bh}$, स्वयम्भुना $\mathrm{S}_{1}$ 81d ०शोकं सु॰] $\mathrm{S}_{1}$, ०शोकस्य $\mathrm{S}_{2} \mathrm{~S}_{3} \mathrm{Bh}$ - After this Bh has 8 pādas with a speaker indication (see $\mathrm{SP}_{\mathrm{RA}}$ 112.3.16-17). $\quad$ 82ab तत्र उत्पातो उतीव ] $\mathrm{S}_{1}^{\mathrm{pc}} \mathrm{S}_{2}$, तत्त्र उ(त्पातो) भीव $\mathrm{S}_{1}^{\mathrm{ac}}$, न्तत्त उत्पातो ती $\left\{\right.$ भी॰ $\left.\mathrm{S}_{3}^{\mathrm{ac}}\right\}$ व $\mathrm{S}_{3}$, भूवन्तुत्पातास्तत्र $\mathrm{Bh}$ (conj.) 82b भीषणः $] \mathrm{S}_{1} \mathrm{~S}_{2}^{\mathrm{pc}}$, भीषण $S_{2}^{\text {ac }}$, भीषण $S_{3}$, भीषणा: $B h$ (conj.) 82cd ०नासीद्निरि॰] $S_{1} B h$, ०नासीड़िरि॰ $S_{2}$, ०नासीं गिरी॰ $\mathrm{S}_{3} \quad$ 82d After this Bh has 20 pādas (see $\mathrm{SP}_{\mathrm{RA}}$ 112.3.18-22) with a speaker indication, conjectures two pādas, and has four pādas with a speaker indication (see $\mathrm{SP}_{\mathrm{RA}} 112.3 .24 \mathrm{~cd}-25 \mathrm{ab}$ ). 83a अन्धको ] $S_{1} S_{2}^{\text {pc }} S_{3} R A B h$, अ(र्थ)को $S_{2}^{\text {ac }}$ - तदा दैत्यः ] em. Bh (silently), तथा दैत्य: $S_{1}$, तदाभ्येत्य $S_{2}^{p c}$, तदा(द्य) म्य $S_{2}^{a c}$, तदाद्यैत्य $S_{3}^{p c}$, तदाद्यत्य $S_{3}^{\text {ac }} \quad 83 b$ पातालान् ] $S_{2} S_{3} A B h$, पाता-

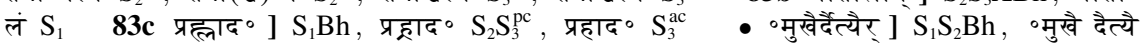
$\mathrm{S}_{3} \quad 83 \mathrm{e}$ ०न्महादैत्य:] $\mathrm{S}_{1} \mathrm{~S}_{2}^{\mathrm{pc} B h}$, ०न्महादैत्य $\mathrm{S}_{2}^{\mathrm{ac}} \mathrm{S}_{3} \quad \mathbf{8 3 f}$ ०रिव $] \mathrm{S}_{1} \mathrm{~S}_{2}^{\mathrm{pc}} \mathrm{S}_{3} B \mathrm{Bh}$, (०रपि) $\mathrm{S}_{2}^{\mathrm{ac}}$ After this Bh has 46 pādas with a speaker indication (see $\mathrm{SP}_{\mathrm{RA}} 112.3 .26-33,36 \mathrm{~cd}-39$ ). $\quad$ 84a सो ऽन्धक: $\mathrm{S}_{1} \mathrm{~S}_{2}^{\mathrm{pc}} \mathrm{S}_{3}$, सो (र्थ)क: $\mathrm{S}_{2}^{\mathrm{ac}}$, सो न्धको $\mathrm{Bh} \bullet$ सुमहावीर्यः ] $\mathrm{S}_{1} \mathrm{~S}_{2}^{\mathrm{pc}}$, सुमहावीर्य $\mathrm{S}_{2}^{\mathrm{ac}} \mathrm{S}_{3}$, विचरंस्तत्र $B h$ 84b सखीभि: ] $S_{1} S_{2} R_{3} A_{7} B h$, सखीभि $S_{3} 84 c$ अपश्यद् ] $S_{1} S_{2} R A B h$, अपश्य $\mathrm{S}_{3}$ - ०देवों तु $] \mathrm{S}_{1} \mathrm{~S}_{2}$, ॰देवी तु $\mathrm{S}_{3} B$ h (typo) 84d After this Bh inserts a separate text of 36 pādas with two speaker indications, saying that it is found only in $\mathrm{A}_{3}$ (see $\mathrm{SP}_{\mathrm{RA}}$ 112.3.41-48). 
दृष्ट्रा भगवतीं देवीं स दैत्यो मूढचेतनः।

प्रणामं नाकरोद्वास अन्ववेक्षत केवलम् ॥ 5, ॥

तं दृष्ट्रानिमिषं दैत्यं पश्यन्तमचलात्मजाम्।

प्रह्लादस्तु महाबुद्धिरिदमाह वचो रर्थवत्॥ ५६॥

जगतो जननी ह्येषा हिमवद्हुहिताव्यया।

उमेति जगति ख्याता तपोयोगबलान्विता॥ ५७॥

यस्य पुत्रो ऽवद्रह्मा सर्वलोकपितामहः।

अस्माकं देवतानां च यो ददाति वराग्छुभान्॥ ५. ॥

यः स्थितः सर्वमाविश्य भूतग्राममशेषतः।

यस्यात्मना सर्वमिदं धार्यते जगदव्ययम्॥ ५९ ॥

पत्नीयं तस्य देवस्य परमेशस्य धीमतः।

शक्ता हीयं जगत्सर्वं क्षणेन दितिजाधिप॥ ९०॥

85-86 ] Instead of this $\mathrm{R}$ has 36 pādas with three speaker indications (see $\mathrm{SP}_{\mathrm{RA}}$ 112.3.41-speaker indication of 49). $87 \mathrm{a}$ जगतो जननी ह्येषा ] इयं लोकस्य जननी $R \quad 87 \mathrm{~b}$ हदुहिताव्यया ] ${ }^{\circ}$ त्तनया शुभा $R \quad 87 \mathrm{c}$ जगति ] लोके वि॰ $R \quad 88 \mathrm{~b}$ सर्वलोकपितामहः ] प्राजापत्यश्च या ददौ $R$ - After this $\mathrm{R}$ has two pādas (see $\mathrm{SP}_{\mathrm{RA}} 112.3 .50 \mathrm{~cd}$ ). $\quad \mathbf{8 8 d}$ यो ददाति वरान्छुभान् ] या वरांस्तोषिता ददौ $R$ 89ab ] Instead of this $R$ has 6 pādas (see $\left.S_{R A} 112.3 .51 \mathrm{~cd}-52\right)$. 89c यस्यात्मना सर्वमिदं ] यस्यास्तु तनुभिः सर्व्व $R$ 90ab ] तस्य रुद्रस्य शर्व्वस्य पत्नीयं दानवेश्वर $R$ pādas (see $\left.\mathrm{SP}_{\mathrm{RA}} 112.3 .54 \mathrm{ab}\right)$. 90d ०न दितिजाधिप ] ०नैवासुरेश्वर $\mathrm{R}$

- After this R has two

85-86 ] Instead of this A has 36 pādas with three speaker indications ( indication of 49). 87a जगतो जननी ह्येषा ] इयं लोकस्य जननी A $87 \mathrm{~b}$ ०हुहिता० ] ०तनया० A $87 \mathrm{c}$ जगति ] लोकवि॰ $\mathrm{A} 88 \mathrm{~b}$ सर्वलोकपितामहः ] प्राजापत्यं च यो ददौ $\mathbf{A}$ - After this $\mathbf{A}$ has two pādas (see $\left.\mathrm{SP}_{\mathrm{RA}} 112.3 .50 \mathrm{~cd}\right) . \quad \mathbf{8 8 d}$ यो ददाति वराभ्छुभान् ] यो वरांस्तोषितो ददौ $\mathbf{A}$ 89ab ] Instead of this $\mathbf{A}$ has 4 pādas (see $\mathrm{SP}_{\mathrm{RA}}$ 112.3.51cd-52ab). 89c-91b ] om. A

$\mathbf{8 5}\left(a^{2}\right) S_{2} \quad \mathbf{8 6}\left\langle c^{1}\right\rangle S_{1},\left\langle a^{1}\right\rangle\left(a^{2}-a^{3}\right) S_{2} \quad \mathbf{8 8}\left\langle a^{5}\right\rangle\left(a^{6}-b^{2}\right) S_{2} \quad \mathbf{8 9}\left(d^{1}\right)\left\langle d^{2}-d^{3}\right\rangle S_{1}$

85a दृष्टा ] $\mathrm{S}_{1} \mathrm{~S}_{2} \mathrm{Bh}$, दृष्टा $\mathrm{S}_{3} \quad 85 \mathrm{ab}$ ०वतीं देवीं स ] $\mathrm{S}_{2} \mathrm{Bh}$, ०वतीन्देवीन्सो $\mathrm{S}_{1}$, ॰वती देवी स $\mathrm{S}_{3}$ $85 b$ चेतन: ] $S_{2} S_{3} B h$, ०चेतस: $S_{1} \quad 85 c$ प्रणामं नाकरोद् ] $S_{2}^{\mathrm{pc}} S_{3} B h$, प्रणामन्नारकोद् $S_{1}$, प्राणामन्नाकरोद् $S_{2}^{\text {ac }} \quad 85 d$ अन्ववेक्षत ] $S_{1} S_{2} S_{3}$, अन्ववैक्षत $B h(e m) \quad$.$86 b ०लात्मजाम् ] S_{2} S_{3}^{p c} B h$, ॰लात्मजान् $S_{1}$, ०लात्मज $S_{3}^{\text {ac }} \quad 86 \mathrm{c}$ हहादस्तु ] $S_{1} B h$, ॰हादस्तु $S_{2} S_{3} \quad 87 a$ जगतो जननी ह्येषा ] $\mathrm{S}_{1} \mathrm{~S}_{2} \mathrm{~S}_{3}$, इयं लोकस्य जननी $\mathrm{Bh}$ 87b ॰वहुहिता॰] $\mathrm{S}_{1} \mathrm{~S}_{2}$, ०वदुहिता॰ $\mathrm{S}_{3}$ (unmetrical), ०वत्तनया० $\mathrm{Bh} \bullet$ व्यया ] $\mathrm{S}_{1}^{\mathrm{pc}} \mathrm{S}_{2} \mathrm{~S}_{3} \mathrm{ABh}$, व्यय $\mathrm{S}_{1}^{\mathrm{ac}}$ 87c ख्याता ] $\mathrm{S}_{1} \mathrm{~S}_{2} \mathrm{~S}_{3} R A$, ख्यता Bh (typo, unmetrical) 88a यस्य ] RABh, यस्या: $\mathrm{S}_{1} \mathrm{~S}_{2} \mathrm{~S}_{3} \quad 88 \mathrm{~b}$ सर्वलोकपितामहः ] $\mathrm{S}_{1} \mathrm{~S}_{2}^{\mathrm{pc}}$, सर्वलोकपितामह $\mathrm{S}_{2}^{\mathrm{ac}} \mathrm{S}_{3}$, प्रजापत्यं च यो ददौ $\mathrm{Bh}$ (typo) - After this Bh has two pādas (see $\mathrm{SP}_{\mathrm{RA}} 112.3 .50 \mathrm{~cd}$ ). 88d वरान्छुभान् $] \mathrm{S}_{1} \mathrm{~S}_{2} \mathrm{Bh}$, वराच्छुभां $\mathrm{S}_{3}$ - After this Bh has two pādas (see $\mathrm{SP}_{\mathrm{RA}} 112.3 .51 \mathrm{~cd}$ ). 89a स्थितः ] $\mathrm{S}_{1} \mathrm{~S}_{2} \mathrm{Bh}$, स्थित $\mathrm{S}_{3}$ (unmetrical) 89b ०मशेषतः ] $\mathrm{S}_{1} \mathrm{~S}_{2} \mathrm{~S}_{3}^{\mathrm{pc} B h}$, ०मषेषतः $\mathrm{S}_{3}^{\mathrm{ac}} 89 \mathrm{8c}$ ०मिद ] $S_{1} S_{2} B h$, ०मिद $S_{3}$ 89d जगद०] $S_{2} S_{3} R B h$, जद० $S_{1}$ (unmetrical) - After this Bh has two pādas (see $\mathrm{SP}_{\mathrm{RA}} 112.3 .52 \mathrm{ab}$ ). 90a पत्नीयं तस्य ] $\mathrm{S}_{2} \mathrm{Bh}$, पत्नी मन्त्रस्य $\mathrm{S}_{1}$, पनीयन्तस्य $\mathrm{S}_{3}$ $90 \mathrm{c}$ हीयं ] $\mathrm{S}_{1} \mathrm{~S}_{2} \mathrm{RBh}$, हीय $\mathrm{S}_{3}$ 
दग्धुं वाप्यथवा हतुं क्षेत्तुं नरक एव वा।

कथमस्याः प्रणामं त्वं नाकरोर्देत्य मोहित॥ ९ १॥

सनत्कुमार उवाच।

अथैवं ब्रुवतस्तस्य धर्मयुकं सुरद्विषः

देवीभि: सहिता देवी क्षणेनान्तर्हिता मुने॥ ९२॥

अथ ते दैत्यपा: सर्वे विचरन्तो महागिरौ।

बहुनिर्झरसंकीर्ण नानापादपसंकुले॥ ९३॥

तत्र ते विचरन्तस्तु एकस्मित्रिर्ईरे स्थितान्।

अपश्यन्सपर्षर्षीन्सिद्धान्योगयुक्तान्महामुनीन्॥ ९ ॥

तान्दृष्ट्रा सो उन्धको उपृच्छ,त्प्रह्लादमसुरोत्तमम् ।

क इमे ऋषयो ह्यत्र किमर्थं चेह संगताः ॥ पू॥

91a वा हतुं ] हन्तुं वा $\mathrm{R}$ 91cd-93 ] Instead of this $\mathrm{R}$ has 22 pādas with a speaker indication (see $\mathrm{SP}_{\mathrm{RA}}$ 112.3.55cd-60). 94a ०स्तु ] ० श्च R 94b ०न्निर्झरे स्थितान् ] ०न्वासरे स्थिता: $\mathrm{R}$ 94cd ] सप्रर्षींस्तपसा शुद्धान् देवानामपि मानवा: $\mathrm{R}$ - After this $\mathrm{R}$ has two pādas (see $\mathrm{SP}_{\mathrm{RA}}$ 112.3.62 cd). 95ab ] तान् दृष्ट्रा ते उसुरास्तत्र अपृच्छन्त परस्परम् $\mathrm{R} \quad 95 \mathrm{c}$ क इमे ] इह मे $\mathrm{R}$ • ह्यत्र ] व्यास $\mathrm{R}$ 95d After this $\mathrm{R}$ has four pādas (see $\mathrm{SP}_{\mathrm{RA}}$ 112.3.64).

91cd-93 ] Instead of this $\mathbf{A}$ has 18 pādas (see $\mathrm{SP}_{\mathrm{RA}}$ 112.3.56cd-60). 94cd ] सपर्षीस्तपसा शुद्धानपश्यन्त महामुनीन् $\mathbf{A} \pm$ - After this $\mathbf{A}$ has four pādas (see $\mathrm{SP}_{\mathrm{RA}}$ 112.3.62). 95ab ] तान् दृष्ट्रा ते सुरास्तत्र अपृच्छन्त परस्परं $A \pm 95 \mathrm{c}$ ह्यत्र ] व्यास $\mathrm{A} 95 \mathrm{~d}$ किमर्थं चेह ] किं वा चेह च $\mathrm{A}$ - After this $\mathbf{A}$ has four pādas (see $\mathrm{SP}_{\mathrm{RA}}$ 112.3.64).

$91\left(d^{2}-d^{3}\right) S_{1} \quad 92\left\langle d^{4}\right\rangle\left(d^{5}\right) S_{1},\left(a^{5}\right) S_{2} \quad 95\left(d^{2}\right) S_{3}$

91a दग्धुं वा॰ $] \mathrm{S}_{1} \mathrm{~S}_{3} \mathrm{RBh}$, दग्धु $\langle($ ग्धु $)\rangle+$ ज्चा० ${ }^{\circ} \mathrm{S}_{2}$ • हत्तुं $] \mathrm{S}_{1} \mathrm{Bh}$, हन्तुं $\mathrm{S}_{2} \mathrm{~S}_{3}$ 91b वा ] $\mathrm{S}_{2} \mathrm{~S}_{3} \mathrm{R}$ $\mathrm{Bh}$, च $\mathrm{S}_{1}$ 91c ०मस्या: ] $\mathrm{S}_{2} \mathrm{~S}_{3} B h$, ०मस्या $\mathrm{S}_{1}$ - प्रणामं त्वं ] $\mathrm{S}_{1} \mathrm{Bh}$, प्रणमन्तं $\mathrm{S}_{2}$, प्रणामन्तं $\mathrm{S}_{3}$ 91d नाकरोर्दे॰] em. Bh (silently), ना (करो)त् दै॰ $S_{1}^{p c}$, नारको दै॰ $S_{1}^{a c}$, नाकरोद्दै० $S_{2}$, नाकरौ दै० $\mathrm{S}_{3}$ • मोहित ] $\mathrm{S}_{1} \mathrm{~S}_{2}^{\text {pc }}$, मोहितः $\mathrm{S}_{2}^{\mathrm{ac}} \mathrm{S}_{3} \mathrm{Bh}$ 92b सुरद्विषः ] $\mathrm{S}_{2} \mathrm{~S}_{3} B \mathrm{Bh}$, सुरद्विशः $\mathrm{S}_{1}$ 92c देवीभि: ] $\mathrm{S}_{1} \mathrm{~S}_{2} \mathrm{Bh}$, देवीभि $\mathrm{S}_{3}$ - देवी ] $\mathrm{S}_{2} \mathrm{~S}_{3} \mathrm{Bh}$, देवि $\mathrm{S}_{1}$ 92d ०नान्तर्हिता ] $\mathrm{S}_{2} \mathrm{~S}_{3} \mathrm{Bh}$, ०ना $\simeq$ (हि)+ता+ $\mathrm{S}_{1}$ - After this Bh conjectures loss of two pādas and has 18 pādas (see $\mathrm{SP}_{\mathrm{RA}} 112.3 .56 \mathrm{~cd}-$ 60). 93a दैत्यपाः ] $S_{1} S_{2} B h$, दैत्यपा $S_{3}$ 93b विचरन्तो ] $S_{1} S_{2} S_{3}$, व्यचरन्त Bh (conj.) 93c

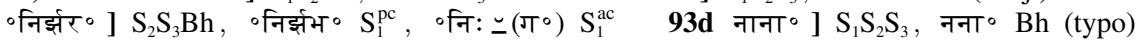
94a विचरन्त०] $S_{1} S_{2}^{\mathrm{pc}} S_{3} R A B h$, वचरन्त० $S_{2}^{\mathrm{ac}}$ 94b ०स्मित्निर्ररे ] $\mathrm{S}_{1} \mathrm{~S}_{2} \mathrm{ABh}$, ०स्मि निज्झरे $\mathrm{S}_{3}^{\mathrm{pc}}$ (unmetrical), ०स्मि निज्ररे $S_{3}^{\text {ac }}$ (unmetrical) 94c अपश्यन्सप्रर्षोन्सिद्धान् ] $S_{1} S_{2}$ (irregular vipulā), अपश्यन्सप्तषीं सिद्धान् $S_{3}$ (irregular vipulā), सिद्धानपश्यन् सप्रर्षोन् Bh (conj.) 94d ०युक्तान्] $S_{1}$ $\mathrm{S}_{2} \mathrm{Bh}$, ०युक्ता $\mathrm{S}_{3} \bullet{ }^{\circ}$ मुनीन् ] $\mathrm{ABh}$, ०मुनीम् $\mathrm{S}_{1}^{\mathrm{pc}} \mathrm{S}_{2} \mathrm{~S}_{3}$, मुनिम् $\mathrm{S}_{1}^{\mathrm{ac}} \bullet$ After this Bh has four pādas (see $\mathrm{SP}_{\mathrm{RA}}$ 112.3.62). 95a उपृच्छत् ] $\mathrm{S}_{1}^{\mathrm{pc}} \mathrm{S}_{2} \mathrm{~S}_{3} \mathrm{Bh}$, प्रच्छत् $\mathrm{S}_{1}^{\mathrm{ac}} \quad \mathbf{9 5 b}$ ॰ह्लादम॰] $\mathrm{S}_{1} \mathrm{Bh}$, ह हादम० $\mathrm{S}_{2} \mathrm{~S}_{3} \quad 95 \mathrm{c}$ ह्यत्र $] \mathrm{S}_{1} \mathrm{Bh}$, यत्त $\mathrm{S}_{2} \mathrm{~S}_{3}$ 95d किमर्थं ] $\mathrm{S}_{1} \mathrm{~S}_{2} \mathrm{RBh}$, कि(म)र्थ $\mathrm{S}_{3}$ (unmetrical)

- After this Bh has four pādas (see $\mathrm{SP}_{\mathrm{RA}}$ 112.3.64). 
प्रह्लाद उवाच।

एते इन्धक महात्मानो ऋषय: सप्त संगताः।

भृगुरत्रिर्मरीचिश्च विश्वामित्रो उड़िरास्तथा॥ ९६॥

भरद्वाजो वसिष्ठश्च योगसिद्वास्तपोधनाः ।

नैषां निष्कारणं मन्ये मन्दरागमनं प्रभो॥ ९७॥

इतो वयमिहैकान्ते स्थित्वा सर्वे उसुरेश्वराः।

मतं गृह्लीम सर्वेषां तूष्णीं तिष्ठत दैत्यपाः ॥ ५ ॥

ततस्तेषु स्थितेष्वेवमसुरेषु दुरात्मसु।

ऋषयस्ते तपोयुका वाक्यमूचुः परस्परम्॥ ९ ॥

न शुद्धो उयं गिरेरेशो गच्छामो उन्यत्र वै द्विजा:।

इहागमो हि दैत्यानां दृश्यते सुदुरात्मनाम्॥ १००॥

96a इन्धक ] चात्र $\mathrm{R} 96 \mathrm{~b}$ ॠषय: ] मुनय: $\mathrm{R}$ 96d उड्रिरास्तथा ] डथ काश्यप: $\mathrm{R}$ 97a वसिष्ठश्च ] वशिष्ठ R (unmetrical) 97b योगसिद्धास्तपोधना: ] ऋषयश्च तथा शुभा: $R$ - After this $\mathrm{R}$ has two pādas (see $\mathrm{SP}_{\mathrm{RA}}$ 112.3.66cd). $\quad 97 \mathrm{~d}$ प्रभो] प्रति $\mathrm{R} \quad \mathbf{9 8 a}$ इतो ] ततो $\mathrm{R} \quad \mathbf{9 8 b}$ स्थित्वा ] स्थिता: $R$ 98cd ] Instead of this $R$ has 8 pādas with a speaker indication (see $\mathrm{SP}_{\mathrm{RA}}$

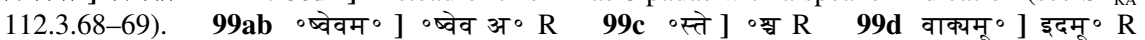
100ab ] अयं देशो ह्यशुद्धो उद्य शक्यामो वयमन्यतः $R \quad 100 \mathrm{~cd}$ ] Instead of this $R$ has four pādas (see $\mathrm{SP}_{\mathrm{RA}}$ 112.3.71c-72b).

96 प्रह्लाद ] सनत्कुमार A 96a उन्धक ] चात्र A 96b ऋषय: ] मुनयः A 97a वसिष्ट०] $\mathrm{A}_{3}$ $\mathrm{A}_{4}$, वशिष्ट० $\mathrm{A}_{7} \quad$ 97b योगसिद्धास्तपोधना: ] सत्तैते ऋषयः शुभा: $\mathbf{A}$ - After this $\mathbf{A}$ has two pādas (see $\mathrm{SP}_{\mathrm{RA}}$ 112.3.66 cd). 97c निष्कारणं ] निरीक्षण $\mathbf{A}$ 97d प्रभो] प्रति $\mathbf{A} 98 \mathrm{9}$ इतो ] ततो A $98 b$ स्थित्वा ] स्थिता: $\mathbf{A}$ - उसुरेश्वरा: ] $\mathrm{A}_{3} \mathrm{~A}_{4}$, उसुरेम्वर $\mathrm{A}_{7}$ 98cd ] Instead of this $\mathbf{A}$ has 8 pādas with a speaker indication (see $\mathrm{SP}_{\mathrm{RA}}$ 112.3.68-69). $\quad 99 \mathrm{a}$ ततस्ते॰ ] तत्र ते॰ $\mathbf{A}$ 99d वाक्यमू० ] इदमू० A 100ab ] अयं देशो ह्यशुद्धो द्य गच्छामो वयमन्यतः A 100cd ] Instead of this $\mathbf{A}$ has four pādas (see $\left.\mathrm{SP}_{\mathrm{RA}} 112.3 .71 \mathrm{c}-72 \mathrm{~b}\right)$.

96 प्रह्लाद ] $S_{1} R B h$, प्रहा $S_{2}$, प्रहाद $S_{3}$ 96a महात्मानो ] $S_{1} S_{2} S_{3} R A$, महात्मान Bh (em.?) 96b ऋषय: ] $S_{1} S_{2} B h$, ऋषय $S_{3}$ (unmetrical) - संगता: ] $S_{2} R A B h$, संगता $S_{1} S_{3}$ 96c ०रत्रिर् ] $S_{1} S_{2} R A B h$, ०रत्ति $S_{3}$ 96d उड्रिरास्त॰] $S_{1} S_{3} A B h$, ड्रिरस्त॰ $S_{2}$ 97a वसिष्ट॰] $S_{1} S_{2}$ $\mathrm{A}_{3} \mathrm{~A}_{4} \mathrm{Bh}$, वसिष्ट० $\mathrm{S}_{3} \quad$ 97b After this $\mathrm{Bh}$ has two pādas (see $\mathrm{SP}_{\mathrm{RA}} 112.3 .66 \mathrm{~cd}$ ) 97c नैषां ] $S_{2} R A B h$, नैषन् $S_{1}^{p c}$, नै(ष्का)न् $S_{1}^{a c}$, नैषा $S_{3}$ 97d मन्दरा॰] $S_{1} S_{2} R A B h$, मन्दारा॰ $S_{3}$ ० ०नं प्रभो ] $\mathrm{S}_{1} \mathrm{Bh}$, ०नम्प्रभो: $\mathrm{S}_{2}$, ०नं प्रभो: $\mathrm{S}_{3} 98 \mathrm{~b}$ सर्वे ] $\mathrm{S}_{2} \mathrm{~S}_{3} \mathrm{RABh}$, सर्व+5+ $\mathrm{S}_{1}$ - After this $\mathrm{Bh}$ has four pādas (see $\mathrm{SP}_{\mathrm{RA}}$ 112.3.68). 98cd ॰षां तूष्णीं ] $\mathrm{S}_{1} \mathrm{Bh}$, ॰षान्तूष्णी $\mathrm{S}_{2}$, ०षां तूष्णी $\mathrm{S}_{3}$ 98d दैत्यपा: ] $\mathrm{S}_{1} \mathrm{~S}_{2} \mathrm{Bh}$, दैत्यपा $\mathrm{S}_{3}$ - After this Bh has four pādas following a speaker indication (see $\mathrm{SP}_{\mathrm{RA}}$ 112.3.69). 99a ततस्ते॰ $] \mathrm{S}_{1} \mathrm{~S}_{2} \mathrm{~S}_{3} \mathrm{R}$, तत्र ते॰ $\mathrm{Bh} \quad 99 \mathrm{~b}$ ० सुरेषु $] \mathrm{S}_{1}^{\mathrm{pc}} \mathrm{S}_{2} \mathrm{~S}_{3} \mathrm{R}$ $\mathrm{ABh}$, सुरुसु $\mathrm{S}_{1}^{\mathrm{ac}}$ 99d वाक्यमूचुः $\mathrm{S}_{1}^{\mathrm{pc}} \mathrm{S}_{3}$, वाक्यमूचु $\mathrm{S}_{1}^{\mathrm{ac}}$, वाक्यान्यूचुः $\mathrm{S}_{2} \mathrm{Bh}$ 100a शुद्धो डयं] $\mathrm{S}_{1} \mathrm{~S}_{2} \mathrm{Bh}$, शुद्धावे $\mathrm{S}_{3}$ - गिरेर ] $\mathrm{S}_{2} \mathrm{Bh}$, गिरिर $\mathrm{S}_{1}$, गिरे $\mathrm{S}_{3} \quad 100 \mathrm{~b}$ गच्छामो उन्यत्र वै ] $\mathrm{S}_{1} \mathrm{~S}_{2} \mathrm{~S}_{3}$, द्य गच्छामो न्यतो $\mathrm{Bh}$ (conj.) $\quad \mathbf{1 0 0 d}$ After this $\mathrm{Bh}$ has four pādas (see $\mathrm{SP}_{\mathrm{RA}} 112.3 .71 \mathrm{c}-72 \mathrm{~b}$ ). 
गतास्ते निधनं सर्वे धर्मं ये नाशयन्त्युत।

राज्यार्थं यदि तै: कररैन धर्मों नाशितो भवेत्।

नैव ते निधनं सर्वे प्राप्ताः स्युरमरद्विषः ॥ १०१॥

स्वराज्यपरिसंतुष्टा भवेयुर्यदि संस्थिताः।

ते ऽपि सर्वेषु लोकेषु बभुः पूज्याः सुरा इव॥ १०२॥

असुरान्प्रति सर्वेषामेवं कथयतां तदा।

आगाद्वाता विधाता च कृतान्तश्च महाबलः ॥ १०३॥

तांस्ते संपूज्य विधिवत्परस्परमनुव्रताः।

ऊचुः क्षेदं भवन्तो उद्य प्रस्थिता लोकधारिणः॥ १०४॥

101c यदि तै: ] प्रहित: $R \quad 101 \mathrm{~cd}$ ०रैर्न धर्मो नाशितो भवेत् ] ०रै: कथमेतन्न संशय: $\mathrm{R}$ 101ef102 ] om. $\mathrm{R}$ - After this $\mathrm{R}$ has 14 pādas with two speaker indications (see $\mathrm{SP}_{\mathrm{RA}} 112.3 .79 \mathrm{~cd}-$ speaker indication of 83). 103ab सर्वेषामेवं ] ते गत्वा कथां $R \quad 103 \mathrm{~b}$ कथयतां तदा ] कथयतान्तथा $R^{\mathrm{ac}}$, कथयितुन्तथा $\mathrm{R}^{\mathrm{pc}} \quad 103 \mathrm{c}$ आगाद् ] अगाद् $\mathrm{R}$ 103d महाबलः ] त्रयः समा: $\mathrm{R}$ 104a तांस्ते ] तांस्तु $\mathrm{R}$ 104b ॰मनुत्रता: ] ॰मतिप्रभा: $\mathrm{R}$ - After this $\mathrm{R}$ has two pādas (see $\mathrm{SP}_{\mathrm{RA}}$ 112.3.84cd). $104 c$ क्षेदं ] कस्माद् $R \quad \mathbf{1 0 4 d}$ ०धारिण: ] ०चिन्तका: $R$

101a सर्वे ] $\mathrm{A}_{3}$, सर्व $\mathrm{A}_{4} \mathrm{~A}_{7} 101 \mathrm{~b}$ धर्मं ] $\mathrm{A}_{3} \mathrm{~A}_{7}$, धम्मं $\mathrm{A}_{4}$ 101c राज्यार्थं ] $\mathrm{A}_{4} \mathrm{~A}_{7}$, राज्यार्य्यं $\mathrm{A}_{3}$ - यदि तै: ] प्रयतै: $\mathrm{A}$ 102a स्वराज्य० ] सुराश्च $\mathrm{A}_{7}$, शूराश्च $\mathrm{A}_{3} \mathrm{~A}_{4}$ 102d पूज्या: ] $\mathrm{A}_{3}$, पूज्या $\mathrm{A}_{4} \mathrm{~A}_{7}$ - After this $\mathbf{A}$ has 32 pādas with 4 speaker indications (see $\mathrm{SP}_{\mathrm{RA}}$ 112.3.75-speaker indication of 83). 103ab सर्वेषामेवं ] तेषां तु कथां $\mathbf{A} 103 \mathrm{c}$ आगाद् ] अगाद् $\mathbf{A} 103 \mathrm{~d}$ महाबलः ] त्रयः \{प्रषः $\left.\mathrm{A}_{7}\right\}$ समा: $\mathbf{A}$ 104a तांस्ते ] $\mathrm{A}_{3} \mathrm{~A}_{4}$, त+त+स्ते $\mathrm{A}_{7}$ (unmetrical) - संपूज्य ] संगृह्य A 104b ॰मनुव्रता: ] ॰मतिप्रभा: $\mathbf{A}$ - After this $\mathbf{A}$ has four pādas (see $\mathrm{SP}_{\mathrm{RA}} 112.3 .84 \mathrm{c}-85 \mathrm{~b}$ ). $104 \mathrm{c}$ क्षेदं ] कस्माद् $A$ 104d ०धारिण: ] ०चिन्तका: A

$101\left(c^{4}-c^{5}, c^{7}\right) S_{1},\left(c^{2}-c^{8}\right) S_{3} \quad 102\left(a^{1}, a^{3}\right) S_{1} \quad 103\left(d^{6}-d^{8}\right) S_{1} \quad 104\left\langle a^{1}-a^{5}\right\rangle\left(a^{6}-a^{7}\right)\left\langle a^{8}\right\rangle\left(b^{1}-b^{8}\right.$, $\left.c^{2}-c^{4}\right) S_{1},\left(b^{3}-b^{6}\right) S_{3}$

$101 b$ धर्म ] $\mathrm{S}_{1} \mathrm{~S}_{2} \mathrm{RA}_{3} \mathrm{~A}_{7} \mathrm{Bh}$, धर्म $\mathrm{S}_{3}$ - नाशयन्त्युत ] RA, नाशयन्तुत $\mathrm{S}_{1}$, नाशयन्त्युतः $\mathrm{S}_{2} \mathrm{~S}_{3}$, नाशयन्तुत $\mathrm{Bh}$ (conj.) 101c राज्यार्थं ] $\mathrm{S}_{2} \mathrm{RA}_{4} \mathrm{~A}_{7} \mathrm{Bh}$, राज्यार्थ $\mathrm{S}_{1}$, रा(ज्यार्थ) $\mathrm{S}_{3}$ • तै: ] $\mathrm{S}_{1}^{\mathrm{pc}}$ $\mathrm{S}_{2} \mathrm{ABh}$, तै $S_{1}^{\text {ac }},-: S_{3} \quad$ 101cd कररेन ] $S_{1} A B h$, कूरैर० $S_{2}$, (करे) र० $S_{3}$ (tops lost) 101e नैव ] $\mathrm{S}_{1} \mathrm{~S}_{3} \mathrm{~A}$, नैवं $\mathrm{S}_{2} B \mathrm{Bh}$ सर्वे ] $\mathrm{S}_{2} \mathrm{~S}_{3} \mathrm{ABh}$, वे $\mathrm{S}_{1}$ (unmetrical; insertion mark before वे, akṣara possibly lost i.m.) $101 f$ प्राप्ता: स्युर० ] $\mathrm{S}_{2} \mathrm{~S}_{3} \mathrm{ABh}$, प्राप्ता सुर० $\mathrm{S}_{1}$ • ०द्विषः ] $\mathrm{S}_{1}^{\mathrm{pc}} \mathrm{S}_{2} \mathrm{~S}_{3} \mathrm{ABh}$, ०द्वि(शम्) $\mathrm{S}_{1}^{\mathrm{ac}} 102 \mathrm{a}$ स्वराज्य॰] $\mathrm{S}_{1}^{\mathrm{pc}} \mathrm{S}_{2} \mathrm{~S}_{3} \mathrm{Bh}$, (स्त)रा(क्य) $\mathrm{S}_{1}^{\mathrm{ac}} \quad \mathbf{1 0 2 b}$ ०यदि ] $\mathrm{S}_{2} \mathrm{~S}_{3} \mathrm{ABh}$, ०युदि $\mathrm{S}_{1} 102 \mathrm{~d}$ बभुः $] \mathrm{S}_{1} \mathrm{~S}_{2}^{\mathrm{pc}} \mathrm{ABh}$, बभू $\mathrm{S}_{2}^{\mathrm{ac}}$, बभू: $\mathrm{S}_{3}$ - पूज्या: $\mathrm{S}_{1} \mathrm{~A}_{3} B \mathrm{~B}$, पूज्या $\mathrm{S}_{2} \mathrm{~S}_{3}$ - After this $\mathrm{Bh}$ has 32 pãdas with 4 speaker indications (see $\mathrm{SP}_{\mathrm{RA}}$ 112.3.75-speaker indication of 83). $103 \mathrm{a}$ असुरान् ] $\mathrm{RABh}$, असुराम् $\mathrm{S}_{1} \mathrm{~S}_{2}$, असुरां $\mathrm{S}_{3} 103 \mathbf{a b}$ सर्वेषामे॰ $\mathrm{S}_{1} \mathrm{~S}_{2} \mathrm{~S}_{3}^{\mathrm{pc}}$, सर्वेषां मे॰ $\mathrm{S}_{3}^{\mathrm{ac}}$, तेषां तु ए० $\mathrm{Bh}(\mathrm{em} . ?) \quad \mathbf{1 0 3 b}$ कथयतां ] $\mathrm{S}_{2}^{\mathrm{pc}} \mathrm{S}_{3} \mathrm{R}^{\mathrm{ac}} \mathrm{ABh}$, कथतान् $\mathrm{S}_{1}$ (unmetrical), कथय(था)न्

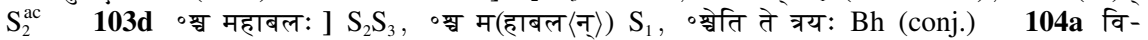
धिवत् ] $S_{2}^{\text {pc } R A B h, ~} f \circ f \cup \simeq S_{1}$, विधिव: $S_{2}^{\text {ac }}$, विधिव $S_{3} \quad 104 b$ ०व्रता: ] $S_{2} S_{3} B h,(\circ$ ब्रता $): S_{1}$ (lower parts lost) - After this $\mathrm{Bh}$ has four pādas (see $\mathrm{SP}_{\mathrm{RA}} 112.3 .84 \mathrm{c}-85 \mathrm{~b}$ ) $\quad$ 104c डद्य ] $\mathrm{S}_{2} \mathrm{~S}_{3} \mathrm{RABh}$, द्या $\mathrm{S}_{1}$ 


\section{विधातोवाच।}

ब्रह्मलोकादुपावृत्ता वयमद्य गता द्विजाः।

ब्रह्मणा स्म समाज्ञाता: कश्यपस्य ततो उन्तिकम्॥ १०४ ॥

अथाब्रवीन्मुनिं धाता कश्यपं तं प्रजापतिम्।

यत्त्वया ज्ञापितो ब्रह्मन्ब्रह्मा लोकपितामहः ॥ १०६॥

असुरा अपि मे पुत्रा देवाश्चापि प्रिया: प्रभो।

तेषां नैव यथान्योन्यं वैरं स्याल्नोकभावन।

तथा कुरु सुरश्रेष्ठ भवेयं निर्वृतस्ततः ॥ १०७॥

105 विधातो॰ ] धातो॰ $R \quad 105 a$ ०लोकादुपा० ] ०णासदपा॰ $R \quad 105 b$ ॰मद्य गता द्विजा: ] ॰मभ्यागता द्विजा+:+ R 105cd ] ब्रह्मणा स्ताः समाहूय उपगम्य त्रयान्तिकं $R$ - After this $R$ has two pādas (see $\mathrm{SP}_{\mathrm{RA}}$ 112.3.87ab). 106ab ] ततो इब्रवीन्मुनीन्द्रांस्तान् कश्यपान् कमलोड़्र: $\mathrm{R}$ 106c ज्ञापितो ] कुपितो $R \quad 107 \mathbf{a}-d$ ] असुरानपि पुत्रा हि देवस्यास्य प्रियाः प्रभो । तेषामेव यथाकामं कामयन्तः परस्परम् $\mathrm{R} \quad 107 f$ भवेयं निर्वृतस्ततः ] ततो यं निर्वृतिस्तव $\mathrm{R}$

105 विधातो॰ ] धातो॰ $\mathrm{A} 105 \mathrm{a}$ ०दुपा०] ०दपा० $\mathrm{A}_{3} \mathrm{~A}_{7}$, ०दया० $\mathrm{A}_{4} 105 \mathrm{~b}$ ०मद्य गता ] ०मभ्यागता A $105 \mathrm{c}$ स्म समाज्ञात्ता:] समनुज्ञाता: $\left\{{ }^{\circ}\right.$ ज्ञाता: $\left.\mathrm{A}_{4}\right\} \mathrm{A} 105 \mathrm{~d}$ कश्यपस्य ] $\mathrm{A}_{7}$, कस्यपस्य $\mathrm{A}_{3}$, कस्यपश्य $\mathrm{A}_{4}$ - After this $\mathbf{A}$ has two pādas (see $\mathrm{SP}_{\mathrm{RA}}$ 112.3.87ab). 106ab ] ततो ब्रवीन्मुनीन् धाता कश्य $\left\{\right.$ ०स्य० $\left.\mathrm{A}_{3} \mathrm{~A}_{7}^{\mathrm{ac}}\right\}$ पस्तु यदुक्तवान् $\mathrm{A} \quad \mathbf{1 0 6 c}$ ज्ञापितो] कुशितो $\mathrm{A}_{3} \mathrm{~A}_{4} \mathrm{~A}_{7}^{\mathrm{ac}}$, कथितो $\mathrm{A}_{7}^{\mathrm{pc}}$ $106 \mathbf{c d}$ ब्रह्मन्त्रह्मा लोक॰ ] ब्रह्मा ब्रह्मलोके $A \quad 107 \mathbf{b}$ प्रिया: ] $\mathrm{A}_{3}$, प्रिया $\mathrm{A}_{4} \mathrm{~A}_{7} 107 \mathrm{c}$ यथा०] $\mathrm{A}_{3}$ $\mathrm{A}_{7}$, यथो॰ $\mathrm{A}_{4} 107 \mathrm{~d}$ वैरं ] नैवं $\mathrm{A}_{4}$, नैव $\mathrm{A}_{3} \mathrm{~A}_{7}$ - स्याल्लोक॰] $\mathrm{A}_{7}$, स्या लोक॰ $\mathrm{A}_{3} \mathrm{~A}_{4}$ 107e सुर॰ ] गुरु॰ $\mathrm{A} 107 \mathbf{f}$ भवेयं निर्वृत० ] भवेयुर्निर्वृता० $\left\{{ }^{\circ}\right.$ वृत० $\mathrm{A}_{4},{ }^{\circ}$ वृता० $\mathrm{A}_{7}^{\mathrm{pc}},{ }^{\circ}$ वृत॰ $\left.\mathrm{A}_{7}^{\mathrm{ac}}\right\} \mathbf{A}$

$\mathbf{1 0 5}$ (speaker indication 4) $\left\langle a^{1}\right\rangle\left(a^{2}, a^{5}-a^{7}\right)\left\langle a^{8}-b^{6}\right\rangle\left(b^{7}\right)\left\langle b^{8}-d^{5}\right\rangle\left(d^{6}-d^{8}\right) S_{1} \quad \mathbf{1 0 6}\left\langle a^{1}-a^{2}\right\rangle\left(a^{3}-b^{2}, b^{4}\right) S_{1}$ $107\left(f^{5}-f^{8}\right) S_{1},\left(b^{5}\right) S_{3}$

105 विधातोवाच ] conj., धातोवा(च) $S_{1}$, धातो उ $S_{2}^{\text {pc }} S_{3}$, धा(वो) $S_{2}^{\text {ac }}$, धातोवाच $B h \quad 105 a$

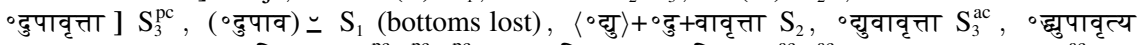
$\mathrm{Bh}$ (conj.) 105b द्विजा: ] $S_{2}^{\mathrm{pc}} S_{3}^{\mathrm{pc}} R^{\mathrm{pc}} A B h, f \simeq \mathrm{S}_{1}$, द्विजा $\mathrm{S}_{2}^{\mathrm{ac}} S_{3}^{\mathrm{ac}} \quad \mathbf{1 0 5 c}$ स्म $] \mathrm{S}_{2} \mathrm{~S}_{3}^{\mathrm{ac}} B \mathrm{C}$, उस्म $S_{3}^{\mathrm{pc}}$ - समाज्ञात्ता:] $\mathrm{S}_{3}^{\mathrm{pc}} \mathrm{Bh}\left(\mathrm{em}\right.$. ?), समाज्ञात्ता $\mathrm{S}_{2} \mathrm{~S}_{3}^{\mathrm{ac}}$ 105d कश्यपस्य ] $\mathrm{A}_{7} \mathrm{Bh}(\mathrm{em}$.$) , का-$ श्यपस्य $\mathrm{S}_{2} \mathrm{~S}_{3}$ - After this $\mathrm{Bh}$ has two pādas (see $\mathrm{SP}_{\mathrm{RA}} 112.3 .87 \mathrm{ab}$ ). 106a ०न्मुनिं धा०] $\mathrm{S}_{1} \mathrm{~S}_{3}^{\mathrm{pc}}$, ॰न्मुनिद्धा० $\mathrm{S}_{2} \mathrm{~S}_{3}^{\mathrm{ac}}$, ॰न्मुनीन् धा॰ $\mathrm{Bh} \mathbf{1 0 6} \mathrm{b}$ कश्य॰] $\mathrm{S}_{1} \mathrm{RA}_{4} \mathrm{~A}_{7}^{\mathrm{pc}} \mathrm{Bh}$, काश्य॰ $\mathrm{S}_{2} \mathrm{~S}_{3}$ • ०पं तं प्रजापतिम् ] $\mathrm{S}_{1} \mathrm{~S}_{3}$, ०पन्तम्प्रजापतिन् $\mathrm{S}_{2}$, ०पं तु यदुक्तवान् $\mathrm{Bh}(\mathrm{em}) \quad .106 \mathrm{c}$ यत्त्वया ] $\mathrm{S}_{2} \mathrm{~S}_{3} \mathrm{RA}$ $\mathrm{Bh}$, यस्त्वया $\mathrm{S}_{1}$ - ज्ञापितो ] $\mathrm{S}_{1} \mathrm{~S}_{3} \mathrm{Bh}$, ज्ञा+प+तो $\mathrm{S}_{2} \quad \mathbf{1 0 6 \mathrm { cd }}$ ब्रह्मन्त्रह्मा ] $\mathrm{S}_{2} \mathrm{~S}_{3}^{\mathrm{pc}} \mathrm{RBh}$, ब्रह्मद्रह्मा $\mathrm{S}_{1}^{\mathrm{pc}}$, ब्रह्मद्रह्म $\mathrm{S}_{1}^{\mathrm{ac}}$, ब्रह्म ब्रह्म $\mathrm{S}_{3}^{\mathrm{ac}} \quad \mathbf{1 0 6 d}$ ०पितामहः ] $\mathrm{S}_{1} \mathrm{~S}_{2}^{\mathrm{pc}} \mathrm{S}_{3}^{\mathrm{pc}} \mathrm{RABh}$, ०पितामह $\mathrm{S}_{2}^{\mathrm{ac}} \mathrm{S}_{3}^{\mathrm{ac}} \mathbf{1 0 7 \mathbf { b }}$ देवा॰] $\mathrm{S}_{2} \mathrm{~S}_{3} \mathrm{ABh}$, देव्या० $\mathrm{S}_{1}$ - प्रिया: ] $\mathrm{S}_{1} \mathrm{~S}_{2} \mathrm{RA}_{3} B h$, (प्रि)या $\mathrm{S}_{3}$ • प्रभो ] $\mathrm{S}_{1} \mathrm{~S}_{2} \mathrm{~S}_{3}^{\text {ac }} \mathrm{RABh}$, प्रभो: $S_{3}^{p c} 107 c$ यथान्योन्यं ] $S_{2} S_{3} A_{3} A_{7} B h$, यथान्योन्य $S_{1}$ 107d स्याल््रोक॰] $S_{1} S_{2} S_{3}^{p c} A_{7} B h$, स्या लोक॰ $S_{3}^{\mathrm{ac}}$ • ०भावन ] $A B h$, ०भानुन: $S_{1}$, ०भावन: $S_{2} S_{3} 107 \mathrm{e}$ कुरु सुर॰] $S_{3}^{\mathrm{pc}} R$, कुरु नर॰ $\mathrm{S}_{1} \mathrm{~S}_{2}$, कुरु (न)र॰ $\mathrm{S}_{3}^{\mathrm{ac}}$, कुर्वमर० $\mathrm{Bh}$ (conj.) - ० श्रेष्ट ] RABh, ० श्रेष्टा $\mathrm{S}_{1} \mathrm{~S}_{2}$, ० श्रेष्टा $\mathrm{S}_{3}$ 107f ०यं निर्वृत॰] $\mathrm{S}_{2} \mathrm{~S}_{3} \mathrm{Bh}$, ०यन्नि(वृता०) $\mathrm{S}_{1}$ (tops lost) 
तत्राहं ब्रह्मणाइाप्तो ब्रवीमि त्वां महामुने ।

देवासुरं यथावृत्तमन्योन्यं सख्यमेव च।

अमृतोत्पादनं चैव राज्यसंस्थां च कृत्स्नशः॥ १०५॥

तस्यैवं पृच्छतः सर्वं भविष्यमृषिसत्तमः।

कथयामास भूतार्थं देवासुरविचेष्टितम्॥ १०९॥

निवेद्य तस्य तत्सवं ब्रह्मणा प्रेषिता वयम्।

इहागता भगवतीं द्रष्टुं हिमगिरे: सुताम्॥ १९०॥

सनत्कुमार उवाच।

तानेवंवादिनो भूयो ऋषयस्ते तपोधनाः।

पप्रच्छुर्नियतात्मानः सर्व एव तदा मुने॥ ??? ॥

देवासुराणां यद्दृत्तं भविष्यं कथितं शुभाः।

तद्वयं श्रोतुमिच्छामो यदि वो उनुग्रहे मतिः॥ १?२॥

$108 \mathrm{a}$ ॰ ज्ञात्रो ] कुत्तो $\mathrm{R} \quad 108 \mathrm{~b}$ महामुने ] महात्मना $\mathrm{R} \quad 108 \mathrm{c}$ देवासुरं ] देवासुर $\mathrm{R} \quad 108 \mathrm{~d}$ ०मन्योन्यं सख्यमेव च ] ०मपि पालय सर्व्वदा $R \quad 108 f$ राज्यसंस्थां च कृत्स्नशः ] ततः संस्कार्य्य यत्पुनः $R$ $109 a$ तस्यैवं पृच्छतः ] त्वयोक्त भगवान् $R \quad 109 b$ भविष्यमृषि॰] भविष्यन् ऋषि॰ $R$ ० सत्तमः ] $\mathrm{R}^{\mathrm{ac}}$, ०सत्तम $\mathrm{R}^{\mathrm{pc}} \quad 109 \mathrm{~cd}$ ] om. $\mathrm{R} 110 \mathrm{~d}$ हिमगिरे: ] भगवतः $\mathrm{R} 111$ सनत्कुमार उवाच ] om. $R$ 111a तानेवंवादिनो भूयो ] तामेव देवतां भतत्वा $R \quad 111 b$ ०स्ते ] ० ग्र $R$ 111c पप्रच्छुर ] पपृच्छुर् $R \quad 112 b$ भविष्यं कथितं शुभा: ] भविष्यति कथं सुरा: $R$

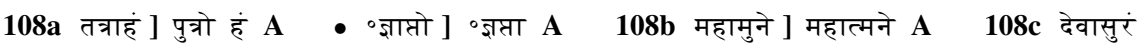
यथा०] देवासुराणां यत् $\left\{\right.$ यं $\left.\mathrm{A}_{7}\right\} \mathrm{A} \quad 108 \mathrm{~d}$ सख्ये $] \mathrm{A}_{3} \mathrm{~A}_{4}$, संख्य ० $\mathrm{A}_{7} \quad 108 \mathrm{e}$ अमृतोत्पादनं चैव ] अदितिश्च दितिश्चैव $\left\{\circ\right.$ श्चै $\mathrm{A}_{4}$ (unmetrical)\} $\mathrm{A} \quad \mathbf{1 0 8 f} \circ$ संस्थां च ] ०संस्था च $\mathrm{A}_{3} \mathrm{~A}_{4}$, ०संस्था(न) $\mathrm{A}_{7}^{\mathrm{pc}}$, ०संस्थाव $\mathrm{A}_{7}^{\mathrm{ac}}$ - कृत्स्नशः ] $\mathrm{A}_{3}$, कृत्स्नस: $\mathrm{A}_{4}$, कृस्नशः $\mathrm{A}_{7}$ 109a तस्यैवं पृच्छुतः ] त्वयोका भगवन् $A 109 \mathrm{~b}$ ०सत्तम: ] ०सत्तम $A$ 109c भूतार्थं ] लोकेशो $A$ 110a निवेद्य तस्य ] निवेदयतु $\mathrm{A}_{3} \mathrm{~A}_{4}$, निवेदयितुं $\mathrm{A}_{7}$ (unmetrical) $\quad 110 \mathrm{c}$ ०गता ] ०गतां $\mathrm{A}_{3} \mathrm{~A}_{7}$, ०गतं $\mathrm{A}_{4} \quad 110 \mathrm{~d}$ द्ट्टुं] दृष्टिं $\mathrm{A}_{3} \mathrm{~A}_{4}$, दृष्टां $\mathrm{A}_{7}^{\mathrm{pc}}$, दुष्टां $\mathrm{A}_{7}^{\mathrm{ac}} 111$ सनत्कुमार उवाच] om. $\mathrm{A} 111 \mathrm{a}$ तानेवंवादिनो भूयो ] तमेव चरतां भूय $\mathrm{A}$ $111 \mathrm{c}$ पप्रच्छुर् ] पृच्छन्ति $\mathrm{A} 112 \mathrm{~b}$ शुभा: ] सुराः $\mathrm{A}$

$108\left(a^{1}-a^{5}\right)\left\langle a^{6}\right\rangle\left(a^{7}\right)\left\langle a^{8}-b^{8}\right\rangle S_{1} \quad \mathbf{1 1 0}\left(d^{8}\right) S_{1}$

108a ०णाज्ञाप्तो ] $\mathrm{S}_{2} \mathrm{~S}_{3}^{\mathrm{pc}},--\simeq \mathrm{S}_{1}$ (second akșara has subscript ज्), ०ण ज्ञात्रो $\mathrm{S}_{3}^{\mathrm{ac}}$, ०णाज़्रो $\mathrm{Bh}$ (em.?) 108b त्वां] $S_{3}^{\text {pc }} R A B h$, त्वा $S_{2} S_{3}^{\text {ac }} 108 d$ ०मन्योन्यं सख्य॰] $S_{1} S_{2} A_{3} A_{4} B h$, ०मन्योन्यसंख्य॰ $S_{3}$ (unmetrical) $108 f$ राज्य॰] $S_{1} S_{3} A$, राज्यं $S_{2} B h$ • संस्थां ] $S_{1} S_{2} B h$, ०संस्था $\mathrm{S}_{3}$ - कृत्स्नशः ] $\mathrm{S}_{1} \mathrm{~A}_{3} B h$, कृत्सस: $\mathrm{S}_{2} \mathrm{~S}_{3}$ 109a तस्यैवं पृच्छुतः $] \mathrm{S}_{1} \mathrm{~S}_{2} \mathrm{~S}_{3}^{\mathrm{pc}}$, तस्यैवं पृच्छुत $\mathrm{S}_{3}^{\mathrm{ac}}$ (unmetrical), त्वयोक्त भगवान् $\mathrm{Bh}$ (em.?) $109 \mathrm{~b}$ ०सत्तमः ] $\mathrm{S}_{2}^{\mathrm{ac}} \mathrm{S}_{3} \mathrm{R}^{\mathrm{ac}}$, ०सत्तम $\mathrm{S}_{1} \mathrm{~S}_{2}^{\mathrm{pc}} \mathrm{Bh} 109 \mathrm{c}$ भूतार्थं ] $\mathrm{S}_{1} \mathrm{~S}_{2} \mathrm{~S}_{3}$, लोकेशो $\mathrm{Bh} 109 \mathrm{~d}$ ०विचेष्टितम् ] $\mathrm{S}_{1} \mathrm{~S}_{2} \mathrm{~S}_{3}^{\mathrm{pc}} \mathrm{ABh}$, ०विचेषित $\mathrm{S}_{3}^{\mathrm{ac}}$ 110cd भगवतीं दृष्ट्र ] $S_{1} S_{2} R B h$, भगवती दृष्टु $S_{3}$ (unmetrical) $110 d$ ०गरे: सुताम् ] $S_{1} S_{2} A B h$, ०गिरे सुतां $S_{3}^{\text {pc }}$, ०गिरे सुभां $\mathrm{S}_{3}^{\text {ac }} 111$ सनत्कुमार उवाच ] $\mathrm{S}_{2} \mathrm{~S}_{3} \mathrm{Bh}$ (सन उ in $\mathrm{S}_{2} \mathrm{~S}_{3}$ ), om. $\mathrm{S}_{1}$ (akṣaras possibly lost i.m.) 111a ०वादिनो ] $\mathrm{S}_{2} \mathrm{~S}_{3} \mathrm{Bh}$, ०वादिने $\mathrm{S}_{1}$ - भूयो ] $\mathrm{S}_{1} \mathrm{~S}_{2} \mathrm{~S}_{3}$, भूय Bh 111b तपोधना: ] $\mathrm{S}_{1} \mathrm{~S}_{2}^{\mathrm{pc}} \mathrm{RABh}$, तपोधना $\mathrm{S}_{2}^{\mathrm{ac}} \mathrm{S}_{3} \quad$ 111c पप्रच्छुर ] $\mathrm{S}_{1} \mathrm{Bh}$, प्रप्रच्छुर् $\mathrm{S}_{2}$, प्रपच्छु $\mathrm{S}_{3}$ - ०तात्मानः ] $\mathrm{S}_{1} \mathrm{~S}_{2}^{\mathrm{pc}} \mathrm{RABh}$, ०तात्मान $\mathrm{S}_{2}^{\mathrm{ac}} \mathrm{S}_{3} \quad \mathbf{1 1 2 b}$ कथितं ] $\mathrm{S}_{1} \mathrm{ABh}$, कथिता $\mathrm{S}_{2} \mathrm{~S}_{3}$ - शुभा: ] $\mathrm{S}_{1} \mathrm{~S}_{2}^{\mathrm{pc}} \mathrm{Bh}$, शुभा $\mathrm{S}_{2}^{\text {ac }} \mathrm{S}_{3} 112 \mathrm{c}$ तद् $] \mathrm{S}_{1} \mathrm{RABh}$, यद् $\mathrm{S}_{2} \mathrm{~S}_{3}$ - ममिच्छामो ] $\mathrm{S}_{1} \mathrm{~S}_{2}^{\mathrm{pc}} \mathrm{RABh}$, ममिच्छामि $\mathrm{S}_{2}^{\mathrm{ac}} \mathrm{S}_{3}$ $112 d$ वो उनुग्रहे ] $S_{2} S_{3} R A B h$, वानुग्रहै $S_{1}^{\text {pc }}$, वानुग्र(हे) $S_{1}^{\text {ac }}$ - मतिः ] $S_{1} S_{2} R A B h$, मति $S_{3}$ 
किं च विज्ञापिता देवी युष्माभिः सुरसत्तमाः।

कथयध्वं च तत्सर्वं यद्यनुग्राह्यता हि नः॥ १९३३॥

तेषां तद्वचनं श्रुत्वा त्रयस्ते देवसत्तमाः।

त्वमाचक्ष्व कृतान्तेति वाक्यमूचुर्महाबलाः॥ १९६ ॥

ततः स तेषां बहुचित्रकारणं यथाभविष्यं कथयांचकार।

सुरासुराणां जयतां च कारणं पुरा विधात्रा विहितं यथार्थवत् ॥ १९४ ॥

इति स्कन्दपुराणे द्वादशोत्तरशतो डध्यायः॥ ११२॥

$113 \mathrm{c}$ च ] हि $\mathrm{R} 113 \mathrm{~d}$ ०ग्राह्यता ] ०ग्राह्यतां $\mathrm{R} 114 \mathrm{~b}$ त्रयस्ते देव॰] तेषान्ते सुर० $\mathrm{R}$ 114cd ] अथाचष्ट कृतान्तो हि वाक्यं वाक्यविशारदान् $R \quad 115 c$ जयतां च] जयतश्च $R \quad 115 d$ पुरा ] सुधा $R$ - विहितं ] विहिता $\mathrm{R}$ Col. इति स्कन्दपुराणे रेवाखण्डे सप्रर्षिसमागमो नामाध्याय: $\mathrm{R}$

113a विज्ञापिता ] $A_{7}$, विज्ञापितं $\mathrm{A}_{3} \mathrm{~A}_{4} \quad 113 \mathrm{c}$ च] हि $\mathrm{A}_{4} \mathrm{~A}_{7}$, दि $\mathrm{A}_{3} \quad 113 \mathrm{~d}$ यद्यनुग्राह्यता हि नः ] यथानुगृह्यता $\left\{{ }^{\circ}\right.$ तां $\left.\mathrm{A}_{7}\right\}$ हि व: $\mathbf{A} 11 \mathrm{bb}$ त्रयस्ते देव ${ }^{\circ}$ ] ततस्ते सुर० $\mathrm{A}_{4} \mathrm{~A}_{7}$, तस्ते सुर० $\mathrm{A}_{3}$ (unmetrical) $114 \mathrm{~cd}]$ तानाचक्षि $\left\{{ }^{\circ}\right.$ क्षी $\left.\mathrm{A}_{7}\right\}$ कृतान्तो हि वाक्यं वाक्यविशारदान् $\mathbf{A} 115 \mathrm{~cd}$ ] om. A Col. इति $\left\{\right.$ इति ग्री॰ $\mathrm{A}_{3}$, ओं॥ इति श्री॰ $\left.\mathrm{A}_{7}\right\}$ स्कन्दपुराणे एकाशीतिसाहस्रयां संहितायामम्बिकाखण्डे सप्तर्षिसमागमनो $\left\{\circ\right.$ गमो $\mathrm{A}_{3}$ \} नाम द्वादशोत्तरशततमो ध्याय: $\mathbf{A}$

$115\left(c^{9}\right) S_{1}$

113a देवी ] $S_{1} S_{2}^{\text {pc }} S_{3} R A B h$, देवि $S_{2}^{\text {ac }}$ 113b युष्माभिः ] $S_{1} S_{2} R A B h$, युष्माभि $S_{3}$ - ०सत्तमाः ] $\mathrm{S}_{1} \mathrm{~S}_{2}^{\mathrm{pc}} \mathrm{RABh}$, ०सत्तमा $\mathrm{S}_{2}^{\mathrm{ac}} \mathrm{S}_{3} \quad 113 \mathrm{c}$ तत्सर्वं ] $\mathrm{S}_{2} \mathrm{~S}_{3} \mathrm{RABh}$, यत्सर्व $\mathrm{S}_{1}$ 113d यद्यनु० ] $\mathrm{S}_{3} \mathrm{RBh}$ (em.?), यदनु॰ $S_{1}$, पद्यनु० $S_{2}^{\text {pc }}$, (द)द्यनु ${ }^{\circ} S_{2}^{\text {ac }}$ • न: $] S_{1} S_{2}^{\text {pc }} S_{3} R B h$, न $S_{2}^{\text {ac }} 114 c \circ$ माचक्ष्व ] $\mathrm{S}_{1}^{\mathrm{pc}} \mathrm{S}_{2} \mathrm{~S}_{3} \mathrm{Bh}$, ०मास्चक्ष्व $\mathrm{S}_{1}^{\mathrm{ac}}$ - कृतान्तेति ] $\mathrm{S}_{1} \mathrm{~S}_{2} \mathrm{Bh}$, कृत्तान्तेति $\mathrm{S}_{3}$ (unmetrical) 114d ०मूचुर ] $\mathrm{S}_{1} \mathrm{~S}_{2} \mathrm{Bh}$, ०मूचु $\mathrm{S}_{3}$ - ०बलाः ] $\mathrm{S}_{1}^{\mathrm{pc}} \mathrm{S}_{2} \mathrm{~S}_{3} \mathrm{Bh}$, ०बला $\mathrm{S}_{1}^{\mathrm{ac}}$ 115a ततः ] $\mathrm{S}_{1} \mathrm{~S}_{2} \mathrm{RABh}$, तत $\mathrm{S}_{3}$ (unmetrical) $115 \mathrm{~b}$ कथयांच॰ $\mathrm{S}_{1} \mathrm{~S}_{2}^{\mathrm{pc}} \mathrm{S}_{3} \mathrm{RABh}$, कथयन्च $\mathrm{S}_{2}^{\mathrm{ac}}$ 115c ०णां जयतां च] conj., ०णाअगताश्च $\mathrm{S}_{1}^{\mathrm{ac}}$, ०णाअगता(च्च) $\mathrm{S}_{1}^{\mathrm{pc}}$, ०णां जगतश्च $\mathrm{S}_{2} \mathrm{~S}_{3} B \mathrm{115d}$ विधात्रा ] $\mathrm{S}_{1}^{\mathrm{pc}} \mathrm{S}_{2} \mathrm{~S}_{3} \mathrm{R}$ $\mathrm{Bh}$, विधाता $\mathrm{S}_{1}^{\mathrm{ac}}$ - यथार्थवत् ] $\mathrm{S}_{2} \mathrm{~S}_{3} \mathrm{RBh}$, यथार्थवदिति $\mathrm{S}_{1}$ (इति part of col.) Col. $\odot \|$ स्कन्दपुराणे मन्दरारोहने १६६ (in letter numerals)॥ $\odot \mathrm{S}_{1}$, स्कन्दपुराणे द्वादशोत्तरशतो ध्याय: $\mathrm{S}_{2}, \odot$ ॥ स्कन्दपुराणे नामाध्यायः। १९४ (in letter numerals)॥ $\odot \mathrm{S}_{3}$, इति स्कन्दपुराणे मन्दरारोहणो नाम द्वादशोत्तरशततमोध्याय: $\mathrm{Bh}$ 
द्वादशोत्तरशते डध्याये स्त्रीव्रतम्।

सनत्कुमार उवाच।

ततः सा हिमवत्पुत्री सावित्रीं वै शुभाननाम्।

पप्रच्छ, ब्रह्मणः पत्नीं व्यास तां वेदमातरम्॥ ? ॥

देव्युवाच।

अहो वः सुमहान्धर्मः श्रूयते ऽतिसुभास्वरः।

श्रवणादेव पूतः स्याद्यस्य मत्यों न संशयः॥ २॥

इदं तु श्रोतुमिच्छामि व्रतं स्त्रीणां तु यद्इवेत्।

अनेनैव चरन्देवि धर्मेण समतां लभेत्।

फलं तु यझ्इवेत्स्रीणां महाकर्मफलं तथा॥ ३॥

सावित्युवाच।

पुत्येका ब्रह्मणः ख्याता शतरूपेति नामतः।

ब्रह्माणमुपसंगम्य आह यत्तन्निबोधत॥ ४॥

शतरूपोवाच।

भगवग्छ्रोतुमिच्छामि स्त्रीणां धर्मविधिं शुभम्।

येन भर्तुः प्रिया सा स्यात्प्रियो भर्ता च सुत्रत॥ $y \|$

न च दुःखं प्रपश्येत अवैधव्यसमन्विता।

पुत्रांश्च सुमहावीर्याअनयेत महागुणान् ॥ ६॥

श्वश्रूश्वशुरयोश्चापि इष्टा बहुमता भवेत्।

रूपयौवनसंपन्ना साध्वी पतिमनुत्रता॥ ७॥

प्राप्नोति सदृशं चैव सर्वकामप्रदं पतिम्।

स्वकर्मनिरतं दान्तं सर्वलोकनमस्कृतम्॥ ५॥

Manuscripts available for this part: R f. $188^{\mathrm{v}}-190^{\mathrm{r}} ; \mathrm{A}_{3}$ f. $113^{\mathrm{v}}-114^{\mathrm{v}} ; \mathrm{A}_{4}$ f. $160^{\mathrm{r}}-161^{\mathrm{v}} ; \mathrm{A}_{7}$ f. $160^{\mathrm{v}}-162^{\mathrm{r}}$.

$1 b$ सावित्रीं वै ] $\mathrm{RA}_{7}$, सावित्रीत्वे $\mathrm{A}_{3}$, सावित्री ते $\mathrm{A}_{4}$ - शुभाननाम् ] $\mathrm{R}$, शुभानना $\mathrm{A}$ 1cd पत्नीं व्यास तां वेद॰ ] $A$, पुत्रीमुच्यतां देव॰ $R \quad 2 a$ व: सुमहान्धर्मः ] $R$, याः सुमहात्मानः $A_{3} A_{4}$, 〈सु $\rangle$ म-

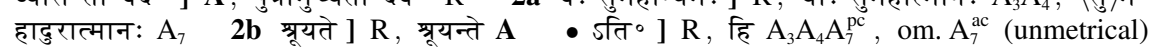
- ०भास्वर: ] $\mathrm{A}_{4} \mathrm{~A}_{7}$, ०भासुर: $\mathrm{R}$, ०भास्वरा: $\mathrm{A}_{3}$ 2cd स्याद्यस्य ] em., स्याद्यश्च $\mathrm{R}$, स्यात् $\left\{\right.$ स्या $\left.\mathrm{A}_{7}\right\}$ स्वस्य $A 3 c$ चरन्] $R$, तु यद् $A$ यद्रवेत् ] $A$, प्रभवेत् $R \quad 3 f$ कर्मफलं] $A$, धर्म्मकरन् $\mathrm{R} 4 \mathrm{~b}$ ०रूपेति ] $\mathrm{RA}_{7}$, ०रूपाभि॰ $\mathrm{A}_{3}$, ०रूपो भि॰ $\mathrm{A}_{4}$ 4d आह ] $\mathrm{A}$, इह $\mathrm{R}$ - यत्तत्रि॰] $\mathrm{A}_{3} \mathrm{~A}_{7}$, यत्तन्न्य॰ $\mathrm{R}$, पुत्रत्रि॰ $\mathrm{A}_{4}$ • ०बोधत ] conj., ०बोधयत् $\mathrm{R}$, ०बोध तत् $\mathrm{A}_{3} \mathrm{~A}_{4}$, ०बोधतां $\mathrm{A}_{7}$ $\mathbf{5}$ शतरूपोवाच ] $\mathrm{R}$, शतरूपा $\left\{{ }^{\circ} \mathrm{C} \mathrm{A}_{4}\right\}$ उवाच $\mathbf{A} \mathbf{5 b}$ स्त्रीणां धर्मविधिं शुभम् ] $\mathbf{A}$, शुभं स्त्रीणान्तु

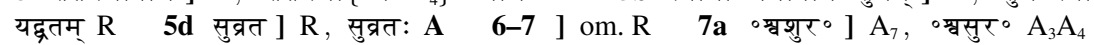




\section{ब्रह्मोवाच।}

शृणु पुत्रि महाधर्मः स्त्रीणां श्रेष्टो यथा भवेत्।

येन सा वर्तमानापि प्रत्यवायं न विन्दति॥ १॥

पतिशुश्रूषणं मूलं स्त्रीणां धर्मः सनातनः।

तस्य चैवानुरोधेन अन्यो धर्मः प्रवर्तते॥ १०॥

इदं नाम करिष्ये इहं यदि स्वामिन्मतं तव।

तेन सा समनुज्ञाता ततः कुर्यात्समाहिता।

कुर्वती तस्य शुश्रूषां तन्मना: तत्सलक्षणा॥ १? ॥

कुमार्यपि पिता तत्र म्राता मातापिता तथा।

अपृष्टा धर्मकार्येषु वर्तते स्वेच्छ,या न हि॥ ?२॥

विधवा या च नारी स्यात्सा तु भर्तुर्मृतस्य वै।

सालोक्यं काड़्क्षमाणा तु कुर्याद्वर्ममतन्द्रिता॥ १३॥

अतो उन्यथा तु या कुर्यान्मोहदुष्टा शुचिस्मिते।

सा गच्छेन्नरक घोरं सुप्रतिष्ठ दुरासदम्।

रौखवं नाम विख्यातं कर्मणा तेन शोभने॥ १४॥

उपवासं तु नारीणां त्रिरात्रान्न परं भवेत्।

अतः परं मनुष्याणामुपवासो विधीयते॥ १४ ॥

अक्षारलवणं या तु मासं मासं समश्नुते।

तस्या रूपं भवेद्विव्यं पतिश्च स्यात्तथाविधः॥ १६॥

शिरो मार्गशिरे दिव्यं सुनासं स्वक्षि चैव हि।

सुगण्डं चारुदन्तौष्ठ सुकर्ण सुशिरोरुहम्।

सुललाटं सुभ्रु चैव फुल्नराजीवलोचनम् ॥ १७॥

9a महाधर्म: ] $A$, यथा पुत्रि $R \quad 9 b$ श्रेष्टो यथा भवेत् ] $A$, श्रेयो ऊभिधीयते $R \quad 10 c$ चैवानु० $] A_{7}$, चानुप ${ }^{\circ} \mathrm{R}$, वैरानु ${ }^{\circ} \mathrm{A}_{3} \mathrm{~A}_{4} \quad 10 \mathrm{~d}$ अन्यो धर्मः प्रवर्तते ] $\mathrm{R}$, अन्येषां न विधीयते $\mathrm{A} \quad 11 \mathrm{~b}$ स्वामिन्मतं तव ] $\mathrm{A}_{3}$, वो नात्र संशय: $\mathrm{R}$, स्वामीन् मतं तव $\mathrm{A}_{4}$, स्वामिन्मतस्तव $\mathrm{A}_{7}$ 11d ततः कुर्यात् ] $\mathrm{A}$, तत्कुर्यात्तु $R \quad 11 \mathrm{e}$ कुर्वती ] $\mathrm{R}$, कर्मणा $\mathrm{A} 11 \mathrm{f}$ तन्मना: तत्स॰ ] conj., देवपत्नी सु॰ $\mathrm{R}$, तन्मना तद्वि॰ $\mathrm{A}_{3} \mathrm{~A}_{7}$, जन्मना तद्वि॰ $\mathrm{A}_{4}$ 12a पिता ] $\mathrm{RA}_{3} \mathrm{~A}_{7}$, तथा $\mathrm{A}_{4}^{\mathrm{pc}}$, ता $\mathrm{A}_{4}^{\mathrm{ac}}$ (an insertion mark before ता cancelled) $12 b$ म्राता माता०] $A$, माता म्राता $R$ ० पिता तथा ] $A$, तथैव च $R$ $12 c$ अपृष्टा ] $A$, अपूजा $R \quad 13 a b$ विधवा या च नारी स्यात्सा तु ] $A$, विविधाशा तथा नारी सा स्याद् $R \quad 13 c$ का ङ्क्माणा ] $R$, वीक्षमाणा $A 14 a$ अतो उन्यथा तु या ] $R$, अन्यथा तु न सा $A$ $14 b$ मोहदुष्टा ] $R$, मोहान्नष्टा $A$ 15a तु ] $A$, हि $R \quad 15 b$ ०रात्रान्न ] $R$, ०रात्रांत० $A_{3}$, ०रात्रांते $\mathrm{A}_{4}$, ०रात्रानु $\mathrm{A}_{7} 16 \mathrm{~b}$ मासं मासं] $\mathbf{A}$, मार्ग्गमासं $\mathrm{R} \quad 16 \mathrm{~d}$ ०श्च स्यात्त॰] $\mathrm{A}_{4} \mathrm{~A}_{7}$, ०स्तस्यास्त॰ $\mathrm{R}$, ० ख्चास्यात्त० $\mathrm{A}_{3} 17 \mathrm{a}$ मार्गशिरे ] $\mathrm{A}_{4} \mathrm{~A}_{7}$, रोमाणि मे $\mathrm{R}$, मार्गसिरे $\mathrm{A}_{3} \mathbf{1 7 b}^{6}-\mathbf{1 8 b}^{5}$ ] om. $\mathrm{A}_{4} 17 \mathrm{c}$ सुगण्डं ] em., सुगण्ड $\mathrm{R}$, युगान्तं $\mathrm{A}_{3} \mathrm{~A}_{7}$ • ॰ दन्तौष्टं ] $\mathrm{A}_{7}$, ॰दन्तास्यं $\mathrm{R}$, ॰दन्तौष्ट॰ $\mathrm{A}_{3}$ $17 \mathrm{~d}$ सुशिरो॰] $\mathrm{RA}_{7}$, शिरो॰ $\mathrm{A}_{3}$ (unmetrical) $17 \mathrm{e}$ सुभु चै॰ $] \mathrm{em}$., सुभूर्चै॰ $\mathrm{R}^{\mathrm{pc}}$, सुभ्रू चै॰ $\mathrm{R}^{\mathrm{ac}}$, सुद्रं चै॰ $\mathrm{A}_{3}$, सुभुग्चै॰ $\mathrm{A}_{7} 17 \mathrm{f}$ फुल्न $] \mathrm{A}_{3} \mathrm{~A}_{7}$, कुन्द० $\mathrm{R}$ 
पौषे ग्रीवा प्रशस्ता स्यान्माघे चैवाप्युरः शुभम्।

सुकण्ठं सन्धिवच्चैव सर्वलक्षणसंमितम्॥ १५॥

फाल्गुने च सुबाहुत्वं हस्तौ चास्याः सुलक्षणौ।

चैत्रे त्रिवलिमध्यत्वं तनुमध्यत्वमेव च।

सुश्लिष्टनाभिता चैव रोमराजी च शोभना॥ १९॥

वैशाखे जघनं दिव्यं विस्तीर्ण पीनमेव च।

ज्यैट्टे मासि वरोरुत्वं नागनासोरुता तथा।

सुगूढगुल्फता चैव आषाढे समुदाहृता॥ २०॥

जड्धे तु श्रावणे श्रेष्टे पादौ भाद्रपदे शुभौ।

पृष्टमश्वयुजे चैव कार्तिके कलभाषिता॥ २? ॥

या तु संवत्सरं पूर्ण लवणं परिवर्जयेत् ।

तस्यान्ते मिथुनं कृत्वा लवणेन समाहिता।

गुडाभरणसंयुक्त भाजने मृन्मये शुभम्॥ २२॥

लवणस्याढक चापि गुडस्य तु तुला-म्-अपि।

बीजानि चैव सर्वाणि रसाश्च विविधाः शुभाः॥ २३॥

अअनीं सशलाकां च फलिकां रोचनोपमाम्।

कुर्चानलककं चैव तुत्थं बिल्वमथापि च॥ २४॥

सुगन्धचूर्णपूर्णं च ताम्बूलं च सुलक्षणम्।

सिद्धार्थकांस्तिलांग्चैव कृत्वा स्थापनमेव च॥ २४॥

$18 \mathrm{~b}$ ॰न्माघे ] $\mathrm{A}$, ॰न्मध्यं $\mathrm{R} 18 \mathrm{c}$ सुकण्ठं] $\mathrm{A}_{3} \mathrm{~A}_{4}$, कन्धरं $\mathrm{R}$, सुकश्चं $\mathrm{A}_{7}$ • सन्धिवच्चै॰] $\mathrm{A}$ सन्धयश्चै० $R$ 19a सुबाहुत्वं ] $A$, शुभाड़्त्वं $R \quad 19 b$ चास्या: ] $R$, चास्य $A$ 19c त्रिवलिमध्यत्वं ] $\mathrm{A}_{3}$, च त्रिवलीमध्यं $\mathrm{R}$, त्रिवलिमध्यस्त्वं $\mathrm{A}_{4} \mathrm{~A}_{7} \quad 19 \mathrm{~d}$ तनुमध्यत्वमेव ] $\mathrm{A}$, सुहनुत्वमथापि $\mathrm{R}$ $19 \mathrm{e}$ सुश्लिष्ट०] $\mathbf{A}$, स्वडुम्ट्ठ $\mathrm{R} 19 \mathrm{f}$ ०राजी च ] conj., ०राजी +मनोरमा+ सु॰ $\mathrm{R}$ (unmetrical), ०राजीव $\mathrm{A} 20 \mathrm{c}$ ज्यैष्ठ ] $\mathrm{RA}_{3} \mathrm{~A}_{7}$, ज्येष्टे $\mathrm{A}_{4}$ - मासि वरोरुत्वं ] $\mathrm{R}$, मूले वरोरुत्वं $\left\{\right.$ ०द्ध $\left.\mathrm{A}_{3}\right\} \mathrm{A}_{3} \mathrm{~A}_{4}$, ज्येष्ठत्वमापन्नं $\mathrm{A}_{7} \quad \mathbf{2 0 d}$ नागनासोरुता ] em., नागनागोरुता $\mathrm{R}$, नागनाशोवता $\mathrm{A}_{3} \mathrm{~A}_{4}$, उरसः शोभनन् $\mathrm{A}_{7} 20 \mathrm{e}$ सुगूढगुल्फता ] $\mathrm{A}_{3}$, स्फीतत्वडुल्फता $\mathrm{R}$, सुगू $\left\{{ }^{\circ}\right.$ गु० $\left.\mathrm{A}_{7}\right\}$ ढगुल्मता $\mathrm{A}_{4} \mathrm{~A}_{7}$ 21a श्रेष्टे ] $\mathrm{A}$, स्वोष्ठौ $R$ 21d कार्त्तिके कलभाषिता ] $\mathbf{A}$, रोमराजी मनोरमा $\mathrm{R}$ (cf. 19f) 22a संवत्सरं ] $\mathrm{A}_{3} \mathrm{~A}_{7}$, संव्वत्सरं $\mathrm{R}$, संवत्सरे $\mathrm{A}_{4} 2 \mathrm{22}$ मिथुनं कृत्वा ] $\mathrm{A}$, हत्वा $\mathrm{R}$ (unmetrical) $22 \mathrm{~d}$ समाहिता ] $\mathrm{RA}_{3}$, समाहिता: $\mathrm{A}_{4} \mathrm{~A}_{7} \mathbf{2 2 f}$ मृन्मये ] $\mathrm{A}_{4} \mathrm{~A}_{7}$, मृण्मये $\mathrm{RA}_{3}$ - शुभम् ] $\mathrm{RA}_{7}$, शुभे $\mathrm{A}_{3} \mathrm{~A}_{4}$ 23b तु ] $\mathrm{A}$, च $\mathrm{R} 23 \mathrm{~d}$ रसाश्च ] $\mathrm{RA}_{3} \mathrm{~A}_{4} \mathrm{~A}_{7}^{\mathrm{ac}}$ ?, रसा(स्तु) $\mathrm{A}_{7}^{\mathrm{pc}}$ • शुभा: ] $\mathrm{A}$, शुभा $\mathrm{R} 2 \mathbf{2 4 a}$ अअनीं ] $\mathrm{RA}_{3} \mathrm{~A}_{4}$, अअलीं $\mathrm{A}_{7}$ - सशलाकां च] $\mathrm{R}$, ससलाकं च $\mathrm{A}_{3}$, सशलाकं च $\mathrm{A}_{4}$, ससनाकम्च $\mathrm{A}_{7} \mathbf{2 4 b}$ फलिकां ] $A$, फणिकां $R$ - न्नोपमाम् ] $R$, ०नोपमम् $A$ 24cd ] om. $A_{7}$ 24c कूर्चानलक्त॰] conj., कुर्व्वन्नलक्त॰ $\mathrm{R}$, कूर्चपादश॰ $\mathrm{A}_{3} \mathrm{~A}_{4}$ 24d तुत्थं ] $\mathrm{R}$, खड्रं $\mathrm{A}_{3} \mathrm{~A}_{4}$ 25a सुगन्ध॰] $\mathrm{R}$, सस्वर्ण० $\mathrm{A}_{3} \mathrm{~A}_{4}$, सुस्वर्ग्ग० $\mathrm{A}_{7} \bullet$ ॰ चूर्णपूर्णं च ] $\mathrm{R}$, ०चूर्णपूर्ण $\langle\leq\rangle \mathrm{A}_{7}$ (unmetrical), ०पूर्णचूर्णं $\left\{\right.$ ०ण्ण० $\left.\mathrm{A}_{4}\right\}$ ता $\mathrm{A}_{3}$ $\mathrm{A}_{4} 25 \mathrm{~b}$ सुलक्षणम् ] $\mathrm{RA}_{7}$, सलक्षणम् $\mathrm{A}_{3} \mathrm{~A}_{4} 25 \mathrm{c}$ सिद्धार्थकांस्ति॰ ] $A$, सिद्धार्थक ति॰ $\mathrm{R} 25 \mathrm{~d}$ कृत्वा ] R, कूर्च० $\mathrm{A}_{3} \mathrm{~A}_{4}$, कूर्श्च॰ $\mathrm{A}_{7}$ 
भक्षांग्च विविधाकारानैक्षवांश्च सुपूजितान् ।

गन्धान्सुमनसश्चैव वस्त्रयुग्मं नवं द्वयम्॥ २६॥

आसनं च चतुःशाखं त्रिरात्रोपोषिता सती।

कार्त्तिकामुदिते हीन्दावेनं दद्यात्सदक्षिणम्॥ २७॥

सुवर्ण रजतं चैव किस्चिदेवात्र दापयेत्।

ततस्तया सुचीर्णं तु व्रतं भवति नान्यथा॥ २६॥

ततः सुरूपतां लब्ध्वा पतिमाप्रोति शोभनम्।

देवरूपं महासत्वमिदमन्यच्छृणुष्व च॥ २९.॥

अनग्निपक्षं या नारी कुरुते व्रतमुत्तमम्।

न सा दुःखमवाप्रोति व्रतेनानेन शोभने॥ ३०॥

सिंहव्रतं तु या नारी चरेदेव परायणा।

तस्या वश्यो भवेद्रर्ता सिंहस्कन्धो महाबलः॥ ३? ॥

यमव्रतं तु या नारी कुरुते सुसमाहिता।

यमं सा हि न पश्येत न वै गच्छेत दुर्गतिम्॥ ३२॥

अर्चयेत्तत्र या सम्यक्कामं कृत्वा हृदि स्थितम्।

सदा नक्त च भुझाना सकृदन्नं यता पुनः।

सा पतिं शोभनं प्राप्य रम्यं च रमते सुखम्॥ ३३॥

प्रसृतं तण्डुलानां च या करोति सदाह्निक् ।

सा पतिं शोभनं प्राप्य बहून्पुत्रान्प्रजन्यते ॥ ३८ ॥

व्रतान्येतानि सर्वाणि संवत्सरमशेषतः।

कुर्यात्तेषां तदन्ते च ब्राह्मणांस्तर्पयदद्वहून्॥ ३४ ॥

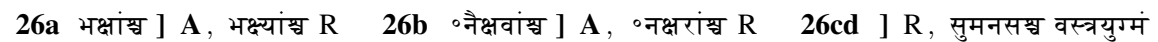
प्रदद्यात्तु द्वयं नवं \{नरं $\mathrm{A}_{3}$, नर: $\left.\mathrm{A}_{4}\right\} \mathrm{A} \pm$ 27a ${ }^{\circ}$ शाखं ] conj., ${ }^{\circ}$ शालं RA 27cd ${ }^{\circ}$ मुदिते हीन्दावेनं ] conj., $\sqcup$ चैन $\mathrm{R}$, ${ }^{\circ}$ मुदिते हीन्दौ $\left\{\right.$ हिंदौ $\mathrm{A}_{4}$, हि $\left.\sqcup \mathrm{A}_{7}^{\mathrm{ac}}\right\}$ तेन $\mathbf{A} 27 \mathbf{d}$ ०त्सदक्षिणम् ] em., ${ }^{\circ}$ त् सुदक्षिणम् $\mathrm{R}$, ०त्सदक्षिणां $\mathrm{A} 28 \mathrm{a}$ सुवर्णं] $\mathrm{RA}_{3} \mathrm{~A}_{7}$, सुवर्ण० $\mathrm{A}_{4} 28 \mathrm{c}$ ०स्तया ] $\mathrm{RA}_{3} \mathrm{~A}_{4}$, ०स्त्वया $\mathrm{A}_{7}$ - सुचीर्णं तु ] $\mathrm{R}$, सुसंपूर्ण $\mathrm{A} 29 \mathrm{a}$ लब्ध्वा ] $\mathrm{RA}_{3} \mathrm{~A}_{4}$, लब्धा $\mathrm{A}_{7} 29 \mathrm{~b}$ पति॰] $\mathbf{A}$, गति॰ $\mathrm{R}$ - शोभनम् ] $A$, शोभनाम् $\mathrm{R} 29 \mathrm{c}$ ०रूपं ] $\mathrm{RA}_{3}$, ०रूप० $\mathrm{A}_{4} \mathrm{~A}_{7}$ 29d ॰ च्छुणुष्व च] $\mathrm{A}_{4}$, ०त् प्रयुज्यते $\mathrm{R}$, ०त् शृष्व च $\mathrm{A}_{3}$ (unmetrical), ०त् शृणुस्व च $\mathrm{A}_{7}$ 30a अनग्निपक्षं या ] conj., इद नि:शड्क्या $\mathrm{R}$, अनग्निपक्षं या $\mathrm{A} 30 \mathrm{~b}$ कुरुते ] $\mathrm{A}_{4} \mathrm{~A}_{7}$, करोति $\mathrm{R}$, कुते $\mathrm{A}_{3}$ (unmetrical) $30 \mathrm{~d}$ शोभने ] $R$, शोभना $A 31 b$ चरेदेव ] $A$, वधोदर $R \quad 31 c$ वश्यो ] $A$, अवश्यं $R$ (unmetrical) 31d ०स्कन्धो ] $\mathrm{RA}_{4} \mathrm{~A}_{7}$, ०कंधा $\mathrm{A}_{3} 32 \mathrm{c}$ सा हि ] $\mathrm{R}$, हि सा $\mathrm{A}_{3} \mathrm{~A}_{4}$, $\sqcup$ हि $\langle($ जा $)\rangle \mathrm{A}_{7}$ (unmetrical) $32 \mathrm{~d}$ वै गच्छेत ] $\mathrm{R}$, च गच्छेत्च $A$ 33a या ] $A$, सा $R \quad 33 b$ ०क्षामं ] $A$, ०क् यमं $R \quad 33 c$ नक्तं च] $\mathrm{A}$, नक्तन्तु $\mathrm{R} 33 \mathrm{~d}$ सकृदन्नं] $\mathrm{A}_{3} \mathrm{~A}_{7}^{\mathrm{pc}}$, सुह्द्रर्ग० $\mathrm{R}$, सकृद्दन्न $\mathrm{A}_{4} \mathrm{~A}_{7}^{\mathrm{ac}}$ - यता ] $\mathrm{R}$, च या $\mathrm{A} 33 \mathrm{f}$ रम्यं च रमते ] $\mathrm{R}$, वश्यं च कुरुते $\mathrm{A} 34 \mathbf{a}$ प्रसृतं ] $\mathrm{RA}_{7}^{\mathrm{pc}}$ ?, प्रसूतं $\mathrm{A}_{3} \mathrm{~A}_{7}^{\mathrm{ac}}$, प्रभूतं $\mathrm{A}_{4}$ $34 c$ पतिं शोभनं ] $\mathbf{A}$, गतिं शोभनां $R \quad 34 d$ प्रजन्यते ] $\mathbf{A}$, प्रजायते $R$ 
तर्पयित्वा च पिष्टेन कृत्वा तांस्तु व्रतान्पुनः।

स्पर्शयेद्राह्मणेम्यस्तु ततस्तत्फलमश्नुते ॥ ३६॥

ब्राह्मणी तु व्रतानेतान्स्वस्मै पत्ये प्रदापयेत्।

इतरेषां तु वर्णानां नियमो नास्ति कश्चन॥ ३७॥

या तु संवत्सरं कुर्याइर्तुरुच्छेषभोजनम्।

न सा योन्यन्तरं प्राप्य पतिमन्यं समश्नुते ॥ ३५॥

या तु कृत्वा हृदिस्थं वै पतिं पतिमनुव्रता।

देववच्चार्चयेत्रित्यं किं तस्यास्तपसा पुनः॥ ३९ ॥

तस्यामेव व्रता नित्यं तेन भावेन तोषिताः।

सर्वान्कामान्प्रयच्छुन्ति धनमायुर्यशो बलम्॥ ४०॥

अष्टमीं चन्द्रकल्पं या चरते देवरूपिणम्।

सा तु सौम्यमवाप्रोति पतिं सर्वगुणैर्युतम् ॥ ४?॥

एतान्येव व्रतानीह मासिकानि गुचिस्मिते ।

चीर्णानि भोगं पश्यन्ति द्वादशाहस्य कर्मणः॥ ४२॥

मासि भाद्रपदे या तु कालरात्रिमुपासते।

कालरात्रं न सा पश्येद्विमुच्येत †समा सती †॥ ४३॥

वर्षाव्रतं तु या कुर्यात्प्रथमे वृष्टिसर्जने ।

सा वृष्टिरिव लोकस्य भर्तुर्भवति वै प्रिया॥ ४४॥

बह्वपत्यव्रतं या तु चरते मासमन्ततः।

पुत्रपौत्रवृता सा तु जायते दु:खवर्जिता॥ ४४ ॥

सर्वेषामेव धर्माणां कार्यों धर्मो न कग्चन।

श्रेष्टः पतित्रतादन्यः सत्यमेतद्रवीमि ते॥ ४६॥

एष धर्मः समाख्यातो नारीणां सुरपूजितः।

आचरस्व महाभागे यथाशत्ता सुनिश्चितम्॥ ४७॥

शतरूपा प्रणम्यैव तथैव पुनरेव च ।

आचचार तदा धर्मं ततः सा शुभलक्षणा॥ ४५॥

चिन्तयित्वा तदात्मानं पुनरेवाभवत्त्थिता॥ ४९.॥

36b तांस्तु व्रतान्पुनः ] $R$, तान् व्रतकाम्यया $A 36$ स्पर्शयेद्वा०] $A$, सा न्याय्यं ब्रा० $R$ ० ${ }^{\circ}$ ह्मणेम्यस्तु ] $\mathrm{A}_{4} \mathrm{~A}_{7},{ }^{\circ}$ ह्मेणेम्यस्तु $\mathrm{R}$, ॰ ह्मणोम्यस्तु $\mathrm{A}_{3} 36 \mathbf{d}$ ततस्तत्फलमश्नुते ] $\mathbf{A}$, तत्तत्फलमवाप्तु $\left\{\left({ }^{\circ}\right.\right.$ ग्नु० $\left.{ }^{\circ}\right)$ $\mathrm{R}^{\mathrm{ac}}$ \}ते $\mathrm{R} \quad 37 \mathrm{~b}$ ०न्वस्मै ] $\mathrm{R}$, ०न् यस्मै $\mathrm{A}_{3} \mathrm{~A}_{4} \mathrm{~A}_{7}^{\mathrm{pc}}$, ०न् $\sqcup \mathrm{A}_{7}^{\mathrm{ac}}$ • पत्ये] $\mathrm{RA}_{7}$, यत्ये $\mathrm{A}_{3}$, पत्यै $\mathrm{A}_{4} 37 \mathrm{c}$ इतरेषां तु वर्णानां ] $\mathrm{A}$, कुत एषान्तु दानानि $\mathrm{R} 38 \mathrm{~b}$ ०रुच्छेष॰ ] $\mathrm{R}$, ०रुच्छ्रेय० $\mathrm{A}_{3} \mathrm{~A}_{7}$, ०रुच्छिष्ट० $\mathrm{A}_{4} \quad 38 \mathrm{c}$ न ] $\mathrm{RA}_{3} \mathrm{~A}_{7}$, om. $\mathrm{A}_{4}$ (unmetrical) • योन्यन्तरं ] $\mathbf{A}$, पत्यन्तरं $\mathrm{R} 39 \mathbf{c}$ देववच्चा०] conj., देवरश्चा० $R$, देवताभ्य॰ $A$ 39d ०स्तपसा ] $A$, ०स्तपस: $R$ 40-col. ] om. $A$ 40a तस्यामेव व्रता ] conj., तस्थावेव च सा $R \quad 40 b$ तोषिता: ] em., तोषिता $R \quad 41 a$ अष्टमीं ] em., अष्टमी R 41b ०रूपिणम् ] conj., ०रूपिणीम् R $42 \mathrm{~d}$ द्वादशाहस्य ] conj., द्वादशन्तस्य R 44a कुर्यात् ] em., कुर्या R 49ab ] Loss of two or more pādas conjectured, om. R 
तामिन्दुबिम्बाननतेजसं शिवामभासत व्याकुलमायताक्ष्यः।

निशामिव क्षीणदिवाकरग्रहां निरीक्ष्य सख्यः सुचिरेण विस्मिताः॥ $y ० \|$

इति स्कन्दपुराणे द्वादशोत्तरशते इध्याये स्त्रीव्रतम्॥ १?२ - १॥

50ab शिवामभासत ] conj., शिवा सभाशत R $50 b$ ममायताक्ष्य: ] em., ॰मायताक्षाम् R Col. इति स्कन्दपुराणे रेवाखण्डे उध्याय: $R$ 


\section{द्वादशोत्तरशते डध्याये देवीशोकपरिहार: ।}

\section{सनत्कुमार उवाच ।}

तां तथा पतिशोकेन चिन्तयन्तीं सुदुः खिताम् ।

अगिकनन्या महासत्त्वा मालिनी तामुवाच ह॥ ? ॥

मालिन्युवाच।

मा शोके मन आधत्स्व हिमवत्तनये उव्यये।

आगमिष्यति ते भर्ता नचिरादेव यज्ञहा॥ २॥

सो ऽपि नूनं महासत्त्वो विरहात्तव शोभने।

भयस्तरेण शोकेन बाध्यते नात्र संशयः।

न हि ते स प्रियो देवि धृतिं लभति कर्हिचित्॥ ३॥

प्रभावत्युवाच।

यथेह मालिनी त्वाह एवमेव न संशयः।

मा त्वं शोके न आधत्स्व सख्य एताः सुमध्यमे॥ ४॥

एता हि तव दुःखेन द्विगुणं दुःखिताः शुभे।

लोकाश्च दु :खिता व्यक्त तव शोकेन सुप्रभे $\|y\|$

त्वं हि धारयसे लोकांस्त्वया दत्तं - - प्रभो।

दुःखेन दुःखितान्मा त्वं दुःखेन समयोजय॥ ६॥

देव्युवाच।

अयं भृड्डिरिटिर्नन्दी ईश्वरस्य सदा प्रियः।

एनं दृष्ट्वा हि शोकेषु मा सीदध्वं मया पुनः॥ ७॥

सनत्कुमार उवाच।

ततो भृड्डिरिटिर्नन्दी निश्चक्राम प्रतापवान्।

तस्माद्नृहान्महासत्त्वः पुर एवाभवत्स्थितः।

गम्यमानाभिचक्राम सखीभिः सा सुखावहा॥ ५॥

मालिन्युवाच।

एष वृक्षो बहुफलो उणडजैस्च बहुभिर्वृतः।

पश्यैनं गणपैर्दिव्यैर्यथा रुद्ध समावृतम्॥ ९॥

Only manuscript $\mathrm{R}$ is available for this part: $\mathrm{R}$ f. $190^{\mathrm{r}}-191^{\mathrm{r}}$

1d मालिनी ] em., मानिनी R 2 मालिन्यु॰ ] em., मानिन्यु॰ $R \quad 2 d$ यज्ञहा ] em., [ज।यज्वहा $\mathrm{R} 3 \mathrm{~b}$ विरहात्तव ] em., विरहातुर $\mathrm{R} 4 \mathrm{a}$ मालिनी ] em., मानिनी $\mathrm{R} 5 \mathrm{c}$ लोकाश्च ] conj., लोकस्य R 5d शोकेन ] conj., लोकेन R $6 b--$ ] conj., om. R (unmetrical) $6 \mathbf{c}$ दु:खितान् ] conj., दुःखिता $R \quad 7 a$ भृड़िरिटि॰ ] em., भृड़्रटि॰ $R \quad 7 b$ ईग्वरस्य ] conj., चेग्वरस्य $R$ $7 c$ एनं ] conj., एवं $R$ - शोकेषु ] conj., लोकेषु $R$ 7d सीदध्वं ] conj., सीद त्व $R \quad 8 a$ भृड़िरिटि॰] em., भृड्धरिटि॰ $R \quad \mathbf{8 b}$ निश्चक्राम ] em., निश्चंकाम $R \quad 9$ मालिन्यु॰ ] em., मानिन्यु॰ $\mathrm{R}$ 
अयं सुपुष्पः सुरसिद्धचारणैर्निषेवितो देवपतिर्यथाभवत् ।

तथा खगैर्मन्दरसानुगोचरैरिषेव्यते देवि च सौख्यद: सदा॥ १०॥

अयं तथान्यः सुरसिद्धवन्दितः सुपुष्पितः स्तूयति मागधैरिव।

खगैः खगीभिश्च त्रिलोकवन्दितो यथामरेशो मुनिभिः पुरन्दरः॥ १? ॥

अयं च सम्यक्सुनवेन्दुतोषितो यथैव कामी वदनैः स्वयोषिताम्।

$\dagger$ ययौ † तथान्यः खगसत्तमः शुभे पपौ तरूणां कुसुमासवं शुभम्॥ १२॥

इमं च चारुज्ज्वलचित्रलक्षणं खगं प्रवर्तन्तमुमे निरीक्षय।

खगीसहायं रुचिराब्जलोचनं यथैव रुद्रं सहितं त्वया उमे॥ १३॥

इमं च मत्तं कुसुमावृतं सखि खगेश्वरं भूतपतिं निशामय।

पुरेव सोमासवमत्तचेतसा मरुत्तयक्षे पतितं पुरन्दरम्थ १४॥

इमं सुधाशड्वतुषारपाण्डरे तडागतीरे शिखिनं निशामय।

वितत्य पक्षावनिशं व्यवस्थितं यथैव युद्धे तुरगेण सादिनम्॥ १५ ॥

इमं तथान्यं वनमध्यगं शुभं द्युतिप्रभासं विटपै: समन्वितम्।

उमे प्रपश्येह यथाम्बुदात्यये सुरेन्द्रपूजाध्वजमेकमुच्छ्रितम्॥ १६॥

इदं $\dagger$ पुरेवे $\dagger$ पतिगीतभाषितं सहैव पत्य्या विभयं शुभानने।

यथैव रुद्द: सहितस्त्वयानघे

इयं च वल्ली बहुपुष्पशोभिता अवेष्टयत्पादपमेनमन्ततः।

यथैव मत्ता सुरताभिकाड्द्रिणी समण्डना कामिनमन्यकामिनी॥ १६॥

अयं च वृक्षो हिमवत्सुते उव्यये शरीरजातेन तथा प्रबाध्यते।

यथैव देवः सुरनाथपूजितो महेम्वरस्त्वन्मदनेन सुत्रते॥ १९ ॥

सनत्कुमार उवाच।

एतच्छुत्वा तु सा देवी प्रहस्य हिमवत्सुता ।

उत्पलेन समाहत्य इदं वचनमब्रवीत् ॥ २०॥

दुः खितामपि मामद्य मर्मस्वेवाह्तयः प्रिये ।

न नाम स तु शोको उस्ति गच्छ त्वं नास्मि ते उव्यथा ॥ २?॥

तां तथावादिनीं सख्य ऊचुः सर्वाः सुमध्यमाः।

तव हास्यार्थमेतद्वै मालिन्या समुदाह्तम् ॥ २२॥

$10 \mathrm{~b}$ देवपति॰] $\mathrm{R}^{\mathrm{pc}}$, वापति॰ $\mathrm{R}^{\mathrm{ac}}$ (unmetrical) 10c ॰र्मन्दर॰] conj., ॰म्मन्द्रर॰ $\mathrm{R}$ 10d सौख्यद: ] conj., मोक्षद: $R \quad 11 a$ तथान्यः ] em., तथान्य० $R$ (unmetrical) 11b मागधै०] conj., सागरै॰ $R \quad 12 a$ ०क्सुनवेन्दु॰ ] conj., ०क् सुनरेन्द्र $R \quad 12 b$ वदनै: स्व॰] conj., वदनैस्च $R$ 12c तथान्य: ] conj., तथायं $R \quad \bullet$ शुभे ] $\mathrm{R}^{\mathrm{pc}}$, (खगे〉शुभे $\mathrm{R} 13 \mathrm{c}$ ०्लोचनं ] em., ०्लोचना $R \quad 13 d$ रुद्रं ] em., रुद्र: $R$ - सहितं त्वया ] conj., सहिस्त्वया R (unmetrical) 14a सखि ] conj., सखे $R \quad 14 b$ निशामय ] $R^{p c}$, निशायय $R^{a c} 14 c$ पुरेव ] conj., पुरे च $R \quad 16 b$ ॰प्रभासं ] conj., ०प्रशामं $R \quad \mathbf{1 7 d}$ ] $R$ has an insertion mark after pāda c, but no insertion i.m.

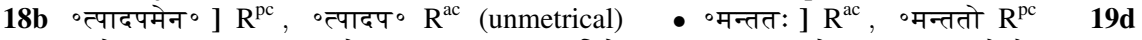
०स्त्वन्मदनेन ] conj., ०स्तन्मदनेन R $21 b$ ०यः प्रिये ] conj., ०यस्त्वये R 21c शोको ] conj., लोको R 21d ऽव्यथा ] conj., यथा R 22d मालिन्या ] conj., मानया R 
जितात्मा अनया सर्वा हास्यभावेन शोभने ।

हास्यं तवोत्पादयन्त्या साधु मालिनि साधुष्य ॥ २३॥

सनत्कुमार उवाच।

ततस्ताः पादचारेण हसन्त्यः कालिनन्दन।

अन्यदेशमनुप्राप्ताः सह शैलादिनाव्ययाः॥ २४॥

ता: स्वर्णलेखा इव शाणयुक्ता यथैव सौदामिनयः प्रकाशाः।

वनं समासाद्य विशोकशल्यं विभान्ति मेघेषु - र् - अतिप्रभावाः ॥ २४॥

इति स्कन्दपुराणे द्वादशोत्तरशते ऽध्याये देवीशोकपरिहारः॥ १९२-२॥

23a जितात्मा ] conj., जिताम्बा $\mathrm{R} 23 \mathrm{~b}$ हास्य॰] conj., दास्य॰ $\mathrm{R} 23 \mathrm{~d}$ मालिनि ] em., मानिनि $R$ 24d शैलादिना० ] conj., सेनादिना० $R$ 25a ताः स्वर्ण॰ ] conj., तामुह्य॰ $R$ शाणयुक्ता ] conj., साभियुक्तां $R \quad 25 c$ ०शल्यम् ] $R^{p c}$, ०शल्याम् $R^{a c} 25 d$ विभान्ति] em., विभाति $\mathrm{R}$ Col. इति स्कन्दपुराणे रेवाखण्डे इध्याय: $\mathrm{R}$ 


\section{द्वादशोत्तरशते ऽध्याये सप्रर्षिसमागमः।}

\section{सनत्कुमार उवाच।}

ततः शुभावती नाम मेरुकन्या सुमध्यमा।

उवाच हिमवत्पुत्रों दर्शयन्ती शुमं वनम्॥ १॥

शुभावत्युवाच।

इदं पर्वतकन्ये त्वं पश्य केलिकलाशुभम्।

वनं सर्वर्तुसंपन्नं यथा विद्वत्सुभाषितम्॥ २॥

अयं प्रपातः सुमहान्पर्वतस्यास्य शोभते।

विदुषामर्थकृत्येषु यथा युक्त प्रभाषितम्॥ ३॥

एष स्वर्णोपलो भाति गिरे: शिखर उत्तमः।

$\dagger$ यथा लक्षणविद्वांसं युको यश्चेन्द्र इत्यपि $\dagger ॥$ ४॥

अयं च मणिमान्नित्यं शिलाग्रः प्रतिभास्वरः।

भाति उद्यत्रिवादित्य: उदयस्थो महायुगे॥ $y \|$

अयं वैदूर्यशिखर इन्द्रनीलतलोपलः।

भाति शर्वाणि † शुभ्राणि स्थलेश्वर $\dagger$ इवोपरि॥ ६॥

अयं गजोत्तमो मत्तः करेणुभिरपावृतः ।

अप्सरोगणमध्यस्थो देवराडिव पर्वते॥ ७॥

Manuscripts available for this part: R f. $191^{\mathrm{r}}-193^{\mathrm{v}} ; \mathrm{A}_{3}$ f. $114^{\mathrm{v}}-116^{\mathrm{r}} ; \mathrm{A}_{4}$ f. $161^{\mathrm{v}}-164^{\mathrm{r}} ; \mathrm{A}_{7}$ f. $162^{\mathrm{r}}-165^{\mathrm{r}}$. This part $\left(\mathrm{SP}_{\mathrm{RA}} 112.3\right)$ corresponds to $\mathrm{SP} 112.73-115$.

1 सनत्कुमार उवाच ] om. A 1a Before this Bh has 26 pādas (see SP 112.73-78) • ततः ] $\mathrm{RA}$, तदा $\mathrm{Bh}$ (conj.) • शुभावती ] $\mathrm{ABh}$, सु\{शु॰ $\left.\mathrm{R}^{\mathrm{ac}}\right\}$ भारती $\mathrm{R} \quad \mathbf{l b}$ मेरु॰] $\mathbf{A B h}$, एक॰ $\mathrm{R}$ $1 d$ दर्शयन्ती ] $\mathrm{RA}_{4} \mathrm{~A}_{7} \mathrm{Bh}\left(\mathrm{em}\right.$. ?), दर्शयन्तीं $\mathrm{A}_{3}$ • शुभं वनम् ] $\mathrm{A}_{3} \mathrm{Bh}$, शुभावहम् $\mathrm{R}$, शुभं बलं $\mathrm{A}_{4}$ शुभां बलं $\mathrm{A}_{7} \mathbf{2}$ शुभावत्युवाच ] $\mathbf{A}$, सु\{शु० $\left.\mathrm{R}^{\mathrm{ac}}\right\}$ भारत्युवाच $\mathrm{R}, \mathrm{om} . \mathrm{Bh} \mathbf{2 b}$ पश्य केलिका०] $\mathrm{A}_{3} \mathrm{Bh}$, सुसम्यक् फलिना $\mathrm{R}$, पश्य केलीकला॰ $\mathrm{A}_{4} \mathrm{~A}_{7} \bullet$ ०शुभम् $] \mathrm{R}^{\mathrm{pc}} \mathrm{ABh}$, वनम् $\mathrm{R}^{\mathrm{ac}} \quad \mathbf{2 c}$ वनं ] $\mathrm{RA}_{3} \mathrm{Bh}$, बलं $\mathrm{A}_{4} \mathrm{~A}_{7}$ 2d यथा विद्वत्सु॰ ] $\mathrm{R}$, यथाधित्वं सु॰ $\mathrm{A}_{3} \mathrm{~A}_{4} \mathrm{Bh}$, यथाधि(घ्यं) सु॰ $\mathrm{A}_{7} 3 \mathrm{3a}$ प्रपातः ] $\mathrm{R}$, प्रसूते $\mathrm{ABh} 3 \mathrm{~b}$ ॰न्पर्वतस्या॰] $\mathrm{R}$, ०न् सपर्वस्या॰ $\mathrm{ABh} \bullet$ शोभते ] $\mathrm{R}^{\mathrm{pc}}$ ?, शोभति $\mathrm{R}^{\mathrm{ac}}$, शोभने $\mathrm{ABh} \quad 3 \mathrm{c}$ ०मर्थकृत्येषु ] $\mathrm{R}$, ${ }^{\circ}$ मथ कृच्छ्रेषु $\mathrm{ABh} \quad 3 \mathrm{~d}$ प्रभाषितम् ] $\mathrm{R}$, सुभाषितं $\mathrm{ABh}$ 4a एष स्वर्णोपलो ] $\mathrm{R}$, तथा स्वर्णोत्पलो $\mathrm{A}$, तथा स्वर्णोपलो $\mathrm{Bh}(\mathrm{em} . ?) \quad \mathbf{4 c d} \circ$ विद्वांसं युक्तो यश्चेन्द्र इत्यपि ] $\mathrm{R}$, ०वद्विद्वान् प्रगीय $\left\{{ }^{\circ}\right.$ त $\left.\mathrm{A}_{7}\right\}$ इव सामग: $\mathrm{ABh} \quad \mathbf{5}$ ] om. $\mathrm{R}$ 5a मात्रित्यं ] $\mathrm{A}_{3} \mathrm{~A}_{4} \mathrm{Bh}$, ०माणिक्य $\mathrm{A}_{7}$ 5b शिलाग्र: ] conj., शिलेग्र० $\mathrm{A}_{3}$, शिलोग्नि० $\mathrm{A}_{4} \mathrm{~A}_{7}$, शैलाग्र: $\mathrm{Bh}$ (conj.) 5d उदयस्थो ] conj., उभयस्तो $\mathrm{ABh} \quad \mathbf{6 a}$ वैदूर्य॰] $\mathrm{RA}_{3} \mathrm{~A}_{7} \mathrm{Bh}$, वैर्डूर्य० $\mathrm{A}_{4} \quad \mathbf{6 b}$ ०तलोपलः ] em. $\mathrm{Bh}$ (silently), ${ }^{\circ}$ तमोपम: $\mathrm{R}$, तलो $\left\{{ }^{\circ}\right.$ नो॰ $\mathrm{A}_{3}$ \}त्पल: $\mathrm{A} \quad \mathbf{6 c}$ भाति ] $\mathrm{R}^{\mathrm{ac}} \mathrm{A}_{4} \mathrm{~A}_{7} \mathrm{Bh}\left(\mathrm{em}\right.$. ?), भान्ति $\mathrm{R}^{\mathrm{pc}} \mathrm{A}_{3}$ - शर्वाणि ] em. $\mathrm{Bh}$, सर्वाणि RA - शुभ्राणि ] $\mathrm{A}_{3} \mathrm{~A}_{4}$, सुस्थायां $\mathrm{R}$, सुभ्राणि $\mathrm{A}_{7}$, विभ्राण: $\mathrm{Bh}$ (conj.) 6d स्थलेश्वर ] $\mathrm{ABh}$, तवेहव $\mathrm{R} \bullet$ इवोपरि ] conj., हवो इपरि $\mathrm{R}$, हरोपरि $\mathrm{ABh} 7 \mathrm{a}$ गजोत्तमो मत्तः ] em., गजोत्तमोन्मत्तः $\mathrm{R}$, मत्तो गजो मत्त० $\mathbf{A}$, मत्तो गजो मत्तः Bh (em.?) $7 \mathbf{b}$ ०रपावृतः ] $\mathrm{R}$, ०रिवावृत: $\mathrm{ABh} \mathbf{7 c - 1 0 b}]$ om. $\mathrm{ABh}$ 
अयं $\dagger$ गजो गजेनैव $\dagger$ सुमहान्पर्वतोत्तमः।

इतो यान्तो दिवि $\dagger$ चमां $\dagger$ दिग्गजे च यथा सुरः॥ ५॥

पश्यामश्चैव लस्यामः प्रदीपमिव संस्थितम्।

अशोकं हिमवत्पुत्रि पल्नवैरुपशोभितम्॥ ९॥

बालारुणनिभो ह्येष वायुनाभिपरित्रुतः।

कृत्वात्राअलयः सुभ्रु पब्लवै: शिरसा नतः॥ १०॥

अहो उस्य रूपं पश्येमं वनराजियुतं शुभे।

यौवराज्ये ऽभिषिकं वै जयन्तमिव चामरै:॥ १?॥

पादपैरेव शर्वाणि पश्यैनं करपत्लवै:।

मातुः समीपे नृत्यन्तं शिशुं प्रियमिवौरसम्॥ ?२॥

मन्ये प्रियावासमिमं देवताया वनस्य ह।

अतीव दीप्यते शोभा नेदृशीं दृष्टवत्यहम्॥ १३॥

सनत्कुमार उवाच।

तस्यास्तद्वचनं श्रुत्वा शुभावत्या गिरे: सुता।

निरीक्ष्य तं तरुं सम्यग्चिमवत्तनयाव्यया।

मनसा चिन्तयामास पुत्रो डयं मम पादपः॥ १४॥

आगते पुनरेवेह देवदेवे अधिष्टिते ।

इमं तेनाम्यनुज्ञाता ग्रहीष्ये पादपं सुतम् ॥ ?५ ॥

$\mathbf{1 5} \approx \mathrm{SP} 112.81$

8c यान्तो ] conj., यन्त्रा $\mathrm{R} 9 \mathrm{~b}$ प्रदीप॰ ] em., प्रदीप्य० $\mathrm{R} 9 \mathrm{~d}$ पत्लवै०] em., पल्ववै० $\mathrm{R}$ 10a बालारुण॰ ] conj., कालाअन० $R$ 10c कृत्वात्राअलयः ] conj., कृत्वा यत्राअनी $R$, कृत्वाभ्यअनयः $\mathrm{A}_{3} \mathrm{~A}_{4} \mathrm{Bh}$, कृत्वाभ्यअलय: $\mathrm{A}_{7}$ - सुभुतु ] $\mathrm{RA}_{3} \mathrm{~A}_{4} \mathrm{Bh}$, शुभ्रू $\mathrm{A}_{7}$ 10d पत्लवै: ] $\mathrm{ABh}$, पल्ववै: $\mathrm{R} 11 \mathrm{a}$ स्य ] RA, सु० $\mathrm{Bh}$ (conj.) • पश्येमं ] $\mathrm{A}_{3} \mathrm{~A}_{7} \mathrm{Bh}$, पश्येम $\mathrm{RA}_{4} 11 \mathrm{~b}$ वन ${ }^{\circ} \mathrm{RA}_{3} \mathrm{Bh}$, बल० $\mathrm{A}_{4} \mathrm{~A}_{7} \bullet$ ०राजियुतं ] $\mathrm{A}_{3} \mathrm{~A}_{4} \mathrm{Bh}$, ०राजीसुतं $\mathrm{R}$, ०राजिसुतं $\mathrm{A}_{7}$ 11c उभिषिक्त ] $\mathrm{RA}_{4} \mathrm{~A}_{7} \mathrm{Bh}$ (em.?), भिमिक्त $\mathrm{A}_{3}$ 11cd वै जयन्तमिव चामरै: ] $\mathrm{ABh}$, मां वैजयन्तमिवापरै: $\mathrm{R}$ 12a पादपैरेव ] conj., पल्ववैरिव $\mathrm{R}$, पादपैरिव $\mathrm{A}_{3} \mathrm{~A}_{7}$, पदपैरिव $\mathrm{A}_{4}$, पादपं चैव $\mathrm{Bh}$ (conj.) • शर्वाणि ] em. $\mathrm{Bh}$ (silently), सर्वाणि RA 12b पश्यैनं ] $A B h$, पश्येम $R$ - ०पल्लवै: ] $R^{a c} A B h$, ०पल्ववै: $R^{p c}$ 12d शिशुं ] $\mathrm{R}$, पुत्रं $\mathrm{ABh} 13 \mathrm{a}$ प्रिया०] $\mathrm{RA}_{3} \mathrm{~A}_{4} \mathrm{Bh}$, श्रिया० $\mathrm{A}_{7}$ ० मिमं ] $\mathrm{ABh}$, ०मिदं $\mathrm{R}$ $13 \mathrm{~b}$ वनस्य ह ] $\mathrm{ABh}$, धनस्य च $\mathrm{R} 13 \mathrm{c}$ अतीव ] $\mathrm{ABh}$, इतीव $\mathrm{R}$ - दीप्यते ] $\mathrm{RA}_{4} \mathrm{~A}_{7}$, दृश्यते $\mathrm{A}_{3} \mathrm{Bh}$ - शोभा ] $\mathrm{RA}_{3} \mathrm{Bh}$, शोभां $\mathrm{A}_{4} \mathrm{~A}_{7} \quad 13 d$ नेदृशीं ] $\mathrm{A}_{3} \mathrm{~A}_{7} \mathrm{Bh}$, नेदृशी $\mathrm{RA}_{4} \quad 14 \mathrm{c}$ निरीक्ष्य तं ] $\mathrm{RA}_{3} \mathrm{~A}_{7}$, निरीक्षंतं $\mathrm{A}_{4}$, निरैक्षित्ट $\mathrm{Bh}$ (conj.) - तरुं] $\mathrm{ABh}$, गुरुं $\mathrm{R} 14 \mathrm{~cd}$ सम्यग्चि॰] $\mathrm{RA}$, बालं हि॰ Bh (conj.) 14d After this Bh has 8 pādas (see SP 112.79-80ab) 14e मनसा ] $\mathrm{ABh}$, सा त्वेवं $\mathrm{R} \mathbf{1 4 f}$ मम पादप: ] $\mathrm{R}$, पादपो $\left\{\right.$ पं $\left.\mathrm{A}_{7}\right\}$ मम $\mathbf{A B h} \bullet$ After this $\mathrm{Bh}$ has two pādas (see SP 112.80cd) 15ab ] (A), om. R, भगवत्यागते ह्येनमनुज्ञाता स्वयंभुवा $\mathrm{Bh}(<\mathrm{S})$ $15 b$ देवे अधिष्टिते ] conj., ॰देवैरतिष्ठत $\mathrm{A}_{3} \mathrm{~A}_{4}$, ०देवै अधिष्टिते $\left.\mathrm{A}_{7} \quad 15 \mathrm{~cd}\right](\mathrm{R})(\mathbf{A})$, ग्रहीष्यामि प्रियं पुत्रं वालाशोकस्य पादपम् $\mathrm{Bh}(<\mathrm{S}) \quad 15 \mathrm{c}$ इमं ] $\mathbf{A}$, इयं $\mathrm{R} \quad 15 d$ सुतम् ] $R$, शुभा $\mathrm{A}_{3} \mathrm{~A}_{4}$, सुता $\mathrm{A}_{7}$ 
ममैवायमपुत्राया भविता पादपोत्तमः।

पुत्रः पुत्रवतां श्रेष्ठः पुत्रशोकविनाशनः॥ १६॥

सनत्कुमार उवाच।

सा विनिश्चित्य तु तदा पादपं प्रति शोभना।

अन्यं देशं परिक्यम्य इमं तत्राभिपश्यत॥ १७॥

शिखरं पर्वतेन्द्रस्य अपतद्वस्यनं विना।

पादपाश्च विना वातमुन्मूलाः संबभूविरे॥ १५॥

उल्काः पतन्ति चाकाशाद्ववौ वायुरशोभनः।

अक्षि सद्यो उस्फुर द्देव्या दक्षिणं कालिनन्दन ॥ १९ ॥

तान्दृष्ट्रा विस्मितं देवी शैलादिमिदमब्रवीत् ।

सख्यय्च सर्वाः कालेय इदं वचनकोविदा॥ २०॥

देव्युवाच।

प्रमत्तो भाति शैलग्च सर्वैस्तैर्वृक्षसंयुतः।

भयं महदिदं मन्ये नैतदाकस्मिकं स्मृतम्॥ २?॥

नाद्यानिमित्तमुत्पाता भवन्त्येते दुरासदाः।

तथा कुरु यथा मे नो भयं यच्छुन्त्यशोभनाः॥ २२॥

\footnotetext{
16a ममैवा॰] RA, मम चा॰ Bh (conj.) • ॰मपुत्राया ] RBh (em.?), ॰मपुत्राय A 16b भविता ] $\mathrm{RBh}$ (conj.?), भेजिता $\mathbf{A} 16 \mathrm{c}$ पुत्रः पुत्रवतां ] $\mathrm{RBh}$ (conj.), पुत्र पुत्रवती॰ A 16cd श्रेष्टः पुत्रशोकवि॰ ] $\mathrm{A}_{7}$, श्रेष्ठश्चाशोकः शोक॰ $\mathrm{R}$, ० श्रेष्ठ पुत्रशोकवि॰ $\mathrm{A}_{3} \mathrm{~A}_{4}$, श्रेष्ठाः पुत्रशोकवि॰ $\mathrm{Bh}(\mathrm{em} . ?)$ $16 d$ ॰नाशनः ] $\mathrm{RA}_{7} \mathrm{Bh}$ (em.?), ०नाशन $\mathrm{A}_{3} \mathrm{~A}_{4} \quad 17 \mathbf{a}$ सा विनिश्चित्य तु ] $\mathbf{A}$, सा विनिश्चित्य $\mathrm{R}$ (unmetrical), सैवं विनिश्चित्य $\mathrm{Bh}$ (conj.?) 17c अन्यं ] $\mathrm{ABh}$, अन्यद् $\mathrm{R}$ - परिक्रम्य ] $\mathrm{ABh}$, परिभ्राम्य $\mathrm{R} \quad \mathbf{1 7 d}$ इमं ] $\mathrm{R}$, उमा $\mathrm{ABh} \mathbf{1 7 d}$ तत्राभि॰] RA, तत्राभ्य॰ Bh (em.?) - After this Bh has four pādas (see SP 112.82) $\quad \mathbf{1 8 b}$ अपतद्यसनं ] conj. Bh, अपतत् स्वसनं $\mathrm{R}$, अपश्यद्वसनं $A 18 c d$ ०तमुन्मूला:] $A_{3} B h$, ०तं समूला $R$, ${ }^{\circ}$ तमुन्मूला $A_{4}$, ${ }^{\circ}$ तमुन्मूनाः $A_{7} 18 d$ संबभूविरे ] $\mathrm{A}_{3} \mathrm{~A}_{4} \mathrm{Bh}$, उन्मुमूलिरे $\mathrm{R}$, स बभाविरे $\mathrm{A}_{7} 19 \mathrm{ab}$ चाकाशाद्ववौ] $\mathrm{A}_{3} \mathrm{~A}_{4} \mathrm{~A}_{7}^{\mathrm{ac}}$, चाकाशे ववौ $\mathrm{R}$, चाकाशद्रवौ $\mathrm{A}_{7}^{\mathrm{pc}}$, चाकाशाद्वाति $\mathrm{Bh}$ (conj.) $19 \mathrm{~b}$ ०रशोभनः ] $\mathrm{ABh}$, ०र्दुरासद: $\mathrm{R} \quad 19 \mathrm{c}$ अक्षि सद्यो $5^{\circ}$ ] conj., दक्षिणच्चा० $\mathrm{R}^{\mathrm{ac}}$, अक्षिणगे $\mathrm{R}^{\mathrm{pc}}$ (unmetrical), अक्षि सव्यं $\mathrm{A}_{3} \mathrm{~A}_{4} \mathrm{~A}_{7}^{\mathrm{pc}}$ ?Bh, अक्षि स(द्य): $\mathrm{A}_{7}^{\mathrm{ac}} 19 \mathrm{~cd}$ ०स्फुरद्देव्या दक्षिणं ] $\mathrm{R}$, स्फुरचापि दिव्या तत् $\mathrm{A}_{3} \mathrm{~A}_{4}$, स्फुरचापि देव्यास्तत् $\mathrm{A}_{7} \mathrm{Bh}$ (em.?) $20 a$ तान्दृष्द्रा ] $\mathbf{A}$, तं दृष्द्रा $R$, तान् वीक्ष्य $B h$ (conj.) - विस्मितं ] $\mathrm{A}_{3} \mathrm{~A}_{4}$, विकृतं $\mathrm{R}$, विस्वितं $\mathrm{A}_{7}$, विस्मिता $\mathrm{Bh}(\mathrm{em} . ?) \quad 20 \mathrm{~b}$ शैलादिमि॰ $\mathrm{A}_{3} \mathrm{~A}_{4} \mathrm{Bh}$, दैत्यानामि॰ $\mathrm{R}$, शैलादी $\left\{\circ\right.$ दि॰ $\left.\mathrm{A}_{7}^{\mathrm{ac}}\right\}$ नि॰ $\mathrm{A}_{7}$ 20cd ] om. R 20c सख्यश्च ] A, सखीश्च Bh (em.) • सर्वा: कालेय ] conj., सर्वकालेया $\mathbf{A B h}$ $20 d$ क कोविदा ] $\mathbf{A}$, ०कोविदा: $\mathrm{Bh}$ (em.?) 21 देव्युवाच ] $\mathrm{RA}_{3} \mathrm{~A}_{7} \mathrm{Bh}$, देव उवाच $\mathrm{A}_{4}$ 21ab ] $\mathrm{A}$, अप्रमेयो भवानस्तु शैलादे गणपै: सह $\mathrm{R}$, प्रमत्तो भाति शैलोयं वृक्षैस्तै: सर्वतो युतः $\mathrm{Bh}$ (conj.?) $21 \mathrm{c}$ मन्ये ] $R^{\mathrm{pc}} A B h$, जातं $R^{\mathrm{ac}} 21 \mathrm{~d}$ स्मृतम् ] $A B h$, शुभम् $R \quad$ 22a नाद्यानि॰ ] conj., न ह्यनि॰ $\mathrm{RA}$ (unmetrical), न चानि॰ $\mathrm{Bh}$ (conj.) $22 \mathrm{~b}$ भवन्त्येते ] $\mathrm{ABh}$, दृश्यन्ते हि $\mathrm{R} 22 \mathrm{c}$ यथा मे ] $\mathrm{ABh}$, यतात्मा $\mathrm{R} 22 \mathrm{~d}$ भयं यच्छन्त्य० ] $\mathrm{ABh}$, मान यच्छति $\mathrm{R}$ • ०शोभना: ] $\mathrm{A}_{3} \mathrm{~A}_{7} \mathrm{Bh}$, शोभन $\mathrm{R}$, ०शोभना $\mathrm{A}_{4}$ - After this Bh conjectures two pādas reading ततो नन्दी प्रणम्याह देवदेवीं कृताअलि:।
} 


\section{नन्द्युवाच।}

शिवा ह्येते महावीरा लोकपालोपमा इति।

कुतो भयं तव शुभे यस्या भर्ता वृषध्वजः॥ २३॥

यतः सवर्व जगत् $†$ सवं दानवानामपश्यत $\dagger$ ।

कुतो भयं भवानि त्वं मातासि त्रिदिवौकसाम् ॥ २४॥

सनत्कुमार उवाच।

तस्यैवंवदतो व्यास देवीं विश्वस्य मातरम्।

अन्धको नाम दैत्येन्द्र: पातालान्मन्दरं ययौ॥ २४॥

स दैत्यानां शतेनैव वरिष्टानां महासुरः।

आगतो मन्दरं द्रष्टुं यथेन्द्रो नन्दनं वनम्॥ २६॥

प्रह्लादश्चानुह्लादश्च शिबिर्बाष्कलिरेव च।

कुण्डस्तुकुण्डो वातापी बलिर्बाणो विरोचनः॥ २७॥

इल्वलो नमुचिर्यंसो विप्रचित्तिर्महासुर:।

सुन्दो निसुन्दो नरको धेनुको उरिष्ट एव च॥ २५॥

मुरः कार्तस्वनश्चैव हस्ती दुर्योधनो मयः।

तारकस्तारकाक्षश्च विद्युन्माली प्रभाकरः ॥ २९ ॥

हालाहलग्च कुम्भश्च शम्बर: कालशम्बर:।

धुन्धुस्तथेन्द्रदमो हयग्रीव: शतोदर:॥ ३०॥

$\mathbf{2 5 c d} \approx \mathrm{SP} 112.83 \mathrm{ab}$

23-24ab ] om. $\mathrm{ABh} 24 \mathrm{c}$ त्वं ] $\mathrm{R}$, त्वां $\mathrm{ABh} 24 \mathrm{~d}$ मातासि त्रि॰ ] conj., यातासि त्रि॰ $\mathrm{R}$, या त्वं माता $\mathrm{ABh} 25 \mathrm{a}$ तस्यैवं०] $\mathrm{RA}_{3} \mathrm{~A}_{4} \mathrm{Bh}$, तथैवं $\mathrm{A}_{7} \bullet$ वदतो ] $\mathrm{ABh}$, ०गदतो $\mathrm{R} 25 \mathbf{b}$ विश्वस्य ] $\mathrm{ABh}$, विश्रम्य $\mathrm{R} 25 \mathrm{c}$ नाम दैत्येन्द्र: ] $\mathrm{RA}$, पि तदा दैत्य: $\mathrm{Bh}(<\mathrm{S})$ 25d पातालान्मन्दरं ] $\mathrm{ABh}$, प्रपातान्मन्दिरं $\mathrm{R}$ - After this $\mathrm{Bh}$ has four pādas (see SP 112.83c-f) 26a शतेनैव ] $\mathrm{A}_{4} \mathrm{~A}_{7}$, शतेनापि $\mathrm{R}$, मतेनैव $\mathrm{A}_{3} \mathrm{Bh} 26 \mathrm{~b}$ वरिष्टानां ] $\mathrm{ABh}$, करिष्यामो $\mathrm{R}$ - महासुर: ] $\mathrm{A}_{3} \mathrm{~A}_{7} \mathrm{Bh}$, न संशय: $\mathrm{R}$, महासुर $\mathrm{A}_{4} 26 \mathrm{c}$ मन्दरं] $\mathrm{ABh}$, मन्दिरं $\mathrm{R}$ - द्रष्ट्ं] $\mathrm{RA}_{3} \mathrm{Bh}$, दृष्ट्ं $\mathrm{A}_{4} \mathrm{~A}_{7}$ 26d यथेन्द्रो नन्दनं वनम् ] $\mathrm{A}_{3} \mathrm{~A}_{4} \mathrm{Bh}$, यथा मन्दो महाबल: $\mathrm{R}$, यथेन्द्रो नन्दनं बलं $\mathrm{A}_{7}$ 27a ० ग्चानुह्लादश्च ] $A B h$, ०श्चापि ये तत्र $R \quad 27 b$ शिबिर्बाष्कलिरेव च ] em., मुनिना च ततो व्यय: $R$, शिबि [शिखिबि० $\mathrm{A}_{3}$ (unmetrical)\}राक्षणिरेव च $\mathrm{A}_{3} \mathrm{~A}_{4}$, शिबिबाक्षलिरेव च $\mathrm{A}_{7}$, शिनिर्बाष्कलिरेव च $\mathrm{Bh}$ (conj.?) $27 \mathrm{c}$ कुण्डस्तुकुण्डो ] em., कुण्डन्तुकुण्डो $\mathrm{R}$, कुण्डो भुकुण्डो $\left\{{ }^{\circ}\right.$ कुडो $\left.\mathrm{A}_{4}\right\} \mathbf{A}$, हुण्डस्तुहुण्डो $\mathrm{Bh}$ (conj.) • वातापी ] $\mathrm{ABh}$, वातापिर् $\mathrm{R} 28 \mathrm{a}$ इल्वलो ] $\mathrm{A}_{3} \mathrm{~A}_{4} \mathrm{Bh}$, इल्नलो $\mathrm{R}$, इ(ल्व)ना $\mathrm{A}_{7}$ • ०व्यंसो ] conj. $\mathrm{Bh}$, ०र्व्यास $\mathrm{RA}_{3}$, वर्वासो $\mathrm{A}_{4}$, ०व्व्यासे $\left.\mathrm{A}_{7} 28 \mathrm{~cd}\right] \mathrm{ABh}$, स्कन्दो निकुम्भो राजेन्द्र: सर्व्व दैत्यगणास्तथा $R$ 29ab ] om. $R$ 29a मुर: ] conj. Bh, सुर: $A$ 29c ०स्तारकाक्ष॰ ] $R^{\mathrm{pc}} \mathbf{A B h}$, ०स्तारकाख्य $\mathrm{R}^{\mathrm{ac}}$ 29d प्रभाकर: ] $\mathrm{ABh}$, तथैव च $\mathrm{R}$ 30ab ] om. $\mathrm{R}$ 30a हालाहल॰ ] $\mathrm{A}_{3} \mathrm{~A}_{7} \mathrm{Bh}$, हलाहल॰ $\mathrm{A}_{4} 30 \mathrm{~b}$ शम्बर: ] $\mathrm{A}_{4}$, संवर: $\mathrm{A}_{3} \mathrm{~A}_{7} \mathrm{Bh} \bullet$ ॰ शम्बर: ] $\mathrm{A}_{4}$, ०संवर: $\mathrm{A}_{3} \mathrm{~A}_{7} \mathrm{Bh}$ 30c धुन्धु० $] \mathbf{A B h}$, धेनु० $\mathrm{R}$ 30cd ${ }^{\circ}$ नो हयग्रीव: शतोदर: ] $\mathrm{A}_{4} \mathrm{~A}_{7} \mathrm{Bh}(\mathrm{em} . ?),{ }^{\circ}$ नः $\left\{{ }^{\circ}\right.$ नो $\left.\mathrm{R}^{\mathrm{ac}}\right\}$ शमनो बहुगणस्तथा $\mathrm{R}$, ०नो हयगीव: शतोदर: $\mathrm{A}_{3}$ - After this $\mathrm{R}$ has two pādas reading हानो बाह्यशिराश्चैव सुप्रमत्तस्तथैव च। (cf. 30a?) 
मेघनादः सिंहनादो दुन्दुभिः शतदुन्दुभिः।

कालनेमिर्बको दण्डो विपाक: पाक एव च॥ ३?॥

वृषपर्वा शतावर्तः पुलोमा शरभस्तथा।

वलो गगनमूर्धा च सूचीलोमा महायशा:॥ ३२॥

असिलोमा प्रलम्बश्च शम्भुर्देवान्तकस्तथा।

महिषो भीमसेनश्च † वायुरादित्य एव च †॥ ३३॥

आटिर्बकश्च वातश्च कुण्डलो मुण्ड एव च।

साल्वो दुमश्च जम्भश्च महाकेतुश्च कामपः॥ ३८॥

कपाली शोषण स्चैव हंस: $†$ विश्वजयस्तथा।

अर्धमत्तश्च वायुश्च कलिनः फल एव च।

उल्कको बन्धकग्च्चैव $\dagger$ मधुः कैटभ एव च॥ ३४॥

अन्ये महाबलाः शूरा असुरा देवकण्टकाः।

अन्धकानुचरा व्यास मन्दरं समुपागताः॥ ३६॥

ते शस्त्रवन्तो जितकाशिनश्च महाबलाधर्मपथस्थिताश्च।

सर्वे च शूरा अनिवर्तिनश्च सहान्धका मन्दरगा बभूवुः॥३७॥

सनत्कुमार उवाच।

तद्धजानामिव कुलं मत्तानां कालिनन्दन।

वर्षतामिव मेघानां सविषाणां सरीसृपाम्॥ ३५॥

31ab ०दो दुन्दुभिः शतदुन्दुभिः ] $\mathrm{ABh}$, ०द: $\left\{{ }^{\circ}\right.$ दो $\left.\mathrm{R}^{\mathrm{ac}}\right\}$ सा+युधा+श्च तथा पुन: $\mathrm{R}$ 31c-32b ] om. $R$ 31c कालनेमिर्बको ] em. Bh (silently), कालनेमि: बको $A_{3}$, कालनेमि: कको $A_{4}$, कालनेस्ये \{काननस्ये $\mathrm{A}_{7}^{\mathrm{ac}}$ \}को $\mathrm{A}_{7}$ 32b ०स्तथा ] $\mathrm{A}_{3} \mathrm{~A}_{7} \mathrm{Bh}$, ०स्तदा $\mathrm{A}_{4}$ 32c वलो] $\mathrm{RA}_{3} \mathrm{Bh}$ (बलो in $\mathrm{Bh}$ ), वालो $\mathrm{A}_{4}$, बाणो $\mathrm{A}_{7} 32 \mathrm{~d}$ सूचीलोमा ] em., शूरो लोको $\mathrm{R}$, सूचिरोमा $\mathrm{A}_{3} \mathrm{~A}_{4}$, शूचीलोमा $\mathrm{A}_{7}$, सूचीरोमा $\mathrm{Bh}$ (em.?) • महायशा: ] $\mathrm{ABh}$, महादन: $\mathrm{R}$ 33a प्रलम्ब॰] $\mathrm{ABh}$, प्रमत्त॰ $\mathrm{R}$ 33b शम्भुर्देवान्तकस्तथा ] $A B h$, निकुम्भः कुम्भसूदन: $R \quad 33 c$ महिषो ] $A B h$, महीयो $R \quad 33 d$ वायुरादित्य ] $\mathrm{R}$, वायुवादित्र $\mathbf{A}$, वायुर्वादित्र $\mathrm{Bh}$ (em.?, in a note Bh suggests वायुरादित्य) 34a-35d ] om. $\mathrm{A}_{3} \mathrm{~A}_{4} \mathrm{Bh}, \mathrm{A}_{7}$ has this in the order of $35 \mathrm{abcd}$ and $34 . \quad 34 \mathbf{a}$ आटिर्बकश्च ] em., चर्चिरूपश्च $\mathrm{R}$, आढिर्बकश्च $\mathrm{A}_{7}$ - वातश्च ] $\mathrm{A}_{7}$, कुण्डश्च $\mathrm{R} 34 \mathrm{~b}$ मुण्ड ] $\mathrm{R}$, मण्ड $\mathrm{A}_{7} 34 \mathrm{c}$ साल्वो] conj., शालो $\mathrm{R}$, शम्बो $\mathrm{A}_{7}$ • जम्भग्च ] $\mathrm{A}_{7}$, जन्तुश्च $\mathrm{R} \quad 34 \mathrm{~d}$ महाकेतुश्च कामपः ] $\mathrm{R}$, एकपादश्च दानवः $\mathrm{A}_{7}$ 35b विश्वजयस्तथा ] $\mathrm{R}$, विश्रो विभाकर: $\left.\mathrm{A}_{7} 35 \mathrm{~cd}\right] \mathrm{R}$, अहस्तमश्च बाणश्च विरूपाक्षो गजस्तथा $\mathrm{A}_{7}$ 35e-36b ] om. ABh, instead, $A_{7}$ has four pādas reading धाता विधाता काव्यश्च महानरक एव च। कपाली शोषणश्चैव शाल्वः कपिल एव च। (cf. 35a) $36 \mathbf{c}$ ०कानुचरा व्यास ] $\mathbf{A}$, ०कानुश्च वात्या च $\mathrm{R}$, ०कानुचराप्येते $\mathrm{Bh}$ (conj.) 36d मन्दरं समुपागता: ] $\mathrm{ABh}$, हयकर्ण्णस्तथैव च $\mathrm{R} \quad 37 \mathbf{a b}$ ०काशिनश्च महाबला॰ ] R, ०देवसंघा महानुभावा $\mathrm{ABh}$ (unmetrical) $37 \mathrm{~b}$ ०स्थिताश्च ] R, ०च्युताश्च $\mathrm{A}_{3} \mathrm{~A}_{4} \mathrm{Bh}$, $\circ$ प्रयुताश्च $\mathrm{A}_{7} \quad 37 \mathrm{c}$ शूरा अ०] $\mathrm{RA}_{3} \mathrm{~A}_{4}$, सूरा अ० $\mathrm{A}_{7}$, शूरा ह्य॰ $\mathrm{Bh}$ (conj.?) 37d सहान्धका ] conj. Bh (silently), सन्नद्धका $\mathrm{R}$, महान्धका $\mathrm{A} \bullet$ मन्दरगा ] $\mathrm{ABh}$, मन्दिरगा $\mathrm{R}$ 38a तद् ] $\mathrm{em} . \mathrm{Bh}$ (silently), तं RA - गजानामिव कुलं ] $\mathbf{A B h}$, पश्यामीह बहुलं $\mathrm{R}$ 38d सविषाणां ] $\mathrm{RA}_{4} \mathrm{~A}_{7} \mathrm{Bh}$ (em.?), सरिषानां $\mathrm{A}_{3}$ 
दर्पितानां वराहाणां बहनामिव चोल्वणम्।

मन्दरे दानवकुलं तथा तत्प्रचचार ह॥ ३९ ॥

सो डन्धको विचरंस्तत्र सखीभिः सह पार्वतीम्।

अपश्यद्दानवः कूरः श्वपाको ब्राह्मणीमिव॥ ४०॥

स पश्यन्नेव कालेय हिरण्याक्षसुतस्तदा।

आविष्टः कलिना योगाद्दानवानामपश्यताम ॥ ४? ॥

नियत्याथ कृतान्तेन मृत्युना मदनेन च।

कोपेनाथ दुरात्मासौ काले प्राप्ते सुरेतरः॥ ४२॥

अध्यासितस्तदा तैस्तु सर्वेलोकवशंकरैः।

लोकधात्रों प्रति शुभामिदं वचनमब्रवीत् ॥ ४३॥

अन्धक उवाच।

केयं सुमध्यमा तन्वी रूपेणाप्रतिमा शुभा।

नेदृशी दृष्टपूर्वा मे कदाचिदपि दानवाः।

दिवि वा भुवि वा सत्यं पश्यतैनां सुमध्यमाम्॥ ४४॥

इयं यदि न मे भार्या कस्याहं पतिरीश्वरः।

को वाहं किं च जीवामि सत्यमेतद्वचो मम॥ ४४॥

$40 \approx \operatorname{SP} 112.84$

39ab ०णां बहूनामिव चोल्बणम् ] conj., ०णां शतानामिव चोल्बणम् $\mathrm{R}$, ०णा $\left\{\circ\right.$ ना० $\mathrm{A}_{3}$, ०णां $\mathrm{A}_{4}^{\mathrm{ac}}$ $\left.\mathrm{A}_{7}\right\}$ माकुलामिव चोल्बणं $\left\{\right.$ ल्बनं $\mathrm{A}_{7}$, ०ज्वनं $\left.\mathrm{A}_{4}\right\} \quad \mathbf{A}$, ०णां महाकुलमिवोल्वणम् $\mathrm{Bh}$ (conj.?) $39 \mathrm{c}$ मन्दरे ] $\mathrm{A}_{7} \mathrm{Bh}\left(\mathrm{em}\right.$. ?), मन्दिरे $\mathrm{R}$, मंदार० $\mathrm{A}_{3} \mathrm{~A}_{4}$ 39d तत्प्रचचार ह ] $\mathrm{ABh}$, तत्प्रहरणाय च $\mathrm{R}$ (unmetrical) 40b सखीभि: ] $\mathrm{RA}_{3} \mathrm{~A}_{7} \mathrm{Bh}$, ऋषिभि: $\mathrm{A}_{4}$ - सह पार्वतीम् ] RA, सहितां तदा $\mathrm{Bh}$ $(<\mathrm{S}) 40 \mathrm{c}$ ०द्दानव: क्रू: ] $\mathrm{RA}$, ०द् देवदेवी तु $\mathrm{Bh}\left(<\mathrm{S}\right.$, typo) 40d श्वपाको ब्राह्मणी॰] $\mathrm{A}_{3} \mathrm{~A}_{4}$, स काले ब्राह्मणी॰ $\mathrm{R}$, स्वपाको ब्राह्मणी॰ $\mathrm{A}_{7}$, वृकः सिंहवधू॰ $\mathrm{Bh}(<\mathrm{S}) \quad 41 \mathrm{a}$ स पश्यन्नेव ] $\mathrm{RBh}$ (conj.?), अपश्यन्नेव $\mathbf{A} 41 \mathrm{~b}$ ०स्तदा ] $\mathrm{ABh}$, ०स्तथा $\mathrm{R} 4 \mathrm{41c}$ आविष्टः कलिना ] conj., अरिष्टः कलिना $\mathrm{R}$, स्वविशन्त इवा॰ $\mathbf{A}$, स्वपिसंत इवा० $\mathrm{Bh}$ (conj.?, Bh suggests अनिमेष इवा०) $41 \mathrm{~d}$ ॰द्दानवानामपश्यताम् ] conj., ०द्दानवनामपश्यत R (unmetrical), ०ददृश्यत दुरात्मवान् ABh 42a नियत्याथ ] $\mathrm{A}_{3} \mathrm{Bh}$, नियम्याथ $\mathrm{R}$, निपत्त्याथ $\mathrm{A}_{4}$, नियत्यप्र० $\mathrm{A}_{7} \quad \mathbf{4 2 b}$ ०ना मदनेन ] $\mathrm{RBh}$ (conj.?), ०ना दमनेन $\mathrm{A}_{3} \mathrm{~A}_{4}$, ०नाथ यमेन $\mathrm{A}_{7}$ 42d सुरेतर: ] $\mathrm{ABh}$, महामति: $\mathrm{R}$ 43a अध्यासितस्तदा तैस्तु ] $\mathrm{ABh}$, अथोषितां तदा तत्र $\mathrm{R} 43 \mathrm{~b}$ सर्वेर $] \mathrm{R}$, सर्व॰ $\mathrm{A}_{3} \mathrm{~A}_{4} \mathrm{Bh}$, सर्वे $\mathrm{A}_{7}$ 43cd प्रति शुभामि॰ ] $\mathrm{R}$, प्रति सो यमि॰ $\mathrm{A}_{3} \mathrm{Bh}$ (unmetrical), प्रती सो यमि॰ $\mathrm{A}_{4}$, प्रति सो थ इ॰ $\mathrm{A}_{7}$ (unmetrical) 44a तन्वी ] $\mathrm{RA}_{7}$, तत्र $\mathrm{A}_{3} \mathrm{~A}_{4}$, ह्यत्र $\mathrm{Bh}$ (conj.?) $44 \mathrm{~b}$ शुभा ] $\mathrm{RA}_{3} \mathrm{~A}_{4} \mathrm{Bh}$, भुवि $\mathrm{A}_{7} \quad 44 \mathrm{c}$ दृष्टपूर्वा ] $\mathrm{RBh}$ (conj.?), पूर्वदृष्टा $\mathrm{A} \quad 44 \mathrm{e}$ दिवि वा ] $\mathrm{RA}_{4} \mathrm{~A}_{7} \mathrm{Bh}$ (em.?), दिवि चा $\mathrm{A}_{3}$ - वा सत्यं ] $\mathrm{RA}_{7}$, चागत्य $\mathrm{A}_{3} \mathrm{~A}_{4} \mathrm{Bh} \quad 44 \mathrm{f}$ पश्यतैनां ] $\mathrm{ABh}$, पश्याम्येनां $\mathrm{R}$ 45a इयं यदि न मे ] $\mathrm{RA}_{7}$, इयं यदि $\{\circ$ दी $\mathrm{A}_{4}$ \} नाम $\mathrm{A}_{3} \mathrm{~A}_{4}$, यदि नाम इयं $\mathrm{Bh}$ (conj.?) 45b कस्याहं ] $\mathrm{R}$, कस्येयं $\mathrm{ABh} \bullet \circ$ रीश्वर: ] $\mathrm{ABh}$, ०रीदृश: $\mathrm{R}$ 
यस्येयं युवती भार्या चारुचित्रायतेक्षणा।

स्वर्गवासेन किं तस्य सुभगस्य महात्मनः।

मिथ्याराज्यमिदं राज्यं यस्येयं मे न कामिनी॥ ४६॥

बहुनि स्त्रीसहस्राणि मम सन्ति शुभानि च।

तानि सर्वाणि दासीत्वे अस्यास्तुल्यानि दानवाः॥ ४७॥

सनत्कुमार उवाच।

तस्य तद्वचनं श्रुत्वा हिरण्यकशिपो: सुतः।

उवाचान्धकमाश्लिष्य बहुचित्रं च कालिज॥ ४५॥

\section{प्रह्नाद उवाच।}

इयं लोकस्य जननी हिमवत्तनयाव्यया।

उमेति लोके विख्याता तपोयोगबलान्विता॥ ४९ ॥

यस्य पुत्रो ऽवद्वह्मा प्राजापत्यं च यो ददौ।

वरेण यश्च पुत्रस्य पुत्रतां ब्रह्मणो गतः॥ ५०॥

अस्माकं देवतानां च यो वरांस्तोषितो ददौ।

आराध्यः सर्वलोकानां देवानां च महायशाः ॥ ४? ॥

इच्छया सर्वमाविश्य निमेषार्धेन संक्षिपेत् ।

सृजेद्वापि ग्रसेद्वापि योगमास्थाय लोलुप ॥ ४२॥

यस्याष्टतनुभिः सर्वं धार्यते जगदव्ययम्।

तस्य रुद्रस्य शर्वस्य पत्नीयं दानवेश्वर ॥ १३॥

इयमप्रतियोगित्वादपचारैः प्रमर्दितुम् ।

शक्ता हीयं जगत्सर्वं क्षणेनैवासुरेश्वर ॥ १४॥

$\mathbf{4 9 a - 5 0 b} \approx \mathrm{SP} 112.87 \mathrm{a}-88 \mathrm{~b} \quad \mathbf{5 1 a b} \approx \mathrm{SP} 112.88 \mathrm{~cd} \quad \mathbf{5 3} \approx \mathrm{SP} 112.89 \mathrm{c}-90 \mathrm{~b} \quad \mathbf{5 4 c d} \approx \mathrm{SP}$ $112.90 \mathrm{~cd}$

46a यस्येयं ] $\mathrm{A}_{3} \mathrm{~A}_{4} \mathrm{Bh}$, पश्य मे $\mathrm{R}$, यश्चेयं $\mathrm{A}_{7}$ - युवती ] $\mathrm{ABh}$, सुदती $\mathrm{R} \quad 46 \mathrm{c}$ स्वर्गवासेन ] $\mathrm{RA}_{3} \mathrm{Bh}$, स्वर्गवासो न $\mathrm{A}_{4}$, स्वर्गे वासो न $\mathrm{A}_{7} \quad 46 \mathrm{e}$ ०राज्य॰ $] \mathrm{A}_{3} \mathrm{~A}_{7} \mathrm{Bh}$, ०राह्य॰ $\mathrm{R}$, ०राज० $\mathrm{A}_{4}$ 46ef राज्यं यस्येयं मे न] conj., यास्याम्यहं येन च $\mathrm{R}$, गुह्यं यस्येयं येन $\left\{\right.$ जन० $\left.\mathrm{A}_{4}\right\} \mathbf{A}$, गुह्यं यस्येयं मे न $\mathrm{Bh}$ (conj.?) 47a स्त्री॰] $\mathrm{R}$, च $\mathrm{ABh} \quad 47 \mathrm{~cd}$ दासीत्वे अस्यास्तुल्यानि दानवा:] $\mathrm{ABh}$, दास्यामि महाकीर्त्ते महातप: $\mathrm{R} 48 \mathrm{~b}$ हिरण्यकशिपो: सुतः ] $\mathrm{ABh}$, प्रह्लादो वै महामति: $\mathrm{R} 48 \mathrm{~d}$ च कालिज ] $\mathrm{A}_{4} \mathrm{~A}_{7}^{\mathrm{pc}} \mathrm{Bh}$ (em.?), कराणि च $\mathrm{R}$, कानिज $\mathrm{A}_{3} \mathrm{~A}_{7}^{\mathrm{ac}} 49$ प्रह्लाद उवाच] $\mathrm{RA}_{3} \mathrm{~A}_{4}$, प्रहाद उवाच $\mathrm{A}_{7}$, om. Bh 49a Before this Bh has 8 pādas (see SP 112.85-86) 49b oयाव्यया] ABh, oया शुभा $R$ 49c लोके विख्याता ] $R$, लोकविख्याता $A$, जगति ख्यता $B h(<S$, typo, unmetrical) $50 b$ प्राजापत्यं ] RA, प्रजापत्यं $\mathrm{Bh}$ (typo) — यो ] $\mathrm{ABh}$, या $\mathrm{R}$ 50c यश्च ] $\mathrm{ABh}$, यस्य $\mathrm{R}$ 51b यो वरांस्तोषितो ददौ] $A$, या वरांस्तोषिता ददौ $R$, यो ददाति वराभ्छुभान् $B h(<S)$ 51c आराध्य: ] $\mathbf{A}$, आराध्या $\mathrm{R}$, आरध्य: $\mathrm{Bh}$ (typo) 51d देवानां च ] $\mathrm{A}_{3} \mathrm{~A}_{7} \mathrm{Bh}$, देवतानां $\mathrm{R}$, देवाना च $\mathrm{A}_{4}$ - After this $\mathrm{Bh}$ has four pādas (see $\mathrm{SP}$ 112.89) 52a इच्छया सर्वमाविश्य ] RA, य: स्वेच्छुया सर्वमिदं $\mathrm{Bh}$ (conj.) 52b ०षार्धेन ] $\mathrm{A}_{3} \mathrm{~A}_{7} \mathrm{Bh}$, ०षार्द्धेण $\mathrm{R}$, ०षार्द्ध न $\mathrm{A}_{4}$ 52c-56b ] om. ABh, instead Bh has 12 pādas with a speaker indication (see SP 112.90-92) 52c सृजेद् ] em., मृजेद् $R$ 52d योग॰] conj., यास॰ $R \quad 53 \mathbf{a}$ यस्याष्ट॰] conj., यस्यास्तु $R$ • सर्वं ] em., सर्व्व $\mathrm{R}$ 
दग्धुं वाप्यथ हन्तुं वा क्षेत्रुं नरक एव वा।

नेह लम्या त्वया देवी †स्थानादेव बहर्यथा †॥ पू ॥

सनत्कुमार उवाच।

प्रह्लादवचनं श्रुत्वा व्याकुलस्य महात्मनः।

अदृश्याः समपद्यन्त ता: स्त्रियो लोकमातरः ॥ पू६॥

अथ ते तासु नष्टासु मन्दरस्य शुभं वनम्।

पादचारेण संप्राप्ता बहुदृश्यसमावृतम्॥ पै $७ \|$

बलाभि: कदलीषण्डै: प्रियड़ुसातिमुक्तकः ।

चम्पकैर्बकुलैर्लोध्रैरशोकैर्नागकेसरै: ॥ पू

पुत्रागैस्तिलकैश्चैव देवदारुवनैरपि।

सरलैर्नारिकेलैश्च पद्मषण्डैश्च शोभितम्॥ पू ॥

गह्वरैश्च नितम्बैश्च गुहाभिर्निईरैरपि।

न तस्माद्रमणीयं हि पृथिव्यां विद्यते क्षचित्॥ ६०॥

तत्र ते विचरन्तस्तु एकस्मिन्निर्झरे स्थितान्।

सप्तर्षोंस्तपसा शुद्धानपश्यन्त महामुनीन्॥ ६? ॥

उपविष्टाम्छितापट्टे कथयन्तो महामुनीन्।

धर्मयुकाः कथाश्चित्रा धार्मिकाश्च सुखावहाः ॥ २२॥

तान्दृष्ट्वा ते उसुरास्तत्र अपृच्छन्त्त परस्परम्।

क इमे ऋषयो ह्यत्र किमर्थं चेह संगताः ॥ ६॥

$\overline{55 a b} \approx \mathrm{SP} 112.91 \mathrm{ab} \quad \mathbf{6 1} \approx \mathrm{SP} 112.94 \quad \mathbf{6 3} \approx \mathrm{SP} 112.95$

55c लभ्या ] conj., सभ्या $R \quad 56 c$ Before this Bh conjectures loss of two pādas. 57a तासु नष्टासु ] $\mathrm{A}_{3} \mathrm{~A}_{7} \mathrm{Bh}$, सुमहातेजा $\mathrm{R}$, सुनष्टासु $\mathrm{A}_{4}$ (unmetrical) 57d ०दृश्यसमा॰] $\mathrm{RBh}$ (conj.?), ०दूश्येदमा० $\mathrm{A} 58 \mathrm{a}$ बलाभिः ] $\mathrm{A}_{3} \mathrm{~A}_{4} \mathrm{Bh}$, धाराभि: $\mathrm{R}^{\mathrm{pc}}$, वाराभि: $\mathrm{R}^{\mathrm{ac}}$, वराभिः $\mathrm{A}_{7}$ क कली॰] $\mathrm{RA}_{4} \mathrm{~A}_{7}$, कलनी॰ $\mathrm{A}_{3} \mathrm{Bh}^{\mathrm{ac}}$, कलमी॰ $\mathrm{Bh}^{\mathrm{pc}}$ (conj.?) - ०षण्डै: ] $\mathrm{A}_{3} \mathrm{~A}_{7} \mathrm{Bh}$, ०खण्डै: $\mathrm{RA}_{4} \quad \mathbf{5 8 b}$ प्रियडुसातिमुक्तके: ] em., प्रियडुसातिमुक्तिकै: $\mathbf{A}$, प्रियड्क्वा चातिमुक्तक $\mathrm{R}$, सातिमुक्तप्रियंगुभिः Bh (conj.?)

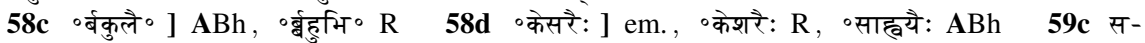
रलै॰] $\mathrm{ABh}$, शरलै० $\mathrm{R} 59 \mathrm{~d}$ ०षण्डैश्च ] $\mathrm{A}_{7} \mathrm{Bh}$ (conj.?), ०खण्डै: सु॰ $\mathrm{R}$, ०खंडैश्च $\mathrm{A}_{3}$, ०मुंडैश्च

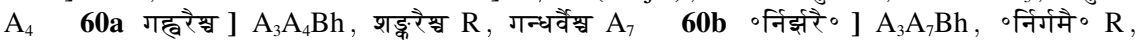
०र्निर्डरै॰ $\mathrm{A}_{4} \quad 60 \mathrm{c}$ ०यं हि ] $\mathrm{ABh}$, ०यन्तु $\mathrm{R}$ 60d पृथिव्यां ] $\mathrm{RA}_{4} \mathrm{Bh}$ (conj.?), पृथिवी $\mathrm{A}_{3} \mathrm{~A}_{7}$ - After this Bh has four pādas (see SP 112.93) $\quad \mathbf{6 1 a}$ ०स्तु ] $\mathbf{A B h}$, ०श्र्च $\mathrm{R} \quad \mathbf{6 1 b}$ ०त्निईरे स्थितान् ] $\mathrm{ABh}$, ०न्वासरे स्थिता: $\mathrm{R}$ 61c सप्रर्षींस्तपसा शुद्धा० ] $\mathrm{RA}_{3} \mathrm{~A}_{7}$, सप्रर्षिस्तपसा शुद्धा० $\mathrm{A}_{4}$, सिद्धानपश्यन् सपर्षर्षी $\mathrm{Bh}$ (conj., cf. S) 61d ०नपश्यन्त महामुनीन् ] $\mathrm{A}_{3} \mathrm{~A}_{7}$, ०न् देवानामपि मानवा: $\mathrm{R}$, न्नापश्यन्तं महामुनीन् $\mathrm{A}_{4}$, ०न् योगयुक्तान् महामुनीन् $\mathrm{Bh}(<\mathrm{S})$ 62ab ] om. $\mathrm{R}$ 62b कथयन्तो महामुनीन् $] \mathrm{A}_{7}$, कथयंस्ते महामुनीन् $\mathrm{A}_{3} \mathrm{~A}_{4}$, मिथः कथयतः कथा: $\mathrm{Bh}$ (conj.) $62 \mathrm{c}$ ०युका: कथाश्चित्रा ] $\mathrm{RA}_{3} \mathrm{~A}_{7}$, ०युक्ता कथाश्चित्रा $\mathrm{A}_{4}$, ०य युक्ताश्च्च चित्रार्था $\mathrm{Bh}$ (conj.) 62d धार्मिकाश्च ] $\mathrm{R}$, धार्मिका: स० $\mathbf{A}$, मार्मिका: सु॰ $\mathrm{Bh}$ (typo, em.?) 63ab ] $\mathrm{RA}_{3}\left(\mathrm{~A}_{4}\right) \mathrm{A}_{7}$, तान्दृष्ट्वा सो न्धको पृच्छत् प्रह्लादमसुरोत्तमम् $\mathrm{Bh}(<\mathrm{S})$ - ०स्तत्र अपृच्छन्त ] $\mathrm{RA}_{3} \mathrm{~A}_{7}$, ०स्त अपृच्छंतः $\mathrm{A}_{4}$ (unmetrical) 63c क इमे ] $\mathrm{ABh}$, इह मे $\mathrm{R}$ - ह्यत्र ] $\mathrm{Bh}\left(<\mathrm{S}_{1}\right)$, व्यास RA 63d किमर्थं चेह ] $\mathrm{RBh}(<\mathrm{S})$, किं वा चेह च $\mathbf{A}$ 


\section{तानुवाच तदा धीमानसुरान्देवकण्टकान।}

हिरण्यकशिपो: पुत्रो बुद्धा मध्ये समास्थितः॥ ६४॥

\section{प्रह्लाद उवाच।}

एते चात्र महात्मानो मुनयः सत्त संगताः ।

भृगुरत्रिर्मरीचिश्च विश्वामित्रो उड्रिरास्तथा॥ ६У॥

भरद्वाजो वसिष्टश्च सत्तैते ऋषयः शुभाः।

इहागता महात्मानस्तपसा दग्धकिल्बिषाः॥ ६६॥

नैषां निष्कारणं मन्ये मन्दरागमनं प्रति।

ततो वयमिहैकान्ते स्थिता: सर्वे उसुरेश्वराः॥ ६७॥

जानीमः किमिमे कार्यमिह कुर्वन्ति साधवः।

एते वै निभृता भूत्वा तूष्णीं कृत्वा महाबलाः॥ ६५॥

सनत्कुमार उवाच।

ततस्ते समयं कृत्वा स्थिता असुरपुंगवाः।

यो उस्माकं तु वदेत्किंचिद्वध्यो नः स भवेदिति॥ ६९ ॥

तत्र तेषु स्थितेष्वेवमसुरेषु दुरात्मसु।

ऋषयस्ते तपोयुका इदमूचुः परस्परम्॥ ७०॥

अयं देशो ह्यशुद्धो उद्य गच्छामो वयमन्यतः।

भवान्यपि गतान्यत्र असुराणां भयार्दिता॥ ७१ ॥

65-66ab $\approx \mathrm{SP} 112.96-97 \mathrm{ab} \quad \mathbf{6 7} \approx \mathrm{SP} 112.97 \mathrm{c}-98 \mathrm{~b} \quad \mathbf{7 0 - 7 1 a b} \approx \mathrm{SP} 112.99-100 \mathrm{ab}$

64a तानु० ${ }^{\circ} \mathrm{RA}$, तमु॰ $\mathrm{Bh}$ (conj.) $64 \mathrm{~b}$ ०नसुरान् ] $\mathrm{RA}_{4} \mathrm{~A}_{7}$, ०न् सुरान् $\mathrm{A}_{3}$ (unmetrical), ०नसुरो $\mathrm{Bh}$ (conj.) - ०कण्टकान् ] RA, ०कण्टकम् Bh (conj.) 64d बुद्वा मध्ये] $\mathrm{A}_{7}$, मध्ये तत्र $\mathrm{R}$, बुद्धा मध्य० $\mathrm{A}_{3} \mathrm{~A}_{4}$, बुद्धा मध्यं $\mathrm{Bh}(\mathrm{em} . ?) \quad \mathbf{6 5}$ प्रह्लाद ] $\mathrm{RBh}(<\mathrm{S})$, सनत्कुमार $\mathbf{A} \quad \mathbf{6 5 a b}$ चात्र महात्मानो मुनयः ] RA, न्धक महात्मान ऋषयस् $\mathrm{Bh}(<\mathrm{S}) \quad \mathbf{6 5 d}$ उड्डिरास्तथा ] $\mathrm{ABh}$, डथ काश्यप: $\mathrm{R} 66 \mathrm{a}$ वसिष्टश्च ] $\mathrm{A}_{3} \mathrm{~A}_{4} \mathrm{Bh}$, वशिष्ठ $\mathrm{R}$ (unmetrical), वशिष्ठश्च $\mathrm{A}_{7}$ 66b सतैते ऋषय: शुभा: ] $\mathrm{A}$, ऋषयश्च तथा शुभा: $\mathrm{R}$, योगसिद्धास्तपोधना: $\mathrm{Bh}(<\mathrm{S}) \quad 66 \mathrm{~d}$ दग्ध०] $\mathrm{ABh}$, हत॰ $\mathrm{R} 67 \mathrm{a}$ निष्कारणं ] $\mathrm{RBh}(<\mathrm{S})$, निरीक्षणं $\mathbf{A}$ 67b प्रति ] $\mathrm{RA}$, प्रभो $\mathrm{Bh}(<\mathrm{S})$ 67c ततो ] $\mathrm{RA}$, इतो $\mathrm{Bh}$ $(<\mathrm{S})$ 67d स्थिता: ] $\mathrm{RA}$, स्थित्वा $\mathrm{Bh}(<\mathrm{S})$ - उसुरेश्वरा: ] $\mathrm{RA}_{3} \mathrm{~A}_{4} \mathrm{Bh}$, उसुरेश्वर $\mathrm{A}_{7} \mathbf{6 8 a}$ जानीमः ] RA, जानीम $\mathrm{Bh}(\mathrm{em}$. ?) - किमिमे ] $\mathrm{ABh}$, किमिद $\mathrm{R} \mathbf{6 8 b}$ साधव: ] $\mathrm{R}$, साधका: $\mathrm{ABh} 68 \mathrm{c}$ वै निभृता ] $\mathrm{ABh}$, च विमना $\mathrm{R} 68 \mathrm{~cd}$ भूत्वा तू॰ $\mathrm{R}$, भूतास्तू ${ }^{\circ}{ }^{\circ}$ स्तु $\left.{ }^{\circ} \mathrm{A}_{4}\right\} \mathrm{ABh}$ 68d महाबला: ] $\mathrm{A}_{7}$, यथाबला: $\mathrm{RA}_{4} \mathrm{Bh}$ (em.?), यथाबला $\mathrm{A}_{3}$ - After this Bh has two pādas (see SP 112.98cd) 69b स्थिता अ०] $\mathrm{RBh}$ (conj.), प्रणम्या॰ $\mathbf{A}$ 69d ०दिति ] $\mathbf{A B h}$, ०दिह $\mathrm{R}$

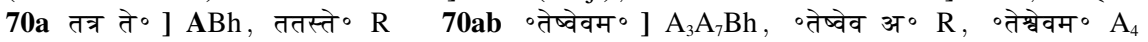
70c ०स्ते ] $\mathrm{ABh}$, ०श्चु $\mathrm{R} \quad 70 \mathrm{~d}$ इदमूचुः ] RA, वाक्यान्यूचुः $\mathrm{Bh}\left(<\mathrm{S}_{2}\right)$ 71a अयं देशो ह्यशुद्धो उद्य ] RA, न शुद्धोयं गिरेर्देशो $\mathrm{Bh}(<\mathrm{S}) \mathbf{7 1 b}$ गच्छामो वयमन्यतः ] $\mathbf{A}$, शक्यामो वयमन्यतः $\mathrm{R}$, द्या गच्छामो न्यतो द्विजा: Bh (conj., cf. S) - After this Bh has two pādas (see SP 112.100cd) 71c भवान्यपि ] $\mathrm{A}_{4} \mathrm{~A}_{7}^{\mathrm{pc}} \mathrm{Bh}\left(\mathrm{em}\right.$. ?), रुद्रश्चापि $\mathrm{R}$, भगवान्यपि $\mathrm{A}_{3}$ (hypermetrical), रत्नान्यपि $\mathrm{A}_{7}^{\mathrm{ac}}$ - गतान्यत्र ] $\mathrm{ABh}$, गतस्तत्र $\mathrm{R}$ 71d भयार्दिता ] $\mathrm{A}_{3} \mathrm{~A}_{7}^{\mathrm{pc}} \mathrm{Bh}$, भयावहः $\mathrm{R}$, भयार्दिता: $\mathrm{A}_{4} \mathrm{~A}_{7}^{\mathrm{ac}}$ 
असुरास्ते दुरात्मानो येषामेष क्षयो ध्रुवः।

गतास्ते निधनं सर्वे धर्मं ये नाशयन्त्युत॥ ७२॥

राज्यार्थं प्रयतैः कूरैन्न धर्मो नाशितो भवेत्।

नैव ते निधनं सर्वे प्राप्ताः स्युरमरद्विषः॥ ७३॥

स्वराज्यपरिसंतुष्टा भवेयुर्यदि संस्थिताः।

ते ऽपि सर्वेषु लोकेषु बभुः पूज्याः सुरा इव॥ ७४॥

सनत्कुमार उवाच।

अड्रिरास्तानुवाचेद न तेषां कामितस्तिवह।

राज्यहेतोः प्रवृत्तानामधर्मः समुपस्थितः ॥ ७४ ॥

उपार्जयति राज्यं वै धर्म एव हि कामितः।

सो डधर्म नैव कुर्वीत स्थैर्यं राज्यस्य किंचन॥ ७६॥

अत्रिरुवाच।

अधर्मे राज्यमिच्छन्ति जयन्ति युधि सर्वदा।

नो प्रियास्चैव लोकस्य भवन्ति हतजीविनः॥ १७॥॥

धार्मिकास्त्वचिरेणैव हत्वा शत्रूनविक्कवाः।

राज्येषु संप्रतिष्ठन्ते तस्माद्धर्म समाश्रयेत् ॥ ७६॥

ये तु राज्यं बलेनैव धर्म त्यत्काशुभे रताः।

इच्छन्तो ऽपि न तद्राज्यं प्राप्तुवन्ति कदाचन॥ ७९ ॥

अथ यत्प्राप्यते राज्यं तैस्तु कूरेण कर्मणा।

न चिरं तझ्ञवेत्तेषां विद्विष्टाश्च भवन्त्युत॥ ५०॥

भृगुरुवाच।

धर्म एव पुरा प्रोको ह्यसुराणां भयापहः।

ब्रह्मणा स्वस्तिकामेन न च ते वर्तयन्त्युत ॥ ५? ॥

72cd-74 $\approx$ SP 112.101-102

72b मेष ] $\mathrm{A}_{3} \mathrm{~A}_{4} \mathrm{Bh}$, ०मेव $\mathrm{RA}_{7}$ - क्षयो ध्रुव: ] $\mathrm{ABh}$, भये स्थिता: $\mathrm{R}$ 72c सर्वे ] $\mathrm{RA}_{3} \mathrm{Bh}$, सर्व $\mathrm{A}_{4} \mathrm{~A}_{7}$ 72d नाशयन्त्युत ] $\mathrm{RA}$, नाशयन्तुत $\mathrm{Bh}$ (conj.) 73a प्रयतैः ] $\mathbf{A}$, प्रहितै: $\mathrm{R}$, यदि तै: $\mathrm{Bh}(<\mathrm{S}) \quad 73 \mathrm{ab}$ ०रेन्न धर्मो नाशितो भवेत् ] $\mathrm{ABh}$, ०रै: कथमेतन्न संशय: $\mathrm{R}$ 73c-79b ] om. $R \quad 73 \mathbf{c}$ नैव ] $\mathbf{A}$, नैवं $\mathrm{Bh}\left(<\mathrm{S}_{2}\right) \quad \mathbf{7 4 a}$ स्वराज्य॰] $\mathrm{Bh}(<\mathrm{S})$, शूराश्च $\mathrm{A}_{3} \mathrm{~A}_{4}$, सुराश्च $\mathrm{A}_{7}$ 74d पूज्या: ] $\mathrm{A}_{3} \mathrm{Bh}$, पूज्या $\mathrm{A}_{4} \mathrm{~A}_{7} \mathbf{7 5 b}$ कामितस्त्वि॰] $\mathrm{A}_{7}$, कामित त्वि॰ $\mathrm{A}_{3} \mathrm{~A}_{4}$, कामिन त्वि॰ $\mathrm{Bh}$ (conj.?) 75d समुपस्थितः ] $\mathrm{A}_{3} \mathrm{~A}_{7}$, समुस्थितः $\mathrm{A}_{4}$ (unmetrical), ससुपस्थितः Bh (typo) $\mathbf{7 6 b}$ कामित: ] conj., कामिक: $\mathbf{A}$, कामिन: Bh (conj.) $\mathbf{7 6 d}$ राज्यस्य ] conj., राज्यं च $\mathbf{A}$, राज्यं न $\mathrm{Bh}$ (conj.) 77a अधर्मे ] $\mathrm{A}_{3} \mathrm{~A}_{4} \mathrm{Bh}$, अधर्मे $\mathrm{A}_{7} \quad$ 77d हत० ] $\mathrm{A}_{4} \mathrm{~A}_{7}$, हित॰ $\mathrm{A}_{3} \mathrm{Bh} \quad 79 \mathrm{c}$ इच्छन्तो ऽपि न] $\mathrm{ABh}$, इच्छुन्तो न च $\mathrm{R} 79 \mathrm{~d}$ प्राप्तुवन्ति ] $\mathrm{ABh}$, न हि यातु $\mathrm{R} 80 \mathrm{~b}$ तैस्तु कूरेण ] $\mathrm{ABh}$, तेन च क्रूर० $R \quad 80 d$ विद्विष्टाश्च भवन्त्युत ] $A B h$, यावदेव समागता: $R \quad 81 a$ एव ] $R$, एष $A B h$ - प्रोको ] conj., उक्तो $R$, प्राप्तो $A B h \quad 81 b$ भयापहः ] conj., भयावह: RABh 81c स्वस्ति॰] $\mathrm{R}$, सृष्टि॰ $\mathrm{ABh}$ 
स्वभावेन च ते सर्वे दारुणा वै निसर्गतः।

दारुणाभिजनाश्चैव तत्कर्म समुपाश्रिताः॥ ५२॥

सनत्कुमार उवाच।

असुरान्प्रति तेषां तु कथां कथयतां तदा।

आगाद्वाता विधाता च कृतान्तश्च त्रयः समाः॥ ५३॥

तांस्ते संपूज्य विधिवत्परस्परमतिप्रभाः।

उपविष्टाः शिलास्वेव मुनयो उपि च ते त्रयः॥ ५४॥

उपविष्टांश्चर्षयस्तानामान्त्र्य बहुमानतः।

ऊचुः कस्माइवन्तो उद्य प्रस्थिता लोकचिन्तकाः ॥ ᄃY ॥

धातोवाच।

ब्रह्मलोकादपावृत्ता वयमभ्यागता द्विजाः।

ब्रह्मणा समनुइ्तप्ता: कश्यपस्य ततो उन्तिकम्॥ ५६॥

भूयो उपि मुनयः प्रोचुः किमुक्तः कश्यपो द्विजः।

ततो उब्रवीन्मुनीन्धाता कश्यपं तु यदुक्तवान्॥ ५७॥

यत्त्वया ज्ञापितो ब्रह्मन्ब्रह्मा लोकपितामहः ।

असुरा अपि मे पुत्रा देवाश्चापि प्रियाः प्रभो॥ ५.।॥

$\mathbf{8 3 a - 8 4 b} \approx$ SP $112.103-104 a b \quad \mathbf{8 5 c d - 8 6} \approx$ SP $112.104 c d-105 \quad \mathbf{8 7 c d - 8 8} \approx$ SP $112.106-$ $107 \mathrm{ab}$

82b वै निसर्गत: ] $\mathrm{A}_{7} \mathrm{Bh}$ (conj.?), मा विषीदत $\mathrm{R}$, वै विसर्गत: $\mathrm{A}_{3}$, वै विसड़्त: $\mathrm{A}_{4} \quad \mathbf{8 2 c}$ ०जनास्चैव ] $\mathrm{R}$, गगमश्चैव $\mathrm{A}$, गगमाच्चैव $\mathrm{Bh}$ (conj.) $83 \mathrm{a}$ तेषां तु ] $\mathrm{ABh}$, ते गत्वा $\mathrm{R} \quad 83 \mathrm{~b}$ कथां ] $\mathrm{RA}$, एवं $\mathrm{Bh}(<\mathrm{S}) \quad$ कथयतां तदा ] $\mathrm{ABh}$, कथयितुन्तथा $\mathrm{R}^{\mathrm{pc}}$, कथयतान्तथा $\mathrm{R}^{\mathrm{ac}} \mathbf{8 3 c}$ आगाद् ] $\mathrm{Bh}$ $(<\mathrm{S})$, अगाद् $\mathrm{RA} 83 \mathrm{~d}$ ०ग्च्च त्रयः समा: ] $\mathrm{RA}_{3} \mathrm{~A}_{4}$, ०श्च्च प्रषः समा: $\mathrm{A}_{7}$, ० ग्चेति ते त्रयः $\mathrm{Bh}$ (conj.) 84a तांस्ते] $\mathrm{A}_{3} \mathrm{~A}_{4} \mathrm{Bh}$, तांस्तु $\mathrm{R}$, त+त+स्ते $\mathrm{A}_{7}$ (unmetrical) - संपूज्य ] $\mathrm{RBh}(<\mathrm{S})$, संगृह्य $\mathrm{A}$ 84b ०मतिप्रभा: ] RA, ०मनुव्रता: $\mathrm{Bh}(<\mathrm{S}) \mathbf{8 4 d}$ मुनयो ] $\mathrm{RA}_{3} \mathrm{~A}_{4}$, मुलयो $\mathrm{A}_{7}$, मनुयो $\mathrm{Bh}$ (typo) - च ते त्रय: ] $\mathrm{ABh}$, जितेन्द्रिया: $\mathrm{R} \quad 85 \mathrm{ab}$ ] om. $\mathrm{R} \quad \mathbf{8 5 a}$ ०विष्टांश्चर्षय॰] conj. Bh (silently), विष्टामृषय॰ A (unmetrical) $\mathbf{8 5 b}$ ॰नामन्त्र्य ] A , ननममश्च Bh (conj.?) $\mathbf{8 5 c}$ कस्माद् ] RA, क्षेद $B h(<S) \quad 85 d$ ०चिन्तका: ] RA, ०धारिणः $B h(<S)$ 86a ब्रह्मलोका०] $A B h$, ब्रह्मणास० $\mathrm{R}$ - ०दपावृत्ता ] $\mathrm{RA}_{3} \mathrm{~A}_{7}$, ॰दयावृत्ता $\mathrm{A}_{4}$, ॰द्युपावृत्य $\mathrm{Bh}$ (conj.) 86b ॰मभ्यागता ] RA, ०मद्य गता $\mathrm{Bh}(<\mathrm{S}) \quad 86 \mathrm{c}$ समनुज्ञप्ता: ] $\mathrm{A}_{3} \mathrm{~A}_{7}$, स्ताः समाहूय $\mathrm{R}$, समनुज्ञाताः $\mathrm{A}_{4}$, स्म समाज्ञात्ता: $\mathrm{Bh}(<\mathrm{S})$ 86d कश्यपस्य ततो] $\mathrm{A}_{7} \mathrm{Bh}$ (em.?), उपगम्य त्रया० $\mathrm{R}$, कस्यपस्य $\left\{{ }^{\circ}\right.$ श्य $\left.\mathrm{A}_{4}\right\}$ ततो $\mathrm{A}_{3} \mathrm{~A}_{4} \quad$ 87b कश्यपो ] $\mathrm{RA}_{4} \mathrm{~A}_{7}^{\mathrm{ac}} \mathrm{Bh}(\mathrm{em} . ?)$, कश्यपे $\mathrm{A}_{3} \mathrm{~A}_{7}^{\mathrm{pc}}$ - द्विजः ] $\mathrm{RA}_{4} \mathrm{~A}_{7} \mathrm{Bh}$ (em.?), द्विजा: $\mathrm{A}_{3} \quad 87 \mathrm{c}$ ततो ]

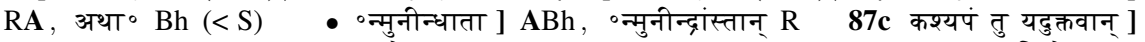
$\mathrm{Bh}$ (conj.?, cf. S), कश्यपान् कमलोड़्रव: $\mathrm{R}$, कश्य $\left\{\right.$ ०स्य० $\mathrm{A}_{3}$ \} पस्तु यदुक्तवान $\mathrm{A} \quad \mathbf{8 8 a}$ ज्ञापितो ] $\mathrm{Bh}$ $(<\mathrm{S})$, कुपितो $\mathrm{R}$, कुशितो $\mathrm{A}_{3} \mathrm{~A}_{4} \mathrm{~A}_{7}^{\mathrm{ac}}$, कथितो $\mathrm{A}_{7}^{\mathrm{pc}} \quad$ 88ab ब्रह्मन्त्रह्मा लोक॰] $\mathrm{RBh}(<\mathrm{S})$, ब्रह्मा ब्रह्मलोके $A \quad 88 c d$ असुरा अपि मे पुत्रा देवाश्चापि ] $A B h$, असुरानपि पुत्रा हि देवस्यास्य $R \quad 88 d$ प्रिया: ] $\mathrm{RA}_{3} \mathrm{Bh}$, प्रिया $\mathrm{A}_{4} \mathrm{~A}_{7}$ 
तेषां नैव यथान्योन्यं वैरं स्याल्लोकभावन।

तथा कुरु सुरश्रेष्ठ भवेयं निर्वृतस्ततः॥ ५९॥

तत्राहं ब्रह्मणाइप्तो ब्रवीमि त्वां महामुने ।

देवासुरं यथावृत्तमन्योन्यं सख्यमेव च।

अमृतोत्पादनं चैव राज्यसंस्थां च कृत्स्नशः ॥ ९०॥

त्वदर्थं भगवान्सवं भविष्यमृषिसत्तम।

कथयामास लोकेशो देवासुरविचेष्टितम्॥ १? ॥

निवेद्य तस्य तत्सर्वं ब्रह्मणा प्रेषिता वयम्।

इहागता भगवतीं द्रष्टुं हिमगिरे: सुताम्॥ ९२॥

तानेव देवतान्भूय ऋषयस्ते तपोधनाः।

पप्रच्छुर्नियतात्मानः सर्व एव तदा मुने॥ ९३॥

देवासुराणां यद्दृत्त भविष्यं कथितं सुराः।

तद्वयं श्रोतुमिच्छामो यदि वो उनुग्रहे मतिः॥९४॥

किं च विज्ञापिता देवी युष्माभिः सुरसत्तमा:।

कथयध्वं हि तत्सर्व यद्यनुग्राह्यता हि न:॥ ९४॥

$\mathbf{8 9 - 9 5} \approx$ SP $112.107 \mathrm{~cd}-113$

89a तेषां नैव ] $A B h$, तेषामेव $R$ - यथान्योन्यं ] $A_{3} A_{7} B h$, यथाकामं $R$, यथोन्योन्यं $A_{4} \quad 89 b$ वैरं स्याल्नोकभावन ] $\mathrm{Bh}(<\mathrm{S})$, कामयन्तः परस्परम् $\mathrm{R}$, नैव $\left\{\right.$ ववं $\left.\mathrm{A}_{4}\right\}$ स्या $\left\{\right.$ स्यात् $\left.\mathrm{A}_{7}^{\mathrm{pc}}\right\}$ लोकभावन $\mathrm{A}$ $89 \mathrm{c}$ कुरु सुर० ] $\mathrm{R}$, कुरु गुरु॰ $\mathbf{A}$, कुर्वमर० $\mathrm{Bh}$ (conj.) $89 \mathrm{~d}$ भवेयं निर्वृतस्ततः ] $\mathrm{Bh}(<\mathrm{S})$, ततो यं निर्वृतिस्तव $\mathrm{R}$, भवेयुर्निर्वृता $\left\{{ }^{\circ}\right.$ वृत० $\mathrm{A}_{4}$, ${ }^{\circ}$ वृत ${ }^{\circ} \mathrm{A}_{7}^{\mathrm{ac}}$, ${ }^{\circ}$ वृता॰ $\left.\mathrm{A}_{7}^{\mathrm{pc}}\right\}$ स्ततः $\mathrm{A}$ 90a तत्राहं $] \mathrm{RBh}$

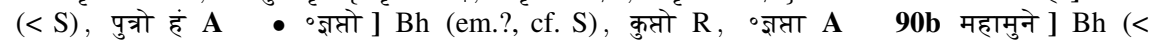
$\mathrm{S})$, महात्मना $\mathrm{R}$, महात्मने $\mathrm{A} 90 \mathrm{c}$ देवासुरं यथा० ] $\mathrm{Bh}(<\mathrm{S})$, देवासुर यथा० $\mathrm{R}$, देवासुराणां यत् $\left\{\right.$ यं $\left.\mathrm{A}_{7}\right\} \mathrm{A} 90 \mathrm{~cd}$ ०तमन्योन्यं सख्यमेव च] $\mathrm{A}_{3} \mathrm{~A}_{4} \mathrm{Bh}$, ०तमपि पालय सर्व्वदा $\mathrm{R}$, ०त्तं अन्योन्यं संख्यमेव च $\mathrm{A}_{7} \quad 90 \mathrm{e}$ अमृतोत्पादनं चैव $] \mathrm{RBh}(<\mathrm{S})$, अदितिश्च दितिश्चैव $\left\{\right.$ ग्रै $\mathrm{A}_{4}$ (unmetrical) $\} \mathrm{A}$ $90 f$ राज्यसंस्थां च कृत्स्नशः ] em., ततः संस्कार्य्य यत्पुन: $R$, राज्यसंस्था च कृत्स्नशः $\left\{\circ\right.$ सः $\left.A_{4}\right\} A_{3} A_{4}$, राज्यसंस्था(न) $\left\{{ }^{\circ}\right.$ व $\left.\mathrm{A}_{7}^{\mathrm{ac}}\right\}$ कृस्नशः $\mathrm{A}_{7}$, राज्यं संस्थाज्च कृत्स्नशः $\mathrm{Bh}\left(<\mathrm{S}_{2}\right)$ 91a त्वदर्थं ] conj., त्वयोक्त $\mathrm{RBh}$ (em.?), त्वयोक्ता $\mathrm{A}$ - भगवान् ] $\mathrm{R}^{\mathrm{ac}} \mathrm{Bh}\left(\mathrm{em}\right.$. ?), भगवन् $\mathrm{R}^{\mathrm{pc}}$ ?A $\mathbf{9 1 b}$ भविष्यमृ॰] $\mathbf{A B h}$, भविष्यन् ऋ० $R$ - ${ }^{\circ}$ त्तम ] $\mathrm{R}^{\mathrm{pc}} \mathrm{ABh}$, ०सत्तम: $\mathrm{R}^{\mathrm{ac}}$ 91cd ] om. $\mathrm{R}$ 92a निवेद्य तस्य ] $\mathrm{RBh}$ $(<\mathrm{S})$, निवेदयतु $\mathrm{A}_{3} \mathrm{~A}_{4}$, निवेदयितुं $\mathrm{A}_{7}$ (unmetrical) $92 \mathrm{c}$ ०गता ] $\mathrm{RBh}(<\mathrm{S})$, ०गतां $\mathrm{A}_{3} \mathrm{~A}_{7}$, ०गतं $\mathrm{A}_{4} 92 \mathrm{~d}$ दृष्टुं ] $\mathrm{RBh}(<\mathrm{S})$, दृष्टिं $\mathrm{A}_{3} \mathrm{~A}_{4}$, दृष्टां $\mathrm{A}_{7}^{\mathrm{pc}}$, दुष्टां $\mathrm{A}_{7}^{\mathrm{ac}}$ - हिमगिरे: ] $\mathrm{ABh}$, भगवतः $\mathrm{R}$ 93a Before this $\mathrm{Bh}$ has सनत्कुमार उवाच। $(<S)$ - तानेव देवतान् ] conj., तामेव देवतां $R$, तमेव चरतां $A$, तानेवं वादिनो $\mathrm{Bh}(<\mathrm{S}) \quad \bullet$ भूय ] $\mathrm{ABh}$, भूत्वा $\mathrm{R} 93 \mathrm{~b}$ ०स्ते ] $\mathrm{ABh}$, ०श्च $\mathrm{R}$ 93c पप्रच्छुर ] $\mathrm{Bh}\left(<\mathrm{S}_{1}\right)$, पपृच्छुर $\mathrm{R}$, पृच्छुन्ति $\mathrm{A}$ 94b भविष्यं कथितं ] $\mathbf{A B h}$, भविष्यति कथं $\mathrm{R}$ - सुरा: ] $\mathrm{RA}$, शुभा: $\mathrm{Bh}(<\mathrm{S})$ 95a विज्ञापिता ] $\mathrm{RA}_{7} \mathrm{Bh}(<\mathrm{S})$, विज्ञापितं $\mathrm{A}_{3} \mathrm{~A}_{4} \quad 95 \mathrm{c}$ हि ] $\mathrm{RA}_{4} \mathrm{~A}_{7}$, दि $\mathrm{A}_{3}$, च $\mathrm{Bh}(<\mathrm{S}) \quad 95 \mathrm{~d}$ यद्यनुग्राह्यता ] $\mathrm{Bh}(<\mathrm{S})$, यद्यनुग्राह्यतां $\mathrm{R}$, यथानुगृह्यता $\left\{{ }^{\circ}\right.$ तां $\left.\mathrm{A}_{7}\right\} \mathbf{A}$ - न: ] $\mathrm{RBh}(<\mathrm{S})$, व: $\mathbf{A}$ 
तेषां तद्वचनं श्रुत्वा ततस्ते सुरसत्तमाः।

$\dagger$ अथाचष्ट कृतान्तो हि वाक्यं वाक्यविशारदान् $\dagger ॥ ९ ६ ॥$

ततः स तेषां बहुचित्रकारणं यथाभविष्यं कथयांचकार।

सुरासुराणां जयतां च कारणं पुरा विधात्रा विहितं यथार्थवत् ॥ १७॥

इति स्कन्दपुराणे सप्रर्षिसमागमो नामाध्यायः ॥ १९२ - ॥

96-97 $\approx$ SP $112.114-115$

96b ततस्ते ] $\mathrm{A}_{4} \mathrm{~A}_{7}$, तेषान्ते $\mathrm{R}$, तस्ते $\mathrm{A}_{3}$ (unmetrical), त्रयस्ते $\mathrm{Bh}(<\mathrm{S})$ • सुर॰ ] RA, देव॰ $\mathrm{Bh}(<\mathrm{S}) \quad 96 \mathrm{c}$ अथाचष्ट $] \mathrm{R}$, तानाचक्षि $\left\{\circ\right.$ क्षी $\left.\mathrm{A}_{7}\right\} \mathbf{A}$, त्वमाचक्ष्व $\mathrm{Bh}(<\mathrm{S})$ कृतान्तो हि ] $\mathrm{RA}$, कृतान्तेति $\mathrm{Bh}(<\mathrm{S})$ 96d वाक्यं वाक्यविशारदान् ] RA, वाक्यमूचुर्महबला: $\mathrm{Bh}(<\mathrm{S})$ 97cd ] om. A 97c जयतां च ] conj., जयतश्च $R$, जगतश्च $B h\left(<S_{2}\right)$ 97d पुरा ] $B h(<S)$, सुधा $R$ - विहितं ] $\mathrm{Bh}(<\mathrm{S})$, विहिता $\mathrm{R}$ Col. इति स्कन्दपुराणे रेवाखण्डे सप्रर्षिसमागमो नामाध्याय: $\mathrm{R}$, इति $\left\{\right.$ इति ग्री॰ $\mathrm{A}_{4}$, ओं॥ इति श्री॰ $\left.\mathrm{A}_{7}\right\}$ स्कन्दपुराणे एकाशीतिसाहस्रचां संहितायामम्बिकाखण्डे सप्रर्षिसमागमनो $\left\{\right.$ ०गमो $\left.\mathrm{A}_{3}\right\}$ नाम द्वादशोत्तरशततमो ध्यायः $\mathbf{A}$, इति स्कन्दपुराणे मन्दरारोहणो नाम द्वादशोत्तरशततमो ध्याय: Bh (cf. $\mathrm{S}_{1}$ ) 
Peter Bisschop and Yuko Yokochi - 978-90-04-46103-1 Downloaded from Brill.com04/26/2023 02:09:47PM 


\section{Bibliography \\ \& \\ Indexes}


Peter Bisschop and Yuko Yokochi - 978-90-04-46103-1 Downloaded from Brill.com04/26/2023 02:09:47PM 


\section{Abbreviations}

\begin{tabular}{|c|c|}
\hline $\mathrm{AiGr}$ & Altindische Grammatik, see Debrunner 1954 \\
\hline AVPariś & Atharvavedapariśișta \\
\hline AYS & Aparārka ad Yājñavalkyasmṛti \\
\hline BḍP & Brahmāṇụapurāṇa \\
\hline BhāgP & Bhāgavatapurāṇa \\
\hline DK & Dānakāṇḍa, see Lakșmīdhara \\
\hline DKK & Dānakriyākaumudī, see Govindānanda \\
\hline DS & Dānasāgara, see Ballālasena \\
\hline DVU & Dānavivekoddyota, see Madanasiṃhadeva \\
\hline GES & A Grammar of Epic Sanskrit, see Oberlies 2003 \\
\hline $\mathrm{HeDKh}$ & Dānakhaṇda, see Hemādri \\
\hline $\mathrm{HeVKh}$ & Vratakhạ̣ḍa, see Hemādri \\
\hline $\mathrm{HV}$ & Harivạ̣śa, Critical Edition \\
\hline Kane I to V & Kane $1930-62$ \\
\hline $\mathrm{KR}$ & Kṛtyaratnākara, see Caṇdeśvara \\
\hline $\mathrm{LiP}$ & Lingapurāṇa \\
\hline MaS & Manusmṛti \\
\hline $\mathrm{MBh}$ & Mahābhārata, Critical Edition \\
\hline $\mathrm{MkP}$ & Mārkaṇdeyapurāṇa \\
\hline $\mathrm{MtP}$ & Matsyapurāṇa \\
\hline PPL & Das Purāṇa Pañcalakṣaṇa, see Kirfel 1927 \\
\hline PS & Pāśupatasūtra \\
\hline Rām. & Rāmāyaṇa, Critical Edition \\
\hline SaPra & Samayapradīpa, see Śrīdatta Upādhyāya \\
\hline $\mathrm{SkP}$ & Skandapurāṇa, Venkatesvara Press \\
\hline $\mathrm{SP}$ & Skandapurāṇa, our edition \\
\hline SP I & Skandapurāṇa, our edition Vol. I \\
\hline SP II A & Skandapurāṇa, our edition Vol. II A \\
\hline SP II B & Skandapurāṇa, our edition Vol. II B \\
\hline SP III & Skandapurāṇa, our edition Vol. III \\
\hline SP IV & Skandapurāṇa, our edition Vol. IV \\
\hline $\mathrm{SP}_{\mathrm{Bh}}$ & Skandapurāṇa, edit. by K. Bhatțarāì \\
\hline TaiSa & Taittirīya-Saṃhitā \\
\hline VāP & Vāyupurāṇa (Venkatesvara ed.) \\
\hline VarP & Varāhapurāṇa \\
\hline VDh & Viṣnudharma, see Grünendahl 1983-89 \\
\hline VDhP & Viṣnudharmottarapurāṇa \\
\hline $\mathrm{ViP}$ & Viṣnupurāṇa \\
\hline ViS & Viṣnusmṛti \\
\hline VK & Vratakāṇḍ, see Lakṣmīdhara \\
\hline $\mathrm{VmP}$ & Vāmanapurāṇa \\
\hline
\end{tabular}




\section{References}

Adiceam, Marguerite E.

1966 Les images de Śiva dans l'Inde du Sud: V. - Harihara. in: Arts

Asiatiques 13 (1966), 83-98.

Agrawala, R.C.

1963 Solar Symbolism of the Boar. Yajña-varāha: An Interpretation. Varanasi.

1970 Hari-Hara in the National Museum, New Delhi. in: East and West 20.3 (1970), 348-350.

Aparārka

(AYS) Yājñavalkyasmṛti [with the] Ṭ̂̄kā [of] Aparārka, [edit. by] Hari Nārāyaṇa Apte. [Poona] 1903. Ananda Ashrama Sanskrit Series 46.

Arthaśāstra

The Kauṭilīya Arthaśāstra, edit. and transl., with a study, by R.P.

Kangle. Bombay 1960-1965. 3 vols. University of Bombay Studies,

Sanskrit, Prakrit and Pali, No. 1-3.

Atharvavedapariśișta

(AVPariś) George Melville Bolling \& Julius von Negelein, The Pariśisțas of the Atharvaveda. Volume I: Text and Critical Apparatus, in 2 Parts. Leipzig 1909-1910.

Bakker, Hans T.

1997 The Vākāțakas. An Essay in Hindu Iconology. Groningen. Gonda Indological Studies V.

2004 Origin and Growth of the Purānic Text Corpus with Special Reference to the Skandapurāna. Edited by Hans T. Bakker. Delhi. Papers of the 12th World Sanskrit Conference Vol. 3.2.

2014 The World of the Skandapurāna. Northern India in the Sixth and Seventh Centuries. Leiden/Boston. Supplement to Groningen Oriental Studies.

2021 The Skandapurāṇa and Bāṇa's Harṣacarita. in: Bisschop, Peter C., \& Elizabeth A. Cecil (eds.), Primary Sources and Asian Pasts. Berlin/Boston. pp. 106-126.

Bakker, Hans T. \& Peter C. Bisschop

2016 The Quest for the Pāśupata Weapon. The Gateway of the Mahādeva Temple at Madhyamikā (Nagarī). in: Indo-Iranian Journal 59.3 (2016), $217-258$.

Ballālasena

(DS) The Dānasāgara of Ballāla Sena, critically edited with introduction and index by Bhabatosh Bhattacharya, Calcutta 1953-56. 4 vols. Bibliotheca Indica 274.

Bhāgavatapurāṇa

(BhāgP) Śr̄̄bhāgavatam [Śrīmad Bhāgavata Mahāpurāna]. Critical Edition by H.G. Shastri et al. Volume I-IV. Bh.J. Institute of Learning and Research, Ahmedabad 1996-98. 4 vols. 
Bisschop, Peter C.

2002 On a Quotation of the Skandapurāṇa in the Tīrthavivecanakāṇda of Lakșmīdhara's Kṛtyakalpataru. Studies in the Skandapurāṇa V. in: Indo-Iranian Journal 45 (2002), 231-243.

2006 Early Śaivism and the Skandapurāṇa. Sects and Centres. Groningen. Groningen Oriental Studies XXI.

2016 A 12th-Century Vārāṇasimmāhātmya and Its Account of a Hypethral Yogin̄-Temple. in: Goodall, Dominic \& Harunaga Isaacson (eds.), Tantric Studies. Fruits of a Franco-German Collaboration on Early Tantra. Pondichéry. Collection Indologie 131 / Early Tantra Series 4. pp. $113-133$

2018 Universal Śaivism. The Appeasement of All Gods and Powers in the Śāntyadhyāya of the Śivadharmaśāstra. Leiden. Gonda Indological Studies 18.

Brahmāṇdapurāṇa

(Bḍ̂) Śrī-Vyāsa-maharșiproktạ̣ Brahmāṇdapurāṇam. (With Introduction in Sanskrit and English and an Alphabetical Index of Verses). Edit. by J. L. Shastri. Delhi etc. 1973. (Reprint of the Venkatesvara edition of AD 1912).

Brick, David

2015 Brahmanical Theories of the Gift. A Critical Edition and Annotated Translation of the Dānakāṇḍa of the Kṛtyakalpataru. Cambridge, MA.

Brinkhaus, Horst

1992 Beobachtungen zur Frühgeschichte der Prādurbhāva-Lehre: Der Ebermythos. in: Slaje, Walter \& Christian Zinko (eds.), Akten des Melzer-Symposiums 1991. Graz. pp. 54-65.

1993 Early Developmental Stages of the Viṣnuprādurbhāva Lists. in: Oberhammer, Gerhard \& Roque Mesquita (eds.), Proceedings of the VIIIth World Sanskrit Conference, Vienna 1990. Wiener Zeitschrift für die Kunde Südasiens und Archiv für indische Philosophie, Band 36, suppl V, Vienna. pp. 101-110.

Brockington, John

1995 Indra and His Banner. in: Channakeshava, B. \& H. V. Nagaraja Rao (eds.), Ānanda Bhāratī: Dr. K. Krishnamoorthy Felicitation Volume. Mysore. pp. 109-117.

2000 Fashions in Formulae: Sanskrit Epic Tradition III. in: Bailey, Greg \& Mary Brockington (eds.), Epic Threads: John Brockington on the Sanskrit Epics. New Delhi. pp. 339-352.

Brown, Norman

1942 The Creation Myth of the Rig Veda. in: Journal of the American Oriental Society 62.2 (1942), 85-98.

Caṇdeśvara

(KR) The Kṛtyaratnākara, a Treatise on Smṛti by Candeśsara Thakkura edit. by Kamala-kṛșna Smṛtitīrtha. Calcutta 1921-25. Bibliotheca Indica 237.

Chandra, Pramod

1970 Stone Sculpture in the Allahabad Museum. A Descriptive Catalogue. Poona.

Debrunner, Albert

1954 Jacob Wackernagel: Altindische Grammatik. Band II,2. Die Nominalsuffixe. Göttingen. [= AiGr II.2] 
De Simini, Florinda

2015 Observations on the Use of Quotations in Sanskrit Dharmanibandhas. in: Journal of Indian Philosophy 43, 601-624.

Derrett, J. Duncan M.

1973 Dharmaśāstra and Juridical Literature. Wiesbaden. A History of Indian Literature IV, fasc. 2.

Dokter-Mersch, Sanne

2020 Visual Story-Telling in Text and Image: The Nāga as Inhabitant of the Cosmic Ocean and the Netherworld. in: Boer, Lucas den \& Elizabeth A. Cecil (eds.), Comparison Across Time and Space. Berlin. pp. 51-74.

forthc. Counter-Narratives: Parallel Themes in Śaiva and Vaiṣnava Mythology. $\mathrm{PhD}$ thesis, Leiden University.

Doniger O'Flaherty, Wendy

1976 The Origins of Evil in Hindu Mythology. Berkeley.

Einoo, Shingo

2004 Notes on the vrssotsarga. in: Griffiths, Arlo \& Jan E.M. Houben (eds.), The Vedas: Texts, Language \& Ritual. Proceedings of the Third

Gonda, Jan International Vedic Workshop, Leiden 2002. Groningen. pp. 35-48.

1969 Aspects of Early Vișnuism. 2nd ed., Delhi.

1984 Prajāpati and the Year. Amsterdam.

Goudriaan, Teun

1978 Māyā Divine and Human. A Study of Magic and Its Religious

Foundations in Sanskrit Texts, with Particular Attention to a Fragment on Viṣnu's Māyā Preserved in Bali. Delhi.

Govindānanda

(DKK) Dānakriyākaumud̄̄ by Govindānanda Kavikan̉kaṇācāryya, edit. by Paṇdita Kamala Kṛ̣̣na Smṛtibhūṣaṇ. Calcutta 1903. Bibliotheca Indica 1028 and 1039.

Granoff, Phyllis

2004 Saving the Saviour: Siva and the Vaișnava Avatāras in the Early Skandapurāṇa. in: Bakker 2004, pp. 111-138.

Grünendahl, Reinhold

1983-89 Viṣnudharmāḥ, Precepts for the Worship of Viṣnu. Part 1: Adhyāyas

1-43. Part 2: Adhyāyas 44-81. Part 3: Adhyāyas 82-105 (with a Pāda-index of Adhyāyas 1-105). Wiesbaden. 3 vols.

Hara, Minoru

1987 'Invigoration'. in: Falk, Harry (ed.), Hinduismus und Buddhismus.

Festschrift für Ulrich Schneider. Freiburg 1987. pp. 134-151.

Harimoto, Kengo

2004 Some Observations on the Revā- and the Ambikākhaṇda Recensions of the Skandapurāṇa. in: Bakker 2004, pp. 41-64.

2006 The Original Skandapurāna, Lakșmīdhara and Candeśvara. Studies in the Skandapurāṇa VIII. in: Indo-Iranian Journal 49, 23-38.

Harivamśa

(HV) The Harivamśa Being the Khila or Supplement to the Mahābhārata. For the first time critically edited by P. L. Vaidya. Poona 1969-71. 2 vols.

Harle, James C.

1974 Gupta Sculptures. Oxford. 
Hemādri

\section{CATURVARGaCintĀMAṆI}

(HeDKh) The Dānakhaṇḍa, edit. by Bhāratacandra Śiromaṇi. Calcutta 1871. Bibliotheca Indica 72 .

(HeVKh) The Vratakhaṇda. Part 1 edit. by Bhāratacandra Śiromaṇi. Part 2 edit. by Bhāratacandra Śiromaṇi, Yajñeśvara Smṛtiratna and Kāmākhyānātha Tarkavāgīśa. Calcutta 1878-79. 2 vols. Bibliotheca Indica 72.

Hopkins, E. Washburn

1915 Epic Mythology. Strassburg. Grundriss der Indo-Arischen Philologie und Altertumskunde III. Band, I. Heft B.

Jaiswal, Suvira

1985 The Demon and the Deity: Conflict Syndrome in the Hayagriva Legend. in: Studies in History 1.1 (1985), 1-13.

Kālidāsa

The Complete Works of Kālidāsa. The text in Sanskrit and Prakrit edited with Introduction by V.P. Joshi. Leiden 1976.

Vallabhadeva's Kommentar (Śāradā-Version) zum Kumārasaṃbhava des Kālidāsa hrsg. von M. S. Narayana Murti, unter der Mitarbeit von Klaus L. Janert. Wiesbaden 1980. Verzeichnis der orientalischen Handschriften in Deutschland, Supplementband 20, 1.

Kirfel, Willibald

1927 Das Purāṇa Pañcalakṣaṇa. Versuch einer Textgeschichte. Leiden.

Knipe, David M.

2015 Vedic Voices. Intimate Narratives of a Living Andhra Tradition. Oxford. Kropman, Martine

2019 The Consecration of Kumāra: The Role of Thanesar and King Harsa in the Composition of the Skandapurāna. in: Journal of the Royal Asiatic Society 29.1 (2019), 95-125.

Kuiper, F.B.J.

1975 The Basic Concept of Vedic Religion. in: History of Religions 15.2 (1975), 107-120.

Lakșmīdhara

\section{KṚTYAKALPATARU}

(DK) Pañcamo bhāgaḥ. Dānakāṇḍam, edit. by K. V. Rangaswami Aiyangar. Baroda 1941. Gaekwad's Oriental Series XCII.

(VK) Șaștho bhāgaḥ. Vratakāṇdam, edit. by K. V. Rangaswami Aiyangar. Baroda 1953. Gaekwad's Oriental Series CXXIII.

Lavy, Paul A.

2003 As in Heaven, So on Earth: The Politics of Viṣnu, Siva and Harihara Images in Preangkorean Khmer Civilization. in: Journal of Southeast Asian Studies 34.1 (2003), 21-39.

Levman, Bryan G.

2005 The Buddhalakșana and the Gaṇdavyūha Sūtra. in: Canadian Journal of Buddhist Studies 1 (2005), 31-57.

Lingapurāṇa

(LiP) Śr̄̄-Vyāsa-maharșiproktam Śrī-Lingamahāpurāṇaṃ, with the Sanskrit Commentary Śivatoṣiṇ̄ by Gaṇeśa Nātu. [Edit. by] Gañgāviṣnu (son of Kṛṇnadāsa). Venkatesvara Press, Bombay V.S. 1981 [= AD 1924]. [Reprinted, with a Ślokānukramaṇī by Nāgaśaraṇa Siṃha, by Nag Publishers, Delhi 1989 (2nd ed. 1996).] 
Madanasimhadeva

(DVU) Madanaratnapradīpa Dānavivekoddyota. An extensive digest on Dānas compiled under the patronage of King Madanasiṃhadeva, [edit. by] K. Deśapāṇde. Hyderabad 1964-67. 3 vols. Sanskrit Academy Series 10, $15-16$.

Magnone, Paolo

2009 Tejas (and śakti) Mythologemes in the Purānas. in: Koskikallio, Petteri (ed.), Parallels and Comparisons. Proceedings of the Fourth Dubrovnik International Conference on the Sanskrit Epics and Purānas, September 2005. Zagreb. pp. 235-256.

Mahābhārata

(MBh) The Mahābhārata. For the first time critically edited by V.S. Sukthankar and others. Poona 1927-59. 19 vols.

Mahāvastu

Le Mahâvastu. Texte Sanscrit, publié pour la première fois et accompagné d'introductions et d'une commentaire, par É. Senart. Tome Deuxième. Paris 1890 .

Manusmṛti

(MaS) Manu's Code of Law. A Critical Edition and Translation of the Mānava-Dharmaśāstra, edit. by Patrick Olivelle. Oxford 2005.

Mārkandeyapurāna

(MkP) Mārkaṇdeyapurāṇam. Vol. I (Adhyāyas 1-75). Critically edited by M.L. Wadekar. Vadodara 2011.

Matsyapurāṇa

(MtP) Śrīmad-Dvaipāyanamuni-praṇītam Matsyapurāṇam, etad pustakam Ānandāśramasthapaṇitaih samśódhitam. [Poona] 1981. Ananda Ashrama Sanskrit Series 54. [Reprint of the ed. of H.N. Apte AD 1907.]

Meulenbeld, G. Jan

1999-2002 A History of Indian Medical Literature. Groningen. 3 Volumes in 5

Newid, Mehr-Ali Parts. Groningen Oriental Studies 15.1-3.

1986 Waffen und Rüstungen im Alten Indien. Dargestellt aufgrund der Quellen in Literatur, Kunst und Archäologie. Inaugural-Dissertation, Oberlies, Thomas Ludwig-Maximilians-Universität zu München. Altendorf bei Bamberg.

1997 Die Textgeschichte der Śvetadvīpa-Episode des Nārāyaṇīya (MBh 12,321-326). in: Peter Schreiner (ed.), Nārāyaṇīya-Studien. Wiesbaden. pp. $75-118$.

2003 A Grammar of Epic Sanskrit. Berlin/New York. Indian Philology and South Asian Studies 5. [= GES]

Pāśupatasūtra

(PS) The Pāśupatasūtra with the Pañcārthabhāṣya of Kauṇdinya. Edit. by R. Ananthakrishna Sastri. Trivandrum 1940. Trivandrum Sanskrit Series CXLIII.

Powers, John

2009 The Bull of a Man. Images of Masculinity, Sex, and the Body in Indian Buddhism. Cambridge, MA/London.

Purānapañcalakṣaṇa

(PPL) see Kirfel 1927. 
Rāmāyạ̣a

(Rām.) The Vālmīki-Rāmāyaṇa. Crit. edit. for the first time by a board of editors. Baroda 1960-75. 7 vols.

Rönnow, Kasten

1929 Some Remarks on Śvetadvīpa. in: Bulletin of the School of Oriental Studies, University of London 5.2 (1929), 253-284.

Śabdakalpadruma

Shabda-Kalpadrum or an encyclopædic Dictionary of Sanskrit words [...] by Raja Radha Kanta Deva. 3rd ed., Varanasi 1967. 5 vols.

Saindon, Marcelle Chowkhamba Sanskrit Series Work No. 93.

2004-05 Quand Kṛṣna Dvaipāyana Vyāsa est considéré comme un avatāra de Viṣnu. in: Bulletin d'Études Indiennes 22-23 (2004-05), 307-321.

Shulman, David

1986 Notes on the Myth of Śiva as Sthāṇu. in: History of Religions 26.2 (1986), 101-124.

Singh, Sarva Daman

1965 Ancient Indian Warfare with Special Reference to the Vedic Period. Leiden.

Sircar, R.C.

1971 Kokāmukha. in: Studies in the Geography of Ancient and Medieval India. Delhi. pp. 275-281.

Skandapurāṇa

(SkP) Śrī-Skāndamahāpurāṇam, [edit. by] Kṣemarāja Śrīkṛ̣ṇadāsa. Venkatesvara Press, Bombay V.S. 1967 [AD 1910]. 7 vols. [Reprinted by Nag Publishers, Delhi 1986 (2nd ed. 1995). 7 vols. Vol. 8, Ślokānukramaṇ̄ by Nāgaśaraṇa Siṃha. Nag Publishers, Delhi 1990].

(SP I) The Skandapurāna, Volume I. Adhyāyas 1-25. Critically Edited with Prolegomena and English Synopsis by R. Adriaensen, H.T. Bakker \& H. Isaacson. Groningen 1998. Supplement to Groningen Oriental Studies.

(SP II A) The Skandapurāṇa, Volume II A. Adhyāyas 26-31.14: The Vārāṇasī Cycle. Critical Edition with an Introduction, English Synopsis \& Philological and Historical Commentary by Hans T. Bakker \& Harunaga Isaacson. Groningen 2004. Supplement to Groningen Oriental Studies.

(SP II B) The Skandapurāna, Volume II B. Adhyāyas 31-52: The Vāhana and Naraka Cycles. Critical Edition with an Introduction \& Annotated Synopsis by Hans T. Bakker, Peter C. Bisschop, Yuko Yokochi, in cooperation with Nina Mirnig \& Judit Törzsök. Leiden/Boston 2014. Supplement to Groningen Oriental Studies.

(SP III) The Skandapurāṇa, Volume III. Adhyāyas 34.1-61, 53-69: The Vindhyavāsin̄̄ Cycle. Critical Edition with an Introduction \& Annotated English Synopsis by Yuko Yokochi. Leiden/Groningen 2013. Supplement to Groningen Oriental Studies.

(SP IV) The Skandapurāṇa, Volume IV. Adhyāyas 70-95: Start of the Skanda and Andhaka Cycles. Critical Edition with an Introduction \& Annotated English Synopsis by Peter C. Bisschop and Yuko Yokochi, in cooperation with Diwakar Acharya and Judit Törzsök. Leiden 2018. Supplement to Groningen Oriental Studies.

$\left(\mathrm{SP}_{\mathrm{Bh}}\right) \quad$ Skandapurāṇasya Ambikākhạ̣ḍh, sampādakaḥ Kṛ̣ṇaprasāda Bhațțarāì. Kathmandu 1988. Mahendraratnagranthamālā 2. 
Speijer, J.S.

1886 Sanskrit Syntax. With an Introduction by H. Kern. Leiden.

Śrīdatta Upādhyāya

(SaPra) Samayapradīpa of Śrīdatta Upādhyāya, edit. by Asoke Chatterjee Śāstrī.

Calcutta 1971. Bibliotheca Indica 296.

Taittirīya-Saṃhitā

(TaiSa) Taittirîya-Saṃhitâ, herausgegeben von Albrecht Weber. Leipzig 1871-72.

2 vols. Indische Studien. Beiträge für die Kunde des indischen

Alterthums.

Törzsök, Judit

2004 Three Chapters of Śaiva Material Added to the Earliest Known

Recension of the Skandapurāna. in: Bakker 2004, pp. 17-39.

Vāmanapurāṇa

(VmP) The Vāmana Purāna. Crit. edit. by Anand Swarup Gupta. All-India

Kashiraj Trust, Varanasi VS 2024 [AD 1967].

Varāhapurāṇa

(VarP) The Varāha Purāṇa. Crit. edit. by Anand Swarup Gupta. All-India Kashiraj Trust, Varanasi 1981.

Vāyupurāṇa

(VāP) The Vāyumahāpurāṇam. Edit. by Khemarāja. Delhi 1983. Nag

Publishers. [Reprint of the Venkatesvara edition of AD 1895.]

Viṣnudharmottarapurāṇa

(VDhP) Viṣnudharmottarapurāṇa. [Edit. by] Kṣemarāja Śrīkṛ̣ṇadāsa.

Venkatesvara Press, Bombay V.S. 1969 [1912].

Viṣnupurāṇa

(ViP) The Viṣnupurāṇam. Crit. edit. by M.M. Pathak. Pāda-Index by Peter Schreiner. Vadodara 1997-99. 2 vols.

Viṣnusmṛti

(ViS) The Viṣnusmṛti with the commentary Keśavavaijayantī of

Nandapandita. Edit. by V. Krishnamacharya. Madras 1964. 2 vols. The Adyar Library Series 93.

Wattelier-Bricout, Amandine

2019 The Tree Adoption Ritual as Presented in the Dharmanibandhas. in: De Jonckheere, Heleene, Marie-Hélène Gorisse \& Agnieszka Rostalska (eds.), Puṣpikā. Tracing Ancient India, through Texts and Traditions: Contributions to Current Research in Indology, Vol. 5.

Oxford/Philadelphia. pp. 95-127.

Williams, J.G.

1982 The Art of Gupta India. Empire and Province. Princeton.

Yājñavalkyasmṛti

Yokochi, Yuko see Aparārka, AYS.

2004 The Relation between the Skandapurāṇa and the Āvantyakhaṇḍa. in: Bakker 2004, pp. 79-110.

forthc. Contents and Composition of the Skandapurāna. An Analysis of its Narrative Structure. Studies in the Skandapurāṇa X. (In cooperation with Hans T. Bakker).

Zysk, Kenneth G.

2016 The Indian System of Human Marks, with editions, translations and annotations. Leiden/Boston. 2 vols. 


\section{Index to the Introduction}

Adbhutasāgara: 29

Agni: 4

amrta: 10

Amṛtamanthana: 10

Andhaka: 3, 4, 8-13, 16-22, 28, 50

Anukramaṇikā: 3, 4, 20, 22, 28

Aparārka: 29, 32, 33

Aśmakapura: 5, 14

aśoka: 3, 8, 16-19, 22, 50

Asura: 3, 5, 9-11, 15-18, 20, 21, 49, 50

Bāna: 11

Dhundhu: 15

Kaitabha: 15

Kālanemi: 11

Madhu: 15

Maya: 11

Vipracitti: 5, 49

Virocana: 10-12

Āti-Baka battle: 10

avatāra: 11

Bali: 10, 11

Ballālasena: 29, 31, 36, 37

Brahmā: 4, 5, 9, 17, 27, 28, 49

Svayambhu: 4

Brahmaloka: 9

cakra: 6,50

Candeśvara: 29-31, 35-37, 39

Caturvargacintāmaṇi (CVC): 30, 33-35

Dānakhạ̣da (HeDKh): 29, 33-35

Vratakhaṇda (HeVKh): 29, 33, 34

Daitya: 3-6, 9-13, 15, 20

dāna: 6, 8, 29

Dānakriyākaumudī (DKK): 30, 31

Dānasāgara (DS): 7, 8, 29, 31, 36-40

Dānava: 5, 10, 11

Devas: 3, 9, 10, 15, 17, 18, 50

Devī: 3, 4, 6-9, 16-23, 25-30, 32, 50

Devadevī: 19

Kauśikī: 21

Pārvatī: $6,8,9,11,16$

Satī: 21
Umā: 16, 18, 19, 21, 23, 27, 28

Vindhyavāsin̄̄: 21

dharma: 3, 6-8, 16, 19, 26, 30

Dhātṛ: 3, 9, 17, 50

Diti: 10

Gaṇa: 14, 15, 18, 20, 22, 26

Gaṇapa: 6

Bhṛngiriți: 26

Garuda: 5

Gaurīkūṭa: 3, 6, 50

Govindānanda: 30-32

Harihara: 13

Śivavișnu: 13

Viṣnuśaṃkara: 13

Hemādri: 29, 30, 33-35, 37

Himavat: 6

Hiranyakaśipu: 3, 10-12

Hiraṇyākṣa: 3-6, 10-12, 14, 17, 49, 50

Indra: 6, 10-13, 50

Jāmadagnya: 11

Kālī: 23

Kapila: 15

Kaśyapa: 9, 10, 17, 50

Kaurava: 10

Kokāmukhasvāmin: 14

Kokavaktra: 6,14

Kṛtānta: 3, 9, 11, 17, 50

Kṛtyakalpataru (KKT): 29, 30, 32-34, 36-38

Dānakāṇḍ (DK): 29, 32-39

Niyatakālakāṇda (NK): 29

Vratakāṇda (VK): 29, 33, 34, 36-39

Kṛtyaratnākara (KR): 29, 30, 35-38

Lakșmaṇasena: 29

Lakṣmīdhara: 29-35, 37, 39

Madanaratnapradīpa: 30, 35

Dānavivekoddyota (DVU): 30, 35

Madanasimhadeva: 30 
Mahābhārata (MBh): 10

mahāvrata: 12,13

Mandara: 3, 6, 8, 9, 11, 16, 17, 20, 21,

Mantra: 4

$$
27,50
$$

mantra: 5, 6

Mātṛ: 8

Mothers: 6, 8

Sāvitrī: 26

Meru: 6

Mitākșara: 33

Nāga: 5

Nala: 5

Nandin: 20-22, 26

Śailādi: 20,26

Nārada: 6, 50

Padmapurāṇa: 37

Pāpmā: 12

Pāśupata: 3, 6, 13, 50

Pātāla: 8

prādurbhāva: 9

Prahlāda: 3, 5, 9-12, 16, 20, 21, 49, 50

Prthiviv: 3

Rasātala: 49

Saiṃhikeya: 11

Śakuni: 15

Samayapradīpa (SaPra): 30, 33, 36-38

Sanatkumāra: 17

Śankha: 6, 50

Saptarși: 3, 9, 17

Śatarūpā: 27, 28

Śeșa

Ananta: 5

Śiva: 3-6, 8-10, 12, 13, 15, 16, 18-22, 27,50

Deva: 7, 8, 16, 19, 20

Mahādeva: 15

Maheśvara: 6, 15, 50

Rudra: 15

Śarabha: 12

Skanda: 3, 6, 13, 16-19, 21-23

Kārttikeya: 6, 12, 14, 50

Naigameśa: 18

Śākha: 18

Viśākha: 18

Skandapurāṇa (SP): 3, 7-10, 12-16, 18, 20-23, 28-30, 32-37, 39-41

Somanandin: 20
Śrīdatta: $30,33,37$

strīvrata: 7, 26-28

śūla: 12

Śveta: 4

Śvetavarāhasvāmin: 14

tapas: 4,5

Tāraka: 11, 21

tejas: 4-6, 50

Udayagiri: 14

upavāsa: 6

Vāmanapurāṇa (VmP): 21, 22, 28

Varāha: see Viṣnu

Vidhātṛ: 3, 9, 17, 50

Virocana: see Asura

Viṣnu: 3-6, 9-16, 49, 50

Dāmodara: 15

Dattātreya: 15

Keśava: 11

Kṛṣnadvaipāyana: 15

Madhusūdana: 4

Mohin̄i: 10

Nandivardhana: 14

Narasiṃha: 3, 4, 9-13

Naravarāha: 4, 14

Rāma: 15

Vāmana: 10-13

Varāha: 3-6, 8-10, 12-14, 18, 49, $50,57,74$

Vṛka: 3, 6, 50

Vyāsa: 8, 17, 23, 26

Kāleya: 23, 24

Kālija: 24

Kālinandana: 23, 24, 26

Yajña: 4

Yājñavalkyasmṛti: 29, 32, 33

yoga: 4, 49

yuga: 4 


\section{Index to the Synopsis}

adharma: 57, 72, 98

Aditi: 53, 56, 75, 82

Āditya: 54, 56, 65, 85, 88

Agni: 51, 82, 84, 88, 89, 95

Bharata: 82

Vahni: 85,88

Airāvata: 78

Ajaka: see Asura

Amrita: 92

Analātmaja: see Skanda

Ānanda: see Asura

Andhaka: 61, 65, 67, 68, 91, 92, 97, 98

Angiras: 57, 92, 98

Anuhlāda: see Asura

Anumatī: see Mātṛ

Anuștubh: 85

Apsaras: 6, 78, 84, 86, 88

Urvaśî: 84

Aptoryāma: 86

Asiloman: see Asura

Aśmakapura: 65, 66, 70, 72

aśoka: 90, 91, 97

Asura: 54, 60, 62, 63, 65-68, 70, 72,

Ajaka: 65

$$
75,77,78,92,98
$$

Ananda: 65

Anuhlāda: 65, 97

Asiloman: 65

Aśvagrīva: 54

Atti: 65

Baka: 65

Bali: 65

Bāna: 65

Bāṣkala: 65

Bāṣkali: 97

Dhundhu: 54, 65

Druma: 65

Dundubhi: 65

Duryodhana: 65

Hāla: 65

Hastin: 65

Hayagrīva: 65, 69

Hradodara: 65

Ilvaka: 65
Ilvala: 65

Jambha: 65

Kabandha: 65

Kaițabha: 54

Kāla: 65

Kālanemin: 65

Kālaśambara: 65, 67, 69

Kārtasvana: 65

Kāśyapa: 65

Kubha: 65

Kujambha: 65

Kunda: 65

Madhu: 54, 59

Mahāmāya: 65

Mahārava: 65

Mahișa: 65

Makara: 65

Maya: 65

Mayūragrīva: 65

Mūka: 65

Mura: 65

Namuci: 65, 69

Pāka: 65

Pilvaka: 65

Pradīpta: 65

Śalabha: 65

Sālva: 65

Śamaka: 65

Śambara: 65, 67, 69

Śambhu: 65

Śarabha: 65

Śatadundubhi: 65

Śataketu: 65

Śatodara: 65

Śibi: 97

Silika: 65

Sini: 65

Tāra: 65

Vāta: 65

Vātāpin: 65

Vipāka: 65

Vipracitti: 61, 65, 67-70, 72

Virādha: 65

Virocana: 65 
Vrsaparvan: 65

Vyamsa: 65

Aśvagrīva: see Asura

Aśvamedha: 86, 87

Aśvins: 56, 65, 88

Ātharvana: 85

Āti: see Asura

Atikṛcchra: 89

Atri: 92, 98

Baka: see Asura

Bali: see Asura

Bāṇa: see Asura

Bāșkala: see Asura

Bāskali: see Asura

Bhagavat: see Śiva, see Viṣnu

Bharadvāja: 92, 98

Bharata: see Agni

Bhava: see Siva

Bhavānī: see Devī

Bhogavatī: 59

Bhṛngiriți: see Gaṇapa

Bhṛgu: 54, 88, 92, 98

Bhṛgus: 57

Bhūta: 85

Brahmā: 52, 55-58, 62, 75, 78, 81, 84, 85, 89-94, 97

Pitāmaha: 51, 52

Prajāpati: 56, 58, 83-85, 89, 90, 92, 97

Svayambhu: 57

Svayambhū: 91

Virāj: 52

Brahmaloka: 92, 98

brahman: 54

Bṛhaspati: 55

cakra: 76,81

Candra: see Soma

Cāndrāyaṇa: 89

Cāraṇa: 74, 95

Citralekhā: 79

Daiteya: see Daitya

Daitya: 51-53, 55, 57-65, 67-70,

Daiteya: 81

$72-77,91,92,97$

Ditija: 60,72

Daityapa: 91, 92

Daityendra: 55

Dāmodara: see Visnu

Dānava: 51-53, 55, 61-74, 76, 77, 91, 97
Danu: 70, see Mātr

Danuja: 62

Dattātreya: see Viṣnu

Deva: 92, 98, see Śiva

Devadeva: see Śiva

Devadeveśa: see Śiva

Devadevī: see Devī

Devamātṛ: 90

Devapati: see Indra

Devarāja: see Indra

Devī: 82, 87, 90-92, 95-98

Bhavānī: 98

Devadevī: 91

Gaurī: 80

Girijā: 91

Himavatputrī: 93

Himavattanayā: 95

Kālarātrī: 94

Mahādevī: 82, 90

Pārvatī: 81, 82, 97

Śarvāṇī: 97

Śivā: 95

Umā: 54, 56, 91, 95, 97

Dharma: 56, 85

dharma: 52, 54, 56, 57, 67, 72, 82, 86,

$$
\text { 87, 90, 92-94, } 98
$$

Dhātṛ: 71, 92, 98, see Śiva

Dhṛti: see Mātṛ

Dhundhu: see Asura

Dhundhumāra: see Viṣnu

Diti: 63, 66, 70, 72, 73

Ditija: see Daitya

Druma: see Asura

Dundubhi: see Asura

Durgā: see Mātṛ

Duryodhana: see Asura

Gaṇa: 54, 81, 88, 95

Gaṇanāyaka: 80

Gaṇapa: 79-81

Bhṛngiriți: 95

Mahāmāya: 69

Meghanāda: 65

Ganapati: 88-90

Gandharva: 56, 78, 82, 84, 86, 88

Ganeśa: 79

Gaṇeśvara: 79

Gaṅgā: 85, see Mātṛ

Garuda

Garutman: 64, 68, 73

Gaurīkūṭa: 79

Gaurīíikhara: 80 
Gāyatrī: 85, see Mātr

Girijā: see Devī

Gosahasra: 86

Govṛșadhvaja: see Śiva

Guha: see Skanda

gunas: 56,57

Hāla: see Asura

Hari: see Viṣnu

Hastin: see Asura

Hayagrīva: see Asura

Hayaśiras: 59

Himavat: 67, 69, 75, 79, 91, 98

Himagiri: 92

Himavatputrī: see Devī

Himavattanayā: see Devī

Hiranyakaśipu: 57

Hiraṇyākṣa: 51, 52, 54, 60-62, 65, 69, $70,72-74,80,81$

Hiranyanayana: 55

Suvarnākșa: 72

Hradodara: see Asura

Ilvaka: see Asura

Ilvala: see Asura

Indra: $69,78,84$

Devapati: 95

Devarāja: 88

Mahendra: 88

Purandara: 55, 95, 96

Sahasrākșa: 61

Śakra: $61,73,78,81,85,88$

İśvara: see Śiva

Jagatī: 85

Jambha: see Asura

Janārdana: see Viṣnu

Kabandha: see Asura

Kaițabha: see Asura

Kāla: 56, see Asura

Kāladanda: 56

Kālanemin: see Asura

Kālarātrī: see Devī

Kālaśambara: see Asura

Kali: 97

Kāma: 94

Kan்ka: 59

Kāpālin: see Śiva

Kapila: 54

Kārtasvana: see Asura

Kārttikeya: see Skanda

Kāśyapa: see Asura
Kaśyapa: 92, 98

Kauśikī: see Devī

kaustubha: 54

Keśava: see Viṣnu

Khaga: 82

Khaśā: see Mātṛ

Khyāti: see Mātṛ

Kimkara: 63, 66

Kīrti: see Mātṛ

Kokavaktra: 79, 80

Kokāmukha: 81

Kokāsya: 79

Kokavadana: 79

Krauñca: 75

Krcchrātikrcchra: 89

Kṛṣnadvaipāyana: see Viṣnu

Krtānta: 92, 98

Ksīroda: 59

Kubera: 88

Yakșarāja: 84

Kubha: see Asura

Kuhū: see Mātṛ

Kujāmbha: see Asura

Kumāra: see Skanda

Kunḍa: see Asura

Laksmī: see Devī

Lokapa: see Viṣnu

Lokapāla: 85

Mādhava: see Viṣnu

Madhu: see Asura

Madhusūdana: see Viṣnu

Mahādeva: see Śiva

Mahādevī: see Devī

Mahāmāya: see Asura, see Gaṇapa

Mahārava: see Asura

Mahāsāṃtapana: 89

Mahendra: see Indra

Maheśvara: see Śiva

Mahī: see Pṛthivī

Mahișa: see Asura

Maināka: 59

Makara: 59, see Asura

Mālin̄̄: see Mātṛ

Mandara: 69, 79, 90-92, 97, 98

Mantra: 51, 85

mantra: 51, 72, 74, 90

Marīci: 92, 98

Mātṛ

Anumatī: 82

Danu: 82 
Dhrti: 82

Diti: 82

Durgā: 82

Gañgā: 82

Gāyatrī: 82

Khaśá: 82

Khyāti: 82

Kīrti: 82

Kuhū: 82

Lakșmī: 82

Mālin̄i: 82, 95, 96

Mothers: 82, 85, 90

Prabhāvatī: 95

Prajñā: 82

Rākā: 82

Sarasvatī: 82

Sāvitrī: 82, 93

Siṃhikā: 82

Sinīvālī: 82

Śrī: 82

Maya: see Asura māyā: 58, 62, 67, 76

Mayūragrīva: see Asura

Meghanāda: see Gaṇapa

Meru: 62, 76, 97

Mitra: 56

mleccha: 83

Mothers: see Mātr

Mrrtyu: 56, 69

Mṛtyudaṇda: 56

Mūka: see Asura

Mura: see Asura

Nāga: 60, 77, 85

Nala: 62

Namuci: see Asura

Nandin: 90

Śailādi: 96, 97

Nandivardhana: see Viṣnu

Nara: see Viṣnu

Nārada: 80

Naraka: 65, 69

Raurava: 93

Narasiṃha: see Viṣnu

Nārāyaṇa: see Viṣnu

Nīlalohita: see Śiva

Pāka: see Asura

Paksin: 86

Panjkti: 85

Pannaga: 56

Parameśa: see Śiva
Parjanya: 59, 82

Pārvatī: see Devī

Pāśupata: 81, 82

Paśupati: see Śiva

Pātāla: 53, 55, 91, 97

Pauṇ̣̂arīka: 86

Pilvaka: see Asura

Pinākin: see Śiva

Piśāca: 86

Pitāmaha: see Brahmā

pitr: 56, 84, 89

Prabhāvatī: see Mātṛ

Pradīpta: see Asura

Prahlāda: 5, 11, 61, 62, 65, 67, 91, 92, 97,98

Prajāpati: see Brahmā

Prājāpatya: 89

Prajñā: see Mātṛ

Pravara: 79

Pṛthivi: 77

Mahī: 78

Vasudhā: 78

Purandara: see Indra

Puruṣa: 54

purușa: 58

Puruṣottama: see Viṣnu

Rāhu: 65,76

Svarbhānu: 65

rajas: 53

Rākā: see Mātṛ

Rākșasa: 56, 83, 86

Rakșas: 82

Rāma: see Viṣnu

Ramañā: 59

Rasātala: 57, 60

Raurava: see Naraka

Rgveda: 85

Rsi: 85

Rudra: 56, 65, 85, 89, see Śiva

Rudradanda: 56

Sādhya: 53, 56, 85

Sahasrākșa: see Indra

Śailādi: see Nandin

Śakra: see Indra

Śakuni: 53, 65

Śalabha: see Asura

Sālva: 54, see Asura

Śamaka: see Asura

Sāmaveda: 85

Śambara: see Asura 
Śambhu: see Śiva, see Asura

Śamkara: see Śiva

Sāṃkhya: 58

samsāra: 58

Sāṃtapana: 89

Samyamana: 72

Sanatkumāra: 51, 82

Śan்kha: 77

Saptarși: 91, 98

Śarabha: see Śiva, see Asura

Sarasvatī: see Mātṛ

Śarva: see Śiva

Śarvāṇī: see Devī

Śatadundubhi: see Asura

Śataketu: see Asura

Śatarūpā: 93, 94

Śatodara: see Asura

Saubha: 54

Śauri: see Viṣnu

Sāvitrī: see Mātṛ

Śeșa: 59

Ananta: 59

Śibi: see Asura

Siddha: $74,76,78,80,95$

Silika: see Asura

Siṃhikā: see Mātṛ

Śini: see Asura

Sin̄̄vālī: see Mātṛ

Śivā: see Devī

Śiva: 57,97

Bhagavat: 57, 61

Bhava: 81

Deva: $58,80,82$

Devadeva: 73

Devadeveśa: 82

Dhātṛ: 57

Govṛșadhvaja: 57, 61

İ́vara: 95

Kāpālin: 57

Mahādeva: 54, 75, 81, 82

Maheśvara: 54, 74-76, 96

Nīlalohita: 57

Parameśa: 91

Paśupati: 62

Pinākin: 76

Rudra: 54, 56, 57, 63, 69, 73, 74, 88, 95,98

Śambhu: 89

Śamkara: 81

Śarabha: 55

Śarva: 54, 57, 82, 89

Sthāṇu: 80
Tālaketu: 57

Tryambaka: 61

Vidhātṛ: 57

Vṛsadhvaja: 97

Śivipisța: see Viṣnu

Skanda: 79,80

Analātmaja: 81

Guha: 75

Kārttikeya: 79-81

Kumāra: 79,81

Soma: 56, 84, 85, 89

Candra: 85

Śrī: 85, see Mātṛ

śrivvatsa: 54

Śubhāvatî: 82, 97

Sumeru: 82

Sura: 74, 92, 95

Surabhī: 59

Suvarṇākṣa: see Hiraṇyākṣa

Svarbhānu: see Rāhu

Svayambhu: see Brahmā

Svayambhū: see Brahmā

Śveta: 53

Takșaka: 59

tapas: $51-53,57,73,74,82,94$

Tāra: see Asura

Tāraka: 65

tattva: 58

tejas: $57,75,76$

Tripiștapa: 83, 87

Triștubh: 85

Tryambaka: see Siva

Tulāpurușaka: 89

Tușita: 88

Umā: see Devī

upavāsa: 87,89

Uraga: 82

Urvaśí: see Apsaras

Vaḍavāmukha: 69

Vahni: see Agni

Vaikuṇṭha: see Viṣnu

Vairāja: 84

Vāmana: see Viṣnu

Varāha: see Viṣnu

varna: 52

Varuna: $55,58,59,83,88$

Vasiștha: 92, 98

Vasudhā: see Pṛthivī

Vāsuki: 59

Vasus: $56,65,85,88$ 
Vāta: see Asura

Vātāpin: see Asura

Vāyu: 56, 85, 88

Veda: 56,93

Vidhātṛ: 92, 98

Vipāka: see Asura

Vipracitti: see Asura

Virādha: see Asura

Virāj: see Brahmā

Virocana: see Asura

Viṣnu: 51-53, 55, 57, 58, 62, 67, 70, $74,81,88$

Bhagavat: 55, 64, 76, 77

Dāmodara: 53

Dattātreya: 53

Dhundhumāra: 54

Hari: 57

Janārdana: 68

Keśava: 63

Kṛṣnadvaipāyana: 53

Lokapa: 69

Mādhava: 75

Madhusūdana: 57, 75, 78

Nandivardhana: 57, 58, 66-69,

Nara: 53 $73-76,78,81$

Narasimha: 53, 55, 70, 74

Naravarāha: 53

Nārāyaṇa: 53, 85

Puruṣottama: 54

Rāma: 53

Śauri: 54

Śivipișța: 54

Vaikuṇtha: 53, 54, 76

Vāmana: 53

Varāha: 53, 55, 57, 58, 60, 63, 64, $67-70,72,74-76,78-81$

Viśvakarman: 69

Viśvāmitra: 92, 98

Viśvedeva: 56

Vṛka: 79-81

Vṛșadhvaja: see Śiva

Vṛșaparvan: see Asura

Vṛșnis: 54

Vyamsa: see Asura

Vyāsa: 51, 82

Yajña: 51, 58

Yajurveda: 85

Yakșa: 56, 78, 80, 82, 84, 86

Yakșarāja: see Kubera

Yama: 53, 55, 56, 63, 68, 69, 71, 88, 94
Yamadanda: 56

Yātudhāna: 78

yoga: $51,52,86,97$

yogin: $52,54,57,58,86$

yuga: $52,66,73,74$ 


\section{Index of Text Passages}

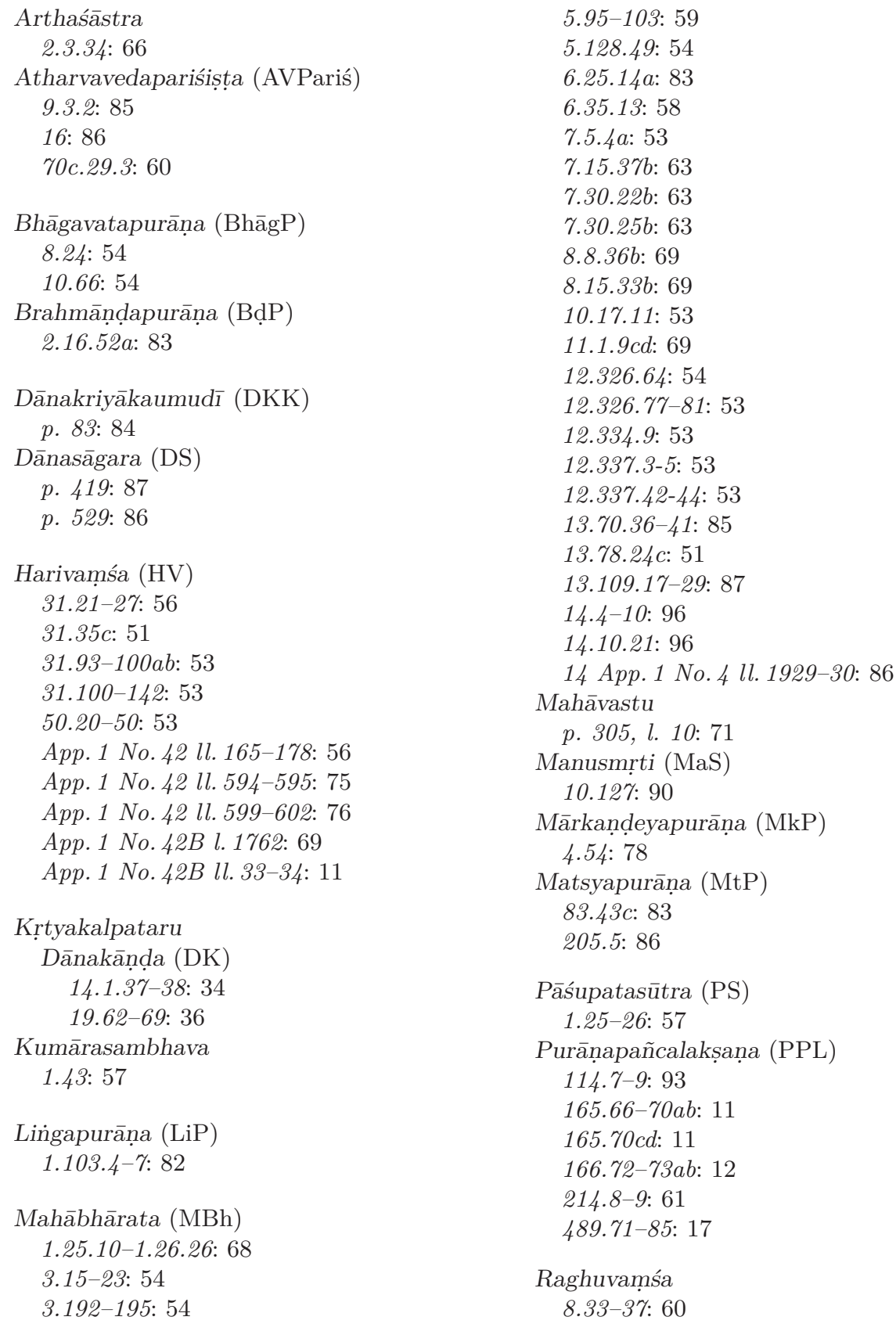




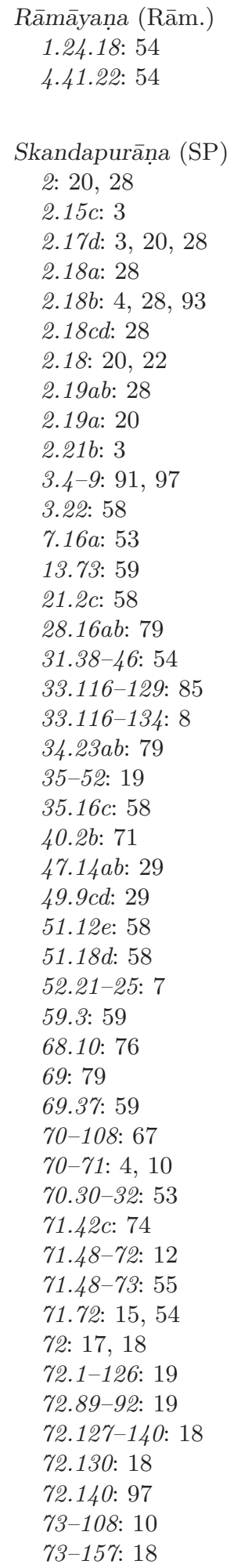

$73.49 d: 73$

73.72d: 73

74: 18

74.23: 9,91

76.46cd: 73

7r. $58-59: 71$

$77.61 \mathrm{~cd}: 71$

77.65: 71

$77.66 \mathrm{c:} 69$

77.67-72: 72

77. 72: 72

78-95: 17

78: 29

$78.7 c d: 29$

78.8ab: 29

79.28c: 67

80.15d: 73

$80.19 \mathrm{c}: 67$

80.24c: 67

80.33a: 63

81.19a: 63

83.5c: 65

84.1-7: 55

85.31a: 74,81

86.9a: 63

87.1c: 67

87.21cd: 73

87.27-38: 68

90.26d: 69

91.9b: 63

91.24c: 67

93.19: 68

93.33: 77

95: 3

95.13: 51,77

95.21-31: 52

95.26ab: 52

96-110: 3

96: 4

96.10c: 51

96.18a: 51

96.32ab: 52

96.34: 52

96.35: 52

9\%: 4

97.8: 76

97.9-10: 4

97.11: 14

97.15-30: 4,14

97.16a: 53

97.28cd-42ab: 54

97.30: 55 
97.35-37: 56

97.35: 55

97.42: 55

97.44: 55

98: 4

98.1-18: 8, 85

98.19b: 55

98.20: 4

98.22d: 73

98.30: 76

98.40: 58

98.51: 58

99: 5

99.4ab: 59

99.25: 62

99.2\%: 60

100: 5

100.3ab: 29

100.3cd: 29

100.30-31: 19

100.50c: 69

100.60b: 63

100.6\%: 63

101: 5

101.6c: 63

101.10d: 69

101.22b: 64

101.30: 64

102: 5

102.38: 66

103: 5

103.24c: 67

103.25-28: 73

103.25b: 67

103.48: 68

104: 5

104.8b: 69

104.15cd: 69

104.19a: 69

104.58: 70

105-10\%: 5

105: 5

105.4b: 71

105.10cd-12: 71

105.34b: 73

150.40c: 73

105.41: 73

106: 5

106.1-5: 67

106.20b: 67

106.2\% : 74

106.33a: 81
106.33: 74

10\%: 3,6

107.3cd-4: 29

107.24: 81

107.27: 29

107.29ab: 29

107.30ab: 29

107.30c: 73

107.41-43: 77

107.28ab: 29

108: 6

108.14: 14

108.15: 57

108.34: 78

109-110: 3,18

109: 6,97

109.5cd: 79

109.20cd: 73

109.48: 80

110: 6

110.31: 82

110.5: 81

110.6b: 73

110.10-15: 12

110.10c: 74

110.27ab: 82

111-112.72: 3

111: 6, 7, 29, 30, 33, 34, 36-39

111.2-7: 95

111.3ab: 95

$111.3 \mathrm{~cd}: 97$

111.9b: 7

111.9: 7

111.10abc: 83

111.11-94: 29

111.13cd: 88

111.14cd-15: 38

111.16c: 7

111.16d: 7

111.21abc: 83

111.22-23: 36

111.22-24: 36

111.22-25: 31

111.22d: 7

111.24ab: 38

111.24: 36

111.26b: 7

111.27b: 7

111.30b: 7

111.31cd: 33,38

111.33d: 7

111.36c: 7 
111.37d: 7

111.41c: 7

111.42-44: 35,36

111.42-59: 36

111.43b: 7

111.44: 36

111.45-48: 31

111.45-52: 36

$111.47 \mathrm{c}: 32$

111.48: 36

111.52: 31

111.53: 35,36

111.54-56: 36

111.54: 36

111.55-56: 36

111.57-58: 31,36

$111.5 \% \mathrm{c}: 7$

111.5\%: 32,35

111.58d: 38

111.58: 32

111.59: 36

111.60b: 7

111.64c: 7

111.66abcd: 35

111.67-68: 32

111.69cd-79: 8

111.75bc: 38

$111.78 c: 8$

111.80-83: 32

111.80b: 38

111.80cd: 32,34

111.82d: 38

111.82f: 38

111.83d: 38

111.84cd: 38

111.85ab: 32

111.85a: 33

111.86c: 38

111.86: 32

111.91d: 7

111.92c: 7

111.92: 7

111.94d: 7

111.94: 31

111.95c: 7

111.96c: 7

112: 4, 6, 8, 17, 23, 25, 27, 33, 34, $36,37,39$

112.1-72: 29,31

112.2-12: 36

112.2-3\%: 29

112.3cd: 33 112.4cd: 36

$112.5 c d: 88$

112.6: 33

112. $7 c: 39$

112. \%: 36

112.8a: 38

112.9a: 38

112.9b: 39

112.10: 36

112.12: 33

112.13-14: 38

112.13-19: 33

112.13c: 51

112.13: 33

112.14c: 38

112.14: 33

112.15c: 38

112.16cd-1\%: 33

112.21cd: 34

112.23b: 34

112.24b: 34

112.26a: 39

112.26b: 39

112.35abcd: 33

112.36: 33

112.37ef: 33

112.49-50: 29, 32, 34

112.50a: 34

112.50d: 33,34

112.56cd: 34

112.62c: 51

112.67-72ab: 19

112.67-72: 7

112.72: 23-27, 40, 90, 93

112.73-115: 16, 23, 27, 40, 96

112.73-74: 26

112.73-81: 8, 16

112.73: 23,26

112.78d: 26

112. $79 a: 19$

112.82-92: 3, 4, 16

112.84c: 19,91

112.88: 97

112.93-115: 16

112.99-102: 9

112.103: 90

112.106ab: 23

112.109b: 18

112.112b: 18

112.115b: 18

112.115: 92,98

112.73-74: 27 


\begin{tabular}{|c|c|}
\hline Skandapurāṇa $\left(\mathrm{SP}_{\mathrm{RA}}\right)$ & 121.21: 13 \\
\hline 112.1: $22-28,40,42,90,95$ & 121.23-122.16: 17 \\
\hline 112.1-3: 90 & 121.37-64: 11 \\
\hline 112.1.1-39: 27 & 122.1-13: 11 \\
\hline 112.1.6-7: 27 & 122.11cd: 76 \\
\hline 112.1.39: 27 & 122.17b: 65 \\
\hline 112.1.40-112.2.25: 27 & 122.36c: 53 \\
\hline 112.1.40: 24,25 & 125: 17 \\
\hline 112.1.49cd-112.2.23: 27 & 129.1-18: 17 \\
\hline 112.1.50: 27,95 & 129.19-46: 17 \\
\hline 112.2: $23-27,40-42,90$ & 130-15\%: 16,17 \\
\hline 112.2.7-8: 26 & 130: $11,20,22$ \\
\hline 112.2.24b: 26,96 & 130.2-41: 4, 20 \\
\hline 112.2.24: $26,27,95$ & 130.2a: 11 \\
\hline 112.2.25: 27,96 & 130.8a: 11 \\
\hline 112.2.49ab: 27 & 130.12c: 11 \\
\hline 112.3: $23,24,26,27,40-42,90$ & 130.13b: 11 \\
\hline 112.3.2-8: 27 & 130.23: 9 \\
\hline 112.3.16a: 19 & 130.30b: 11 \\
\hline 112.3.16: 91 & 130.33c: 11 \\
\hline 112.3.17-56: 20 & $130.67 c d-69 a b: 18$ \\
\hline 112.3.19d: 96 & $130.69 c d-71 a b: 18$ \\
\hline 112.3.20-24: 95 & $130.71 c d-73 a b: 18$ \\
\hline 112.3.20b: 26 & $130.73 c d-75 a b: 18$ \\
\hline 112.3.20c: 96 & 130.80: 18 \\
\hline 112.3.23-24: 26 & 136.17a: 81 \\
\hline 112.3.27-35: 91 & 143.13b: 65 \\
\hline 112.3.50: 91 & 152.4a: 71 \\
\hline $112.3 .87 \mathrm{~cd}: 23$ & 154.16cd: 69 \\
\hline 112.3.97: 98 & 154.42d: 67 \\
\hline & $155: 12$ \\
\hline 113-115: 10,17 & 158-162: 8, 16-19, 22, 91 \\
\hline $\begin{array}{l}113-115: 10,18 \\
113-129: 17\end{array}$ & $158: 16,19,91$ \\
\hline 113-129: 17 & 158.44ab: 34 \\
\hline 113.1: 17 & $158.44 c d-45 a b: 34$ \\
\hline 113.2: 10,11 & $158.47 a b: 34$ \\
\hline 113.3: 10 & 158.49-50: 34 \\
\hline 113.55-65: 10 & 158.54: 34 \\
\hline $114.76 b: 73$ & 158.56-5\%: 34 \\
\hline $115.49 c d-50 a b: 10$ & 158.63a: 19 \\
\hline 116.1-13ab: 10,17 & 158.65: 34 \\
\hline 116.1-13: 10 & 158.68: 34 \\
\hline 116.1-2: 10 & 158.69-71: 91 \\
\hline $116.3 d: 11$ & 158.69a: 19,91 \\
\hline 116.13-117.20: 11 & 158.70-72: 19 \\
\hline 116.13cd-121.22: 17 & 158.72: 19 \\
\hline 116.86: 11 & $158.74 c: 19$ \\
\hline 116.8\%: 12 & $158.74: 19$ \\
\hline 117.28-31: 12 & 158.80-8\%: 7, 19 \\
\hline 118-121: 12 & 159.2c: 90 \\
\hline 121.16-20: 13 & 162: 19 \\
\hline 121.18-20: 13 & 162.57-64ab: 34 \\
\hline
\end{tabular}


162.67-68: 34

162.69a: 19

162.12\%: 19

163-165: 19

163: 16,17

169: 19

169.26d: 19

171.34b: 19

172: 12

172.50-51: 12

\section{Taittirīya-Saṃhitā (TaiSa)}

7.1.5.1: 57

Vāmanapurāṇa (VmP)

29-30: 21

33: 22

33.15-4\%: 21

33.34: 21

37-44: 21

37.19-40.19: 21

Varāhapurāṇa (VarP)

100: 85

103-105: 35

Vāyupurāṇa (VāP)

26.134ef: 69

Vị̣nudharma (VDh)

46.1\%: 86

87.15: 85

88.1-12: 85

Viṣnudharmottarapurāṇa (VDhP)

1.53.13-14: 4, 53

3.87: 94

3.309: 85

3.315.1c: 83

Viṣnupurāṇa (ViP)

1.4.32-34: 56

1.20.32: 11

5.24: 54

5.34: 54

Viṣnusmṛti (ViS)

87.9: 86

Yājñavalkyasmṛti

1.204: 85 